\title{
LAULAMISEN TAPOJA
}

ESITYSAREENA, REKISTERI JA

PAIKALLINEN LAJI

LÄNSI-INKERIL ÄISESSÄ

KALEVALAMITTAISESSA RUNOSSA 

Kati Kallio

\title{
LAULAMISEN TAPOJA
}

\author{
ESITYSAREENA, REKISTERI JA \\ PAIKALLINEN LAJI \\ LÄNSI-INKERIL ̈̈ISESS $\ddot{A}$ \\ KALEVALAMITTAISESSA RUNOSSA
}

Esitetään Helsingin yliopiston humanistisen tiedekunnan suostumuksella julkisesti tarkastettavaksi Arppeanumin auditoriossa lauantaina 14. joulukuuta 2013 kello 10. 
(c) Kati Kallio

http://ethesis.helsinki.fi/

http://urn.fi/URN:ISBN:978-952-10-9566-5

ISBN 978-952-10-9565-8 (nid.)

ISBN 978-952-10-9566-5 (PDF)

Ulkoasu ja taitto: Kalle Kallio

Painotyö: Tammerprint, Tampere 2013
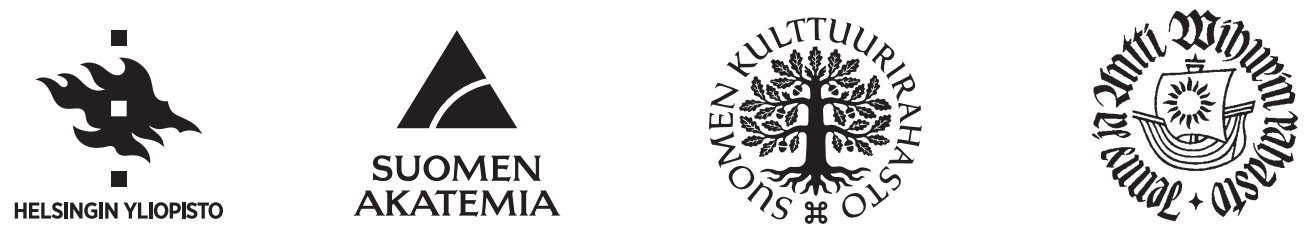

SKS

Suomalaisen Kirjallisuuden Seura

Musiikintutkimuksen valtakunnallinen tohtoriohjelma 


\section{SisëLlySLUETTELO}

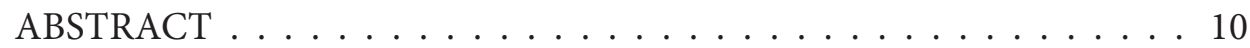

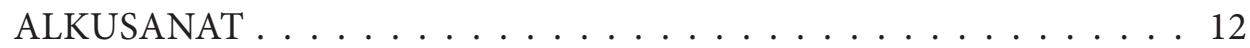

1. JOHDANTO . . . . . . . . . . . . . . . . . . . . 18

Lähtökohdat . . . . . . . . . . . . . . . . . 20

Tutkimuksen rakenne. . . . . . . . . . . . . . . . . . . 24

Inkeriläinen runolaulu . . . . . . . . . . . . . . . . 26

Paikalliset laulun lajit . . . . . . . . . . . . . . . . . . . . 29

Länsi-Inkeri . . . . . . . . . . . . . . . . . . . . . . . 34

Inkerin historia . . . . . . . . . . . . . 37

Etnisyys ja paikallisuus . . . . . . . . . . . . . . . . . . 39

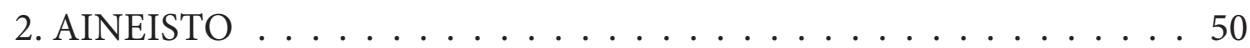

Tallennustyö Länsi-Inkerissä. . . . . . . . . . . . . . . . . . . 52

Runonkeruiden luonteesta . . . . . . . . . . . . . 58

A. A. Borenius-Lähteenkorva . . . . . . . . . . . . . . . 63

Armas Launis . . . . . . . . . . . . . . . . . . . . . . 64

Elsa Enäjärvi-Haavio . . . . . . . . . . . . . . . 72

Aili ja Lauri Laiho. . . . . . . . . . . . . . . . . . . . 73

Tallenteet näkökulmina. . . . . . . . . . . . . . . . . 77

3. TEOREETTINEN TAUSTA JA MENETELMÄT . . . . . . . . . . . . 84

Suullinen runo. . . . . . . . . . . . . . . . . . . . 84

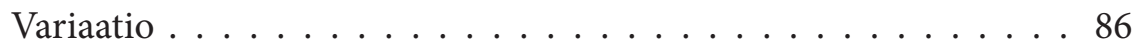

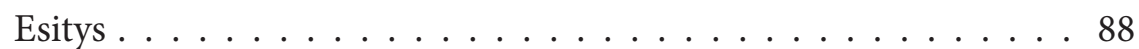

Laji ja rekisteri. . . . . . . . . . . . . . . . . 93

Viittauksellisuus. . . . . . . . . . . . . . . . . 997

Merkitys ja kielenulkoiset piirteet . . . . . . . . . . . . 101

Menetelmät . . . . . . . . . . . . . . . . . . . . 107

Keskeiset termit, käsitteet ja merkintätavat. . . . . . . . . . . . . . . . . . . . . . . . . . . . . . . .

Aineiston valinta ja käsittely . . . . . . . . . . . . . . . . . . . . . . . . . . . . . .

Esityksen monitasoisuus . . . . . . . . . . . . . . . . 117

Rekisteri, laji ja esitysareena . . . . . . . . . . . . . . . . 120

4. LAULUN RAKENNE . . . . . . . . . . . . . . . . . . . . 124

Kalevalamitta . . . . . . . . . . . . . . . . 126

Laulettu runo . . . . . . . . . . . . . . . . . . . 127

Runon sävelmä . . . . . . . . . . . . . . . . . . . . . 131 
Tekstuaalisia piirteitä . . . . . . . . . . . . . 136

Lisätavut . . . . . . . . . . . . . . . . . . . . . . 137

Osakertaukset . . . . . . . . . . . . . . . . . . . 140

Refrenkitavut ja refrengit. . . . . . . . . . . . . . . . . . . 142

Tavumuutokset ja säkeiden täydentäminen . . . . . . . . . . 146

Musiikillisia piirteitä . . . . . . . . . . . . . . . . 150

Rytmi . . . . . . . . . . . . . . . . . . . 151

Melodia. . . . . . . . . . . . . . . . . . . . . . . 154

Muotorakenne ja säkeiden kertaaminen . . . . . . . . . . . . 160

Paikalliset nimitykset . . . . . . . . . . . . . . 166

Rakenteiden käyttö . . . . . . . . . . . . . . . . . . . . . 173

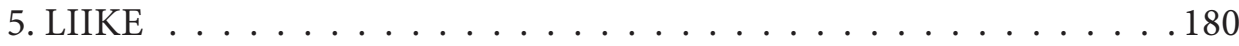

Läpi kylän . . . . . . . . . . . . . . . . . . . . . 183

Kuljeskelu, guljanje . . . . . . . . . . . . . . . . . . 183

Viron veräjät. . . . . . . . . . . . . . . . . . . . 186

Kluutša . . . . . . . . . . . . . . . . . . . . . . . . . 189

Tanssi . . . . . . . . . . . . . . . . . . . . . . . . . 194

Ympärikko . . . . . . . . . . . . . . . . . . . . 194

Pari- ja rivitanssit, leikit . . . . . . . . . . . . . . . . . 198

Paikoillaan laulaminen . . . . . . . . . . . . . . . 202

Liike ja laulu . . . . . . . . . . . . . . . . . . 206

Tihtii tai vienoo . . . . . . . . . . . . . . . . 206

Tanssisävelmät. . . . . . . . . . . . . . . . . . 210

Liikkeen jäsentyminen . . . . . . . . . . . . . . . . 215

6. PRAASNIKAT . . . . . . . . . . . . . . . . . . . 220

Laskiainen, liukuvirsi . . . . . . . . . . . . . . . . . 226

Hevaan liukusäven . . . . . . . . . . . . . . . . . . . . 227

Livukka rekoi lippiä. . . . . . . . . . . . . . . . . . . 228

Pääsiäinen, liekkuvirsi . . . . . . . . . . . . . . . . 236

Vanhat ja nuoret laulajat . . . . . . . . . . . . . 238

La miä katson liekkujani . . . . . . . . . . . . . . . . . . . 240

Juhannus, kokkovirsi . . . . . . . . . . . . . . . . . . . . . . . 244

Kulku kokolle . . . . . . . . . . . . . . . . . . . . . . . . 244

Ai lole lole yötulelle joo. . . . . . . . . . . . . . . . . . . . . . . . . . . . . . . . . . . . . . . . . . . . . . . . .

Pedron ja Iljan virsi . . . . . . . . . . . . . . . . . . . . 250

Tyttöjen laulu kuominassa . . . . . . . . . . . . . . . . 251

Iilia pyhä isäntä . . . . . . . . . . . . . . . . . . . . . 254

Talven kiertueet . . . . . . . . . . . . . . . . . . 257

Martin päivä ja virsi. . . . . . . . . . . . . . . . . . 258

Miikkula, joulupyhät ja kiletoivirsi . . . . . . . . . . . . . 260

Kiertuetapojen muutos . . . . . . . . . . . . . . . . 265

Esitysareena ja laulun jäsentyminen. . . . . . . . . . . . . . . . . 269 
7. PULMAT ． . . . . . . . . . . . . . . . . . . . . 274

Laulu rituaalin kantajana . . . . . . . . . . . . . . . . . . . . . . . . . . . . . . . . . . . . . .

Häiden kulku . . . . . . . . . . . . . . . . . . . . . . 278

Laulajat sosiaalisten ryhmien edustajina . . . . . . . . . . . . 280

Laulun alku: puhuttelu, pyyntö tai kehotus. . . . . . . . . . . . 283

Hääsävelmät . . . . . . . . . . . . . . . . . . . . . . . . . . 286

Rituaalisesti keskeiset laulut . . . . . . . . . . . . . . . . 288

Kaksi häiden valtanuottia . . . . . . . . . . . . . . . . . . . 295

Erityiset sävelmät ja tilanteet. . . . . . . . . . . . . . . . . . . 299

Kokin kiitosvirsi. . . . . . . . . . . . . . . . . . . . . . . . . 299

Yks oli oksa ounapuussa . . . . . . . . . . . . . . . . . 300

Ajaminen häätaloihin. . . . . . . . . . . . . . . . . . . 304

Kosikkisävel ja tyttöjen attoillan laulu . . . . . . . . . . . . 306

Häälaulun rekisterit . . . . . . . . . . . . . . . . . . . 313

8. LAULAMISEN TAPA JA TILANNE. . . . . . . . . . . . . . . . . .318

Juhlassa ja arjessa . . . . . . . . . . . . . . . . . . . 319

Julkisesta yksityiseen . . . . . . . . . . . . . . . . . . . . 319

Esilaulaja ja jälestälaulajat . . . . . . . . . . . . . . . . . 324

Soololaulu . . . . . . . . . . . . . . . . . . 330

Tallennustilanne. . . . . . . . . . . . . . . . . . . 337

Tilanteen monikerroksisuus . . . . . . . . . . . . . . . . . . 343

Leekutusnootti. . . . . . . . . . . . . . . . . . . . . . . . 344

Leino leski . . . . . . . . . . . . . . . . . . . . . . . . . 348

9. MITEN LAULU MERKITSEE? . . . . . . . . . . . . . . . . . . . . . 358

Keruuhetki. . . . . . . . . . . . . . . . . . . . . 360

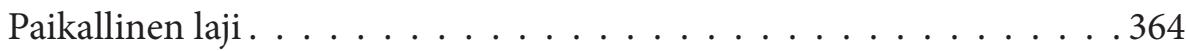

LÄHTEET JA KIRJALLISUUS . . . . . . . . . . . . . . . . . . . . 374

Lyhenteet. . . . . . . . . . . . . . . . . . . . . 374

Arkistolähteet . . . . . . . . . . . . . . . . . . . . . .375

Tietokannat ja verkkoaineistot. . . . . . . . . . . . . 375

Painetut lähteet ja kirjallisuus . . . . . . . . . . . . . . . . 375

Transkriptiosta. . . . . . . . . . . . . . . . . . . . . 390

Runo- ja sävelmähakemisto . . . . . . . . . . . . . . . . . . . . 392

LIITTEET . . . . . . . . . . . . . . . . . . . . . . . . . . . . . 398

Liite 1: 1930-luvun laulajia . . . . . . . . . . . . . . . . . . 398

Anna Kivisoo . . . . . . . . . . . . . . . . . . . . . . . . 399

Tatjana Jegorova. . . . . . . . . . . . . . . . . . . . . . . 399

Valpuri Vohta . . . . . . . . . . . . . . . . . . . 400

Darja Lehti. . . . . . . . . . . . . . . . . . . . . . . . . 401

Mari Vahter . . . . . . . . . . . . . . . . . . . . . . 402

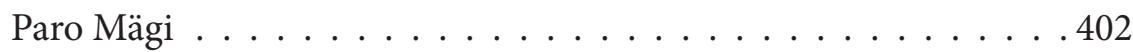

Maria Otsa . . . . . . . . . . . . . . . . . . . . . . . . 402 
Katri Vohta. . . . . . . . . . . . . . . . . . . . .403

Juljaana Pohjalainen . . . . . . . . . . . . . . . 4403

Matrona Bässina. . . . . . . . . . . . . . . . . . . . . . . . 403

Jeodokia Räkälä . . . . . . . . . . . . . . . . . . . . . . . . . . 404

Liite 2: Laulajien taustatietoja . . . . . . . . . . . . . . . 405

Liite 3: Kylät, etniset ryhmät ja keskeiset praasnikat. . . . . . . . . . 407

Liite 4: Sävelmäaineisto . . . . . . . . . . . . . . . . . . . . . . 411

Europaeus 1953 (SKS KRA) . . . . . . . . . . . . . . . 411

Borenius 1877 (SKS KRA) . . . . . . . . . . . . . . . . . 411

Alava 1891-1897 (SKS KRA) . . . . . . . . . . . . . . . . . 4415

Launis $1903(\mathrm{SibA}) \ldots \ldots$. . . . . . . . . . . . . . 416

Levón 1903 (SKS KRA). . . . . . . . . . . . . . . . . . . . .427

Launis 1906 (SKSÄ A 300-301) . . . . . . . . . . . . . . . . . . . . . . . . . .

Mägiste 1920- tai 1930-luvulla (ERA Fon. 372) . . . . . . . . . . . 440

Kreek 1922 (ERA Fon. 207-209) . . . . . . . . . . . . . . . . . .440

Väisänen 1914 (SKSÄ A 302-303) . . . . . . . . . . . . . . . . 441

Väisänen 1931 (SKSÄ A 507) . . . . . . . . . . . . . . . . . . . . 441

Laiho ja Viron yleisradio 1937 (SKSÄ L 87-101) . . . . . . . . . . . 442

Liite 5: Teemottaisia aineistokokonaisuuksia . . . . . . . . . . . . 443

Paikalliset nimitykset . . . . . . . . . . . . . . . . . 443

Liikekuvaukset. . . . . . . . . . . . . . . . . . . . . 445

Saadulmoi-sävelmät. . . . . . . . . . . . . . . . . . . . . . 460

Tanssisävelmät. . . . . . . . . . . . . . . . . . . . 461

Laskiaissävelmät. . . . . . . . . . . . . . . . . . . . . . 463

Liekkusävelmät . . . . . . . . . . . . . . . . . . . . . . . 464

Kokkosävelmät . . . . . . . . . . . . . . . . . . . . 4655

Kokkosävelen kuvaukseen sopivat sävelmät . . . . . . . . . . . . . 465

Pedron ja Iilian sävelmät . . . . . . . . . . . . . . . . . . . . . . . . . . . . . . . . . . . . . . .

Joulunajan juhlien kuvaukset . . . . . . . . . . . . . . . . . . 469

Martin päivän sävelmät. . . . . . . . . . . . . . . . . . . . 471

Kiletoivirret . . . . . . . . . . . . . . . . . . .471

Kiletoi-sävelmät . . . . . . . . . . . . . . . . . . . . . .4772

Häissä laulamisen kuvaukset. . . . . . . . . . . . . . . . . . . 472

Hääsävelmät . . . . . . . . . . . . . . . . . . . . . . . 4476 


\title{
Abstract
}

\author{
LAULAMISEN TAPOJA. ESITYSAREENA, REKISTERI JA PAIKALLINEN \\ LAJI LÄNSI-INKERILÄISESSÄ KALEVALAMITTAISESSA RUNOSSA
}

Ways of Singing. Performance ARENA, Register AND LOCAL GENRE IN WEST-INGRIAN ORAL POETRY

The focus of this doctoral research is on the registers, performance arenas and local genres of kalevalametric singing in Western Ingria (1853-1938). It combines the approaches of folkloristics, ethnomusicology and linguistic anthropology to obtain an understanding of the cultural patterns of singing in one historical performance tradition. The basic question behind the whole work is how to take the performed and sung nature of oral poetry properly into account. The song poetics, musical structures and the performative features are, together with the poems themselves, essential in order to analyse the logic of the local (indigenous, emic) genres. Following the character of the archival material, the research concentrates on Izhorian and Ingrian-Finn festive singing cultures. The local, ethnic and historical backgrounds have a significant position in the analysis.

Western Ingria was a multicultural area with Greek Orthodox Votics, Izhorians and Russians and Lutheran Ingrian-Finns as most substantial ethnic groups. The Finnic groups of the area sung similar types of kalevalametric poems, but the poems, melodies, and the ways of performing them varied according to the group and locality. The present research could be characterized as archival ethnography. It builds on the work of more than thirty fieldworkers with very different kinds of interests, aims and technologies from paper and pen to camera, phonograph and studio equipment. This multiperspectivity is considered as an advantage, although the fragmentary nature of the archival data calls for the detailed analysis of a large corpus.

In the analysis, the concepts of register and performance arena are central tools for understanding the local genres. The register denotes a recurrent speech or singing style, while the performance arena means a recurrent type of situation or situational frame of reference. A register, as noted by the researcher, must be named by the singers themselves in order to be interpreted as a local genre. The registers and local genres are taken as frames of interpretation, which gain their meanings via different kinds of recurrent uses and associations within a speech community. In Western Ingria, the most notable differences between different local genres were on their quality and the amount of variation. While some genres were textually, musically and performatively rather fixed and restricted, others were characterised by the exact opposite, as they were able to merge various texts, melodies, refrains and movements. 
Ingrian oral poetry fits well into theoretical discussions about registers as flexible, layered and complex means of communication. The singers set the interpretive frame of a song in sometimes complementary, sometimes alternative means of poetic themes, opening formulas, rhythms, melodies, patterns of repetition, refrains, additional syllables, movements, tempos and vocal qualities. The notion of the situational character of the use of musical features has not previously been discussed in relation to Ingrian cultures, although the situational local genres have been analysed by Senni Timonen. A new aspect is also the interpretation of the recording situation as a multilayered performance arena, situated in various ways between public and private, formal and informal.

KEY wORDs: local genre, register, performance, Ingria, oral poetry, Kalevala-meter, folk music 


\section{Alkusanat}

Ihastuin kalevalamittaiseen runoon laulamalla sitä, vaikka olin lueskellut Kalevalan ja runojen tutkimiseen liittyviä kirjoja jo aiemmin. Tutustuin metrin hyllytilaa vievään Suomen Kansan Vanhat Runot -kirjasarjaan etsimällä sieltä hyviä sanoituksia. Inkeri löysi nopeasti paikkansa kartalta, sillä suomalaisen nykykansanmusiikin parissa inkeriläiset tekstit ja sävelmät ovat kalevalamittaisen laulun käytetyintä aineistoa. Alueen henkilökohtaisia sävyjä kantavat, vapaasti muotoutuvat runot istuvat helposti nykylaulajankin suuhun, ja uudemmista venäläisistä ja suomalaisista lauluista vaikutteita ottaneet sävelmät tuntuvat riittävän tutuilta ja vaihtelevilta ihastuttaakseen länsimaisen musiikin piirissä kasvaneita kuulijoita. Tästä näkökulmasta katsottuna on oikeastaan ironista, että tämä työ käsittelee pääosin kaikkein yksinkertaisimpia - ja samalla vieraimman tuntuisia - sävelmiä ja muodoltaan kiteytyneimpiä, rituaalisimpia runoja.

Ensikosketus tutkimuskohteeseen ja -traditioon selittää osaltaan työn näkökulmaa, vaikka monet varhaiset oletukseni ovatkin työn kuluessa kääntyneet ylösalaisin. Yksinkertainen, toistuva tai kiteytynyt ei tarkoitakaan tylsää ja monotonista, vaan paikallisen kulttuurin näkökulmasta rituaalista, painokasta ja jopa henkilökohtaisesti merkittävää. Runokulttuurin tallentajien kuvaukset ovatkin usein yhdestä näkökulmasta ja tilanteesta annettuja tuokiokuvia, eivät syvällisiä analyyseja koko laulukulttuurin rakentumisesta. Kulttuuriset laulamisen mallit - joita en aluksi edes tajunnut etsiväni - eivät muodosta yksinkertaisen selkeää, poikkeuksetonta kuviota, ja yksittäisten piirteiden kantamien merkityskenttien ymmärtäminen edellyttää laajan aineiston monikerroksista analyysia.

Pohjimmaisina ihmettelyn aiheina tässä työssä on ihmisten välinen kommunikaatio ja vieraan kulttuurin ymmärtämisen mahdollisuudet. Käsitänkö mitään siitä, mitä sadan vuoden takaiset ihmiset lauluillaan sanoivat? Olen ajatellut tutkimusta ymmärrysharjoituksena, jonka loppuun ei voi päästä, vaikka mahdollisimman pitkälle kannattaa yrittää. Aineistot, henkilöt ja laulukulttuurit eivät tyhjene tulkintoihin. Haron kohti peruskehikkoa: mikä oli tämä laulukulttuuri, miten sitä voisi ymmärtää, ymmärtää sen kokonaisrakennetta yhtä hyvin kuin yksittäistä laulua? Vieraaseen kulttuurin on parasta tutustua rauhassa ja useampaa väylää pitkin. Nähdäkseni laulukulttuurin perusrakenteiden ja yksittäisten esitysten käsittäminen on samanaikainen, kaksisuuntainen prosessi: yksittäinen, ainutkertainen esitys on ainoa väylä laajempiin rakenteisiin, mutta se tulee ymmärrettäväksi vasta laulukulttuurin laajemman tarkastelun myötä.

Parikymppinen folkloristiikan opiskelija ja laulun harrastaja selasi Inkerin runosävelmiä (IRS) ja Suomen Kansan Vanhoja Runoja (SKVR) ihmeissään. Mitä nämä oikein ovat, mitä ne antavat minulle ja mitä ne merkitsivät laulajilleen? Kysymykset olivat myös konkreettisempia. Oliko laulajilla todella aina vapaus laulaa mikä 
runo hyvänsä millä sävelmällä ja tavalla hyvänsä, kuten tutkimuskirjallisuus antoi usein ymmärtää? Voisiko runotekstien yhteydessä esiintyvien lyhyiden mainintojen kautta kuitenkin päästä syvemmälle siihen, miten niitä käytettiin? Mitä merkitystä laulajien kannalta oli sillä, miten runo esitettiin?

Ymmärrysharjoitus oli pitkään ilman haromista, sopivan lähestymistavan, viitekehyksen ja mittakaavan hakemista. Ensimmäinen yritys, pro seminaari -työ muutamasta Maailmansyntyrunosta, päättyi tradition mukaiseen toteamukseen: runoa oli mahdollista esittää lähes millä sävelmällä hyvänsä (Heinonen 2000). Jälkiviisaasti voin todeta, että tietenkin. Tämä runohan on juuri sitä lajia, jota laulettiin mitä moninaisimmissa tilanteissa, mitä moninaisimmilla tavoilla: hiljaa paikoillaan, riehakkaasti tanssien, kulkiessa, yksin ja joukolla, arjessa ja juhlassa. Laulamiset tavat olivat merkityksellisiä, mutta niiden merkityksellisyys liittyi enemmän esitystilanteisiin kuin yksittäisiin runoihin. Runo ei yleensä määrännyt esitystapaa, vaan tilanne. Kun laulajat tallennustilanteissa esittivät Maailmansynnyn kaltaisia monikäyttöisiä runoja, he saattoivat assosioida runon mitä moninaisimpiin tilanteisiin ja esittää sen siten mitä moninaisimmilla erilaisilla tavoilla. Samantyyppisinä esityksinä toistuivat laulajasta ja tallennustilanteesta toiseen lähinnä kiinteän tilannesidonnaiset, rituaaliset runot, jotka liittyivät häihin ja vuotuisjuhliin.

Oli tarpeen käydä läpi arkistoaineistoa yhä uudestaan ja pohtia samalla yksittäisiä laulajia, tallentajia ja tilanteita, oli tarpeen katsella monen eri tutkimustradition suuntaan. Paikallisuus, etnisyys ja tilannesidonnaisuus osoittautuivat merkityksellisemmiksi, kuin olin ajatellut. Pitkälti irrallisina toisistaan tallennetut ja osin fragmentaariset runo-, sävelmä- ja kuva-aineistot alkoivat luennassani asettua rinnakkain ja lomittain, aloin ymmärtää niitä suhteissa toisiinsa ja suhteessa eri aloilla käytyihin teoreettisiin keskusteluihin. Näköalat eivät ole kuitenkaan avartuneet ainoastaan yksin aineiston ja kirjallisuuden äärellä istuessa, vaan keskusteluissa elävien ihmisten kanssa.

Ensimmäinen kiitos kuuluu työni ohjaajille Lauri Harvilahdelle ja Lotte Tarkalle sekä alkuvaiheen ohjaajalleni Anna-Leena Siikalalle. On Laurin ansiota, että tulin jo toisen vuoden opiskelijana ensimmäisiä kirjoitelmia tehdessäni tarttuneeksi yhteen kysymyksenasettelun kannalta parhaimmista aineistoista ja alkaneeksi koota teoreettista viitekehystä, joka on myöhemmin kaivannut lähinnä lisäyksiä ja tarkennuksia. Anna-Leenan ja Loten selvänäköiset kommentit ovat samoin olleet korvaamattomia. Olen teille kaikille loputtoman kiitollinen luottamuksesta, kannustuksesta ja innostuksesta. Pohja työlle syntyi myös Senni Timosen ja Heikki Laitisen luotsaaman Runonlauluprojektin parissa ja sen piirissä käydyissä keskusteluissa. Ajatuskipunoita, tulirososia! Oi miun ehtosat emmooni, teilt on saatuna sanaset. 
Pertti Anttosen johtama akatemiahanke tarjosi tutkimuksen teolle merkittävän yhteisön. Kiitos Pertti, Jouni Hyvönen, Niina Hämäläinen ja Pekka Tolonen elävistä, pitkistä keskusteluista! Työn viimeistelyn aikana taas on ollut onnellista innostua jo seuraavistakin tutkimusaiheista, mistä erityiskiitos Tuomas Lehtoselle, Irma-Riitta Järviselle, Linda Kaljundille, Ilkka Leskelälle ja Senni Timoselle. Sekä Suomalaisen Kirjallisuuden Seuran kansanrunousarkisto ja tutkimusosasto että Helsingin yliopiston folkloristiikan oppiaine ovat olleet minulle inspiroivia ja onnellisia työyhteisöjä kahvihuoneineen ja tutkijaseminaareineen. Työtoverit! Kiitos! Unohtumattomia ovat olleet myös Kansanmusiikin ja populaarimusiikin tutkijakoulun (sittemmin Musikin ja näyttämötaiteen tutkijakoulu, nykyisin Musiikintutkimuksen valtakunnallinen tohtoriohjelma) ja Kulttuuristen tulkintojen tutkijakoulun seminaarit, työpajat ja kesäkoulut sekä Folklore Fellowsin kesäkoulut 2005 ja 2011. Elore-lehden toimituskunta opetti paljon toimittamisesta ja kirjoittamisesta, ja Armas Launis-seura sekä Kansanmusiikintutkimuksen A. O. Väisänen -seura työn kannalta keskeisistä tallentajista. On ollut myös ilo käydä kuuntelemassa ja keskustelemassa Tampereen yliopiston Musiikintutkimuksen oppiaineen tutkijaseminaareissa, Kansantietouden tutkijat -seuran kevätkouluissa sekä monissa yksittäisissä seminaareissa ja konferensseissa. Suuri kiitos kaikille yhteisiä keskusteluita jakaneille!

Rahoitus työlle on tullut monesta purosta. Kiitän Suomen Akatemian hanketta Suullisen perinteen tekstualisaatio ja moderni kontekstualisaatio Suomessa (Pertti Anttonen, Turun ja Jyväskylän yliopisto), Kulttuuristen tulkintojen tutkijakoulua, Jenny ja Antti Wihurin säätiötä ja Suomen Kulttuurirahastoa työni rahoittamisesta sekä Suomalaisen Kirjallisuuden Seuraa käytännön puitteista. Työn viimeistely on tapahtunut osin akatemiahankkeen Suulliset ja kirjalliset kulttuurit keskiajalla ja uuden ajan alussa: kulttuurinen vaihto, kielimaailmat ja kommunikatiiviset verkostot Itämeren piirissä (SKS, hankenumero 137906) puitteissa. Kalevalaseuraa kiitän ihanasta kannustuksesta, joka sattui juuri siihen kohtaan, jossa pienten lasten kanssa valvominen oli sumentanut sekä silmät että ajatukset.

Työn esitarkastajille Jarkko Niemelle ja Janika Orakselle olen kiitollinen kannustavista, tarkoista ja perinpohjaisista kommenteista. Jarkon työ säestyksettömän laulun musiikin ja metriikan parissa on toiminut keskeisenä viitoittajana inkeriläisten laulujen rakenteiden ymmärtämisessä. Jarkolle myös suuri kiitos lupautumisesta vastaväittäjäkseni. Janikan esimerkki on puolestaan ohjannut kohti laulujen, laulajien ja tallentajien herkkäkorvaisempaa kuuntelemista. Vuosien varsille osuneet keskustelut inkeriläisistä ja virolaisista laulukulttuureista, laulamisen estetiikasta sekä arkistoaineistoista ovat avartaneet ajatuksia korvaamattomilla tavoilla: kiitos, Janika!

Työtä ovat kommentoineet tai edesauttaneet monet ihmiset. Koko käsikirjoituksen ovat lukeneet ohjaajien ja esitarkastajien lisäksi Senni Timonen, Pertti Anttonen, Tuomas Lehtonen ja Venla Sykäri. Sennille erityiskiitos korvaamattomasta avusta runoteemojen ymmärtämisessä, tunnistamisessa ja nimeämisessä, Pertille ajatte- 
lua selkiyttäneistä tarkoista kommenteista ja Tuomakselle elävistä keskusteluista ja oppihistoriallisista näkymistä. Venla on avannut huimia ikkunoita nykyajan eläviin runokulttuureihin, runojen käyttöön ja niistä ajattelemiseen. Kiitos! Luvun 5 kommentoi työn loppuvaiheessa Petri Hoppu, suuri kiitos siitä! John Miles Foley on surukseni kiitosteni tavoittamattomissa. John sai ajattelemaan suullisen runon luonnetta ja laulussa muodostuvia viittaussuhteita uusilla tavoilla. Eila Stepanovaa kiitän erityisesti esitysareenan ja rekisterin käsitteiden yhteisestä pohtimisesta sekä venäjänkielisten lähteiden avaamisesta. Frogille erityiskiitos keskustelujen ohella myös pikaisesta kielentarkastuspelastuksesta. Ilona Korhosen kanssa on ollut onnellista taivaltaa rinnakkaisia polkuja inkeriläisen laulun parissa. Jatkukoot ne! Heidi Haapojan tarkat korvat ja näkökulmat arkistoaineistoon ovat olleet sekä suureksi iloksi että avuksi. Ilonalle ja Heidille erityiskiitos myös monista tämän työn sivuilla olevista, yhteisen aineistohankkeen puitteissa syntyneistä nuotinnoksista. Maari Kallbergille kiitos sekä ensimmäisistä runonlaulun oppitunneista että myöhemmistä historiallisten laulukulttuurien pohdinnoista. Anna-Kaisa Liedekselle kiitos erityisesti tajuntaa ja ääntä avartaneista kokemuksista Seurasaari soi! -tapahtuman puitteissa ja Sibelius-Akatemian kansanmusiikin oppiaineen opiskelijoiden kanssa. Elina Sadeniemeä kiitän ystävyydestä ja kaipaan yhteisiä työlounaita. Risto Blomster on jakanut erityisesti innostuksen rahiseviin vahalieriöihin ja tallennushistoriaan, Jukka Saarinen taas runomittaan ja kielellisiin muotoihin. Kummallekin suuri kiitos keskustelujen ja kommenttien ohella myös käytännön avusta aineistojen parissa. Anneli Asplundia haluan kiittää merkitsevistä keskusteluista ja yhä tarpeellisemmaksi osoittautuneesta kirjallisuudesta. Eila Honkaselle olen kiitollinen avartuneista ajattelun, kuuntelemisen ja tuntemisen mahdollisuuksista.

Suuri kiitos kuuluu myös kaikille kirjastoissa ja arkistoissa auttaneille Suomessa ja Virossa. Erityisesti kiitän omia kotijoukkojani, Suomalaisen Kirjallisuuden Seuran arkistojen, kirjastojen sekä hallinto- ja tutkimusosaston väkeä. Kansanrunousarkisto on kotipaikka, jota katson nykyään toisella puolella katua istuessani ikävöiden. Avusta aineistojen ja kirjallisuuden kanssa kiitos etenkin Liisa Lehdolle, Juha Nirkolle, Pirjo Mäkilälle sekä Kristiina Näyhölle.

Laulaminen Paha kurki- ja Loksutada-yhtyeissä opetti lukioaikoina ja ensimmäisinä opiskeluvuosina paljon kalevalamittaisen runon olemuksesta, mahdollisuuksista, mitasta ja aineistoista sekä esittämisen merkityksistä, ja Kaustisten Ala-Könni opisto opettajineen ja kirjastoineen loi pohjan myös käsityksille musiikin teoriasta ja perinnetieteistä. Kiitos laulutoveruudesta Pekko Käppi, Malin Nykänen, Kirsi Ojala, Juulia Salonen ja Ruska Schönberg!

Taarna Valtosen kanssa kuljimme aikanaan pitkin Utsjoen ja Varangin tuntureita milloin vanhoja postipolkuja tai turvekammeja etsien, milloin pääsykoekirjoja mukana kantaen. Kiitos pitkästä rinnalla kulkemisesta, Taarna, kiitos keskusteluista, lasten vaatettamisesta ja jos jonkinlaisesta avusta. Maurice Carrezille kiitos osaksi perhettä ottamisesta, akateemisesta esikuvasta ja kirjoittamisen löytämisestä aika- 
na, jolloin en vielä edes tiennyt, mitä lähtisin opiskelemaan. Ari ja Pirkko Kalliolle kiitos tuulensuojaisista tiloista, juhlahetkistä ja konkreettisesta työ- ja lepoajasta. Piia Susiluodolle kiitos lähellä olemisesta ja jakamisesta. Marja ja Pekka Heinoselle kiitos loppumattomasta avusta, tuesta ja kannustuksesta. Veera ja Aarni Kalliolle kiitos uusista ja ihmeellisistä maailmoista. Perinpohjaisimmin on työhön liittyvät ilot ja huolet jakanut kanssani Kalle Kallio, joka on ollut merkittävin keskustelukumppani historiallisista taustoista aineiston rajauksen kysymyksiin asti ja lopulta kommentoinut läpi ja taittanut koko kirjan. Suurin kiitos kuitenkin onnesta, innostuksesta ja jaetusta elämästä, rakas. Sinun kanssasi on hyvä.

Tampereella 15. marraskuuta 2013

Kati Kallio 


\section{JOHDANTO}




\section{JOHDANTO}

Itämerensuomalaista suullista runoa käytettiin pääosin lauluna. Runo eli tilanteesta toiseen varitoivina esityksinä. Vaikka tämä alkaa nykytutkimuksen piirissä olla itsestäänselvyys, ei se varsinaisena tutkimuksen lähtökohtana sitä ole. Näkökulman laajentaminen runoteksteistä niiden käyttö- tai esitystapoihin johtaa oppialojen rajapinnoille ja monikerroksisempiin tulkintoihin: runotekstin, esitystilanteen ja kulttuuristen taustojen ohella on tarpeen ottaa huomioon myös esimerkiksi musiikki ja tanssi. Samalla tutkija joutuu puntaroimaan sekä arkistoaineiston rajoja että sen antamia mahdollisuuksia.

Länsi-inkeriläinen Valpuri Vohta esitti Leinon lesken runoksi kutsutun, Inkerissä laajasti tunnetun runoaiheen tutkijoille kolme kertaa 1930-luvulla. Kalevalamittaisen runon tallennushistoriassa näinkin laaja yhdeltä laulajalta tallennettujen versioiden sarja on harvinainen. Erityiseksi sen tekee vielä kaksi seikkaa: yksi toisinnoista on äänite ja kahteen käsikirjoitukseen sisältyy poikkeuksellisen laaja runon käyttömahdollisuuksien kuvaus. Vohdan mukaan laulu oli surullinen eli hallee laulu. Sitä lauloivat naiset paikoillaan istuen kaikkein suurimmissa juhlissa, varsinaisten juhlalaulujen jälkeen tai välissä: etenkin häissä eli pulmissa tai Jyrinpäivän praasnikkajuhlilla, mutta toisaalta yhtälailla joen partaalla eli kallaalla aikaa viettäessään.

Pulmissa kun oltii, kai jo väsynneit, mentii lauvan taa ja pantii viinaputeli ettee ja käsi posel ja laulettii. Tämä on sellai hallee laulu. - Kesäl ku istuttii kallal, tämä oli istumalaulu. $^{1}$

Tyttöjen guljanjessa ei laulettu tätä. Tätä ei näet voitu laulaa hulkkuen eikä tanssien. Naiset Jyrinpäivänä saattoivat laulaa tätä. Samoin voitiin tätä laulaa vaikkapa häissä, sitten kun varsinaiset häälaulut olivat ohi tai oli sopiva välikohta, esim. häiden lopulla, kun istuttiin pöydän ympäri sen jälkeen kuin "Tunsit tulla" oli laulettu. ${ }^{2}$

Vaikka nämä kahdelle eri keräjälle annetut kuvaukset eivät mene ristiin toistensa kanssa, painottavat ne erilaisia asioita. Pysyvää niissä on häissä ja istuen laulamisen kuvaus. Tämän ohella lähes varioimattomana esityskerrasta toiseen pysyi paitsi runon sisältö ja muoto, myös Vohdan tapa laulaa runo. Kaikista versioista ilmenee esilaulajan laulaneen kaksi runosäettä ja kuoron kerranneen niistä jälkimmäisen loppuosan kahdesti: äänitetty runo paljastaa tämän muotorakenteen ohella myös sävelmän, laulun rauhallisen tempon sekä laulajien vakavan äänensävyn. Muilta saman alueen laulajilta kerättyjen toisintojen valossa kuva Leinon lesken runosta kuitenkin muuttuu. He antoivat päinvastaisiakin tietoja: runoa voitiin tanssia nopealla tempolla, sitä saattoivat laulaa myös tytöt, se saattoi yhdistyä monin tavoin

\footnotetext{
${ }^{1}$ SKS KRA Laiho A. 2291.

${ }^{2}$ SKS KRA Enäjärvi-Haavio 467.
} 
muihin runoaiheisiin ja sitä saatettiin laulaa monenlaisia sävelmiä ja laulun rakenteita käyttäen. (Ks. luku 8: Leino leski.)

Vohdan laulu kertoo sekä Länsi-Inkeristä ennen toista maailmansotaa tallennetun aineiston mahdollisuuksista että rajoituksista. Aineistoa on paljon ja se on kalevalamittaisen runouden yhteydessä poikkeuksellisen monipuolista - varhaisimmat ja laajimmat äänitekokoelmat ovat tältä alueelta tallennettuja ja toiset kerääjät olivat kiinnostuneita myös runojen esittämistavoista. Toisaalta aineisto on fragmentaarista. Esimerkiksi suurin osa sävelmistä ja runoista on tallennettu toisistaan erillisinä teksteinä. Niiden käyttöä kuvaavat, sieltä täältä löytyvät kommentit ovat tyypillisimmillään yhden tai kahden sanan pituisia. Kattavaa kuvausta alueen etnografiasta saati runojen käytöstä ei ole, vaikka kiinnostus niihin on kulkenut monen kerääjän ja tutkijan työn sivujuonteena. Laulamisen tapojen kuvaukset ovat suhteellisessa runsaudessaankin pääosin hajanaisia, lakonisia mainintoja tai konkreettisesta aineistosta irrallaan, matkakertomusten ja populaarien kuvausten yhteydessä esitettyjä yleistyksiä. Vohdankin kuvaukset herättävät enemmän kysymyksiä kuin vastauksia: minkälaisia laulamisen tilanteita olivat länsi-inkeriläiset häät ja praasnikat, mitä tarkoitti "istumalaulu," miksi juuri tietynlainen sävelmä tai laulun rakenne, miksi Vohta asetti runon juuri naisten lauluksi, miten hänen kuvauksensa suhteutuu muihin alueen laulukäytäntöihin? Mitä kaikkea oli tyttöjen guljanje, hulkkuminen ja tanssiminen, joiden piiriin runo ei Vohdan mukaan kuulunut? Kuinka kattava hänen kuvauksensa oli, ja mitä se kertoo hänen tavastaan tulkita alueella yleinen runoaihe? Yhdenkin esityksen ymmärtäminen ja tulkitseminen edellyttää tarkempia tietoja paikallisista käytännöistä. 


\section{LёHTÖKOHDAT}

Tämän tutkimuksen lähtökohtana on kysymys siitä, millä tavoin suullisen runon tutkija voi käyttää tietoa siitä, että runot elivät lähinnä lauluina, erilaisina esityksinä. Toisaalta kysymyksen voi asettaa myös toisin päin: minkälaisten teoreettisten ja metodologisten keskusteluiden käymiseen sata vuotta vanha, melko fragmentaarinen kalevalamittaisen runon arkistoaineisto kelpaa? Konkreettiselle tasolle kysymys asettuu juuri suhteessa tiettyyn aineistoon: minkälaisia erilaisia näkökulmia on välttämätöntä ottaa huomioon juuri länsi-inkeriläisen aineiston tulkitsemiseksi? Parhaimmillaan runojen laulettujen rakenteiden ja käytön analyysi voi antaa lisää välineitä runotekstienkin tulkinnalle ja kertoa samalla jotain länsi-inkeriläisistä kulttuureista laajemmin.

Työn keskiössä on se, miten kalevalamittaisia runoja Länsi-Inkerissä esitettiin ja millä tavoin laulamisen tapojen ja sävelmien piirteiden voi tulkita olleen osa myös runojen merkitysten rakentumista. Taustalla ovat kysymykset siitä, miten ja missä määrin sanottavan muoto tai rakenne, sen kielenulkoiset piirteet ja konteksti osaltaan luovat merkityksiä tai sävyjä. Esityksellisten piirteiden valinnan ja yhdistelemisen katson osaltaan luoneen kunkin laulun tulkinnallisen kehyksen, jonka ymmärtäminen edellyttää paikallisten laulamisen käytäntöjen tuntemusta yhtä lailla paikalliseen yhteisöön kuuluvalta kuulijalta kuin tutkijaltakin. Abstraktimmalla tasolla kyse onkin inkeriläisen runon lajijärjestelmän ja laulamisen kulttuuristen käytäntöjen tutkimisesta.

Länsi-inkeriläisen laulun lähestyminen tästä näkökulmasta edellyttää useamman teoreettisen ja metodisen näkökulman yhdistämistä ja lisäksi tarkasteltavan kulttuurin ominaispiirteiden sekä tallennushistorian tuottamien reunaehtojen huomioimista. Runojen rakenne, variaatio ja merkitys ovat sidoksissa myös niiden esitystapoihin (esim. Foley 1995; Harvilahti 1998b). Yksittäisessä esityksessä tekstin ja sävelmän rakennepiirteet risteilivät elävänä, monitasoisena kuviona (Laitinen 2004), ja eri runoalueilla keskeiset laulamisen tavat ja runojen esitysyhteydet olivat hyvinkin eri tyyppisiä (Siikala 2000a). Kalevalamittaisen runon yhteydessä erityisesti Lotte Tarkka (2005) ja Senni Timonen (2004) ovat näyttäneet, miten monella tapaa aineistoja voi suhteuttaa toisiinsa: esimerkiksi yhtä runoa sen esittäjästä tai tallentajasta tunnettuihin tietoihin, tiettyjä runoteemoja niiden esiintymisyhteyksiin, yhtä runoa yhden alueellisen, laulajakohtaisen tai lajillisen aineiston kokonaisuuteen tai laajoja kokonaisuuksia toisiinsa. Anna-Leena ja Jukka Siikala (2005, 17-18) ovat nostaneet yksittäisten esitysten tai esityksestä toiseen pysyvien muotojen sijaan keskeiseksi tarkastelun päämääräksi ne periaatteet ja mallit, joiden mukaan alati varioiva ja samalla enemmän tai vähemmän samankaltaisena pysyvä perinne esityksestä toiseen siirtyessään kussakin kulttuurissa ja tilanteessa toimii. Yksikin esitys voi ymmärretyksi tullakseen vaatia suhteuttamista laajempaan aineistoon, toisen tyyppiseen aineistoon tai laajempiin kulttuurisiin kehyksiin. Kuten Siikalat, myös esimerkiksi Richard Bauman ja Charles Briggs $(1990,69)$ huomauttavat, että tutkimuksessa pitäisi jollain tasolla ottaa huomioon sekä poeettiset mallit, sosiaalinen vuorovaikutus että laajemmat sosiaaliset ja kulttuuriset 
kontekstit. Tässä työssä keskeisellä sijalla on laulukulttuurin poeettisten mallien hahmottaminen monitasoisina: ei ainoastaan runon tekstuaalisen ja sisällöllisen, vaan myös sen musiikillisen ja esityksellisen rakenteen, merkityksen ja viittauksellisuuden kautta. Sosiaalisen vuorovaikutuksen huomioonottaminen tarkoittaa tässä työssä myös tallennustilanteiden problematisointia. Länsi-Inkerin historiallista ja etnografista taustaa yritän hahmottaa siinä määrin, kun se aiemman tutkimuksen ja työn keskeisaineiston pohjalta on mahdollista.

Tämän tutkimuksen tärkeimmät näkökulmat ja metodit tulevat folkloristien ja antropologien käymistä suullista runoa ja esitystä käsittelevistä keskusteluista, monitieteisestä runomitan tutkimuksesta sekä etnomusikologian piiristä. Folkloristiikan puolelta keskeisiä ovat kontekstualisoiva ja esityskeskeinen näkökulma, intertekstuaalisten verkostojen hahmottaminen sekä runojen poetiikkaan ja käyttöön liittyvät kysymykset (ks. erit. Bauman 2004; Briggs 1988; Foley 1995; Harvilahti 1992a; 2003; Tarkka 2005; Timonen 2004). Näitä näkökulmia yhdistää yleisempi pyrkimys ymmärtää laulukulttuurin taustalla olevia kulttuurisia malleja (kulttuurisista malleista ks. Apo 2001; Kamppinen 2004). Työn kannalta keskeistä on myös runomitan hahmottaminen kieleen ja murteeseen sidoksissa olevana runon pohjarakenteena (Leino 1982; 1994). Musiikintutkimuksen puolelta keskeinen ajatus on laulun rakenteen hahmottaminen Urve Lippuksen (1995) ja Jarkko Niemen (1998) tavoin kielellisten ja musiikillisten tasojen vuorovaikutuksena: pelkkä runomitan hahmottaminen ei Inkerissä riitä laulun tekstuaalisenkaan rakenteen analyysiin. Sävelmän analyysi perustuu etnomusikologian piirissä syntyneille näkemyksille, mutta liikkuu tässä tutkimuksessa karkealla tasolla. Virolaisen runolaulun eli regivärsin tutkimuksen piirissä on tehty tämän työn kannalta keskeisiä havaintoja runojen, sävelmien ja laulutilanteiden luonteesta sekä niiden liittymisestä toisiinsa (erit. Oras 2001, Särg 2000; ks. myös Tampere 1956-1965).

Keskeisinä tutkimuksen jäsentäjinä käytän esitysareenan, rekisterin sekä paikallisen lajin käsitteitä. Esitysareena (erit. Foley 1995) viittaa kulttuurisesti jaettuihin, tyypillisiin laulamisen tilanteisiin, rekisteri (ks. myös Agha 2004; 2007) tyypillisiin, esitysareenoihin sidoksissa oleviin laulamisen tapoihin ja paikallinen laji (Timonen 2004) käyttäjien itsensä nimeämiin rekistereihin. Näiden käsitteiden avulla jäsennän länsi-inkeriläisiä laulamisen käytäntöjä, niiden kommunikatiivista merkityksellisyyttä ja pohjimmiltaan käytäntöjen taustalla olevia laulamisen kulttuurisia malleja.

Varsinainen analyysi painottuu enemmän laulutilanteiden, sävelmien ja liikkeiden kuin runotekstien käsittelyyn. Tämä johtuu ennen kaikkea aiemman tutkimuksen luonteesta. Keskeiset nykytutkimukset selvittävät perinpohjaisesti inkeriläisen kalevalamittaisen runon poetiikkaa, sen rakentumisen tapoja ja tuottamisen malleja (erit. Harvilahti 1992a; 1992b; 1994; 1998a; 1998b; 2004; Timonen 1974; 2000; 2004). 1900-luvun alkupuoliskolla tehdyt tutkimuksetkin toimivat - nykytutkimukselle vieraasta maantieteellis-historiallisesta viitekehyksestään huolimatta - työn apuvälineenä, sillä ne antavat hyvin yleiskuvaa runoaiheiden variaatiosta (esim. Alava 1909; Enäjärvi-Haavio 1932; 1954; Haavio 1932a; 1932b; Salminen 
1917; 1929a; 1930). Runojen luokittelua on pohdittu ensimmäisten runojen julkaisemisesta lähtien, ja tekeillä on Suomen Kansan Vanhat Runot -teossarjan luokitteluja nykytutkimuksen pohjalta tarkentava SKVR-teemahakemisto (SKVR-hak.). Toisin kuin sävelmien, esitystapojen tai laulukontekstien, on inkeriläisten runojen, runoaiheiden ja tyylipiirteiden tunnistamiselle, nimeämiselle ja käsittelemiselle siis valmiina kattava välineistö. Analyysini rajaus onkin tässä tiukka: pyrin ennemminkin hahmottamaan runojen ja sävelmien suhteita paikallisiin lajeihin ja rekistereihin kuin antautumaan varsinaiseen runo- tai sävelmäanalyysiin. Toivon työn silti antavan välineitä myös runojen ja sävelmien tarkasteluun.

Kohdistan tutkimuksen Länsi-Inkeriin Soikkolan ja Narvusin alueille, joilta on tallennettu kysymyksenasetteluni kannalta lupaavin kalevalamittaisen runon aineisto: runsaiden tekstitallenteiden ohella varhaisimmat laajat ääniteaineistot, paljon käsikirjoitusnuotinnoksia sekä myös tietoja laulamisen tavoista. Alueelta vuosina 1853-1940 tallennettuun aineistoon kuuluu 4634 julkaistua ja noin tuhat julkaisematonta runoa, 172 lauluäänitettä ja 469 runosävelmänuottia sekä kontekstikuvauksia, valokuvia, matkakertomuksia, päiväkirjoja, populaareja kirjoituksia ja muistiinpanoja. Samalla aineiston fragmentaarisuus asettaa omat metodologiset haasteensa. Suurin osa runoteksteistä on tallennettu ilman tietoja sävelmistä tai esitystavoista, suurin osa sävelmätallenteista sisältää vain runon alkusäkeet eikä tallenteisiin usein sisälly edes perustietoja runojen laulajista. Keskeisellä sijalla onkin ollut pohdinta siitä, miten näitä osa-aineistoja on mahdollista suhteuttaa toisiinsa.

Inkeriläisen lajijärjestelmän hahmottaminen edellyttää nähdäkseni aiempaa monisärmäisempää ja samalla paikallisempaa otetta. Aiempi tutkimus on painottunut joko runoihin ja esitystapoihin (Enäjärvi-Haavio 1949, 138-167; Simonsuuri 1972; Timonen 2004) tai sävelmiin (Koski 1974; Gomon 1977; Rüütel 1977). Varhaisimmat yleisesitykset laulamisen tavoista (Enäjärvi-Haavio 1949, 138-167; Simonsuuri 1972) ovat suppeita eivätkä kovin järjestelmällisiä. Tämän takia työn ensimmäisenä askeleena on ollut paikallisten laulamiseen liittyvien kategorioiden systemaattinen hahmottaminen: minkälaisia tekstuaalisia ja musiikillisia rakenteita, nimityksiä, tyylipiirteitä, liikettä tai paikoillaan oloa laulamiseen liittyi, minkälaisina yhdistelminä ja minkälaisissa tilanteissa nämä esiintyivät (luvut 4-7)? Vasta paikallisen käyttö- ja tulkintajärjestelmän kuvauksen pohjalta on nähdäkseni mahdollista pohtia, millä tavoin erilaiset esitykselliset keinot antoivat tietyn puheyhteisön piirissä mahdollisuuksia yksittäisen esityksen luomiseen ja sen synnyttämien tulkintojen ohjaamiseen (luku 8).

Työn etenemisen voi kuvata kahtena vaiheena: 1) yksittäisten tallenteiden ja niiden tekstuaalisten, musiikillisten ja esityksellisten piirteiden analyysi ja kontekstualisointi ja toisaalta 2) paikallisten lajien, laulamisen rekistereiden ja keskeisten esitysareenojen analyysi. Käytännössä analyysi ja tulkinta (tai synteesi) lomittuvat monessa kohden (ks. Kamppinen 2004, 23), vaikka selkeimmin analyysia toki edustaa tässä työssä ensimmäinen ja synteettisempää osiota toinen vaihe. Kontekstualisoinnin kehiä on ensimmäisessä vaiheessa useita: karkeimmillaan voi pu- 
hua tallennustilanteen (henkilöt, tilanne, tekniikka, vuorovaikutus) kontekstista, tutkittavan ilmiön kontekstista (runolaulun lajit, esitystilanteet, runot, sävelmät ja esitystavat) sekä laajemmasta kulttuurisesta, sosiaalisesta ja historiallisesta kontekstista. Samalla näiden tallenteiden kontekstualisoinnissa käytettyjen tekijöiden luonne on myös itse tutkimuskysymyksen ydintä. Humanistinen tutkimus on usein edestakaista liikettä osien ja kokonaisuuden ymmärtämisen välillä. Yksittäisen tallenteen analyysi voi liikauttaa kokonaiskuvaa, mutta yksittäisen tallenteen analyysi tai oikeastaan edes nimeäminen ei onnistu ilman jonkinlaista laajempaa käsitystä tutkittavasta ilmiöstä.

Tutkimusasetelmassa on myös antropologiasta tutun tiheän kuvauksen käsitteen piirteitä. Filosofi Gilbert Ryle (1971; ks. tarkemmin Ponterotto 2006; Pöysä 2010) määritteli tiheäksi kuvauksen, joka ei käsittele pelkästään sitä, mitä ulkoisesti näyttää tapahtuvan, vaan pyrkii tavoittamaan tapahtumisen intentiot ja kontekstit. Tiheä kuvaus on siten tulkintaa ja vaatii tuekseen erilaisia taustatietoja. Laajempaan tietoisuuteen käsitteen nosti Clifford Geertz (1973) antropologista kenttätyötä käsitellessään. Tilanteesta ja kulttuurista riippuen esimerkiksi silmänisku voi tarkoittaa monta asiaa, joten tulkitsijan täytyy ottaa selville, mihin ja miten silmäniskua on mahdollista tietyn kulttuurin piirissä käyttää ja minkälaisiin käyttöihin ja tulkintoihin tietty yksittäinen tilanne antaa mahdollisuuksia. Käsillä olevaa työtä voikin lukea eräänlaisena lauluihin painottuvana arkistoetnografiana ${ }^{3}$, johon pätee antropologian piirissä käyty kriittinen keskustelu etnografian ja ylimalkaan ihmisyhteisön kuvaamisen mahdollisuuksista (ks. Clifford \& Marcus 1986; Barz \& Cooley 1997), mutta johon lisäksi kuuluu vahva lähdekritiikin ja muodostettavan tutkimusaineiston luonteen pohdinnan vaatimus (ks. esim. Fingerroos \& Kurki 2008; Knuuttila 2010). Analysoitavat tallenteet ja kuvaukset eivät ole omia, vaan ne antavat tutkittavaan ilmiöön monta eriaikaista eri tallentajien ja eri laulajien tuottamaa näkökulmaa. Toisaalta moninäkökulmaisuus ja aikaperspektiivin laajuus, toisaalta aineiston fragmentaarisuus erottavat näkökulman omaan kenttätyöhön perustuvista töistä.

Työ ei kurota runojen tallennusajankohtia kauemmas menneisyyteen, vaikka pyrin olemaan tietoinen myös alueen historiallisista ulottuvuuksista. Tuntematonta kohti kurotan silti: omasta näkökulmastani inkeriläinen runolaulu on sekä ajallisesti, maantieteellisesti että kulttuurisesti etäistä ja usein vaikeasti ymmärrettävää (ks. Laitinen 2003a, 313-339). Keskiöön nostan Länsi-Inkerin Soikkolan ja Narvusin kylien inkeroisten ja inkerinsuomalaisten laulukulttuurit, jotka kuitenkin näyttävät lomittuvan monin tavoin paitsi toisiinsa ja lähialueisiin, myös niin vatjalaisten kuin venäläisten ja virolaistenkin lauluun. Inkeriläisellä viittaan tietyllä maantieteellisellä alueella eri aikoina asuneisiin ihmisiin ja siellä esiintyneisiin ilmiöihin, en esimerkiksi pelkästään inkerinsuomalaiseen kulttuuriin. Käytän tässä työssä sekä termiä kalevalamittainen runo että runolaulu viittaamaan myös esimerkiksi kalevalaisena, itämerensuomalaisena tai vanhana runona tunnettuun ilmiöön. Ka-

\footnotetext{
${ }^{3}$ Termiä arkistoetnografia ovat puheenvuoroissaan käyttäneet ainakin Rebecka Lennartsson (2012) ja Karen Gracey (2004). Yleisempi käsite etnografista ja historiallista otetta yhdistäville, arkistoaineistoon perustuville näkökulmille on historiallinen etnografia (ks. Hoffman 1961; Sahlins 1992).
} 
levalasta johdetut termit ovat anakronistisia viitatessaan suulliseen runoon, joka oli jo ennen kansalliseeposta (ks. esim. Anttonen 1994, nootti 2). Ne ovat kuitenkin vakiintuneita termejä. Käytän näitä termejä tarvittaessa myös runomitaltaan ja sisällöiltään samankaltaisen virolaisen, nimillä regivärss ja regilaul tunnetun runouden yhteydessä.

Tutkimus kohdistuu sadan vuoden takaiseen laulukulttuuriin. Laulajat eivät enää ole elossa, vaikka heidän jälkeläisiään löytyy varmasti sekä Venäjältä että Suomesta. Nähdäkseni työhön liittyvät keskeisimmät eettiset kysymykset asettuvatkin yleisemmälle tasolle. Inkeri on vuosisatoja ollut eri valtapiirien kiistakapula: aluetta, sen asukkaita ja näiden kulttuureja on eri suunnista tulkittu, tutkittu, määritetty ja pyritty muokkaamaan hyvinkin erilaisin tavoin. Tämä työ on väistämättä osa pitkää tulkinnan ja määrittämisen jatkumoa, ja liittyy siten osaltaan esimerkiksi Suomen ja Venäjän suhteista tai suomalaisuuden olemuksesta käytäviin keskusteluihin. Tulkintojen ketjun voi katsoa osaltaan vaikuttavan myös itsensä nykyään tavalla tai toisella inkeriläisiksi lukevien ihmisten itseymmärrykseen. Lisäksi jo kalevalamittaisen runon valitseminen tutkimusaiheeksi kytkee tutkijan osin kansallisromanttisesti ja nationalistisesti painottuneeseen pitkään tutkimushistoriaan. Pyrin tekemään analyysiani eriaikaisten ja -suuntaisten tulkintojen taustoista tietoisena ja mahdollisimman monisärmäisiin kuvauksiin pyrkien.

\section{TUTKIMUKSEN RAKENNE}

Aloitan työn katsauksella Länsi-Inkerin historiaan ja etniseen kirjoon. Melko yksityiskohtainenkin kieli-, murre- ja perinnealueita koskevan tutkimuksen sekä ryhmien välisistä vuorovaikutusprosesseista tehtyjen havaintojen esittely on tarpeen tekemieni aineiston rajausten ja tulkintojen perustelemiseksi: Millä tavoilla on mahdollista verrata toisiinsa vaikkapa Kattilan tai Laukaansuun vatjalaisalueilta, Soikkolan inkeroiskylistä ja Narvusin inkerinsuomalais-inkeroiskylistä tallennettuja aineistoja, minkälaiset rinnastukset ovat ylimalkaan mielekkäitä? Nähdäkseni tutkijoiden hahmottamien kieli-, murre- ja perinnealueiden voi katsoa yleisellä tasolla kertovan myös erilaisista ihmisten välisistä vuorovaikutuskentistä. Nämä vuorovaikutuskentät antavat puolestaan suuntaa sille, minkälaisia aineistokokonaisuuksia on mielekästä tulkita suhteessa toisiinsa.

Luku kaksi käsittelee aineiston tallennushistoriaa ja sen painotuksia. Länsi-inkeriläistä kalevalamittaista laulua on mahdollista tutkia ainoastaan toisten tuottamien historiallisten aineistojen kautta, joten lähdekriittinen juonne kulkee väistämättä läpi koko tutkimuksen. Yhä uudestaan on ollut tarpeellista kysyä, keitä olivat nämä kerääjät, mitä he etsivät, mitä heille haluttiin laulaa tai kertoa, miten he tulkitsivat ja tallensivat kuulemaansa ja minkälaisia vuorovaikutustilanteita matkoilla syntyi. Nostan esiin erityisesti työn kannalta keskeisimmät kerääjät ja pohdin heidän tuottamansa aineiston tulkinnallisia reunaehtoja. 
Luvussa kolme esittelen työn teoreettista ja metodologista viitekehystä: erilaisia näkemyksiä suullisesta runoudesta sekä erityisesti esitykseen, laulun rakenteeseen ja erilaisiin viittauksellisuuden tapoihin liittyviä keskusteluita. Käsillä olevan työn luonne edellyttää melko laajaa tulkinnallista taustakehystä, joten en lähde pitkiin oppi- tai käsitehistoriallisiin erittelyihin, vaan pyrin ainoastaan antamaan riittävästi viitteitä lähteisiin, joissa yksittäisiä teoreettisia keskusteluita on käsitelty perinpohjaisemmin. Pääpaino on kalevalamittaisen runon tutkimuksella.

Luku neljä, Laulun rakenne, jäsentää länsi-inkeriläisen kalevalamittaisen laulun tekstuaalisten ja musiikillisten piirteiden kirjoa. Luvun tarkoituksena on luoda pohja seuraavien lukujen tulkinnoille laulujen rakenteiden yhtäläisyyksistä ja eroista. Näytän, millä tavoilla olen päätynyt inkeriläisen laulun rakenteita hahmottamaan ja miten eritasoiset rakenteet liittyvät toisiinsa. Musiikillisten piirteiden osalta luku rakentuu vahvasti aiemman runolaulusta tehdyn tutkimuksen pohjalle. Luku sisältää myös analyysin paikallisista runojen ja sävelmien nimeämiskäytännöistä. Pohdin laulun rakenteita myös seuraavissa luvuissa paljastuvien käyttötapojen kannalta suhteuttaen rakenteellisia piirteitä ja paikallisia lajeja toisiinsa. Luvussa viisi, Liike, käyn läpi muita esittämiseen liittyviä piirteitä: liikettä, paikoillaan oloa sekä laulun nopeutta. Yritän hahmottaa, mitä kaikkea esimerkiksi usein lakonisena runojen yhteydessä esiintyvät maininnat "mäntii ympärikkoo" tai "läpi kylän" ovat voineet lausujilleen tarkoittaa ja minkä tyyppisiin runoihin ja sävelmiin erilaisia liikkumisen tapoja on liittynyt. Keskeisenä kysymyksenä on se, miten paikalliset itse jäsensivät liikettä laulamista kuvatessaan.

Tämän jälkeen lähden tarkastelemaan länsi-inkeriläistä laulua keskeisten julkisen laulun esitysareenoiden eli praasnikkajuhlien ja häiden sekä näihin liittyvien rekisterien ja paikallisten lajien näkökulmasta. Luku kuusi, Praasnikat ${ }^{4}$, rakentuu vuotuisjuhlien kierron mukaan. Pyrin hahmottamaan yksittäisiin esitysareenoihin sidoksissa olevien runoaiheiden sekä muiden samassa tilanteessa laulettujen runojen, laulun rakenteiden ja kuvattujen liikkumisen tapojen välisiä suhteita. Pulmaeli häälauluja käsittelevä luku Pulmat rakentuu häälaulun sävelmäpohjaisten rekistereiden mukaan. Siinä missä praasnikoiden kiinteämuotoisimmat keskeislaulut muodostivat rekisterien kannalta katsottuna erillisiä tilannekohtaisia ryhmiään, vaihtelivat häälaulujen rekisterit pitkän rituaalin kuluessa paitsi tilanteen, myös laulajaryhmän ja laulamisen sävyn mukaan.

Praasnikat ja häät ovat vakiintuneet työn keskeisiksi kohteiksi aineiston perusteella. Niihin liittyvien rekisterien ja esitysareenoiden kulttuurisen keskeisyyden ja rituaalisuuden vuoksi aineistoa on runsaasti ja lisäksi juhliin liittyvät rekisterit ovat riittävän kiteytyneitä tutkimusasetelman kannalta. Esimerkiksi työlauluista tai omaelämänkerrallisesta laulusta ei ole tarpeeksi aineistoa kunnollisten päätelmien tekoon, tanssi- ja kehtolauluista taas aineistoa on, mutta ei riittävästi suhteessa lajien sisäiseen moninaisuuteen ja paikalliseen variaatioon. Praasnikoiden ja häiden

\footnotetext{
${ }^{4}$ Käytän inkeriläistä sanamuotoa praasnikka (praaznikka) karjalaisen, tutkimuskirjallisuuteen vakiintuneen muodon praasniekka sijaan. Sana juontaa venäjän kielen juhlia merkitsevästä sanasta prazdnik. Juhliin liittyvistä keskeisistä runoista puhun sekä praasnikkavirsinä että kalendaarilauluina.
} 
keskeisyys etenkin inkerois- ja vatjalaiskulttuurien laulutilanteina tekee ne oivalliseksi aloituskohteeksi, sillä ne toimivat viittaus- tai vertauskohteina myös muille esitysareenoille ja rekistereille.

Viimeisessä analyysiluvussa Laulu, laulaja, tilanne tarkastelen yksityiskohtaisemmin erilaisia yksittäisiä laulamisen tilanteita ja laulujen siirtymistä tilanteesta toiseen. Keskeisiin esitysareenoihin liittyviä rekistereitä tarkasteltaessa paljon laulamisen moninaisuudesta ja variaatiosta jää huomaamatta. Luvun tarkoitus on avata tätä moninaisuutta ja suhteuttaa samalla juhlissa joukolla laulamista muihin tilanteisiin ja asetelmiin. Keskeinen huomio kohdistuu myös keruutilanteeseen, jonka tulkitsen aineiston ymmärtämisen kannalta keskeiseksi, monikerroksiseksi esitysareenaksi.

John Miles Foleyn (1995, erit. 47-53) käsittein ilmaistuna analyysiluvuissa neljä ja viisi tarkastellaan laulamisen rekistereihin liittyviä laulun rakenteita ja esittämisen tapoja. Jäsennän näitä sekä tekstuaalisten, musiikillisten että esityksellisten piirteiden kautta. Luvuissa kuusi ja seitsemän puolestaan kytketään rekisterien analyysi tiettyjen tyypillisten laulutilanteiden eli esitysareenoiden tarkasteluun. Luvussa kahdeksan taas kyse on sekä laulamisen rekisterien että esitysareenoiden monikerroksisen luonteen yksityiskohtaisemmasta tulkinnasta, jossa erityinen paino on hetkellisen tai henkilökohtaisen ja perinteisen tai totunnaisen välisellä jännitteellä.

Liitteisiin 1-3 olen koonnut analyysiini vaikuttaneita tietoja laulajista sekä tietoja kylien etnisistä koostumuksista ja eri kylissä vietetyistä praasnikkajuhlista. Sävelmäaineisto sekä analyysilukujen keskeisaineistoja on luetteloitu omiin liitteisiinsä (4-5). Olen käsitellyt länsi-inkeriläistä laulua aikaisemmin pro gradu -työssäni (Heinonen 2005) sekä muutamissa artikkeleissa (Heinonen 2008a; 2008b; Kallio 2009a; 2009b; 2010; 2011a; 2011b; 2012). Osia näistä töistä olen hyödyntänyt johdanto-osioissa alueen esittelyn, teoreettisen taustan ja keruuhistorian yhteydessä sekä laulun tekstuaalisten rakenteiden esittelyn kohdalla. Luvun 8 osiot kehto- ja liekkuvirsien suhteista sekä Leinon lesken runosta perustuvat pitkälti aikaisemmin julkaisemaani (Heinonen 2008a; Kallio 2011a).

\section{INKERILÄINEN RUNOLAULU}

Kalevalamittainen runo eli runolaulu oli laaja-alainen, monen tilanteen ja lajin puitteissa käytetty ilmaisumuoto. Samalla runomitalla esitettiin kertovia eli eeppisiä runoja, lyyrisiä runoja eli tunnelmarunoja, balladeja, myyttejä, hälauluja, pilkkalauluja, loitsuja, kehtolauluja, sananlaskuja ja niin edelleen. Useimpia lajeista käytettiin yleensä lauluina, mutta loitsuja ilmeisesti lähinnä resitoituina ja sananlaskuja puheen osana. Samankaltainen runomitta oli käytössä kaikkien itämerensuomalaisten kielten piirissä vepsää ja liiviä lukuun ottamatta. (Ks. esim. Harvilahti 1992; Sarv 2008; Siikala 2012; Tarkka 2005; Timonen 2004.) ${ }^{5}$

\footnotetext{
${ }^{5}$ Muista inkeriläisistä laulun lajeista ks. Asplund 1992a; Grigor’eva 1995, 19-90; Nenola 2002.
} 
Runot, sävelmät ja niiden käyttöyhteydet vaihtelivat alueittain. Esimerkinomaisesti on vastakkain usein asetettu pohjoinen vienalaisten miesten eeppisen yksinlaulun ja eteläinen inkeriläisten naisten lyyrisen kuorolaulun alue. Anna-Leena Siikala (1990; 1994; 2000a) on vertaillut kalevalamittaisen runouden asemaa ja esitysyhteyksiä eri alueilla. Sosiaalinen konteksti, kulttuurin kokonaiskuva, tyypilliset laulutilanteet sekä laulun ja laulajien asema yhteisössä vaikuttavat runouden teemoihin, sävyihin ja painotuksiin:

Esitystilanteissa ja laulutavoissa ilmenevä eri alueiden runostojen institutionaalisten yhteyksien erilaisuus merkitsee sitä, että samakin runo on eri alueilla tulkittu eri tavoin. Koska suullinen runous on orgaanista, alati uudestaan tuotettavaa perinnettä, näkyvät merkityksen muutokset myös aiheiden käsittelytavoissa. Merkityksen muodostus on jatkuva prosessi, ilman sitä runo ei itse asiassa eläisi, vaan tyhjäksi käyneenä muotona kuolisi pois. Niinpä kulttuurikontekstien muutokset näkyvätkin selvinä runoston kehitystrendeinä. (Siikala 1990, 15.) $)^{6}$

Kuten Lauri Harvilahti $(1992 a, 17-18,69-86,141)$ on todennut, suuri osa inkeriläisestä kalevalamittaisesta runoudesta käsittelee perheen ja kylän ihmissuhteita naisen, etenkin nuoren naisen näkökulmasta ja usein minä-muodossa. Tämän tyyppiset lyyris-eeppisiksi kutsutut runot ovat olleet suosittuja kautta eteläisten runoalueiden (vrt. Arukask 2003). Niiden aiheilla on usein yhteyksiä venäläisiin samantyyppisiin runoihin, satuihin ja lännestä kulkeutuneisiin balladien teemoihin (Harvilahti 1998a; Oinas 1969; Kiuru 1994). Samankaltaisten tyylikeinojen käyttö näkyy muissakin runouden lajeissa. Naisen elämään, äitiin ja perhepiiriin kietoutuvaa lyriikkaa on paljon. Lyyriset ja lyyriseeppiset runot puolestaan lomittuivat moninaiseen häärituaaliin liittyvään laulustoon. Myös kertovaa runoutta kuten balladeja, myyttistä syntyrunoutta, kristillisiä legenda-aiheita ja sota-aiheista epiikkaa laulettiin. ${ }^{7}$

Inkerissä runoaiheita yhdisteltiin toisiinsa vapaammin ja enemmän kuin monilla muilla alueilla. Etnisen, tyylillisen ja lajillisen moninaisuuden vuoksi vanhempi tutkimus osin karttoi inkeriläistä runoa tai lähestyi sitä valikoiden, toteaa Senni Timonen (2004, 86; ks. myös Kuusi 1977, 71-72). Miesten laulama juhlava sankariepiikka oli pitkään sekä kalevalamittaisen runouden kerääjien että tutkijoiden huomion keskipisteessä. Satu Gröndahl (1997) on todennut, että inkeriläinen runo ei vastannut kansallisen identiteetin rakentamiseen sidoksissa olevia ihanteita, vaan jäi feminiinisenä ja lyyrisenä osin tutkimuksen marginaaliin. Uudemmassa tutkimuksessa juuri näitä piirteitä on kuitenkin kiinnostavina nostettu keskiöön.

\footnotetext{
${ }^{6}$ Samasta teemasta kirjoittaa Timonen $(2004,85)$ lyriikan yhteydessä: "Vaikka Inkerin runot edustavat samaa kalevalamittaista perinnettä ja ovat paikoin jopa säkeiltään paljolti samoja kuin Pohjois-Karjalan lyyriset runot, teemojen käsittelytavat ja painotukset eroavat toisistaan." (Ks. myös Harvilahti 1994; Launis 1910c).

${ }^{7}$ Inkeriläisen kalevalamittaisen runouden erityispiirteistä ks. Harvilahti 1991; 1998a, 195-200; Laiho 1940, 223-224; Alava 1916, 8; Siikala 1990; Timonen 2004, erit. 85-86.
} 
Valtaosa kerääjille laulaneista inkeriläisistä oli naisia. Väinö Salmisen (1931a, 526-528) laskujen mukaan nimeltä tunnetuista 1200:sta Suomen Kansan Vanhat Runot -teossarjaan päätyneiden runojen esittäjistä vain 104 oli miehiä, ja heidän esittämiensä runojen määrä oli vain 3,4 \% runojen kokonaismäärästä. Kerääjät valittavat miesten laulaneen lähinnä joutavia, uudenaikaisia tai rivoja runoja, joita ei pidetty tallentamisen arvoisina. Armas Launis (1904, 51-52) kertoi etenkin poikien monin paikoin laulavan vain venäläisiä lauluja ja suomalaisia "rallatuksia." Juuri uudempien laulujen suosimista pidettiin syynä siihen, että "ovat ischoorilaiset runot syrjäytymässä yhä enemmän alaa voittavien venäläisten laulujen tieltä," kuten J. Fr. Ruotsalainen $(1901,80)$ asian ilmaisi. Myös erilaiset uskonnolliset liikkeet ja lahkot lauluineen olivat paikoin suosittuja, ja lauluja levisi myös arkkiveisuina ja kirjoina. ${ }^{8}$

Usein mainittuja inkeriläisten, eteläisiin alueisiin kuuluvien laulukulttuurien piirteitä ovat naisvaltaisuus, esilaulun ja kuoron vuorottelu, moniäänisyys, refrenkien eli kertaumien käyttö sekä vaihtelevat rytmit ja melodiat. Runoja lauloivat erityisesti tyttöjen ryhmät liekulla eli kyläkeinuilla, tanssi- ja leikkilauluina, helluntai- ja juhannuskokoilla ja pitkin kylää kulkiessaan. Inkeriläisen aineiston puitteissa tyttö tarkoittaa tyypillisimmin nuorta naimatonta naista: tytöstä tuli nainen naimisiin mennessään. Laulut olivat olennainen osa härituaaleja, praasnikoita ja muita juhlatilaisuuksia. Niitä kuului tietenkin myös arkeen ja työntekoon. Esimerkiksi Armas Launis $(1907,108,110)$ mainitsee metsässä kulkemisen ja lapsen liekuttamisen keskeisinä yksinlaulamisen tilanteina. ${ }^{9}$

Kalevalamittainen laulu on säelaulua: määrämittaisia säkeistöjä ei ole ja sävelmät ovat yleensä yhden tai kahden säkeen mittaisia. Inkeriläisessä aineistossa esiintyy sekä Suomessa että Virossa yleisiä sävelmätyyppejä ja lisäksi paljon sellaisia melodioita, joita ei muualla tavata. Erityisesti Virossa tavattava neli-iskuinen rytmityyppi on tavallinen. Suppean arkaaiset 3-4 sävelen asteikot ovat yleisempiä kuin muualla, mutta toisaalta sävelmistössä on runsaasti eri aikoina etenkin venäläisistä laulutyyleistä omaksuttuja päinvastaisiakin piirteitä, kuten laajoja sävelasteikkoja ja nelisäkeisiä sävelmiä. Inkeriläisten runosävelmien moninaisuudessa näkyy laulukulttuurin kyky sulauttaa itseensä mitä erilaisimpia aihelmia. Tyypillisesti runolaulu on yksiäänistä tai heterofonista eli paikoin moniääniseksi jakautuvaa; selkeästi moniäänisenä sitä esiintyi Viron kaakkoiskulman Setumaan ohella ainoastaan paikoin Inkerissä. ${ }^{10}$ Monien esitystapojen puolesta Inkeri liittyy lähialueiden slaavilaisiin ja balttilaisiin kulttuureihin (Harvilahti 1992a, 18; ks. myös 1998b, 198).

\footnotetext{
${ }^{8}$ Erilaisista uusista lauluista ks. Alava 1916; 1932; Groundstroem 1904, 402; Porkka 1886, 152, 162; Salminen 1929a, 190; Saxbäck 1904, 339; ks. myös Kuusi 1983a, 87, 170; inkeriläisistä miehistä laulajina ks. tarkemmin Heinonen 2008 b.

${ }^{9}$ Inkeriläisen laulamisen kuvauksista ks. esim. Ahlqvist 1904, 209; Alava 1916, 8; Enäjärvi-Haavio 1949, 139-167; Harvilahti 1992a, 18, 69-86,141; 1998b, 195-200; Launis 1907, 1910c; Nenola 2002; Timonen 2004, 84-157, 238-303; ks. myös Salminen 1929a, 41, 51, 63, 72.

${ }^{10}$ Inkeriläisistä runosävelmistä ja laulamisen tavoista ks. Asplund 1981, 37-39; 1992a; Enäjärvi-Haavio 1949, 180-181; Kolehmainen 1977, 30; Launis 1904, 51; 1910c, 225; Lippus 1995.
} 
Kalevalamittaisen runon laulaminen Inkerissä, kuten pohjoisempanakin, muuttui ja väheni 1900-luvulle tultaessa. Eino Kiurun (et al. 1974, 8) mukaan parhailla Soikkolan ja Hevaan laulajilla oli 1960-luvulla käytössään vielä parikymmentä kertovaa runoaihetta. 1990-luvulla suomalaistutkijat kuulivat Soikkolassa enää muutamia lyhyitä runonpätkiä, lähinnä hää- ja kehtolauluja (Asplund 1992a, 164-165; Harvilahti 1991, 220). Pirkko Raevuoren vuonna 1944 haastattelemat soikkolalaiset inkeroisnaiset kertoivat, ettei häissä tuolloin enää itketty, vaikka hääitkuja tallennettiin yksittäisiltä laulajilta vielä 1970-luvulla (Nenola 2002, 44). Muutos on liitetty yleiseen modernisaatiokehitykseen: liikkuvuuden lisääntymiseen, maaorjuuden lakkauttamiseen, kaupungistumiseen ja teollistumiseen, uusien laulunlajien ja soitinten leviämiseen. Inkerissä 1900-luvun tilanteeseen vaikuttivat myös laajat väestönsiirrot toisen maailmansodan jälkeen, Stalinin vainot ja näihin liittyvä itämerensuomalaisten kielen julkisen käytön radikaali vähentyminen jo 1930-luvulta alkaen. ${ }^{11}$

\section{Paikalliset LAUlun Lajit}

Paikallisia, kulttuurisidonnaisia lajijärjestelmiä on tutkittu usean kulttuurin ja tieteenalan puitteissa, erilaisia tekijöitä painottaen. Tällaisia lajijärjestelmiä on kutsuttu usealla termillä: "native" eli kotoperäinen, etninen, paikallinen tai "emic". Tutkimukset perustuvat yleensä omakohtaiseen kenttätyöhön ja yhden ihmisen tai pienen yhteisön haastatteluihin. Paikalliset kategoriat ovat usein suhteellisen selkeitä kaikkein yleisimmällä jäsentymisen tasolla, mutta tulkinnanvaraisuus, päällekkäisyys ja luokkien rajojen hämärtyminen lisääntyy alemmille tasoille siirryttäessä. Yhteisön jäsenten käsitys lajeista voi vaihdella suurestikin. Lajit eivät edes yhden kulttuurin piirissä määrity yhtäläisin perustein, ja kaikki ilmaisun tavat eivät toisaalta välttämättä kuulu paikallisen lajiluokituksen piiriin. (Ben-Amos 1982; Gossen 1974, 50-53, 216; Huuskonen 1998; Kaartinen 2001, erit. 287-337; 2010, 66-81; Moisala 1991b, 158-172; Pekkilä 1988; Siikala 2000b).

Senni Timonen (2004, 238-303) on hahmotellut pohjois-inkeriläisen inkeroisen Larin Parasken poetiikkaa ja osoittaa, että kalevalamittaisen runon laulajalla itselläänkin on voinut olla teoreettisiksi katsottavia näkemyksiä runojensa laulamisen säännöistä, lajeista ja tyylipiirteistä tai ainakin kyky tuottaa niitä kerääjän kysyessä. Paraskelta on tallennettu runoja ja toisintoja enemmän kuin keneltäkään muulta inkeriläiseltä laulajalta. Keskeisin häntä haastatellut kerääjä Ad. Neovius merkitsi satoihin lauluihin muistiin myös Parasken lajinimityksiä tai mainintoja laulutilanteista. Aineisto on siis kalevalamittaisen runon kontekstissa ainutlaatuinen. Tosin aineistoon pätee sama kuin moniin muihinkin paikallisten lajien rakennetta jäsentäviin tutkimuksiin: pelkästään sen perusteella olisi mahdotonta sanoa, mikä kaikki on pelkästään Parasken omaa jäsennystä, mikä laajemman yhteisön jakamaa. Timonen kuitenkin vertailee aineistoaan sekä Pohjois-Inkerin inkeroisilta että muualta Inkeristä tallennettuihin aineistoihin.

\footnotetext{
${ }^{11}$ Kalevalamittaisen laulun käytöstä jäämisestä ks. Asplund 1992a, 173-174; Hakamies 1991, 204. Virosta ks. Oras 2008; Vienasta ks. Tarkka 2005, 374-383.
} 
Paraskella paikalliset lajit määrittyvät ylemmällä tasolla poeettisten piirteiden (itkuvirsi, runo tai rekilaulu), alemmalla tilanteen, paikan tai laulun kohteen mukaan. Alemmalla tasolla lajit menevät osin päällekkäin: runo voi eri tilanteissa tulla nimetyksi eri lajeihin, mutta tietyt runot kuuluvat ainoastaan yhden lajin piiriin. Parasken hahmottamilla lajeilla oli siis kiinteä ytimensä, jota ei laulettu muiden lajien puitteissa, mutta samalla niihin liittyi myös monenlaisia lajien välillä liikkuvia, kahden tai useamman lajin puitteisiin sovitettavissa olevia runoja ja runoteemoja. Esimerkiksi eeppiset runot kuuluivat Paraskella lähes poikkeuksetta ainoastaan liekkuvirren piiriin, mutta monet liekkuvirteen kuuluvat lyyriset elementit sijoittuivat vaihdellen lukuisten muiden lajienkin puitteisiin. Timonen $(2004,266)$ toteaa, että "tällöin voi eron tehdä paitsi tilanne myös esimerkiksi esitystapa tai sävelmä." Paraske nimesikin erikseen esimerkiksi lauluja, joita laulettiin eri tilanteissa kovaa tai kaikuvasti: suuri virsi, mökälaulu, pölkkylaulu (mts. 262-263). Paraskelta tallennetut, Timosen (mts. 267-273) julkaisemat sävelmät jakautuvat muotorakenteiltaan eroaviin suuren eli korkean nuotin viisi-iskuisiin sävelmiin, pienen nuotin kahteen rytmityypiltään erilaiseen sävelmään, joihin saattoi liittyä myös laaritusrefrängejä, yhteen neli-iskuiseen lapsenvirteen sekä yhteen neli-iskuiseen sikasillaleikin sävelmään. Suuri nuotti liittyi Timosen kuvauksen perusteella ensisijaisesti liekkuvirteen, mutta myös ainakin häävirsiin, talkoovirsiin, rekivirsiin ja mojolauluun, eikä siihen koskaan kuulunut laaritus-refrängiä. Pieni nuotti liittyi tanssiin. Sävelmät siis noudattelevat osin laulunlajien tilannesidonnaisia rajoja, mutta sitovat myös tiettyjä lajeja yhteen.

Länsi- ja Keski-Inkerin osalta täytyy tyytyä Paraskelta tallennettua hajanaisemmista aineistoista tehtäviin tulkintoihin. Timonen lähestyy näiden alueiden paikallisia lajeja kolmesta suunnasta: 1) tarkastelemalla laulutilanteiden, paikallisten lajinimitysten, runojen sekä sävelmien välisiin suhteisiin liittyviä kerääjien muistiinpanoja, 2) analysoimalla paikallisten lajien yhteyksissä mainittuja tai tallennettuja runoja ja 3) pohtimalla näitä muistuttavia, kontekstitiedottomia tekstiaineistoja. Länsi- ja Keski-Inkerin kohdalla yksi avainteksteistä on sävelmänkerääjä Armas Launiksen $(1907,105)$ monisivuinen kuvaus:

Koittaessani sen [runojen vanhan esitystavan] ohella päästä selville sävelmäin keskinäisestä yhteydestä sekä niiden alkuperästä, kiinnitti huomiotani erittäinkin se seikka, että sävel, jolla runoa kulloinkin lauletaan, usein riippuu enemmän itse esitystilaisuudesta, kuin runon sisällyksestä tai runosta yleensä. [...] Siten erottavat inkeriläiset [...] ainakin seuraavat erinimiset nuotit: pulmanuotti eli hääsävel, liekkunuotti, liukusävel, metsän sävel sekä nuotit "tantsun päälle". Sitäpaitsi voi satunnaisesti vielä löytyä: Jyrkinsävel, kokkosävel, kesäsävel, lapsennuotti ja kosikkisävel. Nämä eivät kuitenkaan ole yhtä varmasti vakiintuneita, kuin edelliset, vaan saattaa toisinaan niiden nimellä käydä melkein mikä sävel tahansa.

Sävelmien, runotekstien ja laulutilanteiden välillä oli siis Launiksen mukaan selkeitä yhteyksiä, mutta ei ehdottomia yhteenkuuluvaisuuksia. Launiksen (1910b, VIII) mukaan tietty runoteema aloitti usein tietyssä tilanteessa laulamisen. Senni 
Timosen $(2004,154-157)$ analyysin mukaan alkuvirren jälkeen saatettiin jatkaa tilanteeseen, laulajien mielentilaan ja ajankohtaan väljän temaattisesti istuvilla runoilla. Näiden runojen liittyminen yhteen sekä lomittuminen tilanteisiin ja säveliin menee ristiin tutkijoiden perinteisten luokittelun tarpeisiin luomien lajien (epiikka, lyriikka, lyyrinen epiikka, kalendaari- ja riittirunot) kanssa. "Samat runot voivat esiintyä eri laulutilanteissa", toteaa Timonen (mts. 153), mutta "runon sävy muuttuu sen lajinvaihdosten mukana." Runojen tilannesidonnaiset merkitykset syntyvät hänen (mts. 154) tulkinnassaan monen vaikeastikin tavoitettavan tekijän summana. Ne liittyvät "vuodenaikojen ja työn rytmiikkaan, ympäröivän miljöön tiloihin, ilmojen vaihtuvuuksiin, ihmisten erilaisiin ikiin ja asemiin, osanottajajoukkojen koostumuksiin ja laulajien persoonallisiin mielenliikkeisiin" ja muodostavat erilaisia näihin "suhteutuvia tapojen, melodioiden, rytmien, sanojen, askelten, tuntemusten, kosketusten ja etääntymisten yhdistelmiä, jotka kulloinkin näyttävät luovan sävelen.” Timonen ottaa käyttöönsä laulajien käyttämän sävel-termin sävelmää tai laulamisen tapoja laajempana yleiskäsitteenä, myös runot, tilanteen ja laulajajoukon kattavana tutkijoiden laji-käsitteen paikallisena vastineena. Timosen käyttämä sävel-käsite vastaa jotakuinkin tässä tutkimuksessa käyttämääni paikallisen lajin käsitettä. Siinä missä Timonen käsittelee musiikillisiin piirteisiin viittaavia nimityksiä (sävel, nootti, ääl) lähinnä paikallisten lajien tunnuksina tarkempiin musiikillisiin piirteisiin puuttumatta, on tässä työssä musiikillisten piirteiden ja paikallisten lajien suhde osa tutkimuskysymystä.

Selviä, aukottomia, kaikkiin yhden paikallisen lajin toisintoihin tai ainoastaan niihin liittyviä esityksellisiä tai musiikillisia piirteitä ei Timosen $(2004,156)$ mukaan juuri löydy, vaan "kotoperäinen sävelkategoria ja kansanomainen kategoriointi yleensäkin on siis rajoiltaan monella tasolla liukuvaa." Kokkosävelen sävelmämuistiinpanoja tosin sitovat toisiinsa muodoltaan vaihtelevat refrengit eli kertaumat, joissa erilaiset lole- ja luuli-tavut toistuvat, vaikka sävelmät muuten ovat toisistaan melko etäällä. Metsän sävelen yhteydessä Launis $(1907,108)$ puhuu pitkäksi venytetystä loppusävelestä. Kuten Heikki Laitinen (suullinen keskustelu; Timonen 2004, 99) on todennut, osa Inkerin paikallisista musiikillisista lajeista on voinut määräytyä hyvin hienovaraisten painotusten, rytmitysten tai äänenkäytön tapojen kautta. Nämä jäävät yleensä nuottien ulkopuolelle ja äänitteilläkin esiintymisjännitys saattaa vaikuttaa hienovaraisempien esityksellisten piirteiden esiintuloon. Kokkosävel viittaa siihen, että sävelmäryhmää yhdistävä tekijä voi liittyä myös tekstuaalisiin piirteisiin, vaikkapa tietyntyyppisiin refrenkeihin.

Armas Launiksen $(1904,1907)$ antamat, keskenään välillä ristiriitaisilta vaikuttavat tiedot laulutilanteiden, runojen ja sävelmien yhteyksistä selittyvät nähdäkseni juuri laulajien oman lajijärjestelmän liikkuvuudella ja tiukkarajaisten kategorioiden puutteella. Launiksen $(1907,107-110)$ tekemät yleistykset ovat sanavalinnoiltaan valaisevia: "liekkuvirrellä 'La mie katson liekkujani' [...], on ainakin yksi sille varmasti ja pysyväisesti kuuluvat liekkunuotti"; "Erittäin viehättäviä muotoja löytyy metsän sävelestä läpi koko Inkerin"; Lapsensäveltä, kehtolaulua, ei liene vakinaista." Kolme vuotta myöhemmin Launis (1910c, 223-234) tiivistää: "Vain muutamilla, 
kuten esim. hää- ja kiikkulauluilla, on omat, toisista tietoisesti erotetut sävelet, mutta voidaan näilläkin satunnaisesti muita runoja laulaa."12 Laulajilla siis oli selkeitä näkemyksiä siitä, miten tietyissä tilanteissa laulettiin, ja joihinkin tilanteisiin (häät, liekulla keinuminen) liittyi tuon ajan musiikintutkijankin mielestä selkeitä sävelmiä, joita tosin saatettiin käyttää myös muissa tilanteissa. Toisiin tilanteisiin liittyi useita sävelmiä, jotkut sävelet olivat ilmeisesti paikallisia, kehtolaulut hyvin improvisatorisia ja eri laulajien nimeämiä "Jyrkinsäveliä" Launis ei kyennyt musikologisesti lainkaan yhdistämään toisiinsa.

Muiden musiikintutkijoiden havainnot mutkistavat kokonaiskuvaa entisestään. Terttu Koski $(1974,477)$ toteaa joidenkin Länsi-Inkerin inkeroisten sävelmien jakautuvan suhteessa laulutekstien "emotionaaliseen lataukseen", mutta monien tulevan käytetyksi niin hälaulujen kuin lyyristen ja eeppisten runojenkin yhteydessä. Kosken tarkastelussa keskeisiä ovat paitsi sävelmät, myös se, miten niitä lauletaan ja varioidaan välillä yksilöllisestikin tulkiten. Erityisesti esittämistapojen erot tulevat esiin uudemmissa tanssilauluissa ja tšastuskoja muistuttavissa sävelmissä, joita esitettiin Kosken (erit. mts. 482) mukaan räväkämmin, nopeammin sekä voimakkaammalla ja kireämmällä äänellä kuin muita lajeja. Alla Gomon (1977) puolestaan tarkasteli inkeroissävelmiä lyhyemmin ja lähinnä sävelmien ominaisuuksiin keskittyen. Hänen mukaansa yhdessä kylässä oli yleensä vain yksi tai kaksi sävelmää, jolla laulettiin kaikenlaista häälauluista epiikkaan, ja tämän lisäksi "melkein jokaisella esittäjällä" oli runosävelmien repertuaarissaan myös venäläisvaikutteinen sävelmä tai tšastuškasävelmä (mts. 285). Ingrid Rüütel (1977, erit. 267-272) toteaa Länsi- ja Keski-inkerin vatjalaissävelmien jaottuvan karkeimmalla tasolla kahta eri tyyliä edustavaan ryhmään, joista ensimmäinen painottui erityisesti häälaulujen ja toinen, moninaisempi, myös monenlaisen lyriikan ja epiikan yhteyteen.

Näiden inkeriläisiä laulun lajeja koskevien huomioiden välisten erojen keskeisiä syitä on nähdäkseni kaksi: toisaalta tutkijoiden käyttämät aineistot, toisaalta heidän tarkastelukulmansa. Eri tutkijoiden keskeisaineistot ovat peräisin eri ajoilta ja laajuudeltaan erilaisia. Launis luultavasti etsi tietoja vanhoiksi ja yhtenäisiksi olettamistaan laulamisen tavoista, eikä teksteissään tuo ilmi, kuinka laajalta alueelliselta tai etniseltä pohjalta yleistyksensä milloinkin tekee. On myös syytä muistaa, että hänen tieteellinen työnsä liittyi sävelmien universaalin luokittelumallin etsimiseen, ei laulamisen käytäntöjen kuvaukseen, jonka voi katsoa olleen lähinnä oman kenttätöiden myötä syntyneen kiinnostuksen pohjalta noussut sivujuonne. Timonen keskittyy kolmeen lajiin ja suuntaa tarkastelunsa ennen kaikkea laulujen teksteihin ja kontekstitietoihin. Hän tarkastelee lähinnä suomalaisiin arkistoihin tallennettuja aineistoja. Terttu Koski tekee musiikkiin liittyvät päätelmänsä ensisijaisesti itsensä ja muiden petroskoilaisten tutkijoiden 1970-luvulla Soikkolan inkeroisilta tallentaman laajan ääniteaineiston pohjalta. Alla Gomon esittelee huomattavasti suppeampaa, samoin muutamasta Soikkolan kylästä itse 1970-luvulla tallentamaansa aineistoa. Hän keskittyy yksinomaan laulujen musiikillisiin piirteisiin eikä hän ilmeisesti taida inkeroiskieltä. Ingrid Rüütelillä on käytössään sekä itsensä ja

\footnotetext{
${ }^{12}$ Kursiivit KK.
} 
muiden virolaisten ja petroskoilaisten 1970-luvun tallentajien sävelmäaineistot että ennen toista maailmansotaa Suomeen tallennetut kokoelmat, mutta hän keskittyy vatjalaisiin sävelmiin, jota on tallennettu inkeroissävelmiä huomattavasti pienempi määrä. Hänen tarkastelunsa tähtää sävelmätypologian muodostamiseen ja sävelmätyyppien ajoittamiseen, mutta tässä on osansa myös laulutekstien ja kontekstitietojen käsittelyllä sekä vertailulla naapuriryhmien ja lähialueiden perinteisiin.

Eri tutkijat kertovat samasta laajasta ja monisärmäisestä ilmiöstä eri näkökulmista tuoden siten esiin erilaisia asioita, jotka eivät ole niin ristiriidassa keskenään kuin ensisilmäyksellä saattaisi näyttää. Vaikuttaa siltä, että on syytä olla tarkkana ajallisten, paikallisten ja etnisten erojen huomioimisessa. Launis vihjaa, että hää- ja praasnikkalaulut voivat antaa paikallisten lajien anayysille tukevimman lähtöpisteen. Ei ole kuitenkaan etukäteen selvää, mitkä kaikki laulun piirteet saattavat olla paikallisten lajien analyysin kannalta merkittäviä. Lisäksi on huomattava vielä yksi tekijä: kun inkeriläinen laulu osoittautuu tilanteen mukaan rakentuvaksi ja kun keruuhetki on eittämättä tietynlainen tilanne, on pohdittava myös sitä, minkälaisilla tavoilla laulajat ovat mahtaneet juuri tämänkaltaisiin tilanteisiin laulutapojensa suhteen reagoida. Keskeinen on myös jo Herbert Tampereen (1956, 11 alaviite 5) tekemä huomautus: kansanlaulu koostuu tekstistä, sävelmästä ja esitystavasta, joita on syytä tarkastella osana samaa kokonaisuutta.

Kielellisen rekisterin käsite (ks. Agha 2004; 2007; tarkemmin luvussa 3) auttaa osaltaan hahmottamaan inkeriläisen aineiston ja siitä tehtyjen tulkintojen moninaisuutta. Käsitteen lähtöoletuksena on, että kielenkäytön tavat muuttuvat ajan myötä ja että yhdenkin puheyhteisön piirissä voi olla rinnakkaisia tai kilpailevia kielen käyttö- tai tulkintatapoja. Yksi ja sama kielenkäytön piirre voi olla käytössä useamman rekisterin puitteissa ja toisaalta rekisteri voi olla käyttökelpoinen myös epätyypillissä yhteyksissä ja epätyypillisillä tavoilla. Maantieteellisesti, ajallisesti, lajillisesti ja tallennushistoriallisesti laajasta aineistosta on siten turha edes kuvitella löytävänsä yhtenäistä, yksinkertaista tai poikkeuksetonta järjestelmää. 


\section{LÄNSI-INKERI}

Inkeri sijoittuu Pietarin ympäriltä Viron rajalle ulottuvalle Suomenlahden rannikkovyöhykkeelle. Tutkimuksessa alue jaetaan yleensä kolmeen maantieteelliseen kokonaisuuteen: Länsi-Inkeriin, Keski-Inkeriin sekä Itä- ja Pohjois-Inkeriin. Näitä alueita halkoo päällekkäin risteillen monenlaisia hallinnollisia, etnisiä, kielellisiä ja murteellisia sekä uskonnollisia rajoja. ${ }^{13}$

Länsi-Inkerin alueella asui 1800-1900-lukujen taitteessa monia ihmisryhmiä. Itämerensuomalaisista ryhmistä näihin kuului uskonnoltaan ortodokseja inkeroisia ja vatjalaisia, luterilaisia inkerinsuomalaisryhmiä sekä jonkin verran Suomesta ja Virosta tullutta työväkeä. Ortodokseihin venäläisiin puolestaan kuului niin alueella satoja vuosia asuneita, vastikään vapaaehtoisesti tai pakolla siirtyneitä kuin tilapäisiä työn perässä siirtyneitäkin ryhmiä. ${ }^{14}$ Lisäksi alueella asui jonkin verran luterilaisia saksalaisia ja kulki sekä venäjän- että suomenkielisiä romaneja. (Ks. Hakamies 1991; Raudalainen 2007; Sihvo 1991.)

Aluetta jäsensivät hallinnollisten rajojen ohella luterilaisten ja ortodoksisten seurakuntien rajat. Uskonto näyttää olleen yksi keskeisiä ryhmien identiteettejä määrittäviä tekijöitä. Arno Survo $(2001,69)$ kuitenkin huomauttaa, kuinka "väestön etnistä ja uskonnollista koostumusta kuvanneet tilastot vetivät kylien, sukujen ja perheiden halki keinotekoisia kielellisiä ja uskonnollisia rajoja." Ihmisryhmien vuorovaikutusta ja toisiinsa sulautumista Inkerissä ei ole kattavasti tutkittu: missään nimessä prosesseja ei voi pitää yksisuuntaisina tai väestöä halkoneita rajalinjoja yksiselitteisinä ja ylittämättöminä. ${ }^{15}$ Epäilemättä tilanne saattoi aikakauden lisäksi vaihdella alueittain ja kylittäinkin. Senni Timonen $(2004,85)$ on kiteyttänyt Inkerin monikulttuurisesta todellisuudesta:

Huolimatta siitä, että ihmiset pyrkivät pitäytymään omissa piireissään, he kuitenkin elivät vieri vieressä, eri kylissä tai samoissakin, vierasheimoisten ja -kielisten ja -uskoisten kanssa, kuuntelivat heitä, sulauttivat heidän puhettaan omaansa ja loivat yhtä mittaa itseään uudelleen tiedostamalla, omaksumalla ja torjumalla toisenlaisuuksia.

\footnotetext{
${ }^{13}$ Tätä johdantoa laajempia esityksiä etnisten ryhmien kirjosta ja Inkerin historiasta sisältyy useisiin tutkimuksiin ja artikkelikokoelmiin. Inkerin aluetta ovat käsitelleet esimerkiksi Erik Amburger (1980); Pertti Anttonen (1987); Pekka Hakamies (1991); Lauri Honko (1962); Aili Nenola (2002); Pekka Nevalainen ja Hannes Sihvo (1991); Markku Teinonen \& Timo J. Virtanen (1999); Ergo-Hart Västrik (2007). Vanhimmat aluetta koskevat varsinaiset etnografiset lähteet ovat 1800-luvulta (Köppen 1849, 1867; Sjögren 1833; Öpik 1970; ks. myös Västrik 2007).

${ }^{14}$ Vaikka paikallinen venäläinen kulttuuri on vaikuttanut erityisesti ortodoksisten inkeroisten ja vatjalaisten kulttuuriin ja esimerkiksi osaan runosävelmistä ja refrengeistä vahvasti, on se heikosti dokumentoitu (Hakamies 1991, 198). Venäjänkielinen väestö oli myös ilmeisen heterogeeninen ryhmä. Viitteet ensimmäisistä väestönsiirroista ovat peräisin 1400-luvulta: Inkerin siirryttyä Moskovan hallintaan noin 8000 vatjalaista kerrotaan siirretyn tai siirtyneen etelämmäs ja venäläisiä muuttaneen alueelle. Ruotsin vallan alkuaikana venäläisväestön osuus oli ilmeisesti hyvin pieni: sodasta selvinneistä moni oli vetäytynyt Venäjän puolelle rajaa. 1700-luvulla venäläisväestön määrä kasvoi voimakkaasti Pietarin perustamisen myötä. (Hakamies 1991; Novozhilov 1999, 125; Savijärvi \& Savijärvi 1999, 23 nootti 1.)

${ }^{15}$ Uskonnon merkityksestä ja ryhmien välisistä yhteyksistä ks. esim. Anttonen 1987; Hakamies 1991; Harvilahti 1991; 1992; Nevalainen 1991; Sihvo 1991; Raudalainen 2007; Teinonen \& Virtanen (toim.) 1999.
} 


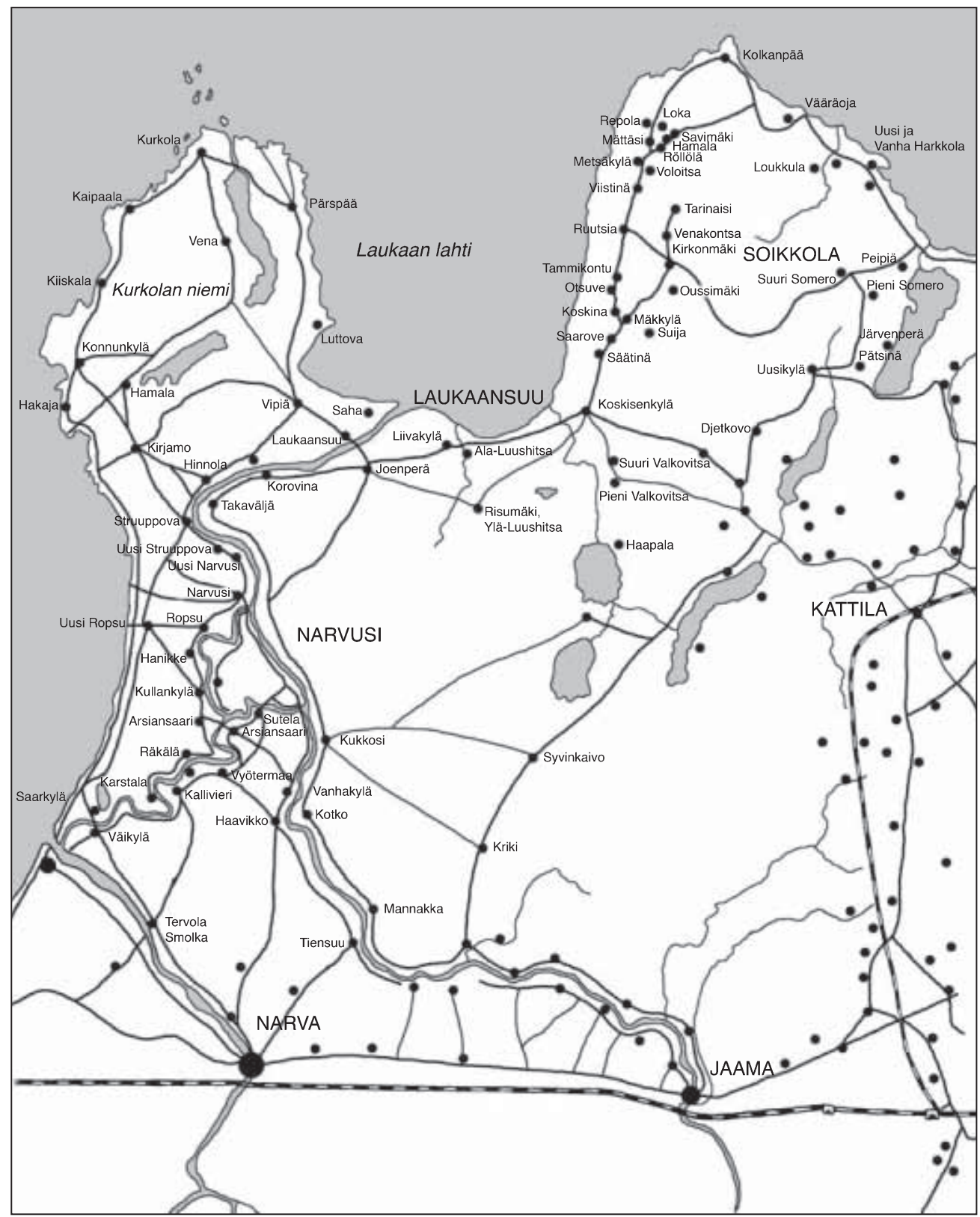

Kuva 1. Länsi-Inkerin Narvusin ja Soikkolan kylät (päälähteenä Mustonen 1931).

Inkerin alueen historiankirjoitus ja etnografia painottuvat kirjoitusajankohdan ja kirjoittajan kansallisuuden mukaan: esimerkiksi ihmisten kielitaidosta tai ryhmien välisistä suhteista on esitetty lähes vastakkaisia tulkintoja. Suomalainen historian-, kielen- ja perinteentutkimus painottuu usein inkerinsuomalaisiin ja ennen toista maailmansotaa Suomeen ja Ruotsiin kertyneisiin aineistoihin, kun taas virolaisella puolella on oltu kiinnostuneita etenkin vatjalaisista ja inkeroisista, hallittu sekä venäjän- että suomenkielinen kirjallisuus ja tehty kenttätöitä läpi 1900-luvun. ${ }^{16}$ ${ }^{16}$ Virolaisesta inkeroisten ja vatjalaisten kielen- ja perinteentutkimuksesta ks. esim. Ariste 1960; 2005;
Laanest 1986; Rüütel 1977; Västrik 2007; ks. myös Anepaio 1999. 
Venäläisellä tutkimuksella on puolestaan käytössään laajat viranomaisarkistot ja etnografisia kuvauksia 1700-luvulta lähtien, mutta Inkerin pieniin itämerensuomalaisryhmiin ei ole aikaisemmin suuntautunut kovin suurta kiinnostusta eikä Suomen puolelle kertyneitä aineistoja usein tunneta. ${ }^{17}$ (Ks. myös Survo 2012a.)

Ergo-Hart Västrik (2007) on näyttänyt, miten ortodoksisen ja luterilaisen kirkon, venäläisen ja ruotsalaisen maallisen vallan sekä suomalaisten, virolaisten ja venäläisten tutkijoiden ja perinteenkerääjien tuottamat eriaikaiset lähteet ja tutkimukset luovat Inkerin etnisistä ryhmistä ja etnografisista todellisuuksista hyvinkin erilaisia, eri tarkoituksiin syntyneitä kuvia. Esimerkiksi käsitykset Inkerin esihistoriasta perustuvat arkeologisille löydöille, joiden suhteuttaminen tiettyyn myöhemmältä ajalta tunnettuun ihmisryhmään tai kieleen on vaikeaa. Varhaisimmat maininnat ja ryhmien nimitykset venäläisissä kronikoissa ovat samoin avoimia vaihteleville tulkinnoille. Myöhempienkään aikojen osalta siitä, miten yksittäiset ihmiset itse ovat määrittäneet itsensä tai miten ryhmien väliset suhteet ovat rakentuneet, ei ole kattavia tietoja.

Niin historian kuin nykyhetkenkin tulkinta on aina sidoksissa tulkinnan tekijään, aikakauteen ja käytettävissä olevaan aineistoon. Viime vuosikymmeninä tämänkaltaisia sidonnaisuuksia on nostettu esiin erityisesti antropologian piirissä, jossa etnografisten kuvausten ja päätelmien tekemisen on katsottu olevan vahvasti yhteydessä tutkijan persoonaan, kulttuuritaustaan ja vallitseviin tieteellisiin kirjoittamisen tapoihin (Clifford \& Marcus 1986; Barz \& Cooley 1997; ks. myös Kalkun 2011). Tämä näkökulma on tarkoittanut sekä runoaineistojen että Inkeriä koskevien kuvausten ja tulkintojen lukemista sen valossa, mitä tiedetään tai on selvitettävissä niiden tallentajista, tekijöistä tai syntyaikakausista.

Yksi tämän tutkimuksen kannalta keskeisistä keskusteluista liittyy ihmisryhmien määrittelytapoihin ja siten etnisyyden ja identiteetin käsitteisiin. Etnisen ryhmän määrittelyssä korostuvat tutkimusalasta ja aikakaudesta riippuen kieli, ryhmän jäsenten oma näkemys tai identiteetti, sukupuut tai genetiikka sekä suullinen ja aineellinen kulttuuri, joiden väliset suhteet ja muutokset eivät useinkaan ole itsestään selviä. Ryhmä voi esimerkiksi vaihtaa kieltään tai tulla määritellyksi uudestaan. Entistä enemmän huomiota on kiinnitetty siihen, että ihminen voi identifioitua tai tuntea kuuluvansa useaan osin päällekkäiseen ryhmään, joiden määrittelyssä etnisyys on ainoastaan yksi tekijä esimerkiksi paikallisuuden, sukulaisuuden, sosiaalisen statuksen ja sukupuolen joukossa. (Balzer 1999; Hylland Eriksen 2001, 261-293; Mathisen 2005; Sivonen 2007, 16-20; Spickard 2013.) Inkerin kohdalla haasteellista on hahmottaa, mitä eri aikakausien tutkijat ja viranomaiset milloinkin ovat erilaisilla etnisiin ryhmiin tai kansallisuuksiin viittaavilla termeillä tarkoittaneet.

${ }_{17}^{17}$ Venäläläisestä tutkimuksesta ks. Teinonen \& Virtanen (ed.) 1999, erit. Chistyakov 1999; Novozhilov 1999; Zadneprovskaya 1999. 


\section{INKERIN HISTORIA}

Arkeologisten tutkimusten pohjalta on ajateltu, että Inkeriä asuttaneiden itämerensuomalaisten lähettyville asettui slaavilaisia ryhmiä jo ensimmäisen vuosituhannen lopulla (Uino 1991, 20). 1900-luvulle tultaessa on siis mahdollista olettaa näiden kieliryhmien välille tuhatvuotinen vuorovaikutus. Varhaisimmat maininnat Inkerin alueesta ja siellä asuneista ryhmistä löytyvät juuri venäläisistä kronikoista. Ensimmäisinä nimeltä mainitaan vatjalaiset vuonna 1069. Toinen varhainen ryhmä koostui inkeroisista (inkerikot, isorit, isurit). Itämerensuomalaiset ryhmät päätyivät varhain Novgorodin ja ortodoksisen kirkon vaikutuspiiriin. 1400-luvulla Novgorod ja samalla Inkeri siirtyivät Moskovan hallintaan. 1500-luvun lopulta kestäneiden sodan ja rauhan kausien jälkeen Ruotsi sai vuonna 1617 Stolbovan rauhassa Inkerin haltuunsa. Suuri osa väestöstä oli kuollut sotiin ja nälkään tai paennut Venäjälle. Itäinen Inkeri oli tyhjentynyt läntisiä osia pahemmin, joten sinne kohdistui suurempi siirtolaisaalto kuin Länsi-Inkeriin. Tyhjille tiloille muutti lähinnä luterilaisia suomalaisia etenkin Karjalan Kannakselta, Kaakkois-Suomesta ja Savosta. Keskeisimmät inkerinsuomalaiset ryhmät, savakot ja äyrämöiset, syntyivät pääosin näiden 1600-luvun muuttoliikkeiden tuloksena. Ruotsin vallan kausi, etenkin 1600-luvun loppu, oli kiivaan inkeroisten ja vatjalaisten luterilaistamisen aikaa, vaikka ortodokseille oli rauhansopimuksessa myönnetty uskonnonvapaus (Saloheimo 1991, 71). Venäjän vallattua Inkerin takaisin 1700-luvun alussa ortodoksien asema helpottui, kun taas luterilainen kirkko oli vaikeuksissa hallinnollisen organisaation muutosten ja kunnollisten pappien puutteen vuoksi. Suomen tultua Venäjän suuriruhtinaskunnaksi vuonna 1809 yhteydenpito Inkerin ja Suomen luterilaisten kirkkojen välillä helpottui ja kirkon toiminta vilkastui. Valtiollinen yhteys teki osaltaan mahdolliseksi myös suomalaisten tutkijoiden kansanrunojen keruuretket (Sihvo 2003). (Haltsonen 1969; Kirkinen 1991; Ranta 1991; Saloheimo 1991; Savijärvi \& Savijärvi 1999; Sivonen 2007; Uino 1991; Västrik 2007; ks. myös Kuujo 1969, 76; Nenola 2002, 11; Novozhilov 1999.)

Uudenkaupungin rauhassa vuonna 1721 Inkeri palasi virallisesti Venäjän haltuun. Tätä olivat edeltäneet pitkät levottomat ajat ja miehityskausi, jonka aikana venäläisasutuksen määrä alueella oli alkanut lisääntyä. Pietari Suuri perusti nimikkokaupunkinsa Nevajoen suistoon vuonna 1703. Pietari nousi nopeasti Venäjän kauppakeskukseksi ja jo vuonna 1712 se nostettiin Venäjän pääkaupungiksi. Suurkaupunki muutti ympäröivän alueen luonteen, vaikka vaikutus ei Länsi-Inkerissä ollut yhtä vahva kuin Itä- ja Keski-Inkerissä. Venäläisten ja ulkomaalaisten määrä kasvoi sekä muuttoliikkeiden että pakkosiirtojen seurauksena: itämerensuomalaisista tuli suuressa kuvernementissa vähemmistö. Kaupungin ja sen lähiympäristön rakentamiseen joutuivat osallistumaan talonpojat läheltä ja kaukaa. Elinkeinorakenne muuttui ja Pietari antoi myös uusia ansiomahdollisuuksia. Talonpojat etnisestä taustasta riippumatta olivat kuitenkin lähinnä joko kruunun tai aateliston maaorjia, joiden verotus ja työvelvoitteet olivat raskaat ja oikeudet vähäiset. Esimerkiksi maaorjien avioitumista ja liikkumista valvottiin. (Alho 1979, 10-12; Ant- 
tonen 1987; Chistyakov 1999; Engman 1991; Flink 2000, 18-42; Harvilahti 1991; Honko 1962, 32-38; Meriluoto 1966, 2-12; Nenola 2002, 16-17; Novozhilov 1999; Ranta 1991, 135-142; Salminen 1917, 23-24.)

Maaorjuuden lakkauttaminen vuonna 1861 oli valtakunnallisten levottomuuksien ja uudistusvaatimuksien seurausta. Se lisäsi paitsi liikkumis- ja ansiomahdollisuuksia, myös paikallista itsehallintoa. Useat tutkijat ovat kritisoineet kerääjien ja 1900-luvun alkupuolen tutkijoiden halua nähdä Inkeri arkaaisena, pysähtyneenä agraarikulttuurina (Anttonen 1987; Engman 1991; Gröndahl 1997, erit. 18; Survo 2001). Juuri keskeisten runonkeruiden aikaan, maaorjuuden päättymisen jälkeen, alue oli murrosvaiheessa. Pietari hovikaupunkeineen levitti moderneja vaikutteita ja etenkin miesväestö liikkui kauppa- ja muilla ansiomatkoilla sekä sotapalveluksessa. Viljelysmaat oli kuitenkin ostettava tai vuokrattava maat yhä omistavilta aatelisilta, eikä niitä useinkaan saanut hankittua tarpeeksi (Porkka 1886, 160; ks. myös Laiho 1940, 229; Mustonen 1931, 12), joten ansiotöissä käyminen yleistyi myös pakon edessä. ${ }^{18}$ Heti maaorjuuden lakkauttamisen jälkeen vuonna 1863 perustettiin Keski-Inkerin Kolppanaan luterilainen, suomenkielinen seminaari kouluttamaan alueelle opettajia ja pappeja, ja 1800-luvun lopulla alkoi itsestään tietoinen inkerinsuomalainen sivistyneistö muodostua sanomalehtineen, laulujuhlineen, kuoroineen ja yhdistyksineen (Flink 2000; Meriluoto 1966; Zadneprovskaya 1999; ks. myös Grigoreva 1995, 90-171).

Levottomat ajat 1900-1800-lukujen vaihteessa ja Venäjän vallankumoukset jakoivat väestöä myös Inkerissä. Inkeri jäi osaksi Neuvostoliittoa lukuun ottamatta itsenäistyneelle Virolle vuonna 1920 luovutettua Narvusin kylien läntisintä kolkkaa, niin kutsuttua Viron Inkeriä. 1920-luvun ja 1930-luvun alun Neuvostoliitossa pienten kansallisuuksien kieltä ja kulttuuria tuettiin, mutta tilanne vaikeutui 30-luvulla maatalouden kollektivisoinnin ja Stalinin vainojen myötä. Kirkot ja omakieliset koulut lakkautettiin ja ensimmäiset väestön pakkosiirrot tehtiin vuonna 1937. (Flink 2000; 2010; Nevalainen 1991b; 1996; 1999; ks. myös Kokko 2007, 21-23.) Toisen maailmansodan aikana Saksa miehitti Inkerin. Noin kymmenentuhatta ihmistä kuoli nälkään, noin 63000 henkeä itämerensuomalaisesta väestöstä etenkin Länsi-Inkeristä siirrettiin Suomeen, Neuvostoliitto taas siirsi Pietarin ympärille jäänyttä väestöä Siperiaan. Sodan jälkeen suurin osa Suomeen siirretyistä inkeriläisistä joko palautettiin tai palasi Neuvostoliittoon, mutta noin kymmenentuhatta henkeä jäi Suomeen tai pakeni Ruotsiin. Sodan jälkeen Inkeri jotakuinkin tyhjennettiin suomensukuisesta väestöstä. Vuodesta 1956 alkaen oli hengissä olevien pakkosiirrettyjen vähitellen mahdollista palata vanhoille kotiseuduilleen, jonne oli tällä välin kuitenkin jo muuttanut uusia siirtolaisia eri puolilta Venäjää. (Engman 1991; Kaivola-Bregenhøj 1999; Kokko 2007, 23-24; Nevalainen 1991b; 1996; Nirvi 1971, VIII; Zadneprovskaya 1999.)

\footnotetext{
${ }^{18}$ Inkerin modernisoitumisesta ja runonkeruiden aikaisista olosuhteista ks. Anttonen 1987, 6, 46-51,
} 178; Engman 1991; Flink 2000; Hakamies 1991, 204; Harvilahti 1992a, 16-17; Ranta 1991. 


\section{ETNISYYS JA PAIKALLISUUS}

Inkerin suurimmat itämerensuomalaiset ryhmät olivat vatjalaiset, inkeroiset ja inkerinsuomalaiset. Länsi-Inkerin inkeroisista ja vatjalaisista koostuva alkuperäisväestö selvisi Ruotsin vallan aikaa edeltäneistä sodista muuta Inkeriä paremmin (Saloheimo 1991, 68). Tämä näkyy myös väestöpohjassa: alueella sijaitsivat Inkerin tiheimmät inkerois- ja vatjalaisasutukset. ${ }^{19}$

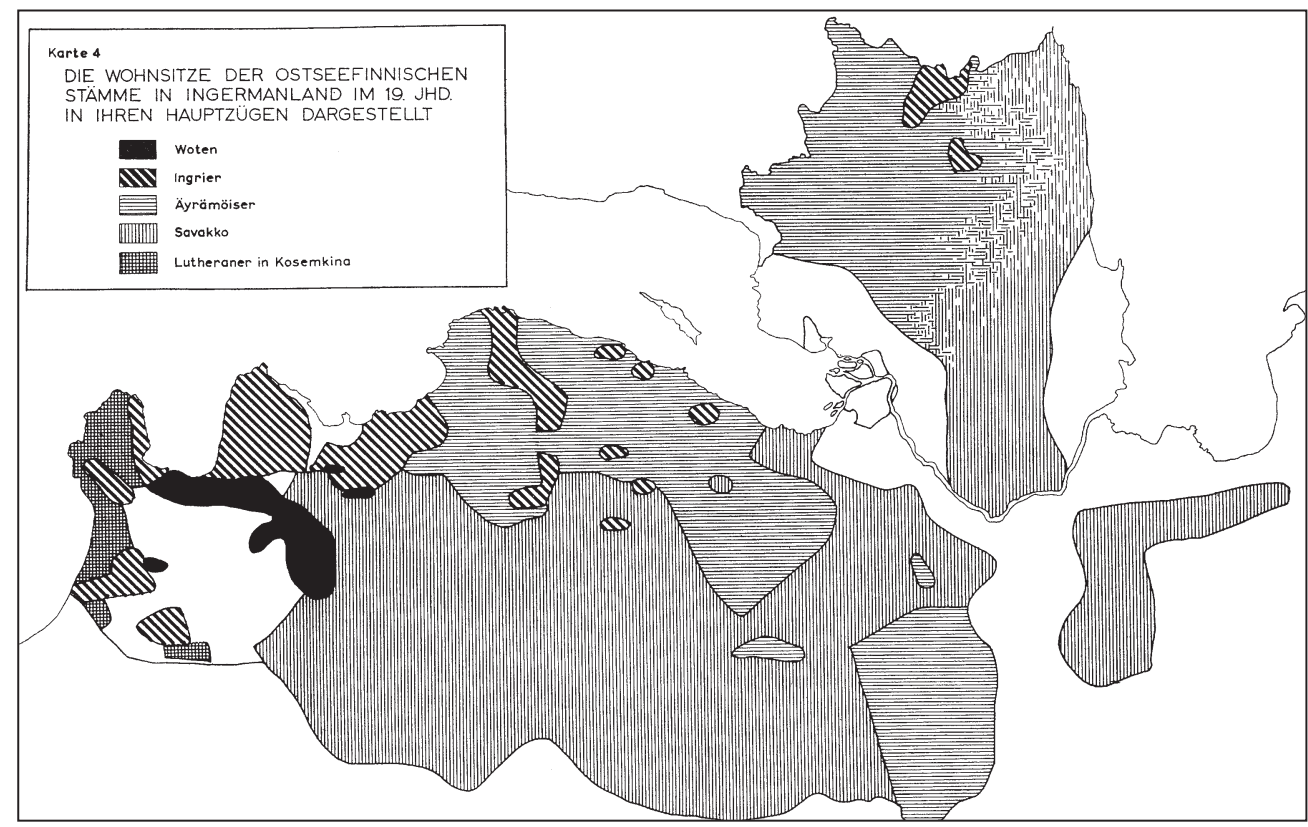

Kuva 2. Itämerensuomalaisten ryhmien pääasuinalueet Köppenin (1867) tietojen mukaan: vatjalaiset, inkeroiset, äyrämöiset, savakot ja Narvusin (Kosemkina) suomalaiset. Venäläisiä kyliä tai esimerkiksi Soikkolan itärannan inkerinsuomalaiskyliä ja Ylä-Laukaan inkeroiskyliä ei kartassa ole huomioitu. (Honko 1962, 51.)

Vatjan lähin sukulaiskieli on viro, mutta kielessä on myös runsaasti venäläis- ja inkeroisvaikutteita. Keskeisin vatjalaisalue oli 1900-luvun alussa Kattilan alue. Etenkin Kattilan vieressä sijaitsevan, tässä työssä Soikkolaan lasketun Laukaansuun alueella oli paljon inkeroisten ja vatjalaisten yhteiskyliä. (Leskinen 1991; Savijärvi \& Savijärvi 1999.) Vatjalaisten venäläistymisestä on paljon mainintoja, mutta heitä sulautui osin myös inkeroisiin (Nenola 2002, 829-841; Savijärvi \& Savijärvi 1999, 24). Vuonna 1961 vatjan kieltä enemmän tai vähemmän puhuvia ihmisiä arvioitiin olevan jäljellä 61 (Heinsoo 1995, 160).

Inkeroisia on kutsuttu myös inkerikoiksi ja isoreiksi. Inkerinsuomalaiset ja kerääjät kutsuivat heitä, kuten vatjalaisiakin, myös venäjänuskoisiksi tai venäläisiksi; pai-

\footnotetext{
${ }^{19}$ Koko Inkerin alueella itämerensuomalaiset olivat jo 1800-luvun puolivaiheilla vähemmistönä: Köppenin (1867) mukaan Inkerissä asui tuolloin runsaat 5000 vatjalaista ja 18000 inkeroista sekä inkerinsuomalaisista 43000 savakkoa, 29000 äyrämöistä sekä 1600 Länsi-Inkerin suomalaista. Virolaisia siirtolaisia oli Inkerissä 1800-luvun loppuun mennessä noin 60 000, suomalaisia (Suomen passilla kulkevia) yli 11000 (Engman 1991, 172-173). Vuoden 1926 tilasto Leningradin alueelta antaa inkerinsuomalaisten lukumääräksi 112153 (Zadneprovskaya 1999, 85).
} 
koin ihmiset itse nimittivät itseään karjalaisiksi (Savijärvi \& Savijärvi 1999, 25). ${ }^{20}$ Inkeroiskielen ja sitä kautta etnisen ryhmän olemuksesta on käyty pitkää keskustelua: kieltä on pidetty myös karjalan murteena (Esim. Nirvi 1961, 99-132; Porkka 1885). Nykyään se katsotaan yleensä omaksi kielekseen (Kokko 2007, 18-19; Laanest 1986, 4; Leskinen 1991, 165; Savijärvi \& Savijärvi 1999, 25). Inkeroiset sulautuivat vähitellen etenkin venäläisiin. Nykyään inkeroiskielen puhujia arvioidaan olevan noin 200 (Savijärvi \& Savijärvi 1999, 24). ${ }^{21}$

Inkeroisten pää-asuinalueet ja murteet jaetaan yleensä Länsi-Inkerin Soikkolan ja Narvusin (eli Ala-Laukaan) alueisiin, Keski-Inkerin Hevaan tienoille keskittyneeseen asutukseen sekä Pohjois-Inkerissä ja Karjalan kannaksella rajan molemmin puolin sijoittuneisiin Lempaalan ja Raudun alueiden inkeroiskyliin. Ylä-Laukaalla Keski-Inkerissä Oredežin alueella asui myös inkeroisia, jotka venäläistyivät melko varhain. Siellä täällä muuallakin, erityisesti Tyrön ja Spankkovan alueilla asui inkeroisten hajaryhmiä. Suomen murteista inkeroismurteet ovat lähimpänä inkerinsuomalaisia äyrämöismurteita (Laanest 1966, 176; Nirvi 1971, VI, X). Juuri murteissa eri etnisten ryhmien välinen pitkä vuorovaikutus näkyi selvänä. Nirvi (1971, IV) arvioi runsaan neljänneksen Inkeroismurteiden sanakirjan sanoista olevan lainoja venäjästä, ja myös viron ja vatjan vaikutus näkyy inkeroiskielessä vahvana.

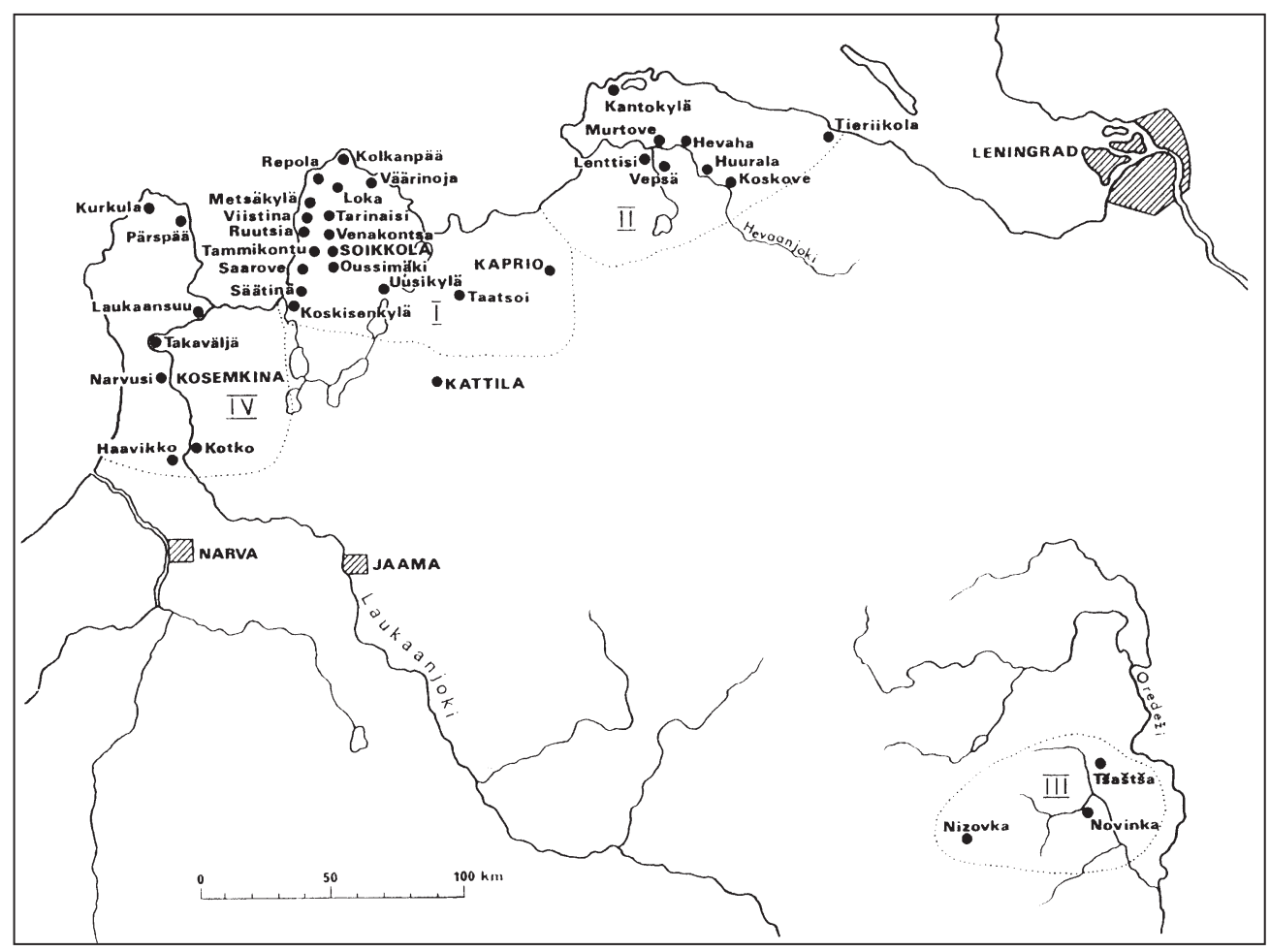

Kuva 3. Soikkolan (I), Hevaan (II), Ylä-Laukaan (III) ja Ala-Laukaan (eli Narvusin alueen, IV) murreryhmät (Nirvi 1971, VII).

${ }^{20}$ Venäjäksi nimitys on ižora, viroksi isurit, saksaksi Ischoren, englanniksi Izhorians ja joskus Ingrians.

${ }^{21}$ Savijärvi \& Savijärvi $(1999,26$; ks. myös Zadneprovskaya 1999, 91) kertovat, että vuonna 1993 tehtyjen haastatteluiden perusteella monet inkeroiset eivät 1930-luvun alun omakielisyyttä kannustavassa ilmapiirissäkään halunneet lastensa opiskelevan inkeroista, vaan mieluummin hyödyllisenä pitämäänsä venäjää. 
Soikkolan, Hevaan ja Ylä-Laukaan inkeroismurteet ovat suhteellisen lähellä toisiaan. Näistä kauempana on Narvusin alueen eli Ala-Laukaan murre, jossa näkyy selvänä alueen inkeroisten ja inkerinsuomalaisten tiivis vuorovaikutus. Ala-Laukaan murteeseen Nirvi (1971, X) jopa lukee sekä alueen inkerinsuomalaisten että inkeroisten kielen, vaikka julkaisikin Inkeroismurteiden sanakirjassa ainoastaan ortodoksikylistä kerätyn sanaston. Narvusin seudun inkeroismurteissa näkyy Nirvin (mts. XI) mukaan erityisen vahvana sekä vatjan että inkerinsuomalaismurteiden vaikutus.

Inkerinsuomalaiset ${ }^{22}$ jakautuvat kolmeen pääryhmään: savakkoihin, äyrämöisiin ja Länsi-Inkerin (tai Narvusin) inkerinsuomalaisiin. ${ }^{23}$ Soikkolan niemen itärannan muutamat luterilaiskylät nimetään yleensä äyrämöiskyliksi. Kielellisesti Soikkolan ja Narvusin inkerinsuomalaiskylät olivat suhteellisen lähellä toisiaan (Nirvi 1971, IX-X). Tämän työn rajauksen kannalta keskeisin inkerinsuomalaisryhmä ovat Narvusin suomalaiset. Ilkka ja Muusa Savijärvi $(1999,29-32)$ arvelevat ryhmän olevan kotoisin savakoita ja äyrämöisiä lännempää: murre on suhteellisen lähellä Säkkijärven murretta. He kuitenkin korostavat, että kielellisten ominaispiirteiden kannalta alkuperää merkittävämpää voi olla se, että ryhmä on elänyt pitkään suhteellisen erillään Keski- ja Pohjois-Inkerin inkerinsuomalaisasutuksesta, inkeroisten ja vatjalaisten naapureina, virolaistenkin. (Ks. myös Kokko 2007, 20.) Murteessa on runsaasti näihin kieliin liittyviä piirteitä, mutta samalla kuitenkin myös joitain savakkomurteen piirteitä (ks. myös Nenola 2002, 14-15; Porkka 1885, 9-11). Veijo Saloheimon (1991) yhteenveto näyttää, että 1600-luvun siirtolaisuus saapui Länsi-Inkeriinkin monesta eri suunnasta: Kannakselta, Kaakkois-Suomesta, Savosta, Suomenlahden saarilta, Virosta, Saksasta, Itä- ja Pohjois-Suomestakin. ${ }^{24}$ Tämä asettaa kohdilleen kansanrunoudentutkijoiden Narvusin suomalaisten alkuperää koskevat arviot, jotka ovat vaihdelleet Vironlahdesta Länsi-Suomeen (esim. Kuusi 1983a, 8-9; Laiho 1940, 221; Porkka 1885, 15; Salminen 1917, 16-17; Salminen 1919, 22). Kingisepin eli Jaaman piirissä, joka kattoi myös Soikkolan ja Narvusin alueet, asui vuoden 1881-82 tilaston mukaan 5992 inkerinsuomalaista eli 36,31 \% väestöstä (Chistyakov 1999, 133). Toisin kuin monet muut Inkerin osat, Soikkola ja Narvusi eivät olleet inkerinsuomalaisten enemmistöalueita.

\footnotetext{
${ }^{22}$ Inkerinsuomalainen on ulkopuolelta annettu termi: ihmiset itse kutsuivat itseään inkeriläisiksi tai suomalaisiksi tai käyttivät paikallisuuksiin liittyviä nimityksiä (Teinonen 1999, 110-111; Raudalainen 2007). Kielenkäytön tarkkuuden vuoksi nimitys puolustaa tutkimuskäytössä paikkaansa: inkeriläisellä viittaan tässä työssä tietyllä maantieteellisellä alueella asuviin ihmisiin, suomalaisella tiettyyn kansallisuuteen.

${ }^{23}$ Savakkoja asui lähinnä Pohjois- ja Keski-Inkerissä, eivätkä he juurikaan asuneet inkeroisten ja vatjalaisten naapurustoissa. Äyrämöisiä taas asui enemmän inkeroisten naapurikylissä, sekakylissäkin. Sosiaalisesti savakkojen kuvattiin olevan äyrämöisiä ylempänä. 1800-luvulla ryhmät erottautuivat selvästi toisistaan etenkin naisten pukeutumisen kautta, mutta kielellisesti erot eivät ilmeisesti olleet kovin suuria - äyrämöiset näyttävät 1900-luvulle tultaessa pitkälti sulautuneen savakoihin sekä kielellisesti että kulttuurisesti (Raudalainen 2007; Savijärvi \& Savijärvi 1999, 29; Sihvo 1991; Zadneprovskaya 1999, 90; ks. myös Leskinen 1991.) Inkerinsuomalaismurteiden tutkimuksesta ks. Kokko 2007, 25-27.

${ }^{24}$ Siirtolaisuus ei ollut yhtä massiivista kuin idempänä Inkerissä. Vuosina 1623-1675 luterilaistalojen määrä kasvoi silloisessa Länsi-Kargalissa (Soikkola ja osa Kattilaa) kahdestakymmenestä viiteenkymmeneen yhteen, Toldolassa (Soikkolan eteläpuolen vatjalaisalue) yhdestä kahteenkymmeneen ja Petrovskissa (Narvusi ja Kurkolan niemi) kahdestatoista sataan.
} 
Inkerin suullisten perinteiden tyylipiirteiden rajat noudattelevat osin kieli- ja murrealueiden rajoja. Runoaineiston perusteella Väinö Salminen (1931a, 528; ks. myös 1934, 40) laskee Narvusin, Soikkolan ja Hevaan alueiden inkeroiset kuuluvaksi yhteen kulttuurialueeseen, mutta pitää sekä vatjalaisalueet eli Kattilan ja Laukaansuun kylät ${ }^{25}$ että varsinaiset inkerinsuomalaispitäjät eli Keski-, Itä- ja Pohjois-Inkerin savakko- ja äyrämöiskylät erillään. ${ }^{26}$ Ilkka Kolehmaisen $(1977,9)$ mukaan savakkojen, äyrämöisten ja inkeroisten käyttämissä runosävelmissä oli eroja. Hänen tutkimiensa viisi-iskuisten ns. kalevalasävelmien puitteissa Inkerissä "yli puolet yksisäkeisistä sävelmistä on kerätty kylistä, joissa tietojen mukaan asui vain inkeroisia," sitä vastoin savakoilta on vain yksi, kaksisäkeinen toisinto. Kaksisäkeisiä kalevalasävelmän toisintoja ei ole tallennettu lainkaan pelkkien inkeroisten asuttamista kylistä. ${ }^{27}$

Itkuvirsien tyylit noudattavat Aili Nenolan (2002, 46-49) mukaan karkeimmalla tarkastelun tasolla perinteistä jakoa Länsi-, Keski- sekä Itä- ja Pohjois-Inkeriin. Näiden alueiden sisällä rajat noudattelevat kuitenkin suurelta osin etnisiä rajoja. Inkeristä tallennetut itkut jakautuvat tyylillisesti kuuteen ryhmään: Pohjois-Inkeri; äyrämöisitkut (Serepetta ja Tyrö), Hevaan alue; Soikkola, vatjalaisitkut ja Laukaan alue (Narvusi). Pohjois-inkeriläiset itkut ovat selkeimmin muista poikkeava ryhmä ja koostuvat ainoastaan inkeroisten esittämistä itkuvirsistä. Narvusin ja Soikkolan alueisiin kuuluvat inkeroisten laulamien ohella myös inkerinsuomalaisten esittämät itkut. Varhaiset vatjalaisitkut muistuttavat läheisimmin Narvusin inkeroisten itkuja. Hevaan inkeroiskylät erottuvat omaksi perinnealueekseen, jonka piiriin kuuluvat tosin myös jotkut läheisistä äyrämöiskylistä saadut itkut. Tyrön ja Serepetan muutamien äyrämöiskylien itkut koostuvat ainoastaan hääitkuista ja muistuttavat läheisesti Hevaan inkeroisten itkuja. Muualla ei luterilaisilta ole itkuja tallennettu, ja Nenola (mts. 47-48) olettaakin inkerinsuomalaisten itkut inkeroisilta 1600-luvulta lähtien omaksutuiksi.

Inkeroisalueilta on Väinö Salmisen (1929b) mukaan tallennettu valtaosa Inkerin eeppisistä, "Kalevalan kertovia runoja" muistuttavista teemoista. Lähes kaikki pitkät Päivänpäästö-, Kilpalaulanta-, Iso härkä-, Kullervo- ja Kultaneidon taonta -runot ovat inkeroisilta tai vahvoilta inkeroisalueilta tallennettuja. Yhtälailla inkeroisalueille liittyy vahvasti myös tiettyjä lyyrisiä teemoja ja kristillisiä legendarunoja (Kuusi 1983a, 169; Pentikäinen 1963; Timonen 2004, 100-107, 161-195; Timonen (tulossa)). Inkerinsuomalaisalueilta taas on Salmisen (1929a, 137-142; 1931a, 527) mukaan kerätty erityisesti balladeja, kuten Annikaisen virsi ja Vesitiellä viipynyt neito. Silloinkin kuin inkerinsuomalaiset ryhmät ja inkeroiset ovat laulaneet samo-

\footnotetext{
${ }^{25}$ A. A. Borenius katsoi yleensä Narvusin alueeseen lasketun vatjalais-inkeroisen Joenperän kylän Soikkolaan kuuluvaksi ja Armas Launis säilytti tämän jaon sävelmäkokoelmassaan (SKS KRA Borenius e; SKVR III 599; Launis 1910a). Joenperän ja Soikkolan laulamisen tapojen yhteyksistä kertovat muutkin lähteet (esim. Laiho 1940), joten Laukaansuun kylät hahmotetaan tässä työssä Soikkolaan läheisesti liittyvänä alueena.

${ }^{26}$ Inkerin kalevalamittaiset runot on julkaistu kolmena Salmisen toimittamana volyyminä, jotka eivät tätä jakoa noudattaneet: Länsi-Inkerin (SKVR III), Keski-Inkerin (SKVR IV) ja Pohjois- ja Itä-Inkerin (SKVR V) runoina, joissa vatjalaisrunot on kuitenkin eroteltu omaksi kokonaisuudekseen osan IV loppuun. Salminen (1931a, 528) kritisoi omaa työtään jo viimeisen osan liitteessä.

${ }^{27}$ Inkeroisten ja vatjalaisten runosävelmistä ks. myös Gomon 1977; Koski 1974; Rüütel 1977.
} 
ja kertovia runoja, ovat niiden perushahmot usein eronneet toisistaan. Esimerkiksi Maailmansyntyrunosta laulettiin Inkerissä kahta eri versiota (Salminen 1929a, 190-193; ks. myös ks. Kuusi 1956). Vaikkapa maaorjarunot levisivät sitä vastoin etnisten ryhmien rajoista riippumatta, jotkut tosin vain suppeilla maantieteellisillä alueilla (Alho 1979, 25, 82-83; Laurila 1956). Esimerkiksi Tytärtensurmaajan runoa ovat Rantasalon (1929; ks. myös Järvinen 1985) mukaan taas koko Inkerissä laulaneet samankaltaisena niin inkerinsuomalaiset kuin inkeroisetkin. Hyvin samanlaisena runoa on laulettu myös Virossa. Oma alueellinen erityistapauksensa on perinnealueidenkin suhteen jälleen Narvusi, jonka kylissä eri ryhmät ovat Salmisen $(1919 ; 1929 a$; ks. myös Kuusi 1983a) tulkinnan mukaan olleet runojen oppimisen suhteen niin tiiviissä vuorovaikutuksessa, ettei runoista ole aina mahdollista tehdä vastaavia päätelmiä.

Vihtori Alava (Forsberg 1893, 53) mainitsee avioitumisen merkittävänä runojen leviämiseen vaikuttaneena tekijänä. Naiset vaihtoivat usein kylää naimisiin mennessään ja veivät osaamansa laulut mennessään, vaikka puoliso usein valittiinkin oman ryhmän ja ennen kaikkea saman uskontokunnan sisältä. Häät ja laajoiltakin alueilta vieraita keränneet praasnikkajuhlat olivat myös merkittäviä laulamis- ja runojen oppimistilanteita. ${ }^{28}$ Lähialueiden laulajat mainitsivat usein Soikkolasta kotoisin olevat ihmiset laulujensa lähteiksi, ja Soikkolasta kotoisin olevat naiset kertoivat tuoneensa runonsa mukanaan Narvusin ja Laukaansuun alueille. ${ }^{29}$ Soikkolan niemeä onkin eri aikoina kutsuttu muinaisrunojen aarreaitaksi, runojen ekspansiokeskukseksi ja kalevalamittaisen kertomarunouden viimeiseksi eheäksi runokulttuuriksi (Harvilahti 1992a, 14, Laiho 1940, 227-230; Salminen 1931a, 529). Vuorollaan sen runot, itkuvirret ja laulutaito on kohotettu lähialueita korkeammalle (Porkka 1886, 155, 158; 165; Launis 1904; 1907; Nenola 2002, 47; ks. myös Pentikäinen 1963, 285).

Ilmeisesti yhtenäinen inkeroisasutus edesauttoi laulun ja muunkin suullisen perinteen omaleimaista säilymistä ja kehitystä. Myös monipuolisten yhteyksien niin Viron kuin Suomenkin suuntaan arvellaan vaikuttaneen soikkolalaisen runokulttuurin elinvoimaan (Harvilahti 1991, 210-215; Kuusi 1983a, erit. 19; Laiho 1940, 223-224). Muuallakin inkeroiskylissä runoja laulettiin runoja ilmeisesti enemmän kuin luterilaisissa. Launis $(1904,50)$ kertoo sävelmistä Narvusista Kurkolan niemeltä: "Eniten taidettiin Pärspään kylässä syystä, että se kreikanuskoisena [inkeroiskylänä] oli säilyttänyt vanhan runolaulutavan, jonka kautta laulut eivät päässeet unohtumaan.” Juho Lukkarisen $(1911,66)$ mukaan Pärspään tsasounaan Kurkolan niemellä vietiin antimia Soikkolasta asti. Toisaalta Narvusista ja kauempaakin käytiin Soikkolassa: "Tuleepa soikkolaisten juhliin runsaasti väkeä Suomen puoleisista saaristakin" (mts. 42). Suomenlahden saarista erityisesti luterilaisten asuttamat Lavansaari ja Seiskari olivat kiinteästi vuorovaikutuksessa Länsi-Inkerin kanssa. La-

\footnotetext{
${ }^{28}$ Runojen oppimisesta ja juhlatilanteiden merkityksestä ks. myös SKS KRA Alava XIII, 199-200, 214-216; Kuusi 1983a, 202; Harvilahti 1991, 213; Salminen 1917, 30.

${ }^{29}$ Etenkin Narvusin seudulta on tallentunut mainintoja: "Se onki Soikkolan virsi ja vielä komiakin" (SKVR III 268, Narvusi), "Kuullut Soikkolan tyttöjen laulavan"(SKVR III 1783, Kallivieri), "Syntyisin Soikkolan Uudestakylästä. Siellä oppinut kaikki sanelemansa virret." (SKVR III 1788, Kallivieri); ks. myös esim. SKVR III 599, 683, 1785, 1866, 1916; vrt. esim. 1215.
} 
vansaarelaiset tekivät kauppaa ja kyläilivät lähinnä Kurkolan niemen luterilaisten kanssa, seiskarilaiset Soikkolan inkerinsuomalais- ja inkeroiskylien kanssa. ${ }^{30}$

Ihmisiä asui sekä useampien ryhmien muodostamissa sekakylissä että yhden ryhmän dominoimissa kylissä. Alexei Novozhilovin $(1999,126)$ mukaan osassa monietnisiä kyliä kylän osat saatettiin nimetä tietyn ryhmän päädyiksi, vaikka käytännössä rajat kulkivat usein enemminkin varakkuuden kuin etnisyyden mukaan. Ainoastaan yhden ryhmän asuttamaksi yleensä mainitussa kylässä saattoi asua myös muutamia muiden ryhmien edustajia, jotka eivät aina näy yleisemmissä kuvauksissa. Esimerkiksi yleensä puhtaaksi inkeroiskyläksi merkityssä Säätinän kylässä asui Vihtori Alavan mukaan myös kolme inkerinsuomalaisperhettä. ${ }^{31}$ Maaorjuuden aikaan jotkut kylät jakautuivat lisäksi kahdelle omistajalle: esimerkiksi tsaarin omistamaan "kuninkaanvaltaan" ja aatelisten omistamaan "herrainvaltaan." ${ }^{2}$ Esimerkiksi Joenperän kylässä tämä jako oli myös etninen jako: herrainvallan asukkaat olivat inkeroisia, kuninkaanvallan vatjalaisia. Kylän osista puhuttiin herrainvaltana ja kuninkaanvaltana vielä 1960-luvulla, sata vuotta maaorjuuden lakkauttamisen jälkeen. ${ }^{33}$ (Vrt. Brunner 1992.)

Inkeriläiset ryhmät viittasivat toisiinsa ja itseensä usein uskonnon, eivät niinkään kielen kautta. Inkeroiset ja vatjalaiset olivat venäjänuskoisia, inkerinsuomalaiset suomenuskoisia. ${ }^{34}$ Luterilainen kirkko väheksyi 1600-luvulta 1900-luvulle saakka inkeroisten ja vatjalaisten uskonnollisuutta ja laski heidät jokseenkin pakanoiden joukkoon sekä venäjän kielen puutteellisen taidon että keskeisten opinkappaleiden hallinnan vähäisyyden takia (Sivonen 2007; Västrik 2007). Toisaalta myös ortodoksikirkko pyrki niin 1500- kuin 1700-luvuillakin karsimaan esimerkiksi uhrilehtojen käyttöä, paikallisten tietäjien valtaa ja ortodoksisiin kirkkopyhiin liitettyjä pakanallisia käytäntöjä (Västrik 2007, 54-71, 94-116). ${ }^{35}$ Oman lisänsä Länsi-Inkerin uskonnollis-etniseen kentään antoivat viimeistään 1800-luvulta lähtien erilaiset lahkot ja herätysliikkeet: hyppääjät, kuohitsijat, lestadiolaiset, vapaakirkolliset, metodistit, babtistit ja helluntailaiset, joista hyppääjien lahko ilmeisesti oli levinnein (Raudalainen 2007, 50-58; ks. myös Nevalainen 1991a).

Etnisten ryhmien välisistä suhteista on ristiriitaisia tietoja. Usein on korostettu erityisesti luterilaisten harrasta uskonnollisuutta ja tiukkaa eroa paitsi ortodokseihin venäläisiin, myös inkeroisiin. "Seka-avioliittoja inkeroisten ja luterinuskoisten

\footnotetext{
${ }^{30}$ Alueiden ja ihmisryhmien yhteyksistä ks. myös Anttonen 1987, 58-69; Kuusi 1983a, 19; Laiho 1940, 231-232; Nenola 2002, 11-16; Hakamies 1991, 201; Harvilahti 1991, erit. 213; Salminen 1929c, 63; $1934,209$.

${ }^{31}$ SKS KRA Alava VII b 1892, s. 183; vrt. Nevalainen \& Sihvo 1991, 408-409.

${ }^{32}$ Eri valtojen työt jakaantuivat eri tavoin, herrainvallassa vaatimusten sanottiin olleen raskaampia, ja avioituminen vallasta toiseen oli hankalampaa kuin vallan sisällä. (Alho 1979; Anttonen 1987, 45; Raudalainen 2007, 38-39 ; aineistossa esim. SKS KRA Laiho L. 4760-4765, 4969.)

${ }^{33}$ ERA RKM, Mgn. II 2790, d.

${ }^{34}$ Esim. SKVR III 2044 nootti 1, 1336, 2131 nootti 4, 2545 nootti 3; 4368; ks. myös Anttonen 1987, 62-64; Katajala 2005, 48-58; Raudalainen 2007; Sivonen 2007.

${ }^{35}$ Inkerissä oli Heikki Kirkisen (1991, 59-61) mukaan jo 1400-luvulla kattava ortodoksisten "seurakuntien, kirkkojen, tsasounien ja luostareiden verkosto," joskaan Valamon tai Konevitsan kaltaisia suurluostareita ei ollut.
} 
kesken sanottiin ani harvoin solmitun entisaikaan", kertoi Väinö Salminen (1929a, 96, ks. myös 95-97; Enäjärvi-Haavio 1949, 160; Hakamies 1990, 100). On vaikea sanoa, paljonko korostukseen onvat vaikuttaneet suomalaiskerääjien omat ihanteet ja paikallisen papiston kautta syntyneet haastattelusuhteet luterilaista kirkkoa lähellä oleviin paikallisiin, aineiston painotukset kun siirtyvät helposti myös tutkimuksiin. Erilaisuudessaan virkistävä on Alexei Novozhilovin (1999, 126-127) ajallisesti kohdistumaton väite: "Keski-Inkerin ylängöllä [on izhora platteau] ortodoksikirkot dominoivat, ja niissä eivät käyneet ainoastaan venäläiset ja inkeroiset, vaan myös inkerinsuomalaiset, jotka eivät olleet kovin uskonnollisia." Hän lisää, että samaisen alueen suomalaiset viettivät pyhiä ortodoksisen kalenterin mukaan siinä kun ortodoksit toisia luterilaisen mukaan. Hänen näkemyksensä mukaan myös seka-avioliitot olivat yleisiä. ${ }^{36}$ Keskitien näkemystä edustaa alueella 1800 luvun lopulla paljon kulkenut Vihtori Alava, vaikka hän ajan tavan mukaan puhuukin "kreikanuskoisista" inkeroisista suomalaisina:

Muutamin paikoin luterilaiset eivät paljon tahdo olla tekemisissäkään oikeiden venäläisten kanssa. Harvoin tapahtuu että luterinuskoinen vaihtaa uskontoa, joskus se kuitenkin tapahtuu avioliiton vuoksi. Tämä seikka se myöskin viepi kreikanuskoisista suomalaisista tyttöjä venäläiseen kansallisuuteen [...]. ${ }^{37}$

Ei tiedetä, kuinka paljon inkeroisia ja vatjalaisia Ruotsin vallan aikana vaihtoi uskontoaan ja tuli siten lasketuiksi inkerinsuomalaisten joukkoon tai sulautuikin näihin (ks. esim. Savijärvi \& Savijärvi 1999, 27; Sivonen 2007; Västrik 2007). Aleksei Krjukov $(1993,125)$ on jopa ehdottanut, aluetta tarkentamatta, että vähintään kolmannes tai jopa puolet inkerinsuomalaisista olisi sukujuuriltaan inkerois- tai vatjalaisperäisiä. Myöskään inkeroisten ja vatjalaisten venäläistymismääristä eri aikakausina ei juuri ole esitetty arvioita, ja vaikuttaa siltä, että heidät on venäläisissä tilastoissa usein laskettu ortodoksisten nimien perusteella venäläisten joukkoon. Toisaalta Alexei Novozhilov $(1999,126)$ huomauttaa, että 1500-luvulta lähtien eri syistä autioituneille tiloille muuttaneet venäläiset ja inkerinsuomalaiset asukkaat muuttivat itselleen vieraaseen ympäristöön ja omaksuivat yleensä hylättyjen tilojen ja kylien käyttöönoton paikalliset maanviljelykäytännöt ja asumismuotoja, jotka pysyivätkin alueella sangen yhtenäisinä 1800-luvun lopulle asti. Sulautumisprosesseja tapahtuikin myös yllättäviin suuntiin. Volmari Porkalle (1886, 158; ks. myös Lukkarinen 1911, 40) kerrottiin, että Soikkolassa sijaitseva Ruutsian kylä oli alkujaan venäläiskylä, joka oli kuitenkin inkeroistunut:

\footnotetext{
${ }^{36}$ 1990-luvulla muutamat ihmiset kertoivat tutkijoille, ettei kirkolla ollut niin väliä, sillä Jumala oli sama, ja tutkijoiden mielestä ihmiset tuntuivat hahmottavan ortodoksisen ja luterilaisen kirkon eron lähinnä käytetyn kielen kautta (Chistyakov 1999, 142). Uskontokuntien välisistä suhteista ks. myös Honko 1990, 119; Lukkarinen 1911, 68; Länkelä 1904, 280; Nevalainen \& Sihvo 1990, 55; Raudalainen 2007, 34-35; Teinonen 1999, 108; SKS KRA Alava VII B 51. Vrt. Vienan Karjalasta Tarkka 2005, 25.

${ }^{37}$ SKS KRA Alava XIII, 159-160. Alava murtaa päiväkirjassaan muutenkin monia stereotypioita. Hän kertoo esimerkiksi keskenään venäjää puhuvista luterilaisista, vaikka yleinen tendenssi oli kuvata inkerinsuomalaiset ehdottoman suomalaismielisiksi. Vaikka yleensä tilanne kuvataan päinvastaiseksi, kertoo hän myös inkerinsuomalaisia "koviksi laulajiksi" kehuvista inkeroisnaisista. Uskonnollisten käytäntöjen väljyyteen puolestaan viittaa kuvaus yhtälailla sekä Valamon luostarissa että Narvusin luterilaisessa kirkossa käyvästä inkeroisnaisesta. (SKS KRA Alava VII B 34/51, 37/54, 64.) Nevalaisen (1991a, 160; ks. myös Zadneprovskaya 1999, 92) mukaan inkerinsuomalaisetkin saattoivat turvautua ortodoksipappeihin, jos luterilaisia ei ollut saatavilla, erityisesti 1700-luvulla ja myöhemminkin LänsiInkerin pienissä seurakunnissa.
} 
Vaan Soikkolassa löytyy ainoastaan pari kolme venäläiskylää. [...] ja vaikkapa viime aikoina juuri näistä venäläisiä lauluja tunkeutuu ischorilaisten joukkoon, niin näyttääpä olleen asian laita päinvastainen. Ainakin kerrottiin minulle, että esim. Ruutsia oli aikoinaan ollut puhdas venäläiskylä, vaan nykyään siellä puhutaan myös suomea ja osataan vanhoja runoja, jospa ruutsialaisten suomea hiukan pilkataankin. ${ }^{38}$

Kylä onkin vuoden 1931 tilastossa merkitty inkerois-venäläiseksi (Mustonen 1931, 60). Oman lisänsä etniseen liikkuvuuteen ja vaikutteiden kulkemiseen toivat romanit, joita liikkui alueella sekä venäjänkielisiä että suomenkielisiä. Viron Inkerissä monet kertoivat romanien tuoneen "tietoja muiden paikkakunnan oloista ja tapauksista" sekä palanneen aina samoihin paikoihin. ${ }^{39}$ Kerrottiin heidän myös välittäneen lauluja ${ }^{40}$ Raudalaisen $(2007,69-72)$ mukaan venäjänkieliset romanit hakivat yösijaa tavallisimmin inkeroisten, suomenkieliset inkerinsuomalaisten luota.

Anttonen (1987, 58-83) toteaa Soikkolan ja Narvusin inkeroisten kuuluneen samaan avioliittokenttään. Myös alueiden inkerinsuomalaiskylien välillä näyttää olleen yhteys: aineistossa on mainintoja myös luterilaiskylien välillä siirtyneistä naisista ja kuten edellä mainittiin, murteet olivat hyvin läheisiä. ${ }^{41}$ Anttonen (1987, 58-69; ks. myös Harvilahti 1991, 213-214) päättelee Narvusin ja Soikkolan inkeroisten olleen sosiaalisesti ja taloudellisesti luterilaisia alempana. Samaan viittaa esimerkiksi vuonna 1916 Soikkolan Mäkkylässä syntyneen Paula Hakulisen eli Pelageja Afanasjevna Kuzminan muistelma siitä kuinka Kurkolan niemen luterilaiset halveksivat inkeroisia ryssinä, venäläiset puolestaan tsuhnina eli suomalaisina (Hakamies 1990, 97-100).42 Darja Lehti kertoi Lauri Laiholle $(1940,228)$ tuntevansa olonsa irralliseksi Narvusissa:

Joenperäl mie oon syntynt ja tyttöpolven kazvant. A sorias Soikkolas miul ol suku. Maamo oli Säädinält, isän emä oli Venakontsast, siso eli miehellä Saarovel. Suku on siellä, mie yksin täällä. Mie oon ain täs kyläs niinko lehmä vieraas karjas. Sannoot, ai sie hullu soikkolaine...

Vaikka vatjalais-inkeroisen Lehden vierauden kokemus inkerois-suomalaisessa Vanhassakylässä saattoi johtua myös vatjalaisesta identiteetistä ja puheenparresta, viittaa hän itse erillisyyteensä nimenomaan soikkolalaisuutena: ei siis etnisyyden tai uskonnon, vaan paikallisuuden kautta. Murteissa ja suullisten perinteiden tyy-

${ }^{38}$ Ks. myös KK Coll. 123.22. Launis 1903, 39; SKS KRA Mannonen 11178.

${ }^{39}$ SKS KRA Enäjärvi-Haavio 847. Esimerkiksi Anna Kivisoo Ropsusta oli oppinut uusimittaisen laulun kahdelta naapuritalossa yöpyneeltä mustalaistytöltä: hän sanoi sen olevan mustalaisten kielellä - laulu näyttää suomenkieliseltä muutamin inkeroismuunnelmin (SKS KRA Enäjärvi-Haavio 567). Luterilainen Juljaana Lulla Kullan kylästä kertoo mustalaisten laulaneen ja tanssineen tullessaan leipää kysymään, ja laulun yhteydessä hän käyttää silelooli-refrenkiä jota ei löydy muusta alueelta kerätystä aineistosta (SKS KRA Laiho A. 2244).

${ }^{40}$ SKS KRA Alava VII B 1882: 167.

${ }^{41}$ SKVR III 1788, 2077; SKS KRA Enäjärvi-Haavio 403.

${ }^{42}$ Saman ulkopuolisen ovat kokeneet myös inkerinsuomalaiset paluumuuttajat 1990-luvulla: Venäjän puolella heidät on laskettu tsuhniksi, Suomen puolella venäläisiksi (Räsänen 1999, 10; Zadneprovskaya 1999, 90). 
leissä näkyvä paikallisuus vaikuttaakin etnisten ja uskonnollisten tekijöiden ohella yhdeltä merkittävältä laulukulttuurien tulkinnassa huomioon otettavalta tekijältä.

Uskonto vaikutti myös väestön koulutukseen. Usein sanotaan ortodoksien vatjalaisten ja inkeroisten pysyneen pitkään lukutaidottomina, sillä 1800-luvun loppupuolelle asti keskeisintä kansalle tarjottua opetusta oli luterilaisen kirkon antama uskonnollinen opetus. Kuten Suomessa, jonkinasteinen lukutaito oli Inkerin luterilaisilla ripille pääsyn ja siten avioitumisen edellytys. Ensimmäisiä kansakoulun edeltäjiä perustettiin seurakuntiin jo 1700-luvun lopulla. Ennen Venäjän vallankumousta Inkerin alueella oli 122 luterilaista kansankoulua, 11 kirkkokoulua sekä yksi oppikoulu (Zadneprovskaya 1999, 92; ks. myös Engman 1991, 177), vuonna 1911 alueella toimi 576 luterilaista pyhäkoulua (Nevalainen 1991a, 162-164). Alavan mukaan ortodokseista ei varsinkaan naisväki osannut venäjää ja ortodoksipapit olivat usein suomen kielen taidottomia. ${ }^{43}$ Hän kertoo muistikirjassaan, että inkerinsuomalaiset kutsuivat kalevalamittaisia runoja piloillaan inkeroisten kirjoiksi:

Virsistä kuulee sanottavan toisinaan että ne ovat (išorilaisten 1.) venalaisten "raamatut" (=kirjat), pilalla sanottu sen vuoksi että he eivät osaa kirjaa lukea mutta virsiä kyllä osaavat. (Vyötermaalla esim. sanotaan niin.) (4 $^{44}$

Venäläisiä koulujakin Länsi-Inkerissä siltioli, Alavan mukaan jopa "tuhkatiheässä." ${ }^{45}$ Oskar Groundstroem $(1904,416)$ kertoi suuriruhtinatar Helena Pavlovnan perustaneen ortodokseille talonpojille "hyvän kansakoulun" Soikkolan Tarinaisiin jo vuonna 1849. Vaikka venäjänkielistä opetusta järjestettiin ja yhteydet Pietariin ja seudun venäläisiin edistivät venäjän tarvetta, osasivat sekä inkerinsuomalaiset että inkeroiset vuoden 1897 väestölaskennan mukaan lukea suomea yleisemmin kuin venäjää, joskin nuoremman polven parissa venäjäntaito oli yleistymässä (Hakamies 1991, 202) ${ }^{46}$ Kielen tai lukutaidon hallinta on tietenkin suhteellinen kysymys. Luterilaisten pappien vaatimukset olivat epäilemättä erilaisia kuin moninaiset käytännön vuorovaikutuksen asettamat tarpeet (ks. Sivonen 2007, 72-79; vrt. Kaukiainen 2005). 1800-luvun lopulle tultaessa syrjäisinkään inkeroiskylä ei kuitenkaan ollut lukutaidon tai venäjän kielen - tai uusien erikielisten laulumuotien - ulottumattomissa, vaikka taidot eivät olleetkaan kaikkien hallitsemia.

Keskeisiä elinkeinoja 1800-luvun lopun ja 1900-luvun alun Länsi-Inkerissä olivat maanviljelys, karjatalous, rannikoilla kalastus ja kauppa sekä ansiotöissä käynti kaupungeissa, etenkin Narvassa ja Pietarissa. Länsi-Inkerin alueelta kerrotaan

\footnotetext{
${ }^{43}$ SKS KRA Alava XIII 186; vrt. Ahlqvist 1904, 229; Tallqvist \& Törneroos 1904, 388.

${ }^{44}$ SKS KRA Alava VII B 112.

${ }^{45}$ SKS KRA Alava XIII 157. "Nyt ei tarvitse luterinuskoisen narvusilaisen enää panna lapsiansa samassa kylässä olevaan venäänkieliseen kansakouluun, kuten ennen usein tapahtui", mainitsi Porkka (1886, 165) kertoessaan Narvusin uudesta kouluhuoneesta.

${ }^{46}$ Venäjän kielen taito sinänsä oli tarpeen jokaiselle, joka halusi käydä oman kieliyhteisönsä ulkopuolella tienaamassa. August Ahlqvist $(1904,229)$ kertoi Pohjois-Inkeristä 1800-luvun loppupuolelta: "Harva mies löytyy, joka ei, vaikka edes solventamalla, puhuisi venäjän kieltä.” Kielitaidoista ks. myös Chistyakov 1999, 135-138; Gröndahl 1997, 16; Haltsonen 1969; Laiho 1940, 226; Nevalainen 1991a, 164.
} 
myös tehtaista eli faabrikoista, sahoista ja tukinuitosta joensuissa. Sotamiehenotto puolestaan vei miehiä pitkiksi ajoiksi eri puolille Venäjää. (Anttonen 1987, 46-48; Porkka 1886, 160; Salminen 1931a, 560; Virtaranta 1993, 202-203. ${ }^{47}$ Soikkolalaisia toimi paimenina pitkin Inkeriä ja Virossa asti (esim. Laiho 1940, 230-231; Saha 1982, 18-26; Chistyakov 1999, 137) ja toisaalta suomalaisia oli Inkerissä tilapäistöissä renkeinä ja paimenina (Länkelä 1904, 288; Tallqvist \& Törneroos 1904, 382). Soikkolan inkeroistyttöjä kävi Narvusin ja Seiskarin saaren luterilaistaloissa piikomassa (Laiho 1940, 229; Simonsuuri 1969). Porkka (1886, 160) oli tavannut soikkolalaisia miehiä ja naisia ansiotöissä ainakin Hevaalla, Rampovassa sekä Narvan lähistöllä. Etenkin naiset, kertoi hän, toivat näiltä matkoilta uusia lauluja kotikyliinsä.

Inkerin historia sekä kielien, murteiden ja erilaisten suullisten perinteiden tutkimus viittaavat pitkiin, vuosisatoja kestäneisiin vuorovaikutussuhteisiin eri etnisten ryhmien välillä. Aivan kuten ei syytä olettaa aineiston syntyajanjaksoa pysähtyneeksi, ei ole syytä kuvitella liiallista pysyvyyttä sitä edeltäneisiin vuosisatoihin. En pyri kurottamaan tulkintojani tutkimusaineiston tallentamista edeltäneisiin aikoihin, vaan keskityn aineiston tallennusajankohtana ilmaistuihin käsityksiin, joista osa voi toki olla kertojiensa menneisyyteen projisoimia, osa aiemmista laulamisen tavoista oikeastikin kertovia. Keskeisintä tämän työn kannalta on se, miten ihmiset omaa lauluaan tallennusajankohtina jäsensivät ja minkälaisia käsityksiä siihen liittivät.

Eri ryhmien kielissä ja suullisessa perinteessä näkyvät erot ovat selkeitä, mutta vahvoja ovat myös pitkien vuorovaikutusprosessien tuomat samankaltaisuudet. Etnisyyden tai paikallisuuden huomioiminen silloin, kun se on mahdollista, on tässä tutkimuksessa keskeinen tulkintojen lähtökohta. Tutkimusaineistoa rajatessani lähdin sekä edellä kuvattujen ylistysten että aineiston painotusten johdosta liikkeelle Soikkolan inkeroiskylistä ja jatkoin matkaa kielen- ja perinteentutkijoiden huomioimiin keskeisiin vuorovaikutussuuntiin. Aineiston määrän ja laadun ehdoilla kulkien Narvusin inkerois- ja inkerinsuomalaiskylät valikoituivat toiseksi tutkimuksen keskeisalueeksi, Hevaan inkeroiskylät ja Kattilan vatjalaiskylät ainoastaan satunnaiseksi vertailuaineistoksi. Näiden alueiden laulamisen tapojen välisten yhteyksien, samankaltaisuuksien ja erojen huomioiminen on keskeinen osa aineiston analyysia ja tulkintaa.

\footnotetext{
${ }^{47}$ Ks. myös SKS KRA Haavio 2286-2287; Laiho L. 5224; Salminen K. sidoksen 1931 b) 224-348 lopussa ilman arkistonumeroita, s. 5 .
} 
Aineisto 


\section{Aineisto}

Kalevalamittaisen runon tutkija on etuoikeutetussa asemassa: aineistoa on tallennettu ja jäsennetty yli kaksisataa vuotta. ${ }^{48}$ Kaikki sadan vuoden takaiset tulkinnalliset kehykset ja menetelmät eivät tietenkään ole nykynäkökulmasta relevantteja. Kahdesta syystä niitä ei kuitenkaan voi ohittaa. Monet maantieteellis-historiallisen metodin piirissä 1800-luvun lopulla ja 1900-luvun alkupuolella syntyneet, aineistoon tiukasti kiinnittyvät ja säetason tarkkuudella liikkuvat runotutkimukset voivat olla osin käyttökelpoisia myös tutkijalle, joka ei jaa samoja teoreettisia taustaoletuksia tai loppupäätelmiä. Vaikka pyrkimyksenä oli tuolloin säetason analyysin kautta hahmottaa runojen kulkureittejä ja alkumuotoja, piirtävät nämä tutkimukset omalla tavallaan kuvaa myös runonkeruiden aikaisesta todellisuudesta, runojen alueellisista variaation mahdollisuuksista. Samalla tavoin sävelmähahmojen vertailuun ja ajoittamiseen keskittyneen 1900-luvun alkupuolen kansanmusiikintutkimuksen piirissä tehtiin myös havaintoja, jotka ovat eri tavoin yhä käyttökelpoisia. (Tarkka 2005, 11; Timonen 2004, 15; Laitinen 2003a, 21, 208.) Toisaalta nykytutkijan käyttämä aineisto on kerätty, jäsennetty ja julkaistu maantieteellishistoriallisen menetelmän ja karelianistisen, kansallisromanttisen ideologian puitteissa. Aineistoa on luettava näiden kehysten läpi, niiden tuottamia painotuksia samalla huomioiden (ks. Tarkka 2005, 35-37, 73). ${ }^{49}$ Kaikkea ihmisten laulamaa ei suinkaan tallennettu, vaan tallentajat valikoivat ja muokkasivat kuulemaansa eri tavoin.

Jokaisen kerääjän tuottama aineisto painottuu eri tavoin ja auttaa siten vastaamaan erilaisiin osakysymyksiin inkeriläisistä laulamisen tavoista ja niiden suhteista runojen merkityksiin. Käsittelen kerääjien tekemiä tallennusretkiä kokonaisuuksina, joiden aikana syntyneet, henkilöittäin vaihtelevat aineistot kuten äänitteet, nuotinnokset, runomuistiinpanot, kontekstikuvaukset ja henkilökohtaiset matkapäiväkirjat sekä matkan pohjalta tuotetut julkaisut kuten matkakertomukset, muistelmat ja tutkimukset vasta rinnakkain asetettuna tuottavat tallennetusta kulttuurista - tai tallentajan kokemuksista ja mielenkiinnon kohteista - mahdollisimman kokonaisvaltaisen kuvan. Perinpohjaisimmin olen tarkastellut tämän työn kannalta

\footnotetext{
${ }^{48}$ Kalevalamittaisen runon aineistojen kokonaisuudesta ks. Tarkka 2005, 11-12; Timonen 2004, 10-11. Kokonaishahmoa runonkeruumatkoista ovat eri näkökulmista Inkerin osalta piirtäneet Anneli Asplund (1992a, 154-165), Lauri Harvilahti (1992a, 167-182), Lauri Laiho (1940), Aili Nenola (2002, 21, 37-49), Martti Haavio (1931), Väinö Salminen (1929a, 7-112) sekä A. O. Väisänen (1917). Kerääjiä ovat tarkemmin käsitelleet Aili Nenola ja Kaarina Koski (Nenola 2002, 829-841), Matti Kuusi (1997) sekä Senni Timonen ja Matti Kuusi (1988). Kriittisesti keruiden ideologisia taustoja ovat pohtineet erityisesti Satu Gröndahl (1997) ja Arno Survo (2001) sekä Ergo-Hart Västrik (2007). Kai Häggman (2012) piirtää SKS:n historiassaan myös seuran keruutoiminnan laajempia linjoja.

${ }^{49}$ Hannes Sihvo $(2003$; 1969) on tarkastellut karelianismina tunnettua Venäjän Karjalan alueille suuntautunutta monialaista, tendensseiltään romantiikasta realismiin vaihtelevaa kiinnostusta. William Wilson (1976) laati ensimmäisen yleisesityksen suomalaisen folkloristisen tutkimuksen, poliittisten pyrkimysten ja nationalismin suhteista. Pertti Anttonen (2005) on tarkastellut perinteeseen suuntautunutta kiinnostusta osana laajempaa modernisoitumisprosessia sekä perinteen käyttöä kansallisvaltion identiteetin rakennuksessa. Lotte Tarkka (1986) on purkanut karelianismin ja etnografian suhteita. Satu Gröndahl (1997) on tarkastellut kriittisesti inkeriläisten runojen tutkimushistoriaa, Arno Survo (2001) puolestaan eritoten tallennushistoriaa.
} 
keskeisimpien kerääjien ja tutkijoiden A. A. Boreniuksen, Armas Launiksen, Elsa Enäjärvi-Haavion sekä Aili ja Lauri Laihon aineistoja. ${ }^{50}$

Työn aineistoa muodostaessani keskeisiä tekijöitä ovat olleet ajallinen ja alueellinen rajaus sekä tutkimuskysymysten luomat puitteet. Alkujaan ajattelin voivani pysyä Soikkolan alueella ja keskittyä Armas Launiksen sieltä vuonna 1906 keräämään fonogrammiaineistoon. Tällöin muiden keräjiien samalta alueelta tallentamat aineistot olisivat toimineet ainoastaan fonogrammeja avaavana ja selittävänä toissijaisena aineistona. Ymmärsin kuitenkin nopeasti, että en voi tehdä päätelmiä laulukulttuurin tyypillisistä piirteistä ainoastaan yhden kerääjän luoman kuvan pohjalta, etenkin kun fonogrammit ovat vain lyhyitä, kontekstitiedottomia laulunpätkiä ja Launis kuvaa laulamisen tapoja matkakertomuksissaan myös Hevaan ja Narvusin alueelta saamiensa tietojen pohjalta, usein tarkemmin erittelemättä ja informanttejaan mainitsematta. Osoittautui välttämättömäksi ottaa aineistoon mukaan paitsi aikaisemmat käsikirjoitusaineistot, myös 1930-luvulla Narvusin alueelta kerätyt, kontekstitiedoiltaan monipuoliset aineistot. Tämä siitä huolimatta, että lopputuloksena on kokonaisaineisto, jonka käyttö vaatii usean aika- ja paikkatason toisiinsa suhteuttamista. Johdantoluvun kuvaus Inkerin historiasta sekä alueiden ja ryhmien välisistä yhteyksistä on osa tätä suhteuttamista, joka jatkuu halki työn.

\footnotetext{
${ }^{50}$ Näyttää siltä, että monella kerääjällä omat kenttäkokemukset ovat suunnanneet yleisluontoisempiakin kirjoituksia. Esimerkiksi Vihtori Alavan (1932) yleisartikkeli "Minkälaisissa tilaisuuksissa vanhoja kansanrunojamme on käytetty?" painottuu Inkeriin, kuten myös Armas Launiksen (1910 b, c) väitöskirjan johdanto-osio sekä artikkeli "Runosävelmistä", jossa tulevat samalla esiin myös Launiksen RajaKarjalasta ja Suistamolta keräämät aineistot. Väinö Salmisen tuotannossa yleensä ja jopa yleisesityksessä kertovista runoista (1934) on Inkeri vahvasti esillä. A. O. Väisäsellä (1990, 48-55, 88-120) huomio kiinnittyy kalevalaisen laulun käsittelyn yhteydessä ennen kaikkea hänelle läheisiin setukaisiin ja vain paimensoiton yhteydessä ensisijaisesti Soikkolaan. Niinpä yleisemmätkin kirjoitukset kertovat toisaalta hieman vaikeasti tulkittavilla tavoilla myös tutkijoiden kenttämatkoista ja toisaalta tiedot kenttämatkoista selittävät myös yleisempien kirjoitusten painotuksia. (Ks. myös Laitinen 2003a, 324.)
} 


\section{TALLENNUSTYÖ LÄNSI-INKERISSÄ}

Ensimmäiset runot Inkeristä tallensi 1830 -luvun alussa Kattilan pappilassa vatjalaiselta Anna Ivanovnalta pietarilainen, suomalaissyntyinen akateemikko A. J. Sjögren. Ivanovnan lauluja merkitsivät muistiin myös samoihin aikoihin G. Rein ja Kattilan kirkkoherran rouva Engla Groundstroem sekä Antal Reguly vuonna 1841, Elias Lönnrot vuonna 1844 sekä August Ahqvist vuosina 1854-1855. Keitään muita paikallisia nämä tallentajat eivät laulattaneet. (Branch 1973, erit. 232; Haltsonen 1958; Nenola 2002, 39; Salminen 1931a, 671-780.) Ensimmäinen laajempi, muutamia nuotinnoksiakin sisältävä inkeriläisten runojen kokoelma syntyi D. E. D. Europaeuksen ja Reinholmin matkalla vuonna 1847 Viipurin läänissä ja PohjoisInkerissä. Seuraavana vuonna Europaeus sai matkarahan Inkeriin ja Tverin Karjalaan. Matkakertomusta ei ole säilynyt, joten on epävarmaa, millä kaikilla seuduin hän Inkerissä kulki - Väinö Salmisen (1929a, 19-25) oletuksen mukaan ei kuitenkaan Länsi-Inkerissä asti. Europaeuksen tuolloisten tietojen mukaan "Inkerin läntinen osa on kumminkin se, josta kaiken todennäköisyyden mukaan useimmat ja tärkeimmät runot ovat saatavissa. Länsi-inkeriläiset toverini vakuuttavat, että siellä lauletaan paljon runoja." (Laiho 1940, 218, alk. SKS:n pöytäkirja 5.6.1850.)

Vuonna 1853 Europaeus matkusti Länsi-Inkerin Narvusiin ja keräsi sieltä alueen ensimmäiset runot ja sävelmät. Hän kertoi jättäneensä parhaimmat alueet ja kylät vielä keräämättä. ${ }^{51}$ Keräelmään ei sisälly laulajatietoja eikä usein paikkatietojakaan, mutta runojen yhteydessä on paikoin lyhyitä kommentteja. Kokoelmaan sisältyvät 4 lyhyttä nuotinnosta ovat luonnosmaisia: yhdestä puuttuvat nuotinkaulat kokonaan. Ne ovat kuitenkin ensimmäiset länsi-inkeriläisten hää- ja liekkusävelmien tallenteet, ja juuri niiden luonnosteleminen muistikirjaan kertoo luultavasti jo Europaeuksen tulkinneen juuri nämä lajit keskeisiksi. ${ }^{22}$ Jo vuoden 1848 matkalla Europaeuksen (1847) toimittama, Pohjois-Inkerin runoja sisältävä kirjanen Pieni Runon-Seppä oli valmis, ja hän jakoi sitä laulajille palkkioksi. Laulut kiersivät nopeasti takaisin suulliseen käyttöön: jo seuraavan kerääjän, Jaakko Länkelän kokoelmaan sisältyy mitä ilmeisimmin Pienestä Runon-Sepästä opittuja lauluja (Salminen 1929a, 42-43; Timonen 2004, 116, myös viite 102).

Viisi vuotta Europaeuksen jälkeen, vuonna 1858, Suomalaisen Kirjallisuuden Seura (SKS) lähetti ylioppilas Jaakko Länkelän stipendiaattina kiertämään Narvusin ja Soikkolan, Seitskarin ja Lavansaaren kyliä. Salmisen (1929a, 38; ks. myös Länkelä 1904) mukaan "hän oli talollisen poika ja maalaisoloihin perehtynyt," mikä helpotti työtä. Länkelä saikin kerättyä siihen asti suurimman, ihastusta herättäneen kokoelman. Hän yhdisteli ja muokkasi SKS:lle luovuttamansa kokoelman keräämistään toisinnoista ja sai kiitosta runojen täyteläisyydestä - tutkijoiden onneksi alkuperäiset käsikirjoituksetkin löytyivät vuonna 1916. Kummatkin versiot on jul-

\footnotetext{
${ }^{51}$ Europaeuksen keruutyöstä Salminen 1929a, 28-27, ks. myös Haltsonen 1957; Laiho 1940; Nenola 2002, 39-41. Europaeuksen asemasta Inkerin löytäjänä ja runonkeruun kentällä ks. Kuusi \& Timonen 1988; Salminen 1929a, 26-38; Sulkunen 2004, 107-118; Sulkusen hahmottamia henkilösuhteita koskevasta kritiikistä ks. Apo 2009.

${ }^{52}$ SKS KRA Europaeus 1853.
} 
kaistu Suomen Kansan Vanhat Runot -sarjassa (SKVR); muokatuissa versioissa on paikoin enemmän kontekstitietoja kuin käsikirjoitusversioissa (vrt. esim. SKVR III 228 ja 3657). Länkelä tallensi myös julkaisematta jääneitä uusimittaisia ja välimuotoisia lauluja, ajankohtaisrunoja sekä seksuaaliaiheita käsitteleviä runoja. Laajaan kokoelmaan ei kuitenkaan sisälly tarkkoja laulaja- ja paikkatietoja. (Salminen

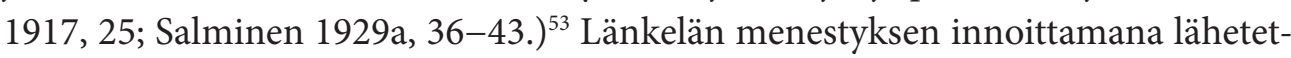
tiin seuraavana vuonna ylioppilaat Th. Tallqvist ja Antti Törneroos (1904) matkaan kiertämään Keski- ja Länsi-Inkerin kyliä. Länsi-Inkerissä asti miehet eivät kuitenkaan ehtineet käydä. (Salminen 1929a, 44-51.)

Keväällä 1861 oli keruuvuorossa Oskar Groundstroem, Kattilan kirkkoherran poika, jonka suomen kielen taito ei ollut täydellinen, venäjän sen sijaan erinomainen. Hän sai suosituspapereineen monissa kylissä suopeamman vastaanoton kuin edeltäjänsä, mutta ei silti tallentanut kovin suurta runomäärää. Matka alkoi Keski-Inkeristä ja päätyi Kattilan kautta Soikkolaan. Groundstroem kertoi luterilaisten olevan halukkaampia laulamaan hänelle kuin ortodoksien, mutta luterilaisten kautta pääsi paremmin puheisiin myös inkeroisten kanssa. Näyttää siltä, että paikallisen papinpojan status vaikutti kahdella tavalla, sekä ihmisten ystävällisyyteen että toisaalta myös vähäiseen keruutulokseen: ilmeisesti papin pojalle ei kaikkea haluttu laulaa. (Groundstroem 1904, 399-416, erit. 412; Salminen 1929a, 54-60.) Jäljempänä esiteltävä A. A. Borenius kävi Länsi- ja Keski-Inkerissä vuonna 1877 Vienasta Viroon ulottuneiden runo- ja sävelkeruumatkojensa yhteydessä.

Volmari Porkka teki ensimmäisen retkensä Narvusiin ja Soikkolaan vuonna 1882. Porkka oli syntynyt Suursaarella ja Aili Nenolan $(2002,41)$ arvion mukaan tutustunut "Inkerin murteisiin ja perinteisiin ehkä hyvinkin varhain." Ensimmäisellä matkallaan hän tallensi lähinnä murteita, itkuja ja häälauluja. Seuraavan kesän matka sai alkunsa Julius Krohnin ehdotuksesta. Sen päämääränä oli Keski- ja Länsi-Inkerin runojen "jälkikorjuu." (Harvilahti 1992a, 168.) Porkka käytti pikakirjoitusta ja sai kerättyä enemmän runoja kuin kukaan muu yhdeltä matkalta. Marie Bono (2003) on näyttänyt, että osa runojen murteellisista muodoista on keräään jälkikäteen puhtaaksikirjoitusvaiheessa lisäämiä. Porkka (1885) tunsi murteet ja teki aiheesta väitöskirjansakin, mutta runot eivät siis välttämättä kerro, minkälaisia sanamuotoja kerääjälle tarkalleen laulettiin. Porkan (1883a, 1883b) merkittävät artikkelit itkuvirsistä kertovat myös häärituaalista. ${ }^{54}$

Vihtori Alava (alk. Forsberg) matkasi Soikkolassa, Narvusissa, Hevaalla ja Koprinassa vuosina 1891 ja 1892 sekä laajemmin Länsi- ja Keski-Inkerissä vuosina 1897 ja 1901. Alavan kokoelma on merkityksellinen erityisesti runsaiden runoihin liittyvien selitysten sekä etnografisten tietojen ja muiden perinteenlajien kannalta.

\footnotetext{
${ }^{53}$ SKS KRA Länkelä 1916.

${ }^{54}$ Porkasta ja hänen kolmesta Inkerin retkestään on tarkan selonteon tehnyt Matti Kuusi (1997; ks. myös Nenola 2002, 41-42; Porkka 1886; Salminen 1929a, 62-74.)
} 
Hän otti paljon valokuvia ja nuotinsi myös joitain sävelmiä. Runomuistiinpanot ovat tarkkoja. Sävelmät ovat luonnosmaisia ja paikoin hyvin tulkinnanvaraisia niin rakenteen, rytmin kuin sanojen sijoittumisenkin suhteen. Kuten Porkka, Alavakin käytti keruuta nopeuttavaa pikakirjoitusta. Kokoelman laajuus ja monipuolisuus sekä matkakertomusten ja kenttäpäiväkirjan positiivisuus antavat kuvan taitavasti ihmisten kanssa toimeen tulleesta kerääästä (Forsberg 1892; 1893; 1895). ${ }^{55}$ Alava toimitti itse omat runonsa SKVR-sarjaan (SKVR III:2, esipuhe). Hänen (1916, 1932) merkittävät joskin hyvin yleisellä tasolla liikkuvat artikkelinsa laulamisen käytännöistä ilmestyivät vasta monta vuotta keruiden jälkeen. Niistä on monin paikoin vaikea päätellä, mihin maantieteelliseen alueeseen mikäkin tieto liittyy ja mitkä tulkinnat perustuvat Alavan omiin kenttäkokemuksiin, mitkä muiden kirjoituksiin.

Vuonna 1891 Johannes Granö merkitsi muistiin häärunoja Narvusin tienoilta Siperiaan muuttaneesta kylästä (Salminen 1946a). J. Fr Ruotsalainen (1901) kävi Narvusin läntisissä kylissä ja Keski-Inkerissä runoja keräämässä vuonna 1900 (ks. myös Salminen 1929a, 91-94). Viljo Tarkiainen (1901) tallensi lähinnä murresanastoa Narvusin alueella yksin vuonna 1899 ja samaa matkaa Ruotsalaisen kanssa vuonna 1900. Väinö Salminen (1929a, 95-97;1934, 178) kulki Narvusin ja Soikkolan kylissä vuonna 1906 keräten lähinnä tietoja häälaulujen sijoittumisesta häärituaalin kokonaisuuteen sekä joitakin runoja. Samuli Paulaharju kävi Soikkolan ja Narvusin kylissä valokuvaamassa ja tallentamassa kansatieteellisiä tietoja vuonna 1911 (Paulaharju 2010), E. N. Setälä kielentutkijana vuonna 1909.56

1900-luvun alussa koitti varsinaisten sävelmänkeruuretkien aika. Vuonna 1903 lähtivät Inkerin runosävelmiä keräämään Ilmari Krohnin oppilaat: Armas Launis Länsi-Inkeriin ja Eino Levón Keski-Inkeriin (Launis 1904; Levón 1904; Suomi 1903, 16-17). Kolme vuotta myöhemmin vuonna 1906 Launis (1907) kävi Soikkolassa, Hevaalla ja Tyrössä äänittämässä runosävelmiä fonogrammilla. Leevi Madetoja ja Lauri Ikonen lähetettiin vielä vuonna 1907 Länsi-Inkeriin "kansansävelmiä" etsimään, mutta he luovuttivatkin SKS:lle ainoastaan 147 venäläistä sävelmää, ilmeisesti lähinnä inkeroisilta ja inkerinsuomalaisilta. Runosävelmien tallentamatta tai puhtaaksikirjoittamatta jättäminen johtui siitä, että he eivät Launiksen jäljiltä löytäneet enää tallentamattomia melodiatyyppejä - toisintojen tallentamista kun ei tuonaikaisen musiikkitieteen piirissä pidetty tarpeellisena. (Asplund 1976, 15-16; Ikonen \& Madetoja 1909; Suomi 1908, 7. $)^{57}$

Armas Otto Väisänen (1985; 1990, 48-55) piipahti Länsi-Inkerissä vuonna 1914 matkallaan Viron Setumaalta Mordvaan. Ainoastaan seitsemässä päivässä hän keräsi kymmenestä Narvusin ja Soikkolan kylästä 163 sävelmää kolmeltakymmeneltä esittäjältä fonogrammeille ja nuottivihkoonsa sekä seitsemän vahalieriöllistä soittoa, puhetta ja laulua Kattilasta. Varsinaisen kenttätyön lisäksi Väisänen äänit-

\footnotetext{
${ }^{55}$ MV Alava 1892; SKS KRA Alava. Alavan keruutyöstä ks. myös Salminen 1929a, 75-88.

${ }^{56}$ MV Setälä 1909.

${ }^{57}$ KRA Ikonen \& Madetoja 1907.
} 
ti vuonna 1931 Helsingin laulujuhlille esiintymään tulleelta Jevdokia Räkälältä ja narvusilaiskuorolta kahdelle vahalieriölle viisi runoa. ${ }^{58}$ Väisäsen Inkerin matkan tehtävänä oli paimensävelmien tallentaminen, joten runolaulua ei ole joukossa paljoakaan. Tällaisena kokoelma tarjoaa kuitenkin ikkunan muutoin hyvin vähälle tallennukselle jääneisiin miesten hallitsemiin soiton ja laulun lajeihin. Paitsi erilaisia paimensävelmiä, kertyi kokoelmaan esimerkiksi tanssisävelmiä, venäläisten laulujen sävelmiä, marsseja, itkuvirttä muistuttavia "halleita soittoja", seitsemän joko soitettua tai laulettua runosävelmää, itkuja ja muita sävelmiä. Suurin osa lauluistakin on truballa, soitulla tai pajupillillä soitettuja. Näiden yhteydessä Väisänen kirjoitti vihkoonsa laulun alkusanat sekä myös sävelmän, jos se poikkesi soitetusta versiosta. (Kallio 2011b.) ${ }^{59}$

Juho Lukkarinen (1911) keräsi runojen lisäksi runsaasti tietoja juhlatavoista ja uskomuksista vuonna 1909 Narvusista, Soikkolasta ja Kattilasta. Hänen kenttätöidensä pohjalta kirjoittamansa kuvaus erityisesti Iilian ja Pedron praasnikoista on praasnikkavirsien analyysin kannalta merkittävä. Tärkeä on myös Lukkarisen tallentama laaja valokuva-aineisto, jonka yhteydessä on usein hyvinkin pitkiä kuvatekstejä. ${ }^{60}$

Venäjän vallankumoukset ja Suomen itsenäistyminen sulkivat Inkerin suomalaisilta kerääjiltä. Muutamissa Viron puolelle jääneissä Narvusin kylissä, niin kutsutussa Viron Inkerissä, kulkivat suomalaiset folkloristit 1930-luvulla: tämän työn kannalta keskeisimpiä ovat Väinö ja Kaarina Salminen, Martti Haavio ja Elsa Enäjärvi-Haavio sekä Lauri ja Aili Laiho (myöh. Simonsuuri). Lisäksi käytössäni on Aleksander Angerian, Sulo Haltsosen, Ilmari Kohtamäen sekä T. Koilon tallentamia käsikirjoitusaineistoja. Siinä, missä pääosa kerääjistä ennen ensimmäistä maailmansotaa oli ylioppilaita, lähti Viron Inkeriin myös nuoria maistereita, tohtoreita ja Kansanrunousarkiston työntekijöitä. Tendenssinä oli tallentaa aiempaa enemmän tietoja runojen käytöstä ja laulajista. Viro ja Inkerin osalta Viron Inkeri olivat ainoat suomalaisille avoimet paikat kuulla runolaulua 1930-luvulla - Suomen alueella ei vanhaa runoa juuri laulettu lukuun ottamatta joitakuita Venäjän Karjalasta ja Inkeristä tulleita pakolaisia. ${ }^{61}$

\footnotetext{
${ }^{58}$ SKSÄ A 507/8-9.

${ }^{59}$ Armas Otto Väisänen (1890-1969) oli Armas Launiksen ja Ilmari Krohnin oppilas ja suomalaisen kansanmusiikin tutkimuksen kolmas uranuurtaja. Väisänen toimi monella taholla: kansanmusiikin kerääjänä, viulistina, Launiksen perustamien kansankonservatorioiden johtajana, Kalevalaseuran sihteerinä, muissa järjestöissä ja vanhoilla päivillään musiikkitieteen professorina. Hän kirjoitti useita artikkeleita kalevalamittaisesta laulusta (Väisänen 1990, 58-123). Ennen Inkerin retkeä hänellä oli ulkomaan keruukokemusta kolmelta Setumaan retkeltä vuosina 1912, 1913 ja 1914. (Väisäsestä enemmän ks. Laitinen 2003b, 257-263; Leisiö 1992; Manninen 1982; Pekkilä 1990; Piela et. al. 2011. Väisäsen Inkerissä tallentamista aineistoista ks. Kallio 2011b; SKS KRA Väisänen 1915 e; SKSÄ A 302/91-303/150, 530/10, 13; MV Väisänen 1914; SKS KRA Väisänen laatikko III 3 a, aa, b, ja c.)

${ }^{60}$ MV Lukkarinen 1909.

${ }^{61}$ Haavioista ja Laihoista enemmän jäljempänä. Aineistoista ks. SKS KRA ERA Angeria 1926; MV Kohtamäki 1931; SKS KRA Enäjärvi-Haavio 1936; Haavio 1936; Haltsonen 1932; Kohtamäki 1931; Koilo 1937; Laiho A. 1937 ja 1938; Laiho L 1937 ja 1938; Salminen V. 1931; Salminen K. 1931.
} 
Väinö Salminen oli keskeisin inkeriläisen runoaineiston systematisoija ja varhainen tutkija. Hän toimitti Suomen Kansan Vanhojen Runojen Inkerin osat ja perehtyi erityisesti hälauluihin $(1916,1917)$. Hän oli ensimmäinen, joka painotti etnisten ryhmien merkitystä myös runoja tutkittaessa, tosin toden teolla vasta häärunotutkimustensa jälkeen (Salminen 1929a, 1929b, 1929c, 1930, 1934; ks. kuitenkin 1917, 27-28). ${ }^{62}$ Salminen teki kenttätöitä Narvusissa ja Soikkolassa 26-vuotiaana ylioppilaana vuonna 1906 ja Viron Inkerissä vaimonsa Kaarina Salmisen kanssa kesinä 1930 ja 1931. Salmiset olivat ensimmäiset suomalaisista 1930-luvun kerääistä Viron Inkerissä. Väinö Salminen (1931b, 37) etsi erityisesti tietoja runojen esittämisestä. Omakohtaisia mainintoja onkin useissa hänen tutkimuksissaan. Yleensä näille ei kuitenkaan löydy vastinetta hänen arkistomuistiinpanoistaan, eivätkä tiedot esittämisestä myöskään kohoa tutkimusten keskiöön. Joko Salminen teki muistiinpanoja erilliseen vihkoon tai päiväkirjaan, jota ei luovuttanut arkistoon, tai sitten hän ei kirjoittanut kaikkia tietoja ylös vaan säilytti ne muistissaan, ne kun eivät arkistoa tuona aikana vielä erityisesti kiinnostaneet. Tämä tekee tiedonmurusten paikantamisesta vaikeaa.

Tämän tutkimuksen keskeisistä laulajista erityisesti Darja Lehti kiersi 1920-luvulla ympäri Viroa esiintymässä musiikkimuseon johtaja August Pulstin järjestämillä kansanmusiikkikiertuella. Tällaisella kiertueella vuonna 1922 Cyrillus Kreek äänitti Lehdeltä fonogrammille viisi laulunpätkää. ${ }^{33}$ Samanlaisella kiertueella vuonna 1932 äänitti Herbert Tampere ääniteaineiston ainoan miehen laulaman sävelmän Peeter Pugatsevilta. ${ }^{64}$ Kontekstitiedottomaksi jäänyt kolmen laulunpätkän fonogrammiäänitys samoilta vuosikymmeniltä on Valpuri Vohdalta myöhemmin äänitettyjen laulujen perusteella tunnistettavissa tämän laulamaksi. Vohdan muistelman mukaan äänittäjä oli Julius Mägiste, joka kävi ”tääl laului ottamassa truban sissää" eli fonografin äänitystorveen. ${ }^{65}$ Teknisesti fonogrammeja parempia ja pidempiä nauhoituksia tekivät Aili ja Lauri Laiho vuonna 1937 Vohdan, Lehden ja neljän muun laulajan kanssa Tallinnassa, ja vuonna 1938 Kansatieteellinen filmi oy kuvasi alueella kaksi kansatieteellistä elokuvaa (Järvinen 1990; Mäkinen 2008). Elokuvien ohjaaja Eino Mäkinen otti myös valokuvia elokuvien aihepiireistä: taloista, häärituaalista, tanssista sekä erilaisten puutöiden tekemisestä. ${ }^{66}$

\footnotetext{
${ }^{62}$ Jouko Hautala (1954, esim. 347) luonnehtii Salmisen tuotannon yleissävyä poleemiseksi, vanhat oletukset kiistäväksi. Tiiviisti maantieteellis-historiallisen menetelmän kehyksessä pysytellyt Salminen $(1929 a, 216)$ pyrki laajentamaan menetelmän puitteita ja totesi kriittisesti toivovansa, "että runojen tutkijat karttavat käsittelemästä Inkeriä altaana ja runojen huuhdinvetenä, joka huljuu sinne käsin, minne altaan luulotellaan kulloinkin olevan kallellaan. Olen yrittänyt osoittaa [...] että eri runoilla on eri levenemistiet ja että on havaittavissa myöskin n.s. pystysuoraa perintöä."

${ }^{63}$ ERA, Fon. 207-209; ERA, ETMM M 234:1, 122-123.

${ }^{64}$ ERA, Fon. 358. Pugatsevin äänenmuodostus kuulostaa modernimmalta, kuorolaulun tai klassisen laulun ihanteita tapailevalta, eikä runon rytminen rakenne ole aivan yhtä säännöllinen kuin yleensä samaa melodiatyyppiä käyttävillä naislaulajilla. 10-säkeisen runon minä on tyttö: Kui miä kasvelin kanaine, noisin nuori neijukkaine (Jalka kiveen).

${ }^{65}$ ERA, Fon. 372; vrt. SKSÄ L 90, 95d, 100b; SKS KRA Laiho L. 5410.

${ }^{66}$ KAVA Mäkinen 1938 Inkeri.
} 
Vuosina 1937 ja 1938 Ulla Mannonen kirjoitti runoja Soikkolasta kotoisin olevilta, Suomeen 20-luvulla paenneilta inkeroisilta, lähinnä Anni Moisefilta, Anni Joutsilta sekä Pauli ja Pauliina Reposelta. ${ }^{67}$ Kati Mikkolan (2009, 101-103, 108-109; (tulossa)) mukaan Mannosen paikoin inhorealistisetkin kuvaukset keruumatkoillaan näkemästä ovat vastakkaisia aikakaudelle tyypillisten kansaa ja luontoa ihannoivien keruukuvausten joukossa. Mannonen valittaa haastateltaviensa epäluuloisuutta ja pelokkuutta sekä kieliongelmia; hän myös havainnoi tarkasti paikallisten suhtautumista herraskaisempiin kerääjiin sekä erilaisia sosiaalisten statusten ja sukupuolinormien keruutyölle aiheuttamia ongelmia. Mannonen oli itseoppinut kansankerääjä, joka vuodesta 1934 lähetti keräämiään aineistoja Kansanrunousarkistoon. Kansanrunousarkiston johtaja Martti Haavio kannusti häntä tallentamaan myös runojen taustatietoja.

Toisen maailmansodan aikana kansakouluntarkastaja Antti Hämäläinen (1944) otti paljon valokuvia Länsi- ja Keski-Inkerin sotatoimialueilla, mutta kuvista suuri osa jäi ilman tietoja kohteistaan. ${ }^{68}$ Vuosina $1937-1956$ aktiivisesti toiminut suurkerääjä Sylvi Sääski keräsi runoja ja kontekstitietoja vuonna 1944 eri puolille Suomea sodan jaloista siirretyiltä inkeriläisiltä, yhteensä 144 informantilta, joiden joukossa oli myös Soikkolan ja Narvusin kylien asukkaita. (Mettomäki 1982, erit. 14-20; Pimiä 2009, erit. 202-203). ${ }^{69}$

Vuodesta 1957 lähtien virolaiset, petroskoilaiset ja leningradilaiset tutkijat tekivät tallennuksia Inkerissä, runolaulun osalta erityisesti Soikkolassa ja Laukaansuussa. Äänitekeruut etenkin vatjalaisten parissa aloitti kansankulttuurista laajemminkin kiinnostunut virolainen kielitieteilijä-folkloristi Paul Ariste (1986; 2005). Hänen oppilaansa kielitieteilijä Arvo Laanest $(1966,1986)$ teki töitä ennen kaikkea inkeroisten kanssa. Kielentutkijoiden ohella virolaiset folkloristit ja musiikintutkijat, erityisesti Ingrid Rüütel $(1977,1982)$ ovat tallentaneet ja tutkineet alueen vatjalaisia ja inkeroisia. (Ks. myös Heinsoo 1995, 152-153.) Petroskoilaiset, Inkeristä kotoisin olevat Eino Kiuru, Terttu Koski ja Elina Kylmäsuu (1974; ks. myös Kiuru 1990) tekivät alueella äänityksiä vuodesta 1965 eteenpäin ja julkaisivat nauhoituksistaan ainesjulkaisun. Vuonna 1972 pietarilainen A. G. Gomon (1977) teki oppilaineen kenttätöitä Soikkolan ja Narvusin alueilla. Monet näistä nauhoittajista äänittivät samoja laulajia, etenkin vatjalaista Oudekki Figurovaa Joenperältä ja inkeroislaulaja Jekaterina Aleksandrovaa Soikkolan Loan kylästä.

\footnotetext{
${ }^{67}$ SKS KRA Mannonen 9752, ks. myös 5703, 5726. Mannonen kertoo kaikkien soikkolalaisten haastateltaviensa olleen ortodokseja. He osasivat lukea venäjää mutta eivät suomea. Hän vakuuttaa näin runojen aitoutta ja suullisuutta. (SKS KRA Mannonen 9752.) Joissain lauluissa näyttää olevan silti selkeitä vaikutteita Kalevalasta (esim. häälauluja SKS KRA Mannonen 9782, 9792 (Anni Moisef); 9797 (Anni Stepanof); karjanlaskuloitsu 9801, mikä ei tietenkään vähennä niiden tutkimuksellista arvoa. Haastateltavat olivat tulleet Suomeen pakolaisina 1920-luvulla, ja "kaikki heistä koettavat puhua täällä puhdasta suomea ja jäljitellä kirjakieltä” (SKS KRA Mannonen 9752). Monet muistelivat erityisesti äitiensä laulaneen runoja, vaikka nuoret lauloivat heidän aikanaan jo paljon venäjäksi, erityisesti "tantsupaikoilla," kertoi Anni Moisef (SKS KRA Mannonen 9785). Suomeen tulleiden inkeroisten lapset eivät Mannosen mukaan osanneet enää äidinkieltään tai lauluja: "ovat supi Suomalaisia" (SKS KRA Mannonen 9752).

${ }^{68}$ SKS KRA Kuva-arkisto Hämäläinen 1943, MV Hämäläinen 1943. Kuvien paikkatiedot ovat osin erilaisia näissä arkistoissa olevissa samankin kuvan vedoksissa.

${ }^{69}$ Sääski nimesi kolme länsi-inkeriläistä kertojaansa useammassa yhteydessä inkeroisiksi, mutta ei ketään inkerinsuomalaiseksi tai luterilaiseksi. Nimien ja asuinpaikkojen perusteella lähes kaikki heistä vaikuttavat inkeroisilta. (SKS KRA Sääski 5336, 5490, 5865.)
} 
Suomen ja Ruotsin puolella haastattelivat erityisesti kielentutkijat ja folkloristit 1930-luvulta lähtien sekä inkerinsuomalaisia että inkeroisiin kuuluvia inkeriläispakolaisia. Suuret toisen maailmansodan jälkeen tuotetut ääniteaineistot, joita ei tämän tutkimuksen puitteissa ole ollut mahdollista käydä systemaattisesti läpi, on tallennettu ainakin Kotimaisten Kielten Tutkimuskeskuksen Suomen kielen nauhoitearkistoon sekä Turun yliopiston Inkerin henkisen kansanperinteen arkistoon. (Ks. Lehto 1996, 19-22; Nenola 2002, 22; Nirvi 1971, VI-XII; Virtaranta 1978, 7-21; 1993, 37-54, 202-207.) Inkeri oli suomalaistutkijoille "suljettu alue 1990luvun alkuun saakka, toisin kuin Karjala, jonne suomalaiset tutkijat pääsivät käymään 1960-luvulta lähtien" (Nenola 2002, 44). 1990-luvulta alkaen suomalaisia tutkijoita kulki jälleen Inkerin alueella, mutta kalevalamittaista runoa ei silloin enää juuri löytynyt tallennettavaksi (Asplund 1992a, 163-165; (tulossa); Harvilahti 1991, 220-221).

\section{RUNONKERUIDEN LUONTEESTA}

Runonkeruiden painotukset vaihtelivat kerääjittäin, alueittain ja aikakausittain. Eri aikoina tallennettuja aineistoja sitovat kuitenkin toisiinsa monenlaiset jatkuvuudet. Suomalaiskerääjät olivat vaihtelevissa määrin tietoisia edeltäjistään ja aiemmista keräelmistä. Lähes poikkeuksetta retket sijoittuivat sulan maan aikaan, kevääseen ja kesään. Kerääjät kulkivat usein samoja reittejä, yöpyivät samoissa taloissa ja haastattelivat osin samoja ihmisiä. Jo Europaeus ja Reinholm tapasivat ensimmäisellä Inkerin retkellään Sjögrenin "jolta saimme joitakuita hyviä tietoja," ja myöhemmin he kohtasivat Inkerin ensimmäisen etnografisen kartan laatijan von Köppenin. ${ }^{70}$ Lukkari Thaluksen kodista Narvusin kirkonkylällä eli Kosemkinassa muodostui varsinainen Länsi-Inkerin kävijöiden kantapaikka, kuten monista muistakin pappiloista ja lukkariloista. ${ }^{71}$

Parhaimpia laulajia kävivät tallentamassa useat kerääjät. Esimerkiksi Aili Laihon päiväkirjasta näkee Laihojen suunnanneen suoraan toisten kerääjien hyviksi havaitsemien laulajien luokse, mutta myös etsineen itse uusia taitajia (Järvinen 1990). Laiho $(1938,40)$ kertoo pyrkineensä välttämään tietyltä laulajalta jo aiemmin tallennettujen runojen muistiinpanemista. Joissain tapauksissa yhden laulajan tallenteet hajautuvat pitkällekin aikavälille. Esimerkiksi Juljaana Pohjalaista laulattivat Vihtori Alava vuonna 1891 ja useat 1930-luvun kerääjät neljäkymmentä vuotta myöhemmin (Salminen 1931a). Valpuri Vohta kertoi nuorena tyttönä 1900-luvun alussa laulaneensa laulun kahdelle nuorelle suomalaiskerääjälle, vaikka hänen nimeään ei ole näihin aineistoihin tallennettu. Virolaisille hän lauloi 1920-luvulla,

\footnotetext{
${ }^{70}$ Suometar 27.10.1847 n:o 43, 2-3.

${ }^{71}$ Ensimmäisenä hänen perheensä luokse majoittautunutta Volmari Porkkaa seurasivat ainakin Alava, Ruotsalainen, Tarkiainen, Launis, Madetoja, Ikonen ja Väisänen (Laiho 1940, 233-234; Porkka 1886, 164; Väisänen 1985, 9). Lisäksi esimerkiksi Launista neuvottiin Fyödermaan (Vyötermaan) kylässä "menemään yöksi myllärin Matille. [...] Samassa paikassa kuului edellisinä vuosina olleen myös Ruotsalaisen ja W. Tarkiaisen." Kallivieressä metsänvartija Paavo Säkki toimi isäntänä monelle 1930-luvun kerääjälle. (Järvinen 1990, 23; Simonsuuri 1956; KK Coll. 123.22 Launis 1903, 7; ks. myös esim. Tallqvist \& Törneroos 1904, 394; SKS KRA Väisänen laatikko III 3aa, s. 3-5, 8-11; 3b, s. 4; 3c, s. 6.
} 
suomalaiskerääjille 1930-luvulla ja sotien jälkeen Suomessa ja Ruotsissa häntä haastattelivat Lauri Honko ja Juha Pentikäinen, Kari Laukkanen ja Urpo Vento sekä Pertti Virtaranta $(1978,14-15)$. (Ks. Liite 1.) Tarinat kerääjistä elivät myös paikallisyhteisöissä: esimerkiksi Volmari Porkasta kerrottiin vielä yli viisikymmentä vuotta tämän keruuretkien jälkeen (Laiho 1937).

Suomalaiskerääjien matkakertomukset ovat kuitenkin täynnä mainintoja paikallisten varovaisuudesta ja yhteistyöhaluttomuudesta. "Asujanten epäluuloisuus - he minua tervehtivät yleensä antikristuksena - ja sitä seuraava pelko ja varominen tekivät työni tuntuvasti vaikeammaksi," kertoi Ruotsalainen $(1901,80)$. Antikristus oli useimmin kerääjästä käytetty termi, mutta yhtälailla saatettiin kerääjää nimittää Pirun lähettämäksi "hihhulipapiksi", vakoojaksi tai koleran kantajaksi. (Esim. Forsberg 1893, 55, 56; Groundstroem 1904, 412; Länkelä 1904, 274-275; Porkka 1886, 153; Salminen 1929a, 23; Saxbäck 1904, 346.) Näyttää siltä, että suhteet paikallisiin riippuivat yhtäältä kerääjän kokemuksesta, persoonasta ja asenteista, toisaalta alueen yleisestä poliittisesta tilanteesta sekä yksittäisten ihmisten, kuten pappien, kylänvanhimpien ja virkamiesten asenteista. Yleiseen tilanteeseen liittyivät esimerkiksi muutokset maanomistusolosuhteissa, tautiepidemiat, yleinen taloudellinen ja uskonnollinen tilanne sekä herätysliikkeet. (Ks. esim. Forsberg 1892; 1893; Niemi 1904; Porkka 1886; ks. myös Harvilahti 1992a, 13-14.) Pappien tai kylän johtomiesten suosion saavuttaminen helpotti kerääjien työtä, samoin läheisempi tutustuminen ja ylipäätään asukkaiden tottuminen runonkeruuseen (Porkka 1886, 153, 160; Salminen 1929a, 11-18; Saxbäck 1904, 363; Tallqvist \& Törneroos 1904, 366, 370). Alavaan (Forsberg 1893, 56; ks. myös Porkka 1886, 164: Väisänen 1990, 157) kohdistuneista antikristus-maininnoista huolimatta kertoo tämä Soikkolasta, että

kansa on erinomaisen vilkasta ja iloista, vaikka köyhyys onkin monellakin hyvin tuntuva kohta. Ennen on kuulemma Soikkolainen ollut hyvin epäluuloinen vierasta kohtaan, mutta ei nykyään enää. Ystävällisyyttä siellä nyt tapaat joka puolella.

Vaikka kerääjät tulkitsivat pelot usein lapsellisuudeksi ja takapajuisuudeksi, oli ihmisten varovaisuus usein perusteltua ja aiheellista. Keruiden aikana yhteiskuntajärjestys oli liikkeessä, paikalliset viranomaiset eivät suhtautuneet aina suopeasti keruutoimintaan, lahkoja ja erilaisia vallankumousliikkeitä esiintyi ja ihmisiä todellakin kuoli kulkumiestenkin mukana liikkuneisiin tautiepidemioihin.

Hyviin suhteisiin vaikuttavia tekijöitä oli useita. Esimerkiksi Lauri ja Aili Laihoon näytetään suhtautuneen poikkeuksellisen suosiollisesti, mihin voi henkilökohtaisten ominaisuuksien lisäksi olla useita syitä. Alueella oli jo yli kahdeksankymmenen vuoden ajan käynyt suomalaisia kerääjiä. Laihot olivat kuitenkin ensimmäisiä suomen itämurteiden puhujia, kotoisin Kannakselta, ja niinpä paikalliset ihmettelivät, kuinka helppoa Laihojen kanssa oli keskustella. Lisäksi he osasivat hyvin viroa, ja tulivat sitä kautta hyvin toimeen 1930-luvun virolaisten viranomaisten kanssa. (Järvinen 1990, 29-30.) Aili Laihon paljon käyttämää muodikasta pukua paikalliset ihmettelevät sarafanaksi, jota erityisesti inkeroisnaiset aiemmin olivat venäläisten tapaan käyttäneet (mts. 16, 33). Laiho arveli, että moni myös tulkitsi laulujen 
levyttämissuunnitelman ansiomahdollisuudeksi, sillä levytyksiin osallistuneille maksettiin palkkio (mts. 27, 31-33). Keskeinen tekijä matkojen runsaille tuloksille olikin selvästi Tallinnaan suuntautunut levytysmatka, jonka jälkeen mukana olleet laulajat ja kerääjät kokivat ystävystyneensä, ja nekin paikalliset, "jotka eivät mukana olleet, suhtautuivat asiaan uteliaan suopeasti ja kertoilivat puolestaan auliisti tietojaan" (Laiho 1937, 24; ks. myös 1961, 24) ${ }^{72}$ Aili Laihon päiväkirjamerkintä kertoo myös keruuretken pituuden ja vuorovaikutussuhteiden tärkeydestä: "Mitä lähemmäs ihmisiä sekä heidän ilojaan ja surujaan pääsee, sitä paremmin he kertovat keräilijöille. Mutta lähestyminen tarvitsee aikaa. Nyt vasta, kun ovat jo lähdön hetket käsillä, tunnemme seudun väestön ja olot niin, että työ käy sujuvasti.” (Järvinen 1990, 40.) Esimerkiksi Launiksen ja Alavan matkakertomuksissa näyttäytyy myös vastavuoroisuuden merkitys: Launis yllätti paikalliset pyrkimällä osallistumaan näiden töihin ja kadonneen pojan etsintöihin. Hän toimi Kaipaalan kylän jumalanpalveluksen lukkarina, mutta opetteli ja lauloi yhtä lailla ortodoksienkin kirkossaan oppimia lauluja. ${ }^{73}$ Alava taas opetti paikallisille suomalaisia kansanlauluja. ${ }^{74}$

Vaikuttaa siltä, että suomalaiskerääjien oli keskimäärin helpompaa tehdä tallennustyötä inkerinsuomalaisten parissa kuin inkeroisten ja vatjalaisten. Luterilaisten kohdalla yhteinen uskonto ja jollain tavoin samaan ryhmään määrittyminen ilmeisesti auttoi keruutyötä, kuten esimerkiksi Volmari Porkan $(1886,164)$ kuvauksesta on luettavissa:

Vaikka Soikkolalainen ischori on yhtä epäluuloinen ja epäuskoinen kuin ischorit muuallakin, niin kuitenkin, jos tutustut vähän hänen kanssansa, hän on herttaisempia ihmisiä maailmassa. Sama on myös luterilaisten laita, joista kristinuskon valo on karkoittanut paljon harhaisia käsitteitä.

Kuten Aili Nenola $(2002,20)$ on huomauttanut, on syytä suhtautua varovasti kerääjien joskus värikkäisiinkin kuvauksiin suomenuskoisten sivistyneemmästä ja edistyksellisemmästä elämäntavasta. Siinä missä suomalaiset kerääjät valittivat etenkin ortodoksiväestön nuivaa suhtautumista, oli tilanne venäläiseltä puolelta katsottuna päinvastainen. Venäläinen professori D. Zolotarev teki kenttätöitä Länsi-Inkerissä 1920-luvun puolivälissä ja kertoi, että inkerinsuomalaisten kanssa oli vaikeampi työskennellä kuin inkeroisten, sillä edelliset "olivat vähemmän seurallisia ja heihin oli vaikeampi saada kontakti" - monet kieltäytyivät yhteistyöstä kokonaan (Zadneprovskaya 1999, 90).

Ennen toista maailmansotaa kulkeneiden kerääjien keskeisenä pyrkimyksenä oli tallentaa muodoltaan kiinteitä runoja: toistuvaa, yleisesti tunnettua, Kalevalan kaltaista, mahdollisimman vanhaksi katsottua perinnettä (vrt. Virosta Kalkun 2011). Laulajat nähtiin pitkään ennen kaikkea runojen enemmän tai vähemmän uskollisina ja taitavina säilyttäjinä:

\footnotetext{
${ }^{72}$ SKS KRA L. Laiho 5422.

${ }^{73}$ KK Coll. 123.22. Launis 1903, 18, 20, 42, 44, 59-61.

${ }^{74}$ KRA Alava VII B, 21, 24, 42.
} 
Se runoaines, jonka Inkerin naiset ovat säilyttäneet ja jättävät jälkimaailmalle [...] muodostaa arvokkaan lisän siihen kalevalaiseen runouteen, josta kansan-eepoksemme on kokoonpantu. (Alava 1916, 9)

Satu Gröndahl (1997, 42-44, 177-180) on todennut inkeriläisten runojen vastanneen huonosti kerääjien etsimää ja varhaisten tutkijoiden arvostamaa jylhän miehistä sankarirunoutta: laulajat olivat naisia, laulut lyyrisesti sävyttyneitä. Keruun päämäärät tosin vaihtelivat ajan myötä. Europaeuksen päämääränä oli vielä kerätä runoainesta Kalevalan toisen laitoksen tarpeisiin; Alavan ja Porkan tehtävänä oli runojen perinpohjainen "jälkikorjuu" ja 1900-luvun kerääjät näyttävät lähinnä tehneen aiempaa joko konteksti- ja laulajatietojen, runojen käytön, sävelmien tai rituaalien osalta täydentäviä tallennuksia (Kuusi 1997, erit. LIII-LVII; Salminen 1929a, 10-112).

"Kansa" ei ollut helposti idealisoitavissa. SKS:n pöytäkirja heijastelee Länkelän (1904, 270-301) matkakertomusta:

Sitten siirtyi [Länkelä] Soikkulan kappeliin, josta, epä-uskoisen ja typerän, mutta lauluja taitavan kansan keskellä pari viikkoa taisteltuansa [...]. [A]lusta loppuun asti kohtaa meitä naissä keräyksissä sama ylen tunnettu ja ylistetty Suomen sulo runotar, joka kansallemme on niin katoomattoman ja ikuisen kunnian tuottanut. [...] Kosemkinasta kokoomansa laulut ovat jo kylliksi arvollisia ja Soikkulasta saadut ylimalkaansa niitäkin paremmat. (Suomi 1859, 388-389.)

Ristiriita on hätkähdyttävä ja heijastuu monista muistakin varhaisista matkakertomuksista. Runonkerääjiin epäluuloisimmin suhtautunut, venäläistynyt ja toisenuskoinen inkeroisväestö lauloi parhaita "suomalaisia" runoja.

Sävelmien ja runojen keruussa pätivät osittain samat säännöt. Laulajan itse tekemäksi tiedetty ei kertonut riittävästi perinteestä ollakseen välttämättä tallentamisen arvoinen. Väisänen (1917, 17; ks. myös Salminen 1929a) kertoo, että myös "sellaisia, joilta puuttui taiteellista viehätystä, samoin ennen kerättyjen toisintoja tai alkuperänsä puolesta vieraiksi otaksuttuja sävelmiä ei pidetty muistiinpanemisen arvoisina." SKS hyväksyi niin runoja kuin sävelmiäkin kokoelmiinsa vain valikoiden (ks. Harvilahti 1992a, 167-169; Salminen 1934, 174; Tarkka 2005, 35-37). Toisaalta huomion kiinnittyminen alueelliseen ja ajalliseen variaatioon tarkensi runotekstien keruuvaatimuksia jo 1800-luvun lopulla: Alavaa ja Porkka ohjeistettiin jo merkitsemään muistiin kaikki kuulemansa vähänkin toisistaan eroavat toisinnot. Vaatimus oli tietenkin pohjimmiltaan mahdoton ja olisi tarkkaan noudatettuna johtanut loputtomaan tallentamiseen. (Harvilahti 1992a, 168; Kuusi 1997; ks. myös Porkka 1886, 168.)

Päätarkoituksena oli 1800-luvun lopulta lähtien kerätä aineistoa historiallisia kehitys- ja lainautumissuhteita hahmottavan tutkimuksen tarpeeseen, ei esimerkiksi yksilöllisen tai esityskohtaisen variaation analyysiin. Sävelmämuistiinpanoissa näkyy tallennustavan rajoitteiden lisäksi jotain myös kerääjien suhtautumisesta me- 
lodiseen ja rytmiseen muunteluun: lähes kaikki käsivaralta tehdyt nuotinnokset Inkeristä ovat säkeen tai kahden mittaisia pelkistyksiä ja kuten Anneli Asplund $(1981,28)$ toteaa, esimerkiksi "pienet melismat saattoivat helposti jäädä muistiinpanijalta huomiotta." Kiinnostuksen kohteet kuitenkin vaihtelivat kerääjittäin, ja moni tuli tallentaneeksi sellaisiakin runoja, sävelmiä tai huomioita, joita ei keruuohjeissa mainittu.

Perinteen haipuminen oli tallentajien parissa yleinen ja myös ilmeisen perusteltu huoli. Runon laulamisen väheneminen kuvastuu lähes kaikista kuvauksista ja matkakertomuksista. Ilmeisiä syitä oli useita: sosiaaliset ja yhteiskunnalliset muutokset 1800-luvun taitteen Venäjällä, pitkäaikainen kirkon taholta tullut valistustyö, uskonnolliset lahkot sekä uudet laulut ja muu musiikkiperinne. (Laiho 1940, 222, 225-226; Nevalainen 1991a, 165; Survo 2001) ${ }^{75}$ Kerääjillä huoli perinteen ja suomalaisuuden katoamisesta sulautui yhteen: syypäänä nähtiin sivistys, mutta ennen kaikkea venäläisyys. Esimerkiksi Max Engman $(1991,177)$ kuitenkin toteaa, että "Pietarista leviävä 'turmellus' ja 'venäläisyys' oli itse asiassa suurkaupungin vaikutusta, 'modernin' elämäntavan säteilyä,' ei niinkään venäläisyyttä.

Vuosisatoja suullisena kulkenut oli kerääjien kannalta arvokkaampaa kuin vastikään kirjoista opittu, vaikka nykynäkökulmasta katsottuna juuri suullisen ja kirjallisen rajapinnat ja siirtymät ovat mielenkiintoisia (esim. Tarkka 1999, 56-63; DuBois 1996). Ruth Finnegan (1977, 19, 24-51; ks. myös Anttonen 2005) kritisoi alkuaikojen folkloristiikkaa toiseuden ja eksotiikan kaipuusta. Hänen mukaansa suullinen runous sijoitettiin primitiiviseen, yhteisölliseen, puhtaaseen, perinteiseen, luonnolliseen, alkeelliseen ja homogeeniseen yhteisöön, ja todelliset olosuhteet jäivät ymmärtämättä. Arno Survo $(2001,33)$ näkee Inkerin symbolisena periferiana, jonne kerääjät heijastivat omia toiveitaan ja pelkojaan: "Inkerin runokylien kartalta vuodelta 1931 ei löydy muuta kuin hajanaisia asutuksia metropolin ympäristössä: metsäsuomalainen kuvitelma ja käsittämätön toiseus sen keskellä.” Monikielisyys, venäläisyys ja alueen modernisoituminen - palkkatyö, tehtaat, ihmisten liikkuvuus - olivat piirteitä, joihin monien kerääjien oli ilmeisen vaikea suhtautua.

Perinteinen antropologinen, folkloristinen ja etnomusikologinen kenttätyö ja tutkimus keskittyivät usein näkyvän miesten julkisen tai rituaalisen kulttuurin ympärille. Pitkälti tämä johtui tallentajien sukupuolesta ja arvostuksista, mutta miestutkijoiden oli myös helpompi päästä sisälle miesten yhteisöihin kuin naisten pariin, ja julkisiin tilanteisiin helpommin kuin arkisiin ja yksityisiin. (Esim. Nettl 1983, 404-418; Hylland Eriksen 2001, 125; Tarkka 2005, 35.) Inkerissä suuri osa kalevalamittaisista lauluista eli kuitenkin tallennusajankohtana naisten julkisena perinteenä, joten tilanne oli hieman erilainen. Ei voida tietenkään olettaa, että naiset olisivat halunneet laulaa yhteisön ulkopuolisille mieskerääjille kaikkea taitamaansa. Arkisia lajeja kuten kehtolauluja ei paljoakaan tallennettu - ja kerääjien

${ }^{75}$ Matkakertomuksista ks. esim. Launis 1904; 1907; 1905: 86, 90; Porkka 1886, 152; Ruotsalainen 1901; vrt. Venäjällä Čistov 1976a, 171. 
matkakertomuksissa on myös kuvauksia laulamisesta kieltäytymisestä ja toisten laulamisen kieltämisestä. Esimerkiksi Tatjana Jegorova lauloi Laihoille monta runoa ja toimi myös yhtenä Tallinnan äänitysten esilaulajista, vaikka aikaisempien tallentajien muistiinpanoissa häntä ei juuri tapaa. Matkan jälkeen

Tatjana kertoili, miten ensin oli ujostellut suomalaisia vieraitaan, mutta nyt "ollaa nii tuttavat" Tallinnan äänilevytysmatkan jälkeen. Samalla sanoi yliop. [Osmo] Niemestä seuraavaa: "No, mitä mie, ku vieras mies tulloo, nii vaa vahin silmät harillaa ja pölkäsin - pari kolt lauluu saoin. - Vahin vaa, jot mänis pois." ${ }^{76}$

Jegorova ei ollut halunnut eikä uskaltanut laulaa vieraille miehille: vasta pariskuntana liikkuneet tallentajat voittivat hänen luottamuksensa. Hyvänkin laulajan runot saattoivat jäädä tallentamatta.

Inkeriläisen laulun kontekstissa on yllättäen vaikeampaa hahmottaa miesten kulttuuria kuin naisten, sillä miesten uudenaikaiseksi tai sopimattomaksi tulkittua laulua ei juuri tallennettu. Miesten laulut tulevat aineistossa esille lähinnä naisten satunnaisesti kertomana ja kuvaamana. (Heinonen 2008a.) Inkeriläistä runoa ovat sukupuolen tai naistutkimuksen näkökulmista eri tavoin lähestyneet erityisesti Satu Gröndahl (1997), Henni Ilomäki (1998), Aili Nenola(-Kallio) (1982, 2002) sekä Senni Timonen (2004).

\section{A. A. Borenius-Lähteenkorva}

Ensimmäisen laajemman sävelmäkokoelman Länsi-Inkeristä keräsi vuonna 1877 A. A. Borenius. ${ }^{77}$ Vaikka nuottien lukumäärä - kaksikymmentä lyhyttä sävelmää - ei ole suuri, on kokoelma ainutlaatuinen, sillä Borenius keräsi huolellisesti sekä laulujen tekstit että sävelmien perushahmot ja hän merkitsi muistiin myös joitain laulujen nimityksiä ja laulajien kommentteja. Kuten Itkonen (1936, 59, 63-65) toteaa, oli Borenius perusteellinen. Runomuistiinpanot ovat kielellisesti tarkkoja. Hän kirjoitti usein runon muistiin sekä sanelusta että laulusta ja tallensi myös tietoja laulajista.

Boreniuksen tullessa Länsi-Inkeriin hänellä oli jo 45 keski-inkeriläistä sävelmää ja 30 runoa tallennettuna. Keski- ja Länsi-Inkeristä kerättyjen aineistojen hahmottaminen kokonaisuutena on tarpeen, sillä vaikuttaa ilmeiseltä, että Borenius

\footnotetext{
${ }^{76}$ SKS KRA Laiho L. 5422. (No mitä minä, kun vieras mies tulee, niin vahdin vain silmät ammollaan ja pelkäsin - sanoin pari kolme laulua. - Vahdin vaan, että menisi pois.)

${ }^{77}$ Axel August Borenius (1846-1931) oli papin poika Porvoosta. Jo opiskeluaikanaan hän keräsi joitain kansansävelmiä. Valmistuttuaan filosofian kandidaatiksi Borenius lähti ensimmäiselle runonkeruuretkelleen Aunukseen ja Vienaan kielentutkija Arvid Genetzin matkakumppanina omilla varoillaan. SKS palkitsi kerääjän kunniapalkinnolla. Vuoden 1872 matka suuntautui suoraan Vienaan. Runosävelmien keruun kannalta merkittävimmät olivat vuoden 1877 kaksi sävelmänkeruumatkaa, ensimmäinen Kannakselle sekä Itä- ja Keski-Inkeriin ja toinen Keski- ja Länsi-Inkeriin, Viroon (erityisesti Setumaalle), Suomen Karjalaan, Raja-Karjalaan, Vienaan sekä Aunukseen. Inkeriin tullessaan Borenius oli siis jo hyvin perehtynyt etenkin vienankarjalaiseen runolauluun. Vuosina 1878-1897 Borenius teki vielä neljä matkaa Suomen sisälle sekä Kannakselle ja Raja-Karjalaan. Lisäksi hän keräsi sävelmiä ja joitain runoja myös muissa tarkoituksissa matkustaessaan.
} 
ei yleensä tallentanut useaan kertaan samantyyppistä sävelmää. ${ }^{78}$ Aineisto ei kerro tarkasti, missä paikoissa tietyn tyyppisiä sävelmiä on käytetty, vaan antaa yleiskuvan Keski- ja Länsi-Inkerin alueella ylimalkaan käytetyistä lauluista. Boreniuksen ensimmäiset Tyröstä keräämät sävelmät ovat kaikki venäläistyyppisiä refrengin eli kertauman sisältäviä sävelmiä. Hän keskittyi itselleen uusiin sävelmiin: tämän tyyppisiä sävelmiä ei nimittäin ole tallennettu idempää tai pohjoisempaa, Boreniuksen aikaisempien tallennusretkien seuduilta. Toisaalta näitä Länsi-Inkerissäkin yleisiä sävelmätyyppejä Borenius ei enää Soikkolasta kirjoittanut muistiin. Sävelmien paikkakuntakohtaisista käytöistä tai yleisyyksistä on tämänkaltaisen kokoelman varassa siis mahdotonta tehdä tarkempia päätelmiä.

Borenius jäi huolellisesta keruutyöstään ja merkittävistä tieteellisistä avauksistaan huolimatta syrjään kansallisten tieteiden kentällä. Vuodesta 1891 lähtien hän toimi koulutarkastajana ja opettajana. On arveltu hänen olleen liian perusteellinen ja hidas. Boreniuksen omiin kenttätöihin perustuva, ilmeisen merkittävä kirjoitus runosävelmistä on säilynyt ainoastaan lyhyenä sitaattina, mutta Jean Sibeliuksen hänen avullaan toimittama Kalevalan selitysteoksen lyhyt nuottiliite oli tieteellisesti edustavin varhaisista sävelmäjulkaisuista. (Itkonen 1936, 68-75, 83, 99-100; Laitinen 2003b, 23-52. ${ }^{79}$ Juuri Sibeliuksen kautta on jotain Boreniuksen runosävelmiin liittyvästä kokemuksesta saattanut siirtyä myös Armas Launikselle, joka varhaisten keruuvuosiensa aikoihin oli Sibeliuksen sävellysoppilas. ${ }^{80}$ Runokokoelmansa Borenius luovutti Suomalaisen Kirjallisuuden Seuralle vasta maaliskuussa 1906 ja sävelmäkokoelman seura lunasti häneltä vuoden 1909 marraskuussa Launiksen aloitteesta ilmeisesti Inkerin runosävelmien (Launis 1910a) sävelmätoimitustyötä varten (Suomi 1907, 7-11; Suomi 1910, 107, 206). Sekä Inkerin että Karjalan runosävelmien esipuheessa Launis (1910a, 1930) ylistää Boreniuksen työtä.

\section{Armas LAUnis}

Laajimmat ja monipuolisimmat sävelmäkokoelmat Inkeristä keräsi Armas Launis muistikirjaansa vuonna 1903 ja vahalieriöille $1906 .{ }^{81}$ Vaikka Launis ei kerännyt runotekstejä sävelmänpätkiin liittyviä alkusäkeitä lukuun ottamatta ja vaikka hän merkitsi käsikirjoituksiinsa vain niukalti kontekstitietoja, antoi hän matkakertomuksissaan olennaisia tietoja inkeriläisestä laulusta. Ennen Launiksen retkiä oli inkeriläisiä runosävelmiä merkitty muistiin ainoastaan reilut sata. Sävelmistä suu-

${ }^{78}$ Ks. Itkonen 1936, 46, 48; SKS KRA Borenius 11 e) 107-129 ja 169-206. Esimerkiksi Boreniuksen Soikkolan Loukkulassa tallentaman "Okrun virren" viereen on kirjoitettu: "Siellä tavallisin nuotti". Lyijykynällä on lisätty nuotin viereen: "(Sama Savimäelläkin)" (SKS KRA Borenius 11 e 188). Kirjoittaessaan Savimäellä Vöglältä ja Okkulilta epätyypillisen liekkuvirren, jota käytettiin myös kehtolaulusävelmänä (198; ks. luku 8), Borenius lisäsi marginaaliin: "vrt. yl. varsinaista" viitaten luultavasti johonkin tarkemmin määrittymättömään aikaisemmin tallennettuun liekkunuottiin.

${ }^{79}$ Boreniuksesta enemmän ks. myös Harvilahti 1998b, 199-200; Salminen 1929a, 61; Väisänen 1917, 30-38; Timonen 2004, 90-91, n77. Vielä vuonna 1921 Borenius sai Alfred Kordelinin säätiöltä apurahan sävelmien järjestelemiseen, mutta Itkosen $(1936,101)$ mukaan tämä ei enää "johtanut toivottuihin tuloksiin."

${ }^{80}$ KK Coll. 123.20. Armas Launis: Taival, jonka vaelsin.

${ }^{81}$ Launis (1884-1959) syntyi puusepän ja talollisen tyttären nuorimmaksi lapseksi Hämeenlinnassa vuonna 1884 ja muutti perheensä kanssa Helsinkiin vuonna 1893. 
rin osa oli A. A. Boreniuksen tallentamia ja tuolloin yhä hänen hallussaan, parikymmentä luonnosta kätkeytyi Vihtori Alavan pikakirjoitusvihkoihin ja muutamia D. E. D. Europaeuksen muistiinpanoihin. On mahdollista, että Alavan ja Europaeuksen sävelmämuistiinpanoja ei tallennustyötä koordinoineen Suomalaisen Kirjallisuuden Seuran piirissä edes tunnettu.

Lähtiessään ensimmäistä kertaa Inkeriin Launis oli opiskellut Helsingin yliopistossa ja Helsingin filharmonisen seuran orkesterikoulussa kaksi vuotta. Stipendiaatiksi valmistumista vuonna 1902 seurasivat kuusi Suomalaisen Kirjallisuuden Seuran tuella tehtyä sävelmänkeruuretkeä. ${ }^{82}$ Launis valmistui filosofian kandidaatiksi vuonna 1906 ja ilmeisesti jo saman vuoden syksynä hän kävi Virossa tutkimassa Oskar Kallaksen avustuksella runosävelmäaineistoja väitöskirjaansa varten..$^{83}$ Vuoden 1910 kesän Launis vietti Pietarissa inkeriläissäveltäjä Moses Putron luona runosävelmien ja venäläisten kansansävelmien yhteyksiä kartoittaen. Runosävelmien luokitteluun keskittyvä väitöskirja "Über Art, Entstehung und Verbreitung der Estnisch-Finnischen Runenmelodien" painettiin vuonna 1910 ja väitöstilaisuus oli seuraavan vuoden alussa. ${ }^{84}$ Vuonna 1910 ilmestyivät myös Inkerin runosävelmät (1910a, IRS) sekä luku Runosävelmistä teoksessa Kalevalan selityksiä (1910c). Launis järjesti samalla kertaa myös Karjalan ja Viron runosävelmät, jotka tosin SKS:n taloudellisen tilanteen takia saivat odottaa painatusta vuoteen 1930 (Suomi 1912, 18-19, 138, 156; Suomi 1915, 55-56; ks. myös Häggman 2012, erit. 133-137;183187; 283-287). Alun perin Inkerin runosävelmien piti sisältää "selonteko laulutavoista ja tutkielma sävelmäin musikaalisesta rakenteesta", mutta ilmeisesti artikkeli ja väitöskirja korvasivat sen (Suomi 1909, 62).

Vuoden 1903 toukokuun kuudentenatoista päivänä 19-vuotias ylioppilas lähti siis Helsingistä kohti Länsi-Inkeriä. Narvusin lukkarilasta hän teki aluksi lyhyempiä matkoja alueen kyliin. ${ }^{85}$ Sävelmiä Narvusista kertyi kahdenkymmenen päivän aikana melkein 160, minkä jälkeen matka jatkui Soikkolan niemelle. Säätinän helluntaipraasnikoilla Launis kertoo saaneensa suurimman "saaliinsa", 150 sävelmää, ja lisäksi tiedon Soikkolan muiden kylien parhaimmista "eessälaulajista." Soikkolan jälkeen Launis kulki vielä Kattilan puolella. (Launis 1904, 50.) ${ }^{86}$

Jos uudesta kylästä ei ensimmäisellä matkalla suhteellisen nopeasti löytynyt sopivia laulajia tai jos näiden laulut tuntuivat liian samankaltaisilta kuin edellisissä kylissä, vaihtoi Launis nopeasti keruupaikkaa. ${ }^{87}$ Ainakin paikoin hän jakoi laula-

\footnotetext{
${ }^{82}$ Kajaanissa (vuonna 1902) yhdessä ja Länsi-Inkerissä (1903) yhtä aikaa Eino Levónin kanssa, Suomen Lapissa (1904), Suomen ja Norjan Lapissa (1905) sekä fonografilla varustettuna Raja-Karjalassa (1905) ja Länsi-Inkerissä (1906). (KK Coll. 123.20 Launis; Hako 1982, 10-11; Suomi 1906, 179; Tomasi 1940.)

${ }^{83}$ KK Coll. 123.20 Launis, 9. Lapista kerätyt joikusävelmät Launis julkaisi tieteellisesti järjestettynä kokoelmana vuonna 1908.

${ }^{84}$ KK Coll. 123.20 Launis: 10-11.

${ }^{85}$ KK Coll. 123.22 Launis 1903, 39, 7-12, 25-27.

${ }^{86}$ SibA Launis 1903.

${ }^{87}$ KK Coll. 123.22 Launis 1903, 5, 6, 16, 20, 41, 48.
} 
jille palkkioksi rahaa. ${ }^{88}$ Parhaiksi laulukyliksi Launis $(1904,50)$ nimeää Soikkolan inkeroiskylät Tarinaisin, Volotsan ja Mäkkylän ja kertoo myös Narvusin alueella inkeroiskylien tyttöjen olleen parhaita informantteja. Launiksen tallentamissa sävelmissä on ainoastaan muutamia sellaisia, joihin kuoro on merkitty mukaan. Ihanteellinen keruuasetelma ensimmäisellä matkalla olikin selvästi yksi laulaja tuvan pöydän ääressä. ${ }^{89}$ Nuorison laulu- ja tanssitapoja Launis kävi erikseen kylän "akkojen" kanssa katselemassa, mutta hän ei mainitse keränneensä tällöin sävelmiä: "Kirjassa olivat jo ne nuotit."90 Matkakertomuksensa lopussa Launis (1904, 53) kehottaa lukijaa täydentämään lyhyen laulamisen tapoja käsittelevän selostuksen avulla yhdeltä laulajalta tallennetut sävelmät, mutta toteaa myöhemmin omankin käsikirjoituskokoelmansa esilaulun ja kuoron vaihtelun osalta puutteelliseksi (Launis 1910b, XIV).

Vuoden 1906 äänitysmatkalla Launis (Launis 1907, erit. 105) nimenomaan pyrki "mikäli mahdollista" kokoamaan sopivia kuoroja tai ottamaan mukaan jälestälaulajan - yksin laulettuja esityksiä on Soikkolan 121 laulunpätkän joukossa ainoastaan 14, näistä kahdeksan heti äänitysten alussa. Launiksen ääniteaineisto välittää inkeriläisestä laulusta huomattavasti paremman kuvan kuin olisivat tehneet pelkästään yksittäisiltä laulajilta nauhoitetut sävelmät, vaikka yksinlaulun tyylipiirteistä kokoelma ei kerro. Keruukertomuksessaan Launis mainitsee koonneensa kuoroja, jotta "fonografi-otteet tulisivat kansan esitystapaa mahdollisimman lähelle." Näin laulu ei hänen mukaansa myöskään kuulostanut hengitystaukojen vuoksi katkonaiselta. Kuoron kokoonpanoon Launis vaikutti aktiivisesti: "köörin muodostin tavallisesti kolmesta tai neljästä laulajasta." Kuoroihin osallistujista ei ole muita tietoja, mutta voi olettaa esilaulajien paikoin laulaneen myös toisten kuoroissa. Toisen matkan laulajat olivat $16-55$-vuotiaita naisia ja tyttöjä, useimmat $20-40$-vuotiaita. ${ }^{11}$

Vuoden 1906 retki suuntautui Launiksen (Launis 1907, erit. 104) parhaaksi katsomille lauluseuduille, Soikkolaan ja Keski-Inkerin Hevaalle ja Tyröön. Soikkolassa hänet jo tunnettiin, Keski-Inkeri puolestaan oli vuonna 1903 kuulunut Eino Levónin keruualueeseen. Launis tiesi, mitä etsi. Retki oli ensimmäistä lyhyempi eikä sen kulusta ole äänityspaikkakuntia tarkempaa tietoa. Säätinän helluntaipraasnikoilla hän äänitti 21 lieriötä täyteen runosävelmiä. Juhlien jälkeen hän sai muutamassa päivässä Mäkkylässä ja Viistinässä loput 58 lieriöstä täyteen "ja useampia eri sävelmiä tuskin enää olisi Soikkolasta löytynytkään.” Hevaalla ja Tyrössä vahalieriöitä täyttyi 31 ja lisäksi hän äänitti lopuksi kuudelle lieriölle soikkolalaisten paimenten soittoa.

Muutamaa säettä pidempiä nuotinnoksia eivät Launis ja Levón vuoden 1903 matkoillaan tehneet, eikä kertaalleen tallennettua sävelmätyyppiä tarvinnut uudesta kylästä enää tallentaa, vaikka toisintojakin kokoelmaan kertyi. Äänitysretken

\footnotetext{
${ }^{88}$ KK Coll. 123.22 Launis 1903, 30.

${ }^{89}$ KK Coll. 123.22 Launis 1903, 16, 18, 30, 35.

${ }^{90}$ KK Coll. 123.22 Launis 1903, 36.

${ }^{91}$ SKSÄ A 300/9-3001/56.
} 
kohteiksi riittivät Hevaa ja Soikkola, sillä muiden lähipaikkakuntien laulut olivat ainoastaan "tärveltyneitä toisintoja mainittujen Inkerin parhaiden runoalueiden sävelmille" (Launis 1907, 104-105). Äänitysmatkalla Launis ilmeisesti pyysi välillä esittämään sävelmiä, joita hän tai Levón olivat tallentaneet kolme vuotta aiemmin. Tähän viittaavat runosäkeiltään, melodialtaan ja tallennuspaikaltaan samankaltaiset käsikirjoitus- ja äänitetoisinnot. ${ }^{92}$

Kuten Marko Jouste $(2004,60)$ toteaa, tallennuksen päämääränä oli äänitysten alettuakin yhä nuottikuva, ei itse äänite. Launiksen laatimat toisen matkan äänitteiden nuotinnokset tuntuvat olevan lähinnä yhteenvetoja äänitteen kulusta, vaikka ne ovatkin käsikirjoitusnuotteja yksityiskohtaisempia. Merkittävimmät ja toistuvimmat muunnelmat tai moniääniset kohdat etenkin äänityksen alusta on merkitty, mutta ei kaikkia, eikä nuotti luonnollisesti anna kuvaa esityksen kulkuun liittyvästä variaatiosta (ks. myös Kolehmainen 1977, 4-6.). Tällaisena näyttäytyy tilanne myös ainoassa tähänastisessa tarkemmassa analyysissä Launiksen fonogrammien ja nuotinnosten suhteista, Yrjö Heinosen (2007) artikkelissa, joka keskittyy yhteen hevaalaisäänitykseen. ${ }^{93}$ Minna Riikka Järvisen $(2004,344)$ mukaan Launiksen nuotinnokset matkoilta "niin Karjalaan, Kainuuseen, Inkeriin kuin Lappiinkin" muistuttavat kovasti toisiaan, ilmeisesti aikakauden musiikkianalyysin periaatteita noudattaen. Taustalla oli vertailevan kansanmusiikintutkimuksen paradigma, jonka materiaaliksi sopivat parhaiten sävelmän perushahmon suhteellisen yksinkertaisesti, konventionaalisesti ja ilman variaatioita esittävät nuotit. Keruutekniikasta ja vallitsevasta tutkimuksen paradigmasta johtuen joikujen "sävelmät ovat pelkistyksiä alkuperäisistä sävelmistä", yleisimmin toistuneen sävelmäaineksen tallennuksia (ks. myös Jouste 2004, 58-60). Tämän voi katsoa pätevän inkeriläiseen aineistoon etenkin enemmän varioivien melodioiden osalta.

Vuoden 1906 Lapin matkaltaan Launis (1906a, 85) kertoo, että ei vaivautunut tallentamaan mitään niiltä esittäjiltä, "joiden laulukorva oli alapuolella keskinkertaisuuden." Hän valikoi Inkerissäkin tallennettavikseen mahdollisuuksien mukaan itseään miellyttäviä laulajia, laulun lajeja ja paikkakuntia. Onkin todennäköistä, että erityisesti muuntelun, moniäänisyyden ja vaihtelevien tai epätavallisten asteikkojen suhteen Launiksen kummankin matkan tulokset antavat inkeriläisestä laulusta jossain määrin oman aikansa taidemusiikin ja kuorolaulun ideaalien suuntaan silotellun kuvan. Vanhan ja esteettisesti tyydyttävän yhdistelmä oli kuitenkin vaikeasti löydettävissä (ks. myös Saarlo 2007; Laitinen 2003a, 15-16; Kallio 2009b). "Primitiivinen runolaulumme" tuntui Inkerissä aluksi "keräilyn kannalta vähä-arvoiselta", muisteli Launis omaelämäkertansa luonnoksessa. ${ }^{94}$ Uudemmista kansanlauluista hän sitä vastoin näyttää aidosti pitäneen..$^{95}$ Inkerissä miellyttivät erityisesti Soikkolan inkeroiskylistä löydetty (suhteellinen) sävelpuhtaus sekä ve-

\footnotetext{
${ }^{92}$ Esim. SibA Launis 311 ja SKSÄ A 300/26a; SKS KRA Levón 470 ja SKSÄ A 301/34a; SibA Launis 311 b ja SKSÄ A A 300/32b sekä SibA Launis 346 ja SKSÄ A 300/34b. Joukossa voi tietenkin olla myös vakiintuneita teksti-melodia-yhdistelmiä.

${ }^{93}$ SKSÄ A 301/43a.

${ }^{94}$ KK Coll. 123.20 Launis.

${ }^{95}$ KK Coll. 123.22 Launis 1902, 9, 19, 41, 78.
} 
näläisistä ja suomalaisista uudemmista lauluista vaikutteita saaneet, laaja-alaisemmat, moniääniset ja useamman säkeen pituiset sävelmät. Launiksen kuulokulma loikin aineiston, jossa myös nuorison uudet laulumuodit kuuluvat. Jo ensimmäisellä matkalla Soikkola nousi laulualueena kirkkaasti ylitse muiden:

Jo tutustuminen heidän [soikkolalaisten] sävelmiinsäkin riitti kyllin antamaan mielenkiintoa. Niiden yksinkertaisuudesta voisi päättää, että ne olisivat varsin vähän musikaalisesti kehittyneen kansan laulamia. Omituista kyllä, on asian laita vallan päinvastainen. Sillä puhumattakaan siitä, että heillä yleensä on tarkka korva muistaa ja laulaa oppimiansa sävelmiä, on heillä ihmeteltävä taito löytää sointuvia intervalleja. (Launis 1904, 49.)

Matkakertomuksen kuvaus keruun alusta Vyötermaan kylässä kertoo nuoren opiskelijan odotuksista ja reaktioista vieraan laulukulttuurin edessä toiseen sävyyn:

Kyläläisten kertomuksen mukaan olivat runonkerääjät saaneet paljon tästä kylästä ja se saattoi minuakin toivomaan runsasta saalista. Tulos oli kumminkin vähäinen. Tässä samoin kuin seuraavissa lähikylissäkin oli jo runonlaulanta syrjään heitetty. Runoja kyllä vieläkin osattiin, mutta ainoastaan harvat muistivat, millä nuotilla niitä oli laulettu. Heidänkin lauluäänensä oli jo ikä vienyt ja samalla nuotin epävarmaksi tehnyt. Työlästä oli siitä tolkkua saada, he kun harvoin lauloivat kahta kertaa samalla tavalla. (Launis 1904, 49.)

Mitä ilmeisimmin nuori Launis ei tarkalleen tiennyt, mitä oli lähtenyt etsimään. Runolaulun tyypillisenä pidetyt piirteet - vähäsävelisyyden, erilaisten sävelmätyyppien vähäisyyden ja sävelmän jatkuvan muuntelun - hän tulkitsi omien musiikkikäsitystensä kautta runolaululle epätyypilliseksi. ${ }^{96}$ Alkumatkan nuotinnokset varioivista sävelmistä ovat vain muutaman säkeen mittaisia pelkistyksiä, joiden yksiselitteisessä kulussa muunnelmat ovat aavisteltavissa ainoastaan kumitusjälkinä. Melodian pysymättömyys tarkoitti Launikselle sen unohtumista, nuotin suppeaalaisuus alkuperäisen sävelmän rappeutumista:

Viimeisen yrityksen tein erään vanhan akan luona ja sainkin hänet vihdoin laulamaan. Mutta siitä en paljon hyötynyt. Nuotti oli unohtunut, ei mikään mennyt kahta kertaa samalla lailla. Muutaman nuotin koetin kuitenkin muistiin panna." ${ }^{37}$

Launis etsi vanhoja, "alkuperäisiä" sävelmiä, mutta piti enemmän uudemmista kansanlauluista ja oletti ainakin keruun alussa nykytiedon valossa vanhakantaisemmat melodiat huonojen laulajien unohtamien sävelmien kaiuiksi. Samankaltaisen ristiriidan ovat sekä Järvinen $(2004,345)$ että Jouste $(2004,66-67)$ havainneet Launiksen kirjoituksissa joikusävelmistä. Syvällisempi perehtyminen runolauluun

${ }^{96}$ Launis (KK Coll. 123.22 Launis 1902, 44) sai ensimmäisen kosketuksen runolauluun jo vuonna 1902 Kainuun retkellään käydessään nopeasti Vornan kylässä Venäjän puolella: ”Heti sain pyydettyäni talon väen laulamaan, mutta nuotti nuljahteli sinne tänne, niin etten siitä selvää saanut." Niinpä hän ei sävelmää ilmeisesti muistiin kirjoittanutkaan; retken tarkoituksenahan oli uudempien kansanlaulujen keruu (SKS KRA Launis 1902).

${ }^{97}$ KK Coll. 123.22 Launis 1903, 6; ks. myös 3. 
muokkasi Launiksen näkemyksiä laulun piirteiden tyypillisyydestä ja vanhuudesta, mutta esteettiset arviot pysyvät samoina. Hän kirjoittaa olevan vaikeaa erotella eri ajoilta peräisin olevia (toisin sanoen erityylisiä) sävelmiä, mutta määrittelee iältään vanhimmiksi ne sävelmät, "joiden musikaalinen muoto on vähemmän kehittynyt." Tämänkaltaisten "alkeellisten" sävelmien tärkeimmäksi tunnuspiirteeksi määrittyi "jotenkin vähän vaihteleva, kehittymätön ja epävakainen melodiikki." (Launis 1910c, 225.) Muuntelun kanssa samansukuinen piirre oli moniäänisyys, jota Launis arvosti ensimmäisestä Inkerin retkestään alkaen. Säveltäjän ja muusikon ihanne ei kuitenkaan kokonaan vastannut kentällä kuuluvaa todellisuutta. Väitöskirjassaan Launis (1910b, XIII) yleistää ilmeisesti omien kokemustensa pohjalta:

Muut äänet ovat yleensä seuraavia terssejä ylä- tai alapuolella. Siten syntyy usein täysi kolmisointu. Mutta moniäänisyys voi syntyä myös laulajien kyvyttömyydestä laulaa yhteen, koska usein esiintyy jopa yhtäaikaisesti soivia sekunteja, joita ei varmasti ole tarkoitettu.

Muuntelun tuottama, länsimaisesta sointuajattelusta poikkeava heterofonia johtui Launiksen tulkinnassa edelleen laulajien taidon puutteesta, ei laulukulttuurin erilaisesta estetiikasta. Sekunti-intervallien vähäisyys Launiksen nuotinnoksissa ei siten tarkoitakaan niiden vähäisyyttä lauluissa, vaan on osin myös nuotintajan tulkintojen tulosta.

Sävelmien kansainväliseen vertailuun katsottiin vielä Launiksen ensimmäisen retken aikaan tarpeellisiksi kerätä lyhyitä ja selkeitä melodian perushahmoja. Näkökulma muuttui nopeasti äänityskeruiden alettua: tieteellisyydelle asetettavat vaatimukset näyttävät kasvaneen muutamassa vuodessa. Voi olla, että Launis itse saneli nämä muuttuvat vaatimukset, sillä hänhän oli ensimmäinen Suomalaisen Kirjallisuuden Seuran fonografin käyttäjä vuonna 1905 ja 1900-luvun ensimmäisen vuosikymmenen merkittävin runolaulun äänittäjä. Launiksen ensimmäisen retken tulokset olivat enimmillään neljän säkeen pituisia, useimmiten yhdeltä laulajalta tallennettuja nuotteja, jonkinlaisia yhteenvetoja enemmän tai vähemmän muunnelleen esityksen perushahmosta (ks. myös Kolehmainen 1977, 4-6). Runosävelmäjulkaisun yhteydessä hän arvioi omankin ensimmäisen keräelmänsä tieteellisessä mielessä vaillinaiseksi:

Ne suuret puutteet ja vajavaisuudet, jotka yleensä haittaavat ilman fonograafia kerättyjä sävelmäkokoelmia, ovat varsin tuntuvia näidenkin kerääjäin [Inkeristä käsin nuotinnetuissa] kokoelmissa. Suurta haittaa tuottaa varsinkin epätietoisuus sävelmäin tonaalisista sävelkorkeussuhteista ja osaksi niiden rytmiikistäkin. (Launis 1910a, II.)

Fonogrammikeruun motiiveja olikin kaksi: "saada heidän esitystapansa elävämpänä säilymään" jälkipolville ja toisaalta lisätä transkriptioiden tieteellistä tarkkuutta (Launis 1906b, 86; Suomi 1906, 179). SKS:n kielitieteellisen valiokunnan fonografin hankintaan liittyvä pöytäkirja mainitsee motiiviksi myös sanojen ja sävelmän suhteen tarkemman tallentamisen: 
Suomal. kansansävelmiä on tähän saakka pantu muistiin yksinomaan tavallisen nuottikirjoituksen avulla, joka kuitenkin - vaikkapa nuotintaja olisi kuinkakin tarkkakorvainen ja tarkkatuntoinen musiikkimies - aina, kirjoittajan tahtomattakin, tulee jossain määrin kaavailluksi ja normaliseeratuksi. [...] Tässä on erikseen huomautettava, että ainoastaan fonografin avulla voimme saada täysin luotettavan kuvan siitä, millä tavalla laulun sanat liittyvät sävelmään, minkä seikan tunteminen kielitieteellisessäkin suhteessa voi olla varsin tärkeä. (Suomi 1906, 19.)

Keruille asetetut odotukset ja ennen kaikkea Launiksen käsitysten muutokset näkyvät osaltaan hänen ensimmäisen matkansa kenttäkäsikirjoituksen, Suomalaisen Kirjallisuuden Seuralle luovutetun puhtaaksikirjoituksen ja seitsemän vuotta myöhemmin julkaistun sävelmäkokoelman välisissä eroissa. ${ }^{98}$ Puhtaaksikirjoituksen yhteydessä Launis lyhensi monia muistiinpanoja ja tulkitsi toisia uudelleen joskus merkittävilläkin tavoilla. Sävelmiä julkaistessaan hän teki uusia muutoksia. Usein lopullinen julkaistu muoto (IRS) on lopulta lähempänä kenttäkäsikirjoitusta kuin puhtaaksikirjoitusta, vaikka viitteet julkaisussa ovatkin pelkästään puhtaaksikirjoitukseen. Keskeisimmät muutokset Launiksen kenttäkäsikirjoituksen (SibA) ja sävelmäjulkaisun (IRS) välillä ovat seuraavan kaltaisia:

1) Nuottikuvissa on paljon toimituksellisia muutoksia, lähinnä sävellajien, tahtiosoitusten ja sävelmän aika-arvojen yhtenäistämistä.

2) Muutama kenttäkäsikirjoituksessa yhtenä toisintona esiintynyt sävelmä on puhtaaksikirjoituksessa ja julkaisussa jaettu kahtia. ${ }^{99}$

3) Muutamassa sävelmässä on teksti vaihtunut tai puuttuva teksti ilmestynyt edeltävästä toisinnosta. ${ }^{100}$

4) Yleisimmin tekstin muutokset ovat kirjoitusasujen yhtenäistämisiä ja korjaamisia lähemmäs Inkerissä tyypillisiä muotoja, esimerkiksi ljoole $\rightarrow$ lole, ”se ihana" $\rightarrow$ "se ihala."101

5) Pieniä poisjääntejä tai lisäyksiä on monin paikoin. ${ }^{102}$

\footnotetext{
${ }^{98}$ SibA Launis 1903; SKS KRA Launis 1903; Launis 1910a=IRS. Kopioimisen ja julkaisemisen painotukset kertovat osaltaan myös yleisemmästä aikakauden eri laulunlajeille suomasta arvostuksesta. Kenttäkäsikirjoituksesta kokonaan kopioimatta jäivät muutamat virolaiset ja venäläiset laulut ja yksi paimensävelmä. Vaikka ne olivat kiinnostaneet Launista muistiin kirjoittamisen verran, eivät ne kuuluneet varsinaisiin keruun kohteisiin. Kaikki kuusi itkusävelmäänsä Launis kopioi ja julkaisi, mutta joko muistiinpanon hataruuden tai toisintojen samankaltaisuuden takia kolme runosävelmää jäi kirjoittamatta puhtaaksi. Kaikki neljäkymmentäviisi rekilaulua eli riimillistä uusimittaista kansanlaulua hän kopioi. Sävelmäjulkaisuunkin Launis (1910a, II) otti mukaan näistä kolme, ne kun olivat "runosävelmäin kaltaisia sävelmiä."

${ }^{99}$ esim. SibA $386 \rightarrow$ IRS 2 ja 5; SibA 179b $\rightarrow$ IRS 193, 241; SibA $395 \rightarrow$ IRS 27, 52.

100 esim. SibA 103 ja IRS 295; SibA 106 ja IRS 694; SibA 227 ja IRS 810.

101 esim. SibA 35 ja IRS 832; SibA 227b ja IRS 301.

${ }^{102}$ Esimerkiksi sävelmän SibA 2 julkaistusta versiosta (IRS 638) on jäänyt kokonaan pois säkeen viimeinen, suluissa ollut tavu nuotteineen. Toisaalla käsikirjoitus ja julkaistu nuotti on merkitty eri korkeuksille ja eri aika-arvoille, ja käsikirjoituksen viimeinen pitkä sävel on julkaistussa versiossa merkitty sekä suhteessa pidemmällä nuottiarvolla että fermaatilla (SibA 7 ja IRS 80). Samoin löytyy joitain yksittäisen sävelkorkeuksien eroja melodialinjoissa, ilmeisesti huolimattomuusvirheitä (esim. SibA 10 ja IRS 402).
} 
6) Sanojen sijoittuminen melodiaan vaihtelee: käsikirjoituksessa sanat onkin usein kirjoitettu säkeen alle hyvin viitteellisesti. ${ }^{103}$

7) Kuoro-osa on suluissa merkitty myös niihin sävelmiin, joiden käsikirjoituksissa sitä ei ole, eli yhdeltäkin laulajalta kerätyt sävelmät on puristettu esilaulajan ja kuoron vaihtelun muottiin (Launis 1910a, VI). Tällöin Launis on tulkinnut myös kuoro-osan pituuden (yksi- vai kaksisäkeinen muotorakenne) ja siten sävelmän perusluonteen. Kaikki tulkinnat eivät mielestäni ole muun aineiston perusteella uskottavia.

Sekä käsikirjoituksen että julkaisun runotekstit ovat muutaman säkeen pituisia, usein kirjakielistettyjä, ja teksteissä on siellä täällä kalevalamittaisen runon ja paikallisen murteen vieraudesta johtuvia väärinymmärryksiä. Paikoin epämääräinen tai murrelma- ja normaalitrokeisissa säkeissä toisistaan eroava tapa sijoittaa sanat sävelmään voi johtua Launiksen vähäisestä kiinnostuksesta runojen kielellisiin yksityiskohtiin, huolimattomuudesta ja kenties painovirheistäkin. ${ }^{104}$ Äänitettyjenkin runojen virhetulkinnat viittaavat siihen, että runoteksti ei yksinkertaisesti Launiksella ollut kovin keskeisellä sijalla: hän keräsi ja tutki musiikkia. ${ }^{105}$ Ainakaan ensimmäisellä matkallaan Launis ei myöskään näytä kiinnittäneen huomiota kertaustapoihin tai kuoron ja esilaulun vaihteluun, jotka kuitenkin väitöskirjassa ovat nousseet keskeiseksi, vajavaisten aineistojen pohjalta selviteltäväksi kiinnostuksen kohteeksi (Launis 1910b: XIV). Ensimmäisen matkan aineistossa on esimerkiksi paljon kaksisäkeisiä muistiinpanoja, joista on vaikea sanoa, onko laulaja kerrannut kahta tai yhtä runosäettä kerrallaan vai jättänyt säkeet kokonaan kertaamatta, ja ovatko mahdolliset kahden säkeen väliset melodiset erot säännöllisesti joka säeparissa toistuvia vai ainoastaan satunnaisia muunnelmia. Tämä vaikeatulkintaisuus ei välity enää julkaisussa. Launis katsoi sävelmäjulkaisua tehdessään esilaulajan ja kuoron vuorottelun yhdeksi tärkeimmistä runolaulun piirteistä ja merkitsi kuoroosan (suluissa tosin) kehtolauluja myöten myös niihin sävelmiin, jotka oli kerätty yhdeltä laulajalta. Muutokset eivät ole kovin systemaattisia, mikä nähdäkseni viittaa kiireeseen.

Monet normaalin toimitustyön ja ilmeisestä kiireestä johtuneiden huolimattomuusvirheiden ulkopuolelle jäävät muutokset selittyvät Launiksen tietojen lisääntymisellä ja teoreettisten käsitysten muutoksilla. Vuonna 1910 hän ei ollut enää runolauluun ensimmäistä kertaa törmäävä ylioppilas, vaan useita keruuretkiä tehnyt, äänitteitä nuotintamisessa apunaan käyttänyt, muiden tutkijoiden kanssa runsaammin keskustellut ja käsikirjoituksia tutkinut maisteri. Toisella retkellään Inkeriin hän oli kiinnittänyt huomiota entistä enemmän myös laulamisen tapoihin. Julkaistessaan ensimmäisiä runolaulunuotinnoksiaan hän yritti uusien tietojensa

\footnotetext{
${ }^{103}$ Esim. IRS 735, 773, 914, 638; vrt. esim. SibA 45 ja IRS 244.

${ }^{104}$ Esim. IRS 735 vrt. 739; 773; 638. Toisaalta on myös mahdollista, että jotkut laulajat ovat sijoittaneet sanoja melodioihin valtavirrasta ja Launiksen suppeammasta äänitekokoelmasta poikkeavin tavoin.

${ }^{105}$ Esimerkiksi Launiksen 7-tavuiseen muotoon "näin mie kukkoi kujassa" tulkitsema säe on kuullakseni "käin miä kukkoina kujassa", kuten tyypillistä tälle runoaiheelle, jolloin myös tavujen rytmitys melodiaan noudattaa tavanomaista säännöllisyyttä (IRS 162; SKSÄ A 301/23b). Monet muutkin ääniteaineiston valossa erikoisilta vaikuttavat rakenteet voivat olla väärinkäsityksiä. Tosin aina on otettava huomioon, että esimerkiksi poikkeukselliset tavat rytmittää runosäe voivat joskus myös edustaa laulutyylejä, jotka eivät ole tallentuneet käsikirjoitusaineistoa suppeampaan ääniteaineistoon.
} 
pohjalta korjata mitä pystyi: sanamuotoja, kertaustapoja, nuottiarvoja. Osa korjauksista ja muutoksista kuitenkin vääristää kuvaa kerääjien kuulemasta ja muistiin merkitsemästä laulusta.

Eniten huomiota Launiksen äänitysmatkan tuloksissa ovat nykytutkimuksen piirissä (esim. Asplund 1992; Timonen 2004) herättäneet hänen matkakertomukseensa (Launis 1907) sisältyvät poikkeuksellisen tarkat laulamista koskevat etnografiset huomiot. Ero edellisen matkan matkakertomukseen (Launis 1904) on huomattava. Äänitysmatkan pohjalta syntynyt kuvaus viittaa tarkkoihin paikallisten kanssa käytyihin laulun lajeja, tyylejä, käyttötapoja ja merkityksiä koskeviin keskusteluihin, jotka eivät olleet tuon ajan tieteellisessä kontekstissa tyypillisiä. Todennäköiseltä muutoksen selitykseltä vaikuttaa yhteistyö toisella Lapin matkalla oppaana toimineen nuoren saamelaisen Piera Helanderin eli Pedar Jalvin kanssa. Vaikuttaa siltä, että myöhemmin koulutielle ja runoilijaksi päätynyt Helander avasi Launiksen silmät laulamisen kulttuurisille ja henkilökohtaisille merkityksille ja sai jaettua jotain sisäpiirin näkökulmastaan. Käänne Launiksen matkakertomusten luonteessa osuu nimittäin juuri toisen Lapin matkan kohdalle. (Ks. tarkemmin Heinonen \& Valtonen 2006; ks. myös Ahmajärvi 2003.) Tarkat laulamisen yksityiskohtia ja merkityksiä koskevat huomiot jäivät silti yleisluontoisiksi kuvauksiksi matkakertomuksiin, eivät arkistomuistiinpanoiksi saati laulamista käsitteleviksi tutkimuksiksi. Aikakauden tieteellisessä kontekstissa ne eivät olleet keskeisiä.

\section{Elsa ENÄJÄRVI-HAAVIO}

Elsa Enäjärvi-Haavio (1901-1951) oli ensimmäinen suomalainen tutkija, joka kirjoitti laajempia kansanrunojen esittämistapoja sivuavia tutkimuksia. Tämä kiinnostus näkyy selvänä hänen vuonna 1936 tekemänsä Inkerin matkan tallennustuloksissa: hän kiinnitti enemmän huomiota laulamisen tilanteisiin ja runojen laulussa saamiin rakenteisiin kuin kukaan runonkerääjä häntä ennen. EnäjärviHaavio (1949, 5-6) kertoo: "Kun sitten vuonna 1936 tein kansanrunouden keräysmatkan Viron Inkeriin, koetin siellä panna muistiin kaiken, mitä noissa Rosonajoen rannan kylissä tiedettiin vanhojen runojen esittämistavoista, laulun säkeiden kertaamisesta, refrengeistä ja ennen kaikkea laulajain asennoista ja liikehtimisestä." Valpuri Vohta kertoi Lauri Laiholle jopa hakeneensa naapurin emännän avuksi, jotta he saivat näytettyä tanssin kulkua Enäjärvi-Haaviolle. ${ }^{106}$

Irma-Riitta Järvinen (1991, 45-46) jakaa Enäjärvi-Haavion työuran kolmeen päälinjaan: 1920-luvulla "kirjallisuuskriitikko ja esseisti, 30- ja 40-luvuilla kansanrunoudentutkija ja yliopiston dosentti ja 40-luvulla yhteiskunnallinen keskustelija ja järjestöihminen." Hän keskittyi etenkin leikkien ja runojen esittämistapoja sivuaviin tutkimuksiin, ja etääntyi Järvisen mukaan näissä tekemisen tapoihin, rituaalisiin yhteyksiin ja runojen merkityksiin liittyvissä pohdinnoissaan maantieteellis-historiallisen tutkimuksen päälinjoista. Enäjärvi-Haavio väitteli vuonna 1932

106 SKS KRA Laiho L. 5410. 
voutisilla-leikin maantieteellis-historiallisella analyysillä The Game of Rich and Poor. Muita esitystapoja sivuavia tutkimuksia olivat miesten kaksinlauluun keskittyvä, mutta inkeriläistä ja virolaistakin kalevalamittaista laulua kuvaava Pankame käsi kätehen (1949) ja laskiaislauluihin keskittyvä The Finnish Shrovetide (1954). Enäjärvi-Haavio kuoli jo vuonna 1951, joten inkeriläisiinkin esitystapoihin liittyvä tutkimus Ritvalan helkajuhlasta jäi hänen miehensä viimeisteltäväksi (EnäjärviHaavio 1953; Hautala 1954, 378-383).

Enäjärvi-Haavion päätös lähteä mukaan miehensä stipendiaattimatkalle Viron Inkeriin näyttää olleen melko pikainen: vielä toukokuun lopussa hän vain toteaa kirjeluonnoksessaan, että hänen tekisi mieli matkustaa mukaan. ${ }^{107}$ Stipendikertomuksessaan Nuorten Tieteenharjoittajien rahastolle Enäjärvi-Haavio kertoo omalla kustannuksella tehdyn matkan osaltaan pohjustaneen hänen seuraavana syksynä alkanutta apurahakauttaan "Kantelettaren kertovien runojen tutkimista varten", sillä hän kiinnitti Inkerissä erityistä huomiota kertovien runojen esitystapoihin. Apurahakauden keskeisenä tutkimuskohteena oli yksi hämäläisten Ritvalan helkajuhlien virsistä, joiden esittämistavoille lähimmät vertauskohdat löytyivät juuri Inkeristä. ${ }^{108}$

Sekä Enäjärvi-Haavio että Martti Haavio ${ }^{109}$ tallensivat vuonna 1936 Viron Inkerissä myös tietoa praasnikoista ja vuotuisperinteistä sekä laulajista itsestään. Sävelmiä kumpikaan ei pannut muistiin, mutta Enäjärvi-Haavion muistiinpanot runojen lauletuista rakenteista kuten kertauksista, osakertauksista ja refrengeistä antavat joskus myös viitteitä niiden laulamiseen todennäköisesti käytetyistä sävelmistä. Heidän muistiinpanoissaan on paljon laulajien omaa kuvausta lauluistaan, osin suorina sitaatteina, osin kirjakielisenä tiivistyksenä. Sitaattien ja kerääjän omien tulkintojen erottaminen toisistaan on usein vaikeaa.

\section{Aili ja LAURi Laiho}

Aili ja Lauri Laiho (vuodesta 1945 alkaen Simonsuuri) tekivät kaksi matkaa Viron Inkeriin vuosina 1937 ja 1938. Ensimmäisenä vuonna tarkoituksena oli runojen ja muun kansanperinteen keruu sekä äänitysmatkan järjestäminen, toisena Aili Laiho keskittyi sanaston keruuseen ja Lauri Laiho toimi Kansatieteellinen Filmi Oy:n työryhmässä (Järvinen 1990; Laiho A. 1938; Laiho 1940; Mäkinen 2008, filmit 2 ja

\footnotetext{
${ }^{107}$ SKS KIA Enäjärvi-Haavion käsikirjoituksia (erillinen luettelo) 5: Päiväkirjamuistiinpanoja. Kirjeluonnos Lindalle 31.5.1936.

${ }^{108}$ SKS KIA Enäjärvi-Haavio XI.2. Stipendikertomuksia (Nuorten Tieteenharjoittajien rahaston stipendien Jakolautakunnalle).

${ }^{109}$ Martti Haavio (1899-1973) oli tiedemies, runoilija ja kustannusalan edustaja. Inkerin keruuretken aikaan Haavio oli dosentti ja Kansanrunousarkiston johtaja. Keruuretkiä hän oli tehnyt Raja-Karjalaan vuosina 1921, 1933 ja 1934 sekä Karjalan Kannakselle vuonna 1921. (Hautala 1954, 351-378.) Inkeriläinen aineisto oli vahvasti esillä romanttisin sävyin kirjoitetussa teoksessa Viimeiset runonlaulajat (1948) sekä runotutkimuksessa Lohikäärme ja neito (1932a). Inkeriläistä aineistoa sivuavan tutkimuksen Leikarit (Haavio 1932b) tutkimusaineiston Elsa Enäjärvi-Haavio luovutti päiväkirjamerkintöjensä mukaan miehensä nimellä julkaistavaksi professuurihaun yhteydessä (Majamaa 2008a; 2008b). Inkerissä Haaviota kiinnostivat ennen kaikkea praasnikkajuhliin liittyneet tavat, joista saadut tiedot toimivat pohjana tutkimuksessa Kuolematonten lehdot (1961).
} 
3; Simonsuuri 1956, 19). Äänityksistä johtuen he kiinnittivät laulamisen tapoihin ja tilanteisiin huomiota myös käsikirjoitusmuistiinpanoja tehdessään (Simonsuuri 1972, 42.) Laihojen kokoelma muodostaa noin puolet Kansanrunousarkiston Viron Inkeristä kerätystä aineistosta. Laihojen tytär Irma-Riitta Järvinen (1990, 15-16) kertoo, kuinka "elämyksellisesti merkitseviä" kokemuksia juuri nämä matkat olivat erityisesti hänen äidilleen, joka vielä viimeisinä vuosinaan suunnitteli tapaamiensa laulajien "elämänkertojen ja henkilökuvien kirjoittamista ja julkaisemista." Lauri Laiho oli keruun aikana Kansanrunousarkiston työntekijä.

Laihojen vuonna 1937 Tallinnassa järjestämässä äänitystilaisuudessa lauloi kuusi naista: Anna Kivisoo, Valpuri Vohta, Darja Lehti, Tatjana Jegorova, Mari Vahter ja Paro Mägi. Itse levytykset tehtiin kahdessa ja puolessa päivässä ja ilmapiiri oli innostunut. (Simonsuuri 1961, 24.) Tuloksena tallennettiin lakkalevyille kolme itkuvirttä, kaksi ja puoli tuntia runolaulua, neljä uusimittaista lauluja, vajaa kymmenen minuuttia loitsuja ja saman verran paimensoittoa sekä satu ja uskomustarina. Äänitys toteutettiin Suomalaisen Kirjallisuuden Seuran sekä Suomen ja Viron yleisradioiden yhteistyönä. ${ }^{110}$

Useat laulajista olivat esiintyneet myös aiemmille 1930-luvun kerääjille, joten etenkin Kivisoon, Vohdan ja Lehden nimet toistuvat tässä tutkimuksessa usein. Naiset olivat kotoisin osin eri kylistä ja edustivat sekä inkeroisia, inkerois-vatjalaisia että inkerinsuomalaisia. Eri ryhmien runoissa ja sävelmissä oli eroja. Tämän takia äänitysten käyttö tutkimusaineistona edellyttää niiden pohtimista hieman tarkemmin. Aineiston arviointia auttaa se, että laulajilta on runsaasti käsikirjoitusmateriaalia ja heidän taustoistaan tiedetään poikkeuksellisen paljon (ks. Liite 1).

Identiteetiltään vatjalainen Lehti kertoi laulujensa silti olevan Soikkolan inkeroislaulujen kaltaisia. Kuten oikealla olevasta taulukosta näkyy, kaikilla laulajilla Paro Mäkeä lukuun ottamatta oli juuria Soikkolassa, myös inkerinsuomalaisella Valpuri Vohdalla Soikkolan luterilaiskylissä (ks. myös Laiho 1940, 227-230). Kolme inkeroislaulajista oli kotoisin Narvusin Ropsun kylästä. Sekä Kivisoo että Valpuri Vohta olivat olleet useamman vuoden palveluksessa Joenperän vatjalais-inkeroiskylässä, josta Lehti oli kotoisin. Asuinpaikat ja sukujuuret kertovat myös siitä, minkä kylien, ryhmien ja alueiden laulamisen tapoihin naiset olivat tottuneet. Nämä tekijät yhdistävät toisiinsa vaihtelevin tavoin kaikki muut paitsi Paro Mäen.

${ }^{110}$ Laiho 1938; SKSÄ L 86-104. 


\begin{tabular}{|c|c|c|c|c|c|c|}
\hline & Kivisoo & LEHTI & Voнta & JEGOROVA & VAHTER & MÄGI \\
\hline SYNNYINKYLÄ & Ropsu & Joenperä & Kallivieri & Ropsu & Ropsu & Väikylä \\
\hline KотікYLÄ 1937 & Väikylä & Vanhakylä & Vyötermaa & Hanikke & Hanikke & Saarkylä \\
\hline $\begin{array}{l}\text { ETNINEN } \\
\text { IDENTITEETTI }\end{array}$ & $\begin{array}{l}\text { inkeroinen } \\
\text { (isä vatj.) }\end{array}$ & $\begin{array}{c}\text { vatjalainen } \\
\text { (äiti ink.) }\end{array}$ & $\begin{array}{l}\text { inkerin- } \\
\text { suomal. }\end{array}$ & inkeroinen & inkeroinen & inkeroinen \\
\hline JUURIA SOIKKOLASSA & $\mathrm{x}$ & $\mathrm{x}$ & $\mathrm{x}$ & $\mathrm{x}$ & $\mathrm{x}$ & \\
\hline ASUNUT JOENPERÄLLÄ & $\mathrm{x}$ & $\mathrm{x}$ & $\mathrm{x}$ & & & \\
\hline $\begin{array}{l}\text { ESILAULAJA OMASSA } \\
\text { YHTEISÖSS̈̈ }\end{array}$ & $\mathrm{x}$ & $\mathrm{x}$ & $\mathrm{x}$ & & & \\
\hline ESIINTYNYT MUUALLA & & $\mathrm{x}$ & $\mathrm{x}$ & & $\mathrm{x}$ & \\
\hline AIEMPIA ÄÄNITYKSÏ̈ & & $\mathrm{x}$ & $\mathrm{x}$ & & & \\
\hline $\begin{array}{l}\text { NIMEÄÄ SUKULAISEN } \\
\text { (ESI)LAULAJAKSI }\end{array}$ & $\mathrm{x}$ & $\mathrm{x}$ & $\mathrm{x}$ & $\mathrm{x}$ & & $\mathrm{x}$ \\
\hline ESILAULUT 1937 & 20 & 2 & 7 & 7 & 2 & 0 \\
\hline SoOLOT 1937 & 1 & 1 & 1 & 0 & 1 & $\begin{array}{c}0 \\
\text { (+loitsuja) }\end{array}$ \\
\hline
\end{tabular}

Suurin ero laulamisen tavoissa oli ilmeisesti inkerinsuomalaisen ja inkeroisten välillä. Lauri Laiho $(1940,229)$ kertoo:

Kuorossa oli vain yksi luterilaisten kylien kasvatti, Valpuri Vohta, joka ollen oppinut laulunsa Arsialla ja kotikylässään Kallivieressä ei voinut toimia inkerikkonaisten muodostaman kuoron esilaulajana. Hänen laulutapansa oli sekä rytmiltään että varsinkin säkeiltään siksi paljon eriävä, ettei kuoro pystynyt kyllin joustavasti toistamaan, vaan aina jonkin aikaa "pruovittuaan" totesi: "Ei mää, ei mää".

Aineiston valossa tämä on yleistys. Vohta lauloi kuitenkin seitsemän runon esilaulut käyttäen kolmea sävelmätyyppiä. ${ }^{111}$ Ilmeisesti moni muu runo tai sävelmätyyppi ei kuitenkaan yhteislauluna toiminut. Vohdalta on käsikirjoituksena dokumentoitu esimerkiksi kaksisäkeinen, refrengillinen laulun muotorakenne, jota ei äänityksiin sisälly. ${ }^{12}$ Samoin Kivisoolta on tallennettu käsikirjotuksiin merkkejä sellaisista laulun rakenteista, joita ei äänitteillä kuulu. Esimerkiksi Tulkaa tytöt yötulille -laulun hän lauloi Enäjärvi-Haaviolle oi lado lado -refrengillä ilman osakertauksia, äänityksissä sen sijaan monissa muissakin lauluissa käytetyllä säkeen lopun kertaavalla tanssisävelmällä. ${ }^{113}$ Vaikuttaa siltä, että äänityksiin valikoitui laulettavaksi yleisimpiä, kaikkien laulajien hallitsemia sävelmätyyppejä.

\footnotetext{
${ }^{111}$ Kolme oli yksisäkeistä, neli-iskuista häälaulua (98d, 100b ja c), kolme yksisäkeistä säkeen lopun kertaavaa tanssilaulua (92c, 95c ja 95d) ja yksi kaksisäkeinen sävelmä, jossa kuoro lauloi refrengin (96b). ${ }^{112}$ SKS KRA Enäjärvi-Haavio 488. Laulussa kuoro kertaa oi lolii, oi lolii, oi li loosinkii moii -refrengin. ${ }^{113}$ SKS KRA Enäjärvi-Haavio 773, ks. myös esim. 475, 549.
} 
Aili Laihon mukaan kuoron laulu vaihteli sekä kylittäin että uskontokunnittain, ja niinpä laulajien kanssa jouduttiinkin kokeilemaan laulua kahtena päivänä ennen äänityksiä (Simonsuuri 1972, 44; ks. myös Simonsuuri 1961, 24). Vaihtelu kylittäin selittää kenties sen, että Paro Mägi ei äänityksissä laulanut yhtään esilaulua, vaikka sekä Laihot että Kaarina Salminen kirjoittivat häneltä myös runoja. Asuinpaikat (Ropsu, Joenperä) ja sukujuuret Soikkolassa yhdistivät toisiinsa kaikkia muita laulajia etnisistä identiteeteistä riippumatta, ainoastaan Mägi kalliviereläisen äidin Väikylässä syntyneenä ja eläneenä tyttärenä jäi verkoston ulkopuolelle. Vai olisiko hän vain parantajana keskittynyt enemmän loitsuihin kuin esilaulajan rooliin?

Halukkaita laulajia olisi ollut enemmän kuin mitä Tallinnan matkalle otettiin mukaan (Järvinen 1990, 31, 33). Matkaan lähteneet naiset sopivat lauluihin esilaulajat sen mukaan, miten mikäkin laulu parhaiten sujui:

Laulajat olivat hyvin taitavia havaitsemaan, kuka kulloinkin sopi esilaulajaksi. "Ei mää, ei mää, An’n’uška laulaa" tai "Senen laulaa iest Tan'a", "Täm om Marin" jne. Esilaulaja määräsi sitten, miten laulettiin; jos oli inkerikko laulajana, toiset seurasivat häntä, jos taas luterilainen ns. suomalainen, laulutapa oli hänelle totunnainen. (Simonsuuri 1972, 44.)

Esilaulaja siis määräsi laulamisen tavan. Kivisoo, Lehti ja Vohta kertoivat kerääjille toimineensa esilaulajina omassa yhteisössään ja Lehti, Vohta ja Vahter olivat käyneet Virossa tai Helsingissä esiintymässä. Ainoastaan yhden esilaulun laulanutta Vahteria lukuun ottamatta jokainen nimeää ainakin yhden lähisukulaisensa (yleensä äiti tai isoäiti) hyväksi laulajaksi. Näiden tietojen - jotka toki voivat olla puutteellisia - ja kerätyn käsikirjoitusaineiston valossa yllättävältä tuntuu kaksi asiaa: Lehden esilaulamien runojen vähyys (ainoastaan kaksi) ja Jegorovan laulamien paljous (seitsemän). Luultavasti Joenperästä kotoisin olevan, vatjalaisen Lehden runosäkeet tai laulamisen tapa poikkesivat narvusilaislaulajien lauluista näiden Soikkola-yhteyksistä huolimatta liiaksi. Vuonna 1922 Cyrillus Creekin fonografiin laulamistaan viidestä laulunalusta Lehti esitti vuonna 1938 ainoastaan yhden, senkin soolona, vaikka hän esimerkiksi käytti vuonna 1922 myös vuoden 1938 äänityksissä yleistä tanssisävelmätyyppiä. ${ }^{114}$ Jegorova puolestaan oli ilmeisesti omaa arkuuttaan jäänyt aiempien tallennusten marginaaliin eikä hän mainitse toimineensa esilaulajana omassa yhteisössään, mutta hän näyttää äänitysmatkalla löytäneen paikkansa varmana esilaulajana (ks. tarkemmin Liite 1).

Laihojen äänityksiä Launiksen tallennuksiin verratessa huomaa, miten erilainen tulos syntyy musiikintutkijan ja kansanrunoudentutkijan työn tuloksena. Laihot pyrkivät ottamaan mukaan erilaisia esitystapoja ja sävelmiä, mutta se ei näytä olleen heille keskeisintä. Toisin kuin Launiksen soikkolalaistallennuksissa, Laihojen äänittämät naiset käyttivät samoja sävelmätyyppejä usean laulun laulamiseen. Näin oli etenkin hää- ja tanssilaulujen kohdalla. Naiset myös nimesivät esityksiä tekstin mukaan virsiksi tai paikoin lauluiksi, eivät sävelmien mukaan nuoteiksi kuten Launiksen informantit. Siinä missä Launiksen kokoelma esittelee kattavasti erilaisia sävelmiä

${ }^{114}$ ERA, Fon. 209 b, c; SKSÄ 101e. 
ja hienovaraisempia laulamisen variaation piirteitä, Laihojen äänitykset antavat paremman kuvan siitä, minkä verran kuuden laulajan joukko erilaisia sävelmiä luontevasti kahden ja puolen päivän laulamisen aikana halusi käyttää, ja toisaalta paljonko erilaisia sävelmiä toisiaan ennalta tuntematon joukko kykeni yhdessä laulamaan.

\section{TALLENTEET NÄKÖKULMINA}

Suullinen esitys toistuu aina tavalla tai toisella ainutkertaisena. Sen lajista ja esittäjästä riippuu, mikä kaikki kerrasta toiseen muuttuu ja kuinka paljon. Kun ainutkertainen esitys tallennetaan, tapahtuu kaksi keskeistä asiaa. Muuttuva esitysten ketju jähmettyy yhdeksi tallenteeksi, jota on mahdollista tarkastella useita kertoja eri aikoina ja jota on mahdollista analysoida paljon tarkemmin kuin kertaluonteista, hetkessä ohi menevää esitystä tai esitysten alati muuttuvaa ketjua. Toisaalta tallentaminen tekstiksi (tai nuotiksi tai jopa äänitteeksi) on valikointia ja kielelliseen kääntämiseen verrattavaa työtä: joitain piirteitä korostuu, toisia jää tallentamatta. Media vaihtuu kasvokkaisesta, monikanavaisesta kommunikaatiosta kirjoitukseen tai äänitallenteeseen ja lopputulos muokkautuu myös näiden medioiden kantamien konventioiden mukaan.

Muistiinmerkitsijä tekee päätökset äänneasun tulkinnasta ja sen tarkkuudesta, merkintätavoista, tallenteen ulkoasusta, kielenulkoisten piirteiden merkitsemisestä tai merkitsemättä jättämisestä ja mukaan tallennettavista oheistiedoista. Tarkinkaan teksti ei koskaan välitä kaikkia esityksen piirteitä, vaikka äänteiden, intonaatioiden ja jopa liikkeiden merkitsemiseen on kehitetty erilaisia menetelmiä. Tarkinkaan nuotti ei pysty kuvaaman äänitallennetta täysin - länsimaisen musiikin kuvaamiseen kehitetyn nuottikirjoituksen muiden kulttuurien musiikin tutkimuksessa soveltamisen ongelmallisuudesta on etnomusikologian piirissä kirjoitettu paljon (ks. esim. Herndon 1974; Lippus 1995, 35-38; Nettl 1983, 42-91). Äänitallenne taas ei välitä laulajien ilmeitä ja liikkeitä. Jopa video näyttää tilanteesta vain tietyn, rajatun näkökulman, eikä välitä kuin kuvan ja äänen. Tunnelmaan vaikuttavia tekijöitä kuten tilan lämpötila, tuoksut ja ilman liike jää tallentamatta. Tallenteen tarkastelija ei tiedä kaikkia tilanteeseen ja sitä kautta esityksen kulkuun vaikuttaneita tekijöitä eikä hän aina tunne tallenteen edustaman perinteen kenttää.

Suullisen esityksen tallentamista tekstiksi on kuvattu tekstualisaation käsitteen avulla. Lauri Honko (1998) tarkoittaa tekstualisaatiolla lähinnä kerääjän tai tallentajan työprosessia eli suullisen esityksen muokkaamista tai siirtämistä kirjalliseen muotoon, mutta käsittelee laajasti myös erilaisia esityksen tietynlaiseksi muotoutumisen ehtoja alkaen esittäjän ja tallentajan välisestä vuorovaikutuksesta aina perinteen ominaispiirteisiin ja erilaisiin esittämiskonteksteihin. Elizabeth C. Fine (1984; ks. myös Jakobson 1959) puhuu samasta prosessista intersemioottisena kääntämisenä yhdestä moodista toiseen, esityksestä tekstiksi. ${ }^{115}$

${ }^{115}$ Esityksestä ja sen tallentamisesta ja tulkitsemisesta ks. myös Bauman 1977; Hymes 1981; Tedlock 1983; intersemioottisesta kääntämisestä ks. myös Mikkonen 2005, 35-42. 
Tallennustilanteeseen vaikuttavat monet tekijät: tallennuksessa käytettävä teknologia, esittäjän ja tallentajan välinen vuorovaikutus, heidän persoonallisuutensa, kompetenssinsa ja mielentilansa, muut läsnäolijat sekä laajemmat kulttuuriset ja sosiaaliset kontekstit. Ikä, asema ja kokemus muodostavat erilaisia hierarkioita, joille osapuolet eivät aina sijoitu yksiselitteisesti. Kumpikin tuo mukanaan omat kulttuuriset ja henkilökohtaiset taustansa, kommunikoinnin tapansa ja ennakkooletuksensa tilanteesta. (Ks. esim. Briggs 1986; Honko 1998, 502-504; Harvilahti 2003, 95-106; Vasenkari \& Pekkala 1999, 63.) Keskeistä onkin miettiä, minkälainen esitys on tekstin tai äänitteen pohjana milloinkin ollut: paljonko tallenne kertoo tallennustilanteestaan, paljonko esittäjästään, paljonko taas esittäjänsä yhteisöstä tai kulttuurista laajemmin? Tämän tutkimuksen osalta keskeisimmäksi keinoksi jää usein tallenteen vertaaminen muihin tallenteisiin sekä kerääien matkakertomusten ja muiden tekstien tarkastelu. Laulajien näkemyksiä esitystensä eri puolista ei ole juuri tallennettu.

Inkeriläisen kalevalamittaisen laulun kohdalla arkistoaineistosta heijastuvat tallennushetket ovat ainoita ikkunoita myös kulttuurisesti vakiintuneemmissa tilanteissa laulettuihin lauluihin. Keruutilanteessa esitys voi joskus toteutua hyvinkin erilaisilla ehdoilla kuin kulttuurissa tyypilliset esitykset, mutta nähdäkseni se rakentuu samoille keinoille. Laulaja käyttää itselleen tuttuja rakenteita silloinkin, käyttää niitä vain osittain tai kun päätyy luomaan niiden pohjalta jotain uutta. Parhaimmillaan, kuten joillain aineiston äänitteillä, esitys keruutilanteessa voi olla kaikin puolin täysivaltainen ja vastata sitä, miten laulajat sanallisesti kuvasivat tallennustilanteen ulkopuolisia hyviä esityksiä.

Erilaisia tallennettavan esityksen rakentumisen vaihtoehtoja on paljon. Laulaja voi esimerkiksi toteuttaa laulunsa lyhennelmänä tai osittaisena kokonaisuutena (Harvilahti 2004, 201). ${ }^{116}$ Tämä voi muistin pettämisen tai lauluhaluttomuuden lisäksi johtua myös esitystilanteeseen liittyvistä tekijöistä. Esimerkiksi Launiksen vahalieriöiltä, joissa äänityspituus oli vain muutamia minuutteja, löytyy muutama laulu, joissa laulajat esittävät pitkän runon tekstin äänitteelle mahtuvana lyhennelmänoloisena versiona. ${ }^{117}$ Silloinkin, kun runo lopetetaan selvästi kesken, tuntuu laulun lopettamisen kohta usein tekstin kokonaisuuden kannalta mielekkäältä ajatus tai osateema ei jää kesken. Joskus laulajat jopa neuvottelevat lopettamisen kohdasta: "Vähä?" kysyy esilaulaja, ja joku vastaa "Vähä," joten esilaulaja jatkaa vielä muutaman säkeen. ${ }^{118}$ Laulajat siis sovittivat esityksensä tallennustilanteen reunaehtoihin, mutta silti monet Launiksen tallentamat lyhyetkin laulut kuulostavat täysiltä esityksiltä.

Toisaalta laulaja voi keruutilanteessa myös intoutua selittämään laulun piirteitä, taustoja tai henkilöitä ulkopuoliselle kerääjälle enemmän, kuin luultavasti tekisi oman yhteisönsä jäsenille esiintyessään (esim. SKVR III 2079; 2170). Hän voi myös

\footnotetext{
${ }^{116}$ Esim. SKVR III 1879; vertaa SKVR III 959 ja 1905, ks. myös esim. 2349.

${ }^{117}$ Erit. SKSÄ A 300/22 b, ks. myös A 300/25 b, 29 b.

${ }^{118}$ SKSÄ A 300/25 b.
} 
päätyä laulamaan jotain, mitä ei ole laulanut koskaan aikaisemmin. Aineistosta löytyy esimerkiksi laulajien tiettyjä juhlatilaisuuksia, vierailuita tai estradiesiintymisiä varten varta vasten sepittämiä lauluja, jotka pohjaavat kuitenkin vahvasti perinteisiin runoteemoihin ja laulamisen tapoihin. ${ }^{119}$ Samalla täytyy muistaa, että inkeriläinenkin laulukulttuuri on pitänyt sisällään myös improvisatorisia piirteitä: lajeittain ja tilanteittain vaihtelevan uuden luomisen mahdollisuuden voi katsoa olleen myös osa perinnettä (Timonen 2004, 274). ${ }^{120}$ Tämän lisäksi myös erilaiset lauluista puhumisen, niiden siteeraamisen tai epämuodollisemmin esittämisen tavat voivat olla osa yhteisön tapoja käyttää lauluja, eivät siis jotain ainoastaan keruutilanteessa syntynyttä (Sykäri 2011; Lukin 2011).

Kuten Lotte Tarkka $(2005,101)$ on todennut, tallennustilanne ohjaa usein laulajaa keskittymään tiettyihin asioihin. Kerääjien kiinnostus johti myös laulajien huomion runoteksteihin ja tiettyihin lajeihin niin, että esimerkiksi vienalaisen epiikan yhteydessä ei laulajan sanoja juuri tallennettu. Jos runotekstejä etsivä kerääjä ei ole kiinnostunut vaikkapa sävelmistä tai kontekstitiedoista, ei tilannetajuinen laulaja näitä hänelle pyri esittämäänkään. Keräjän kiinnostus on osaltaan painottanut kokoelmia eri tavoin. Esimerkiksi Vihtori Alava tallensi myös muutamia sävelmäluonnoksia sekä ilmeisesti joitain runoja laulusta, ja hänen keräelmässään on myös runsaasti erilaisia yksityiskohtien selityksiä ja lyhyitä laulujen luonnetta, laulamisen tapoja ja esitystilanteita kuvaavia sitaatteja laulajilta. Juho Lukkarisen kohdalla painottuivat juhlien ja uskomusten kuvaukset. Armas Launis ei tallentanut runoista kuin muutaman ylimalkaisen alkusäkeen, joten laulajat varmasti nopeasti ymmärsivät, että hänelle oli pitkiä runoja turha esittää - mahdollisimman moninaiset sävelmät sen sijaan olivat tervetulleita. Väinö Salmista kiinnosti ennen kaikkea hälaulujen sijoittuminen rituaalin kokonaisuuteen, mutta esimerkiksi laulujen esittämistavoista ei hänellä ole paljonkaan huomioita. Elsa Enäjärvi-Haavio tallensi runojen oheen nimenomaan kuvauksia lauluun liittyvästä liikkeestä ja laulettuina toteutuneista tekstuaalisista rakenteista, mutta varsinaisia sävelmien kuvauksia hänellä ei suoria sitaatteja ja laulajien käyttämiä nimityksiä lukuunottamatta ole, nuoteista puhumattakaan. Jo Launiksen ja Laihojen äänitekokoelmat rakentuvat eri tavoin: siinä missä Launiksella samoilla runon alkusäkeillä on usein esitetty paljon erilaisia sävelmiä, Laihojen kokoelmassa on monia runoja laulettu samoilla sävelmillä. Launiksen huomio oli erilaisissa sävelmissä, Laihojen erilaisissa runoissa ja niiden tyypillisissä, hyvissä esityksissä.

Myös laulajalla saattoi olla syynsä keskittyä tiettyihin esityksen puoliin. Esimerkiksi Matroona Bässinä esitti runojaan laulamalla 1930-luvulla ainoastaan ensimmäisinä tulleille Väinö ja Kaarina Salmiselle. Näiden jälkeen tulleille kerääjille hän halusi sanella runonsa, vaikka Haavio kertoo hänen jalkojensa joskus samalla tapailleen nopeaa tanssin rytmiä. ${ }^{121}$ Toivo Koilolle Bässina kertoi, että oli unohtanut runojaan sen jälkeen, kun oli esittänyt niitä laulaen Väinö Salmiselle: ”Pää niku

\footnotetext{
${ }^{119}$ SKS KRA Enäjärvi-Haavio 912, 913; Kohtamäki VK 41:6; Laiho L. 5898; Salminen K. 73; SKSÄ A 507/8a; ks. myös Heinonen 2008b.

${ }^{120}$ Länsi-Inkeristä ks. esim. SKS KRA Mannonen 5501, 5591.

${ }^{121}$ SKS KRA Haavio 2286.
} 
rautpata. Mitte ei tye mielee. Jos dohter (= proff Salminen) vielä olisi enemmän kysellyt, siis miul olis olt kai pääss puhtaass."122 Vaikuttaa siltä, että Bässina koki muistin heikkenemisen liittyvän runojen esittämiseen kerääälle laulaen, kokonaisvaltaisina esityksinä. ${ }^{123}$ Samankaltaisesta ilmiöstä, laulujen vieraille esittämisen ongelmallisuudesta, kertoo Salmisen $(1834,178)$ anonyymi sitaatti: "Jos me parhaat virret vieraille annamme, mitä jää meille itsellemme muistettaviksi." Varsinaisissa laulutilanteissa kerääjät eivät aina olleet tervetulleita. Esimerkiksi Tallqvist ja Törneroos $(1904,368,376)$ saivat Keski-Inkerissä paikalle ilmestymisellään nuorison kokonpolton ja laulun loppumaan ja säikäyttivät toisaalla morsiamen kesken häävirtensä. Arno Survo $(2001,47)$ tiivistä: "Runoja esitettiin [kerääjille] tavallisesti mieluiten aitojen käyttötilanteiden ulkopuolella."

Alava $(1916,9)$ kertoo, että haastateltavat eivät aina olleet keruuhetkellä parhaimmillaan: "Muistiinkirjoitetut toisinnot semmoisinaan ovat useinkin vain niin sanoaksemme raaka-ainesta, kiireessä muistiin juohutettuja runoja, jotka eivät aina edusta täydellisintä ja eheintä muotoa.” Väinö Salminen (1917, 26-27) puolestaan kuvaa hääritualissa sukujen välisinä dialogeina edenneiden häälaulujen yksin esittämisen vaikeutta keruutilanteessa. Esitysten tutkimisen kannalta erilaiset tallenteet asettavatkin erilaisia haasteita. Runomuistiinpanoihin, käsikirjoitussävelmiin ja äänitteisiin liittyy osin omanlaisiaan ongelmakenttiä.

Monelle runotekstin kerääjälle olennaisinta oli tallentaa säkeiden ja juonen perushahmo. Yhdestä säkeestä tai sanasta saatettiin merkitä ylös ainoastaan alkukirjain jos runo noudatti kerääjän ennalta tuntemaa kaavaa, ja runot täydennettiin myöhemmin joko kerääjän tai Suomen Kansan Vanhojen Runojen toimittajan toimesta tai merkittiin katkoviivalla. Runo- ja sävelmämuistiinpanoissa ei ole aina edes laulajan nimeä, muista tiedoista tai etnisestä taustasta puhumattakaan. (Anttonen 1987, 59; Asplund 1992, 154-158; Harvilahti 1992a, 13-14; Kuusi 1983a, 8, 147; Salminen 1934, 38-47.) Vihtori Alava ja Volmari Porkka käyttivät aikanaan edistynyttä tekniikkaa, pikakirjoitusta ja etenkin Alavan keräämät runot ovat Marie Bonon (2003) mukaan tallentaneet myös seudun murrepiirteitä huomattavan tarkasti. Bono on kuitenkin osoittanut Porkan täydentäneen murremuodot runoihin pitkälti puhtaaksikirjoitusvaiheessa oman murretuntemuksensa mukaan. Nekään eivät siis kielellisesti täysin vastaa laulajan sanelemaa tai laulamaa versiota.

Yleensä muistiinpanojen yhteydessä ei ole tietoa siitä, onko esittäjä laulanut vai sanellut runonsa. Jukka Saarinen $(1988,198-199)$ on todennut sanelemisen lähinnä vaikuttaneen juuri viimeisen tavun poisjääntiin ja vanhojen sanamuotojen korvautumiseen uudemmilla, usein lyhyemmillä muodoilla. Hän tarkastelee prosessia Boreniuksen vienankarjalaisilta Arhippa ja Miihkali Perttuselta tallentamien monikerroksisten muistiinpanojen pohjalta: tämän keruustrategiaan kuului sekä

\footnotetext{
${ }^{122}$ SKS KRA Koilo 224.

${ }^{123}$ Laulaja saattoi myös jättää syytä kertomatta runonsa lopun sanelematta, kuten "eräs vanha emäntä” Struuppovan kylästä (SKVR III 1879). Olena Oussimäeltä puolestaan kieltäytyi aluksi sanelemasta Neito linnassa läsii (Sairastava neito) -runonsa kolmea viimeistä säettä koska, Alavan mukaan, ”pelkäsi synnin tulevan" (SKVR III 2333). Agotja Nikolajeva suostui vuonna 1953 ainoastaan sanelemaan Maailmansyntyrunonsa, vaikka oli kertomansa mukaan sitä nuorena laulanutkin (SKSÄ A 101/1-2).
} 
sanellun että lauletun version piirteiden tallentaminen. Petri Lauerma $(2001,2002)$ puolestaan on analysoinut samaa ilmiötä Boreniuksen ja tämän ystävän Neoviuksen samalla tekniikalla pohjois-inkeriläiseltä Larin Paraskelta tallentamien runojen osalta. Paraskella lauluun saattoi myös liittyä vain laulukielelle tyypillisiä säkeen lopputavun muunnoksia, jotka eivät sanelusta tallentaneet. Väinö Salmisen (1934, 177) mukaan useat hänen matkoillaan tapaamansa laulajat siirtyivät sanelusta lauluun, jos jonkun kauan käyttämättä olleen runon muistamisessa sanellen oli ongelmia: laulaen oli helpompi tuottaa runo. (Ks. myös Honko 1998, 81-88.)

Melodioiden nuotinnoksia on vain murto-osa tekstien määrästä, ja ne ovat valtaosin säkeen tai parin pituisia. Sävelmänkerääjät olivat perehtyneitä länsimaiseen (taide)musiikin teoriaan ja kasvaneet sen maailmaan. He tulkitsivat kuulemansa toisenlaiseen järjestelmään ja estetiikkaan perustuvan musiikin aiemman kokemuksensa kautta. Nuotinnos on aina tulkinta ja yksinkertaistus kuullusta. 1800-luvun lopun ja 1900-luvun alun taidemusiikin teoria edellytti tietynlaisen tonaliteetin ja säveltasot, tietyt aika-arvot, tietyn rytmityksen ja tietynlaisen musiikillisen hahmotustavan, jotka vaikuttivat siihen kuinka kerääjät musiikin kuulivat ja tulkitsivat. Näin siis etenkään melodian rytmitys, käytetty sävelasteikko ja sävelkorkeuksien keskinäiset suhteet eivät välttämättä nuotinnoksista välity alkuperäistä esitystä vastaavina. (Huttu-Hiltunen 1999, 188-189; Laitinen 2003a, 9-12, 313-333; Moisala 1991a, 111.) Hyväkään nuotinnos (tai litteraatio) ei välitä esitystä alkuperäisen kaltaisena. Monet tutkijat ovat todenneet erityisesti Suomen kansan sävelmiä -teossarjan nuotinnosten kaavamaisuuden ja sen, kuinka vaikeaa on niiden pohjalta saada kuvaa alkuperäisestä esityksestä tai musiikkikulttuurista. "Pari säettä käsittävä kalevalaisen sävelmän muistiinpano on vain kuin karkea yhteenveto muistiinpanijan kuulemasta laulutapahtumasta," kirjoittavat Anneli Asplund ja Heikki Laitinen $(1979,12)$. (Kolehmainen 1977; Kurkela 1991, 98; Laitinen 2003a, 322, 325-331; Lippus 1995.)

Ensimmäisen fonografin kehittämistä vuonna 1878 seurasi tallentamismahdollisuuksien mullistuminen (ks. esim. Ong 1982; Sterne 2003; Tedlock 1983, 3-19). Fonogrammirullat kuitenkin kuluivat kuunneltaessa, vahingoittuivat helposti ja veivät matkalla paljon tilaa. Musiikintutkimuksen päämääränä olikin pitkään mahdollisimman tarkka nuottikuva, johon pyrittäessä äänite oli vain työväline (esim. Lippus 1995, 32; Jouste 2004, 60). 1900-luvun alkupuolella ei vielä kaivattu kokonaisia esityksiä tai esittäjien omia näkemyksiä niistä: melodian perushahmon ja siihen liittyvien sanojen mahdollisimman tarkka ja tieteellinen tallentaminen ja toisaalta ääninäytteiden, "elävän ja uskollisen kuvan" tallentaminen "siitä tavasta, millä kansalliseepoksemme laulajat sanoin ja sävelin perimätietonsa ja taitonsa ilmitoivat" oli kyllin (Suomi 1906, 20).

Pitkissäkin äänitteissä itse äänitystilanne, laitteiden vaatima paikoillaan pysyminen, tilanteen aiheuttama jännitys ja laulajan näkökulmasta epätavallinen tilanne ovat voineet vaikuttaa lopputulokseen. Laulajien täytyi seistä paikoillaan, hyvin lähellä äänitystorvea ja laulaa riittävän voimakkaasti. Kovin suurta kuoroa ei luultavasti riittävän lähelle mahtunut, ja joka tapauksessa lähimpänä seisovan esilaulajan 
ääni kuului äänitteellä yleensä selkeimpänä. Vaikka itse melodia ja runo olisivat samanlaisia kuin luontevammassa tilanteessa laulaessa, saattavat vaikkapa sävelmän muuntelun määrä, äänenkäytön tapa, säkeiden kertaus, laulun tempo tai muut tyylipiirteet poiketa tavallisesta. Esimerkiksi A. O. Väisänen kertoo erään vahalieriölle tallentamansa itkijän taukojen olevan epätyypillisiä, sillä "hän, fonografin vaikutuksesta, oli niin esiintymiskuumeen vallassa, ett' ei muistanut kuin pari säettä yhteen mittaan, sen jälkeen lausui: 'No', jäi odottamaan, kunnes luin hänelle edelleen säeparin." ${ }^{24}$ Tämän huomioon ottaen on hämmentävää, miten hyviltä esityksiltä monet Launiksen ja Laihojen äänittämät laulut kuulostavat.

Yhdenkin inkeriläisen runon voi toteuttaa hyvin erilaisilla tavoilla, erilaisina esityksinä. Se, etsikö tallentaja runoja, sävelmiä vai tietoja esitystavoista, miten perehtynyt hän tallennuskohteeseensa oli tai minkälaisia teknisiä apuvälineitä (käsinkirjoitus, pikakirjoitus, nuotintamistaito, fonografi, äänitysstudio) hänellä oli käytössään, vaikutti siihen, minkälaisia lauluja hänelle esitettiin ja minkälaisia tallenteita näistä esityksistä syntyi. Eri kerääjien kokoelmat ovat siten monin tavoin toisistaan eroavia kokonaisuuksia. Niitä voi tarkastella erilaisina, eriaikaisina näkökulmina yhteen ajassa ja paikassa varioivaan kulttuuriseen ilmiöön. Näitä näkökulmia määrittävät myös tallentajien ja paikallisten väliset vuorovaikutussuhteet.

${ }^{124}$ SKS KRA Väisänen e)11. 1915. 


\section{Teoreettinen tausta JA MENETELM ÄT}




\section{TeOreettinen tausta JA MENETELMÄT}

Suullista runoutta on tutkittu monen oppialan ja suuntauksen puitteissa. Tämän työn kannalta keskeiset folkloristiikan, etnomusikologian ja antropologian piirissä vaikuttaneet suuntaukset voi monin kohdin hahmottaa toisiaan täydentäviksi. Tulkintojeni pohjana on suullisen perinteen perusolemusta käsitteleviä keskusteluita, joista keskeisimmät liittyvät variaation, esityksen, lajin ja viittauksellisuuden kysymyksiin. Analyysilukujen keskeisenä käytännön lähtökohtana on erilaisten esitysyhteyksien ja runon eritasoisten rakenteiden - niin tekstuaalisten, musiikillisten kuin esityksellistenkin - välisten yhteyksien hahmottaminen. Näitä olen päätynyt jäsentämään ennen kaikkea tyypillistä laulutilannetta kuvaavan esitysareenan ja tietynlaista, tilannesidonnaista esitystapaa kuvaavan rekisterin käsitteen kautta (ks. Foley 1995). Käsitteiden avulla pyrin tavoittamaan paikallisia laulamisen käytänteitä, ilmaisun tapoja ja niiden merkityspotentiaaleja. Viime vuosikymmeninä humanistisissa tieteissä yleistyneen ajattelutavan mukaisesti korostan sosiaalisten käytäntöjen keskeisyyttä merkitysten muodostumisessa (ks. esim. Agha 2007; Halliday 1978; Hanks 1996; Lehtonen 1996; Scott 2010; Silverstain \& Urban 1996).

\section{SUULLINEN RUNO}

Suullinen runo on usein laulua tai resitaatiota, ja laulu on monen tekijän summa. Runokielen ja -mitan, runoaiheiden, sävelmien, rytmien, äänenmuodostuksen tapojen ja erilaisten laulamiseen mahdollisesti liittyvien liikkeiden piirteet lomittuvat toisiinsa, ja laajemmin tarkasteltuna laulu liittyy aina yhteisönsä moninaisiin sosiaalisiin ja kulttuurisiin käytäntöihin. Runon rakenne ja merkitys aukeaa eri tavoin näitä tekijöitä eri suunnista lähestyvien tieteenalojen puitteissa, jotka tosin osin limittyvät toisiinsa. Käsillä olevan tutkimuksen kannalta keskeisimmät kalevalamittaista runoa käsittelevät folkloristiset teokset avautuvat vaihdellen erityisesti antropologian, kielitieteen ja kirjallisuustieteen, mutta myös muiden humanististen ja yhteiskuntatieteellisten alojen suuntiin (erit. Harvilahti 1992a; Oras 2008; Siikala 2000a; Tarkka 2005; Timonen 2004). Samoilla kentillä liikkuvat puheen etnografian, performanssiteorian, etnopoetiikan ja oral-formulaic-teorian nimillä kutsutut monialaiset suuntaukset, jotka puolestaan lomittuvat monin kohdin toisiinsa ja ovat tulleet käsitellyiksi myös eri tavoin yhteen syntetisoituina. ${ }^{125}$ Erilaiset

${ }^{125}$ Puheen etnografiasta ks. Bauman \& Sherzer 1989; Hymes 1971; 1974; performanssiteoriasta tai esityskeskeisistä näkökulmista Bauman 1977; 1986; Briggs 1988; Fine 1984; etnopoetiikasta Hymes 1981; Tedlock 1983; erilaisista syntetisoivista näkökulmista ks. Bauman 2004; Bauman \& Briggs 1990; Finnegan 1977; 1992; Foley 1995; Hanks 1996. 
antropologiset, folkloristiset tai kielitieteellisetkin keskustelut ovat usein näkyvillä myös etnomusikologian alaan kuuluvissa tutkimuksissa (esim. Feld 1990; Laitinen 2003a; Niemi 1998, Niemi \& Lapsui 2004). Erityisesti virolaisessa runolaulun (regilaul) tutkimuksessa folkloristiikan ja etnomusikologian perspektiivejä on asetettu rinnakkain (esim. Oras 2008; Särg 2000).

Kalevalamittaisen runon tutkimuksen piirissä on viime aikoina kiinnitetty huomiota runoalueiden eroavaisuuksien taustoihin ja toisaalta alueiden sisäiseen variaatioon. Yhtenä peruskysymyksenä on runojen käyttö: miten niitä on käytetty, mitä niillä on tehty, millä tavoin ne ovat olleet laulajilleen merkityksellisiä? Tällöin huomio keskittyy runojen tallennusajankohtina eläneisiin paikallisyhteisöihin. Anna-Leena Siikala (1990; 2000a; 2012) on pohtinut laulamisen alueellisten käytäntöjen suhteita laulajarooleihin (habitus) ja runostojen painotuksiin: samakin runoaihe on eri alueilla tulkittu eri tavoin. Senni Timonen (2004) on tarkastellut lyriikan käyttöä ja mielikuvastoa eri alueilla, inkeriläisten laulajien itsensä nimeämiä laulun tilannesidonnaisia lajeja ja pohjois-inkeriläisen Larin Parasken käsityksiä laulamisestaan. Lotte Tarkka (2005) on analysoinut Vienan Karjalan Vuokkiniemen pitäjästä tallennettua runokorpusta kokonaisuutena, suhteessa laajempaan etnografiseen aineistoon mutta myös kohdistaen katseensa yksittäisiin laulajiin ja runoihin. Hän (mts. 73-74) korostaa aineistojen ja tulkintojen alueellista ja ajallista rajautuneisuutta. Runokielen merkityksellisyyden tapoihin pääsee käsiksi keskittymällä riittävän pieneen yhteisöön, jonka voi ajatella jakaneen samankaltaisia käsityksiä maailmasta ja kokemuksia laulusta, vaikka kaikki runouden piirteet eivät tietysti olekaan koko yhteisön jakamia. Tulkitsen ajatuksen pätevän yhtälailla runojen käyttötapojen suhteen. Kuten Tarkka ja Timonen näyttävät, yksikin runoesitys voi ymmärretyksi tullakseen vaatia suhteuttamista laajempaan alueellisen runokokonaisuuteen, etnografisiin taustatietoihin, tietoihin keruutilanteesta tai henkilöhistorioista. Kaikkiin laulun tilannesidonnaisiin tai henkilökohtaisiin merkityksiin ei ole pääsyä: osa tallennetuista runoista jää taustatietojen puutteessa väistämättä käsittämättä tai tulee väärinymmärretyksi. Laajoista, monen kerääjän lukuisilta laulajilta keräämistä aineistoista voidaan kuitenkin hahmotella yleisesti jaettuja, konventionaalisiksi tulkittavia runoaihelmien ja erilaisten esityksellisten piirteiden käyttötapoja. Niihin suhteuttamalla on mahdollista tulkita ainakin osaa yksilöllisistä, hetkellisistä tai paikallisista erityisyyksistäkin. 


\section{VARIAATIO}

Suullisessa kulttuurissa runo ja sävelmä varioivat esityskerrasta toiseen: yhtä oikeaksi todistettavaa tai lopullista muotoa ei ole, on vain muotojen variaatioita. Tämä variaatio voi jo tekstinkin puitteissa olla monen tasoista, esimerkiksi sanamuotojen, säkeiden ja teemajaksojen sisällöllistä tai rakenteellista vaihtelua. Runosto ei paikallisellakaan tasolla ole yhtenäistä massaa: toiset teemat ja lajit varioivat enemmän, toiset ovat kiteytyneempiä, tietyt on voitu pyrkiä toistamaan mahdollisimman samankaltaisin kerrasta toiseen, toisaalla improvisaatio on voinut olla ihanne. Lauri Harvilahti $(2000,67)$ on huomauttanut, kuinka kalevalamittaisen runon monitasoisia säännönmukaisuuden ja variaation vaihteluita onkin vaikea mallintaa niin, että kuva ei yksinkertaistuisi ja pelkistyisi liikaa. ${ }^{126}$

Yhtäkin runoaihetta, tarinaa, sävelmää tai muuta kiteytynyttä ilmaisua voidaan tulkita ja käyttää monin eri tavoin ja eri yhteyksissä, sen avulla voidaan sanoa erilaisia asioita. ${ }^{127}$ Lotte Tarkka $(1998,137)$ huomauttaa, että uudessa esitystilanteessa perinteisille aihelmille saatetaan antaa uusia, ajankohtaisia, hetkessä kiinni olevia merkityksiä: "Elävässä runokulttuurissa jokainen suullisesti esitetty runo on laulajansa tuottama omatekoinen teksti, jonka merkitys ei määrity alkuperän ja tekijän intentioiden, vaan performanssien ja niiden tulkinnan kautta."

Tietyistä runoaiheista on tallennettu suuri joukko samankaltaisia versioita, jolloin aihetta on ilmeisesti ollut usein tapana laulaa melko kiteytyneenä - tällöinkin muutamat laulajat ovat saattaneet kuitenkin esittää sen valtavirrasta poikkeavilla tavoilla. Jotkut runot ovat kiteytyneempiä kuin toiset; jotkut säkeet ja säeryhmät esiintyvät yleensä vain tietyissä runoissa, toiset vapaammin kautta koko runoston. (Ks. Harvilahti 1992a, 145-146; Tarkka 2005, 65-66.) Inkerissä aiheet, säejaksot ja päähenkilöt liikkuvat usein eri runojen välillä enemmän kuin pohjoisemmilla runoalueilla, ne liittyvät vaihtelevammin erilaisiin kokonaisuuksiin. Runon taitaja on hallitsemansa runokielen pohjalta voinut sepittää myös täysin uuden runon, joka on puolestaan ajan kuluessa voinut vakiintua osaksi ryhmän yleistä laulustoa. (Hautala 1945, 275-284.) Myös eri laulajien tavat käyttää runokieltä varioivat, osin henkilökohtaisesti, osin alueittain. John Miles Foley (1990) ja Eila Stepanova (2012, 264; ks. myös Stepanova (tulossa)) ovat tarkastelleet ilmiötä kielentutkimuksen mallin mukaan yhden laulajan idiolektin, alueellisen dialektin eli murteen sekä koko perinnealueen kattavan kielen tai rekisterin metaforin.

Variaatio pohjautuu kahteen tekijään: toisaalta muistin toimintaan, toisaalta runojen käyttöön. Se voi olla joko tiedostettua tai tiedostamatonta, tarkoitettua tai tahatonta. Runojen käytön osalta variaatio voi liittyä niin runon merkityksiin (runoa muokataan tai yhdistellään muihin teemoihin sen mukaan, mitä sillä halutaan

126 Variaation eri tasoista kalevalamittaisen runon kohdalla ks. esim. Harvilahti 1992a, 13; 1998, 200-204; 2004; Kuusi 1949; Laitinen 2003a, 328; Lippus 1995, 61; Porkka 1886, 168; Saarinen 1991, 194; Timonen 2004, 84-157, 238-303; Tarkka 2005.

127 Monikäyttöisyydestä kalevalamittaisen runon yhteydessä ks. esim. Harvilahti 1992a; Oras 2008; Tarkka 2005; Timonen 2004; kertomusperinteen kohdalla esim. Koski 2011; Siikala 1984; Siikala \& Siikala 2005. 
sanoa), esitystilanteeseen (esimerkiksi minkä pituisena runoa on tietyssä tilanteessa mahdollista esittää, paljonko yleisöllä on taustatietoja) kuin esteettisiin mieltymyksiinkin (pidetäänkö esimerkiksi parempana pitkää ja monipolvista vai lyhyttä ja napakkaa esitystä). ${ }^{128}$

Keskeisimpiä suullisen runon variaatiota pohtineita 1900-luvun loppupuoliskon suuntauksia on niin kutsuttu oral-formulaic -koulukunta. Milman Parryn (1930) ja Albert Lordin (1960) keskeisenä ajatuksena oli suullisen runon tuottaminen esityksessä, "composition in performance" - runo pohjautui perinteisille ilmauksille ja juonenkuluille, mutta syntyi jokaisessa esityksessä erilaisena, uutena, laulajan omana versiona. Keskeisiä käsitteitä olivat jo aiemminkin käytössä olleet formula eli "joukko sanoja, joita säännöllisesti käytetään samoissa (runo)mitallisissa olosuhteissa ilmaisemaan tietty olennainen ajatus" (Parry 1930, 80; ks. myös Lord 1960, 30-67) sekä teema, joka tarkoitti laajemmassa aineistossa "toistettuja tapahtumia ja kuvaavia jaksoja," ja joka saattoi toistua lyhyempänä tai pidempänä (Lord 1960, 4, 68-98). Jo Lord korosti formuloiden dynaamisuutta ja moniulotteisuutta: ne muuttuvat ja toimivat malleina uusille muodoille. Runon laulajalla on erilaisia yhdistelymahdollisuuksia: teemat ja formulat voivat toteutua pidempinä tai lyhyempinä, jäädä pois, koostua vaihtelevista säkeistä, uusia säkeitä voi synnyttää vanhojen mallien mukaan, juonenkulut voivat olla vaihtoehtoisia. Formula-teoria sai nopeasti paljon sovelluksia, joiden puitteissa on luotu erilaisia käsitteellisiä tasoja ja hierarkioita erilaisille samantyyppisinä toistuville runon osille. Teorian nykysovellukset ja jäsentelytasot vaihtelevat paljon tutkittavan kulttuurin mukaan sekä suhteessa siihen, tutkitaanko ainoastaan teksteinä säilynyttä runoutta vai elävää runokulttuuria. (Foley 1985; 1988.)

Runo, teema ja formula ovat eri tutkijoiden ja tutkimuskohteiden kohdalla saaneet osakseen vaihtelevia määritelmiä ja rinnalleen erilaisia korvaavia tai erittelyä tarkentavia käsitteitä. Kuten Harvilahti (1992a, 29-36, 64-67, 142-143) toteaa, niiden käyttö ja määrittely on sidoksissa analyysitasoon ja tutkittavaan perinteeseen: pohjimmiltaan suullisen runouden luonne on niin monitasoinen, että sen tyhjentävä ja yksiselitteinen kuvaaminen ei yksinkertaisella mallilla onnistu. Tässä tutkimuksessa runo, teema ja formula ovat aineiston kuvaamiseen käytettyjä peruskäsitteitä. Kuten oli jo Lordin periaatteena, ne tunnistetaan aina yhtä runoa laajemman aineiston sisältämien samankaltaisuuksien pohjalta: perusteena on vertailu eli niiden käytön mahdollisuuksien tarkastelu, ei intuitiivinen tunnistaminen. Ne ovat laajuudeltaan vaihtelevia kiteytymiä, joita on mahdollista käyttää erilaisissa yhteyksissä. Kuten Timonen $(2000,634)$ ja Harvilahti (1992a, 141-142) ovat todenneet, Inkerissä edes näiden peruskategorioiden selvärajainen erottaminen analyysin tarpeisiin ei ole aina helppoa: tietty sisällön ja muodon yhdistelmä voi esiintyä enemmän tai vähemmän samankaltaisena, pidempänä tai lyhyempänä

\footnotetext{
${ }^{128}$ Kalevalamittaisen runon tutkimuksen puitteissa Harvilahti (esim. 1992a; 2000; 2004) on pohtinut erityisesti variaation suhdetta muistiin ja runojen tuottamiseen; Timosen (2004) ja Tarkan (2005) töissä taas painottuu runojen käytön ulottuvuus. Variaatiosta ja eeppisestä runosta yleisemmin ks. Honko 1998; kalevalamittaisen runon pituuden variaatiosta saman laulajan eri esityskerroilla ks. DuBois 1994 Saarinen 1991; Timonen 1974.
} 
versiona, osana pitkää runoa tai omana itsenäisenä kokonaisuutenaan. Moni runotekstin variaatiosta sanottu asia pätee yleisellä tasolla myös runojen sävelmiin. Sävelmät ja laulamisen tavat varioivat vaihdellen niin alueittain, laulajittain, esityksittäin kuin esitysten sisälläkin (esim. Huttu-Hiltunen 2008; Laitinen 2006; Lippus 1995; Rüütel 1998). Kysymys siitä, mikä edustaa vielä samaa sävelmää tai sävelmätyyppiä on paikoin yhtä lailla vaikea kysymys kuin runojen tai formuloidenkin kohdalla.

Variaatio ja sen monimuotoisuus on tässä työssä arkistoaineiston ymmärtämisen lähtökohta. Kun puhun runosta tai sävelmästä, tarkoitan joko konkreettista tietyssä hetkessä muotonsa saanutta ja tavalla tai toisella tallennettua laulua tai sitten tiettyä tutkijalle tunnistettavissa olevaa perushahmoa, joka voi saada monta erilaista muotoa ja tulla käytetyksi monin tavoin. Se, mikä oli runo tai sävelmä paikallisesta näkökulmasta, on ennemminkin osa tutkimuskysymystä kuin tutkimuksen lähtökohta. Luvuissa 4-7 levitän nähtäville sekä aineistossa esiintyviä runojen, sävelmien, rakenteen, liikkeen ja tilanteiden yhdistelmien variaatiota että toistuvuutta. Kuvauksen laajuuden yhtenä motivaationa on toisaalta liian yksioikoisen ja yleistävän kuvauksen välttäminen, toisaalta variaation ytimien ja rajojen sekä erilaisten piirteiden käyttömahdollisuuksien kartoitus.

\section{EsITyS}

Esitys, kommunikaatio ja konteksti alkoivat nousta tekstin rinnalle ja ohi suullisen perinteen tutkijoiden huomion kohteena 1960-luvulta alkaen. Tämän työn kannalta merkittävää keskustelua on käyty etenkin sosiolingvistiikan, puheen etnografian, etnopoetiikan ja performanssikoulukunnan nimillä tunnettujen suuntausten leikkauspisteissä. (Ks. Bauman \& Briggs 1990; Foley 1995, 11-15; 2002, 85-93; Harvilahti 2003, 102; ks. myös Briggs 1988; Feld \& Fox 1994; Gumperz \& Gumperz 2008.) Esitystilanne alettiin hahmottaa kehyksenä, jossa sanat ja rakenteet erilaisten esityksellisten ja kielenulkoisten piirteiden nojalla tulkitaan:

Esitys merkitsee [...] referentiaalisen kielenkäytön muutosta [...]. Toisin sanoen tämänkaltaisessa taiteellisessa esityksessä tapahtuu kommunikatiivisessa ajatustenvaihdossa jotain, joka sanoo kuulijalle "tulkitse sanomani jollain erityisellä tavalla, älä ota merkitystä sellaisena kuin sanat yksin, kirjaimellisesti otettuna, välittäisivät." [... ] Esitys asettaa tai merkitsee tulkinnallisen kehyksen, jonka sisällä välitettävät viestit tulee ymmärtää, ja tämä kehys eroaa jyrkästi ainakin yhdestä kehyksestä, kirjaimellisesta. (Bauman 1977, 9.)

Richard Bauman (1977, 9-24; ks. myös Goffman 1974) on käsitellyt esitystä taiteellisena ja vuorovaikutteisena tapahtumana, johon sisältyy eritasoisia merkkejä tai avaimia siitä, missä valossa sanat tulee tulkita. Näistä Bauman hahmotteli seitsemän esityksen avaimiksi (keys of performance) kutsumaansa kategoriaa, mutta muistutti listan olevan suppea: olennaisinta on määritellä kunkin tutkittavan kulttuurin piirissä ne vaihtelevat kommunikatiiviset keinot, joiden kautta esitysten 
merkitys välittyy. ${ }^{129}$ Ruth Finnegan $(1977,241)$ korostaa lisäksi esitysolosuhteiden, esiintyjän tai runoilijan yhteisöllisen aseman sekä yleisön koostumuksen ja toiveiden merkitystä pelkän tekstin pysyvinä tai absoluuttisina pidettyjen piirteiden kustannuksella.

Siinä missä Bauman puhuu esityksen luomasta tulkinnallisesta kehyksestä, ${ }^{130}$ John Miles Foley (1995, erit. 8, 47-56, 79-82) käyttää esitysareenan käsitettä. Metaforisella tasolla käsite viittaa konkreettiseen fyysiseen tilaan, jossa tietyntyyppinen esitys yleensä tapahtuu, mutta Foleylla sen sisältö on monisyisempi ja laajempi. Esitysareena viittaa ennen kaikkea tietyntyyppiseen sosiaaliseen tilanteeseen ja tiettyyn yhteisön jakamaan tulkintakehykseen. Se on sidoksissa rekisterin käsitteeseen: tietyt tyypilliset esitysyhteydet ja niihin tyypillisesti kuuluvat tietyt kielenkäytön tai ilmaisun tavat määrittävät myös toisiaan. Esitysareenan ei aina tarvitsekaan sitoutua tiettyyn fyysiseen tilaan tai edes tyypilliseen tilanteeseen tai sosiaaliseen asetelmaan, vaan se voi myös toimia ainoastaan viittauskohteena tai "kokemuksena ennemmin kuin nimettynä paikkana tai hetkenä" (Foley 1995, 47, alaviite 43; ks. myös Sykäri 2011, 61).

Esitystä käsiteltiin alkuvaiheessa lähinnä kohosteisena, taiteellisena, arkipuheesta selkeästi erottuvana tapahtumana ja siten tutkimuskin keskittyi tämänkaltaisiin esityksiin. Keskeiseksi nousi esityksessä ilmi tulevan kompetenssin käsite: hyvä esittäjä hallitsee esitettävänsä niin sisällön, muodon, esittämisen kuin yleisön kanssa tapahtuvan vuorovaikutuksenkin kannalta. Niin kutsutussa täydessä esityksessä (full performance) esiintyjä käyttää koko esittämiseen liittyvää kompetenssiaan ja hänen suhdettaan yleisöön ja tilanteeseen määrittää vastuun ottaminen esityksen kulusta. (Bauman 1977, 11; Hymes 1981, 84; ks. myös Briggs 1988, 7-8; Bauman \& Briggs 1990, 73; Fine 1984, erit. 60.) Voisi sanoa, että hän esiintyy tosissaan, käyttäen kaikkia yhteisön arvostamaan tietynlaiseen esitykseen tyypillisesti kuuluvia keinoja. ${ }^{131}$ Toisaalta esitys edellyttää myös yleisöltä tiettyä kompetenssia: on tunnettava esitettävä laji ja esityksen sisältämät viittaukset kyetäkseen ymmärtämään ja tulkitsemaan esitystä. Kompetenssiltaan ja taustatiedoiltaan erilaiset yleisön jäsenet tulkitsevat esitystä erilaisin tavoin. Tallennustilanteessa myös keskeisen yleisön eli tallentajan kompetenssi, henkilöhistoria ja sosiaalinen identiteetti vaikuttavat siihen, mitä ja millä tavoin hänelle esitetään ja miten hän esitetyn tulkitsee.

\footnotetext{
${ }^{129}$ Luettelossaan Bauman keskittyy lähinnä siihen, mitkä tekijät esityksessä merkitsevät sen tiettyyn esitystraditioon tai lajiin kuuluvaksi: 1) "Erityiskoodit" eli tietyn lajin esittämiseen käytetty kieli, kuten tässä työssä kalevalamitta 2) "Kuvakieli" (metaforat, metonymiat etc.) 3) "Parallelismi" eli tekstin elementtien toistaminen eri sanoin, 4) "Erityiset formulat" eli kiteytyneet, eri yhteyksissä toistuvat ilmaisun tavat, 5) "Vetoaminen perinteeseen" eli esityksen perinteeksi nimeäminen tai osoittaminen, 6) "Sanoutuminen irti esityskyvystä" eli oman esityskyvyn vähättely sekä 7) "Erityiset paralingvistiset koodit", esimerkiksi tietyn tyyppiseen esitykseen liittyvät eleet, musiikki, tauot tai äänensävyt. Baumanin hahmotelma keskittyy lähinnä erilaisille esityksen kielellisen ilmaisun tasolle (1-4) ja metakommunikatiiviselle tasolle eli esityksen kommentointiin (5-6). Hän viittaa vain viimeisessä kohdassa moninaisiin kielenulkoisiin tekijöihin, jotka ovat tämän tutkimuksen keskiössä.

${ }^{130}$ Kehyksen käsite juontui Gregory Batesonilta (1972) ja Erving Goffmanilta (erit. 1974), joiden vaikutus näkyy esityskeskeisissä lähestymistavoissa monessa kohden (laajemmin ks. Fine 1984, 34-36).

${ }^{131}$ Mihail Bahtin (1986, 76-77; ks. myös Hanks 1987, 672) puhuu finalisaatiosta tarkoittaen hieman samankaltaisesti sitä, että puhuja on sanonut tai kirjoittanut kaiken, mitä hän tietyssä tilanteessa on halunnut, ja tyydyttävällä tavalla. Hän määritti finalisaation kolmen tekijän kautta: "1) teeman semanttinen kattavuus (exhaustiveness), 2) puhujan aikomus tai suunnitelma ja 3) tyypilliset kompositionaaliset ja lajilliset finalisaation muodot."
} 
(ks. Bauman \& Briggs 1990, 69-72; Briggs 1986; 1988; Foley 1995, 42-47.) Tämän takia edellisessä luvussa keskityttiin tarkemmin yksittäisiin tallentajiin ja itse keruutilanteista tallennettuihin tietoihin: ne antavat viitteitä siitä, mistä kaikesta voi olettaa kenenkin kerääjän tai laulajan tuottamien aineistojen kertovan.

Keskittyminen kohosteisiin täysiin esityksiin johti myös tallennustilanteiden problematisointiin. Onko epätyypillisessä tilanteessa tallentajalle esitetty tarina tai runo oikeastaan esitys ollenkaan, vai onko se vain tyypillisistä, täysistä esityksistä raportoimista tai kertomista, kysyi Richard Bauman $(1977,8)$ miettiessään, millä tavoin tallennustilanteet voivat erota muista esitystilanteista. Aiempaa sensitiivisemmistä etnografisten kohtaamisten ja tallennustilanteiden analyyseista huomattiin, että tallennustilanne saattaa toisaalta johtaa jopa kommunikatiivisen kompetenssin (esityskyvyn) korostamiseen, toisaalta monenlaiseen epätasa-arvoisen asetelman tuottamaan vitsailuun, pilana pitämiseen tai stereotypioihin turvautumiseen. Kiinnostus on sittemmin suuntautunut myös vähemmän "täysiin" esityksiin. (Bauman \& Briggs 1990, 72; ks. myös esim. Paredes 1977; Briggs 1986). On todettu esitysten muodollisuuden varioivan lajeittain ja tilanteittain (Bauman \& Briggs 1990, 71).

Äärimmillään esityksenä, dialogina ja monien ristiin menevien äänien tai näkemysten kohtauspaikkana voidaan käsitellä jopa yhden ihmisen mielen sisäistä puhetta itselleen (Tedlock \& Mannheim 1995, 3). Näiden kahden ääripään, kohosteisen ja mielensisäisen, välillä on tietenkin suuri ero esimerkiksi esityksen muodollisuuden suhteen sekä siinä, kuinka tietoisesti ja vakiintuneisiin keinoihin nojaten se luodaan (ks. Tedlock 1983, 14-15.) ${ }^{132}$ Onkin huomattava, että esityksen (performanssin) käsitettä on käytetty eri tutkimustraditioiden puitteissa hyvin erilaisissa asiayhteyksissä kohosteisista, taiteellisista, selkeästi tavallisesta puheesta erottuvista esityksistä aina mahdollisimman arkiseen ja tavanomaiseen kommunikaatioon (ks. Virtanen 2003, 10-21). Tässä asetelmassa kalevalamittainen runo sijoittuu säännöllisen, tunnistettavan muotonsa ansiosta kohosteisen esityksen puolelle arkipuheen lomassa käytettynäkin.

Inkeriläisaineiston perusteella näyttää siltä, että vaikka erilaiset tallennustilanteet eroavat monin tavoin toisistaan, oli kaikilta puoliltaan täysi esitys tietynlaisissa tallennustilanteissa mahdollinen. Äänitteiden arviointi on mahdollista toisaalta keruutilanteiden kuvausten ja äänitteiden itsensä, toisaalta runonkerääjien keruutilanteiden ulkopuolella spontaanisti kuuleman laulun kuvausten perusteella. Tallennustilanteen vaikutus näyttää olevan vahvasti sidoksissa laulun lajiin ja lajinmukaisiin tyylipiirteisiin: esimerkiksi yhtään kaikkia kuvausten perusteella tavanomaisia tyylipiirteitä noudattavaa arkisen kehtolaulun esitystä ei ole tämän työn aineistoon taltioitunut, vaikka kehtolauluäänitteitä on muutama. Kysymys siitä, minkälaisia esityksiä runonkerääjille on suunnattu, mitä niistä on tallennettu

${ }^{132}$ Venla Sykäri (2011) on tarkastellut tilannetta kreetalaisten mantinada-parisäkeiden yhteydessä. Vaikka tätä laulun lajia perinteisesti käytettiin näkyvimmin erilaisissa juhlatilanteissa ja käytetään nykyään etenkin runokirjoissa, tekstiviesteissä ja televisio-ohjelmissa, paljastuu pidemmän kenttätyön aikana myös runokielen merkitys nimenomaan mielen sisäisessä keskustelussa ja arkiseen viestintään liittyvissä tilanteissa. 
ja mitä nämä tallenteet kertovat toisaalta tallennustilanteessa hahmonsa saaneesta esityksestä, toisaalta esityksen taustalla vaikuttavista kulttuurisista malleista, on tässä työssä keskeinen. Kiinnostavia työn kysymyksenasettelun kannalta ovat kuitenkin yhtälailla tyypillisiä esityskäytänteitä tavalla tai toisella raportoimaan, kuvaamaan tai soveltamaan pyrkineet esitykset - sanellut runot, proosakuvaukset tyypillisistä esitystilanteista tai yksin esitetyt sävelmät - kuin kokonaisvaltaiset, niin tekstuaalisilta, musiikillisilta kuin erilaisilta esityksellisiltäkin piirteiltään naisten julkista juhlalaulua kuvastavat tallenteet.

Yhtäkin runoa, tarinaa tai laulua voi käyttää monessa erilaisessa tilanteessa, ilmaisemaan hyvinkin erilaisia asioita. Erilaisissa tilanteissa niitä käytetään erilaisin tavoin ja ne voivat saada toisistaan hyvinkin paljon poikkeavia ilmiasuja. Keskeistä tässä on kaikki se, mikä esitystä ympäröi ja edeltää eli laulun konteksti. Tutkimuskysymystä mukaillen kontekstuaalisia tasoja on mahdollista jaotella monella tavalla. ${ }^{133}$ Käsite on laajentunut esitystilanteeseen ja toisaalta laajempiin kulttuurisiin taustoihin liittyvistä varsinaiseen tekstiin (tai esitykseen) liittyvistä seikoista kattamaan laajemmin tekstin ja ympäröivän todellisuuden välisen suhteen. Tämä suhde on liikkeessä: esittäjä ja yleisö luovat sitä jatkuvasti toisiinsa ja tilanteeseen reagoimalla, konteksti ja esitys punoutuvat toisiinsa. Edeltäneet hetket vaikuttavat siihen, mitä seuraavaksi lauletaan (Sykäri 2011, 152-157), haastattelun edeltänyt hetki vaikuttaa haastattelijan ja haastateltavan uusiin tulkintoihin ja tekoihin (Vasenkari \& Pekkala 2000, 249-525). Konteksti vaikuttaa sekä siihen, mitä osallistujat tekevät että siihen, miten he teot tulkitsevat. Monet tutkijat ovatkin alkaneet puhua kontekstualisaatiosta tai kontekstoinnista ennemmin kuin kontekstista. Olennaista on tällöin se, mitä osallistujat osoittavat kontekstualisoivin vihjein kommunikaation kannalta merkitykselliseksi, mitä he itse nostavat esityksen keskiöön ja miten he osaltaan rakentavat esityksen kontekstia (Gumperz 1982, 130-152). (Ks. Bauman \& Briggs 1990, 68-73; Briggs 1988, 12-16; Hanks 1989, 104-113; Siikala \& Siikala 2005; Tarkka 2005, 54-55.)

Kyse on myös tutkijan tulkintakäytännöistä, joiden yhteydessä Lotte Tarkka (2005, 55) puhuu kontekstualisoinnista tekstin ymmärtämisenä "suhteessa niihin diskursseihin, joihin se suhteutuu kulttuuriympäristössään, performanssiensa vuorovaikutustilanteissa ja yhteisönsä perinteen kokonaiskentässä.” Kuten on useasti todettu, kaikkea kontekstuaalista tietoa ei minkään tutkimuksen tai tulkinnan puitteissa saa kerättyä. Tutkimuskysymys rajaa näkökulman laajuuden ja joskus kontekstuaalista tietoa ei yksinkertaisesti ole saatavilla tarpeeksi tietyn tekstin tai esityksen konkreettisten merkitysten hahmottamiseksi (ks. esim. Briggs 1988, 13). Tällöinkin on silti mahdollista tavoitella sen potentiaalisia, puheyhteisössään mahdollisia merkityksiä (Hanks 1989, 106; Tarkka 2005, 55; ks. myös DuBois 2006).

\footnotetext{
${ }^{133}$ Ks. esim. Apo \& Nenola \& Stark-Arola 1998, 19, 69-70; Bauman \& Briggs 1990, 68; Herndon \& McLeod 1981, 24-39. Esimerkiksi Laura Stark-Arola (1998,69-70) on jaotellut työnsä kannalta merkittäviä kontekstuaalisia kehyksiä tekstuaaliseen, esitykselliseen, sosiaaliseen ja kulttuuriseen kontekstiin sekä kansanuskon, lajien ja lajien välisten suhteiden konteksteihin. Kontekstin vaikutuksesta tulkintoihin aatehistoriassa ks. Skinner 1969; 1972; puheaktiteoriassa Austin 1962.
} 
Tekstin eri esityksissä ja konteksteissa pysyvien ja muuttuvien aspektien suhteita on käsitteellistetty monilla tavoilla ja monin eri termein. ${ }^{134}$ Kyseessä on yksi suullisen perinteen ja kielen tutkimuksen peruskysymyksistä, joka lomittuu myös kysymykseen yksilöllisen ja kollektiivisen suhteesta. Kuten Dell Hymes $(1985,391)$ on todennut, perinteisenkin ilmauksen esittäjä voi samanaikaisesti kertoa sekä jotain henkilökohtaista että jotain kulttuuristaan yleisemmin. "Vaikka vanha kalevalamittainen lyriikka on suuri kollektiivisen mielen tila, se sisältää kollektiivisesta vain yksilöllisiä tulkintoja," on Senni Timonen (2004, 161, ks. myös esim. 196) huomauttanut. Samasta puhuu Lotte Tarkka $(2005,10)$ : "Vaikka kiteytyneillä teksteillä ja perinteen kielellä on tietyssä mielessä autonomiaa ja yliyksilöllinen jatkuvuus, saavat runotekstit merkityksensä vain ihmisten käytössä, heidän tuottaminaan, kuuleminaan ja tulkitseminaan."

Esityskeskeisten lähestymistapojen on kritisoitu vuoroin keskittyvän liikaa kontekstuaalisiin piirteisiin, vuoroin taas esityksessä hahmonsa saavan tekstin yksityiskohtiin. Bauman ja Briggs (1990, 66-78) toteavat, että syytä olisi keskittyä kumpaankin ulottuvuuteen ja ehdottavat vastaukseksi perinteen kontekstista toiseen siirtymisen analyysia esimerkiksi yksittäisten esitysketjujen, yhdessä tilanteessa tapahtuvien uudelleenkerrontojen tai -viittausten tai yksittäisen tekstin yhdessäkin esityksessä kantaman esityshistorian kautta. Anna-Leena ja Jukka Siikala (2005, 31) huomauttavat, että esityksen voima ei ole vain "kontekstuaalisessa käytössä tai esityksessä”, sillä yhtä olennaisia sosiaalisten vaikutusten kannalta ovat myös ne kestävät tekstuaaliset muodot ja sisällöt, joita voidaan käyttää aina uudessa kontekstissa, muokata ja tulkita uudestaan. Näiden muotojen tunnistamiseen ei yksi esitys riitä, vaan on tarkkailtava toistuvia elementtejä useissa eri käyttöyhteyksissä. Kokonaisvaltaisin kuva perinteen merkityksistä saadaan katsomalla sekä esitystilanteiden hetkellisiä tapahtumia että pidempiä ajallisia kaaria, tietyn kertomuksen, laulun tai lajin käyttötapojen pysyvyyksiä, muutoksia ja yhteyksiä muihin ilmiöihin. (Siikala \& Siikala 2005, 29-37.) Tämän työn aineiston puitteissa yksittäisten toisiinsa vaikuttaneiden esitysketjujen tai uudelleenkerrontojen jäljittäminen on yleensä mahdotonta, joten työ asettuu lähemmäs Siikaloiden kuin Baumanin ja Briggsin näkökulmaa. Suullisen perinteen kohdalla on yleensäkin kyseessä ennemmin loputon yksittäisten käyttöjen ja käyttäjien verkosto kuin helposti tavoitettava jatkumo yksittäisiä käyttökertoja. Tarkastelen yksittäisten esitysten tallenteita suhteessa toisistaan riippumattomien esitysten muodostamasta korpuksesta analysoitavissa oleviin jaettuihin ja toistuviin piirteisiin, joita tulkitsen rekisterin ja esitysareenan käsitteiden kautta. Yritän ymmärtää toisaalta sitä, miten ja mitä erilaiset tietyn ilmaisumuodon piirteet merkitsevät, toisaalta sitä, mitä niillä oli tie-

\footnotetext{
${ }^{134}$ Bauman ja Briggs (1990, erit. 73; ks. myös Bauman 2004, 4) kehittivät termit entekstualisaatio ja (re/ de)kontekstualisaatio käsitteellistääkseen kommunikaation pysyviä piirteitä ja toisaalta näiden piirteiden varioivaa käyttöä ja muuntumista eri tilanteissa. Entekstualisaatio kuvaa prosessia, jossa diskurssista tehdään kontekstistaan irrotettavissa oleva yksikkö (teksti) käyttämällä erilaisia rakenteellisia ja lajiin sidoksissa olevia keinoja. Näyttää siltä, että entekstualisaation ohella voisi puhua myös esityksellisen ja tekstuaalisen muodon kiteytytyneisyydestä tai vakiintuneisuudesta, jotka yhtä lailla viittaavat sen siirrettävyyteen. Kontekstista irrottaminen (dekontekstualisaatio) ja uuteen sijoittaminen (rekontekstualisaatio) ovat tässä mallissa saman asian eli uuden käytön kaksi puolta. Termit ovat siirtyneet myös lingvististen antropologien käyttöön, jotka jo aiemmin ovat puhuneet kontekstualisaatiota tarkoittavasta keskittämisestä (centering) (Hanks 1989; Silverstain \& Urban 1996; Silverstain 2005).
} 
tyissä esitystilanteissa mahdollista sanoa. Keskeiseksi muodostuukin tekstin analyysi sen tulkintayhteisön jakamien, tulkinnoissaan käyttämien piirteiden valossa (ks. myös Foley 1991; Tarkka 2005, 61-74).

Esittäjän voi ajatella pohjanneen esityksensä totunnaisille, hallitsemilleen keinoille silloinkin, kun tilanne ja kenties lopputuloskin on poikennut laulukulttuurin kannalta tyypillisestä. Jopa laulajan näkökulmasta parodiaa sisältävä tai epäonnistunutkin esitys kertoo jotain myös laulukulttuurin konventioista ja niiden käytön mahdollisuuksista. Laajassa aineistossa toistuvat piirteet kertovat laulukulttuurin piirissä jaetuista käytännöistä. Tarkastelen aineistoani kerääjälle suunnattujen esitysten tallenteina, joiden suhde yhteisön sisäisiin erilaisiin esittämisen tapoihin on avoin kysymys. Arkistoaineiston tutkijan on olennaista kysyä, minkälaiseen esitykseen mikäkin arkistomuistiinpano mahtaa pohjautua. Tallennustilanne on tutkimuskohde, mutta samalla tulkintani mukaan myös väylä tietoon tyypillisistä yhteisön sisäisistä esitystilanteista ja -tavoista. Tältä kannalta aineiston moninaisuus on ehdoton etu. Käytettävissä on eri asioista kiinnostuneiden runonkerääjien erilaisia kuvauksia sekä tallennustilanteista että niiden ulkopuolelta, eri aikoina eri laulajilta tallennettuja runotekstejä, sävelmämuistiinpanoja ja äänitteitä. Aineiston monipuolisuus antaa mahdollisuuden katsoa inkeriläistä laulua useammasta suunnasta, monenlaisia piirteitä kuvaavien, erilaisiin esityksiin pohjaavien eriaikaisten tallenteiden kautta.

\section{LAJI JA REKISTERI}

Folkloristiikan piirissä käsitys (perinne)lajeista eli genreistä on muuttunut ennen kaikkea arkistoinnin tarpeita palvelevasta, usein tutkijan oman kulttuurin mukaan jäsentyvästä luokittelumallista kohti tutkittavan kulttuurin omien ilmaisumuotojen ja merkitysten välisten suhteiden ymmärtämistä. Esimerkiksi Ruth Finnegan $(1977,15)$ ja Dan Ben-Amos (1992) ovat tuominneet yritykset löytää universaaleja genre-kategorioita mahdottomana, sillä lajit jäsentyvät kulttuureittain eroavilla tavoilla. Lauri Honko $(1998,24-29)$ puolestaan on puolustanut myös tutkijoiden yritystä löytää teoreettisen keskustelun mahdollistavia luokkia ja kuvauksia. "Puhtaita lajeja" voi hänenkin mukaansa esiintyä ainoastaan teoreettisina malleina. Yksi merkittävä erojen tuottaja on keskusteluissa se, pyritäänkö kulttuurien väliseen lajijärjestelmien tai lajillisten piirteiden vertailuun vai yhden kulttuurin lajidynamiikan hahmottamiseen. Ääripäiden välille asettuu näkemys, jonka mukaan lajit ovat sekä tutkijan apuväline että tutkimuksen kohde: tutkimus voi olla liikettä toisaalta tutkijoiden piirissä usean kulttuurin pohjalta hahmoteltujen abstraktimpien luokittelun tapojen tai teoreettisten jäsennysten ja toisaalta tietyn kulttuurin piirissä käytettyjen jäsennysten välillä (Tarkka 2005, 67-70; ks. myös Koski 2011, 49-53, 61-62; Seitel 1999, 14-17). Tässä työssä käytän tutkijoiden luomia lajikategoriota työvälineinä yrittäessäni ymmärtää paikallisia käytäntöjä.

Yksinkertaisimmillaan lajin voi ajatella konventionaaliseksi, totunnaiseksi diskurssityypiksi eli puhumisen tai kommunikaation tavaksi (Bauman 1999, 84). Lajin 
määräytymisen tekijät vaihtelevat sekä kulttuurista että tutkijasta riippuen. Richard Bauman $(1992,54)$ toteaa määritelmien ja luokittelujen pohjautuneen vaihdellen "lähes kaikelle, mitä perinteen suhteen on pidetty merkityksellisenä: muoto, funktio tai vaikutus, sisältö, suhde maailmaan ja maailmankaikkeuteen, totuusarvo, sävy, sosiaalinen jakautuminen ja käytön tavat tai kontekstit." Nykynäkemyksille tyypillistä on lajien ja lajijärjestelmien hahmottaminen joustavina, monitasoisina ja muokkautuvina, liikkeessä olevina. Sekä tutkijoiden että tutkimuksen kohteiden kannalta ne voidaan hahmottaa tekstistä (tai esityksestä) tehtäviä tulkintoja ohjaavina kehyksinä, jotka määrittyvät kulttuureittain ja tapauksittain vaihtelevien piirteiden ja konventioiden kautta. William Hanks $(1987,681)$ toteaa suullisen perinteen lajien määrittyvän ennemminkin keskeisten tai prototyyppisten elementtien kuin yhtenäisten rakenteiden kautta. ${ }^{135}$

Usein muoto, sisältö, käyttöyhteys ja esitystapa eivät osu täysin kohdakkain. Lauri Honko (1998) esimerkiksi näyttää, että yhtäkin eeppistä kokonaisuutta voidaan esittää hyvin erilaisin tavoin: erityyppisissä tilanteissa, soolo- tai ryhmäesityksenä, erilaisilla sävelmillä ja eripituisina kokonaisuuksina: Honko (mts. 75-88) puhuu sekä esittämisen tilannesidonnaisesta tavasta tai moodista (mode of performance) että esityksellisestä tyylistä (performative style). Harvilahti (2003, 78-81) puolestaan osoittaa altailaisen epiikan vaihtelun runo- ja proosamuotojen välillä riippuvan ennen kaikkea esitystavoista (modes of performance), ei niinkään eeppisestä kokonaisuudesta itsestään. Yhtä rekisteriä (esittämisen tapaa) voidaan myös käyttää useamman lajin esittämisessä (ks. myös Misharina 2011). Tällöin lajeista voidaan puhua Harvilahden $(2003,101)$ tavoin "läpinäkyvinä." Anna-Leena Siikala (2000b, 222, 239-240) näyttää, että lajin esittämistapa ja esityksen saama painoarvo on sidoksissa myös esittäjän sosiaaliseen asemaan tai rooliin, habitukseen (ks. myös Hanks 1996, 239). Timo Kaartinen (2001, erit. 287-337; ks. myös 2010) kuvaa, miten Indonesiassa sama teksti eri alueella tai eri tavoin esitettynä voidaan hahmottaa eri lajiin kuuluvana. Lotte Tarkka $(2010,14)$ huomauttaa, että oletettavasti myös runokulttuurin sisällä yksikin esitys voidaan joskus "tulkita useamman lajin edustajaksi, tulkitsijasta riippuen," ja yksikin teksti voi toisaalta eri tilanteissa esitettyinä merkitä erilaisia asioita.

Laji ei ole ainoa käsite, jonka avulla on pyritty hahmottamaan erilaisia puhumisen tapoja. Dell Hymes $(1989,440)$ käyttää alun perin kielentutkijoiden (ks. Halliday $1978,111)$ käyttämää termiä rekisteri kuvaamaan toistuviin tietyn tyyppisiin tilanteisiin liittyviä tärkeimpiä puhetapoja. ${ }^{136}$ John Miles Foley (1995, erit. 50-53) on käyttänyt käsitettä samankaltaisesti, mutta tietyntyyppisten toistuvien tilanteiden eli tässä työssä esitysareenoiden lisäksi myös lajiin sidoksissa olevana käsitteenä, joka kattaa paitsi kielelliset, myös kielenulkoiset piirteet. Yleensä tutkijat käyttävät lähinnä jompaakumpaa käsitettä, ja painottavat niiden kautta enemmän joko

$\overline{{ }^{135} \text { Lajista folkloristiikassa ks. Bauman 2004 }}$; Briggs \& Bauman 1992; Siikala 2000b; lajin käsitteestä yleisemmin ks. Heikkinen et. al. 2012; Mäntynen \& Shore \& Solin 2006. Olli Heikkinen (2010, 39-40) toteaa, että todellisista, historiallisista lajeista puhuttaessa viitataankin usein perheyhtäläisyyden (Ludwig Wittgenstein), ideaalityypin (Max Weber) tai prototyypin (Eleanor Rosch) käsitteisiin.

136 "Major speech styles associated with recurrent types of situation"; rekisteristä ks. myös Foley 1995, 15, 50; Harvilahti 2003, 95; Honko 1998, 62-65. 
kielellistä muotoa ja kielellisiä tyylipiirteitä (rekisteri) tai sisällöllisiä, funktionaalisia tai käyttöön liittyviä piirteitä (genre, laji) (tarkemmin ks. Koski 2011, 324). Funktionaalis-strukturaalisen kielitieteen piirissä on kuitenkin tehty tarkempia teoreettisia jaotteluita käyttäen sekä lajin että rekisterin käsitettä (Halliday 1978; Eggins \& Martin 1997; Martin 1992, 493-588; ks. myös Shore \& Mäntynen 2006, 18-23). ${ }^{137}$ Sovelluksia folkloristiikan ja musiikintutkimuksen puolella on tiedossani muutamia. Lotte Tarkka (2005) käyttää rekisterin käsitettä kuvaamaan kalevalakieltä (runon mitta ja poeettiset piirteet), jota on käytetty useamman lajin (kuten sananlaskut, häävirret, loitsut) puitteissa. Kalevalaista runoa voi pitää erityisenä juuri siinä, että yksi runokieli on ollut käytössä niin monen käytöltään ja esitystavoiltaankin eroavan lajin puitteissa. Kaarina Koski (2011) käyttää kirkonväkeä koskevien tarinoiden analyysissä sekä käsitettä (perinne)laji että (kielellinen) rekisteri: siinä missä perinnelaji viittaa tarinan tunnistettavaan, tyypiteltävissä olevaan sisältöön, kertoo rekisteri tarkemmin sen kielellisestä, kertojan intentioihin ja kerrontatilanteeseen sidoksissa olevista piirteistä. Eila Stepanova (2012) kuvaa rekisterillä perinnelajiin, kommunikaatiotilanteeseen sekä osallistujakokoonpanoon sidoksissa olevaa kielellisten ja kielenulkoisten piirteiden kokonaisuutta. Olli Heikkinen (2010, 35-68) taas päätyy kielitieteilijä J. R. Martinin ja tämän oppilaiden (Eggins \& Martin 1997) kehittämää mallia soveltaen hahmottamaan populaarimusiikin lajin yleisön ja tuottajien tekemään luokitteluun liittyvänä, rekisterin taas musiikin piirteitä ja niiden suhdetta lajeihin kuvaavana käsitteenä, ja käyttää tämän lisäksi moodia esityksen semioottiseen tasoon liittyvänä käsitteenä. ${ }^{138} \mathrm{Kä-}$ sitteiden käyttö- ja määrittelymahdollisuudet näyttävät olevan vahvasti sidoksissa paitsi tutkimuskysymykseen, myös tutkittavaan perinteeseen ja aineiston laatuun: esimerkiksi ainoastaan teksteinä tallennettu historiallinen tarina-aineisto asettaa toisenlaisia haasteita ja mahdollisuuksia kuin populaarimusiikin tutkijaa ympäröivä tiheä äänite-, lehtikirjoitus- ja puhemaailma.

Asif Aghan (2004; 2007, erit. 145-189) käytössä rekisteri-termin keskeinen piirre on sen sosiaalinen rakentuminen: rekisterit ovat tietyn ihmisjoukon jakamia, historiallisesti muuttuvia ja varioivia puhetapoja, kielellisiä repertuaareja. Agha $(2004,24)$ toteaa rekisterin assosioituvan käyttäjäyhteisönsä piirissä sekä "tiettyihin sosiaalisiin käytäntöihin että ihmisiin, jotka osallistuvat näihin käytäntöihin.” Olennaista rekisterin hahmottamisessa on tyypillisyys ja toistuvuus, stereotyyppisyys. Stereotyyppisyys ei tarkoita sitä, että kaikki käyttäjät tekisivät rekistereistä samanlaisia tulkintoja: kompetenssin lisäksi eroja voivat aiheuttaa käyttäjäyhteisön sisällä kilpailevat rekisterien tulkinnat tai käyttäjien kuuluminen eri alaryhmiin. Agha (mts. 30) toteaa myös, että rekistereiden käyttömahdollisuudet ovat

\footnotetext{
${ }^{137}$ Douglas Biber ja Susan Conrad (2009) käyttävät sekä rekisterin (kielelliset tilannesidonnaiset piirteet), genren (rakenteeseen liittyvät tilannesidonnaiset piirteet) että tyylin (ei-tilannesidonnaiset esteettiset, käyttäjä- tai aikasidonnaiset piirteet) käsitteitä.

${ }^{138}$ Heikkinen (2010, 52-68) jaottelee moodit kuuteen: sävelmoodi (eli tämän tutkimuksen terminologialla musiikilliset piirteet), lyriikkamoodi (sanoitus, tekstuaaliset piirteet), esitysmoodi (esitykselliset piirteet kuten äänenväri, fraseeraus), äänitemoodi (ääniteknologiset piirteet kuten studiossa luodut tilavaikutelmat, efektit, äänten keskinäiset suhteet), kuvamoodi (visuaaliset piirteet kuten levynkannet tai musiikkivideot) ja tähtimoodi (esittäjän habitus). Semioottiset moodit ovat "erilaisia musiikillisia ja eimusiikillisia merkityksen muodostamisen tapoja ja välineitä," joita on nimitetty musiikintutkimuksen piirissä erilaisin tavoin (Heikkinen 2010, 53).
} 
aina laajemmat kuin mitä rekistereistä itsestään kulttuurin piirissä eksplisiittisesti kerrotaan. Kuvatessaan rekistereitä ihmiset puhuvat yleensä tyypillisistä käyttötavoista - käytännössähän vaikka yleensä kunnioitusta osoittavaa puheen tapaa voi tietyssä kontekstissa käyttää myös esimerkiksi taitavaan pilkkaan. Tarkastellessaan omaa kulttuuriaan tutkija voi tunnistaa rekistereitä introspektiivisesti, omaan tietämykseensä nojaten. Vierasta kulttuuria tarkasteltaessa ainoa väylä on "julkisesti havainnoitavissa oleva semioottinen käyttäytyminen" (mts. 26) eli se, mitä ihmiset sanovat ja tekevät. Tällainen havainnoitavissa oleva käyttäytyminen on myös kulttuurin sisällä ainoa tapa rekisterien välittymiselle. Suorat kielelliset huomiot ja selitykset ovat selvintä tutkimuksen aineistoa, mutta yhtä lailla voidaan tarkkailla vaikkapa tiettyihin kielenkäytön tapoihin liittyviä kielenulkoisen kommunikaation piirteitä. Yksittäisten ihmisten tiedonannot eivät rekisterien analyysiin riitä, vaan aineistosta täytyy löytyä toistuvia tyypittelyn malleja, vaikka nämä eivät aina olekaan kielellisiä tai eksplisiittisiä.

Olen päätynyt käyttämään sekä lajin että rekisterin käsitettä toisiinsa suhteutuvina analyysin välineinä. Lajin kohdalla suhteutan tutkijoiden yleisesti käyttämiä käsitteitä (kuten epiikka, hääruno, itkuvirsi) paikallisiin muodon, nimeämisen ja käytön kategorioihin eli paikallisiin lajeihin (liekkuvirsi, pulmanuotti, luettelemine). Laji viittaa tässä työssä aina tietyn puheyhteisön - joko tutkijoiden tai tutkimuskohteiden - nimeämiskäytäntöön, joka usein pohjautuu erilaisille rekisterin ja esitysareenan piirteille. Rekisteri määrittyy lähinnä laulun tekstuaalisten, musiikillisten ja esityksellisten piirteiden vakiintuneisuuden kautta: sen kohdalla painottuu siis tietynlainen sanomisen (laulamisen) tapa, lajin kohdalla sitä vastoin käyttö ja nimeäminen. Lajin käsite pitää sisällään myös rekisterin: lajilla on tietty rekisteri tai rekisterien kirjo, ja rekisteri voi olla yhteinen useammalle lajille. Kuten lajilla, rekisterilläkin on erilaisia hierarkkisia tasoja: kalevalamittaista laulua pidän tämän työn kontekstissa ylätasona, jonka koostuu monista alarekistereistä. Sekä laji että rekisteri määrittyvät myös suhteessa tyypillisiin käyttöyhteyksiinsä eli esitysareenoihinsa.

Tutkijoiden lajitermit ovat tässä työssä kuvauksen ja analyysin väline, keino kytkeä tutkimus laajempaan keskusteluyhteyteen, paikalliset lajit ja rekisterit puolestaan tutkimuskohde. Perinteisesti kalevalamittaisia runoja on jaoteltu esimerkiksi lyriikkaan (eli eri tavoin tunteista ja tunnelmista kertoviin, usein juonettomiin runoihin), lyyriseen epiikkaan ja balladeihin (eli kertoviin runoihin, joissa on erilainen kerrontatyyli kuin epiikassa ja toisaalta lyriikan piirteitä), epiikkaan (eli kertoviin runoihin), erilaisiin rituaaleihin liittyviin runoihin, loitsuihin, sekä "tilapäisrunoihin" eli paikallisista tai ajankohtaisista aiheista sommiteltuihin lauluihin. ${ }^{139}$ Jo

\footnotetext{
${ }^{139}$ Kalevalamittaisen runon tutkimuksen puitteissa epiikalla tarkoitetaan yleensä "kertovaa" juonen kulkuun painottuvaa runoa, lyriikalla eli tunnelmarunolla taas henkilöiden tai lyyrisen minän tunteisiin painottuvaa. Balladi viittaa tiettyjä yleiseurooppalaisia malleja ja juonikuvioita noudatteleviin kertoviin, usein traagisiin lauluihin. Tyypillisesti ne ovat riimillisiä ja säkeistöllisiä, mutta termiä on käytetty myös kalevalamittaisen runon puitteissa etenkin silloin, jos runolla on muunkielisiä säkeistöllisiä vastineita. Balladia yleisemmin puhutaan kuitenkin lyyris-eeppisestä runosta. Sillä tarkoitetaan tyypillisesti minä-muotoista, laulajien omaan elämänpiiriin liittyvää, traagista ja tunteita kuvaavaa runoa, joka lyyrisestä runosta poiketen pohjautuu suhteellisen selkeälle juonenkululle (Harvilahti 1998a, 56; 1992a, 205-206; ks. myös Arukask 2003).
} 
inkeriläiset runot julkaissut Väinö Salminen $(1934,236)$ totesi tehtävän olevan haastava: "Kertovien runojen ryhmittely ei ole helppoa. Muutamissa tapauksissa on vaikea määritellä, kuuluuko joku runo varsinaisiin kertoviin vai tunnelmarunoihin." Inkerin runojen hakemiston laatiminen tuotti hänelle etenkin lyyristen runojen osalta tavanomaista suurempaa vaivaa (SKVR III:3, esipuhe). ${ }^{140}$ Senni Timosen $(2004$, erit. 11, 18) mukaan etenkään Inkerissä runot eivät noudatelleet tutkijoiden jakoja (ks. myös Virtanen 1994a, 337). ”Missään ei eeppisen ja lyyrisen raja ole niin häilyvä kuin Inkerissä", hän $(2004,85)$ toteaa ja jatkaa: "Rajat murtuvat myös ilmaisullisesti ja rytmiikaltaan täysin erilaisten ja eri-ikäisten lajien välillä.” Runous ei asetu tutkijoiden perinteisiin luokituksiin, mutta sitä voi tarkastella suhteessa niihin.

Kun lajeja tutkitaan niiden merkityspotentiaalien kannalta, keskeisiksi nousevat paitsi niiden kielelliset ja esitykselliset piirteet, myös niiden käyttö ja paikallinen jäsentäminen. ${ }^{141}$ John D. Dorstin (1983, 413, ks. myös Ben-Amos 1976) sanoin voisi todeta, että kyseessä on "etnografinen yritys, jossa toistuvien käyttäytymismallien ja toistettavien esitystilanteiden tunnistaminen on yhtä tärkeää kuin muodon ja sisällön pysyvyyksien tunnistaminen.” Nämä neljä tekijää muodostavat tämän tutkimuksen ytimen: toistuvia käyttäytymismalleja ja esitystilanteita jäsennän $e s i$ tysareenan, muodon ja sisällön pysyvyyksiä rekisterin käsitteen kautta.

\section{VitTTAUKSELLISUUS}

Kielelliset merkitykset muodostuvat suhteessa paitsi sanomisen hetkeen, myös siihen, mitä aikaisemmin on sanottu. Sanat ja niiden muodostamat laajemmat kiteytymät kantavat mukanaan mielikuvia, merkityksiä, konnotaatioita aikaisemmista ja tyypillisistä käyttökerroistaan. Ilmaukset tulevat tietyssä tilanteessa ymmärretyiksi sekä aikaisempien tai totunnaisten käyttötapojensa että kertaluonteisen käyttöyhteytensä pohjalta. (Ks. esim. Bauman \& Briggs 1990, 60-61; Foley 1991; 1995, xi; Hanks 1996; Lord 1960, 148; Tarkka 2005, 62.) Yksilöllisten versioiden ymmärrettävyys perustuu sille, että ne sisältävät riittävästi elementtejä aikaisemmista esityksistä eli totunnaisista runokielen käyttötavoista (Foley 1995, 23, 45-46). Richard Bauman ja Charles Briggs $(1990,61)$ toteavat, että yhdenkin esityksen "analyysi edellyttää sensitiivistä etnografista tutkimusta siitä, miten esityksen muoto ja merkitys viittaa laajaan kirjoon diskurssityyppejä’, joista kaikki eivät välttämättä ole

\footnotetext{
${ }^{140}$ Suomen Kansan Vanhat Runot -teossarjassa länsi-inkeriläinen aineisto jäsennetään epiikkaan (I Kertovaisia runoja ja runoaiheita), sekalaiseen kategoriaan (II Erilaisia runoja ja runoaiheita), teemoittain jäsentyvään lyriikkaan (III Tunnelmarunoja) häärunoja, juhlapäiviin liittyviä runoja kuin lastenlauluja ja kehtolauluja sisältävään neljänteen kategoriaan (IV Määrätyissä tiloissa ja toimissa) sekä loitsuihin $(V)$. Jaottelu kertoo omalta osaltaan inkeriläisen runouden luokittelun vaikeudesta: toisin kuin vaikkapa Vienassa (SKVR I), aineisto ei edes pääpiirteittäin taipunut yksilöitävissä oleviin kertovaisiin ja lyyrillisiin runoihin sekä loitsuihin, vaan oli turvauduttava runojen lisäksi myös runoaiheisiin, ja määritettävä eräänlainen eeppisen ja lyyrisen väliin sijoittuva kategoria Erilaisia runoja ja runoaiheita. Juuri tämän luokittelemiseen liittyvän hankaluuden takia runot julkaistiin kirjasarjan aikaisemmista osista poiketen kerääjittäin, ei runotyypeittäin.

${ }^{141}$ Näiden hahmottamiseenhan pyrki tavallaan myös Lauri Hongon (1972, 63-105) ehkä selkeimmin edustama perinnelajianalyysi, kuitenkin nykynäkemyksiä enemmän universaaleihin ja yksiselitteisiin kategorioihin pyrkien.
} 
varsinaisten kohosteisten esitysten piirissä esiintyviä. Sosiolingvistien puheyhteisön käsitteestä johtaen historian ja kirjallisuustieteen puolella onkin puhuttu tekstuaalisista tai tulkinnallisista yhteisöistä, jotka jakavat tietoisuuden samoista lähtöteksteistä ja pystyvät siten tulkitsemaan näihin viittaavia tekstejä samankaltaisilla tavoilla. ${ }^{142}$ Siikaloiden $(2005,35)$ mukaan suullisen perinteen elinehto ylimalkaan on juuri "tulkitseva yhteisö, joka kykenee suhteuttamaan tekstit toisiinsa, itsensä teksteihin ja tekstit itseensä."

Etenkin lingvistisen antropologian, sosiolingvistiikan, systemaattis-funktionaalisen kielitieteen ja sosiaalisen semiotiikan piirissä on alettu hahmottaa yksittäisten sanojenkin kantamia merkityksiä aiempaa laajempina, kontekstisidonnaisina ja moniselitteisinä ja käsitellä niiden merkitysten muodostumista sosiaalisten käytäntöjen kautta. ${ }^{143}$ Assosiatiivisuuden ja monitulkintaisuuden ajatus sisältyy käsityksiin runoudesta yleensä lähes itsestään selvänä: runolle tai sen kantamille viittaussuhteille ei usein ole määritettävissä yhtä selkeärajaista, yksiselitteisesti ilmaistavissa olevaa merkitystä; hyvä runo on käyttö- ja ilmaisuvoimainen juuri monitulkintaisuutensa ansiosta. Sanojen, ilmausten tai runojen merkityskentät eivät ole tarkkarajaisia tai helposti määriteltäviä. Ne eivät kuitenkaan liioin ole loputtomia: monitulkintaisintakaan ilmausta ei voi käyttää minkä hyvänsä asian sanomiseen. (Tarkka 2005, 55, 64; Viikari 1990.)

Viittauksellisuutta on folkloristiikassa ja sen lähialoilla käsitelty monen eri käsitteen alla. Keskustelu alkoi käsitteestä intertekstuaalisuus, jonka Julia Kristeva (1969, 85) tiivisti Mihail Bahtinin (1986) dialogisuutta ja ambivalenssia käsittelevistä ajatuksista. Sen puitteissa ajatellaan tekstin (tai ilmauksen) saavan olemuksensa ja merkityksensä vuorovaikutussuhteessa sitä edeltäviin tai ympäröiviin teksteihin. Käsitettä on sovellettu monella tavalla ja tasolla, sekä yleisenä kulttuuriteoreettisena käsitteenä että tarkemmin rajautuvana metodisena työkaluna (ks. Lehtonen 1992; Viikari 1991). ${ }^{144}$

Jo yksin folkloristiikan puitteissa erilaisia intertekstuaalisuuden lajeja on jaoteltu monin tavoin. Paitsi yksittäisten tekstien tai runojen, on viittaussuhteita mahdollista hahmottaa myös laajempien kehysten välillä. Esittäjä voi suoremmin tai hienovaraisemmin viitata myös muihin lajeihin, rekistereihin tai esitystilanteisiin. Suhteellisen selkeästi tietyn lajin piiriin identifioituva esitys voi sisältää erilaisia piirteitä myös muiden lajien piiriin kuuluvista esityksistä: sitaatteja, alluusioita, kommentteja ja parodiaa, muotoon tai sisältöön liittyviä piirteitä. (Dorst 1983,

${ }^{142}$ Tekstuaalisesta yhteisöstä ks. Stock 1983; tulkinnallisesta ks. Fish 1980. Käsitteiden taustalla on William Labovin (1972) kehittämä, erityisesti sosiolingvistiikkaan ja sen kautta folkloristiikkaankin vaikuttanut puheyhteisön käsite.

${ }^{143}$ Lingvistisestä antropologiasta ks. Duranti 1997; sen ja sosiolingvistiikan suhteista ks. Gumperz \& Cook-Gumperz 2008; sosiolingvistiikasta ja puheen etnografiasta Hymes 1971, 1974; systemaattisfunktionaalisesta kielitieteestä Halliday 1978; Jakobson 1960; 1971; siihen tukeutuvasta sosiaalisesta semiotiikasta Hodge \& Kress 1988; Martin 1998; Ventola 2006. Suuntaukset ovat sosiaalista semiotiikkaa lukuun ottamatta toisiinsa lomittuvia, ja niiden taustalla on paitsi Prahan koulukunnan lingvistiikkaa, myös Erving Goffmanin (1974) edustaman etnometodologian piirissä kehitettyjä näkökulmia.

${ }^{144}$ Varhaisista eri suuntiin kehittäjistä ks. Barthes 1977; Genette 1982; käsitteen käyttöönotosta ja käytöstä erityisesti folkloristiikan piirissä ks. Asplund Ingemark 2004, 21-41; Briggs \& Bauman 1992; Tarkka 1993, erit. 169-180. 
415; Tarkka 2005, 61-67.) Toisaalta esitys voi myös sijoittua lajien välille, sisältää piirteitä useammasta lajista sellaisella tavalla, että se ei määrity minkään yksittäisen lajin puitteisiin, mistä on puhuttu monitulkintaisuuden eli ambivalenssin ja hybridisyyden käsitteiden avulla (Dorst 1983, 416; Foley 1991, 5, 6, 19; Kuutma 2006; Tarkka 2010).

Suullisessa kulttuurissa kyse ei ole pysyvien tekstien välisyydestä vaan puhe- tai muiden esitystapahtumien välisyydestä. Osa puheesta ja esityksistä koostuu kiteytyneistä ilmauksista joita on helppo muistaa ja mahdollista käyttää kokonaisena tai osittain myös muissa tilanteissa. Jokainen käyttö on kuitenkin erilainen. Yhteisön sisällä tarina tai runo voidaan tunnistaa joko sisällöstä ja muodosta, nimillä tai tekstin osasten avulla - nimiä ja osasia on mahdollista käyttää kokonaisuuden edustajana tai siihen viittaamisen keinona. (Siikala \& Siikala 2005, 32; ks. myös esim. Blacking 1995, 232; Caraveli 1982, Ricoeur 1991, 131; Särg 2008, 19.) Esityskeskeisen folkloristiikan puitteissa on usein korostettu yksittäisten käyttöjen suhteita toisiinsa, yksittäisten esitysten muodostamia ketjuja (ks. Bauman \& Briggs 1990, 72-78; Haring 1988). Lotte Tarkka (2005, 61-67) huomauttaa, että vaikka yksittäisen laulajan tulkinnoille voivat olla merkityksellisiä myös yksittäiset edeltäneet käytöt, on laajemman yleisön kannalta keskeisintä ilmausten tyypillinen tai yleisin käyttö: mitä yleensä tietyssä tilanteessa lauletaan, mihin yleensä tietyllä ilmauksella viitataan. Yksittäiset käytöt ovat loputtomia, suuri osa muodoista on ajallisesti vanhoja ja uusillakin on juurensa edeltäjissään. Kyseessä on ennemminkin käyttöjen verkosto kuin ketju. Tutkimuksen kohteeksi asettuu tällöin puheyhteisöksi tulkittavissa olevan yhteisön parissa havaittujen tekstien välisten yhteyksien hahmottaminen. Lingvistisen antropologian puolella esimerkiksi Michael Silverstein (2005; ks. myös Solin 2006) käsittelee sekä yksittäisiin käyttökertoihin että yleisiin diskurssityyppeihin suuntautuvaa viittauksellisuutta.

Suullisen perinteen tutkimuksen yhteydessä intertekstuaalisuuden käsitteen tekstiin viittaavia konnotaatioita on välillä pyritty kiertämään erilaisin johdoksin ja uusin termein. Paikoin on siirrytty puhumaan interdiskursiivisuudesta (esim. Asplund Ingemark 2004, 30-33; Bauman 2004, 2; Silverstein 2005), joka kantaa vähemmän assosiaatioita kirjoitettuun kieleen, vaikka diskurssia ei toki voikaan pitää millään tavalla tekstiä yksiselitteisempänä käsitteenä. ${ }^{145}$ Lee Haring $(1988,365)$ on käyttänyt käsitettä interperformanssi (interperformance) tarkoittamaan esityksen suhdetta erilaisiin sen pohjana oleviin edeltäviin esityksiin. John Miles Foley (1991) on puhunut perinteen metonyymisistä ja assosiatiivisista piirteistä immanenssin käsitteen avulla - suullisen perinteen pienikin osa, yksi ilmauskin, voi viitata myös itseään suurempiin ajatuksellisiin tai assosiatiivisiin kokonaisuuksiin. Immanenssin käsitteeseen liittyy keskeisesti myös ajatus tietyn yhteisön piirissä ymmärretystä perinteisestä tai metonyymisestä viittauksellisuudesta (Foley 1995). Anna-Leena ja Jukka Siikala $(2005,29-30)$ ovat huomauttaneet, että jopa hajanaisten mainintojen ja osittaisten käyttöjen takana voi olla konstruoitavissa laajempi tarina tai tarinoiden verkosto, jonka käyttäjät saattavat jollain tasolla hahmottaa, vaikka eivät sitä

\footnotetext{
${ }^{145}$ Ks. Hanks 1989; ks. myös van Dijk 1997; diskurssin käsitteestä alkujaan ks. Benveniste 1966.
} 
yleensä sanallistaisi. Ruth Finnegan (2002, 239-243) käyttää termiä overtonality eli yliäänisyys pohtiessaan viittauksellisuutta kommunikaation multimodaalisuuden kautta. Kun huomio kohdistetaan tekstien kielellisten rakenteiden ja merkityssisältöjen ohella tasavertaisesti myös esitysten musiikillisiin, kielenulkoisiin ja esityksellisiin piirteisiin, on mahdollista puhua interperformatiivisuudesta eli esitysten välisyydestä (Kallio 2011a). Monet tutkijat ovat kuitenkin yksinkertaisesti määrittäneet tekstin ja sitä myötä intertekstuaalisuuden käsitteen kirjallista tekstiä laajemmaksi ja liikkuvammaksi, myös erilaisia suullisia, kielenulkoisia ja esityksellisiä piirteitä kattavaksi (ks. esim. Tarkka 2005). Esimerkiksi William Hanks (1989, 95) määrittää tekstin sellaiseksi merkkien joukoksi, joka on kontekstissaan jollekin käyttäjäyhteisölle yhtenäisellä tavalla ymmärrettävä. Hänen määritelmässään korostuu puheyhteisön, tulkinnan ja kontekstin merkitys.

Esitysten, tekstien ja lajien väliset suhteet voivat olla paitsi kielellisiä, myös musiikillisia ja esityksellisiä: eleitä, melodioita, rytmejä tai äänenkäytön tapoja (ks. esim. Finnegan 2002; van Leeuwen 1999; Tedlock \& Tedlock 1985). Lauri Harvilahti (1998b, 200, 203) on painottanut inkeriläisen runouden yhteydessä esimerkiksi osakertauksen, refrenkien, seitsentavuisuuden ja melismaattisten pidennyksien tärkeyttä paitsi lauletun runon mitan käsittämisen, myös laulun lajien ja laulukulttuurien yhteyksien kuulemisen kannalta. Hän toteaa, että

sivuuttamalla melodian kadottaisimme osittain näkyvistä (ja erityisemmin, kuultavista) tärkeät suhteet eeppisten ja lyyristen laulujen sekä itkujen välillä. [...] Sama melodinen formula on ollut käytössä esitettäessä moninaisiin genreihin kuuluvia lauluja eri traditioissa. (Harvilahti 1998b, 203.)

Lajin, esityksen ja viittauksellisuuden (intertekstuaalisuuden) käsitteet kietoutuvat tämän työn kehyksessä toisiinsa. ${ }^{146} \mathrm{Ne}$ ovat sosiaalisten käytäntöjen tarkastelun kautta perustelunsa saavia analyyttisia näkökulmia suulliseen perinteeseen, mutta samalla niitä voi ajatella myös esittäjän ja yleisön omilla tavoillaan, enemmän tai vähemmän tietoisesti käyttämiksi tulkinnallisiksi kehyksiksi.

Tässä työssä kyse on ennen kaikkea yksittäisten esitysten suhteista enemmän tai vähemmän vakiintuneisiin diskurssityyppeihin, joita hahmotan lajin, rekisterin ja esitysareenan käsitteiden kautta. Tulkitsen myös esityksen eri tasojen voivan viitata toisiinsa: vahvasti tiettyyn esitysareenaan, lajiin tai rekisteriin assosioituvat piirteet kantavat mukanaan muistoa toisistaan. Esimerkiksi tiettyyn sävelmätyyppiin tyypillisesti kuuluvan refrengin voi ajatella kaikuvan esityksen taustalla silloinkin, kun esittäjät eivät sitä syystä tai toisesta käytä ja tietyn tanssilaulun liike saattaa kaikua laulun rytmissä ja intonaatioissa myös laulajien esittäessä sitä studiossa lähes pai-

\footnotetext{
${ }^{146}$ Richard Bauman $(2004,2)$ on kiteyttänyt osuvasti perustellessaan lajin ja esityksen käsitteen keskeisyyttä omassa työssään: "The perspective that I am suggesting here is founded upon a conception of a social life as discursively constituted, produced and reproduced in situated acts of speaking and other signifying practices that are simultaneously anchored in their situational contexts of use and transcendent of them, linked by interdiscursive ties to other situations, other acts, other utterances. The sociohistorical continuity and coherence manifested in these interdiscursive relationships rests upon a cultural repertoires of concepts and practises that serve as conventionalized orienting frameworks for the production, reception and circulation of discourse."
} 
koillaan. Tulkitsen laulun eri piirteiden välisiä viitaussuhteita pääasiassa rekisterin käsitteen kautta: on kulttuurisesti konventionaalista käyttää tietynlaisessa esitystilanteessa tiettyjä piirteitä toistensa yhteydessä. Joskus nämä voivat edellyttää toisiaan myös teknisesti - esimerkiksi mikä hyvänsä refrenki- tai osakertaustyyppi ei istu minkälaiseen sävelmään hyvänsä.

\section{MERKITYS JA KIELENULKOISET PIIRTEET}

Kielitoimiston sanakirja (MOT) antaa sanalle merkitys kaksi merkitystä, joista ensimmäinen on tämän työn kannalta keskeinen: "se mitä jk tarkoittaa, ilmaisee, esittää, symboloi; sanan t. ilmauksen informaatiosisältö; yl. sisältö, olemus." Toinen merkityksen merkitys, "arvo, tärkeys" ei tässä ole keskeisellä sijalla. Merkityksiä lähestytään tässä kontekstin ja kulttuuristen käytänteiden näkökulmasta: miten tietty laulu saa merkityksiä toisaalta tietyn tilanteen, toisaalta sen kautta, miten lauluja on tapana esittää? Merkitykset käsitetään siis sosiaalisesti rakentuneina ja tilannesidonnaisina. Sekä sanotun kirjaimelliset merkitykset että sanomisen tavat erilaisine kielenulkoisine tekijöineen vaikuttavat niiden muodostumiseen.

Kielenulkoisten piirteiden merkitystä on pohdittu viime vuosikymmeninä monilla aloilla. Tässä nostan esiin vielä neljä niitä eri suunnista lähestyvää keskustelua. Etnopoetiikka sijoittuu folkloristiikan, puheen etnografian ja sosiolingvistiikan leikkauskohtaan. Sen piirissä on pohdittu kulttuurisidonnaisia, suullisia poeettisia rakenteita paitsi tekstin kielellisten ominaisuuksien, myös kielenulkoisten piirteiden kautta. Musiikintutkimuksen eri aloilla taas on pohdittu musiikin rakenteita ja merkityksiä. Multimodaalisuuden käsitteen ympärillä käydyn monialaisen, etenkin viestinnän ja semiotiikan aloille sijoittuvan keskustelun puitteissa on pohdittu eri kielellisten ja kielenulkoisten moodien ja medioiden kautta välittyvien viestien monikanavaista luonnetta. Lisäksi psykologian ja viestinnän tutkimuksen piirissä on tehty paljon tutkimusta puheeseen ja kasvokkaiseen kommunikaatioon liittyvästä kielenulkoisesta viestinnästä.

Erilaisia etnopoeettisia ja performanssiteoreettisia näkökulmia yhteen syntetisoinut John Miles Foley (2002, 35, ks. myös Reichl 2000, 2-4) kirjoittaa suullisen runouden tulkinnasta:

Entä jos tämän tai tuon suullisen runouden lajin identiteetti on riippuvainen esimerkiksi äänen muutoksista, tai vokaali- tai soitinmusiikista, tai tanssista tai muista fyysisistä, eleenomaisista piirteistä? Entä jos esittäjä käyttää äänekkyyttä, äänenkorkeutta tai taukoa viestiäkseen yleisölle tietyn lajin sääntöjen mukaisesti? Kuinka säilytämme edes kaiun tällaisesta toiminnasta julkaistussa tekstissä?

Sitaatista käyvät hyvin ilmi etnopoeettisesti suuntautuneiden lähestymistapojen tavoitteet: ymmärtää tietty perinne tai kulttuuri sen omilla esteettisillä ja poeettisilla ehdoilla ja ottaa siten sen tekstualisaatiossa ja tulkinnassa huomioon mahdollisimman paljon myös tekstinulkoisia merkitysten muotoutumiseen vaikuttavia piirtei- 
tä. (ks. myös Anttonen 1994, 113-116; DuBois 1994, 140; Foley 1995, 17-22.) Keskeisimpiä hahmoja tässä suuntauksessa ovat olleet Dell Hymes (erit. 1981; 1989) ja Dennis Tedlock (erit. 1983), joiden työt ovat rakentuneet Pohjois- ja Etelä-Amerikan alkuperäiskansojen tutkimukselle. Kummankin tutkimuksella on ollut lopulta kaksi suuntaa. Toisaalta pyrkimyksenä on hahmottaa esityksestä mahdollisimman paljon sen merkityksiin vaikuttavia tekstinulkoisia tai tekstin rakenteeseen liittyviä piirteitä ja siirtää mahdollisimman paljon niistä paperille. Toisaalta kumpikin on myös analysoinut pelkkien teksteinä säilyneiden muistiinpanojen poeettisia rakenteita ja pohtinut niiden merkitysten ja toteutumisen mahdollisuuksia sen valossa, mitä tiedetään kuultavissa olevista esityksistä. Kummassakin suunnassa keskeistä on esityksellisen rakenteen ja sisällön vuorovaikutuksen pohtiminen. Hymes lähti alkujaan liikkeelle tekstinä säilyneistä perinteistä ja hänellä keskeisimmiksi piirteiksi muodostuivat siten tekstissä olevat kielelliset rakenteet, Tedlock puolestaan ääniteaineistoista, joten hän on keskittynyt enemmän tekstien yksittäisissä esityksissä, kielenulkoisillakin tasoilla saamiin rakenteisiin. Keskeinen kysymys heidän keskinäisessä keskustelussaan on ollut se, mitkä ovat näiden kahden analyyttisen tason väliset suhteet ja painoarvot (ks. myös Anttonen 1994, 114-116).

Kuten John Miles Foley $(1995,23)$ on todennut, olennaista on myös havainnoida sitä, missä määrin mikäkin kielenulkoinen tai rakenteellinen piirre on esitys- tai esittäjäkohtainen, missä määrin laajemmin jaettu, tietylle lajille tai rekisterille ominainen strategia. Kielenulkoisten ja rakenteellisten piirteiden käyttö ja merkityksellisyys vaihtelee myös perinteittäin. Esimerkiksi toisin kuin Tedlockin tutkimissa proosakertomuksissa tai vaikkapa serbo-kroatialaisessa epiikassa (Foley 1995, 24), inkeriläisen kalevalamittaisen runon kohdalla hengityskatkot eivät aina kerro säejaosta, joka on kyllä yleensä selkeänä kuultavissa sekä runomitan, syntaksin että sävelmien tasolla. Säkeet pyritään päinvastoin sitomaan toisiinsa: yksin laulava hengittää yleensä säkeen tai jopa sanan keskellä ollakseen pitämättä taukoa säkeiden välissä ja saattaa joskus jopa jättää jonkin merkityksellisen tavun laulamatta ollakseen katkaisematta laulun rytmiä; esilaulaja ja kuoro puolestaan tarttuvat yleensä toistensa säkeiden loppuihin, jolloin säkeiden väliin ei jää taukoa. Tällöin tauon sijoittaminen säkeen keskelle ei kerro rakenteellisesta jaottelusta vaan ennemminkin esteettisestä ihanteesta esittää laulu ikään kuin tauottomana jatkumona (ks. myös Kallberg 2004, 40). Hymesin ja Tedlockin huomioita kalevalamittaiseen runoon suhteuttaessa on myös olennaista huomata, että kumpikin on keskittynyt pitkälti proosaesityksiin (ks. DuBois 1994, 141; ks. myös Hymes 2000), jolloin tutkimuksen perushaasteena voi olla vaikkapa tekstin poeettisen rakenteen hahmottaminen. Runolaulun kohdalla taas esimerkiksi laulun runomitta ja säejako ovat yleensä selkeinä esillä sekä pelkän tekstin että lauletun esityksen tasoilla.

Etnopoetiikan piiriin sijoittuvia analyysejä on kalevalamittaisesta runosta tehty muutamia. Pertti Anttonen (1994) on kalevalamittaisen runon etnopoeettisessa analyysissään havainnut runoon rakennetta luovia, säkeitä yhdistäviä alkusointuja: määrämitallisten tai runomitan mukaan jakautuvien säkeistöjen puutteesta 
huolimatta runo ei ole rakenteetonta massaa. Thomas DuBois (1994) käsittelee etnopoetiikan mahdollisuuksia Arhippa Perttusen Luojan virren neljän tallennetun version analyysissä pohtien rakenteellistenkin variaatioiden poeettisuutta ja merkityksiä. Kummankin analyysi liittyy Hymesin edustamaan suuntaukseen, jossa tekstinä tallennetusta runosta pyritään kielellisten rakenteiden tarkastelun kautta löytämään erilaisia rakenteellisia tasoja.

Muutamat runolaulua tarkastelevat musiikkiin keskittyvät analyysit rinnastuvat lähtökohdiltaan äänitallenteista liikkeelle lähteviin etnopoeettisiin analyyseihin. Heikki Laitinen (2004) on analyysissään vienalaisen Anni Tenisovan Luojan virrestä huomannut runon sisällöllisten jaksojen, murrelma- ja tasasäkeiden vuorottelun, säkeitten sanarakenteiden, ensimmäisen runojalan rakenteen, alkusoinnun, kerron ja melodiakaavan muodostavan erillisillä tasoilla liikkuvia, toistensa kanssa väliin risteytyviä, mutta pääosin omalla logiikallaan eteneviä linjoja, joiden väliltä selkeitä säännönmukaisuuksia ei löydy. Laitisen analyysissä osoittautuu myös, että Tenisovan runotekstin sisällöllinen rakenne ei ole sidoksissa runon esityksessä saamaan musiikilliseen rakenteeseen muuten kuin runo- ja sävelmäsäkeen vastaavuuden osalta. Samankaltaisia huomioita on tehty esimerkiksi serbo-kroatialaisesta epiikasta (Foley 1995, 24). Toisaalta Pekka Huttu-Hiltunen (2008, 164-166, 214-216) kuitenkin toteaa, että paikoin vienalaislaulajilla on havaittavissa taipumusta käyttää vaihdellen (hengitys)taukoja, hidastuksia ja musiikillisen säerakenteen vaihtelua laulun temaattisen rakenteen mukaisesti, joskaan ei säännönmukaisesti. Janika Oras (2004a; 2010) on sitä vastoin havainnut selkeitä yhteyksiä melodisen muuntelun, säerakenteen ja runon kokonaisrakenteen välillä virolaisessa regilaulussa. Laulajilla on tendenssi käyttää tietynlaisia melodisia muunnelmia uutta informaatiota sisältävissä esisäkeissä tai yksinäisissä säkeissä, ja jotkut laulajat pyrkivät kaksisäkeisillä sävelmillä laulaessaan sijoittamaan uusien tekstuaalisten jaksojen alut sävelmän ensimmäiselle säkeelle (Oras 2010). Oras (mts. 57, 64-65) toteaa laulamisen käytäntöjen vaihtelevan selvästi alueittain ja laulajittain, mikä voi osaltaan selittää eri tutkimusten välisiä eroja.

Näyttää siltä, että kalevalamittaisen runon arkistotallenteissa ei yleensä korosteta yksittäistä runon kohtaa rakenteellisen tai esityksellisen variaation keinoin, vaikka tästäkin on viitteitä (ks. esim. Huttu-Hiltunen 2008; Käppi 2007; Laitinen 2004; Oras 2008; vrt. kuitenkin Inha 1911, 75) ${ }^{147}$ Musiikkiin ja esitykseen liittyvät rakenteelliset piirteet kytkeytyvät enemmänkin runolaulun lajien yleisiin tyylipiirteisiin ja estetiikkaan. Selvää joka tapauksessa on, että lauletun ja mitallisen perinteen herättämät kysymykset eroavat väistämättä proosakerronnan herättämistä. Laulettujen runojen käsittelyyn tarvitaan osin erilaisia analyysivälineitä, sillä olennaisia ovat tekstin piirteiden ja runomitan ohella myös lauletut ja musiikilliset rakenteet. Esitetty kokonaisuus syntyy kielellisten, melodisten ja rytmisten tasojen vuorovaikutuskentässä (Lippus 1995, 10, 151-152; Niemi 1998, 28).

${ }^{147}$ On tietenkin mahdollista, että jännittyneet ja muodolliset äänitystilanteet ovat karsineet tämänkaltaisen esityksellisyyden. Lisäksi kalevalamittaisen runon ääniteaineisto on kerätty valtaosin 1900-luvun loppupuolella, jolloin laulaminen oli monelle laulajalle lähinnä lapsuusajan muistelemista (ks. Oras 2008). 
Kulttuurisidonnaisten rakenteiden, merkitysten ja esteettisten ihanteiden huomioiminen on yhteistä monille etnopoeettisille ja etnomusikologisille lähestymistavoille. Etnomusikologinen tutkimus on todennut musiikin universaaliksi piirteeksi lähinnä vain sen, että musiikiksi määriteltävissä olevaa toimintaa löytyy käytännössä kaikilta maapallolla eläviltä ihmisryhmiltä. Suurimmalta osaltaan musiikkiin liittyvät merkitykset, tunteet ja ihanteet ovat kulttuurisidonnaisia. Muoto kantaa merkitystä ainoastaan yhteisesti jaettujen sosiaalisten konventioiden ja opittujen tulkintatapojen puitteissa. Musiikin olennaiset ja käyttäjiensä kannalta merkitsevät piirteet vaihtelevat musiikkikulttuureittain eikä länsimaisen musiikin analyysissa käytettyjä malleja voi sellaisenaan siirtää muiden kulttuurien musiikin tutkimukseen. (Esim. Blacking 1974; Herndon \& McLeod 1981; Merriam 1964; Moisala \& Seye 2013; Nettl 1983; Niemi 1998, 29-31; Scott 2010.) Rob Bowman (2003) esittää, että populaarimusiikin kappaleiden saamat merkitykset voivat muodostua jopa enemmän esityksellisten piirteiden ja tyylin kuin laulun sanojen, rytmin tai melodian kautta. Marko Aho (2006) taas huomauttaa, että laulajan kielenulkoisen mikrointonaation loputtomat sävyt, tunteita ja tuntemuksia välittävät eleet voivat olla huomattavan olennaisia laulun suosion määrittäjiä.

Hieman toisesta suunnasta kielenulkoisia piirteitä on lähestytty multimodaalisuuden ja intermediaalisuuden käsitteiden kautta. Niiden puitteissa inhimillistä kommunikaatiota on alettu hahmotella useista moodeista koostuvana ja useita medioita käyttävänä. ${ }^{148}$ Kuten Sakari Katajamäki (2010) huomauttaa, niputtavat eri kirjoittajat näiden käsitteiden alle hyvinkin erilaisia ilmiöitä. Riippuu teoreetikosta, puhutaanko esimerkiksi erilaisista kielen suullisista ja kirjallisista käytöistä median vai moodin käsitteen alla. Yleisimmin moodeilla viitataan ihmisen eri aisteihin tai kykyihin perustuviin kommunikaatiokanaviin: näkö-, kuulo-, liike-, tunto-, haju- tai makuaistiin perustuviin erilaisiin viestintätapoihin, joita voidaan vielä jaotella yksityiskohtaisemmin. Toiset jäsentävät myös erilaiset mediat moodi-käsitteen alle. ${ }^{149}$

Multimodaalisuus-keskusteluiden taustalla on toisaalta kielentutkimuksen, toisaalta semiotiikan piirissä tapahtunut käänne kiinteistä merkitysjärjestelmistä kohti sosiaalisissa käytännöissä ja tilanteissa eläviä merkityksiä. Kielentutkimuksen piirissä on alettu hahmottaa sanojen merkityskenttiä ennemminkin suhteessa niiden liikkeessä olevaan käyttöön kuin tutkijan pysyväksi olettamaan yksittäisten käyttöjen takana sijaitsevaan kiinteään merkitysjärjestelmään (Halliday 1978; Martin 1998). Sosiaaliset semiootikot puhuvat koodien tai systeemien kiinteiden merkitysten sijasta erilaisiin merkkeihin sisältyvistä semioottisista eli merkitystä muodostavista resursseista tai potentiaaleista. Merkit tulkitaan monimerkityksisinä, kontekstisidonnaisina, ja niiden merkityskentät löytyvät niiden (tyypillisistä tai mahdollisista) käyttötavoista, sosiaalisista konventioista. Yksi merkki, vaikkapa

\footnotetext{
${ }^{148}$ Samantyyppistä keskustelua on käyty esityskeskeisen folkloristiikan ja antropologiankin piirissä, ks. Fine 1984, erit. 114-148.

${ }^{149}$ Tommi Ilmonen $(2006,22)$ toteaa, että teknologian tutkimuksen piirissä multimodaalisuuden käsitettä on käytetty kolmella tasolla tarkoittamaan joko usean laitteen, usean kyvyn (kirjoittaminen, piirtäminen, elehtiminen) tai usean aistikanavan käyttöä. Käsitteen ympärillä on käyty keskustelua erityisesti uuden median (internet, mobiiliteknologia) tutkimuksen ja kehittämisen piirissä, ja on selvää, että kunkin tutkijan käyttämä aineisto ja näkökulma vaikuttavat myös käsitteen määrittämiseen.
} 
punainen väri, voi eri yhteyksissä tarkoittaa erilaisia asioita, ja toisaalta yhdenkin asian ilmaisemiseen on mahdollista käyttää useampaa keinoa. (Ks. esim. van Hodge \& Kress 1988; Jewitt 2009; Kress 2010; van Leeuwen 1999.)

Kulttuuriantropologian puolelta keskusteluun osallistunut Ruth Finnegan (2002) vyöryttää esiin laajan kirjon esimerkkejä eri kulttuuripiireistä näyttääkseen, miten yleensä jopa ensisijaisesti yhtä moodia käyttävät ilmaukset tarkemmin katsottuna välittyvät useamman kautta. Kommunikaation monitasoisuus tarkoittaa myös sen monitulkintaisuutta. Merkitykset ovat harvoin yksiselitteisiä, yhtenäisiä tai yksinkertaisesti kielellistettävissä. Riippuen kuulijan kompetenssista ja mielentilasta sekä vuorovaikutuksen laadusta tämä saattaa tulkinnassaan painottaa yhtä piirrettä, jättää toisen vähemmälle huomiolle. Multimodaalisuus-teoreetikkojen (ks. Jewitt 2009; van Leeuwen 1999, erit. 9) tapaan Finnegan (2002, erit. 235-239) tulkitsee kommunikaatiossa syntyvien merkitysten muodostuvan useiden eritasoisten ja samanhetkistenkin tekijöiden summana. Viestin kokonaismerkitys syntyy useamman piirteen pohjalta tehtynä kokonaistulkintana, jossa kommunikaation eri tasot määrittävät toistensa merkityksiä, vaikka eri tasoilla välittyvät viestit voivatkin olla keskenään jopa ristiriitaisia ja tulla vastaanottajasta riippuen tulkituksi eri tavoin, eri piirteitä painottaen. Erilaiset piirteet ovat toisaalta monikäyttöisiä, toisaalta erilaisia merkityksiä voi ilmaista usean piirteen tai moodin kautta. Multimodaalinen analyysi hajoaakin väistämättä monitieteiseksi ja monikerroksiseksi.

Kielenulkoista viestintää on tutkittu myös viestinnän, psykologian ja sosiaalipsykologian piirissä. Tutkimuksen piirissä on keskitytty niin intonaatioihin, melodioihin, rytmeihin, tauotuksiin, äänen sävyihin ja voimakkuuksiin, liikkeisiin, asentoihin, eleisiin, ilmeisiin kuin esineisiin ja vaatetukseen, tiloihin ja sijainteihin niissä, tuoksuihin ja hajuihinkin. Kielenulkoinen kommunikaatio voi tarkentaa kielellistä viestiä, muuttaa sen sävyä tai kääntää merkityksen pälälelleen. Sen luomat merkityskentät eivät aina ole helposti sanallistettavia eivätkä ihmiset aina ole tietoisia kaikista käyttämistään keinoista senkään vertaa kuin kielellisellä tasolla liikuttaessa. (Ks. esim. Burgeon \& Buller \& Woodall 1996; Oatley \& Jenkins 1996.)

Kielenulkoinen viestintä liittyy kiinteästi tunteiden ja asenteiden ilmaisuun. Näkökulmia, käsitteiden käyttöä, teorioita ja metodeita koskevista erimielisyyksistä huolimatta jonkinlainen yksimielisyys vallitsee siitä, että tunteet ovat sekä biologiselta pohjalta nousevia että kulttuurisesti rakentuneita. Ne ovat ihmiselle välttämättömiä sosiaalisten suhteiden säätelyn ja ympäristöön reagoimisen kannalta. Niiden analyysi on kuitenkin vaikeaa. Esimerkiksi tunteiden ja kehollisten ilmausten ja tuntemusten suhde on monimutkainen: samat ruumiilliset kokemukset voivat liittyä eri tunteisiin, ja samatkin tuntemukset voivat tulla tulkituiksi kontekstista riippuen eri tunteiksi sekä kokijan itsensä että ulkopuolisten tarkkailijoiden taholta. (Oatley \& Jenkins 1996, 106-124.) Samanlainen yksittäisten ilmausten monitulkintaisuus, monikäyttöisyys ja kontekstisidonnaisuus pätee yhtälailla koko kielenulkoiseen viestintään (Knapp \& Hall 2002). 
Usealla alalla on hahmoteltu eroja kulttuurisesti koodautuneiden tunteiden ilmaisun tai tunteiden esittämisen ja toisaalta universaalimpien, välittömämpien tunteiden ilmaisun tai tunteiden kokemisen välillä. Johnstone \& Scherer (2004, 232-232; ks. myös Scherer 1994) erottavat koettuihin tunnereaktioihin liittyvät "raa’at affektien vokalisaatiot" konventionaalisista, kulttuurisesti koodautuneista vokaalisista tunnuskuvista, "jotka tuotetaan sosiaalisesti stereotyyppisellä tavalla", ja arvelevat, että edelliset tulkitaan jälkimmäisiä "spontaanimmiksi ja uskottavammiksi sekä aidommin tunnetuiksi.” Tämä lähenee tiettyjä musiikintutkimuksen ja semiotiikan piirissä käytyjä keskusteluita. Musiikin ja tunteen yhteyksiä pohdittaessa on pohdittu toisaalta musiikkia (musiikkiteoksia) symboleina, toisaalta esittämisessä syntyvien tunneilmausten kautta (ks. esim. ks. Juslin \& Sloboda 2001; Tarvainen 2012.) Osa tunteiden ilmauksista ja kielenulkoisesta viestinnästä on ihmislajille yleisemmin tyypillistä, osa kulttuurisesti rakentuvaa ja suppeamman yhteisön jakamaa (ks. myös esim. Kress 2010, 8-11). Näiden kahden erottelu toisistaan on vaikeaa: ne lomittuvat, menevät päällekkäin ja vaikuttavat toisiinsa. Inkeriläistä laulua tulkitessa on kuitenkin syytä yrittää erottaa toisistaan toisaalta se, minkälaista tunnesävyä jokin tietty esittämisen piirre voi laulukulttuurissa tyypillisesti välittää (vaikkapa nopea tanssi kepeyttä tai iloa) ja mitä kaikkea tällaisenkin piirteen yhteydessä voidaan hienovaraisemmin, vähemmän koodautuneesti, vaikkapa äänensävyin ilmaista (suru, itku).

Etnopoetiikan, musiikintutkimuksen, multimodaalisuus-keskustelun sekä psykologian ja viestinnän tutkimuksen piirissä käydyt keskustelut tarkentavat edellisissä luvuissa esiteltyjen keskeiskäsitteiden rekisterin, esitysareenan ja paikallisen lajin käyttöä. Yhteistä tämän työn teoreettisille lähtökohdille on ilmiöiden ja merkitysten sosiaalisen rakentumisen, joustavuuden ja kontekstisidonnaisuuden huomioiminen. Moodien sijaan puhun esityksen tasoista. Tulkitsen esityksen eri tasoilla ilmenevien piirteiden määrittävän myös toisiaan ja muodostavan yhdessä esityksen kokonaismerkityksen, joka kuitenkin on viime kädessä kiinni tulkitsijasta ja hänen kompetenssistaan. Merkitykset tulkitsen sosiaalisissa käytännöissä rakentuviksi: tietyn piirteen konventionaaliset käyttötavat ja -tilanteet määrittävät sen merkityspotentiaalin eli sen, mitä sillä ylimalkaan on tietyn yhteisön piirissä mahdollista sanoa. Kuten etnopoetiikassa ja musiikintutkimuksessa, transkriptio on yksi analyysin keskeisistä välineistä. Tässä työssä se pitää sisällään sekä litteraation että nuotinnoksen. Transkription päämääränä ei kuitenkaan ole esittää tutkittavaa perinnettä mahdollisimman kokonaisvaltaisesti vaan näyttää siitä tiettyjä piirteitä analyysin tarpeita varten. Rakenteellisten, poeettisten ja kielenulkoisten piirteiden merkitykset ja käyttötavat tulkitsen pitkälti kulttuurisidonnaisiksi, vaikka esimerkiksi tiettyjen perustunteiden kuten ilon ja surun oletan kuuluvan ihmisäänessä suhteellisen universaalilla tavalla (ks. Heinonen 2008b). 


\section{Menetelmät}

Aineistona on siis suuri määrä irrallisia runotekstejä, parisäkeisiä nuotinnoksia, matkakertomusten paikallistumattomia kuvauksia, rahisevia lauluäänitteenpätkiä, muutama täyspituinen studioäänite sekä lyhyitä sitaatteja ja referaatteja siitä, mitä esittäjät ovat lauluistaan ja laulamisestaan sanoneet. Päämääränä on ymmärtää mahdollisimman paljon siitä, miten erilaiset runojen esitykselliset ja musiikilliset piirteet vaikuttivat laulujen kantamiin merkityksiin ja miten paikallinen lajijärjestelmä rakentui. Valmista mallia inkeriläisen kalevalamittaisen laulun esityksellisten piirteiden hahmottamiseen ei ollut, vaikka yksittäiset soveltamani metodit ovat eri aloilla vakiintuneita menetelmiä.

Keskeistä työssä on laulujen eritasoisten rakenteiden ja tyylipiirteiden analyysi ja näiden rakenteiden kytkeminen sekä tyypillisiin että erityisiin esitystilanteisiin, paikallisiin käytön ja nimeämisen tapoihin. Käytännössä analyysi on edennyt vuorotteluna aineiston läpikäymisen ja systematisoinnin, tutkimuskirjallisuuden lukemisen, analyysimetodien testaamisen, varsinaisen analyysin ja tutkimuksen kirjoittamisen välillä. Aineiston käsittelyssä keskeistä on ollut erilaisten toistuvien piirteiden etsintä, systematisointi ja tulkinta. Yhtenä käytännön työvälineenä on ollut laulaminen. Se on toiminut keskeisenä runo- ja sävelmäaineistoon tutustumisen, sen muistamisen sekä tallenteiden välisten yhteyksien hahmottamisen välineenä ja lisäksi myös runomitan hahmottamisen nopeana ja käytännöllisenä apuneuvona.

Edellä Inkerin historiasta ja etnisistä ryhmistä, kerääjien toiminnasta ja suullisen runon tutkimuksesta kerrottu auttaa asettamaan aineiston osasia yhteyksiinsä ja miettimään, mistä kaikesta tallenteet oikeastaan kertovat. Vielä on tarpeen kuvata työn keskeisiä tulkintatapoja ja menetelmiä sekä niiden suhteita toisiinsa.

\section{KESKEISET TERMIT, KÄSITTEET JA MERKINTÄTAVAT}

Laulu on tässä työssä käytössä kahdessa merkityksessä. Yleisterminä se tarkoittaa samaa kuin laulaminen sekä laaja laulujen ja laulamisten muodostama kokonaisuus. Konkreettisemmin se viittaa yhteen kertaluonteiseen arkistoon käsikirjoituksena tai äänitteenä tallennettuun sävelmän, tiettyyn runotekstin ja laulullisten piirteiden yhdistelmään, mutta välillä puhun myös pelkästä tallennetusta runotekstistä lauluna. Aineiston ja aiemman tutkimuskirjallisuuden pohjalta hahmotan laulun olevan inkeriläisen kalevalamittaisen runon keskeinen olomuoto, vaikka runoja on ilmeisesti voitu käyttää myös puheen osina ja vaikka en yleensä voi tietää, onko yksittäinen tekstinä tallennettu runo alkujaan laulettu vai saneltu kerääjälle. Tulkitsen siis sanellunkin runon yleensä viittaavan laulettuun muotoonsa. ${ }^{150} \mathrm{Lau}$ lutilanne viittaa sekä muistiinpanon, nuotin tai äänitteen taustalla olleen yksittäis-

\footnotetext{
${ }^{150}$ Tämä ei kuitenkaan koske loitsuja, joiden laulamisesta ei Inkeristä ole tietoja (vrt. SKVR III 4345, jossa Anni Porissa kertoo heidän tyttöinä laulaneen Tulen syntyä, kun eivät tienneet sen olevan loitsu) eikä lyhyitä, sananlaskuina tallennettuja runoja.
} 
ten laulun esitystilanteeseen että tiettyihin tyypillisiin, toistuviin esitysareenoihin. Runo viittaa ensisijaisesti laulun kielelliseen muotoon ja sisältöön. Tekstiä tai runotekstiä käytän tarkoittamaan sekä konkreettista muistiinmerkittyä, kirjoitettua tekstiä että esityksen kielellistä osuutta, josta tällaisen tekstin voi kirjoittaa. Tekstin rajaaminen kielelliseen ilmaisuun on tässä tarpeen ilmaisun tarkkuuden vuoksi, vaikka tekstinä onkin usein käsitelty myös kielenulkoisia diskursseja kuten musiikkia (Pekkilä 1988; Hanks 1989).

Käsitteitä runo(tyyppi), (runo)teema ja formula käytän heuristisina apuvälineinä, en absoluuttisina luokittelun keinoina. Ne hahmottuvat sekä runon muodon että sisällön perusteella, aina suhteessa yhtä runoa laajempaan aineistoon. Runotyyppi viittaa tiettyyn, suhteellisen pitkään ja usein omana kokonaisuutenaan esiintyvään muodon ja sisällön yhdistelmään. Formula viittaa lyhyeen, säkeen puolikkaasta muutaman säkeen pituiseen jaksoon, joka sisältää tunnistettavia ja toistuvia leksikaalisia, semanttisia tai syntaktisia elementtejä ja jota usein käytetään samankaltaisiin tarkoituksiin, yleensä osana laajempaa kokonaisuutta. Teema viittaa formulan ja runon välimaastoon sijoittuvaan, formulaa pidempään mutta runoa useammin muiden aihelmien kanssa yhdistyvään aiheeseen, jossa leksikaalinen ja syntaktinen toistuvuus ei välttämättä ole yhtä suuri kuin formulan kohdalla. Inkerissä rajaa formulan ja teeman, teeman ja runon välille on, kuten Senni Timonen (2000, 634; ks. myös Harvilahti 1992a, 141-142) on todennut, vaikea vetää, joten käytän käsitteitä tässä suhteessa joustavasti, työkaluina. Kysymys on samankaltaisuudesta, ei samuudesta. Määritän esimerkiksi säkeet Aik on lusti nuoren ellää, lusti on luita liikutella, jäseniä järkytellä samaksi teemaksi kuin säkeet Täs on lusti nuoren noissa, kaunis kassapään karata, joka on muotona yleisempi ja saa usein jatkokseen ensimmäisen esimerkin kaksi jälkimmäistä säettä: Täss on lusti nuoriin noissa, lusti on luita liikutella, jäseniijä järkytellä. Usein tämä teema aloittaa laulun, mutta yhdelläkin laulajalla se voi välillä esiintyä laulun alussa, välillä sen keskellä ja liittyä monenlaisiin muihin teemoihin. Näistä kolmesta esimerkistä kahden jälkimmäisen ensisäkeet lasken samaksi formulaksi, ensimmäisen näiden kanssa hyvin samankaltaiseksi. Kaikki kuuluvat tanssinaloitusformuloiden joukkoon. ${ }^{151}$ Toisinto tarkoittaa tietyn runo- tai sävelmätyypin piiriin luettavissa olevaa yksittäistä runoa tai sävelmää, runo- tai sävelmätyypin konkreettista ilmentymää.

Laulajaksi (tai runolaulajaksi, runonlaulajaksi) on perinteisesti nimetty lähinnä parhaimmiksi katsottuja laulajia. Omasta näkökulmastani myös kerääjien tai paikallisyhteisön kannalta vähemmän keskeiset tai taitavat laulajat ovat mielenkiintoisia. Tässä työssä käytän laulaja-nimitystä yleisterminä kenestä hyvänsä, jolta on tallennettu laulu tai laulujen joukkoon luettava runo tai joka on kertonut omasta laulamisestaan (ks. Särg 2008, 18). Tutkimuksen kohteena olevasta ilmiöstä käytän tässä työssä nimityksiä runolaulu sekä kalevalamittainen runo tai kalevalamittainen laulu. Kalevalamitasta on käytetty myös nimityksiä vanha runomitta, trokeinen tetrametri sekä kahdeksantavumitta: suosin kalevalamittaa sen vakiintuneisuuden

${ }^{151}$ SKS KRA Enäjärvi-Haavio 468; Haavio 2460; Laiho A. 2115; 2221; Laiho L. 4832, 5329; Salminen K. 29. 
vuoksi. Vaikka virolainen runolaulu eli regilaul eroaa mitaltaan joiltain osin klassisesta kalevalamitasta eikä liity Suomen kansalliseepokseen edes anakronistisesti, puhun siitäkin paikoin kalevalamittaisen runon tai runolaulun piiriin kuuluvana. ${ }^{152}$

Ilmiöiden nimeämisen suhteen liikun tutkijoiden vakiintuneesti käyttämien termien ja aineistossa näkyvien, paikallisten itsensä käyttämien nimeämisen tapojen välillä. Tutkijoiden vakiintuneet termit ja käsitteet ovat työkaluja, paikallisten omat nimeämisen, luokittelun ja käyttämisen tavat puolestaan osa tutkimuskohdetta. Välillä otan käyttööni termejä paikallisesta kielenkäytöstä, jos selkeää vastinetta ei tieteellisestä kielestä löydy tai jos se kantaisi mielestäni mukanaan vääränlaisia mielleyhtymiä. Tällöin termien alat rajautuvat aineistosta hahmotettavissa olevien kielenkäytön tapojen mukaan. Esimerkiksi piiritanssi ja piirileikki ovat tutkijoiden ja tallentajien käytössä olevia nimityksiä, joiden käyttöä kuitenkin vältän: niiden kantama mielikuvakenttä ei tanssillisuudessaan ja leikillisyydessään tunnu kattavan koko sitä alaa, mihin inkeriläislaulaja ympärikko-nimityksellään analyysin perusteella viittaa: tanssin ja leikin ohella myös hitaaseen, vakavaan ja rituaaliseen, myös ringissä kulkemiseen tanssimisen ohella. Samoin esimerkiksi paikallisia runon ja sävelmän lajeja nimeän usein yleisimmillä laulajien käyttämillä termeillä: liekkuvirsi, pulmanuotti, kiletoivirsi. Virsi eli verz viittasi länsi-inkeriläisessä kielenkäytössä ensisijaisesti runoon, nuotti eli nootti sävelmään (ks. IMS, verz; nootti; Timonen 2004, 88-157).

Laulamisen tapa viittaa tässä työssä esityksellisten, rakenteellisten ja musiikillisten piirteiden laajaan joukkoon, jonka enemmän liikkeeseen ja äänenlaatuihin painottuvana synonyymina toimii esitystapa. ${ }^{153}$ Richard Baumanin (1977, 3-4, 11; ks. myös Hymes 1989) termiin puheen tai puhumisen tapa (way of speaking) viitaten laulamisen tavan voi katsoa pitävän sisällään myös ajatuksen esitystavan välittämästä tai luomasta tulkinnallisesta kehyksestä. Tietyntyyppiseen toistuvaan tilanteeseen eli esitysareenaan kiinteästi liittyvästä tietynlaisesta laulamisen tavasta käytän käsitettä rekisteri.

Jäsentäessäni erilaisia runon esitykseen liittyviä piirteitä käytän kuutta osin päällekkäin menevää adjektiivia, joista kaikki eivät rajaudu yleisen kielenkäytön mu-

\footnotetext{
${ }^{152}$ Eri näkökulmista ks. esim. Anttonen 1994, 116-117 sekä viite 2; Huttu-Hiltunen 2008, 22 viite 75; Laitinen 2006; Lippus 1995, 21-22; Sarv 2008, 11-12.

${ }^{153}$ Termiä laulutapa on käytetty inkeriläisen laulun yhteydessä melko runsaasti ja vaihdellen. Armas Launis (esim. 1904, 50, 53; 1907, 105, 110) viittaa termillä niin sävelmään, muotorakenteeseen kuin esityksellisiin piirteisiin (kuten esilaulajan ja kuoron vuorottelu, tanssi tai muodostelmat), mutta myös yleiseen tapaan laulaa runoja, eikä hän sulje pois myöskään runojen tekstuaalisia sisältöjä. Lauri Laiho $(1940,229)$ sisällyttää laulutapaan sekä laulun rytmin että runosäkeet. Aili Laiho $(1961,22 ; 1972$, 44) tuntuu samoin puhuvan sekä runosta että sävelmästä ja esitystavasta, mutta välillä $(1972,42)$ silti erottavan sävelmän ja laulutavan toisistaan. Elsa Enäjärvi-Haavio (1949, esim. 5, 6, 133, 137, 138 , 146) puhuu laulantatavoista lähinnä esittämistapoja kuvatessaan (ketkä laulavat, missä asennoissa tai mitä tehden), mutta mainitsee myös säkeiden kertaustavat ja refrengit sekä satunnaisesti äänenlaadun (setujen "kolea" ääni). Sävelmiä tai runoja hän ei laulantatapojen analyysiin juurikaan kytke, ja käyttää synonyymisesti termejä esitystapa sekä satunnaisesti laulutapa. Matti Kuusella (1983a, esim. 168, 182, 197-205) laulutapa näyttää toimivan redaktion synonyyminä: se viittaa runojen alueellisiin tai etnisiin tyylillisiin ja rakenteellisiin yhtäläisyyksiin. Olen itse aikaisemmin käyttänyt termiä jäljempänä selitettävän muotorakenteen sijasta (Heinonen 2005).
} 
kaisesti. ${ }^{154}$ Sisällöllinen viittaa runon sanojen mukanaan kantamaan sisältöön esimerkiksi rakennetta huomioimatta, kielellinen runon kieleen liittyviin piirteisiin. Runon laulussa saamia rakenteita, kuten lisätavuja, säkeen kertauksia, osakertauksia tai refrenkejä kuvaamaan ei ole valmista kattokäsitettä. Puhun näiden kokonaisuudesta laulun muotorakenteena. Tekstuaalinen viittaa runon kielelliseen rakenteeseen ja äänteellisiin piirteisiin, myös muotorakenteeseen. Musiikillinen kattaa sävelmän piirteitä, esimerkiksi melodian, rytmin ja sävelalan. Esityksellinen viittaa lauletussa tai sanellussa esityksessä tuotettuihin tekstinulkoisiin piirteisiin, esimerkiksi äänensävyihin, taukoihin ja liikkeeseen. Rakenteellinen viittaa sekä kielellisiin, laulettuihin, musiikillisiin että paikoin myös esityksellisiin rakenteisiin runomitasta ja tekstin kokonaisrakenteesta aina runon laulussa saamiin piirteisiin. Kuvallisena esityksenä analyyttisia tasoja kuvaavat käsitteet ja niiden väliset suhteet näyttävät tältä:

\begin{tabular}{|l|l|l|l|}
\hline \multicolumn{5}{|l|}{ LAULU } \\
\hline RUNO & MUOTORAKENNE & SÄVELMÄ & $\begin{array}{l}\text { EsITYKSELLISET } \\
\text { RAKENTEET } \\
\text { (ESITYKSELLINEN) }\end{array}$ \\
\hline sisältö & (TEKSTUAALINEN) & (MUSIIKILLINEN) & \\
\hline kieli & lisätavut & melodia & tempo \\
\hline rakenne & osakertaukset & rytmi & volyymi \\
\hline runomitta & refrengit & sävelala/asteikko & äänensävyt \\
\hline teemat, formulat & $\begin{array}{l}\text { pois jäävät ja } \\
\text { muuttuvat tavut }\end{array}$ & liike \\
\cline { 3 - 4 } & Laulun tekstuaalinen rakenne & & \\
\hline Laulun kokonaisrakenne & & \\
\hline Esityksen kokonaisrakenne (laulamisen tapa, esitystapa $\rightarrow$ rekisteri) & \\
\hline
\end{tabular}

Luen siis musiikin piiriin kuuluvat tempon, volyymin ja äänensävyt esityksellisten ja esityksestä toiseen vaihtelevien piirteiden joukkoon, en varsinaiseen sävelmään. Sävelmää käytän viittaamaan sekä konkreettisiin sävelmätallenteisiin että yleisemmin sävelmätyyppeihin. Sävelmän osatekijöitä ovat rytmi ja melodia: siinä missä sävelmä tarkoittaa näiden yhdistelmää, melodia viittaa ainoastaan sävelkorkeuksien muodostamaan ketjuun, joka voi saada ilmiasunsa myös useamman rytmityypin puitteissa. Runon tekstuaalista ulottuvuutta voisi jäsentää huomattavan paljon hienovireisemmin kuin mihin tässä työssä on mahdollisuuksia.

Lisätavu tarkoittaa varsinaisen runosäkeen ulkopuolista, laulettaessa mukaan lisättävää tavua. Täydennystavu on muutoin vajaamittaisen runosäkeen täydentävä, useimmiten laulussa, mutta mahdollisesti sanelussakin käytettävä tavu. Refrenkitavu on sävelmässä oman paikkansa saava, laulun jokaisessa säkeessä kertautuva

\footnotetext{
${ }^{154}$ Nämä menevät osin päällekkäin, ja eri alojen keskusteluissa niitä on määritelty hyvinkin vaihtelevin tavoin. Tässä käyttämäni pragmaattiset määritelmät ovat aineiston ja tutkimuskysymyksen käsittelyn myötä muokkautuneita, mutta monet inkeriläisen laulun piirteet voisi helposti määrittää useamman adjektiivin alle. Esimerkiksi laulun yksi- tai kaksisäkeisyys on sekä musiikillinen että tekstuaalinen ilmiö.
} 
lisätavu (vrt. Kallberg 2004, 26). Osakertaus on säkeen osittainen kertaus. Perussäe tarkoittaa sellaisenaan, ilman lisätavuja, osakertauksia ja refrenkejä laulettua runosäettä tai monimutkaisemmasta rakenteesta pelkistettävissä olevaa runosäettä. Sanellut runosäkeet ovat yleensä perussäkeitä, joskus tosin vajaita tai poikkeavia. Refrenki tarkoittaa joka säkeen tai säeparin yhteydessä samanlaisena toistuvaa, usein säkeiden kertauksen sijaan laulettua kertaumaa, joka Länsi-Inkerissä usein on peräisin venäjän kielestä. Yksisäkeinen sävelmä tarkoittaa toistuvan melodiajaksonsa puolesta yhden runosäkeen pituista sävelmää, kaksisäkeinen kahden. Runon muotorakenne viittaa säkeen osittaisen tai kokonaisen kertauksen, seitsentavuisuuden, lisätavujen ja refrenkien eri tavoin muodostamaan, tietyssä laulussa tai tietyissä lauluissa esiintyvään tekstuaaliseen perusrakenteeseen variaatioineen. Yksisäkeinen muotorakenne tarkoittaa rakennetta, jossa jokaista runosäettä seuraa sen kertaus tai säkeen korvaava refrenki tai laulu etenee kertauksitta soololauluna yksisäkeisellä sävelmällä. Kaksisäkeisessä muotorakenteessa kertausosa tai refrenki seuraa jokaista säeparia tai kertaukseton soololaulu lauletaan kaksisäkeisellä sävelmällä. Esilaulajan ja kuoron tavasta yhtyä toistensa laulamiin osuuksiin säkeen viimeisillä tavuilla puhun säkeeseen tarttumisena.

Laulujen rakenneanalyysi lähtee runomitan perussäännöistä ja niiden yhteydestä laulujen rytmiin. Laulun rakenteiden havainnollistamiseksi noudatan kahta analyysikäytäntöä, toista laulun tekstuaalisen rakenteen ja toista säkeen rytmin kuvaamiseen. Kuvausten kohteena on laulun yhdelle tai kahdelle runosäkeelle pohjautuva ja yhdestä neljään sävelmäsäettä käsittävä rakenteellinen perusyksikkö, joka inkeriläisessä laulussa toistuu yleensä suhteellisen muuttumattomana läpi laulun. Numerokoodauksen perusidea juontuu Pentti Leinolta (1970) ja Matti Kuuselta (1983a), jotka käyttivät niitä runosäkeen sanarakenteen tavutason kuvaukseen (esim. Pääskylintu päivälintu: 44; Lenteli kesoisen päivän: 332), mutta sovellus on toisenlainen.

Laulun muotorakenteen kuvaus perustuu runosäkeen nousu- ja laskuasemiin eli säeasemiin ${ }^{155}$ joita vastaavat numerot yhdestä kahdeksaan. Muotorakenne kuvaa runomitan ja runon lauletun tekstuaalisen rakenteen suhdetta. Kuten on kalevalamitan rakenteelle tyypillistä, kahteen ensimmäiseen säeasemaan voi sisältyä kaksi tavua kumpaankin. Tällaiset tavut eivät tuota lisämerkintöjä, ellei niitä ole laulettu poikkeuksellisella tavalla rytmittäen. Säettä korvaavat refrengit on näissä jätetty huomiotta, kaksi pystyviivaa || tarkoittaa esilaulajan ja kuoron osuuden välistä rajaa ja lisätavuja merkitsen tähdellä*. ${ }^{156}$ Numerosarja kuvaa säkeen mahdollisine säännöllisesti toistuvine osakertauksineen tai lisätavuineen. Yksittäisten tavujen tulkinnassa otetaan huomioon laulun rytmi, mutta se ei näy merkinnässä itsessään. Yksi tekstuaalinen rakenne on nimittäin voinut olla käytössä hyvinkin

\footnotetext{
${ }^{155}$ Puhun runojalan nousuista ja laskuista Pentti Leinon tapaan nousu- ja laskuasemina tai lyhyemmin säeasemina. Kielentutkimuksessa tavuasema viittaa äänteen asemaan sanassa: tätä mukaillen säeaseman voi ajatella viittaavan tavun asemaan runosäkeen metrisessä rakenteessa. Englanniksi termi on yksinkertaisesti position, mutta suomeksi pelkkä asema jäisi turhan epämääräiseksi.

${ }^{156}$ Tämän lisäksi tähti * on käytössä myös SKVR-tietokannan hakumerkintöjen yhteydessä, jolloin sillä tarkoitetaan sanan katkaisua.
} 
erilaisten sävelmien ja rytmityyppien yhteydessä. Perusmuotoinen säe merkitään yksinkertaisesti 12345678, kaksisäkeisen muotorakenteen yhteydessä 12345678 12345678. Esimerkiksi esilaulajan ja kuoron laulama kokonaisuus issuit kannessa ihala, oi dai issuit kannes issuit kannessa iha merkitään tällä systeemillä 12345678 || ** 1234 1234567, josta näkee nopeasti esilaulajan laulaneen ensin kokonaisen säkeen, kuoron laulaneen kaksi lisä- tai refrenkitavua, säkeen alkupuoliskon ja lopuksi säkeen kokonaan viimeistä säeasemaa lukuun ottamatta.

Laulun rytmin kuvauksessa numerot vastaavat säeasemien ja lisätavujen saamia suhteellisia aika-arvoja. ${ }^{157}$ Yleensä numero 2 viittaa kahdeksasosanuottiin, mutta se voi viitata myös käsikirjoituksen kuudestoistaosanuottiin. ${ }^{158}$ Jos aika-arvojen väliset erot ovat suuria, merkitään yli yhdeksän menevät numerot selvyyden vuoksi sulkeissa (10). Tyypillisen tasarytmisen, neli-iskuisen perussävelmän merkintä on 22222222, viisi-iskuisen niin kutsutun kalevalasävelmän 22222244. Laulun nopeutta ei tässä huomioida: kyse on ainoastaan rytmin suhteesta säeasemiin. Sävelen epäsäännöllisinä toistuvat venytykset ja fermaattimerkinnät käsikirjoituksissa on merkitty aksenttimerkillä '. Lisätavujen ja refrenkisanojen saamat aika-arvot on merkitty hakasulkeisiin, säkeiden ja osakertausten rajat merkitään välilyönneillä. Yllä mainittu issuit kannessa ihala -sävelmä saa rytmikoodikseen 31312222 || [22] 2284 3122318. Nuotinnoksena sama laulusäe näyttää tältä:

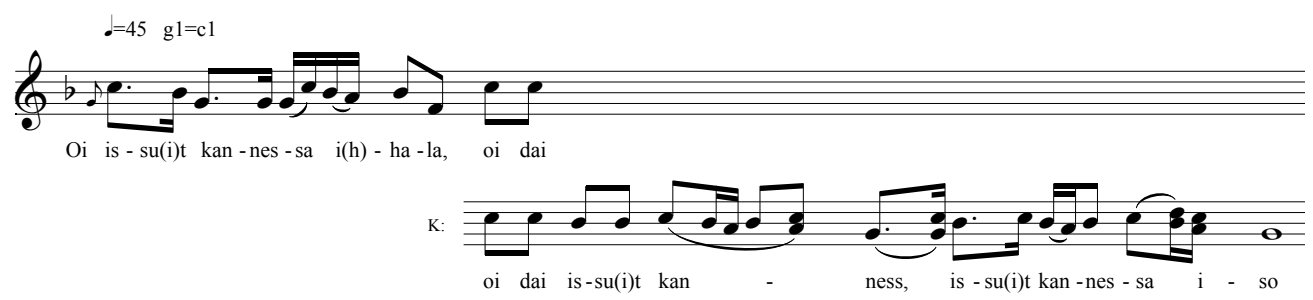

Nuotti 1. Naasto Savasteintyttären ja kuoron Istuttamisvirren ja oi dai -sävelmän ensimmäisen säe (SKS̈̈ A 300/12a, nuotinnos Ilona Korhonen).

\footnotetext{
${ }^{157}$ Erilaisia numerokoodeja on runosävelmien yhteydessä käyttänyt esimerkiksi Pekka Huttu-Hiltunen $(2008,28,146-148)$ melodialinjan kuvaamiseen. A. O. Väisänen $(1990,96)$ kehitti rytmin kuvaamiseen oman kirjainjärjestelmänsä.

${ }^{158}$ Kuten luvun 4 alaluvussa Rytmi todetaan, on käsikirjoitusten tahtilajivalintojen ja tempomerkintöjen tulkinta usein vaikeaa: samaakin sävelmää on voitu nuotintaa eri tahtilajeissa ja erilaisin merkinnöin, eikä merkintäkäytäntöjen suhde nuotintamisen kohteena olleeseen esitykseen ole selvä. Samatkin tallentajat ovat esimerkiksi kirjoittaneet samoja sävelmätyyppejä vaihtelevin tavoin, välillä $1 / 16-$, välillä 1/8-kestoin, ja lisäksi erilaisin tahtiosoituksin.
} 


\section{Aineiston VAlinta JA KäSITtely}

Länsi-Inkeri päätyi tämän tutkimuksen kohteeksi sieltä tallennetun aineiston vuoksi. Soikkolasta on tallennettu laajin toista maailmansotaa edeltävä kalevalamittaisen runon ääniteaineisto, jota on mahdollista suhteuttaa samana aikana ja aikaisemmin kerättyihin laajoihin runo- ja sävelmäkäsikirjoitusaineistoihin. ${ }^{159}$ 1930-luvulla Narvusin läntisimmistä kylistä tallennetut runoaineistot ovat puolestaan yksi tiheimmistä ja monipuolisimmista kalevalamittaisen runon käsikirjoitusaineistoista. Maantieteellisistä alueista nostankin tarkastelun keskiöön Narvusin ja Soikkolan, joiden välisistä yhteyksistä on ollut puhetta ensimmäisessä luvussa. Hevaan inkerois- ja Tyrön inkerinsuomalaiskylät sekä Kattilan vatjalaisalue toimivat tarvittaessa vertailukohtina. Keski-Inkerin muut inkerinsuomalaisalueet jäävät työn ulkopuolelle, sillä niillä ei aikaisemman tutkimuskirjallisuuden eikä runo- ja sävelmäaineistojen perusteella ollut yhtä tiheitä yhteyksiä tutkimuksen keskeisalueille kuin Hevaan ja Kattilan alueilla.

Keskeisimmällä sijalla ovat 1900-luvulla ennen toista maailmansotaa kerätyt aineistot, erityisesti äänitteet ja kontekstitiedot, joita täydennetään 1800-luvun puolella tallennetuilla käsikirjoituksilla. Aikarajaus 1853-1938 määräytyy tallennushistorian mukaan. Sen sisään jää monia muutos- ja murroskohtia, suurimpina maaorjuuden lakkauttaminen ja Venäjän vallankumous. Aikarajauksen päätepiste määräytyy selkeään taitekohtaan: toinen maailmansota ja sitä seuranneet myllerrykset muuttivat alueen kulttuurisia ja sosiaalisia oloja vallankumoustakin enemmän. Sodan jälkeen julkinen runojen laulaminen näyttää lopullisesti lakanneen. Vaikka 1960- ja 1970-luvuilla tallennetut ääniteaineistot ovat laajoja ja monipuolisia, kuvaavat laulajat niissä ainakin julkisen laulamisen osalta menneisyyttä. Toki menneisyyteen suuntasivat myös kysymyksensä monet varhaisetkin kerääjät, ja etenkin praasnikkavirsien laulaminen, kuten analyysiluvuissa käy ilmi, näyttää vähentyneen jo 1800-luvun puolella. Toisen maailmansodan jälkeen tallennettuja ääniteaineistoja käytän paikoitellen lisäaineistona, mutta en ole käynyt niitä läpi systemaattisesti.

Lähtökohtanani on ollut ottaa huomioon kaikki laulamisesta, laulamisen tavoista tai laulamiseen liitetyistä merkityksistä tavalla tai toisella kertova, maantieteellisen ja ajallisen rajaukseni puitteisiin kuuluva arkistoaineisto, oli se sitten tekstiä, nuottia, kuvaa tai ääntä. Aineiston luonteen vuoksi satunnaisotos jättäisi paljon olennaisia, joskus vain yksittäisinä esiintyviä piirteitä analyysin ulkopuolelle. Samalla on tietenkin selvää, että erilaisia tutkimuskysymyksen kannalta olennaisia piirteitä on jäänyt kokonaan tallentamattakin. Tutkimuskysymys ja sen kohdentaminen ensisijaisesti häissä ja praasnikoilla laulamiseen rajaavat aineistoa osaltaan. Vaikka lasken aineistoon kuuluvaksi esimerkiksi jokaisen aikarajauksen sisällä alueelta tallennetun runon, en ole lukenut läpi tai analysoinut kaikkia yksittäisiä runoja, vaan valikoinut erilaisten tekijöiden kuten kontekstitietojen ja runon tee-

\footnotetext{
${ }^{159}$ Launiksen vuoden 1906 Inkerin matka oli toinen tiedossani oleva kalevalamittaisen runon äänitysretki: ensimmäisen retken tekijä vuonna 1905 oli samaten Launis (1906b). Matka suuntautui RajaKarjalaan, ja sen tulokset olivat määrällisesti huomattavasti vaatimattomammat.
} 
mojen sekä apuvälineiden kuten hakemistojen ja tietokantojen avulla kunkin osakysymyksen kannalta relevantin ja mahdollisimman kattavan korpuksen. Ääniteaineiston sekä analyysiluvuissa käytetyt keskeisimmät käsikirjoitusaineistot olen luetteloinut liitteisiin.

Keskeisimpien kerääjien ja muistiinpanojen osalta olen käyttänyt alkuperäiskäsikirjoituksia, mutta muuten olen luottanut Suomen Kansan Vanhat Runot -julkaisuun (SKVR) sekä julkaisemattomien runojen digitoituun kortistoon (KRA). Osa-aineistojen muodostamisessa käytössä ovat olleet aineiston läpiluku, painetun SKVR:n hakemisto, valmistumassa oleva uusi teemahakemisto, SKVR-tietokannan hakutoiminnot ja julkaisemattomien runojen digitaaliseen versioon kohdistamani tekstinkäsitelyohjelman sanahaut. Länsi- ja Keski-Inkerin osalta SKVR:ssä on julkaistu melko kokonaisvaltaisesti myös runoihin liittyvät kontekstitiedot ja selitykset. Julkaisemattomien runojen kortiston osalta taas on jätetty enemmän kontekstitietoja kopioinnin ulkopuolelle ja lisäksi kortiston muodostamisen sekä digitoinnin yhteydessä on syntynyt satunnaisia kirjoitusvirheitä.

Häitä käsittelevässä analyysiluvussa käytän muita lukuja enemmän tukena toisen maailmansodan jälkeen äänitettyjä aineistoja, jotka todentavat joitain suppeamman varhaisen aineiston pohjalta syntyneitä päätelmiä. Tällöin keskeinen on Eino Kiurun, Terttu Kosken ja Elina Kylmäsuun (1974) julkaisema runojulkaisu Narodnye pesni Ingermanlandii (NPI), joka sisältää myös muutamien laulujen nuotinnoksia. Nuotinnosten ja säkeenkertausten tulkintaan liittyy joitain hankaluuksia: lauluista on nuotinnettu vain alkupätkä, transkriptioihin ei sisälly tietoa säkeenkertausten säännöllisyydestä ja paikoin sama nuotti on viitetiedoissa kohdistettu useampaan runoon. Tätä julkaisua olen kuitenkin käyttänyt systemaattisena aineiston täydennyksenä häälauluja käsittelevässä luvussa: ne esittelevät nähdäkseni kattavan kirjon 1900-luvun puolivälin jälkeen alueella muistettuja sävelmiä ja laulamisen tapoja, joista monet ilmeisesti palautuvat esittäjiensä lapsuus- ja nuoruusvuosiin 1900luvun alkupuoliskolla (vrt. Oras 2008; ks. myös Niiranen 2013). Lisäksi avuksi on etenkin häärituaalin tarkastelun kohdalla ollut Aili Nenolan (2002) toimittama Inkerin itkut. Erilaisia etnografisia ja laulamiseen liittyviä tietoja sisältyy paikoin myös käyttämiini inkeroiskielen ja vatjan sanakirjoihin. ${ }^{160}$

SKS:n äänitearkistossa sekä Viron Kirjallisuusmuseon kansanrunousarkistossa säilytettävät fonogrammit olen saanut käyttööni digitoituina äänitteinä. SKS:n hallussa olevat fonogrammit (Launis 1906, Väisänen 1914) on kopioitu magneettinauhalle kahteen otteeseen, 60-luvulla ja vuonna 1984, ja ne on nyttemmin digitoitu. Ääni on kopioinneissa katkeillut eri tavoin, säkeitä tai sanoja on jäänyt pois eri kohdista. Lisäksi osa fonogrammeista puuttuu vaihdellen kummastakin kopioinnista. Analysoidut litteraatiot ja nuotit ovat transkriptio näistä kahdesta kopioin-

\footnotetext{
${ }^{160}$ Inkeroismurteiden sanakirja (IMS); Isuri keele Hevaha murde sõnastik (IKHMS); Vatjan kielen Joenperän murteen sanasto (VKJMS); Vatjan kielen Kukkosin murteen sanakirja (VKKMS); Vadja keele sõnaraamat (VKS). Näihin viittaan sanakirjan lyhenteellä ja kulloinkin kyseessä olevalla hakusanalla.
} 
nista. ${ }^{161}$ Viittaan aineistoihin arkistosignumeilla, en fonogrammin tai julkaistun nuotin numerolla (IRS), jotka kuitenkin löytyvät sävelmien luetteloista liitteessä 4 . Launiksen ensimmäisen matkan käsikirjoitusnuoteista puolestaan on kolme versiota: kenttäkäsikirjoitus (SibA), sen puhtaaksikirjoitus (SKS KRA) sekä julkaistu versio (IRS). Käytän ensisijaisesti viitteitä kenttäkäsikirjoitukseen. Sävelmien käsittelyssä etenkin Boreniuksen, Europaeuksen ja Alavan osalta on suureksi avuksi ollut Elina Sadeniemen laatima runosävelmien käsikirjoitusluettelo (SKS KRA). Käytössäni on ollut myös Senni Timosen sävelmien paikallisiin nimityksiin liittyvä yhteenveto Tiedot sävelistä (tekijän hallussa).

Etenkään rahisevan fonogrammin tulkitseminen ei kaikissa kohdissa ole helppoa. Kopiointeja edeltäneestä vaharullien kulumisesta johtuen äänenlaatu on huono: nuoret naiset kuulostavat usein vanhuksilta, säveltaso ja nopeus heittelehtivät paikoitellen rajustikin, eikä kaikista säkeistä ja lauluista ole mahdollista saada selvää. Selvää on, että mitä tutumpi on kuunneltava runo ja runokieli, sitä helpompi säkeet on tunnistaa (vrt. Sterne 2003, 87-136; Tarkka 1999, 57). Tulkinnan apuna olen käyttänyt aineiston sisältämiä runotoisintoja lähialueilta. Samaten vertailu julkaistuihin nuotteihin ja myöhempiin nauhoituksiin vähentää tulkintavirheiden todennäköisyyttä. Joskus voi toisintoihin vertailu myös johtaa harhaan: epämääräisestä rahinasta on joskus helppoa kuulla säe tai äänne, jonka olettaa kuulevansa. Sama pätee yhtälailla kertauksiin, välisanoihin ja muihin rakennepiirteisiin sekä nuotinnoksen yksityiskohtiin: mielessä oleva malli tai hypoteesi voi ohjata havaintojen tekemistä.

Sävelmäaineiston käyttö vaihtelee luvuittain. Käydessäni seuraavassa luvussa läpi laulun rakenteita pohjaan analyysini ensisijaisesti varhaisten runoäänitteiden (1906-1938) muodostamaan kokonaisuuteen. Käsikirjoitussävelmiin liittyy suurempia lähdekriittisiä varauksia ja uudemmat aineistot sisältävät ennen kaikkea soololaulua, joka ei asetu tämän työn keskiöön. Laulun rakenteiden kohdalla käsikirjoitusaineisto on käytössä lähinnä melodian ja rytmin tarkastelun yhteydessä. Muissa analyysiluvuissa olen valinnut kulloinkin relevantin aineiston laulujen tekstuaalisten, musiikillisten ja sisällöllisten piirteiden sekä kontekstitietojen perusteella. Apuneuvoina olen käyttänyt paitsi työn keskeis- ja oheisaineistosta tekemääni analyysitaulukkoa, myös Launiksen (1910a ja 1910b) musiikillisia luokitteluja sekä paikoin Suomen Kansan eSävelmät -tietokantaa. Olen litteroinut ääniteaineiston (digitaalinen kopio SKS:n kansanrunousarkistossa) ja nuotintanut sitä vaihtelevalla tarkkuudella tarpeellisiksi katsomiltani osin (tekijän hallussa). Osittain olen käyttänyt Launiksen julkaisemia nuotinnoksia ottaen samalla huomioon erot äänitteillä itse kuulemaani, joiltain osin olen tyytynyt kuulonvaraiseen analyysiin ja sanallisiin muistiinpanoihin.

Sävelmäaineisto jakaantuu käsikirjoitussävelmiin, fonogrammiäänitteisiin ja lakkalevyäänitteisiin. Käsikirjoitusnuotteihin (vuosilta 1853-1914) sisältyy harvoin

\footnotetext{
${ }^{161}$ Launiksen fonogrammit on aikaisemmin litteroinut Ulla Kauhanen 60-luvulla (KRA) ja Anneli Asplund on julkaissut niistä osan hieman rahinoista puhdistettuna kasetilla Runolaulua Inkeristä (1992b) sekä joitakin litteraatioina ja nuotinnoksina teoksessa Kansanlauluja Inkerinmaalta (1992a).
} 
runotekstiä muutamaa säettä enempää. Niihin liittyy melko harvoin kontekstiselityksiä tai laulajatietoja, mutta niiden määrä on merkittävä: lähes 300 . Fonografiäänitteet (1906-1922) ovat yleensä lyhyitä pätkiä laulun alusta, ja niihin liittyy harvoin yksilöityjä kontekstikuvauksia. Länsi-Inkeristä tallennettujen fonografiäänitteiden määrä on 130. Vuonna 1937 tallennetut 42 lakkalevyäänitettä ovat täyspitkiä, mutta edustavat harvempia sävelmätyyppejä; lisäksi niissä esiintyvät kuusi laulajaa edustivat sekä inkeroisia, inkerois-vatjalaisia että inkerinsuomalaisia ja ovat kotoisin eri kylistä. Näiltä samoilta laulajilta on melko paljon myös käsikirjoituksina 1930-luvulla kerättyjä runoja, joihin sisältyy usein tietoja laulamisen tavoista ja tyypillisistä esitystilanteista, mutta ei sävelmiä. Sävelmäaineisto on länsi-inkeriläisten sekä Hevaalta ja Tyröstä tallennettujen runosävelmien osalta luetteloitu kokoelmittain liitteeseen 4 .

Satunnaisia, usein hyvin lakonisia kontekstimainintoja ja kuvauksia laulamisen tavoista sisältyy lähes jokaisen Länsi-Inkeristä runoja keränneen tutkijan kokoelmiin, sekä runojen yhteyteen että matkakertomuksiin ja muihin kirjoituksiin. Useat 1800-luvun lopun kerääjät tallensivat niitä runsaastikin. Merkittävimpiä tässä suhteessa ovat kuitenkin 1930-luvulla Narvusin läntisimmistä kylistä runoja keränneet Elsa Enäjärvi-Haavio sekä Aili ja Lauri Laiho. Heidän kuvauksiinsa liittyy harvemmin sävelmiä, mutta käsikirjoitusmuistiinpanoihin on merkitty viitteitä laulujen tekstuaalisesta rakenteesta esilaulajan ja kuoron vuorotteluineen, osakertauksineen tai refrenkeineen. 1930-luvun aineisto vastaa joiltain osin Lauri Hongon (2000) tiheäksi aineistoksi nimeämää ihannetta. Tietyiltä laulajilta ja tietyistä kylistä on arkistoon kertynyt eri tutkijoiden erilaisissa tilanteissa tallentamia moninaisia perinteenlajeja ja kuvauksia, samankin runon eri toisintoja samalta laulajalta.

Valokuvia ja niihin liittyviä taustatietoja olen kartoittanut ensisijaisesti Museoviraston kansatieteellisestä kuva-arkistosta, SKS:n kuva-arkistosta sekä Kansallisesta audiovisuaalisesta arkistosta. Etenkin joihinkin Vihtori Alavan ja Juho Lukkarisen kuviin Museovirastossa liittyy pitkiä taustatietoja, joita ei ole heidän muissa arkistoaineistoissaan. Toisaalta kaikki Alavan sidoksiin (SKS KRA) sisältyvät tiedot hänen matkoilla ottamistaan valokuvista ja itse valokuvat eivät ole kohdennettavissa toisiinsa (ks. myös Kuusi 1983a, 13, 19, 173, kuvaliite). Kuten muukin tämän työn aineisto, valokuvat suuntautuvat yleensä menneisyyteen, eivät niinkään kuvausajankohdan ilmiöihin. Ne ovat samalla tavoin kuvaajiensa valikoimia, rajaamia tai järjestämiä kuin tekstiaineistotkin.

Tallentajat olivat kiinnostuneita erilaisista asioista ja käyttivät erilaisia keruumetodeja. Aineisto on alueellisesti, määrällisesti ja ajallisesti laajempi kuin yksi kenttätutkija pystyisi kokoamaan. Katson eri kerääjien ajallisesti ja paikallisesti hajautuneiden näkökulmien täydentävän toisiaan. Eri kokoelmat vastaavat osin erilaisiin kysymyksiin, ja niitä yhdistämällä on paikoin mahdollista luoda laajempia kokonaiskuvia. Aineisto jakautuu kuitenkin epätasaisesti suhteessa aikaan ja paikkaan. Suurin osa runokäsikirjoituksista on tallennettu 1800-luvun loppupuoliskolla. Suurin sävelmäkokoelma on tallennettu 1900-luvun ensimmäisellä vuosikymme- 
nellä. Konteksti- ja laulajatietojen määrä on tiheimmillään 1930-luvun aineistossa. Laajin kirjo sävelmiä on tallennettu Soikkolan alueelta, eniten kontekstitietoja ja esimerkiksi häärunoja Narvusista. Pyrinkin analyysien yhteydessä pitämään mahdollisimman selkeästi esillä, minkä aineiston pohjalta päätelmiä teen, kenestä kerääjästä ja mistä alueesta on kyse sekä mihin etniseen ryhmään aineisto vahvimmin liittyy. Valtaosin tässä työssä on kyse inkeroisten lauluista.

Monissa varhaisemmissa kokoelmissa laulajat esiintyvät usein nimettöminä tai ainoastaan etunimellään, ilman tarkempia henkilötietoja. Liitteeseen 2 on koottu luettelo työn kannalta merkittävimmistä nimeltä tunnetuista laulajista, heidän syntymävuosistaan sekä synnyin- ja asuinkylistään. Nimettömäksi jääneiden laulajien etnisistä taustoista olen tehnyt arvioita muistiinpanopaikkojen ja aineiston laadun perusteella. Tietoja kylien etnisistä koostumuksista on koottu liitteeseen 3.

\section{ESITYKSEN MONITASOISUUS}

Keskeinen analyysini lähtökohta on esityksen monitasoisuus ja sen tasojen välinen vuorovaikutus. Runon sisältö, runomitta, runon laulussa saama muoto, sävelmä, esitykselliset piirteet ja lauluun liittyvät liike tarvitsevat kaikki omia käsittelytapojaan, vaikka päämääränä on hahmottaa esityksen kokonaisuutta ja tasojen sidoksia toisiinsa. Keskeisiä ovat ne menetelmät, joilla on osoittautunut olevan tämän työn aineiston puitteissa mahdollista eritellä paikallisen lajin, rekisterin ja esitysarenan käsitteisiin liitettävissä olevia tekijöitä.

Inkeriläisen runon kohdalla runotekstejä ja niiden sisältöjä on tutkittu ja luokiteltu perinpohjaisimmin. Niiden hahmottamiseen ja nimeämiseen on aivan toisenlainen perusta kuin sävelmien, esitysareenoiden tai liikkeen, joten tässä kohden on mahdollista nojata pääosin muiden tutkijoiden työhön. Keskeisenä välineenä tässä on uusi SKVR-teemahakemisto. Lauri Harvilahden (1992a; 1992b; 1994; 2000; 2004) tutkimukset inkeriläisten lyyris-eeppisten runojen ja Senni Timosen (1974; 2004) työt lyriikan rakentumisesta toimivat tulkintojani ohjaavana kehyksenä, samoin edellä käyty keskustelu suullisen runouden variaatiosta ja lajeista. Tässä työssä riittää yleensä vain runotyypin tai -teeman ja sen mahdollisten erityispiirteiden tunnistaminen sekä runon keskeissisällön nimeäminen tutkijayhteisön käyttämin nimin. Käytän nimeämisessä viitteitä SKVR-teemahakemistoon, jonka luokitus on tarkempi ja yhtenäisempi kuin vanhojen SKVR-hakemistojen. Käytän kuitenkin monin paikoin lauluja nimetessäni länsi-inkeriläisiä säemuotoja ja annan ainoastaan suluissa, alaviitteessä tai sivulla 392 alkavassa Runo- ja sävelmähakemistossa viitteen teemahakemistossa käytettyyn runotyypin yleisnimeen. Näin pyrin pitämään alkuperäisiä runoja ja niiden kieltä lukijan kannalta paremmin näkyvissä. Monesti yksi runo myös hajoaa useaksi teemahakemiston teemaksi.

Samalla tavoin runomitan hahmottamiseen on olemassa vahva pohja. Kalevalamitan perussäännöt on kuvattu tarkasti, vaikka onkin todettu tarvittavan lisätutkimusta erityisesti runomitan suhteesta laulettuun runoon. Tässä työssä päähuomio 
on niissä tekijöissä, jotka osoittautuvat tarpeellisiksi inkeriläisten laulettujen rakenteiden selittämiseksi. Niinpä tavupainojen ja -pituuksien tarkemmat analyysit jäävät tekemättä, mutta säeasemat, trokee- ja murrelmasäkeen vaihtelu, säkeiden sanarakenteet sekä paralleelisäerakenteet ovat merkityksellisiä lisätavujen, osakertausten, refrenkirakenteiden sekä tiettyjen kertausrakenteiden analyysissa. Runomitan hahmottaminen on välttämätön apuväline myös sävelmien analyysissa, sillä käsittelen sävelmän rakennetta ja sävelmäsäkeiden rytmiä suhteessa runomitan rakenteeseen.

Laulun muotorakenteen analyyttinen erottaminen sävelmän rakenteesta on monin paikoin keinotekoista ja tämän tutkimuksen tarpeisiin luotua. Laulun kokonaisrakenne hahmottuu niiden yhdistelmänä. Laulun muotorakenteen osalta huomion kohteeksi nostetaan erityisesti lisätavut, osakertaukset, refrengit, tavumuutokset ja pois jäävät tavut. Sävelmän osalta käsittelen lähinnä sävelalaa, rytmirakennetta sekä melodiaa. Runomittaa, laulun muotorakennetta ja sävelmän piirteitä sekä näihin liittyviä teoreettisia keskusteluita käsittelen tarkemmin luvussa 4. Sekä laulun muotorakenteen että sävelmän analyysissa käsitän transkription - litteraation ja nuotinnoksen - yhdeksi analyysin ja huomion suuntaamisen välineeksi.

Esitykselliset piirteet kuten laulun tempo ja volyymi, äänensävyt, lauluun liittyvä liike ja laulajien sijoittuminen tilassa ovat aineiston laadusta johtuen hankalimmin tavoitettavissa. Sanallisia tietoja ei ole paljon ja juuri tämänkaltaisten tekijöiden voi olettaa muokkautuvan herkästi tallennustilanteen mukaan. Fonogrammien tekninen laatu ei yleensä anna kovin suuria mahdollisuuksia varmoihin päätelmiin esimerkiksi temposta, äänensävyistä tai volyymistä. Luvussa viisi ja kahdeksan kuitenkin pyrin yhdistelemään käytettävissä olevia tietoja näistä tekijöistä hahmottaakseni niiden käyttömahdollisuuksia ja merkityskenttiä siinä määrin kuin mahdollista. Aineiston luonteen ja työn rajausten takia visuaalisen ja tilallisen tason tarkastelut jäävät tekemättä, vaikka esimerkiksi pukeutuminen ja tilaan sijoittuminen on mitä ilmeisimmin ollut etenkin inkeriläisen juhlalaulun ja rituaalisten laulujen kohdalla keskeinen osa esityksen muotoutumista (vrt. karjalaisista kirjontatöistä Survo 2012b).

Keskeistä tässä tutkimuksessa on sen hahmottaminen, miten esitysten erilaiset piirteet tyypillisesti liittyvät ja vaikuttavat toisiinsa. Käytännössä analyysi on erilaisten toistuvien yhdistelmien etsimistä monitasoisesta aineistosta ja erilaisten aineistokokonaisuuksien - runokäsikirjoitusten, sävelmämuistiinpanojen, ääniteiden, kuvausten - asettamista rinnakkain. Esimerkiksi liekkuvirren yhteydessä osoittautuu, että tietyn tyyppiset runot, sävelmät, laulun muotorakenteet ja esitykselliset piirteet liittyvät tietyn esitysareenan puitteissa yhteen: ne määrittävät liekulla laulamisen rekisteriä. Tämä tulee ilmeiseksi vasta tarkasteltaessa 1) eri aineistokokonaisuuksia, 2) useita analyyttisia tasoja ja 3) yhtä esitysareenaa eli liekulla juhlapyhinä laulamista 4) paikalliset nimeämisen käytännöt huomioiden. Runokäsikirjoitusten ja pidempien äänitteiden tarkastelu antaa mahdollisuuksia päätellä, millä tavoin vain muutaman tekstisäkeen sisältävät sävelmätallenteet olisivat todennäköisesti tai tyypillisesti jatkuneet. Sävelmätallenteiden analyysi antaa 
mahdollisuuksia päätellä, minkä tyyppisiin sävelmiin tietyt nuotittomien runokäsikirjoitusten piirteet kuten muistiinpanot refrengeistä tai kertausrakenteista ovat voineet liittyä. Sävelmäkäsikirjoitukset kertovat tiettyjen runo- ja sävelmätyyppien mahdollisista yhdistelmistä, vaikka eivät sisälläkään runoja kokonaisuudessaan eivätkä kerro sävelmän hienovaraisemmista tai esityksellisistä piirteistä. Etenkin teknisesti heikkolaatuisimpien fonogrammien kohdalla taas jo pelkkä perusanalyysi - runon ja sävelmän transkriptio - edellyttää vertaamista käsikirjoitusaineistoihin. Matkakertomusten kontekstitiedottomia kuvauksia puolestaan on joskus mahdollista yhdistää saman kerääjän tallentamiin runo- tai sävelmäaineistoihin.

Toistuvien piirteiden analyysi antaa mahdollisuuden hahmottaa inkeriläisen laulun tilannesidonnaisia rekistereitä. Käytännön apuvälineenä toistuvien yhdistelmien tunnistamisessa on ollut moninkertaisen läpilukemisen ja teemoittelun ohella aineistojen aineistotyypeittäin vaihteleva koodaus ja muokkaus yksinkertaisiksi, taulukkomuotoisiksi tietokannoiksi. Aineiston luonteen vuoksi jokaista yksittäistä työn kannalta merkittävää tallennetta on ollut syytä tarkastella lähdekriittisesti suhteessa tallentajasta, esittäjästä, paikkakunnasta, etnisestä kontekstista ja keruutilanteesta saatavissa oleviin tietoihin. Suurta osaa tästä ei ole mahdollista kirjoittaa yksityiskohtaisesti esiin, mutta keskeiset tähän tarkasteluun vaikuttaneet tekijät on esitetty Länsi-Inkerin historian, etnisten ryhmien ja keruuhistorian yhteydessä sekä liitteiden paikkakunta-, laulaja- ja aineistotaulukoissa.

Yhdistelmän päätteleminen toistuvaksi ja kulttuurisesti konventionaaliksi edellyttää sen löytymistä useammasta toisistaan riippumattomasta lähteestä, mikä tässä tarkoittaa eri kerääjien eri laulajilta tallentamia oletettavasti toisistaan riippumattomia toisintoja. Tallennushistorian valossa on kuitenkin samalla selvää, että piirteen esiintyminen runsaana aineistossa ei välttämättä merkitse samassa suhteessa sen käytön yleisyyttä. Tallentajat eivät pyrkineet kuvaamaan kattavasti käytössä ollutta inkeriläistä suullista perinnettä tai edes kalevalamittaisen runon kenttää, vaan keskittyivät itseään kulloinkin kiinnostaviin lajeihin ja piirteisiin. Toisaalta laulajillakin oli omat intressinsä keskittyä määrättyihin piirteisiin. Niinpä poikkeavilla, yksittäisilläkin tallenteilla voi tulkinnoissani olla suuri painoarvo, jos muiden tekijöiden nojalla on syytä olettaa niiden edustavan jotain sellaista laulukulttuurin puolta, josta ei tallennushistoriasta johtuen ole paljonkaan jälkiä tallennettu. Pyrkimykseni lukea aineistoista myös niihin heikosti tallennettuja laulukulttuurin piirteitä rinnastuu Kati Mikkolan (2009, 56-61) myötä- ja vastavirtaan lukemisen käsitteisiin. Sekä kerääjien arvostamat ja runsaasti dokumentoimat että heidän vähättelemänsä tai moittimansa piirteet kertovat omilla tavoillaan paikallisista laulamisen tavoista.

Esityksen monitasoisuus merkitsee tulkinnassani myös viittauksellisuuden monitasoisuutta. Kielellisten ilmiöiden puitteissa hahmotetut intertekstuaalisuuden lajit pätevät vaihtelevin tavoin myös kielenulkoisten ilmiöiden piirissä. Runo tai sen osa voi viitata vaikkapa toiseen runoon, tyypilliseen esitystilanteeseen tai lajiin niin sisältönsä kuin muotonsakin kautta, mutta yhtä lailla näin voi tehdä laulun rakenteeseen, sävelmään tai esitystapaan liittyvä piirre. 


\section{REKISTERI, LAJI JA ESITYSAREENA}

Analyysini jäsentyy rekisterin, paikallisen lajin ja esitysareenan käsitteiden ympärille. Rekistereiden analyysi tarkoittaa tiettyjen tilannesidonnaisten, toistuvien laulamisen tapojen tunnistamista. Esitysareenan kautta käsitteellistän tiettyjä toistuvia laulamisen tilanteita. Tietyn esitysareenan puitteissa laulaminen on eri kerroilla osin samankaltaista ja siihen on mahdollista viitata sanallisesti tai esityksellisesti myös muissa tilanteissa. Esitysareenan ja rekisterin suhteessa on kyse toistuvantyyppisen tilanteen ja toistuvantyyppisen laulamisen yhteydestä. Paikallisen lajin käsite puolestaan pohjautuu puheyhteisön jakamille nimeämisen ja käytön tavoille. Tutkijan havaitseman rekisterin ja esitysareenan yhdistelmän käsitteleminen paikallisena lajina edellyttää myös sen paikallista tunnistamista, jonka indikaattorina tässä toimivat juuri nimitykset. Rekisteri on muutenkin käsitteenä paikallista lajia laajempi. Esimerkiksi naisten julkisen laulun rekisteri ei istu paikalliseksi lajiksi, sillä se kattaa paljon erilaisia paikallisia lajeja ja laulamisen tapoja. Näitä kuitenkin yhdistävät julkisen laulun rekisterin tunnuksina esilaulajan ja kuoron vuorottelu ja kovaäänisyys.

Sävelmien, runojen ja laulamisen tapojen variaatio on analyysissani yhtä merkityksellistä kuin aineistosta löytämäni toistuvat piirteet. Toistuvien piirteiden kautta on kuitenkin mahdollista saada näkökulma siihen, mikä laulamisessa on ollut jaettua. Pohjimmiltaan kyse on käytön sosiaalisista konventioista eli siitä, mitä ja miten ihmisillä oli tapana tehdä (toistuvuus) ja näiden konventioiden suomista ilmaisun ja tulkinnan mahdollisuuksista (variaatio). Toistuvien piirteiden ja yhdistelmien analyysin mielekkyys kytkeytyy niiden taustalla oleviin sosiaalisiin käytäntöihin ja sitä myötä jaettuihin käsityksiin lauluista, niiden käyttömahdollisuuksista ja merkityspotentiaaleista. Erilaisten tekstuaalisten, musiikillisten ja esityksellisten piirteiden merkityskenttien katson kytkeytyvän juuri siihen, miten niitä oli tapana ja mahdollista käyttää: yleiset käyttö- ja tulkintatavat asettivat rajat myös sille, mitä oli yksittäisissä ja erityisissä tapauksissa mahdollista tehdä niin, että tekeminen oli merkityksellistä ja ymmärrettävää. Yhteisön jakamat käyttötavat olivat se tulkinnallinen kehikko, jonka puitteissa esittäjät ja yleisöt toimivat ja jota myös tutkija voi analyysinsa kautta tavoitella. Yksittäinen esityskerta sekä nojasi vakiintuneisiin käytäntöihin ja tulkintamalleihin että sisälsi mahdollisuuden niiden muovaamiseen.

Tallentajia kiinnostivat vaihtelevilla tavoilla erilaiset laulukulttuurin piirteet: he eivät etsineet esimerkiksi tiettyyn tilanteeseen liittyviä tiettyjä runoja runoja tietyllä tavalla esitettyinä, vaan joko tietynlaisia runoja tai tietynlaisia sävelmiä. Arkistoitu otos on runojen, sävelmien ja esittämisen tapojen yhdistelmien osalta melko sattumanvarainen, mikä on tämän työn kannalta etu. Tallentajilla ei voi olettaa olleen erityisiä intressejä mainita tai kuvata juuri tietynlaisia yhdistelmiä. Keskeinen tulkinnoissa huomioitava piirre on kuitenkin esitysareenan ja viittauksellisuuden monikerroksisuus. Praasnikka- ja häälauluja ei ole tallennettu keskeisissä käyttökonteksteissaan, vaan omanlaisissaan tallennustilanteissa. Tällöin voi ajatella esittäjien eri tavoin pyrkineen lauluillaan kertomaan, mitä häissä ja praasnikoilla lau- 
laminen oli tai mitä niissä esitettävät laulut olivat. Ei ole kuitenkaan selvää, millä kaikilla esityksen tasoilla esittäjät milloinkin ovat näin tehneet ja missä määrin he ovat sopeuttaneet esityksen eri tasoja tallennustilanteen kontekstiin.

Myös tallennustilannetta on mahdollista tarkastella esitysareenana. Sen tietyt reunaehdot - vieraalle esiintyminen, arjen ja muodollisuuden sekoittuminen, laulujen esittäminen tavanomaisten kontekstiensa ulkopuolella - pysyivät samana muuten runsaasti varioivissa kohtaamisissa, ja kerääjien tihentyneiden vierailuiden myötä voi ajatella tallentamisen myös tulleen Inkerissä paikallisten kannalta tietynlaiseksi, toistuvaksi tilanteeksi, johon kehitettiin erilaisia suhtautumisstrategioita. Luvuissa kaksi ja kahdeksan kuitenkin käy ilmi, että tarkemmin katsottuna eri tallennustilanteiden esitysareenat muodostuivat hyvin erilaisiksi.

Olennaista yksittäisten tallennettujen esitysten ymmärtämiseksi on paitsi esitysareenan monikerroksisuus, myös laulajapositioiden pohdinta. Analyysissa osoittautuu, että moniin rituaalisiin tilanteisiin punoutui suhteellisen pysyvien keskeisteemojen ohella myös erilaisia yleisempiä osuuksia ja toisaalta rituaalisia keskeisteemojakin oli mahdollista käyttää arkisemmissa konteksteissa, esimerkiksi hälalauluja myös omaelämänkerrallisina tulkintoina. Tällöin on otettava huomioon, että laulaja saattaa kuvata tiettyä rituaalista tilannetta yleisellä tasolla (näin on yleensä tapana laulaa), kuvata sitä erityisellä tasolla (näin lauloimme tietyssä yksittäisessä tilanteessa) tai käyttää rituaalisen tilanteen teemoja johonkin arkisempaan kontekstiin sovellettuna (tällaisina tulkintoina käytän näitä runoja jossain muussa tilanteessa). Erilaiset esitysareenan ja laulajaposition yhdistelmät vaikuttavat monin tavoin myös rekistereiden käyttöön. Esitysareenan monikerroksisuutta ja laulun muokkautumista keruutilanteen kontekstissa pohdin pidemmälle luvussa 8 . 


\section{LAULUN RAKENNE}




\section{LAULUN RAKENNE}

Erilaiset musiikilliset ja laulun muotorakenteeseen liittyvät piirteet muokkasivat vahvasti sitä, minkälaiselta kalevalamittainen runo Inkerissä milloinkin kuulosti. Runosävelmät ovat tyypillisesti yhden tai kahden runosäkeen pituisia ja vastaavat rakenteeltaan runon tekstisäettä. Etenkin Inkeristä löytyy kuitenkin myös monimutkaisempia rakenteita: osakertauksia, venytyksiä, lisätavuja, refrenkejä. Pelkistä inkeriläiseen runolauluun liittyvistä laulun rakenteista tai niiden liittymisistä naapurialueiden laulutyyleihin olisikin mahdollista laatia laaja teos. Tässä luvussa on tarkoituksena ainoastaan esitellä laulun rakennetekijöiden peruskehikko seuraavien lukujen tulkintoja varten. Pysyttelen paikallistasolla: tarkastelun alla ovat ensisijaisesti Soikkolan ja Narvusin alueilta ennen toista maailmansotaa tallennetut äänitteet soveltuvin kohdin käsikirjoitusaineistolla täydennettynä. Paikoin otan mukaan myös Hevaalta ja Tyröstä samana ajanjaksona äänitetyt laulut. Aiemman tutkimuksen määrästä johtuen painottuu tekstuaalisten piirteiden kohdalla enemmän aineiston, musiikillisten piirteiden kohdalla tutkimuskirjallisuuden käsittely. Analyysia ohjaavat myös seuraavissa luvuissa käsiteltävät rekisterien ja esitysareenoiden suhteet eli erilaisten rakenteellisten piirteiden tilannesidonnainen käyttö, jonka tulkitsen kertovan paikallisten omista laulun rakenteiden jäsentämisen tavoista. Laulun rakenteiden jako kahteen alalukuun on osin keinotekoinen, sillä laulussa tekstuaalinen ja musiikillinen taso vaikuttavat toisiinsa monin tavoin. Näiden jälkeen käsittelen vielä samoin joko tekstuaaliseen tai musiikilliseen puoleen viittaavia paikallisia nimityskäytäntöjä ennen pohdintaa siitä, mitä seuraavien lukujen analyysit kertovat erilaisten tekstuaalisten ja musiikillisten piirteiden käytöstä.

Runosävelmät on tässä määritelty niihin liittyvän tekstin runomitan perusteella, joten runosävelminä käsitellään myös esimerkiksi monia kalevalamittaiseen tekstiin yhdistettyjä venäläisiä kansanlaulusävelmiä, mutta toisaalta esimerkiksi tyypillisiä runosävelmiä läheisesti muistuttavia rekilauluja tai itkusävelmiä ei ole otettu mukaan, ei myöskään kuusi- ja seitsentavuisen välillä vaihtelevia lastenlauluja tai niin kutsuttuja välimuotoisia eli sekä riimillisen että kalevalamittaisen laulun piirteitä sisältäviä lauluja. ${ }^{162}$ Sävelmäaineistokokonaisuudet eivät jakaudu tasaisesti. Länsiinkeriläistä ääniteaineistoa on 144 tallennetta, joista suurin osa, 117, on kuorolaulua ja sooloja on 27. Keski-Inkerissä äänitetyistä 72 laulusta puolestaan ainoastaan 21 on kuoron tai jälestälaulajan kanssa esitettyjä. Käsikirjoitussävelmiin on harvoin merkitty, onko ne tallennettu yhdeltä vai useammalta laulajalta - useimmiten ilmeisesti yhdeltä. Käsikirjoitussävelmiä on aineistossa 156 kappaletta Narvusista, 321 Soikkolasta sekä 223 Hevaalta ja Tyröstä. Lisäksi ennen toista maailmansotaa tallennettuun aineistoon kuuluu 26 käsikirjoitussävelmää ja kolme äänitettyä sävelmää Kattilan vatjalaisilta. (Ks. Liite 4.)

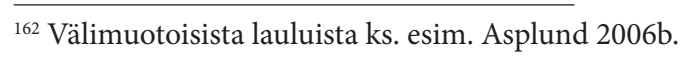


Kuten edellisessä luvussa on todettu, aineisto ei ole tilastollisesti edustava tai yksiselitteinen. Jonkun sävelmätyypin suuri määrä voi johtua siitä, että laulajat pitivät sitä sopivana tallentajille tai tallennustilanteessa laulettavaksi, kerääjät pitivät sitä syystä tai toisesta usein tallennuksen arvoisena tai siitä, että sävelmää käytettiin paljon tai jossain kulttuurisesti keskeisessä tilanteessa. Myös keräelmät painottuvat eri tavoin. Esimerkiksi refrenkejä on esilaulajan ja kuoron esittämässä ääniteaineistossa suhteellisesti runsaammin kuin usein yhdeltä laulajalta kerätyissä käsikirjoitussävelmissä. Ilmeisesti yksin kerääälle esiintynyt jätti ne helpommin laulamatta. Toisaalta ääniteaineistossa on suhteellisesti niukemmin yksinkertaisia, suppea-alaisia, niukasti muuntelevia sävelmätyyppejä kuin käsikirjoitusaineistoissa. Äänittäessä luultavasti katsottiin tähdellisemmäksi tallentaa monimutkaisempia sävelmätyyppejä, sillä yksinkertaisempia sävelmiä oli helpompi nuotintaa ilman apuvälineitä ja niitä oli tallennettu jo paljon käsikirjoituksina. Käsikirjoitusaineistossa taas etenkin monimutkaisempien sävelmätyyppien muistiinpanot vaikuttavat välillä epäluotettavilta ääniteaineiston samankaltaisiin toisintoihin verrattaessa. Kuten edellä on todettu, käsikirjoitussävelmissä on paikoin epätarkkuuksia esimerkiksi sanojen sävelmään sijoittumisen ja säkeen kertausrakenteen suhteen; tiettyjen luonnosmaisten Europaeuksen tai Alavan kirjoittamien ääritapausten kohdalla edes aika-arvojen päätteleminen ei ole mahdollista. Murrelmasäkeiden trokeesäkeistä poikkeava käsittely monien osakertausrakenteiden sekä lisä- ja refrenkitavujen yhteydessä asettaa omat haasteensa: etenkään käsikirjoitustoisinnot, mutta osin myöskään fonogrammitoisinnot eivät aina ole riittävän pitkiä näyttääkseen rakenteen koko variaation erilaisten säetyyppien yhteydessä. 


\section{KALEVALAMitTA}

Runomitan avulla kuvataan runon kieleen sidoksissa olevaa rytmistä pohjarakennetta, joka voi toteutua monin eri tavoin. Pentti Leinon (1986, 22-23) käsitteellistää erikseen runon toteutuneiden tavujen painollisuuden (prominenssi) ja erilaisia toteumia yhdistävät syvärakenteet (ks. myös esim. Jakobson 1960, 364-366). Runomitan tasolla on tarpeen paitsi kuvata rytminen pohjarakenne, myös määrittää ne säännönmukaisuudet, joiden mukaan painoarvoltaan erilaiset tavut säkeissä tai niiden muodostamissa mahdollisissa säkeistöissä tämän pohjarakenteen puitteissa sijoittuvat. Esimerkiksi kalevalamitassa seitsemän- ja yhdeksäntavuinen säe voivat toteuttaa saman rytmisen pohjarakenteen. Myös runon muita piirteitä, kuten riimin tai alkusoinnun käyttö, voi olla tarpeen yhdistää mitan kuvaukseen. Runomitalla kuvataan nimenomaan kielellistä rakennetta: esimerkiksi erilaisten esitystapojen ja esitysten kirjo ei sen piiriin kuulu.

Toisissa kielissä mitallinen runous perustuu ennen kaikkea tavujen painollisuuteen, toisissa niiden pituuteen. Kalevalamitta perustuu näistä kumpaankin. Runomittaa on kuvattu nelipolviseksi trokeeksi, jossa ensimmäistä runojalkaa lukuun ottamatta pitkät pääpainolliset eli sanojen ensimmäiset tavut sijoittuvat runojalan nousuun ja lyhyet pääpainolliset sanojen ensimmäiset tavut runojalan laskuun. Muiden tavujen sijoittuminen on vapaata. Runojalan nousuista ja laskuista voi yksinkertaisemmin puhua Leinon $(1986,130)$ tapaan vain nousu- ja laskuasemina. Tässä käytän vielä lyhyempää termiä säeasema. Tavuja on säkeessä yleensä kahdeksan, kaksi jokaisessa runojalassa eli yksi jokaisessa säeasemassa. Ensimmäisessä runojalassa voi kuitenkin olla kahdesta neljään tavua (esim. Lensipä meren rantuelle). Matti Sadeniemen (1951, 77-79) mukaan vienalaisissa ja pohjois-inkeriläisissä runoissa näitä "keveitä" tavuja voi sijoittua myös toiseen tai joskus kolmanteenkin runojalkaan. Niin kutsutun normaalitrokeen kolmannen ja neljännen runojalan keskellä on kesuura jonka yli sana ei jatku (esim. Pääsköilintu / päivöilintu). Tällöin säkeen sanapaino ja runon rytmin painot, "runokorko", osuvat samoihin kohtiin, sanojen ensimmäisille tavuille. (Kuusi 1985, 197). Murrelmasäkeen keskellä kesuuraa ei sen sijaan ole, ja sanapaino ja runokorko osuvat eri kohtiin (esim. Lenteli kes/soisen päivän). Murrelmasäkeiden ja normaalitrokeen suhde on Matti Sadeniemen (1951) analyysin mukaan Karjalan ja Inkerin "klassisessa kalevalakielessä" noin puolet ja puolet. Pääpainollisten tavujen suhteen poikkeavia, runomitan perusmuotoa rikkovia säkeitä on vienalaisen Arhippa Perttusen runoissa 2,7 \%, inkeriläisessä eeppisessä runoudessa yhden ja kahden prosentin välillä. Erilaiset poikkeamat ovat sitä yleisempiä, mitä lähempänä ne ovat säkeen alkua (Lauerma 2001, 51; Kuusi 1952, 245; Sadeniemi 1951; vrt. Leino 1982, 21-23).

Kalevalamittaisessa runoudessa ei yleensä esiinny määrämittaisia säkeistöjä tai riimin käyttöä. Etenkin säkeensisäinen alkusointu on sitävastoin tyypillinen piirre, ja sisäsointuihinkin on alettu kiinnittää huomiota (ks. Frog \& Stepanova 2011, 201). Loppusointua, säkeenylitystä tai säännöllistä säkeistömuotoa ei esiinny. (Asplund 1981, 21-22; Kuusi 1952; 1963; 1985; Leino 1986; erit. 130.) Pisimmät sanat sijoittuvat yleensä säkeen loppuun, jos runomitta ja sanajärjestys sen suovat (ns. visku- 
rilaki, ks. Kuusi 1985, 189; ks. myös Sadeniemi 1951). Inkerissä tämä tendenssi ei ole yhtä vahva kuin vaikkapa Vienassa (Kuusi 1952, 243-244, 246). Kalevalamittaisen runouden olennaisiin tyylikeinoihin kuuluuvat myös Matti Kuusen (1952, 248-250; 1983a, 196; 1985) tarkemmin hahmottelemat kertauksen lajit. Yleisimpänä esiintyy esisäkeen sisällön synonyyminen, analoginen tai antiteettinen kertaus yhdessä tai useammassa jälkisäkeessä (esim. Etsi maata maataksensa / lehtoa levätäksensä) eli parallelismi. Jälkisäkeessä ei yleensä kuljeteta juonta eteenpäin vaan kerrataan uusin termein tai uudesta näkökulmasta jo sanottua. Myöskään uusia lauseenjäseniä ei esiinny. Säkeensisäinen kertaus on saman asian toistamista eri sanoin saman säkeen sisällä (esim. Pääskylintu, päivälintu). Laajin kertausmuoto on kehyskertaus, jossa samanlaisin rakentein, säkein ja säemallein esitetään monta samankaltaista tai toisilleen vastakkaista episodia. Niin kutsuttu riimikerto (esim. Marjukkainen Karjukkainen) on erityisesti narvusinsuomalaisten parissa käytetty tyylikeino (Kuusi 1983a, 195-196).

Metristen eli runomittaan liittyvien kysymysten kohdalla Petri Lauerma (2001, 5154) painottaa inkeroismurteille tyypillisen yleisgeminaation merkitystä. Lyhyellä pääpainollisella tavulla alkava omena muuttuu pitkällä tavulla alkavaksi, jos se lauletaan tai äännetään ommeena. Yleensä tämänkaltainen sana sijoittuu runosäkeeseen aivan samoin kuin se sijoittuisi lyhyemmässä muodossaan: runokieli kantaa tavallaan mukanaan tajua sanan vanhemmasta muodosta (Kuusi 1983a, 195-196). Tämän tutkimuksen ääniteaineistossa konsonantin kahdentuminen näyttää esiintyvän liukuvana ja vaihtelevan yhdenkin laulun puitteissa. Tämänkaltaisia pidennyksiä en siten laske kalevalamitan tavunpituussääntöjen vastaisiksi.

Eri runoalueilla ja kalevalamittaisen runouden eri lajeissa painottuvat erilaiset tyylipiirteet (ks. esim Kuusi 1963, 136; Sarv 2008; Laitinen 2006, 38). Matti Kuusi $(1952,245)$ kehottikin runomitan yhteydessä puhumaan ennemmin ajallisesti ja paikallisesti vaihtelevista tendensseistä kuin ehdottomista säännöistä. Runokielen ja mitan tendenssit "ennustavat yleisiä säännönmukaisuuksia, mutta eivät yksittäisiä poikkeuksia," on Lauerma $(2001,47)$ lisännyt. Laulajalla oli niin sisällöllisiä kuin tyylillisiäkin vaihtoehtoja, eikä poikkeuksia voi suoralta kädeltä tulkita virheiksi. Kuusi (1983a, 184-187) tulkitsee esimerkiksi inkerinsuomalaiset klassisen kalevalamitan normeja rikkovat säkeet "metrisiksi innovaatioiksi." Teorian puitteissa virheellisiltä näyttävät säkeet voivat Leinon $(1982,315-330$; 1986) mukaan olla myös osoitus teorian puutteellisuuksista.

\section{LAULETTU RUNO}

Kun tarkastellaan klassisesta kalevalamitasta poikkeavia tekstisäkeitä, törmätään usein ongelmiin. Jos säkeestä "puuttuu" tavu, mistä runojalasta se puuttuu ja miksi? Jos ylimääräinen tavu sijoittuu jonnekin muualle kuin ensimmäiseen runojalkaan, miten säe on esitetty? Matti Kuusi (1983a, 187) toteaa, että "kirjoitettujen tekstien pohjalta ei voi varmasti päätellä, miten esimerkiksi 6- tai 7-tavuisiksi supistuneet 233-säkeet [eli yhdestä kaksitavuisesta ja kahdesta kolmitavuisesta sanasta koostu- 
vat säkeet] on sovitettu vanhoihin runosävelmiin." Tulkintavaikeuksia inkeriläisen runouden yhteydessä nähdäkseni lisäävät poikkeavien säkeiden monet syntymahdollisuudet: ne voivat olla paikallisen tai laulajakohtaisen mittakäsityksen mukaan täysin korrekteja tyylipiirteitä, ne voivat liittyä joko tiettyyn laulamisen tapaan tai siihen, että säkeet on saneltu kerääjälle tai sitten kyseessä voi olla laulajan tai kerääjän virhe, käsikirjoituksen kopiointivaiheessa tapahtunut virhe tai joskus jopa pikakirjoitusprosessin tuottama muutos. Saneltu runo saattaa puhekielistyä: joskus pitkät, runokielelle ominaiset sanamuodot lyhentyvät, runomitta väljentyy, sävy muuttuu. Vihtori Alava huomauttaa useassa runomuistiinpanossaan tietyn sanamuodon olevan nimenomaan laulukieleen liittyvä ilmiö. ${ }^{163}$ Toisaalta moni laulaja myös saneli runonsa mitaltaan laulettua vastaavana. Useat kerääjät pyysivät ilmeisesti informanttejaan lausumaan laulamisen sijasta, mutta yleensä teksteistä ei tiedetä, millä tavoin esitetystä runosta ne on tallennettu. (Ks. esim. Harvilahti 1992a, 181-182, Lauerma 2002, 13-32; Reichl 2000, 10; Saarinen 1988, 197-200; Salminen 1934, 200; Väisänen 1990, 100.)

Matti Kuusi (1949; 1983a) ja Matti Sadeniemi (1951) ovat runomittatutkimuksissaan ensin tavalla tai toisella normalisoineet ja täydentäneet tavuluvultaan vajaat säkeet, jolloin tutkijan ennakkokäsitys runomitasta (joka tietenkin parhaimmillaan on laajan aineiston tuntemuksen tuottama ja perusteltu) muokkaa tutkimusmateriaalia jo ennen analyysia. Jos otetaan huomioon tallennusprosessien vaikutukset runokäsikirjoitusten kielelliseen asuun ja runomittaan, oli tietty pelkistäminen varmasti mitan tutkimisen kannalta välttämätöntä. Kirjalliset muistiinpanot eivät kuitenkaan kerro sitä, kuinka laulajat ovat säkeet tulkinneet: usein poikkeavat säkeet olisi mahdollista laulaa tai laulaessa täydentää useammallakin tavalla (Ks. Kuusi 1983a, 184-187; Lauerma 2001, erit. 45 ja 55; ks. myös Bauman 1977, 20; Laitinen 2003a, 208-209; Oras 2001; Särg 2001). Petri Lauerma (2001, 55) toteaakin mitan tutkimuksen äänitteiden pohjalta olevan välttämätöntä käsikirjoitusten avoimiksi jättämien kysymysten selvittämiseksi.

Samankaltaisia huomioita runosäkeiden luonteesta on tehty myös muiden runokulttuurien piirissä. John Miles Foley (2002, 33; vrt. esim. Jakobson 1960, 364) kertoo eteläslaavilaisen epiikan "liian" lyhyistä ja pitkistä säkeistä:

Heidän oman käsityksensä mukaan nämä säkeet ja muut niiden kaltaiset eivät olleet liian pitkiä eivätkä liian lyhyitä. "Ylimääräiset" tavut laulettiin itse asiassa ennen vokaali- ja instrumentaalimelodioiden tavallista aloituskohtaa, kymmentavuisen perussäkeen ulkopuolella, kun säe määritellään musiikillisesti ja rytmisesti eikä ainoastaan tavujen ja tekstin perusteella. Samalla tavoin "puuttuvat" tavut osuivat tosiasiassa yhteen laulun taukojen kanssa, ja nuo tauot olivat täysiarvoisia kymmentavuisen perussäkeen osia.

Myös laulajien tapa jaotella diftongeja tai triftongeja tavuiksi saattaa vaihdella laulun rytmin tarpeiden mukaan. Poikkeavien säkeiden määritteleminen virheellisiksi, mihin Foley kertoo aluksi itsekin aiempien tutkijoiden tavoin syyllistyneensä,

${ }^{163}$ SKVR III 2036, 2105, 2133, 2188, 2551. 
perustuu hänen mukaansa liian kirjallislähtöiseen lähestymistapaan. Timo Leisiö (2000) huomauttaakin olevan tarpeellista käsitellä laulun runomitan analyysissa myös taukoja ja tyhjiksi jääviä säeasemia. Tosin kirjallispohjainenkin mittateoria voi toki huomioida esimerkiksi systemaattisesti esiintyvät tauot ja tiettyjen sanojen erilaiset tavuiksi jakamisen mahdollisuudet (Leino 1982, 120-127, 309; ks. myös Lauerma 2001).

Myös altailaisessa epiikassa säkeen pituuden vaihtelu on Harvilahden (2003, 78-81) mukaan suhteessa musiikilliseen muotoon, jolloin "laulajat selvästi noudattavat perinteisiä sääntöjä," eivät länsimaisen tai kirjallisen runon teoriaa. Lauletussa muodossa säkeen pituus vaihtelee seitsemästä tavusta kahteentoista, ja lisätavujen käyttö on mahdollista, kun laulaja haluaa luoda "erityisiä rytmisiä tehosteita tai melodisia fraaseja" (Harvilahti 2003, 78). Mitan käyttö vaihtelee laulajittain, ja Harvilahti $(2003,80-81)$ toteaa esittäjän voivan käyttää poikkeavaa mittaa myös "antamaan erityistä painotusta kerronnalle."

Nenetsien laulusta paljastuu Jarkko Niemen (1998, ks. erit. 24-45) analyysissa selkeitä metrisiä, paitsi kielen, myös musiikin piirteisiin sidoksissa olevia rakenteita. Näiden havaitseminen kuitenkin edellyttää lauletun aineiston tarkastelua ilman länsimaisen taidemusiikin ja runomittateorioiden lähtökohtia. Niemi (mts. 29) toteaa oman analyysimetodinsa olevan vain osin sovellettavissa muihin musiikkikulttuureihin, sillä jopa lähialueiden laulukulttuurit rakentuvat eri tavoin ja edellyttävät siten osin erilaisia tarkastelutapoja. Jacqueline Pattison Ekgren (2009) on huomauttanut norjalaisen stev-laulun ja Marko Jouste (2008) venäläisen bylinan rakenteen näyttäytyvän kirjallisen runomittateorian puitteissa helposti käsittämättömänä: vasta kielellisen rakenteen suhteuttaminen laulun rytmiin paljastaa runomitan säännönmukaisuuden. Vastaavasti Heikki Laitinen (2003, 205-300) toteaa yritysten määrittää rekilaulujen metrisiä rakenteita päätyvän virhetulkintoihin, jos laulun rytmiä ei oteta huomioon. (Ks. myös Leisiö 2000; Leisiö \& Niemi 2004; Niemi 2009; Niemi \& Jouste 2002; Niemi \& Lapsui 2004; Reichl 2000, erit. 10.)

Niemi $(1998,28)$ analysoi melodian ja tekstin rakenteita kahtena erillisenä, mutta toisistaan riippuvana ja vuorovaikutuksessa olevana tekijänä: "Kun puhe muutetaan laulettuun muotoonsa, ilmaantuu itse asiassa kaksi osin autonomista ja osin toisistaan riippuvaista systeemiä: tekstin runomitta ja sen toteutuminen melodian rytmissä." Samaa sidoksisuutta on korostanut Urve Lippus (1995, 39-42) runolaulun kohdalla. Pentti Leinon (1986, 22-23) tapaan Niemi (mts. 28) hahmottaa säkeiden rakenteessa kaksi eri analyyttistä tasoa eli rakenteellisen runomitan ja sen toteutuman tasot, mutta Niemellä toteuman tason hahmotus pitää sisällään toteutuneen kielellisen rakenteen ohella myös esitykseen ja musiikkiin liittyviä piirteitä ja vaikuttaa siten myös runomitan abstrahointiin. Kyseessä on siis kaksi analyyttisen jaottelun akselia: toisaalta toteuma ja erilaisten toteumien pohjalta abstrahoitavissa oleva syvärakenne, toisaalta musiikin ja kielen laulussa yhdistyvät, osin erilliset ja osiin toisiinsa vaikuttavat rakenteet. Laulun toteuttamisen taustalla olevaa säännöstöä on laajemmalla tasolla tarkasteltu esimerkiksi lauluoppina ja säännöstön toteutumista puolestaan laulutyylinä (Leisiö \& Niemi 2004; Niemi 2004). 
Tämä taas rinnastuu kielitieteen langue-parole -jaottelun (Saussure 1922) piiristä liikkeelle lähteneisiin, folkloristiikan piirissä edelleen kehitettyihin kompetenssin ja performanssin jaotteluihin (ks. Briggs 1988, 7-8).

Heikki Laitinen (2003a, 206-207) jaottelee laulun rakenteen Niemen ja Lippuksen tavoin kahteen päätasoon, musiikkiin ja runoon, jotka hänen mallissaan pitävät kummatkin sisällään melodiikan, rytmiikan ja metriikan tasot. ${ }^{164}$ Sekä musiikin että runon metriikka ovat tutkijan analyysin keinoin ja aineiston ehdoilla esiin nostamia laulun pohjarakenteita - musiikin metriikan sijasta puhun tässä työssä rytmirakenteista. Laulun pintatasolla metriset rakenteet voivat olla joko selvinä näkyvissä tai vaikeammin tulkittavissa: "Metriikan kuvausvälineitä ei siis ole valmiina lauluesityksessä. Niiden valinta on siitä huolimatta tehtävä jatkuvassa dialogissa aineiston kanssa.” Laitinen kertoo päätyneensä käytännön työn kautta siihen, että runon metriikka toimii hyvin kivijalkana myös laulun muiden tasojen analyysille ja niiden vuorovaikutuksen hahmottamiselle. Kuten hän (mts., 19, 205) toteaa, pelkän tekstin pohjalta ei runon metrisiä sääntöjä kuitenkaan aina saa määriteltyä: tarvitaan vähintäänkin tietoisuus laulukulttuurin tyypillisistä musiikillisista rakenteista ja niiden variaation mahdollisuuksista. Laulun yhteydessä Laitinen (mts., 209, 221-233) yhdistää musiikin ja runon metriset kategoriat ja puhuukin runomitan sijaan laulumitasta, runojalan sijaan laulujalasta. Laulujalka viittaa sellaiseen musiikilliseen iskualaan, joka sisältää yhden runojalan (mts., 220-223). ${ }^{165}$ Erityisesti suomenkielisen kansanlaulun yhteydessä laulujalan kategoria on toimiva, sillä siinä "runojalka ja iskuala ovat poikkeuksetta yhteneväisiä, yhtä pitkiä ajan elementtejä." Tämän tutkimuksen aineiston kohdalla ei laulujalan käsite kaikkien sävelmätyyppien yhteydessä toimi, mikä tekee entistä tarpeellisemmaksi runomitan ja sävelmän rakenteiden välisten suhteiden pohtimisen.

Laulun metriikan ja rytmiikan (eli rytmisen syvärakenteen ja pintarakenteen) Laitinenkin (2003a, 223) erottelee toisistaan:

Useimmiten metriikkaan määritellään kuuluvaksi se, kuinka monta tavua tai säveltä esityksen laulujalassa voi olla kussakin kohtaa säettä, säeparia ja säkeistöä. Rytmiikan tasoon kuuluu taas se, kuinka monta tavua tai säveltä kussakin kohdassa itse asiassa on, miten nämä tavut ja sävelet jakavat jalan laulussa saaman ajan ja minkälainen rytminen hahmo säkeelle, säeparille ja säkeistölle näin syntyy.

Omassa metriikan analyysissaan hän kuitenkin ottaa huomioon "myös rytmiikan piiriin kuuluvia seikkoja." Laulun teksti on siis tulkinnan lähtökohta, mutta samalla otetaan huomioon myös laulukulttuurin tavat suhteuttaa toisiinsa runon ja sävelmän rytmi. Joissain tapauksissa nämä eivät ole yksiselitteisiä: joskus runosäe on

\footnotetext{
${ }^{164}$ Näistä runon melodiikka on sangen abstrakti ja jää tässäkin jatkokehittelyä vaille - kenties sen voisi hahmottaa "laulajan runonsa sanoille" antamien merkityksien ohella tai sijasta myös runon äänteiden välisinä suhteina: erilaisina vokaalien ja konsonanttien alku-, sisä- ja loppusointuisuuksina?

${ }^{165}$ Iskuala on musiikin rytmin perusyksikkö. Laitinen (2003a, 222-223) kokeilee laulujalan synonyyminä termiä tahti, vaikka toteaakin sen olevan ongelmallista, termi kun on musiikinteorian puolella vakiintunut, ja saattaa siinä yhteydessä sisältää useamman Laitisen laulujalaksi hahmottaman yksikön. Vaikka termi on houkutteleva, en käytä sitä tässä.
} 
mahdollista suhteuttaa laulun rytmiin useammalla perustavanlaatuisesti erilaisella tavalla - tämänkaltainen on joskus tilanne Inkerin moninaisten sävelmärakenteiden yhteydessä. Useimmiten "musiikin ja runon metriikat" ovat "säestyksettömässä (soolo)laulussa" kuitenkin yhteneväiset (Laitinen 2003a, 217).

Runomitta on laulusta abstrahoitava kielellinen syvärakenne. Inkerissä pelkkä runomitta ei kuitenkaan laulutekstin analyysiin riitä, sillä säkeiden ilmiasuun vaikuttavat myös erilaiset lisätavuihin, osakertauksiin, refrenkeihin sekä tavumuutoksiin ja pois jääviin tavuihin liittyvät rakenteet, joiden käyttö puolestaan on osin sidoksissa paitsi runomitan piirteisiin, myös tietynlaisiin sävelmiin. Tämän tutkimuksen kannalta nämä laululliset ja musiikilliset, runomitan kanssa vuorovaikutuksessa toteutuvat piirteet osoittautuivat olennaisemmiksi kuin itse runomitan variaatio, sillä ne määrittävät enemmän laulun rekistereitä, esitysareenoita ja paikallisia lajeja kuin esimerkiksi painollisten ja painottomien tavujen, parallelismin tai alkusointuisuuden laulukohtainen käyttö. Laulullisten ja musiikillisten piirteiden analyysi kuitenkin pohjaa kalevalamitan peruspiirteille.

\section{RUNON SÄVELMÄ}

Kalevalamittaisen laulun ominaisimpina pidettyjä piirteitä ovat vähäsävelisyys, säkeistömuodon puuttuminen, lyhyen musiikillisen teeman enemmän tai vähemmän muunteleva kertaaminen sekä monilla seuduin yksiäänisyys tai muunteluun pohjautuva heterofonia. Laulu oli etenkin muistiinpanojen perusteella usein syllabista eli yhtä säkeen tavua vastasi yleensä yksi sävel, mutta toisaalta etenkin ääniteaineistossa on monin paikoin kuultavissa vaihtelevaa melismojen eli korusävelten käyttöä. Sävelmät ovat lähinnä yksi- tai kaksisäkeisiä. Urve Lippus (1995) katsoo väitöskirjassaan runolaulun olennaiseksi piirteeksi myös harmoniapohjaisen ajattelun puuttumisen: sävelmän merkitsevät ulottuvuudet ovat melodinen ja rytminen. Laulussa käytetyt sävelasteikot eivät aina noudattaneet länsimaisen taidemusiikin malleja. Joskus esimerkiksi asteikon kolmannen sävelen korkeus saattoi vaihdella yhdenkin esityksen kuluessa. Suomessa ja Karjalassa yleisintä viisi-iskuista ja Virossa tyypillisintä neli-iskuista sävelmätyyppiä on Launiksesta (1910b) lähtien pidetty niiden levinneisyyden, yleisyyden sekä yksinkertaisen, runomittaa mukailevan rakenteensa perusteella vanhimpina. Selkeästi uudempia piirteitä ovat melodioiden sävelalan laajentuminen, liukuminen kohti laajempaa säkeistömuotoa sekä, niin kerääjien kuin informanttienkin mukaan, refrenkien eli kertaumien lisääminen: nämä piirteet ovat yhteneväisiä erilaisten suomalaisten ja venäläisten uudempien kansanlaulujen kanssa, joiden sävelmiä ja rakenteita sovellettiin erityisesti Inkerissä paikoin myös suoraan kalevalamittaisiin teksteihin. Inkeriläisellä runolaululla on niin sanojen kuin sävelmienkin puolesta temaattiset suhteensa ja lomittumiskohtansa myös itkuvirsiin. Juuri sävelmien samankaltaisuuden vuoksi Launis (1910a, II) otti Inkerin runosävelmät -teokseen mukaan myös joitakin itkuvirsiä ja rekilaulumittaisia sävelmiä. (Ks. esim. Asplund 1981, 23-29; Asplund \& Laitinen 1979, 12; Harvilahti 1998, 201-204; Laitinen 2006; Launis 1910b; Nenola 2002, 27-28; Niemi 2002, 696-697; Väisänen 1990, 47, 95-120.) 
Ingrid Rüütel on tehnyt tämän työn aineiston kannalta mielenkiintoisia etenkin virolaisten runosävelmien typologisia jaotteluita. Melodian klusterianalyysin jälkeen tuloksia on vertailtu melodioiden rytmityyppeihin, laulun lajeihin, maantieteellisiin esiintymisalueihin sekä lähiseutujen muiden etnisten ryhmien historiallisiin sävelmätyyppeihin. Tältä pohjalta erottuvat selkeästi 1) suppea-alaiset (3-4 säveltä), yksisäkeiset, rytmityypeiltään vaihtelevat sävelmät, joita esiintyy erityisesti Pohjois- ja Länsi-Virossa, 2) yksisäkeiset, yhden tai kahden tavun pituisella refrengillä laajennetut runosävelmät, jotka ovat tyypillisiä Etelä-Virolle ja samankaltaisia pohjoislatvialaisten rituaalisten laulujen kanssa, 3) yksi- ja paikoin kaksisäkeiset sävelmät, joissa sävelmän melodinen ja rytminen luonne on ristiriidassa runosäkeen perusrakenteen kanssa (jolloin sävelmissä esiintyy vaihtelevasti esimerkiksi tavujen venytyksiä, lisätavuja, osakertauksia). Rüütel olettaa näille erityisesti Võruja Setumaalle (sekä Inkerille) ominaisten sävelmätyyppien syntyneen itämerensuomalaisten ja itäbalttilaisten kulttuurikontakteissa. 4) Hieman laaja-alaisemmat (5-6 säveltä) kaksisäkeiset refrengittömät sävelmät, kuten suuri osa viisi-iskuisista "kalevalasävelmistä" sekä 5) moninaiset uudemmat riimillisestä, säkeistöllisestä laulusta sovelletut sävelmät. (Rüütel 1998.)

Kalevalamittaisessa laulussa runomitan ja melodian rytmin perusrakenteet vastaavat yleensä toisiaan: runojalka tahtijalkaa. Tämä selittyy laulun, kielen ja runomitan kiinteällä yhteydellä: kalevalamitta on kehittynyt lauluna. (Esim. Laitinen 2003a, 170, 209, 221; Leino 1994; Niemi 1922, 2, 37; Väisänen 1990, 95, 102; vrt. kuitenkin Leisiö \& Niemi 2004, 17.) Ilkka Kolehmaisen (1990, 214) mukaan melodisen fraasin kiinteys usein lisääntyy, kuten runomitankin (esim. Saarinen 1988, 198), säkeen loppua kohden. Niin kutsuttujen kalevalasävelmien melodioiden ja runomitan välillä on Kolehmaisen $(1977,202-203)$ mukaan havaittavissa muitakin yhteyksiä: sävelet ovat keskimäärin korkeampia runojalkojen nousuissa ja monissa rytmityypeissä myös pidempiä, mutta vastakkaisiakin tapauksia esiintyy. Virolaisten runojen yhteydessä on sitä vastoin huomattu sävelmän muunnelmien paikoitellen noudattelevan normaalitrokeen ja murrelmasäkeen rakenteita esimerkiksi niin, että sanan ensimmäinen tavu lauletaan kummassakin säetyypissä usein muita korkeampana tai muilla tavoin painollisempana. Piirteen esiintyminen näyttää vaihtelevan laulajittain ja sävelmätyypeittäin. (Ross \& Lehiste 2001; Lippus 1995, 66-67; Oras 2001; 2004b; Särg 2004; 2009.)

Osaan inkeriläisistä melodioista ajatus yksinkertaisesta mitan ja melodian vastaavuudesta ei sovi: inkeriläisen laulun monimuotoisimpia, mitä ilmeisimmin ainakin osin venäläistä tai muuten uudempaa alkuperää olevia piirteitä onkin usein jätetty syrjään tai vähäisemmälle huomiolle muuten koko runosävelmistön kattavissa tutkimuksissa. Launis (1910b) tarkasteli väitöskirjassaan laveimmin juuri neli- ja viisi-iskuisia melodiatyyppejä, mutta käsitteli lyhyemmälti muitakin verraten niitä naapurikansojen sävelmiin. Kolehmainen (1977, erit. 32) jätti analyysissaan kalevalasävelmästä ulkopuolelle ne Inkerin sävelmät, joissa esilaulajan osuus noudatti viisi-iskuista peruskaavaa, mutta kuoron poikkesi siitä, ja totesi esimerkiksi 3/4-tahtilajisten melodioiden erottamisen inkeriläisen monenkirjavan sävelmistön joukosta olevan ongelmallista. Urve Lippus (1995, erit. 51) rajasi työnsä ulkopuo- 
lelle Inkerin osalta pitkät refrengit sekä hitaita, pitkiä melismaattisia sävelkulkuja sisältävät, venäläisvaikutteiset melodiat. Paikallisen laulukulttuurin kokonaisuuden analyysin kannalta tällaisten piirteiden huomioiminen on kuitenkin tärkeää.

Kalevalamittaisen runon piirissä mikä hyvänsä runo on teknisesti sovitettavissa mihin hyvänsä sävelmään. Kuitenkin sävelmien käytön suhteen on havaittu joitain selkeitä aluekohtaisia lajeihin liittyviä painotuksia. Painotukset liittyvät ennemminkin sävelmätyyppeihin tai vielä yleisemmin niiden muotorakenteisiin kuin yksityiskohtaisiin sävelkulkuihin. Vienan Karjalassa ja Suomen Pohjois-Karjalassa yleisin sävelmätyyppi oli niin kutsuttu kalevalasävelmä, joka näyttää toimineen eräänlaisena yleissävelmänä. Häälauluille sen sijaan oli oma sävelmätyyppinsä, jota saatettiin käyttää myös joidenkin muiden runojen laulamiseen. (Heinonen 2009; Huttu-Hiltunen 2008; Käppi 2007; Laitinen 2004; 2006.) Setukaisilla tietyt sävelmät liittyivät selkeästi tiettyihin tilanteisiin, kun taas toiset olivat monikäyttöisempiä. A. O. Väisänen $(1990,88)$ kertoo:

Härunoilla on 'kaasittamisensa', eri leikeillä ja eri talkoolauluilla kullakin omat sävelmänsä (hääl), hää- ja kuolinitkuilla eri ’virtensä’ eikä samat kuten Karjalassa. Sävelmissä on vielä paikallisia sekä laulajista johtuvia eroavaisuuksia. Vihdoin on olemassa 'yleinen sävelmä, viisi-iskuinen tyyppi, joka liittyy esim. kertoviin sekä tilapäisrunoihin.

Virossa on todettu etenkin kalendaari- ja häälauluja esitetyn usein tietyntyyppisillä, usein yksisäkeisillä sävelmillä: sitävastoin kaksisäkeiset sävelmät liittyvät lähinnä erilaisiin lyyrisiin ja lyyris-eeppisiin runoihin. Tilannekohtaisia eroja tehtiin paikoin lyhyillä, säkeen loppuun liitettävillä refrengeillä. (Ks. Oras 2001; Rüütel 1998; 2006.) Herbert Tampere $(1956,12)$ kutsuikin sävelmiä ryhmäsävelmiksi: yhtä sävelmätyyppiä käytetään tyypillisesti tietynlaisten laulujen ryhmän yhteydessä.

Etnomusikologiassa on korostettu kunkin musiikkikulttuurin piirissä merkityksellisten kategorioiden ja piirteiden löytämisen tärkeyttä (ks. esim. Harri 2003, 19-21; Nettl 1983; Niemi \& Jouste 2002; etnomusikologian erilaisista suuntauksista ks. esim. Moisala \& Seye 2013; Padilla 1997). Esimerkiksi Jarkko Niemellä (Niemi \& Lapsui 2004, 40) yhden nenetsilaulajan henkilölaulujen repertuaarin ja laulun rakenteiden analyysin ytimen muodostaa aineistosensitiivinen tukisävelten ja sävelkategorioiden (pitch bands) analyysi, jonka pohjana on näiden molempien esiintymistaajuus, sijainti sekä suhde melodisiin ja metrisiin prosesseihin. Nenetsien laulutyylissä "metri, rytmi ja syntaksi ovat tärkeimpiä melodian organisoijia [...] modaaliset ja sävelrakenteet sekundaarisia." Tämän tutkimuksen teemoihin asetelma kytkeytyy erityisesti tekstin ja melodian vuorovaikutteisten aksentuaatioiden sekä laulujen rakenteen, käyttöyhteyksien ja merkitysten huomioimisen osalta.

Vaikka tässä työssä ei ole mahdollista paneutua esitysten mikrotasoihin, on niiden olemassaolosta syytä olla tietoinen. Esimerkiksi Jaan Ross ja Ilse Lehiste (2001) ovat tutkineet kielen piirteiden, runomitan ja musiikin vuorovaikutusta virolaisen runolaulun äänitteiden pohjalta ja todenneet, että tavujen ominaisuudet vaikuttavat myös laulun rytmin ja intonaation piirteisiin. Pekka Huttu-Hiltunen (2008, 
152-153, 192-199) on osoittanut, että niilläkin äänitteille tallennetuilla vienalaislaulajilla, joiden tutkija helposti korvakuulolta tulkitsee noudattelevan länsimaisia sävelasteikkoja, tietyt säveltasot vaihtelevat melko vapaasti ja joidenkin sävelten asema voi näyttäytyä melko tulkinnanvaraisena (ks. myös Haapoja 2013, 58-75). Tarkka hyvälaatuisesta äänitteestä koneellisesti piirretty kuvaaja kertoo esityksen hienovaraisemmista piirteistä luonnollisesti paljon enemmän kuin konventionaalinen nuottikuva. ${ }^{166}$ Tällainen analyysi auttaa hahmottamaan laulun hienovaraisempaa variaatiota ja näyttämään graafisesti tiettyjä nuottikuvassa vaikeasti ilmaistavia piirteitä. Toisaalta, kuten Jarkko Niemi (Niemi \& Lapsui 2004, 40; ks. myös Lippus $1995,82)$ on tiivistänyt, koneellinen analyysi on vain apuneuvo. Tarkka koneanalyysi ei auta, jos ei kyetä tunnistamaan laulukulttuurin kannalta merkityksellisiä kategorioita:

Ideaalitapauksessa merkitykselliset (additiiviset) rakenteelliset elementit tunnistetaan kompetentin perinteenkantajan ohjauksessa, [omakohtaisen] oppimisprosessin myötä tai musiikkia koskevan kulttuurin sisäisen puheen täydentävän analyysin kautta. Jos tämä ei ole ei mahdollista, tutkijan täytyy päätellä rakenteellisten elementtien ominaisuudet laajemman aineistokorpuksen analyysin avulla.

Keskeinen kysymys tässä tutkimuksessa ovatkin juuri laulukulttuurin kannalta keskeiset kategoriat. Kun perinteenkantajan ohjaukseen ei ole mahdollista päästä, jää ainoaksi keinoksi tallennetun sävelmä- ja kuvausaineiston monitahoinen tarkastelu. Keskeisellä sijalla tässä on erilaisten rakenteellisten piirteiden korrelaatioiden tarkastelu: mitkä piirteet esiintyvät yhdessä ja miten ne suhteutuvat runojen sisältöihin ja lauluista annettuihin kontekstitietoihin?

Kysymykset laulukulttuurin keskeisistä kategorioista ja koneellisista kuvaajista lomittuvat etnomusikologian piirissä paljon keskusteltuihin kysymyksiin musiikin transkriptiosta sekä länsimaalaisen nuottikirjoituksen rajoitteista ja vääristävistä piirteistä (ks. esim. Herndon 1974; Laitinen 2003a, 327-331; Nettl 1983, 65-79; Seeger 1977). Usein on kuitenkin todettu nuotin lopulta olevan helppokäyttöinen ja tutkijayhteisön laajalti jakama kuvausmenetelmä. Esimerkiksi Pirkko Moisala (1991b, 51-57) päätyy Niemen (Niemi \& Lapsui 2004) tavoin käyttämään erikoismerkein lisättyä perinteistä länsimaista nuotinnostyyliä, vaikka toteaa, että vaikkapa nuottiviivastolle piirretyt käyrät antaisivat musiikin luonteesta paremman kuvan. Tämän työn yhteydessä käyttökelpoisimmalta vaikuttaa näkemys, jonka mukaan transkription tärkein tehtävä on kuvata kulloisenkin tutkimuksen kannalta relevantteja musiikin piirteitä: nuotin avulla ei tutkimuksellisessa yhteydessä ole tarvetta pyrkiä esimerkiksi kuvaamaan täydellisesti tai tuottamaan uudelleen alkuperäisen kaltaista esitystä ja kuvaukseen voi toisaalta tarvittaessa käyttää myös erikoismerkkejä, sanallisia keinoja, äänitettä tai koneellisia kuvaajia. Transkription ulkopuolelle jää aina paljon, riippumatta käytettyjen erikoismerkkien määrästä. Mitä tarkempi nuotinnos tai mikä hyvänsä tekstualisaatio on, sitä hitaampi sitä on

${ }^{166}$ Erilaisten kuvaajien ja analyysiohjelmien käytöstä ks. esim. Järvinen 1999, 49-55; Harvilahti 2003, 116-135; Eerola 2009. 
lukea. Mitä enemmän tutkija kehittää juuri omaan aineistoonsa soveltuvia uusia kuvausmenetelmiä, sitä enemmän lukija joutuu paneutumaan uuteen koodikieleen. (Ks. esim. Huttu-Hiltunen 2008, 146-147; Lippus 1995, 31-35; ks. myös Honko 1998, 48; Fine 1884, 95; Tedlock 1983.) Nuotinnos on mahdollista hahmottaa myös tutkijan tekemäksi rakenneanalyysiksi tai tulkinnaksi äänitteestä tai alkuperäisestä esityksestä, jonka voi puolestaan katsoa olevan tutkimuksen varsinainen kohde. Urve Lippus $(1995,31)$ hahmottaa myös varhaisempien tutkijoiden ja kerääjien runosävelmistä tekemät käsikirjoitusnuotinnokset eräänlaisina rakenneanalyyseina: jos tutkimuksen analyysitaso on riittävän yleinen, käyvät nekin tiettyjen lähdekriittisten huomioiden ja varausten jälkeen tutkimuksen aineistoksi.

Tässä työssä musiikkianalyyttiset haasteet asettuvat karkealle tasolle: en jää pitkälti pohtimaan esimerkiksi melodiankuljetuksen piirteitä tai asteikkorakenteita, sillä koeanalyysien perusteella nämä eivät ole ainakaan suoraan liitettävissä tämän työn keskeiskysymyksiin esitysareenojen, rekisterien ja paikallisten lajien yhteyksistä. Äänen laatujen hienovaraisempaan tarkasteluun puutun ainoastaan satunnaisesti. Käsittelen äänitettä tutkimuksen varsinaisena kohteena, transkriptiota analyysin välineenä. Käsikirjoitusmuistiinpanot hahmotan kerääjien omien lähtökohtiensa ja kompetenssinsa pohjalta tekeminä rakenneanalyyseina kuulemistaan musiikkiesityksistä. Vaikka aikaisempi runosävelmiin kohdistunut tutkimus tarjoaa lähtöoletuksia inkeriläisen laulun merkityksellisistä ja olennaisista piirteistä, ovat nämä myös osa tutkimuskysymystä. Tässä työssä keino niiden etsimiseen löytyy ennen kaikkea piirteiden tyypillisistä käyttöyhteyksistä. 


\section{TEKSTUAALISIA PIIRTEITÄ}

Inkeriläisen runolauluaineiston monimutkaisimpienkin muotojen takana on perusmuotoinen kalevalamittainen säe. Monet pintarakenteet ja äkkisilmäyksellä runomitan rikoilta vaikuttavat piirteet selittyvät erilaisten laulamiseen liittyvien muotorakenteiden, kuten lisätavujen, osakertausten, refrenkien ja tavumuutosten tai pois jäävien tavujen kautta. Jos nämä yleensä suhteellisen säännönmukaiset tekijät otetaan huomioon, on mutkikkaimpienkin rakenteiden pohjalla yleensä kuultavissa tai luettavissa selkeitä kalevalamittaisia säkeitä:

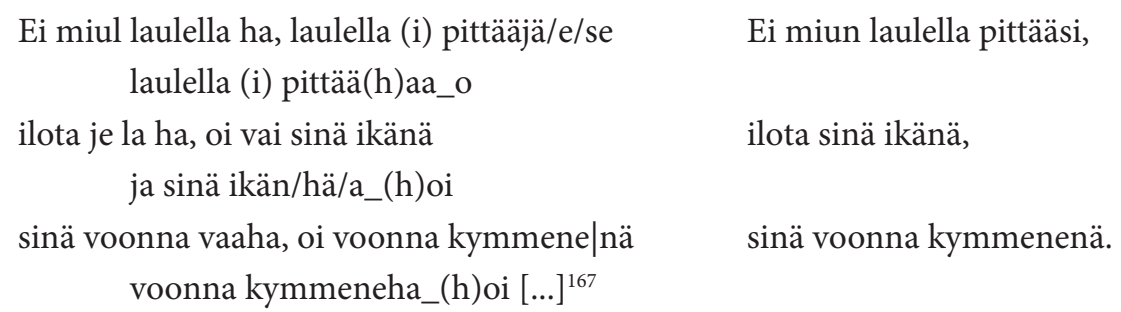

Tulkitsen vain vasemmanpuoleisessa sarakkeessa näkyvät tekstuaaliset piirteet ensisijaisesti laulun rakenteeseen ja tyylipiirteisiin, en varsinaiseen runomittaan liittyviksi piirteiksi. Yllä oleva esimerkki edustaa aineiston tässä mielessä monimutkaisimpia rakenteita. Onkin syytä muistaa, että suurin osa aineiston lauluista etenee selkeästi hahmottuva runosäe tai säepari kerrallaan:

Oi ei miul laulella pittäizi,

eig ilooDa ensinkää,

ei miul laulella pitäisi,

eig ilooDa ensinkää $[\ldots]^{168}$

Saman runon saattoi yleensä laulaa monella eri tavalla. Esimerkiksi Katoi Vydrentytär lauloi Launikselle edellisen version kuoron kanssa säkeitä säännöllisinä kahden säkeen jaksona laulaen, ja vähän myöhemmin saman runon toisella melodialla yksin, säkeitä epäsäännöllisesti kerraten, lisätavuja käyttäen ja jättäen säkeen viimeiset tavut usein laulamatta.

Ei miun laulella pitäi,

eik iloiDa vaa, eik iloiDa ensinGää,

oi ev voi suutani vaa pittääHä,

ev voi suutani pittää. [...] $]^{169}$
Ei miun laulella pitäi[si],

eik iloiDa ensinGä[nä]:

en voi suutani pittääHä,

en voi suutani pittää[hä].

${ }^{167}$ SKSÄ A 300/24a, Liisa Petrontytär ja kuoro.

${ }^{168}$ SKSÄ A 300/51 b. Katoi Vydrentytär ja kuoro.

${ }^{169}$ SKSÄ A 301/4 b. Katoi Vydrentytär. 


\section{LISÄTAVUT}

Lisätavulla tarkoitan varsinaisen runosäkeen ulkopuolista, laulettaessa mukaan lisättävää tavua. ${ }^{170}$ Länsi-Inkerissä lisätavuja on ääniteaineiston perusteella käytetty usein ja monella tavalla: joko kautta laulun, satunnaisesti tai ainoastaan laulun alussa. Kautta laulun esiintyvien lisätavujen tulkitsen tietyissä tapauksissa tavumuutoksien kanssa esiintyessään liittyvän laulun juhlavaan julkisen joukkolaulun rekisteriin, tietyissä tapauksissa taas nopean tanssilaulun rekisteriin, mutta yleisesti ottaen lisätavujen käyttö näyttäytyy yleisenä, useisiin rekistereihin väljästi ja satunnaisesti liittyvänä tyylipiirteenä.

Käsikirjoitusmuistiinpanoissa lisätavuja esiintyy suhteellisen harvoin. Muista kulttuureista saatujen kokemusten mukaan sekä tutkijat että laulukulttuurien jäsenet jättävät ne helposti laulua muistiin pannessaan huomiotta (esim. Foley 2004, 149151; Niemi 1998, 33, 38-39). Kuten refrengit ja osakertaukset, ne liittyvät yleensä nimenomaan laulettuun muotoon ja jäävät näin usein pois myös runoa sanellen tai puhuen esitettäessä. Sanelija tai kirjoittaja (myös tutkittavan yhteisön edustaja) ikään kuin pelkistää ne runon syvärakenteeseen kuulumattomina pois ellei kyse ole varsinaisesta, kohosteisesta esityksestä tai jos tallennuksen huomio ei ole nimenomaan esitystavassa. Aineiston sävelmien käsikirjoitusmuistiinpanot sisältävät niitä suhteellisesti vähemmän kuin ääniteaineisto: kahden säkeen pituisessa, sävelmän tyypillisimpiä piirteitä hakevassa runkonuotissa etenkin satunnaisina esiintyvät lisätavut olisivatkin harhaanjohtavia.

Hyvin karkeasti aineistossa esiintyvät lisätavut voi jaotella 1) säkeen alkuun tai säkeiden väliin ja toisaalta 2) säkeen sisälle sijoittuviin tavuihin. Ne voivat esiintyä laulussa joko epäsäännöllisesti tai säännöllisinä, painollisina tai painottomina. Tämän lisäksi lisätavuja esiintyy 3) osakertausten yhteydessä. Siinä missä refrenkitavut liittyvät usein kiinteästi tiettyihin sävelmätyyppeihin, lisätavut kuuluvat vaihdellen hyvin moninaisiin sävelmiin. On huomattavaa, että lisätavuina yleisimmät tavut voivat myös joskus kuulua varsinaisiin runosäkeisiin; joskus peräkkäin voi sijoittua samanlainen $o i$ - ja $v a a$-tavu kaksi kertaa, jolloin on runon säkeiden tekstuaalista ja musiikillista rakennetta tarkastelemalla pääteltävä, missä asemassa tavut ovat. Esimerkiksi säkeessä Oi oi miun ehtoisa emoin ensimmäinen oi on lisätavu, toinen sen sijaan osa itse runosäettä. ${ }^{171}$

Oi on lauluissa useimmin säkeiden alussa esiintyvä lisätavu. Monessa tapauksessa se ainoastaan aloittaa laulun ensimmäisen säkeen. Rytmisesti se sijoittuu tällöin ennen varsinaista ensimmäisen säkeen melodiaa. $O i$ voi myös esiintyä säkeiden tai säeparien alussa siellä täällä kautta laulun, satunnaisen oloisesti, mutta ei koskaan säeparin toisen säkeen alussa kaksisäkeisten muotorakenteiden yhteydessä. ${ }^{172}$

\footnotetext{
${ }^{170}$ Säännönmukaisesti jokaisessa säkeessä, yleensä vakiintuneella kohdalla ja painollisina esiintyviä lisätavuja kutsun refrenkitavuiksi. Tavuluvultaan vajaamittaisiin säkeisiin lisättyjä, säkeen kahdeksantavuiseksi täydentäviä tavuja nimitän täytetavuiksi (ks. myös Lauerma 2002, 42-60).

${ }^{171}$ SKSÄ A 300/21 a.

${ }^{172}$ Esim. SKSÄ A 300/10b, 51b; 301/3b. 300/11b 'ee', SKSÄ Launis 1906 ph. 22 'ai'.
} 
Erityisesti Soikkolasta tallennetuissa sävelmissä tavu esiintyy välillä joka tai lähes joka säkeen alussa, joko musiikillisesti säkeiden väliin tavallaan omalle paikalleen sijoittuvana ${ }^{173}$ tai edellisen säkeen viimeisen tavun korvaavana tai sen kanssa päällekkäin menevänä. ${ }^{174}$ Jälkimmäisessä tapauksessa lisätavu on säkeen lopputavujen tilalle tuleva esilaulajan tai kuoron aloitustavu näiden tarttuessa toistensa laulamiin säkeisiin. Joissain sävelmäryhmissä oi-tavu kuuluu kiinteästi jokaiseen säkeeseen tai säepariin niin, että sen voisi hahmottaa myös refrenkitavunomaisena pysyvänä elementtinä. ${ }^{175}$ Satunnaisesti esiintyessään tavu voi myös olla todella epäselvä, satunnainen tai sulautua edeltävään vokaaliin niin, että on mahdotonta sanoa missä toinen loppuu ja toinen alkaa, ja myös joitain muita tavuja ja vokaaleita käytetään vastaavalla tavalla. ${ }^{176}$ Joskus voidaan aloitustavun sijasta venyttää laulun ensimmäisen säkeen ensimmäistä tavua muista säkeistä poikkeavalla tavalla (esim. E-ei miun laulella pittäisi). ${ }^{177}$ Lisätavujen käyttö varioi samojen laulajien peräkkäinkin laulamissa eri sävelmissä. ${ }^{178}$ Eniten kirjoa näkyy pelkästään laulun aloittavan oi:n esiintymisessä. Se vaikuttaa täysin satunnaiselta piirteeltä, jonka käytössä ei eri rekistereiden puitteissa ole eroa.

Käsikirjoitustoisinnoissa laulun aloittavaa oi-tavua esiintyy ääniteaineistoa harvemmassa, ja esimerkiksi Launis on välillä jättänyt sen merkitsemättä nuotinnokseensa, vaikka se fonogrammilla kuuluisikin. Etenkään säkeiden välisiä ja niiden kanssa päällekkäin meneviä tavuja ei hänen nuotinnoksistaan juuri löydy: niiden merkintä tiiviisti esitettyihin nuotteihin olisikin sotkenut nuottikuvaa. ${ }^{179}$ Launis (1910b, XIV) tulkitsi etenkin laulun alussa esiintyvän oi- tai ee- tavun oikean säveltason hakemiseksi. Itse pitäisin ilmiötä ennemminkin laulamisen estetiikkaan ja laulun alun korostamiseen liittyvänä piirteenä. Launis myös huomautti tavan olevan venäläisillä erittäin yleinen. Metrisesti oi-tavun voi osassa tapauksia hahmottaa edelliseen säkeeseen tarttumisen tapana ja säkeen lopputavun korvaajana tai vaihtoehtona, tiettyjen venäläistyyppisten sävelmien ${ }^{180}$ yhteydessä puolestaan runolaulun piirissä harvinaisena, mutta slaavilaisissa mitoissa yleisenä kohotavuna (ks. Leisiö 2004). Tämän työn aineiston puitteissa hahmotan sen tällöinkin silti laulamisen tapaan, en varsinaiseen runon metriseen pohjarakenteeseen kuuluvaksi. Se on myös yksi keino sovittaa kalevalamittainen runo toisenlaista rakennetta noudattaviin sävelmiin.

\footnotetext{
${ }^{173}$ Esim. SKSÄ A 300/12a, 15a, 48b; A 301/1a.

${ }^{174}$ Esim. SKSÄ A 300/22a, 51b; toisinnossa SKSÄ A 300/40b 'ehe'.

${ }^{175}$ Soikkolasta esim. SKSÄ A 300/12a, 20c, 37a, 38b, 43b, 45a, 48b; SKSÄ Launis 1906 ph. 22b; Hevaalta SKS KRA Levón 526; SKSÄ A 301/38a. Narvusista 1920-luvulta eteenpäin tallennetuissa äänitteissä ei tämänkaltaisia sävelmiä ole, vaikka tavua satunnaisempana käytetäänkin (esim. ERA, Fon. 208a; ks. kuit. epävarmoista käsikirjoituksista esim. SibA Launis 6, 55b, 68).

${ }^{176}$ Esim. SKSÄ A 300/34b, 3001/11b, 12b, 14b. Myös tavut no (SKSÄ A 300/10b) ja i ('ja' venäjäksi: SKSÄ A 300/18a, 31b; ERA, Fon. 207a) esiintyvät muutaman kerran säkeen alussa. Samaan tapaan esiintyy joskus myös pitkä vokaali oo, ee, tai aa (ks. esim. SKSÄ L 87b; A 300/42b; A 301/11 a; A 507/9b).

177 SKSÄ A 300/35 b.

${ }^{178}$ Esim. Maria Omeljantytär: SKSÄ A 300/10a, 10b, 11a; Naasto Savasteintytär: SKSÄ A 300/12a, 13a, 14a; Liisa Petrontytär: SKSÄ A 300/21b, 22b, 23b; Ljuboi Jeyssen nainen: SKSÄ A 300/ 26a, 26b, 28c.

${ }^{179}$ Vrt. esim. SKSÄ A 300/12a, 20c, SKSÄ Launs 1906 ph. 22b ja IRS 774-779.

${ }^{180}$ Esim. SKSÄ A 300/15, 37a.
} 
Säkeen keskelle sijoittuvat tavut puolestaan jaottuvat suhteessa sävelmään kahteen ryhmään, joiden välinen raja on liukuva ja osin tulkinnanvarainen. Tasarytmisissä syllabisissa sävelmissä säkeen keskelle sijoittuvat lisätavut ovat tyypillisimmin itsenäisiä, painottomia vaa-tavuja tai konsonantin jälkeisiä lisävokaaleja. Itsenäiset lisätavut sijoittuvat säkeeseen melko säännöllisesti, mutta silti runosäkeiden rakenteiden mukaan vaihdellen. Tyypillisimmillään ne sijoittuvat yhden laulun sisällä yhden tai kahden säeaseman alalle. ${ }^{181}$ Jos näihin lauluittain ja toisintoryhmittäin vaihteleviin sopiviin kohtiin ei osu sanavälejä tai yhdyssanan osan välisiä rajoja (esim. käzipuut - käzi(vaa)puut ${ }^{182}$ ), ei tavu säkeessä esiinny. Tämän työn keskeisaineiston osalta itsenäisiä lisätavuja on muutamassa liekkuvirressä ja yhdessä saadulmoi-sävelmän toisinnossa sekä monissa todennäköisissä tanssilauluissa, joissa on myös usein runsaasti svaa-tavuja eli kahden konsonantin väliin lisättäviä vokaaleja (talvi - tal(a)vi). ${ }^{183}$ Juuri tanssi- ja liekkulauluissa ne vaikuttavat laulun rekisterille luonteenomaisilta, joskaan eivät välttämättömiltä piirteiltä.

Lisävokaaleja esiintyy satunnaisina vaihtelevissa kohdin säettä joko svaa-tavuina: "tal(a)vet" tai konsonanttiin loppuvien sanojen lisinä: "jouten(e)." ${ }^{184}$ Niiden käytön mahdollisuudet riippuvat runosäkeiden kielellisistä rakenteista, mutta niitä lisätään harvoin jokaiseen mahdolliseen kohtaan kautta laulun. Tällaisia konsonanttien väliin sekä konsonanttiin päättyvän sanan loppuun lisättyjä vokaaleita on aineistossa paljon. Usein ne ovat yksittäisiä tapauksia, mutta jälleen etenkin tietyissä tanssisävelmissä niiden käytön voi laskea rekisterille ominaiseksi piirteeksi: meil on(o) viinat(a) viijellaiset(e). ${ }^{185}$

Venytetyissä, runosäettä pidemmissä sävelmissä tavujen kirjo on laajempi: Launis (1910b, XXVII-XXVIII) hahmotti tämänkaltaisen lisätavujen käytön yhtenä tapana sovittaa runosäe tavallista pidempään sävelmäsäkeeseen. Nimitän tämänkaltaisia tavuja refrenkitavuiksi niiden suhteellisen pysyvyyden ja painollisuuden takia, ja käsittelen niitä tarkemmin refrenkien yhteydessä. Refrenkitavut liittyvät kiinteästi tiettyihin sävelmätyyppeihin, mutta voivat niiden puitteissa esiintyä vaihtoehtoisena säkeen venytyksen tai osakertausten kanssa.

\footnotetext{
${ }^{181}$ Esim. SKSÄ L 90 a; SKSÄ A 300/10a, 10b, 14a, 17b, 35a. Toisen aseman jälkeen sijoittuessaan lisätavu oikeastaan liittyy myös yleisempään ensimmäisen runojalan rytmiseen, yhdestä neljään tavua kattavaan vapauteen ja variaatioon. Erityisesti tässä kohden on joskus vaikea vetää rajaa lisätavun ja varsinaisen runosäkeeseen kuuluvan tavun välille.

182 SKSÄ A 300/27a.

${ }^{183}$ Liekkuvirsissä (SKSÄ A 300/27 a, A 301/9 b), kylän läpi menemiseen liittyvän saadulmoi-sävelmän yhteydessä (SKSÄ A 300/36 a), muoto- ja rytmirakenteen sekä esitystavan puolesta todennäköisissä tanssilauluissa (SKSÄ A 301/1b, 3a, 14b, SKSÄ L 87d); svaa-tavuja runsaasti todennäköisissä tanssilauluissa (ERA, Fon. 372c, SKSÄ A 507/9 b, 9c; L 87a, 92b, 95c, 95c, 96b).

${ }^{184}$ SKSÄ L 87 a.

${ }^{185}$ SKSÄ L 101b; ks. myös SKSÄ A 507/9b ja c; SKSÄ L87a, 92b, 95c ja d; 96b.
} 


\section{OSAKERTAUKSET}

Osakertauksien kohdalla rakenteen variaatio on erityisen monimuotoista. Väljiä ryhmiä muodostuu neljä, mutta näitä erilaisia osakertaustyyppejä voi esiintyä samassakin laulussa. Laulussa voi kertautua 1) säkeen loppuosa, 2) keskiosa, 3) alkuosa tai 4) seuraavan säkeen alkuosa. Yleisimmin runosta kertautuu kahta runojalkaa vastaava osa eli puolet säkeestä, mutta myös muut pituudet puolikkaasta runojalasta kolmeen runojalkaan ovat mahdollisia. Osakertaukset voivat sijoittua sekä esilauluun että kuoro-osaan tai ainoastaan näistä jompaankumpaan. Kuten säkeensisäisten lisä- ja refrengitavujen, myös osakertausten käytön monet piirteet liittyvät olennaisesti runosäkeiden rakenteisiin. Erilaisia osakertauksia löytyy ääniteaineiston 63 laulusta, niin Soikkolasta, Narvusista kuin Hevaalta ja Tyröstäkin.

Säkeen loppuosan kertaus on aineistossa selkeästi yleisin osakertauksen muoto, joka on käytössä länsi-inkeriläisen ääniteaineiston 37 laulussa. Kerrattava osuus voi olla mitä hyvänsä väliltä kolmesta kuuteen säeasemaa, ja osakertaus voi sijoittua esilaulajan, kuoron tai näistä kummankin osuuteen. Kaikkein yleisin loppuosan kertausmuoto on säkeen loppupuoliskon eli kahta viimeistä runojalkaa vastaavan osan kertaus. Tyypillisimmillään ja yksinkertaisimmillaan se esiintyy sekä esilaulajan että kuoron osuudessa samanlaisena: lauletaan säe ja kerrataan sen loppupuolisko.

Perusmuodossaan ja yksinkertaisimmillaan rakenne esiintyy trokeesäkeiden yhteydessä, jolloin kesuuran jälkeinen osio kertautuu: hyvä kokki kaunis kokki, kaunis kokki. Murrelmasäkeessä ei ole samalla tavoin luontevasti irrotettavissa olevaa kahden runojalan osiota, ja niiden laulamisessa esiintyykin kolme vaihdellen yhdistyvää strategiaa. Usein lauletaan vain säkeen kolme viimeistä tavua ja niitä ennen lisätavu ja, vaan tai joi. ${ }^{186}$ Kerrattavat kolme tavua voivat olla irrallinen sana tai pidemmän sanan loppuosa. ${ }^{187}$ Yhtä hyvin lisätavu voidaan kuitenkin jättää myös kokonaan laulamatta ja kerrata vain kolme viimeistä tavua, jolloin perussäkeenkin laulurytmi hieman muuttuu. Kaikkein yleisimmässä tähän rakenteeseen liittyvässä sävelmätyypissä nelitavuisen osakertauksen yhteydessä jokainen säkeen tavu lauletaan kahdeksasosanuotilla, paitsi kertauksen kaksi viimeistä tavua puolta pidempinä. Kolmitavuisen osakertauksen yhteydessä myös perussäkeen seitsemäs tavu lauletaan muita pidempänä.

\footnotetext{
${ }^{186}$ Esim. ERA, Fon. 372c; SKSÄ A 300/11b, 15; L 87a.

${ }^{187}$ Esim. SKSÄ A 300/48a: säkeestä Oi jokoi sijaruveni kerrataan osa viimeisestä sanasta: "jaruve"; SKSÄ A 301/11b, yhdeksännessä säkeessä "kolmatta emohuttani ja hutta."
} 


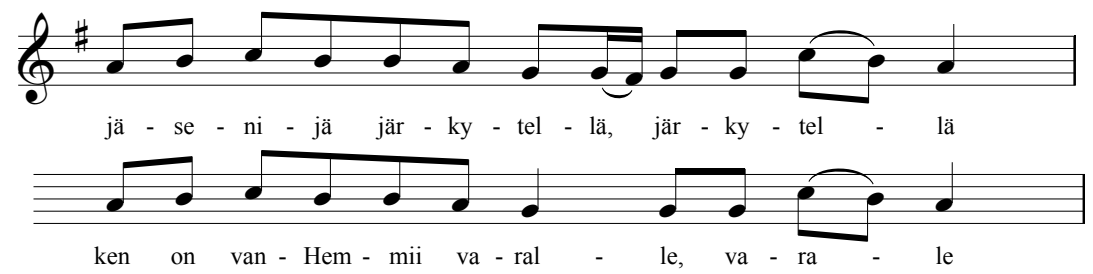

Nuotti 2. Kaksi osakerron rytmitystä sanarakenteeltaan erilaisissa säkeissä (SKSÄ L 89b, esilaulun säkeet 4 ja 5).

Säkeen kokonaiskesto säilyy tällöin samana, mutta perussäkeenkin laulurytmi muuttuu murrelmasäkeiden kohdalla (ks. myös Harvilahti 1998, 201; Rüütel 1977, 262-264). ${ }^{188}$ Kolmas ratkaisu murrelmasäkeen osakertauksissa on säkeen keskiosan satunnainen ottaminen säkeen lopun tilalle. Etenkin jos säkeen lopussa on kaksitavuinen sana, voidaan kerrattava tavu ottaa myös säkeen keskeltä: oi la laulan surusev verrej ja sura ${ }^{189}$ Murrelmasäkeen nelitavuisen osakertauksen tapa saatettiin siis ratkaista useammalla tavalla yhdenkin laulun sisällä, osin runosäkeiden rakenteesta riippuen. Aineistossa on runsaasti myös muita säkeen lopun osakertausrakenteita, joissa kuitenkin usein käytetään periaatteiltaan samoja keinoja murrelmasäkeiden kertauksiin sovittamiseksi.

Ainoastaan Hevaalta on ääniteaineistossa myös muutama esimerkki, joissa esilaulaja laulaa vain säkeen alkupuoliskon kuoron kerratessa koko säkeen. ${ }^{190}$ Kuoron oli näissä lauluissa tunnistettava säkeet niiden alkupuoliskoista, mutta esilaulaja määräsi silti laulun kulun. ${ }^{191}$ Missään laulussa kuoro ei ohjaa runon kulkua, vaan uuden säkeen aloittaminen on aina esilaulajan tehtävä.

Suurin osa osakertauksia sisältävistä lauluista on yksisäkeisiä: esilaulun ja kuoron vuorottelu etenee säe kerrallaan, sitä samalla osittain kerraten. Ainoat poikkeukset ovat niin kutsuttu Hevaan nuotti sekä muutamat sellaiset kaksisäkeiset toisinnot, joissa kuoro kertaa nopeasti esilaulajan jälkimmäisen säkeen loppupuoliskoa. ${ }^{192}$

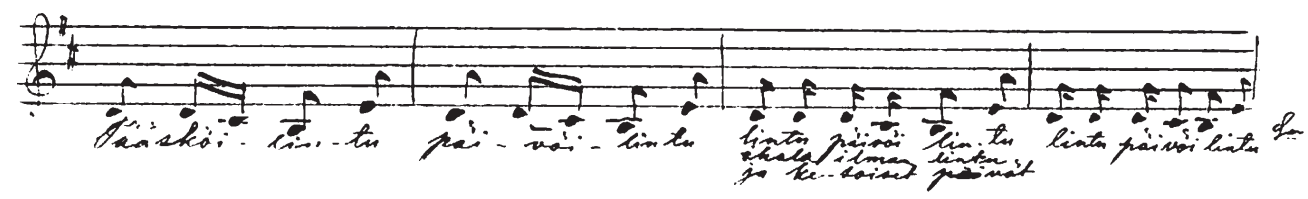

Nuotti 3: Säkeestä Pääsköilintu päivöilintu kuoro kertaa samalla sävelmällä osan tihennettynä: lintu päivälintu, lintu päivälintu. (SKS KRA Borenius e 202).

\footnotetext{
${ }^{188}$ Ks. myös esim. SKSÄ A 300/19a.

${ }^{189}$ SKSÄ A 300/11a, säkeet 3 ja 5; 14b, säe 3; 44b, säkeet 10-1; 48b, säkeet 3 ja 5.

${ }^{190}$ SKSÄ A 301/35a ja b. Käsikirjoitusaineistossa samankaltaisia toisintoja on kuitenkin myös sekä Soikkolasta että Narvusista (esim. SibA Launis 68, 106, 160, 364, 456).

${ }^{191}$ SKSÄ A 300/33b on puolestaan fonogrammiaineiston ainoa esimerkki, jossa seuraavan säkeen alkupuoli joka toisessa uudessa säkeessä kertautuu. Kuoro kertaa säkeet siten, kuin esilaulaja ne laulaa (ks. myös SKSÄ A 301/7a).

${ }^{192}$ Kaksisäkeiset: SKSÄ A 300/34b, 44b ja 301/10b; A 507/8 b; L87c.
} 
Launiksen $(1907,108)$ Hevaan nuotiksi kutsumassa sävelmätyypissä esilaulaja laulaa kaksi runosäettä, joista jälkimmäistä kuoro jää osittain kertaamaan. Muotorakenteesta ja sen usein päättävästä joonoi-refrenkisanasta on erilaisia variaatioita.

$\begin{array}{ll}\begin{array}{l}\text { Mees köyhä vähäväkkiine } \\ \text { vääntäjä vähärammoine } \\ \text { ja vähärammoine } \\ \text { ja rammoine joonoo }\end{array} & \begin{array}{l}\text { Mies köyhä, vähäväkinen, } \\ \text { vääntäjä vähävoimainen }\end{array} \\ \text { vääntäjä vähärammoine } & \\ \text { mäni sooho kyntämähä } & \text { vääntäjä vähävoimainen } \\ \text { kyntä kyntämähä } & \text { meni suohon kyntämään. } \\ \text { kyntämähä joonoo } & \end{array}$

Erilaisia säkeen lopun osakertauksia sisältyy kaikkiin aineiston äänitekeräelmiin, mutta säkeen alkupuoliskon, keskiosan ja seuraavan säkeen alkupuolen osakertauksia sitä vastoin ainoastaan Launiksen kokoelmaan. Tämä voi johtua joko kokoelman ylivertaisesta laajuudesta, alueellisista painotuksista (ainoa laaja keräelmä Soikkolasta), keruuajasta (varhaisin laaja keräelmä) tai Launiksen pyrkimyksestä kerätä kattavasti kaikki runojen laulamiseen käytetyt sävelmätyypit. Näyttää joka tapauksessa selvältä, että ainakaan Narvusin alueella muut osakertaustyypit kuin säkeen lopun kertaus eivät olleet 1900-luvun alkupuoliskolla keskeisiä.

Tyypillisesti osakertausrakenteet liittyvät sävelmäaineistossa laajaan kirjoon lyriikkaa ja lyyristä epiikkaa, ja niitä liitetään niin tanssien kuin paikallaankin laulaen käytettyihin sävelmiin, hitaisiin ja nopeisiin lauluihin. Sitä vastoin osakertauksia ei juurikaan liity Länsi-Inkerin keskeisiin rituaalisiin hää- ja praasnikkalauluihin tyttöjen morsiamelle osoitettua laulua lukuunottamatta. Hevaan nuotti näyttää kuitenkin Keski-Inkerissä toimineen myös monien rituaalisten laulujen sävelmänä. Kuten Heikki Laitinen (2006, 76-77) on todennut, useat monimutkaisimmista rakenteista esiintyvät aineistossa ainoastaan kerran tai pari. Niiden yleisyydestä tai konventionaalisista käyttötavoista on siten vaikea sanoa mitään muuta, kuin että ne olivat ilmeisen monikäyttöisiä ja osin paikallisia.

\section{REFRENKITAVUT JA REFRENGIT}

Yleensä refrengillä eli kertaumalla tarkoitetaan varsinaisiin runosäkeisiin liittymätöntä, kautta laulun samanlaisena toistuvaa sanaa, rallatusta tai kertosäettä. Länsiinkeriläisaineistossa refrengit voi jakaa karkeasti kahtia: osa liitetään runosäkeen alkuun, keskelle tai loppuun, osa taas korvaa kokonaisen runosäkeen, säeparin tai osan säkeestä. Säkeeseen liitettävät refrengit ovat aineistossa lyhyitä (yhdestä kolmeen tavua), joten selvyyden vuoksi kutsun niitä refrenkitavuiksi. Yleensä säkeen

${ }^{193}$ SKS KRA Borenius e 197. 
korvaava refrenki ja säkeeseen liitettävä refrenkitavu eivät esiinny samassa sävelmässä. ${ }^{194}$

Yksinkertaisimmillaan ja selkeimmillään refrenkitavu on vain säkeen loppuun liitettävä tavu tai kaksi: ja, joi, joo, joonoi, vaa joi. Yhtälailla esimerkiksi kuoro voi aloittaa jokaisen kertausosionsa sanoilla oi dai. ${ }^{195}$ Selkeää analyyttistä rajaa refrenkitavun ja edellä käsiteltyjen lisätavujen välille on joissain tapauksissa mahdotonta vetää. Esimerkiksi säännöllisesti säkeiden välissä toistuvan oi-tavun voisi paikoin tulkita yhtä hyvin lisätavuksi kuin refrenkitavuksikin. Erityisesti säkeen keskelle sijoittuvien tavujen kohdalla refrenkitavujen ja edellä käsiteltyjen lisätavujen välinen analyyttinen raja on välillä häilyvä. Refrenkitavun määrittelen tavuksi, joka toistuu yleensä laulun jokaisessa säkeessä jotakuinkin samana ja saa oman asemansa sävelmän rytmisessä rakenteessa. Musiikillinen asema voi tosin vaihdella runosäkeen kielellisen rakenteen mukaan. Refrenkitavut näyttävät yleensä kuuluvan kiinteästi tietyn sävelmätyypin tai muotorakenteen yhteyteen. Esimerkiksi muodoltaan jonkin verran varioiva, säkeen sisälle sijoittuva vaa ha oi -yhdistelmä esiintyy vain tietyn, ainoastaan Soikkolasta tallennetun sävelmätyypin yhteydessä. ${ }^{196}$

Toisin kuin refrengisanat, kaikki aineiston pidemmät refrengit korvaavat säkeen tai säeparin joko osittain tai kokonaan. Kuten on usein todettu, lähes kaikki länsiinkeriläiset sekä Hevaalta ja Tyröstä tallennetut refrengit ovat venäläisperäisiä (ks. Asplund 1981, 39; Hakamies 1991, 201; Kolehmainen 1977, 51; Launis 1907, 111; 1910b ja c; Lippus 1995). Narvusista ja Keski-Inkeristä on tallennettu enemmän omakielistettyjä tai onomatopoeettisia muotoja kuin lähinnä inkeroisten asuttamasta Soikkolasta. ${ }^{197}$ Muutamassa tapauksessa samankaltaista ja samantyyppiseen sävelmään liittyvää refrenkiä on paikoin käytetty venäläisittäin ääntäen: hei hei l'juba dai l’ole, paikoin taas omakielistettynä versiona: hei juu jupatali juu. ${ }^{198}$ Pohjois-inkerille tyypillisiä "onomatopoeettisia" (Simonsuuri 1972, 43) tai "laaritusrefrenkejä" (Alava 1932) on Länsi-Inkerissä niukalti. Refrengit luovatkin lauluun monikielisen, vaikeasti tulkittavan ulottuvuuden. On mahdotonta sanoa, miten laulajat ovat milloinkin kokeneet venäläisen sävelmän ja refrengin yhdistämisen omakieliseen runoon. Selvää on joka tapauksessa se, että osalle laulajista yleisimmät refrengit heisipuineen (kalina), vadelmineen (malina) ja vihreine puutarhoineen (selennoi saadu) ovat olleet kielellisestikin ymmärrettäviä - esimerkiksi

\footnotetext{
${ }^{194}$ Ks. kuitenkin esim. "Kokkolintu vet e korvellindu joo, ai lole lole korvellindu joo (SKSÄ A 301/27b). Tavut vet $e$ ovat säkeen sisälle liitettäviä refrenkitavuja, ja niiden paikka vaihtelee hieman säkeen sanarakenteen mukaan. Refrenkitavu joo lauletaan jokaisen säkeen loppuun. Refrenki ai lole lole korvaa kuoro-osassa kerrattavan säkeen alkupuoliskon. Tällä tallenteella laulaja Katriina Alekseintytär laulaa kuoro-osan myös soolona laulaessaan, samalla sävelmätyypillä laulamansa toisen runon yhteydessä hän kertasi säkeensä vet oi -refrenkitavuineen ilman ai lole lole -refrenkiä. Jotkut yksin esiintyneet laulajat jättivät säkeen kokonaan kertaamatta. (SKSÄ A 301/22b; ks. myös esim. SKSÄ A 301/31a.)

${ }^{195}$ Esim. "Teki väärim miun emmoine ja" (SKSÄ A 300/44a); "VeD ei van(a)Hoista iloa vaa joi" (SKS̈̈ A 300/31a); "Oi issuit kannessa ihala || oi dai issuit kannes, issuit kannessa iso" (SKSÄ A 300/12a).

${ }^{196}$ SKSÄ A 300/23 b, 24a; A 301/8 b. Yhdistelmä esiintyy säkeen sanarakenteesta riippuen muodoissa vaa ha, ha ja ha oi.

${ }^{197}$ Esim. oi kukka kalina, oi kukka malina, "oi kukka heisipuu, oi kukka vadelma" Narvusista (SibA Launis 44); ai tili tili moi, koko hattu omenoi Hevaan Tönttölästä (SKS KRA Levón 476); loo loo lollolloo liilolii Tyröstä (SKSÄ A 301/40a).

${ }^{198}$ SKSÄ A 300/39a Soikkolasta; Siba Launis 83 Narvusista.
} 
kalinamarja ja saadu löytyvät hakusanoina myös inkeroismurteiden sanakirjasta (IMS). Osalle etenkin venäjäntaidottomista inkerinsuomalaisista refrengit ovat ehkä toimineet vain vokaalisina tunnuskuvina, väljinä viitteinä venäläisen lyyrisen laulun ja häälauluston kenttiin.

Koko länsi- ja keski-inkeriläiseen sävelmäaineistoon kuuluu yhteensä 182 säkeitä osin tai kokonaan korvaavaa refrenkiä, kun mukaan lasketaan myös Hevaan nuotit (37 kpl). Yleisimpiä ovat erilaiset lole- ja luuli-tavuille rakentuvat refrengit (45). Seuraavana tulevat kalina- ja malina-sanoille pohjautuvat muodostelmat (24). Vähintään viisi kappaletta löytyy myös laadoi-, oi liaa-, saadulmoi- sekä ee $o i$-tyyppisiä refrenkejä kutakin. Lisäksi aineistoon kuuluu paljon erilaisia refrenkitavuja sekä harvinaisempia joko venäjänkielisiä tai omakielistettyjä refrenkejä. Pohjois-Inkerissä yleisiä säkeen loppuun liitettäviä pitkiä hei loi liirilillaa -tyyppisiä refrenkejä ei länsi-inkeriläisaineistossa esiinny. Länsi-inkeriläiset refrengit eivät lyhyitä yksi- ja kaksitavuisia, säkeeseen liitettäviä refrenkitavuja lukuun ottamatta pidennä laulusäkeiden kestoa säkeen kertaamista enempää kahta poikkeusta lukuun ottamatta (vrt. Virtanen 1968, 60). ${ }^{199}$ Eniten laulun kestoon vaikuttavat runon pituuden ohella laulun tempo ja säkeenloppujen venytykset.

Seuraavissa luvuissa hahmottuvien laulujen käyttöön ja paikallisiin lajeihin perustuvien toisintoryhmien parissa refrengit näyttävät olevan tyypillisiä kokkovirren (ai lole), kylän läpi kulkemisen (saadulmoi) sekä erilaisten tanssisävelmien (laadoi, jotkut kalina-refrengin versiot tiettyihin sävelmiin ja tempoon yhdistyneinä) ja pitkällä äänellä paikoillaan (kalina tiettyihin sävelmiin ja tempoon yhdistyneenä) esitettyjen laulujen yhteydessä. Launis (1910b, 41-42) totesi venäläisperäisten kalina-refrenkien yhteydessä, että "melodiat, joiden ambitus ei ylitä sekstiä, ovat yleensä piiri- tai tanssilauluja."

Länsi-Inkerissä refrenkejä ei liity praasnikka- tai hälauluihin kuin kahdessa tyttöjen käyttämässä hääsävelmäryhmässä ( oi dai ja vaa ja), joille ne näyttävät olevan leimallisia. Erilaisia lole- ja luuli- tavuista koostuvia refrenkejä on puolestaan käytetty sekalaisen lyriikan ja epiikan ohella erityisesti keski-inkeriläisissä kokkovirsissä. Näiden sävelmien keskeisille esitysareenoille on tulkintani mukaan ominaista muita kalendaari- ja häälauluja suurempi väljyys ja esittämistapojen kirjo. Yleisesti ottaen refrenkien puuttuminen on nimittäin rituaalisille lauluille ominaista. Keskiinkeriläisaineistossa Hevaan nuotti on poikkeus, jolla on esitetty niin liukuvirsi, kokkovirsi, liekkunuotti, Jyrin virsi kuin häälaulukin. Sen asema onkin selvästi erilainen kuin muiden refrengin sisältävien sävelmien, joista se poikkeaa rakenteensakin puolesta. Muuten refrengit näyttävät liittyvän tietynlaisiin laulutilanteisiin, laulajaryhmiin tai laulamisen tunnelmiin. Näin länsi-inkeriläinen refrenkien käyttö näyttäytyy samantyyppisenä kuin Virossa, jossa refrengit monin paikoin toimivat juuri tiettyjen laulukontekstien tai laulutyyppien tunnuksina.

${ }^{199}$ SKSÄ A 300/42a sekä SKSÄ L 91-92. 
Refrenkejä liittyy sekä yksi- että kaksisäkeisiin muotorakenteisiin. Sama sävelmä voidaan esittää sekä refrengin kanssa että ilman sitä, ja toisaalta sama refrenki voi esiintyä erilaisten sävelmien yhteydessä. Kuitenkin monet refrenkityypit esiintyvät käytännössä ainoastaan tietyn sävelmätyypin tai muotorakenteen yhteydessä. ${ }^{200}$ Kuoron ja esilaulajan esittämissä lauluissa esilaulajan osuuteen ei koskaan kuulu varsinaista refrenkiä: pidemmät refrengit kuuluvat kuoron laulamiin osuuksiin. Yksin laulaessaan esittäjä saattaa joko laulaa ainoastaan esilaulajan osuudet tai käyttää säkeen kertauksia tai refrenkejä kuin laulaisi myös kuoron osuudet. ${ }^{201}$

Säettä korvaavat refrengit eivät usein ole tavuluvultaan yhtä pitkiä kuin korvattavat säkeet tai niiden osat. Kahdeksanasemaista säettä korvaavan refrengin tavumäärä vaihtelee tyypillisesti kolmen ja seitsemän välillä. Lähes poikkeuksetta ne kuitenkin lauletaan runosäkeen pituisina, mistä seuraa tietynlaista rytmistä variaatiota. Esimerkiksi refrenki kalina malina ${ }^{202}$ korvaa kokonaisen säeparin yhtä lailla kuin refrenki oi kalina timoja, oi malina timoja. ${ }^{203}$ Ainoastaan muutamassa tapauksessa säeparin korvaava refrenki lauletaan huomattavasti pidempänä kuin korvattava säepari. ${ }^{204}$

Länsi-Inkerin ensimmäinen varsinainen sävelmänkerääjä A. A. Borenius kertoo vuonna 1877 venäläisperäisten refrenkien olevan lähinnä nuoren kansan käyttämiä. ${ }^{205}$ Tietoja pidempien "loilotusrefrenkien" myöhäisyydestä on etenkin Pohjois-Inkeristä (Enäjärvi-Haavio 1949, 139, 146-147). Aili Simonsuuri $(1972,44)$ kertoo, että läntisimmässä Inkerissä 1930-luvulla refrenkejä käytettiin lähinnä tiettyjen runojen yhteydessä. Anneli Asplund $(1997,206)$ epäilee kerääjien myös jättäneen refrenkejä "epäolennaisina" merkitsemättä: niitä esiintyy äänitteissä fonogrammeista alkaen huomattavasti enemmän kuin aikaisemmissa muistiinpanoissa. Eroja refrenkien suhteellisessa määrässä onkin havaittavissa myös esimerkiksi Launiksen käsikirjoitus- ja kolme vuotta myöhemmin tallennetun ääniteaineiston välillä. Yhtenä syynä ilmiöön saattaa olla käsikirjoituskeruun painottuminen yksittäisiin laulajiin ja varhaisen äänitekeruun keskittyminen kuorolauluun, refrengit kun liittyvät leimallisesti juuri kuoron osioihin.

\footnotetext{
${ }^{200}$ Esimerkiksi refrenki Saadulmoi saadu selennoi saadu (ven. sad(u) li moj sad, zelënyj sad: puutarha, puutarhani, vihreä puutarha) esiintyy aina saman sävelmätyypin ja rytmin yhteydessä (refrengin muunnelma saaduljmoi saadu sekeljennai saadu tosin esiintyy toisen sävelmätyypin yhteydessä, ks. SKS KRA Levón 441), erilaiset kalina malina -refrengit liittyvät (yhtä hevaalaista käsikirjoitustoisintoa lukuun ottamatta, ks. SKS KRA Levón 412) ainoastaan kaksisäkeisiin muotorakenteisiin, mutta erilaisia laadoi-sanaa toistavia refrenkejä liittyy niin yksi- ja kaksisäkeisiin muotorakenteisiin, osakertauksellisiin ja osakertauksettomiin sävelmiin.

${ }^{201}$ Esim. A 300/28c, A 300/29a vrt. sama sävelmä kuoron ja refrengin kanssa A 300/29b.

202 "Heisipuu, vadelma"

203 "Oi heisipuuni, oi vadelmani"

${ }^{204}$ Esim. SKSÄ A 300/42a; SKSÄ L 91-92.

${ }^{205}$ SKS KRA Borenius e 207, 215.
} 


\section{TAVUMUUTOKSET JA SÄKEIDEN TÄYDENTÄMINEN}

Laulussa käytetty kieli ei aina ole yhteneväistä puhekielen kanssa: se voi sisältää puhekielestä jääneitä tai siihen koskaan kuulumattomia sanoja ja ilmaisuja, lainoja ja lauluun muunneltuja sanoja (ks. esim. Caraveli 1982, 146-153; Honko 1998, 164; Lauerma 2002). Laulukielen erityisyys näkyy myös tavutasolla. Pohjois-inkeriläinen Larin Paraske kertoi, että tiettyjen sävelmien yhteydessä säkeiden lopputavut muuttuivat, ja että ne muuttuivat eri tavoilla esilaulajan ja jälestälaulajan osuuksissa (Timonen 2004, 260-261; ks. myös Lauerma 2002, 42-60). Samankaltaisia ilmiöitä on havaittavissa myös Länsi-Inkerissä.

Laulettuihin muotoihin liittyvät tavutason ilmiöt jakautuvat aineistossa kolmeen ryhmään. Etenkin runosäkeiden viimeiset tavut saattavat laulussa saada tavallisesta poikkeavia asuja. Toisaalta säkeen viimeinen tavu saattaa jäädä myös kokonaan laulamatta, mihin viittaan seitsentavuisuutena. ${ }^{206}$ Kolmanneksi kieliasultaan muuten vajaiksi jääviä säkeitä saatetaan täydentää erilaisilla täydennystavuiksi kutsumillani tavuilla.

Ääniteaineistossa säkeen viimeinen laulettu tavu voi muuntua tai korvautua jollain muulla tavulla. Kyseessä voi olla joko perussäkeen viimeinen tavu, toiseksi viimeinen tavu (jolloin viimeinen jää kokonaan laulamatta) tai osakertauksen säkeen keskeltä sen loppuun tuoman sanan tavu. Yleisimmin tavun vokaali vaihtuu e-, $a$ - tai $o$-äänteen suuntaan. Joskus muuntuminen koskee kaikkien säkeiden loppuja, joskus vain osaa niistä, ja välillä tämä on selkeästi yhteydessä viimeisen tavun vokaaliin. Esimerkiksi i-vokaali muuntuu lähes aina, jos laulussa vain tavumuutoksia esiintyy. Tavumuutokset liittyvät aina esilaulun ja kuoro-osan rajakohtaan: esimerkiksi kaksisäkeisten muotorakenteiden yhteydessä niitä ei koskaan esiinny ensimmäisen säkeen lopussa. Larin Paraske kertoi säkeiden päätetavujen äänneasun varioivan toisaalta sävelmän, toisaalta soolo- ja kuorolaulun osien mukaan (Timonen 2004, 260-261).

Säkeen lopun tavumuutoksia kuuluu selkeinä aineistoni 11 laulussa, jotka ovat viiden soikkolalaisen esilaulajan esittämiä; lisäksi on runsaasti lauluja, joissa esilaulaja tarttuu kuoro-osan loppuun lisätavuiksi hahmottamillani oi-, ee-, tai $e h e$-äänteillä. Joskus viimeisen tavun loppuun liittyy saumatta oi-äänne: paikoin tavumuunnoksia onkin vaikea edes analyyttisesti erottaa säkeen lopun päälle eri tavoin lauletuista lisätavuista. ${ }^{207}$ Joskus tavumuutokset ja viimeisen tavun poisjättö voivat tehdä säkeestä ulkopuolisen kannalta käsittämättömän: hajumiilotoin haree. "Hajamieletöin” tarkoittaa mieletöntä, haree on puolestaan sana harakka, jonka viimeinen tavu on jätetty lausumatta ja toiseksi viimeinen vokaali $a$ korvattu $e e$-äänteellä. ${ }^{208}$

\footnotetext{
${ }^{206}$ Oikeampi nimitys olisi seitsenasemaisuus, sillä tavujahan voi säkeen ensimmäiseen runojalkaan sisältyä vaihdellen kahdesta neljään. Katson kuitenkin, että kyseessä ei ole varsinaisesti runomitan abstraktiotasoon, vaan erilaisiin esitysmuotoihin kuuluva ilmiö, joten käytän kompromissina yleisen tason termiä seitsentavuisuus.

${ }^{207}$ SKSÄ A 300/12 a, 14b, 15, 17 b, 22b, 23a, 24a, 33a, 40a, 43b; A 301/9 b. Esilaulajan tarttumisesta ks. esim. SKSÄ A 300/40 b.

${ }^{208}$ SKSÄ A 300/22 b.
} 
Äänteellisiä muutoksia sisältyy tämän lisäksi myös muutamaan kohtaan, joissa lisätavu sijoittuu keskelle sanaa (vere(va)hilDa - yl. veräjilDä) ${ }^{209}$ Tavumuutoksia liittyy monentyyppisiin sävelmiin ja runoihin: yksisäkeisiin, kaksisäkeisiin, sekä osakertauksia ja refrenkejä sisältäviin että ilman niitä laulettuihin sävelmiin, ja niin kertoviin ja lyyrisiin kuin hää-, laskiais- ja liekkurunoihinkin. Monet tavumuutoksista liittyvät säkeiden seitsemäntavuisena laulamiseen, mutta eivät kaikki.

Kaikki selkeät esimerkit tavumuutoksista ovat peräisin Launiksen Soikkolassa äänittämistä kuorolauluista. Niitä ei esiinny soololauluissa. Tavumuutokset vaihtelevat yhdenkin esilaulajan kohdalla lauluittain tai sävelmätyypeittäin ja samaa sävelmätyyppiä on usein eri laulajilta tallennettu sekä ilman tavumuutoksia että niiden kanssa. Tavumuunnokset ovat yksi selkeästi keruuhistoriaan ja tallennustilanteisiin suhteutuvista laulujen piirteistä. Ä̈niteaineiston ainoat kuorolaulut sisältyvät Launiksen, Väisäsen ja Laihojen äänityksiin. Väisänenhän äänitti pikaisesti vain muutamia lauluja, sillä ne eivät olleet retken eivätkä myöhempien Helsingin tallennusten keskeiskohde. Laihojen äänitysten laulajat taas eivät olleet laulaneet yhdessä kuin kerran ennen äänitysmatkaa eivätkä he käyttäneet kaikkia sävelmätyyppejä, joita yksittäiset laulajat hallitsivat. Launiksen tallennuksissa Hevaalla kuorot taas kuulostavat pienemmiltä ja laulut vähemmän innostuneesti lauletuilta, lisäksi Launis äänitti sieltä myös huomattavasti vähemmän sävelmätyyppejä kuin Soikkolasta. Ne soikkolalaiset laulut, joissa tavumuutoksia esiintyy, kuuluvat innostuneen ja tosissaan lauletun oloisien äänitysten joukkoon. Ne ovat täysiä esityksiä. Toisin kuin Laihojen äänityksissä, laulajat luultavasti tunsivat toisiaan etukäteen. Aineiston painottumisen ja fonogrammeilta aavisteltavissa olevien innostuneiden äänensävyjen ja laulun jäntevyyden pohjalta arvelen, että tavumuutokset ovat nimenomaan esityksellinen piirre, osoitus tosissaan laulamisesta. Ne liittyvät kohosteisiin, julkisiin joukkoesityksiin.

Seitsentavuisuus puolestaan on koko äänite- ja käsikirjoitusaineistossa paikkakunnasta, laulajasta ja kerääjästä riippumatta yleisenä esiintyvä piirre. Se liittyy ennemminkin laulun rakenteisiin kuin varsinaisiin runosäkeisiin: on esimerkiksi yleistä, että sama säe lauletaan saman laulun kuluessa peräperää sekä seitsentavuisena että kahdeksantavuisena. Laulajat saattoivat jättää säkeen viimeisen tavun laulamatta myös silloin, kun se teki säkeen vaikeasti ymmärrettäväksi: tukkoi tuu paljastuu säettä kerrattaessa: tukkoi tuima eli pitkä tukka, lehti lee on lehti leekkui. ${ }^{210}$ Länsi-inkeriläisen laulun kontekstissa kyseessä näyttääkin olevan ennemminkin yleinen, laulamisen estetiikkaan liittyvä piirre kuin kielen muutoksiin ja sanojen lyhentymiseen liittyvä ilmiö.

Seitsentavuisuuden esiintymisessä on tiettyä lauluittain vaihtelevaa säännöllisyyttä, joka ei kuitenkaan näytä edes paikkakuntien puitteissa olevan sidoksissa esimerkiksi runo- tai sävelmätyyppeihin. Kaksisäkeisten muotorakenteiden yhteydessä seitsentavuisuus näyttää kuitenkin olevan muuta yleisempää, etenkin kuo-

\footnotetext{
${ }^{209}$ SKSÄ A 300/14a, säe 3.

${ }^{210}$ SKSÄ A 300/ 22a, 301/5b.
} 
ro-osassa. On myös yleistä, että kaksisäkeisen muotorakenteen ensimmäinen säe lauletaan täysmittaisena, toinen seitsentavuisena. Rakenne on sama kuin venäläisellä riimillisellä tšastuškalla, joiden sävelmiä myös mukautettiin kalevalamittaisen runon laulamiseen. ${ }^{211}$

Seitsentavuisuuden variaation voi esittää neljänä päävaihtoehtona:

1) Laulun kaikki säkeet ovat seitsentavuisia. ${ }^{212}$

2) Kahdeksantavuinen säe tai säepari kerrataan seitsentavuisena. ${ }^{213}$

3) Säeparin ensimmäinen säe lauletaan 8-, toinen 7-tavuisena. ${ }^{214}$

4) Kahdeksan- ja seitsentavuisuus vaihtelevat satunnaisen oloisesti

i) parisäkeen ensimmäisessä säkeessä, toinen on aina 7-tavuinen ${ }^{215}$

ii) parisäkeen jälkimmäisessä säkeessä, ensimmäinen on kahdeksantavuinen ${ }^{216}$.

Joskus vain laulun ensimmäinen säe lauletaan kahdeksantavuisena, muut säkeet seitsentavuisena, tai muuten kahdeksantavuisessa laulussa voi yllättäen olla yksi seitsentavuinen säe. ${ }^{217}$ Poikkeuksia ja vaihtelua siis löytyy, mutta usein säkeen pituuden vaihtelu on yksittäisissä lauluissa melko säännöllistä. Seitsentavuisuus on siis esityskohtainen, melko vapaasti varioiva ja yleinen länsi-inkeriläisen laulamisen piirre. Monissa praasnikka- tai häälauluissa sitä ei kuitenkaan säännöllisenä esiinny.

Seitsentavuisuuden kanssa tavallaan vastakkainen piirre on säkeiden täydentäminen. Laulajilla oli erilaisia keinoja täydentää muutoin vajaatavuiseksi jäävää säettä: voitiin lisätä täytetavu tai -vokaali, jakaa yhden tavun sisältämä diftongi kahta tavua vastaavaksi tai venyttää yhtä vokaalia kattamaan kaksi säeasemaa. Usein täytetavu näyttää olleen vaihtoehto sanan pidemmän, jo puhekielestä jääneen muodon käyttämiselle: kynDämäHä - kynDämää vaa. ${ }^{218}$ Kalevalamittaisen säkeen lopussa ei yleensä ole yksitavuisia sanoja: Sadeniemi $(1951,13,72)$ ja Lauerma $(2001,46)$ ovatkin tulkinneet esimerkiksi säkeen loppuun sijoittuvat, A. A. Boreniuksen paikoin yksitavuisiksi sanoiksi tulkitsemat täydennykset suffiksaalisiksi eli edeltävään

\footnotetext{
${ }^{211}$ Paikoin tšastuškasävelmään saatettiin yhdistää runomitaltaan erilaisia osia. Esimerkiksi Darja Lehden esittämä rekimitan (i mammani minnoo synnytteli / mustas savutuvas) ja kalevalamitan (tuttu luttu miä trubitan, palkkaa minnoa paimeneks) välillä vaihteleva laulu on Eesti Rahvaluule Arhiivin kontekstitiedoissa määritetty musiikin perusteella tšastuškaksi (ERA, fon. 207a).

${ }^{212}$ Esim. SKSÄ A 300/17a, 37b.

${ }^{213}$ Esim. SKSÄ A 300/20c, 301/14a.

${ }^{214}$ Esim. SKSÄ A 300/23a, 25b.

${ }^{215}$ Esim. SKSÄ A 300/21b.

${ }^{216}$ Esim. SKSÄ A 300/22b.

${ }^{217}$ Esim. SKSÄ A 300/37a, 39a, 301/1b.

${ }^{218}$ SKSÄ A 300/10a; ks. myös esim. SKSÄ L 90a, 92b
} 
sanaan kiinteästi liittyviksi tavuiksi. Länsi-inkeriläisaineiston vaa-täydennystavujen kohdalla voisi ajatella kyseessä olevan nimenomaan laulettuun muotoon ja esitykseen liittyvä ilmiö. Irrallinen säkeen loppuun liitetty tavu ei tässä yhteydessä ole siis varsinaisen runomitan piiriin kuuluva ilmiö. Ilmiön raja sekä lisätavun että varsinaiseen säkeeseen kuuluvan tavun suuntaan on häilyvä: juuri vaa-tavua on käytetty myös selkeänä säkeen osana tietyn tyyppisten säkeiden yhteydessä, esimerkiksi miä vaa tyttöi pikkaraine. Tekstitoisinnoissa (SKVR) säkeen lopettavaa vaa-tavua ei esiinny.

Seitsentavuiset säkeet runomuistiinpanoissa on yhdistetty lähinnä kielen muutoksiin ja mitan rappeutumiseen, runojen esittämiseen sanellen ja niiden muistiin merkitsemisen tekniikoihin. Matti Kuusi (1983a, 185-7) kuvaa narvusilaista käsikirjoitusaineistoa: "Vokaalienvälisen h:n kato painottoman tai sivupainollisen tavun jäljessä (juoksemahan > juoksemaa) on johtanut siihen säännönväljennykseen, että säkeen 4. runojalassa kaksi pääpainotonta tavua on korvattavissa yhdellä pitkävokaalisella tavulla." Lisäksi seitsentavuisuutta aiheuttavat hänen mukaansa vokaaliassimilaatio (neitosia > neitosii), yleisgeminaatio (tulevi $>$ tulloo) ja loppuheitto (säärilläsi > säärilläs). Jälkimmäisestä Kuusi arvelee sen voineen esiintyä vain sanellussa runossa: "Laulettaessa lyhytvokaalinen -hes, -läs, jne. vaivoin kattoi 4. runojalan sävelkulkua." Ääniteaineiston tarkastelu kuitenkin näyttää, että laulussa seitsentavuisuus ei ollut millään tavalla sidoksissa säkeiden kieliopilliseen rakenteeseen vaan ennemminkin sävelmään ja esitykseen. Lyhytvokaalinenkin tavu saattoi tulla venytetyksi kahden säeaseman alalle ja säkeen viimeinen sana saattoi tavumuutosten ja seitsentavuisuuden seurauksena jäädä joskus myös melko käsittämättömään muotoon. Tietyissä tšastuškanomaisissa sävelmissä poisjääneen tavun paikalla pidettiin vain lyhyt tauko. ${ }^{219}$ Toisaalta muutoin seitsentavuisiksi jääviä säkeitä saatettiin täydentää sanan päätteen sijasta myös lisätavulla.

Seitsentavuisuus ja tavumuutokset liittyvät runon esittämisen, eivät niinkään runon metrisen pohjarakenteen tasoon. Sama metrinen rakenne ja sama runosäe on erilaisilla sävelmätyypeillä laulettaessa voitu toteuttaa eri tavoin. Tähän viittaa myös se, että seitsentavuisuuden luonne on erilainen lähinnä sanelusta tallennetuissa käsikirjoitusaineistoissa ja tavumuutoksia ei niissä esiinny ollenkaan. Sama pätee luonnollisesti myös muihin tämän alaluvun tekstuaalisiin piirteisiin, lisätavuihin, osakertauksiin ja erilaisiin refrenkeihin. Siten esimerkiksi Launiksen ääniteaineistossa kaksisäkeisten sävelmien yhteydessä runsaana esiintyvä, tšastuškamittaa mukaileva käytäntö laulaa ensimmäinen säe täysimittaisena ja toinen seitsentavuisena on tulkintani mukaan esittämistavan säännöstöihin, ei varsinaisesti runomitan tarkastelun alle kuuluva seikka.

\footnotetext{
${ }^{219}$ Esimerkiksi esilaulajan säe surma suuresta kylästä tuli kuoron kertaamaksi muodossa surma suuresta kyläst (SKSÄ A 301/14a).
} 


\section{MUSIIKILlisia PIIRTEITÄ}

Itämerensuomalaisista runosävelmistä ovat laajoja aineistoja kattavia tutkimuksia tehneet Launiksen (1910b) jälkeen ennen kaikkea Ingrid Rüütel (1977; 1998; 2006), Ilkka Kolehmainen (1977; 1990) ja Urve Lippus (1995). Launis pyrki luokittelemaan kaikki siihen mennessä kerätyt suomalaiset, karjalaiset, virolaiset ja inkeriläiset runosävelmät pääosin niiden musiikillisen rakenteen perusteella, mutta piti tärkeänä myös sävelmän suhdetta esilaulun ja kuoron vaihteluun sekä runosäkeisiin. Ingrid Rüütel on käsitellyt etenkin virolaisia, mutta myös vatjalaisia runosävelmiä niiden muotorakenteen, rytmin, asteikon sekä etenkin melodian kannalta. Keskeistä sekä Launiksella että Rüütelillä on ollut sävelmien tyylipiirteiden luokittelu (Rüütelilla typologisointi), niiden vertailu naapurikulttuurien laulunlajeihin ja niiden ajoituksien pohtiminen. Rüütelillä analyysi on hienovaraisempaa ja yksityiskohtaisempaa ja pyrkii lähtemään liikkeelle runolaulun rakenteista, ei länsimaisen taidemusiikin oletuksista, joissa Launis oli vielä kiinni. Ilkka Kolehmainen puolestaan keskittyi viisi-iskuisen niin kutsutun kalevalasävelmän musiikilliseen, tilastollisesti painottuneeseen analyysiin. Urve Lippus analysoi rytmistä ja melodista ajattelua virolaiskarjalais-inkeriläis-suomalaisessa runolauluaineistossa. Käsikirjoitussävelmien analyysi pohjaa osin hänen kokemukseensa virolaisen runolaulun ääniteaineistosta. Tutkimuksen inkeriläisaineisto koostui inkeroissävelmiksi kutsutuista Inkerin runosävelmistä (IRS) sekä Rüütelin (1977) julkaisemista vatjalaissävelmistä. Heikki Laitinen (ks. 2003a; 2003b; 2004; 2006) on monissa julkaisuissaan käsitellyt runolaulun musiikillisia ja kielellisiä piirteitä. Lisäksi monet tutkijat ovat tutkineet sävelmien ja laulamisen piirteitä suppeampien, alueellisten tai laulajakohtaisten aineistojen valossa (Haapoja 2013; Huttu-Hiltunen 2008; Käppi 2007; Oras 2001; 2004b; 2008; 2011; Pärtlas 2006; Sarv 2008; Sarv 2001; 2004; Särg 2000; 2001; 2004; $2005 ; 2008)$.

Länsi-inkeriläisistä sävelmistä kirjoitti ensimmäisen laajemman esityksen Terttu Koski (1974) aineistokokoelman Narodnye Pesni Ingermanlandii yhteydessä. Artikkeli perustuu 1960-luvulla inkeroisilta tallennettuihin ääniteaineistoihin, mutta pohjana on myös Launiksen (1910a) toimittaman sävelmäkokoelman tuntemus. A. Gomon (1977) kirjoitti oman, suppeamman kenttätyöaineistonsa ${ }^{220}$ pohjalta inkeroisten sävelmistä lyhyemmän esittelyluontoisen artikkelin, jossa painotti lisätutkimuksen ja ainesjulkaisujen tarvetta. Ingrid Rüütel (1977) teki vatjalaisten sävelmien tarkastelussaan huomioita myös inkeroisten lauluista. Hänen artikkelinsa perustuu sekä aikaisemmille kokoelmille että hänen ja muiden 1960-luvulta lähtien Laukaansuun vatjalaisilta, etenkin Oudekki Figurovalta tallentamiinsa ääniteaineistoihin. Rüütel näyttää, miten tarkkoja, myös paikallisten ja laulun lajien kannalta merkittäviä erotteluja perusteellinen musiikillinen analyysi tekee mahdolliseksi ja antaa samalla viitteen siitä, miten paljon tarkemmaksi tämänkin tutkimuksen aineiston käsittelyä olisi jossain toisessa kontekstissa mahdollista viedä. ${ }^{221}$

${ }^{220}$ ERA RKM, Mgn. K 39-46.

${ }^{221}$ Laukaansuun alue Joenperän ja Luuditsan kylineen kuuluu myös tämän tutkimuksen keskeisalueeseen. 
Sekä Kosken $(1974,477)$ että Rüütelin $(1977,218)$ mukaan huomattavan monet runolaulun piirteet yksittäisiä sävelmäryhmiä myöten 1960-luvun aineistoissa vastaavat 1900-luvun alussa ja 1800-luvun lopulla tallennettujen aineistojen piirteitä. Uusina oli Rüütelin mukaan ilmaantunut lähinnä joitain riimillisten laulujen runolauluun sovitettuja sävelmiä.

Pohjimmainen kysymys tässä työssä on se, mitkä musiikilliset piirteet ovat laulajien itsensä kokemana tai käyttäminä olleet merkitseviä, eroja tekeviä. Käytettävissä oleva aineisto antaa joitain mahdollisuuksia etsiä vastauksia. Seuraavissa luvuissa kartoitetaan sävelmien käyttöä tiettyjen tilanteiden yhteydessä laulajien lajimainintojen sekä tilannesidonnaisten runojen ja sävelmätyyppien välisten yhteyksien avulla. Tässä alaluvussa luodaan osaltaan tälle pohjaa tarkastelemalla joitain sävelmiin liittyviä piirteitä suhteessa sävelmäaineiston kokonaisuuteen ja aiempaan tutkimuskirjallisuuteen. Paikoin tarkastelen laulun piirteitä myös seuraavien lukujen tulosten valossa.

\section{RYTMI}

Runolaulussa rytmi- ja melodiatyyppi eivät aina ole sidoksissa toisiinsa. Sama sävelkulku voitiin esittää erilaisilla rytmityypeillä. Yleensä rytmityyppi pysyy samana kautta laulun, mutta rytmistä variaatiota saattoi esiintyä yhdenkin laulun sisällä. (Ks. Lippus 1995, 56, 58.) Taive Särg (2008, 49; ks. myös Huttu-Hiltunen 2008, 146-153) huomauttaa, että usein laulun "sävelkorkeudet ja rytmi eivät ole kovin tiukkarakenteisia." Runonkeräjijien kirjoituksissa tämä näkyy valituksena rytmin epämääräisyydestä ja laulun epävireisyydestä (esim. Madetoja \& Ikonen 1909, 78). Niinpä laajempien aineistojen analyysi edellyttääkin yleensä jonkinasteista rytmin pelkistämistä. ${ }^{222}$

Launis (1910a, 1910b) sovitti julkaisemansa runosävelmät länsimaisen taidemusiikin tahtilajeihin. Kuten Urve Lippus (1995, 28, ks. myös esim. 59) huomauttaa, taidemusiikin rytmisen ajattelun soveltaminen tuo mukanaan runolaulua kuvaamattomia mielikuvia esimerkiksi tietynlaisista vahvoista ja heikoista iskuista, harmonisista implikaatioista, aksenteista ja painoista. Jo Väisänen $(1990,96)$ perusti analyysinsa runojalan ja iskualan vastaavuuksille. Tahtiosoituksia käyttäessäänkin hän (esim. mts., 107) käsitteli runosäettä sitä vastaavine sävelmäsäkeineen yhtenä

\footnotetext{
${ }^{222}$ Runolaulun rytmiä on lähestytty hyvin erilaisilla tasoilla. Useimmiten analyyseissä pysytellään rytmin perushahmon tasolla, tarkimpana nuottiarvona kahdeksasosanuotti mahdollisine lisämerkintöineen. Urve Lippus (1995, 35-38) päätyy analyysissaan jaottelemaan sävelten aika-arvot pääpiirteissään ainoastaan kahteen kategoriaan, pitkään ja lyhyeen, joiden vaihtelu näyttää hänen analyysissaan sävelmien perusrakenteet ja niihin liittyvän musiikillisen ajattelun perustan. Hän kuitenkin huomauttaa, että säkeen prosodian, melodian ja rytmin suhteet ovat monimutkaisia ja rytmin hienovaraisemmat tulkinnat ovat riippuvaisia myös kuulijasta (mts. 39-42). Taive Särg (2005) sekä Jaan Ross ja Ilse Lehiste (2001) ovatkin tehneet tarkkoja mittauksia yksittäisten tavujen kestoista ja voimakkuuksista virolaisista äänitetallenteista. Tässä työssä on aineiston moninaisuuden ja tarkastelun tason vuoksi hyödyksi hieman Lippusta tarkempi erottelu, vaikka rytmin hienojakoisempia piirteitä ei pohditakaan.
} 
kokonaisuutena. Väisäsen jälkeen näin onkin ollut suomalaisten ja virolaisten tutkijoiden parissa tavalla tai toisella tapana tehdä. Siinä missä erirytmisten sävelmien sovitteleminen toisenlaista musiikkikäsitystä edustavien tahtilajien puitteisiin johtaa monissa tapauksissa useisiin mahdollisiin tulkintoihin, on runojalan tai säeaseman ja sen osakseen saaman aika-arvon suhde kohtuullisen yksiselitteinen. Rytmirakennetta ilmaisen tekstissä säeasemien saamien aika-arvojen suhteita kuvaavalla numerosarjalla.

Inkerissä yleisimpiä ovat virolaisille sävelmille tyypilliset neli-iskuiset (22222222) rytmit ja niiden muunnokset; pohjoisempana yleistä viisi-iskuista (22222244), kalevalasävelmäksi kutsuttua rytmityyppiä esiintyy niukemmin. Alueelta on tallennettu runsaasti myös sellaisia rytmityyppejä, joita ei muualla tavata. ${ }^{223}$ Kuten Heikki Laitinen $(2006,76)$ huomauttaa, yleisimpiä ovat kuitenkin suhteellisen yksinkertaiset, keskimäärin jopa muita alueita suppeampialaiset ja lyhyemmät sävelmät. Samalla erilaisten monimutkaisimpien rakenteiden - joista usein voi olla tallennettu vain muutama esimerkki - kirjo on runsas. Urve Lippus (1995, erit. 51, 57) kävi rytmianalyysissaan läpi lähes kaikki inkeriläisetkin sävelmät venäläisperäisiksi tulkittuja ja refrenkirakenteita lukuun ottamatta (pois jätettyjä sävelmiä oli Launiksen julkaisun osalta ilmeisesti 190). ${ }^{224}$ Hänen jaottelunsa kahdestakymmenestä kahdesta päärytmityypistä Inkeristä löytyy kahtatoista. Näistä kahdestatoista tyypistä neli-iskuinen rytmityyppi kattaa 56,6 \% tallennetuista vatjalaissävelmistä ja 48,8 \% muista inkeriläissävelmistä. Muihin rytmityyppeihin sijoittuvat määrät ovat Oudekki Figurovan sävelmiin painottuvissa vatjalaissävelmissä enimmillään 10,8 \% (yleinen hääsävelmätyyppi 44222244), muissa 5,9 \% (niin kutsuttu kalevalasävelmä 22222244). 750 Launiksen julkaisemasta inkeriläissävelmästä nämä kolme rytmityyppiä kattavat 583 sävelmää. Alle kymmenen toisintoa käsittäviä ryhmiä Lippus ei analyysissaan ota huomioon. Hän käsittelee laulun rytmiä yksittäisten säkeiden tasolla, joten yleisin rytmityyppi kattaa sekä yksi- että kaksisäkeiset sävelmät. (Mts. 57.)

Tämän työn aineistossa näyttää siltä, että paikoin pienetkin rytmilliset erot voivat olla merkittäviä sävelmien käytön kannalta. Esimerkiksi varsinaiset länsi-inkeriläiset liekkusävelmät noudattavat kaikki tiukasti rytmirakennetta 22222222. Samaa rakennetta noudattaa yleisin ja laajakäyttöisin hääsävelmien muotorakenne, kun taas neli-iskuisten sävelmien erilaiset rytmiset muunnelmat, kuten 42424242 tai 22231222 keskittyvät hääsävelmien piirissä tiettyihin tilanteisiin (aattoilta, ajaminen häätaloihin) tai tietyille laulajille (tyttöjen laulu morsiamelle). Käsikirjoitussävelmien kohdalla on tietenkin mahdotonta sanoa, paljonko ja millä tavalla kerääjä on kuulemaansa rytmirakennetta pelkistänyt ja tulkinnut. Ääniteaineistonkin kohdalla on syytä varoa ottamasta melko karkeita nuottikuvia ja rytmin numeerisia pelkistyksiä hienovaraisesti varioivan rytmin täsmällisinä kuvaajina.

\footnotetext{
${ }^{223}$ Kolehmainen 1977, 104, 105; Launis 1904, 51; 1910b; Väisänen 1990, 106, 225.

${ }^{224}$ Lippus käsittelee Inkerin runosävelmät -julkaisun sävelmiä vatjalaissävelmiä lukuun ottamatta inkeroissävelminä, vaikka osa on tallennettu inkerinsuomalaisilta (esimerkiksi monet Launiksen fonogrammiäänitykset Tyröstä) tai inkerinsuomalaiskylistä. Tässä puhun Lippuksenkin tulosten kohdalla inkeroissävelmien sijasta inkeriläissävelmistä.
} 
Yhtenä kalevalamittaisen laulun tyylejä olennaisesti erottelevan tekijänä on Launiksesta (1910b) lähtien pidetty runotekstin ja laulun rytmin välistä suhdetta. ${ }^{225}$ Suuressa osassa inkeriläisiä sävelmiä rytmi on runosävelmille tyypillisellä tavalla melko tasainen: jokainen säeasema saa osakseen jokseenkin samansuuruisen tai vaihtelevasti kahta suhteellisen läheistä aika-arvoa edustavan aikajakson. Tällaisia sävelmiä kutsun tasarytmisiksi: laulettujen tavujen rytmi on suhteellisen tasainen. Inkerissä mahdollisia ovat kuitenkin myös yksittäisten tavujen pitkät venytykset. Yksi säeasema tai tavu voi saada osakseen jopa yhtä pitkän aikajakson kuin koko loppusäe yhteensä. Sävelmiä, joissa pisimmän säeaseman saama suurin aika-arvo on yli kolme kertaa lyhyimmän aseman saaman arvon pituinen kutsun paremman termin puutteessa venytetyiksi. Usein venytetyt sävelmät ovat myös hyvin melismaattisia eli yhtä tavua kohden lauletaan useita sävelkorkeuksia. Tämänkaltaisen tyylin on todettu muistuttavan venäläisiä ns. verkkaisia tai venytettyjä lauluja (protjažnyje pesni) (Kolehmainen 1977, 105; ks. myös Koski 1974, 477). Seuraavien lukujen keskeisiksi muodostuvista sävelmäryhmistä tanssisävelmät ovat huomattavan tasarytmisiä, kuten myös suurin osa praasnikka- ja häälaulujen ryhmistä. Venytettyjä sävelmiä kuuluu tämän työn keskiössä olevin lajien puitteissa lähinnä tyttöjen aattoiltana morsiamelle laulamien sävelmien joukkoon, vaikka niitä muuten työn kokonaisaineistossa onkin melko runsaasti. Käsittelen tasarytmisinä myös sävelmiä, joissa runosäettä on pidennetty osakertauksin tai refrenkitavuin, jos vain erilaisten tavujen saamat aika-arvot ovat kyllin lähellä toisiaan. Paikoin tavun venytys voi kuitenkin olla vaihtoehtoinen sanojen sävelmään sovittamisen strategia osakertausten ja refrenkitavujen käytön kanssa. Tämän huomioi jo Launis (1910b, XXVII-XXVIII). Tasarytmiseksi ja venytetyksi kutsumani sävelmät voivatkin melodisesti olla joskus hyvin lähellä toisiaan tai erilaiset osakertausten ja lisätavujen yhdistelmät voivat vaihdella yhdenkin sävelmätyypin puitteissa.
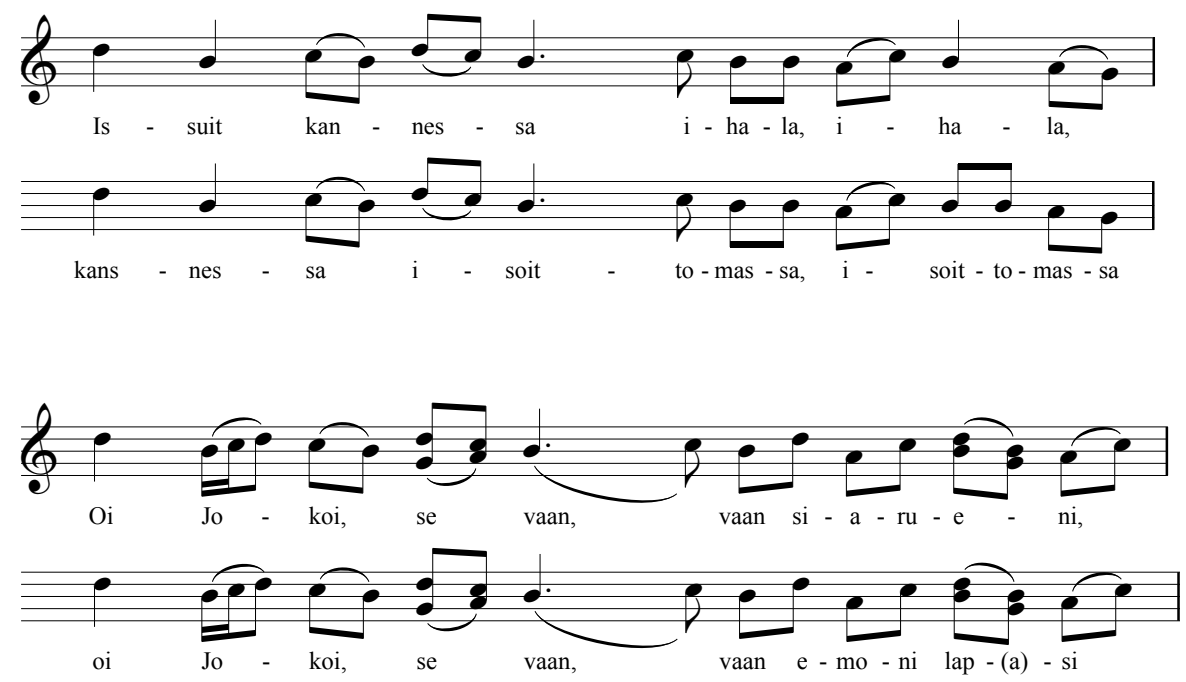

Nuotti 4. Sama sävelmä- ja rytmityyppi, kaksi eri muotorakennetta eli säkeen lopun osakertaus (12345678 5678) ja säkeen keskelle sijoitetut välitavut $\left(123^{* * * 45678)}\right.$ (SibA Launis 170, 358).

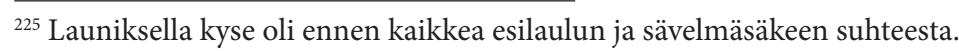


Tämän tutkimuksen aineistossa tietyt rytmityypit yhdistyvät säännöllisesti tietyntyyppisiin melodioihin tai muotorakenteisiin. Tällainen on esimerkiksi saadulmoisävelmäksi kutsumani sävelmätyyppi, jossa tietty rytmityyppi (44224422) yhdistyy yleensä tietynlaiseen melodiaan, yksisäkeiseen muotorakenteeseen ja refrenkityyppiin saadulmoi saadu selennoi saadu. Kuitenkin tätäkin sävelmätyyppiä on voitu käyttää myös esimerkiksi ilman refrenkiä tai ai lole lole -refrengin kanssa. (Ks. Liite 5: Saadulmoi-sävelmät.) Monimutkaisemmat osakertaus- ja refrenkirakenteet liittyvät yleensä myös melko kiinteästi tiettyihin rytmirakenteisiin: esimerkiksi tyttöjen häissä käyttämä oi dai -sävelmä määrittyy niin rytmityyppinsä, melodiakulkunsa kuin muotorakenteensakin kautta. Toisaalta juuri yllä olevat, samaan häiden laulutilanteeseen liittyvät oi Jokoi -sävelmätyypin esimerkit näyttävät, että yksi kontekstisidonnainenkin sävelmätyyppi saattoi myös tulla lauletuksi erilaisin muotorakentein.

Laulun tempo on vanhemmassa aineistossa usein vaikeasti pääteltävissä. Käsikirjoitusnuoteissa tallentajan satunnaiset tempomerkinnät antavat jonkinlaista suuntaa, mutta tarkkoja päätelmiä on mahdotonta tehdä. Nuottiarvojen valinta saattaa joskus antaa suuntaviivoja (ks. Lippus 1995, 64), mutta voi myös olla satunnaista - tähän tuntuisi viittaavan samankaltaisten sävelmien nuotintaminen eri aika-arvoin. ${ }^{226}$ Tosin tämä voi myös viitata siihen, että samakin sävelmä voitiin laulaa erilaisin nopeuksin. Esimerkiksi Launis toteaa, että innostuksen kasvaessa usein myös laulun tempo kasvoi. Sama piirre on huomattavissa monin paikoin myös Laihojen äänityksissä, joissa usein laulun tai useamman laulun myötä sekä tempo kiihtyy että äänenkorkeus nousee jonkin verran. Toisaalta etenkään fonografiäänityksissä alkuperäisen tempon ja äänenkorkeuden tarkka tavoittaminen ei äänityslaitteen teknisistä ominaisuuksista johtuen ole mahdollista. Ääniteaineistojen ja kerääjien kommenttien pohjalta on kuitenkin selvää, että laulun tempo oli yksi olennainen inkeriläisiä laulutyylejä määrittävä tekijä. Tietyt laulut olivat nopeita, toiset hitaita. Kuten seuraavassa luvussa käy ilmi, nopeuteen ja hitauteen myös yhdistyi erilaisia laulun sävyjä: hitaus tarkoitti surullisuutta, juhlavuutta tai vakavuutta, nopeus hilpeyttä, kepeyttä ja iloisuutta.

\section{Melodia}

Melodian tarkastelu jäsentyy tässä useampaan osioon: käytössä oleviin sävelaloihin eli ambituksiin, perussävelen hahmottamiseen sekä lopulta melodian kulkuun ja sen muunteluun sekä tämän tuottamaan heterofoniaan tai moniäänisyyteen. Tässä työssä analyysi liikkuu karkeimmalla ja ylimalkaisimmalla tasolla juuri melodian piirteiden kohdalla.

Sävelalan on runolaulun kohdalla todettu liittyvän sävelmätyyppeihin tai laajemmin sävelmätyyleihin: erityisesti uusimittaisten suomalaisten tai venäläisten laulujen piirteitä sisältävät tai suoraan niistä omaksutut runosävelmät ovat usein myös

${ }^{226}$ Ks. esimerkiksi liukuvirret: IRS 766, 772, SibA Launis 233, 310, 393. 
sävelaltaan muita laajempia (esim. Asplund 1981, 26-27; Launis 1910b). Runosävelmille tyypillistä on viidestä kuuteen säveltä kattava ambitus, mutta Inkerissä ovat Urve Lippuksen (1995, 95; ks. myös Rüütel 1977, 267-272) huomion mukaan erityisen yleisiä myös ainoastaan kolmen tai neljän sävelen alalla liikkuvat sävelmät. Terttu Koski $(1974,479)$ hahmottaa neljän sävelen kvarttirakenteen keskeiseksi monien hieman laajempialaistenkin toisintojen pohjarakenteeksi. Myös Gomon $(1977,282)$ huomauttaa "kvarttisuuden" tuntuvan usein laaja-alaisemmissakin sävelmissä. Lippus $(1995,61)$ toteaa, että yleensä runosävelmät käyttävät kaikkia ambituksen sisään jääviä säveliä.

Samankin sävelmätyypin puitteissa voi esiintyä erisuuruisia sävelaloja: erilaiset sävelmän muunnelmat voivat joko laajentaa tai supistaa käytettävissä olevaa asteikkoa, vaikka melodian perushahmo ja keskeiset tukisävelet pysyisivät samoina. Inkerissä erityisesti kuoro-osan moniäänisyys sekä venäläisiä laulutyylejä muistuttava tapa lopettaa joskus säe, säepari tai laulu äänen alas "tipauttamiseen" laajentavat ambituksia. Kummatkin piirteet näyttävät olleen esitys- tai tilannekohtaisia: yhtä sävelmää oli mahdollista laulaa monella tavalla. Niinpä kuoron kanssa äänitetyt saman sävelmän toisinnot ovat usein sävelalaltaan hieman laajempia kuin ilmeisesti yhdeltä laulajalta tallennetut, muutenkin pelkistetymmät käsikirjoitussävelmät. ${ }^{227}$

Sävelalan sisältämien sävelten keskinäisistä suhteista ja painoarvoista puhutaan asteikon tai asteikkorakenteen nimellä (Lippus 1995, 70-72, 80-86). On yleensä turhaa ja mahdotonta tehdä hypoteeseja suppean sävelalan ulkopuolisista asteikkorakenteista, jos musiikkikulttuurin jäsenillä ei ole näistä näkemyksiä tai tämänkaltaisia tietoja ei ole mahdollista saada (ks. esim. Lippus 1995, 75-80; Herndon 1974; vrt. Väisänen 1990, 109). Niinpä esimerkiksi nuotinnoksen etumerkinnät kertovat ainoastaan runolaulun käytössä olevista sävelistä, ja asteikkoja on turha nimittää länsimaisten käytäntöjen mukaan silloinkaan, kun vaikkapa nelisävelinen asteikko vastaa duuri- tai molliasteikon osaa. Poikkeuksen tästä tekevät jotkut uudempiin kansanlauluihin liittyvät sävelmät, joiden voi tulkita mukailevan länsimaisen sävelajijärjestelmän periaatteita myös sävelkuluiltaan (ks. Lippus 1995, 17).

Runolaulussa etenkin asteikon kolmannen ja välillä muidenkin sävelten korkeudet voivat vaihdella yhdenkin laulun kuluessa, eivätkä asteikon sävelten suhteet aina vastaa taidemusiikin asteikkoja (ks. esim. Lippus 1995, 98-100; Inkeristä Koski 1974, 479). Inkerissä tämä näkyy esimerkiksi tallentajien valituksena laulun epävireisyydestä tai epävakaudesta. Heidi Haapoja $(2013,48-57)$ on 30 Launiksen äänittämän soikkolalaislaulun analyysissa todennut, että usein duuri-molli-tonaliteettia noudattavaksi tulkittavat, laaja-alaisemmat (ja uudemmat) sävelmät ovat myös säveltasoiltaan vakaimpia, kun taas suppea-alaisten, tonaalisesti vaikeatulkintaisempien sävelmien sävelkorkeudet - muutkin kuin kolmas aste - varioivat enemmän sekä säkeen eri kohdissa että laulun myötä. Tyypillisesti runosävelmä on joskus voitu laulaa länsimaisesti ajatellen sekä duuri- ja molliasteikolla että niiden väliltä,

\footnotetext{
${ }^{227}$ Vrt. esim. äänitteitä SKSÄ A 300/12a ja 20c käsikirjoituksiin SibA Launis 332 ja 424, ks. kuit. SKSÄ Launis fon. 22b (ei A-signumia).
} 
ja etenkin terssin sävelkorkeus on voinut vaihdella yhdenkin esityksen puitteissa (Väisänen 1990, 90-91; Lippus 1995, 86; Kolehmainen 1977, 86). Erilaiset melodiaaihelmat ovat tulleet myös käytetyiksi eri asteikoilla (Lippus 1995, 71). ${ }^{228}$ Paikoin voi ajatella tälaisten toisintojen edustavan vaihtoehtoisia sävelkulkuja, jotka ovat voineet kuoro-osioissa kenties esiintyä myös samanaikaisena moniäänisyytenä.
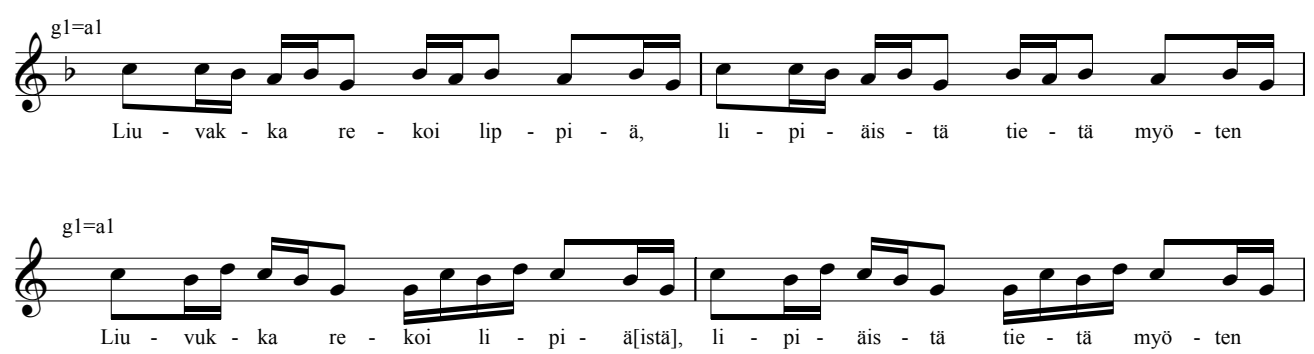

Nuotti 5. Kaksi laskiaisen liukusävelmän toisintoa (SibA Launis 223, 393b). Jälkimmäisessä esimerkissä Launiksen kirjoittamat, muiden toisintojen, runomitan ja sävelmän rytmin perusteella ylimääräiset tavut sanassa lipiä[istä] on merkitty hakasulkuihin.

Tässä yhteydessä on jälleen muistettava, että inkeriläinen sävelmistö on hyvin heterogeeninen ja monia tyylejä sisältävä. Aineistosta löytyy asteikkorakenteen kiinteyden osalta hyvin erilaisia sävelmäryhmiä. Esimerkiksi saadulmoi-sävelmän kohdalla asteikkorakenne vaikuttaa sangen kiinteältä, joskin sävelala voi vaihdella: asteikon ytimen muodostaa kolmen sävelen joukko, joka voi laajentua yhdellä sävelellä ylös tai alaspäin.
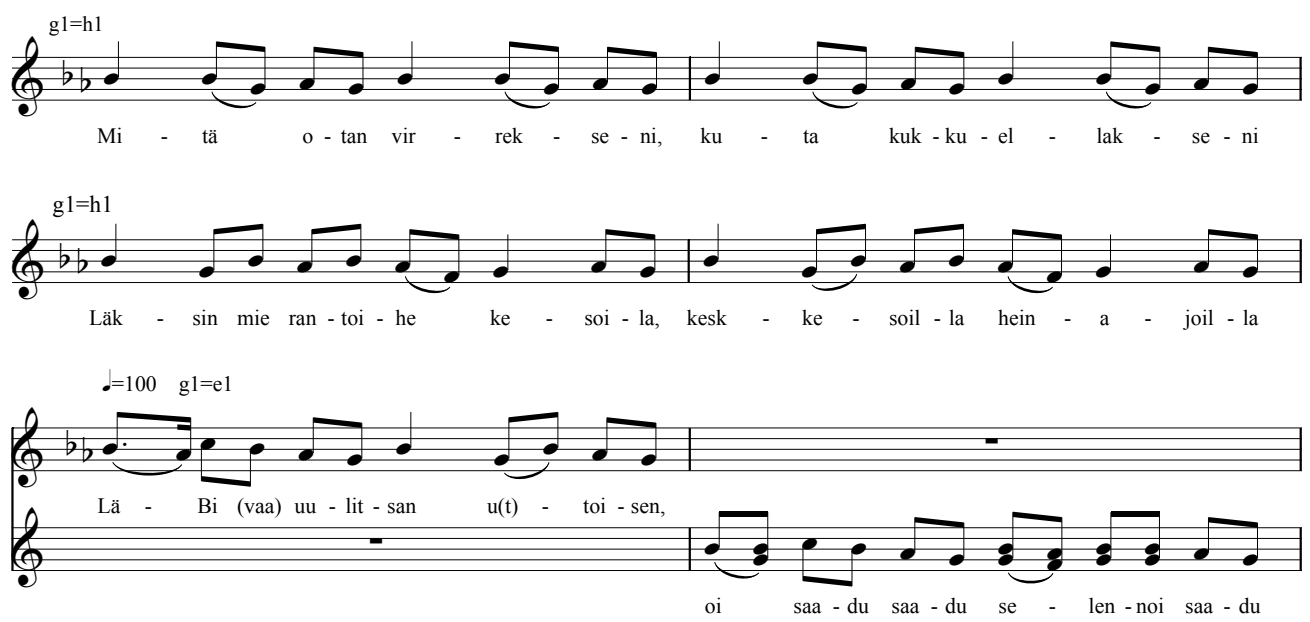

Nuotti 6. Kolme saadulmoi-sävelmän variaatiota, ensimmäinen ja viimeinen käsikirjoituksista ilman kuoro-osioiden merkintää, keskimmäinen kuoron kanssa esitetyltä äänitetallenteelta. (SibA Launis 154; SKSÄ A 300/36, säkeet 3-4; SibA Launis 166/317).

${ }^{228}$ Lippus (mts. 87) toteaa myös, että runolaulun tyyppisessä musiikissa yhteen asteikkoon voi liittyä enemmän erilaisia vaihtoehtoisia tonaalisia rakenteita kuin vaikkapa länsimaisessa klassisessa musiikissa. 
Yleensä asteikon perussävel on mahdollista määrittää runolaulunkin puitteissa suhteellisen pitävästi eri sävelten esiintymistaajuuden, pituuksien ja rakenteellisesti merkittävien sävelten (etenkin säkeen alku- ja loppusävelet) perusteella (ks. Lippus 1995, 75-81). Paikoin tämä on Lippuksen (1995, 88-89) huomion mukaan kuitenkin hankalaa: sävelmällä voi ikään kuin olla kaksi tonaalista keskusta tai sävelmä voi liikkua samanarvoisen tuntuisesti kaikilla suppean asteikon sävelillä ja alkaa ja loppua muunnelmasta riippuen vaihdellen niistä useammalla. Erityisesti näin on joidenkin vain kolme tai neljä säveltä käsittävien edestakaisten, Inkerille tyypillisten sävelmien suhteen. Sävellajien määrittämisen ongelmallisuuteen törmäsi myös Launis (1910a, IV nootti 1, 27), ja samasta ilmiöstä puhuu Gomon (1977, 282-283; ks. myös Haapoja 2013, 49-52). Näyttää myös siltä, että Länsi-Inkerissä säkeen toiseksi viimeiselle tavulle laulettu tai viimeiselle tavulle lauletuista kahdesta sävelestä ensimmäinen saattaa olla rakenteellisesti painokkaampi kuin säkeen viimeinen sävel (Gomon 1977, 282-283; Lippus 1995, 92). Säkeellä ei ikään kuin ole painokasta loppua, vaan se jatkuu suoraan seuraavaan säkeeseen - Lippuksen $(1995,63)$ tulkinnan mukaan viimeinen sävel voi toimia ikään kuin seuraavan säkeen kohotavuna.

Lippuksen $(1995,94-96)$ mukaan inkeriläissävelmät jakaantuvat melko tasaisesti erityyppisiin kolmesta kuuteen säveltä sisältäviin asteikoihin. Yleisimmät ovat hänen merkintätapaansa noudatellen $\operatorname{AHCDE}(13,4$ \% sävelmistä), $\operatorname{AHCD}(12,3 \%)$, GAHC (12 \%), GAHCD (10,8 \%), GAHCDE (5,7 \%) sekä HCDE (4,4 \%). Neljää yleisintä kolmisävelistä asteikkoa edustaa 7,4 \% sävelmistä. Tämän työn aineiston keskeiset praasnikka- ja häälaulut liikkuvat lähinnä kolmesta viiteen sävelen alalla. Sävelala liittyy osittain myös sävelmän pituuteen: yksisäkeiset sävelmät ovat aineistossa keskimäärin asteikoltaan suppeampia kuin kaksisäkeiset. Nelisäkeiset, usein uudemmista kansanlauluista vaikutteita saaneet sävelmät kuuluvat yleensä laajaalaisimpien joukkoon. Kolmisävelisistä ja nelisävelisistä sävelmistä huomattavan suuri osa on neli-iskuisia, perussäettä ilman osakertauksia toistavia ja yksisäkeisiä. Samoin vain puolen säkeen pituisista melodioista koostuvista sävelmistä suurin osa on ambitukseltaan kolme tai neljä säveltä. Kuitenkin kolmisävelisiinkin sävelmiin sisältyy muutama kaksisäkeinen melodia. Kolmella sävelellä lauletuista runoista huomattavan moni eli 41,2 \% kuuluu hää- tai praasnikkalaulujen joukkoon. Erityisesti Soikkolassa kolmisävelisillä sävelmillä on kuitenkin laulettu paljon erilaisia kertovia ja lyyrisiä runoja.

\begin{tabular}{|c|c|c|c|c|}
\hline SÄVELALA & HÄÄVIRSIÄ & $\begin{array}{c}\text { PRAASNIKKA- } \\
\text { VIRSIÄ } \\
\end{array}$ & \% AINEISTOSTA & $\begin{array}{l}\text { SÄVELMIÄ } \\
\text { YHTEENSÄ }\end{array}$ \\
\hline 3 & 16 & 5 & 41,2 & 51 \\
\hline $3+1$ & 1 & 0 & 9 & 11 \\
\hline 4 & 44 & 12 & 25,1 & 223 \\
\hline $4+1$ & 5 & 2 & 25 & 28 \\
\hline 5 & 21 & 6 & 16,7 & 162 \\
\hline $5+1$ & 4 & 0 & 26,6 & 14 \\
\hline 6 & 2 & 1 & 3,4 & 87 \\
\hline
\end{tabular}

Hää- ja praasnikkavirsiä länsi-inkeriläisessä sävelmäaineistossa 
Sitä vastoin seitsemästä kymmeneen säveltä sisältävistä sävelmistä huomattavan suuri osa on joko säkeen kertaukseltaan kaksisäkeisiä tai melodian pituudeltaan kahdesta neljään säettä, eikä niihin sisälly kuin yksi häihin väljästi assosioituva runoteema, praasnikkalauluja ei yhtäkään. Refrenkejä ja erilaisia osakertaustyyppejä liittyy sävelmiin ambituksesta riippumatta. Esimerkiksi erilaisia kalina -tyyppisiä refrenkejä liittyy niin kolmi- kuin kahdeksansävelisiinkin lauluihin. ${ }^{229}$ Yleisimpiä ne ovat silti 4-6-sävelisten melodioiden yhteydessä (20 länsi- ja keski-inkeriläisaineiston 24 toisinnosta).

Samankaltainen sävelkulku on siis välillä voitu laulaa rakenteeltaan tai laajuudeltaan erilaisilla asteikoilla, erilaisten rytmityyppien puitteissa ja pidempänä tai lyhyempänä kokonaisuutena. Ingrid Rüütel $(1977,258)$ antaa havainnollisen esimerkin vatjalaisaineistonsa yleisimmän sävelmätyypin melodian variaatiosta. Rüütel määritti sävelmätyypit tarkkaan, myös asteikon samankaltaisuuden perusteella. Sävelmän ambitus ja sen kulku eri kohdissa voivat vaihdella, mutta tietyt keskeissävelet ja melodiakulut ovat sävelmätyypille tyypillisiä. Esimerkiksi melismojen kohdalla on kuitenkin usein vaikea määrittää, mikä yhdelle säeasemalle osuvista sävelistä mahtaisi olla rakenteellisesti keskeisin: aina se ei inkeroisilla selvästikään ole ryhmän ensimmäinen sävel (ks. Lippus 1995, 91).

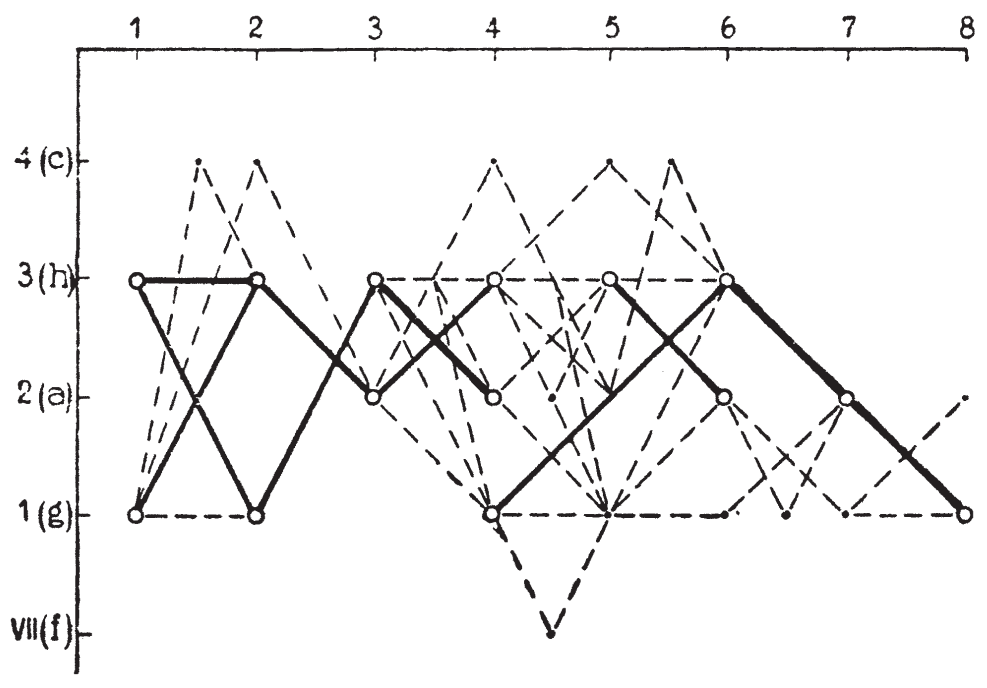

Kuva 4. Yleisen vatjalaisen yksisäkeisen, neli-iskuisen hääsävelmätyypin variaatio (Rü̈̈tel 1977, 258). Numerot VII (f)-4(c) viittaavat säveltasoihin ja numerot 1-8 säeasemiin, tässä käytännössä kahdeksasosanuotteihin. Paksut viivat kuvaavat yleisimpiä sävelkulkuja.

${ }^{229}$ SKSÄ A 300/28c; Siba Launis 6. 
Melodian ja rytmin muuntelun määrä vaihtelee aineistossa paljon toisinnoittain, ja vaikuttaa osittain olevan sidoksissa laulajaan ja sävelmätyyppiin. Terttu Koski $(1974,477)$ kuvaa yksittäisten laulajien sävelmiä hyvin vakaiksi. Hän (mts. 479480) ei puhu sävelmän muuntelusta, mutta kylläkin sävelmää koristelevista pikkusävelistä ja esittäjien taitavuudesta käyttää rajallisia ilmaisukeinoja. Heidi Haapoja $(2013,54,80)$ toteaa Launiksen äänittämän kolmen soikkolalaislaulajan muuntelun olevan hienovaraista ja luonteeltaan lähinnä melodiakulkuja koristelevaa hajasävelmuuntelua, jota esiintyy aineiston kaikissa lauluissa. Toisaalta, kuten Launiksen yhteydessä on todettu (luku 2), tallentajat näyttävät vältelleen runsaati muuntelevia laulajia ja sävelmiä tai kirjoittaneen tämänkaltaisetkin sävelmät lyhyiksi, yksiselitteisiksi yhteenvedoiksi kuulemastaan, ja lisäksi suurempi muuntelun määrä saattoi liittyä kuorolaulua vahvemmin yksinlauluun, josta on tämän työn aineiston osalta kuorolaulua vähemmän äänitetallenteita. On todettu, että runolaulussa muunnelmat usein keskittyvät sävelmätyypin tiettyihin kohtiin. Jos laulajia on monta, johtavat muunnelmat heterofoniaan, ajoittaiseen moniäänisyyteen. ${ }^{230}$ Janika Oras (2004b) on todennut kahden kihnulaisen laulajan soinnuttaneen muunnelmansa toisiinsa eri tavoin yhdessä kuin erikseen laulaessaan.

Ensimmäisenä inkeriläisen laulun moniäänisyyden mainitsi Launis (1904, 51) kertoessaan, miten hänen omia käsikirjoitusnuotteja tulisi tulkita. Käsikirjoituksiin ei moniäänisiä kohtia tai variaatioita yleensä juuri merkitty. ${ }^{231}$ Launis (1910b, XIII) puhuu terssiparalleeleina melodialinjan ylä- ja alapuolella kulkevasta ja paikoin kolmisoinnuillekin rakentuvasta moniäänisyydestä; samanaikaiset sekunnit hän tulkitsee virheiksi. Hän $(1904,51)$ pohti myös moniäänisyyden mahdollista yhteyttä ortodoksiseen kirkkolauluun. Inkeriläinen terssiparalleelleihin ja kolmisointuisuuteen pohjautuva moniäänisyys onki usein ajateltu venäläiseen (kansan) lauluun liittyväksi. Tätä tukee se, että aineistossa selkeimmin moniääniset käsikirjoitus- ja äänitetoisinnot tuntuvat tyyliltään olevan lähellä uudempia kansanlauluja: suppea-alaisiin tyypillisiin runosävelmiin selkeän moniäänisiä rakenteita liittyy harvemmin. Monissa Launiksen ja Laihojen äänittämissä uudemman tyylisissä toisinnoissa taas voi hahmottaa jopa erillisiä stemmoja. Sitä vastoin samojenkin laulajien esittämissä suppea-alaisemmissa sävelmissä moniäänisyys on luonteeltaan muunnelmiin perustuvaa hetkittäistä heterofoniaa. Tällöin äänet ikään kuin menevät varioiden ristiin: melodialla on tietyissä kohdissaan vaihtoehtoisia kulkutapoja, jotka vaikuttavat paikoin lähes samanarvoisilta. Tällöin myös länsimaisittain riitasointuisilta tuntuvat intervallit ovat yleisiä. Muuntelevat kohdat vaihtelevat sävelmätyypeittäin ja osin esityksittäin. ${ }^{232}$ (Ks. myös Haapoja 2013, 53-57.)

\footnotetext{
${ }^{230}$ Asplund \& Laitinen 1979, 14; Asplund 1981, 29; Laitinen 1976, 163; Laitinen 2004; Oras 2004b. Kansanmusiikin muuntelusta yleisemmin ks. Saha 1996.

${ }^{231}$ Boreniuksella ensisilmäyksellä moniäänisyyksiltä tai variaatioilta vaikuttavat merkinnät ovat yleensä korjausten aiheuttamia (pieni yliveto toisen nuotin päällä tai puhtaaksikirjoitus nuotin jäljessä, esim. SKS KRA Borenius e 187-188, 211; ks. kuit. Borenius e 123, 217. Ingrid Rüütelin $(1988,21)$ mukaan Inkerissä etenkin inkeroisten runolaulun moniäänisyys vaikuttaa sekä yksittäisillä laulajilla että tiettyjen esitysten puitteissa luonteeltaan pysyvämmältä ja säännönmukaisemmalta kuin Virossa, esimerkiksi Kihnussa tavattava satunnaisempi heterofonia.

${ }^{232}$ Ks. esim. hää- ja liekkulaulujen äänitteitä (ks. Liite 5: Hääsävelmät/tavalliset pulmanuotit; Liekkusävelmät) ja monia laaja-alaisempien, lähinnä lyyristen ja lyyriseeppisten runojen kanssa käytettyjä sävelmiä kuten SKSÄ L 88, 90a, 91a, 95a; SKSÄ A 300/15, 35a, 35b, 36b, 46a; 301/12b, 13a; sekä myös joitain lyyrisempiä häälauluja (Liite 5: hääsävelmät / Tyttöjen laulu / Oi dai).
} 
Terttu Koski $(1974,482)$ toteaa inkeroisten tyypillisesti laulavan "unisonossa, harvoin terssipoikkeamin" ja varsinaisen kaksi- tai kolmiäänisyyden esiintyvän lähinnä runolaulussa käytettyjen venäläisten sävelmien yhteydessä. Tämä voi osaltaan selittää Launiksen ja Väisäsen inkeriläisen laulun kuvausten eroja. Siinä missä Launis korosti rinnakkaisiin terssikulkuihin perustuvaa moniäänisyyttä, kuvasi nuori Väisänen inkeriläisen laulun yksiääniseksi ja moniäänisen setulaulun jälkeen kuivalta kuulostavaksi. Näyttääkin siltä, että Launiksen monipuolinen kokoelma antaa länsi-inkeriläisestä runolaulusta monimutkaisempien rakenteiden puolelle painottuvan kuvan. Siinä missä Launis viipyi alueella kauan, seurasi laulamista ja parhaita laulajia myös praasnikkahumussa ja etsi nimenomaan monimutkaisempia, itseään miellyttäviä sävelmiä, kävi Väisänen Inkerissä arkisen nopeasti lähinnä paimensävelmiä tallentamassa. Lyhyellä retkellään hän sai kuultavakseen ja tallennettavakseen tyypillisiä yksisäkeisiä, suppea-alaisia runosävelmiä, joihin ei selkeää moniäänisyyttä liittynyt, ennemminkin muuntelun tuottamaa "kakofoniaa." Väisänen saattoi myös Launista selkeämmin olla tietoinen venäläisten laulujen tyyleistä ja välttää niitä vierasperäisinä. Vasta runosävelmiin kunnolla tutkimuksellisesti paneuduttuaan kuvasi hänkin inkeriläisen runolaulun setulaulun tapaan vaatimattomalla tavalla moniääniseksi (Väisänen 1990, 73). (Ks. tarkemmin Kallio 2011b.)

\section{MUOTORAKENNE JA SÄKEIDEN KERTAAMINEN}

Muotorakenteella tarkoitan laulajien käyttämää runosäkeeseen suhteessa olevaa laulun rakennetta eli sitä, montako runosäettä soololauluaja tai esilaulaja ja kuoro laulavat tai kertaavat yhden vuoronsa aikana ja missä muodossa nämä runosäkeet toteutuvat. Käsite kattaa myös lauluun sisältyvät refrenkitavut, puuttuvat tavut ja osakertaukset. Muotorakenne ei aineiston ominaisuuksien johdosta ole suorassa suhteessa sävelmän pituuteen, sillä esimerkiksi kaksisäkeisen (tekstuaalisen) muotorakenteen yhteydessä on voitu yhtä hyvin käyttää neli- kuin yksisäkeistäkin sävelmäjaksoa. Suuressa osassa kalevalamittaista laulua muotorakenne on hyödytön käsite: Inkeriä pohjoisempana lauluun ei juuri refrenkejä tai osakertauksia liity, suurin osa aineistosta on tallennettu yksittäisiltä laulajilta eikä esilaulun ja kuoron vuorotteluna etenevästä laulusta ole tietoa. Esimerkiksi Ilkka Kolehmainen (1977, 36-51) käsitteleekin muotorakenteen nimellä sitä, vastaako sävelmän pituus yhtä, kahta vai neljää runosäettä. ${ }^{233}$

Muotorakenteen analyysin kohdalla käsikirjoitusaineiston käyttö on ongelmallista, sillä etenkään säkeen kertausten tapoja tai kuoron ja esilaulajan vaihtelua ei useinkaan ole nuotteihin merkitty eivätkä kaikki etenkään monimutkaisempien muotorakenteiden merkinnät vaikuta ääniteaineiston valossa luotettavilta. Launis (1910a, 1910b, 1930) nosti silti ilmeisesti Inkerin kokemustensa pohjalta esilaulajan ja kuoron tai jälestälaulajan vuorottelun koko aineiston analyysiaan ja järjestämistään ohjaavaksi periaatteeksi. Näin hän teki myös niiden lajien ja alueiden osalta, joiden piirissä sitä ei esiintynyt, ja päätteli jälkikäteen kuoro-osuudet myös yhdeltä laula-

${ }^{233}$ Sävelmän muodon analyysista ks. esim. Huttu-Hiltunen 2008, 123-124. 
jalta tallennettuihin sävelmämuistiinpanoihin. Kuten luvussa 2 olen todennut, en pidä näitä tulkintoja kaikin osin uskottavina. Keskitänkin muotorakenteen tarkastelun lähinnä ääniteaineistoihin sekä A. A. Boreniuksen muistiinpanoihin.

Inkerissä juuri muotorakenteeksi kutsumani rakenteellinen taso näyttää praasnikka- ja häälaulujen käytön ja nimeämisen kannalta merkittävältä. Sekä sävelmäjakson pituus että säkeiden kertaustapa ovat yhteydessä laulun muotorakenteeseen, mutta eivät ehdotomilla tavoilla. Muotorakenteeltaan yksisäkeinen sävelmä voi aineistossa koostua koko säkeen pituisesta tai muutamasta lyhyemmästä melodia- ja rytmijaksosta. Muotorakenteeltan kaksisäkeinen sävelmä koostuu yleensä säkeen, kahden tai neljän säkeen sävelmäjaksosta. Näiden välillä on monia sekamuotoja: kaksi samankaltaista säettä, kaksi samankaltaista säeparia, kaksisäkeinen esilaulu ja pituudeltaan sekä melodialtaan tästä eroava kuoro-osa. ${ }^{234}$ Muotorakenteeltaan kaksisäkeisten sävelmien esilaulussa ei aineistossa koskaan ole osakertauksia tai refrenkejä. Joskus esilaulu- ja kuoro-osuus voivat olla sävelmältään eripituiset tai muuten erilaiset. Esimerkiksi tyypillisesti kahden runosäkeen kertaukselle perustuva ja siten muotorakenteeltaan kaksisäkeiseksi hahmottamani, kokonaisrakenteeltaan helposti tunnistettava Hevaan nuotti on voinut koostua joko yhden tai neljän säkeen pituisesta melodiajaksosta. ${ }^{235}$ Sävelmän tekstuaalinen rakenne koostuu poikkeuksetta kahdesta runosäkeestä (esilaulaja) sekä niiden osakertauksista ja refrenkisanasta (kuoro), kuten seuraavassa Hevaalta tallennetussa laskiaisen liukusävenessä.

$\begin{aligned} \text { Ennen päivytäk eletty } & 12345678 \\ \text { kupaeltu ilman kuutak } & 12345678 \\ \text { ilman ilman kuutak } & 565678 \\ \text { ilman kuutak joonoi } & 5678^{* *}\end{aligned}$

Refrenkisana on tyypillisimmin joono tai joonoi, mutta myös muita vaihtoehtoja esiintyy. On esimerkkejä myös soololaulajan esittämästä, rakenteeltaan samanlaisesta Hevaan nuotista. ${ }^{236}$ Tämä liukusäven rakentui yhden säkeen pituisesta, muotorakenteen aikana neljä kertaa kertautuvasta sävelmäjaksosta, mutta sävelmäsäkeitä saatettiin myös muunnella nelisäkeiseksi rakenteeksi tai kuoro-osan melodiakulku saattoi poiketa esilaulusta.

\footnotetext{
${ }^{234}$ Ks. esim. SibA Launis 4, 74, 354, 454; SKSÄ A 300/23a, 49b, 50a; 301/3a, 35a.

${ }^{235}$ 1800-luvulla tallennetun säkeistöllisen kansanlaulun nuottiaineiston ja myöhempien arkistoäänitteiden pohjalta Heikki Laitinen $(2003 a, 220)$ toteaa, "etteivät säkeistön osien kertaukset kuulu varsinaiseen rakenteeseen vaan ovat ikään kuin laulajan valinnassa olevia keinovaroja, joilla rakennetta voi esityksessä pehmentää tai jopa hämärtää.” Niiden käyttö varioi samallakin laulajalla ja liittyy välillä tyypillisimmin tiettyihin säkeistörakenteisiin. Säkeistön kertaamisen tavat ovat siis oikeastaan oma esityksellinen tasonsa.

${ }^{236}$ Esim. SKSÄ A 301/48a ja b; myös ilman laulajatietoja tallennetuissa käsikirjoitusmuistiinpanoissa Hevaan nuotti toistuu usein rakenteeltaan melko vakaana (esim. SibA Launis 385).
} 

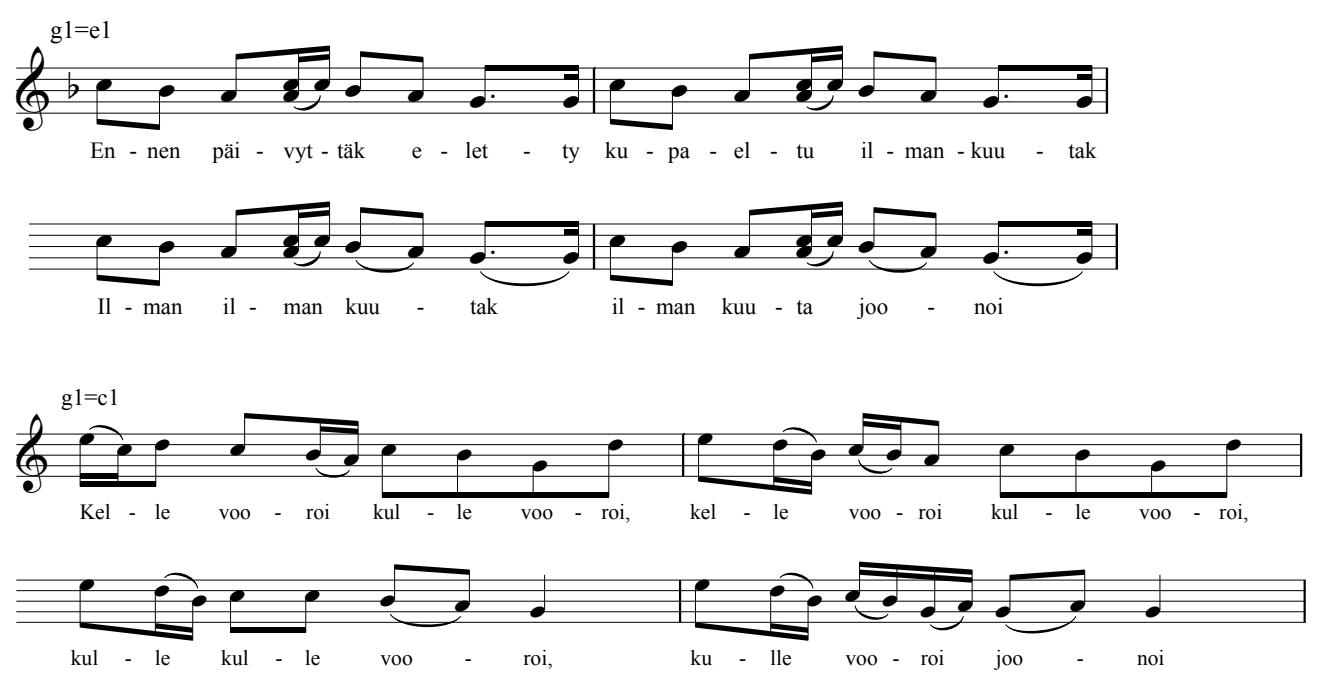

Nuotti 7. Kaksi Hevaan nuotin toisintoa, joista ensimmäinen rakentuu yhden sävelmäsäkeen muuntelemattomalle toistolle, toinen yhden sävelmäsäkeen muunnelmille. (SKS KRA Borenius e 177, 125.)

Eroa yksisäkeisen ja kaksisäkeisen sävelmän välille onkin joskus vaikea vetää: esimerkiksi kuoro-osan muunnelmat tai moniääniset rakenteet voivat luoda tunnun kaksisäkeisyydestä yksisäkeisenkin muotorakenteen yhteydessä ja on toisaalta vaikea määrittää, kuinka monen sävelen täytyisi toisessa sävelmäsäkeessä olla erilainen, jotta kyseessä olisi kaksisäkeinen sävelmä (ks. myös Laitinen 2006, 70-72; Rüütel 1977, 267; Väisänen 1990, 109). Heikki Laitinen (2003, 220-221) toteaa rekilaulun yhteydessä olevan "erillisen tutkimuksen aihe yrittää selvittää äänitteiden avulla, kokeeko laulaja" myös kaksisäkeisellä sävelmällä nelisäkeistä säkeistöä laulaessaan "musiikillisen säkeistön nelisäkeiseksi," eli, tulkintani mukaan, yhdistääkö hän esimerkiksi laulunsa rytmityksellä, painotuksilla tai hengitystauoilla kaksi sävelmäyksikköä aina nelisäkeiseksi kokonaisuudeksi, vaikka ne analyysin karkeammalla tasolla näyttäytyvät erillisenä. A. G. Gomon (1977, 182-184) toteaa soikkolalaisen soololaulun yhteydessä, että hengitystauon säännöllinen sijoittuminen melodialtaan samanlaisen säeparin väliin luo jo tunnelman kaksisäkeisestä rakenteesta siinä missä sen sijoittuminen lähinnä säkeen keskelle päättymättömästä jonomaisuudesta, ja tällöin tunne muotorakenteesta voi hengitystauon käytön myötä vaihtua jopa kesken laulun. Tämän työn ääniteaineistossa hengitystaukojen ja säkeiden toisiinsa sitomisen tavat vaihtelevat sekä esityksittäin että sävelmätyypeittäin. Tyypillisimmin yksin laulava hengittää säkeiden keskellä, joskus jopa runon tavun katkolla korvaten, ja esilaulaja ja kuoro puolestaan tarttuvat yleisimmin toistensa säkeisiin niin, että säkeiden väliin ei tule taukoa. Näyttää tosin siltä, että Launis pyrki ensimmäisten äänitetallenteidensa jälkeen tallentamaan soololauluja lähinnä niiltä laulajilta, joilla ei ollut tapana pitää hengitystaukoja keskellä säettä (ks. Launis 1907, 105). Lyhyillä fonogramminpätkillä soololaulaja saattaa laulaa seitsemänkin säettä ilman hengitystaukoa. ${ }^{237}$ Joskus yksin laulavan hengitystauot voivat kuitenkin osua pääosin säkeiden tai säeparien väliin ja etenkin muutamassa

${ }^{237}$ SKSÄ A 300/29a. 
venäläisvaikutteisessa sävelmässä kuoron ja esilaulun osuuksia ei lauleta päällekkäin - tällöinkään ei säkeiden väliin kuitenkaan tule varsinaista taukoa. ${ }^{238}$

Kaikkein karkeimmalla tasolla aineiston muotorakenteet jakautuvat kahtia. Toisessa esilaulajan ja kuoron yksi vuoro perustuu yhden, toisessa kahden runosäkeen kertaukselle. Kumpaankin voi liittyä tai olla liittymättä erilaisia osakertauksia, refrenkejä ja refrenkitavuja. Länsi-inkeriläisen aineiston praasnikka- ja häälaulut ovat lähes poikkeuksetta muotorakenteeltaan yksisäkeisiä, eikä niihin kokkovirttä lukuun ottamatta liity säettä korvaavia refrenkejä.

Yksinkertaisimmillaan esilaulaja laulaa yhden tai kaksi runosäettä, jotka kuoro kertaa sellaisinaan. Soololaulussa kertaukset voivat jäädä kokonaan pois, tulla lauletuiksi kuten kuoron kanssa tai tulla käytetyiksi osittain, epäsäännöllisemmin. Inkeriläisille muotorakenteeltaan kaksisäkeisille lauluille on lisäksi yleistä, että esitai soololaulaja uuden säeparinsa alussa joskus kertaa edellisen säeparinsa jälkimmäisen säkeen:

$\begin{array}{ll}\begin{array}{l}\text { löim miä jalGoini kiv(v)oiHe } \\ \text { istusin maaHa itkemää } \\ \text { oi liiaa itkemää } \\ \text { istuin maaHa itkemää }\end{array} & \begin{array}{l}\text { Löin minä jalkani kivehen, } \\ \text { istuin maahan itkemään, }\end{array} \\ \begin{array}{l}\text { istusim maaHa itkömäHä } \\ \text { kivem päälle kiljumaa } \\ \text { oi liiaa kil(i)jumaa } \\ \text { kiven päälle kil(i)jumaa }{ }^{239}\end{array} & \begin{array}{l}\text { istuin maahan itkemään, } \\ \text { kiven päälle kiljumaan. }\end{array}\end{array}$

Tämänkaltainen kiertokerroksi kutsumani kertauksen käyttö näyttää olevan osittain sidoksissa runon kielelliseen rakenteeseen: uusi temaattinen jakso aloitetaan herkemmin (joskaan ei aina) säeparin ensimmäisellä säkeellä, eivätkä jakson aloittavat säkeet yleensä tule kerratuiksi. ${ }^{240}$ Kolmen toisiinsa liittyvän säkeen ryhmistä muodostuu usein kertausketjuja: "meijen maille tullessaHa, meijen maille maireHi[lle] / meijen maille maireHille, ilmoille ikihyvi[lle]."241 Aina nämä eivät ole suoranaisia klassisen kalevalamitan sääntöjen mukaisia paralleelisäkeitä. Kaikki runon esisäkeet eivät myöskään aina sijoitu musiikillisen säeparin alkuun edes silloin, kun ne esiintyvät vain kerran.

Laulun jostakin syystä katkettua tai takelleltuaan esilaulaja jatkaa suoraan seuraavasta säkeestä $^{242}$ tai viimeksi laulamastaan tai aloittamastaan säkeestä tai säepa-

\footnotetext{
${ }^{238}$ Täman kaltaisista yksinlauluista ks. SKSÄ A 300/10a, 10b, 11b; kaksisäkeisistä sävelmistä SKSÄ A 300/50b, 301/5b; kuoron kanssa esitetyistä ks. SKSÄ A 300/49a, 49b, 51b, 301/13a (joissa tosin kuoro kuulostaa epävarmalta ja esilaulaja laulaa myös kuoro-osuuksia); 301/3b, 11a.

${ }^{239}$ SKSÄ A 300/26b.

${ }^{240}$ Vrt. kuit. esim SKSÄ A. 300/21b, esilaulun neljäs säe.

${ }^{241}$ SKSÄ A 301/4a

${ }^{242}$ SKSÄ A 300/15, 20a, 22b (säkeet 22-23), 25b (säkeet 21-22).
} 
rista. ${ }^{243}$ Yksisäkeisten muotorakenteiden yhteydessä esilaulaja ei näitä tapauksia lukuun ottamatta koskaan laula kahta kertaa samaa säettä. Kaksisäkeisten muotorakenteiden yhteydessä esilaulajan säkeenkertauksen mahdollisuudet näyttäytyvät runsaampina. Esilaulaja voi 1) laulaa aina uuden säeparin säkeitä kertaamatta, 2) kerrata säeparin jälkimmäisen säkeen seuraavan säeparin ensimmäisenä säkeenä, joko läpi laulun tai satunnaisesti (kiertokerto), 3) kerrata joskus kokonaisen säeparin tai 4) laulaa jokaisessa säeparissa saman säkeen kaksi kertaa. Kuoron erilaiset kertauksen tavat sitä vastoin ovat kaikki sidoksissa laulun yleiseen muotorakenteeseen, joten ne eivät juuri varioi yhden esityksen sisällä. Laulua määrää se, että ennalta tehtyjä sovituksia ei ole: kuoron liikkumavara on esilaulajan, sävelmätyypin ja ilmeisesti osin paikallisten ja tilannesidonnaisten laulamisen tyylien määräämä ja liittyy lähinnä sävelkulun hienovaraiseen variaatioon sekä satunnaisten lisätavujen käyttöön.

Länsi-inkeriläisen ääniteaineiston sisältämässä yksinlaulussa rakenteiden käyttö on selvästi joukolla laulamista vapaampaa, vaikka toisaalta soololaulaja saattoi myös noudattaa täysin samaa rakennetta kuin olisi tehnyt kuoron kanssa laulaessaan. Osa soololauluista noudattelee kertaustavaltaan erilaisia esilaulu-kuoro -malleja ja on täysin verrattavissa kuoron kanssa tallennettuihin lauluihin. ${ }^{244}$ Joissain yksin lauletuissa sävelmissä säkeen kertausta ei ole ollenkaan satunnaista kaksisäkeisten muotorakenteiden kiertokertoa lukuun ottamatta ${ }^{245}$ ja joissain laulaja kertaa vain osan säkeistä tai säepareista ${ }^{246}$ tai käyttää kuoro-osien rakenteita joukkolaululle mahdottomin, epäsäännöllisin tavoin. ${ }^{247}$ Tämä vaihtelu on aineistossa esitys-, ei laulajakohtaista. Muutamassa Launiksen tallentamassa lyhyessä soololaulun alussa laulun perusrakenne jää jopa hieman epäselväksi laulajan ilmeisesti improvisoidessa runo- ja sävelmäsäkeiden suhteita sangen vapaasti. ${ }^{248}$ Ääniteaineistoon kuuluu ainoastaan yksi soololauluna esitetty hää- tai praasnikkavirsi. Darja Lehti esittää häiden tervehdyslaulun jokaisen säkeen kerraten, kuin laulaisi myös kuoron osuudet. Voikin ajatella tämän olevan tyypillisesti kuoron kanssa esitettyjen laulujen kohdalla luontevaa. ${ }^{249}$

\footnotetext{
${ }^{243}$ SKSÄ A 300/17a, 18a, 29c, 31b, 32b, 33b.

${ }^{244}$ ERA, Fon. 207a, 209a; 209c; SKSÄ A 300/9c, 10a, 10b, 11a, 11b, 28c. Keski-Inkeristä ks. SKSÄ A $301 / 16$ c, 17a, 17b, 18b, 20a, 21b, 23a, 24a, 27a-28a, 29a, 29b, 41b-43b, 45b, 46b, 47a, 48b, 50a, 56a.

${ }^{245}$ ERA, Fon. 209b, 358; 372b, 372c; SKSÄ A 300/9a, 50b; SKSÄ L 101e. Keski-Inkeristä ks. SKSÄ A 301/28b, 30a, 31a, 34a, 40b, 43c, 44a, 44b, 50b, 50c.

${ }^{246}$ ERA, Fon. 208a; SKSÄ A 300/29 a, A 301/5 b; SKSÄ L 90b, 90c. Keski-Inkeristä ks. SKSÄ A 301/ 18a, 21a, 22a, 22b, 23b, 25a, 25b, 26b, 30a, 41a.

${ }^{247}$ Ks. erit. SKSÄ A 301/30a, 31b, 40a ja 48a Hevaalta; Länsi-Inkeristä SKSÄ 301/5b; SKSÄ L90 b ja c sekä seuraava viite.

${ }^{248}$ SKSÄ A 301/4b, 7a. Myös Launiksen tallentamassa käsikirjoitusaineistossa on toisintoja, jotka tuntuvat viittaavan rytmisesti hyvin varioivaan esitykseen (esim. SibA Launis 67, 276, 286, 317b).

${ }^{249}$ ERA, Fon. 209b; ks. samoin tanssilaulu (ERA, Fon. 209c) sekä tyypillisesti joukolla laulettu, kalevalamittaiseksi runoksi kesken kaiken liukuva tšastuška (ERA, Fon. 207a); sekä Hevaalta kylän läpi kulkemiseen liittyvät laulut (SKSÄ A 301/20a, 23a); kokkovirsi (SKSÄ A 301/46b), häälaulu (SKSÄ 301/24b) sekä häälaulut, joissa muutama säe jää kertaamatta (SKSÄ 301/25a, 26b). Toisaalta nimettömäksi jäänyt Hevaan Iilian virren (Ukkovirsi) esittäjä ei kerrannut säkeitään (SKSÄ A 301/34a) kuten ei myöskään Katariina Joosepintytär häälauluja esittäessään (SKSÄ 301/40b, 41a, 44a).
} 
Runosäkeitä oli laulun puitteissa mahdollista siis kerrata useammalla tavalla: joko yksi tai kaksi säettä kerrallaan, korvata kertaukset refrengillä, jättää säkeet kertaamatta kokonaan tai kerrata niitä vain satunnaisesti. Näistä kaksi jälkimmäistä esiintyvät ainoastaan soololaulussa. Kuten luvuissa 6 ja 7 käy ilmi, Länsi-Inkerissä kaikki keskeisiin praasnikka- ja häälauluihin liittyvät muotorakenteet perustuvat yhden runosäkeen kertaamiselle: esilaulaja laulaa säkeen, jonka jälkeen kuoro kertaa sen kokonaan tai osin. Laulajilla oli kyseiselle muotorakenteelle oma terminsä, jolla määritettiin nimenomaan häälauluja: ne laulettiin kahel sanal eli säe kerrallaan, yksi säe eli sana kaksi kertaa. Liuku-, liekku-, kiletoi- sekä kahden tyypillisimmän hääsävelmän yhteydessä laulussa käytetty tekstuaalinen rakenne onkin Länsi-Inkerissä yksinkertaisin mahdollinen: laulu etenee säe kerrallaan. Muotorakenteen yksinkertaisuus korreloi tässä yhteydessä sävelmätyypin kanssa: sävelmät, joiden puitteissa runot etenevät sellaisenaan, yksi säe kerrallaan kertautuen, ovat tyypillisesti sävelaltaan suppeita, usein neli-iskuisia ja yhden säkeen pituisia. Länsi-Inkerissä ainoa aineistoon sisältyvä muotorakenteeltaan kaksisäkeinen, varsinaisen häärunon yhteydessä käytetty sävelmä liittyy Yks oli oksa ounapuussa -runoon, joka oli luonteeltaan poikkeuksellisen liikkuva, moneen eri runosikermään ja häärituaalin kohtaan yhdistettävissä oleva teema. Kahel sanal -määritelmää mukaillen esilaulaja kuitenkin tässäkin kertasi oman säkeensä, eli lauloi oman osuutensa aikana ainoastaan yhden uuden runosäkeen. Samankaltaisilla sävelmillä lyyristä epiikkaa laulettaessa esilaulaja esitti aina kaksi uutta runosäettä kerrallaan. Muotorakenne ja säkeiden kertaamisen tapa kytki laulamisen osaltaan soolo- tai kuorolaulun, rituaalisen tai vapaamuotoisemman laulamisen kehyksiin. 


\section{PAIKALLISET NIMITYKSET}

Nimitykset ovat keskeinen avain paikallisiin lajeihin. Se, mitä laulu oli käytännössä - miten erilaiset tekstuaaliset, esitykselliset ja musiikilliset piirteet liittyivät toisiinsa ja tiettyihin laulutilanteisiin - antaa kuvaa laulamisen tilannesidonnaisista tavoista eli rekistereistä. Näistä rekistereistä puhun paikallisina lajeina vasta silloin, kun on syytä olettaa myös puheyhteisön olleen tietoisia niistä. Tämä taas käy ilmi pääasiassa tallentuneista nimityksistä. Karkeimmillaan nimitykset voi tämän työn puitteissa jakaa kolmeen ryhmään. Ne liittyvät joko ensisijaisesti runon tekstiin (virsi, laulu), sävelmään tai esittämistapaan (nuotti, sävel, loru, luku) tai liikkeen tai äänen laatuun (ympärikko, pitkä ääni, tanssi). Liikkeeseen ja äänen laatuun liittyviä nimityksiä käsittelen tarkemmin luvussa 4 . Loitsuihin liittyvät luvut ja vihat on pääosin rajattu tarkastelun ulkopuolelle.

Laulujen paikalliset nimitykset eivät olleet yhdenkään kerääjän keskeinen tallennuskohde. Suhteessa runojen määrään niitä on niukalti, kolmisen sataa. Sävelmien nuotti-nimityksiä on Soikkolasta ja Narvusista 16, laulu-nimityksiä 7, virsi-nimityksiä 24 sekä yksi runo-nimitys. Yllättävää on paikallisten nimitysten niukkuus monien esitystavoista ja sävelmistäkin eri tavoin kiinnostuneiden kerääjien muistiinpanoissa.

Senni Timonen $(2004,91-92)$ on todennut länsi- ja keski-inkeriläisten laulajien nimenneen vaihtelevin, tietoisin ja toisiinsa limittyvin tavoin sekä runojaan että sävelmiään. Timonen kuvaa sävelmiin liittyvien nimitysten jaottuvan ainakin kuuteen osin limittäiseen ryhmään, jotka rakentuvat toiminnan (tantsunuotti), ajankohdan (pääsiäisnuotti), laulupaikan (liekkunuotti), laulun minän tai laulajien (morsiamen nuotti), musiikillisten piirteiden (pillinuotti) tai sävelmän kotipaikan (Hevaan nuotti) mukaan. Järjestelmä oli joustava. Eri nimityksillä on välillä viitattu samaan tilanteeseen tai sävelmään, ja toisaalta joukossa on myös paikallisia ja laulajakohtaisiakin eroja.

Nimitysten kohdalla kaikkein monikerroksisin ja laajin joukko ovat häälaulut. Timonen $(2004,152-153)$ päätyy siihen, että Keski- ja Länsi-Inkerin hää- tai pulmavirsinimitykset ovat koskeneet hyvinkin erilaisia runoja niin, että "mitä tahansa häärituaalin piiriin kuuluvaa hääaiheista runoa saatettiin kutsua tällä nimellä. Moni rajattu teema saa lisäksi tarkemman määrityksen eli asettuu häävirren alakategoriaksi." Niinpä esimerkiksi morsianta kylvettäessä laulettu kylvetysvirsi kuului yleisemmin pulmavirsien joukkoon. ${ }^{250}$ Timonen toteaa kansanomaisten nimitysten painottuneen paikallisesti: "hääsäven tai hääsävene oli käytössä Hevaan inkeroiskylissä, häänuotti Tyrössä ja Skuoritsassa, pulmanuotti tai -nootti Soikkolassa ja Narvusissa ja pulmaääl(i) vatjalaisilla." Runoja taas kutsuttiin nimityksillä heävers ja häävirzi Keski-Inkerissä ja pulmavirzi, pulmavers Länsi-Inkerissä.

\footnotetext{
${ }^{250}$ Esimerkiksi vuoden 1938 äänitysten oheistiedoissa tämä on suoraankin esillä: "morsiamen kylvetysvirsi, pulmavirsi" (SKSÄ L 98 a). Häälaulujen kohdalla yleisotsikkona on usein pulmavirsi, jonka alla lauluja on eritelty joko kontekstiviittein tai tarkemmin nimityksin (esim. SKVR III 395-415).
} 
Monilla runoilla ei vakiintuneita nimiä selvästikään ollut. Nimenä saatettiin ilmeisesti käyttää alkusäkeitä: "Ennen laulettiin tässä niit virsii, että: Jouluna Jumala synty, Parahalla pakkasella" ${ }^{251}$ tai kuvata runoa muuten. Kuvauksia on tosin välillä vaikea erottaa nimityksistä. Tallentaja on saattanut tulkita nimityksen kuvaukseksi tai päinvastoin, ja usein ainoa keino päätellä nimityksen vakiintuneisuutta on tutkia, löytyykö samankaltaisia nimityksiä eri tallentajilta ja eri esittäjiltä. Välillä näyttää siltä, että runonkerääjälle on mainittu runon paikallinen nimitys, mutta hän on katsonut parhaaksi selittää sen sisällön tai kääntää sen kirjakielelle. Esimerkiksi Länkelä ei kirjoittanut runomuistiinpanonsa Iilian ja Pedron virsi, vaan "Pietarin ja Iilian juhlina laulettava virsi."252 Muissa tallenteissa kyseisen runon nimityksenä on Iilian tai Pedron virsi.

Etenkin häälaulujen eli pulmavirsien kohdalla on vaikea erottaa kuvausta ja nimitystä toisistaan. Onko "kuin lähetään kartanosta" häälaulun alanimitys? ${ }^{253} \mathrm{Ky}$ symykseen vastaaminen edellyttäisi tallentunutta tarkempia tietoja yhteisön sisäisistä puhumisen tavoista. Tässä alaluvussa on mukaan otettu ainoastaan selkeän kiteytyneet nimitykset. Etenkin hälauulujen kohdalla laulajat (tai tallentajat) ovat usein suosineet kuvailevia kontekstimainintoja. Esimerkiksi Mari Roju selitti pulmavirsistä laulutilanteisiin viitaten ennen 14-säkeistä runoaan: "Saunast ko tulloo tyttö - siis pessää päätä -, niit' virsii tunnen." (SKVR III 2397; ks. myös esim. SKS KRA A. Laiho 3441.) Vastaavaa runoa on aineistossa nimetty kolmeen otteeseen sauna- tai saunastatulovirreksi.

Oman ongelmansa muodostaa se, missä määrin kukakin tallentaja on kirjoittanut ylös paikallisilta kuulemansa nimityksen, missä määrin omalle kielelleen tai oman käsitejärjestelmänsä mukaiseksi kääntämänsä termin. Liekutusvirsi vai kehtolaulu, pulmanuotti vai häälaulu, ympärikkovirsi vai piirileikki? Suomen kirjakielelle vieraanpuoleiset nimitykset on helppo tunnistaa länsi-inkeriläisiksi, mutta kerääjille tuttuja nimeämistapoja mukailevat ovat vaikea tapaus. Ovatko ne kerääjän käännöksiä vai paikallisten itse käyttämiä? Yhden vastauksen antaa nimitysten tarkastelu tallentajittain, paikkakunnittain ja ryhmittäin.

Alkujaan ajattelin, että määreet nuotti (nootti), virsi (verz) ja sävel antavat selkeän viitteen paikallisten omista termeistä, kun taas laulu ja runo viittaisivat tallentajan muotoiluun. Aineiston analyysi muutti käsitystä. Näyttää siltä, että laulu-määre esiintyy myös monissa suoriksi sitaateiksi tulkittavissa kuvauksissa, useilla luotettavillakin tallentajilla ja yhdistyneenä selkeästi paikallisiin tai kansanomaisiin määreisiin, kuten narrimislaulujen yhteydessä. Laulu-määreet painottuvat inkerinsuomalaisilta ja Narvusin alueelta tallennettuihin runoihin, vaikka niitä esiintyy jonkin verran myös Soikkolasta ja inkeroisilta tehdyissä tallenteissa. Lopullista varmuutta laulu-sanan kansanomaisesta käytöstä ei yksittäisten tapausten osalta ole mahdollista saada. Selvää on, että sitä on jonkin verran käytetty, mutta epä-

\footnotetext{
${ }^{251}$ SKVR III 1784, ks. myös SKS KRA Enäjärvi-Haavio 549, 551; Haavio 2793, 2796; Salminen 2956.

${ }^{252}$ SKVR III 226

${ }^{253}$ SKVR III 8.
} 
selvää on, milloin tallentajat ovat korvanneet sille itselleen tässä yhteydessä vieraampia nuotti- tai virsi-termejä. Sanoja laulu ja laulaa esiintyy runsaasti myös kaikilta Länsi-Inkerin etnisiltä ryhmiltä tallennetuissa runoissa. Sen sijaan runosanaa esiintyy ainoastaan kahdessa Soikkolasta tallennetun Lie tässä runoiksi noussa -teeman toisinnossa, joista ainakin toinen on inkerinsuomalaisesta Väärnojan kylästä. ${ }^{254}$ Tuntuu siltä, että sen käyttö paikallisten nimitysten yhteydessä liittyy lähinnä tallentajien omiin muotoiluihin. Termejä laulu, virsi (vers, verz, virs, vers) ja nuotti (nootti) löytyy runsaasti sekä nimityksistä että itse runoista. Länsi-Inkerissä ei sen sijaan esiinny Hevaalle tyypillisiä sävel- tai säven-termejä lukuun ottamatta Enäjärvi-Haavion muistiinpanoja 1930-luvun Narvusista, joissa esiintyy muutama sävelmän laatua (vilkas, pitkä, hitaampi sävel) kuvaava lajinimitys. ${ }^{255}$ Samaten vatjalaisille tyypillinen ääni-termi esiintyy Länsi-Inkerissä vatjalaisalueen ulkopuolella vain Enäjärvi-Haavion aineistoissa sävelmän nimityksissä pitkä ja suuri ääni sekä yhdessä Boreniuksen muistiinpanossa Soikkolan Loukkulasta ("ääni (=nootti)"). ${ }^{256}$ Ilmeisesti termit on tunnettu, mutta ne eivät ole olleet keskeisiä.

Oheiseen taulukkoon on koottu aineistossa vähintään kaksi kertaa esiintyvät runojen ja sävelmien nimitykset. ${ }^{257}$ Jaottelu noudattelee seuraavien analyysilukujen jäsennystä: ensimmäisenä tulevat tanssiin ja paikoillaan laulamiseen liittyvät nimitykset, sen jälkeen vuotuisjuhliin, sitten häihin ja lopuksi muihin paikallisiin aineistossa esiintyviin lajeihin liittyvät nimitykset. Nimityksiä on yleistetty jonkin verran. Tarkempi aineistoluettelo löytyy liitteestä 5.

\footnotetext{
${ }^{254}$ SKVR III 1591; 4126. SKVR III 261 on ilmeisesti Länkelän jälkimmäisestä toisinnosta ja muista runoista yhdistelemä kokonaisuus.

${ }^{255}$ SKS KRA Enäjärvi 549 (vilkassävelinen), 551 (vilkas sävel, "pitkä" (sävelmä)), 555 (hitaampi sävel). ${ }^{256}$ SKS KRA Borenius 187; Enäjärvi 490 ("pitkällä" "äänellä", 497 (kera suurel äänel), 549 (pitkässä äänessä).

${ }^{257}$ Näiden lisäksi Launis $(1907,105-110)$ liittää matkakertomuksessaan suoraan Länsi-Inkeriin nimitykset pulmanuotti, liekkunuotti, nuotit tantsun päälle, lapsennuotti sekä Hevaan nuotti.
} 


\begin{tabular}{|c|c|c|c|c|c|c|}
\hline & -VIRSI & -LAULU & -RUNO & -NUOTTI & MUITA & YHTEENSÄ \\
\hline TANTSU & 4 & & & 1 & 1 risti-tantsuvirsi & 6 \\
\hline НYPPY & & 1 & & & 1 rinkihyppylaulu & 2 \\
\hline RINKI & & & & & \begin{tabular}{|l}
1 rinkitanssi, \\
1 rinkihyppylaulu \\
\end{tabular} & 2 \\
\hline YMPÄRIKKO & 2 & 1 & & & & 3 \\
\hline LEIKKI & & 1 & 3 & & & 4 \\
\hline ILTA & & 3 & & & & 3 \\
\hline LASKIAIS & & 1 & & & 1 laskiaisluku & 2 \\
\hline LIEKKU & 3 & 4 & 1 & 2 & & 10 \\
\hline URPA & 1 & 1 & & & & 2 \\
\hline JAANI(TULI) & 2 & & & & 1 kokkovirsi & 3 \\
\hline IILIA/Pedro & 5 & & & & & 5 \\
\hline MARTIN & 3 & & & & & 3 \\
\hline KiletoI & 6 & & & & & 6 \\
\hline Joulu & 2 & & & & & 2 \\
\hline PRAASNIKKA & 3 & & 3 & & & 6 \\
\hline Kirtos & 2 & 1 & & & & 3 \\
\hline Pulma & 40 & 12 & & 6 & & 58 \\
\hline Hë̈̈ & 1 & 20 & 5 & & & 21 \\
\hline KYLVETyS ${ }^{25}$ & 6 & & & & & 6 \\
\hline SAUNA/saunASTATULO & 3 & & & & & 3 \\
\hline MORSIAMEN ISTUTTAMIS & 2 & & & & & 2 \\
\hline TERVEHTIMIS/(TERVE)TULO & 5 & & & & & 5 \\
\hline PÖYDÄN LUNASTAMIS & 2 & & & & & 2 \\
\hline KANs(I) & 2 & & & & & 2 \\
\hline OPETUS/NEUVO/NEUVOKKI & 6 & & & & & 6 \\
\hline SUKU & 2 & & & & & 2 \\
\hline KoKIN/KOKIN KIITOS & 5 & 1 & & & & 6 \\
\hline Lёнтӧ & 3 & & & & & 3 \\
\hline LAPSEN/LAPSIEN & 5 & 3 & & & 2 lastenlorua & 10 \\
\hline LIEKUTUS & & 1 & & 1 & & 2 \\
\hline Кенто & & 6 & & & & 6 \\
\hline NARRI(MIS) & & 6 & & & 1 naljalaulu & 7 \\
\hline RAIPPA & & 1 & & & 1 raippaamine & \\
\hline SOTAMIEHEN & & 4 & & & \begin{tabular}{|l|}
1 sotamieheksiotto, \\
1 sotamieheksiottoruno \\
\end{tabular} & 6 \\
\hline Paimen & 1 & 2 & & & & 3 \\
\hline EITSI/ÖITSNIEKKA & 1 & 3 & & & & 4 \\
\hline VIRON & 3 & & & & & 3 \\
\hline SURU/HALLEE & 2 & 2 & & & & 4 \\
\hline YHTEENSÄ & 121 & 68 & 12 & 10 & 12 & 223 \\
\hline
\end{tabular}

Taulukosta huomaa nopeasti muidenkin kuvausten perusteella keskeiset paikalliset lajit. Pulmavirret johtavat ylivoimaisesti (40 kpl). Niitä tukevat häälaulut (20) selittyvät osin tallentajien käännöksiksi suomalaisille vaikeasti ymmärrettävästä pulmavirrestä, vaikka Narvusin alueella termi on selvästi ollut kansanomaisessakin

\footnotetext{
${ }^{258}$ Kylvetys-, kylpömis- tai kylvöttämisen virsi.
} 
käytössä. "Häälauluja eli pulmavirsiä," kirjoitti Sylvi Sääski muistiinpanoonsa Soikkolasta. ${ }^{259}$ Toisena omana ryhmänään tulevat liekkuvirret, -laulut ja -nuotit (10). Narvusilaisia pilkka- eli narri-, narrimis-, nalja- ja raippalauluja on aineistossa 7. Nämä ovat nimenomaan lauluja. Kuuteen kiletoivirteen liittyvät myös kaksi jouluvirttä sekä neljä praasnikkavirsistä ja -runoista ja toinen kiitosvirsistä. Kiitosvirret ja praasnikkavirret liittyvät eri tilanteisiin ja praasnikoihin. Kuusi kehtolaulua on kaikki tallennettu Narvusin inkerinsuomalaisilta, kaksi liekutusvirttä ja yhdeksän lasten- tai lapsenvirttä, -laulua ja -lorua puolestaan Soikkolan ja Narvusin inkeroisilta ja inkerois-vatjalaisilta. Osa lastenloruista on luonteeltaan ennemminkin lasten huvitus- kuin nukutusrunoja ja ainakin yksi lapsiin virsi lapsien itse laulama. Kuusi löytyy sekä tantsuvirsiä tai -nuotteja, häiden aattoillan kylvetysvirsiä, häiden lopun opetus-, neuvo- tai neuvokkivirsiä, häihin liittyviä kokin kiitosvirsiä että sotamiehen virsiä ja sotamieheksiottorunoja.

Ylivoimaisesti eniten löytyy virsi-määrettä (121). Osin tämä voi liittyä tallennusten tekstipainotteisuuteen: puhuttiin lähinnä runoista, joiden paikallinen nimitys oli virsi. Nuotti-nimitykset (10) ovat peräisin sävelmien tallentajilta: Europaeukselta, Boreniukselta ja Launikselta. ${ }^{260}$ Laulu-nimityksistä (68) suurin osa vaikuttaa paikallisilta (Narvusi) tai etnisesti painottuneilta (inkerinsuomalaiset), mutta osa mahdollisesti tallentajien käännöksiltä. Näin on erityisesti silloin, jos tallentaja käyttää ainoastaan laulu-lopuketta. Yhtään piirileikkiä ei itse aineistosta löytynyt, vaikka sana joskus esiintyykin kerääjien ja tutkijoiden kuvauksissa. Tantsu ja hyppy ovat vanhakantaisia tanssin nimityksiä ja ympärikko aineistossa siellä täällä esiintyvä piirin paikallinen vastine (ks. luku 5 sekä esim. Launis 1907, 109). Myös rinkitermi on ilmeisesti ainakin narvusilainen paikallinen nimitys, joka löytyy myös yhdestä Kaipaalasta tallennetusta runotekstistä (SKVR III 929).

Kun taulukoituja nimityksiä vertaa seuraavien lukujen keskeisaineistoihin, herättää huomiota kaksi seikkaa. Urpa- eli virpomisvirsiä261 ja paimen- ja eitsilauluja en käsittele tämän työn puitteissa lainkaan. Tämä johtuu ensisijassa siitä, että yhtään niihin liittyvää sävelmää tai tarkempaa laulukuvausta ei ole tallentunut. Sävelmien ja nimitysten puutteen vuoksi ei työssä käsitellä myöskään naisten kevätjuhlaan liittyviä Jyrin virsiä (ks. Timonen 2004, erit. 129-130). Narrimislaulut ja sotamiehenvirret ovat jääneet tarkastelun ulkopuolelle työn temaattisen rajauksen takia. Liekutuslaulut ja lastenvirret tulevat käsitellyksi vain muutamien

\footnotetext{
${ }^{259}$ SKS KRA Sääski 5974. Muista tallentajista häälaulu tai -runo esiintyy Länkelällä (häälaulu) lähinnä narvusilaistoisinnoissa, narvusilaisissa inkerinsuomalaistoisinnoissa Enäjärvi-Haaviolla (hääruno), joka käytti häälaulu-termiä omilla sanoilla laulajia kuvatessaan (SKS KRA Enäjärvi-Haavio 404-405) sekä Mannosella ja Sääskellä, jotka molemmat käyttivät usein kirjakielisiä ilmauksia - toisaalta Mannonen kertoo myös Suomessa asuneiden soikkolalaisten haastateltaviensa pyrkineen puhumaan kirjakieltä (SKS KRA Mannonen 9752). Narvusilaislaulajien tavoista käyttää virsi- ja laulu sanoja ks. myös SKS KRA L. Laiho 5407-5412.

${ }^{260}$ Ainakin Launis käytti matkapäiväkirjassaan myös itse usein nuotti-nimitystä sävelmän sijaan: hänen näkökulmastaan juuri nuotit, nuotinnokset olivat matkan päämäärä (KK Coll. 123.22 Launis 1903).

${ }^{261}$ Urpimisesta eli virpomisesta paljon muistiinpanoja, joissa ei suoria nimityksiä, vaan erilaisiaverbimuotoja, kuten "urpimaan", "käytiin urpimas" tai "lapset tulee urvottamaa" (esim. SKS KRA Haavio 2674-2686; Laiho, A. 2426-2434). Varsinaisia nimityksiä on kaksi: Porkalla urpalaulu, Alavalla urpavirsi. Urpimisrunon laulamisesta on yksi selvä maininta (SKS KRA Laiho L. 4926; lukemisesta eli sanelemisesta esim. Laiho L. 5055, 6137), mutta sävelmiä ei ole tallentunut.
} 
erityistapausten kautta toisaalta työn temaattisen rajauksen, toisaalta sävelmäaineiston vähäisyyden vuoksi.

Toisaalta yllä olevasta taulukosta puuttuu kokonaan laskiaisen liukuvirsi, jota kuitenkin käytän paikallisen laulunlajin nimityksenä. Olen tulkinnut tallennushistoriaa, aineistoa ja Launiksen kuvauksia siten, että kyseessä on ainakin Soikkolassa ollut paikallinen laji vakiintuneine aloitusrunoineen, esitysareenoineen ja sävelmätyyppeineen, mutta nimityksiä ei Länsi-Inkeristä ole tallennettu. Nähdäkseni on itse runojen sekä hevaalaisten vastineiden perusteella todennäköistä, että lajia olisi voitu Soikkolassa nimittää liukuvirreksi ja -nuotiksi (ks. luku 6). Varmaa tämä ei ole. Liukuvirttä lukuun ottamatta kaikki käyttämäni paikallisten lajien nimet perustuvat tallentuneisiin virsien, laulujen ja nuottien nimityksiin. Kokkonuotista en puhu, sillä sitä ei aineistossa nimetä enkä aineiston pohjalta voi olla varma siitä, minkälaisia kiinteitä tai hajanaisia musiikillisia käytäntöjä kokkovirteen on voinut Länsi-Inkerissä liittyä. Toisaalta tarvittaessa nimeän sävelmiä niiden tekstuaalisilla tai musiikillisilla tunnuksilla (esim. oi dai -sävelmä, neli-iskuinen pulmanuotti), vaikka nämä eivät varmasti ole olleet paikallisten käytössä.

Taulukon ulkopuolelle jää suuri joukko sekä yksittäisiä että yleisempiä nimityksiä. Ainoita esimerkkejä Tapanin ja Jyrin päivien lauluista ovat yksittäiset Stahvana päivän laulu ja Jyrinpäivävirsi. ${ }^{262}$ Häälaulujen yksittäisinä tallentuneita alakategorioita ovat kaasikkovirsi, kysymisvirsi, tytön virret, saattamisvirsi, volkkiin laulu, jälest ajajain laulu, vävyn virsi, apirahavirsi sekä kozimavirsi. ${ }^{263}$ Työlaulun lajeja ovat yksittäiset niittovirsi, iltalaulu niitettäessä, kezrävirsi, talkoivirsi, karjan laulu, sikurin (lammaspaimenen) laulu sekä marjavirz. ${ }^{264}$ Joko tyypilliseen laulajaryhmään, yksittäiseen esittäjään, laulun tekijään tai laulun minään viittaavat vaihdellen nimitykset piikoin virsi, kupparin virsi, noian virsi, poikien laulu (jota tytöt eivät laulaneet), tyttöjen laulu, oma virsi, orjan virsi, miehen veljen laulu, piikatyttöin virs, armottoman lapsen virsi, minjän virsi, toinen armottoman lapsen virsi, Meijä äijä laulu, rekruutin laulu, piikan laulu palveluksessa, piijan laulu, talon tyttären laulu, emän virsi, tytön laulu sekä Vanhan ämmän virsi. ${ }^{265}$ Yllä olevan taulukon paimenlaulut kuuluvat samaan laulajia nimeävään ryhmään. Juhliin ja alkoholinkäyttöön liittyvät oluen virsi, juomarin virs sekä juomalaulu. ${ }^{266}$ Laulun tunnesisältöön tai esitystapaan liittyvät yllä olevan taulukon suruvirsien ohella yksittäiset pitkä virsi; tihti, pitkä, vieno ja lyhyt laulu; pitkä (sävelmä), seisulaulu, loppulaulu, tiukkulaulu (eli leikkilaulu), istumalaulu, paska laulu (kurjasta kohtalosta) sekä rallatusnuotti. ${ }^{267}$

\footnotetext{
${ }^{262}$ SKVR III 482, 1050.

${ }^{263}$ SKVR III 602, 1900, 2494, 3335; SKS KRA A. Laiho 2182; Mannonen 7663; SKS KRA V. Salminen 776, 2921; SibA Launis 318 .

${ }^{264}$ SKVR III 1056, 1057, 2295, 3578, 4581; SKS KRA Enäjärvi-Haavio 534; Haavio 2475.

${ }^{265}$ SKVR III 553, 3823, 4359; SKS KRA Enäjärvi-Haavio 462, 490; Haavio 2457, 2492, 2503, 2514, 2540 , 2548, 2554; A. Laiho 2154 ja 2155, 2374; Länkelä 6:1851; Mannonen 5474, 5487; K. Salminen 40, 41, 249 .

${ }^{266}$ SKVR III 224; SKS KRA Enäjärvi-Haavio 535; SKSÄ L 101 e.

${ }^{267}$ SKVR III 2328; SKS KRA Enäjärvi-Haavio 550, 551; A. Laiho 2217; 2259, 2264, 2291, 2292; SKSÄ A 303/7.
} 
Erityisen mielenkiintoisia ovat yleisemmin laulun lajeja tai eri ryhmien lauluja erittelevät nimitykset. Ne osoittavat laulajien tehneen myös moninaisia ajallisia, paikallisia ja kielellisiä erotteluita. Omakielisistä, kalevalamittaisista lauluista käytettiin termiä maavirsi (maavirz) tai maankielinen virsi, jotka asettuivat erilaisten vennäin virsien ${ }^{268}$ sekä uudempien riimillisten laulujen, tanssilaulujen ja rallitosten vastapooliksi ${ }^{269}$. Suomen virsi tarkoitti vaihdellen joko samaa kuin maankielinen virsi ${ }^{270}$ tai sitten erityisesti inkerinsuomalaisten laulua (suomalaisten virsi). Kalevalamittaisiin runoihin viitattiin myös termeillä vanha tai entinen virsi sekä 1930luvun Viron Inkerissä termillä Inkerin virsi tai laulu. ${ }^{271}$ Nimityksissä voitiin viitata myös paikkaan tai laulajaryhmään: Soikkulan virsi, Vyötermaan virsi, Kukkosten virsi, Lavansaaren poikiin virs, mustilaisten virs. ${ }^{272}$ Nimitysten lisäksi myös monet toteamukset osoittavat laulajien olleen tietoisia ajallisista, kielellisistä ja paikallisista eroista. "Se on oikee niit entisiä," sanoi inkeroislaulaja Jeodokia Räkälä Sato taivas uutta lunta -runostaan. ${ }^{273}$ "Ei ole meiän kohan virs," totesi Nikolai Narvusin Kullalta sinänsä alueelle tyypillisestä Yks oli väärä miun emoni -runosta. ${ }^{274}$ Darja Lehti kertoi Joenperän kylässä lauletun Soikkolan tapaan: "Vatjaks meil ei laulettu; soikkolan kieltä oli laulut. Kylä oli suuri, a vadjan lauluja ei laulettu, kai Soikkolan laului." 275 "Tää virsi on muualta tulleita virsiä, tää ei ole mein Inkerin virsiä vaikka tätäkii siellä laulettiin,” totesi soikkolalainen Pauliina Reponen rekilaulustaan. ${ }^{276}$

\footnotetext{
${ }^{268}$ SKVR III 2376; SKS KRA Haavio 2304, 2711; A. Laiho 2599.

${ }^{269}$ SKVR III 2299; SKS KRA Mannonen 7669.

270 "Ennen laulettii maavirsii soomen kielel" ja "Suomen virsii opettiit Pärspään tytöt" (SKS KRA K. Salminen sidos 1931 b) 224-348 (sidoksen lopussa uusi sivunumerointi, s. 6); SKS KRA V. Salminen 2972.

${ }^{271}$ SKVR III 599, 1336, 2048, 2094, 2298, 2360; SKS KRA Haavio 2304, 2490; L. Laiho 5412; K. Salminen 72, 286; V. Salminen 2952, 2972.

272 SKVR III 268; SKS KRA K. Salminen 102, 104; A. Laiho 227, 2244.

${ }^{273}$ SKS KRA V. Salminen 2911.

${ }^{274}$ SKS KRA V. Salminen 2919.

${ }^{275}$ SKS KRA Haavio 2303.

${ }^{276}$ SKS KRA Mannonen 7667.
} 


\section{RAKENTEIDEN KÄYTTÖ}

Teknisesti ottaen minkä hyvänsä kalevalamittaisen runon voi laulaa millä runosävelmällä tahansa. Erityisesti Viron alueella on sävelmien käytössä kuitenkin havaittu selkeitä alueellisia, runon lajeihin ja käyttötapoihin liittyviä painotuksia. Herbert Tampere $(1956,11 ; 1965)$ yhdistää tyyliltään erilaiset sävelmätyypit ensisijaisesti niiden käyttötapoihin. Tietyillä laulun muotorakenteilla on tendenssi esiintyä tiettyjen laulun lajien tai tietyillä tapaa käytettyjen laulujen yhteydessä (Särg 2000; ks. myös esim. Sarv 2004). Karksin pitäjän alueella erityisesti työhön ja tapoihin liittyvät sävelmät olivat eri laulajilla hyvin samankaltaisia, joskaan eivät identtisiä. Hääsävelmät olivat muotorakenteeltaan tyypillisesti yksisäkeisiä, perässä refrenki kas'ke (Särg 2008, 58). Sen sijaan kertovien ja lyyristen laulujen yhteydessä sävelmät varioivat enemmän. (mts., 49.) Myös Vienan ja Suomen Karjalassa hääsävelmä erosi alueille muuten tyypillisistä runosävelmistä (ks. esim. Asplund 2006a, 316-318; Heinonen 2009; Väisänen 1990, 64).

Seuraavat luvut näyttävät, että kuten Virossa, myös Länsi- ja Keski-Inkerissä tiettyihin tilanteisiin tai tekemisen tapoihin ja kontekstisidonnaisiin runoihin liittyi tietynlaisia sävelmiä. Tilannesidonnaisten runojen esittämiseen tyypillisesti käytetyillä sävelmillä voitiin kuitenkin laulaa myös muita runoja tai muissa tilanteissa. Länsi-Inkerissä selkeän tilannesidonnaiset, etenkin rituaalisesti sävyttyneet praasnikka- ja hääsävelmät ovat kaikki muotorakenteeltaan yksisäkeisiä ja tyttöjen häälauluja lukuun ottamatta muiltakin rakenteiltaan sangen yksinkertaisia sävelmiä. Näitä sävelmäryhmiä yhdistävien piirteiden luonne kuitenkin vaihtelee. Yhdistävä tekijä ei aina ole melodiatyyppi, vaan se voi olla vaikkapa tietyn tyyppinen muotorakenne, suppea sävelala tai tietyntyyppinen refrenki. Melodiatyyppien käyttö on voinut olla hyvin paikkakunta- tai jopa kyläkohtaista: esimerkiksi tyttöjen häissä käyttämää oi dai -sävelmää on tallennettu ainoastaan Soikkolan alueelta, kun taas Narvusissa oli vastaavassa tilanteessa käytössä muunlaisia sävelmiä. Häiden rituaalisesti keskeiset laulut on aineistossa puolestaan laulettu kahdella sävelmätyypillä, joita ei kuitenkaan - ainakaan koko Länsi-Inkerin tasolla - määritä tietty melodiakulku vaan yksisäkeinen muotorakenne, rytmityyppi (22222222 ja 44222244) sekä suppea sävelala. Häiden keskeisiin sävelmiin ei myöskään sisälly osakertauksia, refrenkejä tai säännöllisiä lisätavuja tai seitsentavuisuutta. Samalla tavoin länsiinkeriläisiä liekkunuotteja yhdistää tiukka muoto- ja rytmirakenne, mutta niiden asteikot ja sävelkulut jakautuvat useisiin erilaisiin ryhmiin.

Tilannesidonnaisissa sävelmäryhmissä näkyy myös alueellinen variaatio. Iilian virret on länsi-inkeriläisaineistossa laulettu säkeen lopun kertaavalla, äänitteillä melko verkkaisesti esitetyllä sävelmätyypillä, Keski-Inkerin kaksi toisintoa puolestaan neli-iskuisella, yksisäkeisellä sävelmällä. Hevaalta ja Tyröstä tallennettuja kokkosäveliä yhdistävät erityyppiset, erilaisiin muoto- ja rytmirakenteisiin yhdistyvät $a i$ lole- tai ai luuli -tyyppiset refrengit, Länsi-Inkerin harvat kokkovirren sävelmätoisinnot taas esitettiin muutamilla yksinkertaisilla tanssin yhteydessä yleisillä yksisäkeisillä muotorakenteilla. Etenkin tanssiin liittyi hyvin moninaisia rytmejä, sävelmiä, muotorakenteita ja refrenkejä. 
Monissa tapauksissa myös sävelasteikko määrittää sävelmätyyppejä. Selvintä tämä on muoto-, rytmi- ja melodiarakenteeltaan monimutkaisempien ja suppealla maantieteellisellä alueella esiintyvien sävelmien kuten Länsi-ja Keski-Inkeriin rajoittuvan saadulmoi-sävelmän tai Soikkolan alueelta tallennetun oi dai- sävelmän kohdalla. Näiden sävelmien voi niiden käyttötapojen säännöllisyyden perusteella olettaa olleen myös käyttäjilleen tunnistettavia nuotteja, vaikka niitä ei sellaisiksi ole aineistossa nimetty. Soikkolalaisten liukusävelmien kohdalla taas asteikkorakenteet ja melodiakulut varioivat enemmän, mutta liukusävelmät muodostavat silti tyyliltään, sävelkuluiltaan sekä ennen kaikkea muotorakenteeltaan yhtenäisen ryhmän. Tämän työn aineiston ja kysymyksenasettelun puitteissa ei ole selvitettävissä, missä määrin esimerkiksi erilaisiin neli-iskuisiin, yksisäkeisiin sävelmiin liittyvä asteikollinen ja melodinen variaatio oli käyttäjilleen merkityksellistä ja tunnistettavaa. Etenkin liekkunuotit sekä tavalliset pulmanuotit muodostavat muotoja rytmirakenteeltaan Länsi-Inkerin alueella kiinteitä ryhmiä, joiden sisällä asteikkorakenteet ja melodiakulut kuitenkin varioivat. Osin tämä voi olla paikkakunta-, kylä-, tai laulajakohtaista, ja on luultavaa, että ainakin osa esimerkiksi Launiksen $(1904,49)$ tarkkakorvaisiksi mainitsemista laulajista on tunnistanut tämänkaltaisiakin eroja. Tässä kohden ei ole mahdollista sanoa, mitkä näistä muoto- ja rytmirakenteeltaan samanlaisista, mutta sävelkuluiltaan eroavista sävelmistä olisivat eri laulajien mielestä vielä edustaneet "samaa" nuottia.

Virossa Karksin alueen laulajilla oli Taive Särgin $(2008,19)$ mukaan sävelmiä eri tarkoituksia varten: yleensä yksi tai kaksi sävelmää niille lauluille

joita laulettiin yhdessä työn ja rituaalisen tekemisen yhteydessä, muutama sävelmä erilaisten arkaaisten vokaalilajien osalle sekä yksi tai kaksi sävelmää lyyrillisten ja kertovien laulujen osalle. Lisäksi tunnettiin joitain uudemmasta lauluperinteestä vaikutteita saaneita erikoissävelmiä, joita käytettiin yhden tai parin-kolmen runon kanssa, esimerkiksi Karksissa on sama sävelmä välimuotoisilla lauluilla "Loomine,' 'Tilluke teopoiss', 'Hollandi sulane' jms. (ks. myös Rüütel 1969, 116). Eri laulajien sävelmät olivat samankaltaisimpia työ- ja seremonialaulujen kohdalla, eroja oli enemmän vapaammin käytettävien sävelmien kohdalla.

Laulajilla oli usein joku "perussävelmä", jolla he lauloivat suuren osan repertuaaristaan (Särg 2008, 19). Samalla tavoin kertoo A. G. Gomon (1977, 282) 1970-luvun tilanteesta Länsi-Inkerin inkeroisilla:

Yhdellä alueella tai yhdessä kylässä yleisesti on vain yksi tai kaksi sävelmää, joiden rakenne on sovitettu Kalevalan kahdeksantavumittaan. Niinpä niitä on helppo käyttää erilaisten eeppisten runojen, häärunojen ja muiden runojen laulamiseen.

Näiden lisäksi oli "melkein jokaisella esittäjällä repertuaarissaan" myös joko venäläisvaikutteinen sävelmä tai suoranainen tšastuškasävelmä, joita käytettiin yhtälailla kalevalamittaisten runojen esittämiseen. Terttu Koski $(1974,477)$ puhuu laulajakohtaisista "melodisista varianteista" ja luonnehtii yksittäisten esittäjien sävelmiä "erittäin pysyviksi." 
Etenkin 1960-1970-lukujen aineistoissa, joissa yhdeltä laulajalta on äänitetty runsaasti lauluja ja niiden toisintoja, näyttäytyvät laulajien repertuaareille tyypilliset sävelmät selkeinä. Esimerkiksi aikakauden tunnetuin soikkolalaislaulaja Jekaterina Aleksandrova esitti valtaosan runoistaan kaksisäkeisellä perussävelmällä, joitain lauluja muutamalla venäläistyyppisellä sävelmällä ja erityisesti häälaulut yleisesti niihin liittyvillä yksisäkeisillä sävelmätyypeillä. ${ }^{277}$ Jopa sävelmätyyppien osalta huikeimman kokoelman tallentanut Armas Launis valitti laulajien monin paikoin osaavan vain niukalti erilaisia sävelmiä. ${ }^{278}$ Voikin olettaa Aili ja Lauri Laihon niukemman äänitekokoelman, jossa samoilla sävelmätyypeillä esitettiin monia eri runoja, antavan Launiksen monenkirjavaa sävelmäkokoelmaa paremman kuvan siitä, minkälaisia sävelmätyyppejä laulajat tyypillisesti ja luontevasti laulamiseensa käyttivät. Yhdellä sävelmällä oli mahdollista laulaa pitkään, eikä sävelmää ollut välttämättä tarvetta vaihtaa runon vaihtuessa. Muuten kokoelmat eivät juuri kerro yleisimmin käytetyistä sävelmätyypeistä muiden kuin kontekstisidonnaisten runojen osalta. Poikkeuksia ovat kaksi A. A. Boreniuksen merkintää Soikkolasta. ${ }^{279}$

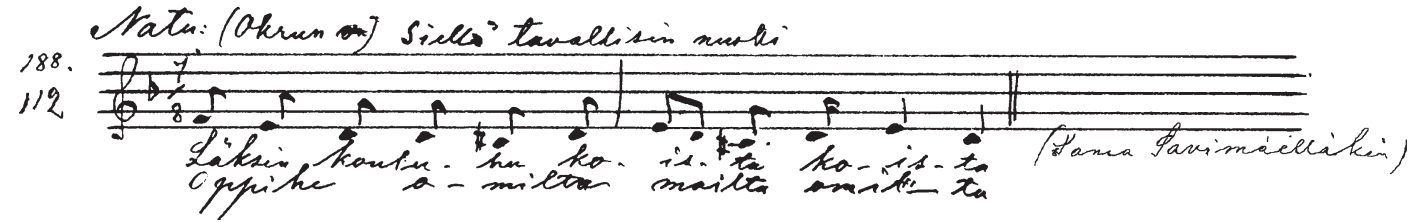

Nuotti 8. Soikkolan Loukkulassa vuonna 1877 yleisesti käytetty sävelmä, "tavallisin nuotti" (SKS KRA Borenius e 188).

Länsi-inkeriläisaineiston moninaisuudesta huolimatta ovat kaikkein yleisimpiä sävelmätyyppejä erilaiset yhden säkeen jaksoissa etenevät, tasarytmiset, suppeahkolla sävelalalla (3-6) liikkuvat sävelmät, joissa ei ole refrenkejä tai säännöllisiä lisätavuja.

Samoin kuin usein Virossa, kaksisäkeiset ja etenkin sävelalaltaan laajemmat sävelmät liittyivät Länsi-Inkerissä lähinnä moninaiseen lyriikkaan ja lyyriseen epiikkaan, eivät keskeisimpiin praasnikka- ja häälauluihin. Toisaalta lyyrisiä ja eeppisiä runoja saatettiin laulaa myös suppea-alaisilla ja yksisäkeisillä sävelmillä, joko sellaisenaan, osina häälauluja tai tiettyjen praasnikkalaulujen, erityisesti liuku-, liekku- ja kokkovirren jatkona. Niitä laulettiin siis monin eri tavoin, monen esitysareenan ja rekisterin puitteissa. Vapaammin rakentuvilla esitysareenoilla myös sävelmien kirjo oli suurta. Erityisesti tanssilaulujen joukkoon liittyy laaja kirjo niin yksi- kuin kaksisäkeisiä, suppea- kuin laaja-alaisiakin sävelmiä. Tämä liittyy nähdäkseni tanssiksi määrittyvän liikkeen moninaisuuteen, sen laajoihin käyttömahdollisuuksiin ja sen sisältämään suureen sävyjen kirjoon. Rituaalisimpiin

\footnotetext{
${ }^{277}$ ERA RKM Mgn. II 2838-2843; RKM Mgn. K 40-41; ks. myös Kiuru et al. 1974, Rüütel 1979. Aleksandrovan kaksisäkeinen perussävelmä ei tosin ollut alueelle erityisen tyypillinen, vaan ilmeisesti henkilö- tai kyläkohtainen erityisyys. Praasnikkoihin liittyviä rituaalisia lauluja - Iilian ja Jyrin virttä - hän lauloi ennen toista maailmansotaa tallennetusta aineistosta poikkeavin tavoin, mikä todennäköisesti johtui näiden perinteiden jäämisestä aktiivikäytöstä jo vuosisadan alkupuolella (ERA RKM, Mgn. II 2843 z, w; ks. myös luku 6).

${ }^{278}$ Ks. erit. KK Coll. 123.22 Launis 1903 sekä luvun 2 alaluku Launiksesta.

${ }^{279}$ SKS KRA Borenius e 188 "Siellä tavallisin nuotti" (Loukkula); 196 "Sitä noottii/ääntä enemmikseen lauletaa" (Savimäki).
} 
praasnikka- ja häälauluihin ei myöskään sisälly muita muuten yleisiä osakertausrakenteita kuin yksinkertaista säkeen loppupuoliskon kertausta. Lisätavut ja äännemuutokset liittyvät kiinteästi tiettyihin sävelmätyyppeihin, toisiin taas niitä ei liity koskaan. Mielenkiintoisimpia ne ovat niissä sävelmätyypeissä, joissa niiden käyttö on ilmeisen valinnaista, mutta yhden laulun puitteissa säännöllistä. Tällöin ne ovat tulkintani mukaan toimineet yhtenä julkisen täydesti laulamisen tunnuksena: ne eivät liity niinkään tiettyihin sävelmätyyppeihin kuin tietynlaisiin esityksiin eli innostuneen kuuloiseen tosissaan joukolla laulamiseen. Yksinlaulajilla tai jännittyneen kuuloisissa joukkoesityksissä ei tämänkaltaisia lisätavuja ja äännemuutoksia esiinny. Refrengit eli kertaumat toimivat tiettyjen rekistereiden tunnuksina. Esimerkiksi refrenki saadulmoi saadu selennoi saadu liittyy aineistossa kiinteästi tiettyyn yksisäkeiseen sävelmään, ja sitä kerrotaan lauletun kylän läpi tanssien tai kulkien kluutšaksi kutsutussa paririvimuodostelmassa usein laulu La lähen läpi kyläsen -runolla aloittaen. Erilaisten hitailla sävelmillä laulettujen kalina-tyyppisten refrenkien taas kerrotaan Narvusissa liittyneen ensisijaisesti surullisiin ja traagisiin runoihin sekä hitaaseen liikkeeseen. Näissä tilanteissa niin refrengin, sävelmän, tanssimuodostelman kuin tyypillisen aloitusrunonkin voi ajatella olleen kiinteästi tiettyyn esitysareenaan ja rekisteriin liittyviä esityksen avaimia.

Laulamisen tempo vaihtelee äänitteillä yhdenkin tilannesidonnaisen laulutyypin puitteissa. Niinpä vaikkapa Iilian virren tai tavallisen pulmanuotin rakenteeltaan samankaltaisista sävelmätoisinnoista toiset lauletaan hitaammin, toiset nopeammin. Paikallisten kuvauksissa laulamisen ja siihen mahdollisesti yhdistyvän liikkeen tempo oli kuitenkin keskeinen laulun lajia ja tunnelmaa määrittävä tekijä. Nopeasti, tihtii, laulettiin keveitä runoja, tanssilauluja, tanssittiin tai kuljettiin nopeasti samalla. Nopeisiin tanssilauluihin liittyi myös erilaisia äänellisiä, rytmisiä tunnuksia, riehakkaan tunnelman merkkejä: taputuksia, napsutuksia, jalkojen kopistamista. Hitaasti, pitkäl äänel, venyttäen laulettiin surullisia ja traagisia runoja paikoillaan istuen ja seisten tai hitaasti kulkien, usein kuoron kertaus erilaisilla kalina-tyyppisillä refrengeillä korvaten. Nopeus liittyi tanssiin ja kepeyteen, hitaus suruun ja paikallaan oloon tai hitaaseen liikkeeseen. Ilmeisesti hitaus liittyi kuitenkin myös juhlavuuteen tai juhlavaan vakavuuteen, sillä tietyissä rituaalisen joukkolaulun tilanteissa, häälaulujen ja Iilian/Pedron lauluissa etenkin, tahti näyttää olleen usein melko rauhallinen. Ääniteaineistot näyttävät myös laulun rytmin merkityksellisyyden: lähes kaikissa julkisiksi ja rituaalisiksi määrittyvissä lauluissa rytmi on tasainen. Vapaampaa rytmin käsittelyä ja säkeen lopun pitkäksi venyttämistä kuuluu etenkin monien ilmeisesti pitkäl äänel laulamiseen liittyvien lyyristen runojen, esimerkiksi iltaan ja suruun liittyvien teemojen yhteydessä. Usein näihin yhdistelmiin liittyy juuri hidas tempo, joskus myös sävelmän laaja aika-arvojen kirjo. Rituaalisesti sävyttyneistä lauluista näitä piirteitä esiintyy tempon hitautta lukuun ottamatta ainoastaan tyttöjen häälaulutyypeissä, jotka lomittuvatkin huolilyriikkaan ja voisivat siten tulla tulkituiksi paikallisen pitkän äänen eli hitaasti ja surullisesti laulamisen kategoriaan kuuluviksi. (Katso luku 5.)

Myös äänen voimakkuus liittyy vahvasti laulamisen tilanteeseen ja luonteeseen. Arkinen laulu oli hiljaisempaa, julkinen juhlien laulu mahdollisimman kovaää- 
nistä. Ihanteena oli äänen kuuluvuus: lauluääni oli kuin kello ja juhlalaulu kuului lähistöllä sijaitseviin naapurikyliin asti. Hyvä esilaulaja oli kankee ja udala, väkevä ja vahva laulaja. Venäläisperäisiin tanssilauluihin kerrotaan liittyneen erityisen kovan äänenmuodostuksen, sitä vastoin ainakin osa häälauluista laulettiin Terttu Kosken $(1974,482)$ mukaan kuitenkin melko hiljaisella äänellä. Olettaisin paitsi arjen ja juhlan, myös sisä- ja ulkotilan vaikuttaneen äänenvoimakkuuteen - häälauluistakin osa laulettiin ulkona, osa sisätiloissa. (Katso luku 8.)

Inkeriläiset 1900-luvun alun runosävelmät ovat heterogeeninen ja monityylinen joukko: kalevalamittaisten runojen esittämiseen sovellettiin myös sävelmiä rekilaulusta ja itkuvirsistä aina moninaisiin venäläisiin lauluihin. Musiikillisia rakenteita käytettiin joustavasti: samantyyppinen melodia saatettiin esimerkiksi sovittaa useampaan rytmityyppiin tai esittää erilaisilla refrengeillä lisättynä. Toisaalta tiettyjen sävelmätyyppien yhteydessä musiikilliset ja tekstuaaliset rakenteet muodostivat hyvinkin kiinteitä, samankaltaisina toistuvia yhdistelmiä. Paikoin ne edellyttivät toisiaan käytännössäkin, vaikkapa tietyt osakertausrakenteet tietyn pituisia sävelmiä. Paikallisten lajien suunnasta tarkasteltuna julkisen ryhmälaulun sävelmäryhmät rakentuvat hyvin erilaisin tavoin. Esimerkiksi 1) kokkovirsien tunnuksena toimi Keski-Inkerissä oi luuli -tyyppinen refrenki, joka saattoi esiintyä monissa asuissa erilaisten sävelmätyyppien puitteissa. 2) Yleisimpien hääsävelmien kohdalla olennaisinta oli laulun neli- tai kuusi-iskuinen rytmityyppi, suppea sävelala ja yksisäkeinen yksinkertainen muotorakenne, joiden puitteissa esiintyy useita erilaisia melodiatyyppejä. 3) Tyttöjen häissä Soikkolassa käyttämä kiinteämuotoinen oi dai -sävelmä oli vaihdettavissa toisaalta muutaman tyyliltään samankaltaisen, toisaalta kahden keskeisimmän hääsävelmätyypin kanssa. 4) Kylien läpi kulkemiseen liittyvä saadulmoi-sävelmä puolestaan toistui kiinteänä tietyntyyppisen melodian, rytmin ja sävelmän kokonaisrakenteen yhdistelmänä joko refrengin kanssa tai sitä ilman. Musiikkianalyyttiselta kannalta katsottuna hyvinkin erilaiset piirteet toimivat siis tietyn paikallisen tilannesidonnaisen lajin määreinä: kokonaisrakenne melodioineen, rytmityyppi tai ainoastaan refrengin luonne. Tietyt melodiatyypit liittyvät useiden eri kerääjien eriaikaisissa aineistoissa samankaltaisiin tai -teemaisiin runoihin tai laulutilanteisiin. Jotkut näistä ryhmistä ovat hyvinkin paikallisia, toiset taas laajemmalta maantieteellisesti tai etnisesti rajautuvalta alueelta löytyviä. Mitään yhtenäistä järjestelmää ei siis löydy, vaan aineiston on ennemminkin syytä tulkita edustavan välillä laajemman, välillä suppeamman alueen paikallisia tapoja, toistuviin tilanteisiin liittyviä enemmän tai vähemmän vaihtelevia konventionaalisia laulamisen tapoja. 


\section{LIIKE}




\section{LIIKE}

Olga Paju muisteli luterilaista Kati Varkkia (ks. Salminen 1931a, 635) neljätoista vuotta tämän kuoleman jälkeen:

[O]li pieni, priskii2 ${ }^{280}$, punanen, ymmyrkäinen niin kuin nauris. Ääni oli niin kuin kello. Koko kylä kutsu kummitätiks, nii hää oli hyvä. Lauloi aina pulmiss, tantsi aina tasaisesti, niin kuin kananmuna vieri. ${ }^{281}$

Paju yhdistää luonteen (nii hää oli hyvä), ulkonäön (punainen, roteva, ymmyrkäinen kuin nauris, kuin kananmuna), lauluäänen (kuin kello) ja tanssin (tasainen) kuvauksen. Vaikka tämänkaltaisia, yhden henkilön tanssin ja laulun kuvauksia ei ole aineistossa muita, toistuvat samat teemat runoissa. Kuvaus antaa vihjeen siitä, että runoissa yleisiä mielikuvia saatettiin käyttää myös runomaailman ulkopuolella (vrt. Tarkka 2005, 52-53).

Runoissa hyvä tanssi eli tantsu on tasaista ja lustia (eli kaunista tai hauskaa). ${ }^{282}$ Tasainen ja lusti oli kontekstikuvauksissa myös hyvä tanssipaikka: aukea, kuiva ja tasainen aukio kauniilla paikalla. Se saattoi olla sopiva kohta vaikkapa kylätiellä, joen penkerellä eli kaltaalla, sillalla tai kyläkeinun tai kokkopaikan vieressä. ${ }^{283}$ Tanssin synonyyminä on välillä vieriminen tai hyppääminen. ${ }^{284}$ Kaunis lauluääni on kuuluva ja voimakas: se kuin kello tai torvi ja laulamisen synonyyminä käytetään huutamista tai kukkumista. ${ }^{285}$ Kellot kuuluivat praasnikkoihin ja häihin myös todellisina esineinä, sillä niitä oli tällöin hevosten aisoissa, valjaissa ja kaulassa: "Ettäältä kuuluu, että 'pulmat tuloot"' "siiz helähytetää hyväst."286 Uusia sukulaisia verrataan häälauluissa kananmuniin, ja kananmunilta ja medeltä tuoksuvat lyyrisissä runoissa myös omat hyvät, lintujen laulua täynnä olevat maat. ${ }^{287}$ Kaunis tyttö on poskilta punainen, verevä. ${ }^{288}$ Tytön tasainen tantsu ja laatuisa laulu "pettelee" pojan eli saa tämän ryhtymään sulhaseksi. ${ }^{289}$ Laulun merkityksestä sulhasen löytymisessä kertoivat myös muutamat laulajat ja keräjät. Jeodokia Räkälä selitti omaa aikaista naimisiinmenoaan 17-vuotiaana juuri laulutaidollaan: "Mokoma laulaja-

\footnotetext{
${ }^{280}$ Priski: (vir. priske) terve, verevä, riski, roteva (ESS: priske; IMS: priski).

${ }^{281}$ Salminen K.: sidoksen 1931 b) 224-348 lopussa ilman arkistonumeroita, alkaa uusi sivunumerointi, jonka s. 9-10.

${ }^{282}$ Esim. SKS KRA Laiho A. 2134.

${ }^{283}$ SKS KRA Enäjärvi-Haavio 551, 556, 558, 830-832; A. Laiho 2615, 3171; joen kaltaalta ks. myös Simonsuuri 1972, 45.

${ }^{284}$ SKVR III 709, 901, säe 16; SKS KRA Laiho L. 6000.

${ }^{285}$ Ks. SKVR-tietokannan haku "kello* ään*", esim. SKVR XV 1195; kulkkutorvi, SKVR III 1484, 2260; laulamisen synonyymit ks. esim. SKVR III 3476.

${ }^{286}$ SKS KRA Enäjärvi-Haavio 873 ja Laiho A. 2591; ks. myös Haavio 2673; Laiho A. 2604; Salminen V. 2960; Sääski 5971.

${ }^{287}$ Häälaulut esim. SKVR 2305, 3038; omien maiden ylistys esim. SKVR III 770, 2402; lyriikan ruokakuvista ks. Timonen 2004, 367-369.

${ }^{288}$ Esim. SKVR III 1801.

${ }^{289}$ Esim. SKVR III 397.
} 
kukko, vietiinhän se," hän totesi kerääjälle. ${ }^{290}$ Myös miesten taitava tanssi herätti ihastusta. Valpuri Vohta kertoi, että hänen isänsä Andreas Orava "oliki oikee kerkee jalalt laulaja ja tantsija, pulmis mäni keputteli nii et." ${ }^{291}$ Kuten Kati Varkin kohdalla, taidokkaan tanssin kuvaus liitetään jälleen häihin eli pulmiin.

Liikkuen laulaminen on toisaalta kerääjien ja tutkijoiden, toisaalta myös laulajien itse etenkin 1930-luvun keruissa usein esiin tuoma laulamisen tapa. Kuvaukset painottuvat naimattomiin tyttöihin, jotka etenkin juhlapäivinä olivat näkyvästi esillä kulkien ja tanssien kyläteillä eli kylän kujilla. (Ks. esim. Enäjärvi-Haavio 1949, 139-167; Harvilahti 1992, 14-22; Launis 1904, 1907; Simonsuuri 1972; Timonen 2004, 84-157; Virtanen 1968, 58-63.) Tytöt olivat koko kylän katseiden kohteina ja juhlapäivät olivat myös keskeisiä morsiamen etsimistilaisuuksia (Länkelä 1904, 290; Sarmela 1969; Tallqvist \& Törneroos 1904, 374; Virtanen 1985, 125). ${ }^{292}$ Yhden tanssitilanteen tai tietyn tanssin tarkkoja kuvauksia on aineistossa hyvin vähän, mutta lyhyempiä mainintoja melko runsaasti. Tyypillisimmillään runon yhteydessä mainitaan vain, että sitä laulettiin vaikkapa "ympärikossa" tai tanssien. Näiden mainintojen ymmärtämiseksi on olennaista hahmotella, minkälaisen kirjon liikkumisen tapoja ja sävyjä tällainen maininta voi pitää sisällään. Tanssi ja paikoillaan laulaminen näyttäytyvät kuvauksissa yhtenä laulun rekisterien piirteenä.

Yhtään tanssiin erikoistunutta tutkijaa ei Länsi-Inkerissä tämän työn aineiston kattamana aikajaksona vieraillut. Sinänsä tilanne ei poikkea paljonkaan historiallisten tanssikulttuurien tutkimuksen yleisestä problematiikasta. Liikkeelliset ja ruumiilliset piirteet (tai lajit) ovat usein hankalasti ja harvoin sanallistettuja ja tarkkoja kuvauksia on niukalti. (Hoppu 1999; 2003; Saarikoski 2003; ruumiillisuudesta ks. myös Piela 2010, 17, 46-47.) Esimerkiksi Elina Paukkunen (2006) kertoo, että Senegalissa tanssijat ovat hyvin tietoisia siitä, mikä on hienoa tai oikein, mutta tätä koskeva sanallinen kommentointi on niukkaa. Petra M. Autio (2003) kertoo kiistasta, joka kiribatilaisten tanssijoiden parissa nousi pienestä tanssiin kuuluvasta kädenliikkeestä. Vaikka tanssimiseen ei juuri liittynyt sanallista kommunikaatiota, yksi elekin saattoi toimia vahvana ryhmiin identifioitumisen ja kylän yhtenäisyyden rikkovana merkkinä tai symbolina. Petri Hoppu $(2003,19-22)$ toteaa, että tanssin ja liikkeiden merkityskentät ovat ruumiillisuudessaan ja moniulotteisuudessaan vaikeasti tavoitettavia (ks. myös Hoppu 1999, 28, 33-34; Knuuttila 1994, 149).

\footnotetext{
${ }^{290}$ SKS KRA Salminen K. 46; ks. myös Porkka 1886, 158.

${ }^{291}$ SKS KRA Laiho L. 5409.

${ }^{292}$ Moni Inkerissä kenttätöitä tehnyt tutkija nostaa tanssin ja kulkemisen keskiöön laajempia alueitakin koskevissa kuvauksissa ja tutkimuksissa (Alava 1932; Launis 1910b; 1910c; Enäjärvi-Haavio 1949; Simonsuuri 1972).
} 
Leea Virtanen (1994a, erit. 336) pohtii inkeriläisen tanssin arjesta erotettua luonnetta ja tanssin luomaa läheisyyden tuntua, jotka hänen tulkinnassaan antoivat mahdollisuuden laajalle ilmaisun kirjolle ja henkilökohtaistenkin ongelmien käsittelylle. Tanssin yleinen merkittävyys käykin länsi-inkeriläisestä aineistosta ilmi. Se kuitenkin antaa vain harvoin tilaisuuden yksityiskohtaisempiin liikkeiden saati niiden merkitysten analyysiin. Keskeinen tavoitteeni tässä luvussa onkin yksinkertaisesti hahmotella runoaineistossa usein lakonisina esiintyvien nimitysten (kuten ympärikkö, kluutša, läpi kylän) ulottuvuuksia ja niihin liitettyjä runoja, sävelmiä sekä laulamisen tapoja. Käytän apunani myös seuraavien lukujen tuloksia. Luettelo liikkeen kannalta keskeisimmistä arkistolähteistä löytyy liitteestä 5. Lähteet painottuvat 1930-luvun aineistoihin ja Narvusin alueelle. Arkistolähteiden lisäksi erityisen keskeisiä ovat tässä luvussa Armas Launiksen (1904, 1907), Elsa EnäjärviHaavion (1949) sekä Aili Laihon $(1961 ; 1972)$ kuvaukset. 


\section{LÄPI KYLÄN}

Läpi kylän laulaen kulkeminen tai tanssiminen on yksi aineistossa useimmin mainituista liikkumisen tavoista. Kuvaukset liittyvät pyhäpäiviin, praasnikkoihin ja häihin. Praasnikoista tarkemmin on mainittu Jyrin, Pedron, Iilian, Miikkulan ja Troitsan päivien lisäksi juhannus, joulu ja laskiainen. Häiden yhteydessä kuvaukset liittyvät hääväen ajamiseen tai kulkemiseen morsius- tai sulhastaloon ja tyttöjen läpi kylän kulkemiseen kihlajaisten yhteydessä. Läpi kylän saatettiin mennä monella tavoin: kävellen, tanssien, ketjuna, paririvinä, vapaissa muodostelmissa, reellä tai rattailla ajaen. Myös maininnat laulajista ja tilanteen luonteesta vaihtelevat. Yksinkertaisimmillaan muistiinpanossa kerrotaan vain, että mentiin "läpi kylän."293

Inkeriläiset kylät olivat usein melko tiiviitä ja monin paikoin myös melko lähekkäin toisiaan. Talot keskittyivät yhden päätien reunoille, talousrakennuksia oli vähän kauempanakin. Suuret juhlat, häät ja praasnikat, keskittyivät kuvausten perusteella yleensä talojen tupiin ja kylän keskuskadulle. Kylän läpi kulkeminen oli hyvin konkreettinen määre: kylän keskellä kulkevaa pääkatua yhdestä päästä toiseen. Reitti kulki jotakuinkin kaikkien talojen ikkunoiden alta: tila oli julkinen ja keskeinen, koko kylä näki. Kylän kadulle myös keräännyttiin tanssimaan. Varsinaisten tanssi-, liekku-, ja kokkopaikkojen kerrotaan kuitenkin usein olleen vähän syrjemmällä.

\section{KulJeskelu, GUlJANJE}

Pyhäpäivien ja praasnikkojen kuvausten yhteydessä mainitaan usein nuorten kuljeskelu, tanssi ja ajan vietto ulkona kylällä. 1930-luvun kuvauksissa tästä tanssin, laulun ja soiton sekaisesta kylällä kuljeskelusta ja seurustelusta käytetään venäjästä lainattua yleisnimitystä gulaittaminen tai $g u l(j) a n j e .{ }^{294}$ Anna Kivisoon mukaan nimitys oli nuori, tapa sitä vastoin ei:

"Tytöt näätku mäntii kesäl - pääskyset ko lentelööt ja pesii tekkööt - yhtee kokkoo tantsimaa, siis ulkon laulettii. Perält siis sanottii: Määmmä gulanjaa. Enne ei vennäi kieltä osattu." 295

1930-luvulla lainasana oli ilmeisen vakiintunut. Samanlaisia kuvauksia on silti tallennettu myös ilman nimityksen käyttöä. ${ }^{296}$ Praasnikkojen aikaan nuoret saattoivat viettää aikaa laulaen ja tanssien ulkona päiväkausia ja vain käydä välillä syömässä sisällä. Laulajina mainitaan ensisijaisesti tytöt ja nuoret naiset. Myös poikia ja nuoria miehiä saattoi olla mukana tai perässä seurailemassa, mutta esilaulajina heitä ei mainita. ${ }^{297}$ Ainoastaan Jyrin päivän naisten juhlissa sekä yhdessä luterilaismuis-

\footnotetext{
${ }^{293}$ SKS KRA Laiho L. 5911; ks. Liite 5: Liikekuvaukset.

${ }^{294}$ Ks. VKS: gul'jan’a; VKKMS: gul'anja, ven. guljan’e: huvit, kävely (VKSS).

${ }^{295}$ SKS KRA Laiho L. 5360.

${ }^{296}$ Esim. SKS KRA Enäjärvi-Haavio 556.

${ }^{297}$ Esim. SKS KRA Laiho A. 2615; ks. myös Groundstroem 1904, 414-415; Lukkarinen 1911, 44.
} 
tiinpanossa neljäntenä joulupäivänä, kun "naiset on vapaat," kutsutaan myös naisten juhlimista gulaittamiseksi. ${ }^{298}$

Gulaittamisen kaltainen termi on myös hulkkuminen. Sana viittaa nimenomaan joukossa kuljeskeluun, mutta siihen ei näytä liittyneen yhtä vahvaa laulun ja tanssin painotusta kuin guljanje-sanaan. ${ }^{299}$ Hulkkuminen on yleisempi termi, joka sulkee sisäänsä joskus myös guljanjen. ${ }^{300}$ Joukolla liikkumisesta tai olemisesta 1930luvun laulajat käyttivät joskus myös nimitystä kampas tai kampanjassa: nimitys ei välttämättä pitänyt sisällään laulua tai tanssia, mutta ei myöskään sulkenut sitä ehdottomasti pois. ${ }^{301}$

Keskeinen ero vanhempien ihmisten ja nuorten juhlinnassa määrittyy kuvauksissa juuri guljanje-termin kautta: "Vanhat ajoivat juttua, nuoret kävivät guljanjalla."302 Vanhemmat ihmiset pysyttelivät pääosin sisällä syömässä ja juomassa, nuoret ulkona tanssimassa ja laulamassa, joskin aikuisetkin saattoivat hetkittäin tulla ulos kulkemaan ja tanssimaan. ${ }^{303}$ Guljanje-termi määrittää paikan (ulkona) lisäksi epäsuorasti usein myös vuodenajan. Talvella nuoret vuokrasivat tai pyysivät ajanviettopaikakseen tuvan, jolloin kyseessä oli beseda, kesällä oltiin ulkona guljanjassa. ${ }^{304}$ Gulaittamisen kuvauksiin sisältyy monenlaisia erotteluja ikä- ja muiden ryhmien välillä. Launiksen $(1904,52)$ mukaan kylällä saattoi juhlapäivinä olla useita eriikäisiä tyttöryhmiä laulamassa. ${ }^{305}$ Tyttöjen joukko saattoi pitää sisällään myös vastikään naimisiin menneitä naisia. ${ }^{306}$ Erotteluja tehdään kuvauksissa myös oman kylän ja muiden kylien tyttöjen välillä ja iän lisäksi aviosäädyn sekä sukupuolen pohjalta: tytöt, pojat, naiset, miehet, vanhat, nuoret, naimisissa olevat. ${ }^{307}$

${ }^{298}$ SKS KRA Haavio 2697; Laiho A. 2585; Laiho L. 5229; joulupäivänä Laiho A. 2607.

${ }^{299}$ Esim. SKS KRA Enäjärvi-Haavio 467, 559; Haavio 2785; ks. myös IMS hulkkua; ESS hulkuda.

${ }^{300}$ SKS KRA Alava 7A: 254; Enäjärvi-Haavio 467, 559, 771; Haavio 2785; Laiho A. 2614; Laiho L. 5188, 5227, 5228, 5362. Kotkon kylän Iilian praasnikoiden neljäntenä päivänä "vanhat naiset kamppanjas hulkuivat" ja Väikylässä Jyrinpäivänä "miehet eivät tohtineet tulla naisten hulkkaa," eli joukkoon (SKS KRA Haavio 2763; Laiho L. 5229).

${ }^{301}$ Esim. SKS KRA Haavio 2796, 2801; Laiho L. 5247, 5987. Tyttöjen tai nuorten tekeminen (tanssi, läpi kylän meno) sisältyy nimenomaan guljanjen käsitteeseen, etenkin miehet sitä vastoin vain olivat joukkona, kampanjassa. Kampassa tai kampanjassa käyminen tarkoittaa joukolla liikkumista eikä siihen aineistossa liity tanssin kuvauksia. (Ks. SKS KRA Enäjärvi-Haavio 815; Laiho A. 2218; Laiho L. 5324, 5987.) Kompanija (ven.): seura; kampas (vir.): joukossa (VKSS, ESS).

${ }^{302}$ SKS KRA Enäjärvi-Haavio 800, ks. myös 770, 771, 790, 794.

${ }^{303}$ Erit. SKS KRA Enäjärvi-Haavio 797; Laiho A. 2576, 2600, 2606; Laiho A. 2607; Laiho L. 5987; 6000

304 "Huonees oli talviaikan besedat, palkattii maja. Kesäl ulkon ku oltii, sanottii, ett oltii gulanjas" (SKS KRA Laiho L. 5255; ks. myös Laiho L. 5989; Enäjärvi-Haavio 1949, 156). Jos satoi, saattoivat nuoret tosin kesälläkin viettää praasnikkaa tuvassa (SKS KRA Laiho A. 2606; vrt. Enäjärvi-Haavio 556). Aineistossani guljanje-termi liittyy ainoastaan kaksi kertaa tanssimiseen tai ajanviettoon talvella tuvassa (SKS KRA Laiho A. 2343; Enäjärvi-Haavio 819). (Ks. myös Čistov 1976b, 197.) Besede (ven.): keskustelu, illanistujainen (VKSS).

${ }^{305}$ Esimerkiksi Martinpäivänä Ropsussa ja Kullalla lapset kävivät taloissa laulamassa ja pyytämässä herkkuja, "korjaamassa", mutta eivät isommat eli "suuret", jotka "kävivät jällee omas kamppas" (SKS KRA Laiho L. 5362).

${ }^{306}$ SKS KRA Haavio 2771; Laiho A. 2347; Laiho L. 5168.

${ }^{307}$ Esim. SKS KRA SKS KRA Haavio 2771, 2792, 2793, Laiho L. 5227, 6001. Anna Hovaskin kertoo, että Haavikon kylän Pedron praasnikoilla "Naiset käytii kampanjas, siis tyttöil ja pojil oli oma kampanja" (SKS KRA Laiho L. 5247). Toisena joulupäivänä Kallivieressä kuvataan tytöt ja miehet erikseen ja korostetaan samalla tyttöjen laulua: "Miehet käytiin kamppanjassa, tytöt läpi kylän mäntii laulu", samoin Soikkolassa Pedron praasnikoilla: "Tytöt pojat mäntii tantsul, miehet noistii käymää kampan'jas" (SKS KRA Enäjärvi-Haavio 815; Laiho L. 5987). 
Jos guljanjeen liittyvää liikkumista tarkemmin kuvataan, kuulostaa se yleensä epämuodolliselta ja vaihtelevalta: "Tytöt kulkivat yhdessä, neljäkin rinnan tietä pitkin. Välillä tanssittiin." ${ }^{308}$ Yhdessä kulkemisen ja välillä tanssimaan pysähtymisen teemat toistuvat: "Pyhäiltoina tytöt kulkivat pitkin kylän teitä käsi kädessä laulaen. Avoimella paikalla oltiin piirileikkiä." ${ }^{309}$ Kylällä kulkiessa kerrotaan usein pidetyn käsistä kiinni tai kuljetun käsikynkkää. ${ }^{310}$ Juljaana Pohjalainen kertoi tyttöjen pyhäisin lounaan jälkeen kulkeneen laulaen "kylän kujilla" ja "läpi kylän" yhtenä joukkona, mutta ei säännöllisessä kulkueessa. Kävellessään läpi kylän he lauloivat "vienoo" eli "pitkällä nuotilla."311

Gulanje piti siis sisällään paljon erilaisia tanssimisen ja kulkemisen tapoja. Se saattoi sisältää myös esimerkiksi ajan viettämistä liekulla. ${ }^{312}$ Valpuri Vohdan kuvaus kuitenkin viittaa siihen, että tarkemmin liikkumisen tavoista puhuttaessa guljanje tarkoittaisi ensisijaisesti vapaamuotoista kuljeskelua. Hän kertoi laulaneensa Varhain kuoli miun emoni -runoa häissä, piirissä käsi kädessä, ja tarkensi: "Ei gulaanjessa eikä istuen."313 Tanssi häissä, muidenkaan kuin varsinaisten rituaalisesti keskeisten häärunojen yhteydessä, ei siis Vohdan mielestä sopinut guljanje-termin alle. Joskus guljanjen epämuodollisuus asetetaankin vastakkain tilannesidonnaisempien laulujen ja käytäntöjen kanssa. Kun Anna Kivisoo kertoo juhannusaaton kokolle kulkemisesta kolme, neljä rinnakkain, hän erikseen korostaa, että kyse ei kuitenkaan ollut guljanjesta. ${ }^{314}$ Rituaalisempien tilanteiden laulu ei sisältynyt guljanjen kehykseen. Guljanjeen tai kuljeskeluun liittyvät muutamat runomuistiinpanot ovatkin yleisiä, moneen tilanteeseen sopivia, usein tyttöjen näkökulmaan sijoitettuja lyyrisiä ja eeppisiä teemoja. Mitään erityisiä aloitusteemoja tai -formuloita ei esiinny. ${ }^{315}$

Vapaamuotoisen laulun, tanssin ja kuljeskelun kuvataan liittyneen praasnikoiden ja pyhäpäivien kehyksiin. Käytetyistä termeistä yleensä nuorison ajanviettoon liit-

\footnotetext{
${ }^{308}$ Tytöt käyttivät refrenkiä sadul moi sadu zeljonoi, joka yleensä liittyi nopeahkoon yksisäkeiseen, jäljempänä käsiteltävään sävelmään (SKS KRA Enäjärvi-Haavio 549, 557).

${ }^{309}$ SKS KRA Sääski 5365; ks. myös Enäjärvi-Haavio 550, 559.

${ }^{310}$ esim. SKS KRA Sääski 5365, 5487; Simonsuuri 1972, 48. Valpuri Vohdan mukaan he kulkivat kahdesta neljään tyttöä rinnan pitäen "toistensa selän takaa kiinni." Hänen mukaansa kaksisäkeisiä refrenkejä kaalina kaalina kaalina maja sekä oi lolii oi lolii oili loošinki moii käytettiin "vain sellaisissa lauluissa, joita laulettiin kävellessä," ja joihin kuului hitaampi sävelmä (SKS KRA Enäjärvi-Haavio 555). Refrengeistä ensimmäinen liittyy luultavasti kaksisäkeiseen venäläisperäiseen sävelmään, jota saman refrengin kanssa käytettiin vuoden 1937 äänityksissä rekryyttilaulun ja paimenrunon laulamiseen (SKSÄ L 91a ja c), toista ei aineistossa löydy yhdenkään sävelmän yhteydessä.

${ }^{311}$ SKS KRA Enäjärvi-Haavio 556.

${ }^{312}$ SKS KRA Enäjärvi-Haavio 832.

${ }^{313}$ SKS KRA Enäjärvi-Haavio 500, vrt. kuit. 555. (Piennä petti miun emoni, vrt. SKVR III 2047.)

${ }^{314}$ SKS KRA Enäjärvi-Haavio 773; ks. myös luku 6: Juhannus, kokkovirsi.

${ }^{315}$ Anna Kivisoo liittää gulanja-kuvaukseensa kosinta-aiheisen Saaren synty -runon, ja toisaalla hän kertoo gulaittaessa lauletun esimerkiksi Täss on tykky tyttölöitä -runoa tai illalla La mie vieretän vilulla -runoa (SKS KRA Enäjärvi-Haavio 482, 549; Laiho L. 5328, 5360). Kylällä kulkiessaan kerrotaan tyttöjen laulaneen tyttären omaisuudetta jäämisestä sekä kotonaan että miehelässä kertovaa Kui mie kazvelin kanane -laulua tai veljen etsimisestä kertovaa runoa (SKS KRA Enäjärvi-Haavio 491; Sääski 5487) "Kera suurel äänel gulanjel laulettiin" Katri Vohdan mukaan Ison kotona ja toiselassa -runoa (SKS KRA Enäjärvi-Haavio 497). Väärnojan Kati-akka kertoi vain tyttöjen helatorstaista Iilian pyhään kävelleen yöllä "pitkin kylää" ja lauleskelleen talojen edustoilla eli "'ikkunoja' möite omia virsiänsä." Katin laulama pitkä teemasta toiseen liikkuva runo alkaa kuvauksella siitä, kuinka oma äiti on pessyt ja pukenut tyttönsä kauniiksi (SKVR III 1580).
} 
tyvä guljanje pitää vahvimmin sisällään ajatuksen myös laulamisesta. Hulkassa tai kampassa kulkeminen viittaa ensisijaisesti vain joukolla kulkemiseen, vaikka ei suljekaan ajatusta laulusta kokonaan pois. Mitään vakiintuneita yksittäisiä rekistereitä tämänkaltaiseen pyhäpäivien juhlintaan ei aineiston perusteella näytä liittyneen, vaan guljanje on monia erilaisia, vaihtelevia lauluja ja laulamisen tapoja sisällään pitävä yleinen juhlien kehys, joka ei pidä sisällään rituaalisempia praasnikoiden tai häiden lauluja.

\section{VIRON VERÄJÄT}

Kylän läpi kulkemisen kuvauksissa esiintyy väljien muodostelmien lisäksi kiinteämpiä ja rituaalisiinkin yhteyksiin liittyviä kulkemisen tapoja, joista käytetään 1930-luvun narvusilaisaineistossa nimityksiä Viron veräjät ja kluutša. Viron veräjät oli "ketjutanssi, johon kuului portistakäynti" ja jota siis tanssittiin yhtenä toisiaan käsistä pitävien laulajien ketjuna. Kluutšaa tanssittiin paririvissä muutamalla erilaisella tavalla, joista jäljempänä tarkemmin. ${ }^{316}$

Kiemurtavan, päädyssä olijoiden käsien alitse pujottelevan jonon ensimmäinen inkeriläiskuvaus on Launikselta $(1904,53)$. Hän kertoi, että tämä laulamisen tapa "vielä kuuluu olevan elossa Keski-Inkerissä", jossa sitä kutsutaan vääräksi piiriksi.

"Piiri se ei kuitenkaan ole, sillä se on avonainen ja pääasemissaan suora. Tytöt ja pojat asettuvat pitkin kylän kujaa pitkään riviin pitäen toistensa käsistä kiinni. Eessälaulaja on jommassakummassa päässä. Toisessa päässä olijat pysyvät paikoillaan ja kahden viimeisen välistä pujottautuvat toiset perätysten. Kun on päästy yhteen jonoon, tekee toinen pää saman kulun samaan suuntaan. Näin käydään kylän otsasta otsaan tavalliseen tapaan laulaen."

Toisen matkansa jälkeen Launis (Launis 1907, 109-110) tarkensi kuvausta edelleen Keski-Inkerin pohjalta: esilaulaja saattoikin seistä missä kohden riviä hyvänsä. Nimityksiä olivat myös pitkä rinki ja läpi liekkusin käynti. ${ }^{317}$ Kulkiessa laulettiin ”jotenkin hitaassa tahdissa, tyynesti kävellen." Launis liitti väärän piirin kokolle eli tanssipaikalle kulkuun ja kertoi sen yhteydessä käytettävän sävelmän usein sisältävän ai ljole- tai ai luuli-refrengin. Näyttää siltä, että tunnusomaista kokkovirren sävelmälle oli ennen kaikkea samantyyppisten refrenkien käyttö, ei niinkään tietty rytmi, muotorakenne tai sävelkulku, jotka vaihtelivat alueittain ja ilmeisesti laulajittainkin. ${ }^{318}$

\footnotetext{
${ }^{316}$ Nimitykset menevät eri kerääjien kuvauksissa jonkin verran ristiin ja jäävät välillä epämääräisiksi. Elsa Enäjärvi-Haavio $(1949,160)$ näyttää kertovan kluutšan ja Viron veräjien nimellä samasta liikkumisen tavasta, Aili Simonsuuri (1972, 47-48) puolestaan kuvaa kluutšan selkeästi mutta jättää Viron veräjät lyhyelle maininnalle. Pirkko-Liisa Rausmaa $(1981,187)$ määrittää näiden kirjoitusten sekä niiden taustalla olevan arkistoaineiston pohjalta tässä esitetyn selkeän jaon, joka näyttää pääpiirteissään pätevän myös laajemman aineiston osalta. Kljuts (ven.): avain, lähde (VKSS).

${ }^{317}$ Etelä-Karjalassa käytettiin myös nimitystä läpi luikkusin samankaltaisesta kulkemisesta polskan yhteydessä. (MV Reinholm: Ilokas, taikka Suomen kansan ajanviettoja (käsikirjoitus), 35. j.)

${ }^{318}$ Ks. myös Timonen 2004, 109-113. Sävelmäkuvausta käsitellään tarkemmin seuraavassa luvussa juhannuksen yhteydessä.
} 


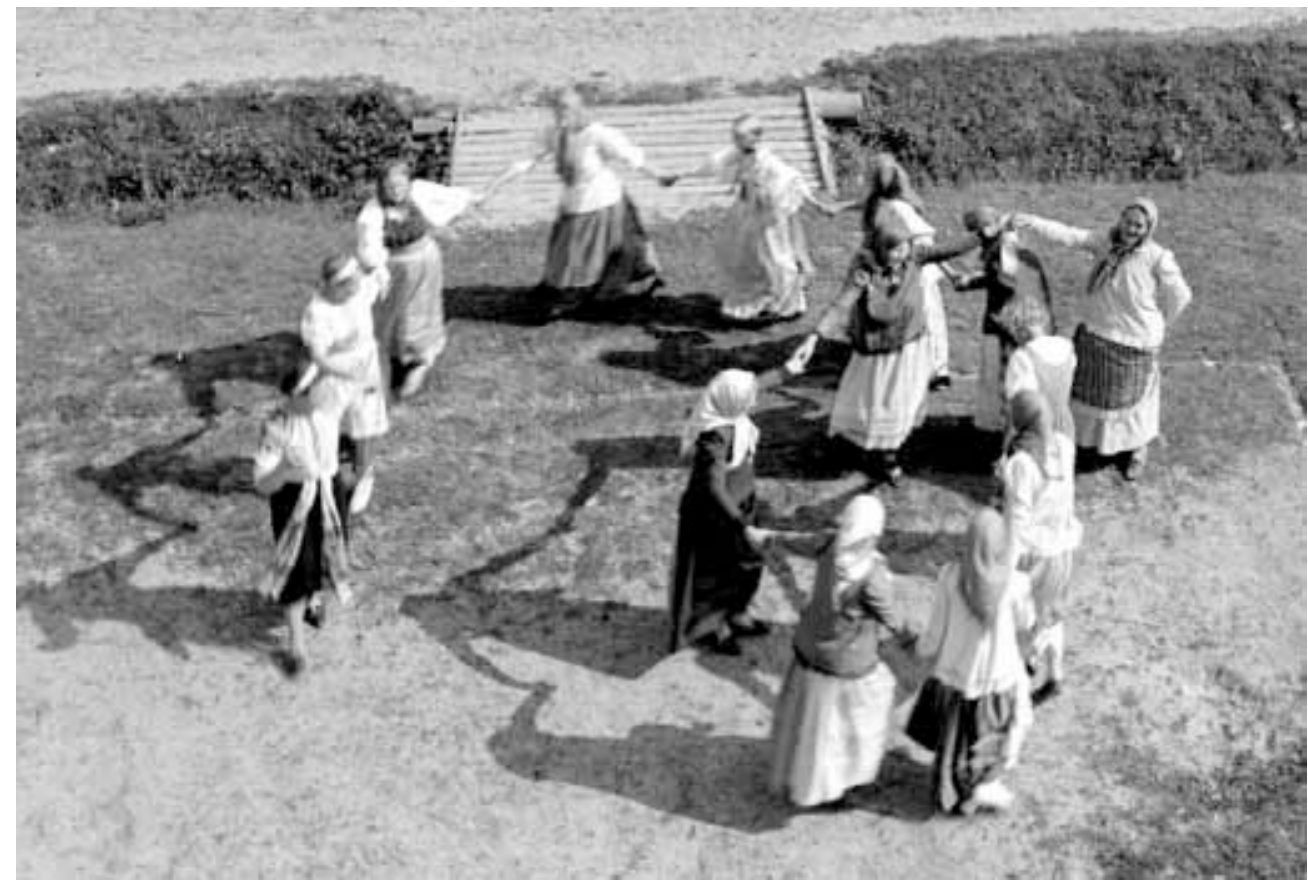

Kuva 5. Viron veräjät. Ketjun oikeassa päädyssä Valpuri Vohta. (KAVA Mäkinen 1938 Inkeri 245/4.)

Samasta liikkumisen tavasta on myös lyhyt elokuvataltiointi Narvusista vuodelta 1938. ${ }^{319}$ Se koostuu nopeasti vaihtuvista näkymistä. Esiintyjiä näytetään seitsemässä eri kohdasta kuvatussa otoksessa yhteensä noin 45 sekuntia. Tanssimassa on viisitoista naista ja tyttöä, joukossa keskellä ainakin Mari Vahter ${ }^{320}$ ja ketjun toisessa päässä Valpuri Vohta. ${ }^{321} \mathrm{Kymmenellä} \mathrm{tanssijoista} \mathrm{on} \mathrm{päässään} \mathrm{naimisissa}$ olevan naisen huivi, kolmella tytön hiusnauha ja kaksi on avopäin. Huivipäisten liikkuminen näyttää yleisesti ottaen tyttöjen vaatteita kantavien liikkumista varmemmalta. Vohta ketjun toisessa päässä näyttää laulavan esilaulua - Aili Laihon $(1972,47)$ mukaan esilaulaja oli yleensä juuri ketjun toisessa päädyssä. Vahterin ${ }^{322}$ lisäksi vähintään osa muistakin laulaa kuoro-osaa. Tanssijoiden ketju kiemurtaa kuvaustilanteen vaatimusten mukaisesti melko suppealla alueella eikä siis siirry eteenpäin. Esiintyjien askeleet vaihtelevat hitaahkosta kävelyaskelesta nopeaan, lyhyeen ja tasaiseen teputukseen (puolijuoksu) sekä erilaisiin vaihtoaskelten ja hypähdysten vaikeasti erottuviin häivähdyksiin. Askeleet tuntuvat varioivat osin kohtauksittain (välillä on ilmeisesti tanssittu hitaammin, välillä nopeammin), osin tanssijoittain sekä suhteessa ketjun liikkeisiin. Elokuvakohtauksen musiikiksi on liitetty Vohdan esilaulama, vuotta aikaisemmin äänitetty Tehkää yksi ympärikkö, mutta sitä ei luonnollisesti ole saatu sopimaan useasta eriaikaisesta palasta leikatun filmin askelten rytmeihin. Äänen kanssa katseltuna vaikutelma on epärytminen; tanssi näyttää paljon varmemmalta ja rytmisemmältä, kun nauhaa katselee ilman ääntä, kohtaus kerrallaan. On mahdotonta sanoa, mitä sävelmää tai sävelmiä fil-

\footnotetext{
${ }^{319}$ Mäkinen 2008, 05:16-06:06.

${ }^{320}$ Mäkinen 2008, 05:25.

${ }^{321}$ Mäkinen 2008, 05:44-05:49.

${ }^{322}$ Mäkinen 2008, 05:54-06:08.
} 
millä lauletaan. Nopeat leikkaukset ja taustamusiikin valinta tuntuvat korostavan vauhtia, ja ovat luultavasti tarkoituksellinen valinta tanssia edeltäneen hitaan morsiamenhunnuttamiskohtauksen jälkeen.

1930-luvun narvusilaisaineistossa yhdessä ketjussa (rita, rääty, pitkä rivi) kulkemiseen ja käsien välitse pujottelehtimiseen liittyvissä kuvauksissa tätä liikkumisen tapaa kutsutaan nimellä Viron veräjät. Siihen liittyviä kuvauksia on tallennettu neljältä luterilaislaulajalta, filmitaltioinnin esilaulajalta Valpuri Vohdalta sekä Juljaana Pohjalalaiselta, Valpuri Haukalta ja Maria Otsalta. Toisin kuin Launiksella, kuvauksissa korostuu vauhti: juostiin ja tanssittiin, mentiin "kiireesti." Muutamissa muistiinpanoissa liikkeen kuvaus jää monitulkintaiseksi. ${ }^{323}$ Viron veräjien käsikirjoituskuvaukset liittyvät naisten ja tyttöjen Jyrinpäivänä ja talkoissa sekä tyttöjen muulloinkin pyhäiltoina laulamiseen. ${ }^{324}$ Niihin liittyvät runot ovat variaatioineenkin kaikki samaa tyyppiä: ${ }^{325}$
Avatkaa Viron veräjät!
Viron vieraat tulloot
Viron vettä katsomaa,
Kui vesi kuvaelloo,
Somerpohja souteloo. ${ }^{326}$

Aloitusteeman jälkeen, kertoivat Haukka ja Pohjalainen, voitiin lisätä "toinen virsi perään" ja laulaa "kenen mieleen mitä tuli, [mitä] tahto laulaa." ${ }^{27}$ Esilaulaja saattoi laulun kuluessa vaihdella: "Ken osasi, se oli eessälaulaja."328 Sävelmiä tai viittauksia laulun muotorakenteeseen ei narvusilaisiin Viron veräjien tanssikuvauksiin liity. Kokkovirren tarkastelun yhteydessä näyttää kuitenkin siltä, että Länsi-Inkerissä tämäntyyppisessä kulkemisessa voitiin käyttää muutamaa yleistä, yksinkertaista tanssisävelmätyyppiä, joiden joukkoon kuuluu myös filmitallenteen taustamusiikiksi asetetun Tehkää yksi ympärikko, ympärikko -laulun edustama sävelmä.

Avatkaa Viron veräjät oli myös keskeinen hääruno, jota laulettiin erilaisina versioina hääjoukon saapuessa juhlataloihin. Häihin liittyviin toisintoihin sisältyy kui-

\footnotetext{
${ }^{323}$ Varpuli Haukan kuvaus antaa mahdollisuuden kahteen erilaiseen liikkeen tulkintaan: tehtiin pitkä kädestä toisiaan kiinni pitävien naisten rivi, kuljettiin läpi kylän ja "yks juoks ympärkautta, laulettii ja tanssittii, laulettii." Edellä kuvatun tanssimisen tavasta poiketen voi olla, että hänen versiossaan tanssijoista yksi kerrallaan irrottautui rivistä juostakseen sen toiseen päähän. (SKS KRA Haltsonen Kl n:o 6530:39; ks. myös Haavio 2704; Laiho A. 2347.) Anna Kivisoon monitulkintaisen kuvauksen suuren tyttöjoukon kulkemisesta "yhessä ritassa" eli rivissä tulkitsi Aili Simonsuuri suorassa, kiemurtamattomassa rivissä kulkemiseksi. (SKS KRA Laiho L. 5348; Simonsuuri 1972, 47.) Koska kuvaus hänen miehensä Lauri Laihon (Simonsuuri) tallentama, saattoi Aili Simonsuurella olla taustatietoa, joka ei arkistomuistiinpanosta välity - pelkän muistiinpanon perusteella kuvauksen voisi tulkita kuuluvaksi yhtä hyvin myös kiemurtavaan riviin tai kenties paririviinkin: muodostelmaa ei siinä määritetä. Rrjad (ven.): rivi, joukko (VKSS).

${ }^{324}$ Ks. Liite 5: Liikekuvaukset.

${ }^{325}$ SKS KRA Enäjärvi-Haavio 553, 555, 556, 754; Haavio 2688, 2704, Haltsonen 6530:39; Laiho A. 2337, 2347; ks. myös Laiho 1944, 106. Selkeimmät kuvaukset ovat Enäjärvi-Haavion Pohjalaiselta ja Vohdalta muistiinmerkitsemiä: niissä kyse on täysin varmasti Launiksen kuvaamasta muodostelmasta (SKS KRA Enäjärvi-Haavio 553, 555, 556).

${ }^{326}$ SKS KRA Haavio 2688.

${ }^{327}$ SKS KRA Haavio 2688, 2704; Laiho A. 2347.

${ }^{328}$ SKS KRA Haavio 2688.
} 
tenkin yleensä tehkää lahti lautaportit -säe ja puuttuu usein edeltävän esimerkin veden katsomisen kuvaus. ${ }^{329}$ Hääkontekstissa teemaa laulettiin yleensä paikoillaan seisten häätalon portille saavuttua, neli-iskuisella häiden pääsävelmällä (ks. luku 7). Viitteitä ei ole Avatkaa Viron veräjä -häärunon yhteydessä käytetyn neli-iskuisen pulmanuotin käytöstä Viron veräjät -kulkemisen yhteydessä.

\section{KLUUTŠA}

Toinen laaja kuvausjoukko liittyy paririvissä kulkemiseen tai tanssimiseen. 1930luvun aineistossa kaikki tällaiset kuvaukset liittyvät kluutša-nimitykseen. Myös Launis $(1907,106-107,110)$ kuvaa tämän muodostelman, mutta ei nimeä tai paikanna sitä. Kuvaukset jakaantuvat kolmeen ryhmään, jotka eroavat toisistaan sen suhteen, ketkä liikkuvat ja millä nopeudella: 1) paririvi pysyy paikallaan ja yksi pari kerrallaan juoksee läpi, 2) rivistö juoksee hitaammin kulkevan portin läpi tai 3) pari juoksee rivistön ulkokautta ensimmäiseksi. Yhdistävä tekijä on eteneminen paririvissä.

Aili Simonsuuri kuvaa Anna Kivisoon kertoman pohjalta ensimmäisen, yleisimmän aineistossa mainitun paririvissä kulkemisen tavan:

Tytöt olivat parittain vastakkain pitäen toisiaan kädestä, ja viimeinen pari juoksi rivistön välistä toisten eteen, sitten taas seuraava. Laulaen joukko eteni kylän kujaa pari kerrallaan. ${ }^{331}$

Kivisoo nimitti käsikirjoitusaineistossa tämän tavan kl’uutšaksi. ${ }^{332}$ Juoksemisen ohella tämän ryhmän kuvauksissa puhutaan myös tanssista. ${ }^{333}$ Toisen ryhmän muodostavat kuvaukset, jossa rivistön kerrotaan paikallaan pysymisen sijaan liikkuneen eteenpäin. ${ }^{334}$ Maria Otsan kuvauksesta piirretyssä kuvassa muodostelma on lisäksi leveämpi kuin muissa kuvauksissa. Tytöt näyttävät seisovan pareittain kukin pari samalla puolella ja kujan läpi kulkee kaksi paria kerrallaan. ${ }^{335}$

${ }^{229}$ SKS KRA Enäjärvi-Haavio 857; Haavio 2468; Laiho A. 2145, 2156, 2258, 3441; ks. myös Laiho A. 2179 , jossa veden katsominen. Länkelä tosin nimesi nimenomaan yhden edeltävän esimerkin kaltaisen runon vesien katseluteemoineen häälauluksi (SKS KRA Länkelä 3:617). Ainakin keruutilanteessa keskeiset esitysareenat saattoivat silti myös liukua päällekkäin. Viron veräjien tanssikuvauksiin liittyvistä runoista yksi kytkeytyy aloitusformulansa (Lankoiseni lintuiseni) kautta selkeästi rituaaliseen hääkontekstiin, vaikka kuvauksessa runo liitetään läpi kylän menemiseen. (SKS KRA Laiho A. 2337.)

${ }^{330}$ Soikkolasta tallennetut kaksi Avatkaa Viron veräjät -fonogrammitoisintoa ovat häälauluja kuten myös veräjien avauspyynnön sisältävä vuoden 1937 äänite (SKSÄ A 300/19b, 20a; SKSÄ L97 b) Ainoastaan yksi Narvusin Arsiansaarelta tallennettu kuusi-iskuinen (44222244), yksisäkeinen toisinto saattaisi liittyä yhtä hyvin kuin häätaloon saapumiseen, myös Viron vettä katsomaan -runoteemaan ja kylän läpi kulkemiseen (SibA Launis 17). Sävelmä kytkeytyy muotorakenteensa ja rytmityyppinsä puolesta väljään sävelmäryhmään, johon Länsi-Inkerissä sisältyy lyyristen ja lyyriseeppisten laulujen ohella monta häälaulua, tanssiin liittyviä runoja sekä erityisen runsaasti Läksin koista kulkemaan -teemaa. Samaa rakennetta käyttäviä häälauluja ks. SibA Launis 30; SKS KRA Borenius 194, 203; SKSÄ A 300/17b, 20b; ks. myös luku 7; tanssiin liittyviä aloitusformuloita tai runoja SibA Launis 107; NPI2; Läksin koista kulkemaa SibA Launis 10, 86, 105b, 125; Oman kylän ylistys: SibA Launis 324; kulkemisen teemoista ks. SibA Launis 23 (Miä kävin kyliä paljon) ja 247 (Niin miä vierin velloistani).

${ }^{331}$ Simonsuuri 1972, 47; ks. myös Enäjärvi-Haavio 1949, 160-161.

${ }^{332}$ SKS KRA Laiho A. 5337; ks. myös; Laiho A. 2210.

${ }^{333}$ SKS KRA Enäjärvi-Haavio 551; Haavio 2456; Laiho A. 2576; Salminen K. 189.

${ }^{334}$ SKS KRA Enäjärvi-Haavio 771, SKS KRA Laiho L. 4902.

${ }^{335}$ SKS KRA Laiho L. 4902. 
Launis $(1907,106-107,110)$ ei toisen ryhmän piiriin kuuluvassa kuvauksessaan nimeä muodostelmaa, mutta kuvaa sitä tarkasti. Hän liittää paririvimuodostelman sekä häätaloon että kisapaikalle kulkemisen kuvaukseen. ${ }^{336}$ Siirryttäessä morsiamen talosta sulhasen taloon naiset lauloivat ja tanssivat aina kulkiessaan läpi matkalla olevien kylien. Samalla tavalla tanssien kulkivat myös tytöt pyhäiltaisin palatessaan kylän toisesta päästä kokolle tai kisapaikalle. Häiden yhteydessä, kertoo Launis, naiset kulkivat hitaasti parijonossa. Pari piti kiinni toisistaan nenäliinan tai päähineen välityksellä. Ensimmäinen pari kohotti liinan yhdistämät kätensä ylös, ja loput kulkivat heidän käsiensä alitse nopean tanssin tahdissa, kunnes ensimmäinen pari oli jonon viimeisenä. Ensimmäiseksi tullut pari nosti vuorostaan kätensä ylös, ja sama toistui läpi kylän. Porttina toimiva pari käveli hitaasti, toiset tanssivat läpi nopeasti. Ainoastaan kylien kohdalla laulettiin ja tanssittiin, muuten vain käveltiin.

Kolmanteen kuvausryhmään kuuluu vain yksi muistiinpano: Matrona Bässina kertoi parien juoksevan rivistön takaa sen eteen ulkokautta kätensä irrottaen. ${ }^{337}$ Muodostelmat ja liikkumisen tavat ovat siis kluutšankin puitteissa vaihdelleet tiettyjen kehysten eli paririvin ja jonkinlaisen kylää pitkin etenemisen sisällä. Osa vaihtelusta voi myös liittyä siihen, että 1930-luvun tanssikuvaukset on yleensä tallennettu yhden laulajan kuvausten perusteella eikä monen tanssijan vaihtuvien sijaintien sanallistaminen ei ole helppoa. Paririvissä kulkemisen kuvauksia liitetään alueen keskeisiin praasnikkoihin: Pedron päivään, Jyrin päivään ja helluntaihin eli Troitsaan. ${ }^{338}$

Muutamassa inkerinsuomalaismuistiinpanossa kerrotaan naisten nimenomaan Jyrinpäivänä kulkeneen tai tanssineen Viron veräjiä tai kluutšaa läpi kylän. ${ }^{339}$ Jyrin päivä on ainoa konteksti, jonka yhteydessä myös naisten juhlimisesta usein puhutaan yleisellä ulkona kuljeskelua, laulamista, tanssimista ja seurustelua merkitsevällä guljanje-termillä. Darja Lehti kertoi miestenkin olleen sitä mieltä, että juuri Jyrinpäivänä naisilla oli oikeus juhlia: "Naizil on yks kord vuues vain praasnikka."340

Aili Simonsuuri $(1972,47)$ kertoo kylää kuvaavien runojen kuten La lähen läpi kyläsen tai Tässä oli ennen kylä olleen kluutšan yhteydessä erityisen suosittuja, mutta lauluksi sopi näiden ohella myös "lyyrissävyinen runo yleensä." Neljä tilanteeseen aineistossa liitettyä runoa alkaakin La lähen läpi kyläsen -teemalla, jolla laulu myös yleensä aloitettiin..$^{31}$ Muissakin kluutšaan liitetyissä runoissa alkusäe tai -teema

\footnotetext{
${ }^{336}$ Launis $(1907,105)$ kertoo nuotti-nimityksiä käytetyn Soikkolassa ja sävel-nimityksiä Hevaalla. Tällä perusteella hänen hääkuvauksensa, johon myös paririvimuodostelman kuvaus sisältyy, paikantuu Länsi-Inkeriin.

${ }^{337}$ SKS KRA Enäjärvi-Haavio 551, ks. myös Laiho A. 2576. Matrona Bässina vaikuttaa joissakin suhteissa hieman epäluotettavalta kertojalta, ks. Liite 1.

${ }^{338}$ Ks. Liite 5: Liikekuvaukset.

${ }_{339}$ SKS KRA Enäjärvi-Haavio 754, 759; Haltsonen /Kl n:o 6530:39; Haavio 2688, 2696, 2704; Laiho A. 2347; Laiho L. 5993, 6149. Samanlaiseen kylän läpi tanssiin liittyy myös yksi soikkolalaisen Pauliina Reposen tarkemmin määrittymättömiin "naisten kyläpraasnikkoihin" liittämistä toisinnoista. (SKS KRA Mannonen 5517, 7648, 11121.)

${ }^{340}$ SKS KRA Haavio 2697; ks. myös Haavio 2696. "Naisilla on praasnikka vain kerran vuodessa." Gulaittamisesta Jyrin päivänä ks. myös SKS KRA Haavio 2692, 2695; Laiho A. 2585; Laiho L. 5229.

${ }^{341}$ SKS KRA Enäjärvi-Haavio 771; ks. myös Laiho A. 2210; Laiho L. 5337; Salminen K. 189.
} 
liittyy joko kulkemiseen tai Oman kylän ylistys -teemaan. ${ }^{342}$ Kluutšan keskeis- ja aloitusteemat ovat siten suorassa viittaussuhteessa esitysareenaan, kylän keskuskatuun, sen läpi kulkemiseen tai oman kylän ja vieraan kylän vertailuun. Alun jälkeen voitiin laulaa kaikenlaista muuta jatkoksi. ${ }^{343}$

Sävelmiä tai refrenkejä ei 1930-luvun kluutša-kuvauksiin sisälly. Ainoa suora viite laulamisen tapaan on Katri Vohdalta, jonka mukaan jokainen säe kerrattiin sellaisenaan. ${ }^{344}$ Laajempi tähän liikkumisen tapaan liittyvä sävelmä- ja refrenkiaineisto aukeaa kuitenkin Launiksen kuvauksen kautta. Vaikka kluutša-muodostelmassa liikuttiin myös häiden yhteydessä kylien läpi kuljettaessa, ei Launis laskenut siinä käytettyä sävelmää varsinaisten pulmanuottien joukkoon. Sulhasen kodin portille saavuttua vaihtui sävelmä tavalliseksi pulmanuotiksi ja runo Avatkaa Viron veräjät -häärunoksi.

Läpi kylien tanssittavasta runosta ja sävelmästä Launis antaa harvinaisen tarkan ja helposti sävelmäaineistoon suhteutettavissa olevan kuvauksen. Launiksenkin mukaan runo alkoi yleensä Lähemmä läpi kyläisen -teemalla. Lauluun liittyi venäläinen refrenki saadulmoi saadu selenoi saadu ja Inkerissä harvinainen, Launiksen kuusi-iskuiseksi nimittämä rytmityyppi.

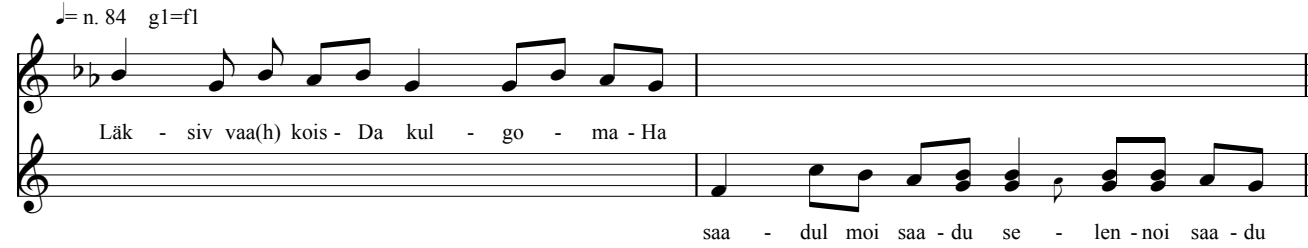

Nuotti 9. Naasto Savasteintyttären ja kuoron vuonna 1906 esittämä variaatio saadulmoi-sävelmästä (SKS̈̈ A 300/14a).

Sekä rytmityypin (44224422) että melodiatyyppien puolesta tähän kuvaukseen liittyvät sävelmät muodostavat poikkeuksellisen selkeärajaisen ryhmän niin, että ilman refrenkiäkin tallennetut tai lauletut sävelmät on yleensä helppo tunnistaa. Refrengillä oli monia muotoja, josta toinen yleisin oli oi saadu saadu selenoi saa$d u .{ }^{345}$ Kutsun sävelmää refrengin mukaisesti saadulmoi-sävelmäksi. Keskeisaineistosta niitä löytyy Länsi-Inkeristä 12 sävelmää ja lisäksi refrengin perusteella 5

\footnotetext{
${ }^{342}$ SKS KRA Haavio 2456; Laiho A. 2576; Laiho L 5338. Varpuli Haukka yhdistää Kulerva Kalervalainen -alkuisen, Oman kylän ylistys -teemaan siirtyvän runonsa sekä kluutšan menemiseen että ympärikon tanssimiseen (SKS KRA Haavio 2525; Laiho L. 5917).

343 "Siin laulettii vaik milline virs, mikä sopi vaa," kertoi Maria Otsa (SKS KRA Laiho L. 4902; ks. myös Laiho A. 2576).

${ }^{344}$ SKS KRA Enäjärvi-Haavio 771. Vohdan kuvaus sopii sävelmän muotorakenteen puolesta hyvin jäljempänä kuvattuun, ilman refrenkiä laulettuun saadulmoi-sävelmään.

${ }^{345}$ Esim. SKSÄ A 300/36 a. Saadulmoi-refrenki tulee suoraan venäjän kielestä: Sad li moj sad, zelenyi sad eli "puutarhani, vihreä puutarha" (ks. Kiuru 1974, 500). Sävelmäryhmän ja refrengin kiinteyden ja maantieteellisen suppea-alaisuuden (tallennettu ainoastaan Länsi- ja Keski-Inkeristä) perusteella voisi arvella sen olevan venäläinen laina (ks. myös Rüütel 1977, 264). Saadulmoi saadu-tyypin refrengeistä ainoastaan yksi toisinto Hevaalta (saaduljmoi saadu sekeljennai saadu) liittyy toisen tyyppiseen sävelmään (4422222222 2244) (SKS KRA Levón 441). Mielenkiintoista on, että tämäkin muistiinpano liittyy kuitenkin sanojensa puolesta tanssiin: Täss on lusti luita lyöä.
} 
runokäsikirjoitusta, jotka on lueteltu liitteessä 5 (Saadulmoi-sävelmät). Launis (1910b, 57-58) toteaa sävelmätyypin esiintyvän vain Länsi- ja Keski-Inkerin alueella. Sävelmää käytettiin myös ilman refrenkiä, jolloin kuoro kertasi esilaulajan sanat. Kahdessa länsi-inkeriläisessä sävelmässä ja kahdessa tyröläissävelmässä refrenkinä on saadulmoin sijaan oi lole lole tai ai lole lole, mikä Launiksen kuvauksen mukaan viittaa kokkovirsiin. Launishan mainitsee myös kokolle kulkemisen tämän liikkumistavan kontekstina, joten refrenkien päällekkäisyys ei ole yllättävää. ${ }^{346}$ Refrenki saattoi vaihtua keskeiskontekstin mukaan. Joenperän vatjalaisilla sekä saadulmoi- että oi lole lole -refrenkejä käytettiin myös ympärikossa. ${ }^{347}$ Sävelmää voitiin Länsi-Inkerin inkeroisillakin käyttää muissa muodostelmissa kuin kluutšassa: Anna Kivisoon mukaan saadulmoi-refrenkiä laulettiin kuljettaessa kylällä muutama tyttö rinnakkain, mikä kuulostaisi viittaavan vapaamuotoisempaan guljanjeen. ${ }^{348}$ Ilmeisesti 1900 -luvun alun Soikkolassa refrengistä kehittyi myös pidempiä muotoja, joihin liittyvistä sävelmistä ei kuitenkaan ole tietoa. ${ }^{349}$ Joenperän vatjalaisia lukuunottamatta aineiston kaikki saadulmoi-tyypin refrenkiin tai sävelmään viittaavat kontekstimaininnat liittävät ne tavalla tai toisella kylän läpi kulkemiseen.

Kylän läpi kulkemisen kontekstiin viittaavat myös sävelmän yhteydessä yleiset $L a$ lähen läpi kyläsen -aloitusformula ja Oman kylän ylistys -teemat (Kylähäni linnahani ja Kenen tuo kylä näkyy). Myös kulkemiseen viittavilla säkeillä Läksin koista kulkomaha yleensä alkava veljeä ja sulhasta vertaava lyyris-eeppinen runo Jalka kiveen on melko yleinen. Refrenkiin liittyykin kylä-tematiikan lisäksi myös muita runoja: huolilyriikkaa, tyttöajan onnen kuvausta ja lyyristä epiikkaa. Keskeisteemojen ohella laulettujen runojen kirjo oli laaja, ja niiden jakauma vastaa kluutšanimitykseen liitettyjä runoja. Kaksi sulhasen taloon saapumiseen sanoiltaan liittyvää tai taustatiedoissa liitettyä tanssituvan pyyntöä La miä kysyn langot teiltä ja

\footnotetext{
${ }^{346}$ Launis 1907, 109; ks. tarkemmin luku 6.

${ }^{347}$ Boreniuksen Joenperältä tallentamaan oi lole lole -sävelmään (44224422) sisältyy runomuistiinpanon yhteyteen merkitty viite ympärikko-tanssiin (SKVR III 599; SKS KRA Borenius e) 201). Ympärikkoon viittaa myös vatjalaisen, Joenperältä kotoisin olevan Oudekki Figurovan saadulmoi-kuvaus. Hän kertoi häissä lauletun piirissä Kui miä kazvelin kannaine -runoa, jokaisen toinen käsi edellä kulkevan olalla, toinen käsi sivulla kaaressa eteen ja taakse liikkuen, kopistavin askelin, "kuten on tavallista venäläisissä tansseissa.” Laulussa käyttämäänsä saadulmoi-sävelmää Figurova lauloi voimakkaasti ja rytmiä painottaen. (Rüütel 1977, 240, 255, laulu nro 73 .)

${ }^{348}$ SKS KRA Enäjärvi-Haavio 549, 557.

${ }^{349}$ Muutamassa Soikkolasta ensimmäisen maailmansodan jälkeen lähteneiltä pakolaisilta tallennetussa käsikirjoitustoisinnossa esiintyy saadulmoi-ryhmään liittyvä yhdistelmärefrenki, jota ei esiinny muissa aineistoissa. Näissä muistiinpanoissa saadulmoi-teemainen refrenkin toistuu eri muodoissa ja eripituisena ja yhdistyy erilaisin tavoin Ras kalina -refrengin variaatioihin. Konteksteina on kulkemista ja tanssia kesäpraasnikoilla sekä sulhastaloon saapumista. Vaikuttaa siltä, että kertojat eivät kovin hyvin muistaneet monia lauluja, mihin saattaa viitata myös refrenkien epätyypillinen variaatio. He olivat paenneet Suomeen 1920-luvulla, alle 30-vuotiaina. Toisaalta samantyyppisten refrenkien esiintyminen kahdella kerääjällä ja eri kertojilla viittaa siihen, että 1900-luvun alkupuolen Soikkolassa käytettiin saadulmoi-refrengistä myös yhdistelmämuunnosta, jota refrengin rakenteen perusteella luultavasti laulettiin jollain toisella melodialla kuin pelkän saadulmoi-refrengin sisältäviä lauluja. Sitä kuitenkin käytettiin samoissa tilanteissa kuin muiden keräelmien saadulmoi-refrenkiä. (SKS KRA Mannonen 5517, 5553, 5705, 7648, 11121; Sääski 5970.)
} 
Terve tuttuva tuppaa viittaavat siihen, että hääkontekstissa sävelmä saattoi paikoin vaihtua tavalliseen pulmanuottiin vähän myöhemmin kuin Launis mainitsi, ei vielä sulhastalon pihalla vaan vasta sisälle päästyä. ${ }^{350}$

Kluutšaan ja saadulmoi-sävelmäryhmään liittyvät kontekstimaininnat viittaavat siis kylän läpi kulkemiseen joko praasnikkojen tai häiden yhteydessä tai kahdessa tapauksessa heti häätaloon saapumista seuraavaan tanssituvan pyyntöön. Sävelmä ei ole varsinainen häänuotti eikä praasnikkojen rituaalisissa lauluissa käytetty sävelmä, mutta se liittyi kiinteästi seremonialliseen tanssien kulkemiseen, joka puolestaan liittyi nimenomaan häiden ja praasnikkojen yhteyteen. Laulajiksi mainitaan tilanteesta riippuen sekä naiset (praasnikkojen yhteydessä), morsiamen (nais) sukulaiset että tytöt (pyhänä). Ilmeisesti tytöt ovat voineet kulkea laulaen pitkin kylää tavallisinakin sunnuntai-iltoina, mutta naiset ovat ryhtyneet julkiseen ryhmälauluun ainoastaan häissä ja suurina praasnikkapyhinä, erityisesti Jyrin päivänä. Kaikki nämä tilanteet pitivät sisällään myös moninaisten lyyristen ja lyyriseeppisten runojen laulamista.

\footnotetext{
${ }^{350}$ Lisäksi Tatjana Jegorovan kosintaan liittyvän La lähen läpi kyläsen -tekstitoisinnon kuvaus paikantuu uunipellin (kiukaan lauta) hakkaamisen ja tyttöjen kutsumisen perusteella siihen kosinnan vaiheeseen, jossa tytöt kulkivat laulaen ja peltiä rämisyttäen läpi kylän kosinnan hyväksymisen jälkeen. Jegorova toteaa, että - ilmeisesti toisin kuin muissa kylissä - heillä "ei laulettu tätä muulloi." (SKS KRA Laiho L. 4736; ks. luku 7).
} 


\section{TANSSI}

Kalevalamittaisten runojen yhteydessä, kertoo Enäjärvi-Haavio (1949, 156-157), oli piiri eli ympärikko, karavana tai rinki edellä käsiteltyjen kulkemiseen liittyvien muotojen ohella yksi yleisimmistä tanssimuodostelmista. Muutamia kuvauksia on tallennettu myös paritanssista ja rivitanssista, joskin ne liittyvät useammin soitinmusiikkiin kuin runolauluun. Lisäksi joidenkin leikkien yhteydessä tanssittiin kalevalamittaisia runoja, mutta leikeistä ei Länsi-Inkeristä ole tallennettu paljoakaan tietoja.

Hyvän kuvan tanssiin liittyvien sävelmien variaatiosta ja vuorottelusta antaa Armas Launiksen $(1904,52)$ kuvaus ensimmäiseltä matkaltaan Soikkolasta:

Melkein joka pyhä-ilta laulavat täällä tytöt, kun kylän nuoriso on koolla, kisojen lomassa runoja. He muodostavat piirin ja kulkevat pitämättä toistensa käsistä kiinni pitkin kehää laulun tahdissa. Kävely muuttuu tanssiksi, jos tahti on nopeampi. Eessälaulajana ovat vuorotellen taitavimmat tytöistä laulaen yksinään säkeen, johon toiset liittyvät köörissä. Nämä joko kertaavat eessälaulajan sanat ja nuotin, tai laulavat joka kerralla aina uudistuva sanat, niinkuin: 'laadoi, laadoi, laadoi majoi' tai 'oi Kaalina, oi Maalina'. Kööri loppuu pitkään fermaattiin, josta ääni hiljaa putoaa alaterssiin. Joskus laulaa myös eessälaulaja kaksi säettä, molemmat samalla nuotilla, jollain kööri kertaa kahdesti säkeet sovittaen ne molemmat samaan nuottiin tahti-osia jakamalla. [...]

Ilmeisesti kuvaus on tiivistys, yleistys ja yhteenveto Launiksen matkallaan kuulemasta ja kokemasta. Se kuitenkin kertoo samalla myös vapaamuotoisten tanssitilanteiden elävyydestä: sävelmät, nopeudet, tyylipiirteet ja liikkeet vaihtelivat. Tanssiin liittyi useita erityyppisiä melodioita, rytmejä ja refrenkejä, joita voitiin kuitenkin käyttää myös tanssimatta. Laulu eteni yksi tai kaksi säettä kerrallaan, refrengeillä tai ilman. Nuotteja nimetessään Launis puhuukin useista nuoteista "tantsun päälle", ei yhdestä sävelmästä (Launis 1907, 108; ks. myös Timonen 2004, 148-149; Launis1910b, VIII; 1910c, 224). Launiksen lisäksi tietoja tanssin muodostelmista ja liikkeestä löytyy erityisesti Elsa Enäjärvi-Haavion ja lisäksi pieniä mainintoja Vihtori Alavan, Juho Lukkarisen, Väinö Salmisen, Martti Haavion sekä Lauri Laihon tallentamista aineistoista. ${ }^{351}$

\section{YMPÄRIKKO}

Ympärikko eli piirissä tanssiminen tai kulkeminen on kaikkein useimmin länsi-inkeriläisaineistossa runojen yhteydessä mainittu tanssimisen tapa. Enäjärvi-Haavio $(1949,158)$ jakaa piirissä tanssimisen kahteen ryhmään. Toisessa käveltiin hitaasti, käsistä kiinni pitämättä peräkkäin joko yksinkertaisessa tai kaksinkertaisessa piirissä, toisessa tanssittiin nopein askelein piirissä kulkevana parijonona. Nopeassa

${ }^{351}$ Lähialueiden tanssiperinteistä ks. esim. Malmi 1993; Niemeläinen 1982; Põldmäe \& Tampere 1938; Stepanova 1965; Tampere 1975. 
tanssissa parit saattoivat myös muodostaa pyörivän tähtikuvion. Tätä jakoa tukevat Enäjärvi-Haavion itse keräämän aineiston lisäksi myös muutamat muut kuvaukset. ${ }^{352}$ Vaikuttaa kuitenkin siltä, että yhteys nopeuden ja käsistä kiinni pitämisen välillä ei ollut aivan näin selvärajainen tai ehdoton: muutamat kuvaukset viittaavat päinvastoin nopeaan tanssiin ilman käsiotetta tai hitaaseen tanssiin käsistä kiinni pitäen, yksinkertaisessa piirissä. ${ }^{353}$ Silloinkin, kun askeleet olivat nopeita, saattoivat ne samalla olla niin lyhyitä, että piiri pyöri hitaasti (Simonsuuri 1972, 46). Launiksen (1910b, VIII) mukaan tahti vaihteli myös laulajien innostuksen mukaan. Erilaisia ympärikon kuvauksia liittyy kalevalamittaisten runojen lisäksi muutamia myös rekilauluihin, välimuotoisiin lauluihin sekä venäläisten tanssien kuvauksiin. ${ }^{354}$

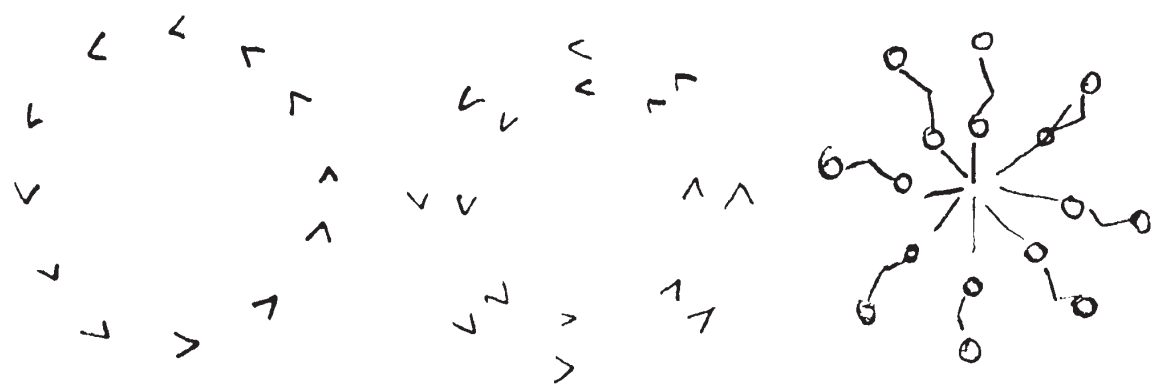

Kuva 6. "Kaavakuvia inkeriläisten tyttöjen tavallisista laulajaryhmityksistä ulkosalla kylän kisailupaikalla tai sisällä tuvassa laulettaessa" (Enäjärvi-Haavio 1949, 159).

Ympyrässä tanssimiseen viitataan useammalla termillä. Yleisin näistä on ympärikko (ympärikkö, ymbrikko jne.). Puhutaan myös ringistä, karavanasta, karavoodasta, krugasta, piiristä ja piirileikistä. ${ }^{355}$ Aineiston pohjalta on mahdotonta hahmottaa, onko eri termejä käytetty erityyppisistä tanssimisen tavoista, eri aikoina tai alueilla, sillä vain harvat kuvaukset kertovat tarkemmin, miten piirissä tanssittiin. Ympärikko-nimitystä saatettiin käyttää myös leikistä, jossa istuttiin ringissä eikä tanssittu ollenkaan. ${ }^{356}$ Ympärikko, rinki ja piiri vaikuttavat joka tapauksessa yleisiltä piirissä tanssimisen kattokäsitteiltä - näistä rinki ja piiri saattavat tosin paikoin olla piirileikin tavoin kerääjien omaa sanastoa. Ympärikko-termin käyttäminen on yleisintä niillä tallentajilla, joilla muutenkin oli tapana kirjoittaa ylös suoria sitaatteja laulajilta. Ympäriköllä selitetään välillä muita termejä ja ympärikkoa puolestaan muilla termeillä. Esimerkiksi karavanaa voidaan käyttää tarkennuksena "mäntii ymbrikkoo karavanas", rinnakkaisterminä "ympärikköä eli karavanaa" tai itsenäisenä määreenä. ${ }^{357}$ Paralleelisina ympärikko ja karavana näyttäytyvät myös

\footnotetext{
${ }^{352}$ Ks. esim. SKS KRA Enäjärvi-Haavio 500, 536, 549, 550, 551, 552, 554, 771; ks. myös SKVR III 1899; Launis 1910b, IX.

${ }^{353}$ SKS KRA Haavio 2558, Laiho L. 5396; ks. myös Launis 1904, 52; Simonsuuri 1972, 45-56.

${ }^{354}$ SKS KRA Enäjärvi-Haavio 566; Laiho A. 2264; Laiho L. 5256.

${ }^{355}$ Karavana, karavooda ja kruga tulevat venäjän piiritanssia tarkoittavista sanoista horovod (piirileikki) ja kruga (piiri). Ilmeisesti kruga-nimisiä tansseja on tanssittu sekä suljetussa että avonaisessa piirissä (eli kiemurtavassa ketjussa). (Ks. Malmi 1993, 20-25; Niemeläinen 1983, 23.)

${ }^{356}$ SKS KRA Laiho A. 2536.

${ }^{357}$ SKS KRA Laiho L. 4735; Enäjärvi-Haavio 869; Enäjärvi-Haavio 552; ks. myös IMS: karavooda, kruga.
} 
tanssinaloitusformulassa Tehhää yksi ympärikko, karavoodi kainokkaine. ${ }^{358}$ Karavanan selittää Enäjärvi-Haavio kulkemiseksi piirissä peräkkäin, käsistä kiinni pitämättä, ${ }^{359}$ eikä aineistossa olekaan käytetty sitä käsistä kiinni pitämistä mainiten. Karavanan yhteydessä puhutaan silti sekä kulkemisesta että tanssimisesta. ${ }^{360}$

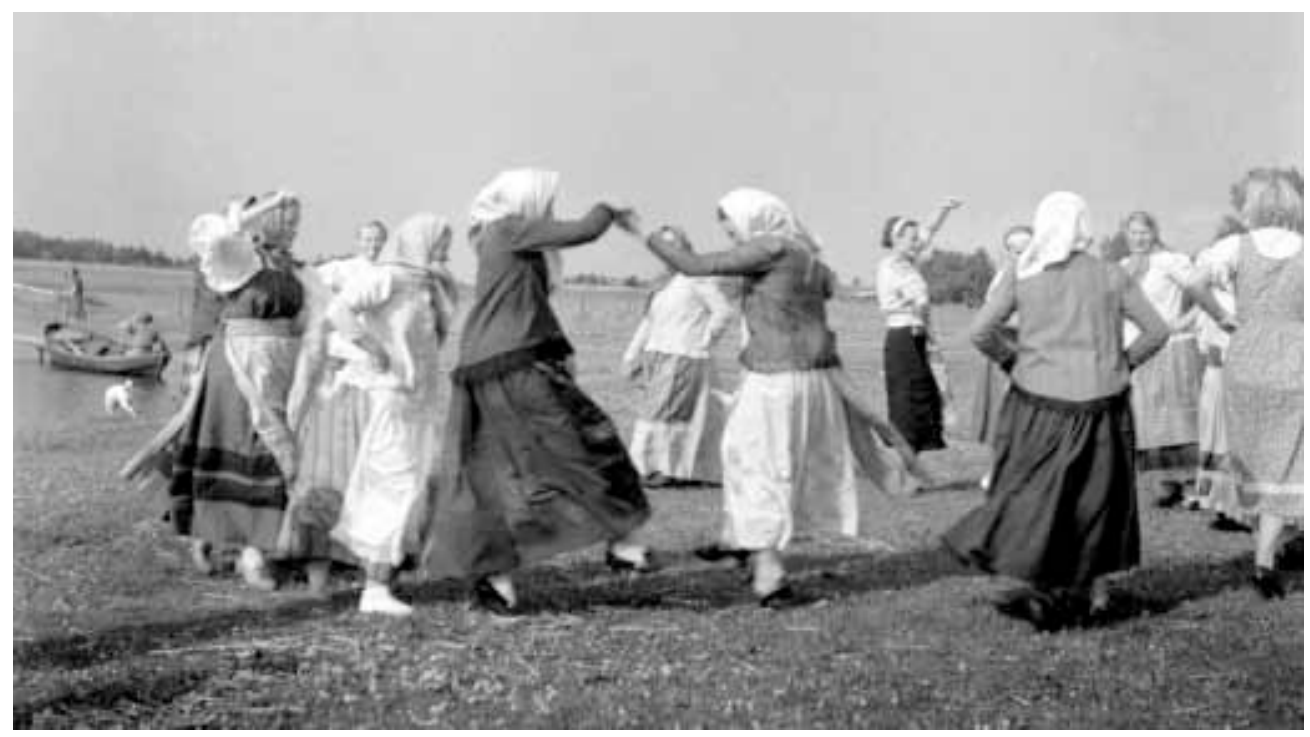

Kuva 7: Vauhdikas ympärikko vuodelta 1938 (KAVA Mäkinen 1938 Inkeri 246/9).

Aili Laiho (Simonsuuri 1972, 44; Simonsuuri 1961, 24) mainitsee esilaulajan laulaneen ja tanssineen ringin keskellä, toisaalla taas kerrotaan erikseen, että ringin keskellä ei ollut ketään. ${ }^{361}$ Paro Mäen mukaan piirissä ei saanut pitää kiinni käsistä vaan huivista tai nenäliinasta, kädet kun olivat hikiset. Peräkkäin tanssiessa kädet saattoivat olla myös lanteilla (Simonsuuri 1972, 46). Pyörimisen suunta saattoi vaihtua välillä. ${ }^{362}$ Armas Launiksen (1910b, VIII; ks. myös 1907, 108) mukaan "askelta vastaa melodiassa tavallisesti yksi tahtijalka," mutta kuoro-osan laulun ja tanssin tahti saattoi olla myös esilaulua nopeampi. Tanssin ja laulun tahti saattoi vaihdella: "Käynnin nopeus, jonka musiikin tempo määrittää, on yleensä melko hidas, tosin tämä voi myös merkittävästi kohota, jos innostus lisääntyy." Viisitoista vuotta kenttätöidensä jälkeen Launis $(1921,167)$ antoi ylvään kuvan tyttöjen keskittyneestä, lauluun uppoutuneesta hitaasta peräkkäin kulkemisesta Soikkolan korkeimmalla mäellä helluntaipraasnikoiden aikaan.

Tanssin vauhdikkuudesta ja temperamenttisuudesta kertoivat sekä Elsa EnäjärviHaavio $(1949,5)$ että Aili Simonsuuri $(1972,46)$. Tallqvist ja Törneroos $(1904,374)$ mainitsivat venäläisiä tansseja muistuttavasta "tepistelemisestä" ja " letkuttelemisesta” Keski-Inkerissä. Länsi-Inkerissä voitiin heilutella esiliinoja tai käsissä olevia

\footnotetext{
${ }^{358}$ Esim. SKS KRA Laiho L. 4998.

${ }^{359}$ SKS KRA Enäjärvi-Haavio 771.

${ }^{360}$ Esim. SKS KRA Enäjärvi-Haavio 552, 879; Laiho L. 4735. Kuvauksista voi aavistella, että kulkeminen voisi yleensä tarkoittaa hitaita askeleita, tanssi kenties nopeampia; mistään ei kuitenkaan voi päätellä, onko näin todella. On mahdollista, että tanssi voi viitata sekä nopeampaan että hitaampaan tanssiin.

${ }^{361}$ SKVR III 1899; Pohjois-Inkeristä ks. myös Enäjärvi-Haavio 1949, 138-139 (esilaulaja ringin keskellä).

${ }^{362}$ SKVR III 1899.
} 
nenäliinoja, "visattiin jalkaa," pyörähdeltiin ja "käänteleh[dittiin] sivuille," laskeuduttiin välillä kyykkyyn tai tanssittiin "ketterästi lyhyin askelin" (Simonsuuri 1961, 24; 1972, 44-46; Enäjärvi-Haavio 1949, 5). ${ }^{363}$ Osa riehakkaista elementeistä liittyi rytmin tekemiseen ja vahvistamiseen. Saatettiin lyödä jalalla lattiaa tai kopisuttaa jalkoja, napsuttaa sormia, lyödä käsiä yhteen, hakata "kahta keppiä yhteen" tai kiljahdella "kuin sudet" laulun rytmin mukana. (Simonsuuri 1961, 24; 1972, 46; Launis 1904, 36.) $)^{364}$

Kaksi Valpuri Vohdalta tallennettua kuvausta osoittaa, että ympyrässä tanssimiseen saattoi sisältyä monenlaisia liike-elementtejä, jotka eivät yleensä ole tulleet mainituiksi. Vohta oli laulanut Yks oli väärä miun emoni (Piennä petti miun emoni) -runoa häissä kädet käsissä "piirissä, kädet ylhäällä." Välillä mentiin vastakkain ja kiihdytettiin askelia. Inkeroisnaisten hän taas kertoi laulaneen Oma emo - vieras emo -runoa "karavuotii" tanssien: "Kykkää löit: 'Katsokaa leppälinnun leikkii.' Leppälintu hyppii oksal ylös alas, ylös alas - niin naiset ka mäntii leppälinnun leikkii tantsus." Hänen kuvauksissaan ringissä tanssimiseen liittyy siis niin käsien ylhäällä pitämistä, hitaampia ja nopeampia askeleita, jonkinlaisia vastakkain menoja kuin niiaamisia tai kyykistymisiäkin. ${ }^{365}$ Vaikka monista Vohdan kertomista asioista ei ole muita lähteitä, eivät hänen kuvauksensa myöskään mene ristiin muiden kanssa. Ne kertovat siitä, miten paljon erilaisia yksityiskohtia on jäänyt dokumentoimatta.

Lyhyet ympärikko- ja tanssimaininnat voivat siis tarkoittaa monenlaista liikkumista hitaasta ringissä kulkemisesta riehakkaaseen pyörähtelyyn, käsistä kiinni pitäen, peräkkäin kulkien tai parimuodostelmissa. Nopeasta ja riehakkaasta tanssista on kuvauksia tallennettu huomattavasti enemmän kuin Launiksen keskeiseksi nostamasta hitaasta piirissä peräkkäin kävelystä - voi olettaa sen monimuotoisempana kiinnittäneen myös tanssista kiinnostuneiden kerääjien huomiota hidasta kulkemista enemmän. Kuvausten ei voi olettaa kattavan koko länsi-inkeriläisen tanssin kirjoa, mutta tyypillisimmistä tavoista ne nähdäkseni luovat jonkinlaista kuvaa. ${ }^{366}$

\footnotetext{
${ }^{363}$ SKVR III 1900, SKS KRA Enäjärvi-Haavio 550; Laiho L. 5396; Pohjois-Inkeristä vrt. SKS Neovius 3090 s. 3.

${ }^{364}$ SKVR III 1904; SKS KRA Enäjärvi-Haavio 550, 551, 885; Laiho L. 5396.

${ }^{365}$ SKS KRA Enäjärvi-Haavio 500; Salminen V. 3019.

${ }^{366}$ Vihtori Alavan (1932) mukaan piirissä tanssiminen oli uusi asia. Väitteeseen liittyvä kuvaus liittyy luultavasti joltain muulta alueelta kerättyyn toisintoon ja vaikuttaa sekä länsi-inkeriläisaineiston että nykyisten laajempien tietojen ja tanssin tyylikausihypoteesien valossa hämmentävältä. Alavan mukaan "aikaisemmin on tanssia esitetty niin, että yksi pari - poika ja tyttö - tai erinäisissä tanssilajeissa pari kolme tai neljäkin paria tanssi vastakkain keskellä ja muu väki oli syrjemmällä, naisväki laulaen, (jos tuvassa oltiin, olivat naiset eri ryhmässä peremmällä, mutta miehet ovensuun puolella päin).” Alavan jälkeen on ollut tapana ajatella, että erilaiset soolo-, ketju- ja rinkitanssit ovat Euroopassa paritansseja vanhempi ilmiö (Hoppu 2006; Rausmaa 1981; Sarmela 1969, 210-217). Alavan kuvauksen pohjana on kenties hänen muistiinpanonsa Valkeasaaresta (SKS KRA Alava VIIIa:1; ks. myös VIIIb s. 239 Toksovasta). Länsi-inkeriläiskuvauksia piiritanssista liittyy Alavan muistiinpanoihin joulunajan kiletoivirsistä sekä häälauluista (SKVR 1899-1904; 2137, 2442, 2510, 2515). Paritanssista Alavalta löytyy LänsiInkeristä vain yksi tyttöparien keskenään tanssiman Hyppää nukke -laululeikin kuvaus Anni Porissalta (SKVR III 2254).
} 


\section{PARI- JA RIVITANSSIT, LEIKIT}

Aineistossa on kuvauksia monenlaisista usein venäläisillä nimillä kutsutuista ja soitinten säestyksellä tanssituista pari- ja rivitansseista. Kalevalamittaisia runoja näihin liitetään vain muutaman kerran, mutta kokonaiskuvan saamiseksi on niitäkin syytä sivuta. Paikoin paritanssin, piiritanssin ja rivitanssin kuvauksia on nimittäin vaikea erotella toisistaan. Esimerkiksi Enäjärvi-Haavion tallentaman rekilaulukuvauksen: "Parit ympäri rinkiä" voi tulkita ringin sisällä vuorotellen tanssiviksi pareiksi kuten oli hänen mukaansa rekilauluille tyypillistä - yhtä lailla se voisi kuitenkin viitata myös parijonossa tanssivaan piiriin. ${ }^{367}$ Sama erottelun vaikeus koskee paikoin myös laulun ja soiton lajeja. Esimerkiksi Katri Mark mainitsee ristitantsun, jota toisin kuin hänen kuvaamiaan ruskavaa, kadrillia ja kazatškaa tanssittiin laulun eikä soiton säestyksellä - laulun lajia tai edes kieltä hän ei kuitenkaan tarkemmin määritä. ${ }^{368}$

Juuri venäläisiä tansseja kerrotaan usein tanssitun soitinten säestyksellä. Yleisimmiksi tansseiksi mainitaan ruskovat, kadrilli ja kašatska. ${ }^{369}$ Anna Hovaskin kuvaa muut soittoon liittyvät tanssit myöhäisemmiksi: "Perrää päi alettii tantsii polkkaa ja muuta." ${ }^{370}$ Näistä kolmesta yleisimmästä tanssista niukimmin mainintoja liittyy kašatskaan. Anna Kivisoon mukaan sitä tanssittiin nelistään, "neljän kes ain hypitti." ${ }^{371}$ Tarkimman ja silti sangen epämääräisen kuvauksen antaa Enäjärvi-Haavion välityksellä Katri Mark: "tanssijat pitelevät pienestä rätistä kiinni ja pujottelevat täten syntyneen portin lävitse."372

Ruskovaksi tai ruskavaksi nimitettiin useita erilaisia tansseja, joista puhuttiin myös monikossa. ${ }^{373}$ Anna Hovaskinin mukaan poikien ruskavaa tanssittiin vastakkain kahdestaan, vuorotellen: "kun toine väsy, sis toine."374 Luultavasti samankaltaista miesten tanssia kutsuu Anni Stepanov ripatskaksi: "jalat oikein sukkelaan käivät, ja välistä piti tanssia kyykkysillään ja taasen lyyvä kantapäitä yhteen ja taasen nousta ylös." Sitä tanssittiin soiton tai laulun säestyksellä. ${ }^{375}$ Tyttöjen ruskavassa sitä vastoin "mäntii ymprikkoo," vaikka Anna Hovaskin ei kerrokaan tarkemmin, miten tai kuinka suurella joukolla. ${ }^{376}$ Voitiin taputtaa käsiä tai tehdä rytmiä laudalla ja

\footnotetext{
${ }^{367}$ SKS KRA Enäjärvi-Haavio 566; ks. myös Enäjärvi-Haavio 1932, 27. Samankaltaisesti Valpuri Haukka kertoi, että joen kaltaalla tanssittiin leikkimisen lomassa: piirin eli tarhan sisällä tanssi kaksi henkeä - ei ole tietoa, tanssivatko ringissä olijat (SKS KRA Haavio 2570). Anni Stepanov Soikkolasta kertoi, että vakkovilla eli Iilian tai Pedron praasnikoilla naiset lauloivat välimuotoista Skasii kenellä on lupa kulaijaa -laulua (eli "Sano kenellä on lupa gulaittaa") ja tanssivat kaksi naista vastatusten, ja "kyllä niillä oli kepiät jalat, ja ne tanssi niin sukkelaan ja tahissa, itse lauloivat." Kuvaus voi liittyä joko riveissä vastakkain tanssittuun katrilliin tai kahdestaan vastakkain tanssimiseen. (SKS KRA Mannonen 9838.)

${ }^{368}$ SKS KRA Enäjärvi-Haavio 559. Ristitantsu tanssikaamme -runosta lähimmät toisinnot on tallennettu Seiskarin saarelta (SKVR III 234; ks. myös XIII 977a, 1239 Koivistolta; vrt. Maie-runo, jossa tyttö tanssii risti kaulassaan, esim. SKVR III 1887).

${ }^{369}$ Esim. SKS KRA Enäjärvi-Haavio 559, 801; Laiho L. 5987.

${ }^{370}$ SKS KRA Laiho L. 5256.

${ }^{371}$ SKS KRA Laiho L. 5987.

372 SKS KRA Enäjärvi-Haavio 559.

${ }^{373}$ Esimerkiksi "ruskovii," SKS KRA Enäjärvi-Haavio 801; ks. myös Väisänen 1985, 17.

${ }^{374}$ SKS KRA Laiho L. 5256; ks. myös Enäjärvi-Haavio 896.

${ }^{375}$ SKS KRA Mannonen 9839.

376 SKS KRA Laiho L. 5256.
} 
olla soittavinaan silloinkin, kun säestyksenä oli vain laulua. ${ }^{377}$ Ruskavaa tytöt ja pojat tanssivat usein erikseen ja eri tavoin. ${ }^{378}$

Kadrillia tanssivat Katri Vohdan mukaan tytöt ja pojat yhdessä. ${ }^{379}$ Anna Kivisoo taas

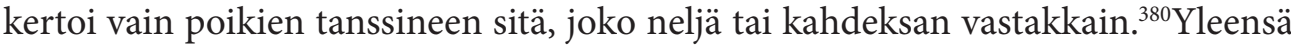
nimityksellä tarkoitetaan vastakkain kahdessa rivissä tanssittavaa tanssia, joka koostuu erilaisista osioista. ${ }^{381}$ Launis luonnehti "taitavan harmonikan-soittajan" säestämää kahdeksan parin kadrillia, "jonkinlaista françaisea," jota hän seurasi Säätinän helluntaipraasnikoilla: "Sirosti pyörivät neitoset ja rehentelevästi pojat saappaitaan yhteen klopsuttelivat." 382 Kadrillin eri osioihin saattoi liittyä erilaisia soitinsävelmiä. Prokoi Vil'lon Tarinaisista soitti kadrilliinsa kuusi erilaista osiota eli kolenaa. ${ }^{383}$

Yleisimmin ruskovien, kadrillien ja kazatškojen säestäjänä mainitaan haitari eli pilli tai garmoni ${ }^{384}$ jotka viittaavat lähinnä venäläistyyppisiin yksi- tai kaksirivisiin, pienehköihin soittimiin. Lukkarisen $(1911,46,76)$ mukaan haitari toimi 1900luvun alun Länsi-Inkerissä ensisijaisena tanssisoittimena. Tämän lisäksi saatettiin tanssin säestykseksi soittaa balalaikaa, kannelta ja trubaa eli tuohitorvea, ja myös viulu eli skripka mainitaan kerran. ${ }^{385}$ Aiemmin ilmeisen yleinen kannel oli 1900luvulle tultaessa lähes jäänyt käytöstä, sitä lähinnä muisteltiin (Väisänen 1990, 74; Lukkarinen 1911, 46-47, 76). ${ }^{386}$ Kanteleella saatettiin soittaa samannimisiä tanssisävelmiä kuin haitarillakin. ${ }^{387}$ Truba ei sitä vastoin ollut mikään tanssisoitin, totesi A. O. Väisänen: raskas puhaltaminen edellytti tanssin keskeyttäviä hengähdystaukoja ja ääni oli liian kova sisätiloihin. Paimen saattoi silti etenkin syksyllä työnsä päättäessään soittaa tanssijoillekin. ${ }^{388}$

\footnotetext{
${ }^{377}$ Katri Vohdan mukaan ruskavaa tanssittaessa "taputettiin käsiä, heilutettiin esiliinaa (SKS KRA Enäjärvi-Haavio 771). Naisten juhlassa naiset tanssivat ruskavaa laulun säestyksellä, "vaatteen silityslaudalla lyötiin tahtia ja oltiin soittavinaan," kertoi Valpuri Vohta (SKS KRA Enäjärvi-Haavio 754).

${ }^{378}$ SKS KRA Laiho A. 2607, Laiho L. 5256. Anna Kivisoon mukaan ruskovaa tanssittiin kuuden kesken, kun taas Katri Markin mukaan sitä tanssivat pojat "vastakkain tyttöjen kanssa", kaksi tai neljä kerrallaan (SKS KRA Laiho L. 5987; Enäjärvi-Haavio 559).

${ }^{379}$ SKS KRA Enäjärvi-Haavio 771.

${ }^{380}$ Tytöt sen sijaan tanssivat esimerkiksi "kahen tytön ymbrikkoo," ilmeisesti siis jonkinlaista paripyörintä.̈. SKS KRA Enäjärvi-Haavio 674; kadrillista ks. myös 559.

${ }^{381}$ Katrillista ja samankaltaisista tansseista yleisemmin ks. Hoppu 2006, 357-361; ks. myös Launis 1910b,VIII-IX

${ }^{382}$ KK Coll. 123.22 Launis 1903, 30. Hevaalla Launis (1907, 108-109) kertoo tanssitun pareittain, vastakkaisissa riveissä kalevalamittaista runoa La ka katson kannoillani, vieren varpahaisillani (Onko sillat lakeat) laulaen. Tanssiessa "pareista molemmin puolin lähtee toinen päinvastaiselle puolelle ja mennessään välttelee ja kumartelee vastaantulijaa samaan tapaan, kuin useissa yleiseurooppalaisissa tansseissa."

${ }^{383}$ SKS KRA Väisänen s 135a; 128. Runoaineiston yhteydessä mainitaan myös poikien häissä tanssima kolena, jonka säestyksenä he lauloivat tytöille kalevalamittaista runoa (SKS KRA Mannonen 5447).

${ }^{384}$ Ks. esim. SKS KRA Enäjärvi-Haavio 674.

${ }^{385}$ SKS KRA Väisänen 1914 Laatikko III 3a, s. 11; 3c, s. 5; Laiho A. 2588; Laiho L. 5165.

${ }^{386}$ SKS KRA Alava VII A:7b, Laiho L. 5987.

${ }^{387}$ Kanteleella soitettiin "virolaista, venäläistä, katsanskoita, ympärkäyvää y.m.” (SKS KRA Alava X. u. 1897, 6). Suuria ja pieniä kanteleita oli ollut ennen Soikkolassa paljon, kertoi Alava: "Niillä soiteltiin näiden Suomen runojen nuottia sekä muitakin" (SKS KRA Alava IV Tietoja Soikkolan puolelta s. 195). Myös venäläisissä kylissä soitettiin kanteleita (Väisänen 1985, 12).

${ }^{388}$ SKS KRA Väisänen laatikko III 3c, s. 5-6. Tanssimaan pakottavasta trubansoitosta kerrottiin silti sekä saduissa että henkilökohtaisessa kerronnassa (SKS KRA Alava VII A: 36; Laiho A. 2625).
} 
Omalta osaltaan tanssien ilmeisen laajaa ja varioivaa kirjoa valaisee Väisäsen (1985) soitinsävelmäkokoelma Soikkolasta ja Narvusista vuodelta 1914. Kadrillin, ruskavan ja kašatskan lisäksi sävelmäkokoelmassa esiintyvät esimerkiksi nimitykset kamarinski (joka kerran nimetään myös ruskavaksi), krakoviak eli polkka, saksina (jota tytöt tanssivat ensin selät ja sitten vatsat vastakkain), tšižik eli "tanssi neljän kesken", valtsi, kalikanttinen, kaide troika sekä vain "tantsun päälle" ja viroksi tantsutükk. ${ }^{389}$ Kahta Nattal'a Vassilan paimensoitulla esittämää tanssisävelmää lukuun ottamatta Väisäsen $(1985,128,130)$ kokoelman tanssisävelmät ovat kaikki miehiltä tallennettuja.

Tanssiminen, soittaminen ja laulaminen näyttäytyvätkin aineistossa sukupuolittain jakautuneena. Eri instrumenttien soittajina mainitaan tanssikuvauksissa lähes pelkästään pojat tai miehet, esilaulajina tytöt. Samoin tyttöjen ja poikien tanssit erotellaan usein toisistaan. Näyttää siltä, että laulutanssit olivat lähinnä tyttöjen laji, soitintanssit poikien, vaikka moniin soitinmusiikkiin liittyviin tansseihin osallistuivat välillä tytötkin. ${ }^{390}$ Muutama laulaja kertoi tyttöjen vastustelleen tai näytelleen vastustamista ja poikien vieneen heitä väkisin tanssimaan soitinten säestämiä tansseja. ${ }^{391}$ Paikoin taas kerrotaan tyttöjen tai naisten tanssineen laulutanssejaan nimenomaan silloin, kun soittajaa ei ollut paikalla. ${ }^{392}$

Myös tiettyihin leikkeihin liittyi erilaisia tanssimuodostelmia - leikit myös saattoivat lomittua muun tanssin tai laulun lomaan. ${ }^{393}$ Joihinkin leikkeihin liittyi kalevalamittaisia runoja, toisiin välimuotoisia lauluja. ${ }^{394}$ Kuten esimerkiksi Enäjärvi-Haavio (1932, 25, 66; ks. myös Hoppu 2006, 344) on todennut, yhteenkin leikkiin on voinut liittyä vaihtelevia käytäntöjä: näytelmäleikeissä dialogit on esimerkiksi voitu joko laulaa tai puhua ja samaakin leikkiä on voitu tanssia eri pituisena ja eri tavoin, yhtälailla vaikkapa piirissä kuin kahdessa rivistössäkin. Muutama muistiinpano ei siis vielä kerro leikistä kaikkea. Toisin kuin vaikkapa Karjalan Kannakselta, ${ }^{395}$ Länsi-Inkeristä lauluun liittyviä varhaisia leikkikuvauksia on vain muutamia.

Yksi kalevalamittaiseen runoon liittyvä leikin kuvaus on Länsi-Inkerissä tallennettu samalta laulajalta kahtena toisintona. Ne näyttävät, kuinka ongelmallista lyhyitä, tiivistettyjä kuvauksia on ylimalkaan tulkita. Anni Porissa Kaipaalasta lauloi sekä Volmari Porkalle että Vihtori Alavalle Hyppää nukke, karkaa nukke -runon. ${ }^{396}$

\footnotetext{
${ }^{389}$ SKS KRA Väisänen 1914 e; ks. Väisänen 1985, 143, 72 ja 100, 55, 32, 29, 31, 80, 81, 130, 91; ks. myös 17. Vrt. Malmi 1993.

${ }^{390}$ SKS KRA Enäjärvi-Haavio 550, 557, 774, 838.

${ }^{391}$ SKS KRA Enäjärvi-Haavio 674, 771.

${ }^{392}$ Esim. SKS KRA Enäjärvi-Haavio 774; 838; ks. myös 896.

${ }^{393}$ SKS KRA Laiho A. 2607.

${ }^{394}$ Esim. SKVR 1067. Välimuotoisesta Muijen muijal päät olla -laulusta, joka kuvaa ruumiinosien keksimistä (esimerkiksi pää kaalinpäästä) ruumiinosattomalle "muijalle" Juljaana Pohjalainen kertoi: "tehtii sellain, niiku laulus lauletaa, se pantii keskel ja sit mentii ympärikkoo kaik tytöt" (SKS KRA Laiho A. 2264).

${ }^{395}$ Ks. esim. Simonsuuri 1972, 50.

${ }^{396}$ SKVR III 1068, 2254.
} 
Porkka kertoi leikkirunoa tanssitun pareittain, "toinen toisensa perässä." Muun aineiston perusteella ilmeisin tulkinta olisi tanssijaparien muodostama peräkkäinen piiri. Alava kuitenkin tallensi yksityiskohtaisemman kuvauksen sitaatteineen:

Tantsuiss' lauletaa - kun yks' pari tantsii, tytöt keskenää - ens' laulaa yks' pari tantsiessa tämän virren: [Hyppää nukke...] - - Yks’ pari tantsi, kun tätä laulettii, Siis laulettii: [Kenen kerta heittämää eli runon loppuosa] - - Siit toinen pari noisee tantsimaa, ja taas lauletaa se sama virs. Yks tyttö laulaa iess, siss toiset tarttuut kaik kiin, yks sanoo ain sanan."

Parit eivät siis tanssineetkaan toistensa perässä jonomuodostelmassa vaan yksi pari kerrallaan, ajallisesti peräkkäin, vaikka kaikki lauloivat. Alava tallensi myös Porissan käyttämän sävelmän. ${ }^{397}$

Porkka tallensi samasta Kaipaalan kylästä myös Leikarit-runon ja kuvauksen: "Tätä runoa laulettaissa ovat tytöt jaetut kahteen riviin siten, että toisella puolella on vaan 2 tyttöä, toisella vaikka kuinka monta. Laulun loputtua joka kerta yksi tytöistä siirtyy sinne puolelle, missä alussa vaan oli kaksi tyttöä." ${ }^{398}$ Neljännen leikkikuvauksen Porkka tallensi Säätinältä, jossa Uljaana esitti Rikkaan ja köyhän runon. Sitä mentiin "rinkitanssissa:"

Virttä laulaa kaksi henkilöä, köyhä ja rikas, edellinen vienolla suruisella nuotilla, joll’aikaa häntä ontuvaa molemmasta kädestä talutetaan ympäri ympärikkoa. Rikas sitä vastoin hyppiellä tanssii, iloisesti laulaen. Kun virsi näin on laulettu loppuun asti, niin köyhä ja rikas vaihtavat osansa ja alkavat uudestaan. ${ }^{399}$

Leikkilauluiksi on aineistossa mainittu monia muitakin runoja, joihin ei kuitenkaan liity tarkempia kuvauksia. ${ }^{400}$

\footnotetext{
${ }^{397}$ Luonnosmainen sävelmä jakautuu kahteen osaan. Ensin lauletaan kaksi kertaa säkeen alkupuolisko (hyppää nukke hyppää nukke), sitten kaksi kertaa koko säe (hyppää nukke karkaa nukke). Sanojen sijoittuminen on alkuosassa tulkinnanvarainen: melodian perusteella sen kulkua voi arvailla. Rytmin voisi tulkita näin: 42424242 || 2222444422224444 . (SKS KRA Alava VIIa:425.) Muita runoon liittyviä sävelmiä ei ole aineistossa, vaikka tekstitoisintoja löytyykin (SKVR-teemahakemisto: Hyppää nukke) Jaakko Länkelä nimesi ilmeisesti Kaipaalassa tallentamansa Hyppää nukke -runotoisinnon rinkihyppylauluksi, mikä viittaisi myös ympyrässä laulamiseen tai tanssimiseen. SKVR III 3967. Matti Kuusi (1983b) on päätellyt ainakin osan Länkelän Kaipaalasta tallentamista runoista olevan todennäköisesti Anni Porissan esittämiä.

${ }^{398}$ SKVR III 1067. Myös Lavansaarella kerrotaan Leikarit-runoa tanssitun "kahdessa rivissä vastatusten" (SKVR III 4174)

${ }^{399}$ SKVR III 1581. Toiseen Soikkolasta tallennetun, leikkirunoksi nimetyn ja dialogiksi jaetun Rikkaan ja köyhän runon yhteyteen Porkka ei merkinnyt tarkempaa kuvausta (SKVR III 1583). Rikkaan ja köyhän runosta Eino Levón tallensi Hevaalta kaksi sävelmää ja kertoi tyttöjen leikkineen Uljaanan kuvauksesta poiketen kahdessa vastakkaisessa rivissä, joista toinen lauloi ensin köyhän laulun ja sitten toinen rikkaan laulun toisella sävelmällä (SKS KRA Levón 467, 468). Köyhän sävelmä on yksisäkeinen, neljällä sävelellä liikkuva melodia, josta ei tiedä onko se laulettu yhden vai kahden säkeen jaksoissa (24242424). Rikkaan sävelmätyyppi on kaksisäkeinen, ja aina kahden säkeen jälkeen toistuu kertauma "syökää juokaa pitäkää puolee." Melodian pituus on neljä säettä: kaksi säettä ja kaksisäkeinen kertauma. Sävelmä liikkuu viiden sävelen alueella ja rytmityyppi on erilainen (22222222) kuin köyhän sävelmässä.

${ }^{400}$ Esimerkiksi Porkka tallensi Soikkolasta leikkilauluksi nimeämänsä Lohikäärme ja neito -runon ilman tarkempaa kuvausta: Käykää rinnan Riian neiot, SKVR III 1582. Runosta ks. Haavio 1932a. Borenius tallensi Hevaalta yhden runoon liittyvän Hevaan nuotilla lauletun sävelmän (SKS KRA Borenius 3 172), Levón yhden yksisäkeisen, neli-iskuisen sävelmämuistiinpanon (SKS KRA Levón 464).
} 


\section{PAIKOILLAAN LAULAMINEN}

Vaikka länsi-inkeriläisaineistossa liikkeen merkitys korostuu, kaikkia runoja ei laulettu liikkuen. Tietyissä tilanteissa laulettiin paikoillaan istuen tai seisten. Osa näistä tilanteista oli arkista työntekoa, osa kuului praasnikkojen ja häiden kehyksiin. Enäjärvi-Haavion Anna Kivisoolta saamien tietojen mukaan "paikallaan seisten tai istuen" laulettiin "joitakin puhtaasti lyyrillisiä lauluja," mutta tanssien tai kulkien laulaminen oli paikoillaan laulamista yleisempää. ${ }^{401}$ Aineistossa onkin huomattavasti enemmän tanssiin ja kulkemiseen kuin paikoillaan laulamiseen liittyviä kuvauksia.

Useat paikoillaan laulamisen kuvaukset sijoitetaan ulkotiloihin. La mie vieretän vilulla ja Nyt on tyynet nurmen nurkat -teemoja laulettiin Kivisoon mukaan ulkona seisten silloin kun "oli hyvä ilta, kaunis, lusti, vakane ilta." ${ }^{02}$ Pääskylintu päivälintu -runoa kerrotaan lauletun seisten esimerkiksi joen kallaalla. ${ }^{403}$ Matrona Bässina kertoi myös tyttöjen istuessaan laulaneen samaa runoa hitaasti ja venyttäen, "pitkäs ja venytettään." ${ }^{404}$ Hän kertoi tyttöjen pyhänä istuskellessaan laulaneen myös poikien sotaan viemisestä kertovaa laulua Lensi lintu alta linnan (Sotasanomat). ${ }^{405}$

Tyttöjen kerrotaan usein kesäisin istuneen ja laulaneen joen kallaalla. ${ }^{406}$ Näissä Narvusin joenvarsikylistä kotoisin olevilta laulajilta tallennetuissa kuvauksissa mainitaan suurempien pyhäpäivien ${ }^{407}$ ohella "viikon pyhä" eli tavalliset sunnuntait sekä iltahämärissä eli arki-iltoinakin istuminen. Pyhänä oli pojilla soittimet mukana kallaalla ja välillä mentiin läpi kylän. ${ }^{408}$ Iltahämärissä taas lauleltiin ja "tehtiin naljaa" poikien kanssa tai kokoonnuttiin pienemmällä joukolla. ${ }^{409}$ Joen rannalla myös tanssittiin ja leikittiin sekä laulettiin seisten. ${ }^{410}$ Kallaalla lauletuiksi runoiksi mainitaan sekä huoli- että tanssilyriikkaa, lyyristä epiikkaa ja häälaulun teemoja käyttävä tervehtimislaulu, jolla tervehdittiin vieraita eli kauempaa tulleita poikia. ${ }^{411}$ Veneellä "liukumassa" ollessa laulamisesta kertoivat myös useat laulajat erilaisten

\footnotetext{
${ }^{401}$ SKS KRA Enäjärvi-Haavio 549.

${ }^{402}$ SKS KRA Enäjärvi-Haavio 507, 508, 549.

${ }^{403}$ SKS KRA Enäjärvi-Haavio 551; Laiho A. 2148.

${ }^{404}$ SKS KRA Haavio 2431.

${ }^{405}$ SKS KRA Haavio 2462.

${ }^{406}$ Varpuli Haukka selitti, että "se oli niinku kauniip paikka" (SKS KRA Laiho A. 2615; ks. myös 2086, 2096, 2097).

${ }^{407}$ Pedron (SKS KRA Laiho L. 5987) ja juhannuksen (SKS KRA Laiho L. 6127).

${ }^{408}$ SKS KRA Enäjärvi-Haavio 550; Laiho A. 2082, 2132, 2147, 2614.

${ }^{409}$ SKS KRA Laiho A. 2614, 2615.

${ }^{410}$ SKS KRA Haavio 2570; Laiho A. 2534, 2535; Laiho L. 4832; seisten Laiho A. 2148.

${ }^{411}$ SKS KRA Laiho A. 2086 (huolilyriikkaa); Laiho A. 2132 (huolilyriikkaa); Laiho L. 4832 (tanssinaloitus ja Leino leski); Laiho A. 2097 (Mari marjasta tulee), Laiho A. 2148 (Pääskylintu päivälintu (Maailmansynty)), Laiho A. 2291 (Leino leski); Haavio 2570 (tervehtimislaulu), Laiho A. 2096 (tervehtimislaulu). Ropsussa tai Väikylässä tytöt lauloivat Pedron praasnikkana kallaalla Pedron virttä (SKS KRA Laiho L. 5987).
} 
soutamiseen (Souva laiva jouva laiva; Liuvu vene tervarinta) ja veneen veistämiseen (Veneenveisto) liittyvien runoaiheiden yhteydessä. ${ }^{412}$

Talvikaudella, syksystä kevätpaastoon asti, nuoriso kävi arki-iltoina "iltaa istumassa." Tytöt tekivät käsitöitä, kehräsivät ja lauloivat, pojat pitivät seuraa eli "muiten istuivat." ${ }^{413}$ Iltaa viettäessä kerrotaan lauletun Älä nukuta unonen -alkuista runoa, jossa kuvataan tarvittavien käsitöiden paljoutta sekä Sotasanomat-runoa. ${ }^{414} \mathrm{Keh}$ räämiseen liitetään tilannetta tarkemmin avaamatta sekä suoraan kehräämisestä tai kutomisesta puhuvia runoja että huonosta naimakaupasta varoittavaa lyriikkaa. ${ }^{415}$ Jotkut töitä tehdessä, vaikka pellavia kolkkiessa tai käsikivillä jauhaessa lauletut runot taas kerrotaan seisten lauletuiksi. ${ }^{416}$ Heinäpellolla laulamista on myös muutamia mainintoja. ${ }^{417}$ Launis $(1907,108)$ puolestaan kuvaa metsän sävelten laulamista vastoja tai karjalle lehtiä taiteltaessa ja metsässä kulkiessa. ${ }^{418}$

Keskeisin rituaalisen paikoillaan laulamisen kontekstin olivat häät, joita käsitellään tarkemmin luvussa 7. Seisoen laulaminen liittyy kuvauksissa erityisesti häätaloihin saapumisiin, mutta myös häistä lähtemiseen sekä moniin rituaalisiin tilanteisiin keskellä häitä. ${ }^{419}$ Häiden monissa vaiheissa mainitaan myös lauletun pöydässä istuen. Laulujen joukkoon kuului sekä rituaaliin sidoksissa olevia lauluja että muita kuin varsinaisia häälauluja. ${ }^{420}$ Ennen häitä tytöt kokoontuivat joukolla iltaisin erityisesti lahjoiksi tarvittavia käsitöitä valmistamaan: tällöin laulettiin Väinö Salmisen $(1934,137)$ mukaan sekä häihin väljästi liittyviä lauluja että harjoiteltiin varsinaisia häälauluja. Pöydässä laulaminen liittyi myös praasnikkoihin ja pienempiinkin juhliin: syömisen lomassa ja jälkeen saatettiin muun seurustelun ja kerronnan ohella myös laulaa. ${ }^{421}$

Paikoillaan laulettuihin lauluihin liitetään viidessä istumiseen viittaavassa runokäsikirjoituksessa kolme erilaista muotorakennetta: joko yksi säe kerrattiin, kaksi

\footnotetext{
${ }^{412}$ SKS KRA Enäjärvi-Haavio 469 (Veneenveisto), 519 (Suomeen pako); Laiho A. 2277 (Suomeen pako); Laiho L. 4979 (Suomeen pako: muunnelma, jossa mennään Venäjälle); Salminen K. 188 (Suomeen pako); Salminen V. 2969 (Suomeen pako). Yleensä säkeellä souva laiva jouva laiva alkavassa Suomeen paossa kyse on veneellä matkaamisesta. Ks. myös SKS KRA Haavio 2810.

${ }^{413}$ SKS KRA Haavio 2833; Enäjärvi-Haavio 835, 836; Laiho L. 4916; ks. myös Laiho A. 2372. Paikkana mainitaan yleensä sauna, mutta voitiin myös olla tuvassa.

${ }^{414}$ SKVR III 1053; SKS KRA Haavio 2462.

415: SKVR 2295n1 (Neito heenoa tekköö); SKS KRA Laiho L. 5354 (Keträän keträän keikuttelen / Kehräämisvirsi)); SKS KRA Haavio 2500 (Ilotkaat iloizet nuoret / Nuorena aika iloita - kasvakaa kauan kotona - Parempi pajuilla maata - Laulajan lopetussanoja)).

${ }^{416}$ SKS KRA Enäjärvi-Haavio 464; käsikivillä Laiho L. 5353; Haavio 2547. Maininta on myös rieskasia tehdessä lauletusta runosta (SKS KRA Salminen K. 186) ja Tytärtenhukuttaaja -runon loppukommentin laulamisesta lähdettäessä verkkoja laskemaan (SKS KRA Mannonen 5497).

${ }^{417}$ SKVR III 1056, 1057; SKS KRA Enäjärvi-Haavio 500; Laiho A. 2133; Salminen K. 217. Väinö Salmisen $(1934,150)$ kuuleman mukaan maaorjuuden aikaan toisaalla kiellettiin töitä tehdessä laulaminen, toisaalla vaadittiin sitä.

${ }^{418}$ Metsän sävelestä ks. myös Timonen 2004, 93-107; SKS KRA Mannonen 5460. Paimenpoikien kerrotaan soittamisen ohella myös laulaneen metsässä (esim. SKS KRA Laiho L. 5350; ks. myös Laiho A. 2105).

${ }^{419}$ Esim. SKS KRA Enäjärvi-Haavio 906; Laiho L. 4980; Salminen V. 2986; lähtemisestä ks. esim. Haavio 2429; hunnun nostosta esim. Enäjärvi-Haavio 908.

${ }^{420}$ Esim. SKVR III 1717, 2132; SKS KRA Laiho L. 4982, 5309; Sääski 5969; Enäjärvi-Haavio 467.

${ }^{421}$ Pedron praasnikat SKS KRA Laiho A. 2576; akkajaiset SKS KRA Laiho A. 2581.
} 
säettä kerrattiin tai esilaulaja lauloi kaksi säettä ja kuoro kertasi ne osittain. ${ }^{422}$ Viitteitä sävelmäaineistoihin ei istuen tai seisten laulamiseen sisälly, mutta muutamassa tapauksessa käsikirjoitustoisintoja on mahdollista yhdistää ääniteaineistoihin. Valpuri Vohta korosti, että Leinon lesken runoa laulettiin istualtaan: muotorakenteen perusteella ja sävelmäaineiston kokonaisuuteen verraten hän käytti samaa sävelmää kuin samaa runoa Tallinnassa laulettaessa, jolloin Mari Vahter toimi esilaulajana. ${ }^{423}$ Yks oli väärä miun emoni -runon yhteydessä Vohta antoi kaksi erilaista muotorakennetta. Ympärikossa tanssittaessa laulettiin säkeen loppu osakerraten, kuten hän teki kahdella äänitteellä samaa runoa tyypillisellä tanssisävelmällä laulaessaan. ${ }^{424}$ Paikoillaan istuttaessa hän kertoi käytettävän toista nuottia, jossa laulettiin kaksi säettä kerrallaan ilman osakertauksia. ${ }^{425}$ Tämä rakenne sopisi useampaan Tallinnan äänitysten hitaaseen venäläistyyppiseen, refrengittömään sävelmään. ${ }^{426}$ Hidastempoinen oli myös Anna Kivisoon samassa tilanteessa tämänkaltaisella sävelmällä esilaulama La ko vieretän vilulla, jonka käsikirjoitustoisinnon Kivisoo yhdisti illalla ulkona seisten laulamiseen. ${ }^{427}$ Suppeasta aineistosta ei voi vetää kovin pitkälle meneviä johtopäätöksiä, mutta tämänkin perusteella on selvää, että paikoillaan laulamiseen liittyi useita erilaisia Länsi-Inkerissä yleisiä muotorakenteita ja sävelmätyyppejä, joita liittyy paitsi paikoillaan laulettuihin, yhtä lailla myös tanssiin liitetyihin sävelmiin.

Launis $(1904,52)$ kertoo, että erityisesti vanhemmat naiset usein lauloivat paikoillaan seisten tanssimisen sijasta. Tämä vaikutti hänen mukaansa myös laulun rytmitykseen: "Jos eessälaulajana ja köörissä oli vanhempia naisia, ei kävelty, vaan muodosti kööri puolikehän tämän edessä. Tällöin köörin loppufermaatti tuli puolta pitemmäksi, koska laulajat alallaan ollen paremmin jaksoivat sen pitää." Launiksen mukaan samoja sävelmiä saatettiin ilmeisesti käyttää tanssiessa ja seisten laulaessa, mutta seisottaessa säkeen loppuja pidemmiksi venyttäen. Samalla tavoin metsässä laulamisen yhteydessä Launis $(1907,108)$ korostaa loppusävelen pitkäksi venyttämistä.

Laulajien muodostelma ei Launiksen kuvauksessa suuntautunut (mahdollista) yleisöä kohden, vaan naiset lauloivat ilmeisesti kasvokkain, esilaulaja vasten kuoroa. Toisaalta erilaisissa häihin ja muihin tilanteisiin liittyvissä tervehtimis- tai vastaanottotilanteissa voi olettaa esilaulajankin suunnanneen kasvonsa ja osoittaneen laulunsa toiselle osapuolelle. Vatjalaisen Oudekki Figurovan mukaan suurin osa varsinaisista häälauluista laulettiin seisten, jolloin esilaulaja seisoi joukon keskellä, "väe syämes." Laulajat eivät hänen mukaansa seisseet missään erityisissä muodostelmissa. ${ }^{428}$ Muodostelma ei seisten laulettaessa luultavasti aina ollutkaan säännöl-

\footnotetext{
${ }^{422}$ SKS KRA Enäjärvi-Haavio 467, 469, 486; Haavio 2570; Laiho A. 2291.

${ }^{423}$ SKS KRA Elsa Enäjärvi-Haavio 467; Laiho A. 2291; SKSÄ L 87 c; tarkemmin ks. luku 8.

${ }^{424}$ SKSÄ L 95d; ERA, Fon. 372c.

${ }^{425}$ SKS KRA Elsa Enäjärvi-Haavio 486 (Yks' oli väärä miun emoni (Piennä petti miun emoni; (Emo, iso, Jumala väärä).

${ }^{426}$ Kaksisäkeisiä hitaita sävelmiä esim. SKSÄ L 93a, 94b, 95a, kaikki ilmeisesti venäläisperäisiä.

${ }^{427}$ SKSÄ L 95a; SKS KRA Enäjärvi-Haavio 507.

${ }^{428}$ ERA RKM, Mgn. II 2844, 05:00-05:50; 11:19-12:20.
} 
linen puolipiiri, vaan tiivis, vapaa ryhmitelmä, joko pyöreähkö tai rivinomainen. Tähän viittaavat muutamat ulkopuolisten vieraiden vastaanottamiseen liittyvät 1930-luvulla otetut valokuvat. Ilmari Kohtamäki kuvasi rivistönä seisovia, Viron presidentille laulavia ja kumartelevia naisia. Kuvasta on tosin vaikea sanoa, laulavatko kaikki naiset. ${ }^{429}$ E. N. Setälän vieraillessa Kullan kylässä Kustaa Vilkuna otti kuvia vieraiden saapumisesta. Kolmessa kuvassa näkyy vieraita vastaanottamassa ollut kylän "emäntien kuoro." Kymmenisen talvipukuista naista laulaa vaihdellen pyöreämmässä tai rivimäisemmässä muodostelmassa, kaikkien kasvot kohti vierasta. Esilaulajaa ei joukosta ole fyysisen sijainnin puolesta erotettavissa. ${ }^{430}$

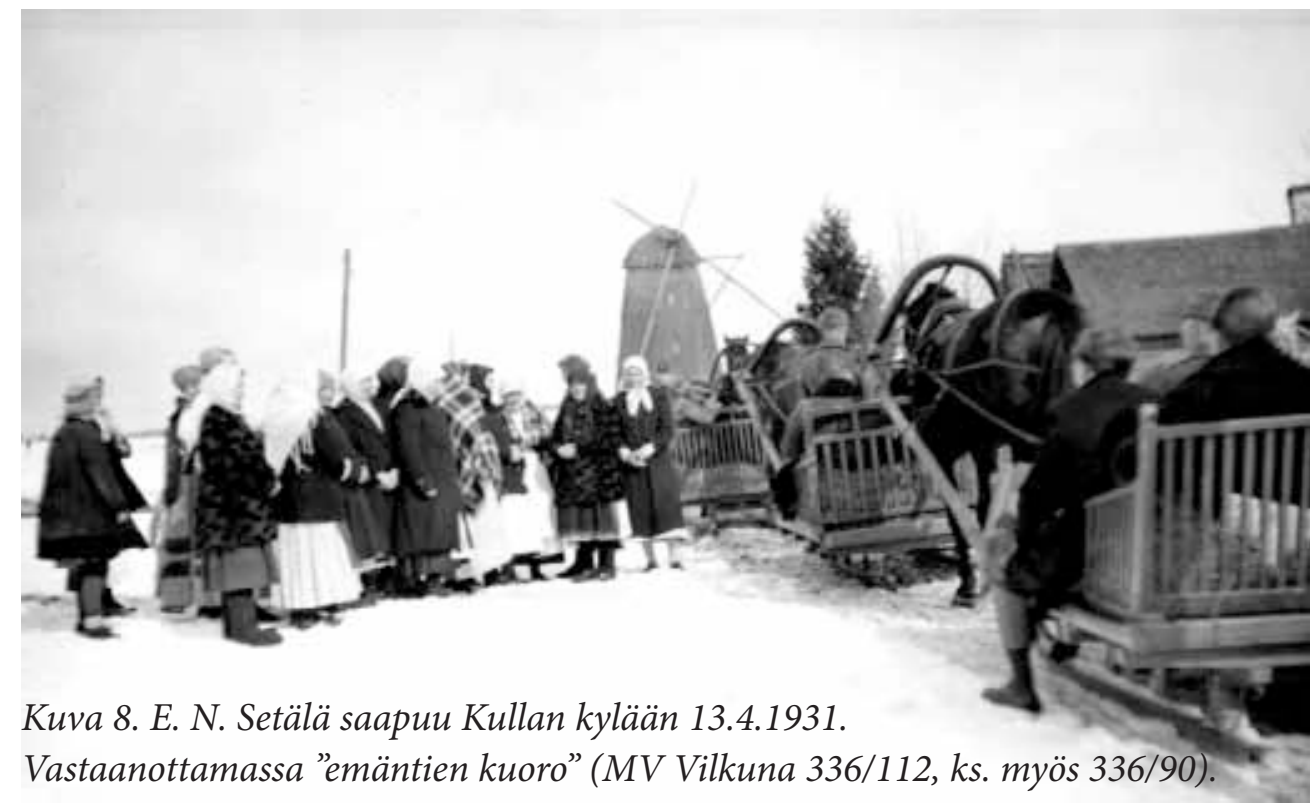

Länsi-inkeriläisaineistossa ei ole selviä kuvauksia paikoillaan seisovassa piirissä laulamisesta, vaikka muilta Inkerin ja Etelä-Karjalan alueilta tämänkaltaisia kuvauksia löytyy muutama (Enäjärvi-Haavio 1949, 130). Tämä ei tietenkään tarkoita, etteikö näin olisi voitu laulaa: maininnat vain ovat kovin tulkinnanvaraisia. Samalla tavoin jää avoimeksi, voisiko ympärikko-maininta pitää sisällään myös piirissä paikoillaan laulamisen, ja mahdollisesti kattaa myös epäsäännöllisemmän puolipiirin. Launiksen $(1904,52)$ kuvauksen perusteella samoja tai samantyyppisiä sävelmiä oli joka tapauksessa mahdollista laulaa sekä ympärikossa että paikoillaan seisten.

Voi ylimalkaan olla, että paikoillaan laulaminen niin itsestään selvä tai arkinen muoto, että toisin kuin tanssi ja kulkeminen, se ei kirvoittanut laulajilta erityismainintoja tai ollut kerääjistä erityisen merkittävä tieto. Erilaisia sävyltään lyyrisiä tai surullisia runoja mainitaan paikoillaan laulamisen yhteydessä eniten ja laulamisessa painottuu hitaus, säkeiden lopputavujen venyttäminen sekä muutamassa kohden hitaat, venäläisperäiset sävelmät.

${ }^{429}$ MV Kohtamäki 336:70. ”Inkeril[äiset] naiset tervehtivät vanhoin kansallislauluin riigivanem K. Pätsiä Narva-Joensuussa kesällä 1931," kirjoitti Kohtamäki kuvatekstiksi.

${ }^{430}$ MV Vilkuna 336:90, 111, 112. 


\section{LIIKE JA LAULU}

Liikekuvausten ja sävelmäaineiston yhdistäminen ei ole kovin yksinkertaista. Valtaosaltaan ne on tallennettu toisistaan irrallaan. Kluutšan ja saadulmoi-sävelmän yhteydessä Launiksen poikkeuksellisen tarkka, muun aineiston tukema kuvaus antoi yhdistämiseen mahdollisuuden, kun taas Viron veräjien yhteydessä vain muutama sävelmätoisinto oli mahdollista yhdistää kuvauksiin eikä päätelmistä siten tullut kovin vahvoja. Viittaukset laulamisen tapoihin voivat olla monenlaisia: sanallisten kuvausten lisäksi laulun sisältöön, sävelmiin tai muotorakenteisiin liittyviä. Joidenkin runotekstien yhteydessä erityisesti 1930-luvun kerääjät kertoivat, minkälaiseksi laulun tekstuaalinen rakenne saattoi refrenkien ja kertausten osalta muuttua tietyssä tilanteessa laulettaessa. Silloin, kun tähän rakennetyyppiin liittyvät sävelmät muussa aineistossa ovat keskenään samankaltaisia voidaan olettaa, että laulajan käyttämä tai tarkoittama sävelmä on todennäköisesti ollut niiden kaltainen. Joihinkin sävelmiin tai rakennekuvauksiin taas liittyy kontekstikuvauksia tai laulajien itsensä käyttämiä nimityksiä, ja toisaalta runon tekstikin saattaa suoraan viitata johonkin toimintaan. Esimerkiksi Eino Levón keräsi Hevaalta $\mathrm{La}$ ka katson lautojan, silittelen siltojan -säkeillä alkavan sävelmän, jonka runosäkeet liittävät sen tanssilattian sileyden kokeilemiseen. Harvinaista kyllä, tällä kertaa Levón myös merkitsi sävelmän yhteyteen "tantsun päälle."431 Jos tietynlaisista runoaiheista tai kontekstikuvauksista huomattava osa liittyy tietyntyyppisiin sävelmiin, voi olettaa niiden puitteissa tyypillisesti lauletun tällä sävelmällä. Ennen näin syntyvien sävelmäryhmien käsittelyä on kuitenkin syytä tarkastella liikkeeseen ja lauluun liittyvää paikallista käsitteistöä, jonka puitteissa merkittävimmältä näyttää jako hitaaseen ja nopeaan.

\section{Tihti tai Vienoo}

Nopeaa laulua ja liikettä kuvattiin läntisimmässä Inkerissä sanoilla tihtii (tiheästi), kiireesti tai nopeasti, hidasta puolestaan sanoilla vienoo tai pitkällä äänellä. Nämä ovat 1930-luvun laulajien useimmin laulun ja tanssin tarkempaan luonnehtimiseen käyttämät termit. Nimitykset ovat peräisin lähes yksinomaan liikkeestä eniten kiinnostuneen tallentajan Elsa Enäjärvi-Haavion sekä hänen puolisonsa Martti Haavion tallenteista. Nopeuden vaihtelu tulee kuitenkin esille myös laajemman aineiston yhteydessä sekä läpi kylän kulkemisen että ympärikon kuvausten yhteydessä: kuljettiin joko hitaasti tai tanssittiin nopein, lyhyin askelin.

Tihtii eli tiheästi tarkoitti sekä nopeaa, "maata kahnuttavaa" tanssiaskelta että siihen liittyvää nopeampitempoista laulua. ${ }^{432}$ Enäjärvi-Haavio (1949, 158-159) liittää nimityksen muihinkin kuvauksiin tanssin riehakkuudesta ja ympärikössä tanssivista tytöistä. Tihtii tai kiireesti mentii Viron veräjää tai tanssittiin kaksinkertaisessa

\footnotetext{
${ }^{431}$ SKS KRA Levón 448.

${ }^{432}$ SKS KRA Haavio 2286; Enäjärvi-Haavio 549.
} 
ympärikossa ja myös "vanha akka" lauloi ja tanssi tihtii Nastasjan päivän juhlissa. ${ }^{433}$ Jälkimmäisen kuvauksen runoon Tuterina taterina sisältyy aineiston ainoa suoraan tihtii-nimitykseen liittyvä viite laulun muotorakenteeseen eli jokaisen säkeen jälkeen toistuva, säkeen osittain korvaava refrenki oiloliilolee. Tämän lisäksi voi olettaa myös monien nopeatahtisten, rytmikkäästi painotettujen laulujen kuuluvan tihtiin esitettyjen joukkoon. Parhain esimerkki on Tallinnassa vuonna 1937 äänitettyjen nopeiden, säkeen lopun osakertauksen sisältävien tanssilaulujen sarja, joiden esittämiseen liittyi riehakkaita, kuoro-osioita rytmittäneitä kiljahduksia. ${ }^{434}$ Myös esimerkiksi kluutšaan liittynyt saadulmoi-sävelmä on äänitteillä yleensä nopeasti ja rytmikkäästi esitetty. Tyypillisesti nopeat sävelmät vuorottelevat äänityksissä hitaiden kanssa, joten nopeaa tempoa ei yleensä voi pistää esiintymisjännityksen syyksi.

Vienoo laulamisen yhteydessä puhutaan myös pitkästä äänestä. Nimityksiä käytetään sekä hitaasti piirissä että läpi kylän vapaassa muodostelmassa kulkemisen yhteydessä. Lisäksi pitkällä äänellä saatettiin laulaa myös istualtaan tai seisten. ${ }^{435}$ Enäjärvi-Haavion (1949, 157-169) kuvauksessa joukkoon kuuluvat nähdäkseni aiheellisesti myös ne hitaasti kulkemisen kuvaukset, jossa ei suoraan mainita näitä termejä. Laulun rakenteeseen viittaavia mainintoja on pitkän äänen yhteydessä muutama. Valpuri Vohdan mukaan refrenkeihin oi lolii oi lolii oili loošinki moii ja kaalina kaalina kaalina majaa kuului hitaampi sävel ja niitä käytettiin vain kävellen esitettävien laulujen yhteydessä. ${ }^{436}$ Näiden refrenkien yhteydessä laulun muotorakenne oli kaksisäkeinen. Ensimmäisen refrengin Vohta liitti myös runoon Noin saneli miun emoni (Elä lapsi paljon laula), jota tanssittiin ympärikossa. ${ }^{437}$ Vohdan mainitsemaa kaalina-refrenkiä käytettiin vuoden 1937 äänityksissä sekä rekryyttilaulussa, huolirunossa Vasta mie kullan kuolettelin että paimenrunossa Tuttu luttu miä trubitin (Tuttul luttul mie trupitan), jotka kaikki laulettiin sangen hitaasti. ${ }^{438}$ Muodoltaan hieman erilaisen vot kalina vot malina -refrengin Juljaana Pohjalainen puolestaan liitti vienoo laulamiseen ympärikossa: esimerkiksi hän antoi runon Anoin maata velloltani (Myyty neito). ${ }^{439}$ Anna Kivisoo liitti oiloliiloleerefrengin tihtii tanssimisen ohella myös pitkään ääneen ja Tytöt lustit luuraelloot -runoon. ${ }^{440}$ Tämä eri tyyppisten refrenkien paljous suhteellisen suppeassa aineistossa viittaa siihen, että pitkäksi ääneksi kutsuttiin hyvinkin erilaisia sävelmiä, joita laulettiin suhteellisen hitaasti. Kivisoon oiloliilolee-refrengin liittäminen sekä tihtii tanssimiseen että vienoo laulamiseen viittaa puolestaan siihen, että laulun raken-

\footnotetext{
${ }^{433}$ SKS KRA Enäjärvi-Haavio 556; 550; 510, 797.

${ }^{434}$ SKSÄ L 87b, 89b, 92b, 92c, 95 c, 101a; ks. myös 87d, 95d. Näistä kaikki muut paitsi 87d ovat säkeen loppupuolen kertaavaa sävelmätyyppiä.

${ }^{435}$ SKS KRA Enäjärvi-Haavio 549, 500, 550, 551, 554, 555, 556; Haavio 2431, 2445.

${ }^{436}$ SKS KRA Enäjärvi-Haavio 555.

${ }^{437}$ SKS KRA Enäjärvi-Haavio 488.

${ }^{438}$ SKSÄ L 91 ab, 91 b2, 96a.

${ }^{439}$ SKS KRA Enäjärvi-Haavio 554.

${ }^{440}$ SKS KRA Enäjärvi-Haavio 490, 510.
} 
teet saattoivat näiden kahden kategorian puitteissa olla joskus samojakin. Tällöin niiden esittämisen tempo ilmeisesti ratkaisi, kenties myös muut laulamisen hienovaraisemmat tyylipiirteet. Toisaalta Vohta ja Pohjalainen painottavat, että tietyt refrengit (ja mitä ilmeisimmin siis myös sävelmät) kuuluivat nimenomaan pitkällä äänellä laulamiseen. ${ }^{441}$

Anna Kivisoolta tallentamansa muistiinpanon yhteydessä Enäjärvi-Haavio kirjoitti pitkällä äänellä lauletuista runoista: "Muutamia lauluja lauletaankin etupäässä tuvassa ja tavallisin tai hitain askelin liikkuen. Olin huomaavinani, että näihin yleensä kuuluvat kertovat, balladintapaista toimintaa sisältävät laulut." ${ }^{\text {442 }}$ Pitkän tai vienon äänen tai hitaan sävelen yhteydessä mainitaan aineistossa lauletun kertovia runoja Anoin maata velloltani ja Pääskylintu päivälintu sekä lyriikkaa Piennä petti miun emoni, La miä vieretän vilulla ja Tytöt lustit luuraetii. ${ }^{443}$ Enäjärvi-Haavio $(1949,157)$ liittää näihin myös kävellen esitetyiksi mainitut, aineistossaan olevat runot Tytärtenhukuttaja, Laivassa surmattu veli, Oma emo - vieras emo, Läksin koista kulkemaan (Äidin kuolo) sekä rekryyttilaulun Nyt tuloo syvä sykysy. ${ }^{444}$ Kaikki pitkään ääneen suoraan liitetyt olevat runot ovat, kenties runoa La mie vieretän vilulla lukuun ottamatta, traagisiksi tai surullisiksi tulkittavia, myös Tytöt lustit luuraeltii, joka tänä pitkään ääneen yhdistyvänä versiona päätyy kuvaamaan onnetonta naimakauppaa sekä Tuttu luttu miä trubitin (Tuttul luttul mie trupitan), jossa paimenta torutaan kadonneesta lehmästä ja joka usein saattoi jatkua paimenen suojattomuuden kuvauksella. ${ }^{445}$ Lisäksi pitkän äänen yhteydessä erityisesti mainittuihin kalina-refrenkityyppeihin liittyy Länsi-Inkerissä usein traagista lyyristä epiikkaa, kuten Suka mereen tai Tytärtenhukuttaja sekä huolilyriikkaa. ${ }^{446}$

Enäjärvi-Haavion $(1949,158)$ mukaan pitkällä äänellä lauletut runot olivat yleensä vakavia. Aili Simonsuuren $(1972,42)$ mukaan pitkällä äänellä lauletut sävelmät olivat "surumielisiä ja hitaita" siinä missä tihtiin mentäessä käytetyt olivat "vilkkaita ja iloisia." Myös Terttu Koski (1974, 477, 481), joka käsittelee lähinnä 1960-luvulla Soikkolasta tallennettua ääniteaineistoa, toteaa, että tietyt länsi-inkeriläiset sävelmäryhmät "jakautuvat emotionaalisen latauksen mukaan." Surullisiin lyyriseeppisiin runoihin liittyy usein "vakaa melodian liike ja hidas tempo." Sitä vastoin "iloisemmat tekstit saivat myös vastaavan musiikillisen ilmaisun, sävel on tanssirytminen ja nopeatempoinen." Koski korostaa rytmin ja melodian ohella erityises-

\footnotetext{
${ }^{441}$ A. A. Borenius huomautti vuonna 1877 Kattilassa, kierrettyään ensin Tyrön ja Soikkolan kyliä, että nimenomaan nuoriso lauloi erilaisia venäläisperäisiä kalina-refrenkejä sisältäviä, mollivoittoisia sävelmiä. Toisaalta Tyrössä hän nimesi yhden vot kaalina -refrengin sisältävän sävelmän miesten sävelmäksi. (SKS KRA Borenius e 207, 215, Tyröstä 186.)

${ }_{442}$ SKS KRA Enäjärvi-Haavio 549.

${ }^{443}$ SKS KRA Enäjärvi-Haavio 490, 549, 554, 555; Haavio 2431, 2445.

${ }^{444}$ Ks. SKS KRA Enäjärvi-Haavio 460, 549, 463, 470, 472.

${ }^{445}$ SKS KRA Laiho L. 5132, 5350. Vuoden 1937 äänitteellä naiset tosin kuulostavat Tuttul luttul -laulun kohdalla lähinnä lempeän huvittuneiltä: paimenen ahdinko näyttäytyy etäistettynä (SKSÄ L91c.)

${ }^{446}$ Esim. SKSÄ A 300/28c, 35b, 36b, 40a, 42a, 22b. Ainoana poikkeuksena joukkoon kuuluu myös kaksi saman esilaulajan toisintoa Käeltä oppinut laulut -runosta, SKSÄ A 300/21b, 22a. Toisaalta Keski-Inkerissä samantyyppisiin refrenkeihin liitetään muutaman traagisen aiheen ohella esimerkiksi Oman kylän ylistys- ja Iso tammi -aiheisia runoja, joiden sävy ei ole millään tavalla surullinen tai traaginen (SKSÄ 301/30b; SKS KRA Borenius e 186; Levón 412; traagisista SKS KRA Borenius 111 (Kouluun kotoa); SKSÄ A 301/29a (Syntymistään sureva)).
} 
ti sävelmän esittämisen tapaa tunnelman määrittäjänä. Tämän lisäksi hän kertoo, että monet lyyriset häälaulut ja kertovat laulut "lauletaan erittäin pehmeästi ja kertovasti, vapaalla äänellä, kun taas tanssilauluissa ja venäläisperäisissä tšastuskoissa lauluääni on voimakas ja kireä, tempo nopeampi.

Laulun välittämä tunne tai sävy oli siis usein yhteneväinen sekä runon sisällön että laulamisen nopeuden ja liikkeen laadun kanssa. Toisaalta löytyy myös muutamia esimerkkejä siitä, että vaikkapa nopearytmiseen ympärikkosävelmään voitiin liittää myös surullisia runoja, joita tanssirytmillä laulaessaan esittäjä saattoi jopa itkeä (Kallio 2009). ${ }^{447}$ Rajat laulamisen tapojen ja sävyjen välillä eivät siis olleet ehdottomia, vaan erilaisia tyylipiirteiden yhdistelmiä oli mahdollista käyttää myös joustavina, tilannesidonnaisina ilmaisun keinoina. Tietyt laulamisen muodot tai tyylit näyttävät kuitenkin tyypillisesti liittyneen tietynlaisiin tilanteisiin, sävyihin tai aihelmiin.

Kiinnostavaa tässä yhteydessä on erityisesti se, miten laulajat sijoittivat joskus runoja samanarvoisesti useampaan kontekstiin, joihin saattoi edellä esitetyn valossa liittyä myös erilainen esitystapa. Yks oli väärä miun emoni (Piennä petti miun emoni) -runoa laulettiin tanssiessa yksisäkeisenä säkeen loppu kerraten, mutta istuessa toisella nuotilla, kaksisäkeisenä ilman osakertauksia, kertoi Valpuri Vohta. ${ }^{448}$ Muissa vastaavissa kuvauksissa ei laulamisen muotorakenteisiin vihjata, vaan ainoastaan vaihtoehtoisiin konteksteihin. Kassa’ani kallistani (Päätä pantaessa) -runoa laulettiin Juljaana Pohjalaisen mukaan "[t]uvassa istuen tai kävellen. ${ }^{499}$ Tytärtenhukuttaja-runoa laulettiin Katri Vohdan mukaan joko "karavanas ympäri" tai paikallaan istuen, Matrona Bässinan mukaan joko istuen tai ympäri kylää kulkien. ${ }^{450}$ Oman kylän ylistys -runoa sekä lyyristä runoa Hoz mie itken (Ei päiväni parane, itken tai laulan) kerrottiin lauletun sekä kylän läpi kulkien etta joen kallaalla. ${ }^{451}$ Nämä kuvaukset saattavat kaikki Vohdan tanssimainintaa lukuun ottamatta liittyä vienoo eli pitkällä äänellä laulamisen kenttään, joka piti sisällään yhtä hyvin paikoillaan kuin hitaasti kulkien tai tanssienkin laulamisen.

\footnotetext{
${ }^{447}$ ERA RKM, Mgn. K 42 (3); SKSÄ L 89b; ks. myös luku 8.

${ }^{448}$ SKS KRA Enäjärvi-Haavio 486.

${ }^{449}$ SKS KRA Enäjärvi-Haavio 503.

${ }^{450}$ SKS KRA Enäjärvi-Haavio 470; Haavio 2464.

${ }^{451}$ SKS KRA Laiho A. 2082, 2147; 2132.
} 


\section{TANSSISÄVELMÄT}

Jo pelkästään Launiksen $(1904,52)$ ja Alavan (1932) kuvausten ja esimerkkien valossa tanssiin liittyi Länsi- ja Keski-Inkerissä paljon erilaisia melodioita ja rytmejä. ${ }^{452}$ Laulu eteni yksi tai kaksi säettä kerrallaan, refrengeillä tai ilman, ja siihen saattoi liittyä myös säkeen viimeisen tavun pitkäksi venytyksiä. Kuten edellä kävi ilmi, erilaisia liikkumisen tapoja oli paljon. Nuotteja nimetessään Launis (1907, 105) puhuukin nuoteista "tantsun päälle", ei yhdestä sävelmästä. ${ }^{453}$

Tanssiin liittyviä laulusävelmiä on mahdollista tunnistaa neljästä eri suunnasta käsin. 1) Muutama Launiksen antama tanssin kuvaus on mahdollista liittää hänen keräämäänsä sävelmäaineistoon. 2) Joihinkin lauluihin liittyvät nimitykset tai kuvaukset taas määrittävät ne selkeästi tanssilauluiksi: tantsuvirsi, tanzunuotti, tantsun päälle, menkää ympärikkoo. ${ }^{454} 3$ ) Tietyt aloitussanat viittaavat samoin suoraan tanssiin, esimerkiksi Täss on lusti nuoren noissa, Tehkää yksi ympärikko, Hypätkäämme hyrjätkäämme, Tässä tanssivat tasaset tai La ka katson kannoillani. 4) Lisäksi joskus, kun kaikki tiettyyn runoon liittyvät tarkemmat kontekstimaininnat viittaavat tanssiin, voi olettaa myös runon yhteydessä kerättyjen sävelmien todennäköisesti olevan tanssiin liittyneitä sävelmiä. Näitä ovat esimerkiksi seuraavassa luvussa käsiteltävät Iilian ja Pedron virret sekä talvipraasnikkoihin liittyvät laulut tai häissä laulettu kokin kiitosvirsi, joiden muotorakenteet ovat myös sangen vakiintuneita.

Ensimmäisen matkansa matkakertomuksessa Launis $(1904,52)$ kuvaa tyttöjen piiritanssia Soikkolassa. Hän kertoo sekä hitaasta piirissä kävelemisestä että nopeammasta piirissä tanssimisesta niitä tarkemmin erittelemättä tai kuvauksiaan tarkemmin jompaankumpaan kohdistamatta. Välillä kuoro kertasi esilaulajan "sanat ja nuotin” sellaisenaan, välillä jonkin refrengin, joista Launis nimeää laadoi laadoi laadoi majoi ja oi kaalina oi maalina -refrengit. Esilaulajan runo- ja sävelmäsäkeen sellaisenaan kertaavia sävelmiä on aineistossa niin paljon, että tämän tyyppisten tanssinuottien tunnistaminen on sen puitteissa mahdotonta. Launiksen mainitsemat refrengit sen sijaan ovat selkeitä sävelmän määreitä: ne löytyvät viidestä vuoden 1903 keräelmän sävelmästä. ${ }^{455}$ Launis jatkoi kuvaustaan: välillä kuoro kertasi esilaulajan laulamat kaksi säettä kahdesti nämä esilaulajan sävelmään tihennettyinä sovittaen. Sävelmiä, joissa kuoro-osa on nopeutettu, on aineistossa useita. ${ }^{456}$ Launis antaa lisäksi esimerkeiksi tanssilauluista Suomalaisen Kirjallisuuden Seuran arkistoon luovuttamansa puhtaaksikirjoituksen numerot 78, 145 ja $446 .{ }^{457}$

\footnotetext{
${ }^{452}$ Alavan (1932) kuvauksessa on tosin paikoin mahdotonta erottaa, mikä yleistys on tehty minkäkin alueen pohjalta tai kuinka laajaan aineistoon havainto perustuu: mukana on selkeitä viitteitä myös pohjois-inkeriläisiin ja kannakselaisiin laulutapoihin.

${ }^{453}$ Tanssisävelmistä ks. myös Timonen 2004, 148-149; Launis 1907, 108; 1910b, VIII; 1910c, 224; KK Coll. 123.22 Launis 1903, 35-36.

${ }^{454}$ SKS KRA Borenius e 111, 201, 208, 219, 223; SibA Launis 187, SKS KRA Levón 448; SKSÄ L 89b. Esim. SKSÄ L 89b (tantsuvirsi); SibA Launis 187 (tanzunuotti); SKS KRA Levón 448 (tantsun päälle); SKS KRA Borenius e 201 ("Menkää ympärikkoo").

${ }^{455}$ SibA Launis 6, 10, 142, 343, ks. myös 118.

${ }^{456}$ SibA Launis 5, 15, 42, 68, 69, 77, 106, 113, 137, 160, 316, 454, 456.

${ }^{457}$ SibA Launis 76, 141, 454.
} 
Näistä ensimmäinen on yksisäkeinen viiden sävelen alalla liikkuva kuusi-iskuinen sävelmä (44222244). Vaikka säkeen kertausta ei ole merkitty, kertaa kuoro tämäntyyppisissä sävelmissä esilaulajan osuuden yleensä sellaisenaan.

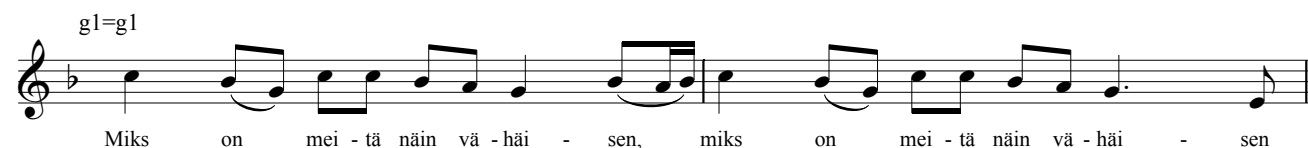

Nuotti 10. Launiksen muistiinkirjoittama ensimmäinen tanssilaulu Kurkolan kylästä (SibA Launis 76).

Sävelmä edustaa toiseksi häissä keskeiseksi pulmanuotiksi luvussa 7 paljastuvaa sävelmätyyppiä, joihin liittyviä häärunojakin voitiin paikoin tanssia. Toinen Launiksen antama sävelmä on tyypillinen rekilaulu. Kolmas vastaa edellä olevaa kuvausta: siinä kuoro kertaa esilaulajan neli-iskuisen säeparin kahdesti, nopeammalla tempolla.

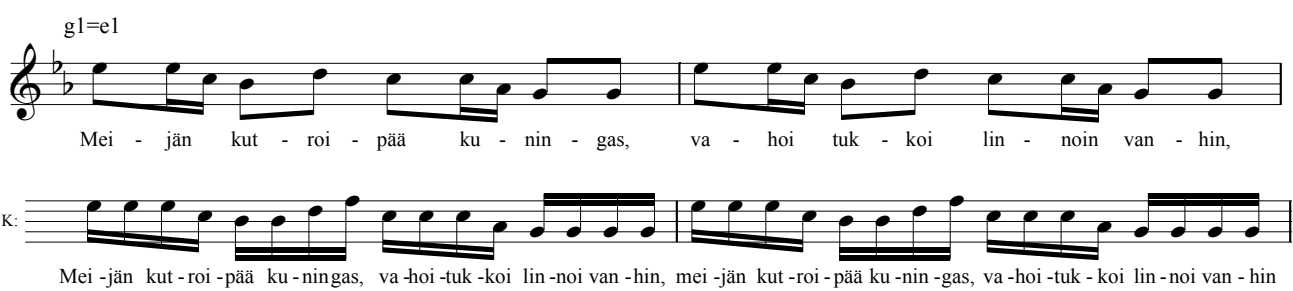

Nuotti 11. Launiksen kolmas tanssilaulumuistiinpano Uudestakylästä (SibA Launis 454).

Toisen matkansa matkakertomuksessa Launis $(1907,108-109)$ kuvaa ensin edellisen kaltaisen yleisen tanssisävelmien muodon: esilaulaja laulaa kaksi runosäettä, jotka kuoro kertaa kahdesti. Esilaulajan ja kuoron laulama sävelmä on yhtä pitkä, joten kuoro laulaa säkeet nopeammin kuin esilaulaja. Esilaulajan laulun aikana käveltiin laulun tahdissa, kuoro-osan aikana neljä kertaa esilaulajan osuuden tahtia nopeammin. ${ }^{458}$ Tarkemman kuvauksen Launis antaa kolmesta tämän tyyppisiin sävelmiin Hevaalla liittyneistä tanssimisen tavoista esimerkkirunoineen. Kaikkia esimerkkejä vastaavat runot sisältyvät hänen Hevaalla Vassu Kaurilantyttäreltä tallentamiinsa sävelmiin. Muilta laulajilta hän ei niitä matkallaan tallentanut. Kaurilantyttären näiden runojen yhteydessä käyttämät sävelmät eivät kuitenkaan täysin vastaa Launiksen kuvausta. Käsi kädessä ringissä kulkien laulettiin Launiksen mukaan runo Kysyin maata velloltani (yl. Myyty neito). Kaurilantyttären sävelmässä

\footnotetext{
${ }^{458}$ Lasken Launiksen kuvauksen kattamaan alaan mukaan myös samantyyppisiä rytmivaihteluita sisältävät sävelmät, joissa joko esilaulu tai kuoro sisältää osakertauksen. 1) Esilaulaja kertaa kaksi kertaa säkeen alkupuoliskon, 2) kuoro toistaa säkeestä vain loppupuoliskon tai 3) kuoro laulaa säkeen ja sen loppupuoliskon kahdesti. Näin muodostuviin sävelmäryhmiin kuuluu myös tanssinaloitussanoja (SibA Launis 69; SKS KRA Alava VIIa:425) ja Launiksen myöhempään kuvaukseen sopivia sävelmiä (SKSÄ A $301 / 35 a$ ja b).
} 
esilaulaja laulaa kaksi kertaa säkeen alkupuoliskon, ja kuoro kertaa koko säkeen kahdesti samalla sävelmällä lisäten vielä loppuun osakertauksen:459

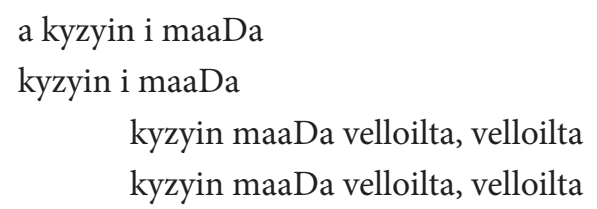

Samanlainen rakenne on myös Kaurilantyttären laulamassa runossa Hekkoi tyttöi hemme tyttöi (yl. Hekon runo), jota tanssittaessa kädet olivat vapaina ja yksi tanssija kerrallaan piirin keskellä. Näissä lauluissa Kaurilantytär käytti esilaulussa kolmesta viiteen runosäkeen tavua ja sijoitti väliin usein lisätavuja (i, on, siä). Kolmannessa Launiksen mainitsemassa ja Kaurilantyttären laulamassa runossa La ka katson kannoillani (yl. Onko sillat sileät) sekä esilaulaja että kuoro laulavat samat kaksi säettä samalla sävelmällä ja rytmillä. Samalla tanssittiin pareittain vastakkaisissa riveissä.

Luultavasti Launis siis halusi vain antaa yleiskuvan tanssimisen tavoista tai Kaurilantyttären kertomasta eikä ollut kovin tarkka sävelmän muodon suhteen: kuvauksen ja aineiston muotorakenteet eivät täysin vastaa toisiaan kuin yhden sävelmän kohdalla. Arvelen, että Launis vain pelkisti matkakertomuksen kuvaustaan, mutta on toki mahdollista, että hän puhui sellaisen tiedon pohjalta, jota edustavia lauluja hän ei tallentanut. ${ }^{460}$

Alkusanojen tai -formuloiden, paikallisten nimitysten sekä Launiksen kuvausten perusteella tanssiin käytetyiksi sävelmiksi voi olettaa liitteessä 5 esitetyt toisinnot. Ne koostuvat yksittäisten sävelmätyyppien ohella muutamasta suuremmasta ryhmästä. Yksisäkeisiä, neli-iskuisia sävelmiä on yhdeksän, kaikki Hevaalta ja Kattilasta. Muita yksisäkeisiin sävelmiin liittyviä rytmityyppejä, erityisesti kuusiiskuisia $(44222244,22442244)$ on puolestaan tallennettu nimenomaan Narvusin ja Soikkolan alueelta. Joukkoon kuuluu myös esimerkiksi yksi viisi-iskuinen sävelmä (22222244) sekä yksi säkeeseen lisättävällä refrenkitavulla joo lisätty viisi-iskuinen sävelmä (22222244[4]). Säkeen lopun kertaavia yksisäkeisiä sävelmiä (22222222 2244) on tallennettu eniten Narvusista, mutta yksittäisinä myös Soikkolasta, Kattilasta ja Hevaalta. Erilaisia muotorakenteeltaan kaksisäkeisiä, neli-iskuisia sävelmiä on viisitoista Narvusista, Soikkolasta, Hevaalta ja Tyröstä: näihin kuuluu niin refrengillisiä kuin säepareja sellaisinaankin toistavia sävelmiä sekä Hevaan nuotteja. Näiden lisäksi tulee vielä kuusi muotorakenteeltaan kaksisäkeistä sävelmää, jossa kuoro-osa lauletaan esilaulua nopeampana sekä muutamia yksittäisiä muunlaisia sävelmiä.

\footnotetext{
${ }^{459}$ SKSÄ A 301/35a.

${ }^{460}$ Tarkasti kuvausta vastaavia sävelmiä Launis oli äänittänyt yhden Soikkolasta (SKSÄ A 301/14a), ja kuvausta vastaavan soikkolalaissävelmän hän antoi myös esimerkkinä tanssisävelmistä edellisen matkansa matkakertomuksessa (SibA Launis 454; muita kuvausta vastaavia ks. SibA Launis 15, 42, 113 , 137).
} 
Näiden pääryhmien sisällä rakenteet, rytmit ja melodiat varioivat suuresti, mutta joitain yhteisiä piirteitä on silti havaittavissa. Sävelmien peruspulssi on yleensä melko tasainen, rytmi koostuu useimmiten yhdestä tai kahdesta aika-arvosta. Ä̈nitetoisinnoissa laulun tahti on reipas ja tasainen. Huomion arvoista on myös se, mitä kaikkea tanssisävelmien joukosta ei löydy. Venytettyjä sävelmiä tai säkeen loppuja ei esiinny, vaikka Launiksen $(1904,52)$ kuvauksesta voi päätellä myös loppuvenytysten olleen tanssittaessa mahdollisia, erityisesti venäläisperäisten refrenkien kanssa laulettaessa ja ympyrässä kävellessä. Säkeen lopun tai alun osakertausta monimutkaisempia osakertausrakenteita ei esiinny. Joukkoon kuuluu ainoastaan yksi refrenkitavuja sisältävä sävelmä, muuten refrengit ovat kaikki säettä korvaavia. Vaikuttaakin siltä, että tanssilauluiksi identifioitavissa olevat toisinnot edustavat valtaosin tihtii laulamista, nopeaa laulua ja tanssia. Tähän on kaksi varmaa poikkeusta: Launiksen mainitsemat Oi kalina oi malina -refrengit sekä Iilian virteen liitetyt sävelmät.

Kalina-refrengit liitetään narvusilaisaineistossa pitkään ääneen. Sävelmäaineistoa tarkastellessa käy selväksi, että kalina-refrenkejä oli hyvin erityyppisiä, eikä näitä kaikkia pitkän äänen yhteydessä suinkaan mainita. Monissa sävelmätoisintoihin liittyvissä runoissa kyllä painottuvat sävyltään surulliset tai traagiset, kuolemasta ja vaikeista ihmissuhteista tai elämäntilanteista kertovat runot. Jotkut Soikkolassa äänitetyt toisinnot on toisaalta laulettu hyvinkin nopealla ja rytmikkäällä tavalla. ${ }^{461}$

Iilian virren sävelmien voi kuvausten perusteella olettaa varmuudella kuuluneen hitaasti ympyrässä kävelemisen piiriin. Näiden sävelmien muotorakenne ja paikoin melodiakin on kyllä sama kuin monien nopeatempoisten tanssinuottien, joita käytettiin myös Kokin kiitosvirren ja Martin virren yhteydessä. Äänitetoisintoja on vain kaksi. Laulun tempo ei ole erityisen hidas, mutta laulajat eivät liitä mukaan sellaisia lisätavuja tai kiljahduksia kuin monia tanssilauluja esittäessään. He eivät myöskään painota laulun rytmiä, vaan laulavat tasaisen kuuloisesti. ${ }^{462}$ Vaikuttaa siis siltä, että joskus yksi ja sama muotorakenne, kenties sävelmäkin, saattoi tilanteesta ja esitystavasta riippuen tulla lauletuksi joko tihtii tai pitkällä äänellä.

Kokonaisuutena liikkeeseen liittyvä aineisto saakin miettimään tanssin paikallista määrittymistä ja sitä, minkälaisena tanssi tallentajille näyttäytyi. Paikallisten kuvauksissa keskeisin jakolinja ei kulkenut tanssin ja paikallaan olon vaan laulun nopeuksien välillä. Hidas liike ja paikallaan laulaminen sijoittuivat samaan pitkän äänen

\footnotetext{
${ }^{461}$ SKSÄ A 300/35b (Ei minun laulella pitäisi); SKSÄ L 96a (Ei minun laulella pitäisi); SKSÄ L 92a2 (Kalevanpojan kosto); SKS KRA Alava X s. 22-25; Alava X 87 (Sotamiehenotto); SKSÄ A 300/28c (Emo pani piennä piikuveen); SKSÄ A 300/40a (Ylösnousemusvirsi); SKSÄ A 300/21a (Osasi emo omenan tehdä) SibA Launis 188; SKSÄ A 300/42a (Suka mereen); SKSÄ A 300/22b (Tytärten hukuttaja); SKSÄ L 91 b2 (Kalevanpojan kosto); SKSÄ A 300/36b (Jalka kiveen). Muutamat toisinnot tosin eivät mitenkään ilmeisellä tävalla näytä surusävyisiltä, joskaan eivät erityisen riehakkailtakaan: SibA Launis 49 (älkää tytöt valitko kaunista); SibA Launis 6 (Oi tytöt sulat sisaret; aloitusformula voi jatkua monella tavalla); A 300/18a (Saaren neito); SKSÄ A 300/21b ja 22a (Käeltä oppinut laulut); SKSÄ A 300/30b (Varkaalle menijä).

${ }^{462}$ Toinen Iilian virren äänitetoisinnoista on Darja Lehden ja kuoron Tallinnassa (SKSÄ L 101b), toinen Ustenja Miikkulantyttären ja kuoron Launikselle Säätinän helluntaipraasnikoilla esittämä (SKSÄ A 300/47b). Lehti ei tanssilauluja esilaulanut, mutta sama kuuden laulajan ryhmä esitti niitä paljon, esilaulajia vaihdellen.
} 
kategoriaan. Tunnistettavissa olevista tanssisävelmistä valtaosa taas kuuluu mitä ilmeisimmin tihtiin laulamisen ja tanssimisen kategoriaan. Voikin olla, että hidas liike ei paikallisten näkökulmasta määrittynyt tantsun kategoriaan, vaikka tulikin nimetyksi ympärikoksi ollessaan piirimuotoista. Kuvausten vähäisyyden perusteella voi olettaa, että myös kerääjiä kiinnosti enemmän riehakas tanssi kuin hidas, eleetön piirissä peräkkäin kulkeminen. Ilmeisesti kävellen ympärikössä esitettyjä sävelmiä ei nimetty tanssinuoteiksi eikä niitä tallennustilanteissa aloitettu tyypillisin tanssisäkein, vaikka ympärikko-termi selvästi kattaa sekä nopean, hitaan että paikoillaan piirissä laulamisen.

Ei voi olettaa, että tämä aineistosta syntyvä 48 tanssisävelmän otos kattaisi kaikki länsi- ja keski-inkeriläiset tanssiin käytetyt sävelmät. Samoin on selvää, että sävelmäaineistossa on paljon tanssisäveliä, joita ei ole nimetty tai joihin ei liity tanssinaloitussanoja ja jotka eivät siten ole tunnistettavissa. Lisäksi toisintomäärät eivät kerro sävelmätyyppien yleisyydestä. ${ }^{463}$ Luultavasti otokseen kuitenkin sisältyvät ainakin tyypillisimmät 1800-luvun lopussa ja 1900-luvun alussa käytetyt nopeat tanssisävelmät.

${ }^{463}$ Esimerkiksi Launiksen tyypilliseksi tanssisävelmäesimerkiksi nostamaa sävelmätyyppiä 44222244 löytyy ainoastaan kolme varmasti tanssiin liittyvää toisintoa, ja toisaalta säkeen lopun kertaavista tanssisävelmistä kuusi kymmenestä on Tallinnan äänityksiin osallistuneilta laulajilta. 


\section{LIIKKEEN JÄSENTYMINEN}

Tanssin ja läpi kylän kulkemisen keskeiskonteksteja olivat häät ja praasnikka-juhlat. Erilaisiin liikkumisen tapoihin liittyi osin omanlaisiaan runoja, sävelmiä tai laulamisen tyylipiirteitä, mutta osaa piirteistä oli mahdollista käyttää useampien liikkumisen tapojen yhteydessä. Tanssiin liittyy Inkerissä laajempi kirjo erilaisia sävelmätyyppejä ja laulamisen rakenteita kuin mihinkään muuhun yksilöitävissä olevaan yksittäiseen tilanteseen tai tekemiseen.

Yleisimmäksi tanssin muodoksi mainitaan kalevalamittaisten runojen yhteydessä ympärikko, joka saattoi saada monenlaisia, sävyltään ja tyyliltään hyvin erilaisia muotoja hitaan juhlavasta peräkkäin piirissä kulkemisesta riehakkaaseen, muodostelmiltaan ja liikkeiltään vaihtelevaan tanssiin. Ympärikon ja muunkin tanssin yhteydessä oli mahdollista käyttää laajaa sävelmien kirjoa. Aineistossa yleinen toteamus "mäntii ympärikossa" ei siis vielä kerro runon esityksellisestä sävystä kaikkea. Tanssiin saattoi liittyä monenlaisia aloitusteemoja, sävelmiä ja laulamisen tyylipiirteitä. Aineiston luonteesta johtuen jää usein avoimeksi, minkälaista liikettä tiettyyn tanssisävelmään tyypillisesti mahtoi liittyä tai miten runot, sävelmät ja liikkeet lomittuivat toisiinsa konkreettisissa tanssitilanteissa. Keskeistä kaikessa liikkeessä kuvataan olleen nopeuden: se oli yhteydessä niin liikkeiden laatuun, käytettyihin runoihin ja sävelmiin kuin laulamisen kantamiin tunnesävyihin. Niinpä sekä paikoillaan että hitaasti liikkuen laulamista kuvattiin samoilla termeillä, kun taas nopealle liikkeelle oli omansa.

Pitkällä äänellä eli vienoo voitiin laulaa sekä paikoillaan seisten tai istuen että hitaasti kulkien läpi kylän tai piirissä peräkkäin, vaikka sävelmä- ja runoaineistossa kulkemiseen, tanssiin ja paikoillaan laulamiseen liittyy osittain myös erityyppisiä runoja ja sävelmiä. Nopeasti eli tihtii laulamisesta ja hitaasta pitkästä äänestä tallennetut suhteellisen harvat muistiinpanot eivät riitä kovin pitkälle meneviin päätelmiin, ja suuresta osasta sävelmiä emme tiedä, minkälaisin tai kuinka erilaisin tavoin niitä saatettiin käyttää. Karkeimmillaan laulamisen tavoista ja tyyleistä voi silti piirtää seuraavankaltaisen kuvion:

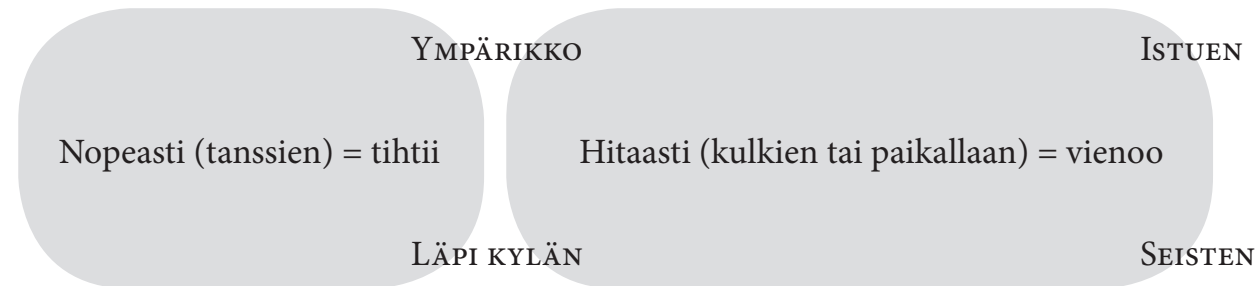

Eri tavoin läpi kylän mentäessä ja ympärikossa voitiin laulaa ja liikkua joko nopeasti (tihtii) tai hitaasti (vienoo). Paikoillaan ollessa eli istuen tai seisten laulettiin yleensä hitaasti (vienoo). Hitaasti kulkeminen ja paikallaan olo olivat molemmat hitaan laulun esitysareenoja, ja tulivat kutsutuksi samalla nimityksellä. Läpi kylän kulkemisesta erottuu kaksi pääkategoriaa. Joko kuljeskeltiin ja käveltiin kylällä vapaamuotoisemmin aikaa viettäen, tanssien ja laulaen (guljanje), tai kuljettiin sere- 
moniallisemmin läpi kylän erilaisissa muodostelmissa, joko ketjussa tai paririvissä, nopeasti tanssien tai hitaasti kulkien. Läpi kylän laulaen menemiset liittyivät, kuten tanssikin, ennen kaikkea juhlapyhiin ja häihin.

Viron veräjiin ja kluutšaan liittyvissä kuvauksissa on mielenkiintoisia ja monisyisiä lomittumiskohtia, vaikka ne kulkemisen tapoina muodostavat selkeästi toisistaan eroavat ryhmät. Kummassakin ryhmässä liikekuvaukset vaihtelevat ja ovat paikoin tulkinnanvaraisia, mutta tyypillinen liikkumismuodostelma ja ryhmien pääpiirteet hahmottuvat selvinä:

\begin{tabular}{|c|c|c|}
\hline & & \\
\hline & $\begin{array}{c}\text { VIRON VERÄJäT } \\
\text { (VÄ̈̈RÄ PIIRI, PITKÄ RINKI) }\end{array}$ & KLUUTŠA \\
\hline LIIKE & kiemurtavassa ketjussa & parijonossa \\
\hline Aloitusruno & Avatkaa Viron veräjät & La lähen läpi kyläsen tms. \\
\hline KonteKsti & $\begin{array}{l}\text { praasnikat ja pyhät, kokolle } \\
\text { kulku, runoteema eri muodossa } \\
\text { myös häärunoissa }\end{array}$ & $\begin{array}{l}\text { praasnikat, kokolle palaaminen, } \\
\text { häätaloon kulku }\end{array}$ \\
\hline S̈̈VELMÄ & $\begin{array}{c}\text { joukko erilaisia yksinkertaisia } \\
\text { tanssisävemiä }\end{array}$ & $\begin{array}{l}\text { yksisäkeinen, kuusi-iskuinen } \\
\text { saadulmoi-sävelmä }\end{array}$ \\
\hline REFRENKI & $\begin{array}{l}\text { erilaisia lole- ja luuli-tavuja } \\
\text { käyttäviä refrenkejä tai refrengit- } \\
\text { tömiä tanssisävelmiä }\end{array}$ & $\begin{array}{c}\text { saadulmoi-typpinen refrenki, } \\
\text { ehkä muitakin? }\end{array}$ \\
\hline
\end{tabular}

Varsinaiset tanssimaininnat painottuvat kalevalamittaisten runojen kohdalla piirimuotoisiin ympärikko-kuvauksiin. Kuten seuraavissa luvuissa käy ilmi, ympärikko on myös ainoa tanssimuodostelma, joka mainitaan monien rituaalisten ja kontekstisidonnaisten praasnikka- ja häärunojen yhteydessä (Pedron ja Iilian sekä Martin virret, kiletoivirret, rituaalisesti keskeiset häävirret, kokin kiitosvirsi). Tanssi saattoi ottaa monia muotoja ja sen tahti vaihdella. Saatettiin kulkea hitaasti piirissä peräkkäin tai tanssia nopeasti pareittain tai kädet käsissä, lisätä erilaisia vauhdikkaita ja rytmikkäitä liike-elementtejä. Oma lukunsa ovat leikkeihin liittyvät tanssilliset elementit, joista ei aineistossa kuitenkaan ole kovin paljoa mainintoja. Soitinsävelmiin taas liittyy ympärikkojen ohella erilaisia pari- ja rivitanssin kuvauksia, joiden säestyksenä saatettiin myös laulaa. Paikoillaan laulaminen puolestaan liittyi niin arkeen kuin juhlaankin, työlauluista rituaalisiin häälauluihin ja juhlissa pöydän ääressä istuttaessa laulettuihin lauluihin.

Praasnikkojen ja häiden kiteytyneisiin laulutilanteisiin liittyi kiinteästi erilaisia tanssimisen, kulkemisen, ajamisen, keinumisen sekä paikoillaan laulamisen käytäntöjä, mutta ei suinkaan koko aineiston kuvaamaa liikkeen kirjoa. Vapaamuotoisemman, ei niin vakiintuneen kylällä kuljeskelun ja tanssin yhteyteen liittyy moninaisia sellaisiakin liikkumisen ja esittämisen tapoja, runoja ja sävelmiä, joita ei seuraavien lukujen kuvaamissa rituaalisissa tilanteissa mainita käytetyn. Vaikka 
näidenkin keskeinen käyttöyhteys oli praasnikoiden ja häiden aika, sijoittuivat ne vähemmän latautuneisiin, moninaisempiin tilanteisiin.

Tanssin ja kulkemisen tapojen tarkastelu luo taustan sille, kuinka laajasti lakonisia kontekstimainintoja, kuten "mäntii ympärikkoo" tai vain "läpi kylän" on mahdollista tulkita: kumpikin viittaa juhlaan, mutta kattaa omanlaisensa kirjon sävyltään, nopeuksiltaan ja sävelmiltään varioivia laulamisen tapoja. Tarkka kohdentaminen tietyntyyppiseen liikkeeseen, nopeuteen saati sitten sävelmään on pelkän tämänkaltaisen maininnan pohjalta usein mahdotonta. Silti kaiken variaationkin keskellä löytyy selkeitä säännönmukaisuuksia: esimerkiksi läpi kylän tanssittavaan kluutšaan liitetään aineistossa ainoastaan tiettyä sävelmätyyppiä siihen liittyvine saadulmoi-refrenkeineen ja tanssiin liitetyissä sävelmissä on yllättävän laajoja samaa muotorakennetta tai sävelmätyyppiäkin edustavia sävelmäryhmiä. Tietynlaiset runot ja sävelmien piirteet ovat tyypillisiä tietynlaisille tekemisen tavoille, mutta erilaisten piirteiden käyttökenttien laajuudet vaihtelevat. Esimerkiksi saadulmoi-refrenkiä ja sävelmää ei aineistossa liitetä mihinkään muuhun kontekstiin kuin kylän läpi kulkemiseen ja säkeen lopun osakertausta ei mihinkään muuhun kuin hitaaseen tai nopeaan ympärikkoon. 


\section{PraASNIKAT}




\section{PRAASNIKAT}

Vihtori Alava (esim. Forsberg 1893, 53) nosti esiin häiden ja praasnikka-juhlien keskeisen merkityksen runojen laulamis-, oppimis- ja keksimistilanteina Inkerissä. Juhlien kuluessa laulettiin paljon, kaikenlaisia lauluja. Tiettyihin juhliin liittyi myös tiettyjä tilannesidonnaisia runoja, jotka tässä luvussa toimivat analyysin pohjana. Myös Armas Launis (1910c, 223) mainitsee keskeisimpänä kalevalamittaisten runojen laulutilanteena hääjuhlan, ja tiivistää sitten muista Viron, Inkerin ja Karjalan kannaksen laulutilanteista:

Niinikään kuuluu vuoden huomatuimmille juhla-ajoille omat laulunsa, jotka kukin esitetään tilaisuuden mukaan eri tavalla. Pääsiäisenä lauletaan kiikussa keinuen, laskiaisena reellä ajaessa tai mäkeä laskiessa, helluntaina ja juhannuksena iltatulilla, praasnikkaja muina juhla-aikoina kylän tanhuvilla piirissä pyörien. [...] Pyhän Martiinuksen ja Katariinan päivinä kulkevat nuoret pojat ja tytöt keskiajan teinien tapaan talosta taloon laulaen Mardi- ja Kadri-lauluja isäntäväelle keskityksen ja lahjain toivossa. Pyhän Petron, Iilian ja Jyrkin päivinä lauletaan niinikään puolipakanallisten juhlamenojen yhteydessä runoja.

Juuri juhlapyhiin liittyvät myös Launiksen mainitsemat laskiaisen rekiajelut, pääsiäisen keinumiset, juhannuksen kokon polttamiset ja talvenpyhien talosta taloon kiertämiset. ${ }^{464}$

Ortodoksikylillä oli Inkerissä yleensä oma nimikkopyhimyksensä, jonka juhlapäivänä käytiin kirkossa ja kokoonnuttiin sitten juhlimaan useaksi päiväksi. Praasnikka saattoi olla myös muu keskeinen pyhäpäivä. Praasnikat keräsivät etenkin inkeroisia ja vatjalaisia, mutta ilmeisesti myös inkerinsuomalaisia laajoiltakin alueilta. Ainakin Narvusin alueella myös luterilaiset kutsuivat tiettyjä pyhiään praasnikoiksi. Juhlat pitivät yllä kylien välisiä sukulaisuus- ja muita suhteita: majoittautuminen ja kestitys olivat usein vastavuoroisia. Monilla tavoilla oli kiinteät yhteydet vatjalaisiin, slaavilaisiin, virolaisiin ja suomalaisiin tai laajemminkin yleiseurooppalaisiin perinteisiin. (Ks. esim. Enäjärvi-Haavio 1949, 154-156; Lukkarinen 1911.) ${ }^{465}$ Praasnikat olivat edellisessä luvussa kuvatun laulun, tanssin ja kuljeskelun aikaa. Niiden aikana "laulettiin joukolla, kuten sanottiin 'vaik millsii virsii,"' (Salminen 1931a, 531).

Lähden liikkeelle etenkin Armas Launiksen (1904, 1907, 1910c) kuvausten pohjalta muodostetusta hypoteesista: moniin juhliin tai juhlapyhiin liittyi yleisen laulupaljouden ohella myös tiettyjä runoteemoja, joita laulettiin tietyissä tilanteissa

${ }^{464}$ Launiksen kuvaus näyttää Kadrilauluja lukuun ottamatta nojaavan pitkälti hänen omiin Inkerin kenttätöihinsä.

${ }^{465}$ Yhteyksistä lähialueisiin ja näiden vastaavista pyhistä ja tavoista ks. myös Ariste 1966; 1969; Čistov 1976b; Hiiemäe 1998; Sarmela 1969. Laskiaisesta lähialueilla ks. Enäjärvi-Haavio 1954; kokon poltosta Sarmela 1969, 130-132; talvisista kiertueista ja naamioituna kulkemisesta Pohjois-Euroopassa ks. Gunnell 2007. 
tietyin, joskin kenties paikallisesti vaihtelevin tavoin. Käyn läpi laulamisen tilanteita niihin liittyneiden runojen, sävelmien ja laulamisen tapojen kannalta. Nostan esiin aineistoja ja aiemman tutkimuksen tuloksia Keski-Inkeristä, vatjalaisilta tai Pohjois-Inkeristä silloin, kun ne rinnastuvat länsi-inkeriläisiin aiheisiin tai aineiston niukkuus edellyttää laajempaa tarkastelua. Toisaalta aineiston epätasaisuudesta, toisaalta juhlien ja laulujen erilaisuudesta johtuen alaluvut rakentuvat eri tavoin. Laskiais-, liekku-, ja kokkolaulujen kohdalla lähden liikkeelle Senni Timosen (2004, 84-157) teksti- ja kontekstianalyysien pohjalta vieden niitä paikallisemmiksi ja enemmän sävelmiin pureutuen. Runojen alkusäkeet ja -teemat ovat tässä luvussa olennaisia, koska ne ovat ainoa avain moniin yhdestä neljään runosäettä sisältäviin melodiamuistiinpanoihin. Liitteeseen 5 olen luetteloinut eri tilanteisiin ja runoihin liittyvän keskeisen sävelmäaineiston. ${ }^{466}$

Praasnikka-sana on laina venäjän juhlaa ja rituaalista aikaa merkitsevästä sanasta; Länsi-Inkerissä käytettiin lähinnä muotoa praasnikka, Karjalassa praasniekka. Kaikkia juhlia ei aineistossa kutsuta praasnikoiksi, vaan toisiin viitataan ainoastaan juhlina, pyhinä tai pyhäpäivien nimillä. Tämän työn kannalta kiinnostavia ovat lähinnä ne juhlapyhät, joista on riittävästi kuvauksia ja joihin liittyy tilannesidonnaisia runoja: laskiainen, pääsiäinen, Troitsa eli helluntai, Jaani eli juhannus, Pedron (Pietari, 12.7.) ja Iilian (Elias, 2.8.) päivät, Martinpäivä (11.11.) sekä Miikkulanpäivän (Nikolaus, 6.12.) ja loppiaisen (6.1.) välinen aika. Kerääjät näyttävät välillä käsitelleen ortodoksien Miikkulanpäivää (6.12.) ja luterilaisten Mikkelinpäivää (29.9.) samana pyhänä, mikä aiheuttaa paikoin tulkintavaikeuksia. Venäjällä oli vuoteen 1918 asti käytössä juliaaninen kalenteri, jota maan ortodoksinen kirkko noudattaa yhä (Oja 2010, 38-48), joten pyhät sijoittuivat 1800-luvun Venäjällä kaksitoista, 1900-luvulla kolmetoista päivää Suomen suuriruhtinaskunnassa voimassa ollutta käytäntöä myöhemmäksi.

Eri kylissä vietettiin eri praasnikkoja, joten ihmisten kokemukset juhlista ovat vaihdelleet sen mukaan, mistä kylästä he olivat kotoisin ja missä heillä oli sukulaisia. Toisten kylien praasnikoita mentiin viettämään niihin kyliin, joihin oli sosiaalisia siteitä: näistä sukulaisuussiteet näyttävät olleen merkittävimpiä. Tietoja praasnikoista on melko epätasaisesti, monista kylistä ei ollenkaan. Voi olla, että näissä kylissä on vietetty joitain vähemmän keskeisiä pyhiä, tai sitten keskeisimmät tietyn praasnikan viettämiskylät vain korostuvat arkistoaineistossa. Liitteenä 3 olevasta taulukosta näkyy praasnikkojen jaottuminen etnisen ryhmän tai oikeammin sanottuna uskontokunnan mukaan. Ortodoksisten inkeroiskylien, vatjalaiskylien ja inkeroisia runsaasti sisältävien sekakylien keskeisimmät praasnikat olivat Iilia,

\footnotetext{
${ }^{466}$ Luvussa mainittua enemmän etenkin liekku-, Pedronpäivä- ja kiletoi-aiheisia runoja löytyy SKVR-
} teemahakemiston sekä KRA:n julkaisemattomien runojen teemakortiston kautta. 
Pedro, Troitsa ja Miikkula, ja lisäksi mainitaan muutaman kerran Subotta. ${ }^{467}$ Soikkolan inkerinsuomalaiskylistä ei varmoja tietoja praasnikoista juuri ole, muutamasta inkerois-virolaiskylästä ei ollenkaan. Narvusin inkerinsuomalaiskylien yhteydessä sekä niissä sekakylissä, joissa selkeä enemmistö oli inkerinsuomalaisia mainitaan usein Mikkelinpäivä sekä kerran pyhäinmiestenpäivä. ${ }^{468}$ Joulu on usein satunnaisesti mainittu praasnikaksi niissä kylissä, joista ei muita tietoja ole. Taulukosta on jätetty pois ne praasnikat, joita näytetään vietetyn tavalla tai toisella lähes joka kylässä ja joihin ei näytä liittyneen suurimittaisia naapurikylissä vierailuita.

Sekakylissä myös vähemmistönä ollut ryhmä saattoi viettää kylän praasnikkaa. ${ }^{469}$ Esimerkiksi Sutelan viisi luterilaisperhettä viettivät Troitsaa, mutta toisin kuin inkeroisilla, heillä ei vielä ensimmäisenä praasnikkapäivänä käynyt vieraita. ${ }^{470}$ Toinen ryhmä saattoi myös osallistua toisten praasnikkaan, vaikka se ei heille olisi varsinainen praasnikka ollutkaan. Matroona Bässinan mukaan Väikylässä luterilaiset eivät "pitäneet praasnikkaa," mutta "rupesivat nekin tuomaan yhteiseen olueen maltaita." ${ }^{\text {"71 }}$ Yhteisten pyhien kohdalla saattoi riippua osin ortodoksien ja luterilaisten kirkonmenojen aikataulueroistakin, milloin juhlittiin yhdessä ja milloin erikseen. ${ }^{472}$ Yhdessä kylässä mainitaan useimmiten vietetyn yhtä tai kahta praasnikaksi nimettyä juhlaa. Inkeroisten ja inkerinsuomalaisten kylien praasnikkapäivät eroavat selkeästi toisistaan. Inkerinsuomalaiskylien praasnikkoihin (jouluun, Mikkelinpäivään ja pyhäinmiestenpäivään) ei liittynyt sellaisia runoja ja laulamisen tapoja, jotka olisivat tämän tutkimuksen keskiössä, vaikka kuvauksia inkeroiskylien keskeisistä praanikoista on jonkin verran tallennettu myös inkerinsuomalaisilta. Tässä luvussa siis painottuvat inkeroisten juhlat, vaikka välillä näitä kuvaavat myös inkerinsuomalaiset.

Etenkin inkeroisten praasnikkakuvauksissa toistuvat oluenkeiton, vieraiden ja ylenpalttisen ruokatarjoilun keskeisyys. Praasnikaksi kutsuttiin etenkin sellaisia pyhiä, jolloin kylässä keitettiin olutta ja sinne kerääntyi runsaasti vieraita. Pelkkä viinan juonti ja vieraiden kestitys eivät kuitenkaan aina olleet riittäviä tekijöitä juhlan kutsumiseksi praasnikaksi. ${ }^{473}$ Praasnikaksi määrittyy inkeroisilla etenkin sellainen pyhä, jolloin kylän olut keitettiin yhteisesti. ${ }^{474}$ Tosin silloinkin kun keitettiin kylän yhteisolut, keitettiin samalla olutta myös taloissa yksityisesti, joten lyhyitä mainintoja oluenkeitosta on paikoin vaikea tulkita. ${ }^{475}$ Varsinaisista kyläpraasni-

\footnotetext{
${ }^{467}$ Subotta eli subotan suovatta tai pominaine suovatta, vainajien muistamislauantai (Lukkarinen 1911, 63).

${ }^{468}$ Ropsussa ja Vyötermaalla joulu mainitaan vain inkeroisten praasnikkana (SKS KRA Enäjärvi-Haavio $799,802-806)$.

${ }^{469}$ Ks. myös Novozhilov 1999, 127.

${ }^{470}$ SKS KRA Enäjärvi-Haavio 771; ks. myös Haavio 2748 Narvusin kohdalta.

${ }^{471}$ SKS KRA Haavio 2766.

${ }^{472}$ SKS KRA Enäjärvi-Haavio 802-806; ks. myös 807-815.

${ }^{473}$ Esim. KK Coll. 123.22 Launis 1903, 28-33; SKS KRA Alava VII u B II, 39/56-41/58; SKS KRA Enäjärvi-Haavio 730-732, 785, 790; Haavio 2762; Laiho A. 2436; Laiho L. 6000, 6001; ks. myös Sääski $5333,5336$.

${ }^{474}$ Vrt. kuit. SKS KRA Haavio 2792.

${ }^{475}$ Esim. SKS KRA Haavio 2771.
} 
koista yhteisoluen kuvaukset painottuvat Pedron ja Iilian päiviin - Miikkulan ja Troitsan kuvauksissa mainitaan välillä joka talon keittäneen oman oluensa. ${ }^{476}$

Katri Vohdan mukaan joulu oli Sutelassa ainoastaan inkeroisten praasnikka, sillä luterilaiset eivät keittäneet olutta eikä heillä käynyt vieraita. Luterilaiset kyllä kävivät toisena joulupäivänä kirkon jälkeen rannan puoleisissa luterilaiskylissä ja kolmantena ja neljäntenä joulupäivänä oman kylän inkeroisten luona viettämässä praasnikkaa. Vohta selitti praasnikan käsitettä kerääjälle: "Rantakunnassa siis pidettiin joulua praasnikkana, vaikka he olivatkin luterinuskoisia. Ei siitä silti käytetty nimitystä praasnikka. Kun oli viinaa ja olutta, niin tiesi, että oli praasnikka. Kun niitä ei ollut, oli tavallinen pyhä." ${ }^{377}$ Praasnikka-termi oli Vohdan mukaan ensisijaisesti inkeroisten, mutta sillä oli mahdollista kuvata myös luterilaisten sellaisia juhlia, jotka täyttivät praasnikan kriteerit. Kylien nimikkojuhlat nimetään yleensä praasnikoiksi ja pelkkä pyhä-termi viittaa yleensä näitä pienempiin pyhiin. Praasnikat voidaan myös jättää nimeämättä praasnikoiksi ja vain todeta että "piettii neljä päivää Pedroo" tai "Troitsaa piettii." ${ }^{378}$

Keskeisistä kirkkopyhistä etenkin pääsiäinen, mutta myös helluntai, joulu ja juhannus olivat muutamien laulajien mukaan suuria, kalliita tai vakasia pyhiä, eivät varsinaisia praasnikkoja saati tavallisia pyhiä. ${ }^{479}$ Joskus niistä kuitenkin puhutaan myös praasnikoina. ${ }^{480}$ Toisin kuin muut praasnikat, ne eivät olleet kylän tai kirkon nimikkopyhimyksen päiviä tai jostain syystä "luvattuja"481 pyhiä, vaan "yli maailman pyhät." ${ }^{82}$ Kalliin pyhän erotti praasnikasta se, että "käytii kallihin pyhän aina kirkossa, ei muualla” eli ensimmäisenä pyhäpäivänä käytiin ainoastaan kirkossa ja vieraisille mentiin tai vieraita otettiin vastaan vasta seuraavana päivänä. ${ }^{483}$ Esimerkiksi joulua kerrotaankin vietetyn joka kylässä. ${ }^{484}$ Pauliina Reposen mukaan ensimmäisenä pyhäpäivänä "ei saanut kukkaa mennä kyllää, ei naapuriinkaan."485 Anna Kivisoo mainitsee myös, että vakasena pyhänä, Troitsana, ei olutta keitetty vaikka viinaa olikin ja juhlaa vietettiin neljä päivää. ${ }^{486}$ Tämänkaltaiset nimitykset ja

\footnotetext{
${ }^{476}$ Esim. SKS KRA Haavio 2801; Laiho L. 5228, 5989. Jos kylässä oli kaksi vuotuista praasnikkaa, saattoi olla, että yhteisolutta ei toisena keitetty. Darja Koivusen mukaan Kotkossa joulu oli kylän toinen (siis ilmeisesti Iiliaa vähäisempi) praasnikka ja silloin ei yhteistä olutta keitetty, vaikka vieraita olikin paljon. (SKS KRA Haavio 2789; ks. myös Haavio 2791 Pärspäästä.) Toisaalta oli myös mahdollista viettää juhlaa ja keittää yhteinen olut, vaikka tästä juhlasta nimenomaan sanottaisiin, että se ei ollut praasnikka (SKS KRA Haavio 2781; ks. myös Haavio 2795).

${ }^{477}$ SKS KRA Enäjärvi-Haavio 802-806; ks. myös 807-815.

478 SKS KRA Laiho L. 5247; Laiho A. 2600.

${ }^{479}$ SKS KRA Enäjärvi-Haavio 811-815; Laiho A. 2589; Laiho L. 6001; Mannonen 5730, 11147, 11163; Haavio 2671; ks. kuit. Laiho A. 2592.

${ }^{480}$ Esim. Launis 1904, 50; 1907, 104; SKS KRA Laiho 2592.

${ }^{481}$ Praasnikoita oli luvattu viettää esimerkiksi eläinten sairastumisen tai hukkumistapausten takia (Laiho A. 3296, Laiho L. 4749, 5996).

${ }^{482}$ SKS KRA Laiho 2589.

${ }^{483}$ SKS KRA Enäjärvi-Haavio 811-815

${ }^{484}$ IMS: joulu.

${ }^{485}$ SKS KRA Mannonen 11147. Luterilaiset eivät tosin noudattaneet tapaa ja pahoittivat usein hänen isoäitinsä mielen.

${ }^{486}$ SKS KRA Laiho L. 6001; vrt. kuit. Enäjärvi-Haavio 770: olutta ja viinaa, vieraita. Yhdenkin laulajan kuvaus samasta pyhästä on joskus ristiriitainen: toisaalla Kivisoo (Haavio 2748) kertoo, että Troitsana ei Ropsussa käynyt vieraita.
} 
maininnat ovat Valpuri Vohtaa lukuun ottamatta inkeroisilta tallennettuja. Samaa sanastoa käyttäen pääsiäistä edeltävää ortodoksien pitkää paastoa saatettiin kutsua suureksi paastoksi, se oli "kallis aika." ${ }^{487}$ Jaottelu vastaa ortodoksisen kirkon omaa luokittelua.

Käytännössä juhlapyhän vietto riippui siitä, oliko se oman kylän nimikkopraasnikka, mentiinkö sitä viettämään jonnekin muualle vai vietettiinkö praasnikkaa samanaikaisesti kaikissa kylissä. Oman kylän praasnikkaa juhlittiin kolme tai neljä päivää, mutta muissa kylissä saatettiin samaa pyhää pitää vain yksi tai kaksi päivää. ${ }^{488}$ Kun useat lähikylät pitivät samaa praasnikkaa, saatettiin sitä pitää vuoropäivin, niin että isäntäväki ja vieraat vaelsivat kylästä toiseen (Lukkarinen 1911, 46). ${ }^{489}$ Joka kylässä vietettäviä juhlia nimetään harvemmin praasnikoiksi, yleensä muistiinpanoissa puhutaan vain niiden viettämisestä, juhlista tai pyhistä. ${ }^{490}$ Yleensä se, että juhlapäivää ei mainittu praasnikaksi, ei tarkoittanutkaan sitä, etteikö sitä olisi voitu silti kylässä viettää. Esimerkiksi laskiaista, juhannusta, Nastasjan päivää ja Martin päivää ei kylien varsinaisina praasnikkapäivinä mainita, vaikka juhlakuvauksia on tallennettu runsaasti. Niitä vietettiin varsinaisia kyläkohtaisia praasnikkoja yleisemmin ja laajemmin, ilmeisesti lähinnä omissa kylissä, eikä niihin siten liittynyt samanlaista suurimittaista vieraiden kestitystä kuin suurimpiin praasnikkoihin. Näistä juhlista on kyläkohtaisia praasnikoita tasaisemmin kuvauksia myös inkerinsuomalaisilta. Kylien praasnikat listaavasta taulukosta puuttuu kokonaan myös Jyrin päivän "naisten praasnikka." Sitä eivät kerääjät tai kertojat nimenneet luetteloihin kylien praasnikoista, vaikka siitä puhuttiin pyhän ohella nimenomaan praasnikkana. ${ }^{491}$ Tämä saattaa johtua juhlan kyläkohtaisesta ja sukupuolisidonnaisesta luonteesta: Jyrki oli naisten praasnikka, jota vietettiin jokaisessa kylässä. Vaikka yhteinen olut usein keitettiinkin, ei juhlaan kuulunut vieraiden kestitystä paimenta lukuun ottamatta. Koko kylä ei osallistunut juhlaan samalla tavoin kuin muissa juhlissa. ${ }^{492}$

Juhlien viettotavat varioivat kylittäin. Vaikka yleensä esimerkiksi Jyrin päivän juhlien kuvaukset kertovat omassa kylässä juhlimisesta ja Matrona Leppik nimenomaan vahvisti, että Kurkolan kylässä "ei vieraaseen kylään menty", kävivät Vanhakylässä naiset Asjatiija Leppikin mukaan yhdessä "toises kyläs" juhlimassa. ${ }^{493}$ Vaikka yleensä kerrotaan kylän naisten keittäneen yhteisen juhlaoluen, juotiin Kurkolan juhlissa Matrona Lepikin mukaan ainoastaan viinaa, ei olutta. ${ }^{494}$ Välil-

\footnotetext{
${ }^{487}$ SKS KRA Laiho L. 5143, 6136; Koilo 319.

${ }^{488}$ SKS KRA Laiho L. 5987; Sääski 5336.

${ }^{489}$ Lukkarinen $(1911,47)$ kertoo, että Soikkolassa Iilian päivänä vieraita ei kestitty kuin kaksi ensimmäistä päivää, ja loppupäivät juhlittiin oman kylän väen kesken - tavan sanottiin kuitenkin olevan nuori.

${ }^{490}$ Ks. kuit. SKS KRA Mannonen 9843.

${ }^{491}$ Esim. SKS KRA Haavio 2695, 2698, 2704; Laiho A. 2585; Mannonen 11120.

${ }^{492}$ Sama pätee Darja Lehden kuvaamaan Rukeen Maareen kylvöjuhlaan, joka oli ainakin Joenperällä "miehie praasnikka" yhteisoluineen mutta ilmeisesti ilman vieraita (SKS KRA Laiho L. 5163).

${ }^{493}$ SKS KRA Haavio 2696; 2692.

${ }^{494}$ SKS KRA Haavio 2696; yhteisen oluen keitosta esim. Haavio 2695, 2697, 2704, 2698; Laiho A. 2585.
} 
lä kerrotaan miestenkin jossain vaiheessa liittyneen naisten joukkoon, ${ }^{495}$ toisaalla mainitaan, että "miehet eivät tohtineet tulla naisten hulkkaa [joukkoon]" tai miehet vain "toruivat, ajoivat jäles, tahtoivat piestä." ${ }^{996}$ Muutama laulaja nimesi myös jonkun muun ajankohdan tai praasnikan naisten juhlaksi. ${ }^{497}$

Praasnikan kriteerit, määreet ja nimitykset siis vaihtelevat. Etenkin inkeroisilla olennaista oli oluen ja vieraiden yhdistelmä. Praasnikka määrittyi kollektiivisuuden ja vieraanvaraisuuden kautta juhlaksi, jossa kestittiin oluella runsasta vierasjoukkoa. Luterilaisilla termin käyttö vaihteli enemmän, ja toisaalta ortodoksitkin saattoivat joskus käyttää termiä muiden pyhien kuvaamiseen, puhtaasti juhlasanan vastineena. Kokemusten voi olettaa vaihdelleen sen mukaan, mistä kylästä kertoja oli syntyisin, missä kylässä asunut ja missä kylissä hänellä oli sukulaisia. Toisten kylien praasnikkoihin liittyviä lauluja ei esimerkiksi välttämättä muistettu yhtä hyvin kuin oman kylän. ${ }^{498}$

\footnotetext{
${ }^{495}$ SKS KRA Haavio 2697; Laiho L. 5165; ks. myös Haavio 2696.

${ }^{496}$ SKS KRA Laiho L. 5229; ks. myös Haavio 2698

${ }^{497}$ SKS KRA Mannonen 5517; Laiho A. 2576.

${ }^{498}$ Esim. SKS KRA Mannonen 5446.
} 


\section{LASKIAINEN, LIUKUVIRSI}

Laskiainen oli Inkerin ortodokseilla paaston aloittamisen juhla. Ennen seitsemän viikon pituisen pääsiäispaaston alkamista syötiin hyvin ja pyydettiin kaikilta anteeksi pahoja tekoja. Paaston aikana ei tanssittu eikä leikitty, "ei kukkaa tiukus käynny" eikä mäkeäkään saanut laskea. ${ }^{499}$ Laskiaispyhä oli inkeroisille liukupäiv, luterilaisille laskiainen. ${ }^{500}$ Muistiinpanojen tulkintaa hankaloittaa paikoitellen sanan "liukua" kaksoismerkitys: se viittaa sekä kylistä toiseen reellä kulkemiseen että mäen laskemiseen.

Darja Lehden mukaan Joenperällä laulettiin jo viikkoa ennen laskiaista joka ilta sillalla kaikenlaisia lauluja. Laskiaispyhänä käytiin siten lounaan jälkeen "pojat i tytöt hevosenkaa liukumas" eli rekiajelulla kahteen tai kolmeen lähikylään, ja reessä oli kelloja kuin häissä ikään. Kun tultiin pois, mentiin tiettyyn taloon tanssimaan. ${ }^{501}$ Reessä laulettiin. Nuoriso saattoi kiertää useitakin tuttuja kyliä ja poiketa monessa talossa tanssimassa, usein käytiin vuosittain samoissa kylissä. ${ }^{502}$ Reellä ajamassa saattoi olla myös vanhempia ihmisiä, ja vastanaineet pariskunnat kävivät vaimon vanhempien luona kyläilemässä. ${ }^{503}$ Lapset, narvusilaisten tietojen mukaan paikoin myös nuoret tai vaimot, laskivat mäkeä ja paikoin rakennettiin napakelkka. ${ }^{504}$ Muutaman tiedonannon mukaan ajaminen sijoittui laskiaissunnuntaihin tai se aloitettiin jo laskiaislauantaina, mutta mäkeä laskettiin vasta laskiaistiistaina. ${ }^{505}$ Laskiaisesta alkoi seitsemän viikon paasto, jonka aikana ei tanssittu eikä laskettu mäkeä. ${ }^{506}$ "Ne oltii lauluviikot, siis mentii suuree pyhhää", totesi Asastiija Leppik. ${ }^{507}$ Suurena pyhänä eli pääsiäisenä loppui pitkä hiljaisuus ja alkoi kesän kestänyt laulaminen ulkosalla.

\footnotetext{
${ }^{499}$ SKS KRA Laiho A. 2343, 2591, 2604; Laiho L. 4891 sekä Enäjärvi-Haavio 734.

${ }^{500}$ Tosin luterilainen Maria Otsa puhuu tästä poiketen liukupäivästä ja inkeroisiin kuuluva Aleksandra Yrjönen laskiaisesta (SKS KRA Enäjärvi-Haavio 734; Laiho L. 4925; Sääski 5008).

${ }^{501}$ SKS KRA Laiho A. 2604, ks. myös Haavio 2673; Narvusin inkeroisilta esim. Haavio 2671.

${ }^{502}$ SKS KRA Haavio 2669; Laiho A. 2343; Laiho L. 5249. Laulamisesta esim. SKVR III 4632.

${ }^{503}$ Enäjärvi-Haavio 599; Haavio 2665; Laiho A. 2591; vastanaineista ks. Enäjärvi-Haavio 734; Haavio 2669; Laiho L. 6136.

${ }^{504}$ SKS KRA Enäjärvi-Haavio 599, 734; Haavio 2669-2673; Laiho A. 2343, 2573, 2604.

${ }^{505}$ SKS KRA Enäjärvi-Haavio 734; Haavio 2670.

${ }^{506}$ SKS KRA Enäjärvi-Haavio 835; Haavio 2671; Koilo 319; Laiho A. 2591, 2604; Laiho L. 4891, 6136.

${ }^{507}$ SKS KRA Haavio 2671.
} 


\section{HeVAAN LIUKUSÄVEN}

Armas Launis $(1907,107)$ kertoo saaneensa tietoja laskiaisen liukusävelistä vasta ja ainoastaan Hevaalta:

Liukusäveltä lauletaan laskiaisena, jolloin kyläläiset lähtevät ajelemaan pitkin omaa ja naapurikyliä. [...] Liikkeelle lähtiessä alotetaan virrellä: Lähe Jumala aviksi, senjälkeen voi tulla kysymykseen mikä virsi tahansa. Samaten kuin läpi kylien kulkiessa häiden yhteydessä, ei liukuessakaan katsota tarpeelliseksi laulaa muulloin kuin kyläkohdissa.

Soikkolassa ollessani en kuullut mitään mainittavan tämäntapaisesta laskiaisen vietosta, vasta Hevaalla tiesivät kertoa sen, mitä yllä on esitetty. Liukunuottina sanottiin käytettävän tuota Hevaan tavallisinta runosävelmämuotoa, jonka parhaiten tuntee siitä, että sen kööri päättyy kahteen yhtä pitkään - mutta ei aina samaan - säveleeseen sanoilla "joo-noi".

Launiksen (1906) ja Levónin (1903) sävelmäkokoelmissa ei kuitenkaan ole yhtään Lähe Jumala aviksi -säkeellä alkavaa, Hevaalla tai hevaalaisilta tallennettua runoa. Sävelmää, muotorakenteeltaan helposti tunnistettavaa ja sävelkuluiltaan vaihtelevaa niin kutsuttua "Hevaan nuottia", on sitä vastoin tallennettu runsaasti. Ilmeisesti sitä oli Launiksen matkan loppuvaiheessa jo kyllin äänitetty, joten liukunuotti jäi ainoastaan maininnaksi. Kaikkiin Launiksen välittämiin tietoihin ei siten suoraan liity sävelmäaineistoa. Launiksen mainitsemilla alkusäkeillä alkavan runon lauloi kuitenkin Taroi Päntyn tytär vuonna 1891 Hevaan Lenttisissä Vihtori Alavalle. Hän kertoi: "Laskiaisena kun liuvutaan, lauletaan (enstään kujasta lähetään, saotaan):

Lähe Jumala aviks',

Lähe Luojoi liikkehelle,

Jumala rekoisehennek!

Katsoin tätä oroojain’

Katsoin kimo kankarojain

Onka söötelty oroin, $(\ldots)^{508}$

Laulun loppuosassa kuvataan hevosta (oro, kankaro) ja pyydetään sitä vetämään rauhallisesti, että tytöt eivät tippuisi maahan. Lopuksi todetaan: "Ken ei laula laskiaisen', reki heetöin ei helise, se ei laula sinä kesäänkää." Laulun jälkeen Taroi jatkoi kuvaustaan proosalla: "Heppoisell' ajetaan; tytöt on reessä, Mies-elokas ajaa hevosta. Sitä tytöt kiittelööt, ja hevost' kiittäät, siin’ reessä laulaat." Launis sanoo alkuvirren jälkeen lauletun mitä virsiä tahansa, mutta Senni Timosen $(2004,151)$ mukaan Keski-Inkerissä tämä "mitä tahansa" piti yleensä sisällään muita ajamisen ja kevätauringon teemoihin sointuvia runoja, Hevaalla esimerkiksi auringon löytymisestä kertovan Päivän päästö -runon, josta on tallennettu myös yksi Lähe jumal aviksi -säkeellä alkava toisinto. ${ }^{509}$

\footnotetext{
${ }^{508}$ SKVR IV 4060.

${ }^{509}$ SKVR IV, 1837. Pohjois-Inkerin Vuoleelta kotoisin olevan inkeroismies Ontropon mukaan samaa virttä saatettiin laulaa sekä laskiaisena että joulun pyhinä reessä ajaessa (SKVR V2 1742).
} 
Ainoa Hevaan laskiaisnuotin varma muistiinpano on A. A. Boreniuksen käsialaa. "Liukumass lauletaan viinaan" kirjoitti hän hevaalaisen Paraskoi Huoterin tyttären liukusäveneksi kutsuman, päivänpäästörunon sisältävän Hevaan nuotin viereen: ${ }^{510}$

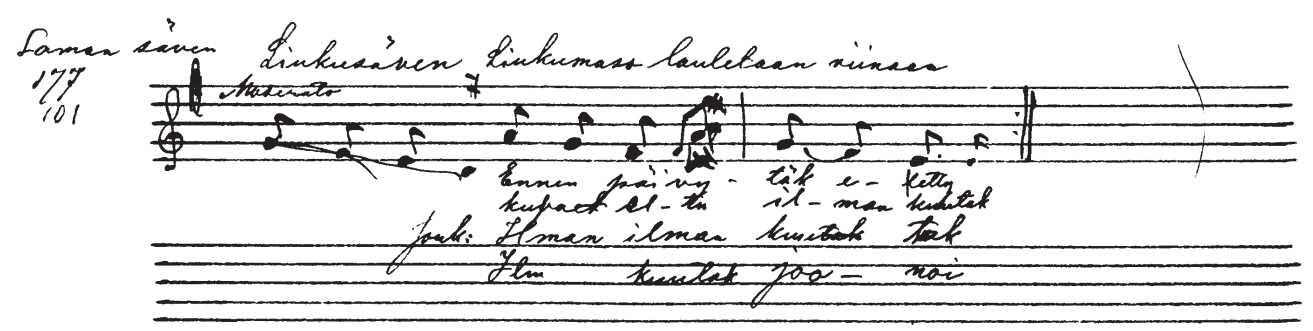

Nuotti 12. Hevaan liukusäven Päivänpäästörunon alkusäkeillä: Ennen päivätäk eletty, kupaeltu ilman kuuta; ilman ilman kuutak, ilman kuutak joonoi (SKS KRA Borenius e 177).

Muita varmoja sävelmätoisintoja ei Hevaalta tästä runosta aineistossa ole, mutta joonoi-sävelmätyyppi näyttää Launiksen kuvauksen, Alavan samasäkeisen runon sekä Boreniuksen nuotin perusteella alueella vähintäänkin tärkeimmältä laskiasisävelmältä - viitteitä muihin sävelmätyyppeihin ei ole. ${ }^{511}$ Vaikka runo- ja sävelmätoisintoja ei ole paljon, näyttää liukuvirsi Hevaalla olleen selkeä paikallinen laji.

\section{LIVUKKA REKOI LIPPIÄ}

Vaikka Launis ei kuullut tietoja laskiaisena laulamisesta Soikkolasta, tallensi hänen jälkeensä tullut Juho Lukkarinen sieltä kokonaisen ajamiskuvauksen runoineen. Laskiaissunnuntaina eli maaslitsana nuoret liukuivat "reessä ajaen pitkin kyliä, tytöt eri reessä kuin pojat." Paikoin noustiin taloihin tanssimaan. Samassa reessä saattoi matkata viisitoistakin henkeä. Ajaessa tytöt lauloivat: ${ }^{512}$

\author{
Livukka reko lipiä \\ Lipiäistä tietä myöten, \\ Koliaista jäätä myöten! \\ Aja, aja ainuein, \\ Aja aino veljyein, \\ Aja hiirakka hikeen, \\ Aja paatti palloloihin! \\ Oro juoksi matka joutui, \\ Reko liukui tie lyheni.
}

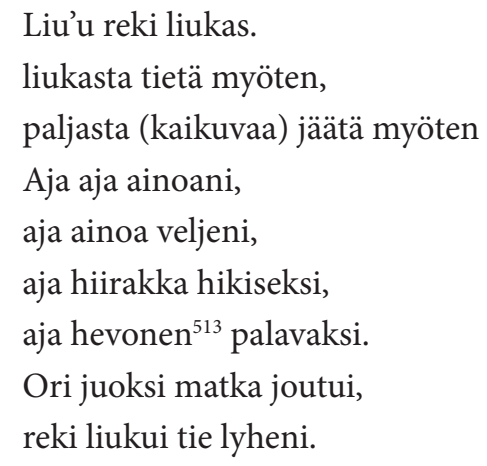

\footnotetext{
${ }^{510}$ SKS KRA Borenius e 177; 6: 899.

${ }^{511}$ Temaattisen yhteyden ja sävelmätyypin perusteella saattaisi laskiaiseen Launiksen kokoelmassa kuitenkin liittyä joonoi-rakenteella laulettu Satoi ukko uutta lunta -runo (ks. Heinonen Y. 2008).

${ }^{512}$ SKVR III 4632. Aleksandra Yrjönen Soikkolan Loukkulasta kertoi Sylvi Sääskelle: "Laskiaisena ajeltiin hevosella ja rekeen ruvetessa huudettiin: Liuvutka, regoi lippiä! Ajellessa laulettiin, illalla pidettiin juhlaa. Oli varattu pyhäruokia sekä viinaa ja makeisia. Tanssittiin myöhään iltaan." (SKS KRA Sääski 5008.) Hevosilla oli kelloja kauloissa, "helähytetää hyväst", kertoi Narvusin Vyötermaan kylästä syntyisin oleva inkeroinen Katri Mark (SKS KRA Laiho A. 2591). Maslenitsa (ven.): laskiainen (VSSS).

${ }^{513}$ Vrt. esim. SKVR IV 34, 1685.
} 
Sama rekeä liukumaan kehottava aloitusformula Livukka rekoi lippiä (liu’uhan reki liukas) ja samankaltaiset ajamisen teemat toistuvat myös muissa Soikkolan inkeroisilta myöhemmin tallennetuissa laskiaisrunoissa ja kuvauksissa. ${ }^{514}$ Muista aineiston runoista säettä ei löydy, ei myöskään lähialueilta. Launiskin silti tallensi Soikkolasta näillä säkeillä alkavia sävelmiä. Nämä neljä Livukka rekoi lippiä -säkeellä alkavaa sävelmää voidaankin päätellä laskiaisajoon liittyviksi lauluiksi, vaikka Launikselle $(1907,107)$ itselleen ei lauluja Soikkolassa nimetty eikä laskiaisajoa kuvattu, eikä hän sävelmäryhmää tunnistanut. Tämän lisäksi yksi sävelmätoisinto sisältyy Narodnie pesni Ingermanlandii -julkaisuun. ${ }^{515}$ On todennäköistä, että joku matkan loppupuolella tavattu laulaja tuli kertoneeksi Launikselle kaikenlaista, mitä tämä ei ollut osannut kysyä aikaisemmin, ja sen takia matkakertomuksen kuvaus painottuu Hevaalle.

Livukka rekoi lippiä -alkuiset runot liitetään muistiinpanoissa kahta poikkeusta lukuun ottamatta laskiaisen reellä ajamiseen. Ne on kaikki tallennettu Soikkolan alueelta 1900 -luvun alkupuoliskolla ja mitä ilmeisimmin inkeroisilta. ${ }^{516}$ Sen sijaan mäenlaskuun liitettyjä runoja on Narvusin alueelta runsaammin. Narvusin luterilaisilta on ajaessa lauletuksi mainittuja runoja aineistossa vain yksi, ja se rakentuu eri tavoin kuin inkeroisten runot. Maria Otsa aloittaa runon säkeillä " Liuvu, liuvu laskiaine, liinat pitkät liukujalle."517 Tämänkaltaiset pellavien eli liinan kasvuun liittyvät runosäkeet liittyvät yleensä mäen laskun kontekstiin ja ne mainitaan välillä lauletuiksi, välillä huudetuiksi. ${ }^{518} \mathrm{~J}$. Joutsen puolestaan nimesi oman mäkeä laskettaessa lauletun laulunsa Liu liu laskijaista, kasvakoot pellavaat pitkii laskijaisluvuksi, minkä voi katsoa viittaavan sen luvun- eli loitsunomaiseen vaikuttavuuteen. Tässä runossa, kuten paikoin muissakin pellavaan liitetyissä säkeissä säkeet murtautuvat lopussa täysin ulos kalevalamitasta: Lehmät lypsäkööt maitoa kuin vettä / ja lampaat olkoot villasii kuin kuontalot! Vapaa mitta saattaa viitata niiden esittämiseen nimenomaan huutamalla, jolloin laulun rytmi ei ohjaa esitystä määrämittaan. ${ }^{519}$ Valpuri Vohdan mukaan "sen pellava kasvoi parhaimmin," jonka kelkka liukui kauimmaksi. ${ }^{520}$ Mäenlaskuun liittyviä tietoja ei ole Soikkolan inkeroisilta, mikä voi johtua myös keruun painotuksista. ${ }^{521}$ Toisin kuin Pohjois-Inkeristä ja Etelä-Karjalasta tallennetuissa muistiinpanoissa, länsi-inkeriläisessä aineistossa

\footnotetext{
514 SKS KRA Mannonen 5514; Sääski 5009, 5011 ja 5013; NPI 30/12. Etnisyys on määritetty asuinpaikkojen tai mainintojen perusteella.

${ }^{515}$ SibA Launis 233, 310, 393b; A 300/48a; NPI 30/12.

${ }^{516}$ Lauletuiksi on mainittu SKVR III 4632; SKS KRA Sääski 5009, 5013; huudetuiksi SKS KRA Sääski 5008, 5011; poikkeukset lasten laulamaksi sanottu SKS KRA Sääski 5012 sekä ilman kontekstitietoa SKS KRA Mannonen 5514

${ }^{517}$ SKS KRA Laiho L. 4925; vrt. Laiho L. 4918. Otsan mukaan ajaessa laulettiin lähinnä venäjäksi.

${ }^{518}$ Lauletuiksi mainittu SKVR III: 1804; 4606; ks. myös SKS KRA Laiho L. 4918; 5249; huudetuiksi SKS KRA Enäjärvi-Haavio 734. Runoista ks. tarkemmin SKVR-hakemisto: Laskiaishuuto.

${ }^{519}$ SKS KRA Mannonen 7672; muita kalevalamitan murtavia ks. Laiho L. 4925, 5249.

${ }^{520}$ SKS KRA Enäjärvi-Haavio 599; ks. myös Laiho L. 4918.

${ }^{521}$ Anni Joutsin "laskijaislaulussa" Livukka rekoi lippiä -säe yhdistyy pitkien pellavien toivotukseen, ja laulun nimi - laskijaislaulu, ei liukuvirsi - viittaa inkerinsuomalaisuuteen, vaikka laulaja olikin kerääjän mukaan inkeroinen (SKS KRA Mannonen 5514). Mannosen informanttien pitkä oleskeluaika Suomessa tosin näyttää vaikuttaneen jonkin verran heidän kieleensä, mikä saattaa selittää laskiais-sanan käytön.
} 
ei ole myöskään tietoja miesten rekiajeluista ja laulamisesta, vaan laskiaisen reellä liukujia ovat lähinnä kylän nuoret. ${ }^{522}$

Soikkolan liukuvirsiaineisto on pienempi kuin muihin praasnikkalauluihin liittyvä aineisto. Samalla siihen liittyy samankaltaisia variaatioon ja runojen käyttöön piirteitä kuin muihinkin tilannesidonnaisten runojen ryhmiin kuten liekkuvirsiin, kokkovirsiin sekä moniin tanssiin ja kylän läpi menemiseen liittyviin runoihin. Laskiaisaineiston pienuuden takia se on mahdollista esitellä tässä muita ryhmiä tarkemmin. Laskiaisen ajamiseen liittyviä runojen käsikirjoitusmuistiinpanoja on aineistossa kuusi, lauluäänitteitä kolme ja kahden säkeen sävelmämuistiinpanoja kolme. Aloitusformula Liuvukka rekoi lippiä, lipiäistä tietä myöten toistuu hieman eri muodoissa ja eripituisena yhtä lukuun ottamatta joka runossa. Sen viittaussuhde juuri laskiaiseen ja rekiajeluun näyttää aineiston perusteella vahvalta. Kuten muualtakin Inkeristä tallennetuissa Rekivirsissä (SKVR-hakemisto), runotekstien teemat liikkuvat pääosin ajamisen, tyttöjen, orin ja ajajan ympärillä. ${ }^{523}$ Sylvi Sääsken tallentama 7-säkeinen versio sisältää aloitusformulan lisäksi tyttöjen liu’uttamisen ja ajamiskehotuksen teemat; Ulla Mannosen tallentama 8-säkeinen runo kehystää alussa ja lopussa toistetulla aloitusformulalla pellavan kasvamisen teeman. ${ }^{524} \mathrm{Lau}-$ niksen fonogrammilla Ustenja Miikkulantytär ehtii ennen äänityksen loppumista laulaa viisi esilaulusäettä, jotka kehoittavat aloitusformulan jälkeen rekeä olemaan kaatumatta ja kuulijoita lähtemään "jumalasihe," ilmeisesti siis jumalille tai pyhille vieraaksi. ${ }^{525}$

\footnotetext{
${ }^{522}$ SKS KRA Laiho L. 5164. Aili Laiho (1972, 50) kertoo laskiaisena erityisesti miesten laulaneen laskiaisvirsiä ajaessaan "Inkerissä ja Karjalan kannaksella pitkin kylää hevosella." Laihon kenttäkokemukset sijoittuivat Inkerin läntisimpiin kyliin, mutta kuvauksessa mainittuja runoja Juokse, juokse musta ruuna, Käy oro omille maille, Mitä puuta on rekeni, Nuu nuu, orosueni, sekä Hyvä mies, hyvä hevonen ei löydy hänen tai Lauri Laihon keräelmistä eikä läntisistä aineistoista juuri muutenkaan. Ne ovatkin ilmeisesti peräisin muilta alueilta kerätyistä runoista. Eniten reellä ajamiseen liittyviä laskiais-, liukumis- ja rek(i) virsiä on tallennettu Pohjois-Inkeristä, mutta myös Keski-Inkerin inkeroisilta (IV:4060), luterilaisilta (luult. IV:766, V2:1727) sekä vatjalaisilta (IV:4662, 4663, 4671, 4677, 4691). Vatjalaisten yksi toisinto alkaa yleisin tulelle kutsun sanoin (IV:4663). Ks. tarkemmin SKVR-hakemisto: Rekivirsi.

${ }^{523}$ Ks. SKVR-hakemisto: Rekivirsi. Ajamisen teemoja laulettiin ainakin Länsi-Inkerissä laskiaisen ohella myös häiden yhteydessä. Länsi-inkeriläisissä Livukka rekoi lippiä -runoissa runon keskellä joskus esiintyvää säettä Aja aja velvyeni ja Hevaalla liukuvirren usein aloittanutta säettä Lähekko Jumal' aviksi on mainittu Narvusin alueella lauletun alkusäkeenä etenkin sulhasen ajaessa tai lähtiessä ajamaan morsiamen taloon. (SKVR III 8, 34, 50, 1897, 1900, 2451, 2489, 2545, 3000, 4262.) Laskiaisrunoksi mainittujen toisintojen alkusäkeinä niitä ei esiinny. Niinpä sävelmäaineiston näillä säkeillä alkavia länsi-inkeriläisrunoja ei voi suoraan identifioida laskiaiseen liittyviksi: ne voivat liittyä yhtä hyvin tai todennäköisemminkin häihin, mihin viittaavat myös niiden sävelmätyypit (SibA Launis 107b, 357b, 394b; SKS KRA Borenius e 204; SKS KRA Europaeus 12:184; häiden tyypillisistä sävelmistä ks. luku 7).

${ }^{524}$ SKS KRA Mannonen 5514; Sääski 5013.

${ }^{525}$ SKSÄ A 300/48 a.
} 


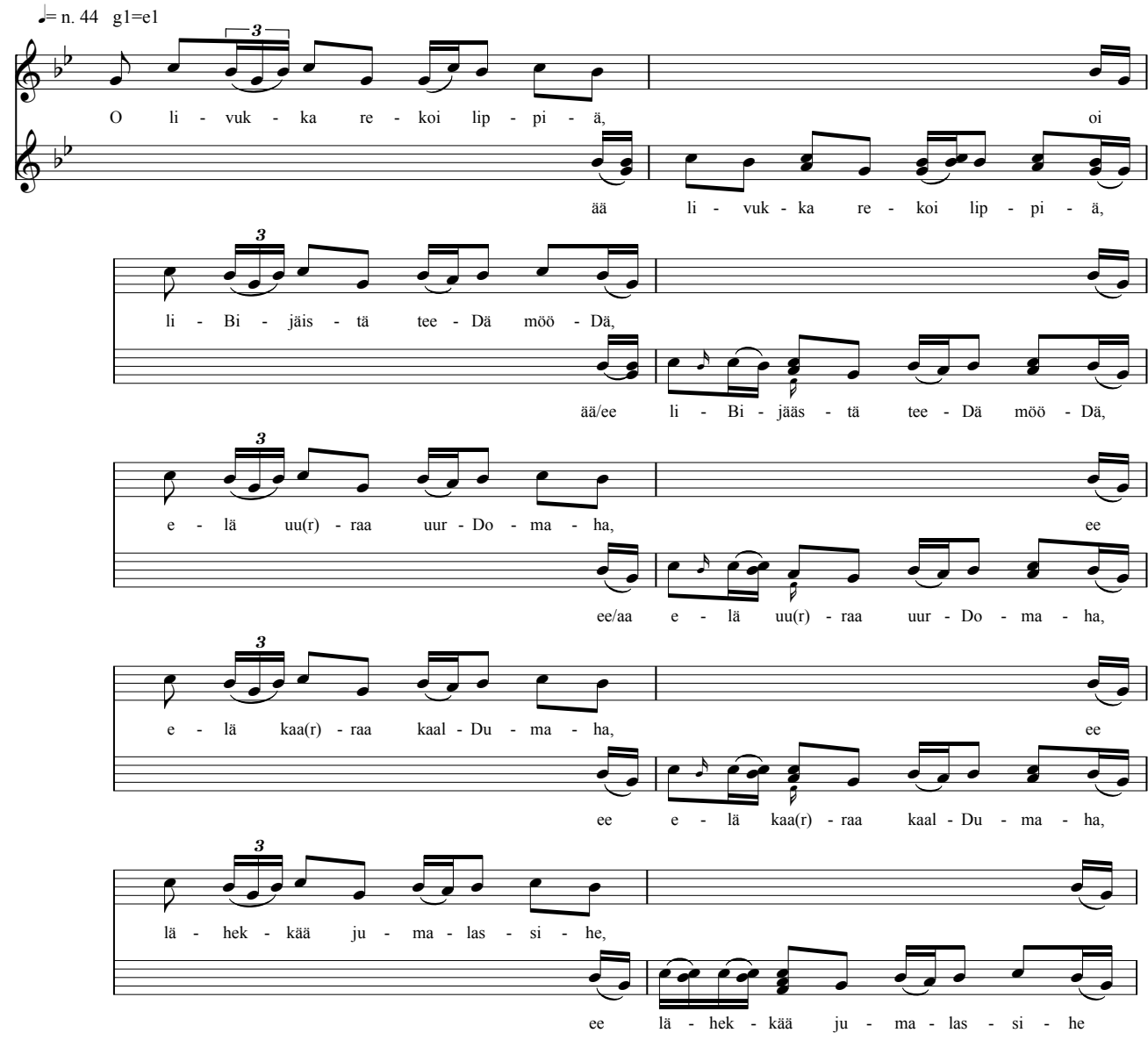

Nuotti 13. Soikkolan liukusävelmä, Ustenja Miikkulantytär ja kuoro (SKSÄ A $300 / 48 a)$.

Launiksen kokoelmaan sisältyy toinenkin samaa sävelmätyyppiä edustava, Anna Mitrintyttären ja kuoron laulama äänitys, joka aloitusformulan puuttumisesta huolimatta liittyy todennäköisesti juuri laskiaiskontekstiin. Aloitussäettä Njo njo njo heboisueni on nimittäin tallennettu muualta Inkeristä juuri laskiaiseen liittyvien laulujen aloituksena, ja sitä seuraavat tyttöjen kuljettamisen ja hevosen ajamisen (Aja aja ainueni) kehotukset ovat samoja kuin Lukkarisen ja Sääsken tallentamissa Livukka rekoi lippiä -toisinnoissa. ${ }^{526}$

Kaikissa näissä toisinnoissa lyhyehkö laulu koostuu ainoastaan laskiaiseen liittyvistä teemoista. Näitä pidemmän version esittivät Maria Elizarovna Nikitina Soikkolan Savimäeltä ja Maria Feropontevna Jeremejeva Loankylästä Eino Kiurulle ja Terttu Koskelle vuonna 1968. ${ }^{527}$ Edellisistä toisinnoista poiketen he punoivat aloitusformulan jatkoksi yleisempiä laulun, puuttuvien laulajien ja läpi kylän me-

${ }^{526}$ SKSÄ A 300/40 b. Laulun alkusäkeet löytyvät hieman erimuotoisina myös vatjalaisilta ja pohjois-inkeriläisiltä inkeroisilta tallennetuista laskiaislauluista, mutta ei muualta. SKVR IV 4677; V 1732, 1741.

${ }^{527}$ NPI 30/12. En ole kuunnellut alkuperäistä nauhaa, vaan käytän tässä Kiurun litteraatiota ja Kosken nuotinnosta. Kiurun $(1974,459)$ mukaan myös Jekaterina Aleksandrova lauloi hänelle "tämän laskiaisrunon fragmentin", jota ei otettu kuitenkaan kirjaan mukaan. 
nemisen lyyrisiä teemoja. Laulaessa Jeremejeva kertasi Nikitinan laulamat säkeet sellaisenaan, melodiaa hieman eri tavalla muunnellen:

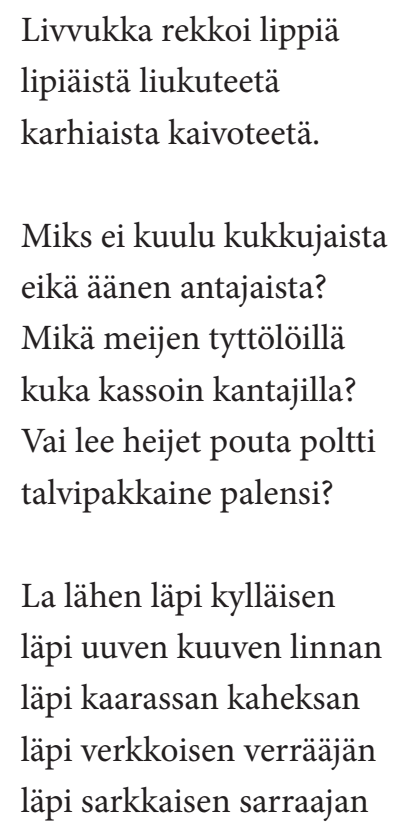

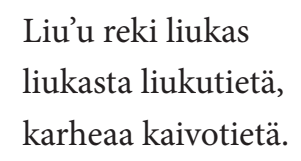

Nyt lähden läpi kylän, läpi kuuden uuden linnan, läpi kahdeksan Kaarastan [kaupungin], läpi verkkoisen [?] veräjän, läpi [pelto]sarkojen keskellä olevan heinäladon

Tulkitsen runon yhdeksi osoitukseksi tilannesidonnaisen laulun rakentumisen mahdollisuuksista. Aloitusformula saattoi olla lyhytkin. Kuten Senni Timonen (2004, 82-157) on todennut, saattoi tilannesidonnaisten aloitusten jälkeen seurata monenlaisia lyyrisiä ja kertovia teemoja. Usein kylien läpi tanssittavan kluutšan aloittava yleinen La lähen läpi kyläsen -teema sopi mainiosti myös kylien läpi reellä ajamisen kontekstiin, mutta tällöin se ei aloittanut laulua vaan ainoastaan punoutui sen osaksi. Aloitusformulana se olisi määrittänyt laulamisen lajin ja kontekstin, runon keskellä se ennemminkin viittasi toiseen keskeiseen kylien läpi kulkemisen kontekstiin ja laulamisen lajiin. Yhden tilanteen tyypillinen aloitusteema saattoi toisessa kontekstissa punoutua vähemmän korostetuksi runon osaksi.

Puuttuvien laulajien teemaa voi nähdäkseni tässä tulkita paitsi laskiaisen, myös keruuhetken kontekstista käsin: laulajia oli vain kaksi ja kalendaarilaulujen laulaminen oli 1960-luvulla jo puhtaasti oman nuoruuden muistelua. Julkisesti, keskellä kylää ei enää laulettu. Nuoruudessaan luultavasti joukolla laskiaisenakin laulaneet naiset kuitenkin käyttivät runoja ja sävelmiä perinteisellä tavalla: punoivat yhteen yleistä ja hetkellistä, tilanteisiin ja läsnäolijoihin liittyvää kontekstia. Puuttuvia laulajia kuvaava teema on sovitettavissa moneen tilanteeseen ja saattoi epäilemättä tulla aikanaan käytetyksi myös laskiaisen kontekstissa.

Samalla tavoin osin laskiaisen yleiseen kehykseen, osin keruuhetken tilanteeseen liittyväksi voi uumoilla Anna Arehjevan vuonna 1944 Sylvi Sääskelle esittämää runoa. Arehjeva oli tullut pakolaisena Suomeen toisen maailmansodan jaloista, nälänhädän ja poltettujen kylien keskeltä. "Laskiaisena (liukupäivänä) ajellessa 
laulettiin", kehysti hän paikoin hieman proosaa kohti liukuvan, luultavasti sanellun runonsa. ${ }^{528}$
Aja, aja, ainuein,
Aja, aja, ainoani [veljeni]
liuvu, regoi lippiä,
liu'u, liukas reki
liuvu lipiäistä tiitä möit,
liu’u liukasta tietä myöten
lagiaista jäätä möit,
laakeaa jäätä myöten
ja lagiaista luuta möit.
ja laakeaa luuta ${ }^{529}$ myöten
My hyvästä laulamma
Me laulamme hyvin/hyvästi
ja kovasta liuvumma
ja liu'umme kovaa/kovin
ja määmmä myy yhtehe talloo.
ja menemme yhteen taloon
Siillä myy tantsut piämmä
ja poikiin kans läkäämmä
siellä me pidämme tanssit
kaikki hyvät i pahhaist.
ja puhumme ${ }^{530}$ poikien kanssa
kaikki hyvät ja pahat (asiat)
Silhä my tušat tuulutamma
ja halut harutamma.
Niinhän me tuskat heitämme tuuleen (puhdistamme) ${ }^{531}$
ja ikävät haroitamme (ilmaan)
Eitkä tiiä yksikkää
eik ymmärrä yheksäkkää
mitä miul on miilessäin
ja kuta kurjen tuumaissain
ja vakka syttä on varia vatsassain.
Eikä tiedä yksikään
eikä yhdeksänkään ymmärrä
mitä minulla on mielessäni
ja kuta (minun) kurjan tuumissani

Runon perinteisillä liukusäkeillä alkava, laskiaisenviettoa kuvaileva ja lopulta huolilyriikkaan vaihtuva sävy on sangen erilainen kuin muiden laskiaiseen liittyvien runotoisintojen. Ensimmäiset viisi säettä ovat tavallisia laskiaisteemoja. Niistä runo jatkaa preesensissä mahdollisesti Arehjevan itse sepittämillä laskiaisen ajelua ja tanssimaan kokoontumista kuvaavilla säkeillä. Säkeille ei löydy vastinetta muusta aineistosta eivätkä ne noudata klassista kalevalamittaa: ennemminkin painollisten tavujen käsittely tuo mieleen uusimittaisen riimillisen laulun, vaikka säkeet eivät liioin noudata esimerkiksi rekimittaa. Tanssilla, laululla ja puhumalla tuskat tuullutetaan eli helpotetaan, jatkaa runo perinteisin kalevalamittaisin säkein. Tästä Arehjeva siirtyy yleiseen huolirunon teemaan: kukaan ei ymmärrä laulun minän tuskaa, kyte-

\footnotetext{
${ }^{528}$ SKS KRA Sääski 5009. Sanelun puolesta puhuvat lauletuille muodoille epätyypillinen "ylimääräinen" sanan toisto (liuvu lipiäistä tiitä möit) sekä pikkusanat (lähinnä ja), mahdollisesti myös säkeiden lopputavujen karsiutuminen, sillä laskiaislauluissa seitsentavuisuutta ei yleensä esiinnyt. Runomitan liukumat kohti uusimittaista tavupainoihin perustuvaa laulua (säkeet 6-11) ja lopussa kohti itkuvirttä (säkeeet 17 ja 18) voisivat tosin toimia laulettuinakin.

529 "Luu" tarkoitti luun lisäksi myös pellavan korren kovaa osaa, "luukivi" piikiveä tai muuta valkeaa, sileää kiveä (IMS: lū).

${ }^{530}$ Läätä tarkoitti yleensä puhumista, mutta ilmeisesti myös itkuvirren laulamista (IMS: lääDä)

${ }^{531}$ Tuultaminen oli ensisijaisesti viljan puhdistamiseen liittyvä termi: puitua viljaa heitettiin sopivalla tuulella ilmaan, jolloin tuuli erotteli jyvät akanoista. Tuskien tuultaminen oli myös huolilyriikassa yleinen mielikuva. (IMS: tūltā; Nenola 1982, 88-89; 2002, 27; Timonen 2004, 351.)
} 
viä sysiä vatsassa. Lopussa säkeen pidentyminen ja alkusoinnun määrä viittaa vielä kolmanteen laulun lajiin, itkuvirteen: ja vakka syttä on varia vatsassain. ${ }^{532}$

Runon minämuotoinen kuvaus tyttöjen ja poikien laskiaisajelusta ja tanssista on 72-vuotiaan laulajan näkökulmasta myös viittaus omaan nuoruuteen ja oman kylän väkeen. Voisi ajatella, että laskiaisen kuvaaminen preesensissä toimi tässä kuten Timosen (2004, 350-386, erit. 355) tulkinnan mukaan utooppiset kuvat kalevalamittaisessa runossa yleensä: toi mielikuvien ja tunteen tasolla poissaolevan tai puuttuvan hetkeksi läsnä olevaksi, lohdutti. Siirtymän tuskien helpottamisen teemasta huolilyriikkaan voi tulkita myös siirtymänä muistoista ja menneiden laskiaisten läheistetystä kuvauksesta nykyhetken todellisuuteen: oman väen parissa tuskat helpottuivat laululla, tanssilla ja puheella, mutta pakolainen ei löydä ympäriltään samanlaista yhteyden kokemusta. Vaikka tulkinta jääkin tarkempien taustatietojen puutteessa monin tavoin avoimeksi, kertoo Arehjevan runo joka tapauksessa runoteemojen käytön ja eritasoisiin konteksteihin viittaamisen joustavuudesta. Teemojen monikäyttöisyydestä todistaa myös Anastasi Ruokosen esittämä lasten "liukupäivänä" laulama kahdeksansäkeinen laulu, jonka alkusäkeet liittävät sen laskiaisen rekiajeluun (livukka regoi lippiä), loppusäkeet lastenrunoihin (jänis juoksi jäätä myöten). ${ }^{533}$ Lapsia ei rekiajelun kuvauksissa koskaan mainita, mutta hekin saattoivat siis ottaa ajeluun viittaavat laskiaisen keskeissäkeet oman laskiaisenviettonsa osaksi.

Variaatioineenkin laskiaisrunot muodostavat alkusäkeidensä osalta yhtenäisen ryhmän. Kaksi kertojaa mainitseekin ainoastaan aloitusformulan: Aleksandra Yrjösen mukaan "rekeen ruvetessa huudettiin: Liuvutka, regoi lippiä!" Ajaessa laulettiin, mutta hän ei tarkentanut, mitä. Paraskeva Kaurila mainitsi samoin ajaessa huutamisen: Liuvukka, rekoi lippiä, libiäistä tiitä myyte! ${ }^{534}$ Olettaisin huutamisen viittaavan tässä hyvin kovaääniseen laulamiseen, joka saattoi, kuten pidemmistä esimerkeistä on pääteltävissä, jatkua monin eri tavoin joko pidemmillä laskiais- ja ajamisteemoilla tai muilla, yleisemmillä runoilla. Darja Lehti kertoikin joenperäläisestä reessä laulamisesta: "Ken laulo yhtä, ken toista". ${ }^{35}$

Kaikkien Livukka rekoi lippiä-runoon liittyvien laulujen sävelmä on neli-iskuinen, tasajakoinen, neljällä tai viidellä sävelellä edestakaisin liikkuva ja refrengitön. Ne ovat laskettaviksi samaksi sävelmätyypiksi, jopa samaksi sävelmäksi, vaikka yhden sävelmän asteikkorakenne poikkeaakin muista. Kaikkein koristelluin on Maria Elizarovna Nikitinan esilaulama versio. Terttu Koski $(1974,480)$ mainitsi juuri

\footnotetext{
${ }^{532}$ Säkeen tavallinen, runomittaan istuva perusmuoto olisi vakka syttä vatsassaini. Toki sysien kuumuuden korostus voi myös olla vain ulkopuoliselle kerääjälle suunnattu selvennys. Tämän laskiaisrunon lisäksi Arehjeva saneli Sääskelle ainoastaan lyhyen virpomisrunon sekä Iljan päivän runon. Hänen Iljan virtensäkin liukuu henkilökohtaisiin, Iilian virrelle epätyypillisiin tunnelmiin: Kelle tahtoo sille antaa [... Loojoil on lykyn avvaimet - Jumala suo tai on suomatta onnen eli lykyn tahtonsa mukaan. Arehjevan repertuaari vihjaa, että hän olisi voinut laulaa toisessa tilanteessa kerääjälle paljon muutakin. Hän kertoi lyhyesti mutta asiantuntevasti Soikkolan keskeisimmistä pyhäpäivistä: laskiaisesta, pääsiäisestä ja Iilian praasnikoista, ja hallitsi myös lyyrisiä runoja. (SKS KRA Sääski 5175, 5333).

${ }^{533}$ SKS KRA Sääski 5012.

${ }^{534}$ SKS KRA Sääski 5008, Sääski 5011.

${ }^{535}$ SKS KRA Haavio 2673, ks. myös Laiho L. 2604.
} 
tälle kalendaarilaululle ominaiseksi "erittäin tylsän ja monotonisen esittämisen." Koski tuntuu sävelmien esittelyssään painottavan tunneilmaisuun liittyviä seikkoja, joiden suhteen kyseinen laulu ei ilmeisesti häntä puhutellut. Launiksen äänitetoisinnoissa huomiota puolestaan kiinnittävät vahva äänenmuodostus sekä säkeen loppujen äännemuutokset. Usein viimeinen vokaali muuttuu e-äänteeksi ja Anna Mitrintytär tarttuu laulun kuoro-osuuksiin rytmikkäällä ehe-tavulla. Uskoisin sekä "monotonisen esittämisen" että tavumuutoksien liittyvän laskiaislaulun luonteeseen: laulettiin ulkona, joukolla, kovaa. Liukusävelmän sävelmätyyppiä esiintyy myös seuraavassa alaluvussa käsiteltävien liekkusävelmien joukossa, mikä voi viitata näiden paikallisten lajien yhteyteen pääsiäispaaston aloittajana ja lopettajana.

Narvusista Livukka rekoi lippiä -teemaa tai suoraan laskiaiseen liitettävissä olevia sävelmiä ei ole tallennettu. Reellä ajamisen ja laulamisen kuvauksia on kyllä, mutta niiden yhteydessä ei usein tarkenneta, mitä oikeastaan laulettiin. Luterilainen Maria Otsa kertoikin reessä lauletuksi mainitsemansa Liuvu liuvu laskiainen runonsa yhteydessä, että lähinnä "laulettii vennäi kielel."536 Otsan antama pitkä kuvaus on kielimainintaa lukuun ottamatta samansuuntainen kuin Soikkolan inkeroisten lisäksi Vyötermaalla hänen mukaansa myös soitettiin ajaessa. Narvusin alueelta on mainintoja laskiaisen hevosajelusta sekä inkeroisilta että inkerinsuomalaisilta. ${ }^{537}$

Ennen Lukkarista ei Soikkolastakaan kerätty Livukka rekoi lippiä -teemaa lukuun ottamatta Launiksen muutaman säkeen pituisia sävelmämuistiinpanoja ja yhtä fonogrammiäänitystä. Voi olla, että kerääjien lähinnä loppukeväällä ja kesällä kulkiessa eivät laskiaiseen liittyvät teemat olleet aktiivisina ihmisten mielissä, eivätkä kerääjät niitä tienneet kyselläkään. Ei ole todennäköistä, että kalevalamittainen laskiaistraditio olisi Länsi-Inkerissä kehittynyt vasta 1900-luvun puolella, runolaulun käytön vähentyessä ja korvautuessa erilaisilla venäläisillä ja suomalaisilla uusimittaisilla lauluilla. Lukkarinen oli ensimmäinen vuotuisjuhliin ja pyhäpäivien viettoon erityisesti keskittynyt kerääjä, Launiksella taas kiinnostus sävelmiin näyttää ohjanneen keruuta eri suuntaan kuin aiempien kerääjien runojen kysely. Mahdollisimman kattava sävelmien kirjo tallensi myös suhteellisen kattavan kontekstisidonnaisten alkusäkeiden kirjon. Soikkolan toisintojen vähäisyys rajoittaa tietenkin tulkintojen kattavuutta. Runotoisintoja on kuitenkin viideltä kerääjältä, sävelmiä näistä kahdelta, ja ajallinen haitari kattaa vuodet 1903-1968. Se, että sävelmien keskeisin keräää ei itse edes huomannut tallentaneensa hyvin samankaltaisten, samalla runosäkeellä alkavien sävelmien ryhmän, lisää nähdäkseni laskiaislauluista tekemieni tulkintojen painoa.

\footnotetext{
${ }^{536}$ SKS KRA Laiho L. 4925, ks. myös 4918.

${ }^{537}$ Inkeroisilta SKS KRA Laiho A. 2343; 2591; 2604; Haavio 2665; inkerinsuomalaisilta Enäjärvi-Haavio 734
} 


\section{PÄÄSIÄINEN, LIEKKUVIRSI}

Liekku, kyläkeinu, oli kesäaikana nuorison huvittelu- ja laulupaikka Inkerin kaikilla suuremmilla etnisillä ryhmillä. Liekkuvirren nimellä löytyykin tekstejä koko Inkerin alueelta. Keväisellä keinumisella on oletettu olleen yhteys hedelmällisyysriitteihin kasvukauden alkaessa. ${ }^{538}$ Liekkuminen aloitettiin pääsiäisenä: silloin kylän pojat joko rakensivat, kokosivat tai kunnostivat liekun. ${ }^{539}$ Juhla lopetti ortodokseilla seitsenviikkoisen paaston, jonka aikana ei tanssittu. ${ }^{540}$ Pääsiäisen ohella helluntai mainitaan toisena keskeisenä liekkumistilanteena. ${ }^{541}$

Ilmeisesti keinuja oli kahta päätyyppiä: ainakin Keski- ja Länsi-Inkerissä suuria, kiinteärakenteisia ulkoliekkuja ja lisäksi koko Inkerin alueella etenkin pääsiäiseksi, mutta myös muina aikoina riihen tai tuvan orteen narusta ja laudoista rakennettuja muutaman hengen istuttavia keinuja. Väinö Salmisen (1931b, 25) mukaan suureen keinuun mahtui kaksikymmentäkin henkeä, joista muutama seisoi ja antoi vauhtia. ${ }^{52}$ 1800-luvun loppupuolella keinuminen alkoi ilmeisesti vähentyä, osin onnettomuuksien seurauksena. Ainakin luterilaiset kirkonmiehet ilmeisesti paikoin paheksuivat pyhäisin keinumista ja lahkolaisuudenkin kerrotaan hävittäneen liekkuja. ${ }^{543}$ Virallisesti liekut oli kielletty ensimmäisen kerran Venäjällä jo vuonna 1648 (Zguta 1978, 60-61).

\footnotetext{
${ }^{538}$ Kuhu leekku lendenöhö, sinne velloi ozran kylvi, sisoi sinne niittämähä, laulettiin usein liekkuvirressä (esim. SKVR III 597). Ks. tarkemmin Haavio 1948, 332; Mansikka 1932; Salminen 1931, 27, 38; 1934, 140-141, 148-149.

${ }^{539}$ SKS KRA Sääski 5596; Laiho A. 3171 Maria Otsa; Haavio 2690; Laiho L. 5232; Salminen 1931b, 27; liekun rakentamisesta tai kunnostamisesta SKS KRA Enäjärvi-Haavio 830, 831, 832; Haavio 2689, ks. myös Laiho L. 5390.

${ }^{540}$ SKS KRA Koilo 319; Laiho A. 2604; Laiho L. 5143; ks. myös Laiho L. 5225. Anni Moisefin mukaan pääsiäisenä oltiin koko sunnuntain vastainen yö kirkossa, käytiin aamulla nukkumassa silmäys, sitten syötiin ja mentiin naapurien ja sukulaisten luo kyläilemään. Iltapuolella nuoret lähtivät ulos kylän tanssipaikalle - Moisef ei puhu liekkumisesta vaan ainoastaan siitä, että pääsiäisenä päästiin kevään ensimmäistä kertaa tanssimaan. (SKS KRA Mannonen 11163.)

${ }^{541}$ SKS KRA Laiho A. 3171.

${ }^{542}$ Näiden kahden keinutyypin käytön ajalliset ja paikalliset erot näyttävät vaikeasti selvitettäviltä. Launis puhuu yhtäällä pääsiäisen nuoraliekuista ja liekkumisen häviämisestä $(1904,52)$, toisaalla $(1907$, 107) yleisesti suurista liekuista Länsi-Inkerissä myös pääsiäisen yhteydessä; Salminen (1931b, 26-27, 31-34; ks. myös 1934, 139-149; SKS KRA Salminen 2967) kertoo Soikkolassa käytetyn pääsiäisenä naruliekkuja, mutta suuret liekut oli hävitetty loukkaantumisten vuoksi - Narvusissa ja Keski-Inkerissä suuria liekkuja olisi vielä ollut enemmän. Tietoja sekä naruliekuista (SKS KRA Laiho A. 3171) että liekkujen hävittämisestä on myös 1930-luvun Narvusista (SKS KRA Laiho L. 5232). Keskeiseksi mainitusta laulutilanteesta, pääsiäisestä, ei myöskään ole tarkkoja kuvauksia: yksikään keräää ei ole ollut paikan pälllä pääsiäisliekkumista katsomassa, eikä kukaan näytä keruuaikanaan olleen tästä tilanteesta riittävän kiinnostunut yksityiskohtia kyselläkseen. Moni viittaa Ad. Neoviuksen kuvauksiin pohjoisinkeriläisestä liekkumisesta ja Larin Parasken kertomasta, Väinö Salminen ottaa mukaan omia lapsuusmuistojaan Suomen puolelta ja paikoin kuvaukset tuntuvat viittaavan Viroonkin. (Enäjärvi-Haavio 1949, 149-150; Simonsuuri 1972, 43-44; Salminen 1931b).

${ }^{543}$ Runoissa pyydetäänkin välillä liekkua olemaan "langettelematta", heittämättä maahan, ks. esim. SKVR III 597. Uskonnollisten auktoriteettien vaikutuksesta ks. Salminen 1934, 147. Salminen (1934, 140-141) kertoo, että hänen vuoden 1906 keruuretkensä aikana Soikkolassa käytettiin enää pääsiäisen naruliekkuja, Narvusissa sitä vastoin oli vielä runsaasti suuria puisia liekkuja. Ks. myös Launis 1904, 52-53; 1907, 107; Salminen 1929c, 63; 1931; 1934, 148; Timonen 2004, 149-151.
} 
Liekkusävelmiä ja -runoja on kerätty runsaasti koko Länsi-Inkerin alueelta, mutta kontekstitietoja on jälleen eniten 1930-luvun Viron Inkeristä. Myös ainoastaan muutamia sävelmiä tallentaneet Europaeus ja Alava merkitsivät muistiin liekkusävelmän toisinnot, mikä nähdäkseni antaa osaltaan viitteen paikallisen lajin vakiintuneisuudesta ja keskeisyydestä.

Kuva 9. Risumäen kylän tytöt poseeraavat A. O. Väisäselle paikallaan olevassa liekussa vuonna 1914. (MV Väisänen 128/11).

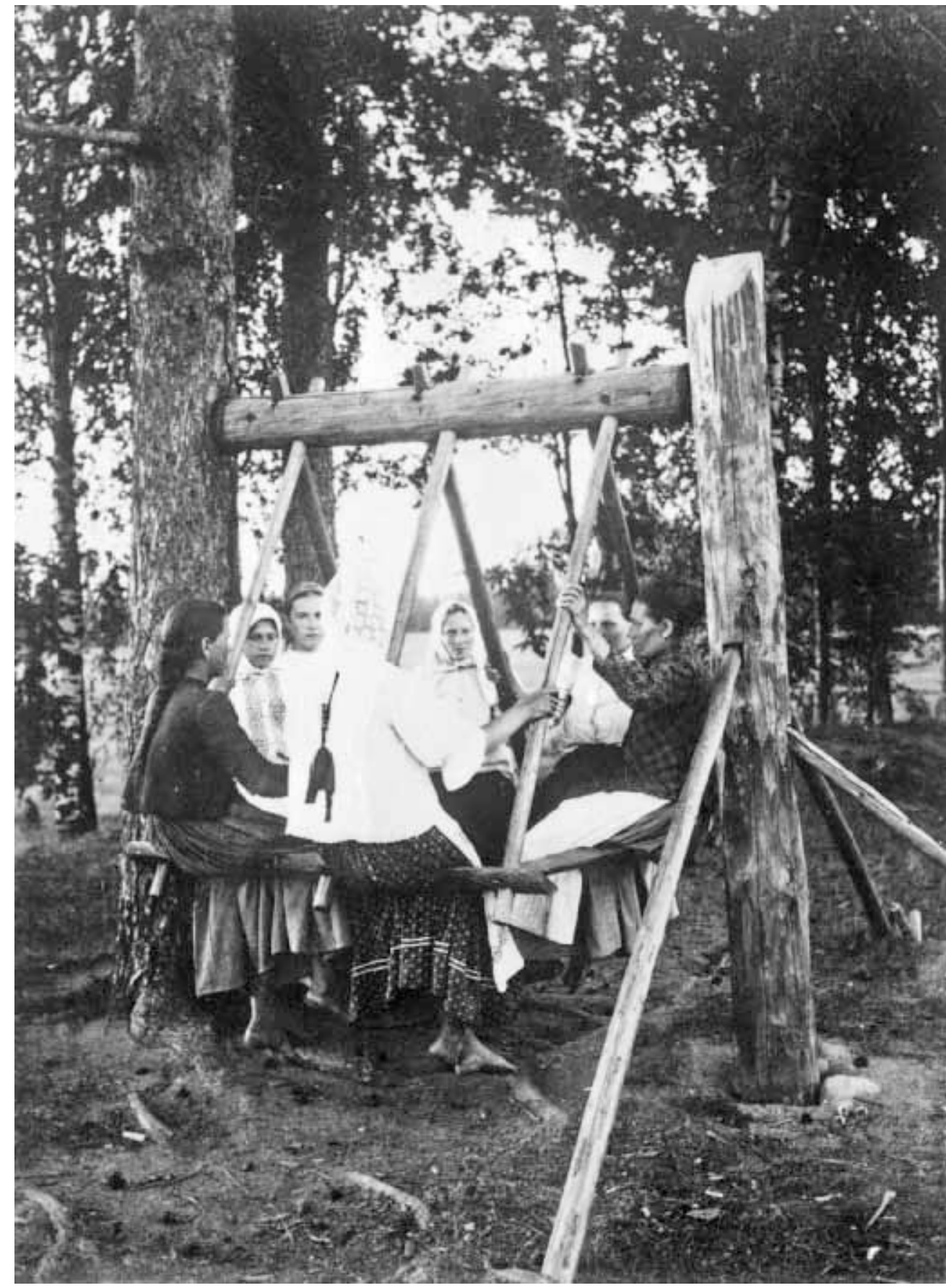




\section{VANHAT JA NUORET LAULAJAT}

Liekulla laulamisen yhteydessä keskeisinä näyttäytyvät pääsiäisen ja muiden kesäisten pyhien väliset erot. Pääsiäisenä oli mukana kaikenikäistä väkeä oman kylän lisäksi kauempaakin, ja liekkuminen näyttäytyy kerääjien kuvauksissa yhtenä pyhän keskeisistä tapahtumista. ${ }^{544}$ Muiden pyhien yhteydessä liekkuminen näyttäytyy vain yhtenä nuorten laulamiseen ja kuljeskeluun eli gulaittamiseen sisältyvänä vaihtoehtona ${ }^{545}$ Salminen $(1929 c, 63)$ mainitsee pääsiäisen laulajiksi tyttöjen ohella Länsi-Inkerissä myös aikuiset miehet:

Niinpä kerrottiin minulle sekä Kurkolan niemekkeellä että Soikkolassa, että pyhiksi saattoi veneillä tulla suurliekuille nuorisoa jopa Virosta asti, joten saatiin kuulla uusia lauluja. Liekuilla laulettiin yleensä kaikenlaisia lauluja, sillä oli mahdotonta ajatella, että siinä oli väkeä keinumassa ilman, että samalla kuului tyttöparven laulua ja miesten jorotusta.

Myös toisaalla hän (Salminen 1931b, 27; ks. myös 1934, 141) kertoo, että Soikkolassa "pääsiäisliekussa oli sekä vanhan että nuoren heilahdeltava ja laulettava, ken vain osasi." Pääsiäisenä liekkumisesta ei ole tämän tarkempia kuvauksia, vaan kuvaukset painottuvat nuorten läpi kesän kestäneeseen liekulla huvitteluun. Tähän vaikuttaa oletettavasti se, että yksikään kerääjä ei ollut pääsiäisenä itse seuraamassa laulamista.

Liekun käyttöaikaa oli maan sulamisen ja lumen tulon välinen aika. ${ }^{546}$ Pääsiäisen jälkeisinä kevään ja kesän pyhäiltoina ja praasnikoina kylän nuoriso saattoi kylällä kulkemisen ja esimerkiksi joen kallaalla laulamisen ohella kokoontua myös liekulle, ja vanhemmatkin saattoivat tällöin tulla katsomaan laulua ja keinumista. ${ }^{547}$ Laulamisen lisäksi liekulla leikittiin ja tanssittiin, myös garmonin eli pienen haitarin säestyksellä. ${ }^{58}$ Liekulla käytiin yleisesti pyhäiltaisin: "Pyhäiltoina gulanjella kun oltii, mäntii liekkumaa," kertoi esimerkiksi Katri Vohta Sutelasta. ${ }^{549}$ Vanhempia ihmisiä ei pääsiäistä lukuun ottamatta mainita liekulla laulajina. ${ }^{500}$ Väinö Salmiselle (1931b, 27) oli vuonna 1906 Mannakan kylässä kerrottu tyttöjen kulkeneen kylän "otsalla" eli päädyssä sijaitsevalle liekulle "parvessa peräkkäin," mikä saattaisi viitata Viron veräjien tai kluutšan tyyppiseen laulaen kulkemiseen tai tanssimiseen

\footnotetext{
${ }^{544}$ Launis 1904, 52-53; 1907, 107; Salminen 1931b; ks. myös SKS KRA Haavio 2690.

${ }^{545}$ Esim. SKS KRA Enäjärvi-Haavio 832, 834.

${ }^{546}$ SKS KRA Enäjärvi-Haavio 831, Haavio 2689; Laiho A. 2346, 3171.

${ }^{547}$ SKS KRA Laiho A. 3171.

${ }^{548}$ SKS KRA Laiho A. 3069, 3171 (Maria Otsa kertoo tavoista Syvillä kaivoilla); ks. myös Salminen 1934, 141 sekä Hämäläinen 1944 (sivunumerottoman kirjan loppupuolelta löytyvä kuva liekusta ja piiristä sen vierellä osiossa Kansantavat ja muinaisrunous).

${ }^{549}$ SKS KRA Enäjärvi-Haavio 832; ks. myös esim. Enäjärvi-Haavio 834; Laiho L. 3590; Haavio 2689; Laiho L. 5232; Laiho L. 3590.

${ }^{550}$ Matrona Bässinan mukaan Vanhakylässä pojatkin liekkuivat, mutta vain tytöt lauloivat (SKS KRA Haavio 2689). Darja Lehden mukaan Joenperällä lauloivat sekä tytöt että pojat, vanhempia ihmisiä hän ei mainitse edes pääsiäisenä (SKS KRA Haavio 2690). Yhdeltä laulajalta saadut tiedot voivat näyttää ristiriitaisiltakin: Anna Kivisoon mukaan liekkuvirren jälkeen pyhäiltaisin ei muuta laulettu (SKS KRA Laiho L. 3590, ilmeisesti Ropsussa), vaikka toisaalta hän kertoi Enäjärvi-Haaviolle (SKS KRA EnäjärviHaavio 549): "Keinussa laulettiin keinulauluja."
} 
samalla tavoin kuin kokolle mentäessä tai praasnikoilla yleisemminkin. Salminen myös suhteuttaa leikin ja tanssin liekkumiseen: "Ne tytöt ja pojat, jotka eivät mahtuneet liekkuun, "käivät tiukkamaa" eli leikkimään ja "ympärikköö laulamaa", kunnes tuli heidän vuoronsa päästä keinuun." ${ }^{551}$ Liekulla laulettiin myös erilaisia uusimittaisia suomen- ja venäjänkielisiä lauluja. ${ }^{552}$

Anni Bedan mukaan liekkuun mahtui 10 tyttöä ja kahdesta neljään poikaa. ${ }^{553}$ Anna Kivisoo puolestaan kertoi, että "tytöt lauloivat liekussa istuessa [...]. Pojat ja tytöt sekaisin istuivat, pojat keinuttivat." ${ }^{354}$ Kivisoon mukaan liekkuun mahtui yhteensä 16 henkeä, Maria Hauen mukaan $12-14 .{ }^{555}$

Liekulla laulamisen tyyli oli Salmisen (1931a, 530; ks. myös 1931b, 38) mukaan sidoksissa laulutilanteeseen. Lauantai- ja pyhäiltoina tytöt lauloivat "täyttä kurkkua", mutta arki-iltoina tytöt "istuivat keinun laudoille, keinu sai seistä paikallaan tahi liekutettiin sitä vain hyvin hiljaa ja niin hyräili "iessälaulaja" säkeen muiden hiljaa "jälestä järistäessä", niin ettei laulu edes kylälle kuulunut." Kaikissa liekkusävelmän äänitetoisinnoissa laulu etenee yhden esilaulajan ja kuoron vuorotteluna. ${ }^{556}$ Tarkempia tietoja siitä, miten sävelmä rytmitettiin keinumisen tahtiin, ei Launiksen (1910b, VIII-IX) mukaan Inkeristä ole. Vihtori Alavan käsikirjoitusmuistiinpanosta (Kuusi 1983b, 58; SKS KRA Alava pk IV 706) löytyy kuitenkin hatara viite. Alava jakoi yksisäkeisen, neli-iskuisen sävelmän tahtiviivoilla neljään yhtä pitkään osaan, ja kirjoitti ylle "tahti liekun mukaan." Voisi siis olettaa, että säkeen aikana liekku olisi tehnyt kaksi edestakaista heilahdusta: tämä sopisi yhteen äänitteillä usein kuuluvan melko hitaan tahdin sekä laulun melismaattisuuden kanssa.

\footnotetext{
${ }^{551}$ Mannakan kylässä todettiin Salmiselle tiukasti, että vain pääsiäisenä ja kesäpyhäisin liekuttiin: ”arkena ei olt aikaa."

${ }^{552}$ Esim. SKS KRA Laiho L. 5232; Mannonen 5554; Sääski 5620-5622.

${ }^{553}$ SKS KRA Salminen V. 2967.

${ }^{554}$ SKS KRA Enäjärvi-Haavio 539; ks. myös Laiho 3171.

${ }^{555}$ SKS KRA Enäjärvi-Haavio 831; Laiho L. 5232; ks. myös Enäjärvi-Haavio 830. Salmisen (1931b, 25) inkeriläisten liekkuvirsien esittelyn lomaan upottama omakohtainen nuoruusmuistelma suomalaisliekuista on väljä ja elävä: pojat pitivät seisten huolta keinuttamisesta, tytöt istuivat ja lauloivat. Keinuttaminen oli siinä määrin raskasta, "ettei siinä voinut laulaa," mutta kerto-osaan saattoi kuitenkin osallistua. Hyvä-ääninen poika saattoi myös istua laulamassa tai seistä keinuttamatta. Tämä näyttää menevän yhteen myös inkeriläisten kuvausten kanssa.

${ }^{556}$ Sekä Elsa Enäjärvi-Haavio $(1949,149-150)$ että Aili Simonsuuri $(1972,43-44)$ mainitsevat kahden kuoron vuorottelun sekä poikien tai nuorten miesten laulamisen liekulla Etelä-Karjalassa ja Inkerissä. Kuorojen vuorottelusta mainitaan sekä kahden kuoron kahden esilaulajan johdolla laulaminen että kahden kuoron vuorolaulu niin, että kuoroista toinen toimi esilaulajana. Enäjärvi-Haavio viittaa Salmiseen (1931b), joka kuvaa vuonna 1930 joltakulta vatjalaismieheltä saamiaan tietoja siitä, miten ennen oli tapana laulaa. Salminen (mts. 27-29) esittää vatjalaisen liekkuvirren tyttöjen ja poikien kuoroille jaoteltuina osina: muissa arkistolähteissä (esim. SKVR IV 4651, 4670, 4682) se on esitetty yhtenäisenä runona, mikä toki voi johtua myös keruutekniikasta. Länsi-Inkeristä en ole löytänyt kahteen kuoroon viittaavia arkistolähteitä. Silloin kun asiaa tarkemmin eritellään, mainitaan laulajina yleensä vain tytöt. Launis kertoo kahden kuoron vuorottelusta löytyvän mainintoja ainoastaan Karjalan Kannakselta ja Virosta (Launis 1010b, XIV).
} 


\section{LA MIÄ KATSON LIEKKUJANI}

Soikkolassa liekulla laulaminen aloitettiin Armas Launiksen (1907, 107; ks. myös 1910c, 223-224) mukaan tietyllä runolla, joka usein laulettiin tietyllä sävelmällä:

Liekkuvirrellä: La mie katson liekkujani, Kiusaelen kiekkujani, on ainakin yksi sille varmasti ja pysyväisesti kuuluva liekkunuotti. Niinkuin jo nimikin sanoo, tapahtuu runojen laulanta tällöin liekussa keinuessa. Inkerin liekut ovat yleensä suuria ja enimmäkseen keinutaan niissä liekussa istujaan nähden sivullepäin. Silläaikaa kun kaksi liekun kummassakin päässä seisovaa poikaa panee liekun liikkeelle, laulavat heidän välillään istuvat tytöt tavalliseen tapaan "eeltä ja jäleltä" monenlaisia runoja alkaen mainitusta liekkuvirrestä. Liekkuminen kuuluu erityisesti pääsiäisen ajanviettoihin.

Tietyllä liekkumiseen liittyvällä runolla aloittamisesta kertovat myös myöhemmät muistiinpanot Narvusista. ${ }^{557}$ Muita liekkuvirren aloitussäkeitä kuin Launiksen mainitsema La mie katson liekkujani ovat runoaineistossa Liekutaja kiekuttaja sekä Lee lee leekkuistani muunnelmineen. Sävelmien alkusäkeinä on näiden lisäksi säkeiden Elä liekku langettele, Liekkuani kiekkuani sekä Lie lie liekku kie kie kiekku variaatioita - aloitusformuloita yhdistää niiden suora liittyminen keinuun ja keinumiseen. ${ }^{558}$ Samankaltaista runoaineistoa on muistiinpanoissa vuodesta 1853 vuoteen 1944. Aineistossa liekkusäkeet liitetään muutamaa yksittäistä, luvussa 8 käsiteltävää kehtolauluihin viittaavaa poikkeusta lukuun ottamatta aina kyläkeinulla laulamiseen. Esimerkiksi Narvusin Kullan kylästä syntyisin oleva inkerinsuomalainen Valpuri Saksa kertoi:

Kullan kyläs oli suur liekku, se oli Kalmoomäel, entinen sotakalmoott. Siel oli pojat ja tytöt liekkumas, ain laulettii: Lie lie liekkuu, kie kie kiekkuu. Se oli ain ensimmäin laulu. Kui tuli suojat i kuivat, siis jo kevääl alettii, syksyyn ain nii kauvan, kun lumi tuli. Siel issuttii ja tiukettii. ${ }^{59}$

Liekkuruno jatkui Senni Timosen $(2004,149-151)$ analyysin mukaan vaihtelevasti erilaisilla keinumista, liekun rakentamista ja sen rakentajia, veljiä tai kylän poikia käsittelevillä teemoilla. Tämän jälkeen saattoi seurata monenlaisia lyyrisiä ja lyyriseeppisiä aihelmia kuten Tytärten hukuttaja, Olin orja vellolleni, Oman kylän ylistys,

\footnotetext{
${ }^{557}$ SKS KRA Sääski 5596; Laiho A. 2346; Haavio 2555.

${ }^{558}$ Ks. myös SKVR-hakemisto: Aloitussäkeitä liekkulauluihin.

${ }^{559}$ SKS KRA Laiho A. 2346. Kullan kylässä oli suuri lieku, se oli Kalmoomäellä, joka on entinen sotakalmisto. Siellä olivat pojat ja tytöt liekkumassa, aina laulettiin: Lie lie liekkuu, kie kie kiekkuu. Se oli aina ensimmäinen laulu. Kun tulivat suojat ja kuivat ilmat, jo keväällä alettiin (ja jatkettiin) syksyyn aina niin kauan, kunnes lumi tuli. Siellä istuttiin ja leikittiin (tai tanssittiin).
} 
Äidin kuolo tai Annikaisen virsi. ${ }^{560}$ Kaksi muistiinpanoa painottaa näitä muitakin runoja lauletun liekkunuotilla. Oute Joenperältä kertoi sävelmänsä yhteydessä: "On virsii a yks nootti o." 561 Anni Porissa puolestaan lauloi liekkunuottinsa Olin orja vellolleni -runon alkusäkeillä. Alava kirjoitti sävelmän yhteyteen: "Se kelpaa kaikkiin liekkulauluihin."562

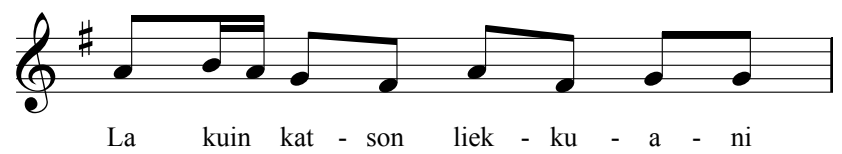

Nuotti 14. Tyypillinen länsi-inkeriläisen liekkunuotin perushahmo Narvusin Vanhakylästä vuodelta 1853 (SKS KRA Europaeus 12: 194a).

Alkusäkeiden tai paikallisten nimitysten perusteella liekkunuotiksi on tunnistettavissa 27 sävelmätoisintoa Länsi- ja Keski-Inkeristä (ks. Liite 5: Liekkusävelmät). Käsittelen sävelmien yhteydessä poikkeuksellisesti myös keski-inkeriläisiä toisintoja, sillä liekkunuotin yhteydessä sävelmätyyppien paikalliset erot tulevat erityisen selvästi näkyviin. Kaikki länsi-inkeriläiset liekkunuotin toisinnot ovat yksisäkeisiä, refrengittömiä, 3-5 sävelen alalla liikkuvia tasaisen neli-iskuisia sävelmiä, kuten suurin osa keski-inkeriläisistäkin. Kaksi muuten samankaltaista, mutta rytmiltään viisi-iskuista länsi-inkeriläissävelmää paljastuvat käsikirjoitusten marginaalimerkintöjen perusteella kehtolauluiksi eli leekutusvirsiksi. ${ }^{563}$ Sävelkulut ja käytetyt asteikot vaihtelevat. Sävelmätoisinnot ovat peräisin vuosilta 1853-1931 ja usealta eri kerääjältä: Alavalta, Europaeukselta, Boreniukselta, Launikselta, Levónilta ja Väisäseltä. Keski-Inkerin luterilaisalueilta sen sijaan on kerätty muutamia muista selkeästi poikkeavia sävelmätyyppejä.

Länsi-inkeriläiset liekkusävelmät ovat neli-iskuisia ja jossain määrin melismaattisia. Niissä kaikissa on yhdestä viiteen kahden sävelen melismaa säettä kohden. On todennäköistä, että käsikirjoitusmuistiinpanoissa melismoja on jäänyt myös merkitsemättä. Muutamissa sävelmissä käytetään välillä lisätavuja vaa tai mie ja paikoin myös svaa-tavuja. ${ }^{564}$ Kattilan vatjalaisilta tallennetut kaksi sävelmää ovat

\footnotetext{
${ }^{560}$ Europaeuksen muistiinpanoissa Narvusin Vanhakylästä merkitty liekkunuotti alkusäkeineen näyttää yhdistyvän Tytärten hukuttajan runoon (SKS KRA Europaeus 12: 194, 194a). Vihtori Alavan Anni Porissalta Narvusin Kaipaalassa keräämä Olin orja velloilleni -runo sävelmineen on samoin nimetty liekkulauluksi (SKS KRA Alava pk IV 706; SKVR III: 1905, ks. myös 959.) Kurkolan niemellä syntyneelle Sarlotta Kuulille olivat Pärspään inkeroisvaltaisen kylän tytöt opettaneet "Suomen virsii", myös oman kylän ylistys -teemaisen liekulla lauletun runon (SKS KRA Salminen V. 2978). Tatjana Jegorova kertoi tyttöjen laulaneen liekulla ja muuallakin myös Mänin maammolleni marjaan (Äidin kuolo)-runoa, joka päättyi oma emo-vieras emo -teemaan (SKS KRA Laiho L. 4732), Juljaana Pohjalainen puolestaan kelvottoman sulhasen kurjasta lopusta kertovaa Annikaisen virttä (SKS KRA Haavio 2558). 1940-luvun soikkolalaispakolaisilta kerätyssä aineistossa on myös muutama uusmittainen liekkulaulu (SKS KRA Sääski 5620-5622) sekä yksi rekimittaa ja kalevalamittaa sekoittava laulu, jota "lauloit tytöt liekulla" (SKS KRA Mannonen 5554).

${ }^{561}$ SKS KRA Borenius e 200. "On (erilaisia) runoja, mutta yksi nuotti (vain) on."

${ }^{562}$ SKS KRA Alava pk IV 706.

${ }^{563}$ Käsikirjoituksissa kehtolauluiksi mainittuja sävelmiä (SibA Launis 37; SKS KRA Borenius 198) käsitellään tarkemmin luvussa 8.

${ }^{564}$ SKSÄ A 301/9b ja A 300/27a; A 507/9a; ks. myös SKS KRA Enäjärvi-Haavio 539. Säkeen viimeinen tavu korvautuu laulussa A300/27 ee-äänteellä.
} 
muuten länsi-inkeriläistoisintojen kaltaisia, mutta rytmityyppi on hieman erilainen (24242424), samanlainen kuin monissa Pohjois-Virolle tyypillisissä keinusävelmissä (ks. Tampere 1960, 128-153). Joenperän vatjalaiselta Outelta tallennettiin sitä vastoin länsi-inkeriläiseen kaavaan istuva sävelmä. Sanat näyttävät olleen inkeroisen ja vatjan sekoitusta, ja Oute totesi melodiasta: "Lõekkunootti (Suomen o melkein)." Hän kertoi siis sävelmänsä muistuttavan joko inkerinsuomalaisten tai inkeroisten liekkusävelmää. Outen sävelmä (22222222) onkin rytmiltään lähempänä länsi-inkeriläistoisintoja kuin Kattilan vatjalaisilta kerättyjä sävelmiä. ${ }^{565} \mathrm{Lau}$ nis tallensi yhden 24242424-rytmisen sävelmän myös Narvusin Kurkolasta, mutta kirjoitti käsikirjoitukseen sävelmän olevan "Lavansaaren liekkunuotti." ${ }^{566}$

Keski-Inkeristä on tallennettu kymmenen samantyyppistä vähäsävelistä, yksisäkeistä sävelmää kuin Narvusista ja Soikkolasta. Näistä neljä Hevaan, Kaprion ja Tyrön kylistä kerättyä vastaa Länsi-Inkerin neli-iskuisia sävelmiä täysin, muissa on joitain eroavaisuuksia. Kahdessa Hevaan inkeroiskylistä ja ja yhdessä luterilaisesta Skuoritsasta kerätyssä sävelmässä viimeinen tavu lauletaan pidempänä (22222224) - muotorakenne on näissä kuitenkin sama kuin länsi-inkeriläistoisinnoissa. Kolmessa luterilaistoisinnossa Skuoritsasta ja Kolppanasta muotorakenne poikkeaa: $o i$ - tai joi-tavu sijoitetaan jokaisen neli-iskuisen säkeen alkuun niin, että ensimmäinen runojalka täytyy laulaa tihennettynä ([2]11222222). Näiden lisäksi Hevaan ja Tyrön luterilaiskylistä on tallennettu kaksi säerakenteeltaan ja rytmityypiltään täysin poikkeavaa sävelmää: Tyröstä yksi Hevaan nuotin liekkusävelmätoisinto ${ }^{567}$ ja Hevaan Harmaalasta yksi säkeen loppupuoliskon kertaava toisinto. ${ }^{568}$

Sävelmätyypit jaottuvat siis osin alueellisesti, osin etnisten ryhmien valta-alueiden mukaan. Länsi-inkeriläisillä sävelmillä on huomattavasti enemmän samankaltaisuuksia Keski-Inkerin inkeroispaikkakuntien kuin luterilaisseutujen sävelmien kanssa, vaikka erojakin löytyy. Sävelmien nimeämisestä naapurialueen (Lavansaari) nuotiksi tai samankaltaiseksi kuin lähikylien nuotit voi päätellä ihmisten itsensäkin hahmottaneen eroja sävelmien alueellisten käyttöjen välillä. Etenkin Länsi-Inkerissä yhtenäisyys on huomattavaa: kaikki omiksi liekkunuoteiksi nimetyt sävelmät edustavat samaa sävelmätyyppiä. Liekkuvirren yhteydessä laulamisen tapojen paikallisuus ja etnisyys näkyy selkeänä.

\footnotetext{
565 SKVR III 600; SKS KRA Borenius e 200. Oute sanoi virsien tulevan "Soikkoilan tavaal," "Seell maavirzii lauletaa" (SKVR III 599).

${ }^{566}$ SibA Launis 104. Tämän tyypin käyttö sekä Soikkolan eteläpuolella Kattilassa että Narvusin inkerinsuomalaiskyliin yhteyksissä olleella Lavansaarella antaa olettaa, että muunnos ei välttämättä ollut tuntematon Narvusissa ja Soikkolassakaan.

${ }^{567}$ Vaikka olen merkinnyt taulukkoon sävelmän pituudeksi neljä säettä, ovat nämä neljä luettavissa myös yhden säkeen neljäksi muunnelmaksi.

${ }^{568}$ Tästä analyysistä on jätetty pois ainoastaan tekstinä tallennettu Juljaana Pohjalaisen ympärikossa laulettu ai luuli luulii -refrengillinen Annikaisen virsi: hän kommentoi: "Tätä laulettiin liekullakin" tulkintani mukaan puhuu runosta, ei sävelmästä (jota ei muistiin merkittykään), tai sitten hän viittaa ympärikön tanssimiseen liekun lähettyvillä.
} 

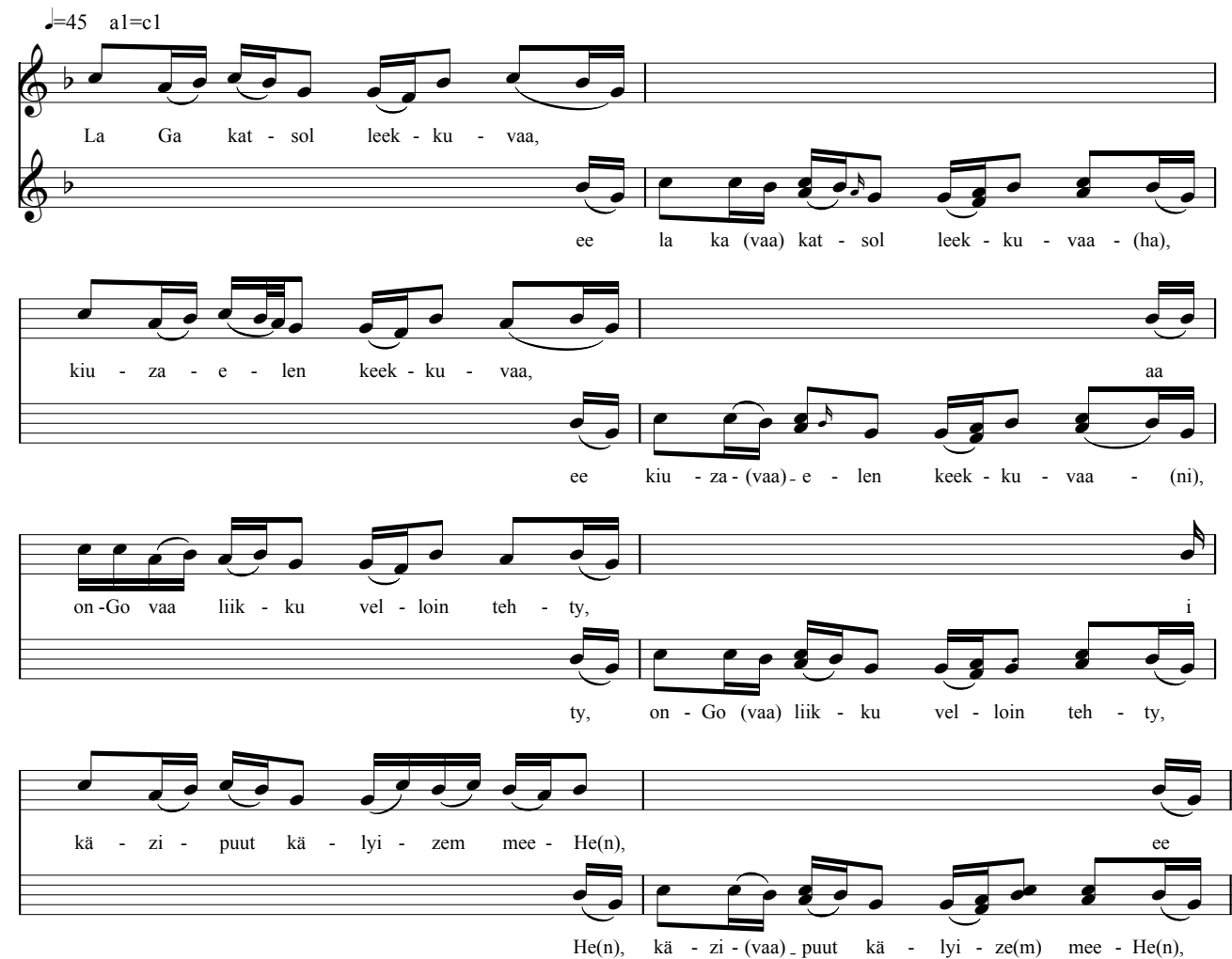

Nuotti 15. Ljuboi Jeyssen naisen ja kuoron liekkunuotti (SKSÄ A 300/27a; vrt. SKS̈̈ A 300/48a edellisessä alaluvussa).

Liekkuvirren äänitetoisinnoissa on kuultavissa paitsi melismoja myös säkeen lopettavia $e e$-äänteitä ja muita tavumuutoksia sekä säkeen sisällä vaa-lisätavuja ja svaa-äänteitä, aivan kuten laskiaisen liukuvirsissäkin. ${ }^{569}$ Muutamat länsi-inkeriläiset liekkuvirret edustavat jopa samaa melodiatyyppiä kuin edellä käsitellyt laskiaissävelmät. ${ }^{50}$ Onkin luontevaa ajatella, että nämä laulut voivat käyttää samaa tai samankaltaista musiikillista ja esityksellistä rekisteriä. Kumpiakin laulaessa istuttiin paikoillaan (reessä tai liekussa) ja maailma ympärillä liikkui. Siinä missä reessä laulaminen aloitti lauluttoman ja tanssittoman paastonajan, liekulla laulaminen lopetti sen. Laulun aloitusteemat tai -formulat ja sen jatkona esitettyjen runojen keskeisteemat olivat kuitenkin ajaessa ja liekkuessa erilaisia. Liukuvirren ja liekkuvirren rekistereissä oli siten myös samaa, mutta esitysareena, liike ja runot erottivat ne omiksi tunnistettaviksi kokonaisuuksikseen.

\footnotetext{
${ }^{569}$ SKSÄ A 301/9 b; A 300/27 a; A 507/9 a.

${ }^{570}$ Vrt. esim. SKSÄ 300/40b, 48a ja A 301/09b.
} 


\section{JUHANNUS, KOKKOVIRSI}

Kokolle kulkemiseen liitettiin samanlaisia alkusäkeitä kautta Inkerin: Tulkaat työ tytöt kokolle, vanhat ämmät valkialle, tuokaa tulta tullessanne, kekälettä kielessänne... Laulajina olivat ennen kaikkea naimaikäiset tytöt. Aloitussanat aloittivat laulamisen, joka saattoi jatkua myöhään yöhön. Runo seurasi toistaan. (Timonen 2004, 108-113; Lukkarinen 1911, 81-83; ks. myös Launis 1907, 110; Mansikka 1940.) Väinö Salminen (1929c, 41) kirjoittikin: "Kävisi liian pitkäpiimäiseksi luetella, mitä kaikkia runoja on liittynyt kokkovirteen." Senni Timonen (2004, 107-126) on todennut, että teemat silti usein lomittuivat tyttöjen kokemuspiiriin ja mielenliikkeisiin: omaan tyttöjoukkoon ja perheeseen sekä odotettuihin, pelättyihin kosijoihin. Länsi-Inkerissä sekä inkeroiset että inkerinsuomalaiset polttivat kokkoja lähinnä juhannuksena, kun taas Keski-Inkerissä keskeinen kokonpolton aika oli helluntai.

\section{KulKu KOKOLLE}

Länsi-Inkerissä selkeät kokkovirren yhteyteen sijoittuvat kontekstimaininnat liittyvät juhannukseen ja ovat lähinnä 1930-luvulla tallennettuja. Vaikka juhannus eli jaani piirtyykin esiin ensisijaisena kontekstina, eivät muistiinpanot sulje pois muitakaan kokon polton tilaisuuksia. Katri Vohdan mukaan kokollekutsurunoa laulettiin juhannuksen lisäksi "muutenkin." ${ }^{571}$ Aineiston ainoa länsi-inkeriläismaininta nimenomaan helluntaikokon poltosta sisältyy Launiksen $(1921,167)$ romanttiseen muistelmaan helluntaipraasnikoilta. Siinä tytöt kulkevat verkkaisessa piirissä Saaren neito -runoa laulaen Soikkolan korkeimmalla kunnaalla kokkotulen lähistöllä poikien istuessa katselemassa. ${ }^{572}$

Juhannukseen liittyvän laulun tarkempina kehyksinä voivat länsi-inkeriläisissä aineistoissa olla kokolle kutsu, matka kokolle tai ajanvietto kokolla. ${ }^{573}$ Tyttöjä kulki kokolle kolme, neljä rinnan, mutta "tämä ei kuitenkaan ollut mikään gul’anje," korosti Anna Kivisoo. Kyseessä ei siis ollut tavallinen tyttöjen juhliin liittyvä kuljes-

\footnotetext{
${ }^{571}$ SKS KRA Enäjärvi-Haavio 775. Valpuri Vohta puolestaan kertoi, että "Soikkolan puolella ja vatjan kylissä" laulettiin runoa juhannuksen lisäksi myös "kevättulilla" (SKS KRA Salminen V. 3016). Salminen kirjoitti, että runoa "laulettiin kevättulilla 'jaaniyön"' joka nähdäkseni on mahdollista tulkita kevättulilla ja juhannusyönä, sillä virosta lainattu sana jaani tarkoittaa muissa lähteissä sekä sanakirjoissa (IMS, KMS) ainoastaan juhannusta). Kati-akka Soikkolan Väärnojalta liitti kokolle kutsun teeman loppuosaksi pitkää runoaan, jota tytöt lauloivat "ilta-valveilla" helatorstaista Iilian päivään (SKVR III 1580).

${ }^{572}$ Launiksen päiväkirjassa (KK Coll. 123.22 Launis 1903) mainintoja kokosta ei ole, mutta hän kävi kummallakin matkallaan Soikkolassa juuri helluntaipraasnikoiden aikaan. Hänen matkakertomustensa kuvaukset kokkosävelestä liittyvät käytettyjen termien ja paikkaviitteiden perusteella ensisijaisesti keski-inkeriläisiin käytäntöihin. Termi nuotti oli Launiksen $(1907,105)$ mukaan käytössä Narvusissa ja Soikkolassa, sävel puolestaan Hevaalla. Kokkosäveleen liittyvien väärän piirin ja pitkän ringin yhteydessä taas Launis $(1904,53 ; 1907,109-110)$ viittaa ainoastaan Keski-Inkeriin. Termejä ole tallennettu Länsi-Inkerin alueelta. Ks. myös Timonen 2004, erit. 88-93 sekä luku 5.

${ }^{573}$ SKVR 2252; SKS KRA Salminen 2953 (tulta sytyttäessä: sytytyssanat); 2954 (tulelle kutsuessa); 2971 ( tulella); 3016 (tulella); Laiho L. 4729 (tulelle mennessä tai tulella); 4835 (tulella); 5252 (tulella: sytytyssanat); 5355 (tulelle mennessä); 5356 (sytyttäessä: sytytyssanat); Enäjärvi-Haavio 775 ("Juhannustulilla. Juhannusiltana ja muutenkin").
} 
kelu ja ajanvietto. ${ }^{574}$ Kuvauksissa piirtyvät toistuvasti esiin laulu ja kokon poltto, joskus myös tanssi. Lukkarinen $(1911,82)$ mainitsee hänelle Soikkolassa kerrotun "poltettavan usean kylän kesken kokkoja ja polton kestävän koko yön juhannuspäivään asti." Polttamisen aikana "tanssitaan ja lauletaan."575 Silloin kun laulajat muistiinpanoissa erikseen identifioidaan, he ovat tyttöjä. ${ }^{576}$ Anni Beda tarkensi, että "jaani-virttä" laulettiin tanssien tulen ympärillä: "Tuli oli keskpaikass, tytöt ympärikkoo tantsiit." ${ }^{577}$ Kokonpolton yhteydessä on mainintoja myös haitarin soitosta, liekkumisesta, leikkimisestä sekä venäjänkielisestä laulamisesta. ${ }^{578}$ Launiksen $(1907,109)$ maininta antaa yhden keskeisen tulkinnallisen vihjeen: kokkopaikka saattoi tarkoittaa samalla myös tanssipaikkaa, joten kokollekutsu oli samalla myös tanssipaikalle kutsu.

Kuten Senni Timonen (2004, 254; ks. myös Timonen (käsikirjoitus)) on todennut, tyttöjen laulutilanteissa tiivistyi oman tyttöjoukon ja tulevaisuuden pohdinta: etenkin kokkovirsien jatkona lauletut teemat lomittuivat monin tavoin häissä laulettuihin runoihin. Suuri osa naisten taitamista lauluista liittyikin suoremmin tai epäsuoremmin häihin: omasta kodista lähtemisen ja vieraassa kodissa asumisen tematiikkaan (vrt. Virosta Särg 2008, 61). Lyriikan ja häärunoston suhteet ovat Timosen mukaan voineet käytännössä olla vieläkin läheisemmät. Sama runo voi esiintyä samanarvoisesti sekä kokkosävelen että häiden yhteydessä ja runo on voitu nimetä häävirreksi, vaikka sen sanat eivät sisältäisi yhtäkään suoraa viittausta häihin.

Toisaalta kokkovirren kiinteitä aloitusteemojakin saatettiin käyttää myös muulloin kuin juhannuksena tai helluntaina kokolle suunnatessa, varsinaisen kontekstinsa ulkopuolella. "Iltavalveilla" läpi kesän tytöt kuljeskelivat kylällä ja lauloivat, kertoi Väärnojan Kati-akka. ${ }^{579}$ Katin tässä yhteydessä laulama runo tytärtään pukevasta äidistä jatkui Tulkaa tytöt yötulelle -teemalla, jonka yleensä kerrotaan aloittaneen kokkovirren. Aineistossa on myös kaksi muuta ilmeisesti inkerinsuomalaisilta tallennettua runokäsikirjoitusta, jossa kokkovirren aloitusteemaa käytetäänkin keskellä runoa. Maria Nyrhin laulama runo vaikuttaa improvisoidulta. ${ }^{580}$ Laulaja jopa pohtii kesken lauluaan runosäkein, muistaisiko vielä jotain lisää. Hän liittää tyttöyden ja kodista luopumisen aihelmia pitkäksi ketjuksi, joka kokkoteeman jälkeen siirtyy morsiamen kylvetys- ja itketyssanoihin. Kaikessa assosioivuudessaan runo

\footnotetext{
${ }^{574}$ SKS KRA Enäjärvi-Haavio 773.

${ }^{575}$ Lukkarinen näyttää kuvauksensa $(1911,80-83)$ perusteella viettäneen juhannusta Kattilassa, jossa se oli varsinainen kolmipäivänen praasnikka ja niinpä Kattilaan painottuu myös hänen selostuksensa juhannuksen vietosta.

${ }^{576}$ Matrona Bässinan mukaan myös nuorikot saattoivat olla tyttöjen joukossa laulamassa (SKS KRA Laiho A. 2531). Matrona Leppi Narvusin Vanhakylästä kertoi: "Etsittii kyläst tervatynnörit. Tytöt ja pojat. Siel laulettii, tanssittii, piettii jaanitulle" eli juhannustulta (SKS KRA SKS KRA Haavio 2582).

577 SKS KRA Salminen 2968. Tulen ympärillä tanssista ja laulusta mainitsi myös Anna Andrejeva Soikkolasta (SKS KRA Sääski 5312).

${ }^{578}$ SKS KRA Enäjärvi-Haavio 539; Haavio 2707-271; Laiho L. 5233. Kaikki kuvaukset eivät kuitenkaan ole yhteneväisiä: Luterilainen Juljaana Pohjalainen kielsi kokkoa poltetun juhannuksena ja korost vakavaan, uskonnolliseen habitukseensa sopivaa pyhänä rukoilemista: Kullan kylässä saatettiin hänen mukaansa polttaa enintään joku vanha tuohikontti (SKS KRA Haavio 2713; Pohjalaisesta ks. Liite 1).

${ }^{579}$ SKVR III 1580.

${ }^{580}$ SKVR III 2799.
} 
on oikeastaan looginen kodista irtautumista kuvaava jatkumo. Runon ei selkeistä häärunoteemoista huolimatta voi katsoa olevan esitys siitä, miten häissä oli tapana laulaa. Ennemminkin se on tulkittavissa yhdeksi esimerkiksi siitä, miten eri tilanteisiin viittaavia, mutta samoja aihelmia käsitteleviä teemoja oli mahdollista punoa toisiinsa rituaalisten tilanteiden ulkopuolella.

Katrina Uudesta Narvusista puolestaan kertoi lyhyempää runoaan esitettävän "häissä tanssien." ${ }^{81}$ Runon alussa kehotetaan tyttöjä suremisen sijasta iloitsemaan, sillä saatte sulhot surematta ja täss on lusti nuoren noissa. Sanat ennen ja jälkeen kokkoteeman puhuvat juuri tanssimisesta. Laulu ei ole varsinainen häärituaaliin liittyvä laulu, vaan osa häiden väljempiä osuuksia ja nuorison tanssia. Häiden yhteydessä ei tiettävästi kokkoa poltettu. Maria Nyrhin ja Katrinan runoissa kokkoteema näyttäytyykin ennemmin yhteisiin aikaisempiin kokolle (tai kokkopaikalle, joka usein oli myös tanssipaikka) kulkemisiin viittaavana tai tyttöjen yhteyden ilmaisijana kuin minkään konkreettisen, läsnä olevan tilanteen kuvauksina. Keskeiseltä tässä tuntuu Timosen $(2004,153)$ huomioima kokkovirren yhteys häälauluihin: niissä esiintyvät teemat punoutuivat toisiinsa kummassakin kontekstissa, ja lisäksi samoja teemoja käytettiin myös muissa laulutilanteissa.

\section{Ai LOLE LOLE yötULELLE JOO}

Vaikka kokon polttoon liittyviä runoja ja kontekstimainintoja on Länsi-Inkeristäkin melko runsaasti, on sävelmistä ja laulamisen tavoista vaikea tehdä päätelmiä. Kokkovirren sanoihin liittyviä sävelmiä on ennen vuotta 1938 tallennettu LänsiInkeristä ainoastaan kaksi, Hevaalta viisi ja Tyröstä kolme. Lisäksi on Hevaalta yksi "helluntaivirreksi" nimetty sävelmä. Keski-Inkerin muilta alueilta sävelmätoisintoja ja kuvauksia löytyy runsaasti (Timonen 2004, 107-126). Senni Timonen (mts. 111-112) huomauttaa, että näitä sävelmiä näyttävät yhdistävän toisiinsa samankaltaiset, joskin runsaasti varioivat refrenkirakenteet.

Kontekstikuvausten kautta laulutilanteeseen on kuitenkin mahdollista kytkeä myös joitain muita länsi-inkeriläissävelmiä. Anna Kivisoolta on hänen vuonna 1937 esilaulamansa kokkovirren lisäksi tallennettu myös kaksi kokkovirren käsikirjoitustoisintoa sekä useamman hänen mukaansa tyypillisesti juhannuksena lauletun runon sarja. Hän kertoi Enäjärvi-Haaviolle tyttöjen juhannusaattona kulkeneen ensin ryhmänä kokolle ja laulaneen sitten sytytyssanoja piirissä oi lado lado -refrengillä osan kerratusta säkeestä korvaten:

Syty, sytyttö tuli!

Oi-lado-lado-la tuli.

Pala pantu valkiaini!

Oi lado-lado valkiaini. [...] $]^{582}$

\footnotetext{
${ }^{581}$ SKVR III 3305.

${ }^{582}$ SKS KRA Enäjärvi-Haavio 773.
} 
Laulun muotorakenteesta voi päätellä sävelmän olleen yksisäkeinen. Yhden täysin samaa muotorakennetta noudattavan sävelmätoisinnon Launis tallensi Pärspäästä. ${ }^{583}$

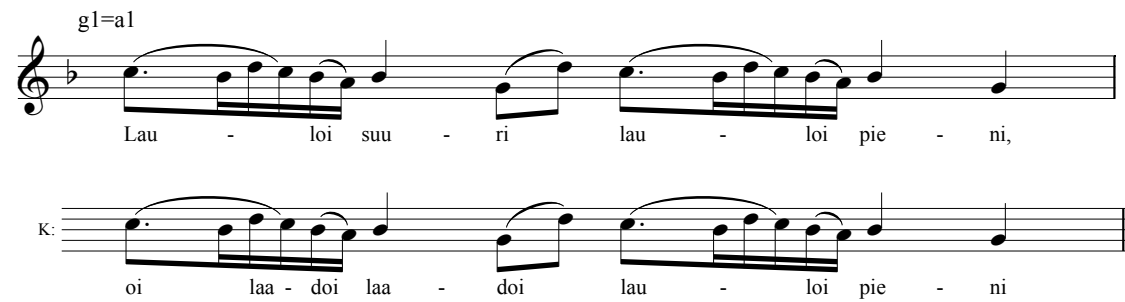

Nuotti 16. Lauloi suuri lauloi pieni, oi laadoi laadoi lauloi pieni (SibA Launis 50).

Kivisoo ei kuitenkaan laulanut yhtäkään tähän refrenkiin liittyvää sävelmää vuoden 1937 äänityksissä: voi olla, että kaikki muut laulajat eivät sitä hallinneet. Kokkovirtensä hän esilauloi tuolloin yksisäkeisellä, säkeen lopun kertaavalla, äänityksissä paljon käytetyllä tanssisävelmällä. Mahdollisuus vaihtaa sävelmää kertoo osaltaan paikallisten lajien joustavuudesta. ${ }^{584}$

Äänityksistä löytyy muutama vastine myös Kivisoon vuotta myöhemmin Lauri Laiholle esittämään pidempään juhannukseen liittyvien runojen sarjaan. Laulaminen alkoi Kivisoon mukaan tilannesidonnaisilla, konkreettisesti tekemiseen liittyvillä teemoilla. Tulkaa tyttäret tulella -runoa laulettiin kokolle mennessä, Syty sytytty tuli -säkeitä tulta sytyttäessä ja tanssilaulua Nyt on lusti nuoren noissa myöhemmin yön aikana. Vuoden 1937 äänityksissä Nyt on lusti nuoren noissa laulettiin tantsuvirreksi nimitettynä kokkovirren tavoin, nopealla sävelmällä ja säkeen loppu kerraten. Tanssilaulun tulkitsisin yhdeksi esimerkiksi siitä laulujen kirjosta, mitä kokolla saatettiin illan mittaan esittää. Lopulta "ko korjahuvat kaik tytöt yhtee kokkoo siis laulavat" La ko vieretän vilulla -runon. ${ }^{585}$ Tämän runon Kivisoo kytki toisaalla myös yleisemmin illalla ulkona paikoillaan laulamiseen sekä tyttöjen gulaittamiseen illalla. ${ }^{586}$ La ko vieretän vilulla laulettiin vuonna 1937 hitaalla, kaksisäkeisellä venäläisellä sävelmällä, jonka säkeenloppuja kuoro venytti pitkäksi. ${ }^{587}$ Hidas, edellisen luvun jäsennyksen perusteella pitkällä äänellä laulettu iltaruno toimi nopeasti eli tihtii laulettujen, tanssiin sopivien laulujen päätöksenä.

Länsi-Inkeristä on Kivisoolta ja kuorolta äänitetyn toisinnon lisäksi tallennettu 1960-luvulla ainakin kaksi varmaa kokkovirren sävelmää. Sekä Maria Nikitina Savimäeltä että Natalia Lukina Joenperältä lauloivat virtensä 44222244-rytmisellä sävelmätyypillä, joka liittyy tanssi- ja häälaulujen yhteydessä usein piirissä kulke-

\footnotetext{
${ }^{583}$ SibA Launis 50: Lauloi suuri lauloi pieni, oi lado lado lauloi pieni (yksisäkeinen sävelmä ja osan säkeestä korvaava oi lado lado -refrenki).

${ }^{584}$ SKSÄ L 101c.

${ }^{585}$ SKS KRA Laiho L. 5355-5358. "Kun kaikki tytöt kerääntyvät lopuksi yhteen, he laulavat."

${ }^{586}$ SKS KRA Enäjärvi-Haavio 549, 507; Laiho L. 5328; ks. myös Laiho A. 2133; SKVR III 1057.

${ }^{587}$ SKSÄ L 89b, 95a.
} 
miseen tai tanssimiseen. ${ }^{588}$ Länsi-inkeriläiset kokkovirteen liitettävissä olevat sävelmät edustavat siten muodoltaan erilaisia yleisiä sävelmätyyppejä, joita on muissa yhteyksissä käytetty myös ympärikossa tanssisävelminä.

Armas Launiksen (1907, 109-110; ks. myös 1904, 53) äänitysretken matkakertomuksen kokkovirren kuvaus on monipolvinen. Hän paikantaa kertomansa KeskiInkeriin. Launiksen mukaan tytöt kulkevat illalla kokkopaikalta läpi kylän pitkänä kiemurtavana ketjuna laulaen kokolle kutsun sanoja. Alkusanat ovat Launiksen mukaan keskeinen tekijä: niiden jälkeen saattaa runona jälleen "olla mikä tahansa." Sävelmän Launis vihjaa voivan välillä olla myös joku muu kuin tyypillisin kokkosävel, ja toisaalta tyypillisin kokkosävel kuulostaa olevan yleinen muussakin käytössä: "Kokkosävelenä on useimmiten eräs yleinen inkeriläinen runosävel, jonka refrängi alkaa sanoilla 'ai ljole' tai joskus 'ai luuli', ja päättyy säkeen loppusanain kertauksella." ${ }^{589}$ Laulun ja kävelyn tahti on rauhallinen. Kokkopaikalle palatessa kulku käy Launiksen mukaan sitä vastoin nopeammin, parijonossa ja tanssiaskelin: hänen käyttämänsä paluuta kuvaava ilmaisu "erilainen laulutapa" sisältää luultavasti myös melodian. Launiksen mukaan matka kokolta kylän toiseen päähän laulettiin siis rauhallisessa tahdissa kokkovirrellä aloittaen ja ai lole tai ai luuli -tyyppistä refrenkiä käyttäen edellisessä luvussa Viron veräjiksi ja vääräksi piiriksi nimetyssä ketjumuodostelmassa, paluumatka kisailupaikalle sen sijaan nopeammin, Länsi-Inkerissä kluutšaksi kutsutussa parijonomuodostelmassa, johon länsiinkeriläisessä aineistossa liittyy vahvasti saadulmoi-sävelmä.

Tarkalleen Launiksen sävelmäkuvaukseen (kuoro-osassa ai ljole eli ai lole tai ai luu$l i+$ säkeen loppuosan kertaus) sopivia sävelmiä löytyy Keski- ja Länsi-Inkeristä useampaa tyyppiä, joista kahteen liittyy myös varsinaisia kokkovirren tekstejä. Luettelo näistä sävelmistä löytyy liitteestä 5. Eniten kokkovirren sanoja sisältävässä ryhmässä sävelmä on yksisäkeinen ja runosäettä pidempi. Yleensä siihen kuuluu joko lisätavuja (vet on) tai säkeen muutaman tavun kertaus keskellä säettä. Refrenkinä on ai lole lole kuoro-osassa sekä joo-tavu jokaisen säkeen lopussa.

Toisen ryhmän kaksisäkeisissä sävelmissä rytmi on tasainen, lisätavuja ei esiinny ja refrengin muoto vaihtelee edellistä ryhmää enemmän (ai lole; ai lole pai lole; ai lole ai lole). Näitä kahta muotorakennetta on tallennettu sekä Hevaalta että Tyröstä ja kaksisäkeistä lisäksi Soikkolasta ja Narvusista. Tämän lisäksi on suuri joukko Länsi- ja Keski-Inkeristä tallennettuja yksisäkeisiä sävelmiä, joiden refrengit ovat muotoa ai lole lole ja ai ta lole lole ja joihin ei kuulu lisätavuja. Lasken tähän joukkoon kuuluvaksi myös rakenteeltaan samanlaiset Anna Kivisoon kokkovirren käsikirjoituksen yhteydessä mainitut oi laadoi laadoi -refrengilliset sävelmät.

Näihin ai lole -sävelmätallenteisiin liittyy kokkovirren ohella monenlaista etenkin lauluun ja tyttöihin liittyvää lyriikkaa (kuten Mitä myö tytöt suremme, Lauloin en-

\footnotetext{
${ }^{588}$ NPI 31/5, 32/3. Tanssilauluista ks. luku 5, häälauluista luku 7.

${ }^{589}$ Runosävelmätutkimuksessaan Launis $(1910 \mathrm{~b}, 41)$ huomautti Virossa yleisimmän refrengin tai -refrenkisanan olevan vot luuli variantteineen.
} 
nen lapsempana, La mie viukasen vilulla) ja (lyyristä) epiikkaa (Sinon kylväjä, Suka mereen, Tytärtenhukuttaja, Kalervo ja Untamo, Päivän päästö, Veneenveisto). Rituaalisiin tai seremoniallisiin tilanteisiin liittyviä muita runoja kuin kokkovirttä ei näiden sävelmien yhteydestä löydy yhtä poikkeusta lukuun ottamatta. ${ }^{590}$

Edellisten lukujen kaltaisia selkeitä sävelmäryhmiä ei kokkosävelmien joukosta löydy. Joukossa on erilaisia rytmityyppejä, muotorakenteeltaan ja sävelmältään sekä yksi- että kaksisäkeisiä toisintoja, erilaisia refrenkejä ja osakertauksia. Yhtä Hevaan nuottia lukuun ottamatta kaikki ovat kuitenkin vaihtelevine rytmityyppeineenkin joko refrengiltään ai lole -ryhmiin kuuluvia tai yksisäkeisiä, säettä sellaisenaan toistavia sävelmiä. Kaikki sävelmät liikkuvat 3-5 sävelen alueella. Erilaiset ai lole -refrengit ovat tyypillisiä nimenomaan keski-inkeriläisille kokkosävelmille. Kahta lukuun ottamatta kaikki kokkovirren sävelmät on tallennettu soololaulajilta. Kuten luvussa 4 on todettu, tällöin refrengit jäävät useammin laulamatta kuin joukolla laulettaessa, joten joihinkin refrengittä tallennettuihin sävelmiin olisi saattanut kuoron kanssa laulettaessa yhdistyä myös ai lole -tyyppinen refrenki. Sekä Hevaan nuotti että käytetyt yksisäkeiset sävelmät ovat tyypillisiä monissa eri tilanteissa käytettyjä yleissävelmiä..$^{591}$

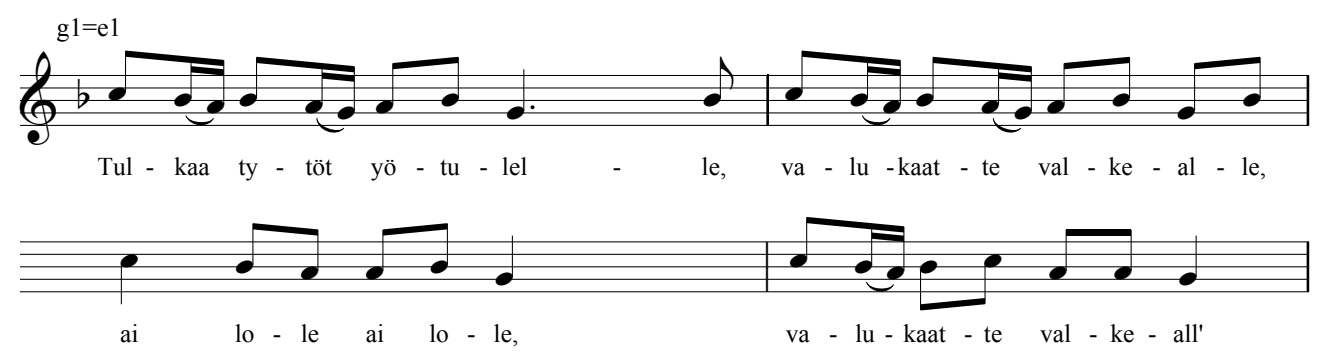

Nuotti 17. Kokkosävel Hevaalta. (SKS KRA Levón 484).

Länsi-inkeriläinen aineisto ei anna mahdollisuuksia kovin kattaville johtopäätöksille. Kokkovirttä laulettiin juhannuksena ja mahdollisesti myös määrittymättöminä kevätpyhinä kun kuljettiin kokkopaikalle, tanssittiin siellä tai kuljettiin vain pitkin kylää laulamassa. Kokkovirren sävelmätoisinnot viittaavat tanssiin, mutta niiden yhteydessä ei kukaan laulajista erikseen kuvaa kulkemisen tapaa. Luultavasti saatettiin mennä Viron veräjiä tai kluutšaa kuten Keski-Inkerissä.

\footnotetext{
${ }^{590}$ Aineiston ainoaa ai luuli -refrengin kanssa esitettyä häälaulua käsitellään tarkemmin luvussa 8 kokkovirsien ja häälaulujen lomittumisen tarkastelun kohdalla. Se, kuten seuraavassa taulukossa näkyvä tyypillisellä keski-inkeriläisellä hääsävelmällä laulettu kokkovirsikin ovat Onikka Jokorontyttären Launiksen fonogrammille laulamia. (SKSÄ A 301/46b, 47a).

${ }^{591}$ SKSÄ A 301/46b; vrt. SKS KRa Levón 349, 353; SKSÄ A 301/43c, 46a. Yhdeksästä Tyröstä ja Hevaalta tallennetusta kokkovirren sävelmästä viisi sopii vaihtelevine muotoineenkin Launiksen oi lole-kuvaukseen. Lopuista neljästä keski-inkeriläissävelmästä kaksi voisi rytmityyppinsä puolesta laulaa myös oi lole -ryhmän refrengeillä. Vaikka tämä ei tarkoita sitä, että laulajat olisivat näin kuoronkaan kanssa välttämättä tehneet, Launiksen kuvauksen voi väljässä mielessä ajatella sulkevan sisäänsä kaikki kokkosävelen keski-inkeriläistoisinnot hevaan nuottia ja Jokorontyttären häälaulua lukuun ottamatta.
} 


\section{PEDRON JA ILJAN VIRSI}

Kesän praasnikoista keskeisimmät olivat Länsi- ja Keski-Inkerin inkeroisilla Pedron (12.7.) ja Iilian (2.8.) päivien juhlat. Lukkarisen $(1911,40)$ mukaan niitä vietettiin juhlavirren ensisäkeiden järjestystä lukuun ottamatta "aivan samoja menoja noudattaen." Juhlissa yhdistyi ortodoksisen kirkon pyhimyskalenteri esikristillisiin maanviljelysyhteiskunnan rituaaleihin. Tavat olivat pitkälti samoja kuin vatjalaisilla ja lähialueiden venäläisillä, osittain koko Euroopassakin. Pedron ja Iljan juhlat eli "vakkovet" kytkeytyvät monin teemoin suomalaisiin ja virolaisiin esikristillisinä nähtyihin ilmiöihin: pyhiin lehtoihin, puihin ja kiviin, Ukolle uhraamiseen ja Ukon vakkojen juomiseen. (Groundstroem 1904, 413-415; Lukkarinen 1911, 37-62; Mansikka 1939; ks. myös Haavio 1961.) Seikkaperäisimmän, muun arkistoaineiston tukeman yleiskuvauksen Iljan ja Pedron praasnikoista on antanut omien Länsi-Inkerin alueiden kenttätöidensä pohjalta Juho Lukkarinen (1911).

Oluen keittäjiksi valitut henkilöt keräsivät hyvissä ajoin oluentekotarpeet ja valmistivat kylän yhteisen juhlaoluen. Praasnikka-aamuna kylään kerääntyi parhaisiinsa pukeutunutta juhlaväkeä lähikylistä: "Mukana ovat sekä nuoret että vanhat, niin hyvin omasta, kuin naapurikylästäkin. Tuleepa soikkolaisten juhliin runsaasti väkeä Suomen puoleisista saaristakin." (Lukkarinen 1911, 42.) Aamupäivällä kuljettiin tervehtimässä tuttavia. Kymmenen aikoihin pidettiin jumalanpalvelus, jolloin väki kerääntyi kirkon lähistölle, vaikka kaikki eivät koko aikaa kirkossa sisällä olleetkaan. Kulutettiin aikaa, nuoret kävellen tai varjossa istuen, vanhemmat kirkkomaalla tai kapakassa vaihtamassa kuulumisia. Jumalanpalveluksen jälkeen lähdettiin pyhäinkuvia kantaen, pappi etunenässä, kohti juhlapaikkaa. Lukkarisen mukaan Soikkolassa mentiin yleensä riihen kuominaan eli tilavaan puintihuoneeseen, Narvusin alueella oltiin usein ulkona saunan, vilja-aitan tai tsasounan läheisyydessä. ${ }^{592}$ Matkalla saatettiin kiertää viljelysmaat niiden siunaamiseksi. Perillä pappi siunasi "sekä kantajat että läsnäolevan väen, heitellen pyhittämäänsä vettä sen päälle, että olutkorvot ja tynnyrit, joiden laidoissa silloin palaa tuohuksia." (Lukkarinen 1911, 42-43.) Pappi otti toimituksesta maksun, mutta saattoi myös osallistua loppujuhlaan. Tämän jälkeen kylän tytöt, joukossa joskus myös nuorempia naisia, lauloivat Iljan tai Pedron virren. Kuominassa alkoi oluen jako, joka jatkui kunnes keittäjät katsoivat, että riittää, jolloin siirryttiin yksityistaloihin jatkamaan pitoja. (Lukkarinen 1911, 37-47.) Jokaisen talon eteisessä tai tuvassa oli kukkuroillaan oleva pöytä ja kaikki taloon tulijat kutsuttiin syömään. Vanhemmat ihmiset jäivät pöydän ääreen "juttua ajamaan", juomaan, syömään ja ylistämään isäntäväkeä, mutta saattoivat välillä käydä ulkona katsomassa nuorten tanssia, joskus tanssimassa itsekin. Kylän tanhualla taas pidettiin "nuoren väen herkeämätöntä karkeloimista." "Läpi päivän, vielä myöhään yöhönkin, kuulee sen laulujen sekä karkelosävelmäin herkeämättä kajahtelevan," kirjoitti Lukkarinen. ${ }^{593}$

\footnotetext{
${ }^{592}$ Esimerkiksi Väikylässä oli Alavalle kerrotun mukaan ennen uhrattu leppälehdossa (SKS KRA Alava X, s. 21).

${ }^{593}$ Vanhempien ihmisten seurustelusta ks. SKS KRA Enäjärvi-Haavio 770, 771, 800; Haavio 2797. Nuorten tanssista ks. esim. Groundstroem 1904, 413-415; Enäjärvi-Haavio 1949, 154; Lukkarinen 1911, 44; Mansikka 1939; ERA RKM, Mgn. II 1236 d.
} 
Yhteensä praasnikat kestivät kolme tai neljä päivää, ja jokaisen päivän pidot alkoivat samassa paikassa rituaalisella oluen juomisella. Paikoin on myös tietoja myös eläinuhreista ja kylän uhriaterioista praasnikkojen ensimmäisenä päivänä. Juhliin käytettyjen varojen ja ruokatarpeiden määrää kauhistelivat useat kerääjät suhteettoman suuriksi yleisen varallisuuden huomioon ottaen: oli tärkeää, että kaikki vieraat, tuntemattomatkin, saatiin kestitettyä ylenpalttisesti. (Lukkarinen 1911, 37-47.) Vihtori Alava kuvaa tilannetta elävästi kerääjän kannalta:

Mäkkylässä meitä pyydettiin "vakkoveelle": riihen luona oli koko kylän väki olutta juomassa ja siinä tytöt kohta laulelemaan että minä saisin kirjoittaa virsiä. Eihän siinä voinut mitään kirjoittaa vaikka oli iessälaulajakin. [...] Tynnyriä näkyi olevan koko joukko yhdellä seinällä siellä riihen sisässä luultavasti niissä olutta oli. Kyytimiestäni kestitsivät oluella minkä hän jaksoi juoda siinä. Minulle kovasti tarjosivat. ${ }^{594}$

Seuraavassa Venakontsan kylässä kutsuttiin Alavaa myös kestittäväksi, mutta hän totesi olevan tappeluiden vuoksi viisaampaa pysytellä sisätiloissa.

\section{TytTÖJEN LAULU KUOMINASSA}

Lukkarisen $(1911,43)$ mukaan Soikkolassa Pedron tai Iilian virren lauloivat tytöt eli "kylien neitoset" yhdessä papin siunattua kuominan: "Lauluun ottavat osaa vain tytöt, harvoin nuoremmat naiduista naisista. Miehet seisovat sillaikaa sivuilla kuunnellen äänettöminä juhlavirren esitystä.” Lukkarisen ilmeisesti itse kuulemien tietojen mukaan kuominassa ei laulettu muita virsiä. Oskar Groundstroemin (1904, 413-414) lyhyemmän ja epämääräisemmän kuvauksen mukaan vanhat ja nuoret kokoontuivat kuominaan, laulettiin Iilian tai Pedron virsi, pirskotettiin sen jälkeen "riihen seinille ja lattialle olutta" ja juotiin sitten "loppu olut laulaen ja piiritanssia tanssien." 595

Soikkolaan liittyvät Iilian tai Pedron virren kuvaukset paikantuvat kaikki riiheen ja juhlan alkuun. Laulajia ei yleensä mainita, mutta jos mainitaan, he ovat lähes poikkeuksetta tyttöjä. Anna Arehjevan mukaan Iilian virsi laulettiin piirissä riihen puintihuoneessa, jossa myös soitettiin ja tanssittiin. ${ }^{596}$ Paraskeva Kaurila kertoo papin ensin siunanneen oluen riihessä, johon sitten saapui muukin väki ja jossa laulettiin Iilian virsi; sen jälkeen kaikille annettiin olutta, ja nuoriso jäi aina lopuksi "puintihuoneeseen tanssimaan." ${ }^{97}$ Oussimäen kylässä syntynyt, Kattilan kylän Suur-Otsaan miehelään muuttanut anonyymi nainen kertoi tyttöjen laulaneen laulun kuominaan ensimmäisinä tullessaan. He saivat hyvää olutta palkakseen; esilaulaja sai olutta kaikkein ensimmäisenä. Oluen jaon jälkeen laulettiin ja tanssittiin:

\footnotetext{
${ }^{594}$ SKS KRA Alava VII B u 1892 Matkam. II, 39-41/56-58.

${ }^{595}$ Groundstroemin kuvaus näyttäisi viittaavan muidenkin laulujen esittämiseen kuominassa.

${ }^{596}$ SKS KRA Sääski 5333.

${ }^{597}$ SKS KRA Sääski 5336.
} 
"A miehet istuut, juovat, nuoristo iloissetaa." ${ }^{998}$ Anna Kivisoo kertoo tyttöjen Soikkolassa laulaneen Iiljan virtensä "ringissä, tavallisin käymäaskelin liikkuen."599 Pedron tai Iilian virren laulamista kuvaavat Soikkolan inkeroiskertojista tarkemmin Kivisoon lisäksi ainoastaan Darja Lehti ja Anna Arehjeva, mutta kyseiset kuvaukset antavat laulamisesta melko yhtenäisen kuvan. Virttä laulettiin piirissä hitaasti kulkien. ${ }^{600}$ Riehakkaan ja nopean tanssin kuvauksia ei Iilian ja Pedron virsien yhteyteen liity. Rituaalinen juhlavirsi asettui siten rekisterinsä osalta selkeästi erilleen tilaisuuteen kuuluneesta tanssista.

Ainoa Soikkolan inkerinsuomalaiskylistä kotoisin oleva kuvaus poikkeaa joiltain osin inkeroiskuvauksista. Soikkolan Uudestakylästä Kalliviereen miehelään muuttaneen Helena Säkin mukaan juhla vietettiin kyllä Soikkolalle tyypillisesti riihen kuominassa. Hänen mukaansa vieraat lauloivat saapuessaan ensin tanssituvanpyyntörunon. Iilian virttä laulettiin sisään tultaessa ja pöytään käydessä. Syönnin ja oluen juomisen jälkeen laulettiin ja tanssittiin. Pois lähtiessä laulettiin pitkä kiitosvirs. Säkin esittämien tuvanpyyntö- ja kiitoslaulujen kaltaisia runoja löytyy muusta aineistosta lähinnä talven juhlien yhteydestä. ${ }^{601}$ Ei ole selvää, kertoiko Säkki kotikylänsä laulukäytännöstä vai kuvasiko jonkun muun kylän tapoja, sillä Uusikylän praasnikoista ei aineistossa ole tietoja. ${ }^{602}$ Kuulostaa siltä, että inkerinsuomalaiset olisivat Soikkolassa omaksuneet inkeroisten juhlaperinteen, mutta soveltaneet sitä omalla tavallaan joulunajan juhlia muistuttavaksi.

Narvusin alueen praasnikkavirsien kuvaukset muodostavat kaikin puolin Soikkolaa hajanaisemman joukon. Niitä on tallennettu myös kylistä, jossa Iilia tai Pedro eivät olleet kylän varsinaisia praasnikkoja. Anna Kivisoon mukaan Ropsussa, toisin kuin Soikkolassa, pidettiin Pedroa vain yksi päivä ja sitten lähdettiin heinään. Hän sijoittaa Pedron virren laulamisen nuorison keskinäisen ajanviettopaikan epämuodolliseen lauluun: "Tytöt laulettii kallaal Pedronna." Kivisoon kuvauksen mukaan Ropsussa ei keitetty yhteistä olutta, mutta toisena päivänä pappi pirskotti kuitenkin karjan vedellä, joka oli loppiaisena otettu Rosona-joesta. ${ }^{603}$ Toisaalla Kivisoo kertoo Iilian praasnikan vietosta Kotkon kylässä, jossa tytöt ja pojat eivät menneet riihen kuominaan, vaan ainoastaan isännät ja emännät: "Siel laulettii ja

\footnotetext{
${ }^{598}$ Nimettömäksi jäänyt nainen kertoi inkeroismurteella Iilian praasnikan vietosta ja esitti Soikkolan toisintoja vastaavan runon (SKVR III 2575; synnyinkylästä ks. 2569). Darja Lehti puolestaan kertoo, että olutta juotiin Iiljana ja Pedrona kuominassa. ”Tytöt ja nooret naiset - ken kehtas - laulovat, mäntii ymbrikkoo seel riihe koominas. Laulettii." Toisen Pedron kuvauksensa hän paikantaa selkeästi Soikkolaan: kun pappi oli pitänyt jumalanpalvelusta kuominassa eli "kuumnas" ja lähti kylälle, "siis tytöt ja pojat lauloi kuumnas." (SKS KRA Laiho L. 5168; Haavio 2770, 2774; yleisempi kuvaus ks. Haavio 2792.)

${ }^{599}$ Kivisoo kertoi myös käyneensä Tarinaisissa "pienen tyttön," ja siellä "Iiljan lauloivat." Kolmannessa yhteydessä hän kertoo käyneensä myös Koskisen kylässä Iilian praasnikoilla, jossa olutta juotiin illalla "ulkona, riihen luona." (SKS KRA Laiho L. 5359; Enäjärvi-Haavio 536; 790.)

${ }^{600}$ Erit. SKS KRA Enäjärvi-Haavio 536 (Anna Kivisoo). Darja Lehti mainitsi vain ympärikon: ”Tytöt ja nooret naiset - ken kehtas - laulovat, mäntii ymbrikkoo seel riihe koominas" (SKS KRA Laiho L. 5168) ja Anna Arehjevan mukaan virttä yksinkertaisesti "laulettiin piirissä" (SKS KRA Sääski 5333).

${ }^{601}$ SKVR III 2077-2079; ks. edempänä Martin ja Miikkulan päivästä.

${ }^{602}$ Julius Krohn (1894, 179-181) kertoo tosin samankaltaisesti Soikkolassa juhlavieraiden laulaneen riiheen tullessaan "pitkän tuliaisvirren, jossa pyytävät isäntää avaamaan oven ja antamaan juomista," ja Iilian virttä lauletun pöytään käydessä. Tässä kohden Krohn saattaa tosin pohjata kuvauksensa juuri Säkiltä tallennettuun muistiinpanoon, johon hän henkilökohtaisen W. Forsbergilta eli Vihtori Alavalta saamansa tiedonannon ohella myös viittaa.

${ }^{603}$ SKS KRA Laiho L. 5987.
} 
hypittii, ku saatii päät kihisemmää.” Ainoastaan alkusäkeellä viitatun Iilian virren laulamista ei tässä muistiinpanossa tarkemmin paikanneta, mutta asiayhteys viittaisi siihen, että sitä lauloivat vanhemmat ihmiset riihessä. ${ }^{604}$ Kotkon kylän Iilian praasnikoista on tallennettu melko paljon muistiinpanoja pässiuhrin ja pässin sisälmysten tai pään veteen uhraamisen yhteydessä: muualla ei kuitenkaan mainita Iilian virttä Väinö Salmisen yhtä nelisäkeistä muistiinpanoa lukuun ottamatta. ${ }^{605}$ Haavikon kylässä lauloivat Anna Hovaskinin mukaan tarkemmin määrittymättömänä hetkenä naiset, ja hänen esittämänsä runo poikkeaa samoin pilvien pois ajamisineen tyypillisestä Pedron virrestä, jossa sadetta nimenomaan pyydetään. ${ }^{606}$ Inkerinsuomalaislaulajat Valpuri Vohta ja Juljaana Pohjalainen sijoittivat muutaman säkeen Iilian virtensä Soikkolan kyliin ja Narvusin inkeroiskyliin eli kertovat inkeroisten perinteestä. ${ }^{607}$ Inkeroistaustaisen Sohvin mukaan Kallivieressä Iilian päivänä keitettiin olutta ja keräännyttiin kylän laidalla joen kaltaalla olevan uhriaitauksen luokse "illottelemaa" ja laulamaan. ${ }^{608}$

Matrona Bässinan mukaan Väikylässä Pedron virttä lauloivat oman kylän nuoret tytöt ja naiset läpi kylän kulkien praasnikoiden ensimmäisenä päivänä. ${ }^{609}$ Sekä Martti Haaviolle että Aili Laiholle hän kertoi virttä lauletun myös syömisen jälkeen, Laihon muistiinpanon mukaan kiitokseksi. ${ }^{610}$ Maria Feodorovna Kalasnikoff Väikylästä puolestaan kertoi, että kun naiset menivät jokeen huuhtomaan olutastioita "nii lustist lauloivad" Pedron virttä, jota hän ei kuitenkaan muistanut ensisäettä enempää. Astiat huuhdottiin riehakkaasti yleensä praasnikoiden 4.-6. päivänä. ${ }^{611}$ Sekä Bässina että Kalasnikoff muistivat tai halusivat esittää virrestä ainoastaan ensimmäisen säkeen Pyhä Pedro kormelitsa. Tässä muodossa alkusäettä onkin tallennettu ainoastaan Väikylän ja Haavikon kylistä. ${ }^{612}$ 1800-luvun lopulla Tun’animinen inkeroisnainen Väikylästä kyseli Pedron virren Alavalle Mapu-nimiseltä naiselta, joka ei uskaltanut sitä itse kerääjälle sanella. Tuna aloitti pitkän, tyypillisistä soikkolalaisista virsistä monin kohdin eroavan laulunsa samalla säkeellä kuin Bässina ja Kalasnikoff. Hän ei kertonut tarkemmin, koska tai miten laulu esitettiin, mutta kuvasi nelipäiväisiä pitoja syömisineen, oluen juomisineen ja olutastioiden huuhtomisineen. Hänen mukaansa Väikylässä oli viimeksi pidetty Pedron praasnikkaa kahdeksan vuotta takaperin eli vuonna 1884. Ei siis ole ihme, jos esimerkiksi vuonna 1851 syntynyt ja pitkin Länsi-Inkeriä elantonsa perässä kierrellyt Bässina ei 1930-luvulla enää muistanut käytöstä jäänyttä juhlarunoa pidemmälti. ${ }^{613}$

\footnotetext{
${ }^{604}$ SKS KRA Laiho L. 6000.

${ }^{605}$ SKVR III 4626. Pässiuhrista ks. Haavio 1961, 69-72; SKS KRA Haavio 2762, 2763, 2766; Laiho A. 2605, 3296; Laiho L. 4749, 5996, 6000.

${ }^{606}$ SKS KRA Laiho L. 5247.

${ }^{607}$ SKS KRA Salminen V. 3017; Haavio 2769.

${ }^{608}$ SKS KRA Salminen V. 2951.

${ }^{609}$ SKS KRA Haavio 2771, 2796.

${ }^{610}$ SKS KRA Haavio 2793; Laiho A. 2576.

${ }^{611}$ SKS KRA Salminen K. 341; astioiden huuhtomisesta ks. SKVR III 2098; SKS KRA Haavio 2763, 2796; Laiho A. 2576; Laiho L. 5227; ks. myös Krohn 1894, 179.

${ }^{612}$ Bässinan ja Kalashikoffin lisäksi Laiho L. 5247 Haavikosta; SKVR III 2051, erit. viite 1; 2098. Kormilitsa (ven.): syöttäjä, imettäjä (fem.) (VSSS).

${ }^{613}$ Bässinasta ks. Liite 1.
} 
Laulajina ovat siis narvusilaiskuvauksissa tytöt kallaalla (Ropsu), isännät ja emännät kuominassa (Kotko), naiset (Haavikko), tytöt ja naiset läpi kylän kulkien juhlan ensimmäisenä päivänä (Väikylä), määrittämättömät laulajat ruokailun jälkeen (Väikylä) tai naiset juhlien lopuksi olutastioita huuhtoessaan (Väikylä). Osa kuvauksista liittyy praasnikan myöhempiin päiviin, ei ensimmäiseen päivään, johon soikkolalaiset laulajat ja Soikkolasta kertovat narvusilaislaulajat säännönmukaisesti kerääjille laulamansa runot yhdistivät. Muihin tilanteisiin liittyvät virret eivät tietenkään sulje pois laulamista rituaalisessa oluenjuontitilaisuudessa. Ennemminkin ne kertovat juhlavirren laajemmista käyttömahdollisuuksista: kylän läpi mennessä, tyttöjen kaltaalla laulaessa, ruuasta kiittäessä, praasnikkojen lopuksi. Laulajien keskittyminen juuri näihin tilanteisiin ja Narvusiin viittaavien rituaalikuvausten puute viittaa nähdäkseni siihen, että Narvusin alueella Iilian tai Pedron rituaalit eivät olleet ainakaan 1930-luvun laulajien mielissä enää keskeisiä tai edes muistin ulottuvissa. Soikkolassa taas juuri rituaalinen oluenjuomisen tilanne korostuu niin, ettei runon mahdollisia muita käyttöjä edes mainita. ${ }^{614}$

\section{IILIA PYH ̈̈ IS ̈̈NT $\ddot{A}$}

Ilian ja Pedron virret erosivat toisistaan olennaisimmin ensimmäisten säkeittensä järjestyksen osalta. Iilian päivänä puhuteltiin ensin Iiliaa, sitten Pedroa, Pedron päivänä toisin päin. Tietyt toistuvat perusteemat yhdistävät pituudeltaan paljonkin varioivia versioita. Usein viisikymmensäkeisestäkin runosta lauloi Soikkolan Tarinaisista kotoisin ollut Naastoi 18-säkeisen Iljan päivän version:

Iilia, pyhä isäntä,

Pyhä Pedro armolliine,

Tye meille veerahisse!

Meill' on viinat, meill' oluet,

Meill' on saijat sarvelliist,

Kakut kahen-kuorelliist.

Tye olut-tynnyrin tyvvee,

Viinavaatin varjosee!

Laskii maaha taivosest',

Nossa pilvoi pikkarain,

Nossa harva hattarain!

Ei kazva kasessa kagra

Eikä noise notossa odra.

Liottele liinojamme,

Kastele kapustojamme,

Ojentele odriamme,

Ruttele rukehiiamm. ${ }^{615}$
Iilia pyhä isäntä,

Pyhä Pedro armollinen,

Tule meille vieraaksi!

Meillä on viinat, meillä oluet,

Meillä on sarven muotoiset vehnäleivät,

Kaksikuoriset kakut.

Tule oluttynnyrin viereen,

Viinatynnyrin varjoon!

Laskeudu maahan taivaasta,

Nosta pikkarainen pilvi,

Nosta harva hattarainen!

Ei kasva kaskessa kaura,

Eikä nouse notkossa ohra.

Liottele pellaviamme,

Kastele kaalejamme,

Ojentele ohriamme,

kiirehdi ${ }^{616}$ rukiitamme.

\footnotetext{
${ }^{614}$ Muisto keskeispraanikoista kantoi myös yllättävän kauas: vuonna 1976 Jekaterina Aleksandrova lauloi kerääjälle lyhyen Iilian virren, jota ei hänen mukaansa hänen elinaikanaan oltu enää käytetty. Hänen käyttämänsä sävelmä (22222222) ei enää noudattanutkaan varhaisempien länsi-inkeriläisten Iilian ja Pedron virsien muotorakennetta. (ERA RKM, Mgn. II 2843 z, w).

${ }^{615}$ SKVR III: 2255; pitkistä runoista ks. esim. SKVR III: 1570, 2098.

${ }^{616}$ IMS: ruttā, ruttīssa = kiirehtiä
} 
Naastoin versio sisältää Iljan ja Pedron päivän runojen keskeisimmät toistuvat teemat: pyhimyksen kutsun vieraaksi, juomien (ja ruokien) runsauden kuvauksen sekä sateen ja viljan kasvun pyytämisen. ${ }^{617}$ Nämä teemat voivat toistua eri muodoissa ja eripituisina. Toisin kuin liuku-, liekku- tai kokkovirsiin, Iilian ja Pedron runoihin ei sisälly mitään viitteitä erilaisten lyyristen tai eeppisten runoteemojen liittämisestä runon jatkoksi. Runo oli oma kokonaisuutensa, jonka jälkeen vaihdettiin rekisteriä hitaan juhlavasta riehakkaaseen tanssiin.

Hevaan Lenttisistä tallensi Volmari Porkka Varvana-eukolta pitkän Ukkovirren ${ }^{618}$ Porkka kertoo:

Ukkovirsi, tehty Lentisissä, lauletaan Pedroin pyhänä, 13 p:nä Heinäkuuta. Ken laulaa Ukko-päivänä, saa ensiksi maistaa olutta. Lentisin kylässä löytyy aidattu paikka, jossa ennen juotiin ukko-olutta ja luultavasti uhrattiin "palveltiin ukkoa". Vielä nytkin niillä paikoin olevan tuvan luona lauletaan Ukko-virsi. - Tämän runon laulaja, Varvana oli - - - nuorempana ollessaan tämän runon laulanut. (SKVR IV 1810.)

Lenttisten ukkovirrestä on kaksi hyvin samanlaista sävelmätoisintoa: ensimmäisen kirjoitti muistiin Eino Levón vuonna 1903, toisen äänitti Armas Launis kolme vuotta myöhemmin. ${ }^{619}$ Tarkemmasta esitystavasta ei Hevaalta ole tietoja. Launikselle esiintynyt nainen koki runon ilmeisen arkaluonteiseksi: toisin kuin lähes kaikista tuon matkan laulajista, hänestä tiedetään ainoastaan epiteetti "eräs akka", eikä Launis selvästikään saanut koottua kuoroa esilaulajan tueksi. Runo oli ainoa Launiksen Lenttisistä äänittämä laulu, joten hän ilmeisesti haki ukkovirren varta vasten. ${ }^{620}$

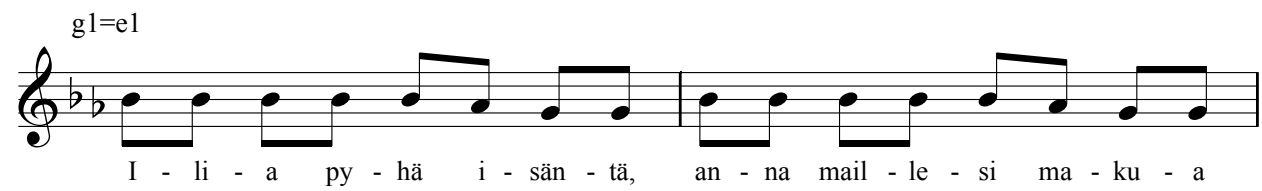

Nuotti 18. Lenttisten ukkovirsi (SKS KRA Levón 470).

Länsi-Inkeristä on ennen toista maailmansotaa tallennettu kolme Iilian virren sävelmätoisintoa Soikkolasta ja yksi Darja Lehden esilaulama toisinto vuoden 1937 äänityksissä. Lisäksi Launiksen Pärspäästä tallentamat säkeet Meil on viinat viijenlaiset, oluet meon sekaiset liittyvät yleensä Iilian tai Pedron virteen, joskaan ne eivät yleensä aloita varsinaita juhlavirttä - laulun säkeen loppupuoliskon kertaava

\footnotetext{
${ }^{617}$ Ks. SKVR-teemahakemisto: Iilian virsi; ks. myös NPI 33, 34.

${ }^{618}$ Runon keskelle sijoittuvaa kuvausta Sämpsöin keväisestä herättämisestä löytyy ainoastaan muutama toisinto Soikkolasta ja Hevaalta (SKVR III 1139; IV 4029; SKSÄ A301/L34 a; ks. myös Haavio 1961, 9-31; Varvanasta ks. Timonen 1970).

${ }^{619}$ SKS KRA Levón 470; SKSÄ A301/L34a.

${ }^{620}$ Myös Länsi-Inkerissä Vihtori Alavan (Forsberg 1893, 52; SKS KRA Alava VII B 8/25-9/26) oli mahdotonta saada Väikylässä asuvaa laulajaa laulamaan hänelle Ukko-virttä. Hän kertoo erään toisen naisen lopulta keräilleen hänelle laulun useammalta kylän akalta. (SKVR III 2098.)
} 
muotorakenne on kuitenkin sama kuin Soikkolan Iilianvirsien. ${ }^{621}$ (Ks. Liite 5: Pedron ja Iilian sävelmät.)

Sävelmät ovat kaikki yksisäkeisiä, refrengittömiä ja suppea-alaisia, mutta ne jakautuvat selkeästi alueen mukaan. Länsi-Inkerin sävelmät ovat kaikki samantyyppisiä säkeen lopun kertaavia suppea-alaisia sävelmiä, Lenttisistä kerätyt neli-iskuisia perussäkeitä. Läntiset toisinnot ovat peräisin kolmelta toisistaan riippumattomalta tallentajalta. Ne alkavat kaikki Iiliaa puhuttelevalla säkeellä.

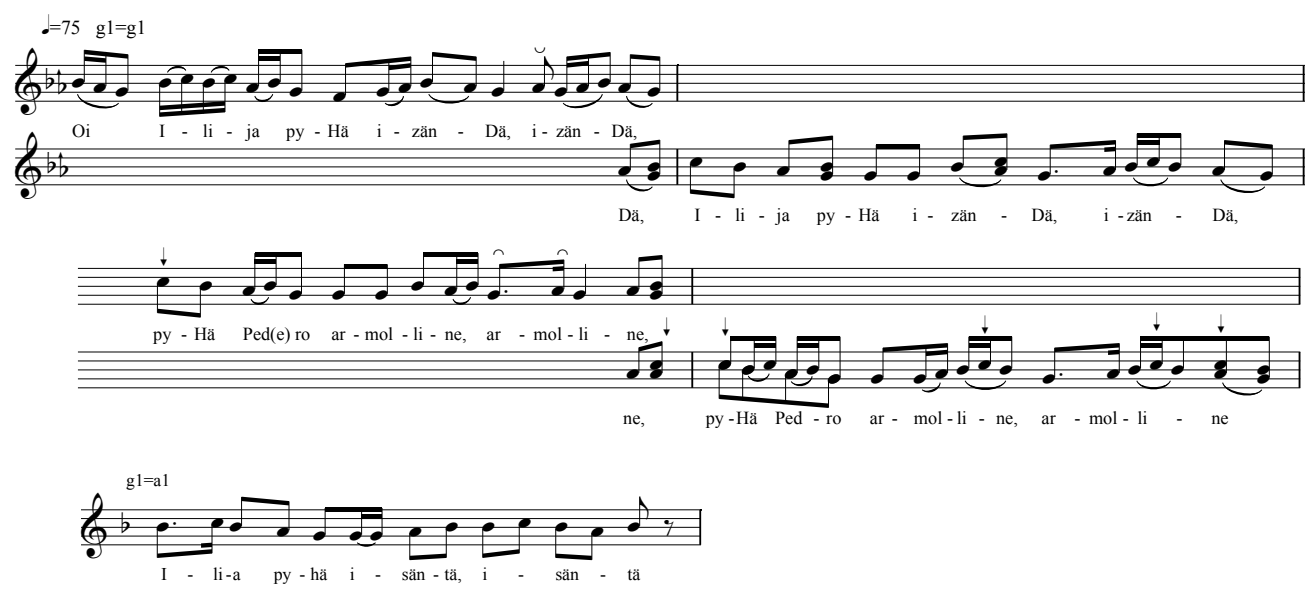

Nuotti 19. Soikkolan Iilian virren toisinnot Launiksen fonogrammilta ja Vihtori Alavan käsikirjoituksesta (SKSÄ A 300/47b, säkeet 1-2, nuotinnos Heidi Haapoja ja Kati Kallio; SKS KRA Alava VI a 826).

Vuoden 1938 äänitysten laulajat käyttivät samaa sävelmätyyppiä monien tanssilaulujen sävelmänä. Varsinaisista tanssilauluista poiketen Darja Lehti esilauloi Pedron virren hieman hitaammin ja rytmiä laulussaan korostamatta, eivätkä muutkaan laulajat lisänneet kuoro-osaan muiden tanssilaulujen rytmisiä kiljahduksia. Tämä sopiikin hyvin Lehden, Anna Kivisoon sekä soikkolalaisen Anna Arehjevan kuvauksiin laulun laulamisesta ympyrässä ilmeisesti hitaasti kulkien. Kaiken kaikkiaan Soikkolan ja siihen tiiviisti yhteydessä olevien ortodoksikylien (Joenperä, Pärspää) Iilian ja Pedron virsien rekisteri ja esitysareena näyttäytyvät korostuneen yhtenäisinä. ${ }^{62}$ Narvusin kylien kohdalla hajonta on suurempaa, mikä kertoo nähdäkseni juhlavirren monikäyttöisyydestä, mutta myös alueellisista ja kyläkohtaisista eroista sekä rituaalisten perinteiden käytöstä jäämisestä. Juhlavirren marginaalisuudesta tallennusaikana kertovat myös narvusilaisten tekstitoisintojen vähäisyys ja sävelmätoisintojen puute.

\footnotetext{
${ }^{621}$ SibA Launis 48; vrt. esim. SKS KRA Mannonen 7646. Säkeet liittyvät paikoin myös häissä ja praasnikoilla esitettäviin kokin kiitosvirsiin, esim. SKVR III 1605, 2515, 3015, 3338, mutta tyypillisimmin Iilian ja Pedron virsiin (ks. esim. SKVR-tietokannan haku "viina* viie ${ }^{\star "}$ ja "viina ${ }^{\star}$ viije $\left.{ }^{\star ”}\right)$.

${ }^{622}$ Toisen maailmansodan jälkeisiltä äänitteiltä löytyy muutama poikkeava länsi-inkeriläistoisinto. Joenperän vatjalainen Oudekki Figurova lauloi Iilian virren eräällä kerralla kuusi-iskuisella sävelmällä (44222244), joka on yleinen häälaulujen yhteydessä ja liittyy paikoin myös tanssikuvauksiin (ERA RKM, Mgn. II 1236 d; Rüütel 1977, 241, 256, sävelmä 81), kahdella toisella kertaa neli-iskuisella, yksisäkeisellä sävelmällä (Rüütel 1977, 227-228, 252, sävelmät 17 ja 18). Jekaterina Aleksandrova lauloi Iilian virren kaksisäkeisellä, neli-iskuisella perussävelmällään. Hän kertoi Venakontsan kylässä vietetyn ennen Iilian praasnikkaa, mutta hänen aikanaan ei enää riihissä olutta keitetty eikä laulua laulettu. (ERA RKM, Mgn. II 2843 z.) 1900-luvun jälkipuoliskolla aikaa sitten käytöstä jääneen Iilian virren sävelmä ei selvästi enää ollut vakiintunut.
} 


\section{TALVEN KIERTUEET}

Talvikauden juhlien kuvaukset painottuvat länsi-inkeriläisessä aineistossa kolmeen ajankohtaan: Martin ja Miikkulan eli Nikolauksen päiviin sekä joulun ja loppiaisen väliin. Näihin liittyy runsaasti talosta taloon kestittävänä tai antimia pyytäen kiertämisen, laulamisen ja naamioitumisen kuvauksia. Kaksi kiertämisen yhteydessä usein toistuvaa termiä ovat igrǐ̌šat ja kiletoiminen, joista igriššat on suora johdos venäjän kisailu-sanasta igrištše, kiletoi luultavasti talvisia kulkueita ja kulkuelauluja tarkoittavasta slaavilaisesta koleda/koljada-termistä, jota on paikoin käytetty myös näiden laulujen refrenkinä (Mansikka 1929, 313 ks. myös Čistov 1976b, 199-201).

Lukkarinen (1911, 63-74) käsittelee Martin, Miikkulan ja joulukauden lauluja niitä toisistaan erottelematta. Miikkulan (Nikolauksen) päivä näyttää menneen sekaisin erityisesti luterilaisten Mikkelinpäivän kanssa (esim. Launis 1910b, IX-X; Lukkarinen 1911, 63-64; Simonsuuri 1972, 49). V. J. Mansikka (1938) sen sijaan tarkastelee lauluja kahtena kokonaisuutena: kiletoivirsina (Miikkulan päivä ja joulu) sekä Martinvirsinä. Martinvirret ovat hänen (mts., 232, 236) huomionsa mukaan hyvin samankaltaisia kuin virolaiset vastineet, jotka puolestaan muistuttavat saksalaisia lauluja. ${ }^{623}$ Praasnikka- ja kiletoivirsien nimellä kulkevat runot muistuttavat sen sijaan enemmän slaavilaisia koleda-lauluja, vaikka niillä onkin joitain yhteisiä piirteitä myös Martinlaulujen kanssa (mts., 237). Kutsun Marttia puhuttelevia runoja tässä Martinvirsiksi, Miikkulaan ja joulupyhiin liittyviä kiletoivirsiksi. Kuten Väinö Salminen (1917, 204, 334-335, 367) huomauttaa, kumpaakin runoryhmään liittyvillä teemoilla on joitain yhteyksiä myös häälauluihin. ${ }^{624}$

Vaikka sekä näiden kahden runoryhmän kuvauksiin että itse runoihin sisältyy päällekkäisyyksiä, on aineistossa silti selkeitä painotuksia. Liitteeseen 5 taulukoitujen muistiinpanojen perusteella runoteemat, ajankohdat ja käytetyt termit jakautuvat. Vaikka sekä Martinvirressä että kiletoivirsissä keskeisenä toistuva aihe on kestityksen pyyntö, painottuvat pyynnöt Martinvirsissä ruuan, kiletoivirsissä taas oluen tai rahan pyytämiseen. Lisäksi Martinvirret ovat yleensä lyhyempiä: siinä missä aineiston pisin Martinvirsi on 41-säkeinen, on pisin kiletoivirsi 227-säkeinen. ${ }^{625}$ Igriššat-termi liittyy narvusilaisaineistossa joulun ja loppiaisen välipäivien ohella ainoastaan Martin päivään, kiletoi puolestaan Narvusissa ja Soikkolassa joulunajan ohella ainoastaan Miikkulan praasnikkaan. Nämä aineistoa halkovat rajalinjat an-

\footnotetext{
${ }^{623}$ Virolaisyhteyksistä ks. myös SKVR III 231; XIII4:11093, 11094.

${ }^{624}$ Ks. myös pulmavirreksi nimetty SibA Launis 30 (Laskaa suojahan väkeni).

${ }^{625}$ SKVR III 2826, 1565.
} 
tavat aihetta Martin päivän ja Miikkulan päivän sekä igriššat- ja kiletoi-kuvausten käsittelemiseen omina ryhminään. ${ }^{626}$

\section{MARTIN PÄIVÄ JA VIRSI}

Martin päivä yhdistää kahden Martin juhlinnan: se oli alkujaan pyhimys Martinuksen päivä, jonka aattona vietettiin myöhemmin myös Martti Lutherin päivää (Mansikka 1938). Martinpäivänä vilja oli saatu korjattua ja paimenet pääsivät vapaalle karjan siirtyessä takaisin sisätiloihin (Lukkarinen 1911, 64). ${ }^{627}$ Keskeisinä juhlan kuvauksissa toistuvat talosta taloon kiertäminen ja ruuan pyytäminen, usein myös naamioituna kulkeminen sekä tanssiminen. Martinpäivän kiertäjiksi ja laulajiksi mainitaan tytöt, lapset, pojat tai paimenet. Joskus painotetaan, että kiertämässä kävi ainoastaan jokin näistä ryhmistä tai rajataan jokin ryhmä ulkopuolelle, esimerkiksi että "suuret eivät käyneet korjaamas." ${ }^{28}$ Useammassa kuvauksessa kerrotaan, että antimien korjaamisen jälkeen kokoonnuttiin yhteen taloon, missä saadut ruuat keitettiin. ${ }^{629}$ Martinvirren esittäjissä on sekä luterilaisia että joitain inkeroisia. ${ }^{630}$

\footnotetext{
Tups, tups, tups, Martikkine,

Siiher saaher Santikkine,

Ei ole Martti maasta tullut,

Martti on tullut taivahasta

Kultasta korentaa myö(ten),

Hopiaista ortta myö(ten),

Vaskista varoa myö(ten).

Tuokaa Martille munia,

Saakaa Santille papuja. ${ }^{631}$
}

Varioivilla Marttia puhuttelevilla säkeillä kuten Hups hup hups hups Martikkine tai Sittur sattur Martikkine alkava runo liittyy aineistossa aina Martin päivään. Sitä on

\footnotetext{
${ }^{626}$ Kiertueperinteitä ja oma laulunsa liittyi myös tapaninpäivään. Kuvauksia on tallentunut erityisesti Pohjois-Inkeristä: "Tahvananpäivänä kulettiin ennen talosta taloon. Hevonen ajettiin suoraan tupaan ja sille annettiin pöydältä olutta juoda. Tahvanan virttä veisattiin taloon tullessa," kertoi Tapanin virtensä yhteydessä pohjoisinkeriläinen inkeroinen Ontropo Melikov, laajarepertuaarinen mieslaulaja (SKVR V1 518). Runotekstejä on Länsi-Inkeristä tallennettu lähes 20, mutta kuvauksia niukalti ja sävelmiä ei yhtäkään, joten tapaninpäivä jää tässä yhteydessä tarkemmin käsittelemättä. Hevaalta Launis tallensi yhden yksisäkeisen, viisi-iskuisen sävelmän (SKSÄ 301/36a). Yksi kontekstimaininta löytyy Narvusista, jossa Anni Porissa kertoi, että ” Tahvana-iltan' käyvää(n) piiat laulamass' ja tantsimass' ja nuoret pojat ja joka talossa. Siis kun ei lastu heitä tuppaa(n), siis piikoilla piti olla kirja, piti viijä passi tuppaa(n). Miehet siis humalassa luettii(n) sitä kirjaa, vanhoi kirjoi, kunhan oli läkki päällä! Siis luettii(n) vanhat miehet." (SKVR III1 897). Ks. SKVR-hakemisto: Tapanin virsi.

${ }^{627}$ SKS KRA Laiho A. 2571, 3176.

${ }^{628}$ SKS KRA Laiho L. 5362; ks. myös Laiho L. 5990 ("täystytöt," eli vanhemmat tytöt). Välillä naamioituneet kiertäjät mainitaan erikseen, omissa vaatteissaan oleva laulajatytöt erikseen (SKS KRA Laiho L. 5990; Laiho A. 2339). Valpuri Saksan mukaan lapset kävivät Marttina kiertämässä, mutta "ennen naisetki" (SKS KRA Laiho A. 2339).

${ }^{629}$ SKS KRA Haavio 2717, 2719; Laiho A. 2341, 2342; Laiho L. 4750, 5362, 5990.

${ }^{630}$ Anna Kivisoo kertoo kylän luterilaisten ja inkeroisten tyttäjen käyneen yhdessä "Martin santissa" (SKS KRA Laiho L. 5990), mutta inkeroinen Matrona Bässina sijoittaa Martin virtensä Vyötermaan luterilaisten suuhun (SKS KRA Haavio 2718).

${ }^{631}$ SKVR III 3531, Kurkola.
} 
tallennettu Narvusista ja Lavansaarelta, mutta Soikkolasta ei löydy yhtään toisintoa. Tyypillisimmillään runossa kerrotaan Martin tulleen taivaasta ja pyydetään sen jälkeen isäntäväkeä hakemaan laulajille syötävää. ${ }^{632}$ Runoon voi liittyä myös ajankohtaa määrittävä, sananlaskunomainen Martti maalle, karttu jäälle, paimenet kylän kululle -teema sekä erilaisia kiitos- ja moittimisteemoja joko erillään kerrottuna tai osana samaa runoa. ${ }^{63}$ Suurin osa runoista on 5-25-säkeisiä, mutta Narvusin inkerois-inkerinsuomalaiskylistä on tallennettu myös kolme 36-41-säkeistä joko muitakin teemoja tai muutamia kiletoivirsissä yleisiä aihelmia sisältävää runoa. ${ }^{634}$

Jos laulamista tarkemmin kuvataan, kerrotaan sen tapahtuneen tuvassa ympärikossa tai yleisemmin vain tanssien. ${ }^{635}$ Valpuri Saksa kertoi, että laulajilla "oli vakat käes. Toiset tantsivat." ${ }^{36}$ Tupaan päästyä tai ruuankeräyksen jälkeen yhteen kokoontuessa mainitaan myös tanssitun. ${ }^{637}$ Tanssien laulaminen sointuu yhteen myös keskeisaineiston ainoan Narvusista tallennetun sävelmätoisinnon kanssa. Tatjana Jegorovan esilaulama säkeen lopun kertaava yksisäkeisen sävelmän muotorakenne ja tyyppi on sama kuin näiden äänitysten tanssisävelmien. Laulu on rytmikästä, mutta kaksipäiväisten äänitysten lopulla hieman väsyneen kuuloista. Lisäksi Lavansaarelta on tallennettu yksi yksisäkeinen, neli-iskuinen ja melodian muunnelmia sisältävä sävelmä.

$\begin{array}{llllll}\text { Paikkakunta } & \text { Vitte } & \text { Muotorakenne } & \text { Rytmi } & \text { Melodian PituUs } & \text { Sävelala } \\ \text { Narvusi (1937) } & \text { SKS L 101 a } & 123456785678 & 222222222244 & \text { säe } & 6 \\ \text { Lavansaari (1914) } & \text { KRS } 127 & 12345678 & 22222222 & \text { säkeen variaatioita } & 5\end{array}$

Narvusin lisäksi Martinvirttä onkin tallennettu runsaasti juuri Lavansaarelta. ${ }^{638}$ Esittäjinä Lavansaarella mainitaan käännettyihin turkkeihin pukeutuneet tai muuten naamioituneet nuoret miehet, pienet pojat, lapset ja vanhat miehet, jotka keräsivät ruokatarpeita omia pitojaan varten tai elämisen avuksi. ${ }^{639}$ Kahdessa muistiinpanossa mainitaan viinan pyytäminen. ${ }^{640}$ Kuvaukset virren esittämisestä kertovat riehakkaan vapaamuotoisesta laulamisesta: laulettiin ringissä, tanssittiin, hakattiin

\footnotetext{
${ }^{632}$ Oluen mainitsee runossaan ainoastaan inkeroislaulaja Matrona Bässina (SKS KRA Haavio 2718; kertojan muista informanteista poikkeavista tiedonannoista ks. Liite 1).

${ }^{633}$ Ainoan Martinvirteen liittyvän sisäänpääsynpyyntörunon esitti Valpuri Saksa ennen varsinaista Martinvirttään (SKS KRA Laiho A. 2339).

${ }^{634}$ SKVR III 2614 (myös Revon itku sekä Taikina-Matti); 2746 (myös kiletoivirsien teemoja), 2826 (myös kiletoivirsien teemoja). Ks. tarkemmin SKVR-hakemisto: Martinpäivänä; Mansikka 1938, 236.

${ }^{635}$ Ympärikossa: SKS KRA Laiho L. 2345; 5990, 5362; 4750; tanssien: SKS KRA Haavio 2717; Laiho A. 2138, 2341

${ }^{636}$ SKS KRA Laiho A. 2339.

${ }^{637}$ SKS KRA Laiho A. 2138, 2339, 2341; ruuankeräyksen jälkeen: Laiho A. 2342

${ }^{638}$ Mansikka 1938; SKVR XIII 4902-4913, 11092; 11093-11094 Tytärsaarelta. Ainoassa Seiskarilta tallennetussa toisinnossa kerrotaan Martin vietosta nimenomaan Lavansaarella (SKVR XIII 4901).

${ }^{639}$ SKVR XIII 4901, 4903, 4904, 4906, 4910, 4912, 4913, 11092. Maria Klausin mukaan naiset eivät käyneet kiertämässä (SKVR XIII 4913).

${ }^{640}$ SKVR XIII 4901, 4913.
} 
jalkaa, "jollakin tapaa hypättiin." ${ }^{641}$ Myös kahta vuonna 1935 tallennettua mainintaa sävelmästä leimaa tietty epämääräisyys: "ei laulussa mitään erikoista säveltä ole," "sitä laulettiin niin kuin kukin halusi ja taisi." ${ }^{42}$ Kuvaukset sopivatkin mihin hyvänsä suppea-alaiseen ja muuntelevaan yksi- tai kaksisäkeiseen sävelmään. Tytärsaarelaisen Eeva-Liisa Kiisken mukaan "Viros käyvät tantsimas Martin santtina. Sielt ne oppiit laulunkin." ${ }^{643}$ Virossa Katariinan ja Martin päiviin (Kadri ja Mardi) onkin liittynyt runsaasti kiertue- ja lauluperinnettä. Martin päivä oli miesten, Katariinan päivä naisten kiertuepäivä. (Hiiemäe 1998, 223-237.) ${ }^{644}$

Martinvirsiä on siis tallennettu runsaasti ensimmäisestä keräjästä 1930-luvulle asti, mutta ainoastaan Narvusista ja Lavansaarelta. Ne liittyvät ainoastaan Martin päivään, joskin niissä on muutamia yhteisiä teemoja kiletoivirsien kanssa. Martinvirsien kontekstitietoihin sisältyy paljon kuvauksia naamioitumisesta, laulun esittämistä tanssien ja ruuan keräämisestä.

\section{MiIKKUla, JOULUPYHÄT JA KILETOIVIRSI}

Miikkula eli Nikolaus oli etenkin Soikkolan kalastajakylissä keskeinen pyhimys, meren herra. Hänen joulukuun kuudennen päivän praasnikkaansa vietettiin monessa Soikkolan inkeroiskylässä ja paikoin Narvusissakin neljä päivää. ${ }^{645}$ Paraskeva Kaurilan mukaan hänen praasnikkaansa vietettiin, "että meri jäätyisi" ja kalastajat pääsivät talvikalaan. ${ }^{646}$ Hän oli myös karjan suojelija, jota saatettiin Pyhän Jyrkin ohella puhutella lehmiä laitumelle laskettaessa (Mansikka 1941a; Waronen 1990, 82-83) ${ }^{647}$ Jokseenkin kaikilla Miikkulaan liittyvillä tavoilla ja uskomuksilla on Mansikan (1941a, 192) mukaan vastineensa itäslaavilaisilla. Miikkulan päiviä oli kaksi, niin kutsuttu talvi-Miikkula (6.12.), josta tässä luvussa on kysymys, sekä kevät-Miikkula (9.5.) (mts., 179). ${ }^{648}$

Kiletoi-nimitys esiintyy aineistossa kahta poikkeusta lukuun ottamatta ainoastaan Miikkulan ja joulunpyhien yhteydessä. ${ }^{649}$ Näihin päiviin liittyvä juhlalaulu saatettiin nimittää kiletoivirreksi, laulu saatettiin aloittaa kiletoi kaletoi -säkeellä, sitä laulamassa kiertävät tytöt voitiin nimetä kiletoijiksi tai itse runossa saatettiin viitata

\footnotetext{
${ }^{641}$ SKVR XIII 4906; 4912; 4910; 4913; ks. myös Simonsuuri 1972, 50. Eevert ja Anni Mulli kuvasivat tanssia vapaamuotoiseksi: "Tuvassa pyytäessään tanssivat, tai oikeastaan hyppäävät 'kunhan vain"' (SKVR XIII 4912).

${ }^{642}$ SKVR XIII 4912; 4913

${ }^{643}$ SKVR XIII 11094.

${ }^{644}$ Kadrin päivän viettämisestä mainitsee länsi-inkeriläisaineistossa ainoastaan Matrona Bässinä yhdellä lauseella (SKS KRA Haavio 2718).

${ }^{645}$ Esim. SKVR III 3496; SKS KRA Laiho A. 2588; Laiho L. 5989; Sääski 5328, 5344.

${ }^{646}$ SKS KRA Sääski 5345; ks. myös Mansikka 1941a, 181-183.

${ }^{647}$ Ks. myös SKVR III 4627; SKS KRA Sääski 5088, SKS KRA Levón 369, 473. Nikolaukselle pyhitettyjä kirkkoja oli Länsi-Inkerissä ja Kapriossa jo vuonna 1500 kolme (Kirkinen 1991, 59).

${ }^{648}$ Venäjän ajanlaskun ero teki sen, että käytännössä "miikkulan praaznikka oli suunnilleen meidän joulumme aikoihin" eli 19.12. (IMS, s. 312).

${ }^{649}$ Poikkeukset: SKS KRA Haavio 2731 (joulun ja loppiaisen välissä, kertoi Matrona Bässinä); Haavio 2733 ja Laiho L. 5363 (Anna Kivisoon mukaan giletoimas käytiin Soikkolassa Pedron päivänä, tästä enemmän luvun lopussa).
} 
laulajiin kiletoijina. Sanan runko esiintyy monessa muodossa: kiletoi, giletoi, gilidoi, geletoi. ${ }^{650}$

Jo runoissa itsessään kerrotaan, mistä laulutilanteessa oli kyse: pyydettiin päästä tupaan sisälle kun oli talvi ja kylmää, pyydettiin kestitystä - etenkin olutta - ja tanssittiin. Näitä teemoja toistavat myös kontekstitiedot. Ajankohta oli ilta. ${ }^{651}$ Länkelän mukaan kiletointi oli sama kuin "tyttöin anomassa käynti". ${ }^{652}$ Laulajina mainitaankin aina tytöt, jotka "käyvät pitkin taloja," vuoroin jokaisessa talossa laulamassa ja tanssimassa. Joskus mainitaan mukana kulkemassa myös pojat. ${ }^{653}$ Laulajille annettiin "rahaa, olutta ja viinaa" ja he saivat syödäkseen ja juodakseen. Ensimmäinen viinaryyppy kuului esilaulajalle. ${ }^{654}$ Toisin kuin Martinvirsien kohdalla, kiletoivirsien yhteydessä ei mainita naamioitumista eikä ruuan keräämistä mukaan. Miikkulaan ja jouluun liittyy etenkin inkeroisilla myös yleisempiä praasnikkakuvauksia: keitettiin olutta, pappi kävi taloissa siunaamassa, kävi vieraita, syötiin ja juotiin; tanssittiin, soitettiin ja laulettiin, tapeltiin. ${ }^{655}$

Miikkulaan, joulupyhiin tai kiletoi-nimitykseen liittyviä runoja on aineistossa 18, minkä lisäksi löytyy neljä sisällöltään ja rakenteeltaan näitä läheisesti muistuttavaa kontekstitiedotonta toisintoa (ks. Liite 5: Kiletoivirret). ${ }^{656}$ Miikkulaa ei runoissa puhutella, mutta runon alussa saatetaan mainita Jumalan kulkevan laulajien mukana: Tulloo Luoja joukkonee, Jumala perehinnee, Kiesus kenkäpoikineen. ${ }^{657}$ Neljä säettä toistuu laulujen aloitussäkeenä. Näistä Kiletoi kaletoi liittyy aina Avatkaa uksianne -teemaan, joka puolestaan esitetään välillä irrallisena: se laulettiin talon ulkopuolella tai eteisessä. ${ }^{658}$ Taloon sisään tultua saatettiin esittää tervehdys hyvää iltaa terve teille (tai taloihe) tai puhutella suoraan isäntäväkeä. Isäntäväen (yleisimmin peremies pereisäntä) puhuttelua toistettiin yleensä myös useassa kohtaa pitkin laulua, ja se esiintyykin kahta runoa lukuun ottamatta jokaisessa toisinnossa. Tutkimuksen aineistossa nämä säkeet näyttäytyvät nimenomaan kiletoivirsille tyypillisinä, mutta osaa - kuten myös runon jatkon teemoja - löytyy myös häälauluis-

\footnotetext{
${ }^{650}$ Esim. SKVR III 227, 1047, 1566, 2041, 2282, 2358, 3496; Ankeria 209; Laiho L. 5363; Salminen K. 216.

${ }^{651}$ SKVR III 227, 1047, 1565, 4234.

${ }^{652}$ SKVR III 3657.

${ }^{653}$ SKVR III 1047, 1565, 2358, 3496; laulusta ja tanssista: SKVR III 2014, 2310, 2284, 3493; SKS KRA Ankeria 209; pojat mukana: SKVR III 1897, 2282; SKS KRA Ankeria 209.

${ }^{654}$ Viinaa ja olutta: SKVR III 1047, 3657, 1903, rahaa: SKVR III 2358, SKS KRA Sääski 5343, Ankeria 209; viinaryyppy esilaulajalle: SKVR III 1900; kestitystä: SKVR III 227+4234, 228, 230, 1567, 2310 2282, 2283; SKS KRA Sääski 5343, Ankeria 209. Jos talossa oli vieraita tai matkalaisia, laulajat pyysivät näiltäkin rahaa (SKVR III 227+4234, 1047, 1903, 3914).

${ }^{655}$ Erit. SKS KRA Enäjärvi-Haavio 799-801, inkerinsuomalaisilta Enäjärvi-Haavio 802-815; Laiho A. 2588, 2607; Laiho L. 5228; Sääski 5345.

${ }^{656}$ Tarkempi taulukko runoista löytyy liitteestä 5. Kontekstitiedollisista runoista seitsemän liittyy Miikkulaan, kuusi toiseen joulupäivään tai yleisemmin joulupyhiin ja viisi nimetään vain praasnikkarunoik si tai kiletoivirsiksi. Joko runossa tai kontekstitiedoissa esiintyvä kiletoi-termi liittyy näistä 18 runosta kolmeentoista ja lisäksi löytyy kaksi kontekstitiedotonta runoa, joiden säkeissä puhutaan kiletoijista Kahdessa muistiinpanossa kiletoi-termi tai kiletoivirsiä noudattava runo kytketään Pedron praasnikkoihin; näitä käsitellään tarkemmin kiertuetapojen muutosten kohdalla (SKVR III 2077 ja 2079; SKS KRA Laiho L. 5363).

${ }^{657}$ Esim. SKVR III 1568.

${ }^{658}$ SKVR III 1565, 3493; SKS KRA Ankeria 209; kuten myös Laske suojaan väkeni -teema SKVR III 1047, 3915; ks. myös SKVR III 228+3657.
} 
ta. ${ }^{659}$ Näiden puhuttelujen jälkeen seuraa erilaisia teemoja, joista keskeisimpiä ovat oluen tai rahan pyytäminen sekä lopuksi erilaiset kiitokset ja hyvän toivotukset tai moitteet, jos mitään ei annettu. Saatettiin myös eri tavoin kuvata saapuvaa joukkoa, pyytää lupaa tulla tanssimaan tai kysyä onko tupa tai riihi lakaistu. ${ }^{600}$ Miikkulan viettoon tai kiletoi-nimitykseen liittyvät laulut ovat keskimäärin huomattavasti Martinvirsiä pidempiä, yleensä 50-150-säkeisiä; pisin on Väärnojan luterilaiskylän Kati-akan laulama 227-säkeinen kokonaisuus. Teemat voivat liittyä toisiinsa monin tavoin ja eri järjestyksessä.

Muutamassa kuvauksessa runoissakin mainitusta tanssimisesta kerrotaan tarkemmin. Tytöt tanssivat tupaan tullessaan tai laulaessaan tuvan lattialla eli "pertin maassa"; he lauloivat "käyden tai tanssien ympäri"; aterioituaan he kävivät ympäri tupaa, "plakuttivat" käsiä ja lauloivat; ulos päästyään he tekivät pihalla suuren piirin (kruga) ja kylän lapset "mörnivät" tyttöjen jäljessä. ${ }^{661}$ Mörniminen tarkoittaa huutamista, joten viimeinen kuvaus viittaa hyvin kovaääniseen laulamiseen. ${ }^{662}$

Vaikka suuri osa kiletoivirren pitkistä toisinnoista on tallennettu inkeroisilta tai vatjalaisilta, on tarkin kuvaus luterilaisesta Kaipaalan kylästä kotoisin olevan Anni Porissan antama. Hän lauloi sekä Volmari Porkalle että Vihtori Alavalle pitkän kiletoivirren. Porkan tallentama virsi julkaistiin yhtenä lyhyiden kontekstitietojen katkomana runona, Alavan useampana peräkkäisenä toisiinsa liittyvänä runona ja pidemmin selityksin varustettuna. ${ }^{663}$ Alavan versiossa tapahtuma alkoi "passin" lukemisella: humalaiset miehet lukivat tyttöjen ulkona heille antamaa "vanhaa kirjaa." ${ }^{664}$ Sillä aikaa tytöt lauloivat porstuassa pyytäen peremiestä päästämään väki sisään, kunnes isäntä avasi uksen. ${ }^{665}$ Tytöt kiittivät laululla sisäänpääsystä. Sen jälkeen he pyysivät pitkällä laululla rahaa ja olutta. Porissa kertoi: "Tätä laulaissa tantsitaan ringissä, yksippäin ja toisippäin. Toine(n) käyp’ toisens' perässä.” Ainoastaan tytöt tanssivat. Ketään ei ollut piirin keskellä. ${ }^{666}$ Tämän jälkeen annettiin ensin viinaa ja sen päälle olutta kaikille, esilaulajalle ensimmäisenä. Tytöt kiittivät antimista toivottamalla laululla perheenjäsenten kotieläimille menestystä ja perheen pojalle metsäonnea. Laulaessa tanssittiin, ja samalla "visataa(n) jalkaa ja lyyään, niin että kumisee," kertoi Porissa. ${ }^{667}$ Sitten poistuttiin tuvasta laulaen ja jäätiin talon eteen eli "ikkun'alle" laulamaan. ${ }^{668}$ Lopuksi Porissa lauloi vielä runot, jotka laulettiin rahan

\footnotetext{
${ }^{659}$ Esimerkiksi kiletoivirsiin liittyvät kiitososiot saattoivat olla samankaltaisia häiden lopun kiitoslaulujen kanssa (esim. Laiho A. 2182; Laiho L. 4848). Peremies pereisäntä -säe löytyy taulukon aineiston lisäksi muutamasta tuvanpyyntölaulusta sekä yhdestä Martin virttä edeltävästä irrallisesta sisäänpääsypyynnöstä (SKVR III 2433, 3739; SKS KRA Laiho A. 2339). Hyvää iltaa -toivotus löytyy kahden ja Avatkaa uksianne neljän häälaulun alusta, joskus lankoiseni lintuiseni -puhuttelun jäljessä (SKVR III 3005, 3335; SKVR III 1716, 2501, 2542, 3016).

${ }^{660}$ Ks. Liite 5: Kiletoivirret; ks. myös Mansikka 1929.

${ }^{661}$ SKVR III 2041, 2284, 3493; SKS KRA Ankeria 209.

${ }^{662}$ IMS : mörnää.

${ }^{663}$ SKVR III 1047; 1897-1904.

${ }^{664}$ SKVR III 1897.

${ }^{665}$ SKVR III 1898.

${ }^{666}$ SKVR III 1899.

${ }^{667}$ SKVR III 1900.

${ }^{668}$ SKVR III 1901-1902.
} 
pyytämiseksi talossa olevilta muilta vierailta ja näiden kiittämiseksi. Hän tarkensi vielä tanssin kuvaustaan: " Tantsiessa lyyää käsiää yhtee(n), ja monet lyövät solkkuu" eli napsuttivat sormiaan. ${ }^{669}$ Porissan kuvaus vastaa kaikin puolin nopeaa eli tihtii ympärikossa tanssimista erilaisine variaatioineen. Alava tallensi myös Porissan laulun neli-iskuisen, suppea-alaisen sävelmän rungon: ${ }^{670}$

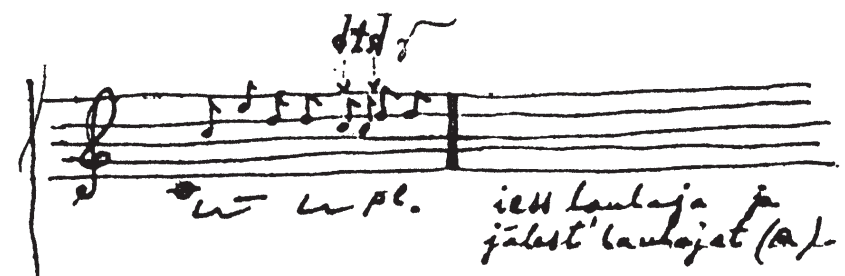

Nuotti 20. Anni Porissan kiletoivirren sävelmä Alavan pikakirjoitusvihkossa (SKS KRA Alava pk IV 706).

Tämä on ainoa varma kiletoivirteen liittyvä sävelmä. Matti Kuusi (1983b, 59) on arvellut sen linkittyvän slaavilaiseen koleda-sävelmistöön. Porissan sävelmän lisäksi on kuitenkin tallennettu useampi kiletoivirsien tyypillisiin alkusäkeisiin liittyvä kontekstitiedoton sävelmä. ${ }^{671}$ Näistä Oussimäen Teppanjalta tallennetun yhteydessä Alava tallensi myös runon. ${ }^{672}$ Launis puolestaan merkitsi kahteen narvusilaissävelmäänsä runoa neljä säettä: peremies pereen isäntä, perennainen naisukkainen, lupailetko tupaistasi, lainailetko lattiatasi. ${ }^{673}$ Anna Kivisoo aloitti esilaulunsa myös samoin säkein vuonna 1937, mutta laulu on sisältönsä ja Kivisoon antamien kontekstitietojen pohjalta tulkittavissa yleisemmäksi ja kiletoivirsiä lyhyemmäksi nuorison tanssituvanpyyntörunoksi (Peremies, pereisäntä, perenaine naisukkaine: luppaat meille tupahaista, kussa tantsu lyyväkseni...), mitä toki voivat olla myös Launiksen tallentamat sävelmät. Toisin kuin nämä, Kivisoon laulu poikkeaa kuitenkin oi galina lee -refrenkeineen ja rytmirakenteineen (22442244) muista, sangen yhtenäisen ryhmän muodostavista sävelmistä. ${ }^{674}$

Kaikki varsinaisiin kiletoivirsiin mahdollisesti liittyvät sävelmät ovat yksisäkeisiä, refrengittömiä, kolmen tai neljän sävelmän alalla liikkuvia neli-iskuisia sävelmiä (ks. Liite 5: Kiletoi-sävelmät). Kiletoivirret ovat ainoa konteksti, jossa neli-iskuinen, yksisäkeinen, suppea-alainen sävelmä liittyy selkeästi nopeaan ja riehakkaaseen ympärikkotanssiin. Tämä ei tietenkään tarkoita sitä, etteivätkö tämänkaltaiset

\footnotetext{
${ }^{669}$ SKVR III 1903-1904.

${ }^{670}$ SKS KRA Alava pk IV 706.

${ }^{671}$ Näistä pois on jätetty käsikirjoituksen mukaan pulmavirsiin eli häälauluihin kuuluva SibA Launis 30 (Laskaa suojahan väkeni).

${ }^{672}$ SKVR III 2310-2012.

${ }^{673}$ Säe esiintyy SKVR:ssä muodoissa Lainaell' et lattiaas (III 227), Lainaele lattiais (III 2077), Lainaelet lattiata (III 2433). Toisessa sävelmäkäsikirjoituksessa (SibA 131) sanojen sijoittuminen säkeen alle on osin tulkinnanvaraista erityisesti tavuluvultaan vajaassa perenain naisukkaine -säkeessä. Melodiajaksoltaan puolisäkeiset yksisäkeiset neli-iskuiset sävelmät ovat yleensä tasajakoisia, joten tulkitsen rytmin käsikirjoituksen ensimmäisen ja toisen sävelmäsäkeen mukaisesti. Julkaistun sävelmän (IRS 756) toisen sävelmäsäkeen muunnelma on painovirhe.

${ }^{674}$ SKSÄ L 87d; SKS KRA Enäjärvi-Haavio 835b; Laiho L. 5343, 5989; Salminen K. 241. Enäjärvi-Haavion käsikirjoituksen mukaan Kivisoo esitti saman runon myös säkeen lopun kertaavalla tanssisävelmällä.
} 
sävelmät olisi voineet myös olla yleisiä tanssisävelmiä ja jäädä vain tanssisävelmien moninaisuuden keskellä huomiotta. Kattilan alueelta on tallennettu hyvin samantyyppisiä kiletoivirsiä ja -kuvauksia kuin Länsi-Inkeristä675 sekä neljä Peremmeez pereizätä, perennaine naizueni -säkeistä neli-iskuista, yksisäkeistä, suppea-alaista sävelmää, ja näistä Boreniuksen tallentamat kaksi toisintoa on erityisesti mainittu tantsuääliksi eli tantsunooteiksi. ${ }^{676}$ Inkeroisilla yksisäkeiset yksinkertaiset neliiskuiset sävelmät eivät kuitenkaan kiletoivirsiä luukuunottamatta näytä toimineen minkään tanssiin liittyvän paikallisen lajin keskeisinä tunnuksina.

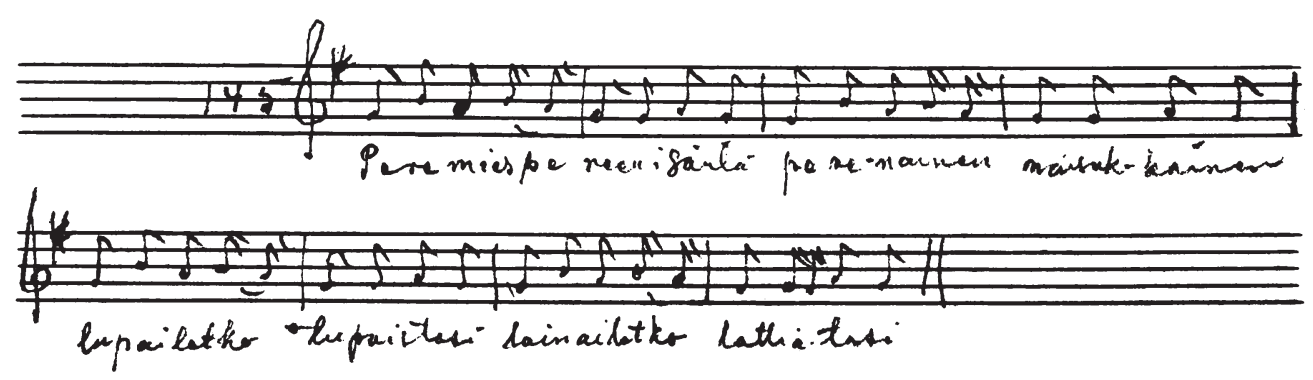

Nuotti 21. Launiksen vuonna 1903 muistiinpanema yksisäkeinen "Tanssituvan pyyntö" Narvusin Struuppovasta: "Peremies peren isäntä, perennainen naisukkainen, lupailetko tupaistasi, lainailetko lattiatasi" (SibA Launis 145).

Kahden runotekstin alussa esiintyvää kiletoi kaletoi -säettä on V. J. Mansikka (1929, 312-313) arvellut laulamiseen liittyneeksi kertaumaksi, refrengiksi. Tosin tämänkaltaista refrenkien merkitsemistapaa runon alkuun ei muissa käsikirjoitusaineistoissa ole havaittavissa. Refrenkiin saattaisi silti viitata myös Alavan julkaisematta jäänyt muistiinpano, jossa kiletoi kiletoi -säe on kolmesäkeisen kiletoidessa jouluna esitetyn kiitosteeman jäljessä. ${ }^{677}$ Sävelmäaineistossa sitä ei esiinny. On kuitenkin huomattava, että ilmeisesti kaikki yllä olevat sävelmät on tallennettu yksittäisiltä laulajilta, jolloin refrengit jäävät helposti laulamatta.

Hevaan inkeroiskylistä on samankaltaisia juhlalaulujen kuvauksia, mutta ainoa tallennettu yksisäkeinen sävelmä on viisi-iskuinen, mikä viittaa jälleen rekisterien paikallisiin eroihin silloinkin, kun esitysareenat ja itse runot ovat sangen samankaltaisia. ${ }^{678}$

\footnotetext{
${ }^{675}$ Esim. SKVR III 456, 481, 2576; IV3 4681.

${ }^{676}$ SKS KRA Borenius e) 208 ja 219; SKS KRA Alava XII:21 ja 107. Vatjalaiset nimittivät joulun pyhinä laulamista venäläisittäin koledoimiseksi, ja Paul Aristen $(1966,199)$ mukaan silloin esitettiin lauluja, "joista suurin osa on aina ollut venäjänkielisiä". Inkeroisilta tietoja näistä ei juuri ole, mikä voi johtua myös siitä, että venäjänkieliset laulut eivät kerääjiä kiinnostaneet.

${ }^{677}$ SKS KRA Alava X, s. 126-127.

${ }^{678}$ SKVR IV 1449; 4104; 4158; SKS KRA Levón 512 (Hyvä iltanen taloihin; ks. samankaltaisia myös SKVR IV 2228 Kapriosta ja 22229 Medussista). Toisin kuin länsi-inkeriläiskuvauksissa, kerrotaan hevaalaistyttöjen Miikkulana laulaessaan käyneen yhteen riviin ja tanssineen vastakkain, kenties siis katrillin tapaisesti (SKVR IV 4158).
} 


\section{Kiertuetapojen muUtos}

Kaksi kiertämisen yhteydessä usein toistuvaa termiä ovat igriššat ja kiletoiminen. Kiletoi-termi liittyi ensisijaisesti tyttöjen kulkuun tuvasta tupaan laulaen kestitystä pyytämässä, sanalla igriššat taas kuvattiin Narvusissa 1930-luvun aineistossa naamioituneena kylällä kulkemista. ${ }^{679}$ Kiletoi liittyy lähinnä Miikkulaan sekä joulun ja loppiaisen väliin, igriššat joulun ja loppiaisen väliin. Kummastakin on myös satunnaisia mainintoja muissa yhteyksissä, ja muutama muistiinpano yhdistää termit.

Valtaosaan igrišša-kuvauksista ei liity runoja. Yleisimmin igriššoilla käynti sijoitettiin joulun ja loppiaisen välipäiviin ja tarkoitti lähinnä nuorten, mutta paikoin myös aikuisten naamioituneena kiertämistä talosta taloon tai lähikylissä. Kuvauksiin liittyy usein myös mainintoja tanssista ja laulusta. ${ }^{680}$ Katri Vohdan mukaan igriššoja pitivät "sekä luterilaiset että inkerikot." ${ }^{681}$ Kahdessa toisinnossa igriššattermi liittyy Martin päivään ja runoon, toisaalla kerrotaan, että joulun ja loppiaisen väliset igriššat vietettiin kuin Marttina, mutta ei laulettu Martin virttä eikä kerätty syötävää. ${ }^{62}$ Muutaman muistiinpanon perusteella voi olettaa termin olleen laajemmassakin käytössä, vaikka ensisijaisesti se näyttää liittyneen joulun ja loppiaisen välipäiviin. Sillä kuvattiin myös naamioitumisleikkejä ja hulluttelua häissä. ${ }^{683}$ Igrišša-nimitystä käytetään lähinnä 1930-luvun narvusilaisaineistossa, mutta yksi maininta löytyy myös 1800-luvun lopun Narvusista Alavalta. Hän kuitenkin kääntää sanan "tyttöjen iltavalvonnoilla" ja mainitsee sen yhteydessä ainoastaan pyhävaatteisiin pukeutumisesta. ${ }^{644}$ Soikkolan Saaroven kylästä on maininta, jonka mukaan siellä käytettiin pelleehys-sanaa nuorison kiertämisestä kylällä oudoissa vaatteissa loppiaisen ja laskiaisen välillä. ${ }^{65}$ Termit näyttävät siis painottuvan alueellisesti ja muuntuvan ajassa, mutta olevan samalla käyttöaloiltaan melko laajoja.

Igrišša-kuvaukset keskittyvät eri teemoihin kuin Miikkulan, kiletoin ja Martinpäivän kuvaukset. Ainoastaan kahdessa inkeroisilta tallennetussa kuvauksessa igriššoihin liittyy antimien pyytämistä, ja tällöinkin kuvaus painottuu naamioitumiseen ja kiertämiseen. ${ }^{686}$ Erityisesti luterilaiset korostavat, että igriššoilla antimia ei pyydetty tai igriššavieraille ei tarjottu mitään. ${ }^{67}$ Luterilaisen Anders Saksan kertomuksen vanhastapiiasta, joka "teki itsee igrissaks" eli naamioitui, mutta joka "juotettii humalaa ja kuoli tuonne Räkälän metsään" voi tulkita varoitustarinaksi humalaisena vieraissa kylissä kiertämisestä. ${ }^{688}$

\footnotetext{
${ }^{679}$ Ks. myös IMS, igrišša, pellēhüs. Termi tulee venäläisestä nuorison leikkejä merkitsevästä sanasta igrištša (Ćistov 1976b, 197).

${ }^{680}$ Esim. SKS KRA Haavio 2728, 2731; Laiho L. 4758.

${ }^{681}$ SKS KRA Enäjärvi-Haavio 818.

${ }^{682}$ SKS KRA Laiho A. 2339, 3176; 2597.

${ }^{683}$ SKS KRA Enäjärvi-Haavio 896; Laiho A. 3070. Naamioituminen (ilman igriššat-termiä) mainitaan myös Pedron, Nastassien ja Jyrin praasnikkojen yhteydessä (SKS KRA Enäjärvi-Haavio 675; Laiho L. 5226, 5995).

${ }^{684}$ SKS KRA Alava VII b Valokuvain luettelo 1892 nro 73.

${ }^{685}$ IMS: pelehellä, pellēhüs; VKKMS: igriššaD, pelehüs.

${ }^{686}$ SKS KRA Laiho L. 5188, 5254.

${ }^{687}$ SKS KRA Enäjärvi-Haavio 801, 817, 819; Laiho A. 2597.

${ }^{688}$ SKS KRA Laiho L. 4766.
} 
Vaikka tanssin ja laulun kuvaukset ovat igrišša-kuvauksissa yleisiä, liittyy niihin harvemmin varsinaisia runoja. Laukaansuussa kerrottiin, että joulun tienoon igriššoilla pukeutuneet nuoret "kiersivät kylää laulaen kaikenlaisia lauluja, rivojakin." ${ }^{699}$ Mari Vahterin mukaan igriššoilla hänen aikanaan laulettiin venäjänkielisiä lauluja, käytiin taloissa laulamassa ja tanssimassa ${ }^{690}$ Haitari, truba tai viulu soi, kertovat muut kuvaukset. ${ }^{691}$ Sopimattomina pidettyjä, uusia tai venäjänkielisiä lauluja eivät runonkerääjät juuri tallentaneet, joten niiden puuttuminen aineistoista ei kerro niiden yleisyydestä.

Martti Haavion Anna Kivisoolta tallentama kuvaus kytkee igrišša-illat, naamioitumisen ja tanssituvanpyyntörunon: joulun ja loppiaisen välillä menivät tytöt ja pojat naamioituneina toisiin kyliin, jossa kokoonnuttiin isäntäkylän nuorison maksamaan tupaan tanssimaan. Tanssitupaa pyydettiin laulamalla: "Peremies pereisäntä..." Haavio ei tallentanut runoa, oletettavasti koska hänen vaimonsa, joka haastatteli Kivisoota kolme päivää, oli jo tallentanut tämän tuvanpyyntölaulun. ${ }^{692}$ Enäjärvi-Haaviolle Kivisoo myös kuvasi nuorison joulun ja loppiaisen välin iltojen "huvittelu- ja tanssitilaisuuksia," mutta käytti tällä kertaa tilaisuuksista ainoastaan nuorison illanviettoon tuvassa viittaavaa termiä besedat. Kylän pojat vuokrasivat jonkin talon tuvan, jossa tanssittiin haitarin säestyksellä ruskovia, katrillia ja kazatškaa. Vieraistakin kylistä tuli nuoria, mutta tilaisuudessa ei tarjottu "mitään suuhunpantavaa." ${ }^{693}$

Kivisoon eri kerääjille antamien kuvausten talvisen tuvanpyytämisen ja tanssin ympärillä kiertävä variaatio viittaa siihen, että suhteellisen laajaankaan kontekstikuvaukseen ei välttämättä mahdu laulajan tuntema runon käytön koko kirjo. Tulkitsisin Kivisoolta tehtyjen muistiinpanojen kokonaisuuden näin: Talvikauden sunnuntai-iltoina kylän nuoriso pyysi vaihtelevista taloista lupaa päästä tupaan tanssimaan: tähän riitti pelkkä tyttöjen laulu. Samalla tavalla tupaa pyydettiin tanssiin myös Miikkulana. ${ }^{64}$ Joulun ja loppiaisen välissä kylän pojat vuokrasivat yhden tuvan nuorison käyttöön koko ajaksi - tähän kuvaukseen ei tanssituvanpyyntörunoa liity. ${ }^{695}$ Joulun ja loppiaisen välin iltoina tanssittiin sekä oman kylän itse vuokratussa tuvassa että lähdettiin naamioituneina toisiin kyliin. Kun toisessa kylässä pyydettiin päästä kyseisen kylän nuorison vuokraamaan tupaan tanssimaan, laulettiin jälleen tuvanpyyntöruno. ${ }^{696}$ Tuvanpyyntölaulu ja tuvan varsinainen vuokraaminen eivät siis olleet tarpeen samanaikaisesti.

Kiletoi-termiä ei Kivisoon tuvanpyyntölaulujen kuvauksissa esiinny, vaikka hän kytkeekin runon yhden version Miikkulan praasnikkoihin. Matrona Bässina sen

\footnotetext{
${ }^{689}$ IMS: igrišša.

${ }^{690}$ SKS KRA Laiho A. 2599.

${ }^{691}$ SKS KRA Laiho A. 2588; Laiho L. 5228, 5235.

${ }^{692}$ SKS KRA Enäjärvi-Haavio 404, 835b.

${ }^{693}$ SKS KRA Enäjärvi-Haavio 801.

${ }^{694}$ SKS KRA Enäjärvi-Haavio 835b; Laiho L. 5343; 5989.

${ }^{695}$ SKS KRA Enäjärvi-Haavio 801.

${ }^{696}$ SKS KRA Haavio 2741.
} 
sijaan yhdistää termit: "Igriš-illal kiletoimassa käytiin, ennen kressenjaa [loppiaista], joulun jälkeen alettiin.” Pukeuduttiin tytöt naineiksi naisiksi, miehet naisiksi, naiset miehiksi, mentiin naapurikyliin, vuokrattiin kesäistä niittämistä vastaan joku oman kylän talo tanssiin: "Kaikenlaisia virsiä laulettiin." ${ }^{697}$ Igriššojen ja kiletoimisen ajankohdat menevät osin päällekkäin. Molempien puitteissa kerrotaan talosta taloon kiertämisestä, laulamisesta ja tanssimisesta. Kiletoin yhteydessä vain korostuvat pitkät runot ja oluella kestitys, igriššojen yhteydessä naamioituminen, tanssiminen ja kestityksen puute. ${ }^{698}$

Anna Kivisoolta on tallennettu myös kaksi hämmentävää kiletoivirren (giletoivirs) muistiinpanoa:

$\begin{array}{ll}\text { Giletoo, galetoo, } & \text { kiletoi kaletoi } \\ \text { kana sittu gańevoo, } & \text { kana ulosti ojaan } \\ \text { giletoo, galetoo, ----- } & \text { kiletoi kaletoi ------ }\end{array}$

Näin lauloivat ennen tytöt Soikolassa ja vatjan puolessa kun he kävivät kiletoimassa eli kestittävinä eri taloissa, kertoi Kivisoo. Kaksi kuvausta eroavat hieman toisistaan, mutta kumpikin on menneessä aikamuodossa. Haavion tallentaman version mukaan kiletoimassa käytiin tarkemmin määrittymättömänä praasnikkana, jolloin tytöt kokoontuivat yhteen ja kiersivät taloissa: "Ympäri menivät, tanssivat, annettiin olutta ja viinaa, siis pois.” Näin oli Kivisoon ropsulainen isä eli ätti kertonut. ${ }^{699}$ Laihon tallentama kuvaus sijoittuu Pedron päivän praasnikkaan, jolloin "tytöt käivät vierahis toisillaa, giletoimas." He söivät, joivat ja vaihtoivat paikkaa ja lauloivat välillä yllä olevan kiletoivirren. ${ }^{700}$ Kivisoolla ei siis ollut omakohtaisia kokemuksia kiletoivirsistä eikä hän käyttänyt nimitystä joulunajan kiertämisen ja tuvanpyyntörunojen yhteydessä. Sen sijaan hänen isänsä oli kertonut niistä jotain, mikä poikkesi runosäkeeltään ja laulamisen ajankohdaltaan muista kiletoivirsistä, mutta toisti muuten kuvauksille tyypillisiä tyttöjen kestittävänä kiertämisen teemoja. Lähin Kivisoon runoteemaa muistuttava runo Rinki ranki, kana sittu pankiin kertoo ketun tehneen olutta kukon ja kanan jätöksistä ja Matin kehuneen sitä makiaksi. Runo vaikuttaa oluenjuontiin liittyvältä pilkkarunolta. ${ }^{701}$ Kivisoon isän laulama kana sittu gan'evoo -säe voisikin olla naureskellen tai pilkalla laulettu ja viitata humalaisten tyttöjen laulamiin renkutuksiin varsinaisten sisällöllisesti suhteellisen eheiden kiletoivirsien asemasta. Laulu tuntuu edustavan jonkinlaista vastarekisteriä, varsinaisen kiletoivirren pilkka- tai parodiaversiota.

\footnotetext{
${ }^{697}$ SKS KRA Haavio 2731.

${ }^{698}$ Joulunajan praasnikkarunoilla on muutamassa muistiinpanossa yllättävä yhteys myös kesäpraasnikkoihin. Soikkolan Uudestakylästä Narvusin Kalliviereen miehelään muuttanut Helena Säkki lauloi Pedron praasnikan kuvauksensa yhteydessä ensin kiletoivirsien teemoja vastaavan sisäänpääsy- ja antimienpyyntörunot, jotka hän sijoitti riiheen saapumiseen ja sieltä syömisen ja juomisen jälkeen lähtemiseen (SKVR III 2077, 2079). Vaikka kyseessä on riihessä vietettävä oluenjuontitilaisuus, pyydetään ensimmäisessä runossa isäntää ja emäntää nousemaan vuoteestaan ja hakemaan kammarista olutta. Kiletoi-nimitystä näihin muistiinpanoihin ei sisälly. Runoteemojen soveltamisala näyttää siis laajalta, vaikka aineiston painopiste on talvipraasnikoissa.

${ }^{699}$ SKS KRA Haavio 2733.

${ }^{700}$ SKS KRA Laiho L. 5363.

${ }^{701}$ SKVR III 3500.
} 
Ilmeisesti kiletoiminen tapana, nimityksenä, kestityksen pyyntönä ja laulukokonaisuuksina väheni ja hävisi 1800-luvun lopulla ja 1900-luvun alussa. Maailmansotien välillä haastatelluista laulajista ainoastaan nimensä perusteella ortodoksi Katri Labanov Narvusin alueelta sekä kaksi Luuditsasta kotoisin olevaa vatjalaisnaista lauloivat kerääjille varsinaisia kiletoivirsiä. ${ }^{702}$ Katarina Jakovleffin mukaan "perrää" eli ilmeisesti hänen nuoruutensa jälkeen 1800-luvun loppupuolella "pappi kielsi gilidoittamisen." Vuonna 1925 Jakovleff oli 64-vuotias. ${ }^{703}$ Naastoi Säätinältä kertoi jo vuonna 1892, että "Soikkolassa ei käydä enää kiletoissa. Liivakylässä vieläkin käydään."704 Onttaman naisen mukaan (inkerois-inkerinsuomalaisessa) Harkkolassa oli ennen vietetty Miikkulaa neljä päivää ja laulettu, mutta vuonna 1909 "ei laulua enää lauleta." ${ }^{705}$ Narvusin inkerinsuomalaisella Struuppaalla Mäkisen emäntä kertoi vuonna 1897 kiletoimisessa menneessä aikamuodossa eikä sanonut muistavansa runoa kolmea säettä enempää. ${ }^{706}$ Muutenkin lauluiltaan venäläistyneessä inkerois-venäläisessä Väikylässä, kertoi Maria Hauki vuonna 1938, laulettiin Miikkulana kaikki "vaa vennäiks."707 Monia kiletoivirsiä tallentanut Alava kertoo inkeroisten kiletoimisesta samoin menneessä aikamuodossa, ja sijoittaa luterilaisten laulamisen sitäkin kauemmas menneisyyteen: "Ennen käytiin kiletoimassa joulun ja veseristan [loppiaisen] väliin ja käytiin taloissa ja yhtä ja toista korjattiin rahaa ja mitä mistäkin annettiin. Vennäin uskoiset näin kävivät. Mutta ennenmuinoin Suomen uskoisetkin." ${ }^{708}$ Inkerinsuomalaiset olivat saattaneet 1600- ja 1700-lukujen kuluessa omaksua inkeroisilta ja vatjalaisilta praasnikoihin liittyviä tapoja (ja ortodokseja oli saattanut vaihtaa etnistä ryhmää uskonnon vaihtamisen myötä 1600luvulla), mutta 1700-luvulta eteenpäin sekä ortodoksinen että luterilainen kirkko pyrkivät karsimaan kansanomaisia rituaaleja (ks. esim. Västrik 2007). Lukkarinen (1911, 64-65) kertoo, että kiertämistä nimitettiin ennen kiletoimiseksi, mutta hänen käyntinsä aikaan jo kamppanjaksi, ja että ajankohta oli siirtynyt Miikkulan aatosta itse juhlapäivään ja tapoja oli siistitty.

Joulunajan keskeinen esitysareena siis pysyi, mutta siihen liittyvät rekisterit ja laulun paikalliset lajit vaihtuivat. Nuorison joulunajan kiertäminen kylän taloissa ja toisissa kylissä pysyi kiletoimisen loppuessakin: igrišša-kuvauksiin ei kuitenkaan liity samanlaista kestitystä ja muutamissa muistiinpanoissa nimenomaan tähdennetään, että mitään ei tarjottu. Kuvauksista käy myös ilmi, että kaikki eivät suhtautuneet tällaiseenkaan kiertämiseen suopeasti. ${ }^{709}$ Kiletoinnin myötä myös pitkät siihen liittyneet, tanssinkin säestyksenä toimineet runot katosivat ja korvautuivat muilla lajeilla: "kaikenlaisilla" lauluilla, venäläisillä lauluilla ja soitinmusiikilla.

\footnotetext{
${ }^{702}$ SKS KRA Ankeria 209; Salminen K. 216; Sääski 5343.

${ }^{703}$ SKS KRA Ankeria 209.

${ }^{704}$ SKVR III 2284. Liivakylä oli inkerois-vatjalainen.

${ }^{705}$ SKVR III 3496.

${ }^{706}$ SKVR III 2358.

${ }^{707}$ SKS KRA Laiho L. 5228.

${ }^{708}$ SKS KRA Alava X, s. 126-127. Veseristasta ja loppiaiseen asti kulkemassa käymisestä ks. esim. SKS KRA Enäjärvi-Haavio 826; Haavio 2734-2744; Laiho L. 5188.

${ }^{709}$ SKS KRA Laiho L. 5254, 5990.
} 


\section{ESITYSAREENA JA LAULUN JÄSENTYMINEN}

Keskeiset praasnikkalaulut osoittautuvat rekisteriensä ja esitysareenoidensa suhteen yllättävän yhtenäisiksi ryhmiksi. Kun alueelliset ja etniset erot otetaan huomioon, muodostavat kuvaukset, runot ja sävelmätyypit tai laulun muotorakenteet hyvinkin kiinteitä yhdistelmiä. Tiettyihin rituaalisiin tai juhlaviin tilanteisiin keskeisesti liittyvien laulujen esityksissä ja näiden laulujen kuvauksissa toistuvat tietyt runoteemat, aloitusformulat, sävelmät, muotorakenteet, lauluun liittyvä liike, laulajaryhmät sekä laulamisen aika ja paikka samankaltaisina. Yhteistä eri praasnikoiden esitysareenoille oli yleensä kirkkopyhä, jumalanpalvelus, vieraiden ruualla ja juomalla kestitys sekä etenkin nuorison yleinen tanssiminen ja laulaminen ulkotiloissa. Kaikkien vakiintuneiden praasnikkalaulujen rekistereille yhteistä oli joukolla esilaulajan ja kuoron vuorotteluna laulaminen, suhteellisen yksinkertaiset ja ilmeisen vanhakantaiset musiikilliset rakenteet sekä suhteellisen kiinteät runoteemat joko laulun alussa tai läpi koko laulun. Samalla eri praasnikat eroavat toisistaan sekä esitysareenoina että rekisteriensä puolesta.

Laskiaisen rekiajeluun liittyi Soikkolan inkeroisilla, kuten Hevaallakin, tietty paikallinen sävelmätyyppi ja tyypillinen aloitusformula (Liuvukka rekoi lippiä, Hevaalla Lähe Jumala aviksi), jonka perään saatettiin punoa erilaisia väljemmin laskiaiskontekstiin liittyviä runoteemoja. Teemat liittyivät usein jotenkin ajamiseen, ajajaan ja laulaviin tyttöihin. Laulajina mainitaankin useimmin nimenomaan tytöt. Liukuvirren rekisteri aloitusformuloineen, sävelmätyyppeineen, esityksellisine piirteineen (kova ääni, lisätavut ja tavumuutokset) ja siihen kytkeytyvine esitysareenoineen (laskiaisen rekiajelu) hahmottuu aineistosta selkeärajaisena kokonaisuutena. Liukuvirteen liittyviä muita runoteemoja tarkastellessa ilmeiseksi käy rekisterin joustavuus ja laulamisen tilanteen vaikutus. Pakolaisnainen ja kaksi 1960-luvun laulajaa muokkasivat virrestä omanlaisensa, nuoruuden kadotettua yhteisöä kuvaavat versiot. Vaikka paikallisen lajin nimityksiä (liukuvirsi, liukunootti) ei, toisin kuin Hevaalta, ole Soikkolasta tallennettu, näyttää rekisterin kiinteyden ja esitysareenan (liukupäivä) nimitysten vakiintuneisuuden perustella todennäköiseltä, että tässä liukuvirreksi nimeämäni kategoria olisi ollut myös laulajien tunnistettavissa.

Pääsiäisen ja kesäkauden liekkuvirsi aloitettiin kiinteästi keinuun ja keinumiseen liittyvällä aloitusteemalla (yleisimpänä La ka katson liekkuani), ja sitä kannatteli samantyyppinen sävelmä kuin liukuvirsiä. Laulun jatkoksi punoutui monenlaisia lyyrisiä ja eeppisiä runoja. Tämänkaltaisia runoja nimettiin joskus liekkuvirsiksi ilman aloitusteemaakin, jos ne oli esitetty tallentajalle liekkusävelmällä. Liekkuvirsien laulaminen kerrotaan aloitetun pääsiäisenä, jolloin suuri kyläkeinu otettiin käyttöön. Kesän ensimmäinen tilanne näyttäytyy erityisenä: se on ainoa tilanne, jolloin kerrotaan myös aikuisten ihmisten kertyneen liekulle laulamaan. Muina kesän pyhäpäivinä liekku oli nuorison aluetta, yksi ajanvieton ja laulamisen paikoista, ja laulajat lähinnä nuoria naisia.

Kokkovirsi (Tulkaa tyttäret tulelle) muodostaa esitystapansa ja kontekstinsa puolesta väljemmän kokonaisuuden kuin liuku- ja liekkuvirret. Länsi-Inkerissä kes- 
keisin (rituaalinen) kokon polttamisen konteksti ja siten kokkovirren esitysareena oli juhannus, Keski-Inkerissä helluntai. Tulia poltettiin ja kokkovirttä laulettiin myös muina kevätpyhinä. Virttä tai sen osia saatettiin laulaa niin kokkopaikalle muodostelmana kulkiessa, tulta sytyttäessä kuin kokolla ympärikossa tanssittaessa tai kuljettaessa. Kokkovirren länsi-inkeriläiset sävelmätoisinnot viittaavat tanssiin, mutta niiden yhteydessä ei kukaan laulajista erikseen kuvaa kulkemisen tapaa. Keski-Inkerissä Launis mainitsee kokolle kulkemiseen liittyneen sekä hitaasti ketjumuodostelmassa (Viron veräjät) että nopeammin, tanssien paririvissä (kluutša) kulkemisen. Tyypillisen, melko pitkän aloitusteeman (Tulkaa tyttäret tulelle) jälkeen saatettiin jälleen laulaa muita runoja. Sävelmä oli vähemmän vakiintunut kuin liuku- ja liekkuvirsissä, ja toisaalta laulamiseen liittynyt tekeminen ei ollut yhtä kiinteästi määräytynyttä. Kokolle kulkemiseen liittynyt keski-inkeriläissävelmä määrittyi lähinnä refrenkityypin mukaan, kun taas Länsi-Inkerissä sävelmäksi sopivat muutamat yksinkertaiset tanssisävelmätyypit. Illan kuluessa sävelmät saattoivat vaihdella erilaisen liikkeen (kulkeminen, tanssi) ja paikoillaan olon vaihdellessa.

Pedron ja Iilian virret olivat pyhälle Pedrolle ja Iilialle (tai Hevaalla Ukolle) kesän suurimmilla inkeroisten praasnikkajuhlilla osoitettuja riittivirsiä (Pyhä Pedro armollinen, Iilia pyhä isäntä). Laulun keskeissisältö oli rajattu - pyhimyksen kutsu pitoihin, oluen, viinan ja ruuan kuvaukset sekä sateen pyyntö - eikä laulua kerrota jatketun muilla teemoilla. Kuvaukset kytkevät sen praasnikkajuhlan aloittavaan rituaaliseen kylän yhteisoluen juomiseen. Tämän jälkeisissä juhlissa laulaminen jatkui, mutta ei riittivirren suorana jatkumona. Vaikka laulajiksi sekä Hevaalla että Soikkolassa mainitaan tytöt, eivät laulamisen paikat olleet nuorison ajanviettopaikkoja, vaan eri tavoin liminaalitiloiksi määrittyviä kohtia: riihen kuomina, uhrilehto, saunan tai tšasounan edusta. Sävelmätyyppi oli vakiintunut, mutta erilainen Hevaalla ja Soikkolassa. Tyttöjen kerrotaan laulaneen runon hitaasti piirissä. Narvusin alueella kuvausten kirjo on myöhäisempi ja hajanaisempi kuin Soikkolassa ja Hevaalla, mutta antaa paremman kuvan riittivirren mahdollisista muistakin käytöistä: sitä saatettiin laulaa vähemmän rituaalisesti pitkin monipäiväistä praasnikkajuhlaa kylän läpi kulkiessa, tyttöjen viettäessä aikaa syrjemmällä, ruuasta kiitettäessä tai tyhjiä olutastioita praasnikkojen lopuksi huuhdeltaessa. Tavat saattoivat vaihdella kylittäinkin.

Sävyltään keveämpiä ja leikillisempiä, mutta samalla tavoin melko rajattuja ja pyhimykselle suoraan osoitettuja ovat Narvusin alueelta tallennetut, virolaisia toisintoja läheisesti muistuttavat Martinvirret, joita laulettiin pyhimyksen nimikkopäivänä talosta taloon kierrellen. Runo alkaa pyhimyksen puhuttelulla (Hups hups hups hups Martikkine) ja jatkuu ruuan ja kestityksen pyytämisellä sekä paikoin kiitoksen tai moitteen teemoilla. Sitä lauloivat kuvausten mukaan vaihdellen lähinnä tytöt, pojat, lapset tai paimenet, jotka olivat usein naamioituneita. Aineiston ainoa sävelmätoisinto on tyypillinen nopea tanssisävelmä, ja ympärikossa tanssien laulamisesta puhuvat myös laulamisen kuvaukset. Runoteemoja ei aineistossa liitetä mihinkään muihin konteksteihin. Toisin kuin muut praasnikkavirret, Martinvirsi painottuu inkerinsuomalaisille lähellä Viroa sijaitseville luterilaisalueille. 
Viimeinen laajempi praasnikkoihin liittyvä laulujoukko koostuu Miikkulanpäivän ja joulunajan kiletoivirsistä. Runot alkavat Kiletoi kaletoi -säkeellä, avaamiskehotuksella tai talonväen tervehtimisellä. Pyhimystä ei runossa puhutella, mutta Jumalan saatetaan laulaa kulkevan talosta taloon kiertävien tyttöjen mukana. Kiletoivirsi saattoi muodostaa pitkänkin sikermän oluen tai rahan pyyntöjä, laulajajoukon kuvausta, pyyntöä päästä sisään tanssimaan sekä lopussa erilaisia kiitoksia ja toivotuksia tai moitteita jos mitään ei oltu annettu. Muita lyyrisiä tai eeppisiä teemoja ei laulun jatkoksi liitetty. Laulajina mainitaan aina tytöt, joiden joukossa saattoi kuitenkin kulkea myös poikia. Heille annettiin taloissa olutta, viinaa, rahaa ja syötävää. Runosikermä lomittui toimintaan: taloon pyrkimiseen, sisälle pääsemiseen, lattialla tanssimiseen ja isäntäväen kiittämiseen kestityksen jälkeen. Tanssista löytyy riehakkaitakin kuvauksia, mutta toisaalta kerrotaan tyttöjen voineen laulaa myös hitaassa ympärikossa. Suppea, osin tulkinnanvarainen länsi-inkeriläinen sävelmäaineisto koostuu yhtä myöhäistä poikkeusta lukuun ottamatta samantyyppisistä yksinkertaisista, neli-iskuisista sävelmistä.

Eri paikallisten lajien puitteissa runot rakentuvat hyvin eri tavoin. Siinä missä laskiaisen liukuvirsissä, pääsiäisen ja kesäkauden liekkuvirsissä tai juhannuksen kokkovirressä alkurunoa tai -teemaa saattaa suoraan seurata moninaisia lyyrisiä ja eeppisiä teemoja, ei jatkoteemoista Pedron, Iilian, Martin ja Miikkulan virsissä ole merkkejä. Liuku-, liekku- ja kokkorunojen alku rakentuu tekemisen - ajamisen, liekkumisen, kokolle kulkemisen - ympärille. Pedron, Iilian ja Martin runot taas alkavat pyhimyksen puhuttelulla ja jatkuvat kyseiseen juhlaan suoraan liittyvillä teemoilla: Pedron ja Iilian virret sateen pyynnöllä ja oluenjuonnin teemoilla, Martin virsi kestityspyynnöillä ja kiitoksilla. Miikkulanpäivän ja joulukauden kiletoivirsissä ei pyhimystä puhutella, mutta laulun alussa usein viitataan Jumalaan kulkemassa laulajien mukana; runojen teemat liittyvät kulkijoiden kuvaukseen, kestityksen pyyntöön, olueen ja kiitoksiin tai moitteisiin. Kiletoivirsien yhteyteen ei liity mainintoja muista runoista ollenkaan: varsinainen runosykli oli hyvin pitkä ja sitä kierrettiin laulamassa useissa taloissa. Pedron, Iilian ja Martin päivän kuvauksiin sitä vastoin liittyy mainintoja muustakin laulamisesta ja tanssista varsinaisen juhlavirren esittämisen jälkeen - samanlainen näyttää tilanne Länsi-Inkerissä olleen myös Senni Timosen (2004, erit. 129-130) käsittelemän Jyrin virren kohdalla. Missään ei kuitenkaan sanota, että laulu olisi jatkunut suoraan juhlarunosta tai samalla sävelmällä, päinvastoin: hitaan ja juhlavan rituaalirunon jälkeen laulamisen rekisteri vaihtui riehakkaammaksi. Jyrin, Pedron, Iilian ja Martin päivän virsien paikalliset lajit olivat runoteemoiltaan suppeita eivätkä ottaneet monikäyttöistä, liikkuvaa lyyristä ja lyyriseeppistä ainesta osakseen. Sen sijaan liekku-, liuku- ja kokkorunojen kerrotaan voineen jatkua suoraan samalla sävelmällä lauletuilla muilla teemoilla ja runoilla. Käytetyt sävelmätyypit erosivat toisistaan sekä praasnikoittain että alueittain: alueellisissa eroissa näkyy myös etnisiä painotuksia. 
Pulmat 


\section{Pulmat}

Häät eli pulmat olivat Länsi-Inkerissä etenkin inkeroisilla, mutta ainakin paikoin myös inkerinsuomalaisilla monipäiväinen juhla, johon lomittui enemmän lauluja ja itkuvirsiä kuin mihinkään muuhun tilaisuuteen. Häät alkoivat morsiustalossa ja päättyivät sulhasen kotiin, ja niiden yhteydessä innostuttiin laulamaan paljon muutakin kuin varsinaisia häälauluja. (Esim. Salminen 1916; 1917, erit. 30.) ${ }^{710}$

Häärituaali ja häälaulut vaihtelivat alueittain. Yhteistä näyttää Vienasta Viroon asti olevan häiden kaksiosaisuus sekä runolaulun tai itkuvirsien keskeisyys. Sen sijaan itse runot tai itkut ja niiden laulamiseen käytetyt sävelmät eroavat eri alueilla toisistaan. Kuten Lotte Tarkka (2005, 49-50; ks. myös Sarmela 1978) toteaa, häistä saatava kuva vaihtelee sen mukaan, mihin lajiin keskitytään. Niin Vienassa kuin Inkerissäkin itkuvirret ja runot vuorottelivat. Matti Sarmela (1978; ks. myös 1981) on käsitellyt vienankarjalaisia häitä nimenomaan lauluhäinä, Unelma Konkka (1985, 116-186) itkuhäinä. Virolaisia häätapoja on tutkinut erityisesti Ülo Tedre $(1973,1981)$.

Inkerin osalta ensimmäiset kirjoitukset häärituaalista julkaisi Volmari Porkka (1883a; 1883b), joka kuvasi lähinnä itkuvirsien käyttöä. Ensimmäiset varsinaiset häärunotutkimukset teki Väinö Salminen $(1916,1917)$, jonka oli alkujaan ilmeisesti tarkoitus jatkaa tutkimustaan muille maantieteellisille alueille. Hän totesi, että häiden kohdalla runoja ei voi ymmärtää käsittelemättä niitä häärituaalin osana ja myöhemmin hän totesi olennaiseksi myös häärunoston ja häätapojen tarkastelun suhteessa etnisten ryhmien välisiin eroavaisuuksiin. Henni Ilomäki (1998) on pohtinut, minkälaista kuvaa häärunosto antaa naisesta ja naisen asemasta Inkerissä. Aili Nenola $(1982,2002)$ on tutkimuksissaan valottanut paitsi hääitkuja ja häärituaalia, myös itkuvirsien ja runojen välisiä suhteita. Pertti Anttonen (1987; 1992; 1994) on käsitellyt inkeriläisiä häitä van Gennepin siirtymäriittiteorian näkökulmasta ja keskittynyt erityisesti häiden pilkkaamiskäytäntöihin. Senni Timonen (käsikirjoitus; 2004) on tarkastellut lyriikan ja häälaulujen suhdetta erityisesti keski-inkeriläisen aineiston pohjalta.

Inkerissä häiden kulku näyttää olleen niin monimuotoinen ja kylittäin, ryhmittäin tai jopa häittäin vaihteleva, että yhden yhtenäisen skeeman luominen edes LänsiInkerin alueelta on mahdotonta. Tietyt runot sijoittuvat kuitenkin eri laulajienkin kuvauksissa niin säännönmukaisesti tiettyihin seremonian kohtiin ja alkavat niin tyypillisillä säkeillä tai teemoilla, että monet aineiston kontekstitiedottomatkin laulut ja sävelmät on mahdollista paikantaa tyypillisen häärituaalin osaksi. Hälauluissa olisi ainesta useaan perinpohjaiseen monografiaan: tässä luvussa on tarkoitus ainoastaan hahmotella häälaulujen rekistereistä. Väinö Salmisen $(1916,1917)$ yleisesitykset säeluetteloineen ja tarkkoine viitetietoineen antavat tässä pääpiirteit-

${ }^{710}$ SKS KRA Alava 13, 195. 
täin riittävän pohjan kontekstitiedottoman tekstiaineiston sijoittamiseen, mutta tarvittaessa käytän myöhempääkin runoaineistoa. ${ }^{711}$ Aili Nenola $(2002,43-44)$ toteaa, kuinka Salmisen (1916) "esityksestä käy ilmi, miten vaikeaa on yrittää kuvata Inkerin eriheimoisten asukkaiden häitä yhdessä tai erikseen: osista ei synny kokonaisuutta ja kokonaisuus ei kuitenkaan kuvaa minkään heimon häitä.” 712 Tähän on syynä sekä Salmisenkin pahoittelema lähdemateriaalin puutteellisuus että alueen pitkä monikulttuurinen vuorovaikutus: "Inkerissä 1800-luvulla eläneet häätraditiot sisälsivät niin paljon erilaisia eri puolilta peräisin olevia piirteitä, että niiden sijoittaminen yhtenäiseen kuvaukseen on yhäkin täysin mahdotonta," toteaa Nenola. Nähdäkseni tilannetta monimutkaistaa lisäksi muutama muukin seikka. Vaikuttaa siltä, että laulajat ovat voineet esittää runoja erilaisista näkökulmista eli vaikkapa jommankumman suvun tai tietyn häiden roolinhaltijan suunnasta käsin tai toistaa joitain yksittäisissä häissä esitettyjä käytäntöjä, vaikka toiset esittäjät ovat toki voineet myös pyrkiä antamaan kattavaa kuvausta häissä yleensä lauletuista lauluista. Rituaaleille on ylimalkaan ominaista niiden muuntuminen tilanteen mukaan, vaikka monet piirteet pysyvätkin samana ja toistuvuus on usein yhteisön itsensä keskeisenä pitämä asia. ${ }^{713}$ Oman lisänsä aineiston moninaisuuteen tuo lisäksi vielä se, että Salmisen $(1917,20 ; 1934,178)$ mukaan naiset lauloivat häihin liittyviä lauluja myös hääkontekstin ulkopuolella, omaa elämänkohtaloa kuvaavina. Voi olettaa, että runot ovat tällöin muokkautuneet ja punoutuneet toisiinsa ja muihin aihelmiin vapaammin kuin osana häärituaalia. Tällöin taas on vaikea päätellä, milloin kerääjille esiintyneet naiset ovat pyrkineet kuvaamaan nimenomaan häärituaalia, milloin taas käyttäneet runoja kuten niitä on käytetty hääkontekstin ulkopuolella. Tässä luvussa tarkastelun karkea taso kuitenkin pääpiirteittäin riittää. Runojen tilannesidonnaiseen muokkautuvuuteen palaan seuraavassa pääluvussa.

Aineistoni kertoo vahvimmin inkeroisten häätavoista, vaikka ryhmien välisiä eroja ei ole tässä mahdollista tarkemmin jäljittää. 1800-luvun loppupuolella luterilaiseen väestöön kohdistui erityisen voimakas häätapojen "siistimiseen" tähtäävä paine, ja viimeistään tällöin perinteiset häätavat lauluineen jäivät monin paikoin

\footnotetext{
${ }^{711}$ Väinö Salminen (1917, III) kertoi päättäneensä "ryhtyä häärunoja tutkimaan" vuonna 1905. Inkerin härunojen hän (mts. 2) kertoo kenttämatkojen tuloksena muodostuneen hänelle "osittain myöskin eläväksi tiedoksi." Vuoden 1906 matkalla kuullusta ja keskustellusta oli siis syntynyt kokonaisnäkemys, joka helpotti runojen jäsentämistä: Salmisen häärunotutkimuksessa keskeisellä sijalla oli usein hajanaisina tallennettujen runonpätkien sijoittaminen rituaalisiin konteksteihinsa. Ensimmäisen retkensä tuloksiin Salminen suhtautui myöhemmin kuitenkin kriittisesti, sillä hän ei ollut selvittänyt tarkemmin kunkin "laulun aikana tapahtuvaa toimintaa," eikä hänkään ollut tehnyt muistiinpanoja aidossa tilanteessa, häissä. Salmisen vuoden 1930 muistiinpanoissa on kontekstimainintoja huomattavasti enemmän kuin ensimmäiseltä retkeltä, mutta etnisten taustojen merkitseminen ei ole tällöinkään systemaattista. Nuoruuden keruuretkiä leimasi Salmisen (1946b; 1946c) muistelmien mukaan tietty huolettomuus: painotus tuntuu olleen enemmän maailman näkemisellä, runojen kuulemisella ja Venäjän armeijan pakoilulla kuin säntillisellä arkistoaineiston kartutuksella.

${ }^{712}$ Salminen $(1917,48-49,70,73,86-89$, 92, etc.) toteaa monen häärunon kohdalla, että sitä on tallennettu vain Länsi- ja Keski-Inkeristä, ja usein muistiinpanot näyttävät painottuvan inkerois- ja vatjalaisalueille, vaikka joitain toisintoja on tällöinkin usein tallennettu myös inkerinsuomalaisilta.

${ }^{713}$ Rituaaleista yleisemmin ks. esim. Anttonen 1992; Seeger 1987, 70-83; Senft \& Basso 2002.
} 
käytöstä (Laiho 1937). Kuitenkin myös inkeroisten ja vatjalaisten parissa juhlatavat olivat ilmeisesti muutoksessa. Inkeroislaulaja Uljaana Kipatsa kertoi, että vuonna 1897 oli jo Laukaalla vietetty häät, joissa "ei sanaakaan laulettu, ei suomeksi eikä venäjäksi." ${ }^{114}$ Inkerinsuomalaisten laulut välittyvät tässä työssä häiden osalta lähinnä Valpuri ja Katri Vohdan antamien runsaiden kontekstitietojen kautta. Molemmat laulajat kertoivat eri yhteyksissä myös inkeroisten tavoista ja lauluista.

Varsinaisia häärunoja on tallennettu suhteellisen paljon ja sävelmäaineistoakin melko runsaasti. Vuonna 1917 oli Salmisen $(1917,31)$ käytössä jo 470 häärunoa Narvusista, 52 Joenperältä, Soikkolasta 108, Kattilasta 2 sekä Siperian siirtolaisilta 26. Kontekstitiedot ovat häärunoaineistossa yleisempiä kuin muualla, vaikka usein kerrotaankin vain kuka laulaa ja missä tilanteessa. Myös laulamisen tavoista on runojen yhteydessä paikoin mainintoja, laulajien etnisistä taustoista harvemmin. Tämän luvun keskeisaineistoon kuuluu 99 häärunoon liittyvää laulamisen tavasta tarkemmin kertovaa kuvausta, joista suurin osa on tallennettu Narvusista (81, joista 56 muistiinpanoa 1930-luvulta), Soikkolasta ja Joenperältä vain 18. Sävelmien kohdalla aineisto on tasaisempi: 45 häälaulua Narvusista (joista 19 äänityksiä) ja 53 häälaulua Soikkolasta (joista 11 äänityksiä). Häälauluiksi toisinnot määrittyvät runotekstien, paikallisten nimitysten tai kontekstitietojen perusteella. Täydennän sävelmäaineistoa tässä luvussa Eino Kiurun ja kumppaneiden Soikkolan inkeroisilta 1960-luvulla keräämillä ja vuonna 1974 julkaisemilla 27 häärunolla, joihin liittyy muutaman rivin nuotinnos ja tieto laulun sijoittumisesta häärituaaliin. ${ }^{715}$ Aineistot on luetteloitu seuraavien alalukujen järjestystä noudatellen liitteeseen 5 (Häissä laulamisen kuvaukset; Hääsävelmät).

\footnotetext{
${ }^{714}$ SKVR III 2548.

${ }^{715}$ Lisäksi Hevaalta on tallennettu 23 häälaulua (joista 5 äänityksiä), Tyröstä 16 (4 äänitystä), Kattilasta 10 käsikirjoitusta ja lisäksi liitteessä 5: Hääsävelmät on luetteloitu paikkakunnittain myös Inkerin runosävelmissä julkaistut muut keski-inkeriläiset hääsävelmät. Lisäksi käytän runojen käsikirjoitustoisintoja sekä toisen maailmansodan jälkeen tallennettua ääniteaineistoa tarvittavin osin. 1960-luvun lähinnä yksittäisiltä laulajilta tai laulajapareilta tallennettuun ääniteaineistoon liittyy muutamia lähdekriittisiä tekijöitä. Häissä laulaminen vähentyi 1900-luvulle tultaessa ja loppui monin paikoin jo ennen toista maailmansotaa. Narodnye Pesni Ingermanlandii -julkaisun litteraatiot vaikuttavat muutamin paikoin hieman epätarkoilta, nuotinnokset sisältävät yleensä vain muutaman säkeen ja säkeiden kertaus ei aina käy yksiselitteisesti litteraatiosta, tähtimerkinnöistä ja nuotinnoksesta ilmi, vaikka yleensä runot on pyritty litteroimaan refrenkeineen ja osakertausrakenteineen. Runo- ja sävelmätyypit näkyvät aineistosta kuitenkin riittävän selkeinä.
} 


\section{LAULU RITUAALIN KANTAJANA}

Häihin liittyvä runojen ja itkuvirsien laulaminen alkoi Länsi-Inkerissä jo kihlajaistilaisuudessa. Morsian sekä hänen äitinsä ja kummitätinsä luettelivat eli lauloivat itkuvirsiä (Nenola 1982, erit. 113-181; 2002; Porkka 1883a; 1883b), muu väki lauloi runoja. Keskeisimpiä laulajia olivat naiset ja tytöt. Häissä laulettiin sekä häistä toiseen hyvin samanlaisina pysyviä että tilanteen mukaan muokattavia runoja. Kuten Pertti Anttonen (1987, 84-91) toteaa, jokaisissa häissä vanhatkin laulut tulkittiin osin uudelleen, ja uusia lauluja voitiin tehdä. Päiviä kestäneen tapahtumasarjan kuluessa laulajat, laulut ja laulamisen sävyt vaihtelivat. Häihin liittyviä muita lauluja, kuten morsiamelle kohdistettua lyriikkaa ja lyyristä epiikkaa, eivät laulajat välttämättä laskeneet varsinaisten "pulmavirsien" joukkoon. (Alava 1932; Salminen 1934, 175; Timonen (käsikirjoitus).) ${ }^{716}$ Vaikka häät olivat naisten laulun aluetta, myös miehet saattoivat, "etenkin kannua kallisteltuansa" ryhtyä "muita runoja vetelemään, jopa runokilpailuunkin," kertoo Salminen $(1934,89)$.

Tyypillisimmät häälaulujen esittämistavat läntisessä Inkerissä olivat paikallaan seisominen, istuminen ja piirissä peräkkäin käveleminen. Usein laulutilanteeseen liittyi myös jotain muuta rituaalisesti sävyttynyttä tekemistä, esimerkiksi pihaan saapumista, sormuksen sovittamista morsiamen käteen, lahjojen jakamista tai morsiamen hunnuttamista. (Launis 1910b, VIII, IX-X, vrt. Salminen 1917, 202-204.) Häät muodostivat monipolvisen siirtymäriitin, jossa morsian asettui sulhasen kotiin ja sukujen väliset suhteet järjestettiin uudestaan (Anttonen 1987). Lahjojen, lähinnä käsitöiden ja rahan vaihto oli joka vaiheessa runsasta, ja rituaalinen viinanjuonti kuului moneen tilanteeseen. (Ks. Salminen 1916, 1917.)

Hääkuvausten moninaisuus viittaa siihen, että tavat ovat vaihdelleet kylittäin, ryhmittäin ja häittäin. Juho Lukkarisen mukaan "monilla kylillä, vieläpä niissä eri taloillakin on nykyisin omia tapoja (vanhaa perua), joita ei enää toiset noudata (Salminen 1917, 30)." Häiden kulku siis vaihteli jopa suvuittain - nähdäkseni Lukkarisen havainto on nimittäin välttämätöntä tulkita ilman oletusta aiemmasta kokonaisvaltaisesta yhtenäiskulttuurista. Näyttää myös siltä, että esimerkiksi jotkut luterilaiset laulajat ovat esittäneet inkeroisille tyypillisiä lauluja ja ortodoksisuuteen viittaavia teemoja. Myös venäjänkielisiä kohtia, uusimittaisia suomenkielisiä lauluja ja luterilaisia virsiä saattoi häämenoihin sisältyä, vaikka niistä harvoin on tallennettu edes mainintoja. ${ }^{717}$ Morsiamen ja sulhasen suvun laulajat saattoivat myös innostua laulukilpailuun, jossa Salmisen $(1917,30)$ mukaan laulettiin "kaikki, mitä ikinä osataan, myöhempinä aikoina yksin virsikirjan virretkin yhtenä loruna."718

\footnotetext{
${ }^{716}$ SKVR III: 2344; SKS KRA Alava 13: s. 195; Haavio 2587; Laiho A. 2087-2089, 2092, 2276; vrt. Čistov 1976b, 213, erit. nootti 1.

${ }^{717}$ Toisen ryhmän sanastoon liittyviä selityksiä ks. esim. SKVR III 2131 viitteet 2 ja 4; vihjeitä venäjänkielisistä häämenoista SKVR III 1721, 2376, 2442, 2482, 2548; SKS KRA Alava X 106, 115; uusimittainen "Nyt isän majasta lähtet" osana kalevalamittaisten häärunojen ketjua SKS KRA Laiho A. 3441, ks. myös SKS KRA Laiho L. 4921; virsistä SKS KRA Enäjärvi-Haavio 871-872.

${ }^{718}$ Ks. myös esim. SKS KRA Laiho A. 2276.
} 
Monipäiväisen, useiden ryhmien dialogina etenevän rituaalin selittäminen ulkopuoliselle oli vaikea tehtävä. Selvitellessään runojen liittymistä häätapahtumiin Väinö Salminen $(1917,27)$ kertoo pyytäneensä välillä useampaa naista näyttämään tapahtumien kulun. Hän pahoittelee:

Kaikkia muistiinpanoja haittaa se, etteivät ne ole häissä tehtyjä. Laulajan on täten täytynyt muistiinkirjoittajalle esittää häissä esiintyvien eri henkilöiden sekä sulhasen että morsiamen puolen osia ja siitä johtuu taitavankin laulajan sotkeutuminen.

Aina ei kuitenkaan voi olla varma siitä, johtuuko aineistosta löytyvä yksittäinen poikkeus laulajan "sotkeutumisesta" vai rituaalin ja runojen variaatiosta. Harva laulaja lähti myöskään esittämään kerääjälle kaikkia häihin liittyneitä runoja. Ulla Mannonen referoi soikkolaisen Anni Moisefin kertomaa: "Meillä Inkerin maalla kestivät häät monta päivää, ja aina laulettiin. Sulhaselle laulettii, morsijamelle laulettii, kaasoille laulettii, lähtiessä laulettii, morsijainta itkettäessä kylän naiset lauloivat, niin paljon oli lauluja, että ei niitä kaikkia kukaan kerralla muista."’19

Seuraava kuvaus häiden kulusta onkin lähinnä Salmisen $(1916,1917)$ yhteenvetojen pohjalta tehty yleistys, eräänlainen peruskaava, jonka kaikkia elementtejä ei välttämättä jokaisiin häihin sisältynyt ja joka kuvaa ennen kaikkea länsi-inkeriläisiä inkeroishäitä.

\section{HÄIDEN KULKU}

Häitä pidettiin erityisesti joulunajan ja laskiaisen välillä sekä suurina kesäpraasnikoina, erityisesti helluntaina, Pedrona ja Iiliana. ${ }^{720}$ Lukkarisen (1933, 125-126) mukaan perinteinen tapa oli pitää häät talvikautena. Häät alkoivat oikeastaan jo kosimistilaisuudessa: sulhasehdokas tuli puhemiehineen morsiamen taloon tupakoille. Puhemies oli usein rist'isä eli kummisetä. Onnistunutta kosintaa seurasivat kihlajaiset, kädenlyönti, jonka jälkeen alkoi lahjatarvikkeiden ja varojen keruu kylästä ja sukulaisilta. Ennen häitä morsian kokoontui iltaisin kylän tyttöjen kanssa tekemään yhdessä häitä varten tarvittavia lahjoja: samoissa tilanteissa myös harjoiteltiin häärunoja ja laulettiin morsiamelle. (Salminen 1917, 32-46.) . $^{721}$

Häiden aattoon kuului ainakin Länsi-Inkerin inkeroisilla ja vatjalaisilla kupelileivän paistaminen. Tapa on sama kuin venäläisillä: omalla tahollaan sekä morsiamen että sulhasen sukulaisnaiset kokoontuivat leipomaan suuren leivän (tai piirakan), jonka onnistumisesta ennustettiin tulevan liiton onnellisuutta ja jota käytettiin myös häärituaalin myöhemmissä vaiheissa. (Salminen 1917, 46-49; 1916, 44-49; Pork-

\footnotetext{
${ }^{719}$ SKS KRA Mannonen 9833.

${ }^{720}$ SKS KRA Haavio 2672; Laiho L. 6136; helluntaista IMS: troitsanūlitsa; Pedrosta ja Iiliasta ks. Lukkarinen 1911, 42; SKS KRA Alava X, s. 114.

${ }^{721}$ SKS KRA L. Laiho 4736.
} 
ka 1883b, 262. ${ }^{722}$ Varsinaiset häärunot alkoivat häiden aattoillasta, ${ }^{723}$ jolloin sekä morsian että sulhanen tahollaan kylvetettiin joko oikeasti tai ainoastaan rituaalisesti. Runoja liittyi niin morsiamen ja sulhasen istuttamiseen pöydän taakse pyhäinkuvanurkkaan, kengittämiseen matkaa varten, lahjojen (apiraha) keräämiseen sukulaisilta, sulhasen morsiustaloon lähdön valmisteluihin kuin itse matkaankin. Etenkin morsian ja hänen äitinsä itkivät itkuvirsiä (ks. Nenola 1982, 113-181; 2002, 357-542), tytöt lauloivat runoja (Salminen 1916, 54). (Salminen 1917, 46-116.)

Saavuttuaan morsiustalolle sulhasen saattojoukko pyysi laululla talon väkeä avaamaan portit. Saapumistilaisuuteen ja tupaan siirtymiseen liittyi paljon lauluja, monenlaista pahoilta katseilta suojautumista, tervehtimistä, kehumista sekä sulhasen ja hänen joukkonsa kiusoittelua, suoranaista pilkkaakin. (Salminen 1917, 50-253; Anttonen 1987.) Kun tupaan oli asetuttu ja sulhasväen eteen kannettu ruokaa ja juomaa, alkoivat nämä laulaen vaatia piilossa olevaa morsianta nähdäkseen. Seurasi pitkä runomuotoinen dialogi, jonka tuloksena puhemies lähti hakemaan morsianta aitasta tai muusta piilopaikasta, jossa laulu jatkui. Äitinsä sylissä olevalla morsiamelle tarjottiin vähän leipää ja olutta, hänen käteensä sovitettiin sormus ja hän jakoi sulhasväelle lahjoja. Tupaan paluuta seuranneen monimuotoisen laulujenvaihdon seurauksena morsian valmisteltiin lähtöön, hunnutettiin ja kengitettiin itkujen ja runojen säestyksellä. (Salminen 1917, 254-326). Vihillä kirkossa saatettiin käydä tässä kohden tai sitten myöhemmin, häiden jälkeenkin. ${ }^{724}$

Sulhasjoukon saapuessa sulhasen taloon laulut kohdistuivat sekä sulhaselle että ennen kaikkea morsiamelle, jota kehotettiin laululla laskeutumaan ajoneuvosta, kumartamaan ja antamaan lahja maan haltijoille. ${ }^{725}$ Jonkun ajan kuluttua saapui jäljestä morsiamen puolen suku, jälkijuojat, ja pyysi laulaen päästä sisään. Sisään päästyä morsiamen puoli lauloi tulleensa kadonnutta hanhea, kuuta tai siskoa etsimään, eikä tahtonut ruokaa eikä juomaa ennen kuin sai morsiamen nähdäkseen. Keskeinen tapahtuma sulhastalossa oli morsiamen lahjojen jakaminen sulhasen sukulaisille. Morsiamen suku puolestaan kävi aitassa eli huhmarella tarkistamassa ja kehumassa lauluin talon ruokavarojen määrän. Morsiamen ja sulhasen työkykyä kehuttiin sukujen välisen dialogin muodostavissa runoissa. Juhlat sulhastalossa kestivät useamman vuorokauden. Morsiamen neuvokkivirsissä morsiamen puoli antoi neuvoja uudessa talossa elämistä varten, sulhasen neuvokkivirsissä puolestaan kehotettiin kohtelemaan vaimoa lempeästi. Sekä morsiamen että sulhasen talossa laulettiin kestityksen päätyttyä piirissä tanssien kokin kiitosvirsi. Ennen sulhastalosta lähtemistä morsiamen suku lauloi morsiamelle lähtövirren. Saatettiin myös toivottaa laululla onnea isäntätalon väelle. (Salminen 1917, 327-409.)

\footnotetext{
${ }^{722}$ SKVR III 3478; SKS KRA Enäjärvi-Haavio 854, 860. Leipomisen jälkeen morsian katsoi, oliko leipä "onnileipä", mutta totesi sen "itkuleiväksi": tilaisuuteen liittyikin lähinnä morsiamen itkuvirsiä. Hevaan Lenttisistä on Varvana-eukolta kirjattu leivän leipomisesta kertova ja leivän kohoamista toivova runo (SKVR IV 2301), joka laulettiin sulhaselle - morsiamelle hänen mukaansa vain itkettiin.

${ }^{723}$ Veternoilta (SKVR III 395, 1675), kenkisilta (SKS KRA Sääski 5982) tai someroilta (SKS KRA Salminen V. 2947).

${ }^{724}$ SKVR III 2264; 3274; SKS KRA Enäjärvi-Haavio 874; Laiho A. 2158, 2312, 2616; Mannonen 5504; Sääski 5966.

${ }^{725}$ Esim. SKS KRA Salminen V. 2933.
} 


\section{LAULAJAT SOSIAALISTEN RYHMIEN EDUSTAJINA}

Tiedot häissä laulavista ryhmistä ja häiden roolinhaltijoista ovat moninaisia ja osin keskenään ristiriitaisia, mutta naimisissa olevat naiset näyttävät yleensä pitäneen hallussaan keskeisintä roolia. Vihtori Alavan $(1916,8)$ mukaan häissä "esiintyivät tavallisesti vanhemmat naiset." ${ }^{\text {726 }}$ Samoin yleistää Launis (1910b, XII): "Eri tilanteissa, kuten esimerkiksi häissä esittävät aikuiset rouvat esilaulajina tärkeintä roolia." Volmari Porkka $(1886,164)$ huomauttaa erikseen, että vaikka Joenperän Olena Osipan nainen olikin vielä nuori, oli hän jo käynyt esilaulamassa kolmissakymmenissä häissä. Olena oli kuitenkin jo naimisissa, ja nuoruuden korostaminen viittaa sen poikkeuksellisuuteen. Toisaalta Salmiselle $(1934,92)$

Inkerissä kerrottiin, että 1870-luvulla, joskus 16-vuotiaskin neito juhlissa sai olla esilaulajina. Narvusin puolella oli nuori tyttö, jolla oli harvinaisen heleä ääni, nostettu savupirtin uunin päälle. Sieltä hän yli kaiken häärahvaan esitti laulut, joita muut 'maasta' 'jälest järistivät. ${ }^{\text {727 }}$

Muistiinpanojen perusteella näyttääkin siltä, että laulajina ja esilaulajina oli tilanteesta riippuen sekä vanhempia että nuorempia naisia: yksi laulaja ei esilaulanut kaikkea. Kuten Pertti Anttonen (1987, 117-120) toteaa, esimerkiksi suurin pilkkarunoista näyttää olleen morsiamen vertaisryhmän, kylän tyttöjen laulamia ja sulhaseen kohdistamia. Eri runojen laulaminen kuului vaihteleville sosiaalisille ryhmille ja osa sulhasen, osa morsiamen väelle. Monin paikoin laulut muodostivatkin sukujen välisen dialogin. ${ }^{728}$ Ilmeisesti tässä dialogissa merkittävämmät puheenvuorot olivat vanhempien naisten esittämiä.

Miesten laulamista häärunoista on ainoastaan yksittäisiä mainintoja. Väinö Salminen $(1917,27)$ kertoo Länsi-Inkeristä:

Tiedustellessani häärunojen esittämisestä, kerrottiin kaikkialla, että laulajina häissä ovat, niin kauan kuin muistetaan, esiintyneet miltei yksinomaan naiset. Miehet laulavat kumminkin sulhasta kylvetettäessä ja usein kokin ylistysvirren. Muidenkin häärunojen laulamiseen saattaa miesväki ottaa osaa, mutta eivät ole esilaulajina. ${ }^{729}$

Yleensä miehiä ei mainita edes lauluun osallistujina - runojen yhteydessä mainitaan nähdäkseni yleensä lähinnä esilaulajat tai kaikkein keskeisin laulajaryhmä, ei erikseen kaikkia lauluun mahdollisesti osallistuneita ryhmiä. Kuvauksissa hy-

\footnotetext{
${ }^{726}$ Ks. myös SKS KRA Mannonen 5505. Sylvi Sääski (SKS KRA Sääski 5956) tuntuu tulkinneen haastateltavansa vierasta murretta osin väärin kertoessaan, että Soikkolassa "Esilaulajina toimi kaksi $u k k o a$, sulhasen ja morsiamen sukulaisia. Muu väki yhtyi lauluun," sillä kaikki muut maininnat kertovat naisista sukuja edustavina esilaulajina.

${ }^{727}$ Salminen lisää vielä täysin paikantumattoman ja ajoittumattoman kommentin: "Paitsi nuorten kisoissa ja keinulla ei nuorten muinaisina aikoina sopinut 'nousta' laulajaksi vanhojen läsnäollessa." Luultavasti tiedot ovat peräisin joltakulta Salmisen vuonna 1906 tai 1931 haastattelemalta vanhalta ihmiseltä. On huomattavaa, että Salminen ei tarkenna, kuinka keskeisiä tai mitä häälauluja muistelma koskee - tai kertooko se nuorten aikuisten esilaulajana toimimisen harvinaisuudesta vai yleisyydestä.

${ }^{728}$ SKVR III 2259-2266, 2493-2517

${ }^{729}$ Ks. myös SKS KRA Enäjärvi-Haavio 869.
} 
vin yleisten mainintojen sulhasen tai morsiamen suvusta tai väestä laulajina voikin helposti tulkita kattavan sekä naiset että miehet. Muutama esimerkki suoraan miesten suuhun ja hääkontekstiin sijoittuvista lauluista kuitenkin löytyy. Nämä eivät kuitenkaan kuulu rituaalisesti keskeisten laulujen joukkoon. ${ }^{730}$

Häiden roolinhaltijoilla oli osin omat laulunsa. Morsian ja morsiamen äiti lauloivat lähinnä itkuvirsiä ja sulhanen pysyi pitkälti vaiti (Nenola 1982, 113-181; Porkka 1883b). ${ }^{731}$ Välillä kuvataan kylän tyttöjen, morsiamen vertaisryhmän, laulaneen tiettyjä runoja "morsiamen puolesta": heitä kutsuttiin "tytön väeksi" tai "morsiamen tytöiksi." "32 Maininnat koko sukuja edustavista esilaulajista ovat hieman ristiriitaisia, mutta ilmeisesti rituaalisesti keskeisimpien laulujen esilaulajat olivat usein vanhempia naisia. Hyvä laulaja saattoi toimia palkattuna esilaulajan kymmenissä häissä. (Porkka 1886, 155-156, 158, 162; Salminen 1917, 28.) Hevaalaiselta Varvanalta kävivät nuoremmat Porkan (1886, 155-156) mukaan oppimassa häärunoja vielä silloinkin, kun tämä ei itse enää vanhuuttaan jaksanut häihin. Esilaulaja saatettiin pyytää vieraasta kylästäkin, mutta ilmeisesti yleensä oman uskontokunnan keskuudesta. ${ }^{733}$

Häiden roolinhaltijoita kutsuttaan kuvauksissa useammilla, osin tilannesidonnaisilla ja puhuttelijasta riippuvilla nimillä. Keskeishahmot olivat tietenkin morsian ja sulhanen. Morsianta nimitetään kontekstimaininnoissa yleensä morsiameksi tai tytöksi. ${ }^{734}$ Sulhasta nimitetään yleensä sulhaseksi, senihkaksi, vävyksi, peikomieheksi tai pojaksi. ${ }^{735}$ Hääväkeä kutsutaan pulmaväeksi (pulmalliset), ja tätä voidaan käyttää myös tarkoittamaan joko morsiamen tai sulhasen sukua. ${ }^{736}$ Sulhasen sukua voidaan

\footnotetext{
${ }^{730}$ Anni Moisef esitti kerääjälle "sulhasten kanssa tulleiden miesten" laulaman tervehdyslaulun ja kertoi Musta Okru -nimisen miehen olleen erityisen taitava pilkkaamaan sulhasta (SKS KRA Mannonen 5503, ks. myös 5505, 5956; Mustasta Okrusta ks. Mannonen 5501). Matti Pukonen soitti tuohitorvella "pulmanuotin" A. O. Väisäsen vahalieriölle ja Väisänen tallensi nuottina myös hänen samalla sävelmällä laulamansa lyyris-eeppisen, narvusilaisen Hanhi kadonnut -runon tyypillisen alkusäkeen (SKSÄ A 303/8; SKS KRA Väisänen laatikko 3:3 Inkerinmaa. Vihko sävelmämuistiinpanoja, s. 2. Ks. myös SKS KRA Laiho L. 5001.) Pukosen sävelmä on tyypillinen jäljessä käsiteltävän "tavallisen pulmanuotin" toisinto.

${ }^{731}$ Ks. kuitenkin myös SKVR III 3661; SKS KRA Mannonen 5511.

${ }^{732}$ Esim. SKVR III 403, 1696, 1704, 2133, 2259.

${ }^{733}$ SKVR III 2551n3; SKS KRA Alava XIII 184; ks. myös Kuusi 1983a, 197, 215-219. Väinö Salminen näyttää vaihtaneen kantaansa kokemuksen karttuessa. Varhaisen (Salminen 1917, 28, ks. myös 30) tiedonannon mukaan "esilaulajat, joista on riippunut koko runojen esitys, ovat esiintyneet toisuskoistenkin häissä" huolimatta siitä, että muuta kanssakäymistä oli vähänlaisesti, ja muuten häihin ei olisi kutsuttu eriuskoisia samastakaan kylästä. Salmisen todisteina siteeraamista Porkan esimerkeistä ei mikään kerro toisuskoisten häissä esiintymisestä ja myöhemmässä, 1930-luvun keruuretkien jälkeisessä kirjoituksessa $(1934,217)$ näkemys onkin muuttunut: "Inkeroisilla ei ollut tapana palkata luterinuskoista esilaulajaa eikä päinvastoin." Vuonna 1931 julkaistu etnisten erojen kuvaus on puolestaan laajemman aineiston valossa toiseen suuntaan liioitteleva: Salmisen (1931 b, 527) mukaan etnisillä ryhmillä ei ollut mitään tekemistä keskenään, eikä runoja opittu ryhmien välillä. Vuonna 1906 Salminen (1931a, 646) kertoo kuulleensa Kattilasta kotoisin olleen vatjalaislaulaja Anna Ivanovna esiintyneen myös "suomalaisten" häissä.

${ }^{734}$ Esim. SKVR III 22, 2440. Paikoin myös uusikoksi (SKVR III 410), nuorikoksi (SKS KRA Haavio 2568), vietevikoksi (SKVR III 2436) naissulhoksi (SKVR III 3491) tai sisoksi (SKVR III 2548). Anna Kivisoon (SKS KRA Laiho L. 5307) mukaan "Vietvikko oli morsian vihille asti, sitten nuorikko." Orpo morsian on "armotoin tyttö" (SKS KRA Salminen K. 120).

${ }^{735}$ Esim. SKVR III 49, 2145, 2539, 3485; SKS KRA Laiho A. 2336. Senihka esiintyy myös muotoissa ženihka, SKVR III 2018; 2259; ženihhamies SKVR III 2548 ja zenihha SKS KRA Haavio 2568. Sulhasta kutsutaan myös vävymieheksi (SKVR III 2548), kosjolaiseksi (SKVR III 401) ja vatjalaisten parissa pei-
} komieheksi (SKVR III 2376, ks. myös 2372).

${ }^{736}$ SKVR III 2404, 2510, 2511, SKS KRA Enäjärvi-Haavio 883, 884. 
kutsua myös saajaväeksi, sulhon väeksi, sulhasen puoleksi, ottoväeksi tai ottajiksi, morsianta sulhastaloon seurannutta, saattamassa olevaa morsiamen sukua peräst ajajiksi, jälkijuojiksi, volkiksi eli susiksi tai nuoteiksi eli nuohinaisiksi. ${ }^{737}$ Peremies tarkoittaa sen talon isäntää, jossa ollaan eli yleensä tilanteen mukaan joko morsiamen tai sulhasen isää. ${ }^{738}$ Varsinainen pulmaväki voidaan hahmottaa suhteessa ulkona häitä seuraavaan ääriväkeen tai ristirahvaaseen eli kuokkavieraisiin. Ristirahvas viittaa vaihtelevasti myös varsinaiseen pulmaväkeen, sukulaisiin. Ä̈̈riväki voi tarkoittaa myös morsiamen kylän tyttöjä. ${ }^{739}$ Pulmaväki esiintyy kuvauksissa usein häälaulujen laulajana, mutta tällöin on vaikea päätellä, kohdistuuko kuvaus kaikkiin läsnäolijoihin, ainoastaan morsiamen tai sulhasen pulmallisiin vai kenties vielä rajatumpaan ryhmään. Yleensä esilaulajaa ei erikseen mainita, puhutaan vain laulajaryhmästä, vaikka mikään inkeriläisen laulun kuvauksissa ja sävelmäaineistoissa ei viittaa siihen, että olisi ollut tapana laulaa ryhmänä ilman esilaulajaa. Ilmeisesti Alavan ja Launiksen keskeiseksi mainitsemat häiden esilaulajat, aikuiset naiset, ikään kuin sulautuvat edustamaansa joukkoon.

Hääväestä keskeisimpinä esitetään kuvauksissa sekä inkeroisilla että inkerinsuomalaisilla kummit eli rist'isä (eli rist’ätti, ristitaatta) ja rist'emä (eli kaazonain, kaasanainen). ${ }^{740}$ Rist'isä oli usein myös puhemies. ${ }^{741}$ Hänestä tai morsianta hakemaan tulleesta sulhasväestä laajemminkin saatetaan käyttää nimitystä kosjolainen (kosjolaset, sulhaset) ${ }^{742}$ Kummit ovat tärkeässä roolissa häärituaaleissa, mutta heitä ei yleensä mainita häälaulujen laulajiksi. ${ }^{743}$ Hääparin vanhempia ei laulajina mainita lainkaan. Varsinaisen häärituaalin aikana he pysyivät omissa taloissaan, matkaa talojen välillä tekivät muut sukulaiset puhemiehen kanssa.

Morsiamen ja sulhasen puolesta laulaviin henkilöihin viitataan useammalla nimityksellä. Vihtori Alavan mukaan pulmissa oli esilaulajan ohella "5-6 tyttöä kaasekkeloi," ja morsiamen puolesta "laulaa kaksi korvallista." ${ }^{44}$ Näyttää siltä, että kaasikkeina (kaazikat) on voitu puhua sekä morsiamen että sulhasen puolesta laulavista tytöistä. ${ }^{75}$ Nimitys kaase viittaa joskus myös laajemmin sulhasen tai morsiamen pulmaväkeen, joko sukulaisiin tai muihin mukana olijoihin. ${ }^{746}$ Korvoit eli korvalliset viittaavat morsiamen sukulaistyttöihin jotka pesevät tämän päätä tai istuvat

\footnotetext{
${ }^{737}$ Sulhasen suvusta: SKVR III 412, 2499, 3480, 2482; SKS KRA Salminen V. 2940; morsiamen suvusta: SKVR III 2513; SKS KRA Mannonen 5509; Salminen V. 2926, 2959; Sääski 5973; Enäjärvi-Haavio 906; ks. myös Salminen 1917, 322-323.

${ }^{738}$ SKVR III 401; SKS KRA Salminen K. 95.

${ }^{739}$ SKVR III 407, 2134, 2265.

${ }^{740}$ SKVR 1678, 1681, 1711, 1734, 2131, 2134, 2261, 2545; SKS KRA Enäjärvi-Haavio 871-872, 889; Laiho A. 2616; Mannonen 9840.

${ }^{741}$ Esim. SKVR III 1678.

${ }^{742}$ SKVR III 401, 1678, 2131, 2134, 2261, 2542; Enäjärvi-Haavio 871; Mannonen 5506, 5507.

${ }^{743}$ Ks. kuit. SKS KRA Salminen V. 2959.

${ }^{744}$ SKS KRA Alava IV 194.

${ }^{745}$ SKVR III 22, 27-29, 602, 1657-1721, 2440.

746 "Kaase on pulmaväki pojan puolell, pojan suku" (SKVR III 2261), "morsiamen kaasit ja sukulaiset" (Mannonen 5509).
} 
tämän vieressä eli korvalla, mutta löytyy maininta myös sulhasen korvoipojista. ${ }^{747}$ Usein puhutaan vain tytöistä tai kylän tytöistä, joskus kerrotaan näiden olevan joko sulhasen tai useimmiten morsiamen "kasvo-parvi" eli kasvinkumppaneiden joukko. ${ }^{748}$ Runossa kaasikat ja korvalliset saatetaan esittää rinnasteisina morsianta puhutellessa: "terve kaksi kaasikkea, kolmed korva vierellistä." 74

Nimitykset ovat osin kontekstisidonnaisia, ja ne määrittävät myös laulajan asemaa suhteessa hänen keruutilanteessa laulamiinsa lauluihin. Esimerkiksi siso morsiamen nimityksenä kertoo laulajan sijoittaneen itsensä joko sisaren tai ikätovereiden ryhmään ja laulaneen runonsa kerääjälle heidän näkökulmastaan. Selkein ero tehdään kontekstitiedoissa sulhasen ja morsiamen puolen välille: näiden kesken käytiin häiden merkittävimmät dialogit. Nimitykset saattavat kuitenkin vaihdella yhdenkin kuvauksen puitteissa. Esimerkiksi O'l'a Voloitsasta viittasi yhden runon kontekstitiedossa samaan laulajaryhmään termeillä "tytön väki", "tytöt" ja "tytön suku." ${ }^{750}$ Nimitykset ovat usein huomattavan epämääräisiä. Selitysvaihtoehtoja on useita: kenties tiettyjen runojen asema kokonaisuudessa on tuntunut monille laulajille itsestään selvältä, laulajaryhmät eivät ole aina olleet niin tarkasti määrittyneitä tai sitten, kuten Salminen $(1917,27)$ antaa ymmärtää, monimutkaisen - ja luultavasti häittäin varioivan - tapahtumaketjun selvittäminen äkkiseltään usein ollut yksittäiselle laulajalle häiden ulkopuolella hankala urakka.

\section{LAULUN ALKU: PUHUTTELU, PYYNTÖ TAI KEHOTUS}

Suurin osa häärunoista alkaa tiiviisti häihin liittyvällä kiinteällä puhutteluformulalla (esim. Oi Mari sisarueni), tilannesidonnaisella pyynnöllä tai kehotuksella (Avatkaa Viron veräjä) tai yleisemmällä häihin liittyvällä aloitusformulalla (Yks oli ounapuu kylässä). Tämä tekee vain lyhyitä runon alkuja sisältävien fonogrammi- ja nuottiaineistojen tulkinnasta mahdollista. Joskus yksi formula voi kuitenkin liittyä useaan häiden vaiheeseen ja kontekstista riippuen viitata useampaan toimijaankin. Etenkin sukulaisten puhutteluformulat (Lankoiseni lintuiseni) voivat viitata sekä morsiamen että sulhasen puoleen eri kohdissa häitä.

Puhutteluformulan keskeisyydestä kertoo osaltaan se, että vuoden 1937 äänityksissä laulajat aloittivat laulun sillä jopa mainitessaan laulun edellisen runon jatkoksi. Sitä myös joskus toistettiin keskellä laulua. ${ }^{71}$ Ainakin morsianta puhuttelevat runot oli näiden laulajien mukaan häiden ulkopuolellakin tärkeä kohdistaa jollekulle läsnä olevalle ja sosiaalisesti sopivalle henkilölle. "Lesken on hyvä ellää," sanoi

\footnotetext{
${ }^{747}$ SKVR III 2264, 2269, 3480; SKS KRA Sääski 5973. Korvallisia oli kaksi, yksi kummallekin puolelle (IMS: korvoi).

${ }^{748}$ Esim. SKVR III 418, 592, 1674, 1696, 2138, 2147, 2265, 2270; SKS KRA Enäjärvi-Haavio 864; Laiho L. 5307; Salminen V. 2933.

${ }^{749}$ Esim. SKS KRA Salminen V. 2939.

${ }^{750}$ SKVR III 2259.

${ }^{751}$ Kylvetysvirsi SKSÄ L 98a on viitetiedoissa merkitty jatkoksi ja lopuksi 97a:han, ja kummatkin alkavat samalla Oi Mari sisarueni -puhuttelulla, ks. samoin 99b ja 100a. Lauluissa SKSÄ L 99a ja b formulaa toistettiin keskellä laulua.
} 
Anna Kivisoo, kun lauluja ennen matkaa harjoiteltiin. Hän piti lesken elämästään, joten häälauluja ei voitukaan osoittaa hänelle. Niinpä naiset aloittivat äänityksissä kaikki viisi morsiamelle osoitettua runoa säkeellä Oi Mari sisarueni, osoittaen runon Mari Vahterille. Vahter oli myös leski, mutta ilmeisesti halukkaampi uuteen naimakauppaan. "Paamma siis Marin miehelle," totesivat laulajat. (Simonsuuri 1961, 24.) Sulhasen nimi korvattiin keruutilanteessa usein vain sanalla vävy tai sulho (Sulhoani velloani tai oi vävy vävyjyeni). ${ }^{752}$ Joissain tallennetuissa runoissa morsiamen nimi korvataan nimityksellä siso tai ainue eli ainoa. ${ }^{733}$ Voi olla, että puhutteluformuloiden puuttuminen kokonaan monista runo- ja sävelmätoisinnoista liittyy juuri siihen, että ketään sopivaa laulun kohdetta ei ollut läsnä. Vatjalainen Oudekki Figurova päätyi laulamaan morsiamelle osoitetun laulun lyhyen pohdinnan jälkeen omalla nimellään: "No jotta m- no kui, ni miä... Olkkoo, võttan oman nimen. Võttan oman nimen." Runoissa käytettiin tuttavallisia puhuttelumuotoja: esimerkiksi Oudekki oli laulussa Oto tai Otoi: oi Oto sisaruveni. ${ }^{754}$ Muutamassa runokäsikirjoituksessa erityisesti korostetaan nimen vaihtuneen aina sen mukaan, kuka oli morsian tai sulhanen. ${ }^{755}$

Morsiamen puhuttelumuoto on häärunojen aloitusformuloista selkeimpiä. Aineistossa ei ole yhtään viitettä siitä, että Oi Mari sisarueni -tyyppiset morsiamen nimen tai sisar-puhuttelun sisältävät formulat viittaisivat johonkuhun muuhun kuin morsiameen. Samoin sulhasen puhuttelut nimellä tai veli-nimityksellä muodostavat selkeän ryhmän (Juko hellä velvyiveni, Aja aja velvyeni). Sulhasen puoli puhuttelee morsianta minjueksi tai marjueksi. ${ }^{756}$ Morsiamen puoli puhuttelee sulhasta vävyksi, morsiamen puolesta laulavat tytöt samoin kuin sulhasen kaaset myös veljeksi, ja pilkkarunoissa sulhasta nimitetään myös nimityksellä mökkö. ${ }^{757}$ Morsianta voidaan kutsua myös muodolla neitsyeni naisukkoni. ${ }^{758}$ Morsiamen puolesta laulavia tyttöjä sulhasen suku saattoi puhutella muihinkin runoihin ja tilanteisiin liittyvällä muotoilulla tytöiksi ja siskoiksi: Oi tytöt sulat sissoit. ${ }^{759}$

Kumpikin suku kutsuu toistaan langoksi ja aloittaa laulun usein aloitusformulalla Lankoiseni lintuiseni. ${ }^{760}$ Lanko-termi kattaa laajan joukon sukulaisia: "pojan ja tytön isäd ja emäd ja muu suku" tai "kaikki kummivanhempia ja enon lapsia myöten.$^{711}$ Puhemiehenä toimi yleensä sulhasen kummisetä eli rist'isä tai rist’ätti. Häärunoissa puhemiestä puhutellaan kuitenkin ainoastaan isämieheksi tai pää-

\footnotetext{
752 Esim. SKVR III 419; SKSÄ L 100c.

${ }^{753}$ Siso: SKVR III 3025, 3270, 3273; ainue: SKVR III 3194, 3269, 3274.

${ }^{754}$ ERA RKM, Mgn. II 1235 k. (Võttaa = ottaa.)

${ }^{755}$ SKVR III 417; ks. myös SKS KRA Enäjärvi-Haavio 907.

${ }^{756}$ SKVR III 2544; Salminen V. 2904. Säe Aja aja velvyeni esiintyy myös laskiaisrunoissa, mutta, kuten luvussa 6 todettiin, ei Länsi-Inkerissä yleensä aloita niitä.

${ }^{757}$ Esim. SKVR III 27, 1674, säe 52, 1682, 1755, 2271, 2304, 2546, säkeet 2 ja 45, 3481, SKS KRA Laiho

L. 4850; Sääski 5953.

758 SKVR III 410.

${ }^{759}$ Esim. SKVR III 2260, vrt. esim. 1530, 2494.

${ }^{760}$ Esim. SKVR III 414.

${ }^{761}$ SKVR III 2131, 2264.
} 
mieheksi, tyttöjen moittimisrunoissa myös kosjolaiseksi. ${ }^{762}$ Isämieheksi mainitaan puhutellun myös peremiestä, talon isäntää eli sulhasen tai morsiamen isää. ${ }^{763} \mathrm{Pe}$ remies-nimitystä ei länsi-inkeriläisen aineiston häärunoiksi mainituissa teksteissä esiinny, toisin kuin häärunojen kontekstitiedoissa ja praasnikkoihin liitetyissä Tanssituvanpyyntörunoissa. ${ }^{764}$ Hääväkeä laajemmin tai joskus kuokkavieraita kutsuttiin runoissa nimellä ristirahvas ${ }^{765}$ Runojen sisältämät puhuttelumuodot ovat siis huomattavasti kaavoittuneempia ja osin erilaisia kuin kontekstimaininnoissa esiintyvät vastaavien henkilöiden nimitykset.

\footnotetext{
${ }^{762}$ Esim. SKVR 1678, 1681, 2261; ks. SKVR-korpus: isämies, isämees.

${ }^{763}$ SKVR III 401.

${ }^{764}$ Ks. SKVR-tietokannan haut "perem*" ja "peren*".

${ }^{765}$ Esim. SKVR III 407, 454, 1706; SKS KRA Enäjärvi-Haavio 908
} 


\section{HÄÄSÄVELMÄT}

Tyypilliset hääsävelmät ovat praasnikkasävelmien tapaan suhteellisen yksinkertaisia. Yksisäkeiset, säettä sellaisenaan kertaavat muodot ovat yleisimpiä, ja muunkin tyyppisissä sävelmissä esilaulajan osuus ja kuoron kertaus perustuvat poikkeuksetta yhden runosäkeen toistamiseen. Katri Markin mukaan morsiusparille laulettavaa häärunoa "laulaessa kerrataan jokainen säe, kuten useimmissa muissakin häärunoissa."766 Muutamat laulajat viittaavat yksi säe kerrallaan etenevään kertausmuotoon nimityksellä kahel sanal. "Kaik pulmavirret laulettii kahel sanal," kertoi Valpuri Vohta, joka äänityksissä lauloikin kaikki esilaulamansa häälaulut yksi säe kerrallaan. ${ }^{767}$ Toisaalla Vohta nimitti jälestälaulajia eli kuoroa "toisel sanal" laulajiksi. ${ }^{768}$ Sana tarkoitti pohjois-inkeriläisen Larin Parasken mukaan säettä, ja samankaltainen säkeitä tai muita kiteytyneitä kielellisiä yksiköitä määrittävä nimitystapa on löydettävissä useissa muissakin laulukulttuureissa (Timonen 2004, 257-258; ks. esim. Foley 1995, 2). Näyttää siltä, että esilaulajan ja kuoron laulamat kaksi säettä - säe ja sen kertaus - miellettiin tässä yhdeksi kahden sanan eli säkeen kokonaisuudeksi. Kahel sanal tarkoittaa siis samaa kuin tämän tutkimuksen termi yksisäkeinen muotorakenne. Kahel sanal laulaminen määritti pulmavirsien yleisen rekisterin.

Vaikka erilaisia sävelmätyyppejä löytyy Inkeristä paljon, laulettiin suuri osa häiden lauluista muutamalla sävelmällä. Useimmat yksittäiset laulajat lauloivat kerääjälle yhdestä kolmeen yleisimpiä hääsävelmätyyppejä mukailevaa sävelmää, samoin vuoden 1937 äänityksissä laulajat käyttivät häälauluihinsa ainoastaan kolmea sävelmätyyppiä. ${ }^{769}$ Yleisin sävelmätyyppi kattaa häälauluaineistosta $40 \%$, toiseksi yleisin 10,5\%.

\footnotetext{
${ }^{766}$ SKS KRA Enäjärvi-Haavio 871-872.

${ }^{767}$ SKS KRA Laiho L. 4994. Yksisäkeisinä mainitsi Enäjärvi-Haavio lauletun sulhasten sukulaisten karavanassa tanssien laulamaa runoa Saimme saunan lämmittäjän, morsiusparille laulettua runoa Yhen muotoiset molemmat sekä morsiamen Neuvokkivirttä (SKS KRA Enäjärvi-Haavio 879, 871-872, 910). Valpuri Vohta kertoi kahel sanal lauletun Vävyn opetusvirttä, Kokin kiitosta ja Kylpemisvirttä ( SKS KRA Laiho L. 4994, Salminen K. 267, Laiho A. 3345). Näistä ensimmäisen hän esilauloi äänityksissä säkeen sellaisenaan, toisen säkeen lopun kerraten (SKSÄ L 100 c, 92 c). Kylpemisvirren laulamiseen hän osallistui kuorossa esilaulajan säkeen kerraten (SKSÄ L 97 a, 98 a). Katri Mark ja Anna Kivisoo käyttivät termiä kahel sanal myös liekkuvirsien yhteydessä, jotka samaten olivat aineiston perusteella tyypillisesti yksisäkeisiä (SKS KRA Laiho A. 2614, Laiho L. 5390). Mark kuvasi laulamista tarkemmin: "Kahella sanalla alattii, alkaja alko sanat, siis temmataa toiseD mukkaa. [...] Yks sano sanat i toiset otettii kai jäles kii.” Kivisoon kuvaus on aineiston valossa hämäävämpi: esilaulaja ”laulo kaks sannaa, jälellaulajal laulavat ne samat kaks sannaa." Liekkuvirren tai -sävelmän muotorakenteeltaan kaksisäkeisiä toisintoja ei kuitenkaan aineistossa ole.

${ }^{768}$ SKS KRA Enäjärvi-Haavio 548.

${ }^{769}$ Ks. esim. SKS KRA Alava X: 85, 103-104b; Borenius 193-195; lisäksi SKVR III 591, 592 viite 19; Borenius 203-205; SKS ̈̈ L 92b, c; 97-100.
} 


\begin{tabular}{|c|c|c|}
\hline MUOTORAKENNE & Rутмі & MÄ̈̈R̈̈ \\
\hline $1234567(8)$ & 22222222 & 50 \\
\hline 12345678 & 44222244 & 13 \\
\hline 12345678 & 42424242 & 5 \\
\hline $1234567(8) 567(8)$ & 222222222244 & 7 \\
\hline$\left(^{*}\right) 1234(* * *) 345678567\|\|^{*} 123434567$ (var) & 4244222222224 || [4] 224422224 (varioi) & 6 \\
\hline $12345678 \|^{* *} 12341234567$ & 31312222 || [22] 22843122218 (varioi) & 7 \\
\hline
\end{tabular}

Länsi-inkeriläisaineiston yleisimmät hääsävelmien (110 kpl) rakenne- ja rytmityypit (yli kolme toisintoa).

Suurin ryhmä muodostuu yksisäkeisistä, neli-iskuisista ja suppealla alalla (3-5 säveltä) liikkuvista sävelmistä. Tällaisia ovat myös kaikki Kattilan alueelta (vatjalaisilta) tallennetut hääsävelmät. Tämän lisäksi aineistossa on muitakin yksisäkeisiä ja suppealla alalla liikkuvia, erilaisia rytmityyppejä edustavia sävelmiä. Näissä yleisin on keskeltä tihennetty, kuusi-iskuinen rytmityyppi (44222244) variaatioineen, ja useampia kappaleita löytyy myös neli-iskuisen rytmin muunnosta (42424242). Osakertauksia sisältävät, vähintään kolmena toisintona tallennetut hääsävelmät jakautuvat kolmeen alaryhmään. Yleiset tyypit ovat kaikki yksisäkeisiä sävelmiä, joissa 1) säkeen loppupuolisko kerrataan, 2) säkeen keskellä on osakertauksia tai sananulkoisia lisätavuja tai 3) esilaulaja laulaa säkeen sellaisenaan ja kuoro lisää siihen refrenkisanat oi dai sekä osakertauksen. Näillä osakertauksia sisältävillä sävelmillä näytetään lauletun vain tietyn tyyppisiä tai tiettyihin tilanteisiin liittyviä runoja. ${ }^{770}$

Sävelmissä kiinnittää huomiota kaikki se, mitä niistä ei löydy. Joukossa on ainoastaan kaksi muotorakenteeltaan kaksisäkeistä sävelmää, ja niissäkin esilaulaja melko epätyypillisesti kertaa oman säkeensä. ${ }^{771}$ Yhtään säettä korvaavaa refrenkiä ei ole varsinaisten hääsävelmien joukossa. Ainoat refrenkisanat kuuluvat osakertausryhmään 3, säkeestä erilliset lisätavut puolestaan ryhmään 2. Sävelmät ovat pääpiirteittäin suppea-alaisia: ainoastaan muutama sävelmä ulottuu kuuden tai seitsemän sävelen alueelle. Nämä ovat kaikki käsikirjoitusmuistiinpanoja eivätkä Boreniuksen tallentamaa kuusisävelistä laulua lukuun ottamatta kuulu sanojensa osalta rituaalisesti keskeisimpien häälaulujen joukkoon. ${ }^{772}$

Eri alueilla hääsävelmät painottuvat eri tavoin. Länsi-Inkerissä ovat yleisimpiä tyyppejä neli- ja kuusi-iskuinen sävelmätyyppi. Kuusi-iskuinen tyyppi on yleisempi 1960-luvun aineistossa (NPI), vanhemmissa aineistoissa neli-iskuinen. Kattilan vatjalaisilta on tämän työn keskeisaineiston puitteissa tallennettu pääasiassa neliiskuista hääsävelmätyyppiä (vrt. Rüütel 1977, jossa runsaasti muitakin tyyppejä). Hevaan ja Tyrön alueilla neli-iskuinen ja viisi-iskuinen (22222244) sekä säkeen lopun osakertauksen sisältävä sävelmätyyppi (24222262 2262) dominoivat. Keski-

\footnotetext{
${ }^{770}$ Sävelmässä SibA Launis 337b on toinen säe Viivyit viivyit velvyeni tulkittu paralleelisäkeeksi, ei osakertaukseksi.

${ }^{771}$ SKSÄ A 300/34b; SibA Launis 346.

${ }^{772}$ SKS KRA Borenius e 194 (Päämies on pojut Kalervoin); SibA Launis 82 (välimuotoinen), 134 (Laai linttisi lipulle), 368 (Kosolainen kielikoira).
} 
Inkerin muilla luterilaisilla alueilla neljäntoista hääsävelmän Inkerin runosävelmissä julkaistu aineisto painottuu säkeen lopun osakertauksen sisältäviin erilaisiin rytmityyppeihin ja muutamiin neli-iskuisiin sekä masurkka-rytmisiin (22442244) sävelmiin. Pohjois-Inkerissä kaikki A. A. Boreniuksen keräelmään sisältyvät hääsävelmät ovat viisi-iskuista rytmityyppiä. ${ }^{773}$ Nähtävissä on sekä selvää paikallista että etnistä vaihtelua: eri kyläkunnissa ja eri ryhmien parissa laulettiin omilla tavoilla. Ajallinen variaatio selittynee osin tallennushistorialla, osin häälaulujen jäämisestä pois julkisesta käytöstä 1900-luvun myötä. Varhaisissa tallennuksissa näyttävät painottuvan rituaalisesti keskeiset hää- ja praasnikkasävelmät: esimerkiksi Europaeuksen viiden sävelmän kokoelmaan sisältyy sekä liekkusävelmä että neli-iskuinen hääsävelmä. 1960-luvulle tultaessa sävelmien käyttö tuntuu väljentyneen ja muuttuneen yksityisemmäksi: rituaalisten laulujen sävelmätyypit osin poikkeavat aikaisemmista kokoelmista.

Länsi-inkeriläiset hääsävelmäryhmät painottuvat osin erityyppisiin laulutilanteisiin tai eri laulajaryhmille. Näiden ryhmien mukaan jaottuu pääpiirteittäin myös seuraava häälaulujen analyysi. Yksisäkeisiä, säettä sellaisenaan kertaavia sävelmiä käsitellään lähinnä tässä alaluvussa: niiden joukkoon asettuvat kaikkein yleisimmät, lähes kaikissa häiden laulutilanteissa käytetyt sävelmät. Erilaisia poikkeuksia tarkastellaan tapaus kerrallaan seuraavassa alaluvussa. Ne liittyvät selkeästi tiettyihin, rajattuihin laulutilanteisiin. Kuten edelläkin on mainittu, sävelmien käsittely liikkuu tässä karkealla tasolla. Puhuessani hääsävelmätyypistä viittaan yleensä tiettyihin sävelalan, rytmityypin ja muotorakenteen yhdistelmiin. Tarkempi melodiatyyppien analyysi saattaisi paljastaa aineistosta hienojakoisempiakin, osin kenties alue-, laulaja- tai aikasidonnaisia erotteluja. ${ }^{.74}$

\section{RituAALISESTI KESKEISET LAULUT}

"Pulmanuottia on kaksi päätyyppiä, toinen hitaanpuoleinen - käytetty etenkin Narvusissa - toinen taas nopeatahtinen tanssisävel, joka oivallisesti sopii laulettavaksi häävirsiä tanssien esitettäissä. Missä määrin viimeksimainittu eroaa tavallisista 'tantsunuoteista' on vaikea määritellä, mutta voisi ehkä lyhyesti sanoa siitä, että tanssien lauletussa pulmanuotissa kööri kertaa esilaulajan sanat tai ainakin nuotin jotenkin sellaisenaan, jota vastoin tavallinen tanssisävel - kuten edempänä käy selville - on tässä suhteessa toisenlainen." (Launis 1907, 106.)

Armas Launis nimeää kaksi sävelmätyyppiä keskeisimmiksi hääsävelmiksi, joskin tanssien lauletun sävelmän kuvaus saattaisi epämääräisyydessään sisältää useampia muotoja. Tästä nopeatahtisesta tanssisävelestä Launis ei anna esimerkkiä, vaan kuvaa sen ainoastaan suhteessa muissa tilanteissa käytettyihin tanssisävelmiin. Häiden tanssisävelmän yhteydessä kuoro ei laula osuuttaan esilaulajaa nopeam-

\footnotetext{
${ }^{773}$ Ks. hääsävelmien kokonaistaulukko liitteessä 5. Pohjois-Inkeristä SKS KRA Borenius e 78, 80, 84, 96, 97, 717 (runot ja osa muistiinpanoista, ks. SKS KRA Borenius 6: 770, 795, 808, 826-828).

774 Tarkemman analyysin mahdollisuuksista ks. Rüütel 1977.
} 
malla tahdilla eikä häälaulujen yhteydessä käytetty tanssisävelmissä yleisiä säettä korvaavia refrenkejä tai kaksisäkeisiä kertausrakenteita, kuten aineistokin näyttää. Hitaanpuoleinen Launiksen tavalliseksi pulmanuotiksi kutsuma sävelmä on hänen antamansa kuvauksen ja tallentamansa aineiston pohjalta mahdollista tunnistaa saman tien. Sitä käytettiin Launiksen (Launis 1907, 106; ks. myös Timonen 2004, 152) mukaan esimerkiksi silloin, kun morsiamen saattoväki oli saapunut sulhastalon luokse ja pyysi päästä veräjästä sisään laulamalla Avatkaa Viron veräjät. ${ }^{775}$ Matkalla naiset ovat tanssineet ja laulaneet saadulmoi-sävelmällä (44224422), mutta perille saavuttaessa sävelmä vaihtuu, ja "joukkue pysähtyy sulhasen kodin edustalle ja laulaen tavallisella pulmanuotilla, pyytää: Avatkaa Viron veräjä, Viron vierahat tulevat - - -." ${ }^{776}$ Launiksen mainitseman runon perusteella ainakin kaksi hänen keräämänsä fonogrammiaineiston peräkkäistä, hyvin samankaltaista toisintoa edustaa toista hänen mainitsemistaan yleisimmistä hääsävelmätyypeistä eli niin kutsuttua tavallista pulmanuottia. ${ }^{777}$

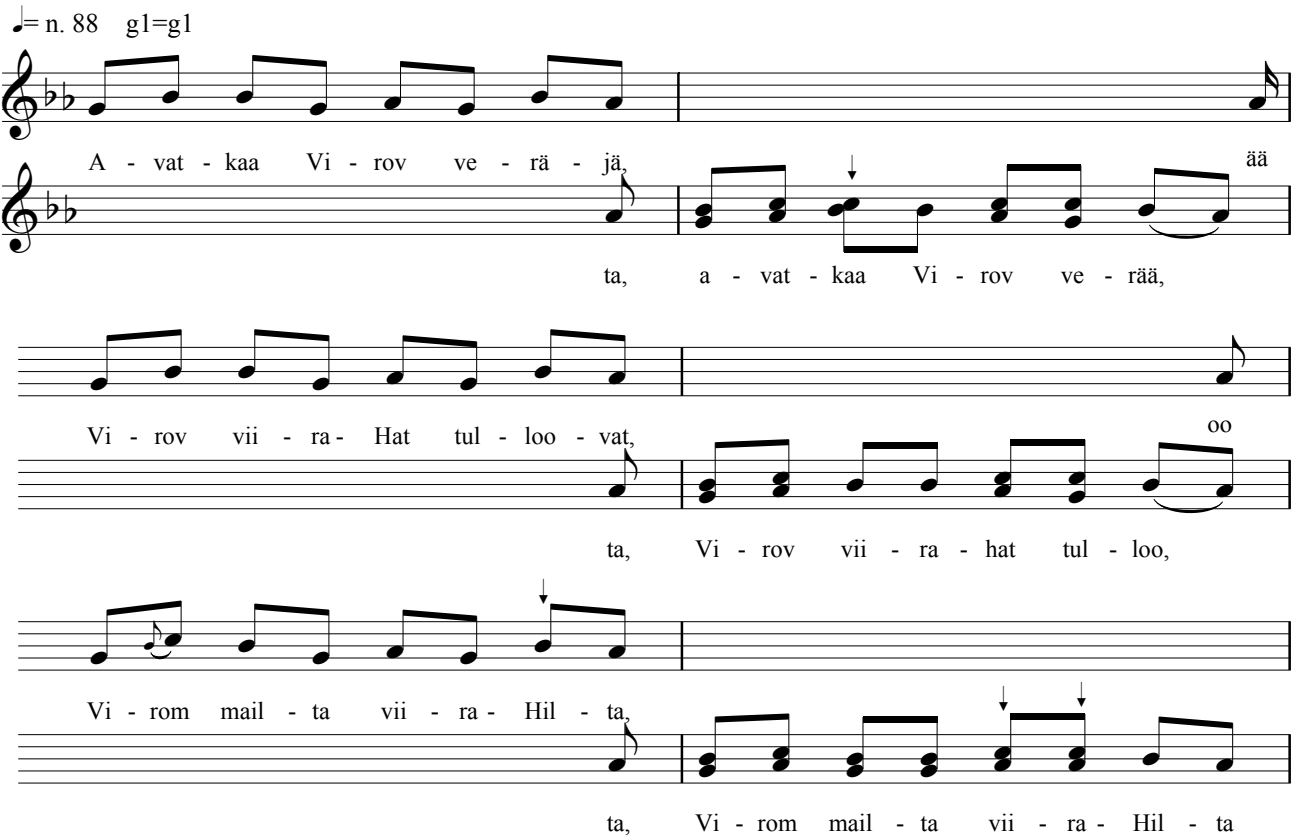

Nuotti 22. Soikkolan tavallinen pulmanuotti, laulajina Okkuliina Ivanantytär ja kuoro (SKSÄ A 300/2a, nuotinnos Heidi Haapoja).

\footnotetext{
${ }^{775}$ Säkeellä Avatkaa Viron veräjät tai Avatkaa avoveräjä alkavaa runoa lauloi sisään pyrkivä, vastakkaisen suvun edustajista koostuva vierasjoukko sekä morsiustaloon että sulhastaloon saavuttaessa (esim. SKS KRA Salminen V. 2927, 2946). Runosta ks. SKVR-hakemisto: Avatkaa Viron veräjät.

${ }^{776}$ Avatkaa Viron veräjät -runoa mainitaan lauletun myös sulhasväen sulhastalosta matkaan lähtiessä (SKVR III 1683). Runon alkusäkeet liittyivät myös luvussa 5 Viron veräjien nimellä käsiteltyyn kylän läpi ketjussa kulkiessa tai tanssiessa laulettuun aloitusteemaan. On mielenkiintoista, että huolimatta tekstuaalisista yhteyksistä juuri Viron veräjät -muodostelmaa ei kuitenkaan kuvauksissa liitetä häätalosta toiseen kulkemiseen, toisin kuin kluutšan nimellä kulkeva paririvimuodostelma, joka Launiksen kuvauksessa edeltää häätaloon saapumista ja nuotin vaihtumista varsinaiseksi pulmanuotiksi. Häärunolla on yhtymäkohtansa myös talvipraasnikoilla vastaavassa tilanteessa laulettaviin runoihin, joihin saattoivat sisältyä hääkontekstiinkin joskus liittyvät alkusäkeet Avatkaa uksianne ja Hyvää iltaa -toivotus sekä sisäänpääsyn pyyntöjä ja vieraiden kuvausta (Salminen 1917, 158-163; SKVR III 51; SKS KRA Salminen K. 156; Salminen V. 2927). Talvipraasnikoiden yhteydessä samankaltaisuudet ovat selkeän kontekstisidonnaisia, tupaanpääsypyyntöihin liittyviä. Häitähän pidettiin myös talvella, jolloin oli myös luontevaa laulaa esimerkiksi talvipraasnikkalauluissa yleisestä syksyisestä ja vihmaisesta säästä.

777 Ensimmäinen on 16-vuotiaan säätinäläisen Tarja Platonontyttären, jälkimmäinen 38-vuotiaan Koskinasta kotoisin olevan Okkuliina Ivanantyttären Säätinän praasnikoilla laulama runon alku (SKSÄ A 300/19b, 20a).
} 
Sävelmät ovat klassisen runosävelmän perikuvia: ne liikkuvat viiden sävelen alueella, ovat säännöllisen neli-iskuisia ja yksisäkeisiä. Esilaulaja laulaa säkeen, jonka kuoro kertaa ilman välisanoja tai refrenkejä. Kuoro-osan viimeinen tavu jää satunnaisesti laulamatta. Melodia muuntelee hieman ja on kuoro-osassa paikoin kaksi- tai kolmiääninen, vaikka kaikkia ääniä onkin fonogrammin rahinasta mahdotonta erottaa. Mukana kuuluu myös joitain Launiksen nuottiensa ulkopuolelle jättämiä samanaikaisia sekunti-intervalleja. Runosta on muussa sävelmäaineistossa yhteensä kaksi toisintoa. Anna Kivisoo ja kuoro aloittivat vuonna 1937 Avatkaa Viron veräjät -laulun Lankoiseni lintuiseni -puhuttelulla. He käyttivät neli-iskuista viidellä sävelellä liikkuvaa sävelmää ja lauloivat kaikki säkeet viimeistä tavua myöten. Launiksen inkerinsuomalaisesta Arsiansaaresta muistiin kirjoittama toisinto puolestaan noudattaa toista häälaulujen yhteydessä yleistä, kuusi-iskuista rytmityyppiä (44222244). ${ }^{778}$

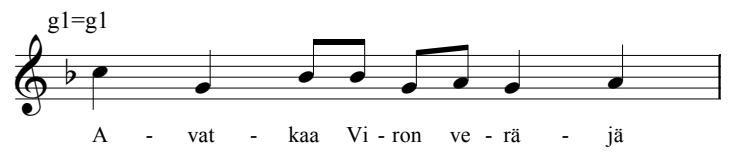

Nuotti 23. Kuusi-iskuinen pulmanuotti (SibA Launis 17).

Avatkaa Viron veräjät -runon yhteydessä tallennetut yksisäkeiset sävelmät kuuluvat kahteen häälauluaineiston yleisimpään rytmityypin ja muotorakenteen yhdistelmään, joita kutsun tässä neli-iskuiseksi (22222222) ja kuusi-iskuiseksi (44222244) hääsävelmäksi eli pulmanuotiksi, ensimmäistä myös tavalliseksi pulmanuotiksi. Tämä Launiksen käyttämä nimitys on työn aineiston valossa osuva, sillä samankaltaista yksisäkeistä, neli-iskuista sävelmätyyppiä edustaa 40 \% hääsävelmäaineistosta. Kuusi-iskuinen taas on hääsävelmien toiseksi yleisin sävelmätyyppi. Aineiston valossa vaikuttaa siltä, että kuusi-iskuinen pulmanuotti on Launiksen kuvaama häiden tanssinuotti. Tätä rakennetta noudattavan lyyrisen runon säkeillä varustetun sävelmän Launis $(1904,52)$ myös osoitti ensimmäisen matkan aineistostaan yhdeksi esimerkiksi tanssinuotista. ${ }^{779}$ Tosin Terttu Koski $(1974,477)$ kuvaa - hieman epämääräisesti - nimenomaan kuusi-iskuista rytmityyppiä lauletun hitaasti, neli-iskuista taas nopeammin. Voi siis olla, että kumpikin rytmityyppi kävi sekä hitaan että nopean, yhtä lailla paikoillaan seisten, hitaasti piirissä kävellyn kuin nopeasti tanssitunkin laulun sävelmäksi, mihin viittaa myös niiden käyttö samojen runojen yhteydessä.

Sisäänpääsypyynnön ohella on monta muutakin tilannesidonnaista runoaihetta tai teemakenttää, joita esiintyy aineistossa ainoastaan tai lähinnä neli- ja kuusi-iskuisilla hääsävelmillä laulettuina. Näihin kuuluu etenkin sellaisia lauluja, jotka hahmotan rituaalisesti keskeisiksi. Tarkoitan tällä sitä, että runo viittaa suoraan hääri-

\footnotetext{
${ }^{778}$ SibA Launi 17. Samaa rytmityyppiä (44222244) edustaa myös yksi tekstin perusteella (Avatkaa uksianne) joko häihin tai talvipraasnikkoihin liittyvä sävelmätoisinto (SibA Launis 281b).

${ }^{779}$ SibA Launis 76: Miks on meitä näin vähäisen, kanaisia kassapäitä.
} 
tuaaliin, liittyy kiinteästi rituaalin kulkuun ja kuuluu niihin häälauluihin, joiden keskeissisältö ja sijainti rituaalissa on aineistossa suhteellisen vakiintunut. Kiinteän luonteensa ansiosta näihin lauluihin liittyvät runo- ja sävelmätallenteet on mahdollista paikantaa osana tyypillistä häärituaalia. Ainoastaan alkusäkeen sisältävien, kontekstitiedottomien sävelmämuistiinpanojen kohdalla tämä edellyttään melko yksityiskohtaista runojen, sävelmätyyppien ja rituaalin kulun tarkastelua. Häiden kulun ja sävelmäryhmien mukaan jaotellut hääsävelmätoisinnot löytyvät tarkemmin liitteestä 5 .

Aattopäivänä kokoontui vatjalais- ja inkeroishäissä taloon sukulaisnaisia paistamaan kupelileipää (Salminen 1917, 46-49). Tähän liittyvän runon alkusäkeillä Launis tallensi Soikkolasta yhden ja Kattilasta vatjalaisilta kaksi neli-iskuisen pulmanuotin piiriin kuuluvaa sävelmää. ${ }^{780}$ Aattoiltana kylvetettiin sekä morsian että sulhanen, ja samalla lauloivat kylän tytöt saunan eteisessä tai ulkopuolella Kylvetysvirren (Salminen 1917, 50-70). ${ }^{781}$ Ilmeisesti kylvettäminen oli lähinnä inkeroisten tapa: inkerinsuomalaisilla ainakin sulhasen kylvetys saattoi olla myös symbolinen ja tapahtua kammarissa. ${ }^{782}$ Runon sävelmätoisinnot ovat kahta Tatjana Jegorovan peräkkäin esilaulamaa kuusi-iskuista toisintoa ja yhtä 1960-luvun toisintoa lukuun ottamatta neli-iskuisia. Näihin kahdeksaan neli-iskuiseen toisintoon sisältyy myös häälauluaineiston ainoa, neljä sävelmää sisältävä sävelmäryhmä, jossa sekä esilaulaja että kuoro laulavat laulun kaikki säkeet seitsemäntavuisina. Kylvetyssävelmien ryhmään sisältyy myös yksi neli-iskuisen rytmityypin muunnelmaksi tulkittavissa oleva sävelmä, johon sisältyy häälauluissa harvinainen säännöllinen vaa-lisätavu kolmannen aseman jälkeen (312[1]13122). Kylvetysvirren esityksellinen rekisteri poikkesi hiukan monista muista rituaalisesti keskeisistä häälauluista, se koostui laajemmasta sävelmätyyppien ja muotorakenteiden joukosta.

Saunasta tultaessa morsiamelle laulettiin ainakin inkeroisten ja vatjalaisten parissa Saunastatulovirsi, jossa saattoi Salmisen (1917, 70-77; ks. myös SKVR-hakemisto) mukaan olla temaattista päällekkäisyyttä itkujen kanssa. Kylvetysvirttä laulaneiden tyttöjen lisäksi paikalla saattoi olla muitakin ihmisiä, lähinnä sukulaisia tai "kylänväkeä." ${ }^{783}$ Tytöt lauloivat ympyrässä morsiamen ympärillä, kertoi Sarlotta Kuuli. ${ }^{784}$ Ilmeisesti he lauloivat paikoillaan seisten - tanssia tai ympärikkoa ei yhdessäkään aattoillan laulukuvauksessa mainita. Saunastatulovirressä pyydettiin yleensä ensin ristirahvasta väistymään ja kehotettiin sitten morsianta kumartamaan ja ristimään itsensä. Laulamisen aikana morsian kumarsi maahan asti eri

\footnotetext{
${ }^{780}$ SibA Launis 379, 392, 395.

${ }^{781}$ Ks. esim. SKVR III 2113; SKS KRA Laiho A. 3345; Laiho L. 4987, 5307; Salminen K. 124, 236, Laulajina mainitaan kerran myös naiset (SKVR III 3479). Kylvettäjänaisen täytyi kalliviereläisen Sohvin mukaan olla äitinsä ensimmäinen lapsi (SKS KRA Salminen V. 2950). Maria Otsan mukaan pesijänä oli sisar tai kylän tytöt, Aksenia Nikitinin mukaan korvoitytöt (Sääski 5896), mutta Kivisoon mukaan morsian meni saunaa kahden tytön kanssa (Laiho L. 5307). Morsiamen äiti saattoi samalla itkeä morsiamelle (SKS KRA Enäjärvi-Haavio 853.)

${ }^{782}$ SKVR III 2018; Salminen 236; SKS KRA Länkelä 3: 617; SKS KRA Sääski 5982 inkeroisilta morsiamesta; ks. myös SKVR III 417, 418, 2436, 2493, 3348; SKS KRA Salminen V. 2997, 2999.

${ }^{783}$ Esim. SKS KRA Enäjärvi-Haavio 853; Salminen K. 125; Salminen V. 2949. Kylänväki saattaa tietenkin tarkoittaa myös joko kylässä asuvia sukulaisia tai morsiamen ikäryhmän tyttöjä.

${ }^{784}$ SKS KRA Salminen V. 2975.
} 
ilmansuuntiin vihdan päällä seisten. ${ }^{785}$ Muutamia tilanteeseen usein liittyviä teemoja voitiin laulaa myös aattoiltana sisällä tuvassa ja esimerkiksi sulhasen lähtiessä hääaamuna matkaan (Salminen 1917, 147, 151). ${ }^{786}$ Säkeillä Ristimä rinnallesi ja Blaslovitekka Jumala (tai Last avitakka Jumala tai Laslavikka laulamahan) alkavat kontekstitiedolliset runot sijoittuvat kuitenkin kaikki aikaan ennen sulhasjoukon saapumista morsiustaloon ja ovat joko morsiamelle tai sulhaselle kohdistettuja. Näillä säkeillä alkaa aineistossa neljä neli-iskuista sävelmää, yksi neli-iskuisen sävelmän muunnelma (42424242) sekä kaksi kuusi-iskuista sävelmää.

Sulhasväen saavuttua ja pihaan päästyä seurasi pitkä, ylistyksestä pilkkaan vaihteleva dialogi sulhasväen ja morsiamen puolta edustavien tyttöjen välillä. Nämä laulut esiintyvät monenlaisina yhdistelminä ja sarjoina: sama teema saatettiin selvästikin laulaa eri häissä tai eri kylissä hieman eri kohdissa. ${ }^{787}$ Laulu alkoi pihalla ja päättyi tupaan. Tuvassa sulhasjoukko kehotti laulaen puhemiestä lunastamaan sulhaselle paikan pöydästä: Isämies isyen poika, osta sija sirkulleni (Pöydän lunastus, ks. Salminen 1917, 189-202). Monen runon yhteydessä todetaan morsiamen puolen tyttöjen laulaneen joko pihalla eli ikkunan alla tai tuvan lattialta eli maasta tai permannolta saapuvalle tai jo pöydän ääreen istumaan päässeelle sulhasväelle. ${ }^{788}$ Sävelmäaineistossa yleisimmät saapumistilanteen teemoista ovat sulhasta kunnioituksella tervehtivä Terve kuu terve päivä (Tytöt tervehyttävät sulhasta, $6 \mathrm{kpl}$ ) $^{789}$ sekä usein pilkan sävyjä sisältävä Mihin viivyit velvyeni (Missä mökkä myöhään viivyit, $6 \mathrm{kpl}$ ). Näitä tytöt saattoivat laulaa joskus jo pihalla tai useimmiten vasta tuvassa sulhasväen pöytään päästyä. ${ }^{790}$ Tämän lisäksi sävelmäaineistossa on kolme toisintoa sulhasen tuloa kuvaavaa, yleensä pihalla laulettua Luulin tuulen tuulevan -runoa, yksi Tunnen vävyn tulevan (Mistä tunnet vävyn väen) -teema, yksi vävyn hevosen hoitoa kuvaava runo (La miä kysyn lankoiltani), yksi Mistä puusta pertti tehty -aloitusformula, kaksi istumapaikan eli sijan lunastamiseen liittyvää laulua, yksi vävyn ylistys (Oi vävy kuvattu kulta) sekä kolme pilkkarunoa (Tunnen tunnen kev vaa tulloo sekä Älä huuda hullu kuusi) jotka ovat tosin saattaneet liittyä myös pilkkaamistilanteisiin sulhasen kodissa (ks. Salminen 1917, 172-189). Näistä lauluista kaksikymmentä on neli-iskuisia, kolme kuusi-iskuisia. Toinen Luulin tuulen tulevan -toisinnoista on neli-iskuisen sävelmätyypin variaatio (13131322).

\footnotetext{
${ }^{785}$ Esim. SKS KRA Salminen K. 151; Salminen V. 2998; ks. myös SKVR III 2270, 2397.

${ }^{786}$ SKVR III 46, 49, 603, 1676, 1729. Teemat menevät osin päällekkäin myös seuraavassa luvussa käsiteltävien, morsiamelle tai sulhaselle tuvassa laulettavien Lootikka pohulle polvin kumarruttaminen -teemojen kanssa (ks. SKVR III 594; SKS KRA Borenius e 195).

${ }^{787}$ Ks. esim. SKVR III 403, 421, 1674, 1696, 1702-1704, 2145-2152, 2259, 2260, 2265, 2266, 2376, 2497 , 3272, 3304, 3480; SKS KRA Enäjärvi-Haavio 864; Salminen K. 206-210; Salminen V. 2942, 2960.

${ }^{788}$ Laulajista ja laulupaikoista ks. esim. SKVR 403, 1696, 2499, 2500; SKS KRA Enäjärvi-Haavio 864; Salminen K. 116, 208, 210; Salminen V. 2942, 2960, 2962 paikoin puhutaan tyttöjen sijaan yleisemmin tytön suvusta, ks. esim. Salminen K. 152; Salminen V. 2942.

${ }^{789}$ Terve kuu terve päivä -teemaa saatettiin käyttää myös esimerkiksi sulhasväen tervehtiessä morsianta tämän ensi kerran nähdessään (SKS KRA Alava 10: 103). Samassa tilanteessa saatettiin myös käyttää tuvan tervehtimisen teemaa (SKVR III 2262).

${ }^{790}$ Terve kuu terve päivä ja Mihin viivyit velvyeni -teemojen laulajista (tytöt) ja paikoista ks. esim. SKS KRA Enäjärvi-Haavio 864, 857-858, Salminen V. 2942, 2960; Sääski 5953, 5962; 5973 (morsiamen sukulaisnaiset laulavat veräjällä Kuhu viivyit, velvyein); SKVR III 604 ("Vastaa otetaa, kui tulee sulhain ottamaa”).
} 
Kun sulhasväki oli saanut sijansa pöydässä lunastettua, alkoi se vaatia morsianta nähtäväksi. Puhemies lähti kaasikkeiden kanssa toiseen huoneeseen tai aittaan "syöttämään morsianta" ja katsomaan, sopiko sormus morsiamen käteen. Sormusta sovitettua morsian jakoi lahjoja syöttämään tulleille sulhasen sukulaisille. (Salminen 1917, 254-287). Tämän jälkeisten tapahtumien yhteyteen liittyvistä kuvauksista löytyvät ensimmäiset häiden kulkuun liittyvät maininnat tanssista, ympärikosta. Sormuksen sovittua, kertoi esimerkiksi inkerinsuomalainen Juljaana Pohjalainen, "ympärkautta tantsittiin ja laulettiin Olkoo kiitetty Jumala, Mahtu sormus sormeen." 791 Lahjoja saaneet sukulaiset tanssivat kiitoslaulun Ei oom maannut meie minoi (Hyvät oli lahjat minnoillani). ${ }^{792}$ Tämän jälkeen siirryttiin tuvan puolelle, jossa laulettiin, syötiin ja tanssittiin (Salminen 1917, 294-310). ${ }^{793}$ Näihin tilanteisiin paikantuu aineistossa kuusi sävelmää, joista kolme neli-iskuista, kolme kuusi-iskuista. Tanssi ilmaantuu siis häärituaalin kuvauksiin vasta morsiamen osoitettua suostumuksensa sulhasväelle.

Seuraavat sävelmäaineiston runot liittyvät jo sulhasen kotiin saapumiseen. Sulhasen suku lähti matkaan morsiamen kanssa edeltäkäsin. Sulhastalon pihamaalle tultua saattoivat odottamassa olleet sukulaiset ja perheenjäsenet laulaa miniälle ja sulhaselle. Astuttuaan sisään, kertoi luterilainen Katri Vohta, "sulhasen sukulaiset alkavat karavanassa s.o. peräkkäin piirissä kulkien laulaa Saimme saunan lämmittäjän. Vohdan mukaan jokainen säe kerrattiin. Ainoa tilanteeseen liittyvä 1960luvulla tallennettu sävelmä on neli-iskuinen pulmanuotti. ${ }^{794}$ Morsiamen sukulaiset eli jälkijuojat saapuivat sulhastaloon vähän myöhemmin. Matkalla laulettaessa he käyttivät usein saadulmoi-sävelmää, jonka laulaminen, kuten aiemmin kluutšan yhteydessä todettiin, saattoi aineiston perusteella joskus jatkua jopa sulhastaloon sisälle asti. Pihaan tullessa, kertoi Launis $(1907,106)$, vaihtui nuotti kuitenkin yleensä tavalliseksi pulmanuotiksi.

Kun morsiamen suku pääsi sisään, se kyseli ympärikkoa tanssien lattian sileydestä ja kehui hyvin rakennettua tupaa: La ko katson langon siltoi (Onko lankoin sillat lakeat). Lauluun saattoi liittyä myös tuvan tervehtimisen teemoja. Näihin runoteksteihin liittyy huomattavan paljon mainintoja tanssista ympyrässä. Vaikka osin samoja runoteemoja on voitu laulaa myös sulhasväen saapuessa morsiustaloon, liittyy tanssimainintoja aineistossa vain sulhastaloon saapumiseen. ${ }^{795}$ Salminen (1917, 202-204) huomauttaa, että ainoastaan "hääruno ei siltojen sileyden tiedustelu ole, sitä lauletaan tanssivirtenä, kun pyydetään isännältä tupaa, että nuoriso saisi pirtissä kisailla." ${ }^{796}$ Kuvaukset muuttuvat riehakkaammiksi. Inkerinsuomalai-

\footnotetext{
${ }^{791}$ SKS KRA Salminen K. 212; ks. myös Sääski 5973 ("Laulaessaan sulhasen sukulaiset, tytöt ja pojat, miehet ja naiset, tanssivat piirissä"); SKVR III 2510 ("Siis noissaa ympärikköö tantsimaa se pulmaväki, ket ollaa siel ottamassa, pojan väki ain ollaa.") Runoteemasta ks. SKVR-hakemisto: Näytä käki kätesi.

${ }^{792}$ SKVR III 2442; SKS KRA Enäjärvi-Haavio 895.

${ }^{793}$ Esim. SKVR III 1710; SKS KRA Mannonen 7663.

${ }^{794}$ SKS KRA Sääski 5969; SKS KRA Enäjärvi-Haavio 879.

${ }^{795}$ Esim. SKVR III 3336; SKS KRA Laiho A. 2166, 2217; Laiho L. 5313, 5899; Salminen V. 2927-2928, $2957,2985,3028$.

${ }^{796}$ Salminen liittää kuvauksensa sulhasen suvun morsiustaloon saapumiseen, mutta aineistossa kuvaukset liittyvät kuitenkin morsiamen sukulaisten lauluun sulhastaloon tultua.
} 
sen Valpuri Vohdan mukaan ensin "seistii uksen suus ja laulettii Terve tupa neljänurkka", sitten "hypättii tanssimaan ympärikkoo: La ko katson langon siltoi." Katri Vohta kertoi, että kun päästiin runon kohtaan, jossa lattia todettiin laajaksi ja kauniiksi "aloitettiin vielä kovemmast tantsii, lyövä jalkaa maahan." 798 Tämä on ensimmäinen tilanne, johon liittyy riehakkaan, vauhdikkaan tanssin kuvauksia. Siihen liittyvien runojen sävelmätoisinnoista kaksi on kuusi-iskuisia hääsävelmiä, yksi neli-iskuinenja yksi saadulmoi-sävelmä. ${ }^{799}$ Sitävastoin kaikki morsiustaloon saapumiseen liittyvät tuvantervehdysteemat on 1960-luvun aineistossa esitetty neli-iskuisilla pulmanuoteilla, vaikka kyseinen sävelmätyyppi on tässä osa-aineistossa kuusi-iskuista huomattavasti harvinaisempi.

Saapumisen jälkeen pöytään asettuneille morsiamen sukulaisille tarjottiin ruokaa, jota he kuitenkin kieltäytyivät syömästä ennen kuin saisivat morsiamen nähdäkseen. Kun morsian lopulta saatiin nähtäville, lauloivat hänen sukulaisensa morsiamen omaksi tunnustavan runon Meijän lintu meijän liitso ja suostuivat syömään. (Salminen 1917, 334-352.) ${ }^{800}$ Kolme runon sävelmätoisintoa on kaikki laulettu kuusi-iskuisella hääsävelmällä. Sekä sulhasen että morsiamen kotona vieraisilla ollut suku kävi aitassa tarkistamassa ruokavarojen määrän (Salminen 1917, 365367; (Aitassa käynti)). Tähän tilanteeseen liittyy yksi yleisimmistä pulmanuoteista poikkeava, länsi-inkeriläisen häälauluaineiston ainoa viisi-iskuinen toisinto ${ }^{801}$ sekä yksi kuusi-iskuinen toisinto.

Häiden lopussa, ennen morsiamen sukulaisten lähtöä kotiin lauloivat suvut sulhaselle ja morsiamelle erilaisia Neuvokkivirsiä eli ohjeita ja varoituksia tulevaan elämään. Sävelmäaineistossa on neljä sulhaselle tai morsiamelle kohdistuvaa neuvomissäkeitä Kuule kuule kui opetan, Tunsit olla tunne pitää ja Kääri kyyneleet kerälle sisältävää sävelmää, jotka kaikki on laulettu neli-iskuisella sävelmätyypillä.802 Aivan viimeiseksi sukulaisten morsiamelle laulaman Myö määmmä siun jätämmä (tähän kylmään kylään) -runon kaksi sävelmätoisintoa ovat kuusi-iskuista tyyppiä ja yksi toisinto neli-iskuisen sävelmätyypin muunnos (42424242). (Salminen 1917, 352-396.)

\footnotetext{
${ }^{797}$ SKS KRA Laiho L. 4980-4981; ks. myös 5900; Enäjärvi-Haavio 883-885; sekä Salminen K. 97; Sääski 5977.

${ }^{798}$ SKS KRA Enäjärvi-Haavio 885.

${ }^{799}$ Lisäksi yhden epävarmemmin paikantuvan runon (Mistä puusta pertti tehty) sävelmä on neli-iskuinen.

${ }^{800}$ SKVR III 2264, 2404, 2443-2444; SKS KRA Laiho L. 4982-4985; Salminen K. 202; Salminen V. 2925, 2956, 3040; Sääski 5978.

${ }^{801}$ Tämä soikkolalaisesimerkki tekee mielenkiintoisen särön aineiston muuten vahvoihin painotuksiin. Keski-Inkerissä viisi-iskuinen sävelmätyyppi on häiden yhteydessä yleisempi: aineistoon kuuluu viisi tällaista Hevaalta ja Tyröstä tallennettua sävelmää. Soikkolalaistoisinnosta poiketen ne liittyvät sulhasen suvulle laulettuihin tervehdys- ja pilkkalauluihin, morsiamen hyvästelylauluihin ja neuvokkivirsiin, eli tilanteisiin, joissa Länsi-Inkerissä esiintyy lähinnä neli-iskuista rytmityyppiä ja joihin ei liity tanssin kuvauksia. (SKS KRA Borenius 180, Levón 399, 413, 446; SKSÄ A 301/25a.) Viisi-iskuiset keski-inkeriläissävelmät liittyvät läheisesti alueen muihin häälaulujen rytmityyppeihin, joissa viimeisten sävelien lisäksi myös joitain säveliä säkeen keskeltä lauletaan pidempinä (ks. esim. SKSÄ A 301/46a; SKS KRA Levón 349). Pohjois-Inkerin inkeroisilla viisi-iskuinen yksisäkeinen sävelmätyyppi näyttäytyy Boreniuksen kokoelmassa yksinomaisena hääsävelmänä (Borenius e 78, 80, 96, 97; 6:826; ks. myös luvun 2 osuus inkeriläisistä paikallisista laulun lajeista ja Larin Parasken lajijärjestelmästä (Timonen 2004, 238-303)).

${ }^{802}$ Neli-iskuisella, yksisäkeisellä sävelmällä lauloi opetusrunoja myös esimerkiksi vatjalainen Oudekki Figurova Joenperältä 1960-luvulla (esim. ERA RKM, Mgn. II 1235 j, k; ks. myös Rüütel 1977, 225, 228; vrt. 238).
} 
Tarkemmin paikantumatta jäävät useat pelkän sukulaisten, sulhasen, puhemiehen tai morsiamen puhuttelun sisältävät sävelmät, jotka olisivat voineet jatkua monella tavalla ja sijoittua useaan häärituaalin kohtaan. Näihin sisältyy sekä kolme neli-iskuista ja yksi kuusi-iskuinen hääsävelmä sekä yksi neli-iskuisen muunnos (42424242) ${ }^{803}$ Lisäksi yksi lyyriseeppinen runo ja yksi hääteemoja käyttävä tervehdysruno on esitetty neli-iskuisella pulmanuotilla sekä yksi kestityksestä kiittäminen kuusi-iskuisella. Aineistoon kuuluu myös kaksi inkerinsuomalaisesta Kurkolan kylästä tallennettua välimuotoista häälaulua.

Suuri joukko rituaalisesti keskeisiä lauluja laulettiin siis kahdella häiden keskeissävelmällä, jotka näyttävät olleen osin vaihtoehtoisia. Joidenkin runojen, erityisesti kylvetysrunon kohdalla laulaminen sisälsi näidenkin sävelmien puitteissa erityisiä rekisterin piirteitä, säännöllistä viimeisen tavun pois jättämistä tai muuten pulmanuoteille epätyypillistä vaa-tavun käyttöä.

\section{KAKSI HÄIDEN VALTANUOTTIA}

Kahden yleisimmän sävelmätyypin välillä näkyy edellä joitain selkeitä painotuksia, vaikka monissa tilanteissa ne näyttävät olleen myös vaihdettavissa. Monin paikoin aineisto on toki niin suppea, että kattavia päätelmiä yksittäisen runon esittämisestä on mahdotonta tehdä. Edelleen on tarpeen pitää mielessä laulukäytäntöjen mahdollinen paikkakunta- ja sukusidonnainen variaatio. Joihinkin hienovaraisempiin erotteluihin on paikoin mahdollista päästä käsiksi aineistoa lähemmin tarkastelemalla. Samalla on huomattava, että tässä sävelmien muoto- ja rytmirakenteen mukaan jaottelemani sävelmätyypit sisältävät melodiansa puolesta monenlaisia sävelmiä. Esimerkiksi neli-iskuisesta sävelmätyypistä on tallennettu näinkin erilaisia toisintoja:

\footnotetext{
${ }^{803}$ Laajempaa sukulaisjoukkoa puhuttelevista Lankoiseni lintuiseni -aloituksista kaksi neli-iskuista toisintoa voi paikantua lähes mihin kohtaan rituaalia hyvänsä. Kolmas lyhyt, kuusi-iskuinen fonogrammisävelmä sisältää lankojen puhuttelun uusikkaisiksi ja vertaa heitä tuoreisiin kananmuniin. Tämä pidempi versio puhuttelumuodosta näyttää runoaineistossa liittyvän usein kohtaan, jossa morsiamen sukulaiset sulhastaloon tultuaan kieltäytyvät kestityksestä jolleivät saa morsianta nähdäkseen tai tämän episodin jälkeisiin puhutteluihin. (Ks. SKVR III 2264; SKS KRA Salminen V. 2926, 3009; tähän liittynee myös SKS KRA Länkelä 3:1592. Kananmuniksi lankoja puhuteltiin myös ainakin kestityksistä kiittäessä ja lahjoja sulhastalonssa jaettaessa, ks. SKVR III 1673, 2305, 2550, 4233.) Yksi paikantumaton puhemiehen puhuttelu on laulettu neli-iskuisella sävelmällä (SibA Launis 26). Paikantumattomista morsiamen puhutteluista yksi sävelmä on neli-iskuinen, yksi neli-iskuisen variaatio sekä kaksi osakertauksellista.
} 

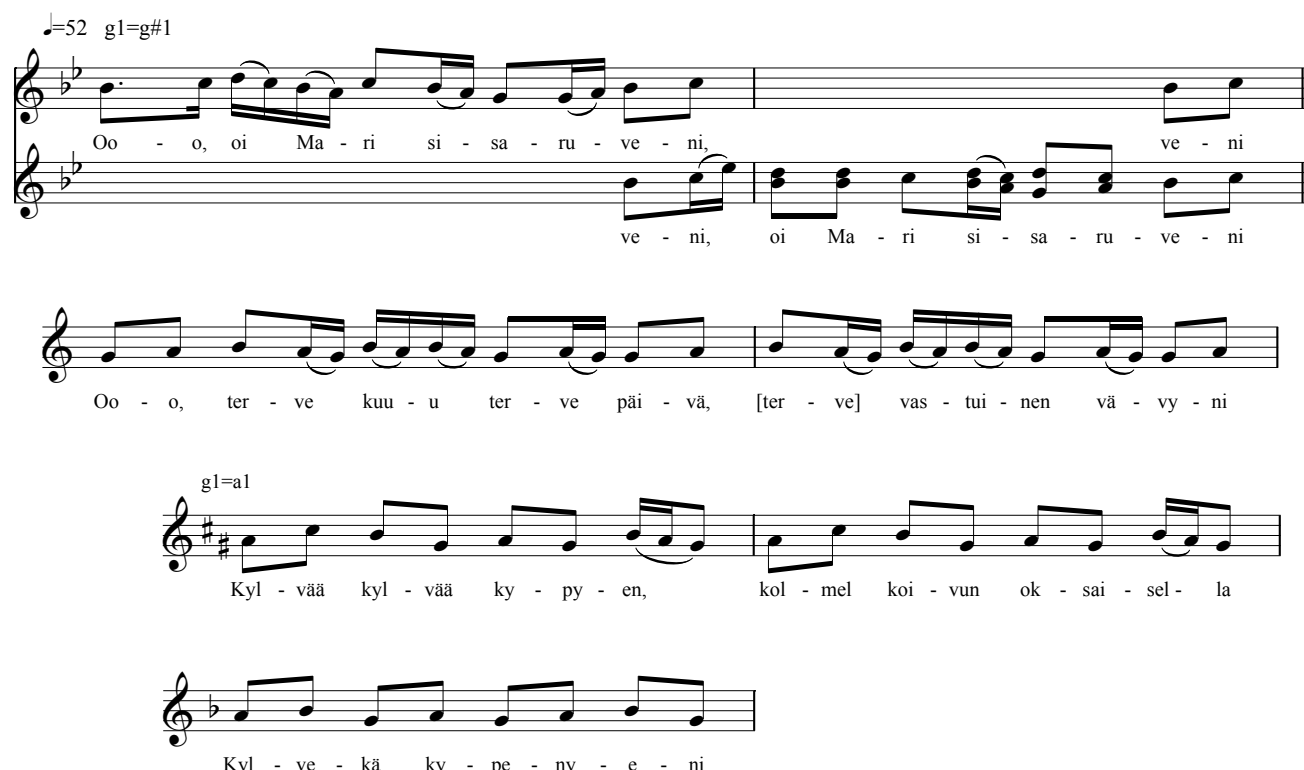

Nuotti 24. Erilaisia neli-iskuisen pulmanuotin toisintoja. Kolme alimmaista ovat käsikirjoitustoisintoja, joihin ei ole merkitty kuoron säkeenkertausta. Kahdessa ylimmäisessä näkyy esilaulajan ensimmäisen säkeensä alussa laulama oo-tavu, joka ei toistu myöhemmissä säkeenaluissa. (SKSÄ L 99a; SibA Launis 288; SKS KRA Borenius e 193; SibA Launis 87.)

Ingrid Rüütel (1977) on vatjalaisia sävelmiä tarkastellessaan huomauttanut yksisäkeisten, neli-iskuisten, suppea-alaisten ja melodiakulultaan laskevien sävelmien mukailevan pisimmälle sekä runosäkeiden ja itämerensuomalaisen kielen puheintonaation rakenteita. Hän toteaa myös samankaltaisten, mutta sävelkulultaan edestakaisten sävelmien olevan Inkerissä yleisiä. Laajemmat sävelalat ja säkeen lopussa nousevat sävelkulut hän tulkitsee usein uudemmiksi vaikutteiksi, jälkimmäiset lähinnä venäläisvaikutteiksi. Esimerkeistä viimeisin, vuoden 1937 äänitysten laulajilla yleinen sävelmätyyppi vastaa sävelkulultaan pitkälti Rüütelin antamaa inkeroisilta tallennettua esimerkkiä venäläisestä häälaulusta, vaikka tavumäärä, rytmi sekä käytetty sävelasteikko yhden sävelen osalta ovat erilaisia:

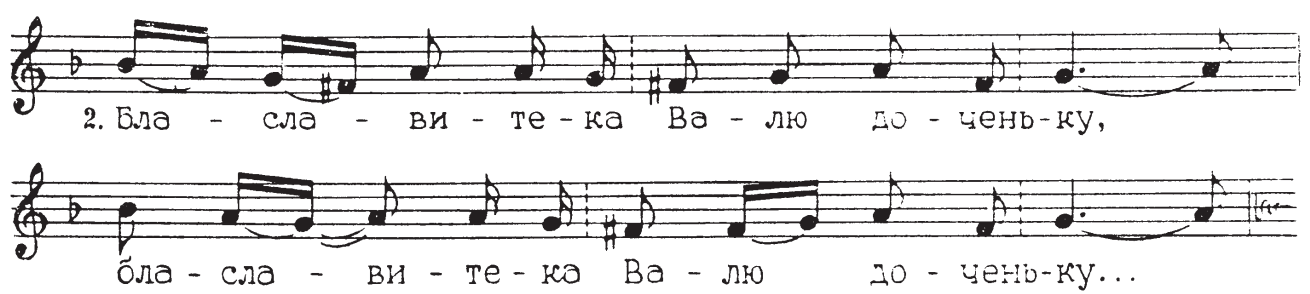

Nuotti 25. Venäläinen häälaulu Dunja Trofimovalta Laukaansuun Luuditsan kylästä. (Rü̈̈tel 1977, 270; ERA RKM, Mgn. II 2334 i.)

Launis (1910c, 237-238; ks. myös Rüütel 1977, 265) taas liittää kuusi-iskuisen sävelmätyypin selkeästi slaavilaislainoista periytyvien sävelmien joukkoon. Olennaista tässä on nähdäkseni kuitenkin havainto siitä, että vaikka melodiakulku saattaa varioida ja saada vaikutteita myös naapurikulttuurien laulusta, näyttävät eten- 
kin muoto- ja rytmirakenteet rituaalisesti keskeisten häälaulujen kohdalla pysyvän vakaina. Pulmavirret laulettiin "kahdel sanal", yksi säe kerrallaan, ilman refrenkejä, pääosin kahdella yleisellä rytmityypillä.

Sävelmätyyppien käytössä on havaittavissa joitain painotuksia. Neli-iskuinen sävelmätyyppi painottuu vahvasti morsiamelle lauletuissa aattoillan rituaalisissa runoissa, sulhasen ja morsiamen puolen häiden alussa käymässä dialogissa sekä morsiamen suvun sulhastalossa morsiamelle laulamien neuvokkivirsien yhteydessä. Kuusi-iskuinen sävelmätyyppi puolestaan esiintyy suhteellisesti vahvimpana niiden runojen yhteydessä, jotka liittyvät morsiamen suvun tanssiin sulhastaloon saavuttua.

Neli-iskuista tyyppiä näytetään käytetyn erityisen runsaasti tilanteissa, joissa sukujen välillä voi hahmottaa jännitteen: sulhasta odottaessa, ennen kuin sulhasväki oli saanut morsiamen nähtäväkseen ja sulhasta ja morsianta häiden lopuksi puolin ja toisin neuvottaessa. Kuusi-iskuinen sävelmä, kuten tanssin kuvauksetkin, taas painottuvat hetkiin, joissa jännitys on juuri lauennut: kun morsian on hyväksynyt sulhasen suvun tarjoaman ruuan ja sormuksen, kun morsiamen suku on päässyt sulhastaloon. Tanssin kuvaukset ja kuusi-iskuinen sävelmä eivät kuitenkaan täysin osu samoihin yhteyksiin: sulhasen suvun ja morsiamen ensikohtaamiseen liittyvistä sävelmistä ainoastaan yksi neljästä on kuusi-iskuinen. Tässä yhteydessä on jälkeen hyvä muistaa luvussa 5 tanssisävelmistä tehty huomio: myös neli-iskuisia, yksisäkeisiä sävelmiä tanssittiin, ja toisaalta kuusi-iskuinen sävelmäkään ei selvästi edellyttänyt tanssia. Ilmeisesti näiden sävelmätyyppien käyttö oli osin joustavaa tai paikallisesti painottuvaa. ${ }^{804}$ Ainoa yhdeltä laulajalta kahteen otteeseen eri äänityksissä tallennettu häälaulu on Valpuri Vohdan esittämä pilkkalaulu Tunnen tunnen ken vaa tuloo, joka ei kuulunut keskeisimpien häälaulujen joukkoon. Hän lauloi laulun yksin Julius Mägisten fonografille ja joitain vuosia myöhemmin kuoron kanssa Tallinnassa. Ensimmäisellä kerralla sävelmä oli neli-iskuinen, toisella kuusi-iskuinen hääsävelmä. ${ }^{805}$ Ainakin tällaisten vähemmän keskeisten häälaulujen yhteydessä sävelmätyypit olivat ilmeisesti vaihdettavissa.

Sävelmien jakautumisen pohjalta näyttää kuitenkin siltä, että neli-iskuinen sävelmätyyppi oli rituaalisesti painokkaampi: sitä tavattiin käyttää kaikkein vaativimmissa kohdissa.

Laulun säännöllinen seitsentavuisuus liittyy hääsävelmäaineistossa ainoastaan kylvetysvirren yhteyteen ja satunnaisetkin seitsentavuisuuden esiintymät kuuluvat tyttöjen laulamien laulujen piiriin. Juuri kylvetysvirteen ja tyttöjen aattoillan lau-

\footnotetext{
${ }^{804}$ Jelena Ropsusta kertoi, että hänen laulamansa häiden pääsävelmän tahdissa sulhasjoukko lauloi mennessään "tyttöö syöttämään" (jolloin ei minkään kuvauksen mukaan vielä tanssittu), toisen neliiskuisen sävelmän tahdissa puolestaan "ympär mennään" sulhasen suvun morsianta lahjoista kiittäessä sormuksen käteen asettamisen jälkeen (SKS KRA Alava X 103-105). Alavan pikakirjoituksen lomasta löytyvä muistiinpano häiden yleisimmästä sävelmästä on epäselvä: se saattaisi olla kuusi-iskuisen sävelmätyypin muunnos (44422244). Sävelmä on kopioitu pikakirjoituksen puhtaaksikirjoitukseen toisenlaisin aika-arvoin (22222222/22444444). Jelenalla rytmityypit saattoivat siis mennä juuri toisinpäin kuin aineistossa muuten näyttää olevan tendenssinä: kuusi-iskuinen yleissävelmänä ja neli-iskuinen tanssinuottina.
}

${ }^{805}$ ERA, Fon. 372 b; SKSÄ L 100b. 
luihin liittyvät myös erilaiset neli-iskuisten rytmityyppien muunnokset sekä ainoa vaa-lisätavun esiintyminen. Tyttöjen aattoillan laulujen osalta sävelmien ja laulun tyylipiirteiden variaatio oli siis yleisempää kuin rituaalin muissa kohdin, joskin tässä käsiteltyjen tavallisilla pulmanuoteilla esitettyjen laulujen kohdalla melko hienovaraista ja neli-iskuisen, yksisäkeisen muotorakenteen puitteissa pysyttelevää. Tytöillä oli vapaus varioida.

Yksi reitti häissä laulamisen hienojakoisempiin erotteluihin on yksittäisten tallennuskokonaisuuksien tarkastelu. Esimerkiksi Vöglä ja Okkuli Soikkolan Savimäeltä lauloivat Boreniukselle vuonna 1877 kolme häälaulua. Ensimmäisenä esitetty kylvetyslaulu edusti neli-iskuista sävelmätyyppiä. Laulajat nimesivät sen nimityksillä pulmavers ja pulmanootti, ja Borenius tarkensi sulkuihin "kylvetysvirsi." Laulajat nimesivät sekä sävelmän (nootti) että sanat (vers, virsi) häälauluihin kuuluviksi, ja tarkensivat sitten, että myös lapsille saatettiin laulaa samalla sävelmällä. Toisena seurasi kuusi-iskuisella sävelmällä laulettu sulhasväen puhemiehelle osoitettu morsiamen piilopaikan kertova laulu, jonka sävelmän laulajat samoin nimesivät pulmanootiksi. Kolmas laulu oli häiden aattoiltaan liittyvä, morsiamelle laulettu Teekkä risti rinnallesi, joka jatkui ikonille kumartamisen kehotuksella sekä lyyriseeppisellä kuvauksella vastasyntynyttä tytärtään suojelevasta äidistä, jonka mies toivoi poikaa ja olisi halunnut surmata tyttären (Poikako vai tyttö). Runon naiset lauloivat säkeen loppupuoliskon kertaavalla sävelmätyypillä. He kutsuivat laulua nimellä pulmavers, mutta eivät siis ilmeisesti nimenneet sävelmää varsinaiseksi hääsävelmäksi. Myöskään runo ei selvästi kuulunut rituaalisesti painokkaimpien häälaulujen joukkoon. Tässä tulkitsisin esitysjärjestyksen kuvanneen myös hääsävelmien tärkeysjärjestystä: ensin neli-iskuinen tavallinen pulmanuotti, sitten kuusi-iskuinen pulmanuotti ja lopuksi harvinaisempi, tyttöjen aattoillan lauluun liittyvä hääsävelmätyyppi. ${ }^{806}$ Samalla tavoin moni muukin laulaja - esimerkiksi Ol’ona Joenperältä vuonna 1877 Boreniukselle; Elina eli Jelena Alavalle vuonna 1897 sekä Launikselle vuoden 1906 helluntaipraasnikoilla laulaneet tytöt ja naiset ${ }^{807}$ - näyttävät laulaneen ensisijaisesti neli-iskuisen tai kuusi-iskuisen hääsävelmän toisinnon sekä satunnaisia muita, lähinnä seuraavassa alaluvussa käsiteltäviä häihin liittyviä sävelmätyyppejä. Anna Kivisoo esilauloi vuoden 1937 äänityksissä kaikki kymmenen häälauluaan neli- ja kuusi-iskuisilla sävelmätyypeillä. ${ }^{808}$ Sävelmätyyppien asemat rituaalisesti tärkeiden laulujen hierarkiassa olivat erilaisia. Sävelmät kuuluivat osin eri tilanteisiin ja eri laulajaryhmille. Tulkitsen hälaulujen rekistereiden määräytyneen myös käytettyjen sävelmätyyppien kautta.

\footnotetext{
${ }^{806}$ SKS KRA Borenius e) 193-195; 6:917-920.

${ }^{807}$ SKS KRA Borenius e) 204-205, 6: 929-930; Alava X: 85, 103, 104a, 104b, 105; SKSÄ A 300/12, 13, 17b, 19b-20c, 34b, 37b, 48b.

${ }^{808}$ SKSÄ L 97-100.
} 


\section{ERITYISET SÄVELMÄT JA TILANTEET}

Yleisimpien kahden, monessa yhteydessä käytetyn hääsävelmätyypin ohella aineistosta hahmottuu neljä tarkemmin runoaiheen tai laulutilanteen mukaan rajautuvaa sävelmäryhmää. Näistä selkeämmin rajautuvia ovat Kokin kiitosvirteen sekä Yks oli oksa ounapuussa -runoon liittyvät sävelmät. Tätä määrällisesti pienemmän ryhmän muodostavat häätaloon ajamiseen ja Aja aja velvyeni- runoon liittyvät sävelmät, määrällisesti ja tyylillisesti laajemman ryhmän taas erilaiset osakertauksia ja venytettyjä sävelkulkuja sisältävät, lähinnä morsiamelle aattoiltana osoitetut laulut.

\section{KOKIN KIITOSVIRSI}

Kummassakin häidenviettopaikassa, sekä morsiamen että sulhasen kodissa, päätyi vieraisilla ollut suku morsiamen löydyttyä lopulta pöydän ääreen syömään. Syömisen jälkeen kiitettiin kestityksestä lauluilla. (Salminen 1917, 396-404.) Kokin kiitokseen liittyy ainoastaan ympärikko-tanssin kuvauksia, ei siis lainkaan kuvauksia paikoillaan istuen tai seisten laulamisesta. ${ }^{809}$ Anna Markus kuvasi laulamista vauhdikkaaksi: "Kokkia kiitettäessä kuljetaan peräkkäin jalkaa polkien lyhyin tanssiaskelin. Heilutetaan kättä pään päällä. Lopussa lyödään käsiä yhteen pään yläpuolella. Reipasta menoa." ${ }^{810}$ Uljana Kipatsa painotti, että kiitoslaulu laulettiin sekä morsius- että sulhastalossa: "Tytön i pojan pulmis, ain kokin virs lauletaa." ${ }^{11}$

Kaikki kokin kiitokseen liittyvät seitsemän länsi-inkeriläissävelmää ovat yksisäkeisiä, säkeen lopun kertaavia sävelmiä: Hyvä kokki kaunis kokki, kaunis kokki. ${ }^{812}$ Vuoden 1937 äänityksissä laulu kuulostaa rytmikkäältä ja riehakkaalta, ja paikoin laulua rytmittävät lisätavut tedret(e) lehtikorvat(a).

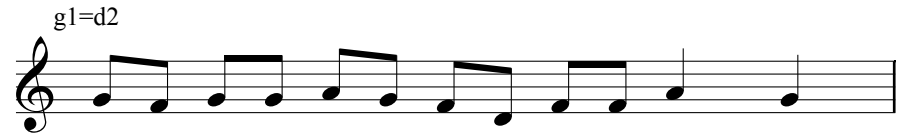

Hy - vä kok - ki kau - nis kok - ki, kau - nis kok - ki,

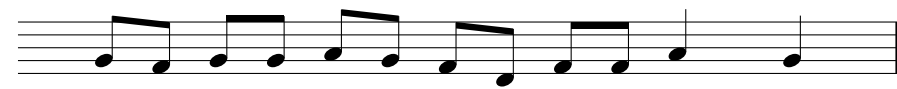

keit - ti lie -men miel - tä myö -ten, miel - tä myö - ten
Nuotti 26. Kokin kiitosvirsi. Käsikirjoitustoisintoon ei ole merkitty kuoron säkeenkertausta. (SibA Launis 40b)

\footnotetext{
${ }^{809}$ Kokille osoitetusta kiitoslaulusta ks. SKVR III 2137, 2423, 2515; SKS KRA Enäjärvi-Haavio 869; Laiho L. 5396; Salminen K. 214; sukulaisille, isäntäväelle tai talolle osoitetusta kiitoslaulusta tai kestityksen ylistyksestä ks. SKVR III 2305, 4233; SKS KRA Enäjärvi-Haavio 870; Laiho L. 4848; Salminen V. 2948 Laulut saatettiin esittää kerääjälle myös perättäin, ks. esim. Enäjärvi-Haavio 869-870 ja 880; Salminen V. 2922-2923 tai osana yhtä runoa, ks. Salminen K. 214.

${ }^{810}$ SKS KRA Laiho L. 5396.

${ }^{811}$ SKVR III 2550. Ogru Timon nainen taas selitti pitkälti, kuinka ruuan jälkeen noustiin laulaen pöydästä lattialle eli maahan ja alettiin tanssi (SKVR III 2515). Katri Vohdan mukaan lähinnä naiset lauloivat, mutta joku mieskin saattoi olla mukana (SKS KRA Enäjärvi-Haavio 869). Kokin kiitosta voitiin laulaa myös talkoiden päätteeksi pöydästä noustessa (SKS KRA Laiho L. 5053).

${ }^{812}$ Joenperän vatjalainen Oudekki Figurova lauloi vuonna 1970 kuitenkin Hyvä kokki kaunis kokki -runon neli-iskuisella pulmanuotilla (Rüütel 1977, s. 15 ja 252, sävelmä 15), minkä voi tulkita kertovan sävelmien käytön väljentymisestä häälaulujen siirtyessä muistelun piiriin, mutta yhtä lailla myös tavallisen pulmanuotin monikäyttöisyydestä.
} 
Kokin kiitos ja siihen liittyvä sävelmätyyppi liittyvät aineistossa vahvasti tanssiin. Kuten edellisissä luvuissa on todettu, kyseinen muotorakenne ja sävelmäryhmässä yleisin rytmityyppi (22222222 2244) liittyy etenkin Narvusin alueella huomattavan useisiin tanssi- ja praasnikkalauluihin. Säkeen lopun osakertaus ei kuitenkaan ole ehdoton nopean tanssin tai edes tanssin osoitus, mikä nähtiin jo Iilian virren yhteydessä luvussa 6. Hääsävelmien puitteissa säkeen lopun kertausta esiintyy kokin kiitosten lisäksi ainoastaan yhden sävelmätoisinnon yhteydessä. Boreniuksen Soikkolan Savimäeltä Vöglältä ja Okkulilta tallentama Teekkä risti rinnallesi -runo jatkuu kehotuksella polvistua pyhäinkuvanurkkaan ja hääkontekstin ulkopuolellakin esiintyvällä runolla vastasyntyneen tyttären suvun vastustuksesta huolimatta pitäneestä ja hoitaneesta äidistä (Poikako vai tyttö). ${ }^{813}$ Häiden aattoiltaan ei kuitenkaan aineistossa liity yhtään kuvausta tanssista, ainoastaan laulusta ja itkuvirsistä. Boreniuksen muistiinpanojen perusteella säkeen lopun osakertaus näyttääkin Soikkolan alueella liittyneen monikäyttöisiin yleissävelmiin. Vöglän ja Okkulin pulmanuottia läheisesti muistuttavan sävelmätoisinnon yhteyteen Borenius kirjoitti Soikkolan Loukkulassa: "Siellä tavallisin nuotti." Luultavasti Savimäelle saavuttuaan hän kirjoitti lyijykynällä sulkuihin marginaaliin: "Sama Savimäelläkin."\$14 Sävelmätyyppi siis oli ainakin kahdessa Soikkolan kylässä tavallinen yleissävelmä. Kyseisissä esimerkeissä se esiintyy traagissävyisten runojen yhteydessä, joita ei yleensä mainita lauletun nopeilla tanssinuoteilla vaan paikoillaan tai hitaassa liikkeessä. Vaikuttaisi siis siltä, että säkeen lopun osakertaus ei pelkkänä tekstuaalisena rakenteena hahmotu tietyn sävyisenä, vaan olennaista on tiettyyn rytmityyppiin yhdistyvät melodiatyyppi ja lisäksi laulamisen tapa ja tempo. Lisäksi rakenteen käyttö näyttää olevan osin paikkakuntasidonnaista. Vöglän ja Okkulin Teekkä risti rinnallesi -runoa onkin syytä arvella liittyväksi jäljempänä käsiteltävien morsiamelle hitailla osakertauksia sisältävillä sävelmillä aattoiltana laulettujen laulujen piiriin.

\section{YKS OLI OKSA OUNAPUUSSA}

Länsi-inkeriläisten hääsävelmien joukkoon kuuluu ainoastaan yksi muotorakenteeltaan kaksisäkeinen sävelmä. Kyseessä on kahtena lyhyenä toisintona Soikkolasta tallennettu laulu Yks oli ounapuu kylässä, jossa esilaulaja laulaa kaksi säettä ennen kuoron osakertauksista ounapuussa, ounapuussa koostuvaa osuutta. ${ }^{815}$ Runo kuvaa morsiamen kylän ainoan omenapuun ainoalla oksalla kasvavana ainoana

\footnotetext{
${ }^{813}$ SKVR III 594, SKS KRA Borenius e 195. Runon alku yhdistää sen häiden aattoiltana morsiamelle laulettuihin runoihin, mutta varsinaisiin rituaalisesti keskeisiin runoihin se ei kuutta alkusäettä lukuun ottamatta kuulu. Kuten edellisessä alaluvussa on todettu, Vöglä ja Okkuli näyttävät esittäneen ensin kaksi tyypillisintä hääsävelmää, sitten yhden aattoiltaan liittyvän harvinaisemman sävelmätyypin. Aattoillan lauluja käsitellään vielä tarkemmin jäljempänä.

${ }^{814}$ Kyseisen sävelmän Borenius tallensi yleisen, surullissävyisen lyyroeeppisen Läksin kouluhun kotoa (Kouluun kotoa)-runon yhteydessä. (SKS KRA Borenius e 188; SKVR III:585; ks. myös Harvilahti 1998b, 200-201.)

${ }^{815}$ Launis tallensi ensimmäisen Yks oli ounapuu kylässä -sävelmänsä käsikirjoituksena ja toisen seuraavalla matkallaan äänityksenä (SibA Launis 346; SKSÄ A 300/34b). Kattilasta Launis tallensi Ounapuu-teeman vatjankielisenä, neli-iskuisella pulmanuotilla laulettuna (SibA Launis 396). Teema yhdistyy 1960-luvun aineistossa Puhemiehen moittimiseen ja venäläisperäiseen yksisäkeiseen sävelmään (22626262) (NPI 22/99).
} 
omenana, jonka sulhanen on saanut poimituksi tai varastetuksi. Väinö Salmisen $(1917,301)$ mukaan luonteeltaan varioivaa runosikermää, johon myös Yks oli ounapuu kylässä kuuluu, laulettiin monessa kohtaa häitä.

Kun morsian on tuotu pöydän ääreen sulhon viereen istumaan [morsiamen kotona], lauletaan länsi-inkeriläisissä häissä useita runoja, jossa kehutaan sulhasta ja hänen onneaan naisen valitsemissa. Näillä runoilla ei ole varsin kiinteää muotoa; useat kohdat esitetään myöskin uudelleen sulhasen kotiin palattua.

Runoaineistossa Ounapuu-teema liittyykin useaan kohtaan ja osaksi monenlaisia runoja - myös muita kun Salmisen mainitsemaa sikermää. Teemaa on laulettu morsianta "rekeen pannessa", sormuksen sovittua morsiamen sormeen, kun morsiamelle oli pantu myssy päähän, sulhasväen istuessa pöydän ääressä, morsiustalon oven suuhun kokoontuneelle kuokkaväelle morsiamen ja sulhasen tunkeutuessa näiden lomitse ulos sekä sulhastaloon saapuessa. ${ }^{816}$ Uljaana Kipatsa lauloi runon viidentenätoista ja viimeisenä häälaulunaan. Kun Neuvokkivirren jälkeen syötiin, juotiin ja tanssittiin, laulettiin sulhastalossa hänen mukaansa kaikenlaista muutakin. ${ }^{817}$ Ounapuu-teemaa "lauletaa ja tantsitaa taikka pöyvän takana taikka ken kons tahtoo". ${ }^{818}$ Sitä saatettiin laulaa yhtälailla tanssien kuin pöydän ääressä istuenkin. Runoteemaa saatettiin siis esittää useammassakin tilanteessa häiden kuluessa. Se ei kuulunut keskeisimpiin, rituaalisimpiin, sijainniltaan vakiintuneisiin häärunoihin.

Launiksen kahtena toisintona tallentaman sävelmän esilaulun säkeet istuvat neliiskuisen, vähäsävelisen melodian kaavaan, mutta esilaulaja kertaa itse säkeensä ja kuoro toistaa säkeen loppupuolen: " $y k s$ oli oinepuu kylässä, $y k s$ oli oinepuu kylässä; ja kylässä, ja kylässä." Kuoro-osa ei vastaa melodialtaan eikä rytmiltään esilaulua, vaan on kolmi-iskuinen. Laulu on kaksisäkeisten muotorakenteiden joukossa monella tavoin erityistapaus: yleensä osakertaukset liittyvät yksisäkeisiin muotorakenteisiin ja yleensä kaksisäkeisten melodioiden yhteydessä säeparissa ei kerrata samaa runosäettä.

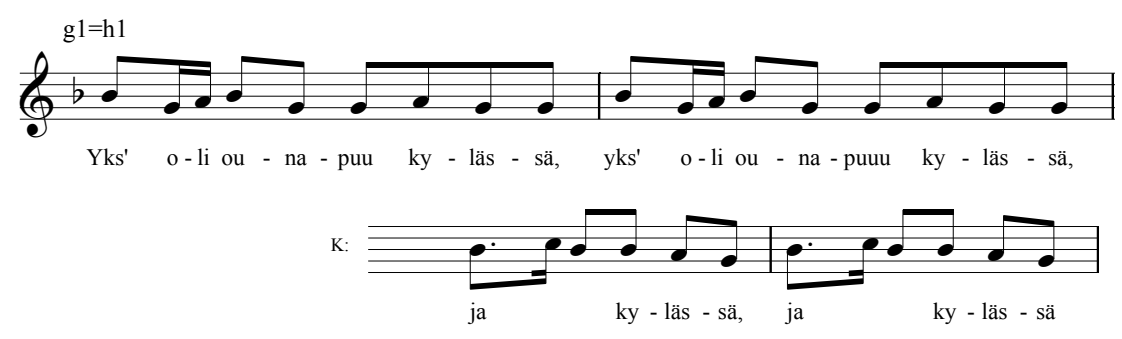

Nuotti 27. Yks oli ounapuu kylässä (SibA Launis 346).

\footnotetext{
${ }^{816}$ SKVR III 33, 407, 1716, 2263, 2413; SKS KRA ERA Angeria 68; SKS KRA Sääski 5964.

${ }^{817}$ SKVR III 2548 ("Tämän jälkee ken mitä tahtoo"); 2549 viitteet 1 ja 6, ” (Muites on vielä, ken kui tahtoo paljo laulaa").

${ }^{818}$ SKVR III 2551.
} 
Rytmisesti ja melodisesti Ounapuun sävelmää muistuttavia toisintoja on aineistossa ainoastaan muutama. Lähimpänä sävelmää on soikkolalaisen Vögle Timontyttären laulama lyyris-eeppinen laulu Velloini venoisen seppo (Veneenveisto). Esilaulaja ei kuitenkaan tässä kertaa säettään vaan laulaa kerralla kaksi säettä, ja melodia liikkuu hieman eri tavalla kuin Ounapuu-sävelmässä. ${ }^{819}$ Kun aineisto viittaa siihen, että hääkontekstissa laulettiin runot yksi säe kerrallaan, näyttää siltä, ettei Timontytär assosioinut kyseistä lauluesitystään hääkontekstiin. Toinen Ounapuusävelmää läheisesti muistuttava sävelmätoisinto on tallennettu tuntemattomilta laulajilta. Tässä Suka mereen -runon käsikirjoitustoisinnossa sävelmän rytmi on sama, mutta melodia kaartaa hieman kauempana Ounapuu-toisinnoista. ${ }^{820}$ Ylipäätään sekä Velloini venosen seppoi- että Suka mereen -runoa on aineistossa laulettu hyvin monenlaisilla sävelmärakenteilla, mikä on tyypillistä monille kertoville ja lyyrisille teemoille. ${ }^{821}$

Narvusilainen Valpuri Vohta liitti Ounapuu-sävelmää muistuttavalla sävelmätyypillä ja muotorakenteella esittämänsä Leinon lesken runon vahvasti hääkontekstiin. Laulu ei ollut hänen mukaansa varsinainen häälaulu, vaan sitä saatettiin laulaa häiden loppupuolella, pöydässä istumisen ja seurustelun lomassa. Vohdan laulamana laulu eteni kaksi säettä kerrallaan, vaikka juuri Vohta oli edellä siteeratussa kommentissaan sitä mieltä, että häälaulut laulettiin aina yksi säe kerrallaan, "kahel sanal." ${ }^{222}$ Kaksisäkeisten sävelmien kohdalla näyttääkin piirtyvän esiin ero varsinaisten pulmavirsien (muotorakenteeltaan yksisäkeiset sävelmät), luonteeltaan liikkuvampien pulmavirsien (muotorakenteeltaan kaksisäkeinen sävelmä yhtä runosäettä kerraten esitettynä) ja häissäkin välillä laulettujen, mutta ei tällöinkään varsinaisiksi pulmavirsiksi laskettavien runojen välillä (lyyris-eeppisiä runoja myös kaksisäkeisillä sävelmillä).

Keskeisaineistoon kuuluu Ounapuu-toisintojen lisäksi ainoastaan kolme Soikkolasta tallennettua laulua, jossa esilaulaja kaksisäkeisen muotorakenteen yhteydessä kertaa säkeensä. Kaikki ovat äidin huolenpidosta liikkeelle lähtevää lyyristä epiikkaa: 1) Emo synnytti minuista (Suka mereen), 2) Emo neuvoi neitojaan sekä 3) Miun too ehtoisa emoin, kasvatti kanoja paljon. Kahden ensimmäisen laulun esityskonteksti tallennustilanteessa viittaa niiden assosioitumiseen häihin. Emo synnytti minuista seuraa muistiinpanoissa häärunojen ja -sävelmien sarjaa. ${ }^{823}$ Emo neuvoi nei-

\footnotetext{
${ }^{819}$ SKSÄ A 301/10a. Vögle Timontyttäreltä ei yhtä hääitkua (SKSÄ A 301/5 a) lukuun ottamatta ylimalkaan tallennettu häälauluja: hän lauloi lähinnä lyriikkaa ja lyyristä epiikkaa. Tämä voi johtua siitä, että hän oli viimeinen Launikselle Soikkolassa esiintynyt laulaja, eikä Launis enää halunnut äänittää lisää yksisäkeisiä, suhteellisen yksinkertaisia hääsävelmiä, joita hänellä oli jo perustyypit kattava kokoelma. ${ }^{820}$ SibA Launis 53; samankaltaisista ks. myös SibA Launis 382b. Tämänkään laulun aivan lähiympäristössä ei muistiinpanoissa ole häälauluja, lähin hääitku on muutamaa muistiinpanoa kauempana (SibA Launis 57).

${ }^{821}$ Velloini venosen seppo (Veneenveisto) ks. esim. SibA Launis 333b, SKSÄ A 300/16b, 37a, 47a; Suka mereen ks. SibA Launis 118, 328, 343; SKSÄ A 300/28a. Ounapuu-sävelmän piirteet esiintyvät toisaalta muissakin lyyristen ja lyyris-eeppisten runojen sävelmissä: melodiakulkua käyttävät muutamat Soikkolasta tallennetut yksisäkeiset sävelmät (esim. SKSÄ A 300/9c) ja samaa kuoron osakertausrakennetta noudattavat monet sävelmät, joissa kuoro-osa on tihennetty (esim. SKSÄ A 301/1b).

${ }^{822}$ SKS KRA Elsa Enäjärvi-Haavio 467; A. Laiho 2291; SKSÄ L 87 c; ks. myös SKSÄ A 507/8b.

${ }^{823}$ SKS KRA Borenius e) 206; SKVR 605; ks. myös SKS KRA Borenius e) 203-205. Sävelmä oli muotorakenteeltaan kaksisäkeinen ja pituudeltaan yksisäkeinen, kuoro-osan alku korvautui oi liaa -refrengillä.
} 
tojaan puolestaan laulettiin juuri ennen käsikirjoituksena tallennettua Ounapuutoisintoa. ${ }^{824}$ Kolmannen laulun ympärillä ei suoraan häihin liittyviä runoja ole, mutta tämäkin runo kuuluu siihen suureen joukkoon kodin ja kodista lähtemisen teemoja käsittelevää lyyristä epiikka ja lyriikkaa, jota on ilmeisesti voitu häissä laulaa. ${ }^{825}$ Näiden toisintojen lisäksi Valpuri Haukka kertoi, että runoa Poika tuoreesta tuloo (Aja aja velvyeni) lauloivat kylän tytöt kaksisäkeisellä kertaustavalla sulhasen tullessa morsiamen kanssa vihiltä kotiinsa, säkeitä kokonaisina kerraten. ${ }^{826}$

Yks oli ounapuu kylässä -runon soikkolalaiset sävelmätoisinnot ovat siis häälaulujen joukossa poikkeus, joka kuitenkin luo näkymän sävelmien käytön yleisempiin piirteisiin. Valpuri Haukan käsikirjoitustoisinnon ohella ne kuuluvat länsiinkeriläisen varsinaisen häälauluaineiston ainoina esimerkkeinä kaksisäkeisten muotorakenteiden piiriin. Kuitenkaan niissäkään esilaulaja ei yhden laulamansa kaksisäkeisen jakson aikana laula kuin yhtä runosäettä: muusta sävelmäaineistosta poiketen hän kertaa oman säkeensä. Ounapuu-sävelmää muistuttavat sävelmät ja ne kaksisäkeistä muotorakennetta noudattavat sävelmätoisinnot, joissa esilaulaja kertaa oman säkeensä, ovat sanoiltaan kaikki vaihtelevaa, häiden teemoihin väljästi liitettävissä olevaa lyyristä epiikka ja lyriikkaa. Tämänkaltainen muotorakenne on voinut olla yksi laulamisen tapa juuri häihin vapaammin liittyvien lyyristen ja lyyris-eeppisten laulujen yhteydessä. Näyttääkin todennäköiseltä, että ainakin Soikkolassa esilaulajan saman säkeen kertaus on assosioitunut hääkontekstiin - ei kuitenkaan keskeisimpiin yksisäkeisillä rakenteilla laulettuihin häälauluihin, vaan väljemmin sijoitettavissa oleviin häälauluihin. Kaksisäkeisillä rakenteilla ilman esilaulajan oman säkeensä kertausta taas on voitu laulaa rituaaliseen kontekstiin varsinaisesti kuulumattomia lyyrisiä ja lyyriseeppisiä runoja. Hevaalla ja Tyrössä samankaltaista yhteyttä kaksisäkeisten samaa säettä kertaavien muotorakenteiden ja häihin väljemmin liittyvien laulujen kohdalla ei ole havaittavissa. ${ }^{827}$

\footnotetext{
${ }^{824}$ SibA Launis 345, ks. myös 346. Muotorakenteeltaan kaksisäkeinen Hevaan nuotti, pituudeltaan nelisäkeinen sävelmä.

${ }^{825}$ SKSÄ A 300/44b. Muotorakenteeltaan kaksisäkeinen Hevaan nuotti, pituudeltaan yksisäkeinen sävelmä. Hevaalaisissa ja tyröläisissä Hevaan nuotin äänitetoisinnoissa esilaulajan oman säkeensä kertausta esiintyy useammin (ks. SKSÄ A 301/27a, 32a, 33a, 37a, 38b, 48a, 48b, 56a; SKS KRA Levón 474; ks. myös SKS KRA Levón 478).

${ }^{826}$ SKS KRA Haavio 2568.

${ }^{827}$ Hevaalla ja Tyrössä ilmiö on yleisempi etenkin kaksisäkeisen ns. Hevaan nuotin yhteydessä. Esilaulaja kertaa oman säkeensä kymmenen Hevaan nuotin yhteydessä (SKS KRA Levón 451, 478; SKSÄ A 301/16a, b, 33a, 34b, 38b, 48a, 48b, 56a), yhden ai lole lole -refrengin yhteydessä (SKSÄ A 301/27a) sekä kahden säkeet sellaisenaan kertaavan muotorakenteen yhteydessä (SKSÄ A 301/32a, 37a). Näihin lauluihin kuuluu niin epiikkaa, lyriikkaa kuin lyyristä epiikkaakin, mutta myös yksi häihin liittyvä Lankoiseni lintuiseni -aloitusformula (SKS KRA Levón 451) sekä kaksi häissäkin käytettyä tanssilattian kokeilurunoa (SKS KRA Levón 478; SKSÄ A 301/37a; ks. runohakemisto Onko lankoin sillat lakeat; Onko sillat sileät). Hevaalla tapa näyttää siis olevan laajemmin käytössä; toisaalta suuri osa äänitetoisinnoista on Launiksen yhdeltä laulajalta, Vassu Kaurilantyttäreltä, tallentamia eivätkä käsikirjoitukset välttämättä kerro säkeen kertaustapoja tarkasti. Etenkin Hevaalla näyttää ylimalkaan siltä, että esilaulaja saattoi välillä kerrata säkeensä lähes säännöllisesti, välillä laulaa kokoajan uusia säkeitä niitä kertaamatta ja vaihdella näitä tapoja samankin laulun puitteissa.
} 


\section{AJAminen hä̈̈TALOIHIN}

Se, miten häätalojen välillä kuljettiin, riippui oletettavasti useasta tekijästä: vuodenajasta, etäisyydestä sulhasen ja morsiamen kotien välillä sekä perheiden varallisuudesta. Ilmeisesti ainakin sulhanen siirtyi yleensä vuodenajasta riippuen joko reellä tai vaunuilla. "Reessä lauletaan mennessä kaiken matkaa," kirjoitti Europaeus Narvusissa sulhasta ajamaan kannustavan ja Luojaa mukaan pyytävän runon yhteyteen. ${ }^{828}$ Katri Vohdan mukaan morsiamen suvun matkatessa sulhastaloon jokaisessa ajopelissä oli oma "eessälaulajansa." ${ }^{829}$ Joitain viitteitä on siitä, että nimenomaan kylien kohdalla laulettiin sekä ajoneuvolla mentäessä että hääväen kävellessä, mutta kylien välillä saatettiin olla laulamattakin. ${ }^{830}$ Kuten morsiustaloon matkatessa, myös morsiamen kanssa sulhastaloon palatessa laulettiin: Anni Moisefin mukaan ajettiin "ympäri kyliä [...] pyhävaatteet päällä ja kaikki lauloivat, morsianta näytettiin kylälle." ${ }^{\text {311 }}$ Matkassa saattoi olla "kymmenen hevosta tai enemmänkin. Näillä oli vempeleissä kellot ja kirjavia nauhoja," kertoi Paraskeva Kaurila. ${ }^{832}$ Hääväen saapuminen kuului kauas: "Hevosella on suuret kellot aisois-

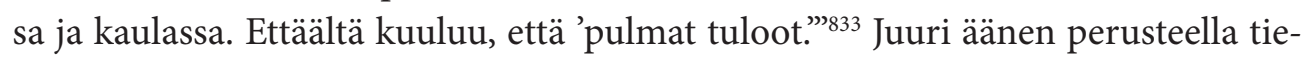
dettiin morsiustalossa, että sulhasväki oli saapumassa. ${ }^{834}$ Häitä varten koristetut ja kelloin varustetut hevoset olivat selvästi vahva mielikuva, jolla selitettiin kerääjälle myös laskiaisen rekiajelua: "Heposet kuin pulmalliset, kellot lookis." ${ }^{335}$ Riitta Rainio $(2010,187-188)$ tulee siihen johtopäätökseen, että sekä rautakautisessa että 1600-1800-lukujen kontekstissa "kulkusten ja kellojen helinä sijoittuu yhteisön territoriaalisille, sosiaalisille ja kosmologisille rajoille ja tekee näistä rajoista korvin kuultavia." Samalla tavoin 1800-1900-lukujen vaihteen Länsi-Inkerissä niistä kerrotaan eniten rituaalisten siirtymien eli häiden ja laskiaisen yhteydessä. Helinä liittyy kaikkiin Rainion mainitsemiin tasoihin. Kyse on juuri 1) territoriaalisista rajoista eli oman ja vieraiden kylien välillä liikkumisesta, 2) sosiaalisista rajoista eli oman ja vieraan suvun tai kyläyhteisöjenn välisten yhteyksien ylläpidosta ja uusintamisesta (ja häiden yhteydessä sosiaalisten roolien muuttamisesta) sekä 3) kosmologisista rajoista ainakin paastoon laskeutumisen yhteydessä (vuoden keskeisimmän kirkkopyhän valmistautumisaikaan siirtyminen). Hääthän myös usein sattuivat yhteen keskeisten praasnikoiden kanssa.

Ajamiseen liitetyt länsi-inkeriläiset häärunot sisältävät yleensä joko alkusäkeenä tai muuten laulun alkupuolella säkeen Aja aja velvyeni tai Aja aine velvyeni. Runot voivat alkaa myös erilaisilla Jumalalle suunnatuilla mukaantulopyynnöillä: Laslavittakoon Jumala; Lähe Luoja luokalleni tai Lähekko Jumala aviks, lähe lykky

\footnotetext{
${ }^{828}$ SKVR III 50; ks. myös esim. SKVR III 8, 399, 1685, 1728, 2382.

${ }^{829}$ SKS KRA Enäjärvi-Haavio 881-882.

${ }^{830}$ SKVR III 2516; SKS KRA Enäjärvi-Haavio 881-882; kylien läpi kävelystä ks. myös Launis 1907, 106.

${ }^{831}$ SKS KRA Mannonen 5704.

${ }^{832}$ SKS KRA Sääski 5971.

${ }^{833}$ SKS KRA Enäjärvi-Haavio 873.

${ }^{834}$ SKS KRA Salminen V. 2960.

${ }^{835}$ SKS KRA Haavio 2673. "Hevoset kuin häähevoset, kellot valjaissa" (suom. KK.).
} 
liikkeelle, Pyhä-henki pyytämää. Ajamiseen liittyviä runoja liitetään niin sulhastalosta lähtemiseen, matkan tekemiseen kuin morsiamen talon lähettyville saapumiseenkin. ${ }^{836}$ Niihin liittyy välillä samankaltaisia teemoja kuin naisten niin häiden kuin praasnikoidenkin yhteydessä kylän läpi kulkiessaan ja tanssiessaan laulamiin runoihin: oman kylän ylistystä tai toisen kylän pilkkaa, pyyntö olla tulematta torutuksi peltojen tallomisesta. ${ }^{837}$

Ajamiseen liittyviä runoteemoja on hieman eri muodoissa liittynyt myös luvussa 6 käsiteltyyn laskiaisena ajamiseen. Länsi-inkeriläisaineistossa Aja aja velvyeni -säkeellä alkavat runot ovat kuitenkin kaikki häätalosta toiseen ajamiseen liittyviä runoja. ${ }^{838}$ Siinä missä morsiustaloon ajamiseen liittyviä runoja on tallennettu lähinnä Narvusista (ks. myös Salminen 1917, 152), sävelmiä on Narvusista kaksi ja toiset kaksi Soikkolan inkeroiskylistä. Yksi on Europaeuksen, kolme Launiksen käsikirjoituksina tallentamia.

\begin{tabular}{|c|c|c|c|c|c|}
\hline PAIKKAKUNTA & Arkistovitte & AlKusÄKeEt & MuOtORAK. & Rутмі & SÄV. \\
\hline $\begin{array}{l}\text { Soikkola, } \\
\text { Mäkkylä }\end{array}$ & SibA Launis 357b & $\begin{array}{l}\text { Aja aja ainueni, } \\
\text { aja ainuu velvyeni }\end{array}$ & 12345678 & 22231222 & 4 \\
\hline $\begin{array}{l}\text { Soikkola, } \\
\text { Mättynen }\end{array}$ & SibA Launis 394b & $\begin{array}{l}\text { Aja aja ainueni, } \\
\text { aja aja vel(e)vyeni }\end{array}$ & 12345678 & 22231222 & 4 \\
\hline $\begin{array}{l}\text { Narvusi, } \\
\text { Vanhakylä }\end{array}$ & $\begin{array}{l}\text { KRA Europaeus 12: } \\
184\end{array}$ & Aja aja velvyeni & 12345678 & 42424244 & 4 \\
\hline $\begin{array}{l}\text { Narvusi, } \\
\text { Kaipaala }\end{array}$ & SibA Launis 107b & $\begin{array}{l}\text { Aja aina velvyeni, } \\
\text { tietä myöten tetryen }\end{array}$ & $i^{12345678}$ & $\begin{array}{l}22316262 \\
22316244\end{array}$ & 4 \\
\hline
\end{tabular}

Nämä Aja aja velvyeni -tyyppisiin alkusäkeisiin liittyvät neljä käsikirjoitussävelmää ovat kaikki yksisäkeisiä ja suppea-alaisia sävelmiä, mutta niiden rytmityypit varioivat ${ }^{839}$ Erityistä on se, että juuri näitä kyseisiä rytmityyppejä ei muusta sävelmäaineistosta löydy lainkaan, ei edes laskiaisena ajaessa laulettujen sävelmien joukosta. Ne siis näyttävät olevan suhteellisen harvinaisia, ainoastaan tai vähintäänkin tyypillisesti häissä ajamiseen liittyviä rekisterin piirteitä.

\footnotetext{
${ }^{836}$ SKVR III 8, 50, 399, 1685, 1728, 2382, 2451, 2516, 3568, 3625. Ks. SKVR-hakemisto: Kehotus ajamaan kovemmin.

${ }^{837}$ Esim. SKVR III 399, 1728; SKS KRA Enäjärvi-Haavio 881-882; ks. tarkemmin luku 5. Ajamisen teema on voitu punoa lauluun myös vasta lähtöä sulhastalosta valmistellessa, ja toisaalta sitä on käytetty myös häiden loppuessa lauletun jäähyväisvirren osana, jolloin on viitattu morsiamen suvun takaisin kotiinsa ajamiseen (SKVR III 8; SKS KRA Sääski 5975; SKVR XV 1167).

${ }^{838}$ SKVR-tietokannan haku "Aja velvy*"; liukuvirren yhteydessä keskellä laulua ks. SKSÄ A 300/40 b. Säettä esiintyy hieman yllättävästi myös laulun keskellä tyttöjen morsiustalossa laulamien laulujen yhteydestä (SKS KRA Salminen K. 276) ja kylän ihmisten tai tyttöjen laulamaksi morsianta tuodessa mainitun laulun yhteydessä (SKS KRA Haavio 2568; Salminen K. 141). Teema kuuluu SKVR-hakemistossa häälauluotsikon Kehotus ajamaan kovemmin alle.

${ }^{839}$ Kaipaalasta tallennetun sävelmän voi tosin tulkita myös kaksisäkeiseksi: joka toisen säkeen päätössävel on korkeampi ja kahden viimeisen säeaseman rytmi hivenen erilainen (62/44).
} 


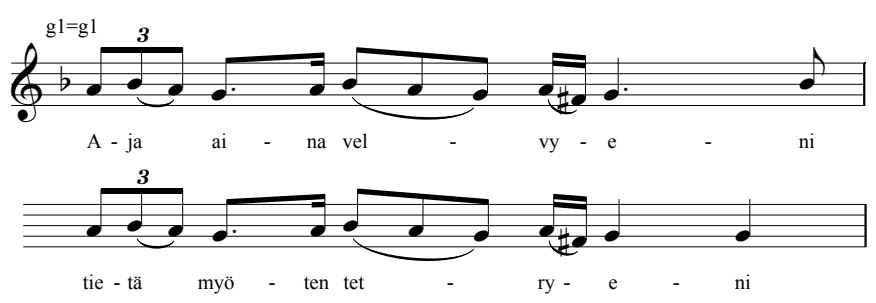

Nuotti 28. Aja aja velvyeni-runoon liittyvä sävelmätoisinto inkerinsuomalaisesta Kaipaalan kylästä (SibA Launis 107b).

Yksi varhaisimpia inkeriläismainintoja laulaen ajamisesta tai kulkemisesta liittyy häissä laulamiseen. Saksalainen, Venäjällä matkannut luonnontieteilijä J. G. Georgi kirjoitti 1700-luvun lopulla, että inkeriläisissä häissä koko matkan kirkkoon lauloi "kaksi hunnutettua naista päättömiä lauluja" (Salminen 1917, 22; Georgista ks. Västrik 2007, 119). Kirkkomatkalla laulamisesta kuitenkaan ei tämän työn aineistossa ole viitteitä, mikä antaa kuvaukselle ainakin kolme tulkintavaihtoehtoa: joko papisto oli saanut karsittua tavan 1800-luvun loppupuoliskolle tultaessa, kyseessä oli väärinkäsitys tai sitten kirkkomatkan laulut eivät olleet rituaalisesti määräytyneitä ja kulttuurisesti keskeisiä eivätkä siten tulleet erikseen kerääjille mainituiksi. Runsaasti kuvauksia tai runotoisintojahan ei ole myöskään ole häätalosta toiseen siirryttäessä lauluista lauluista.

\section{KOSIKKISÄVEL JA TYTTÖJEN AATTOILLAN LAULU}

Häälaulujen joukkoon kuuluu vielä muutama sävelmäryhmä, jotka poikkeavat muista häihin liittyvistä sävelmistä. Eniten toisintoja on kahdesta sävelmätyypistä, joita kutsun tässä oi dai - ja oi Jokoi -sävelmiksi. Sävelmiin sisältyy vaihdellen erilaisia osakertauksia, tavun venytyksiä, lisätavuja ja refrenkitavuja eli piirteitä, jotka asettavat ne selkeästi erilleen etenkin kahdesta tavallisesta pulmanuotista sekä ajamiseen liittyvistä sävelmistä. Äänitetyissä toisinnoissa niiden tahti on rauhallinen ja esitystapa rytmiä painottamaton, mikä erottaa ne myös osakertauksia sisältävistä kokin kiitoksista.

Selkeitä häärunoihin liittyviä oi dai -sävelmiä aineistossa on seitsemän, joista äänitteitä viisi. Kaikki laulajat ovat kotoisin Soikkolasta. Jo Launis (1910b, 91-92) nimeääkin tämän sävelmätyypin paikalliseksi, soikkolalaiseksi hääsävelmäksi.

Esilaulun melodia on rakenteeltaan tyypillinen neli-iskuinen neljän sävelen alalla liikkuva runosävelmä, jonka tunnusomaisena piirteenä on laulun aloittava kolmen sävelen laskeva sävelkulku. Tyypillisestä runosävelmän rakenteesta kauemmaksi etääntyvän kuoro-osan aloittavat refrengitavut oi dai, minkä jälkeen kerrataan esilaulajan säkeen alkupuolisko ja lopuksi koko säe viimeistä tavua lukuunottamatta. Kuoro-osa sisältää lähinnä terssisoinnuille perustuvia moniäänisiä kohtia ja se päättyy joskus kestoltaan vaihtelevaan pitkään ääneen. Laulun tempo on äänitteillä melko hidas ja vapaa. Moniäänisyyteen liittyvät variaatiot laajentavat paikoin sävelalaa yhdellä sävelellä ylöspäin, ja joskus kuoro-osan viimeinen pitkä ääni tipute- 


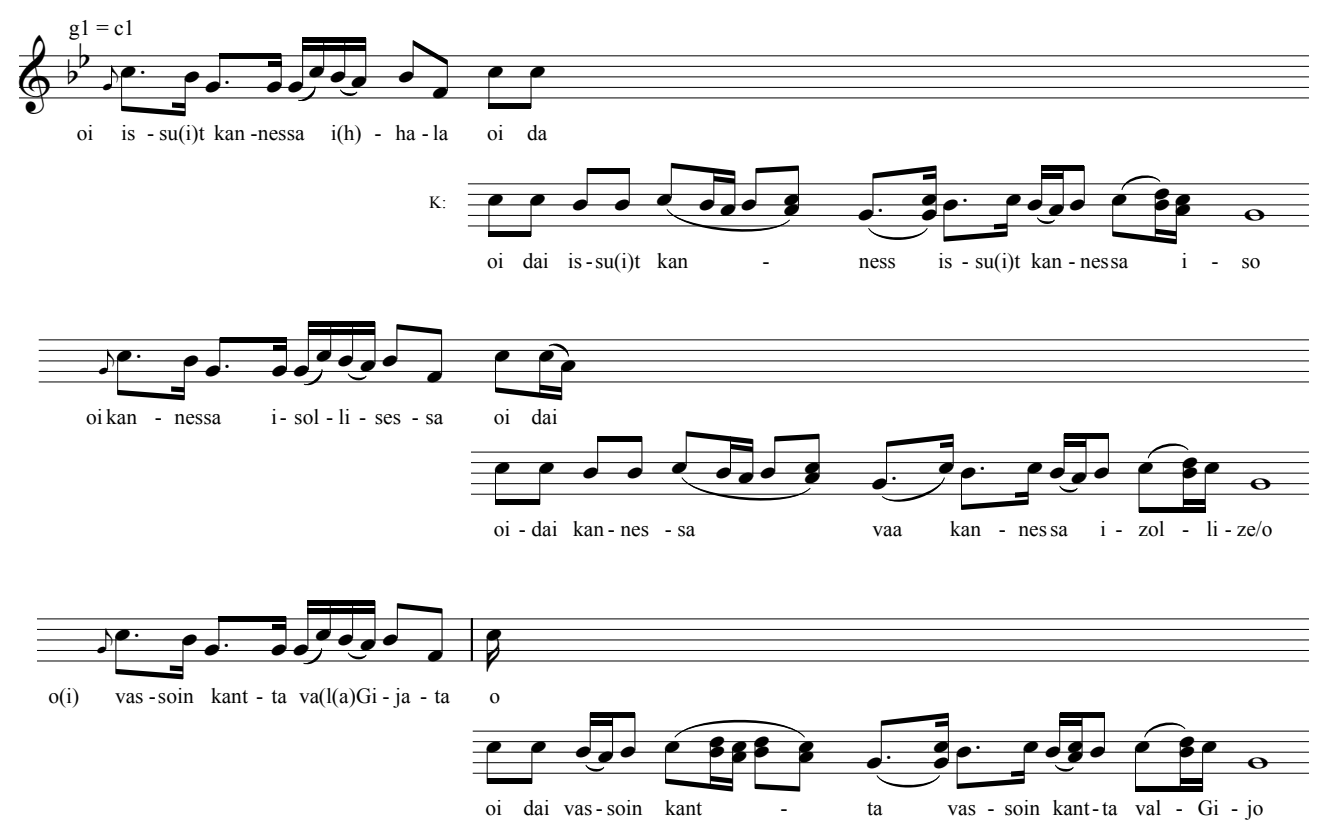

Nuotti 29. Naasto Savasteintytär ja kuoro esittivät oi dai -sävelmällä Istuttamisvirren Launiksen fonogrammille (SKSÄ A 300/12a. Nuotinnos Ilona Korhonen).

taan lopussa laulun muun sävelalan alapuolelle. Aineistosta löytyy myös muutama yhdeltä laulajalta ilman kuoro-osaa tai tavallista lyhyemmän kuoro-osan kanssa tallennettu versio. ${ }^{840}$

Oi Jokoi -sävelmästä aineistoon sisältyy kuusi häärunoihin liittyvää toisintoa, joista kolme on äänitteitä. Yksi on tallennettu Hevaalta, muut kaikki Soikkolasta. Ryhmä on muodoltaan hajanaisempi kuin oi dai -sävelmään liittyvä. Äänitteillä esilaulajan osuuteen sisältyy sekä säkeen keskiosan että sen loppupuoliskon kertaus, kuoro sitä vastoin kertaa ainoastaan säkeen keskiosan. Säkeen keskiosan kertaukset voivat korvautua osittain tai kokonaan lisätavuilla. Yleensä esilaulaja aloittaa osuutensa oi-tavulla.

\footnotetext{
${ }^{840}$ SibA Launis 260, 319; ks. myös A-K 126/12.
} 


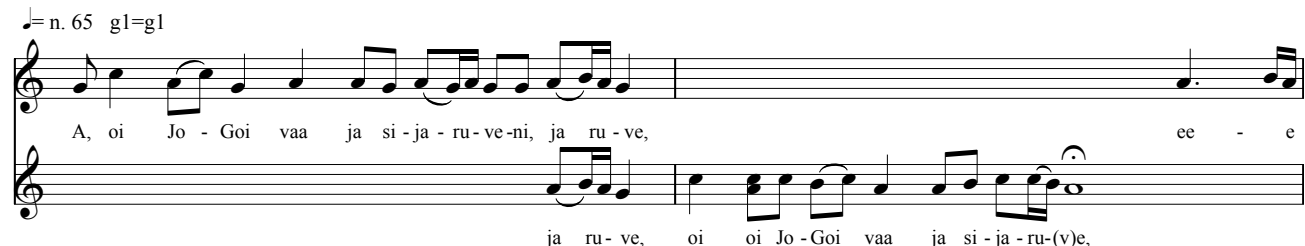

ja ru-ve, oi oi Jo-Goi vaa ja si-ja-ru-(v)e,

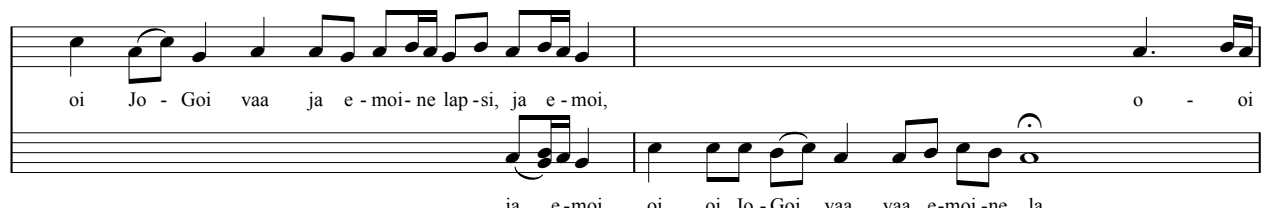

ja e-moi, oi oi Jo-Goi vaa vaa e-moi-ne la,
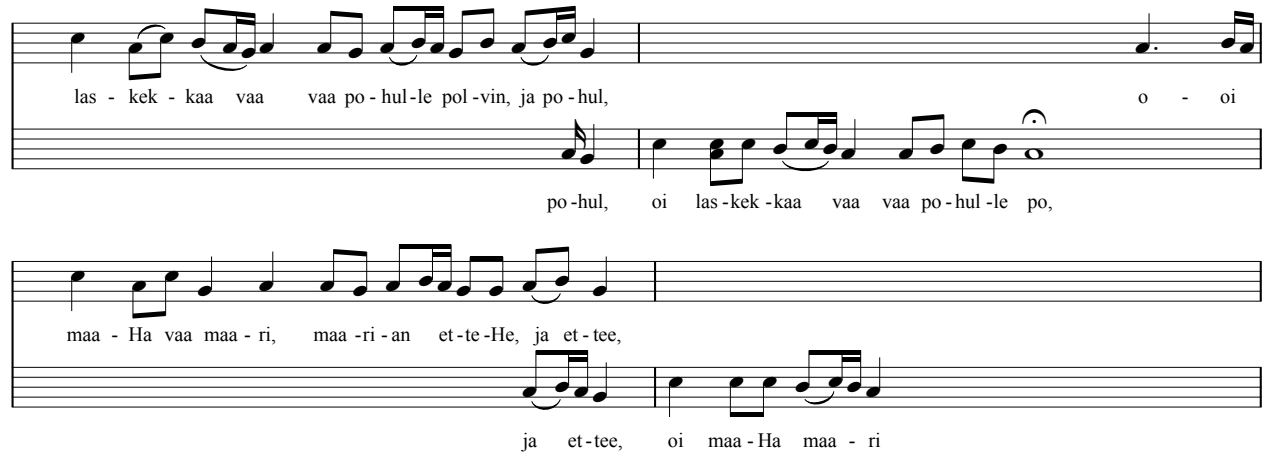

Nuotti 30. Ustenja Miikkulantyttären esilaulama oi Jokoi -sävelmä. Kuoro-osassa vain yhden laulajan ääni kuuluu selkeänä. (SKSÄ A 300/48b.)

Käsikirjoitusmuistiinpanoissa sävelmä voi myös koostua ainoastaan esilaulajan osuudesta tai jopa tavallista lyhyemmästä esilaulajan osuudesta ilman säkeen lopun osakertausta. Tunnistettavaksi sävelmätyypin tekee kaikessa moninaisuudessaankin melodiakulkujen samankaltaisuus, sävelmän keskiosan kertaus (tai lisätavut sen sijasta) sekä säkeen aikainen rytminen vaihtelu. Toisinnoissa sävelalan laajuus vaihtelee neljän ja kuuden sävelen välillä. Oi dai - ja oi Jokoi -sävelmätyyppien perushahmot ovat sangen tunnistettavia, vaikka asteikon laajuus, rytmirakenne ja sävelsuhteetkin paikoin vaihtelevat. ${ }^{841}$

Oi dai- ja oi Jokoi -tyyppisiin sävelmiin liittyvät häärunot ovat enimmäkseen morsiamelle kosintatilanteen yhteydessä ja häiden aattoiltana laulettuja runoja, jotka alkavat joko morsiamen puhuttelulla kuten Oi Jokoi sisarueni, tälle suunnatulla kehotuksella kuten Lootikka pohulle polvin (polvistu pyhäinkuvanurkkaan) tai laulutilannetta tilannetta kuvailevalla säkeellä Issu(i)t kannessa ihala (istu(i)t pöydässä ihana). Jälkimmäiset teemat kuuluvat SKVR-hakemistossa teemaan Kumarruttaminen ${ }^{842}$ Näiden runojen yhteydessä ovat yleisiä myös erilaiset itketysteemat sekä tyttöjoukosta ja lapsuuskodista eroamista käsittelevät lyyriset teemat. Myös lyyris-eeppinen runo Neidon linna liitetään runokäsikirjoituksissa aattoillan tyttö-

\footnotetext{
${ }^{841}$ Käsikirjoitusaineistosta löytyy myös muutamia niitä eri tavoin muistuttavia sävelmiä, joita on kuitenkaan vaikea lukea samojen sävelmätyyppien edustajiksi (SibA Launis 298, 362, 455).

${ }^{842}$ Morsianta puhutteleva runo liittyy sävelmäaineistossa kerran myös häiden loppupuolelle, jolloin laulussa muistellaan tyttöaikojen vapaata laulua Käeltä oppinut laulut -runon kautta. Esimerkiksi Jekaterina Aleksandrova aloitti Neidon linna -runonsa aina morsiamen puhuttelulla, käytti oi dai -sävelmää ja kertoi kylän tyttöjen laulaneen laulua kosimistilanteen yhteydessä läpi kylän kulkien.
} 
jen lauluihin. ${ }^{843}$ Sävelmät ja runot muodostavat selvästi morsiamen vertaisryhmän oman häärekisterin.

Oi Jokoi -sävelmien käsikirjoitustoisintoihin liittyy näiden erilaisten morsiamelle laulettujen runoteemojen lisäksi kolme sulhaselle suunnattua aihelmaa. Joukossa on yksi vävyä hellittelevä (Oi vävy sisoin suloinen) ja kaksi puhemistä siskon pettäjäksi syyttävää aloitusformulaa (Pitkä keeloi pettelikko, petteli miun sissoini sekä Kosjolainen kielikoira). Ensimmäisen tyyppiset formulat (Oi vävy sison sulanen; Oi vävy vävyjyeni, oi vävy sison sulhane; Ai vävy, kuvattu kulta) liittyvät yleensä Neuvokkivirteen, joissa tytöt pyytävät sulhasta olemaan lyömättä vaimoaan ${ }^{844}$ Jälkimmäiset formulat liittyvät yleensä tyttöjen morsiustalossa laulamaan pilkkalauluun, jossa puhemiehen syytetään pettäneen morsiamen perheen, kun on houkutellut tytön naimisiin tai kun ei ole tuonut maagisia esineitä, jotka täyttäisivät tytön jättämän tyhjän paikan (Puhemiehen moittiminen). ${ }^{845}$ Tiettyä sulhasen puolelle osoitettua pilkkalaulua voitiin siis laulaa paitsi tavallisilla pulmanuoteilla, myös tyttöjen omaa eron ja jäähyväisten rekisteriä käyttäen. Kaikkia tervehdys- tai pilkkalauluja (esim. Terve kuu terve päivä tai Missä mökkä myöhään viivyit) tämä ei kuitenkaan koske. Tämä laajentaa silti käsitystä pilkan sävyistä: tässä tapauksessa pilkkaa ei esitetty keskeisimmillä pulmanuoteilla painokkaan rituaalisesti, vaan itkunvirsiensekaisesti tyttöjen omilla, surullisiin ja lyyrisiin runoihin assosioituvilla sävelmillä. Voi olla, että laulu suuntautui puhemiestäkin puhutellessaan enemmän morsiamelle ja tytöille itselleen, punoutui osaksi eron ja surun keskinäistä käsittelyä.

Varsinaisten häälaulujen lisäksi näihin sävelmätyyppeihin kuuluvia toisintoja on tallennettu muutamien lyyristen, lähinnä laulusta puhuvien runoteemojen yhteydessä. Oi dai -sävelmään liittyy kaksi lyyrisen runon toisintoa. Näistä ensimmäinen on lyhyt nuorison tanssin- tai laulunaloitusformula Nyt on aika nuoren noissa (yl. Nuorena aika laulaa). Sen jatkosta ei ole tietoa. Toinen on lyhyt lyyrisen runon alku, jossa kerrotaan isän antaneen (tytölle) luvan laulaa: $N y D$ miä laulan nyD miä jouvan [...] nytD antoi volin issoini (yl. Isoni iloita käski).

Oi Jokoi -sävelmiin liittyviä lyyrisiä teemoja on enemmän: yhteensä neljä muuta kuin varsinaista häärunoa, joista kolme on käsikirjoitustoisintoja, yksi lyhyt fonogrammiäänite. Kahdessa toisinnossa todetaan, että ei pitäisi laulaa - yleensä nämä teemat liittyvät surusta ja läheisen kuolemasta puhumiseen (Vet en laula laulujani; Ei miul laulella pittäisi. Yl. Ei minun laulella pitäisi). Yksi toteaa, että kaikesta huolimatta on mahdotonta olla laulamatta: Vet en voi ilotta olla, enhän voi ilotta olla. Tämän lisäksi joukkoon kuuluu yksi Emo neuvoi neitojaan -alkusäe. Yleensä kyseinen säe jatkuu kuvauksella tytöstä, joka neuvoista huolimatta rakastui huonoon mieheen. Kaikki toisinnot siis kertovat joko laulusta, surusta tai naimisiin menosta.

\footnotetext{
${ }^{843}$ SKVR III 602, 1675, 2494-2496, 3269, 3490.

${ }^{844}$ SKVR III 406, 425, 1751, 2133, 2548, 4229.

${ }^{845}$ SKVR III 427, 1704, 1851; SKS KRA Mannonen 5507, 11118.
} 
Lyyrisille toisinnoille löytyy nähdäkseni kaksi tulkintavaihtoehtoa, jotka eivät sulje toisiaan pois. Kuten jo edellä on todettu, hääkontekstissa laulettiin myös paljon kaikenlaista muuta, väljemmin tilanteeseen lomittuvia runoteemoja. Erityisesti tyttöjen kosimistilanteen ja häiden aattoillan ympärille liittynyt laulu näyttää rakentuneen sekä runotekstien että sävelmien osalta melko vapaasti. Toisaalta voi hyvin olla, että vahvasti hääkontekstiin ja morsiameen assosioituvilla rekistereillä on ollut käyttöä myös tyttöjen laulaessa häihin ja omiin kohtaloihinsa liittyviä lauluja hääkontekstin ulkopuolella. Koko häälauluston ja laajemmin inkeriläisen laulun kontekstista käsin katsottuna näihin kahteen sävelmätyyppiin lomittuu moninaisuudessaankin suhteellisen selkeärajainen runokokonaisuus: morsiamelle ennen häitä ja häissä suunnattuja lyriikansekaisia varsinaisia häälauluja, morsiamen puhuttelulla tai hääformulalla alkavaa tyttöjen asemaan liittyvää lyyristä epiikkaa (Neidon linna, Käeltä oppinut laulut, Poikako vai tyttö; Älkää tytöt valitko kaunista) sekä vain väljästi hääkontekstiin assosioitavissa olevaa surua ja laulua käsittelevää lyriikkaa, jota on voitu laulaa häätilanteissa morsianta itketettäessä, illanistujaisissa ennen häitä ja yhtälailla muuallakin. Rituaalissa nämä laulut lomittuivat morsiamen äidin ja morsiamen itsensä laulamiin itkuvirsiin.

Oi dai - ja oi Jokoi -sävelmiin keskeisesti liittyviä runoteemoja on tallennettu muutamia myös muilla sävelmätyypeillä. Näistä yleisin on osakertausten ja lisätavujen variaation suhteen oi Jokoi -sävelmää muistuttava sävelmätyyppi, jolla on esitetty yksi Kumarruttamisvirsi, yksi vävyn puhuttelu (yl. Neuvokkivirsi) sekä yksi morsiamen puhuttelu, jonka yhteydessä on kerrottu sävelmällä voitavan laulaa myös lyyris-eeppistä Sairastava neito -runoa (Neito linnassa lässii). Samaan sävelmätyyppiin liittyy yksi laulunaloitusformula (Miks on meitä näin vähäsen), kaksi yleensä Neitojen linna -runon aloituksena toimivaa säettä Sanoin siulle tän kesoja sekä kaksi tätä muistuttavaa aloitusformulaa La katson vaan kesoista kieltä. Sävelmätyypillä esitettyjen runojen luonne on sama kuin oi dai - ja oi Jokoi -sävelmätyypeilläkin. Tämän lisäksi tyttöjen laulamiin häärunoihin liittyy vielä muitakin yleisempiä sävelmätyyppejä. Yhden neli-iskuisen sävelmän muunnoksen (42424242) Launis nimesi kozimavirreksi. ${ }^{846}$

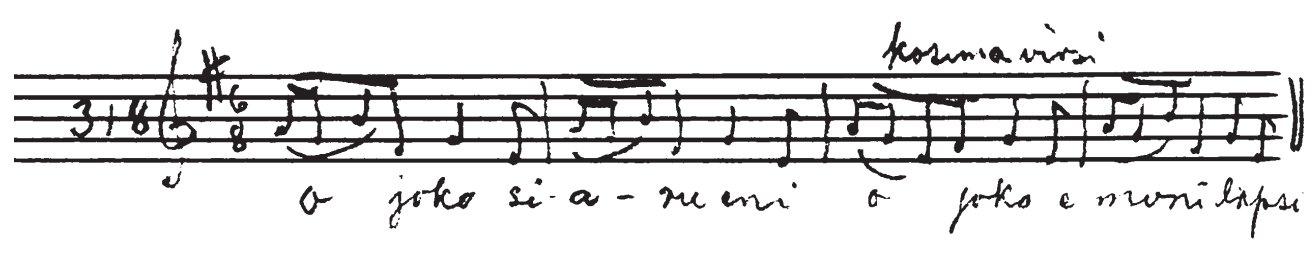

Nuotti 31. O Joko siarueni, o Joko emoni lapsi (SibA Launis 318).

Samaa rytmityyppiä esiintyy muidenkin morsiamelle suunnattujen laulujen eli yhden paikantumattoman morsiamen puhuttelun, yhden morsiustalossa morsiamelle osoitetun lyyrisen laulun sekä yhden Kumarruttamisvirttä edustavan Tehkää

846 SibA Launis 318. Launis tallensi rytmityypiltään poikkeavan (22622222) kumarruttamisvirren heti edelläolevan "kozimisvirren" jälkeen lisämaininnalla "Kun poikia viedään sotamiehiksi" (SibA Launis 319) - eron ja itkuvirsien sävyttämä tilaisuus sekin. 
risti rinnallesi -säkeen yhteydessä. Kolmessa tapauksessa morsiamelle on laulettu myös tavallisia pulmanuotteja käyttäen: Anna Kivisoo esilauloi Kumarruttamisvirtensä neli-iskuisella pulmanuotillaan, Oute Joenperältä taas käytti morsiamelle osoitettuun Neidon linna -runoonsa kuusi-iskuista pulmanuottia. ${ }^{847}$ Tämän lisäksi kaksi Kumarruttamisvirttä ja yksi puhemiestä moittiva laulu on laulettu poikkeavilla yksisäkeisillä rytmityypeillä (22622222; 2231222[?]; 22626262).

Näyttääkin siltä, että tyttöjen kosimistilanteeseen ja aattoiltaan keskittynyt monimuotoinen, lähinnä morsiamelle suuntautunut laulu on voinut tavallisten pulmanuottien ohella käyttää paljon laajempaa laulun rakenteiden kirjoa kuin varsinaiset häälaulut ja punoa samalla muita herkemmin osakseen erilaisia lyyrisiä ja lyyriseeppisiä teemoja. Voisi uumoilla juuri tämän väljän ja varioivan sävelmäryhmän liittyneen Launiksen $(1907,111)$ kosimistilanteeseen liittyvään kommenttiin, vaikka sävel-termi viittaakin Hevaan suuntaan: "Kosikkisävelestä puhuvat inkeriläiset kyllä paljonkin, mutta omasta puolestani en voinut mitään pysyväistä kosikkisäveltä huomata. Kosikkivirttä lauletaan onnistuneen kosinnan jälkeen talossa, jonne kosija puhemiehineen on saapunut." Tunnistamisvaikeuden syynä on luultavasti juuri kosikkisäveleen liittyvän rekisterin laajuus. Soikkolan alueelta tallennetussa aineistossa oi dai - ja oi Jokoi -sävelmät silti dominoivat selkeästi sekä kosimistilanteeseen että häiden aattoiltaan liittyvien runojen yhteydessä. Niiden ohella on voitu käyttää sekä tavallisimpia pulmanuotteja että sävelmätyyppejä, joita ei muiden häälaulujen yhteydessä tavata lainkaan. Häälaulujen kontekstissa tämä rekisteri on ollut tunnistettava ja muista erottuva nimenomaan laajuudessaan, joustavuudessaan ja tavassaan viitata itsensä ulkopuolelle häitä edeltäviin tyttöjen laulutilaisuuksiin, lyriikkaan sekä itkuvirsiin. Senkään puitteissa ei kuitenkaan käytetty esimerkiksi muotorakenteeltaan kaksisäkeisiä sävelmätyyppejä tai säettä korvaavia refrenkejä.

Tyttöjen morsiamelle suunnatun laulun piiriin liittyy itketyksen ja eron tematiikkaa käsitteleviä runoteemoja ja laulu liittyy keskeisesti tilanteisiin, jossa itkuvirret dominoivat. Itkuvirsien esittäminen loppui morsiamen lähtöön kotoaan (Nenola 1982, 121), ja samoin tyttöjen laulu painottuu lähtöä edeltävään aikaan. Aili Nenola (1982, 79-95) mainitsee inkeriläisen kalevalamittaisen lyriikan ja itkujen olevan usein lähellä toisiaan. Tämän työn aineistossa myös esitykselliset yhteydet kalevalamittaisen runon ja itkujen välillä näkyvät juuri tyttöjen aattoillan lyyrisesti sävyttyneen, itkuvirsien kanssa vuorotelleen laulun kohdalla.

Ei olekaan yllättävää, että sävelmäaineistoon sisältyy myös yksi oi dai -sävelmää muistuttava itkutoisinto, joka on selvästi morsiamen versio pöydässä istumisen teemasta, vastine hänelle laulettuun Issuit kannessa ihala -teemaan.

\footnotetext{
${ }^{847}$ SKS Borenius e 203; SKVR III 602.
} 


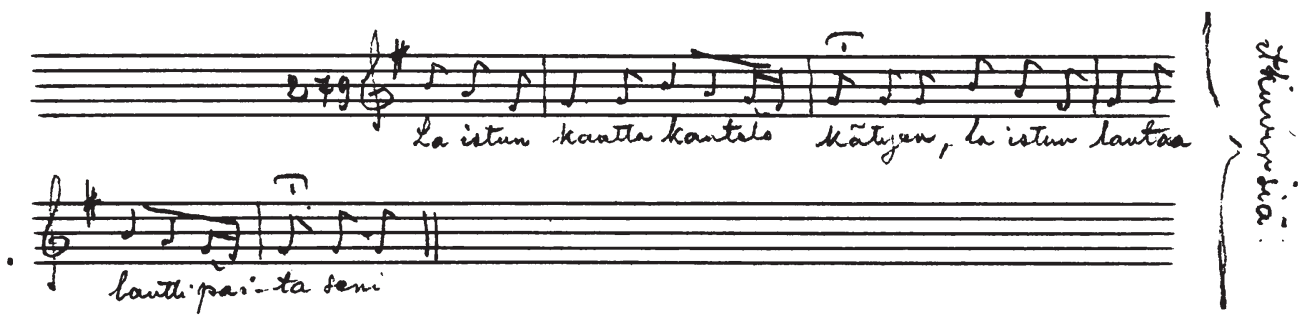

Nuotti 32. Oi dai -sävelmää muistuttava morsiusitku Soikkolan Voloitsasta (SibA Launis 279).

Tämän lisäksi on löydettävissä myös yksi morsiusitku ja yksi omaelämäkerrallinen itku, joissa toistuu oi dai -sävelmälle tyypillisiä laskevia sävelkulkuja. ${ }^{848}$ Tässä luvussa tyttöjen rekisteriksi tunnistettujen venyttelevien hääsävelmien ja itkujen sävelasteikkojen yhteyksistä mainitsee myös Terttu Koski (1974, 477-480). Lisäksi hän huomauttaa kyseisten hääsävelmien muistuttavan myös tiettyjä venäläisiä lyyrisiä lauluja. Oi dai -sävelmän yhteydessä vähintäänkin refrenkitavut ja melodian pituus, oi Jokoi -sävelmän yhteydessä etenkin melko suurin harppauksin etenevä sävelmä antavat samoin aihetta uumoilla venäläisiä vaikutteita, samoin melko selkeisiin rinnakkaisiin terssikulkuihin perustuvat moniääniset piirteet. Musiikilliset ja tekstuaaliset muotorakenteet kuitenkin erottavat kalevalamittaisen runon, itkut ja venäläiset hitaat laulut toisistaan: kyse on ennemminkin monitasoisista viittaussuhteista lajien välillä kuin niiden hybridisaatiosta.

Tyttöjen morsiamelle suunnattu häälaulurekisteri punoi yhteen viitteitä moniin lajeihin ja esitysareenoihin. Se sisälsi leimallisesti juuri tähän rekisteriin ja sen keskeisiin esitysareenoihin assosioituvia sävelmiä ja runoteemoja, mutta saattoi sulauttaa osakseen myös tavallisia pulmanuotteja tai muutamia yleissävelmiä sekä yleisempiä runoaiheita. Muihin häiden rekistereihin verrattuna keskeisenä näyttäytyy juuri rekisterin laajuus. Tyttöjen laulun puitteissa kuitenkin tietyt esitysareenat, tietty laulun kohde, tietyt runoteemat ja -sävelmät sekä tietty laulajaryhmä liittyvät vahvasti yhteen. Heidän käyttämänsä rekisteri toi läsnä olevaksi myös häitä edeltäneet tyttöjen laulun kontekstit ja asettui samalla sekä tekstuaalisella, musiikillisella että esityksellisellä tasolla dialogiin runojen kanssa vuorotelleiden itkuvirsien kanssa.

\footnotetext{
${ }^{848}$ NPI nuotti 38 (Evdokia Sorokina, omaelämänkerrallinen itku); Rüütel 1979, raita 10 (Natjo Lukina, Joenperä morsiusitku); ks. myös Niemi 2002, 701-702. Joidenkin itku- ja runosävelmien samankaltaisuudesta mainitsee myös Launis (1910a, II), joka sijoitti itkusävelmiä runosävelmäkokoelmaansa. A. A. Borenius puolestaan tallensi Hevaan Outelta vapaarytmisen metsänvirren, jonka sävelmä oli hänen mukaansa samanlainen tai samakin kuin itkuvirsien (SKS KRA Borenius e 185). Yksittäisiä esimerkkejä on myös runon vaihtumisesta itkuvirteen kesken kaiken tai itkuvirren kaltaisten piirteiden ilmaantumisesta runon loppuun (SKS KRA Laiho A. 2132, 3247; Sääski 5009).
} 


\section{HÄÄLAULUN REKISTERIT}

Häälaulut muodostavat praasnikkalauluja laajemman ja moninaisemman ryhmän, jotka esitystapojensa ja kontekstiensa puolesta myös jäsentyvät toisella tavalla. Keskeiset häälaulut alkavat sangen selkeillä aloitusformuloilla, jotka tyypillisesti joko osoittavat laulun jollekulle häiden roolinhaltijoista (Oi Mari sisarueni) tai sisältävät tilannesidonnaisen pyynnön tai kehotuksen (Avatkaa Viron veräjä). Etenkin useimmin nimetyt runot, kuten vaikkapa kylvetysvirsi näyttävät pysyvän keskeissisällöltään hyvin samankaltaisina eikä niihin liity lyyrisiä tai eeppisiä jatkoteemoja. Toisten runojen yhteydessä variaatio on suurempaa. Esimerkiksi tyttöjen sulhasväelle laulamat moninaiset tervetulon, ylistyksen ja pilkan aihelmat yhdistyvät runoaineistossa toisiinsa monin erilaisin tavoin, vaikka sijoittuvatkin kontekstikuvauksissa kaikki samaan rituaalin vaiheeseen. Muutamat runoteemat, kuten Yks oli ounapuu kylässä, ovat puolestaan voineet liittyä moneen häiden vaiheeseen. Tyttöjen morsiamelle laulamien runojen yhteydessä on taas muita häärunoja enemmän lyyrisiä ja lyyris-eeppisiä teemoja varsinaisiin kontekstisidonnaisiin ja rituaaliin liittyviin teemoihinkin punoutuneena: näiden kohdalla laulu on hetkeen (Issut kannessa ihala) tai kohteeseen (Oi Mari sisarueni) liittyvän aloituksen jälkeen voinut jatkua hyvin varioivin tavoin. Tämän lisäksi häissä mainitaan lauletun varsinaisten häärunojen ohella myös kaikenlaista tilanteeseen assosioituvaa lyriikkaa ja epiikkaa.

Jos häälauluja tarkasteltaisiin yhtenäisenä joukkona, tultaisiin helposti siihen lopputulokseen, että mitään erityisiä sävelmiä ei ollut, kaikenlaiset sävelmät kävivät yhtäläisesti, kunhan sävelmän muotorakenne oli yksisäkeinen. Runoista, laulajaryhmistä ja laulun asemasta rituaalin kokonaisuudessa lähtevä tarkastelu kuitenkin näyttää, että tosiasiassa häiden laajaan kokonaisuuteen liittyi useita keskenään vuorottelevia laulamisen rekistereitä. Ne kuulostivat erilaisilta, niillä sanottiin erilaisia asioita, niitä käyttivät osin erilaiset laulajaryhmät ja ne liittyivät häiden sisällä erilaisiin esitysareenoihin. Se, millä tavalla häärunoa on tyypillisesti laulettu näyttää vaihdelleen osin runon rituaalisen aseman, sisällön ja esityskontekstin, osin näihin sidoksissa olevan laulajaryhmän mukaan.

Häälaulujen rakenteet ja sävelmät ovat sangen yksinkertaisia. Ne laulettiin kaikki kahel sanal eli säe kerrallaan kerraten, ilman refrenkejä. Ne ovat suppea-alaisia, muotorakenteeltaan yksisäkeisiä sävelmiä, joissa ei esiinny pidempiä, venäläisperäisiä refrengejä tai säkeen loppuun liitettäviä refrenkitavuja. Häiden yleissävelminä, keskeisimpinä pulmanuotteina toimi kaksi muoto- ja rytmirakenteen pohjalta määrittyvää sävelmätyyppiä, jotka osin olivat vaihtoehtoiset, mutta painottuvat tiettyihin rituaalin vaiheisiin. Kahdella perussävelmätyypillä laulettiin tulkintani mukaan etenkin rituaalisesti keskeisimmät laulut: sukujen väliset dialogit ja häiden siirtymiin kiinteästi liittyvät laulut. Keskeisin laulajaryhmä oli monista praasnikkatilanteista poiketen aikuisten naisten joukko. Ilmeisesti suurin osa hälauluista esitettiin paikoillaan istuen tai seisten tai hitaasti piirissä liikkuen - tarkempia kuvauksia on valitettavan vähän. Vauhdikkaan tanssin kuvauksia liittyy vain muutamiin kohtiin, joissa sukujen välisen jännitteen voi katsoa lauenneen. Tiettyjä runoja 
on aineistossa laulettu ensisijaisesti ainoastaan toisella rytmityypillä. Häiden alussa ja aivan lopussa on käytetty eniten neli-iskuista muotoa. Kuusi-iskuinen muoto näyttää liittyneen vahvimmin tilanteisiin, joihin liittyy myös mainintoja tanssista. Tulkitsen neli-iskuisen tyypin keskittyvän vahvasti häiden kohtiin, joissa kyse oli sukujen välisestä latautuneesta dialogista, kuusi-iskuisen esiintyvän runsaampana niissä kohdin, joissa lataus oli juuri lauennut. Säännöllistä seitsentavuisuutta esiintyy näiden pulmanuottien puitteissa ainoastaan tyttöjen laulamissa aattoillan neli-iskuisissa Kylvetysvirsissä, joiden rekisterin voi katsoa lähenevän tavallisia pulmanuotteja väljempiä muotoja käyttäneitä, samaa tilannetta jatkaneita tyttöjen istuttamis- ja itkettämisvirsiä.

Näiden kahden yleissävelmän lisäksi tarkkarajaisemmassa käytössä oli muitakin sävelmätyyppejä. Kokin kiitosvirttä on aineistossa esitetty ainoastaan säkeen lopun osakertauksen sisältävillä yksisäkeisillä sävelmillä ja runoteksteihin liittyvät maininnat korostavat nopeaa tanssia. Laulamisen tapa asettaa kiitosvirren häälaulujen valtavirrasta poiketen selvästi riehakkaiden tanssilaulujen joukkoon. Häätaloon ajamiseen taas liittyy neljä rytmityypiltään varioivaa yksisäkeistä sävelmää, jotka ovat sävelmäaineiston ainoat rytmityyppinsä edustajat. Tämä on harvinaista, sillä yleensä vahvastikin tiettyyn esitysareenaan tai paikalliseen lajiin assosioituneet sävelmät ovat voineet tulla käytetyiksi myös muissa puitteissa. Vaikka laskiaisena ajamiseen on liittynyt joitain samoja runosäkeitä kuin häätaloon ajamiseen, ei näihin tilanteisiin liitetyillä sävelmillä ole yhteyttä toisiinsa. Häissä ajamisen ja laskiaisajelun rekisterit erosivat toisistaan selkeästi, vaikka kellojen ja kulkusten helinä, ajaminen sekä muutamat runosäkeet liittivätkin niitä toisiinsa.

Hääsävelmäaineiston ainoa muotorakenteeltaan kaksisäkeinen laulu liittyy Yks oli oksa ounapuussa -teemaan, mutta siinäkin esilaulaja kertasi oman säkeensä, jolloin laulu siis eteni yksi säe kerrallaan. Vaikka Ounapuu on selkeä hääteema, saattoi se kytkeytyä moneen kohtaan häärituaalia eikä ilmeisesti tullut lasketuksi kaikkein keskeisimpien häälaulujen joukkoon. Vapaasti hääkontekstissa liikkuviin häälauluteemoihin ja muihin väljemmin häihin assosioituviin teemoihin voitiinkin käyttää keskeisimmistä häälauluista poikkeavaa rekisteriä. Läheisesti samankaltaisia muotorakenteeltaan kaksisäkeisiä sävelmiä ja säkeenkertauksen tapoja liittyy aineistossa muutamiin lyyris-eeppisiin, lähinnä perhesuhteita tai äidin huolenpitoa käsitteleviin lauluihin. Ryhmää tarkasteltaessa piirtyy esiin ero varsinaisten pulmavirsien (yksisäkeiset sävelmät), luonteeltaan liikkuvampien hääteemojen (muotorakenteeltaan kaksisäkeinen sävelmä yhtä runosäettä kerraten laulettuna) ja häissäkin välillä laulettujen, mutta ei varsinaisiksi pulmavirsiksi laskettavien lyyristen ja lyyris-eeppisten runojen välillä (muotorakenteeltaan kaksisäkeiset sävelmät). Muotorakenteeltaan yksisäkeisiä sävelmiä oli mahdollista käyttää näiden kaikkien laulamiseen, kaksisäkeiset eivät sen sijaan varsinaisten pulmavirsien esittämiseen käyneet.

Erityissävelmistä laajimman ryhmän muodostavat erilaisiin kylän tyttöjen morsiamelle esittämiin lauluihin liittyvät sävelmät. Sävelmiin liittyy etenkin kosimistilanteessa ja häiden aattoiltana morsiamelle laulettuja runoja, mutta näiden lisäksi myös 
tyttöydestä, laulusta, surusta ja erosta kertovaa lyriikkaa ja lyyristä epiikkaa sekä muutama Puhemiehen moittiminen. Runotoisintoja yhdistävät, Soikkolan alueelle painottuvat oi dai ja oi Jokoi -sävelmiksi kutsumani sävelmätyypit ovat rytmiltään hitaita, sisältävät osakertauksia ja refrenki- tai lisätavuja, muodostavat yhtenäiset ryhmät myös melodiakulkujensa osalta ja ovat tulleet joidenkin piirteidensä osalta yhdistetyiksi sekä itkusävelmiin että venäläisiin lyyrisiin lauluihin. Lisäksi samoihin runoihin liittyy myös muita hääsävelmiksi epätyypillisiä tallenteita. Tyttöjen morsiamelle suuntautunut laulu piti sisällään aivan omanlaisiaan lyyrisiä, sekä sisällöllisiä, tekstuaalisia että musiikillisia piirteitä. Tyypillisyyksineen ja kiinteine hääteemoineenkin se rakentui paljon vapaammin kuin sukujen välillä käyty rituaalinen dialogi. Hitaat osakertausrakenteet, venytetyt säkeen loput ja melismaattiset pitkät sävelkulut tai lisätavurakenteet muodostivat omankuuloisensa, muodoiltaan varioivan rekisterin, joka asettui vuoropuheluun etenkin hääitkujen kanssa.

Koko hääsävelmäaineiston tarkastelun jälkeen Launiksen vuoden 1906 fonogrammikokoelma Soikkolasta näyttäytyy huomattavan edustavana. Kymmenen häärunoihin suoraan liittyvää sävelmää pitävät sisällään neljä toisintoa neli-iskuisesta pulmanuotista, kaksi kuusi-iskuisesta, kaksi oi dai -sävelmästä, yhden oi Jokoi -sävelmästä sekä yhden kaksisäkeisestä ounapuu-sävelmästä. Keskeisistä, tyypillisistä hääsävelmistä Launis ilmeisesti halusi tallentaa eri esilaulajien versioita sävelmien samankaltaisuudesta huolimatta - voi myös olla, että juuri niitä hänelle ahkerimmin tarjottiin äänitettäviksi. Muutkin laulajat esittivät tallentajille yleensä ensin kaksi tavallista pulmanuottia ja sitten yhden tai useampia häiden erityissävelmistä.

Karksista tallennetusta virolaisesta aineistosta löytyy tapauksia, joissa laulaja on esittänyt joukon häälauluja joskus yhdellä sävelmällä, joskus taas sävelmiä vaihdellen (Särg 2008, 48). Tämä on linjassa inkeriläisaineistosta tehtävissä olevan havainnon kanssa: tyypillisimmät hääsävelmät näyttävän käyneen runon kuin runon esittämiseen, mutta ne ovat voineet korvautua myös erityisemmillä, tiettyyn tilanteeseen ja laulajaryhmään assosioituvilla sävelmillä, jotka puolestaan eivät liity mihin häärunoon hyvänsä. Voi olla, että äänitystilanteen kontekstissa, yhden laulajan tai laulajaryhmän esittäessä paljon erilaisia häärituaaliin liittyneitä runoja, sävelmä on voinut jäädä vaihtumatta helpommin kuin häätilanteessa paikkojen, laulajaryhmien ja tilanteiden vaihdellessa laulun myötä. Myös tallentajien mielenkiinnon kohteet ovat painottaneet aineistoja. Launiksen kannalta runojen sanoilla ja sisällöillä ei näytä olleen niin merkitystä, mutta mahdollisimman erilaisten sävelmätyyppien tallennuksesta hän oli tarkka; vuoden 1937 äänityksissä taas juuri runot olivat tallentajien ominta alaa ja laulajat esittivätkin Kokin kiitosvirttä lukuun ottamatta koko edustavan häärunosikermänsä vain kahdella tyypillisimmällä hääsävelmätyypillä. Omalta osaltaan tähän saattoi myös vaikuttaa joukon monietninen tausta: esiintyjien täytyi käyttää niitä laulun rakenteita, jotka kaikki taisivat. Lisäksi voi olla, että laulajien kotiseudulla Narvusin alueella ei yksinkertaisesti ollut käytössä yhtä monia häiden erityissävelmiä kuin Soikkolassa, jonka alueelta on tallennettu erityisesti suurin osa tyttöjen morsiamelle suunnattuun lauluun liittyvistä sävelmätoisinnoista. 
Erilaisissa tilanteissa lauletut runot jaottuivat musiikillisten ja esityksellisten piirteiden kautta hyvinkin erilaisilta kuulostaviksi rekistereiksi. Kolmen edeltävän luvun pohjalta onkin mahdollista kuvitella praasnikoiden ja usein niiden aikana pidettyjen häiden monisyisiä äänimaisemia, joissa erilaiset äänet muodostivat juhlan akustisen kokonaisuuden ja kertoivat kauemmaskin, mitä missäkin oli tapahtumassa. Esimerkiksi saadulmoi-sävelmä kuuluvine kuoro-osan refrenkeineen kertoi kylän läpi joko praasnikoiden tai häiden kunniaksi kulkevasta tyttötai naisryhmästä, vaihtelevat lauluun sovitetut tanssisävelmät erityisesti nuorison tanssista kylän aukeammilla paikoilla. Tietyt laulamisen rekisterit liittyivät juhlien rituaalisiin kohokohtiin, kuten kokon sytyttämiseen tai rituaaliseen oluenjuontiin. Kyläkeinulta, joka sijaitsi usein myös kylän parhaalla tanssipaikalla, saattoi kantautua nuorison liekkuvirsi. Tuvissa voitiin laulaa tai soittaa kaikenlaista, mutta pihapiiristä kuuluvat häälaulujen rekisterit kertoivat satunnaisemmillekin kuulijoille häiden eri vaiheista.

Erilaisten rekisterien vaihtelu rytmitti juhlia ja rituaaleja. Morsiustalossa aattoiltana vaihtelivat sooloina esitetyt itkuvirret, joukolla lauletut rituaalisen selkeät tavalliset pulmanuotit sekä itkusävelmän sävelkulkuja ja venäläisten lyyristen "venytettyjen" laulujen kaltaisia pitkiä melismaattisia venytyksiä käyttävät tyttöjen runosävelmät. Sulhasjoukon saapumien kellojen ja kulkusten kilinöineen ja ajamiseen liittyvine erityisine sävelmineen kuului kauas. Keskeinen sukujen välinen dialogi käytiin tavallisilla pulmanuoteilla, etenkin neli-iskuisella, mutta väliin punoutui itkuja sekä tyttöjen vapaampia rekistereitä käyttäviä lauluja. Puhemiehen ja häiden muiden roolinhaltijoiden puheesta ei valitettavasti ole aineistossa kuvauksia, mutta muiden alueiden pohjalta on oletettavaa, että siinäkin käytettiin omaa, rituaalisesti sävyttynyttä rekisteriään (Tarkka 2005, 49, 227). Morsiamen osoitettua suostumuksensa tuli lauluun mukaan ensimmäisiä tanssin sävyjä, liikettä, kenkien kopinaa tuvan lattiaan. Riehakkaimmat kohdat näyttävät olleen kokin kiittäminen kestityksen päätyttyä sekä morsiamen että sulhasen kotitalossa. Sulhastaloon siirtymiseen liittyi taas omia ajamiseen tai kylien läpi tanssimiseen liittyviä sävelmiään. Perillä, morsiamen suvun saavuttua, alkoi paikoillaan tai hitaasti piirissä kulkien esitetyn laulun väleihin sekoittua entistä enemmän nopeampaa, riehakasta tanssia, ja pitojen edetessä alettiin laulaa yhä enemmän kaikenlasta muutakin, erilaisilla sävelmillä. Pitkin häiden kulkua saattoi ulkoa myös kantautua sisään praasnikkaväen hälinää tai nuorison tanssiin liittyvää laulua ja soittoa. 


\section{LAULAMISEN TAPA JA TILANNE}




\section{LAULAMISEN TAPA JA TILANNE}

Keskeisimmät länsi-inkeriläiset praasnikka- ja häälaulut olivat naisten tai tyttöjen julkista joukkolaulua. Laulamisen tavat - sävelmät, runot, äänensävyt, liike - riippuivat laulamisen tilanteesta. Esitysareenat ja rekisterit olivat toisiinsa kytköksissä vaihtelevin tavoin. Yleensä kaikkein keskeisimpien esitysareenoiden rekisterit - jotka usein olivat myös laulajien nimeämiä paikallisia lajeja - olivat selkeästi tunnistettavia, oman kuuloisiaan. Usein juhlatilanteissa laulettiin lisäksi suhteellisen kiteytyneen alun jälkeen tai kiteytyneiden runokokonaisuuksien ohella paljon kaikenlaista muutakin, joko laulun aloittaneeseen rekisteriin punoen tai esitystapaa vaihtaen. Moninaiset lyyriset, eeppiset ja lyyris-eeppiset teemat olivat tilannesidonnaisesta lajista toiseen helposti siirtyviä elementtejä. Niihin ei aineistossa liity samanlaisia selkeärajaisia kuvaustihentymiä kuin keskeisiin hää- ja praasnikkalauluihin. Kuten Senni Timonen (2004, 155-157) on todennut, monikäyttöistenkään teemojen yhdisteleminen ei silti ollut mielivaltaista, vaan sidoksissa paikallisiin käsityksiin tilannesidonnaisista lajeista, laulamisen käytännöistä ja toisiinsa liittyvistä teemoista.

Edellisissä luvuissa olen hahmotellut länsi-inkeriläisen laulun tulkinnallisia kehyksiä. Tämän olen tehnyt toisaalta rekisteriin liittyvien piirteiden kuten laulun erilaisten rakenteiden, lauluun liittyvien liikkumisen tapojen ja runojen sisältöjen että keskeisimpien ja useimmin mainittujen inkeriläisten esitysareenoiden eli praasnikoiden ja häiden kautta. Luvut luovat kuvaa siitä, miten ihmiset kertoivat juhlatilanteissa lauletun ja minkälaisia säännönmukaisuuksia liittyy heidän näihin tilanteisiin liittämiinsä runoihin ja sävelmiin. Aineiston laajuuden ja yksittäisten tallenteiden toisistaan riippumattomuuden ansiosta voi olettaa näin muodostuvan kuvan kertovan Länsi-Inkerissä keskeisimpinä pidetyistä laulamiseen liittyvistä käsityksistä suhteellisen kattavasti. Vaikka monet kuvauksissa esiintyvät piirteet eivät tallennusajankohtina välttämättä olleet enää käytössä, arvioin niiden silti edelleen ihmisten mielissä jäsentäneen kalevalamittaisten runojen laulamista. Olennaista on kuitenkin vielä kysyä, mitkä tekijät ja kehykset missäkin yksittäisessä laulutilanteessa painottuivat ja miten laulu näiden avulla tehtiin tietynlaiseksi esitykseksi. 


\section{JUHLASSA JA ARJESSA}

Inkeriläisen julkisen juhlalaulun kovaäänisyys toistuu usein kerääjien kuvauksissa. Kuten Leea Virtanen (1994a, 332-333) on todennut, se näyttää olleen juhlien olennainen piirre. ${ }^{849}$ Epämuodollisesta arjen laulusta on vähemmän kuvauksia, vaikka, Anna-Leena Siikalan (2000a, 275) sanoin, "yksityinen tai spontaani areena oli varmasti yleisempi" kuin julkinen. Vaikka aineisto ei anna paljoakaan aineksia yksityisen laulamisen tai soololaulun tarkasteluun ja vaikka juuri julkinen juhlalaulu asettuu tämän työn keskiöön, on silti syytä paneutua hetkeksi laajemmin inkeriläisen laulun kirjoon. Laulujen tallennustilanteet näyttävät nimittäin asettuvan moniselitteisin tavoin julkisen ja yksityisen laulamisen rajapinnoille ja juuri tallennustilanteet puolestaan ovat ainoa väylä myös edellisissä luvuissa käsiteltyihin julkisen juhlalaulun piirteisiin. Varsinaisista juhlatilanteista ei paljoakaan tallenteita ole.

\section{JULKISESTA YKSITYISEEN}

Julkisenkin laulun piirissäkin oli arkistoaineiston puitteissa vaikeasti tavoitettavia aste-eroja. Väinö Salminen (1931a, 530; ks. myös 1931b, 38) asettaa vastakkain tyttöjen laulamisen pyhä- ja arki-iltoina ja antaa samalla keskeisen avaimen monien epämääräisempien laulukuvausten tulkintaan. Lauantai- ja pyhäiltoina lauloivat tytöt liekulla keinuen "täyttä kurkkua," mutta arkena "keinu sai seistä paikallaan tahi liekutettiin sitä vain hyvin hiljaa ja niin hyräili 'iessälaulaja' säkeen muiden hiljaa 'jälestä järistäessä, niin ettei laulu edes kylälle kuulunut." Laulun liekkupaikalla ja ryhmässä voi tavallaan aina hahmottaa julkisena, mutta arkena se ei ollut sitä samalla tavoin kuin pyhänä. Muita ihmisiä ei arkena kokoontunut laulamista katsomaan eikä ollut sopivaa laulaa niin kovaa, että ääni olisi kuulunut kauemmas. Paikka oli yhä julkinen, tilanne ja aika ei. Samoja sävyjä voi aavistella muutamissa kontekstikuvauksissa. Arkena istuttiin nuorten kesken, laulettiin ja kiusoiteltiin, kun oli päästy päivän töistä: "Iltahämärissä tytöt saattoivat istua joen rannalla ja laulella. Pojatkin kokoontuivat siihen ja tehtiin naljaa." ${ }^{850}$ Sunnuntaina pojilla oli kovaääniset soittimensa mukana ja joen kallaalla laulamisen lisäksi voitiin myös kulkea laulaen läpi kylän. ${ }^{851}$ Juhlapäivinä nuorison oli mahdollista ottaa kylän julkinen tila laulullaan, soitollaan ja liikkeellään kovaäänisesti ja näkyvästi haltuun, arkena vain "lauleltiin".

Pyhäiltojen ja praasnikkojen lisäksi kovaääninen laulu kuului erityisesti häihin. Anni Joutsi Soikkolasta kertoi, että kosimistilanteen laulua, laulun sanojakin, kuunneltiin naapurikylissä asti:

\footnotetext{
${ }^{849}$ Ks. myös SKS KRA Enäjärvi-Haavio 497.

${ }^{850}$ SKS KRA Enäjärvi-Haavio 550.

${ }^{851}$ SKS KRA Laiho A. 2615. Talviaikaan vastaava ilmiö oli illanistujaisten jaottuminen varsinaiseen arkiseen (tyttöjen) töidentekoon ja toisaalta juhlakauden tanssi- ja huvittelutilaisuuksiin, bessedoihin.
} 
"Kosjalaiset käivät keyväillä, ennen heinäaikaa, siit kun lauloit oikein kaunihisti, niin ulkona kun lauloit sukulaiset kosjalaisellen, nii se kuului naapuri kyllää asti. Mie muistan kerrankii kun emmoin tuli ja herätti. Nous lapsein yllää ketä hää taas laulettane, niin kauniisti kuuluu. Mäntiin kuuntelemmaa niin kaikki kuului kun lauloivat, ja nimikii kuului."

Kosimistilanteen kovaääninen laulu oli Joutsin kuvauksessa niin merkittävää ja kaunista, että sitä kannatti herättää nukkuva lapsikin kuuntelemaan. Kuvauksessa painottuu paitsi kuuluvuus, myös sanoista selvän saamisen merkittävyys. Häälauluissa, joissa ei säkeen korvaavia refrenkejä käytetty ja joita laulettaessa kuoro siis kovaäänisesti kertasi varsinaiset runosäkeet, sanojen kuuluvuus olikin paras mahdollinen. Sekä sävelmä, joukkolaulu, laulamisen ajankohta että laulun sanat kertoivat omalta osaltaan, mitä yhteisön sosiaalisessa rakenteessa oli tapahtumassa.

Häissä laulamisesta ja toisaalta arjen ja juhlan eroista kertoo osaltaan myös Launiksen kokemus Soikkolasta, Mättähän kylästä. Keruuretken loppuvaiheessa ilmeisen hyvä maine kiiri jo kerääjän edellä, ja laulunhaluisia naisia kokoontui majapaikan edustalle heti, kun kuultiin Launiksen saapuneen kylään. Päiväkirjassaan Launis ei vaikuta kovin innostuneelta: naiset eivät "paljonkaan tainneet 'äänilöitä" eli sävelmiä. Tässä vaiheessa alueella käytetyt sävelmätyypit oli jo melko kattavasti tallennettu Launiksen muistikirjaan, joten uutta tulosta ei syntynyt: "Sinä iltana en sitte saanutkaan paljo toimitetuksi." Tuona aivan tavallisena arki-iltana kylän naiset innostuivat kuitenkin laulamaan kerääjälle tosissaan. Naiset lauloivat kovaa: "Rupesivat laulamaan joukolla eessälaulajan jälessä ja niin "romahuttivat " että

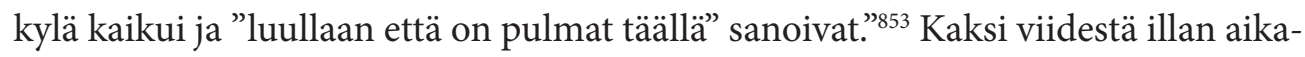
na muistikirjaan piirtyneestä sävelmästä onkin häälauluja, yksi laskiaisen liukuvirsi. ${ }^{854}$ Vaikka Launis kirjoitti ylös ainoastaan viisi muutaman rivin sävelmää, naiset ilmeisesti lauloivat koko illan. He käyttivät julkiseen juhlalauluun liittyvää esityksellistä rekisteriä: kovaa ääntä ja yksinkertaisia, erityisesti rituaalisiin tilanteisiin liittyviä laulun rakenteita. Kommenttinsa perusteella he tiesivät, että pitkin kylää ja luultavasti naapurikyliinkin kaikuva laulu tulkittaisiin totunnaisen viitekehyksen mukaisesti. Aineiston perusteella keskeisin tulkinnallinen vaihtoehto aikuisten naisten kovaäänisen laulun esitysareenaksi tiettyjen suurimpien pyhäpäivien ulkopuolella oli hääkonteksti (ks. myös esim. Alava 1916; Launis 1910a, XI-XII). Naisten innostuminen ja heidän oma tulkintansa tilanteesta avaa yhden ikkunan myös keruutilanteiden sävyjen kirjoon: arkiympäristöön sijoittuva tilanne saattoi olla hyvin julkinen, juhlavakin, jos kerääjä oli vain onnistunut voittamaan paikallisyhteisön luottamuksen.

\footnotetext{
${ }^{852}$ SKS KRA Mannonen 5703. Tässä on syytä jälleen muistaa, että Soikkolan monet kylät olivat tiheitä ja toisiaan lähellä. Nimen kuuluminen viittaa häälauluissa keskeisiin morsianta puhutteleviin laulunaloitusformuloihin (Oi Mari sisarueni), jotka edellisessä luvussa näyttäytyivät sekä häälauluille keskeisinä että häälauluja tallennustilanteessa esitettäessä ongelmallisina: laulu näyttää olleen olennaista tällöinkin kohdistaa läsnä olevaan henkilöön, joka oli sekä halukas että sovelias menemään naimisiin.

${ }^{853}$ KK Coll. 123.22 Launis 1903, 45.

${ }^{854}$ Ks. SibA Launis 392-394b.
} 
Keruuhetken erottumiseen arjesta tai tavanomaisesta liittyy nähdäkseni myös toinen Launiksen kokemus juuri ennen Mättähälle saapumista. Venakontsan kylän naisia hän lähti laulattamaan työn ääreen, sillä nämä olivat metsässä taittelemassa kupoja eli kerppuja karjalle. Laulatettuaan naisia Launis yritti osallistua työhön, mutta naiset pyrkivätkin nostamaan hänet "käsivarsille ilmaan ja siitä vaatia runsaat juomarahat," eikä työhön osallistumisesta tullut mitään. ${ }^{85}$ Tämä ilmeisesti venäläisiltä omaksuttu tapa oli yleinen rituaali esimerkiksi Jyrinpäivän juhlissa, jolloin naisjoukon nostamaksi tuli ennen kaikkea kunniavieraana ollut paimen, mutta myös naiset itse, joskus syrjässä pysyttelevät kylän miehetkin (Timonen 2004, 128-129, 135). Launiskin kertoo noston olleen tavallinen vieraalle tehty "tepponen." Hahmottaisin nostamisen samaan aikaan sekä kunnianosoituksena että tilanteen haltuunottona. Naiset eivät päästäneet Launista rauhassa ja vaivihkaa osallistumaan työhönsä vaan sulkivat tämän kunnianosoituksella oman arkensa ulkopuolelle. Arkisessa työssä kerääjällä ei ollut roolia.

Kerääjän kannalta pysytteleminen arkipäivän viitekehyksessä juhlien lauluista ainoastaan raportoiden oli usein epäilemättä helpommin hallittava ja keruun kannalta otollisempi tilanne kuin vaihto juhliin liittyviin rekistereihin ja omaehtoinen laulamisesta innostuminen. Yleensä Launis näyttääkin ensimmäisellä matkallaan pyrkineen suhteellisen rauhallisiin tilanteisiin mielellään tuvan pöydän ääressä, jossa oli helppo kirjoittaa. ${ }^{856}$ Vihtori Alava viittasi juhlatilanteen hankaluuteen keruutilanteena kertoessaan päiväkirjassaan Soikkolan Iilian päivän praasnikoista: "Mäkkylässä meitä pyydettiin 'vakkoveelle': riihen luona oli koko kylän väki olutta juomassa ja siinä tytöt kohta laulelemaan että minä saisin kirjoittaa virsiä. Eihän siinä voinut mitään kirjoittaa vaikka oli iessälaulajakin." ${ }^{857}$ Ropsussa häihin osallistuessaan Alava kirjoitti jonkin verran kuulemiensa "virsien nuottia ja osaksi sanoja muistiin." Hyväksi havaitsemaltaan Elina-nimiseltä esilaulajalta hän kuitenkin keräsi sanat kunnolla vielä erikseen rauhallisemmassa tilanteessa, ja tallensi myöhemmin lukkarilassa tältä lisää virsiä sanelusta. ${ }^{858}$ Laajemmat yhdeltä laulajalta tallennetut keräelmät tuntuvatkin syntyneen yleensä rauhallisessa arkiympäristössä. Kerääjän näkökulmasta varsinaiset juhlatilanteet olivatkin kaksijakoisia: ihmiset olivat vapaalla ja lauloivat mielellään, mutta monet olivat myös humalassa ja jotkut riidanhaluisia. ${ }^{859}$ Riippui kerääjästä, kuinka hän kykeni tilaisuuksia käyttämään hyväkseen.

Vaikka Launiskin $(1904,50)$ paheksui praasnikka-ajan alkoholinkäyttöä, sai hän ensimmäisellä retkellään praasnikoilta kuitenkin parhaan "saaliinsa" ja lisäksi tiedot alueen parhaina pidetyistä esilaulajista ${ }^{860}$ Hän keräsi lauluja tytöiltä ja naisilta,

\footnotetext{
${ }^{855}$ KK Coll. 123.22 Launis 1903, 43-44.

${ }^{856}$ KK Coll. 123.22 Launis 1903, erit. 16, 18, 22-23, 33, 35-36.

${ }^{857}$ SKS KRA Alava VII B II: 39.

${ }^{858}$ SKS KRA Alava X, 119, 121.

${ }^{859}$ Kerääjistä ja juhlatilanteista ks. Forsberg 1893, 55; Ikonen \& Madetoja 1909, 79; Kärki 1909, 122 ; Saxbäck 1904, 347; Tallqvist \& Törneroos 1904, 375, 392; SKS KRA Alava VII B II, 56-59; ks. myös Groundstroem 1904, 415; Tallqvist \& Törneroos 1904, 375-377; kuitenkin Saxbäck 1904, 322-335.

${ }^{860}$ KK Coll. 123.22 Launis 1903, 28-29.
} 
jotka ilmeisesti eivät olleet miesten veroisessa humalassa. ${ }^{861}$ Yksi- tai kaksisäkeisten sävelmien perushahmojen tallentaminen on tietenkin melko erilainen tehtävä kuin mahdollisimman eheiden ja pitkien runotekstien etsiminen: se käy nopeammin eikä keskeytyksistä tai hälinästä ole samalla tavoin haittaa. Sitä vastoin Launiksen $(1907,104)$ toisella keruuretkellä praasnikoiden väentungos uteliaine ihmisineen osoittautui äänittämisen kannalta ongelmalliseksi. Paitsi kerääjän persoona ja suhteet paikallisiin, myös tallennuksen kohde (runoteksti, sävelmän perushahmo vai lauluesitys) ja tallennustekniikka vaikuttivat olennaisesti syntyviin aineistoihin ja toimivaan tallennusstrategiaan.

Praasnikkoihin viittaava tunnelma syntyi myös Aili ja Lauri Laihon kootessa narvusilaisnaisia harjoittelemaan Tallinnan matkaa varten. Tässä tilanteessa siirtymä juhlatilanteen rekisteriin näyttää erityisesti innostaneen ja ilahduttaneen myös kerääjiä. "Hilpeä seurustelu ja lauluinto valtasi jokaisen tuona kesäkuun keskiviikkona 1937 Ahosen vierastuvassa", kertoo Aili Laiho (Simonsuuri 1961, 24). Oli arkipäivä, mutta yhteen laulamaan ja seurustelemaan kokoontuminen siirsi tulkinnallisen kehyksen praasnikkoihin: "'Samavarasta' riitti tee, ja leikkisät sutkaukset sinkoilivat. 'Ollaa kui praasnikas ikkää,'' totesivat naiset (Simonsuuri 1961, 21). Laulajat innostuivat tanssimaankin, mikä teki Aili Laihon kirjoittamista elävistä tanssikuvauksista päätellen kerääjään suuren vaikutuksen (Simonsuuri 1961, 24; 1972, 44).

Praasnikoilla laulettiin kovaa ja paljon. Tallentajat tulkitsivat tällaisen laulun yleensä epävireiseksi ja monotoniseksi huutamiseksi. ${ }^{862}$ Esimerkiksi Launiksen korviin tyttöjen laulu Soikkolan helluntaipraasnikoilla kuulosti moniääniseltä kirkumiselta, joskin kauempaa, naapurikylistä kaikuessaan se kuulosti "sangen hauskalta." A. O. Väisänen $(1990,153)$ jättää hienovaraisesti liekkulaulun laadun kuvaamatta romanttisessa runo- ja paimensoittokylien maalailussaan. Neljä vuotta varhaisemmassa päiväkirjassa hänen kuulemansa liekkulaulu "oli alussa täynnä kakofoniaa" ja inkeriläinen laulu yleensä kuulosti moniäänisen setulaulun jälkeen "kuivalta."864 Kaduilla kulkevien ja tanssivien tyttöjen värikkäät kansanpuvut herättivät monessa kerääjässä ihastusta, mutta tilanteeseen liittyvä ääni jäi usein kuvaamatta: kenties se olisi särkenyt kauniin, usein kansallisromanttisesti sävyttyneen kuvan (esim. Haavio 1948, 308-309, 336-337; Länkelä 1904, 290; ks. myös Launis 1921, 167; Lukkarinen 1911, 44; vrt. kuitenkin Tallqvist \& Törneroos 1904, 374).

\footnotetext{
${ }^{861}$ KK Coll. 123.22 Launis 1903, 34.

${ }^{862}$ Esim. Ahlqvist 1904, 214 ("laulannot eli nuotit ovat hirmuisen rumia, niinkuin se näissä seuduin muuallakin pyytää olla laulantojen kanssa"); Tallqvist \& Törneroos 1904, 368 ("laulunuotti jokapaikassa on yhtä ikävää ja pitkä-piimäistä jonoa"); Ikonen \& Madetoja 1909, 78 ("Jo täällä - Kosemkinassa saimme muuten oppia tuntemaan muutamia inkeriläisten laulajien ominaisuuksia: m. m. epäpuhtaan ja rytmillisesti haparoivan esitystavan.").

${ }^{863}$ KK Coll. 123.22 Launis 1903, 35-36, vrt. 30-32.

${ }^{864}$ SKS KRA Väisänen, laatikko II: 3a, päiväkirja s. 5-7.
} 
Paikallisesta näkökulmasta taas pyhäpäivien näkymä ja äänimaisema näyttävät liittyneen erottamattomasti toisiinsa. Kovaääninen laulu liittyi olennaisella tavalla tanssiin ja pitkin katuja kulkeviin, juhlapukuisiin tyttöihin tai naisiin. ${ }^{865}$ Laulu oli kaunista, kertoi Pauliina Reponen, joka painotti praasnikkojen yhteydessä nimenomaan aikuisten naisten laulua:

"Ja niin paljon naiset praasniekka-aikana lauloivat että niillä oli perästä päin ääni kaatuneena monta päivää. Mie muistan, kun miunkii maamo oli praasnikoilla millon laulamassa, niin haastaa ei voinut moneen päivään, aina oli ääni maassa. Ja kuin se oli kaunista, kaikki naiset kulki kauniissa vaatteissa pitkin katuja ja tanssi ja lauloi, miehet käveli perässä tai tien reunoja myöten."\$66

Samaan kokonaisuuteen kuului olennaisena myös vieraiden paljous ja kestityksen ylenpalttisuus, ruoka, itse keitetty olut ja ostettu viina, kirkossa käynti ja nuorten puolison etsintä. Pyhäpäivien kuvauksissa lomittuvat juhla-asujen, ulko- ja sisätilojen, tarjoiluiden, liikkeen ja laulun tasot: kyseessä oli moniulotteinen ja monen aistin kautta koettava kokonaisuus. Pidemmät juhlakuvaukset kattavat usein tasavertaisesti sekä tuvat että kylän kadut, sisätilan ja ulkoilman:

\begin{abstract}
"Iljan päiväksi kaikki toiset kylät kokkoutuivat meijän kylän praasniekoille, lauvantaina tuli jokaiseen talloon praasniekkavieraita, niille laitettiin hyvät ruuat ja juomat, tehtiin hyvää olutta, ja ostettiin viinaa, ja leivottiin piirakkoi, käytiin ensin aamupäivällä kirkossa ja sitten koko pyhäpäivä kulettiin nuoret ja vanhat kylän kattuija [katuja], ja laulettiin, ja juotiin ja tanssittiin, ja jokaisessa talossa oli vierahia, pojat käivät katsomassa toisissa taloissa tyttöjä, mistä sais morsiamen ottaa; ja vanhatkin lauloivat, ja pitivät lystiä, pitihän jokkaisen iloita omana praasnikkana." ${ }^{\text {"67 }}$
\end{abstract}

Nimenomaan praasnikoilla vanhemmatkin naiset innostuivat laulamaan, vahvisti Reponen myös kertoessaan syyspraasnikoista: ”Ja sitten taas laulettiin ja juotiin ja tanssittiin. [...] meillä Inkerissä aina vanhat naiset praasnikoilla lauloivat, ne osasivat laulaa vanhoja lauluja, miehet ei niinkään osanneet." ${ }^{\text {668 }}$

\footnotetext{
${ }^{865}$ Pyhäpäivän kuvauksia laulajilta ks. esim. SKS KRA Enäjärvi-Haavio 549, 556, 559; Laiho A. 2614, 3171; Laiho L. 5987; ks. myös luku 5. Tyttöjen kuljeskelusta esim. SKVR III: 1580, 3535, IV: 4158; SKS KRA Enäjärvi-Haavio 482, 486, 491, 504, 549-553, 556-559; 770-798; 830-832; Haavio 2558, 2773; A. Laiho 2346; 2347; L. Laiho 4979, 5247, 5328, 5360. Parhaisiin pukautumisesta esim. SKS KRA EnäjärviHaavio 770, 771, 773; ks. myös A. Laiho 2581. Moniin runoihinkin sisältyy positiivisesti latautuneita kuvauksia hyvästä äidistä, joka pesi ja puki tyttärensä laulamaan kylän kujilla muiden ihasteltavana tai mainintoja tytön vaatettamisen vaatimasta työmäärästä (esim. SKVR III: 1053, 1580; SKS KRA Haavio 2527; ks. myös Timonen 2004, 124).

${ }^{866}$ SKS KRA Mannonen 11121.

${ }^{867}$ SKS KRA Mannonen 11148.

${ }^{868}$ SKS KRA Mannonen 11164. Samalla tavoin vanhempien naisten asemaa laulujen taitajina sekä häissä että praasnikoilla laulajina korostivat esimerkiksi Anni Joutsi ja Anni Moisef (SKS KRA Mannonen 5702, 5705). Vaikka nämä kaikki kolme Mannosen haastattelemaa inkeroisnaista olivat Soikkolasta Suomeen 1920-luvulla muuttaneita pakolaisia, joiden nuoruusvuosina 1900-luvun alussa nuoret yhä enemmän lauloivat venäjäksi, liittyvät kuvaukset muun aineiston ja edellisten lukujen perusteella vahvasti myös naisten joukkolaulun yleisempään luonteeseen.
} 
Naisten julkinen joukkolaulu oli erityistä ja juhlavaa. Se liittyi häihin ja tiettyihin praasnikkajuhliin. Aineiston sisältämistä laulamisen kuvauksista suuri osa painottuu kuitenkin tyttöjen julkiseen lauluun. Myös aikuiset naiset kertoivat tallentajille usein juuri omien tyttöaikojensa laulusta. ${ }^{869}$ Sekä kerääjien että paikallisten näkökulmasta tyttöjen yhtä lailla jokaviikkoisiin pyhäpäiviin kuin häihin ja praasnikkoihinkin liittyvä laulu oli epäilemättä näkyvämpää ja yleisempää kuin harvemmin esiin pulpahtava naisten julkinen, esityksellinen laulu. Tytöt olivat myös pyhäisin korostetusti esillä, kylän katseiden kohteena. Leea Virtasen (1987; 1994a) tulkinnan mukaan kovaääninen, arjesta erotettu laulu oli myös tyttöjen mahdollisuus saada oma äänensä kuuluviin.

\section{ESILAULAJA JA JÄLESTÄLAULAJAT}

Julkisessa joukkolaulussa esilaulajalla oli keskeinen rooli. ${ }^{870}$ Kuten Laulun rakenneluvussa kävi ilmi, aineistossa ei ole yhtäkään viitettä sellaisesta laulamisen rakenteesta, jossa kuoro laulaisi säkeen, jota esilaulaja ei olisi jo laulanut. Muutaman sävelmätyypin yhteydessä kuoron tosin täytyy kyetä tunnistamaan säe jo sen alkupuoliskosta. Viitteitä ei ole myöskään esimerkiksi Vienan Karjalassa tai Kihnun saarella yleisestä tavasta laulaa joukolla ilman esilaulajaa, kaikki yhteen ääneen (Heinonen 2009; Kõiva 1987). Inkerissä esilaulaja aloitti laulun eli tietyn runon tietyllä sävelmällä, ja määräsi runon suunnan.

Kuka tahansa ei ollut hyvä esilaulaja eli iess(ä)laulaja tai iestalkaja. ${ }^{871}$ Itsestään selvää on, että hyvän esilaulajan täytyi osata paljon runoja. ${ }^{872}$ Moni kuvaus viittaa kuitenkin sanojen taitamisen ohella yhtä hyvin hyvään lauluääneen tai laulun muiden tyylipiirteiden hallitsemiseen: "Ken osas paremmin laulaa, se ain niinku

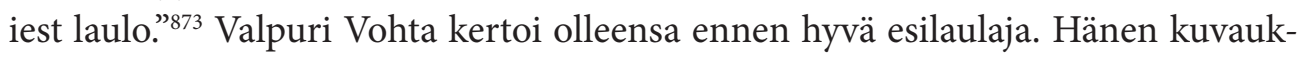
sessaan punoutuvat saumatta yhteen hyvä ääni ja runojen tai laulamisen tapojen muistaminen: "Miul oli nuorena kera ääni hyvä, a nyt olen jäänyt mokomaks, ku muistutellaa mielee siis saan otsast kii." Hänen äitinsä "tunsi paljon laului." ${ }^{874}$ Anna Kivisoon sisko Jelena "oli selvä laulamaa," joten häneltä toisetkin oppivat, Kivisookin. ${ }^{875}$ Adjektiivin selvä eli taitava ohella kuvattiin hyvää laulajaa ainakin sanoilla kankee eli väkevä ja udala eli vahva, rohkea tai huimapäinen sekä suuri laulaja. ${ }^{876}$

\footnotetext{
${ }^{869}$ Naisten kuvauksia omasta laulustaan ks. esim. Timonen 2004, 84-157; SKVR III 3336; SKS KRA esim. Enäjärvi-Haavio 467, 510, 748; 869; 895; A. Laiho 2576; L. Laiho 5247; Mannonen 11121. Naisten kuvauksia tyttöaikojensa laulusta ks. esim. SKS KRA Enäjärvi-Haavio 482, 486, 490, 549-558, 773; Haavio 2460, 2549, 2570, 2728; A. Laiho 2096, 2346, 2531, 2595, 2601, 2604, 2614, 2615, 2974, 3171; L. Laiho 4735.

${ }^{870}$ Ks. esim. SKS KRA Salminen K. 189.

${ }^{871}$ Termit toistuvat aineistossa usein, ks. esim. Enäjärvi-Haavio 548; Laiho L. 3590.

${ }^{872}$ Esim. SKVR III 2019; SKS KRA Haavio 2688; Mannonen 9833; ks. myös Salminen 1934, 138.

${ }^{873}$ SKS KRA Laiho A. 2615.

${ }^{874}$ SKS KRA Laiho L. 5409. (Minullakin oli nuorena hyvä ääni, mutta nyt olen jäänyt tällaiseksi, kun muistutellaan mieleen niin saan (laulun) alusta kiinni.)

${ }^{875}$ SKS KRA Laiho L. 5412; Salminen K. 249.

${ }^{876}$ SKVR III 2019, 2486; SKS KRA Haavio 2585; Laiho L. 5414. Udal' (ven.): huimapäisyys, rohkeus, urheus (VSSS).
} 
Selväksi kuvattiin hyviä laulajia myös sävelmiä etsineelle Launikselle, joten adjektiivi näyttää viitanneen runotekstin taitamista laajempaan kompetenssiin. Launiksen itsensä laulua paikalliset kutsuivat ihailevasti käpjäksi eli kauniiksi, kuten vaaleahiuksista nuorta miestä itseäänkin. ${ }^{877}$

Laulun kuluessa esilaulajat saattoivat vaihdella. Esimerkiksi tyttöjen mennessä kylän läpi laulettiin aloitusteeman jälkeen "kenen mieleen mitä tuli, tahto laulaa", ja se, joka "osasi, se oli eessälaulaja; yhen kerran yks - - "?78 Matroona Bässina korosti useille kerääjille omaa esilaulajuuttaan: "Jos joku osasi, se tunsi, se lauloi," hän selitti. ${ }^{879}$ Lauluvuoron vaihtamisen teema on esillä myös runoissa: Laulo suuri, laulo pieni, laulo kerta keskimäine, nyt tuli minuisen vuoro. ${ }^{880}$

Poikia ja miehiä ei aineistossa koskaan nimetä esilaulajiksi, vaikka miesten laulusta onkin jonkin verran käsikirjoitusmuistiinpanoja ja kuvauksia. Launiksenkin (1910a, XI-XII) mukaan Inkerissä esilaulajina toimivat ennen kaikkea nuoret tytöt, ja lisäksi tietyissä tilanteissa kuten häiden rituaalisesti keskeisimpien runojen yhteydessä aikuiset naiset. Fyysisesti esilaulaja saattoi sijoittua joko osaksi muuta laulajajoukkoa tai siitä hieman erilleen: piiriin keskelle, ketjun päätyyn, seisovan puolikaaren eteen tai sisällä uunin päälle, josta ääni kantoi paremmin tanssijoidenkin yli (Launis 1904, 52; Salminen 1934, 92). ${ }^{881}$

Laulajuus, samoin kuin osa runoista, kulki ilmeisesti ainakin osin suvuittain, etenkin naisille keskeisten häälaulujen kohdalla. Salmisen (1934, 137-138) Inkeriä koskevan yleistyksen mukaan äiti opetti tyttärelleen viimeistään häitä edeltävissä illanistujaisissa hälalaulut. Häissä suvun esilaulajana toimi kummi tai joku suvun naisista. Suvun ulkopuolinen esilaulaja pyydettiin Salmisen mukaan illanistujaisiin ja häihin vain siinä tapauksessa, että kukaan kaukaisemmistakaan sukulaisista ei kyennyt roolissa toimimaan. Toisaalta, kuten edellisessä luvussa huomattiin, yhtä lailla häissä keskeinen oli, oman rekisterinsä puitteissa, kylän tyttöjen laulava joukko. Sukujen, kylien ja ikäryhmien muodostamiin sosiaalisiin verkostoihin ei tämän työn puitteissa ole mahdollista päästä tarkemmin käsiksi, vaikka ne kaikki epäilemättä vaikuttivat siihen, minkälaisiksi keskenään laulavat ryhmät muodostuivat ja mitä ihmiset toisilleen lauloivat.

Häissä esilaulajana toimiminen näyttää kuvauksissa olevan laulajuuden korkein aste. Tällöin ei puhuta tytöistä vaan aikuisista, naimisissa olevista naisista. ${ }^{882}$ Esimerkiksi Maria Otsa kertoi äitinsä olleen "hyvä laulaja": "Vielä vanhana käytii kutsumassa pulmii laulamaa." Otsa korosti oppineensa kaikki laulut äidiltään ja

\footnotetext{
${ }^{877}$ KK Coll. 123.22 Launis 1903, 16, 42-43; ks. IMS: selvä, kankia, käppiä; VKKMS: udalō; vrt. ESS kange.

${ }^{878}$ SKS KRA Haavio 2688.

${ }^{879}$ SKS KRA Haavio 2439; ks. myös SKS KRA Haavio 2453; Laiho A. 2575.

${ }^{880}$ SKVR III 1043; ks. myös esim. SKVR III 296, 805, 2611, 3620 sekä SKVR-hakemisto: Laulajan sanat.

${ }^{881}$ SKS KRA Laiho L. 5165, ks. luku 5.

${ }^{882}$ Ks. esim. SKVR III 2546 ja 2551; Porkka 1886, 156, 162, 164.
} 
käyttäneensä niitä sekä häissä että muutenkin surujen helpottajina: "Kävin pulmissa ja kuhu mänin, ain lauloin. Muistuttelin äitin laului. Ku tuli tuska ja ikävä, aina lauloin." Hänen laulujaan olivat sitten oppineet monet muutkin. ${ }^{883}$ Vaikka, kuten edellisissä luvuissa on käynyt ilmi, tyypillisin laulajajoukko näyttää aikuistenkin naisten kuvauksissa olevan kylän tyttöjoukko praasnikoilla, kohdistuvat tarkemmat maininnat esilaulajana toimimisesta kuitenkin lähinnä aikuisen naisen lauluun häissä. ${ }^{84}$ Varsinaisissa häälaulukuvauksissa puhutaan esilaulajan sijasta kuitenkin tyypillisesti suuremmasta laulajajoukosta, esilaulajan ja jälestlaulajien muodostamasta kokonaisuudesta: pulmaväki, sulhasen tai morsiamen suku, tytöt. ${ }^{855}$ Esilaulaja tavallaan sulautuu osaksi edustamaansa, runosäkeitä kertaavaa joukkoa.

Äidiltä ja suvulta oppiminen ei kuitenkaan ollut ainoa väylä lauluihin. Juljaana Pohjalainen kertoi 1930-luvun kerääjille, että hänen äitinsä "rakasti Jumalan sannaa, ei hän laulant." Niinpä Pohjalainen oli oppinut lauluja lapsena ja nuorena Pärspään ja Sutelan inkeroisvaltaisissa kylissä praasnikoilla käydessään. Hänen äitinsä oli syntyisin Pärspäästä, vaikkakin inkerinsuomalainen. Joitain "jumalattomii, häppeemättömii virsii” Pohjalainen oli oppinut paimenessa soikkolalaiselta pojalta. Aikuisena hän ei enää laulanut niin paljon häissäkään käydessään eikä oppinut enää uusia lauluja. Laulut oli opittu lapsena ja nuorena. Synnyinkylästään Kullalta tai miehensä kylästä Kalliviereltä, jotka kummatkin olivat inkerinsuomalaisvaltaisia kyliä, hän ei kerro 1930-luvun kerääjille lauluja oppineensa. ${ }^{886}$ Toisaalta nuorempana hän mainitsi Vihtori Alavalle oppineensa useamman lyyrisen tai lyyris-eeppisen runon nimenomaan synnyinkylässään Kullalla. ${ }^{887}$ Aili Laihon (1944) anekdootti valaisee osaltaan monikerroksista laulujen oppimista. Hän kertoi vanhan Pohjalaisen muistelleen nuorena Pärspään ja Sutelan praasnikoilla oppimiaan lauluja ja nuorten kulkemista läpi kylän Viron veräjät -runoa laulaen. Pohjalainen intoutui muistelemaan myös, miten hänen synnyinkylässään runoon "ain lisättii" Kylähäni linnahani -teema. Runo siis liittyi hänen muistoissaan sekä lähikylien että oman kylän lauluihin, vähän erilaisina versioina. Yhteys inkeroiskylien praasnikkoihin nousi Pohjalaisella 1930-luvulla keskeisempänä esiin, mutta se ei silti ollut ainoa konteksti, johon laulut hänen mielessään liittyivät. Pohjalaisen antamat tiedot sekä vahvistavat esimerkiksi Alavan ja Väinö Salmisen huomion häistä ja praasnikoista keskeisimpinä laulujen leviämisen konteksteina että laventavat sitä. Hän oli oppinut lauluja useassa tilanteessa, usealta taholta, ja eri kerääjille eri aikoina laulettaessa painottuivat erilaiset kontekstit. Jukka Saarinen $(1988,215)$ toteaakin vienalaisen runolaulun yhteydessä, että laulajan taitamalle yksittäisellekään "runolle on tuskin koskaan yhtä ainoaa lähdettä." Laulaja saattoi

\footnotetext{
${ }^{883}$ SKS KRA Laiho L. 5411; äidiltä oppimisesta ks. myös esim. SKVR III 2382-2386; Mannonen 5460. ${ }^{884}$ SKS KRA Laiho A. 2276; Laiho L. 5411, 5412; Mannonen 5505; 5593, 5702, 5732; Salminen V. 2949; ks. kuit. esim. SKS KRA Laiho L. 5414; Salminen K. 46.

${ }^{885}$ Monikossa esilaulajat esiintyvät ainoastaan muutamassa samaten häiden yhteyteen sijoittuvassa kuvauksessa. Häätaloon ajaessa jokaisessa ajoneuvossa - reessä tai rattaissa - oli oma esilaulajansa, kertoi Katri Vohta (SKS KRA Enäjärvi-Haavio 881-882). Samoin morsiustalon porteilla kertoo Sofia Kataks sulhaskansan seisoneen veräjän takana samalla, kun "lauloivat heidän esilaulajansa" Avatkaa Viron veräjät -runoa (SKS KRA Salminen V. 2986).

${ }^{886}$ SKS KRA Laiho L. 5407.

${ }^{887}$ Ks. SKVR III 1796, 1807, 1810-1819.
} 
myös olla tietoinen laulamisen tapojen paikallisista tai etnisistä eroista, kuten Pohjalainen Viron veräjät runon kohdalla tai Valpuri Vohta kuvatessaan inkeroisten kokkovirttä. ${ }^{88}$ Tämänkaltaisen kokemuksellisen moninaisuuden tallentaminen arkistoaineistoon on kuitenkin ollut harvinaista.

Huolimatta monista taitamistaan runoista Pohjalainen ei näytä yhteisössään määrittyneen esilaulajaksi. Kotitalossaan asuneelle Volmari Porkalle nuori Pohjalainen ei ollut kovin halukas laulamaan. ${ }^{889}$ Viitisenkymmentä vuotta myöhemmin Pohjalaisen miniä ohjasi Martti Haavion anoppinsa luo, ei kukaan perheen ulkopuolinen. Pohjalainen itse kertoi laulaneensa niukalti, "koska hänellä ei ole hyvää korvaa," vaikka runot olivatkin "tarttuneet päähän" tytöiltä kuullessa. Pohjalaisen olemus teki silti Haavioon $(1948,352)$ vaikutuksen, ja hän nosti Pohjalaisen yhdeksi teoksensa Viimeiset runonlaulajat päähahmoista: "Juuri hänenlaisekseen voi kuvitella parhaita menneen polven runolaulun edustajia: hillitty, rauhallinen, vakava; mieleltään syvästi uskonnollinen.” Toisaalta juuri tämä uskonnollinen suuntautuneisuus ja luonteen hillittyys luultavasti osaltaan vaikutti Pohjalaisen haluttomuuteen esiintyä laulajana. ${ }^{890}$ Esimerkiksi saman ajan aineistoissa kuvatuista Anna Kivisoosta ja Valpuri Vohdasta kerääjät luovat selvästi maallisempia, riehakkaampia ja ulospäin suuntautuneempia kuvia kuin Pohjalaisesta. ${ }^{891}$ Hyvään laulajuuteen liittyvät maininnat kankee ja udala, vahva ja huimapäinen, eivät nekään käy yhteen Pohjalaisesta syntyvän mielikuvan kanssa. Haavio ei selvästi piirtänytkään kuvaansa inkeriläisestä ihannerunonlaulajasta paikallisten kriteerien mukaan.

Vuoden 1937 äänitysten kuudesta laulajasta kolme, Anna Kivisoo, Valpuri Vohta ja Darja Lehti mainitaan esilaulajiksi, ja heistä Kivisoo ja Vohta kertoivat toimineensa tässä roolissa paljon nimenomaan häissä. Kaikki kolme nimesivät myös läheisen naissukulaisensa laulajaksi tai esilaulajaksi. Laulajuus ja etenkin esilaulajuus näyttää näiden naisten kohdalla kulkeneen suvussa. ${ }^{892}$ Mari Vahter puolestaan ei Lauri Laihon mukaan osannut "laulaa sanoja, mutta omaa hyvän heleän äänen, joten pystyy laulamaan jälestä." Hänen äitinsäkään "ei ollut laulaja." Vahter nimeääkin itselleen merkittäväksi esilaulajaksi poikkeuksellisesti omaan ikäryhmäänsä ilmeisesti kuuluneen tytön Tatjana Nikolajevan synnyinkylästään Ropsusta, ei muiden tavoin ketään sukunsa tai kotikylänsä vanhempaa naista. ${ }^{893}$

Vaikka ei mieltänyt itseään esilaulajaksi, Vahter esitti silti esilaulun kahteen äänitettyyn lauluun. Nekin, joita ei yhteisössä varsinaisesti nimetty esilaulajiksi saattoivat hyvinkin sellaisena joskus toimia. Sitä vastoin äitinsä laulajaksi nimennyt Paro Mägi ei esilaulanut yhtäkään laulua. Tässä saattaa näkyä esilaulajuuden konteksti-

\footnotetext{
${ }^{888}$ SKS KRA Salminen V. 3016.

${ }^{889}$ SKS KRA Laiho L. 5407. Porkan julkaistujen runojen joukossa ei ole yhtäkään Juljaana-nimiseltä tytöltä Narvusissa tallennettua runoa.

${ }^{890}$ Ks. myös SKS KRA Haavio 2296.

${ }^{891}$ Esim. SKS KRA Enäjärvi-Haavio 404; Haavio 2289; Laiho L. 5412.

${ }^{892}$ Vrt. soittamaan oppimisesta Talvitie-Kella 2010, 115-126.

${ }^{893}$ SKS KRA Laiho L. 5415. Vahter kertoi laulun ja tanssin kuitenkin olleen merkityksellistä, vaikka hän ei esilaulaja ollutkaan: "Mie elin tyttöpolven nii ilosest, lasin lauluu ja tantsii."
} 
sidonnaisuus: esilaulajuus muodostui suhteessa jälestälaulajien joukkoon. Kuten luvussa 3 todettiin, erilaiset synnyin- ja asuinkyliin liittyvät tekijät sitoivat yhteen muita viittä laulajaa näiden erilaisista etnisistä taustoista huolimatta: Mägi jäi ainoana tämän verkoston ulkopuolelle. Vuoden 1937 äänityksiin osallistuneet eri etnisiä ryhmiä ja kyliä edustavat naiset olivat Aili Laihon $(1972,44)$ mukaan myös "taitavia havaitsemaan, kuka kulloinkin sopi esilaulajaksi" niin, että joukko kykeni laulamaan yhdessä. Esilaulaja määritti laulamisen tavan eli "laulutavan," jota Laiho ei kuitenkaan tarkemmin määritä. Äänitysten tarkastelun pohjalta olettaisin, että tämä piti sisällään oikeastaan laulamisen kokonaistyylin: paitsi runon rakenteen, murteen ja säemuodot, myös melodian tyypin ja laulamisen hienovaraisemmat piirteet, erilaisten esityksellisten tyylikeinojen käytön. Nämä vaihtelivat jonkin verran ryhmittäin, alueittain ja lajeittain, joten naiset eivät esittäneet äänityksissä kaikkea taitamaansa, vaan valitsivat niitä runoja ja laulun muotoja, jotka kaikki riittävässä määrin hallitsivat. Esilaulaminen vaati siis paitsi laulun tekstuaalisten, musiikillisten ja esityksellisten tasojen hallintaa, myös esilaulajan paikallisen tai etnisen tyylin hallitsevan jälestälaulajien joukon. (Ks. myös Frog 2010, 53-57.)

Esilaulajan ja kuoron vuorottelu näyttäytyy aineistossa normina. Esimerkiksi Anna Kivisoo kertoi yksinkertaisesti: "Laulettaessa oli ieltalkaja ja jälellaulajat.""94 Kuoroa nimitettiin jälest(ä)laulajiksi tai jälest(ä)järistäjiksi, Valpuri Vohdan mukaan myös toisel sanal laulajiksi eli toisella säkeellä laulajiksi, kertaajiksi. ${ }^{895} \mathrm{~A}$. A. Boreniuksen Soikkolasta ja Joenperältä tallentamista nuottikäsikirjoituksista löytyy jälellälaulajien lisäksi myös termit perästlaulaja ja auttaja: esimerkiksi häiden kylpemisvirressä säe kerrataan eli "kerrotaan, jos auttajia." ${ }^{896}$ Yksinäinen laulaja ei siis ilmeisesti Boreniuksen kokemuksen mukaan välttämättä keruutilanteessa säkeitään kerrannut.

Silloin, kun kuoro kertasi esilaulajan sanojen sijasta refrengin, oli ehkä mahdollista hahmottaa, että oikeastaan vain esilaulaja lauloi varsinaista runoa. Naisten kulkiessa praasnikoilla yksi heistä "lauloi erikoista laulua, ja toiset kulkivat perästä ja hyppivät ja lauloivat koko ajan" pitkää refrenkiä, kertoi Anni Moisef. ${ }^{897}$ Hänen kuvauksessaan vain esilaulaja laulaa "erikoista laulua." On tietenkin myös mahdollista, että muotoilu on vain kerääjälle selittämisen tulosta. Anni Joutsi kertoi refrengillisen laulun yhteydessä samankaltaisesti: "Edellälaulaja laulaa aina muita asioita, kuoro kertaa välillä saman kertosäkeen." ${ }^{898}$

Jälestälaulaminen edellytti jaettua tietoa, sillä laulajan oli tunnettava säkeiden perushahmot ja laulamisen tyylipiirteet. Vähemmän kohosteinen jälestälaulaminen arkisemmassa tilanteessa oli kuitenkin myös tapa oppia runoja. Häitä edeltävissä

\footnotetext{
${ }^{894}$ SKS KRA Laiho 3590.

${ }^{895}$ Esim. SKS KRA Enäjärvi-Haavio 548; Laiho L. 3590. Samantapaista, usein yksisäkeiseen laulurakenteeseen viittaava termiä kahella sanalla (eli säkellä ja sen kertauksella) saatettiin käyttää samaan tapaan: "Tyttö ain alko iest. Kahella sanalla alattii, alkaja alko sanat, siis temmataa toiseD mukkaa." (SKS KRA Laiho A. 2614; ks. myös Laiho 3590.)

${ }^{896}$ SKS KRA Borenius e 193, 197, 200.

${ }^{897}$ SKS KRA Mannonen 5553.

${ }^{898}$ SKS KRA Sääski 5970.
} 
illanistujaisissa, kertoo Väinö Salminen $(1934,137)$, lauluja opeteltiin niitä esilaulajan johdolla laulamalla. Darja Lehti puolestaan kertoi, kuinka hänen lapsena ollessaan äiti, maamo, "meit pani kaik permannol istumaa, hän kedräs ja laulo, meit pani kaik jälest laulamaa." ${ }^{899}$ Vanhempien ihmisten roolia korostaa myös Matrona Bässinä: "Vanaskyläs yks vanha suomalaine ihmine opetti meit laulaa. Vanhat eess lauloit, nuoret jäles oppiit." 900 Anna Kivisoota ja muita lapsia oli "naapurin akka" opettanut aikanaan laulamaan. ${ }^{901}$

Muutamat maininnat saavat pohtimaan tarkemmin iessä- ja jälestälaulajien suhteita. Aineistosta löytyy yhtä lailla kuvauksia, joissa runo tuntuu ikään kuin kuuluvan esilaulajalle kuin sellaisiakin, jossa laulajaksi määrittyy selkeästi kollektiivi. Muutamassa kuvauksessa nämä sävyt punoutuvat yhteen. Anna Kivisoo kertoo, että eräs vanha nainen "aina lauloi ja tantsi tihtii" Tuterina taterina -runoa naisten juhlissa Nastasjan päivänä. Runo henkilöityy tähän naiseen, ja kuvauksen alkuosa näyttää ensisilmäyksellä viittaavan sooloesitykseen. Laulun jälkeen seurannut jatko kuitenkin kytkee esityksen joukolla laulamisen kehykseen: Kivisoo kertoi passiivissa, jonka tässä yhteydessä tulkitsen siirtymäksi monikkoon, että "jokainen säe kerrattiin" säkeen alku refrengillä korvaten, kuten oli tyypillistä etenkin kuorolaululle. Hän myös avaa äkkiseltään ahtaaksi jäävää kontekstualisointia: ”Lauloi tätä laulua se akka muulloinkin kuin Nastasjan päivänä." Kuvaus siis laventuu yhden naisen tietyssä tilanteessa esittämästä laulusta kuoron kertaamaksi ja toisaalta naisen muissakin tilanteissa käyttämäksi. Kaarina Salmiselle Kivisoo oli muutamaa vuotta aikaisemmin sijoittanut saman runon itsensä lapsena laulamaksi. Runo ei siis laajemmassa kontekstissa määrity ainoastaan tämän vanhan naisen ainoastaan tässä tilanteessa laulamaksi, mutta tietyssä tallennushetkessä Kivisoo sijoitti sen ensisijaisesti hänen suuhunsa ja osaksi hänen nopeaa tanssiaan. ${ }^{902}$ Tämänkaltaiset esimerkit näyttävät, miten nopea, hetkellinen, osittainen väläys monesta runosta on tallennettu: kuvaukset kertovat usein yhden puolen tai yksityiskohdan laulun käytöstä, eivät koko käytön kirjoa. Vain harvoin moninaisuus murtautuu esiin yhden kuvauksen puitteissa. Matroona Bässina kehystää Tytärtenhukuttaja -runonsa sijoittamalla sen synnyinkyläänsä ja esilaulajan performanssiksi: "Vanhassakylässä, tekoaikana. Esilaulaja:". Runon jälkeen hän ottaa Kivisoon tavoin passiivilla puhuen mukaan laajemman laulajajoukon ja laventaa tilanteen. Runoa voidaan laulaa istuen tai läpi kylän kulkien: "Istutaan, ehk ymbäri kylä kuljetaan."903

Esilaulaja saattoi joskus osoittaa sanansa suoraan jälestälaulajille tai läsnä oleville toisille esilaulutaitoisille: erityisesti tämä näkyy erilaisten laulajan sanojen, pilkan ja kerskausten yhteydessä. ”Tässä laulussa ieslaulaja kyssyy anteeks," kertoi Valpuri Vohta lyhyen säkeillä Älkää pankaa työ pahaksi, et mie virren väärin laulon

\footnotetext{
${ }^{899}$ SKS KRA Laiho L. 5413.

${ }^{900}$ SKS KRA Koilo 212.

${ }^{901}$ SKS KRA Koilo 216.

${ }^{902}$ SKS KRA Enäjärvi-Haavio 510; Salminen K. 280.

${ }^{903}$ SKS KRA Haavio 2464. Samaten Valpuri Vohta kertoo ensin orvon Iro-tytön laulaneen Varhain heitti miun emoni -runoa heinämaalla ja muiden itkeneen, toisaalta itse laulaneensa runoa häissä joukolla tanssien (SKS KRA Enäjärvi-Haavio 500).
} 
alkavan teeman yhteydessä, jota tanssittiin ympärikossa, ilman poikia. ${ }^{904}$ Matrona Bässina kertoo aloittaneensa laulamisen tanssin yhteydessä oman laulutaitonsa kerskauksella: "tein itseni suuremmaks laulajaks ja toiset tein alle jalan. Tällä laululla aloin." ${ }^{\prime 95}$ Toisen laulajan pilkkaan tai kenties kerskaukseenkin saattoi vastata Mitäs huuvvat hullu kuusi -teemalla: "Kun katsotaa pahaks toisen laulu, siis lauletaa vastaan tämä," kertoi Juljaana Lulla. ${ }^{906}$ Usein pilkan ja kerskauksen teemoja liittyi juuri häiden rituaalisiin pilkkaamiskäytänteisiin (ks. Anttonen 1987), mutta näitä muutamia tarkemmin kontekstualisoimattomia mainintoja voi tarkastella myös yleisemmällä tasolla, monenlaisiin jännitteisiin tilanteisiin sopivina lauluina. Useimmiten laulukuvaksissa korostuu kuitenkin esilaulajan sijasta ainoastaan laulajajoukko, kuten on nähty edeltävissä luvuissa. Esimerkiksi pilkkalaulua Tunnen tunnen ken vaa tuloo, kertoi Vohta, oli laulettu kerran kesken häitä sammuneelle miehelle, mutta kuvauksessa Vohta ei mainitse esilaulajaa lainkaan: "Hypättii vastaa laulukaa hänelle, otettii häntä käest kii ja mäntii ympärikkoo."907

\section{Soololaulu}

Vaikka suuri osa runoja ja sävelmiä on kerätty arjen puitteissa yksittäisiltä laulajilta, painottuu laulamisen ja laulutilanteiden kuvauksissa julkinen joukolla laulaminen. Aineistoon kuuluvia työlauluja on sivuttu seisoen ja istuen laulamisen yhteydessä luvussa 3 - kehtolaulujen ohella nämä ovat ilmeisimpiä arkeen liittyviä kategorioita. Muistiinpanojen yhteydessä ei kuitenkaan mainita, miten työlauluja laulettiin: millä sävelmillä tai rakenteilla, yksin vai yhdessä. Mitä todennäköisimmin arkinen laulu on voinut olla huomattavan monimuotoista ja väljästi rakentuvaa.

Vihtori Alavan (1932) mielestä yksinäisyydessä laulaminen oli mahdollista, mutta ei keskeistä: ”Tunnetaan kuitenkin sitäkin, että runolaulaja toisinaan yksinään metsässä ollessaan tai tietä kulkiessaan on hyräillyt, jopa ääneenkin laulanut mieleistään runoa. Tämä ei ole runojen käytölle ominaista." Narvusilaisnaiset kuitenkin selittivät Väinö Salmiselle $(1934,178)$, tämän ihmetellessä pitkien ja lukuisien häärunojen muistamista, että "he usein yksin ollessaan niitä muistelevat," koska runot olivat merkittäviä myös henkilökohtaisesti. Salminen ei tosin kertonut, tapahtuiko tämä ääneen, puoliääneen vai hiljaa. Launis $(1907,108,110)$ mainitsee yksinlaulamisen tilanteista yksin metsässä kulkemisen ja lapsen liekuttamisen: "Lapsensäveltä, kehtolaulua ei liene vakinaista, mutta sen sijaan saa usein kuulla sangen somia improvisatsiooneja kehdon ääressä istuvan äidin suusta." ${ }^{\text {’08 }}$

\footnotetext{
${ }^{904}$ SKS KRA Laiho L. 5000 (Älkää pahaksi panko, kylä kirotko).

${ }^{905}$ SKS KRA Haavio 2439.

${ }^{906}$ SKS KRA Laiho A. 2260 (Mitä laulat lappahuuli); ks. myös esim. SKS KRA Laiho A. 2974; Länkelä 6:1792.

${ }^{907}$ SKS KRA Laiho L. 4993.

${ }^{908}$ Pohjois-inkeriläisellä Larin Paraskella oli Timosen $(2004,265)$ mukaan jopa oma termi usein yksin metsässä tai tiellä lauletulle runolle, "mojolaulu." Aihelmina oli usein omia tunteita käsittelevää lyriikkaa. Ks. myös Salminen 1934, 178; Simonsuuri 1972, 50; Timonen 2004, 93-107; SKS KRA Alava S VII B: 217.
} 
Soololaulusta kerrotaan aineistossa huomattavasti harvemmin ja vähemmän kuin joukolla laulamisesta. Vähäisinäkin maininnat silti avartavat kuvaa inkeriläisen laulun käytöstä. Vielä kotona asuvan tytön elämästä kertovaa Kui mie kaszvelin kanane -runoa kertoi Maria Siller erään tytön laulaneen yksin muiden kuunnellessa: "Yks tyttö vaa laulo. Tytöt ja naiset tulivat katsomaa." ${ }^{009}$ Laulusta kerrotaan tarinanomaisesti myös arkisen, hienovaraisen kommunikaation kehyksessä. Mari Otsalta tallennettiin kertomus miniästä, joka ei osannut naimisiin mennessään ommella paitaa. Hänen yrittäessään anoppi ei sanonut mitään, mutta lauloi muutamalla runosäkeellä ohjeen. ${ }^{910}$ Yksinlaululla kerrottiin myös sukulaisten kommunikoineen Venäjän ja Viron rajan yli (Järvinen 1990, 38). ${ }^{911}$

Soololauluun selkeästi viittaavien kuvaustenkaan kohdalla ei yleensä voi olla täysin varma siitä, lauloivatko muut läsnäolijat kuitenkin mukana kuoro-osia. Esimerkiksi Darja Lehti kertoi isoäitinsä laulaneen kehrätessään, lasten kuunnellessa ympärillä. ${ }^{912}$ Matrona Bässina kertoi kerran piikana ollessaan saaneensa niittoapua kylän nuorisosta, kun lauloi La mie vieretän vilulla -runoa. ${ }^{913}$ Valpuri Vohta oli oppinut orpoudesta ja huonosti kohtelevasta emännästä kertovan Piennä petti miun emoni -runon orvolta, vieraasta kylästä tulleelta Iro-nimiseltä tytöltä, joka oli laulanut sitä samoin heinämaalla joen yli. Laulaja sai kuulijansa itkemään. Runon jälkeen tallennettu lisä kertoo, että Vohta oli kuullut Iron laulavan laulua monta kertaa - mahdollisesti myös erilaisissa tilanteissa, eri tavoin. ${ }^{914}$ Mari Orava kertoi erään leskeksi jääneen miehen laulaneen tietynlaista versiota Piennä petti miun emoni -teemasta "aina pellavia kolkkiessaan." ${ }^{15}$ Darja Lehti käyttää kahdesti nauhallekin soolona laulamansa juomalaulun Juu kurkku kanna kagla käsikirjoitusmuistiinpanon yhteydessä mielenkiintoista sanamuotoa. Kun "kampas juuvvaa" eli juhlitaan ja juodaan joukolla, kertoi hän, "toin toisel lauletaan." 916 Lauloivatko lapset kehräävän isoäidin mukana, tuliko kylän nuoriso niittomaalle mukaan laulamaan vai ainoastaan lyömään heinää, yhtyivätkö niittäjät itkunsa lomassa orvon tytön lauluun, lauloiko mies yksin, tarkoittiko "toin toiselle laulaminen" toisen soolon kuuntelemista vai tämän lauluun liittymistä? Kukaan ei kerro, lauloivatko muut läsnäolijat kuoro-osia vai eivät, mutta tilanteet näyttävät kuvauksissa joka tapauksessa määrittyvän sooloesityksiksi. Kuten edellä kävi ilmi, soololaulun kaltaisesti saatettiin kuitenkin puhua myös esilaulajan osuuksista.

\footnotetext{
${ }^{909}$ SKS KRA Haavio 2586.

${ }^{910}$ SKS KRA Laiho A. 2971.

${ }^{911}$ SKS KRA Laiho L. 5415.

${ }^{912}$ SKS KRA Haavio 2500, ks. myös 2490.

${ }^{913}$ SKS KRA Laiho A. 2133. Yleisemmällä tasolla Bässina mainitsi runoa lauletun usein heinämaalta tultaessa.

${ }^{114}$ SKS KRA Enäjärvi-Haavio 500, 501; ks. myös Timonen 2004, 9-10. "Kaik itkettiin," kertoi Vohta, joka oli itse laulanut runoa häissä joukolla.

${ }^{915}$ SKS KRA Enäjärvi-Haavio 464. Samankaltaisia mahdollisesti soololaulusta kertovia kuvauksia ks. myös SKS KRA Enäjärvi-Haavio 500; Mannonen 5497, 7654; Salminen K. 101.

${ }^{16}$ SKS KRA Laiho A. 2218; äänitetyt toisinnot: ERA, Fon. 209b; SKSÄ L 101e. Ensimmäistä toisintoa äänitettäessä Lehti oli yksin tallennuksen kohteena. Toista äänitettäessä laulu oli hänen ainoa sooloesityksensä. On todennäköistä, että Lehti mielsi laulun soololauluna, mutta yhtä lailla on mahdollista, että muut laulajat eivät vain osanneet juuri tätä laulua - säkeitä, sävelmää tai laulamisen tyyliä yleisemmin. Selkeimmin soololauluiksi määrittyvät monet kehtolaulut, ks. esim. SKS KRA Laiho A. 2330; Salminen K. 54, 228.
} 
Suhteellisen harvinaisissa kuvauksissa miesten laulusta korostuu laulaminen juhlissa tai humalassa. Miestenkin laulutilanteista kertoivat huomattavan usein kerääjille naiset. ${ }^{917}$ Näistäkään kuvauksissa ei yleensä käy selkeästi ilmi, viittaako kuvaus soololauluun vai onko läsnäolijajoukko tyypillisesti toistanut esilaulajan säkeitä. Esimerkiksi Katri Vohta kertoi erään vanhan miehen aina juovuksissa laulaneen olut-aiheisia teemoja sivuavaa runoa. ${ }^{918}$ Vihtori Alavalle kerrottiin, että "Suomest' oli yks' ukko, täss' Kaipaalassa eli, Pärtty Lepikko, hänen ympärilleen lapset kokoontuivat aina; kons' sai viinaa päähä, siis lauleli ain’: Tuotii härkä Hämälästä..."919 Anni Moisef kuvaa häissä sosiaalisesti sopimattomaan pilkkaan yltynyttä sulhasen veljeä, jonka valituslauluun yleisö ei selvästikään osallistunut, vaan sulhasen suku talutti ilmeisesti humalaisen veljen aittaan nukkumaan. ${ }^{920}$

Selkeimmin miehen soololauluksi määrittyvät Anni Moisefin kuvaamat Mustan Okrun performanssit. Tämä oli tunnettu, lajinsa hallitseva pilkkalaulujen tekijä: "sille jos antoit ryypyn viinaa, niin se siit vast osais sulhaset haukkuu; se siit haukkui välil niin hävittömästi; että kaik saivat nauraa." Moisef lauloi tai saneli kaksi versiota Mustan Okrun lauluista ja kertoi, että mies "kun sai viinaa nii hää tantsi tätä, yksinnää ja lauloi, ja kaikki nauroit toiset.” Runot pohjaavat monin paikoin kalevalamittaisiin säkeisiin (täitä tappo turkistaan), mutta suurin osa säkeistä rikkoo mittaa tai liukuu kohti uusimittaisten laulujen tyylipiirteitä (Pien oot vätys ja väärä sääri). Toiseen lauluun sisältyy epäsäännöllisenä esiintyvä refrenki Ras kalina kaal malina, piivaa sekä viinuskii, jonka loppuosa korostaa laulukuvauksessakin esiintyvää alkoholin käyttöä, olutta (piiva) ja viinaa. Laulut vaikuttavat improvisatorisilta myös siinä, että ne poikkeavat vakiintuneista runoaiheista, säemuodoista ja kuorolaulun säännöllisistä rakenteista. ${ }^{921}$ Toisaalta pilkkalaulut eivät selvästikään olleet korkealla kerääjien arvoasteikolla, eikä niitä siten juuri tallennettu. Miesten humalaisia renkutuksia, sopimattomia, uudenaikaisia ja tekstuaalisesti hajanaisia runoja lähinnä valitettiin keruukertomusten sivuilla. (Groundstroem 1904, 400; Launis 1904, 52; Porkka 1886, 155; Salminen 1906, 68; Saxbäck 1904, 339, 358-359; Tallqvist \& Törneroos 1904, 367, 372; ks. tarkemmin Heinonen 2008.)

\footnotetext{
${ }^{917}$ Praasnikkakuvausten pohjalta katson näiden kahden määreen, juhlan ja humalan, liittyvän kiinteästi toisiinsa, vaikka toki aineistossa on myös kuvauksia ja runoja juopoista miehistä, jotka siis ilmeisesti joivat liikaa viinaa juhlien ulkopuolella. Juhlien ja humalan positiivista tai neutraalia kuvausta ks. esim. SKVR III 2077-2079, 2089; SKS KRA ERA Angeria 124; SKS KRA Enäjärvi-Haavio 730-733, 770-771; 790-798; 748. SKS KRA L. Laiho 5903; 5989. Tosin tappeluita tuli ja murhiakin kerrotaan humalapäissä tehdyn (SKS KRA A. Laiho 2600; L. Laiho 5528, 5987; Enäjärvi-Haavio 770, 771). Vienan Karjalassa humala värittyi juhliin ja lauluun liittyvissä paikallisten kuvauksissa usein positiivisesti ja yhteisöllisesti, mutta hyväksytyt rajat ylittävä juoppous näyttäytyi negatiivisena (Tarkka 2005, 42-43, 102-106, 147, 330). Humalaisten negatiivisista kuvauksista Länsi-Inkerissä ks. esim. SKS KRA Haavio 2457, Mannonen 5732. Naisista miesten laulun kuvaajina ks. tarkemmin Heinonen 2008b, 259-265.

${ }^{918}$ SKS KRA Enäjärvi-Haavio 520.

${ }^{919}$ SKVR III: 2249.

${ }^{920}$ SKS KRA Mannonen 7656. Valpuri Vohta kertoi enonsa laulaneen häissä äidiltään oppimaa Läksin raukka raatamaa -runoa (SKS KRA Laiho L. 5001). Ryhmässä laulamiseen tuntuu viittaavan suoraan Juljaana Pohjalaisen kuvaus Ison sian runosta: "Pojat lauloivat, ei tytöt. Kun pojat oli juomassa, he tätä lauloivat" (SKS KRA Haavio 2518). Samankaltaisesti kertoi Anni Moisef Soikkolasta poikien (joukolla?) häissä laulaneen tytöille "hävitöintä" laulua näitä haukkuakseen tai kiusatakseen (SKS KRA Mannonen 5447). P. Putkonen kirjoitti ilman sen tarkempia laulajatietoja Tyröstä keräämänsä sävelmän viereen: "Tähän tapaan laulawat vanhat ukot 'suomenvirsii', kun ovat vähän humalassa." (SKS KRA Putkonen 2: 168). Ks. myös SKS KRA Laiho L. 5222.

${ }^{921}$ SKS KRA Mannonen 5501, 5591. Häiden pilkkalauluista ks. enemmän Anttonen 1987.
} 
Erityisesti naisten kuvaaman miesten laulun kohdalla näyttäytyy hyvin selkeänä muunkin aineiston tulkinnan kannalta keskeinen kysymys laulun ja esityksen kerrostuneisuudesta. Kun naiset kuvasivat, lauloivat tai sanelivat miesten suuhun sijoittamiaan lauluja, mitä kaikkea he oikeastaan tekivät? Aineistoa ei ole riittävästi sen hahmottamiseen, minkälaisia rekistereitä ja laulamisen tyylejä yleisesti ottaen oli miesten käytössä ja paljonko heille tyypillisen laulun piirteet mahdollisesti erosivat naisten käyttämistä tyyleistä. Selvältä silti näyttää, että ainakin osa laulamisen tavoista oli sukupuolisidonnaisia. Ääriesimerkki tästä löytyy itkuvirsien puolelta: vaikka itkut selkeästi olivat naisten laji, saattoivat miehet kuitenkin esittää erilaisia instrumentaaliversioita itkuista. A. O. Väisänen (1985; 1990, 153-158; ks. myös Kallio 2011b) tallensi näitä joko suoraan itkuiksi nimettyjä luettelemisia tai surullisiksi lauluiksi ja soitoiksi nimettyjä haluvirsiä ja halioita soittoja lukuisilta miessoittajilta vuonna 1914. Muutamat näistä sävelmistä noudattelevat hyvinkin tarkkaan itkuvirsien tyypillistä melodiikkaa ja tyylipiirteitä, toiset vain kevyesti viittaavat niihin. Lauri Laiho kertoo tällaisen sävelmän äänityksestä Peeter Liivandilta vuonna 1937: "Soittaessaan äänilevyyn pienen karjalapsen itkun, valuivat hänen silmistään hereät kyyneleet ja ympärillä istuvat runonlaulajanaisetkin, jotka tuttu resitatiivinen sävel herkisti, itkivät."922 Soitettu sävel siis toimi samankaltaisesti tunteiden välittäjänä kuin laulettukin itkuvirsi. Se oli miesten käytössä oleva keino käyttää muuten selkeästi naisille kuuluvaa surun ja menetyksen rekisteriä.

Hevaalla Boreniukselle nimettiin miesten säveleksi yksi Hevaan nuotti ja yksi muotorakenteeltaan samoin kaksisäkeinen vot kalinata vot malina -refrengin sisältävä sävelmä. ${ }^{223}$ Nimeäminen osoittaa, että runosävelmiä määritettiin myös sukupuolen mukaan, vaikka ne saattoivatkin samalla edustaa hyvin yleisessä ja monipuolisessa käytössä olevia sävelmätyyppejä, kuten tässä on asian laita. Onkin mahdotonta sanoa, millä perusteilla nämä kaksi sävelmää määrittyivät juuri miesten sävelmiksi, mitkä tekijät (kuten sävelkulku, muotorakenne, refrenki, laulamisen hienovaraisemmat, nuottiin tallentumattomat piirteet) olivat tässä olennaisia tai kuinka paikallisesta, laulajakohtaisesta tai hetkellisestä määrittelystä on kyse.

Kun Valpuri Vohta lauloi enonsa kerran häissä Struuppovalla laulamaa, alueella ilmeisesti melko kiteytynyttä laulua, lauloiko hän sitä, kuten oli tottunut muutenkin laulamaan vai tavoitellen joitain enonsa esityksen tyylipiirteitä? Vohdalta laulu tallennettiin kolme kertaa: ilmeisesti sooloesityksiin pohjautuvina käsikirjoituksina ja yhtenä kuoron kanssa laulettuna äänitteenä. ${ }^{924}$ Oliko hänen enonsa käyttänyt samanlaista hoi goorja hoi pedaa -refrenkiä (hoi suru hoi onnettomuus), jota Vohta käytti jokaisessa tallennetussa versiossaan niin yksin kuin esilaulajanakin, tai samantyyppistä kaksisäkeistä sävelmää, jonka muotorakenne näkyy myös Vohdalta teksteinä tallennetuissa toisinnoissa? Kuuluiko harvinainen, aineistossa ainoastaan

\footnotetext{
${ }^{922}$ SKS KRA Laiho L. 5416.

${ }^{923}$ SKS KRA Borenius e) 184, 186; ks. myös Timonen 2004, 154 ja nootti 142. Refrengin kirjoitussu näyttää, miten tallentajat eivät eri syistä aina tunnistaneet venäläisiä laulun piirteitä. Oikea sanarakenne olisi "vot kalina ta vot malina" ("tuossa heisipuu ja tuossa vadelma").

${ }^{924}$ SKS KRA Enäjärvi-Haavio 546; Laiho L. 5001; SKSÄ L 96 b.
} 
tähän runoon liittyvä refrenki niin kiinteästi lauluun, että soololaulajakin esitti aina kuoron kertausosat?925 Asettuiko enon esitys kuorolaulun vai soololaulun piiriin, ja paljonko näillä kahdella lopulta oli länsi-inkeriläisissä laulukulttuureissa eroa? Emme tiedä. Tai kuinka tarkasti Anni Moisef kykeni tavoittamaan ilmeisen improvisatorisia Mustan Okrun pilkkalauluja, ja lauloiko vai saneliko hän ne kerääjälle? Missä määrin mitallisesti vaikeatulkintaiset säkeet ovat Mustan Okrun laulukieltä, missä määrin Moisefin muistelma niistä ja missä määrin sanelun tai kerääjän muokkauksen tulos? Kysymykset jäävät vastaamatta, tulkinnat tässä avoimiksi. Kun laululle ei löydy toisintoja eikä inkeriläisen laulun improvisatorisimpia puolia tallennettu samoissa määrin kuin kiteytyneempiä runoja (vrt. Kalkun 2011, 35-90), on tie tämänkaltaisten laulujen tulkitsemiseen mutkainen. Osittaista kuvaa soololaulun mahdollisuuksista luo kuitenkin varhaisten joukolla ja soolona tallennettujen ääniteaineistojen vertailu.

Länsi-inkeriläisen varhaisimman ääniteaineiston esilaulajalta ja kuorolta tallennetut laulut ovat kaikki rakenteeltaan säännönmukaisia ja vakaita. Melodia ja rytmikin voi muunnella jonkun verran, vaikka tyypillisesti variaatio on melko hienovaraista. Laulun muotorakenne ja sävelmän perusrakenne pysyvät kuitenkin samana läpi laulun, eikä esimerkiksi refrengin tai osakertauksien käyttö varioi yhden esityksen sisällä.

Äänityksiin kerääjät valikoivat hyviä laulajia ja on todennäköistä, että heidän kannaltaan hyvä kuoroesitys oli myös kiinteämuotoinen. Lisäksi on todettu äänitystilanteiden usein vähentävän laulun muuntelun määrää. Sooloesityksistä on puolestaan yleisesti ottaen vaikea sanoa, minkälaiseen rekisteriin laulaja on laulunsa sijoittanut: jos yksinlauluun ja ryhmälauluun liittyi hänen mielessään osin erilaisia esityksellisiä mahdollisuuksia ja sävyjä, kumpia hän halusi käyttää? Hän saattoi yksinkin laulaessaan haluta liittää laulunsa julkisen ryhmälaulun rekisteriin, laulaa kuin laulaisi kuoron kanssa. Sooloäänitykset eivät siis välttämättä kerro pelkästään yksinlaulun mahdollisuuksista.

Monet yhdeltä laulajalta äänitetyt sävelmät vastaavat rakenteeltaan täysin kuoron kanssa laulettuja, säkeenkertauksineen tai refrenkeineen. ${ }^{926}$ Toinen yleinen vaihtoehto oli laulaminen muutoin samalla tavoin, mutta ilman kuoron osuuksia: säkeitä ei yksinkertaisesti kerrata tai refrenkejä lauleta. Esimerkiksi häälaulujen yhteydessä käsitellystä oi dai -sävelmästä ei aineistoon sisälly yhtään kuoron kanssa laulettua versiota, joka ei sisältäisi tunnusomaista refrenkitavujen ja osakertauksen yhdistelmää. Sen sijaan yksin esiintyvä laulaja saattoi joko laulaa ainoastaan esilaulajan yksisäkeiset osuudet tai kerrata myös kuoro-osan. Ilmeisesti säännöllinen refrengin käyttö oli yleisempää kuoron kanssa laulettaessa kuin soololauluissa, joiden yhteydessä niitä esiintyy aineistossa harvemmin. ${ }^{927}$ Armas Launis tallensi esi-

\footnotetext{
${ }^{925}$ Sekä Alavan että Ruotsalaisen vyötermaalaismuistiinpanoissa refrenkisäe Hoi goorja, hoi bedaa toistuu kerran tai kaksi kuin osana runoa, Ruotsalaisella venäjäksi kirjoitettuna (SKVR III 2391, 2818).

${ }^{926}$ SKSÄ A 300/9c, 10a, 10b, 11a, 11b, 28c; ERA, Fon. 207a, 209a, 209c.

${ }^{927}$ Ks. luvut 4 ja 7.
} 
merkinomaiselta vaikuttavat kaksi peräkkäistä äänitettä: ensin soololaulun ilman refrenkiä ja sitten saman melodian kuoron ja refrengin kanssa. ${ }^{928}$

Muutamissa yhdeltä laulajalta tallennetuissa sävelmissä esiintyy kuitenkin täysin kuorolauluista poikkeavaa rakenteellista variaatiota. Laulaja voi kerrata runosäkeitä epäsäännöllisemmin, vaihtelevammin, tai laulaa säkeidensä väliin refrenkejä ainoastaan satunnaisesti. Refrenki voi myös hieman varioida. Joskus laulaja liittää mukaan satunnaisia osakertauksia, toisaalla sävelmärakenteen ja runotekstin suhde ei vain ole tavanomaisen kiinteä. ${ }^{929}$ Launiksen lyhyelti Vögle Timontyttäreltä tallentamasta huolirunonpätkästä (Huolihevonen) on jopa vaikea sanoa, mikä sävelmäsäkeen perusmuoto mahtaisi olla. Laulaja tuntuu punovan runosäkeitä ja niiden osia suhteellisen kiinteämuotoiseen sävelmäänsä vapaasti, improvisoiden:

Nuotti 33. Vögle Timontyttären huolilaulu. Vahalieriön kierrosnopeus vaihtelee ja paikoin äänenlaatu on hyvin heikko. (SKSÄ 301/7a, nuotinnos Heidi Haapoja.)

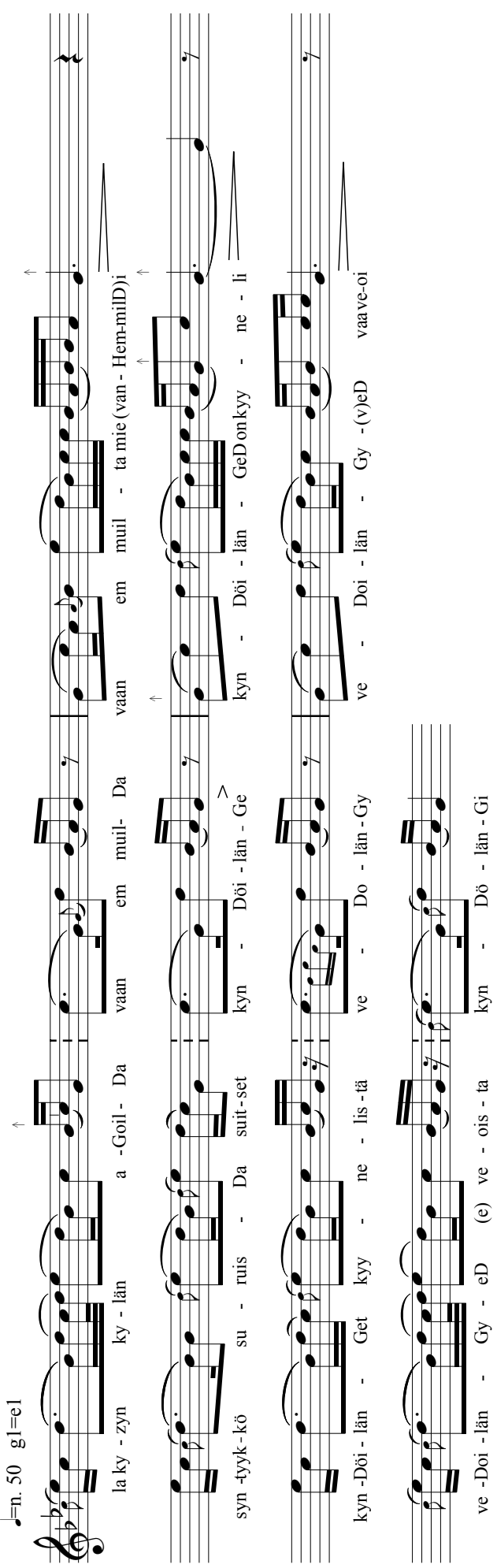

\footnotetext{
${ }^{928}$ SKSÄ A 300/29 a ja b; samankaltainen sävelmäpari yhdeltä laulajalta ks. SKSÄ A 301/30 a ja b.

${ }^{929}$ Erilaisista kuorolaulua epäsäännöllisemmistä yksinlaulun rakenteista ks. erit. SKSÄ A 301/4b; 5 b; 7 a; 31b; 48a; SKSÄ L90 b ja c. Launis näyttää toisella matkallaan tallentaneen muutamia esimerkkejä variaation mahdollisuuksista hyvin tietoisesti. Esimerkiksi Palagea Jefimontytär lauloi saman Oman kylän ylistys -runon kahdesti samalla sävelmätyypillä. Ensimmäinen versio eteni tasaisesti ilman säkeenkertauksia tai refrenkejä, toinen rakenteeltaan epäsäännöllisempänä hieman varioivan $A i$ kali ai kali, ai kalinuska maja -refrengin kanssa. Jefimontytär lauloi kaikki seitsemän äänitettyä lauluaan yksin, varman kuuloisesti, ja niihin sisältyi myös monia rakenteeltaan säännöllisiä lauluja. On silti tietenkin mahdollista, että Oman kylän ylistys -runon epäsäännöllinen versio syntyi vaikeudesta vaihtaa laulun rakennetta saman sävelmän puitteissa nopeasti, esiintymisjännityksen alaisena. (SKSÄ A $301 / 30$ a ja b.)
} 
la kyzyn kylän aGoilDa vaan en muilDa vaan en muilta mie (vaneHilD) [?] i syntyykkö suruisDa suitset kynDölänGe kynDöilänGeD vaa kyynelist kynDöilänGet kyynelistä veDolänget veDolänget veD vaa veoist veDoilänget ved e veoista kyndölänget ${ }^{930}$

\author{
La kysyn kylän akoilta \\ vaan en muilta [vanhemmilt ja?]: \\ Syntyykö surusta suitset, (kyntölänget), \\ kyntölänget kyynelistä, \\ kyntölänget kyynelistä, (vetolänget) \\ vetolänget vaa veoista, \\ vetolänget vaa veoista, (kyntölänget)
}

Samankaltaiseen improvisatorisuuteen tuntuu viittaavan Boreniuksen maininta Hevaan Vepsän kylän Outelta tallentamansa metsän virren yllä: "Vapaa rytmi ja sävel." Vaikka sanat noudattavat kalevalamittaisen säkeen rakenteita, kirjoitti Borenius sävelmän olevat "samanlainen tai aivan samakin" kuin itkuvirsien sävelmä. ${ }^{931}$ Soololauluun saattoi liittyä sellaista laulun rakenteellista variaatiota, joka ei ryhmässä laulaessa olisi edes mahdollista ilman etukäteen päätettyä tarkkaa sovitusta, joka taas ei tiettävästi kuulunut runolaulun luonteeseen.

Erityisesti muutamat kehtolaulujen tallenteet viittaavat hyvin toisenlaisiin esittämisen mahdollisuuksiin kuin edellisissä luvuissa käsitellyt julkisen piiriin kuuluvat kuorolaulut. Kehtolauluja voitiin laulaa hiljaa ja pehmeästi, voitiin myös käyttää muita tilanteita enemmän merkityksettömiä tavuja säkeiden osina tai hymistä lähes ilman sanoja. Lauluun saatettiin punoa monenlaisia teemoja - myös esimerkiksi julkisen laulun piiriin viittaavia hää- ja liekkuaihelmia. Laulaja saattoi vaihdella yhden ja kahden säkeen jaksojen välillä, lisätä joukkoon pituudeltaan ja äänneasultaan vaihtelevia refrenkejä, rytmittää säkeen eri tavoin sävelmäänsä. (Heinonen 2008; Kallio 2009b.)

Ennen toista maailmansotaa tallennetut esimerkit tämän kaltaisesta variaatiosta ovat lähes kaikki peräisin äänittämistä varten esitystapoihin erityishuomiota kiinnittäneen Lauri Laihon käsikirjoituskeräelmistä. ${ }^{932}$ Sävelmäkäsikirjoituksissa variaatio pelkistyy usein tavoittamattomiin. "Vaihtelevaa ja sen tähden vaikea saada kirjaan," kirjoitti Borenius Vepsän kylän Tatjanalta tallentamansa lapsenvirren kaksisäkeisen, muunnelmattoman nuotinnoksen yhteyteen. ${ }^{933}$ Kehtolaulut saattoivat rakentua julkista joukkolaulua vapaammin sekä tekstuaalisesti että musiikillisesti (Heinonen 2008; Kallio 2009a), vaikka samalla on selvää, että niiden joukkoon kuului myös monenlaisia kiinteämuotoisia, lajityypillisiä runoteemoja, sävelmiä ja esitystapoja.

\footnotetext{
${ }_{930}$ Perusmuotoinen runo kuuluisi: La kysyn kylän akoilta, vaan en muilta vanehilt i [=vanhemmilta], syntyykö suruista suitset, kyntölänget kyynelistä, vetoilänget vet veoista [=vesistä].

${ }^{931}$ SKS KRA Borenius e 185b. Myös Launiksen tallentamassa käsikirjoitusaineistossa on toisintoja, jotka tuntuvat viittaavan rytmisesti hyvin varioivaan esitykseen (esim. SibA Launis 67, 276, 286, 317b).

932 SKS KRA L. Laiho 4720, 4986, 5133, 5340; vrt. samoilta laulajilta ilman kertaumia esim. SKS KRA Enäjärvi-Haavio 528; Haavio 2488; Laiho A. 2325; Laiho L. 5341; Salminen K. 284. Ennen 1930-lukua ainoastaan Eino Levón sattui tallentamaan samankaltaisen kehtosävelmän Tyröstä, mutta neljä runosäettä sisältävä kaksisäkeinen sävelmämuistiinpano, joista ensimmäinen on refrenkisäe pai pai pai pai, antaa vain aavistaa refrengin mahdollisesti toistuneen epäsäännöllisenä (SKS KRA Levón 378). Ks. myös Launis 1907, 110; SKS KRA Alava VII b s. 217.

${ }^{933}$ SKS KRA Borenius e) 183.
} 

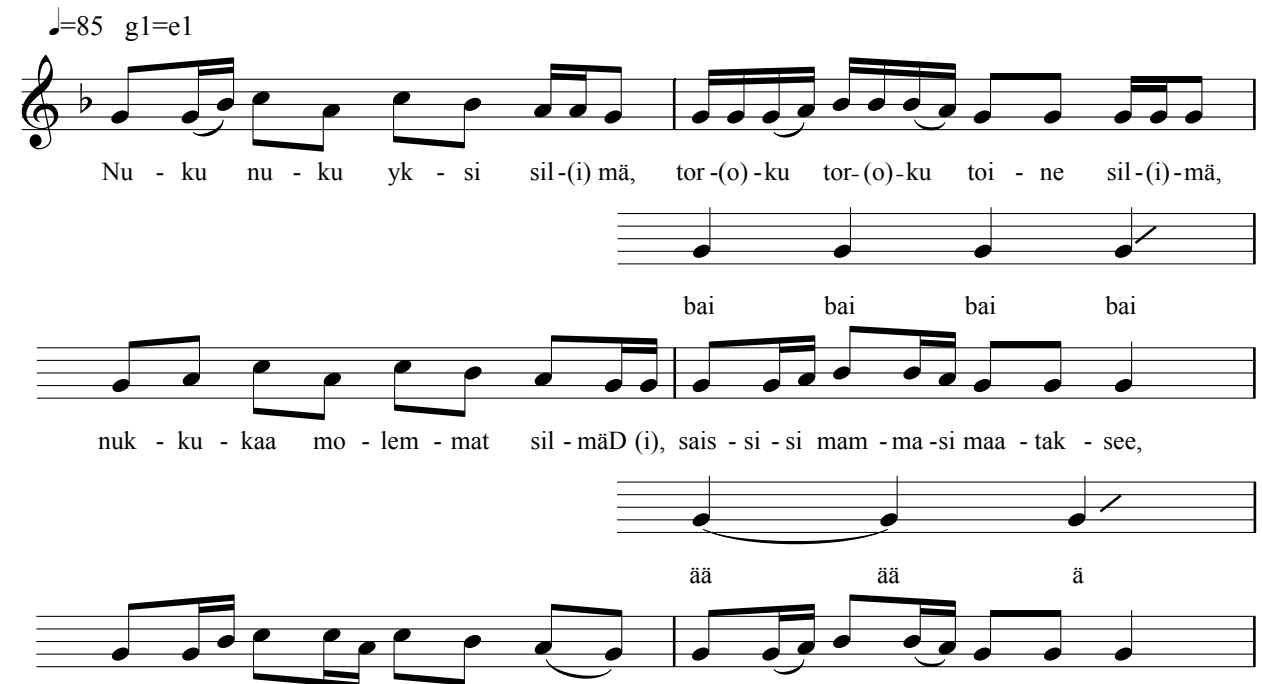

sais - si - si mam - ma -si maa - tak - see,

ja ky - läs - sä käy - väk - see,

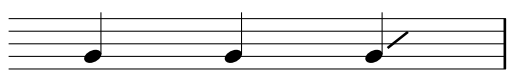

bau bau bau
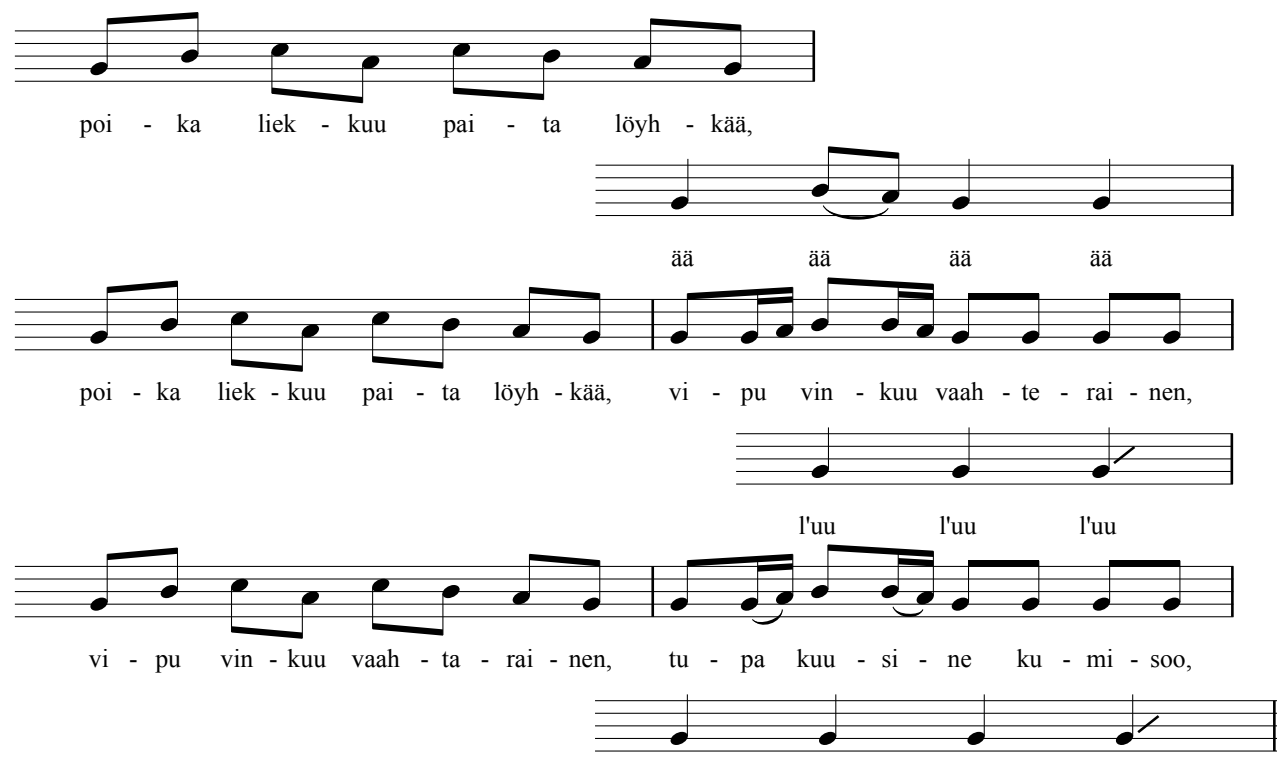

ää ä ä ä ä a

Nuotti 34. Anna Kivisoon kehtolaulu (SKSÄ L 90c).

\section{TALlenNUSTILANNE}

Länsi-inkeriläinen laulamisen kirjo piti jo yksin kalevalamittaisten runojen piirissä sisällään moninaisia sävyjä: laulu saattoi olla arkista ja epämuodollista tai ritualisoitua, yleistä tai henkilökohtaista, varioivaa tai mahdollisimman samankaltaisena toistettua, ja nämä tekijät saattoivat ilmetä laulun monella tekstuaalisella, musiikillisella ja kielenulkoisella tasolla. Laulaja saattoi äänitystilanteessakin innostua 
esitykseen, jota Richard Bauman (1977, 11; ks. myös Hymes 1981, 84) kutsuu varsinaiseksi tai täydeksi esitykseksi (full performance). Laihot ja Launis kertovat muutamista tämänkaltaisista tilanteista ja laulajien innostus kuuluu myös monilla heidän tallentamillaan äänitteillä, jotka pitävät sisällään taitavaa laulua ja monenlaisia hyviä esityksiä. Toisaalta täyden esityksen luonne riippuu myös laulun lajista: kehtolaululla ja häälaululla se on hyvin erilainen.

Keruutilanne vaikutti monella tavalla siihen mitä laulaja halusi esittää tai suostui esittämään. Kaikki ei silti riippunut vain kerääjästä tai tallennustekniikasta. Keruuajankohdan lisäksi laulajan oman tilanteen ja mielentilan vaikutus näkyy selvänä esimerkiksi Vihtori Alavan tallentaman Tarinasin kylän Naastoin kohdalla. Tämä Tarinaisin kylästä syntyisin oleva nainen esitti Alavalle paljon pitkiä runoja vuonna 1891 kotonaan Säätinällä. Seuraavana vuonna Naastoi oli vain käväisemässä kotona praasnikkajuhlien välissä kerääjän saapuessa paikalle. Päivän keruutulos oli viisi lyhyttä runoa. Alava kirjoitti päiväkirjaansa, että tällä kertaa Naastoi "oli huonolla tuulella praasnikat taisivat tuntua (oli ollut Tarinaisissa praasnikoilla) kun niin laiskasti virsiäkin antoi." Juhlatilanne näkyi kuitenkin ensimmäisen laulun valinnassa, sillä kuten praasnikkoihin sopi, Naastoi aloitti laulunsa Ilian virrellä. ${ }^{934}$

Joissain tapauksissa laulamisen tilannesidonnaisuuden logiikat näyttävät päteneen keruutilanteessa hyvin suorallakin tavalla. Esimerkiksi Launiksen käsikirjoitussävelmäkokoelmassa on huomattavan paljon erilaisia Mitä noisen laulamaan; Ei miun laulella pittäisi; Lauloin ennen lapsempana ja La miä laulan nyt miä jouvan -tyyppisiä laulamista pohtivia aloitusformuloita, niin kutsuttuja Laulajan sanoja. Niitä on suhteessa paljon enemmän kuin muiden tallentajien runokäsikirjoituksissa. Tutkijan kannalta tämänkaltaiset aloitusformulat tuntuvat harmillisilta, sillä niiden jälkeen laulu on voinut jatkua lähes miten hyvänsä. Formula ei kytke runoa mihinkään erityiseen tilanteeseen tai tekemisen tapaan, vaan ainoastaan itsestään selvään laulamisen tematiikkaan. Näiden formuloiden suuri määrä on nähdäkseni kuitenkin yksi osoitus laulun sopeuttamisesta tilanteeseen. Toisin kuin aiemmat teksteihin keskittyneet tallentajat, Launis pyysi laulamaan erilaisia sävelmiä. Sanoista hän ei välittänyt, vaan huomio oli itse laulamisessa. Samalla tavoin lauluun suuntautui luultavasti myös esittäjien huomio, minkä tuloksena tallentui runsaasti juuri lauluun liittyvien lyyristen runoteemojen alkuja. Launis kertoo useassa kohden päiväkirjaansa, että hänen oli etenkin alkumatkasta vaikea saada ujostelevia tyttöjä laulamaan. Esimerkiksi Työ käsette laulamaan, laulamaan, rohtinenko ruohtinenko, ruohtinenko onkin yleisen laulunaloitusformulan ohella tulkittavissa hy-

\footnotetext{
934 SKS KRA Alava VIIB II 39/56; SKVR III 2255, 2268, ks. myös 2267. Ei tietenkään voi olla varma siitä, tapahtuiko praasnikkavirrellä aloittaminen kerääjän vai laulajan itsensä aloitteesta. Aloittaminen laulutilanteen määrittävällä teemalla on kuitenkin selkeästi Länsi-Inkerissä tyypillinen tapa. Samoin teki myös toinen, Säätinältä kotoisin ollut Naastoi samana päivänä. Säätinän Naastoi tuntuu lisäksi kontekstualisoineen Iljan virren nimenomaisesti Sätinän kylään puhuttelemalla runon aloitusformulan toisessa säkeessä Pyhän Pedron sijasta Troitsaa eli Säätinän keskeisintä praasnikkaa helluntaita. Laulajien ajatukset näyttävät muutenkin eläneen praasnikkojen teemoissa. Säätinän Naastoi kertoi samassa yhteydessä myös esimerkiksi kerjäläisten praasnikoilla kestitsemisen tärkeydestä kertovan legendan - mahtoiko runoja pyytelevä kerääjä rinnastua myös tähän pyytäjien joukkoon, jolle tuli olla vieraanvarainen silloinkin, kun olisi ollut parempaakin tekemistä? (SKS KRA Alava VII A 457.) Naastoista enemmän ks. Harvilahti 1992a, 175-180.
} 
vin perustelluksi, kohteliaaksi ja samalla vieraan miehen laulupyynnön täyttäväksi vastaukseksi. ${ }^{935}$

Tallentajan keskittyminen sävelmiin saattoi toisaalta tuoda runonkeruuta helpommin esiin myös tiettyihin keskeisiin rekistereihin ja esitysareenoihin assosioituvia aloitusformuloita. Näyttää siltä, että laulajan esittäessä vahvasti johonkin paikalliseen tilannesidonnaiseen lajiin liittyvän sävelmän tämä sävelmä ikään kuin veti mukaansa usein myös tyypillisen aloitusformulan. Selkeimmin tämänkaltaista selitystä tuntuisi edellyttävän Vögle Timontyttären ja kuoron osakertauksin laulama, hieman yllättävän oloinen yhdistelmä, jossa laulun iltaan paikantava kaksisäkeinen aloitusformula Jo too illakko tuloo, hämärikköi viettelöö saa suoraan jatkokseen muutaman säkeen Sisaren turmeluksen runon alusta. Tämäntyyppistä formulan käyttöä ei näy muussa samankaltaisissa runoissa; yleensä illakko-teema esiintyy pidempänä ja usein myös omana kokonaisuutenaan. Sisaren turmeluksen käsikirjoitustoisinnoissa sitä ei tavata. Launiksen seuraavaksi tallentaman hyvin erityyppisen sävelmän yhteydessä Timontytär aloittaa saman Sisaren turmeluksen runon ilman aloitusformulaa, suoraan runon tyypillisesti aloittavalla säkeellä Turoi tuimoi mees kavala. Aavistelisin ensimmäisen sävelmän liittyvän kiinteästi illalla laulamiseen, sillä illasta kertoviin runoteemoihin liittyvistä sävelmistä moni on samalla tavoin loppusäveliä venyttävä, hidastempoinen ja joskus osakertauksia sisältävä. ${ }^{936}$ Tästä iltalaulusta Timontytär sitten assosioi muihin saman runoteeman - ei saman aloitusformulan tai laulutilanteen - yhteydessä mahdollisiin sävelmiin. Laulujen väliset assosiaatiot tai temaattiset yhteydet saattoivat sijoittua monelle eri tasolle.

Aloitusformuloiden ja -teemojen pituus ja luonne vaihtelee suuresti: lyhimmillään aloitusformula voi olla säkeen pituinen, pisimmillään esimerkiksi liekkumisen aloittaneet liekkuvirret ovat monikymmensäkeisiä. Samoin vaihtelee tapa, jolla aloitusformulat viittaavat laulamisen tilanteisiin. Liuku-, liekku-, kokko-, kulkemis- sekä tanssiformulat ja -teemat puhuvat suoraan tilanteessa tekeillä olevasta asiasta eli ajamisesta, keinumisesta, kokolle kulkemisesta, läpi kylän kulkemisesta tai tanssista. Häälaulut alkavat tyypillisimmin joko kohteensa puhuttelulla tai tiettyyn tilanteeseen liittyvällä kehotuksella tai toteamuksella. Luonteeltaan kiinteät praasnikkavirret, erityisesti Iilian ja Pedron virret, mutta myös Martin virret, alkavat pyhimyksen puhuttelulla, kiletoivirret taas laulutilanteeseen liittyvillä tervehdyksillä tai kehotuksilla. Aloitusformula voi hahmottua 1) kiinteästi osana tiettyä yksittäistä runotyyppiä, 2) laulun tietyssä tilanteessa käytännössä poikkeuksetta aloittavana, muuallakin käytettävissä olevana teemana tai 3) satunnaisena, valin-

\footnotetext{
${ }^{935}$ SibA Launis 14. Luonnollisesti tämäntyyppiset aloitukset ovat olleet käytössä myös yhteisöjen sisäisissä laulutilanteissa: esimerkiksi Juljaana Pohjalainen osoitti tämänkaltaiset aloitussanat usein tyttöajan vertaisryhmälle: Oi tytöt sulat sisaret [...] työ käsettä laulamaa [...] tohtinenko rohtinenko, kehannenko kelvannenko (Käsetään laulamaan, Kehannenko, kelvannenko). Lähes 80-vuotiaan vanhuksen suussa alkusäe viittaa väistämättä selkeästi keruuhetken ulkopuolelle, tässä nähdäkseni omaan tyttöaikojen lauluun, johon Pohjalainen viittasi usein myös sanallisesti. (SKS KRA Haavio 2551; ks. myös KRA Haavio 2540; Salminen K. 50, 231. Tyttöaikojen laulusta kertomisesta ks. esim. SKS KRA Enäjärvi-Haavio 556.)

${ }^{366}$ SKSÄ L 95a; A 300/43b; SibA Launis 148, 222b, 322, 336; ks. kuitenkin myös SibA Launis 214, 282, 371. Metsän sävelistä Timonen 2004, 93-107.
} 
naisen oloisena erilaisiin runoihin tietyissä tilanteissa kytkeytyvänä kehystäjänä, kuten tanssinaloitusten kohdalla.

Eri tallentajien kokoelmia erottavista tilannesidonnaisista piirteistä ilmeisin on monen eri runon alkuun sopivien aloitusformuloiden käyttö: suhteellisesti tiheimmin niitä esiintyy esitystapoihin - joko puhtaasti sävelmiin tai ainoastaan esityksellisiin tekstuaalisiin piirteisiin ja kontekstitietoihin - keskittyneiden tallentajien, etenkin Armas Launiksen ja Laihojen keräelmissä. Monilla lähinnä runotekstejä ylös kirjoittaneilla tallentajilla tilannesidonnaisia, helposti useisiin erilaisiin runoihin yhdistyviä aloitusformuloita on runojen yhteydessä melko niukasti. ${ }^{937}$ Tämänkaltaisille aloitusformuloille on ominaista liikkuvuus. Ne jäävät ilmeisen helposti esittämättä, jos laulutilanne ei anna niiden käytölle aihetta.

Esimerkiksi Valpuri Vohta esitti Kui miä kazvelin kanaine -runon eri kerääjille neljä kertaa vuosina 1931-1937. Runoteksti pysyi aloitusformulaa Tehkää yksi ympärikko ja yhtä paralleelisäettä lukuun ottamatta säkeestä säkeeseen samana tallennustilanteesta toiseen. Kyseessä oli siis Vohdalla erityisen kiinteä kokonaisuus. Aloitusformulan hän lisäsi laulun alkuun äänitystilanteen lisäksi ainoastaan runojen esittämisestä kiinnostuneen Lauri Laihon kirjoittaessa runoa muistiin; muissa tallennustilanteissa runo jäi kehystämättä. Äänitteellä runo lauletaan riehakkaalla, nopealla tanssinuotilla, rytmikkäiden kiljahdusten säestämänä. ${ }^{938}$ Lauri Laiholle yksin esittämänsä, tanssiformulalla alkavan versionsa Vohta paikansi samoin kuin äänitteen: "Se mäntii ympärikkona." Kaarina Salmiselle Vohta nimesi ilman aloitusformulaa esittämänsä version pulmavirreksi eli häärunoksi, ja antoi tässäkin tarkemman kuvauksen: "Männää ympärikkoo." Vohdan Elsa Enäjärvi-Haaviolle kahta vuotta aikaisemmin laulama runo jäi sitä vastoin täysin ilman sekä kontekstimainintoja että aloitusformulaa. Vohta kuitenkin kuvasi Enäjärvi-Haaviolle toisessa yhteydessä erikseen kyseisen aloitusformulan merkitystä ja käyttöä: "Kaksi rinnan kulki piirissä; tähän sopivat sanat: Tehkää yksi ymbärikko, Karavooti kaunokkainen. Ymbärikko ja karavooti siis tarkoittivat tällaista liikuntatapaa." Tätä formulaa ei ole alueelta tallennettu kovinkaan runsaasti, kenties juuri sen irrallisen luonteen takia. Enäjärvi-Haavion keräelmässä se esiintyy ainoastaan Vohdan lyhyessä kuvauksessa, ei yhdenkään runon yhteydessä. Täysin samassa muodossa se esiintyy Vohdan toisintojen lisäksi ainoastaan Väinö Salmisen anonyymiksi jääneen runon Yks oli väärä miun emoni alusta. Tämäkin on luultavasti Vohdan laulama: hänet on merkitty muistiinpanoissa seuraavan laulun esittäjäksi, ja kyseinen runo tallennettiin häneltä myös äänitteinä kaksi kertaa. Kummallakin äänitteellä sävelmä ja laulamisen tapa on sama kuin Kui miä kazvelin kanaine -runon yhteydessä, mutta aloitusformula puuttuu. Voikin uumoilla Tehkää yksi ympärikko -formulan ja kyseisen

\footnotetext{
${ }^{937}$ SKVR:stä ei esimerkiksi Tehkää yksi ympärikko -formulaa löydy ollenkaan. Nyt on lusti nuoren nois$s a$ - formula esiintyy useammin, mutta vanhemmissa keräelmissä (Alava ja Porkka) ainoastaan vakiintuneen oloisena yhdistelmänä vanhempien kuolemasta kertovan aihelman kanssa (SKVR III 881, 2428; vrt. SKS KRA Haavio 2495; Laiho A. 2221; Laiho L. 5357; Salminen 2909); useampien aihelmien yhteydessä formulaa esiintyy vasta runojen jälkikorjuussa olleilla Ruotsalaisella ja Salmisella, ks. SKVR III 2647, 2720, 2928, 3245 (vrt. SKS KRA Laiho L. 4832); sekä keskellä runoa SKVR III 3305, säe 11 (vrt. SKS KRA Enäjärvi-Haavio 468). 1930-luvun keräelmissä aihelmaa esiintyy kummankin tyyppisissä yhteyksissä (edellisten lisäksi SKS KRA Laiho A. 2094; Salminen K. 29).

${ }^{938}$ SKS KRA Enäjärvi-Haavio 481; Laiho 4998; Salminen K. 265; SKSÄ L 95c.
} 
tanssisävelmän liittyneen Vohdalla kiinteästi yhteen. Aloitusformulan käyttö ei kuitenkaan ollut mitenkään välttämätöntä edes lauletussa esityksessä, ja formula siirtyi helposti yhden runon yhteydestä toiseen. ${ }^{939}$

Vaikka erilaiset tanssinaloitusformulat, kuten $\mathrm{Nyt}$ on lusti nuoren noissa tai $\mathrm{Hy}$ pätkäämme hyrjätkäämme, ovat Inkerissä yleisiä, on juuri Vohdan käyttämän kaltainen tanssinaloitusformula tallennettu hänen lisäkseen vain Anna Kivisoolta. Kivisoo esitti formulan hieman eri muodossa ja aineistossa yleisempään tanssinaloitusformulaan yhdistyneenä: Tehhää yksi ympärikko, kaksi kallist karavoodii, täs on lusti nuoren noissa. Kivisoon aloitusformula on tallennettu irrallisena ainoastaan katkoviivojen ilmaistessa, että jatkoksi saatettiin laulaa muutakin. ${ }^{940}$ Tuntuukin luonnolliselta, että tämänkaltaisia suhteellisen irtonaisia ja tilannesidonnaisia formuloita esiintyy runsaammin laulamisen tavoista kiinnostuneiden 1930-luvun kerääjien aineistoissa ja ääniteaineistoissa kuin varhaisempien, ensisijaisesti kiinteitä runoja tallentamaan pyrkineiden kerääjien tallenteissa.

Etenkin Launiksen käsikirjoituskokoelman nuotit sisältävät usein ainoastaan säkeen tai parin pituisen yleisen aloitusformulan, vaikkapa La miä laulan nyt miä jouvan, nyt miä jouvan laulamaa, jonka jatkona mahdollisesti seurannutta runoa ei voi edes arvailla. Tämänkaltaiset toisinnot kertovat ainoastaan tiettyjen sävelmien ja aloitusformuloiden yhteydestä, eivät siitä, minkälaisia pidempiä runokokonaisuuksia näiden yhteydessä on käytetty. Erot keräjijien välillä näkyvät myös runojen ja sävelmien yhdistelmien variaatiossa: siinä missä Launiksella samoja runonalkuja esiintyy usein lukuisten erilaisten sävelmien yhteydessä ja erilaisia sävelmätoisintoja on enemmän kuin missään muussa inkeriläisessä sävelmäkeräelmässä, Laihojen äänityksissä samoilla sävelmillä on usein laulettu monia erilaisia runoja eikä sävelmätyyppien kirjo ole likimainkaan yhtä suuri. Tallentajasta ja tilanteesta riippuen laulajat saattoivat joko lähinnä pysytellä muutamien yleissävelmien puitteissa tai ilmeisesti lähinnä erikseen pyydettäessä - vaihdella sävelmiä enemmän ja käyttää myös tilannesidonnaisempia erityissävelmiä. Vain tietyt vahvasti tilannesidonnaiset, usein rituaalisesti keskeiset runot näyttävät tallentajasta ja tämän intresseistä riippumatta tulleen lähes poikkeuksetta lauletuiksi omilla erityissävelmillään.

Asetelmaa onkin syytä käsitellä laulun tilannesidonnaisuuden eli esitysareenan ja rekisterin kiinteän yhteyden kautta. Tallennustilanteessa itse tallennustilanne oli ensisijainen esitysareena, jonka puitteissa laulaja saattoi esityksen eri tasoilla kertoa tyypillisestä tai erityisestä laulamisesta muissa tilanteissa. Sekä 1) ensisijaisen esitysareenan luonteesta eli siitä, minkälaiseksi laulaja ja kerääjä tilannetta omilla tavoillaan muokkasivat ja tulkitsivat että 2) erilaisiin muihin esitysareenoihin si-

${ }^{939}$ SKS KRA Enäjärvi-Haavio 481, 552; Laiho L. 4998; Salminen K. 265. Yksi oli väärä miun emoni: SKS KRA Salminen 3013 ja 3014 (viitetiedot); ERA, Fon. 372c; SKSÄ L95 d. Valpuri Vohdalle riehakkaaseen tanssiin liittyvä Tehkää yksi ympärikko -formula näyttää poikkeavan tallennustiheyden perusteella olleen hänelle jollain tavalla merkittävä ja kenties tiivistäneen jotain hänen suhteestaan laulamiseen. Hänen esilaulunsa vuoden 1937 äänityksissä painottuvat vahvasti nopeiden tanssi- ja pilkkalaulujen suuntaan. (SKSÄ L 92c, 95c ja d, 96 b, 98d, 100b ja c.) Traagisia, hitaasti esitettyjä lauluja häneltä ei sitä vastoin ole äänitteinä tallennettu.

${ }^{940}$ SKS KRA Laiho L. 5329. 
toutumisen vahvuudesta riippui se, minkälaisina laulaja runoja esitti. Jos tallennustilanne kannusti keskittymään tekstuaaliseen tasoon, vaihtuivat lähinnä runot. Laulaja saattoi sanella ne tai käyttää esittämiseen vain yhtä yksinkertaista yleissävelmää. Jos laulaja keskittyi musiikillisiin tai esityksellisiin tasoihin, saattoivat sävelmät ja muotorakenteet vaihdella, ja lopputuloksena saattoi tekstin osalta tallentua ainoastaan lyhyitä aloitusformuloita.

Kuten Lauri Harvilahti (1998b, 199) on todennut, eivät SKVR:n teksteissä runojen lauluissa saamat rakenteet juuri näy. Pitkälti tämä selittyy tietenkin kerääjien kiinnostuksen kohteilla ja keruutekniikalla. Tallennustilanteita on kuitenkin syytä miettiä myös laulajien kannalta. Huolimatta esimerkiksi Launiksen ilmeisestä kiinnostuksesta monimutkaisempiin musiikillisiin rakenteisiin, on suurin osa tallennetusta sävelmäaineistosta kuitenkin yksi- tai kaksisäkeisiä sävelmiä ilman osakertauksia, lisätavuja tai refrenkejä. Säkeitä sellaisenaan toistavat sävelmät olivat yleisimpiä. Myös myöhemmissä ääniteaineistoissa monet laulajat esittävät valtaosan runoistaan muutamalla yksinkertaisella perussävelmällä. Runonkerääjille esiintyi ilmeisesti usein yksi ihminen kerrallaan, ja päähuomio oli runoissa itsessään. Tämän lisäksi suuri osa lauluista oli sangen vapaasti paikallisesta lajista toiseen siirrettäviä lyyrisiä ja lyyris-eeppisiä runoja. Laulajat näyttävät usein esittäneen tämänkaltaiset moneen tilanteeseen sopivat runot määrittämättä esityksellisillä keinoilla niiden rekisteriä ja siten kytkemättä niitä tiettyyn esitysareenaan. Miksi haastateltava olisi siirtynyt rakenteeltaan monimutkaisempiin sävelmiin tai laulanut väliin refrenkejä, vaikka olisikin sanelun sijasta laulanut runonsa? Juuri tämän takia muutamat joko kerääjän tai laulajan tekemät poikkeukset vaikuttavat tärkeiltä. Esimerkiksi Vihtori Alavan tallentamat muutamat yllättävät, yksittäiset refrengit keskellä runoa tai yksittäisen laulajan kuten vaikka Maria Hauen repertuaarin ainoa viite laulamisen rakenteisiin merkitsevät jonkinlaista murtautumista laulullisuuden puolelle ja merkitympiin esitysrakenteisiin eli tiettyihin esitysareenoihin sidoksissa oleviin rekistereihin. ${ }^{941}$

Siinä missä sävelmänkerääjän keskittyminen lauluesityksiin vaikutti laulamiseen liittyvien aloitusformuloiden yleisyyteen, saattoi runonkerääjän keskittyminen (usein saneltuihin) runoteksteihin vähentää tämänkaltaisia tilannesidonnaisia elementtejä. Yksi runo tai runoteema saattoi saada monia ilmiasuja, ei vain sisältönsä ja säeasunsa vaan myös muotorakenteensa (kertaukset, osakertaukset, refrengit ja lisätavut) sekä musiikillisten ja liikkeellisten piirteidensä suhteen. Kuten keräjä loi kuulemastaan tietynlaisen tallenteen muuttamalla hetkessä kuulemansa laulun tietynlaiseksi, määrättyjä piirteitä sisältäväksi pysyväksi tekstiksi tai siihen rinnastuvaksi äänitteeksi, valitsi myös laulaja joko tietoisesti tai tiedostamattaan runonsa esitykseen tietynlaisia piirteitä. Sekä laulaja että kerääjä vaikuttivat osaltaan siihen, mitä lauluja ja millaisina esityksinä tallennettiin.

${ }_{941}$ SKVR III 2391 (hoi goorja hoi beda), 2425 (oi kolina); SKS KRA Alava pikakirjoitusvihko I 1897, s. 47. Maria Hauesta ks. alaluku Leinosta leskestä; SKS KRA Laiho L. 5213, 5214. 


\section{TILANTEEN MONIKERROKSISUUS}

Edellisissä luvuissa olen hahmotellut kuvia länsi-inkeriläisen julkisen laulun tilannesidonnaisuuksista häissä ja praasnikoilla. Laulun alkusäkeet, runoteemat ja moninaiset musiikilliset piirteet määrittyivät usein laulutilanteen mukaan. Laulutilanne puolestaan näyttää, karkealla tasolla, määrittyneen vaihdellen ainakin vuodenajan, pyhän tai arjen, laulajajoukon ja yleisön sekä lauluun liittyvän tekemisen laadun kautta. Sävelmä - sen muotorakenne, melodia, rytmi tai siihen liittyvä refrengi, joskus ehkä vain laulamisen vaikeammin määrittyvä yleinen sävy, tempo, äänenväri - kannatteli osaltaan tilannetta. Se saattoi joko pysyä samana pitkän aikaa tai vaihtua laulun, laulajan ja tilanteen luonteen mukaan. Esimerkiksi liekulla laulamiseen ei aineistossa liitetä kuin yksisäkeistä laulamisen muotorakennetta ja sävelmät ovat kaikki neli-iskuisia ja suppea-alaisia - mutta toisaalta liekun lähettyvillä saatettiin keinuvuoroa odotellessa ilmeisesti laulaa monenlaisia tanssilauluja, ja tanssilauluja puolestaan esitettiin tyypillisesti hyvin moninaisilla sävelmillä. Häissä suuri osa keskeisistä lauluista laulettiin kahta yksinkertaista sävelmätyyppiä käyttäen, mutta tietyt laulut, erityisesti kokin kiitos ja jotkut morsiamen puolen lähinnä morsiamelle osoittamat laulut, laulettiin usein omilla osakertauksia sisältävillä sävelmätyypeillään.

Kun inkeriläisen laulun havaitsee, Launista (1907) ja Timosta (2004, 82-157, 238-303) seuraten, sekä tekstuaalisilta että musiikillisilta piirteiltään osin tilanteen mukaan muokkautuvaksi ja ketjuuntuvaksi, on edessä väistämättä tallennustilanteiden uudelleenarvioiminen. Minkälaisin tavoin laulu muokkautuu tallennustilanteessa? Mihin tilanteeseen tai tilanteisiin laulaja suhteuttaa kerääjälle laulamisensa: keruuhetkeen, tiettyyn (erityiseen) aikaisempaan tilanteeseen vai kulttuurisesti tyypilliseen tilanteeseen? Jos hän laulaa häälaulun, laulaako hän yleistyksen tyypillisestä laulusta, joissain tietyissä häissä laulamansa laulun, jossain häiden ulkopuolisessa tilanteessa käyttämänsä häälaulun vai häälaulun sovitettuna juuri tiettyyn keruutilanteeseen? Minkälaisia esityksellisiä piirteitä laulaja punoo mukaan, mihin ne viittaavat? Esityksellisten piirteiden valinta on osa esityksen kontekstualisaatiota (ks. Bauman \& Briggs 1990, 68-73; Briggs 1988, 12-16; Hanks 1989, 104-113), laulun ja sen kontekstien suhteiden ja siten esityksen tilannesidonnaisen merkityksen luomista. Ei tietenkään voi edes olettaa, että yksin arkena keräään pyynnöstä laulamaan ryhtynyt nainen pystyisi tuottamaan samanlaisen esityksen, kuin pyhäpäivänä suuren, kenties jo hieman juopuneen häävierasjoukon kanssa laulaessaan. Erityisesti häälaulujen yhteydessä laulajilla näyttääkin olleen välillä kerääjän näkökulmasta katsottuna ongelmia: yhden ihmisen oli vaikea nopeasti tuottaa koko monipäiväistä, dialogista rituaalia ja erotella eri toimijoiden laulamia osia toisistaan.

Mitä siis olivat kerääjille sanellun tai lauletun suhteet tyypillisempiin laulutilanteisiin, ja miten laulamisen tilannesidonnaisuuden logiikat mahtoivat toimia keruutilanteissa? Olennaisin ja kenties itsestään selvin huomio on, että keruutilannekin on tilanne (Timonen 2004, 288; ks. myös Bauman 2004, 10, Tarkka 2005, 101). Laulaja mukautuu ja reagoi osaamansa ja aiemmin kokemansa pohjalta keruuhetkeen siinä 
kuin mihin hyvänsä muuhunkin tilanteeseen. Lopputulos riippuu sekä kerääjästä, laulajasta, että näitä ympäröivistä olosuhteista. Kulttuurisesti tyypilliseksi laulun voi olettaa, jos samankaltaisia tekstuaalisten, musiikillisten ja esityksellisten piirteiden yhdistelmiä on tallennettu useammilta laulajilta: juuri näitä tyypillisyyksiä on etsitty edellisissä luvuissa. Tyypillisyyksien valossa voi myös tiettyjä yksittäisiä tilanteita ja tallenteita lähteä pohtimaan tarkemmin. Seuraavat esimerkit ovat erityistapauksia, joiden katson laajempaan kehykseen suhteutettuna kuitenkin kertovan laulun muotoutumisen tavoista yleisemminkin.

\section{LEEKUTUSNOOTTI}

Liekkuvirret muodostavat tekstuaalisesti ja musiikillisesti yhden kiinteimmistä praasnikkoihin liittyvistä lauluryhmistä. Keinusta ja keinumisesta puhuvat aloitusteemat ovat helposti tunnistettavia ja niihin liittyvät länsi-inkeriläiset sävelmät ovat kaikki samantyyppisiä: yksisäkeisiä, suppea-alaisia, neli-iskuisia. Sävelmiin on kuitenkin kaksi viisi-iskuista poikkeusta.

$\begin{array}{lccccccc}\text { Arkistovitte } & \text { PAikKa } & \text { Kylä } & \text { IRS } & \text { Alkusäe } & \text { Muotorakenne } & \text { Rytmi } & \text { SÄvelï̈ } \\ \begin{array}{l}\text { SKS KRA } \\ \text { Borenius e 198 }\end{array} & \text { Soikkola } & \begin{array}{l}\text { Savi- } \\ \text { mäki }\end{array} & 178 & \begin{array}{c}\text { Leekuttaja } \\ \text { keekuttaja }\end{array} & 12345678 & 22222244 & 4 \\ \text { SibA Launis 37 } & \text { Narvusi } & \text { Ropsu } & 805 & \begin{array}{c}\text { La mie katson } \\ \text { liekkujani }\end{array} & 12345678 & 22222244 & 6\end{array}$

Sävelmien yhteyteen merkityt runosäkeet ovat selkeitä liekkuvirsiä: Leekuttaja keekuttaja ja La mie katson liekkujani. Nämä molemmat sävelmät on kuitenkin kerääjien muistivihkoissa kytketty lapsen keinuttamiseen: ensimmäinen on nimetty leekutusvirreksi, toinen kehtolauluksi. Sana liekkua tarkoitti sekä suuressa kyläkeinussa liekkumista että lapsen keinumista kätkyessä. ${ }^{942}$ Yleensä suurella liekulla laulettavat liekkurunot on, eri kieli- ja murremuodoin, nimetty liekkuvirsiksi, -runoiksi, -lauluiksi tai -nuoteiksi (nootti), Keski-Inkerissä myös pääsiäisnuoteiksi. ${ }^{943}$ Liekutusvirsi-termillä Anna Kivisoo puolestaan puhui kehtolaulustaan, ja liekuttamiseen liittyviä erilaisia verbimuotoja käyttivät muutkin laulajat lapsenvirsiä kontekstualisoidessaan. ${ }^{944}$

Ensimmäisen viisi-iskuisen liekkusävelmän lauloivat Boreniukselle Vöglä ja Okkuli Soikkolan Savimäellä. Vöglältä tallentui myös sävelmällä laulettu hyvin tyypillinen liekkuruno. Vaikka Vöglä nimesi runon lapsenvirteen viittaavalla termillä, hän kontekstualisoi runon silti pääsiäisen julkiseen keinumiseen: ”Leekutusvers.

\footnotetext{
${ }^{942}$ Ks. esim. SKS KRA Salminen K. 54.

${ }^{943}$ SKVR 44 viite 1, 600, 1069, 1905; SKS KRA Laiho L. 5342; Borenius e 200, 207, 209; SibA Launis 104; ks. myös Launis 1907, 107; Timonen 2004, 149-150.

944 SKS KRA Laiho L. 5340; ks. myös SKVR III 1061-1065; SKS KRA Laiho L. 4852; Haavio 2424; Salminen K. 228; Salminen V. 2895; lapsenvirrestä esim. SKVR III 3814; SKS KRA Salminen K. 284; Borenius e 182 .
} 
Pääsiäisel leekutaan.” Samaa määrettä laulajat käyttivät sävelmän yhteydessä, mutta tällöin he korostivat erityisesti lapselle laulamista: "Leekutusnootti (jolla myöskin lapsia nukutetaan)." ${ }^{\text {945 }}$

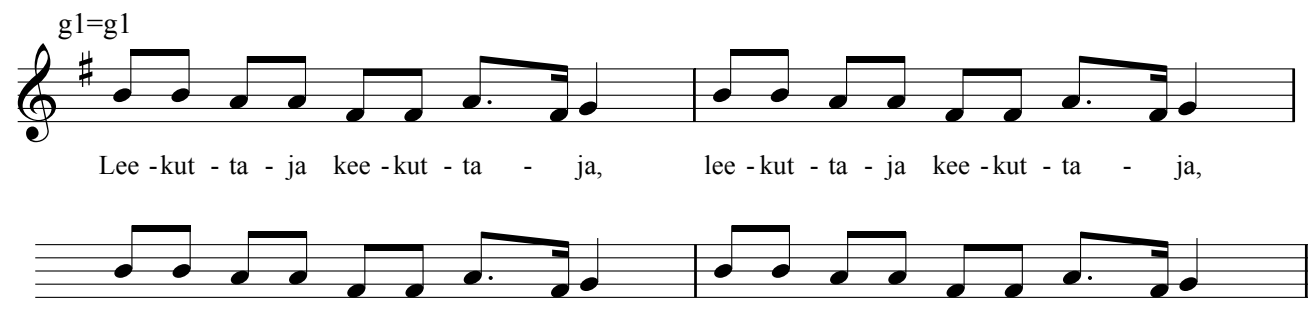
vas - ki - se vi - na - hut - ta - ja vas - ki - se vi - na - hut - ta - ja

Nuotti 35. Vöglän ja Okkulin leekutusnootti Soikkolasta (SKS KRA Borenius e 198).

Sävelmän valintaan, nimityksiin ja kommenttiin oli ilmeisesti syynä pienen tytön läsnäolo sävelmien ja runojen ketjuna edenneessä tallennustilanteessa. Tyttö lauloi ainakin yhden laulun naisten kanssa ja olettaisin hänen läsnäolonsa vaikuttaneen myös Vöglän ja Okkulin ensimmäisenä esittämän häälaulun kommenttiin: "Samalla pulmanootill lauletaan lapselleki ja muitaki versii" - lapselle ja muutenkin saatettiin siis laulaa myös tyypillisesti seremoniallisempiin tilanteisiin liittyvien laulujen sävelmillä, liekkuvirsien lisäksi häälaulujenkin. ${ }^{946}$ Borenius oli ilmeisesti jo tallentanut "varsinaisen" liekkunuotin, ja tyytyi vain merkitsemään itselleen pienen muistiinpanon "vrt. yl. varsinaista."947 Toisin kuin Vöglän runo, Vöglän ja Okkulin sävelmä ei tämän muistiinpanon, muun aineiston ja poikkeavan nimityksen perusteella mitä ilmeisimmin ollut "varsinainen" liekkunuotti, vaikka ehkä sitä saatettiin käyttää myös keinuessa. Se oli erityisesti lasten nukutukseen käytetty sävelmä: liekutusnuotti, ei liekkunuotti. Tätä liekkuvirsien yhteydessä epätyypillistä sanamuotoa laulajat käyttivät myös runon yhteydessä. Vöglän runon sanat olivat silti varsinaisia liekkuvirren sanoja. Kiinteän tilannesidonnainenkin runo oli käyttökelpoinen useamman esitysareenan puitteissa ja määrittyi osin niiden mukaan. Lapsen mukanaolo määritti myös tallennustilanteen esitysareenaa ja laulujen siinä saamia tulkinnallisia kehyksiä, sekä runojen ja sävelmien nimeämisiä että laulujen esityksellisten piirteiden valintaa. Runo oli liekkuvirsi, jota saatettiin laulaa myös lapsen viihdytykseksi, liekutusvirtenä.

Pienillekin lapsille saatettiin laulaa myös kaikenlaista muuta kuin varsinaisia kehtolauluteemoja, vaikka tästä ei inkeriläisessä aineistossa ole paljoakaan mainintoja. Pauliina Reponen kertoi laulavansa lapselleen häälaulua. Narvusilainen Mari Särkkinen puolestaan lauloi Kirsti Mäkisen (1990, 209-210) mukaan runoa maailmansynnystä (Saaren neito) kehtolauluna. Seiskarin saarella oli Aili Simonsuuren $(1969,122)$ mukaan usein talvisin töissä inkeroistyttöjä Länsi-Inkerin Soikkolasta.

\footnotetext{
${ }_{945}$ SKVR III 597; SKS KRA Borenius e 198.

${ }^{946}$ SKS KRA Borenius e 197; 193.

${ }_{947}$ Ainoa Boreniuksen aiemmin keräämä liekkuvirren länsi- tai keski-inkeriläinen toisinto on Tyrön Ylikylästä tallennettu epätyypillinen Hevaan nuotti (SKS KRA Borenius e 125). Voi olla, että joku muun runon yhteydessä esitetty sävelmä oli nimetty liekkunuotiksi, mutta kerääjä ei ollut tullut kirjoittaneeksi sitä ylös. Vöglän ja Okkulin jälkeen Borenius tallensi selvän liekkuvirren vielä Joenperältä ja Kattilasta (SKS KRA Borenius e 200, e 207, 209).
} 
Nämä "paikkasivat [...] verkkoja, olivat lasten hoitajina ja 'lauloivat lapsille aamusta iltaan', niin kuin Seiskarin huntupäinen emäntä 1935 kertoi." ${ }^{\prime 48}$

Toisen viisi-iskuisen liekkuvirren toisinnon (La mie katson liekkuani) merkitsi muistiin Launis Ropsun kylästä. Tyypillisestä liekkuvirren alkusäkeestä huolimatta kerääjä kirjoitti toisinnon yläpuolelle yksiselitteisesti "kehtolaulu." ${ }^{499}$ Kumpikin viisi-iskuinen sävelmä vaikuttaa siis lapsille laulamiseen liittyvältä poikkeukselta neli-iskuisten länsi-inkeriläisten liekkusävelmien joukossa. Matkakertomuksessaan Launis $(1904,53)$ tekeekin kytkennän liekku- ja kehtolaulujen välillä toiseen suuntaan: "Liekussa laulettiin erityisiä liekkunuotteja, joita joskus kehtolauluinakin käytettiin.” Tämä kertoo saman kuin Vöglän ja Okkulin pulmanuotti ja Vöglän liekkuruno: varsinaisesti seremoniallisempiin tilanteisiin liittyviä runoja ja sävelmiä laulettiin myös lapsille. Tällöin niiden jotkut piirteet tai niiden saamat nimet saattoivat vaihtua. ${ }^{950}$ Liekkuvirren teemoja saatettiin käyttää myös vapaasti kehtolaulun lomaan upottaen. Darja Lehti esitti Väinö Salmiselle sarjan kehtolauluteemoja ja lasten parannukseen käytettyjä loitsuja. Yhden kehtolaulusarjan aloitti kolmisäkeinen liekkuvirren teema ja lapsen liekkumiseen tai liekuttamiseen Lehti viittasi myös kahden varsinaisen kehtolauluteemansa alussa. ${ }^{951}$

Kummatkin tavallisista liekkunuoteista poikkeavat viisi-iskuiset sävelmätoisinnot selittyvät (myös) kehtolauluiksi. Liekkunuotin kategoria näyttäytyykin sisään sulkevana. Liekulla laulettiin ainakin aloitusteema yleensä tietyllä sävelmällä, mutta samaa sävelmää voitiin käyttää myös toisissa tilanteissa. Kehtolauluja kutsuttiin liekutusvirsiksi, joissa saatettiin käyttää joko varsinaisesta liekkuvirrestä rytmiltään poikkeavaa sävelmää tai, Launiksen mukaan, myös varsinaista liekkuvirren sävelmää. Voi tietenkin olla, että viisi-iskuisella sävelmällä laulettiin tai oli aikaisemmin ollut tapana laulaa myös varsinaisia liekkulauluja, vaikka tästä ei ole tallennettu selkeitä esimerkkejä. Pohjois-Inkerissä liekkusävelmä oli nimenomaan viisi-iskuinen. Keski-Inkerissä ja Virossa taas sävelmiä oli useampia paikallisia tyyppejä.

Vaikka kehtolaulut olivat tyypillisesti soololauluja, eivät ne olleet sitä täysin ehdottomasti. Launiksen laajan länsi- ja keski-inkeriläisen fonogrammikokoelman kenties hämmentävin laulu on esilaulajan ja kuoron esittämä kehtolaulu. ${ }^{952}$ Väinö Salminen $(1934,169)$ kritisoi äänitettä todeten terävästi, että "käytännössä ei liene tapa kutsua kuoroa lasta nukuttamaan." Launiksen oppilas ja seuraaja, A. O. Väisänen (1990, 64; ks. myös 108, 212) esitti opettajansa sävelmienjulkaisumetodia kritisoidessaan yksiselitteisenä, epäilemättä omiin kenttätöihinsä perustuvana

\footnotetext{
${ }_{948}$ SKS KRA Mannonen 11109; Borenius 6: 1093, ks. myös 6: 1006; Borenius e 714. Karjalasta ks. Virtanen 1968, 18-21; Tarkka 2005, 49; Huttu-Hiltunen 2008, 250-251, 271, 300. Pitkistä ja vanhoista virsistä esim. SKS KRA Alava VIIIa, 734a; Borenius e 84 ja 6: 808; e 102, ja 6: 847. Kullervo-runosta kehtolauluna ks. Timonen 2004, nootti 141.

${ }^{949}$ SibA Launis 37. Termi kehtolaulu on ilmeisesti Launiksen käännös liekutusvirrestä, lapsenvirrestä tai jostain muusta paikallisesta termistä, sillä kehtolaulu-termiä ei aineistoissa muuten esiinny.

${ }^{950}$ Rituaalisten laulujen käytöstä muissa konteksteissa ks. myös Virtanen 1994b, 236.

${ }^{951}$ SKS KRA Salminen V. 2892-2900. Näitä samoja lapsenvirren teemoja Lauri Laiho tallensi Lehdeltä yhtenäisenä, merkityksettömiä tavuja ja vaihtelevia refrenkisäkeitä sisältävänä ketjuna, joka ei kuitenkaan sisältänyt liekkuvirren aloitussanoja (SKS KRA Laiho L. 5133).

${ }^{952}$ SKSÄ A 300/42 b.
} 
mielipiteenään, että "nimenomaan kehto-, lypsy- ja paimenrunot on aina esitetty yksinlauluna." Kritiikkiin voisi tehdä muutaman loivennuksen: miksi ei olisi mahdollista, että useampi läsnäolija yhtyisi Vöglän ja Okkulin tavoin lapselle laulamiseen, vaikka tyypillisesti lapselle laulettaisiinkin yksin? Laululla voi myös olla monta samanaikaista kohdetta. Launiksen fonogrammilla kaksisäkeisellä sävelmällä laulettu runonpätkä jatkuukin muutaman nukutukseen liittyvän säkeen (Nukuta jumala lasta, makahuta maaria; tuu siä ukko uulitsalta, tuu siä unta tullessas; tuu siä unta tullessas ja vii siä itku mennessä) jälkeen huolilyriikan säkein (mitä tehnem miä polloine, mitä tehnen kui ellää; mitä tehnen kuin elläine, kuin miä kunniam pittää), joiden kaltaisia laulettiin tyypillisesti myös esilaulajan ja kuoron vuorotteluna. ${ }^{953}$

Yksityiseen piiriin kuuluvan kehtolaulun tuominen julkiseen äänitystilanteeseen saattoi olla hämmentävää. Tähän viittaa myös Valpuri Vohdan tapaus. Laulaessaan kolme laulua ilmeisesti Julius Mägisten fonografiin, hän esitti ensimmäisenä kehtolauluteeman, jonka viimeisten säkeiden väliin ja loppuun sekoittui hänen nauruaan. Tämän lisäksi hän lauloi nauramatta yhden häiden pilkkalaulun ja yhden tanssilaulun. Kertoessaan aikaisemmista tallennustilanteista Lauri Laiholle Vohta mainitsi näistä kolmesta laulusta ainoastaan kehtolaulun, vaa-sanalla sen laulamista merkiten: "Mägiste kävi tääl laului ottamassa truban sissää. Mie lauloin vaa: ää ää ämmän lasta." Muina tapauksina Vohta mainitsi ensimmäisen häneltä 17-vuotiaana tallennetun runon, Salmisen käynnin (arkisten) tuvanpesijäisten aikaan sekä sen, kuinka oli Enäjärvi-Haaviolle näyttänyt tanssimista naapurin rouvan kanssa, kaikki tavalla tai toisella erityisiä tai epätyypillisiä tilanteita. Vohdan naurureaktion ja jälkikäteen muistelemisen tulkitsisin tilanteen hämmentävyyden osoitukseksi. ${ }^{954}$

Launiksen tallentama kuoroversio kehtolaulusta saattoi tietenkin olla vain tallennustilanteen tuottama poikkeus. Voi olla, että esilaulaja, Ustenja Miikkulantytär Porfein nainen, ei halunnut laulaa yhtäkään laulua fonogrammille yksin ja arkisesti ilman kuoroa, tai sitten Launis itse halusi syystä tai toisesta liittää kuoron tähänkin lauluun. Laulun huolilyriikasta koostuva loppupuoli tuntuu joka tapauksessa suuntautuvan ennemminkin aikuisille kuulijoille tai (esi)laulajalle itselleen kuin nukutettavalle lapselle (vrt. Virtanen 1968, 20-21). Sen loppusanojen voi kohdistuvan myös kerääjään ja äänitystilanteeseen: mitä tekisin, kuinka olisin, kuinka pitäisin kunniani tässä vieraan miehen äänityslaitteeseen epämuodollista kehtolaulua laulaessani. Joka tapauksessa laululla näyttää olevan monta päällekkäista viitekehystä lapsen nukuttamisesta julkiseen joukkolauluun ja tallennustilanteeseen. Ne kaikki vaikuttivat omalta osaltaan lopputulokseen.

\footnotetext{
${ }_{953}$ Esim. SKS KRA Enäjärvi-Haavio 500; SKSÄ L89 b, 94 b.

${ }^{954}$ ERA, Fon. 372a; SKS KRA Laiho 5410; ks. myös Liite 1 laulajista. Mägisten fonogrammille tallentunut, alussa hieman häiriöitä sisältävä laulunpätkä ei sisällä Vohdan Laiholle mainitsemaa säettä, joka kuitenkin usein, myös vuoden 1937 äänityksissä, punoutuu osaksi samankaltaista teemojen ketjua. Olennaisinta muisteluksessa olikin ehkä vain se, että Vohta oli laulanut äänitystilanteessa juuri kehtolaulun.
} 


\section{LEINO LESKI}

Monenlaisia runoja saatettiin laulaa sekä rituaalisesti keskeisten runojen jatkona että itsenäisinä kokonaisuuksina tai teemaketjuina muissa tilanteissa, mutta näiden lyyristen ja eeppisten runojen laulamisesta tallennettiin kontekstimainintoja paljon vähemmän kuin rituaalisesti keskeisistä runoista. Tarkastelen seuraavassa vielä esimerkinomaisesti länsi-inkeriläisiä lyyris-eeppisen Leinon lesken runon toisintoja ja kontekstikuvauksia. Edellisten lukujen analyysit muodostavat tässä kehyksen, johon on mahdollista suhteuttaa myös muita kuin rituaalisesti keskeisiä lauluja.

Inkerinsuomalainen Valpuri Vohta lauloi Leinon lesken runon Elsa Enäjärvi-Haaviolle vuonna 1936 ja Aili Laiholle vuonna 1937 ja oli mukana kuorossa runon äänityksessä Tallinnassa vuonna $1937 .{ }^{955}$ Häneltä käsikirjoituksinakin tallennetuissa versioissa toistuu sama laulun perusrakenne ja sävelmän tuottama muoto kuin äänityksessä. Esilaulaja lauloi kaksi säettä ja kuoro toisti jälkimmäisen säkeen kuusi viimeistä tavua kahdesti. Vohta toisti kaikille tallentajille myös kuoron kertaukset, vaikka lauloi runoa muistiinkirjoittaneille kerääjille todennäköisesti yksin. Joko yksin laulamiseen tai kerääjien tulkintavaikeuksiin viittaa kertausrakenteen epäsäännöllisyys käsikirjoitusversioissa. ${ }^{956}$ Vohta teki kuitenkin selväksi, että kuoron tuli laulaa säkeen osittaiset kertaukset. Tämä kuoron osuuden painottaminen tuntuu korostaneen laulamisen kollektiivista luonnetta, vaikka se voi toki olla myös seurausta kummankin kerääjän kiinnostuksesta esittämistapoihin (ks. EnäjärviHaavio 1949; Simonsuuri 1972).

Saman laulun - sävelmän ja runon alun - oli äänittänyt jo A. O. Väisänen Helsingissä vuonna 1931 vierailleelta, inkeroislaulaja Jeodokia Räkälän johtamalta narvusilaiskuorolta. ${ }^{957}$ Räkälä oli Tallinnan äänitysten aikaan ilmeisesti kuollut tai siirtynyt Venäjän puolelle, mutta hänen kanssaan Helsingissä laulanut Mari Vahter esitti Tallinnassa Leinon lesken esilaulun. ${ }^{958}$ Kyseisestä sävelmätyypistä tai tekstuaalisesta muotorakenteesta ei ole aineistossa muita toisintoja. Se tosin muistuttaa Soikkolasta tallennettua, häälaulujen joukossa poikkeuksellista ounapuu-sävelmää, mutta kuoron osuus on yhden musiikillisen iskun ja yhden runomitallisen aseman pidempi ja eri tavoin rytmitetty. Muotorakenteen harvinaisuus viittaa siihen, että Vohta todennäköisesti käytti myös kerääjille ennen äänityksiä laulaessaan samankaltaista sävelmää kuin Tallinnassa laulaessaan:

\footnotetext{
${ }^{955}$ SKS KRA Elsa Enäjärvi-Haavio 467; A. Laiho 2291; SKSÄ L 87 c.

${ }^{956}$ Vain yhden säkeen pituiset esilaulajan osuudet täydentyisivät laulettuina luultavasti kerratulla edellisellä säkeellä, ja kolmen säkeen pituiset osiot laulettaisiin samanlaisen kertauksen avulla kahtena kuoro-osan erottamana parisäkeenä. Esilaulaja laulaisi siis aina kaksi säettä kuoro-osuuksien välillä, kuten äänitetyissä versioissakin. Näiden tekstitoisintojen vertaaminen äänitteisiin näyttää osaltaan, että lauletuista rakenteista kiinnostuneidenkaan keräjiien muistiinpanot eivät ole aina kaikilta osin tarkkoja.

${ }^{957}$ SKSÄ A 507/8b.

${ }^{958}$ Ks. Liite 1 Räkälästä ja Vahterista.
} 

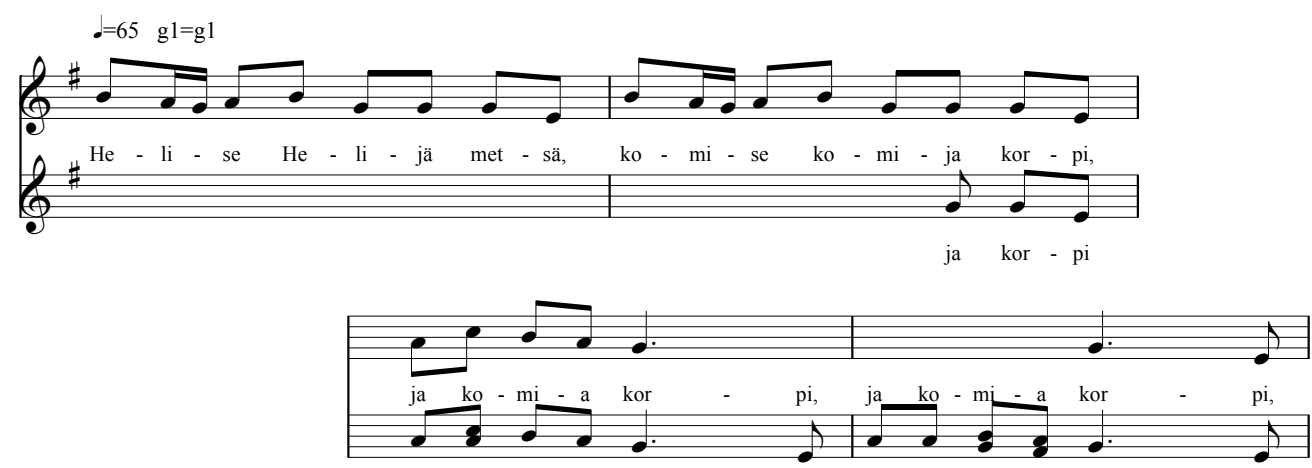

ja ko - mi - a kor - pi, ja ko - mi - a kor - pi,
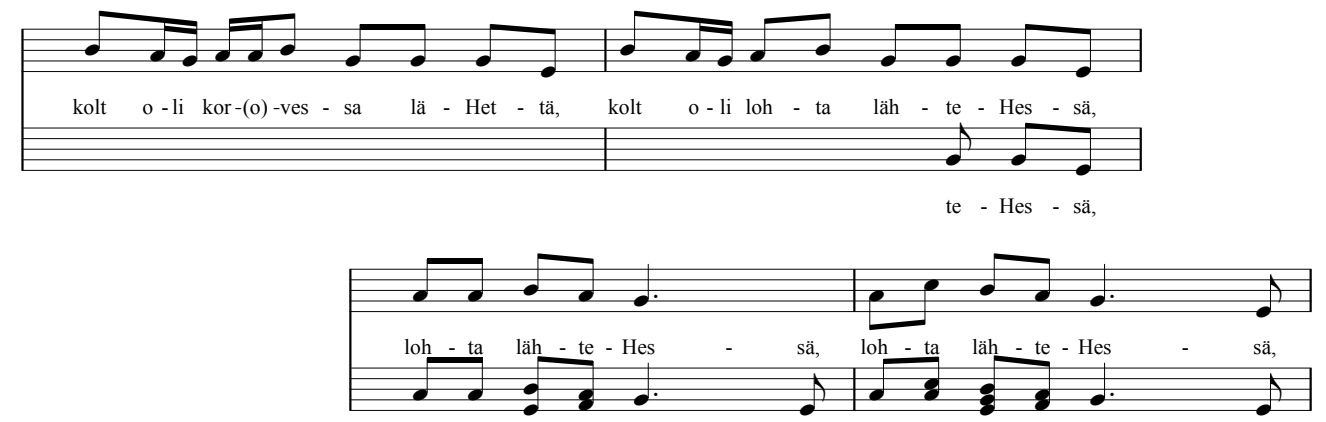

loh - ta läh - te - Hes - sä, loh - ta läh - te - Hes - sä,

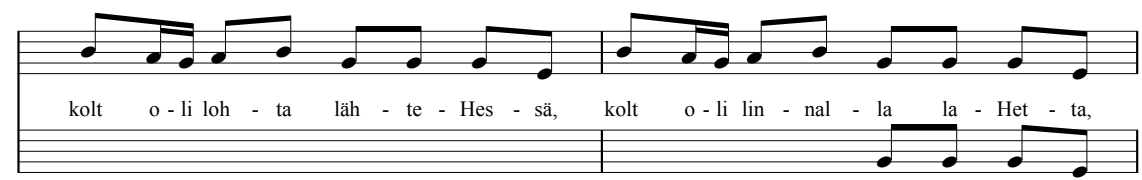

la la - Het - ta,

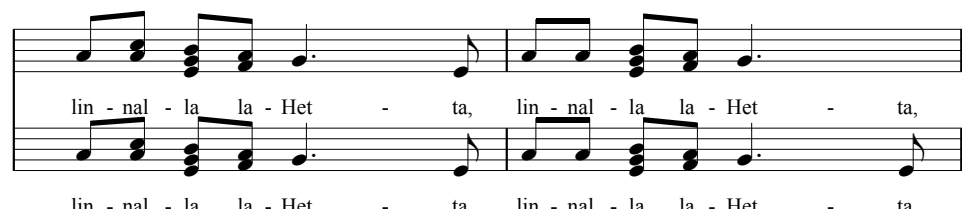

Nuotti 36. Ensimmäiset säkeet Mari Vahterin ja kuoron esittämästä Leinon lesken runosta, alla esilaulajan tekstiosuudet koko runosta (SKSÄ L 87c).

Helise Helijä metsä,

komise komija kor(o)pi!

Kolt ol'i kor(o)vessa läHettä,

kolt ol'i lohta l'ähteHessä,

kolt oli lohta lähteHessä,

kolt oli linnalla laHetta:

yks ol'i nuoren n'eijol l'inna,

toin ol'i nuorem mor(o)sijammen,

toin ol'i nuorem mor(o)sijamme(n),

kolomas(a) leski leina l'inna.

Kump ol'i nuorem mor(o)sijammen, se ol'i kullalla kuvattu,

kump ol'i nuorem mor(o)sijammen,

se oli hopialla huol'itettu,

kump ol'i leskel leina l'inna,

se ol'i vas(s)ella val'ettu.

En oo leski leina leski,

om miulla kolomet(e) vaa pojutta:

yks ono Ruotsissa rovasti,

toin ono piispa pappilassa,

toin ono piispa pappilassa,

kol(o)mas on(o) kotine herra. 
Runossa kehotetaan metsää helisemään ja komisemaan eli kumisemaan ja luodaan surrealistinen kuva kolmesta lähteestä metsässä, kolmesta lohesta lähteissä ja kolmesta linnasta lohissa. Runo viittaa naisen elämään kolmessa sosiaalisessa, asteittain huononevassa asemassa: nuoren neidon linna on tehty kullasta, nuoren morsiamen hopeasta ja leinon lesken vaskesta. Surulliseksi eli leinoksi nimetty leski kertoo, että hänellä ei ole syytä olla surullinen: hänellä on kolme poikaa, joista yksi on rovasti, toinen piispa ja kolmas "kotinen herra." Vohdalta ja kuoroilta tallennetut versiot eivät jatku yleisellä teemalla poikien kuolemasta - joka on usein tulkittu rangaistukseksi lesken edeltäneestä ylpeydestä (esim. Harvilahti 2004, 202; ks. myös Krohn 1932) - ja sitä seuranneesta lesken surusta ja turvattomuudesta (nyt oon leski nyt oon leina, nyt oon turvatoin tutilas). Ilman lisätietoja Vohdan laulamat versiot voisi siis tulkita vain puheenvuoroksi poikien äidin ylpeydestä. ${ }^{959}$ Äänitteillä laulavien naisten äänensävyt sekä laajempi käsikirjoitusaineisto kuitenkin vihjaavat, että runon laulamatta jääväkin loppu määrää laulun perussävyn. Äänitetyissä versioissa laulajien äänensävyt ovat vakavia ja heidän laulamisensa tasaista, ei esimerkiksi millään tavoin tanssinomaisesti rytmitettyä. Surullista eli halleeta sävyä ja paikoillaan laulamista toistavat myös Vohdan kontekstikuvaukset:

Pulmissa kun oltii, kai jo väsynneit, mentii lauvan taa ja pantii viinaputeli ettee ja käsi posel ja laulettii. Tämä on sellai hallee laulu. - Kesäl ku istuttii kallal, tämä oli istumalaulu. ${ }^{960}$

Tyttöjen guljanjessa ei laulettu tätä. Tätä ei näet voitu laulaa hulkkuen eikä tanssien. Naiset Jyrinpäivänä saattoivat laulaa tätä. Samoin voitiin tätä laulaa vaikkapa häissä, sitten kun varsinaiset häälaulut olivat ohi tai oli sopiva välikohta. esim. häiden lopulla, kun istuttiin pöydän ympäri sen jälkeen kuin "Tunsit tulla" oli laulettu. ${ }^{961}$

Kontekstikuvaukset osoittavat, että Vohta ei tulkinnut runon liittyvän mihinkään tarkkarajaiseen, tilannesidonnaiseen lajiin. Laulua voitiin laulaa useissa eri tilanteissa: sulhasen talossa hääpöydässä varsinaisten häälaulujen jälkeen, naisten Jyrinpäivän praasnikoilla tai joen kaltaalla istuessa. Vohta oli kuitenkin tarkka siitä, kuinka, missä ja keiden toimesta hänen surulliseksi (hallee) nimeämänsä runo voitiin laulaa. Vohdan antama tulkinta on poikkeuksellisen vahva ja selkeästi rajautuva. Laulajia olivat naiset, eivät tytöt, ja runoa tuli laulaa ainoastaan istuen, ei kuljeskellen (guljaanjes, hulkkuen) eikä tanssien. Laulun nimettyjä keskeiskonteksteja olivatkin naisten tärkeimmät laulutilaisuudet, Jyrin praasnikka ja häät.

\footnotetext{
${ }^{959}$ Myös osan laulamatta jättäminen tai runon osittain esittäminen voi olla tulkinta. Jekaterina Aleksandrova Soikkolasta lauloi Eino Kiurulle $(1990,108)$ ensimmäisen tapaamisen aluksi runon Kalervon ja Untamon veljessodasta ainoastaan "vainolaisten voimattomuutta kuvaavaan kohtaukseen" asti. Kiuru kertoo: "Kysyin, onko laululle jatkoa? Ei, ei kuulemma ollut." Seuraavalla tapaamiskerralla Aleksandrova kuitenkin lauloi myös runon traagisen lopun. Kiurun tulkinnan mukaan tämä johtui siitä, että ensimmäisellä tapaamisella laulaja halusi "korostaa ajatusta ihmisen sitkeydestä" ja päättää runon positiiviseen loppuun - ehkä hän ei myöskään halunnut syystä tai toisesta esittää traagista loppua täysin vieraalle ihmiselle. Keskeneräisen tai katkonaisen oloiset runot eivät aina ole sitä laulajan osaamattomuuden tai muistamattomuuden takia, vaikka sekin on kontekstitiedottomien runojen kohdalla yksi tulkinnallisista vaihtoehdoista (ks. myös Anttonen 1994, 199).

${ }^{960}$ SKS KRA Laiho A. 2291.

${ }^{961}$ SKS KRA Enäjärvi-Haavio 467.
} 
Tämä poikkeuksellisen laaja ja monisävyinen kontekstikuvaus ei kuitenkaan kerro kaikkea runon laulamisesta edes Vohdan kotikylässä Kallivieressä. Inkerinsuomalainen, lähes 70-vuotias Maria Otsa lauloi saman runon Lauri Laiholle vuonna 1938. ${ }^{962}$ Hänen kontekstikuvauksensa asettuu oikeastaan Vohdan kuvauksen vastakohdaksi. Otsan mukaan runoa lauloivat nuoret tytöt tanssiessaan: "Kons mäntii kallaalle nuoret, siis mäntii ympärikkoo ja laulettii." Runo alkaa kontekstikuvausta vahvistavalla tanssiformulalla Täs on lusti nuoren noissa, kaunis kassapään karata ja jatkuu lähes sanasta sanaan samana Leinon lesken runona kuin Vohdan laulamat versiot.

Näiden kahden samaa etnistä ryhmää edustavan, samassa kylässä asuneen naisen vastakkaiset tulkinnat voisi selittää useammalla tavalla. Voisi olla, että laulajat vain kertoivat kerääjälle eri ikäryhmän näkökulmat: Vohta aikuisen naisen surullisen laulun, Otsa nuoren naisen tanssilaulun. Runossahan on toisaalta kuvattu neidon elämä eli linna kultaiseksi, toisaalta nostettu esiin aikuisen naisen leskeyden ja turvattomuuden mahdollisuus: eri ikäryhmien laulamana saattoi tulkinnassa painottua jompikumpi. Tytön näkökulmasta runo saattoi näyttäytyä joko varoituksena tulevasta tai oman huolettoman elämän ylistyksenä. Naisen näkökulmasta, leskestä puhumattakaan, runo saattoi kertoa konkreettisemmista uhkakuvista tai jo tapahtuneista asioista. Tyttöaikojen huolettomasta vapaudesta ja laulusta luopuminen naimisiin mennessä - Leinon lesken runossa linnan vaihtuminen yhä huonompaan - on runostossa ja itkuissa ylenpalttisena esiintyvä teema (ks. Nenola-Kallio 1982, 113-181; Timonen 2004, 117-125)..$^{963}$

Vohdan ja Otsan tulkintojen eroihin on kuitenkin muitakin mahdollisia selityksiä. Kumpikin laulajista asui tallennushetkellä Kallivieressä, mutta siinä missä Vohta oli Kallivierestä syntyisinkin, oli Otsa kotoisin Vyötermaan kylästä. Hän oli muuttanut Kalliviereen naimisiin mennessään. Vohta puolestaan oli naimisiin mennessään muuttanut ensin miehensä kotikylään Vyötermaalle, mutta pariskunta oli tullut jo neljän vuoden kuluttua takaisin hoitamaan Vohdan vanhempien taloa. Vohta kertoi alueellisten erojen olevan tunnistettavia: "Neljä vuotta vaa olin Fyödermaalla. Siel oli jo toine murre lauluil." ${ }^{964}$ On vaikea sanoa, mihin kaikkeen "laulun murre" voi viitata: kielen ja runoteemojen käsittelyn lisäksi kenties myös laajemmin laulamisen tapoihin. Kahden laulajan erilaiset Leinon lesken tulkinnat voivat siis viitata myös alueellisiin laulukäytäntöjen eroihin.

\footnotetext{
962 SKS KRA Laiho L. 4832.

${ }^{963}$ Esim. SKVR III 904, 1015.

${ }^{964}$ SKS KRA Laiho L. 5409. Vrt. Maria Luukan laulamisesta runojen murteen ja sisällön puolesta joko kaipaalaisittain tai vyötermaalaisittain (Kuusi 1983a, 201).
} 
Jos tarkastellaan Narvusin alueen inkeroisten Leinon lesken runosta antamia tulkintoja, laajenee kuva entisestään. Inkeroislaulajilla Leinon lesken runo yhdistyy vahvasti metsässä tai läpi kylän kuljettaessa laulamiseen ja tyttöihin. ${ }^{965}$ Anna Kivisoo kertoi tyttöjen laulaneen runoa metsään joukolla lähtiessään, kun "lähettii tytöt yhes kampas metsää marjoi syömää."966 Tällä kertaa, kuten Senni Timonen (2004, 100-102) on todennut, runon avausformula Helise heliä metsä kytkee sen luontevasti myös paikalliseen metsän virren kategoriaan. ${ }^{967}$ Toisaalta Kivisoo esitti toisella kertaa laulun ilman metsä-johdantoa ja kontekstimainintaa, aloittaen Kolt oli korvessa lähdettä -teemasta. ${ }^{968}$ Toinen inkeroislaulaja, Maria Hauki, käytti Lauri Laiholle laulaessaan saadulmoi-refrenkiä, joka aineistossa tyypillisesti liitetään rituaaliseen kylien tai kylän läpi kulkemiseen praasnikoilla ja häissä. ${ }^{969}$ Saadulmoi-sävelmä lauletaan ääniteaineistossa aina suhteellisen nopealla tempolla, selkeästi rytmittäen. Hauki lauloi ensin usein tähän refrenkiin liittyvän oman kylän ylistyksen Kylähäni linnahani mainiten samalla: "Tytöt laulavat kulkiessa." Kylän ylistys kuitenkin päättyi äidin kuoleman teemaan: ei vaa pitäs miulla laulaa [...] mie vast kullan kuolettelin, maamon maaha mättäelin. Heti tätä seurasi Leinon lesken runo, johon liittyi hänen mukaansa sama refrenki. Muita runoja laulaessaan hän ei refrenkejä maininnut. Hauella tyttöjen kulkemisenkin tilanne pitää sisällään selkeän surullisia teemoja. ${ }^{970}$ Saadulmoi-sävelmään liittyykin aineistossa myös huolilyriikkaa ja traagista lyyristä epiikkaa. Surullinen painotus näyttäytyy selvästi yhtenä tällaiseen laulamiseen liittyneenä tunnetilana, vaikka sävelmä viittaakin ripeään tanssiin tai kulkemiseen ja tyypilliset luvussa 5 tarkastellut aloitusteemat ovat valoisia Oman kylän ylistyksiä.

Leinon lesken runoon tyypillisesti liittyviä alkusäkeitä tallennettiin Länsi-Inkeristä useilla erilaisilla sävelmätyypeillä. Näitä liittyi myös moniin sellaisiin sävelmiin, joita ei lainkaan esiinny hää- tai praasnikkalaulujen yhteydessä. ${ }^{971}$ Monista muutaman säkeen pätkistä on toisaalta mahdotonta sanoa, mahtoiko alkusäkeitä todella seurata Leinon lesken runo vai jotain aivan muuta, sillä runolle tyypilliset alkusäkeet saattoivat joskus liittyä myös muihin teemoihin.

Runoa tallennettiin moninaisina kontekstitiedottomina ja sävelmättöminä versiona muiltakin länsi-inkeriläislaulajilta, sekä inkeroisilta että inkerinsuomalaisilta. Sen variaatiota on tarkemmin käsitellyt Lauri Harvilahti (2004). Runo voitiin lau-

\footnotetext{
965 Samankaltaisella tavalla inkerois-inkerinsuomalainen, nimensä perustella ortodoksi Fenja Filippova Pärspään kylästä esitti saadulmoi-sävelmällä ensin valoisasti oman kylän ylistyksen teemoja, mutta lauloi runon lopuksi särkyvällä äänellä kylän vieressä olevan meren tappaneen häneltä miehen (Rüütel 1979, raita 22). Okuliina Nikkanantytär Hevaan Vepsän kylästä jatkoi laulajan sanojen Kui miä noisen laulamaha jälkeen Leinon lesken alkusanoja, kuoron kerratessa saadulmoi-refrengin (SKSÄ A 301/20 b).

966 SKS KRA Laiho L. 5324.

${ }^{967}$ Ks. myös Launis 1907, 108.

968 SKS KRA Salminen K. 279.

${ }^{969}$ SKS KRA L. Laiho 5213, ks. luku 5.

970 Samalla tavoin Väärnojan suomalaiskylästä kotoisin ollut Sohvi lauloi Savimäen inkeroiskylässä Porkalle Oman kylän ylistyksen teemoja, jotka päätyivät Leinon lesken runoon (SKVR III 1586).

${ }_{971}$ SibA Launis 33, 36, 60, 274, SKS KRA Alava X s. 28. Pikakirjoitusvihko I (II); Hevaalta SKS KRA Levón 449, 506.
} 
laa sellaisenaan ${ }^{972}$ tai yhdistää se muihin lyyrisiin ja lyyris-eeppisiin teemoihin. ${ }^{973}$ Jälkimmäisessä tapauksessa yhdistelmien mahdollisuuksia on paljon - yksi laulaja jopa yhdistää lesken pojat traagisesta veljessodasta kertovaan Kalervon ja Untamon runon hahmoihin. ${ }^{974}$ Tyypillisimmin kokonaisuudet kuitenkin kertovat naimiisiin menneen naisen kohtalosta joko kuvaten, varoittaen tai valittaen; runoon yhdistyvien teemojen yleinen sävy on yleensä traaginen tai surullinen. ${ }^{975}$

Kaksi runoteksteihin liittyvää kommenttia vahvistaa paikallisen tulkinnan traagista pohjavirettä. Sekä inkeroislaulaja Naastoi Soikkolan Tarinaisista että inkerinsuomalainen Juljaana Pohjalainen Narvusista esittivät Leinon lesken perusteeman ilman erityisiä avausformuloita, laulullisia rakenteita tai runoon assosioituvia lisäteemoja. Kumpikin heistä viittasi kuitenkin samalla läheisen sukulaisen kuolemaa seuranneeseen vuoden kestävään suruaikaan. Naastoi kertoi: "Meillä kun kooloo, siis leinataa: ei pietä punaista mitää, eikä lauleta eikä tantsita siis." ${ }^{\prime 976}$ Pohjalainen selitti tarkemmin: leina tarkoitti murhetta. Suruajan nimi oli lein-aasta (vuosi) tai lein-aika: "Pilliki seisoo seinäl, ei sitä saa soittaa."977 Suruaikana ei heidän mukaansa laulettu, tanssittu eikä soitettu, eikä ilmeisesti praasnikoillakaan pidetty punakirjonnoilla koristettuja juhlapaitoja. Samankaltaisesti Volmari Porkka $(1886,153)$ kertoo Hevaan inkeroiskylissä ihmisten kieltäytyneen laulamasta, jos heiltä oli lähiaikoina "joku läheinen sukulainen kuollut." Kummallakin länsi-inkeriläislaulajalla juuri Leinon lesken runon esittäminen johti lisäselityksiin.

Ensisilmäyksellä näiden kommenttien ja runoon yhdistyvien teemojen surulliset ja traagiset sävyt näyttävät olevan selkeässä ristiriidassa suhteessa Maria Otsan kuvaukseen tanssivista tytöistä tai inkeroislaulajien viitteisiin juhlavasta tai tanssillisesta läpi kylän kulkemisesta. Runoteeman käyttömahdollisuuksien hahmottaminen edellyttääkin vielä katsausta inkeriläisen tanssin ja surun liittymäkohtiin. Kuten luvussa 5 todettiin, monet 1930-luvun laulajat yhdistivät hitaasti laulamisen suruun ja paikoillaan oloon tai hitaasti kulkemiseen, nopeasti laulamisen riehakkaseen, hilpeään tanssiin. Muutamat toisinnot kuitenkin estävät yksiselitteisten yleistyksien tekemisen.

Maria Otsan Leinon lesken runossa käyttämä aloitusformula Nyt on lusti nuoren noissa oli yleinen tanssinaloitusformula, jota käytettiin myös runojen keskellä. ${ }^{978}$ Vuoden 1937 äänityksissä Tallinnassa Anna Kivisoo aloitti yhden esilaulunsa juuri tällä formulalla. Naiset lauloivat nopealla, säkeen lopun osakertauksen sisältävällä sävelmällä, jota he käyttivät myös moniin riehakkaisiin tanssilauluihin sekä sellaisiin praasnikkalauluihin, joita laulettiin ympärikossa tai tanssien. Laulu on rytmi-

\footnotetext{
${ }^{972}$ SKS KRA Haavio 2530, L. Laiho 4803; SKVR III 1817.

${ }_{973}$ SKVR III 1407, 1445, 1509; XV:805; SKS KRA L. Laiho 5112; ks. myös Harvilahti 2004, 206.

${ }^{974}$ SKVR XV 805.

${ }^{975}$ Ks. esim. SKVR III 1445, 1509.

976 SKVR III 2293, nootti 4; laulusta ks. myös Harvilahti 2004, 202-206.

${ }^{977}$ SKS KRA Haavio 2530.

${ }^{978}$ Esim. SKVR III 881; 2428; 2531; 2647; 2720; 2928. Yksi tuntematon narvusilaislaulaja kytki aloitusformulan Otsan tavoin Leinon lesken runoon (SKVR III 3245).
} 
kästä, nopeaa ja tanssinomaista, kuoro-osaa vielä rytmitetään paikoin korkeilla kiljahduksilla. Juuri tämän laulun yhteydessä laulajat kuitenkin kuulostavat samalla kuolemanvakavilta. Runossa todetaan, että tanssi on lustia eli hauskaa ainoastaan sille, jonka vanhemmat ovat elossa. Runon minä päätyy ikävissään äitinsä haudalle puhumaan, itkemään ja riitelemään ristin kanssa. Äiti vastaa haudasta ja kehoittaa tytärtä tyyntymään, sillä täm on tehnyt Luojoin seppä, Luojoin vasarat takkoonu (Emon haudalla). ${ }^{979}$

Hyvin samankaltainen, vielä selkeämpi esimerkki löytyy myöhemmältä äänitteeltä. Vuonna 1972 Natalja Ivanovna Lukina lauloi lyyrisen huolirunon läheisen kuolemasta aivan samaa tanssisävelmää ja muotorakennetta käyttäen. ${ }^{980} \mathrm{Hän} \mathrm{lau-}$ loi nopeasti ja rytmikkäästi, jokaisen säkeen osakertauksineen kerraten, kuin olisi laulanut kuoron kanssa, ja kertoi, että kyseistä laulua laulettiin ympärikossa tanssien. Laulunsa hän aloitti toisella tanssiin liittyvällä yleisellä aloitusformulalla, mutta Maria Otsan käyttämä säe seurasi sitä: Tehkää yksi ympärikkö, ympärikkö [...]. Täss on lusti nooren noissa, nooren noissa; lusti ol luita liikutella, liikutella. Runo siirtyy jonkin ajan kuluttua yleiseen, usein ilman aloitusformuloita esiintyvään aiheeseen: el luvannut laulaella, laulaella [...]: vast mie kullan hautasin $i$, hautasin $i "$ (Ei minun laulella pitäisi). Nauhalta voi kuulla laulajan itkevän laulaessaan. Nopeatahtisen tanssin aikana oli siis mahdollista laulaa myös henkilökohtaisesta surusta, itkeäkin. Ehkä se oli myös keino praasnikkojen ja häiden viettoon osallistumiseen. Suruaikana ei ollut sopivaa laulaa ja tanssia, mutta jos samalla toi surun laulullaan esiin, saattoi rajoituksen kenties ohittaa - toinen vaihtoehto tietenkin on, että surun teemoja käytettiin tanssissa vasta varsinaisen lein'ajan jälkeen. Olennaisinta on kuitenkin huomata, että länsi-inkeriläinen juhlinta piti laulajien kuvauksissakin sisällään suuren kirjon erilaisia sävyjä. Esimerkiksi Darja Lehden Jyrinpäivän praasnikan kuvauksessa itkuvirret tai kyynelillä itku ("itettii") lomittuvat luontevasti osaksi tanssia ja laulua: "Tantsittii, itettii, laulettii, kiukaal oli ieslaulaja, toiset löivät tantsuu permannol." ${ }^{\text {981 }}$ Otsan kuvaus tanssivista tytöistä ei lopulta mitenkään kiellä Leinon lesken runon traagista taustavirettä, sillä tanssi, laulu, nauru, suru ja itku mahtuivat samaan tilanteeseen.

Valpuri Vohdan kahdelle kerääjälle, Enäjärvi-Haaviolle ja Laiholle antamat kontekstikuvaukset kuuluvat ennen toista maailmansotaa tallennetun aineiston piirissä ehdottomasti monisyisimpien joukkoon. Silti ne eivät ole täydellisiä, kaikenkattavia selityksiä runon käyttömahdollisuuksista. Vohta liittää laulun moniin tilanteisiin kuin antaen esimerkkejä sen käytöstä, mutta samalla kuvauksen keskeiset piirteet pysyvät samoina kummassakin kuvauksen versiossa: häät olivat keskeinen runon esitysareena, laulajia olivat naiset, jotka istuivat. Silti nämä tyypillisyydet eivät kerro kaikista laulun painotuksista Länsi-Inkerissä, Narvusissa tai edes Kallivieren kylän inkerinsuomalaisten parissa. Näyttää siltä, että kerääjän kysyessä jonkin runon konteksteista laulajat eivät suinkaan pyrkineet kattavaan selitykseen,

\footnotetext{
${ }^{979}$ SKSÄ L 89b.

${ }^{980}$ ERA RKM, Mgn. K 42 (3).

${ }^{981}$ SKS KRA L. Laiho 5165.
} 
vaan ennemminkin viittasivat johonkin itselleen keskeiseen tilanteeseen. Rituaalisesti painokkaimpien ja tiettyyn esitysareenaan keskeisesti kuuluvien laulujen yhteydessä kuvaukset ovat suhteellisen yhteneväisiä, muiden runojen kohdalla ne hajoavat enemmän. Erilaiset yksilölliset tulkinnat saattoivat olla laulajan ikäryhmän, etnisen ryhmän, kylän, perheen tai näiden kaikkien jakamia, mutta ne eivät välttämättä kuvastaneet ainoaa mahdollista tulkinnallista kehystä. Esimerkiksi samassa kuorossakin laulamaan kyenneiden Valpuri Vohdan ja Anna Kivisoon antamat tiedot Leinon lesken runon käyttöyhteyksistä olivat hyvin erilaisia.

Yhteenkin runoteemaan voi liittyä osin vastakkaisia tulkintoja ja assosiaatioita, joita voidaan luoda monella esityksen tasolla: runotekstin, musiikin, laulun muotorakenteen, liikkeen tai vain tiettyyn tilanteeseen sijoittamisen kautta. Tuntuu siltä, että monet lyyriset ja lyyris-eeppiset teemat olivat juuri tällaisia: vapaita sekä vakiintuneille käytöille että moninaisille tulkinnoille. Tätä vakiintuneisuuden ja vapauden dialektiikkaa käsittääkseni kuvaa myös Leinon lesken runonkin yhteydessä tehtävä havainto siitä, että vaikka teemojen ja runojen moninainen toisiinsa yhdistyminen on käsikirjoitusaineistossa hyvin yleistä, esiintyvät jotkut runot tyypillisesti sangen kiinteinä tekstuaalisina kokonaisuuksina. 


\section{Miten laulu Merkitsee?}




\section{Miten laulu merkitsee?}

Länsi-Inkeristä on tallennettu yksi laajimmista ja monipuolisimmista kalevalamittaisen runon esittämisen tavoista kertovista aineistoista. Inkerissä julkinen ja rituaalinen kalevalamittainen laulu oli naisten hallussa, ja se oli muodoiltaan vakiintuneempaa kuin esimerkiksi arkinen laulu tai miesten laulu. Naisten julkinen laulu kiinnosti kerääjiä niin paljon, että sitä tallennettiin runsaasti. Tallenteiden määrä tekee mahdolliseksi jaettujen käytäntöjen tarkastelun, minkä kautta on tulkintani mukaan mahdollista pyrkiä myös kohti esitystapojen kantamien merkityskenttien ymmärtämistä. Tallenne - muistiinpano tai äänite - on ainoa nykytutkijan ulottuvilla oleva ikkuna inkeriläiseen kalevalamittaiseen lauluun. Samalla se on kuitenkin syntynyt hyvin erityisessä tilanteessa. Inkeriläisen laulun tilannesidonnaisen rakentumisen vuoksi tallennustilanteen luonteen ymmärtäminen on erityisen tärkeää. Käsillä olevassa työssä keskeistä onkin ollut esittäjien ja kerääjien kohtaamisen, tallennushetken, tallenteen, tallennuksen kohteena olleen esityksen ja sen taustalla olleiden laulajan hallitsemien kulttuuristen mallien suhteiden pohtiminen.

Tutkimus on ollut edestakaista liikettä yleisen ja yksittäisen välillä: yksittäisen laulun, esittäjän, hetken, tallennustilanteen tai muistiinpanon ja yleisten tulkintakehysten, tapojen tai konventioiden, arkistoaineistosta havaittavissa olevien toistuvuuksien ja poikkeuksien. Olen käynyt läpi laajan aineiston ja etsinyt siinä toistuvia tietynlaisen tilannesidonnaisen esitystavan eli rekisterin ja tietyn kulttuurisesti tyypillisen esitystilanteen eli esitysareenan yhdistelmiä, joita olen tulkinnut totunnaisina ja paikallisyhteisöissä jaettuina laulamisen malleina. Laulajien nimeämät rekisterit ovat myös tunnistettavissa paikallisiksi lajeiksi. Työn taustalla on teoreettinen malli, jonka mukaan kiteytyneet kielenkäytön ja esittämisen tavat assosioituvat tyypillisiin käyttöyhteyksiinsä ja saavat sosiaaliset merkityksensä ja monikäyttöisyytensä juuri näiden assosiaatioiden kautta. Rekisterit ja esitysareenat ovat tulkinnallisia kehyksiä, joiden aktivoimiseksi ei kuitenkaan aina tarvita kaikkia niihin tyypillisesti kuuluvia tekijöitä. Olenkin etsinyt myös pieniä ja yksittäisiäkin viitteitä erilaisten piirteiden merkityksellisyydestä sekä siitä, miten niitä eri yhteyksissä käytettiin. Lopulta olen palannut tulkitsemaan yksittäisiäkin laulutilanteita - niistä tallennettuja muistiinpanoja, äänitteitä ja kuvauksia -toistuvien piirteiden pohjalta luomieni laajempien kehysten kautta.

Työn merkittävimmät huomiot koskevat esityksen ja sitä kautta viittauksellisuuden, lajijärjestelmän ja merkitysten muodostamisen monitasoisuutta, tallennustilanteessa syntyneiden esitysten kerrostuneisuutta sekä runon tekstuaalisten, musiikillisten ja esityksellisten piirteiden osin käytännöllisiä, osin kulttuurisesti konventionaalisia sidoksia. Samalla vahvistuu ja monipuolistuu Senni Timosen (2004) esiin nostama huomio tilanteen ja tekemisen keskeisyydestä inkeriläisen laulun paikallisten käytänteiden ymmärtämisessä. Uutta on havainto julkisen rituaalisesti sävyttyneen laulun kiinteydestä: tiettyihin tilanteisiin viittaavissa lauluissa tietyn- 
tyyppiset runot, sävelmät ja laulamisen tavat liittyvät säännöllisesti toisiinsa. Tämä muistuttaa läheisesti virolaisesta runolaulusta tehtyjä huomioita.

Keskeistä työssä on ollut esityksen monitasoisuuden ja sen rakentumisen ehtojen hahmottaminen. Laulaja ei tehnyt valintoja ainoastaan runonsa kielellisen sisällön ja muodon, vaan myös esitystavan moninaisten, toisiinsa kietoutuvien piirteiden suhteen. Siinä missä tietyt runot, myös esitystavat kantoivat erilaisia viitteitä kulttuurisesti tyypillisiin laulutilanteisiin ja laulamisen sävyihin: sävelmä saattoi olla vaikkapa liekkunuotti, runosäkeiden välissä toistuvat refrengit saattoivat konventionaalisen käyttöyhteytensä kautta viitata joukolla läpi kylän kulkemiseen, hidas laulamisen tahti kantoi mukanaan surullista tai juhlavaa tulkintakehystä tai tunnelmaa. Esitys rakentui toisaalta paikallisten konventioiden, toisaalta lauluhetken tarjoamien mahdollisuuksien mukaan. Se, mikä varioi ja miten runoaiheita, sävelmiä ja erilaisia esityksellisiä piirteitä punottiin toisiinsa, vaihteli tilanteittain.

Erilaiset laulamisen piirteet assosioituvat ja liittyvät hyvinkin vaihtelevin tavoin toisiinsa, tilanteisiin, runoihin, tunnelmiin ja tiloihin. Laulukulttuurin jäsenille ne tulkintani mukaan kertoivat laulun tunnelmasta, juhlallisuuden tai muodollisuuden asteesta, lajista ja kontekstista, laulajan suhteesta lauluunsa. Ne loivat laulussa muotonsa saaneelle runolle tietynlaisen esteettisen ja tulkinnallisen kehyksen. Arkistoaineistosta esityksellisten piirteiden merkityskentät ovat usein jäljitettävissä ainoastaan epäsuorasti ja vaillinaisesti. Etsiessäni laulukulttuurin tyypillisiä piirteitä keskeiseksi on muodostunut se, mikä toistuu usean kerääjän aineistossa. Yhden tulkinnallisen haasteen asettaa kommunikaatiojärjestelmien joustavuus. Aineistosta löytyy viitteitä siitä, että erilaisia piirteitä voi käyttää monin tavoin, monen sävyisinä. Jollain piirteellä voi olla tyypillisin, ensisijainen assosiaatiokenttänsä ja lisäksi erilaisia toissijaisia tai hetkellisiä merkityksiä. Esimerkiksi kokkovirren aloitussanat Tulkaa tytöt tulelle viittaavat ensisijaisesti kokolle kulkuun, mutta ne tulivat käytetyksi myös osana tyttöjen häävirsiä, jolloin kyse ei ollut konkreettisesta tulelle kutsusta vaan ennemminkin viitteestä tyttöjoukon yhtenäisyyteen ja yhteiseen historiaan. Nopeilla riehakkailla tanssisävelmillä taas saatettiin laulaa myös surusta, vaikka yleisenä käytäntönä olisikin ollut laulaa surusta hitaasti. Etenkin poikkeuksellisten yhdistelmien kohdalla olen joutunut erikseen miettimään, millä tavalla tallenne tulisi tulkita ja ottaa huomioon: onko kyseessä sattuma, virhe vai jollain tavalla merkityksellinen yhdistelmä? Kun ensisijaisena tutkimuskohteena eivät ole yksittäiset piirteet vaan se, miten niitä käytetään ja miten laulukulttuuri jäsentyy, ovat poikkeuksetkin mielekkäitä tarkastelun kohteita. Ne kertovat variaation rajoista ja mahdollisuuksista. 


\section{KERUUHETKI}

Inkeriläinen laulu ja paikalliset käsitykset laulamisen lajeista olivat tilannesidonnaisia. Laulaminen on aina multimodaalista: sen voi hahmottaa erilaisten tekstuaalisten, musiikillisten ja esityksellisten tekijöiden summana. Näitä olivat Inkerissä esimerkiksi erilaiset runosäkeet, kertaukset ja osakertaukset, rytmit, tempot, sävelkulut, refrengit, äänenlaadut ja -voimakkuudet, lisätavut, tavumuutokset ja liikkeet. Erilaiset piirteet viittaavat mikä vahvemmin, mikä heikommin erilaisiin tyypillisiin käyttöyhteyksiinsä (esitysareenoihinsa) ja näihin liittyviin lajeihin, esittäjiin, sävyihin, tunnelmiin, vuodenaikoihin ja tiloihin. Piirteet kantoivat erivahvuisia siteitä toisiinsa: tietyt piirteet edellyttivät toisiaan (vaikkapa tietynlaiset osakertaukset tai refrengit tietyn pituista sävelmää), toiset olivat vaihtelevammin tai moninaisemmin yhdisteltävissä. Juuri tilanne ja laulamisen tapa määrittivät paikallisten lajien luonnetta. Keskeisimpien, rituaalisimpien tai vakiintuneimpien esitysareenoiden ja rekistereiden ulkopuolella laulu rakentui vapaammin, ja tällöin oli mahdollista myös hyödyntää vakiintuneempien esitysareenoiden ja rekistereiden piirteitä. Ne olivat laulajien käytössä olevia keinoja muokata esityksen sävyä ja sen kantamia merkityksiä, luoda esityksen tulkinnallinen kehys.

Luvussa 3 käsittelin arkistoaineiston syntyä runonkerääjien ja laulajien kohtaamisissa toisaalta kummankin osapuolen henkilökohtaisten ominaisuuksien, tavoitteiden ja kykyjen, toisaalta käytetyn tallennustekniikan ja tallennuksen tavoitteiden tuloksena. Näiden tekijöiden myötä eri kerääjien tuottamat aineistot eroavat toisistaan huomattavasti. Vaikka vain harvoin on yksityiskohtaisempaa tietoa siitä, minkälaisen konkreettisen vuorovaikutuksen tai yhteistyön tuloksena aineistot ovat muodostuneet, on joitain päätelmiä mahdollista niissä esiintyvistä piirteistä tehdä. Emme tiedä hetkellisestä kommunikaatiosta, mutta nähtävillä on sen tuloksena tallennettu tietynlaisten runojen, sävelmien tai laulujen ketju. Ketju ei sisällä kaikkea laulajan ehdottamaa tai keräjän kysymää, vaan ainoastaan ne runot tai sävelmät, jotka ovat kerääälle kelvanneet ja jotka laulaja on sekä halunnut että osannut esittää.

Tallentajan lähtökohtia ja tulkintoja on usein luettavissa matkakertomuksista, päiväkirjoista tai hänen myöhemmin julkaisemistaan tutkimuksista. Esittäjän tulkinnoista voimme tietää ainoastaan sen, mitä tallennetun aineiston pohjalta on mahdollista päätellä. Tässä laulukulttuurin perusteiden, sen kommunikaatioluonteen ja merkitysten muotoutumisen logiikan ymmärtämisellä on keskeinen rooli. Samalla on selvää, että kerääjät saati heidän aineistojaan jälkikäteen tulkitsevat tutkijat ei ole voineet eivätkä voi tavoittaa kaikkea siitä, mitä laulukulttuurin täysivaltainen edustaja olisi yksittäisistä lauluista ymmärtänyt, saati sitä, mitä kaikkea yksittäisen laulun esittäjä laulullaan tarkoitti tai mitä kaikkea esitys hänelle merkitsi.

Tallennustilanteet olivat erilaisia. Arkipäivään sijoittuva kerääjän ja esittään kohtaaminen tuvan pöydän ääressä oli aivan muuta kuin kerääjän ilmestyminen keskelle hää- tai praasnikkahumua. Toisinaan myös arjen piiriin sijoittuva kohtaaminen määrittyi arjen ulkopuolelle: naisjoukko saattoi innostua laulamaan kovaääni- 
sesti juhlalauluja tavallisena arki-iltana ja viitata tällöin sanallisestikin tilanteeseen juhlien viitekehyksen kautta. Paljon riippui myös tallennustekniikasta ja -teknologiasta. Yhden ihmisen tallentaminen tuotti joiltain osin erilaisia esityksiä kuin ihmisjoukon, sanelusta tallentaminen erilaisia kuin laulusta, kynällä ja paperilla tallentaminen erilaisia kuin fonografilla, laulajien tallentaminen paikan päällä erilaisia kuin muutaman ihmisen vieminen kaupunkiin äänitettäväksi radiostudiossa. Nämä tekijät eivät vaikuttaneet ainoastaan siihen, mitä runoja tallennettiin, vaan myös siihen, minkälaisia piirteitä esittäjät laulussaan käyttivät, miten he laulunsa nimesivät ja miten he laulunsa luonteen kautta määrittivät myös itse esitystilannetta.

Tallenteiden kuvaamiin esityksiin näyttää tallennustekniikkaakin enemmän vaikuttaneen tallennuksen päämäärä. Vaikka kaikki tässä työssä tarkastellut kerääjät tallensivat kalevalamittaista runoa, olivat he kiinnostuneita sen eri puolista. $\mathrm{He}$ pyysivät eri asioita: tietynlaisia tekstejä, konteksti- tai esitystietoja, sävelmiä, lauluesityksiä. Lähinnä runotekstejä (usein sanellen) tallentamaan pyrkineet kerääjät tuottivat aineiston, jossa erilaiset laululliset rakenteet ja esitykselliset tai tilannesidonnaiset piirteet eivät juuri näy, jossa ne murtautuvat esiin vain erityistapauksissa. Esimerkiksi kehystäviä, luonteeltaan irrallisia aloitusformuloita kuten Tehkää yksi ympärikko esiintyy suhteellisen harvoin sävelmäkokoelmiin verrattuna. Muutamat runonkerääjät olivat kiinnostuneita tekstien ohella esityksellisistä ja musiikillisistakin tasoista: 1800-luvun runonkerääjistä Vihtori Alava onkin ainoa, jonka runomuistiinpanoissa vilahtaa myös muutama refrenki. Hänen aineistonsa kontekstitiedot ja esittäjiltä tallennetut sitaatit tekevätkin siitä yhden tämän tutkimuksen keskeisistä lähteistä. 1930-luvun keräjïstä taas erityisesti Elsa EnäjärviHaavio sekä Aili ja Lauri Laiho olivat kiinnostuneita runojen esittämistavoista ja laulussa saamista rakenteista: niinpä esittäjät innostuivat paitsi kertomaan tästä sanallisesti, myös kehystämään runojaan osin aiemmin tallentamattomillakin aloitusformuloilla ja käyttämään erilaisia, laulujen muistiinmerkityistä muotorakenteista pääteltävissä olevia, erilaisiin esitysareenoihin ja rekistereihin viittaavia sävelmätyyppejä. Sävelmiä tallentanut Launis, jota runotekstit eivät kiinnostaneet, puolestaan tallensi sävelmämuistiinpanoissaan muita runsaammin aloitusformuloita: tulkintani mukaan sävelmien tallennuksen ensisijaisuus sai esittäjät käyttämään myös runsaammin niiden keskeisiin käyttötilanteisiin liittyviä tekstuaalisia aloitustapoja.

Tallentajan intressit ja käytetyt tallennustekniikat vaikuttivat sekä siihen, mitä ja miten laulaja esitti, että siihen, mitä esityksestä tallentui. Arkistoaineistoa tarkasteltaessa näiden kahden olennaisen tekijän - mitä esitettiin, mitä siitä tallennettiin - keskinäisiä suhteita ei ole aina mahdollista tavoittaa. Tallenne asettaa rajat sille, mitä sen kohteena olleesta esityksestä on jälkikäteen tulkittavissa. Ei esimerkiksi ole varmuutta siitä, mahdettiinko lähinnä runotekstejä tallentaneillekin kerääjille kuitenkin kehystää runoja aloitusformuloin, puhjeta niitä sanellessa hetkittäin lauluun ja sitä myötä erilaisiin laulullisiin ja esityksellisiin rakenteisiin tai mahtoivatko laulajat kommentoida laulujaan, selittää niiden merkityksiä ja tyypillisiä käyttökonteksteja. Voi olla, että paikoin oli näin, mutta monet kerääät jättivät tämänkal- 
taiset piirteet merkitsemättä muistiin. Kiinteämuotoisista runoista kiinnostuneelle tutkijalle ne olivat arvottomia. Toisaalta voi olla, että tallentajien keskittyminen tekstiin ja manuaalisen muistiinpanotekniikan käyttö sai laulajatkin keskittymään lähinnä runoteksteihin ja jättämään muihin konteksteihin viittaavia tekijöitä käyttämättä. Olen tulkinnut esityksellisten piirteiden ja runojen taustoista, käytöistä ja merkityksistä kertomisen liittyvän usein paitsi kerääjän henkilökohtaisiin kiinnostuksenkohteisiin, myös tämän pidempään alueella oleskeluun tai muuten suhteellisen välittömiksi muodostuneisiin suhteisiin paikallisten kanssa.

Laulajan tulkinnat tilanteesta ja esityksistään välittyvät lähinnä satunnaisten tallennettujen kommenttien, runovalintojen, esityksellisten piirteiden ja näiden heijastamien tulkinnallisten kehyksien kautta, kerääjän suodattamina. Samalla lähes kaikki, mitä tiedämme inkeriläisestä laulukulttuurista, juontuu näistä samoista aineistoista. On mahdotonta ymmärtää laulukulttuurin kannalta merkityksellisiä esitysten piirteitä ymmärtämättä kulttuurisesti keskeisiä esitysareenoita ja rekistereitä. Tallenteiden tulkitseminen edellyttää niiden takana olevien kulttuuristen mallien ja käytänteiden ymmärtämistä, mutta samalla tallenteet ovat ainoa lähde näiden mallien ja kehysten tavoittamiseen. Ymmärryksen mahdollistaa, rajoittaa ja muokkaa aineisto, joka toimii laulukulttuurin yleisten mallien mukaan, mutta ei välttämättä edusta laulua keskeisimmillä esitysareenoillaan tai tyypillisimmissä rekistereissään.

Tämän huomioon ottaen on oikeastaan yllättävää, että tiettyihin praasnikka- ja häälauluihin liittyvissä sävelmätoisinnoissa ja kuvauksissa laulamisen rekisterit näyttäytyvät niin kiinteinä, lähes poikkeuksettomina. Poikkeavat tekstin ja sävelmän yhdistelmät ovat kaikki selitettävissä rekisterien joustavuudesta ja esitys- tai tallennustilanteen viitekehyksestä käsin. Liekkuvirsi oli mahdollista siirtää sävelmän vaihdoksella kehtolaulun kontekstiin; hää- ja kokkovirret sekä -nuotit saattoivat tulla käytetyiksi paitsi toistensa, myös arkisempien ja henkilökohtaisempien esitysareenoiden puitteissa; liikkuvampi, vähemmän keskeinen häälauluteema oli mahdollista esittää keskeisimmistä pulmavirsistä poiketen kaksisäkeiselläkin sävelmällä. Vaikka keskeisimpien julkisten juhlalaulujen kohdalla esitysareenoiden ja rekisterien suhde näyttäytyy kiinteänä, sallivat nekin varsinaisten esitysareenoidensa ulkopuolella monia variaatioita. Rituaalisten juhlalaulujen luonne kuitenkin johti tallennustilanteissa yleensä hyvin kiinteämuotoisiin esityksiin.

Kiteytyneen juhlalaulun esittämistä keskeisen esitysareenansa ulkopuolella, tallennustilanteessa, voi ajatella Richard Baumanin $(1977,11)$ termein toisaalta "täyden esityksen", toisaalta erilaisten referoimisen ja esityksestä kertomisen tapojen kautta. Laulun täysi esittäminen edellyttäisi paitsi tietynlaisia tekstuaalisia, myös tiettyjä musiikillisia ja esityksellisiä piirteitä sekä tietynlaisen laulajajoukon. Laulun kuvaaminen tai referoiminen voi sen sijaan tuottaa jonkun näistä tasoista, vaikkapa runon, sävelmän tai esityksellisiä tyylipiirteitä, keskeiseen esitysareenaan kuuluvan esityksen mukaisena, mutta johtaa rekisterin vaihdokseen tai sen sävyn muuntumiseen toisilla esityksen tasoilla. Liikkuvampien ja monikäyttöisempien runoaiheiden - epiikan, lyyrisen epiikan, lyriikan - kohdalla tilanne on kuitenkin toisenlainen kuin kiteytyneiden esitysareenoiden ja rekisterien tunnusrunojen. Näillä runoilla 
ei välttämättä ollut ensisijaisia tai keskeisimpiä esitysareenoita muutoin kuin yksittäisten laulajien henkilökohtaisina tulkintoina. Tällöin erilaisten rekisterisidonnaisten tekijöiden käytön voi hahmottaa ensisijaisesti keinona kontekstualisoida ja kehystää sekä runoja että itse esityksiä, määrittää niiden tulkinnallinen kehys.

Keruutilanteissa sijoittivat itsensä vaihtelevin tavoin suhteessa julkiseen ja yksityiseen, rituaaliseen ja henkilökohtaiseen, juhlaan ja arkeen. Narvusilainen Matroona Bässina ei suostunut enää kuin sanelemaan Väinö Salmisen jälkeisille kerääjille, mutta teki tämän ilmeisen mielellään ja kertoi myös laulujen esittämisestä. Hän kieltäytyi siis käyttämästä edes arkisimpia laulamisen rekistereitä, mutta kuvasi keskeisiä esitysareenoita sanoilla, korosti omaa esilaulajan asemaansa ja esitti runoja sanellen. Naastoi Tarinaisista esitti Iilian praasnikoiden aikaan kotona käväistessään kerääjälle vain muutamia runoja, mutta aloitti kyseisten praasnikoiden keskeisimmällä laululla, Iilian virrellä, tuoden näin praasnikoiden viitekehyksen läsnä olevaksi myös keruutilanteeseen. Anna Arehjeva puolestaan esitti pakolaisena tallentajalle ainoastaan kolme rituaalista praasnikkoihin liittyvää runoa, mutta toi niihin lyyrisillä teemoilla vahvana omaelämäkerrallisen, henkilökohtaisen huolilaulun sävyn. Mättähän kylän naiset innostuivat arki-iltana laulamaan Launikselle julkisen juhlalaulun rekisterillä yksinkertaisia, Launiksen jo tallentamia sävelmiä, ja kerääjä koki naisten innostuksesta huolimatta iltansa menevän hukkaan.

Keruutilanteessa saattoi läsnä olevaksi tulla samanaikaisesti useita tulkintakehyksiä, päällekkäisiä esitysareenoita. Hyvä esimerkki tästä on A. A. Boreniuksen kohtaaminen Vöglän ja Okkulin sekä pienen tytön kanssa. Naiset aloittivat laulamisen hääsävelmillä, jatkoivat muutamalla yleissävelmällä ja siirtyivät liekkuvirteen. $\mathrm{He}$ pysyttelivät siis toisaalta keskeisimpien juhlalaulujen, toisaalta yleisimpien sävelmien puitteissa, kuin antaen kerääjälle yleiskuvaa julkisen laulun piiristä. Lapsen läsnäolo kuitenkin toi läsnä olevaksi toisenkin, päällekkäisen kehyksen. Naiset kertoivat ensimmäisellä häänuotilla laulettavan yhtälailla lapsille, ja esittivätkin liekkurunonsa liekkunootin sijaan liekutusnootilla eli kehtolaulusävelmällä. Läpikuultavina päällekkäin voi siis tässä kohtaamisessa tulkita olleen ainakin keruutilanteen, julkisen juhlalaulun sekä arkisen kehtolaulun tai lapsen viihdyttämisen tulkintakehykset: ne kaikki vaikuttivat siihen, minkälaisia esityksiä kerääjä sai kuultavakseen.

Lauluillaan ja laulamisen tavoillaan esittäjät itse määrittivät keruutilanteen luonnetta. Helpointa kerääjän kannalta näyttää olleen arkisen laulun viitekehyksessä pysyminen: yksittäiset tai muutamat laulajat, hiljainen ääni, paikoillaan pysyminen. Riehaantuminen vaikeasti keskeytettävään kovaääniseen joukkolauluun tai tanssiin viehätti ainoastaan muutamia erityisesti esitystavoista kiinnostuneita tallentajia, muille se oli lähinnä tallennusta hankaloittava tekijä. Keruutilanteen rekisterin voi hahmottaa muodostuneen suhteessa esimerkiksi tallennuksen hetkeen, vuodenaikaan, vuorokaudenaikaan, arkeen tai pyhään, tilaan, läsnäolijoihin ja niiden paikallisessa kulttuurissa luomiin viitekehyksiin eli samoihin tekijöihin, joiden pohjalta myös paikallisten lajien sävyt muokkautuivat. 


\section{PAIKALLINEN LAJI}

Keskeisin länsi-inkeriläisen sävelmä-aineiston tallentaja Armas Launis (1907) kuvasi, kuinka Inkerissä kalevalamittainen laulu rakentui usein tilanteen tai tekemisen mukaan. Laulajat nimesivät niitä myötäillen toisaalta runojaan, toisaalta niiden laulamiseen käytettyjä sävelmiä: kihlajaisvirsi, nootti tantsun päälle, metsän sävel. Tietyssä tilanteessa tietty runo tai runoteema usein aloitti laulamisen. Tilanteisiin liittyi myös omia sävelmiään, joista selkeimpinä ryhminä Launis mainitsi hää- ja liekkusävelmät.

Senni Timonen (2004) on avartanut Launiksen antamaa kuvaa laajemman keski- ja länsi-inkeriläisen aineiston avulla ja asettanut sen rinnakkain pohjois-inkeriläisen Larin Parasken lajikäsitysten kanssa. Timonen päätyy hahmottamaan inkeriläistä kotoperäistä lajijärjestelmää nimenomaan laulutilanteiden kautta, mutta toteaa lajien muodostuneen huomattavan monisyisesti: tilanteen, paikan, tekemisen, liikkeen, laulajan tai laulajien, laulun kohteen, sävelmien tai laulun tyylipiirteiden, runojen ja teemojen, persoonallisten mielenliikkeidenkin erilaisina, joustavina yhdistelminä. Kiinteiden aloitusteemojen jatkona laulettavat moninaiset, tilannesidonnaisesta lajista toiseen liikkuvat lyyriset ja eeppiset runotkaan eivät olleet aiempien tulkintojen mukaista "mitä tahansa", vaan ne valikoituivat ja painottuivat näiden lajiin liittyvien määrittäjien mukaan.

Lähdin tarkastelemaan inkeriläisen laulun tilannesidonnaisuutta 1) Launista ja Timosta paikallisemmalla ja etniset erot tarkemmin huomioivalla tasolla, 2) kaikkein kiinteimmiksi oletettavien tilanteiden pohjalta ja 3) runojen ja sävelmien suhteeseen sekä esitystapoihin tarkemmin keskittyen. Tällöin syntyi yksityiskohtaisempi käsitys niistä moninaisista tavoista, joilla lauluun liittyvät piirteet tyypillisesti eri tilanteissa toisiinsa punoutuivat. Inkeriläisen kalevalamittaisen runon paikallisesti hahmottuvat lajit määrittyivät suhteessa laulamisen tilanteisiin (esitysareena) ja niihin liittyvään laulamisen tapaan (rekisteri). Erilaisina esitystä määrittävinä tekijöinä saattoi toimia niin tekstuaalisia, musiikillisia kuin esityksellisiäkin piirteitä. Lajeihin liittyi sekä kiinteämpiä, ensisijaisesti yhteen lajiin kuuluvia tai viittaavia piirteitä että lajista toiseen helposti siirtyviä elementtejä. Tarkemmin katsottuna tilannesidonnaiset lajit rakentuvat hyvin eri tavoin ja monitasoisesti.

Yleisimmällä tasolla länsi-inkeriläinen laulu ja musiikki jakautuvat helposti hahmotettaviin, vanhastaan tunnettuihin lajeihin, joiden rekisterit ja osin esitysareenatkin eroavat toisistaan selkeästi. Kalevalamittaiset runot eli virret, itkuvirret eli luettelemiset, uusimittaiset kansanlaulut, erilaiset venäläiset laulut sekä moninaiset soitetut tanssi- ja muut soitinsävelmät eroavat nimitystensä, runomittansa, kielensä ja tyypillisten sisältöjensä tai sanattomuutensa, tyypillisten musiikillisten piirteidensä ja käyttöyhteyksiensä puolesta toisistaan. Silti näidenkin lajien välillä oli yhteyksiä.

Itkuvirret ja runolaulu saattoivat lomittua toisiinsa tai lainata toisiltaan sekä sisältöjen, käytön että rekisterien tasolla: Inkerissä jopa itkujen runomitassa voi hetkittäin 
näkyä kalevalamitan kaltaisia piirteitä. Etenkin tyttöjen kalevalamittainen laulu morsiamelle käytti hyväkseen sekä itkujen musiikillisia että sisällöllisiä teemoja, ja tuli lisäksi esitetyksi lomittain varsinaisten hääitkujen kanssa. Selkeät runosäkeet, sävelmä ja laulun rakenne määrittivät sen kuitenkin runojen, ei itkuvirsien piirissä liikkuvaksi. Tšastuška- ja rekilaulutyyppisiä säkeitä saattoi punoutua runolauluun, runosäkeitä uusimittaiseen lauluun. Rekilaulusävelmissä oli myös yksinkertaisia, tyypillisiä runosävelmiä muistuttavia sävelmiä, ja toisaalta laaja-alaisempiin uudemman kansanlaulun sävelmiin sijoitettiin myös kalevalamittaisia runoja. Musiikillisten samankaltaisuuksien vuoksi Launis otti sekä uusimittaisten kansanlaulujen sävelmiä että itkusävelmiä mukaan Inkerin runosävelmiin. Venäläiset kansanlaulut puolestaan näkyvät runosävelmäaineistossa sekä suorina sävelmälainoina, erilaisten melodia-, rytmi- ja refrenkiaiheiden sovituksina että hienovaraisempina tyylipiirteinä. Inkeriläisissä tanssin tavoissa ja soitetussa tanssimusiikissa on paljon yhtäläisyyttä erityisesti venäläisten tanssien kanssa ja soitintansseja saatettiin tanssia myös tanssisävelmiin sovitetun kalevalamittaisen laulun säestyksellä.

Näillä suhteellisen selkeillä lainautumisen ja lomittumisen tasoilla on selkeää puhua lajien välisestä viittauksellisuudesta: esimerkiksi kalevalamittainen runo voi viitata itkuvirsiin joko temaattisella, runomitallisella tai sävelmiin ja esittämiseen liittyvällä keinolla. Tämän viitteen taas voi tulkita tuovan jotain itkuvirsien tyypillisestä tulkintakehyksestä - suru, menetys, ero, siirtymät rajojen yli - runon piiriin. Rekilaulu- tai tšastuškasävelmän käyttäminen taas tuo runoon tanssin ja käsittääkseni jonkinlaisen leikillisyyden sävyn. Samanlaisia pidempiä kertovia kokonaisuuksia kuin runolaulussa ei näissä lajeissa esiinny, ja suosituimpia olivat erilaiset tyttöjen ja poikien seurusteluun ja kiusoitteluun liittyvät aihepiirit. Sävelmän vaihdolla kalevalamittaisen runon saa siirrettyä uusimittaisen tanssilaulun kontekstiin: sointikuva, tunnelma ja laulun mahdollistama liike voi muuttua. Tässä sävelmän ja tekstin rakenteet luovat omat rajoituksensa. Neli-iskuiseen tšastuška- tai rekilaulusävelmään on helppo istuttaa kahdeksantavuinen kalevalamittainen säe, ehkä vain viimeinen tavu pois jättäen. Sitä vastoin vapaamittaisen itkusävelmän käyttö runosävelmänä edellyttää suurempaa joko sävelmän tai runon tekstuaalisen rakenteen muokkaamista. Moninaisia säkeen muokkaamisen tapoja - venytyksiä, lisätavuja, osakertauksia, tavujen poisjättöjä - käytettiin myös sovitettaessa kalevalamittaisia runoja erilaisiin venäläisiin sävelmiin.

Paikoin lajien välisen viittauksellisuuden hahmottaminen on vaikeaa: hyvä esimerkki on inkeriläisen laulun suhde venäläisiin lauluihin. Runonkerääjät kertovat, että länsi-inkeriläiset lauloivat venäläisiä lauluja, vaikka näitä eivät kerääjät juuri tallentaneet muutamia poikkeuksia lukuun ottamatta. Venäläisten laulujen käsitteleminen yhtenä nippuna olisi harhaanjohtavaa: joukossa oli erilaisia, eri tilanteisiin liittyviä, eri aikoina levinneitä lajeja. Kielentutkijoiden ja arkeologien arviot sijoittavat slaavilaisten ja itämerensuomalaisten ryhmien vuorovaikutuksen alun vähintäänkin tuhannen vuoden taakse. On arveltu, että laajalti inkeriläisen runolaulun piirissä käytetyt tyylipiirteet kuten laulun aloittavan oi-tavun käyttö tai vanhakantaisiin venäläisiin kalendaari- ja tanssilauluihin viittaavat piirteet saattavat olla iäkkäitäkin lainoja. Lajien välisten viittauksellisuuden kannalta tällä voi 
katsoa olevan merkitystä. Jos laina on vanha ja omaan traditioon sopeutettu, jos piirre hahmotetaan jo kiinteästi oman ryhmän lauluun kuuluvana, ei se välttämättä käyttäjiensä kannalta kanna mukanaan viitettä toiseen lajiin tai toisenkieliseen laulukulttuuriin. Se on otettu omaksi samalla tavoin kuin vanhat, kieleen sopeutuneet lainasanat. Sen sijaan ainakin lähellä venäjänkielistä muotoaan pysyneiden refrenkien tai kokonaisten uudempien venäläisten kansanlaulujen sävelmien käytön kalevalamittaisten runojen yhteydessä voi olettaa selkeästi viitanneen kalevalamittaisen runon ulkopuolelle runojen tallennusajankohtanakin. Tähän viittaavat sekä monet kerääjien maininnat niiden uutuudesta että niiden käytön puuttuminen ilmeisen hitaasti muuttuvien praasnikka- ja häälaulujen piiristä. Uusien sävelmien käyttö oli myös keino tuoda uudenaikaisia, muodikkaita laulun piirteitä tai lajeja omakielisen laulun piiriin.

Lajien ja niiden käyttämien rekisterien hahmottaminen monimutkaistuu entisestään, kun siirrytään kalevalamittaisen runon paikallisiin lajeihin, joita olen hahmottanut esitysareenoiden, rekisterien ja paikallisten nimeämiskäytänteiden kautta. Tiettyihin esitysareenoihin liittyviä rekistereitä, joissa runot, sävelmät ja esitykselliset piirteet muodostavat kiinteitä yhdistelmiä, on helppo nimetä kalevalamittaisen runon paikallisesti määrittyviksi lajeiksi tai alalajeiksi. Niiden tekstejä ja sävelmiä paikallisetkin nimesivät tilanteeseen ja tekemiseen liittyvin vakiintunein termein kuten kokkovirsi tai liekkunuotti. Samalla tekstien ja sävelmien tarkastelu osoittaa monenlaista variaatiota ja monikäyttöisyyttä, joustavuutta ja luokkien liukumia - kuten on muiden paikallisia tai kansanomaisia lajeja ja kategorioita käsittelevien tutkimusten valossa odotettavissakin. Näitä tilannesidonnaisten lajien rakentumisen tapoja voi tarkastella useilla tasoilla, mutta kokonaiskuva syntyy vasta, kun niin tekstuaaliset, musiikilliset kuin esityksellisetkin piirteet otetaan huomioon.

Esimerkeiksi tilannekohtaisen lajin rakentumisen luonteesta nostan tässä viisi tapausta: Iilian virren, liekkuvirren, kiletoivirren, liekutusvirret sekä pulmavirret. Iilian virsi oli vain yksi, tietyssä tilanteessa tietyllä tavalla ja sävelmällä esitetty runo, jonka alkusäkeet olivat kiinteät mutta loppupuoli ja pituus vaihtelevat tiettyjen oluenjuonnin teemojen puitteissa. Samalla sävelmällä tai muuten kiinteästi virren jatkona ei mainita esitetyn muita erillisiä runoja. Liekkuvirressä kiinteää, kontekstiin viittaavaa alkuteemaa tai -runoa seurasi mitä erilaisimpia lyyrisiä ja eeppisiä runoja, kaikki laulettuna samalla liekkunuotilla ja samassa paikassa, kyläkeinulla. Ympärillä saattoi kuulua muuta laulua muiden lajien puitteissa: kokkovirttä, tanssilauluja. Kiletoivirret puolestaan olivat pitkä, yhtenäinen sikermä, jonka lomaan tai jatkoksi muita runoja ei sijoitettu. Sikermä varioi vastaanoton ja tilanteen mukaan, mutta toistui talosta taloon kierrettäessä jotakuinkin samanlaisena talon pihalta tupaan ja takaisin etenevänä jatkumona. Ilmeisesti koko sikermä laulettiin samalla sävelmällä. Liekutusvirret eli kehtolaulut ovat vapaamuotoinen ja ilmeisen improvisatorinen laji. Lauluun voitiin punoa niin tyypillisiä kehtolauluteemoja, sanatonta hyminää kuin liekku- tai pulmavirsiä tai lyyristen ja eeppisten runojenkin pätkiä. Sävelmiä oli monenlaisia ja niinä oli mahdollista käyttää myös muiden lajien sävelmiä; paikoin laulun sävelmärakenne ja refrengit varioivat enemmän kuin 
missään muissa tämän työn puitteissa sivutuissa lajeissa. Pulmavirret ovat tässä käsitellyistä lajeista laajin joukko monine alakategorioineen. Kyseessä on oikeastaan tilannesidonnainen alalaji, joka jakaantuu vielä useisiin vahvuudeltaan erilaisiin alalajin alalajeihin. Kuten kiletoivirsi, pulmavirretkin laulettiin suhteellisen yhtenäisenä, häistä toisiin varioiden toistuvana jatkumona. Häät olivat kuitenkin paljon joulunajan kiertueita pidempi, monipolvisempi ja varioivampi tapahtuma. Näytelmä alkoi aattoiltana sekä sulhasen että morsiamen taloissa, eteni hääpäivänä morsiustalon pihalta sisään tupaan, sieltä lopulta kahtena joukkona sulhastaloon, pihalta tupaan ja takaisin. Runoja oli suuri määrä. Niiden rituaalinen tärkeys vaihteli, ja varsinaisten hälalaulujen lomassa kerrotaan lauletun myös runoja, jotka eivät suoraan liittyneet käsillä olevaan tilanteeseen. Sävelmä ja tulkintani mukaan sitä seuraten myös laulun rekisteri vaihteli runon aseman, laulajien ja esitystilanteen mukaan, mutta suurin osa runoista laulettiin jommallakummalla kahdesta yleisimmästä pulmanuotista.

Kaikkiin näihin paikallisiin lajeihin sisältyy tekstuaalisia elementtejä - teemoja tai runokokonaisuuksia - jotka olivat tyypillisiä juuri kyseiselle lajille ja useissa tapauksissa ilmeisen välttämättömiä lajin määrittymisen kannalta. Usein kiinteimmät, tyypillisimmät säkeet tai teemat sijoittuivat laulun alkuun. Lähes kaikkiin esimerkkeihin sisältyy myös vapaammin muokkautuvia osuuksia, joko yhteen runoon punottuna (Iilian virsi), aloitusteeman jatkona (liekkuvirsi, liekutusvirsi) tai kiinteämpien runojen väleissä tai jälkeen (pulmavirret). Liekkuvirren, liekutusvirsien sekä pulmavirsien jatkona, osana tai lomassa saatettiin esittää myös runoja ja teemoja, jotka klassisten jaotteluiden mukaan kuuluvat epiikan tai lyriikan piiriin. Kiletoivirsien pitkään sikermään ei aineiston perusteella näytetä punotun tällaista väljemmin liikkuvaa, moneen tilannesidonnaiseen lajiin liitettävissä olevaa aineista. Pitkä, saman illan aikana useasti kylän eri taloissa laulettu sikermä ei tunnu antaneen tilaa muulle laululle. Iilian virsi taas oli oma selkeä kokonaisuutensa, jonka suorana jatkona ei kerrota lauletun mitään muuta. Iilian virsi ja sitä seurannut oluenjuontirituaali kuitenkin avasivat monipäiväisen praasnikkajuhlan, johon liittyi paljon erilaista laulua ja tanssia. Narvusin alueelta tallennettu aineisto osoittaa, että Iilian sisaruspraasnikan Pedron virttä saatettiin ainakin rituaalisen oluenjuonnin hiivuttua esittää pitkin praasnikoita monenlaisissa konteksteissa: kiitoksena tarjoiluista, kylän läpi kuljettaessa, olutastioita lopuksi pestäessä. Pedron virsi myös näyttää, mitä saattoi tapahtua laulun siirtyessä toisenlaiseen kontekstiin, toisen ryhmän käyttöön: muutamat inkerinsuomalaiset olivat muokanneet inkeroisten rituaalirunosta version, jossa pyydettiin sateen tuomisen sijasta pyhimystä viemään pilvet naapurikyliin heinänkorjuun tieltä.

Sävelmän suhde osoittamaansa lajiin näyttää olleen parhaimmillaan yhtä vahva kuin lajiin kuuluvien tyypillisimpien runosäkeiden. Sävelmä tuli nimetyksi samoin termein kuin runokin: liekkuvirsi, liekkunuotti. Tietyt lajit edellyttivät tietyn sävelmän: praasnikka- ja häälauluja ei edes yhteisön ulkopuoliselle ja paikallisiin lajeihin perehtymättömälle tallentajalle laulettu millä hyvänsä sävelmällä. Samalla näitä tilannesidonnaisia, lajinimillä nimettyjä sävelmiä oli toki mahdollista käyttää myös keskeisimpien käyttötilanteidensa ulkopuolella. Hää- tai liekkusävelmällä 
saatettiin myös vaikkapa laulaa lapselle. Myös pelkkä sävelmä, ilman runotekstiä, riitti joskus lajin tunnukseksi. Liekkunuotilla laulettu yleinen lyyris-eeppinen runo Olin orjoi vellolleni tuli nimetyksi liekkulauluksi ilman liekkuvirren aloitusteemaakin. Vahvin todiste sävelmän tunnistettavuudesta ja merkityksellisyydestä ovat paimensoittimella esitetyt sanattomat itkuvirsisävelmät eli haluvirret ja luettelemiset sekä niiden estetiikkaa mukailevat haliat soitot, joita paikalliset tulkitsivat itkuvirren viitekehyksestä käsin.

Liikkumisen tavatkin olivat tiettyjen rituaalisten lajien kohdalla hyvin kiinteitä. Iilian virsi ja monet häälaulut laulettiin hitaasti piirissä peräkkäin kävellen, häälauluja ilmeisen paljon myös paikallaan seisten. Liekussa keinumisen tahti oli suhteessa laulun rytmiin. Kiletoivirsiin ja sävyltään kevyempiin häälauluihin taas liittyi riehakas ympärikkotanssi rytmisine elementteineen. Näyttää siltä, että kun laululla pyrittiin saamaan jotain merkittävää aikaan (sade eli hyvä sato, morsian sulhaselle), oli tahti ja liike hidasta, juhlavaa. Nopea tanssi oli painoarvoltaan keveämpää. Hitauden ja nopeuden välistä eroa kuvattiin aineistossa eksplisiittisesti tanssilaulujen kohdalla, mutta hieman toisin: hidas oli surullista ja vakavaa, nopea keveää ja iloista. Iilian virttä rituaalisine, pyhimykselle osoitettuine sateen pyyntöineen ja oluenjuomisteemoineen voi tuskin tulkita surulliseksi tai traagiseksi, joten on todettava nopeuden määrittäneen rituaalisia lauluja hieman eri sävyin kuin vapaammin muodostuvia tanssilauluja. Yksittäisen piirteenkin merkitys muokkautuu siis lajin myötä, vaikka piirre toimii samalla myös yhtenä lajin tunnuksena. Rituaalisesti sävyttyneiden laulujen kohdalla hitaus ja nopeus muokkaavat esityksen sävyä erilaisella tavalla kuin laajempaan tilannekirjoon liittyvien tanssilaulujen. Toisaalta esitykselliset piirteet eivät määrittäneet lajia poissulkevalla tai ehdottomalla tavalla: kepeällä, nopealla tanssisävelmällä oli mahdollista laulaa myös itkien läheisen kuolemasta. Erilaiset esitykselliset piirteet toisaalta määrittyivät suhteessa monen tekijään, toisaalta määrittivät niitä osaltaan.

Vaikka samanlaiset piirteet tulivat tyypillisesti käytetyiksi useiden paikallisten lajien puitteissa, ne eivät silti sopineet mihin hyvänsä lajiin. Esimerkiksi liekkuvirren ja liukuvirren, samoin kuin Ilian virren ja kokin kiitosvirren muotorakenne oli sama, joskus sävelkulkukin - liekkuvirren ja kokin kiitosvirren sitä vastoin koskaan ei. Samoja lyyrisiä ja lyyris-eeppisiä teemoja saatettiin punoa sekä liekkuvirren ja liukuvirren jatkoksi että sovittaa itsenäisinä varsinaisten häälaulujen välissä laulettavaksi, mutta Ilian virteen tai kokin kiitosvirteen niitä ei koskaan yhdistynyt.

Laji muodostui monien tekijöiden kokonaisuutena. Esittäjän käytössä oli monia erilaisia keinoja laulun lajin ja aikomansa tulkinnallisen kehyksen määrittämiseksi, ja nämä keinot olivat osin vaihtoehtoisiakin. Usean paikallisen lajin puitteisiin sopivan runon saattoi kehystää tiettyyn hetkeen ja lajiin yhtä hyvin aloitusformulalla kuin sävelmälläkin. Aineistosta ei löydy paljon esimerkkejä tapauksista, jossa runo ja sävelmä edustavat eri lajia. Ei siis ole selvää, mitkä ovat lajiksi määrittymisen kulloisetkin minimiehdot: minkälaisissa tapauksissa tietynlainen sävelmä määritti koko esityksen lajin, milloin ainoastaan loi viittauksellisen suhteen toiseen lajiin, esitysareenaan tai rekisteriin? Keskeisten esitysareenoidensa ulkopuolella eri 
lajien tai rekistereiden piirteitä oli joka tapauksessa mahdollista käyttää ilmeisen vapaasti, monin eri tavoin. Häälaulun rekisteri oli sovellettavissa yhtälailla tervehdyslaulua runonkerääjille tai yhteisön ulkopuolisille merkkihenkilöille esitettäessä kuin lasta nukutettaessakin. Sellaisenaan sitä ei kuitenkaan tällöin käytetty: lapsille laulettiin useammin soolona kuin esilaulajan ja kuoron vuorotteluna ja lisäksi hiljempaa kuin juhlissa; merkkihenkilöille laulettaessa taas laulun sanoja muokattiin ja yhdisteltiin uusiin teemoihin.

Inkeriläinen kalevalamittainen runo näyttäytyykin ennen kaikkea joustavana, monin tavoin ja monella tasolla esittäjänsä muokattavissa olevana lauluna. Vaikka olen laulamisen merkityksiä hakiessani keskittynyt siihen, mikä näyttäytyy yleisenä, kiinteänä, kiteytyneenä tai toistuvana, näyttäytyy suuri osa tekstuaalisista, musiikillisista ja esityksellisistä piirteistä hyvin vapaasti liikkuvina ja sovellettavina. Inkeriläisen paikallisen lajijärjestelmän kohdalla onkin olennaista kiinnittää huomiota paitsi tilanteeseen ja tekemiseen sidoksissa oleviin lajeihin, myös lajista toiseen liikkuviin elementteihin. Kuten Senni Timonen (2004, 154, 156, 262-274) on havainnut, suuri osa lyriikasta ja epiikasta näyttää siirtyneen sulavasti tilanteesta toiseen, mutta tulleen tietyn rekisterin tai esitysareenan puitteissa kutsutuksi satunnaisesti myös jollakin paikallisella lajinimellä. On myös suuri joukko sävelmiä - tallennettujen sävelmien valtaosa - jotka eivät ole liitettävissä mihinkään tiettyyn tilanteeseen tai tekemisen tapaan. Osin tämä on epäilemättä sidoksissa tallennushistoriaan: riittävästi tietoja ei yksinkertaisesti ole, suuri osa runoteksteistä ja sävelmistä on tallennettu ilman mitään käyttöön tai tulkintaan liittyviä mainintoja. Runojen monikäyttöisyys näkyy kuitenkin paitsi satunnaisissa nimeämisissä, myös yhdistelmien laajassa variaatiossa. Toisin kuin huomion keskipisteenä olleet tilannesidonnaiset, rituaalisesti sävyttyneet runot, monet kertovat ja lyyriset runoaiheet tulivat lauletuksi hyvin laajalla sävelmien kirjolla, monenlaisen kuuloisina lauluina.

Kalevalamittainen runo jäsentyi Länsi-Inkerissä vaihteleviksi paikallisten lajien muodostelmiksi. Näitä muodostelmia määrittivät runotekstit, sävelmät, esitystavat, esittäjät, tilanne ja tekeminen. Runot ja runoteemat liittyivät toisiinsa hyvin erilaisin tavoin: kiinteähkö runokokonaisuus tai runosikermä, aloitusteema ja sen jatkona kaikenlaista tai pitkä näytelmä, jossa oli sekä kiinteämpiä että vähemmän kiinteitä kokonaisuuksia. Välillä on mahdotonta sanoa, missä määrin laulajat hahmottivat tiettyyn tilanteeseen liittyvät runot erillisinä tai yhtenäisinä jatkumoina. Esimerkiksi saman laulajan kiletoivirren kokonaisuus on toisella kerääjällä merkitty muistiin yhtenäisenä runona, toisella usean runon sarjana.

Hyvin karkealla tasolla tämän työn piirissä sivutut paikalliset lajit voisi jakaa niiden tekstuaalisen, musiikillisen ja esityksellisen kiinteyden osalta kolmeen: 1) suhteellisen kiinteisiin rituaalisiin lauluihin (keskeiset häälaulut, Iilian ja Pedron virret, kiletoivirret), 2) rituaalisiin tilanteisiin väljemmin sidoksissa oleviin lauluihin (liekku- laskiais- ja kokkovirret, tyttöjen laulu morsiamelle, kylän läpi kulkeminen) sekä 3) tilannesidonnaisiin, ei-rituaalisiin lauluihin (kehtolaulut, yksin laulaminen, kenties monet tanssilaulutkin). Ensimmäisen ryhmän piirissä tietyt ru- 
nokokonaisuudet esitettiin tietyillä sävelmillä, tietyssä kontekstissa, tietyllä tavalla, tiettyjen laulajaryhmien toimesta. Toisen piirissä kiinteisiin alkuihin ja tietyntyyppisiin sävelmiin saatettiin laulaa jatkoksi kaikenlaisia runoteemoja. Kolmannessa laulamisen tilanne määritti kyllä tavalla tai toisella runoteemoja, aloitusformuloita, sävelmiä ja laulamisen tapoja, mutta variaation mahdollisuudet olivat paljon suurempia.

Laulajilla oli käytössään laaja ja multimodaalinen semioottisten resurssien kirjo: runosäkeitä ja -teemoja, sävelmiä, äänensävyjä, lisätavuja, refrenkejä, eleitä, liikkeitä. Yksittäisen esityksen merkitys muodostui näiden kaikkien toisiaan muokkaavana summana. Niiden kautta määrittyi laulun merkityspotentiaali, esimerkiksi sen laji, muodollisuus tai julkisuus ja tunnesävy. Esitysten erilaiset piirteet kantoivat tiiviimpiä tai väljempiä assosiaatioita tiettyihin konventionaalisiin, keskeisiin tai ensisijaisiin laulutilanteisiin, paikkoihin, lajeihin, laulajaryhmiin tai muihin merkityskenttiin. Jotkut piirteet, kuten vaikkapa yleissävelmiksi kuvatut sävelmät, olivat merkityksiltään neutraalimpia: niitä oli tyypillistä käyttää monessa tilanteessa, joten ne eivät assosioituneet niin vahvasti mihinkään yksittäiseen tulkintakehykseen. Toiset liittyivät kiinteästi tiettyyn tilanteeseen, tietyntyyppisiin runoihin, tiettyihin sosiaalisiin ryhmiin, tietynlaiseen tekemiseen, ja kantoivat näin vahvempia viitteitä kulttuurisesti tyypillisiin käyttöyhteyksiinsä. Osa laulamisen piirteistä oli myös vahvemmin kulttuurisesti koodautuneita, osa taas välittömämpiä ja samalla helpommin ulkopuolelta ymmärrettäviä. Surullinen äänensävy, traaginen teksti ja liikkeen hitaus välittävät kulttuurin ulkopuoliselle laulun tunnesävyn helpommin kuin vaikkapa tietty rytmirakenne, refrenki tai sävelkulku. Suhteellisen universaalit perustunteet - ilo, suru - tulevat ymmärretyksi helpommin kuin laulun muodollisuus, rituaalisuus, kepeys, yksityisyys, vakavuus tai esimerkiksi aloitusformulan, sävelmän tai refrengin kantama viittaussuhde tiettyyn juhlatilanteeseen, vuodenaikaan tai tietyn laulajajoukon muodostamaan yhteisöön.

Lauluesityksessä toisiinsa punoutuvat piirteet vaihtelivat painoarvoiltaan. Liekkusävelmän käyttö saattoi määrittää moneen tilannesidonnaiseen lajiin sopivan runon liekkurunoksi, mutta toisinaan yleisempään nuottiin sovitettu varsinainen liekkuruno saattoi - tyypillisen kohteen eli lapsen ollessa läsnä - muuttua myös liekutusrunoksi eli kehtolauluksi. Laulun eritasoisten piirteiden kantamat merkityspotentiaalit saattoivat myös viitata useaan eri suuntaan ja jopa olla toisilleen vastakkaisia, ristiriidassa keskenään. Nopeaan, rytmikkääseen, kepeäksi määrittyvään tanssisävelmään oli mahdollista yhdistää surullisia tai traagisiakin runoja ja vakavia äänensävyjä. Yksikin piirre saattoi toisaalta saada erilaisia merkityskenttiä erilaisiin lajin tai tilanteen määrittämiin konteksteihin sijoittuessaan tai eri tavoin toteutuessaan: laulun hitaus merkitsi eri tavoin tanssilaulun (surullisuus, vakavuus) ja rituaalisen laulun (juhlavuus, painokkuus, rituaalisuus) yhteydessä, eikä riehakkaan ja nopean, napsutusten ja kiljahdusten säestämän ympärikko-tanssin voi olettaa kantaneen samanlaisia sävyjä kuin tasaisesti piirissä peräkkäin hitaan häälaulun tahdissa kuljetun ympärikon. Toisaalta samankaltaisen vaikutuksen saattoi luoda ilmeisen moninaisin keinoin: laulun surullisuus saattoi toteutua runoaiheina, tiettyinä hitaasti laulettuina sävelminä tai niihin tyypillisesti liittyvinä 
refrenkeinä, itkuvirren kaltaisina sävelkulkuina tai jopa surullisiin runosäkeisiin liittyvänä äänensävynä yleensä hilpeäksi määrittyvän nopean tanssinuotin yhteydessä.

Tietyt musiikilliset ja esitykselliset piirteet yhdistivät ja erottivat lajeja ja tilanteita, toimivat niiden tunnuksina ja linkkeinä niiden välillä. Keskeinen tämän työn läpi kulkeva teema on ollut laulun monikerroksisuus. Esitys muotoutuu erilaisten tekstuaalisten, musiikillisten, esityksellisten ja tilannesidonnaisten tekijöiden vuorovaikutuksena, ja nämä tekijät voivat kantaa mukanaan erilaisia viittaussuhteita toisiin esityksiin, toisiin lajeihin tai tyypillisiin tai keskeisiin esiintymisyhteyksiinsä. Hahmotankin esitystavan yhtenä laulajan hallussa olevana moniulotteisena keinona sijoittaa runo tulkinnalliseen kehykseen ja antaa sille tilannesidonnainen merkitys. 


\section{LÄHTEET JA KIRJALLISUUS}




\section{LÄHTEET JA KIRJALLISUUS}

\section{LYHENTEET}

A-K: Tampereen yliopiston Yhteiskunta- ja kulttuuritieteiden yksikön Kansanperinteen arkisto

ERA: Eesti Rahvaluule Arhiiv

RKM: Riikliku Kirjandusmuuseum

ETTM: Eesti Teatri ja Muusikamuuseum

FF: Folklore Fellows

FFC: Folklore Fellows Communications

ESS: Eesti-soome sõnaraamat (Kokla \& Pikamäe 2006)

HY: Helsingin yliopisto

IKHMS: Isuri keele Hevaha murde sõnastik (Laanest 1997).

IRS: Inkerin runosävelmät (Launis 1910a)

KIA: Suomalaisen Kirjallisuuden Seuran kirjallisuusarkisto

KMI: Kansanmusiikki-instituutti

KK: Kansalliskirjasto

KRA: Suomalaisen Kirjallisuuden Seuran kansanrunousarkiston käsikirjoituskokoelmat.

KRS: Karjalan runosävelmät (Launis 1930)

$\mathrm{KV}$ : Kalevalaseuran vuosikirja

NPI: Narodnye pesni Ingermanlandii (Kiuru et al. 1974)

SES : Suomen Etnomusikologinen Seura

SibA: Sibelius-Akatemia

SF: Studia Fennica

SFF: Studia Fennica Folkloristica

SHS: Suomen Historiallinen Seura

SHST: Suomen Historiallisen Seuran toimituksia

SKS: Suomalaisen Kirjallisuuden Seura

SKST: Suomalaisen Kirjallisuuden Seuran toimituksia

SKSÄ: Suomalaisen Kirjallisuuden Seuran kansanrunousarkiston äänitearkisto

SUS: Suomalais-ugrilainen Seura

SUST: Suomalais-ugrilaisen Seuran toimituksia

SKVR: Suomen Kansan Vanhat Runot

VKJMS: Vatjan kielen Joenperän murteen sanasto (Tsevetkov 1995)

VKKMS: Vatjan kielen Kukkosin murteen sanakirja (Suhonen \& Posti 1980)

VKS: Vadja keele sõnaraamat (Adler \& Leppik / Grünberg 1990-2011)

VSSS: Venäjä-suomi-suursanakirja (Kuusinen 2006) 


\section{ARKISTOL ̈̈HTEET}

A-K: Tampereen yliopiston Yhteiskunta- ja kulttuuritieteiden yksikön Kansanperinteen arkisto. Erkki Ala-Könnin nauhoitekokoelmat.

KK: Kansalliskirjasto

KK Coll. 123.20: Armas Launiksen arkisto 1900-1959. Elämäkerrallista aineistoa.

Launis, Armas (päiväämätön): Taival, jonka vaelsin. Itse-biografia matkamuistelmien värittämänä.

KK Coll. 123.22: Armas Launiksen arkisto 1900-1959. Elämäkerrallista aineistoa. Launis, Armas 1902: Päiväkirja. Koskeva etupäässä sitä matkaa, jonka allekirjottanut teki Kajaanin kihlakuntaan, sekä muita 'varsin tärkeitä' asioita

Launis, Armas 1903: Päiväkirja käsittäen runosävelmien keräysmatkan Inkerissa kesällä 1903, ja laulajaismatkan 4p-19p Heinäk. sekä oleskelun Nokiassa.

ERA: Eesti Rahvaluule Arhiivin kokoelmat

ERA, Fon: fonogrammikokoelma

RKM, Mgn. K. 39-46: Alla Gomonin Inkerissä vuonna 1972 tekemien äänitteiden kopiot

RKM, Mgn. II: Riikliku Kirjandusmuuseumi, ääninauhoitukset, mononauhat.

ERA III: Eesti Rahvaluule Arhiivin käsikirjoituskokoelma 1827-1944, kolmas sarja (nuotit). ETMM M 234:1: Pulst, August: Mälestusi muusika alalt. Käsikirjoitus Eesti Teatri ja Muusikamuuseumissa, käytetty Eesti Rahvaluule Arhiivissa säilytettävää kopiota.

MV: Museoviraston kansatieteellinen kuva-arkisto.

SibA: Sibelius-Akatemian kirjasto

Launis 1903: Armas Launiksen nuottikäsikirjoitus Länsi-Inkeristä.

SKS KRA: Suomalaisen Kirjallisuuden Seuran kansanrunousarkiston käsikirjoituskokoelmat. ERA Angeria: SKS:ssä säilytettävät kopiot Eesti Rahvaluule Arhiivin (ERA) kokoelmista. Runosävelmien käsikirjoitusluettelo (Elina Salminen) Runosävelmä-äänitteiden litteraatiot (Kati Kallio).

SKSÄ: Suomalaisen Kirjallisuuden Seuran äänitearkiston kokoelmat.

\section{TIETOKANNAT JA VERKKOAINEISTOT}

MOT: Kielitoimiston sanakirja, verkkoversio. Kielikone 2012.

SKVR-hak.: Suomen Kansan Vanhat Runot -teemahakemisto. Viimeisteillä SKS:ssa, käytetty vuosina 2005-2013. Liitetään myöhemmin SKVR-tietokantaan.

SKVR-tietokanta (Suomen Kansan Vanhat Runot sähköisessä muodossa). SKS. www.finlit.fi/skvr.

Suomen Kansan eSävelmät-tietokanta. Jyväskylän yliopiston musiikin laitos ja SKS. http://www.jyu.fi/ musica/sks/.

\section{PAINeTUT LÄHTEET JA KIRJALlisUUS}

Adler, Elna \& Leppik, Merle / Grünberg, Silja (toim.) 1990-2011: Vadja keele sõnaraamat. Tallinn: Signalet / Eesti Keele Instituut.

Agha, Asif 2004: Registers of Language. - Alessandro Duranti (ed.): A Companion to Linguistic Anthropology. Malden: Blackwell, 23-45.

Agha, Asif 2007: Language and Social Relations. Cambridge: Cambridge University Press.

Ahlqvist, A. 1904: Matka etelä-osassa Viipurin lääniä v. 1854. - Niemi (toim.) 1904, 199-230.

Ahmajärvi, Jouni 2003: "Se maa on taikamaa, on maa mun kaipauksen." Armas Launiksen kuva Lapista ja saamelaisista. Julkaisematon pro gradu -tutkielma. Oulun yliopisto, Historian laitos.

Aho, Marko 2006: Laulu Irenelle - Olavi Virta, eleet ja tulkinta. - Etnomusikologian vuosikirja 17: 72-93. Alava, Vihtori 1909: Vatjalaisia häätapoja, häälauluja ja itkuja. - Suomi IV:7:2. Helsinki: SKS.

Alava, Vihtori 1916: Naiset runolaulajina Inkerissä. - Uusi Suometar 251: 8-9.

Alava, Vihtori 1932: Minkälaisissa tilaisuuksissa vanhoja kansanrunojamme on käytetty? - Uusi Suomi 58: 10. Alho, Olli 1979: Orjat ja isännät. Tutkimus Inkeriläisistä maaorjarunoista. Suomi 123: 1. Helsinki: SKS. 
Amburger, Erik 1980: Ingermanland: eine junge Provinz Russlands im Wirkungsbereich der Residenz und Weltstadt St. Petersburg - Leningrad. 1. Köln: Böhlau.

Anepaio, Terje 1999: The Land Next to Ingria: Ingrian Finns in North-East Estonia After World War II. - Teinonen \& Virtanen (eds.) 1999, 155-181.

Anttonen, Pertti 1987: Rituaalinen pilkka länsi-inkeriläisissä kylähäissä. Julkaisematon pro gradu -tutkielma. Helsingin yliopisto, folkloristiikka. S 351.

Anttonen, Pertti 1992: The Rites of Passage Revisited: a New Look at van Gennep's Theory of the Ritual Process and its Application in the Study of Finnish-Karelian Wedding Rituals. Temenos 28, 15-52.

Anttonen, Pertti 1994: Ethnopoetic Analysis and Finnish Oral Verse. - Siikala \& Vakimo (ed.) 1994: 113-37.

Anttonen, Pertti J. 2005: Tradition through Modernity. Postmodernism and the Nation-State in Folklore Scholarship. SFF 15. Helsinki: SKS.

Apo, Satu 2001: Viinan voima: näkökulmia suomalaisten kansanomaiseen alkoholiajatteluun ja -kulttuuriin. SKST 759. Helsinki: SKS.

Apo, Satu 2009: Uusin Lönnrot-myytti ja kansanrunouden editiohistoria. Elore 16 (2), [1-21]. http:// www.elore.fi/arkisto/2_09/katsart_apo_2_09.pdf [15.9.2013].

Apo, Satu \& Nenola, Aili \& Stark-Arola, Laura (toim.) 1998: Gender and Folklore. Perspectives on Finnish and Karelian Culture. SFF 4. Helsinki: SKS.

Ariste, Paul 1960: Vadjalaste laule. Emakeele Seltsi Toimetised 3. Tallinn: Eesti NSV Teaduste Akadeemia.

Ariste, Paul 1966: Omaa ja vierasta vatjalaisten kalenterissa. - KV 46, 196-205.

Ariste, Paul 1969: Vadja Rahvakalender. Eesti NSV Teaduste Akadeemia Emakeele Seltsi Toimetised 8. Tallinn: Valgus.

Ariste, Paul 1986: Vadja rahvalaulud ja nende keel. Eesti NSV Teaduste Akadeemia Emakeele Seltsi toimetised 22. Tallinn: Eesti NSV Teaduste Akadeemia.

Ariste, Paul 2005: Vadja päevikud 1942-1980. Toim. Ergo-Hart Västrik ja Peeter Olesk. Litteraria: Eesti kirjandusloo allikmaterjale, vihik 22. Tartu: Eesti Kirjandusmuuseum.

Arukask, Madis 2003: Jutustava regilaulu aspektid: 19. sajandi lõpu setu lüroeepiliste regilaulude žanr ja struktuur. Dissertationes folkloristicae Universitatis Tartuensis 3. Tartu: Tartu Ülikooli kirjastus.

Asplund, Anneli 1976: Fonografista nauhuriin. - Heikki Laitinen \& Simo Westerholm (toim.): Paimensoittimista kisällilauluun. Tutkielmia kansanmusiikista 1. Kaustinen: KMI, 7-28.

Asplund, Anneli 1981: Kalevalaiset laulut. - Anneli Asplund \& Matti Hako (toim.): Kansanmusiikki. SKST 366. Helsinki: SKS, 18-43.

Asplund, Anneli 1992a: Kansanlauluja Inkerinmaalta. SKST 557. Helsinki: SKS.

Asplund, Anneli 1992b: Runolaulua Inkeristä. Perinnelipas 4. Helsinki: SKS.

Asplund, Anneli 1997: Murros, muutos ja mitta: metriikan, rakenteen ja sisällön välisistä suhteista suomalaisissa kansanlauluissa. Julkaisematon lisensiaatintutkimus. Helsingin yliopisto, Kulttuurien tutkimuksen laitos / folkloristiikka. S 459 I ja II.

Asplund, Anneli 2006a: Häämusiikki. - Anneli Asplund, Petri Hoppu et al. 2006, 308-339.

Asplund, Anneli 2006b: Runolaulusta rekilauluun: kansanlaulun murros. - Anneli Asplund, Petri Hoppu et al. 2006, s. 108-159.

Asplund, Anneli (tulossa): artikkelikäsikirjoitus inkeroisten laulajista ja laulujen tallentamisesta.

Asplund, Anneli \& Hoppu, Petri \& Laitinen, Heikki \& Leisiö, Timo \& Saha, Hannu \& Westerholm, Simo (toim.) 2006: Suomen musiikin historia 8: Kansanmusiikki. Helsinki: Werner Söderström.

Asplund, Anneli \& Laitinen, Heikki 1979: Kalevalaisia lauluja. Sävelmät, sanat ja selitykset Nelipolvisetkasettiin. Helsinki: SKS, Kansanmusiikin keskusliitto \& KMI.

Asplund Ingemark, Camilla 2004: The Genre of Trolls. The Case of a Finland-Swedish Folk Belief Tradition. Abå: Åbo Akademi University Press.

Austin, J. L. 1962: How to Do Things with Words. Cambridge, MA: Harvard University Press.

Autio, Petra M. 2003: Nostan tanssini kovaan lyöntiin. Kiribatilainen tanssi, sosiaalisuus ja kovuuden käsite. - Saarikoski, Helena (toim.) 2003, 147-88.

Bahtin, Mihail 1986: The Problem of Speech Genres. - Bahtin, M.: Speech Genres and Other Late Essays. Austin: University of Texas Press, 60-102.

Balzer, Marjorie Mandelstam 1999: The Tenacity of Ethnicity: a Siberian Saga in Global Perspective. Princeton (NJ): Princeton University Press.

Barthes, Roland 1977: Image - Music - text. Essays, selected and translated by Stephen Heath. London: Fontana.

Barz, Gregory F. \& Cooley, Timothy J. (eds.) 1997: Shadows in the Field. New Perspectives for Fieldwork in Ethnomusicology. New York \& Oxford: Oxford University Press.

Bateson, Gregory 1972: Steps to an Ecology of Mind. New Yourk: Ballantine Books.

Bauman, Richard 1977: Verbal Art as Performance. Prospect Heights. Illinois.

Bauman, Richard 1986: Story, Performance and Event: Contextual Studies of Oral Narrative. Cambridge: Cambridge University Press.

Bauman, Richard 1992: Folklore, Cultural Performances, and Popular Entertainments: a Communications-centered Handbook. New York: Oxford University Press.

Bauman, Richard 1999: Genre. - Journal of Linguistic Anthropology 9(1-2): 84-87.

Bauman, Richard 2004: A World of Others' Words. Cross-Cultural Perspectives on Intertextuality. Malden \& Oxford \& Carlton: Blackwell Publishing. 
Bauman, Richard \& Briggs, Charles S. 1990. Poetics and Performance as Critical Perspectives on Language and Social Life. - Annual Review of Anthropology 19:59-88.

Bauman, Richard \& Sherzer, Joel (ed.) 1989: Explorations in the Ethnography of Speaking. Cambridge: Cambridge University Press.

Ben-Amos, Dan 1976: Folklore genres. Austin: University of Texas Press.

Ben-Amos, Dan 1982 [1969]: Analytical Categories and Ethnic Genres. - Dan Ben-Amos: Folklore in Context. Essays. New Delhi: South Asian Publishers, 38-64.

Ben-Amos, Dan 1992: Do We Need Ideal Types (in Folklore)? An Address to Lauri Honko. - Nordic Institute of Folklore. Papers 2. Turku: Nordic Institute of Folklore.

Benveniste, Émile 1966: Problème de linguistique générale, I. Paris: Gallimard.

Biber, Douglas \& Conrad, Susan 2009: Register, Genre, and Style. Cambridge: Cambridge University Press.

Blacking, John 1974: How Musical is Man? Seatle \& London: University of Washington Press.

Blacking, John 1995: Music, Culture, \& Experience: Selected Papers of John Blacking. Chicago: University of Chicago Press.

Bono, Marie 2003: Volmari Porkan vuonna 1883 Inkeristä keräämien runojen pikakirjoitusmuistiinpanot. Julkaisematon pro gradu -tutkielma. Helsingin yliopisto, folkloristiikka. S 545 I-III.

Bowman, Rob 2003: The Determining Role of Performance in the Articulation of Meaning: the Case of "Try a Little Tenderness." - Moore, Alan F. (ed.): Analyzing Popular Music. Cambridge: Cambridge University Press, 103-130.

Branch, Michael 1973: A. J. Sjögren: Studies of the North. SUST 152. Helsinki: SUS.

Briggs, Charles L. 1986: Learning How to Ask: a Sociolinguistic Appraisal of the Role of the Interview in Social Science Research. Cambridge: Cambridge University Press.

Briggs, Charles L. 1988: Competence in Performance. The Creativity of Tradition in Mexicano Verbal Art. Philadelphia: University of Pennsylvania Press.

Briggs, Charles L. \& Bauman, Richard 1992: Genre, Intertextuality and Social Power. - Journal of Linguistic Anthropology 2, 131-172.

Brunner, Otto 1992: Land and lordship: Structures of Governance in Medieval Austria. Philadelphia, PA: University of Pennsylvania Press.

Burgeon, Judee K. \& Buller, David B. \& Woodall, W. Gill 1996 [1989]: Nonverbal Communication: the Unspoken Dialogue. Second edition. New York: McGraw-Hill companies, inc.

Caraveli, Anna 1982: The Song Beyond the Song: Aesthetics and Social Interaction in Greec Folksong. - Journal of American Folklore 95, 129-159.

Chistyakov, Anton 1999: Traditional Everyday Culture of Ingrian-Finns in South Ingria. - Teinonen \& Virtanen (ed.) 1995, 131-143.

Čistov, K. V. (toim.) 1976: Venäläinen perinnekulttuuri: Neuvostoliiton Pohjois-Euroopan venäläisväestön etnologiaa 1800-luvulta 1900-luvun alkuun. SKST 322. Helsinki: SKS.

Čistov, K. V. 1976a: Kansanrunous. - Čistov (toim.) 1976, 162-195.

Čistov, K. V. 1976b: Riitit ja rituaalinen folklore. - Čistov (toim.) 1976, 196-228.

Clifford, James \& Marcus, George E. 1986: Writing Culture. The Poetics and Politics of Ethnography. Berkeley \& Los Angeles: University of California Press.

Dorst, John D. 1983. Neck-riddle as a Dialogue of Genres. Applying Bakhtin's Genre Theory. - Journal of American Folklore 96, 413-433.

DuBois, Thomas 1994: An Ethnopoetic Approach to Finnish folk Poetry: Arhippa Perttunen's Nativity. - Siikala \& Vakimo 1994, 138-179.

DuBois, Thomas A. 1996: The Kalevala Received: From Printed Text to Oral Performance. - Oral Tradition 11(2), 270-300.

DuBois, Thomas A. 2006: Lyric, Meaning, and Audience in the Oral Tradition of Northern Europe. Notre Dame, Indiana: University of Notre Dame Press.

Duranti, Alessandro 1997: Linguistic Anthropology. Cambridge Textbooks in Linguistic. Cambridge: Cambridge University Press.

Eerola, Jari 2009: Examination of Stylistic Traits in Sound Production of the Veps Lühüd Pajo Songs Using Computer-Aid Music Analysis. - Jarkko Niemi (ed.) 2009, 160-197.

Eggins, Suzanne \& Martin, J. R. 1997: Genres and Registers of Discourse. - Teun van Dijk (ed.) 1997, 230-256.

Ekgren, Jacqueline Pattison 2009: Dipod rules: Norwegian Stev, Paired Accents and Accentual Poetry. - Tonya Kim Dewey \& Frog (eds.): Versatility in Versification: Multidisciplinary Approaches to Metrics. Berkeley Insights in Linguistics and Semiotics 74. New York, Bern, Berlin, Bruxelles, Frankfurt am Main, Oxford, Wien: Peter Lang.

Enäjärvi-Haavio, Elsa 1932: The Game of Rich and Poor: a Comparative Study in Traditional Singing Games. FFC 100. Helsinki: Suomalainen Tiedeakatemia.

Enäjärvi-Haavio, Elsa 1949: Pankame käsi kätehen. Suomalaisten kansanrunojen esittämistavoista. Porvoo: WSOY.

Enäjärvi-Haavio, Elsa 1953: Ritvalan helkajuhla. Jälkeenjääneen käsikirjoituksen täydentänyt ja painoon toimittanut Martti Haavio. Porvoo: WSOY.

Enäjärvi-Haavio, Elsa 1954: The Finnish Shrovetide. FFC 144. Helsinki: Suomalainen Tiedeakatemia.

Engman, Max 1991: Pietari ja Inkeri. - Nevalainen \& Sihvo 1991, 167-178.

ESS: Kokla \& Pikamäe 2006. 
Eriksen, Thomas Hylland 2001: Small Places, Large Issues: an Introduction to Social and Cultural Anthropology. London: Pluto Press.

Europaeus, D. E. D. 1847: Pieni runon-seppä, eli, Kokous paraimmista Inkerinmaan puolelta kerätyistä runo-lauluista: ynnä Johdatuksia runon tekoon. Helsinki: Simeliuksen perilliset.

Feld, Steven 1990 [1982]: Sound and Sentiment. Birds, Weeping, Poetics, and Song in Kaluli Expression. Second edition. Philadelphia: University of Pennsylvania Press.

Feld, Steven \& Fox, Aaron A. 1994: Music and Language. -Annual Review of Anthropology 23, 25-53.

Fine, Elizabeth C. 1984: The Folklore Text. From Performance to Print. Bloomington: Indiana University Press.

Fingerroos, Outi \& Kurki, Tuulikki 2008: Ääniä arkistosta. Haastattelut ja tulkinta. SKST 1194. Helsinki: SKS.

Finnegan, Ruth 1977: Oral Poetry: its Nature, Significance and Social Context. Cambridge: Cambridge University Press.

Finnegan, Ruth 2002: Communicating: the Multiple Modes of Human Interconnection. London: Routledge.

Fish, Stanley Eugene 1980: Is There a Text in This Class? The Authority of Interpretive Communities. Cambridge (MA): Harvard University Press.

Flink, Toivo 2000: Maaorjuuden ja vallankumouksen puristuksessa. Inkerin ja Pietarin suomalaisten sivustys- kulttuuri- ja itsetuntopyrkimyksiä vuosina 1861-1917. Turku: Turun yliopisto.

Flink, Toivo 2010: Kotiin karkotettavaksi: inkeriläisen siirtoväen palautukset Suomesta Neuvostoliittoon vuosina 1944-55. Historiallisia tutkimuksia 251; Arkistolaitoksen toimituksia 10. Helsinki: SKS.

Foley, John Miles 1985: Oral-Formulaic Theory and Research. An Introduction and Annotated Bibliography. Garland folklore bibliographies 6. New York: Garland.

Foley, John Miles 1988: The Theory of Oral Composition: History and Methodology. Bloomington: Indiana University Press.

Foley, John Miles 1991: Immanent Art. From Structure to Meaning in Traditional Oral Epic. Bloomington and Indianapolis: Indiana University Press.

Foley, John Miles 1995: The Singer of the Tales in Performance. Bloomington and Indianapolis: Indiana University Press.

Foley, John Miles 2002: How to Read an Oral Poem? Urbana and Chicago: University of Illinois Press.

Foley, John Miles 2004: The Wedding of Mustajbey's Son Bećirbey as performed by Halil Bajgorić. Edited and translated by John Miles Foley. FFC 283. Helsinki: Suomalainen Tiedeakatemia.

Forsberg [Alava], Vihtori 1892: Kertomus kansanrunouden keräämis-matkasta, jonka kesällä v. 1891 Inkerinmaalle teki V. Forsberg. - Suomi II: 6. Keskustelemukset, 26-28.

Forsberg [Alava], Vihtori 1893: Kesämatkani Länsi-Inkeriin v. 1892. - Suomi II: 7. Keskustelemukset, 51-57.

Forsberg [Alava], Vihtori 1895. Kuvauksia kesämatkaltani Inkerissä v. 1894. - Suomi 3(12), Keskustelemukset, s. 100-110.

Frog \& Stepanova, Eila 2011: Alliteration in (Balto-)Finnic Languages. - Jonathan Roper (ed.): Alliteration in Culture. Houndmills: Palgrave Macmillan, 195-218.

Geertz, Clifford 1973: The Interpretation of Cultures. Selected Essays. New York: Basic Books.

Genette, Gérard: Palimpsestes: La littérature au second degré. Paris: Editions du Seuil.

Goffman, Erving 1974: Frame analysis. New Yourk: Harper Colophon.

Gomon, A. 1977: Pesni ižor. - Ingrid Rüütel (toim.) 1977, 282-291.

Gossen, Gary H. 1974: Chamulas in the World of the Sun: Time and Space in a Maya Oral Tradition. Cambridge (MA): Harvard University Press.

Gracy, Karen 2004: Documenting Communities of Practice: Making the Case for Archival Ethnography. - Archival Science 4:(3-4), 335-365.

Grigor'eva, Inga Petrovna 1995: Muzykal'naja kul'tura ingermanlandskih finnov vtoroj poloviny XIX i XX stoletij. Sankt-Peterburg: Bukva.

Groundstroem, Oskar 1904. Kertomus kesällä 1861 muutamassa osassa Inkeriä tehdystä runonkeruumatkasta. - Niemi (toim.) 1904, 399-416.

Gröndahl, Satu M. 1997: Den ofullkomliga traditionen: bilden av Ingermanlands kvinnliga runotraditionen. Studia Uralica Upsaliensia 27. Uppsala: Universitas Upsaliensis.

Gumperz, John J. 1982: Discourse Strategies. Studies in Interactional sociolinguistics 1. Cambridge: Cambridge University Press.

Gumperz, John J. \& Jenny Cook-Gumperz 2008: Studying Language, Culture, and Society: Sociolinguistics or Linguistic Anthropology? - Journal of Sociolinguistics 12(4), 532-545.

Gunnell, Terry (ed.) 2007: Masks and Mumming in the nordic area. Acta Academiae Regiae Gustavi Adolphi 98. Uppsala: Kungl. Gustav Adolfs Akademien för svensk folkkultur.

Haapoja, Heidi 2013: La miä laulal laiHa lindu. Kolmen länsi-inkeriläisen runolaulajan sävelmistön analyysi. Julkaisematon pro gradu -työ. Sibelius-Akatemia, Kansanmusiikin osasto.

Haavio, Martti 1931: Kansanrunouden keruu ja tutkimus. Suomi V: 12. Helsinki: SKS.

Haavio, Martti 1932a: Lohikäärme ja neito: vertaileva runotutkimus. Suomi V: 14: 1. Helsinki: SKS

Haavio, Martti 1932b: Leikarit: vertaileva kansanrunoudentutkimus. Suomi V: 14: 2. Helsinki: SKS

Haavio, Martti 1948: Viimeiset runonlaulajat. Porvoo: WSOY.

Haavio, Martti 1961: Kuolematonten lehdot: Sämpsöi Pellervoisen arvoitus. Porvoo: WSOY.

Hakamies, Pekka 1990: "Soikkulassa" ja Suomessa. - Pekka Nevalainen \& Hannes Sihvo (toim.): Dokumentteja Inkerinmaalta. Studia Carelia Humanistica II. Joensuu: Universitas Joensuensis, 97-117. 
Hakamies, Pekka 1991: Inkeri monietnisenä alueena. - Nevalainen \& Sihvo 1991, 197-204.

Hako, Pekka 1982: Armas Launis 1884-1959. - Felix Krohn, Armas Launis, Ernst Linko. Hämeenlinna: Hämeen läänin taidetoimikunta.

Halliday 1978: Language as Social Semiotic: the Social Interpretation of Language and Meaning. London: Edward Arnold.

Haltsonen, Sulo 1957: Runoretki Inkeriin v. 1953: lisätietoja D. E. D. Europaeuksen runokeruun historiaan. Suomi 107:4. Helsinki: SKS.

Haltsonen, Sulo 1958: Antal Reguly: Vatjalaismuistiinpanot 1841. Julk. Sulo Haltsonen. SUS:n Aikakauskirja 60. Helsinki: SUS.

Haltsonen, Sulo 1969: Inkerin suomalaisen koulun ja kansanvalistuksen vaiheita. - Sulo Haltsonen (toim.): Inkerin suomalaisten historia. Helsinki: Inkerin Sivistyssäätiö, 187-290.

Hanks, William 1987. Discourse Genres in a Theory of Practice. - American Ethnologist 14, 668-692.

Hanks, William 1989. Text and Textuality. - Annual Review of Anthropology 18, 95-127.

Hanks, William F. 1996: Language and Communicative practices. Boulder (Colo.); Oxford: WestviewPress.

Haring, Lee 1988: Interperformance. Fabula 29(3-4), 365-372.

Harri, Jopi 2001: Kahdeksansävelmistö ja venäläinen traditio. Julkaisematon lisensiaatintutkimus. Turun yliopisto. http://www.synaxis.info/psalom/research/j_harri/harri2001_FinnOcto.pdf [15.9.2013].

Harvilahti, Lauri 1991: Milloin viime virren lauloin. - Nevalainen \& Sihvo (toim.) 1991, 205-221.

Harvilahti, Lauri 1992a: Kertovan runon keinot. Inkeriläisen runoepiikan tuottamisesta. SKST 522 Helsinki: SKS

Harvilahti, Lauri 1992b: The Production of Finnish Epic Poetry - Fixed Wholes or Creative Compositions? - Oral Tradition, 7(1), 87-101.

Harvilahti, Lauri 1994: The Ingrian Epic Poem and its Models. - Siikala \& Vakimo (eds.) 1994, 91-112.

Harvilahti, Lauri 1998a: Runoepiikan julma rakkaus. - Jyrki Pöysä \& Anna-Leena Siikala (toim.): Amor, genus \& familia; kirjoituksia kansanperinteestä. Helsinki: SKS, 56-73.

Harvilahti, Lauri 1998b: The Poetic "I" as an Allegory of Life. - Lauri Honko, Jawaharlal Handoo, John Miles Foley (ed.): Epic. Oral and Written. Mysore: Central Institute of Indian Languages, 193-206.

Harvilahti, Lauri 2000: Variation and Memory. - Lauri Honko (ed.) 2000, 57-76.

Harvilahti, Lauri 2003: The Holy Mountain. Studies on Upper Altay Oral Poetry. FFC 282. Helsinki: Academia Scientiarum Fennica.

Harvilahti, Lauri 2004: Vakiojaksot ja muuntelu kalevalaisessa epiikassa. - Siikala et. al (eds.) 2004, 194-214. Hautala, Jouko 1945: Lauri Lappalaisen runo. Vertaileva kansanrunoudentutkimus. SKST 227. Helsinki: SKS. Hautala, Jouko 1954: Suomalainen kansanrunoudentutkimus. Helsinki: SKS.

Heikkinen, Olli 2010: Ä̈̈nitemoodi:äänite musiikillisessa kommunikaatiossa. Jyväskylä studies in humanities 133. Jyväskylä: Jyväskylän yliopisto. http://urn.fi/URN:ISBN:978-951-39-3939-7 [15.9.2013].

Heikkinen, Vesa \& Voutilainen, Eero \& Lauerma, Petri \& Tiililä, Ulla \& Lounela, Mikko 2012: Genreanalyysi - tekstilajitutkimuksen käsikirja. Kotimaisten kielten keskuksen julkaisuja 169. Helsinki: Gaudeamus.

Heinonen, Kati 2000: Pääsköilintu, päivöilintu - pohdiskelua länsi-inkeriläiseen maailmansyntyrunoon liittyvien runomelodioiden ja -tekstien suhteesta. Julkaisemanton proseminaari-tutkielma. Helsingin yliopisto, folkloristiikka. S 496.61.

Heinonen, Kati 2005: Armas Launiksen fonogrammit Soikkolasta: laulutavan, runon ja laulutilanteen välisiä yhteyksiä kalevalamittaisessa runoudessa. Pro gradu- työ, folkloristiikka, Helsingin yliopisto. http://urn.fi/URN:NBN:fi-fe20051845 [15.9.2013].

Heinonen, Kati 2008a: Inkeriläisen runolaulun monta estetiikkaa. - Seppo Knuuttila \& Ulla Piela (toim.): Kansanestetiikka. KV 87. Helsinki: SKS, 249-270.

Heinonen, Kati 2008b: Tunne ääninauhalla: äänensävyjä ja aukkoja. - Outi Fingeroos \& Tuulikki Kurki (toim.): Ääniä arkistosta. Haastattelut ja tulkinta. SKST 1194. SKS, 234-260.

Heinonen, Kati 2009: Vienalaisen hääsävelmän joukolla laulamisesta. - Musiikin suunta 3-4, 32-41.

Heinonen, Kati \& Valtonen, Taarna: Kaksi kulttuuria kohtasi kesällä 1905. - Hiidenkivi 2/2006, 23-25.

Heinonen, Yrjö 2007: Runolaulun kaksi elämää - Värttinän Ukkolumen ja inkeriläisen runosävelmän Satoi ukko uutta lunta etnopoeettinen analyysi. - Etnomusikologian vuosikirja 19, 151-182.

Heinsoo, Heinike 1995: Tšeeli veeb vaikka Viipurii - Vatjalaisista ja vatjalaisuudesta. - Mauno Jokipii (toim.): Itämerensuomalaiset. Heimokansojen historiaa ja kohtaloita. Jyväskylä: Atena Kustannus Oy, 147-160.

Herndon, Marcia 1974: Analysis: The Herding of Sacred Cows? - Ethnomusicology XVIII(2), 219-262.

Herndon, Marcia \& McLeod, Norma 1981 [1979]: Music as Culture. 2nd edition. Norwood: Norwood Editions.

Hiiemäe, Mall 1998: Der estnische Volkskalender. FFC 268. Helsinki: Suomalainen Tiedeakatemia.

Hodge, Robert Ian Vere \& Kress, Gunther R. 1988: Social Semiotics. Cambridge: Polity Press.

Hoffman, Bernard G. 1961: Cabot to Cartier: Sources for a Historical Ethnography of Northeastern North America 1497-1550. Toronto: University of Toronto Press.

Honko, Lauri 1962: Geisterglaube in Ingermanland. FFC 185. Helsinki: Suomalainen Tiedeakatemia.

Honko, Lauri 1972: Uskontotieteen näkökulmia. Porvoo-Helsinki-Juva: Wsoy.

Honko, Lauri 1990: Inkerin tutkimus tienhaarassa. - Pekka Laaksonen \& Sirkka-Liisa Mettomäki (toim.): Inkerin teillä. KV 69-70. Helsinki: SKS, 113-123.

Honko, Lauri 1998: Textualising the Siri Epic. FFC 264. Helsinki: Suomalainen Tiedeakatemia. 
Honko, Lauri 2000: Thick Corpus and Organic Variation: an Introduction. - Lauri Honko (ed.) 2000, 3-28.

Honko, Lauri (ed.) 2000: Thick Corpus, Organic Variation and Textuality in Oral Tradition. SFF 7. Helsinki: SKS.

Hoppu, Petri 1999: Symbolien ja sanattomuuden tanssi: menuetti Suomessa 1700-luvulta nykyaikaan. SKST 767. Helsinki: SKS.

Hoppu, Petri 2003: Tanssintutkimus tienhaarassa. - Helena Saarikoski (toim.) 2003, 19-51.

Huttu-Hiltunen, Pekka 1999: Anni Lehtosen runolauluoppi. - Pekka Laaksonen \& Sirkka-Liisa Mettomäki (toim.): Tuulen jäljillä: kirjoituksia kansanperinteestä ja kulttuurihistoriasta. KV 77-78. Helsinki: SKS, 180-203.

Huttu-Hiltunen, Pekka 2008: Länsivienalainen runolaulu 1900-luvulla. Kuuden runolaulajan laulutyylin kulttuurisensitiivinen musiikkianalyysi. Kuhmo: Juminkeko.

Huuskonen, Marjut 1998: Kotoperäiset perinnelajitermit tulkinnan viitoittajina. - Sananjalka 40, 95-117.

Hymes, Dell 1971: Sociolinguistics and the Ethnography of Speaking. In Edwin Ardener (ed.): Social Anthropology and Language. London: Tavistock, 47-93.

Hymes, Dell 1974: Foundations in Sociolinguistics: An Ethnographic Approach. Philadelphia: University of Pensylvania Press.

Hymes, Dell 1981: 'In Vain I Tried to Tell You': Essays in Native American Ethnopoetics. Philadelphia: University of Pensylvania Press.

Hymes, Dell 1985: Language, Memory, and Selective Performance: Cultee's "Salmon's Myth" as Twice Told to Boas. - The Journal of American Folklore 98(390), 391-434.

Hymes, Dell 1989 [1974]: Ways of Speaking. - Richard Bauman ja Joel Sherzer (eds.): Explorations in the Ethnography of Speaking. Cambridge: Cambridge University Press, 433-451.

Hymes, Dell 2000: Sung Epic and Native American Ethnopoetics. - Lauri Honko (ed.) Textualization of Oral Epics. Trends in Linguistics 128. Berlin \& New York: Mouton de Gruyter, 291-342.

Häggman, Kai 2012: Sanojen talossa. Suomalaisen Kirjallisuuden Seura 1890-luvulta talvisotaan. Helsinki: SKS.

Hämäläinen, Antti 1944: Kadonnutta Inkeriä. Porvoo: Werner Söderström.

IKHMS: Laanest 1997.

Ikonen, Lauri \& Madetoja, Leevi 1909: [Matkakertomus Länsi-Inkeristä vuodelta 1907, ei otsikkoa]. Suomi IV: 6, Keskustelemukset. Helsinki: SKS, 78-80.

Ilmonen, Tommi 2006: Tools and Experiments in Multimodal Interaction. Publications in telecommunications software and multimedia 15. Espoo: Teknillinen korkeakoulu.

Ilomäki, Henni 1998: The Image of Women in Ingrian Wedding Poetry. - Satu Apo, et al. (toim.) 1998, 143-174.

IMS: Nirvi 1971.

Inha, I. K 1999 [1911]: Kalevalan laulumailta. Toim. Pekka Laaksonen. Kolmas, uudistettu painos. SKST 739. Helsinki: SKS.

IRS: Inkerin runosävelmät = Launis 1910a. Viittaukset laulujen numeroihin

Itkonen, Erkki 1936: A. A. Borenius-Lähteenkorva. Kansanrunouden keräjä ja tutkija. Suomi V: 18. Helsinki: SKS.

Jakobson, Roman 1959: On Linguistic Aspects of Translation. - Reuben A. Brower (ed.): On Translation. Cambridge: Harvard University Press, 232-239.

Jakobson, Roman 1960: Closing statement: Linguistics and Poetics. - T. A. Sebeok (ed.): Style and Language. Cambridge (MA): MIT Press, 350-377.

Jakobson, Roman 1971: "Linguistics and Poetics." - Selected Writings II. Word and Language, 62-94. The Hague: Mouton.

Jewitt, Carey (ed.) 2009: The Routledge Handbook of Multimodal Analysis. London \& New York: Routledge.

Johnstone, Tom \& Scherer, Klaus R. 2004 [2000]: Vocal Communication of Emotion. - Lewis, Michael \& Haviland-Jones, Jeannette M. (eds.) 2004: Handbook of emotions. Second edition. New York: Guilford Press, 220-235.

Jouste, Marko 2004: Armas Launiksen vuoden 1904 Lapin matkan joikusävelmien keräys ja soiva vertailuaineisto. - Musiikin suunta 26(2), 58-81.

Jouste, Marko 2008: Venäläisen bylinan ja kolttasaamelaisen leuddin välisestä yhteydestä. - Musiikin suunta 30(3-4), 11-31.

Juslin, Patric N. \& Sloboda, John A. (eds.) 2001: Music and Emotion. Theory and Research. Oxford: Oxford University Press.

Järvinen, Irma-Riitta 1985: Tytärten hukuttaja. - Noidannuolia. Tutkijanaisten aikakauskirja. Toimittaneet Auli Hakulinen, Hannele Kurki, Päivi Setälä ja Liisa Uusitalo. Helsinki: Gaudeamus, 115-122.

Järvinen, Irma-Riitta 1990: Aili Laihon päiväkirja Viron Inkeristä kesällä 1937. - Pekka Laaksonen \& Sirkka-Liisa Mettomäki (toim.): Inkerin teillä. KV 69-70. Helsinki: SKS, 15-45.

Järvinen, Irma-Riitta 1991: Elsa Enäjärvi-Haavio (1901-1951). - Eeva-Liisa Kinnunen (toim.): Sata vuotta suomalaista folkloristiikkaa. Helsingin yliopiston folkloristiikan laitoksen toimite 9. Helsinki: Yliopistopaino, s. 44-48.

Järvinen, Minna Riikka 1999: Maailma äänessä: tutkimus pohjoissaamelaisesta joikuperinteestä. SKST 762. Helsinki: SKS.

Järvinen, Minna Riikka 2004: Ummikkona Pohjan perille. - Launis, Armas: Tunturisävelmiä etsimässä. Lapissa 1904 ja 1905. Toim. Minna Riikka Järvinen. Helsinki: SKS, 341-351. 
Kaartinen, Timo 2001: Songs of Travel, Stories of Place: a Study of Tradition, Subjectivity and Otherness in Banda Eli (East Indonesia). A Dissertation submitted to the faculty of the social science, Department of Anthropology. Chicago, Illinois.

Kaartinen, Timo 2010: Songs of Travel, Stories of Place: Poetics of Absence in an Eastern Indonesian Society. FFC 299. Helsinki: Suomalainen Tiedeakatemia.

Kaivola-Bregenhøj, Annikki 2003: The Narrator's Emotions. - Tarkka, Lotte (ed.), Dynamics of Tradition. Perspectives on Oral Poetry and Folk Belief. SFF 13. Helsinki: Finnish Literature Society.

Kalkun, Andreas 2011: Seto laul eesti folkloristika ajaloos. Lisandusi representatsiooniloole. Dissertationes folkloristicae Universitatis Tartuensis 18. Tartu: Tartu Ülikooli Kirjastus. http://hdl.handle. net/10062/18222 [15.9.2013]

Kallberg, Maari 2004: A. O. Väisänen ja Miitrelän Ilja. Vienankarjalaisten joikujen piirteitä. Kuhmon musiikkiopiston julkaisuja no 4. Kuhmo: Kuhmon kaupunki / musiikkiopisto.

Kallio, Kati 2009a: Kehtolaulun poetiikkaa. - Ulla Piela \& Seppo Knuuttila (toim.): Korkeempi kaiku. KV 88. Helsinki: SKS, 127-137.

Kallio, Kati 2009b: Laulaa, tulkita, käsittää. Kokemuksia tanssitusta surusta. - Musiikin suunta 31(2): 5-11.

Kallio, Kati 2010: Tehkää yksi ympärikko. - Seppo Knuuttila, Ulla Piela \& Lotte Tarkka (toim.): Kalevalamittaisen runon tulkintoja. KV 89. Helsinki, SKS, 287-306.

Kallio, Kati 2011a: Interperformative Relationships in Ingrian Oral Poetry. - Oral Tradition 25(2), 391427. http://journal.oraltradition.org/issues/25ii/kallio [15.9.2013].

Kallio, Kati 2011b: A. O. Väisänen Kullervon mailla. - Knuuttila, Piela \& Blomster (toim.) 2011, 120-135.

Kallio, Kati 2012: Tulkintoja kerääjän kokemuksista: Armas Launis, runosävelmät ja Inkeri. - Mari Sarv (toim.): Regilaulu müüdid ja ideoloogiad. Eesti Rahvaluule Arhiivi toimetused 29. Tartu: Eesti Kirjandusmuuseum, 147-177.

Kamppinen, Matti 2004: Tulkinta uskontoetnografiassa. - Tieteessä tapahtuu 7/2004, 20-24.

Katajala, Kimmo 2005: Suurvallan rajalla: ihmisiä Ruotsin ajan Karjalassa. Historiallinen arkisto 118. Helsinki: SKS.

Katajamäki, Sakari 2010: Pienestä äänestä pohjapiirrokseksi: sonettirunouden metamodaalisuus. - Tarja Knuuttila \& Aki Petteri Lehtinen (toim.): Representaatio: tiedon kivijalasta tieteiden työkaluksi. Helsinki: Gaudeamus, 172-195.

Kirkinen, Heikki 1991: Inkerin keskiaika ja uuden ajan alku vuoteen 1617 - Nevalainen \& Sihvo 1991, 35-66.

Kiuru, Eino 1990: Soikkolan viimeisiä runonlaulajia tapaamassa. - Pekka Laaksonen \& Sirkka-Liisa Mettomäki (toim.): Inkerin teillä. KV 69-70. Helsinki: SKS, 103-110.

Kiuru, Eino 1994: The Wife-Killer Theme in Karelian and Russian Songs. - Siikala \& Vakimo 1994, 220-235.

Kiuru, Eino \& Koski, Terttu \& Kjul'mjasu [Kylmäsuu], Elina (toim.) 1974: Narodnye pesni Ingermanlandii. Leningrad: Nauka.

Knapp, Mark L. \& Hall, Judith A. 2002: Nonverbal Communication in Human Interaction. 5th ed. South Melbourne: Wadsworth/Thomson Learning.

Knuuttila, Seppo 1994: Tyhmän kansan teoria: näkökulmia menneestä tulevaan. Tietolipas 129. Helsinki: SKS.

Knuuttila, Seppo 2010: Tutkimusaineistojen muodostaminen. - Jyrki Pöysä \& Helmi Järviluoma \& Sinikka Vakimo (toim.): Vaeltavat metodit. Kultaneito VIII. Joensuu: Suomen Kansantietouden Tutkijain Seura, 19-42.

Kokko, Ossi 2007: Inkerinsuomen pirstaleisuus: eräiden sijojen kehitys murteen yksilöllistymisen kuvastajana. Joensuun yliopiston humanistisia julkaisuja 48. Joensuu: Joensuun yliopisto.

Kokla, Paul \& Pikamäe, Arno 2006: Eesti-soome sõnaraamat. Tallinn: Valgus.

Kolehmainen, Ilkka 1977: Kalevalasävelmän musikologista syntaksia. Julkaisematon pro gradu -tutkielma musiikkitieteessä ja sivulaudaturtyö suomalaisen ja vertailevan kansanrunouden tutkimuksessa. Helsingin yliopisto, Musiikkitiede ja folkloristiikka.

Kolehmainen, Ilkka 1990: The Kalevalaic musical variation technique in Karelia. - Congressus septimus internationalis fenno-ugristarum 6. Debrecen: [Kossuth Lajos Tudományegyetem], 211-215.

Konkka, Unelma 1985: Ikuinen ikävä. Karjalaiset riitti-itkut. SKST 428. Helsinki: SKS.

Koski, Kaarina 2011: Kuoleman voimat: kirkonväki suomalaisessa uskomusperinteessä. SKST 1313. Helsinki: SKS.

Koski, Terttu 1974: O napevah ingermanladskih pesen. - Kiuru \& al. 1974, 476-485.

Kress, Günther 2010: Multimodality: a Social Semiotic Approach to Contemporary Communication. London: Routledge.

Kristeva, Julia 1969: Le mot, le dialogue et le roman. - Sèméiotike. Recherches pour une sémanalyse. Paris: Éditions du Seuil, 82-112.

Krjukov, Aleksej 1993 [1987]: Ingermanland och ingermanländarna. - Sulo Huovinen (red.): Ingermanland - om land och folk. Kulturfonden för Sverige och Finland, 19-32.

Krohn, Julius 1894: Suomen suvun pakanallinen jumalanpalvelus: neljä lukua Suomen suvun pakanallista jumaluus-oppia. SKST 83, 1. Helsinki: SKS.

Krohn, Kaarle 1932: Leinon lesken runo. - Valvoja, s. 270-274.

Kurkela, Vesa 1991: Etnomusikologian historiattomuus ja nykyajan haasteet. - Pirkko Moisala (toim.): Kansanmusiikin tutkimus. Metodologian opas. Helsinki: VAPK-kustannus, 86-101.

Kuujo, Erkki 1969: Inkerin vaiheita keskiajalta 1700-luvun loppuun. - Inkerin suomalaisten historia. Helsinki: Inkeriläisten sivistyssäätiö, 45-96. 
Kuusi, Matti 1949: Sampo-eepos. Typologinen analyysi. SUST XCVI. Helsinki: SUS.

Kuusi, Matti 1952: Kalevalaisen säkeen, säeryhmän ja runon painavoituvuudesta. - Virittäjä 56, 241-261.

Kuusi, Matti 1956: Virolais-suomalainen Maailmansyntyruno. - KV 36, s. 49-84.

Kuusi, Matti 1963: Varhaiskalevalainen runous. - Matti Kuusi (toim.): Suomen kirjallisuus I. Kirjoittamaton kirjallisuus. Helsinki: SKS \& Otava, 129-215.

Kuusi, Matti 1977: Introduction. - Matti Kuusi, Keith Bosley \& Michal Branch (eds.): Finnish Folk Poetry: Epic. An anthology in Finnish and English. Helsinki: SKS, 21-77.

Kuusi, Matti 1983a: Maria Luukan laulut ja loitsut. Tutkimus läntisimmän Inkerin suomalaisperinteestä. SKST 379. Helsinki: SKS.

Kuusi, Matti 1983b: Jaakko Länkelä ja Porisan Anni. - Pertti Virtaranta et al. (toim.): Kentältä kentälle. Juhlakirja Erkki Ala-Könnin 70-vuotispäiväksi 2.2.1981. Tampereen yliopiston kansanperinteen laitoksen julkaisu 10. Tampere: Tampereen yliopisto, 53-59.

Kuusi, Matti 1985 [1979]: Kalevalakielestä. - Matti Kuusi: Perisuomalaista ja kansainvälistä. Tietolipas 99. Helsinki: WSOY, 184-197.

Kuusi, Matti 1997: Volmari Porkka. - Toim. Matti Kuusi \& Senni Timonen: SKVR XV. SKST 685. Helsinki: SKS, XLIX-LXV.

Kuusi, Matti \& Timonen Senni 1988: Suurmies? Kummajainen? Uhrilammas? Keskustelua Europaeuksen elämästä ja työstä. - Matti Kuusi, Pekka Laaksonen \& Senni Timonen (toim.): D. E. D. Europaeus: suurmies vai kummajainen? KV 67. Helsinki: SKS, 23-50.

Kuusinen, Martti (toim.) 2006: Venäjä-suomi-suursanakirja. Moskova \& Helsinki: Karjalan tiedekeskus, Kielen, kirjallisuuden ja historian instituutti \& Russki jazyk \& WSOY.

Kuutma, Kristin 2006: Collaborative Representations: Interpreting the Creation of a Sámi Ethnography and a Seto Epic. FFC 289. Helsinki: Suomalainen Tiedeakatemia.

Kõiva, Ottilia 1987: Kihnun vanha laulutapa. - Leea Virtanen (toim.): Viron veräjät. Näkökulmia folkloreen. Tietolipas 105. Helsinki: SKS, 52-71.

Käppi, Pekko 2007: "Kelpaisko lauluiks" - Musiikkianalyyttinen katsaus Marina Takalon kalevalamittaisiin lauluihin. Pro gradu -työ, Tampereen yliopiston Musiikintutkimuksen laitos. http://urn.fi/ urn:nbn:fi:uta-1-17062. [15.9.2013]

Kärki, Frans 1909. [Matkakertomus Liissilästä ja Lugan pitäjästä] - Suomi IV:6, Keskustelemukset s. 118-124.

Köppen, Peter von 1849: Etnographische Karte des St. Petersburgshen Gouvernements. St. Petersburg.

Köppen, Peter von 1867: Erklärender Text zu der Etnographischen Karte des St. Petersburger Gouvernements. St. Petersburg.

Laanest, Arvo 1966: Izhorskie dialektnye teksty. Isuri murdetekste. Tallinn: Eesti NSV Teaduste Akadeemia Keele ja Kirjanduse Instituut.

Laanest, Arvo 1986: Isuri keele ajalooline foneetika ja morfoloogia. Tallinn: Valgus.

Laanest, Arvo (toim.) 1997: Isuri keele Hevaha murde sõnastik. Tallinn: Eesti Keele Instituut.

Labov, William 1972: Language in the Inner City: Studies in the Black English Vernacular. Philadelphia: University of Pensylvania Press.

Laiho, Aili 1937: Muistitietoa Volmari Porkan runonkeruumatkoilta puolen vuosisadan takaa. Virittäjä 41, 444-448.

Laiho, Aili 1938: Stipendiaattikertomus. Suomalaisen Kirjallisuuden Seuralle. - Suomi, Keskustelemukset, 39-40.

Laiho, Aili 1944: Vanhan runolaulajan muisto. - Kotiliesi 4, 106-107.

Laiho, Lauri 1937: Syitä Inkerin vanhan häälaulun kuolemiseen. - Virittäjä 41, 411-444.

Laiho, Lauri 1938: Ä̈̈nilevyihin otettua Viron Inkerin kansanrunoutta. 21.22.VI.1937. - Suomi V: 20. Keskustelemukset 6/X.1937, 31-35.

Laiho, Lauri 1940: Viron Inkeri kansanrunouden maana. - Virittäjä 44. Helsinki, 218-236.

Laitinen, Heikki 2003a: Matkoja musiikkiin 1800-luvun Suomessa. Tampere: Tampere University Press. (http://urn.fi/urn:isbn:951-44-5707-2 [15.9.2013].)

Laitinen, Heikki 2003b: Iski sieluihin salama. SKST 942; KMIJ 55. Helsinki: SKS.

Laitinen, Heikki 2004: Anni Tenisovan Marian virsi. - Siikala et. al. (toim.) 2004, 157-193.

Laitinen, Heikki 2006: Runolaulu. - Asplund et. al. (toim.) 2006, 14-79.

Lauerma, Petri 2001: Larin Parasken metriikasta. - Virittäjä 1, 44-58.

Lauerma, Petri 2002: Larin Parasken epiikan kielellisestä variaatiosta. Suomi 189. Helsinki: SKS.

Launis, Armas 1904: Kertomus runosävelmien keräysmatkasta Inkerissä kesällä v. 1903. - Suomi IV: 2, Keskustelemukset, 49-53.

Launis, Armas 1906a: Kertomus sävelkeruumatkasta Norjan ja Suomen Lapissa kesällä vuonna 1905. Suomi IV: 4, Keskustelemukset, 79-85.

Launis, Armas 1906b: Kertomus runosävelmäin keräysmatkasta Karjalassa kesällä vuonna 1905. - Suomi IV: 4, Keskustelemukset, 86-87.

Launis, Armas 1907: Kertomus sävelkeruumatkasta Inkerissä kesällä 1906. - Suomi IV: 5, Keskustelemukset, 103-116.

Launis, Armas 1908: Lappische Juoigos-Melodien. SUST 26. Helsinki: SUS.

Launis, Armas 1910a: Suomen kansan sävelmiä IV: 1. Inkerin runosävelmät. Helsinki: SKS.

Launis, Armas 1910b: Über Art, Entstehung und Verbreitung der Estnisch-Finniscen Runenmelodien. Helsinki: SKS 
Launis, Armas 1910c: Runosävelmistä. - Kalevalan selityksiä. Eri tutkijain avustamana toimittanut A. R. Niemi. SKST 126. Helsinki: SKS, 221-242.

Launis, Armas 1921: Kullervo-oopperan esihistoriaa. - KV 1, 164-176.

Launis, Armas 1930: Karjalan runosävelmät. Suomen kansan sävelmiä V: 2. SKST 68:2. Helsinki: SKS.

Laurila, Vihtori 1956: Suomen rahvaan runoniekat sääty-yhteiskunnan aikana. 1. osa, Yleiset näkökohdat. Helsinki: SKS.

Lehto, Manja Irmeli 1996: Ingrian Finnish: Dialect Preservation and Change. Studia Uralica Upsaliensia 23. Uppsala: Acta Universitatis Upsaliensis.

Lehtonen, Mikko 1996: Merkitysten maailma. Kulttuurisen tekstintutkimuksen lähtökohtia. Tampere: Vastapaino.

Lehtonen, Tuomas M. S. 1992: Jo luettua: Intertekstuaalisuus kulttuuriteoriana tai metodina? - tiede \& edistys 17(1), 68-70.

Leino, Pentti 1970: Strukturaalinen alkusointu Suomessa. Folklorepohjainen tilastoanalyysi. SKST 298 Helsinki: SKS

Leino, Pentti 1982: Kieli, runo ja mitta. Suomen kielen metriikka. SKST 376. Helsinki: SKS.

Leino, Pentti 1986: Language and metre. Metrics and the metrical system of Finnish. SF 31. Helsinki: SKS.

Leino, Pentti 1994: The Kalevala Metre and its Development. - Siikala et al. (toim.) 1994, 56-74.

Leisiö, Larisa 2004: Runomitta ja aika. Erikoiskohteena slaavien lauluruno. - Musiikin suunta 2, 18-36.

Leisiö, Timo (toim.) 1992: Setumaalta Harjumaalle. A. O. Väisäsen tutkimusmatka Viroon vuonna 1913 Tampere: Kansanperinteenlaitoksen julkaisuja 13. Tampere: Tampereen yliopisto.

Leisiö, Timo \& Niemi, Jarkko 2004: Tutkimuskohteena läntisen Euraasian lauluperinteet. - Musiikin suunta 2, 3-17.

Leisiö, Timo 2000. Metri, rytmi, metrinen tyhiö ja musiikillinen aika. - Musiikin suunta 2, 14-24.

Lennartsson, Rebecka 2012: Archival Ethnography, or: Reflections on a Lost Note.H-Soz-u-Kult, 27.6.2012, http://hsozkult.geschichte.hu-berlin.de/forum/id=1813\&type=diskussionen [15.9.2013].

Leskinen, Heikki 1991: Inkerin kielimuodot. -Nevalainen \& Sihvo 1991, 222-233.

Levón, Eino 1904: Kertomus matkastani Inkerinmaalla kansansävelmien keräämistä varten kesällä v. 1903. - Suomi IV:2, Keskustelemukset s. 65-68.

Lippus, Urve 1995: Linear Musical Thinking: a Theory of Musical Thinking and the Runic Song Tradition of Baltic-Finnish Peoples. Studia Musicologica Universitas Helsingiensis VII. Helsinki: University of Helsinki.

Lord, Albert B. 1960. The Singer of Tales. Cambridge: Harvard University Press. [Repr. 2000.]

Lukin, Karina 2011: Elämän ja entisyyden maisemat. Kolgujev nenetsien arjessa, muistelussa ja kerronnassa. SKST 1339. Helsinki: SKS.

Lukkarinen, J. 1911: Inkeriläisten praasniekoista. - Suomalaisen Kansanrunousseminaarin julkaisuja II. Suomi IV:11. Helsinki.

Lukkarinen, J. 1933: Suomalaisten naimatapoja. Aineksia suomalaisten kansojen avioliiton historiaan. I. Helsinki: SKS.

Länkelä, J. 1904 [1859]. Matkakertomus. - Niemi (toim.) 1904, 270-301.

Majamaa, Raija 2008a [2004]: Haavio, Martti (1899-1973). - Kansallisbiografia-verkkojulkaisu. Studia Biographica 4. Helsinki: SKS.

Majamaa, Raija 2008b [2003]: Enäjärvi-Haavio, Elsa (1901-1951). - Kansallisbiografia-verkkojulkaisu. Studia Biographica 4. Helsinki: SKS.

Malmi, Viola 1993: Karjalaisen kansantanssin lähteillä. Helsinki: Vapaan sivistystoiminnan liitto.

Manninen, Hannele 1982: A. O. Väisänen suomensukuisten kansojen kansanmusiikin tutkijana. Julkaisematon pro gradu -tutkielma. Kansanperinne, Tampereen yliopisto.

Mansikka, V. J. 1929. Inkeriläisistä kiletoivirsistä. - Virittäjä 33, 312-314.

Mansikka, V. J. 1932. Inkerin liekkulauluista. - Suomi V:14:3. Helsinki: SKS.

Mansikka, V. J. 1938: Martin- ja Tapaninvirsistä. - KV 18, 228-241.

Mansikka, V. J. 1939: Pyhän Iljan palvonnasta. - KV 19, 142-164.

Mansikka, V. J. 1940: Kokkotulista. - Virittäjä 44, 193-205, 276-277.

Mansikka, V. J. 1941a: Pyhä Miikkula. - KV 20-21, 176-197.

Martin 1998: English Text: System and Structure. Philadelphia: John Benjamins Publishing.

Mathisen, Stein R. 2005: Folklore in Northern Multicultural Contexts. - FF Network 32, 3-9.

Meriluoto, Marja 1966: Inkeriläisten henkinen kulttuuri vuosina 1863-1917. Julkaisematon pro gradu -tutkielma. Helsingin yliopisto, Historian laitos.

Merriam, Alan P. 1964: The Anthropology of Music. Evanston: Northwestern University Press.

Mettomäki, Sirkka-Liisa 1982: Sylvi Sääski perinteenkerääjänä. Julkaisematon pro seminaari -esitelmä. Helsingin yliopisto, folkloristiikka. S 292.

Mikkola, Kati 2009: Tulevaisuutta vastaan. Uutuuksien vastustus, kansantiedon keruu ja kansakunnan rakentaminen. SKST 1251. Helsinki: SKS.

Mikkola, Kati (tulossa): käsikirjoitus itseoppineista perinteenkerääjistä.

Mikkonen, Kai 2005: Kuva ja sana. Kuvan ja sanan vuorovaikutus kirjallisuudessa, kuvataiteessa ja ikonoteksteissä. Helsinki: Gaudeamus.

Misharina, Galina 2011: Funeral and Magical rituals among the Komi. - Folklore. Electronic Journal of Folklore 47, 155-172. http://www.folklore.ee/folklore/vol47/misharina.pdf [15.9.2013]. 
Moisala, Pirkko 1991a: Antropologinen musiikintutkimus. - Moisala, Pirkko (toim.): Kansanmusiikin tutkimus. Metodologian opas. VAPK-kustannus. Helsinki, 105-137.

Moisala, Pirkko 1991b: Cultural Cognition in Music. Continuity and Change in the Gurung Music of Nepal. SES:n julkaisuja 4. Helsinki: SES.

Mustonen, Juuso 1931: Inkerin suomalaiset seurakunnat. SKST 191. Helsinki: SKS.

Mäkinen, Eino 2008 [1938]: Inkerin vanhaa kyläelämää. Kuvaus Eino Mäkinen, asiantuntija Lauri Laiho. Kuvattu vuonna 1938, valmistunut vuonna 1941. - Isien työt III. Eino Mäkisen Kansatieteellinen Filmi Oy:lle kuvaamia lyhytelokuvia. Helsinki: Suomen Kulttuurirahasto.

Mäkinen, Kirsti 1990: Alussa oli nainen. - Aili Nenola ja Senni Timonen (toim.): Louhen sanat: kirjoituksia kansanperinteen naisista. SKST 520. Helsinki: SKS, 209-213.

Mäntynen, Anne \& Shore, Susanna \& Solin, Anna 2006: Genre - Tekstilaji. Tietolipas 213. Helsinki: SKS.

Nenola-Kallio, Aili 1982: Studies in Ingrian Laments. FFC 234. Helsinki: Suomalainen Tiedeakatemia.

Nenola, Aili 2002: Inkerin itkuvirret. Ingrian Laments. SKST 735. Helsinki: SKS.

Nettl, Bruno 1983. The Study of Ethnomusicology. Twenty-nine Issues and Concepts. Urbana \& Chicago: University of Illinois Press.

Nevalainen, Pekka \& Sihvo, Hannes (toim.) 1991: Inkeri. Historia, kansa, kulttuuri. SKST 547. Helsinki: SKS.

Nevalainen, Pekka 1991a: Silmäys Inkerin kirkollisiin oloihin 1704-1917. - Nevalainen \& Sihvo (toim.) 1991, 159-166.

Nevalainen, Pekka 1991b: Inkerinmaan ja inkeriläisten vaiheet 1900-luvulla. - Nevalainen \& Sihvo (toim.) 1991, 234-299.

Nevalainen, Pekka 1996: Rautaa Inkerin rajoilla. Inkerin kansalliset kamppailut ja Suomi 1918-1920. Helsinki: SHS

Nevalainen, Pekka 1999: Viskoi kuin Luoja kerjäläistä: Venäjän pakolaiset Suomessa 1917-1939. Helsinki: SKS.

Niemeläinen, Päivyt 1983: Suomalainen kansantanssi. - Päivyt Niemeläinen (toim.): Suomalainen kansantanssi. Helsinki: Otava, 19-46.

Niemi, A. R. 1922 [1918]: Vanhan suomalaisen runomitan synnystä. - Suomi IV: 19. Helsinki: SKS.

Niemi, A. R. (toim.) 1904: Runonkerääjiemme matkakertomuksia 1830-luvulta 1880-luvulle. SKST 109. Helsinki: SKS.

Niemi, Jarkko 1998: The Nenets Songs: a Structural Analysis of Text and Melody. Acta Universitatis Tamperensis 591. Tampere: University of Tampere.

Niemi, Jarkko 2002: Inkeriläisten itkuvirsien musiikilliset rakenteet. - Nenola (2002), 694-707.

Niemi, Jarkko 2004: Mansilaiset lauluaineistot ja Länsi-Siperian alkuperäiskansojen laulutyylivyöhykkeet - Melodian ja metrin modaliteetin ongelmia. - Musiikin suunta 2, 37-57.

Niemi, Jarkko (toim.) 2009: Perspectives on the Song of the Indigenous Peoples of Northern Eurasia: Performance, Genres, Musical syntax, Sound. Tampere: Tampere University Press.

Niemi, Jarkko \& Jouste, Marko 2002: Teesejä pohjoisen laulun analyysiin: tarkastelussa nenetsit ja saamelaiset. - Etnomusikologian vuosikirja 14, 161-209.

Niemi, Jarkko \& Lapsui, Anastasia 2004: Network of Songs. Individual Songs of the Ob' Gulf Nenets: Music and Local History as Sung by Maria Maksimovna Lapsui. SUST 248. Helsinki: SUS.

Niiranen, Elina 2013: Maria Feodorovan laulupolut. Vienankarjalaisen kansanlaulajan repertuaari musiikkisukupolven rakentajana. Acta Universitatis Tamperensis 1836. Tampere: Tampere University Press. (http://urn.fi/URN:ISBN:978-951-44-9162-7 [15.9.2013].)

Nirvi, R. E. 1961: Inkeroismurteen asema. - KV 41, s. 99-132.

Nirvi, R. E. 1971: Inkeroismurteiden sanakirja. Lexika Societatis Fenno-Ugricae XVIII. Helsinki: SUS.

Novozhilov, Alexei 1999: Ethnocultural Relations and Processes of Interaction between Ingrian-Finns, Russians and Veps. - Teinonen \& Virtanen (eds.) 1999, 125-131.

NPI = Kiuru et al. 1974

Oatley, Keith \& Jenkins, Jennifer M. 1996: Understanding Emotions. Cambridge, MA: Blackwell Publishers.

Oinas, Felix 1969: Studies in Finnic-slavic Folklore Relations. FFC 205. Helsinki: Suomalainen tiedeakatemia.

Oja, Heikki 2010 [1999]: Aikakirja. Verkkoversio. Helsinki: Helsingin yliopiston almanakkatoimisto. http://almanakka.helsinki.fi/aikakirja/Aikakirja2010kokonaan.pdf [1.10.2011].

Ong, Walter J. 1982: Orality and Literacy: the Technologizing of the Word. London and New York: Methuen.

Oras, Janika 2001: Muhu regilaulu rütmid. -Tiiu Jaago \& Mari Sarv (toim.): Regilaul - keel, muusika, poeetika. Tartu: Eesti Kirjandusmuuseum, Eesti Rahvaluule Arhiiv \& Tartu Ülikool, Eesti ja võrdleva rahvaluule õppetool, 153-194.

Oras, Janika 2004a: Helmi Villa regilauluviisid - korrastatud mitmesesisus. - Mari Sarv (toim.): Regilaulu - loodud või saadud? Tartu: Eesti Kirjandusmuuseum, Eesti Rahvaluule Arhiiv, 89-121.

Oras, Janika 2004b: Heterofoonia ühe regilaulu traditsioonilises ja tänäpäevases interpretatsioonis. - Ingrid Rüütel (toim.): Pärimusmuusika muutuvas ühiskonnas. Töid etnomusikoloogia alalt 2. Tartu: Eesti Kirjandusmuuseumi etnomusikoloogia osakond, Eesti Rahvuslik Folkloorinõukogu, 65-76.

Oras, Janika 2008. Viie 20. sajandi naise regilaulumaailm. Arhiivitekstid, kogemused ja mälestused. Eesti Rahvaluule Arhiivi toimetused 27. Tartu: Eesti Kirjandusmuuseumi Teaduskirjastus. (http:// www.ema.edu.ee/vaitekirjad/doktor/Janika_Oras.pdf [15.9.2013].)

Oras, Janika 2010: Musical manifestations of textual patterning in Estonian regilaul. - Journal of Ethnology and Folkloristics 4(2), 55-68. (http://www.jef.ee/index.php/journal/article/view/55/pdf_53 [15.9.2013].) 
Padilla, Alfonso 1997: Etnomusikologinen musiikkianalyysi. - Musiikin suunta 19:2, 4-17.

Paredes, Americo 1977: On Ethnographic Work Among Minority Groups: a Folklorist's Perspective. New Scholar 6, 1-32.

Parry, Milman 1930: Studies in the Epic Technique of Oral Verse-Making I: Homer and Homeric Style. - HSCP, 41, 73-147.

Paukkunen, Elina 2006: Ruumiillisen tiedon jäljillä. - Musiikin suunta 28 (4), 29-38.

Paulaharju, Maarit (toim.) 2010: Samuli Paulaharjun Inkeri. SKST 1292. Helsinki: SKS \& Museovirasto.

Pekkilä, Erkki 1988: Musiikki tekstinä: kuulonvaraisen musiikkikulttuurin analyysiteoria ja -metodi. Acta Musiocologia Fennika 17. Helsinki: Suomen musiikkitieteellinen seura.

Pekkilä, Erkki 1990: A. O. Väisäsen elämänura. - Väisänen 1990, 9-19.

Pentikäinen, Juha 1963: Ken emon unohtanevi. - KV 43, 262-286.

Penttinen, Yrjö 1947: Sotasanomat. Inkeriläinen kansanruno ja sen kansainvälistä taustaa. SKTS 232 Helsinki: SKS.

Piela, Ulla 2010: Kansanparannuksen kerrotut merkitykset Pohjois-Karjalassa 1800- ja 1900-luvuilla. Dissertations in Education, Humanities, and Theology 8. Joensuu: University of Eastern Finland. (http://urn.fi/URN:ISBN:978-952-61-0208-5 [15.9.2013].)

Piela, Ulla \& Knuuttila, Seppo \& Tarkka, Lotte 2010: Kalevalamittaisen runon tulkintoja. KV 89. Helsinki: SKS

Piela, Ulla \& Knuuttila, Seppo \& Blomster, Risto 2011 (toim.): Tiede, taide, tulkinta: kirjoituksia A. O. Väisäsestä. KV 90. Helsinki: SKS.

Pimiä, Tenho 2009: Tähtäin idässä: suomalaisten sukukansojen tutkimus toisessa maailmansodassa. Jyväskylä studies in humanities 124. Jyväskylä: Jyväskylän yliopisto. http://urn.fi/URN:ISBN:978 951-39-3686-0 [23.8.2011].

Ponterotto, Joseph G. 2006: Brief Note on the Origins, Evolution, and Meaning of the Qualitative Research Concept "Thick Description." - The Qualitative Report 11 (3), 538-549. http://www.nova. edu/ssss/QR/QR11-3/ponterotto.pdf [15.9.2013].

Porkka, Volmari 1883a: Inkerin itkuvirsistä. - Valvoja, 199-208.

Porkka, Volmari 1883b: Inkerin itkuvirsistä. II. Hää- eli pulma-itkut. - Valvoja, 261-271.

Porkka, Volmari 1885: Über den Ingrischen Dialekt mit Berücksichtigung der übrigen finnischingermanlandischen Dialekte. Helsingfors.

Porkka, Volmari 1886: Kertomus runonkeruu-matkasta, jonka v. 1883 kesällä teki Inkeriin Volmari Porkka. - Suomi II: 19, 149-169.

Põldmäe, Rudolf \& Tampere, Herbert 1938: Valimik Eesti rahvatantse. Eesti Rahvaluule Arhiivi toimetused 8. Tartu: Eesti Rahvaluule Arhiivi Kirjastus.

Pärtlas, Žanna 2006: „Sümmeetrilised laadid“ ja monointervalliline mitmehäälsus vokaalses rahvamuusikas: Mõningaid paralleele setu ja Lõuna-Venemaa rahvalaulu vahel. - Aado Lintrop (toim.): Regilaul - esitus ja tôlgendus. Eesti Rahvaluule Arhiivi toimetused 23. Tartu: Eesti Kirjandusmuuseum, 219-248.

Pöysä, Jyrki 2010: Lähiluku vaeltavana käsitteenä ja tieteidenvälisenä metodina. - Jyrki Pöysä \& Helmi Järviluoma \& Sinikka Vakimo (toim.): Vaeltavat metodit. Kultaneito VIII. Joensuu: Suomen Kansantietouden Tutkijain Seura, 331-360.

Rainio, Riitta 2010: Suomen rautakautiset kulkuset, kellot ja kelloriipukset: äänimaiseman arkeologiaa. Suomen musiikkikirjastoyhdistyksen julkaisusarja 138. Helsinki: Suomen musiikkikirjastoyhdistys. (http://urn.fi/URN:ISBN:978-952-10-6170-7 [15.9.2013]

Ranta, Raimo 1991: Inkerinmaan hallinto ja oikeuslaitos 1617-1917. - Nevalainen \& Sihvo (toim.) 1991, 103-158.

Rantasalo, A.V. 1929: Inkeriläinen kertova runo tytärten surmaaja. Suomi 5:9. Helsinki: SKS:

Raski, Jaakko 1932: Inkerin kirkko kansallisena kasvattajana. Kangasala.

Raudalainen, Taisto Kalevi 2007: Multietniline ja -konfessionaalne Ingeri pärimusajaloolisest vaatepunktist. - Madis Arukask (toim.): Muutused, erinevused ja kohanemised eesti kultuuriruumis ja selle naabruses. Viljandi: Tartu Ülikool, Viljandi Kultuuriakadeemia, 31-82.

Rausmaa, Pirkko-Liisa 1981: Vanhat laulutanssit. - Pekka Laaksonen (toim.): Pelit ja leikit. KV 61. Helsinki: SKS, s. 186-196.

Reichl, Karl 2000: Introduction: The Music and Performance of Oral Epics. - Karl Reichl (ed.): The Oral Epic: Performance and Music. Intercultural music studies 12. Berlin: Verlag für Wiss und Bildung.

Ricoeur, Paul 1991: Essays in Hermeneutics. Vol II. Translated by Kathleen Blamey and John B. Thomson. Evanston: Northwestern University Press.

Ross, Jaan \& Lehiste, Ilse 2001: The Temporal Structure of Estonian Runic Songs. Berlin \& New York: Mouton de Gruyter.

Ruotsalainen, J. Fr. 1901: Matkakertomus Länsi-Inkeristä. - Suomi III: 19, Keskustelemukset, 80.

Ryle, Gilbert 1971: Collected Papers. Volume II collected essays, 1929-1968. London: Hutchinson.

Räsänen, Matti 1999: Background and Anatomy of the Project The Research Project in Ethnicity and Identity. - Teinonen \& Virtanen (ed.) 1999, 9-17.

Rüütel, Ingrid 1977: Vadja rahvamuusika tüpoloogia ja stiilid. - Rü̈̈tel (toim.) 1977, 216-281.

Rüütel, Ingrid 1979. Soome-ugri rahvaste laule: Vadja ja isuri rahvalaule. LP «Melodija». Tallinn-Riia.

Rüütel, Ingrid 1982: Oudekki Figurova vadja rahvaviisid. - J. Linnus (toim.): Läänemeresoomlaste etnokultuuri küsimusi. Tallinn: Valgus, 41-52. 
Rüütel, Ingrid 1998: Estonian Folk Music Layers in the Context of Ethnic Relations. Folklore 6(6), 32 69. http://www.folklore.ee/folklore/vol6/ruutel.htm [15.9.2013]

Rüütel, Ingrid 2006: Eesti regivärsiliste rahvalaulude musikaaline tüpoloogia. - Mare Kõiva (koost.): Võim ja kultuur. Tartu: Eesti Kirjandusmuuseum, Eesti Kultuuriloo ja Folkloristika Keskus, 83-102.

Rüütel, Ingrid (toim.) 1977: Soome-ugri rahvaste muusikapärandist. Tallin: Eesti Raamat.

Saarikoski, Helena (toim.) 2003: Tanssi tanssi. Kulttuureja, tulkintoja. Tietolipas 186. SKS: Helsinki.

Saarinen, Jukka 1988: Variaatio Arhippa ja Miihkali Perttusen epiikassa. Julkaisematon pro gadu -tutkielma. Helsingin yliopisto, folkloristiikka. S 371.

Saarinen, Jukka 1991: Miihkali Perttusen Päivölän virsi. - Pekka Laaksonen \& Sirkka-Liisa Mettomäki (toim.): Kolme on kovaa sanaa: kirjoituksia kansanperinteestä. KV 71. Helsinki: SKS, 193-208.

Saarlo, Liina 2007. Vana ja ilus - Eesti regilaulu väärtuse otsimisest. Esitelmä seminaarissa Kirjoitetun ja lauletun runon tutkimuksen metodologia ennen ja nyt. 6.9.2007. Helsinki, SKS.

Sadeniemi, Matti 1951: Die Metrik des Kalevala-verses. FFC 139. Helsinki: Suomalainen tiedeakatemia.

Saha, Hannu 1982: Teppo Repo. Repertoaari ja asema suomalaisessa musiikkikulttuurissa. Tampereen yliopiston Kansanperinteen laitoksen moniste 3. Tampere: Tampereen yliopisto.

Saha, Hannu 1996: Kansanmusiikin tyyli ja muuntelu. KMI:n julkaisuja 39. Kaustinen: Kansanmusiikkiinstituutti.

Sahlins, Marshall 1992: Anahulu: the Anthropology of History in the Kingdom of Hawaii. Volume one. Historical ethnography. (Ed. Patrick V. Kirch and Marshall Sahlins; with assistance of Dorothy B. Barrère.) Chicago \& London: The University of Chicago Press.

Salminen, Kaarina 1931: Selonteko Inkerin matkasta kesällä 1931. - Suomi V:14. Keskustelemukset 7.5.1931, 34-35.

Salminen, Väinö 1916: Inkerin kansan häärunoelma muinaisine kosimis- ja häämenoineen. SKST 155. Helsinki: SKS

Salminen, Väinö 1917: Länsi-Inkerin häärunot. Synty- ja kehityshistoriaa. Helsinki: SKS.

Salminen, Väinö 1919: Häätapain kuvaus Narvusin Kallivieren kylästä. - Virittäjä 23, 17-22.

Salminen, Väinö 1929a: Kertovien runojen historiaa. Inkeri. Suomi V:8. Helsinki: SKS.

Salminen, Väinö 1929b: Kalevalan kertovat runot Inkerissä. - KV 9, 52-76.

Salminen, Väinö 1929c: Tutkimus vatjalaisten runojen alkuperästä. Eripainos aikakauskirja Suomen V jakson 7. osasta. Helsinki: SKS.

Salminen, Väinö 1930: Sotamiehenottorunot. - KV 10, 171-192.

Salminen, Väinö 1931a: Inkerin runonlaulajat ja tietäjät. - Väinö Salminen (toim.): Suomen Kansan Vanhat Runot V:3. Helsinki: SKS, 525-649.

Salminen, Väinö 1931b: Keinu l. liekku ja liekkuvirret. - KV 11, 23-39.

Salminen, Väinö 1934: Suomalaisten muinaisrunojen historia I. Helsinki: SKS.

Salminen, Väinö 1946a: Inkerin siirtolaisten Siperiassa säilyttämä häärunosikermä. - KV 25-26, 217-229.

Salminen, Väinö 1946b: Vaeltajan tarinoita. Otava: Helsinki.

Salminen, Väinö 1946c: Vallattomilta vaellusvuosilta. Otava: Helsinki.

Saloheimo, Veijo 1991: Inkerinmaan asutus ja väestö 1618-1700. - Nevalainen \& Sihvo (toim.) 1991, 67-82.

Sarmela, Matti 1969: Reciprocity Systems of the Rural Society in the Finnish-Karelian Culture Area: with Special Reference to Social Intercourse of the Youth. FFC 207. Helsinki: Suomalainen Tiedeakatemia.

Sarmela, Matti 1978: Vienalaiset lauluhäät. - KV 58, 262-274.

Sarmela, Matti 1981: Suomalaiset häät. - Matti Sarmela (toim.): Pohjolan häät. Tietolipas 85. Helsinki: SKS, 9-55.

Sarv, Mari 2008: Loomiseks loodud: regivärsimõõt traditsiooniprotsessis. Eesti Rahvaluule Arhiivi toimetused 26. Tartu: Eesti Kirjandusmuuseum.

Sarv, Vaike 2000: Setu itkukultuur. Ars musicae popularis 14. Tartu \& Tampere: Eesti Kirjandusmuuseum \& Tampereen yliopisto.

Sarv, Vaike 2001: Setu vanema meestelaulu meetrumist rütmilise ja tonaalse organisatsiooni taustal. Tiiu Jaago \& Mari Sarv (toim.): Regilaul - keel, muusika, poeetika. Tartu: Eesti Kirjandusmuuseum, Eesti Rahvaluule Arhiiv \& Tartu Ülikool, Eesti ja võrdleva rahvaluule õppetool, 95-116.

Sarv, Vaike 2004: Jutustavate laulude hääled Anne Vabarna viisivaramus. - Setumaa kogumik 2. Uurimusi Setumaa arheoloogiast, rahvakultuurist, rahvaluulest, ajaloost ja geograafiast. Tallinn: Ajaloo Instituut, 59-80.

Saussure, Ferdinard de 1922: Cours de linguistique générale. Publié par Charles Bally et Albert Sechehaye avec la collaboration de Albert Riedlinger. Paris: Payot.

Savijärvi, Ilkka \& Savijärvi, Muusa 1999: Language contacts in Ingrian-Finnish. - Teinonen \& Virtanen (eds.) 1999, 23-47.

Saxbäck, F. A. 1904. Lehtilöitä matkaltani Inkerissä. 1859. - Niemi (toim.) 1904, 315-363.

Shevzov, Vera 1994: Popular Orthodoxy in Late Imperial Rural Russia. A Doctoral Dissertation. Ann Arbor: UMI.

Scherer, Klaus R. 1994: Affect Bursts. - van Goozen, Stephanie H. M. \& van de Poll, Nanne E. \& Sergeant, Joseph A. (eds.), Emotions: Essays on Emotion Theory. New York: Macmillan.

Scott, Derek B. 2010: Musical Style and Social Meaning. Selected Essays. Farnham: Ashgate.

Seeger, Anthony 1977 [1958]: Prescriptive and Descriptive Music Writing. - Studies in Musicology 1935-1975. Berkeley, Los Angeles \& London: University of California Press, 168-180. 
Seeger, Anthony 1987: Why Suyá sing: a Musical Anthropology of an Amazonian People. Cambridge studies in ethnomusicology. Cambridge: Cambridge University Press.

Seitel, Peter 1999: The Powers of Genre: Interpreting Haya Oral Literature. Oxford studies in anthropological linguistics 22. New York: Oxford University Press.

Senft, Gunter \& Basso, Ellen K. (eds.) 2002: Ritual Communication. Oxford \& New York: Berg.

Seppä, Tiina 2010: Samassa tilassa tekstin kanssa - kansanrunousaineistojen lukemisesta ja ymmärtämisestä. - Jyrki Pöysä \& Helmi Järviluoma \& Sinikka Vakimo (toim.): Vaeltavat metodit. Kultaneito VIII. Joensuu: Suomen Kansantietouden Tutkijain Seura, 409-425.

Shore, Susanna \& Mäntynen, Anne 2006: Johdanto. - Mäntynen \& Shore \& Solin 2006, s. 9-41.

Sihvo, Hannes 1969: Karjalan löytäjät. Helsinki: Kirjayhtymä.

Sihvo, Hannes 2003 [1973]: Karjalan kuva. Karelianismin taustaa ja vaiheita autonomian aikana. SKST 940. Toinen tarkistettu ja täydennetty painos. Helsinki: SKS.

Sihvo, Pirkko 1991: Savakoita, äyrämöisiä, inkerikoita. - Nevalainen \& Sihvo (toim.) 1991, 179-196.

Siikala, Anna-Leena 1984: Tarina ja tulkinta. Tutkimus kansankertojista. SKST 404. Helsinki: SKS.

Siikala, Anna-Leena 1990: Runolaulun käytäntö ja runoston kehitys. - Hakamies, Pekka (toim.): Runo, alue, merkitys. Kirjoituksia vanhan kansanrunon alueellisesta muotoutumisesta. Joensuu: Joensuun yliopisto, 7-28.

Siikala, Anna-Leena 1994: Transformations of the Kalevala Epic. - Siikala \& Vakimo (eds.) 1994, 15-38.

Siikala, Anna-Leena 2000a: Body, Performance, and Agency in Kalevala Rune-singing. - Oral Tradition $15(2), 225-278$.

Siikala, Anna-Leena 2000b: Variation and Genre as Practise: Strategies for Reproducing Oral History in the Southern Cook Islands. - Honko (ed.) 2000, 215-242.

Siikala, Anna-Leena 2012: Itämerensuomalaisten mytologia. SKST 1388. Helsinki: SKS.

Siikala, Anna-Leena \& Siikala, Jukka 2005: Return to Culture: Oral Tradition and Society in The Southern Cook Islands. FFC 287. Helsinki: Suomalainen Tiedeakatemia.

Siikala, Anna-Leena \& Harvilahti, Lauri \& Timonen, Senni (toim.) 2004: Kalevala ja laulettu runo. SKST 958. Helsinki: SKS.

Siikala, Anna-Leena \& Vakimo, Sinikka (eds.) 1994: Songs beyond the Kalevala. Transformations of Oral Poetry. SFF 2. Helsinki: SKS

Sildoja, Krista 1998: August Pulsti mälestuse "Mälestusi muusika alalt" systematiseerimine. Kursusetöö. Viljandi. [Julkaisematon opinnäytetyö, käytetty Eesti Rahvaluule Arhiivissa säilytettävää kopiota.]

Silverstein, Michael 2005: Axes of Evals: Token versus Type Interdiscursivity. - Journal on Linguistic Anthropology 15(1), 6-22.

Silverstein, Michael \& Urban, Greg (eds.) 1996: Natural Histories of Discourse. Chicago \& London: The University of Chicago Press.

Simonsuuri, Aili 1956: Maria Otsa, Rosonan rannan runonlaulaja. - Joulukellot 1956, 18-19.

Simonsuuri, Aili 1961: "Avatkaa avoveräjät..." Inkerin runoperintöä tallentamassa. - Joulukellot 1961, 21-24.

Simonsuuri, Aili 1969. Seiskarin ja Lavansaaren sekä Länsi-Inkerin välisistä suhteista. - Kotiseutu 2-3, 121-127.

Simonsuuri, Aili 1972: "La mie tantsin tapsuttelen, kenkiäni kuluttelen”. Piirteitä eteläisten runoalueiden laulutavoista. - Vakkanen. Kalevalaisten naisten vuosikirja. Helsinki: Kalevalaisten naisten liitto, 39-51.

Simonsuuri, Lauri 1949: Huomioita kansanperinteen tallentamisesta äänilevyihin. - Virittäjä 53, 125-131.

Sivonen, Mika 2007: "Me inkerikot, vatjalaiset ja karjalaiset." Uskonnollinen integrointi ja ortodoksisen vähemmistön identiteetin rakentuminen Ruotsin Inkerissä 1680-1702. Bibliotheca Historica 111. Helsinki: SKS.

Sjögren, A. J. 1833: Ueber die Finniche Bevölkerung des St. Peterburgischen Gouvernements und ueber den Ursprung des Names Ingermanland. St. Petersburg.

Skinner, Quentin 1969: Meaning and Understanding in the History of Ideas. - History and Theory 8, 3-53.

Skinner, Quentin 1972: Motives, Intentions and the Interpretation of Texts. - New Literary History 3(2), 393-408.

SKVR III-V: Suomen Kansan Vanhat Runot III-V. Länsi-Inkerin, Keski-Inkerin sekä Itä- ja PohjoisInkerin Runot. 1915-1931. Toimittanut Väinö Salminen. Helsinki: SKS.

SKVR XV: Suomen Kansan Vanhat Runot XV. Runoja Henrik Florinuksen, Kristfrid Gananderin, Elias Lönnrotin ja Volmari Porkan kokoelmista. 1997. Toimittaneet Matti Kuusi \& Senni Timonen. SKST 685. Helsinki: SKS.

Solin, Anna 2006: Genre ja intertekstuaalisuus. - Mäntynen \& Shore \& Solin (toim.) 2006, s. 72-95.

Spickard, Paul (ed.) 2013: Multiple Identities: Migrants, Ethnicity, and Membership. Bloomington: Indiana University Press.

Stark-Arola, Laura 1998: Magic, Body and Social Order. The Construction of Gender Through Women's Private Rituals in Traditional Finland. SFF 5. Helsinki: SKS.

Stepanova, Eila 2012: Mythic Elements of Karelian Laments. The Case of syndyzet and spuassuzet. Frog, Anna-Leena Siikala \& Eila Stepanova (eds.): Mythic Discourses. Studies in Uralic Traditions. SFF 20. Helsinki: SKS, 257-287.

Stepanova, Eila (tulossa): Seesjärven itkuvirret: itkurekisteri, sisällöt ja merkitykset. Väitöskirjakäsikirjoitus. Sterne, Jonathan 2003: The Audible Past. Cultural Origins of Sound Reproduction. Durham \& London: Duke University Press. 
Stock, B. 1983: The Implications of Literacy. Written Language and Models of Interpretations in the 11th and 12th Centuries. Princeton.

Suhonen, Seppo \& Posti, Lauri 1980: Vatjan kielen Kukkosin murteen sanakirja. Lexica Societatis Fenno-Ugricae 19. Helsinki: SUS.

Sulkunen, Irma 2004: Suomalaisen Kirjallisuuden Seura 1831-1892. SKST 952. Helsinki: SKS.

Suometar 1847, n:o 43.

Suomi 1859: Suomi I. SKS:n Keskustelemiset 1858 1/9-1859 16/3. Helsinki: SKS, 361-400.

Suomi 1903: Suomi IV:1, SKS:n Keskustelemukset 1902-1903. Helsinki: SKS, V.

Suomi 1906: Suomi IV:4, SKS:n Keskustelemukset 1905-1906. Helsinki: SKS, III.

Suomi 1907: Suomi, IV:5, SKS:n Keskustelemukset 1906-1907. Helsinki: SKS

Suomi 1908: Suomi IV:6, SKS:n Keskustelemukset 1907-1908. Helsinki: SKS.

Suomi 1909: Suomi IV:7, SKS:n Keskustelemukset 1908-1909. Helsinki: SKS, IV.

Suomi 1910: Suomi IV:8, SKS:n Keskustelemukset 1909-1910. Helsinki: SKS.

Suomi 1912: Suomi IV:10, SKS:n keskustelemukset 1910-1911. Helsinki: SKS, III.

Suomi 1915: Suomi IV:14, SKS:n Keskustelemukset 1913-1914. Helsinki: SKS, V.

Survo, Arno 2001: Magian kieli: Neuvosto-Inkeri symbolisena periferiana. SKST 820. Helsinki: SKS.

Survo, Arno 2012a: The Mythology of a "Forgotten" Text. - Frog, Anna-Leena Siikala \& Eila Stepanova (eds.): Mythic Discourses. Studies in Uralic Traditions. SFF 20. Helsinki: SKS, 380-395.

Survo, Vera 2012b: Mythologems of Embroideries. On Karelian Sources. - Frog, Anna-Leena Siikala \& Eila Stepanova (eds.): Mythic Discourses. Studies in Uralic Traditions. SFF 20. Helsinki: SKS, 328-352.

Sykäri, Venla 2011: Words as Events: Cretan Mantinádes in Performance and Composition. SFF 18. Helsinki: SKS.

Särg, Taive 2000: Vanemate rahvalaulutekstide ja -viiside seosed Karksi kihelkonna kalendrilauludes. - Tiiu Jaago, Ülo Valk (toim.): Kust tulid lood minule ...: artikleid regilaulu uurimise alalt 1990. aastatel. Tarto: Tartu Ülikooli Kirjastus, 277-327.

Särg, Taive 2001: Karksi regilaulude värsiehitusest esituse põhjal. - Tiiu Jaago, Mari Sarv (toim.): Regilaul - keel, muusika, poeetika. Tartu: Tartu Ülikooli Kirjastus, 195-238.

Särg, Taive 2004: Värsiehitusega seotud viisivariatsioonid Karksi laulikutel. - Mari Sarv (toim.): Regilaulu - loodud või saadud? Tartu: Eesti Kirjandusmuuseum. Eesti Rahvaluule Arhiiv, 123-170.

Särg, Taive 2005: Eesti keele prosoodia ning teksti ja viisi seosed regilaulus. Dissertationes folkloristicae Universitatis Tartuensis 6. Tartu: Tartu Ülikooli Kirjastus. (http://hdl.handle.net/10062/551 15.9.2013].)

Särg, Taive (toim.) 2008: Karksi vanad rahvalaulud. Viisidega. I. Ars Musicae Popularis 18. Eesti Kirjandusmuuseumi Teaduskirjandus. Tartu: Eesti Kirjandusmuuseum.

Tallqvist, Th. \& Törneroos, A. 1904 [1862]. Kertomus Runonkeruu-matkasta Inkerissä, kesällä 1859. Niemi (toim.) 1904, 363-399.

Talvitie-Kella, Tuuli 2010: Hääpolskasta haitarijatsiin. 1900-luvun alun tanssimusiikkikulttuuri eteläpohjalaisten tanssisoittajien kertomana, kokemana ja soittamana. Acta Universitatis Tamperensis 1572. SES:n julkaisuja 19. Tampere: SES. (http://urn.fi/urn:isbn:978-951-44-8293-9 [15.9.2013].)

Tampere, Herbert 1956-1965: Eesti rahvalaule viisidega I-V. Tallinn: Eesti Riiklik Kirjastus / Eesti Raamat / Valgus.

Tampere, Herbert 1965: Eesti regivärsilise rahvalaulu meloodika stiilitüüpid. - Etnograafiamuuseumi aastaraamat 20, 50-66.

Tarkiainen, Viljo 1901: Kertomus stipendiaattimatkastani Länsi-Inkerissä kesillä vv. 1899 ja 1900. Suomi III:19. Keskustelemukset 1900-1901, 78-79.

Tarkka, Lotte 1989: Karjalan kuvaus kansallisena retoriikkana. Ajatuksia karelianismin etnografisesta asetelmasta. - Seppo Knuuttila \& Pekka Laaksonen (toim.): Runon ja rajan teillä. KV 68. Helsinki: SKS, 243-257.

Tarkka, Lotte 1993: Intertextuality, Rhetorics, and the Interpretation of Oral Poetry: The Case of Archived Orality. - Pertti J. Anttonen \& Pekka Laaksonen (eds.): Nordic Frontieres: Recent Issues in the Study of Modern Traditional Culture in the Nordic Countries. NIF Publications 27. Turku: Nordic Institute of Folklore, 165-193.

Tarkka, Lotte 1998: Sulhasen synty - sanan voima vienankarjalaisessa mieronvirressä. - Lea Laitinen ja Lea Rojola (toim.): Sanan voima. Keskusteluja performatiivisyydesta. Tietolipas 160. Helsinki: SKS, 137-183.

Tarkka, Lotte 1999: Smötkyn Riiko - mikrohistoriallinen kertomus vienalaistietäjän elämästä ja runoudesta. Pekka Laaksonen \& Sirkka-Liisa Mettomäki (toim.): Tuulen jäljillä: kirjoituksia kansanperinteestä ja kulttuurihistoriasta. KV 77-78. Helsinki: SKS, 41-94.

Tarkka, Lotte 2005: Rajarahvaan laulu. Tutkimus Vuokkiniemen kalevalamittaisesta runokulttuurista 1821-1921. SKST 1033. Helsinki: SKS.

Tarkka, Lotte 2010: Lajisiirtymiä kalevalamittaisessa runossa: Kuivajärven Moarien tapaus. - Seppo Knuuttila, Ulla Piela \& Lotte Tarkka: Kalevalamittaisen runon tulkintoja. KV 89. Helsinki: SKS, 13-34.

Tarvainen, Anne 2012: Laulajan ääni ja ilmaisu. Kehollinen lähestymistapa laulajan kuuntelemiseen, esimerkkinä Björk. SES:n julkaisuja 20. Tampere: Tampere University Press. (http://urn.fi/ urn:isbn:978-951-44-8803-0 [15.9.2013].)

Tedlock, Barbara \& Tedlock, Dennis 1985: Text and textile: Language and technology in the arts of the Quiché Maya. - Journal of Anthropological research 41(2), 121-146. 
Tedlock, Dennis 1983: The Spoken Word and the Work of Interpretation. Philadelphia: University of Pennsylvania Press.

Tedlock, Dennis \& Mannheim, Bruce (eds.) 1995: The Dialogic Emergence of Culture. Urbana and Chicago: University of Illinois Press.

Tedre, Ülo 1973: Eesti pulmad. Lühiülevaade muistsetest kosja- ja pulmakommetest. Tallinn: Eesti raamat.

Tedre, Ülo 1981: Eestiäiset häät. - Martti Salrmela (toim.): Pohjolan häät. Tietolipas 85. Helsinki: SKS, 79-108.

Teinonen, Markku 1999: The Present as a Mirror of the Past: What it Means to be an Ingrian-Finn in North-West Russia Today. - Teinonen \& Virtanen 1999, 98-121.

Teinonen, Markku \& Virtanen, Timo J. (eds.) 1999: Ingrians and Neighbours. Focus on the Eastern Baltic Sea Region. SEF 5. Helsinki: SKS.

Timonen, Senni 1970: Varvana, Jarmanan leski: inkeriläinen runonlaulaja. - Kotiseutu, 170-176.

Timonen, Senni 1974: Illakko minun isoni. - Sampo ei sanoja puutu. Matti Kuusen juhlakirja. KV 54, 417-431.

Timonen, Senni 2000: Thick Corpus and a Singer's Poetics. - Honko (ed.) 2000, 627-659.

Timonen, Senni 2004: Minä, tila, tunne. Näkökulmia kalevalamittaiseen kansanlyriikkaan. SKST 963. Helsinki: SKS.

Timonen, Senni (käsikirjoitus): Hääsävel: naiseus ja muutos. Julkaisematon käsikirjoitus.

Timonen, Senni (tulossa): Inkeroisten pyhät laulut. Käsikirjoitus.

Tomasi, Henri 1940: Armas Launis. Notes Biographiques. Kullervo. Autres œuvres. Préface de H.Holma. London.

Tsevetkov, Dmitri (toim.) 1995: Vatjan kielen Joenperän murteen sanasto. Lexica Societatis FennoUgricae 25. Helsinki: SUS.

Uino, Pirjo 1991: Inkerinmaan esihistoria. - Nevalainen \& Sihvo 1991, 11-34.

van Dijk, Teun A. (ed.) 1997: Discourse as Structure and Process. Discourse Studies: A Multidisclipnary Introduction 1. London: Sage.

van Leeuwen, Theo 1999: Speech, Music, Sound. Basingstoke: Macmillan Press.

Vasenkari, Maria \& Pekkala, Armi 1999: A Path to an Understanding. Construction of Life Story in a Research Interview. - Teinonen \& Virtanen (eds.) 1999, 61-82.

Vasenkari, Maria \& Pekkala, Armi: Dialogic methodology. - Honko (ed.) 2000, 243-254.

Ventola, Eija 2006: Genre systeemis-funktionaalisessa kielitieteessä. Esimerkkinä asiointitilanteet. Mäntynen \& Shore \& Solin (eds.) 2006, 96-121.

Viikari, Auli (toim.) 1991: Intertekstuaalisuus: suuntia ja sovelluksia. Tietolipas 121. Helsinki: SKS.

Viikari, Auli 1990: Lyriikan runousoppia. - Mervi Kantokorpi, Pirjo Lyytikäinen \& Auli Viikari: Runousopin perusteet. Helsinki: Yliopistopaino, 39-102.

Virtanen, Leea 1968: Kalevalainen laulutapa Karjalassa. Suomi 113: 13. Helsinki: SKS.

Virtanen, Leea 1985: Naiset kalevalaisen lyriikan esittäjinä. - Kotiseutu, 124-130.

Virtanen, Leea 1987: Setukaiset kertovat lauluistaan. - Virtanen Leea (toim.): Viron veräjät. Nälökulmia folkloreen. Helsinki: SKS, 161-194.

Virtanen, Leea 1994a: Women's Songs and Reality. - Siikala ja Vakimo (toim.) 1994, 330-342.

Virtanen, Leea 1994b: Singers on their Songs: the Act of Singing as Perceived by Singers in the Setu Region of Estonia today. - Michael Branch \& Celia Hawkesworth (eds.): The Uses of Tradition. A Comparative Enquiry into the Nature, Uses and Functions of Oral Poetry in the Balkans, the Baltic, and Africa. London \& Helsinki: University of London \& SKS.

Virtanen, Tea 2003: Performance and Performativity in Pastoral Fulbe Culture. Research Series in Anthropology. Helsinki: Helsingin yliopisto. http://urn.fi/URN:ISBN:952-10-1398-2 [4.11.2011]

Virtaranta, Pertti 1978: Inkeriläisiä sananlaskuja ja arvoituksia. Castreanumin toimitteita 18. Helsinki: SUS.

Virtaranta, Pertti 1993: Kynällä kylmällä - kädellä lämpimällä. Muistiinpanoja tapauksista ja tapaamisista. SKST 582. Helsinki: SKS.

VKJMS: Tsevetkov 1995.

VKKMS: Suhonen \& Posti 1980.

VKS: Adler \& Leppik / Grünberg 1990-2011.

VSSS: Kuusinen 2006.

Väisänen, A. O. 1917: Suomen kansan sävelmäin keräys, vaiheet ja tulokset. Helsinki: SKS.

Väisänen, A. O. 1985: Karjasoitto. A.O. Väisäsen keräämiä paimensävelmiä Inkeristä. Toim. Ilkka Kolehmainen. Kansanmusiikki-instituutin julkaisuja 15. Kaustinen: KMI.

Väisänen, A. O. 1990: Hiljainen haltioituminen. A. O. Väisäsen tutkielmia kansanmusiikista. Toim. Erkki Pekkilä. Helsinki: SKS

Västrik, Ergo-Hart 2007: Vadjalaste ja isurite usundi kirjeldamine keskajast 20. sajandi esimese pooleni. Alliktekstid, representatsioonid ja tõlgendused. Dissertationes folkloristicae Universitatis Tartuensis 9. Tartu: Tartu Ülikooli Kirjastus. (http://hdl.handle.net/10062/3458 [15.9.2013].)

Waronen, Lili 1990: Pappilan emäntänä Kaprion seurakunnassa. - Pekka Laaksonen \& Sirkka-Liisa Mettomäki (toim.): Inkerin teillä. KV 69-70. Helsinki: SKS, 67-93.

Wilson, William Albert 1976: Folklore and Nationalism in Modern Finland. Bloomington: Indiana University Press.

Zadneprovskaya, Alexandra 1999: The Destiny of Ingrian-Finns and their National Culture on the Native Land - Teinonen \& Virtanen (eds.) 1999, 85-97.

Zguta, Russell 1978: Russian Minstrels. A History of the Shomorokhi. Oxford: Clarendon Press.

Öpik, Elina 1970: Vadjalastest ja isuritest XVIII saj. lõpul. Etnograafilisi ja lingvistilisi materjale Fjodor Tumanski Peterburi kubermangu kirjelduses. Toim. A. Viires. Tallinn: Valgus. 


\section{TRANSKRIPTIOSTA}

Tässä työssä pysytellään sekä litteraation että nuottikuvien suhteen melko yksinkertaisella tasolla. Pidän äänitteitä ensisijaisina lähteinä, transkriptiota analyysin ja havainnollistamisen apuvälineenä. Lähteitä siteerattaessa on käytetty niissä esiintyviä muotoja paikkojen ja henkilöiden nimistä.

Aineistossa etenkin inkeroismurteiden piirteet ovat huomattavissa esimerkiksi yleisenä diftongiutumattomuutena: kuuletin, ei kuoletin; minä-sanan muotona miä; tiettyjen konsonanttien $(\mathrm{t}-\mathrm{d}, \mathrm{k}-\mathrm{g}, \mathrm{s}-\mathrm{z}, \mathrm{p}-\mathrm{b})$ puolisoinnillistuneina muotoina; yleisgeminaationa: vettee-vetee, ommeena-omena; sekä i:n muuttuminen e:ksi r-kirjaimen edellä: verren, ei virren. Lauluissa tämän tyyppiset muodot tuntuvat kuitenkin vaihtelevan paikoin melko vapaasti. H-kirjain ääntyy erityisesti geminaatoissa ja tavun lopuissa vahvahälyisenä, hieman g:tä muistuttaen ja yksittäistapauksissa venäjän kielen ääntämystä muistuttaen. (Ks. tarkemmin esim. Leskinen 1991.)

\begin{tabular}{|c|c|c|}
\hline MERKKI & ESIMERKKI & SELITYS \\
\hline- & aijoim päällä vaan va--- & epäselvä tavu \\
\hline () & o(i) vassoin kantta val(a)gijata & heikosti kuuluva tai kuorossa vain osan laulama \\
\hline l & $\mathrm{e} / \mathrm{a}$ & $\begin{array}{l}\text { joko e tai a, kuoro-osassa kummatkin saattavat kuulua } \\
\text { eri laulajien laulamana }\end{array}$ \\
\hline , & oi l'ole l'ole & liudennus (palatalisaatio) \\
\hline[] & sannoova [yl. sijoa] & oma kommentti \\
\hline$\check{s}$ & oi tunjuška & suhu-s \\
\hline $\mathrm{z}$ & laze leinäzä alemma & soinnillinen s \\
\hline $\mathrm{H}$ & kaHen & vahvahälyinen, joskus g-äännettä muistuttava h \\
\hline$B, D, G, Z$ & ymBärikko, linDu & puolisoinnillinen konsonantti \\
\hline
\end{tabular}

\section{Taulukko 1. Litteraatiossa käytetyt merkit.}

Kuoron laulamat säkeet on litteraatiossa sisennetty. Välillä käytän sisennystä erikseen mainiten myös selkeyttämään yhden laulajan käyttämän kertaustavan rakennetta. Tarkastelun kiinnittyessä ensisijaisesti runon sisältöön olen joskus jättänyt säkeenkertaukset tai kuoro-osat kokonaan merkitsemättä ja maininnut asiasta ainoastaan alaviitteessä. Vaikeampiselkoisten runojen yhteydessä on suomennos viimeisellä palstalla. Selkeämmissä itse runo voi jakaantua kahdelle palstalle.

Nuotinnoksissa päämääränäni on ollut havainnollisuus ja luettavuus, joten ne ovat myös ääniteaineiston osalta melko karsittuja. Olen pääosin pyrkinyt ns. paradigmaattiseen nuotintamiseen, osoittamaan laulun rakennetekijöitä ja sisäisiä samankaltaisuuksia myös graafisella tasolla asettelemalla sävelmän samankaltaiset osiot mahdollisuuksien mukaan allekkain. Runosävelmäthän ovat pääosin melko yksinkertaisia: usein tekstuaalinen ja musiikillinen säe osuvat yksiin. Tahtiosoituksia en ole käyttänyt ja tahtiviivoja olen käyttänyt lähinnä säkeiden tai niihin vertautuvien osien rajaajina. Sekä käsikirjoitusten että äänitteiden osalta sävelmien perussävel 
on nuoteissa $\mathrm{g}^{1}$ silloin, kuin perussävel on luontevasti sävelmästä määritettävissä. Yhtä iskua (ja runojalkaa) vastaa tämän työn nuotinnoksissa yleensä neljäsosanuotti, jonka keskimääräinen kesto äänitteellä ilmoitetaan metronomimerkinnällä nuotin yllä. Etenkään fonogrammien alkuperäistä tarkkaa pyörimisnopeutta ei ole mahdollista määrittää. Sävellajimerkintä sijaitsee useampirivisessä nuotissa ainoastaan ensimmäisellä rivillä, mutta pätee kautta nuotin. En ole tehnyt oletuksia laulun ambituksen ulkopuolelle jäävistä sävelistä, joten sävellajimerkinnät koskevat ainoastaan käytössä olevia säveliä. Mikrointervalleja en ole juurikaan merkinnyt, mutta ylös- tai alaspäin suuntautuvalla nuotin yläpuolisella nuolella osoitan joskus suurimpia poikkeamia nuottiviivaston ilmaisemista sävelten välisistä suhteista. Glissandoja merkitsen suorilla vinoviivoilla, melismoja pikkunuoteilla. Ilman vartta merkityillä pikkunuotinpäillä merkitsen kuoro-osien heterofonisia kohtia silloin, kun niiden tunnistaminen on vain aavistelun varassa. 


\section{RUNO- JA SÄVELMÄHAKEMISTO}

Työssä on viitattu runohin ja runoteemoihin joko SKVR-teemahakemistonimillä, paikallisilla lajinimityksillä tai runojen alkusäkeillä näiden luonteesta, vakiintuneisuudesta ja yleisyydestä riippuen. Hakemistoon on otettu ne länsi-inkeriläiset runot ja sävelmät, joita työssä käsitellään ja nimetään tarkemmin: kaikkia yksittäisiä mainintoja ei ole otettu mukaan. Kirjan sähköisestä versiosta ne löytyvät tarvittaessa selaimen tekstihaulla. Alla olevassa luettelossa runojen alkusäkeet ja paikalliset runojen nimitykset on merkitty kursiivilla paitsi silloin, jos ne ovat samoja kuin teemahakemiston otsikot. Tapauksesta riippuen viitataan SKVR-teemahakemiston eri hierarkiatasoihin. Merkintä 242n568 tarkoittaa alaviitettä 568 sivulla 242.

Aitassa (huhmarella) käynti: 296

Aja aja ainueni (osana liukuvirttä): 228-229

Aja aja velvyeni (Kehotus ajamaan kovemmin (Häälauluja)): 299, 303, 304-306, 306 (nuotti 28)

Annikaisen virsi (Annikka turusen tyttö): 42, 241, 242n568

Avatkaa Viron veräjät (Häälauluja, Avatkaa Viron veräjä): 188, 189, 191, 283, 289 (nuotti22), 290, 313

Ei minun laulella pitäisi (Vet en laula laulujani, Ei miun laulella pittäisi, Vast miä kullan kuolettelin): 136, 207, 213n461, 309, 352, 354

Ei päiväni parane, itken tai laulan (Hoz miä itken, hoz miä laulan): 209

Elä lapsi paljon laula (Noin saneli miun emoni): 207

Emo pani piennä piikuveen (En miä emoa kiitä): 213n461

Emon haudalla: 354

Hanhi kadonnut: 281n730

Hekon runo (Hekkoi tyttöi hemme tyttöi): 212

Hevaan nuotti: 141, 142, 144, 163, 162 (nuotti 7), 303n825, 303n827, 333, 345n947

Huolihevonen (La kyzyn kylän akoilta): 335

Huolilaulut (Laulut huolesta, surusta ja murheesta, suruvirsi): 169, 176, 202n411, 208, 233, 234, 347, 363

Hyppää nukke, karkaa nukke: 197n366, 200-201

Hypätkäämme hyrjätkäämme (Laulajan alkusanoja): 210, 341

Hyvät oli lahjat minnollaini (Ei oo maannu meie minoi): 393

Häävirsi ks. Pulmavirsi

Iilian ja Pedron virret (Pyhä Iilia isäntä, Pyhä Pedro armollinen, Pyhä Pedro kormelitsa, Pyhä ukko armollinen): 167, 169, 173, 175n277, 176, 210, 213, 250-256, 255

(Ukkovirsi; nuotti 18), 256 (nuotti 19), 270, 271, 300, 338, 339, 363, 366-369

Iso härkä: 42, 332

Iso sika: 332n920

Iso tammi: 42 , $208 \mathrm{n} 446$

Ison kotona ja toiselassa: $185 \mathrm{n} 315$

Itkuvirsi: 30, 42, 53, 70n98, 234, 274, 277, 279, 291, 300, 311, 312, 333, 336, 354, 364

Jalka kiveen (Läksin koista kulkomaha, Löin miä jälgoini kivoihe): 56n64, 163, 189n330, 192, 213n461

Jo too illakko tuloo: (169), 339 
Juo kurkku kanna kagla: 331

Jyrinpäivävirsi (Jyrkinsävel, Jyrin virsi, Pyhä Jyrki metsän herra, Pyhä Jyrki armollinen, Miikkula meron isäntä): 30, 32, 170, 171, 175n277, 271

Kalervo ja Untamo (Kullervoruno, Mees köyhä vähäväkkiine): 42, 142, 249, 350n959, 353

Kalevanpojan kosto (Tuttu luttu miä trubitin, paimenlaulu): 148n211, 169, 207, $213 n 461$

Kalina-tyyppiset refrengit (Oi kalina oi malina, Oi kalina timoja, oi malina timoja, etc.): 143-145, 158, 176, 192n349, 194, 207, 208, 210, 213, 333, 335n929

Kasvakaa kotona kauan (Oi tytöt sulat sisaret, myös pelkkänä aloitusformulana): 213n461, 284,

Kehräämisvirsi: 203n415

Kehtolaulu ks. Lapsenvirsi

Kiitosvirsi (praasnikkavirsien yhteydessä): 169, 170, 252, 299n809

Kiletoivirsi (Kiletoi, kaletoi, Avatkaa uksianne, Peremies pereisäntä, Anna tuppaa tullaksee, jouluvirsi, praasnikkavirsi): 165, 169, 170, 197n366, (252), 257, 260 268, 263 (nuotti 20), 271, 366-369

Kokin kiitosvirsi (Kiitosvirsi kokille kestityksestä, Hyvä kokki kaunis kokki, Kaik oli saatu kaik oli tuotu): 169, 170, 210, 213, 286n767, 299-300, 314, 343

Kokkovirsi, kokkosävel (Tulkaa tytöt yötulille) 30, 31, 75, 144, 169, 171, 173, 175, 244-249, 249 (nuotti 17), 269-270, 339, 359, 362

Kosikkisävel (tyttöjen häälaulurekisteri) 30, 112 (nuotti 1), 144, 152, 153 (nuotti 4), 154, 171, 173, 176, 297, 298, 306-316

Kouluun kotoa (Läksin kouluhu koista): 175 (nuotti 8), 208n446, 300n814

Kui miä kazvelin kanane: 185n315, 192n347, 331, 340

Kukon tappo (Tuterina taterina, Meijän kukko tapettiin): 207, 329

Kumarruttaminen (Istuttamisvirsi, Issut kannessa ihala, Lootikka pohulle polvin, (Ristimä rinnallesi)): 112 (nuotti 1), 169, 292n786, 298, 307 (nuotti 29), 307-313

Kursi l. kupelileipää paistaessa: 292

Kuusi-iskuinen pulmanuotti: 211 (ks. myös nuotti 10), 286-298, 290 (nuotti 23)

Kylvetysvirsi (kylvettämisvirsi, kylpövirsi): 166, 169, 170, 286n767, 291, 296 (nuotti 24), 297, 298, 313, 314, 328

Käeltä oppinut laulut (Käki kukkui maa kumisi): 208n446, 213n461, 310

La ka katson lautojan, La miä kysyn kannoiltani ks. Onko sillat sileät, Onko lankoin sillat lakeat

La lähen läpi kyläsen ks. Lähemme läpi kyläsen

La mie vieretän vilulla (La ka vieretän vilulla):185n315, 202, 204, 208, 247, 248, 331

Lahjojen jako piilopirtissä (Hyvät oli lahjat minnoillani, Ei oom maannut meie minoi): 293

Laivassa surmattu veli (Etsin viikon velloani): 208

Lapsenvirsi (kehtolaulu, liekutusvirsi, lastenvirsi, lapsensävel): 30, 31, 167, 169, 170, 234, 330, 336, 337, 344-347, 362, 363, 366-370

Laskiaishuuto (Laskiaislaulu, Liuvu liuvu laskiainen): 73, (169), 229, 235

Laulajan alkusanoja (La laulan mokoman verren, Lauloin ennen lapsempana, Vet ei vanhoista iloa, Miks on meitä näin vähäsen, Mitä noisen laulamaan, La miä laulan nyt miä jouvan, Työ käsette laulamaan): 248-249, 310, 329, 338, 339n935, 341 
Laulajan sanat ks. Laulajan alkusanoja

Lauloi suuri, lauloi pieni: 247 (nuotti 16)

Leikarit: 201

Leino leski (Helise heliä metsä): 18-19, 26, 202n411, 204, 302, 348-355, 349 (nuotti 36)

Liekkuvirsi (Liekkulaulujen aloitussäkeitä, liekkuvirsi, liekkunuotti, La mie katson liekkuani, Liekuttaja kiekuttaja, Lie lie liekku, kie kie kiekku): 30, 31, 52, 152, $165,169,170,173,174,175,236-243,241$ (nuotti 14), 269, 271, 339, 343, 344$346,362-364,366-370$

Liekutusvirsi ks. lapsenvirsi

Liukuvirsi (Rekivirsi laskiaisena, liukusäven, Liuvukka rekoi lippiä, Njo njo njo heboisuveni, Lähe Jumala aviksi): 30, 139, 156 (nuotti 5), 161, 162 (nuotti 7a), 165, $169,171,174,175,226-235,269,271,320,339$

Lohikäärme ja neito: $201 \mathrm{n} 400$

Luulin tuulen tuulovan: 292

Lähemme läpi kyläisen / pitolaulut (La lähen läpi kyläsen): 176, 190, 191, 192, 193n350, 232

Läksin koista kulkomaha ks. Jalka kiveen

Läksin raukka raatamaa: 332

Maailmansyntyruno (Pääskyläinen päivöilintu): 12, 43, 141 (nuotti 3), 202, 208

Martinpäivänä (Martin virsi, Tsup tsup tsup tsup Martikkine): 169, 213, 257-260, $270,271,339$

Me menemme, sinut jätämme (lähtövirsi, Myö määmmä siun jätämmä): 169, 294

Meijän lintu meijän liitso (Tahdomme neittä nähdäksemme): 294

Metsän sävel, metsän virsi: 30, 31, 203, 336, 352

Mihin viivyit velvyeni (Missä mökkä myöhään viivyit): 292 , 311

Mitä myö tytö suremme: 248

Miä kävin kyliä paljon: 189n330

Morsiamen päätä pantaessa (Kassa’ani kallistani): 209

Morsiustalon pöydässä (esim. Neidon nimi pyydetään saada tietää ja hänet nähdä, Neito on aitassa): 293

Myyty neito (Anoin maata velloltani): 207, 208, 211-212

Neidon linna (Saoin siulle tän kesoja): 308-311

Neuvokkivirret (Neuvokkivirret sulhaselle (Oi vävy sisoin suloinen, Tunsit olla tunne pitää) ja Neuvokkivirret morsiamelle (Kääri kyynelet kerälle, Jo hylkäät hyvän kyläsi): 169, 170, 286n767, 294, 301, 309, 310

Niin miä vierin velloistani: $189 \mathrm{n} 330$

Njo njo njo heboisuveni ks. Rekivirsi laskiaisena

Nyt miä laulan nyt miä jouvan, nyt antoi volin issoini (Isoni iloita käski): 309

Näytä käki kätesi - Jo näytti käki kätensä (Olkoon kiitetty Jumala): 293

Oi dai -sävelmä: 112 (nuotti 1), 144, 154, 171, 173, 174, 306-312, 315, 334

Oi Jokoi -sävelmä: 144, 154, 306-312

Oi tytöt sulat sisaret ks. Kasvakaa kauan kotona

Olin orja vellolleni: 240, 241

Oma emo - vieras emo: 197, 208

Oman kylän ylistys (Kylähäni linnahani, Kenen tuo kylä näkyy): 189n330, 191, 192, 208n446, 209, 240, 326, 335n929, 352 
Onko lankoin sillat lakeat (häälaulu) (La miä kysyn kannoiltani): 293, 303n827

Onko sillat sileät (tanssilaulu) (La miä/ka kysyn kannoiltani): 199n382, 206, 210, $212,303 n 827$

Osasi emo omenan tehdä (Oi miun ehtoisa emmoin): 213n461, 302

Osta sija sirkulleni (Pöydän lunastus, Pöydän lunastamisvirsi): 169, 292

Piennä petti miun emoni (emo, iso, Jumala väärä, Yks oli väärä miun emoni): 172, 197, 204, 208, 209, 329n903, 331

Pilkkalaulut (narrimislaulut, naljalaulut, Mitä laulat lappahuuli, Älä huuda hullu kuusi, Tunnen tunnen ken vaa tulloo): 169, 170, 267, 297, 330, 332

Pitkä ääni (vienoo, paikoillaan laulaen) 142, 153, 169, 171, 176, 185, 206-217, 247

Poikako vai tyttö: 298, 300, 310

Praasnikkavirret: 54, 113, 144, 157, 158, 163, 169, 170, 220-271

Pulmanuotti, pulmavirsi: ks. Häävirsi

Pulmavirret (Häälauluja, pulmanuotti, häälaulu, häävirsi): 30, 31, 52, 53, 55, 152, $157,158,163,166,167,169-171,173,174,209,174-316,320,339,340,343$, $345,359,362-364,366-369$

Päivän päästö: 42, 227-228, 249

Pääskylintu päivälintu ks. Maailmansyntyruno

Rekilaulu: 30, 70n98, 172, 198, 211, 365

Rekryyttilaulut (Sotamiehenotto, sotamiehen laulu, Nyt tuloo syvä sykysy): 169, $170,208,213 n 461$

Rikas ja köyhä: 201

Ristitantsu tantsikaamme: $198 \mathrm{n} 368$

Saadulmoi-sävelmä: 139, 143-145, 154, 156 (nuotti 6), 174, 176, 191 (nuotti 9), 206, 216-217, 248, 288, 293, 294, 352

Saaren neito (Nurmen neito, Kullervoi kalervoin poikoi): 185n315, 213n461, 244, 345

Saimme saunan lämmittäjän: 286n767, 293

Sairastava neito (Neito linnassa lässii): 310

Sato taivas uutta lunta (Satoi ukko uutta lunta): 174

Saunastatulovirsi (Blasloviitekka Jumala, Ristimä rinnallesi, Tehkää risti rinnallesi, Laslavikka laulamahan): 167, 169, 291, 292, 298

Sikasilla: 30

Sinon kylväjä: 249

Sisaren turmelus (Rutsa, Turoi tuimoi mees kavala): 339

Sotamiehenotto ks. rekryyttilaulut

Sotasanomat (Lensi lintu alta linnan, Meijän kutroipää kuningas): 202, 203, 211 (nuotti 11)

Suka mereen: 208, 213n461, 249, 302

Sulhasen lähtövirret: 292

Sulhasväen tervehtiminen (aineistossa myös morsiusväen tervehtiminen, tervehtimisvirsi, Hyvää iltaa terve teille, Terve tupa neljänurkka): 164, 169, 193, (202n411), 292, 294

Sulhon istuttaminen morsiustalon pöytään (Onko lankoin sillat lakeat vai onko sian tonkimia): 292

Suomeen pako (Souva laiva jouva laiva): 203

Syntymistään sureva: 208n446 


\section{Talkoovirsi: 30, 171}

Tanssituvan pyyntö (Peremies pereisäntä, lupaatteko meil tupaista, La miä kysyn langot teiltä, myös kiletoivirressä): 192-193, (252), (261), 263, 265, 266

Tantsuvirsi (tanssilaulut, tanssinaloitusformulat, tantsunuotti, nuotit tantsun päälle) 30, 139, (142, 144), 153, 141 (nuotti 2 ja 3), 169, 170, 173, 175, 194-201, 166, 206-217, 247, 300, 339, 340, 341, 370

Tavallinen pulmanuotti (neli-iskuinen pulmanuotti): 171, 176, 191, 286-300, 289 (nuotti 22)

Tehkää yksi ympärikko: 187, 188, 196, 210, 340, 341, 354

Terve kuu terve päivä (Tytöt tervehyttävät sulhasta): 292, 296 (nuotti 24), 309

Tihtii: 176, 206-217

Tšastuška (tšastuškasävelmä): 32, 148, 149, 209, 365

Tulen synty: 107n150

Tulkaa tyttäret tulelle (Tulkaa työ tytöt kokolle)

Tunnen vävyn tulevan (Mistä tunnet vävyn väen): 292

Tytärten hukuttaja (Tytärten surmaaja, Ehittelin velloani) 43, 203n416, 208, 209, $213 n 461,240,249,329$

Tytöt lustit luuraelloot: 207, 208

Täss on tykky tyttölöitä: $185 \mathrm{n} 315$

Tässä on lusti nuoren nousta (Nuorena aika laulaa): 108, 141 (nuotti 2), 210, 246, $247,309,341,351,353,354$

Tässä tanssivat tasaset (Tuossa tanssivat tasaset): 210

Ukkovirsi ks. Iilian ja Pedron virsi

Varkaalle menijä (Lähe neitoinen minulle): 213n461

Veneenveisto: (Velloini vennosen seppo): 203, 249, 302

Vienoo ks. Pitkä ääni

Viron veräjät / pitolaulut (Avatkaa Viron veräjät): 188, 326, 327

Yhen muotoiset molemmat: 286n767

Yks oli väärä miun emoni ks. Piennä petti miun emoni

Yksi oli ounapuu kylässä: 165, 283, 299-303, 313, 314, 348

Ylistys- ja pilkkalaulut / häät (esim. Puhemiehen moittiminen (Pitkä keeloi pettelikko, Kosjolainen keelikoira), Sulhasen pilkka, Sulhasen kodin pilkka, Sulhasen ylistys, ks. myös yläotsikko Morsiamen kotona / Sisälle mentäessä): 292, 309, 311,315

Ylösnousemusvirsi: 213n461

Äidin kuolo (Läksin koista kulkemaan): 208, 241

Älkää pahaksi panko, kylä kirotko: 329

Älkää tytöt valitko kaunista (Emo neuvoi neitojaan): 213n461, 304, 309, 310

Älä nukuta unonen: 203 


\section{LiITTEeT}




\section{LIITTEET}

\section{LIITE 1: 1930-LUVUN LAULAJIA}

Monet tämän työn päätelmät nojaavat vahvasti 1930-luvulla Narvusin läntisimmästä kolkasta tallennettuun, aiempaa runsaammin konteksti- ja esitystapatietoja sisältävään aineistoon. Monista 1930-luvulla haastatelluista laulajista on aiempiin keruisiin verrattuna myös huomattavan paljon elämäkerrallisia tietoja, jotka antavat nähdäkseni kuvaa 1800-luvun loppupuolella syntyneiden, runoja vielä käyttäneiden länsi-inkeriläisnaisten elämästä yleisemminkin. Tähän olen koonnut tekemieni tulkintojen kannalta olennaisia tietoja työn kannalta keskeisimmistä tämän aikakauden laulajista siinä määrin, kun niitä on tallennettu. Keskeisiä ovat etenkin ensimmäisten kokonaisia lauluja sisältävien äänitysten kuusi laulajaa vuodelta 1937: Anna Kivisoo, Tatjana Jegorova, Valpuri Vohta, Darja Lehti, Mari Vahter sekä Paro Mägi. Lisäksi olen ottanut mukaan muutamia kerääjien keskeisiksi informanteiksi mainitsemia ja paljon haastattelemia naisia: Maria Otsan, Katri Vohdan, Juljaana Pohjalaisen, Matrona Bässinan sekä Jeodokia Räkälän.

Laulajien suppeatkin tiedot kertovat joistain tämän tutkimuksen tulkintojen kannalta keskeisistä maaorjuuden jälkeen eläneiden länsi-inkeriläisnaisten elämänkuluista. Monet olivat vaihtaneet kylää naimisiin mennessään, mutta eivät kaikki. Yllättävän moni ortodoksi on osittain vatjalainen, osittain inkeroinen. Osa oli kiertänyt monissa eri kylissä muiden palveluksessa, joku tehtaassakin töissä, osa elänyt vanhempiensa kanssa naimisiinmenoonsa asti. Moni kertoi oppineensa keskeiset laulunsa äidiltä tai muilta naissukulaisilta, osa kuitenkin kylän tytöiltä tai naapurikylien praasnikoilta. Laulajien kuvaamisen ja esiin nostamisen tavat taas riippuvat huomattavasti kerääjästä. Selkeimmillään tämä näkyy Valpuri Vohdan ja Juljaana Pohjalaisen kohdalla.

Tallinnan äänitysten laulajista (Simonsuuri 1961), Maria Otsasta (Simonsuuri 1956) sekä Juljaana Pohjalaisesta (Laiho 1944) hahmotteli muotokuvia jo Aili Laiho (Simonsuuri), Matrona Bässinasta, Anna Kivisoosta, Katri Vohdasta, Darja Lehdestä sekä Juljaana Pohjalaisesta Martti Haavio (1948, 303-337, 351-363). Varhaisempien Länsi-Inkerin keruiden laulajista on laajemmin käsitelty Maria Luukkaa (Haavio 1948, 320-322; Kuusi 1983a), Anni Porissaa (Kuusi 1983b), Soikkolan kahta Naastoita (Harvilahti 1992a, 172-180); Väärnojan Katia (Haavio 1948, 322-324; Harvilahti 1992a, 169-170), Vappu Oravaa (Nenola 2002, 836-837). Inkerin laulajista ovat kirjoittaneet myös Anneli Asplund (tulossa) sekä itkuvirsien kannalta Aili Nenola ja Kaarina Koski (Nenola 2002, 829-841). Väinö Salminen (1931a) kokosi SKVR:n viidennen osan lopun liitteeseen tietoja ennen vuotta 1931 tallennetuista laulajista. Vähän muita pidemmälti tulivat Länsi-Inkerin osalta kuvatuiksi Eudokia Danilovna Feodorova, Sofia Kataks, Maria Luukka, Naastoi Tarinaisista, Oke (Gareo-baba), Juljaana Pohjalainen, Tun’a Väikylästä, Vaasseli-noita, Kati Varkki sekä Väärnojan Kati. 


\section{AnNa Kivisoo}

Anna Kivisoo syntyi vuonna 1881 Ropsussa. Hänen äitinsä oli vatjalainen "ieslaulaja" Hovrenja Platonovna Soikkolasta, Luuditsan kylästä, isä oli inkeroinen Juhan (Ivan) Kajava Ropsusta. Kivisoo määritellään käsikirjoituksissa inkeroiseksi, mikä luultavasti siis oli hänen etninen, uskonnollinen (ortodoksi) tai kielellinen identiteettinsä. Yhdeksänvuotiaana hän meni neljäksi vuodeksi kummitätinsä luokse lastenhoitajaksi kotikylään. Sen jälkeen hän kävi "saksoil ja hovis tienimäs" eli ansiotyössä ensin Narvusissa, sitten Haavikon kylässä ja lopulta neljä vuotta Joenperässä. Siellä hän tutustui myös Darja Lehteen, jonka kanssa "elimmä siel yhessä." Palveluksessa hän oppi venäjän kielen. 25-vuotiaana Kivisoo meni naimisiin Aleksei Buššinin kanssa ja muutti tämän kotikylään Väikylään. (SKS KRA Laiho L. 5412; Salminen K. 168, 249; ks. myös Nenola 2002, 830.) Kivisoo on siis hänen ja hänen miehensä 1920-luvulla virolaistettu sukunimi, Buššina alkuperäinen. Hän esiintyy keräelmissä myös nimellä Suursoo.

Väikylässä Kivisoo mainittiin "taitavaksi laulajaksi" (SKS KRA Enäjärvi-Haavio 404; ks. myös Haavio 1948, 312).

"Laulut kai Ropsus ja Joenperäl oppisin, ei tääl Väikyläs mittää olt. Vanhemps siso minnuu ain opetti laulamaa. Pulmis mie ain lauloin ies. Minnuu pulmii ain laulamaa vieti. [...] Tääl (Väikylässä) laulettii vennäiks. Kaik suu auki vahittii, ku lauloin tääl Inkerin virsii, vastumaist laulut olivat.” 982 (SKS KRA Laiho L. 5412.)

Väikylässä laulettiin ja puhuttiinkin 1930-luvulla pitkälti venäjää (Laiho 1940, 222; SKS KRA Laiho L. 2225-2226) SKVR:ssä kylästä kerättyjä lauluja on julkaistu vain muutama: 15 todennäköisesti väikyläläistä runoa Jaakko Länkelältä ja kaksi varmaa Vihtori Alavalta (SKVR-tietokanta: Väikylä). Maria Hauen mukaan Väikylässä "Vennäiks laulettii liekul, maaks ei laulettu täs.” Anna Kivisoo kertookin tuoneensa laulut Ropsusta ja Joenperältä Väikylään, jossa ei ennen häntä juuri laulettu (SKS KRA L. Laiho 5412). Kivisoo oli oppinut lauluja myös äidinäidiltään Soikkolassa käydessään (SKS KRA Enäjärvi-Haavio 472) ja pienenä Tarinaisissa praasnikoilla (SKS KRA Laiho L. 5359). Joenperällä ollessaan hän oli käynyt Koskisten kylässä Iilian praasnikoilla (SKS KRA Enäjärvi-Haavio 536, 790). Hän kertoi myös eri praasnikkojen vietosta Soikkolan kylissä (SKS KRA Laiho L. 5987, 5989, 5996, 6000). Enäjärvi-Haavio ja Haavio kehuvat häntä hyväksi ja selkeäksi kertojaksi ja laulajaksi. (SKS KRA Enäjärvi-Haavio 404; Haavio 2289; Laiho L. 5412.)

\section{TATJANA JEgorova}

Tatjana Jegorova syntyi vuonna 1894 Ropsussa. Hän oli inkeroinen. Isä Simo Nikolajev oli Ropsusta kotoisin. Isänäidin Darja Varlamovan Jegorova mainitsee suureksi laulajaksi, joka oli "iessälaulaja aina”, ja kertoo tältä myös oppineensa paljon lauluja. Äidistään hän ei kerää-

\footnotetext{
${ }^{982}$ Opin kaikki laulut Ropsussa ja Joenperällä, ei täällä Väikylässä mitään ollut. Vanhempi sisko minua aina opetti laulamaan. Minua pyydettiin aina häihin laulamaan esilaulua. Täällä Väikylässä laulettiin venäjäksi. Kaikki tuijottivat suu auki, kun lauloin täällä kalevalamittaisia runoja, ne olivat (kylässä) uusia.
} 
jille näytä kertoneen. Viisitoistavuotiaana Jegorova lähti piiaksi, ensin omaan kylään, sitten tehtaaseen ("Vaabrika") ja Iittovan moisioon. Hän meni Ropsuun naimisiin, mutta miehen loukkaannuttua sodassa ja kuoltua hän meni uudestaan miehelle Hanikken kylään. Ennen Laihoja häneltä ei juuri mitään tallennettu, mutta Tallinnan äänityksissä vuonna 1937 hän toimi myös esilaulajana. (SKS KRA Laiho L. 5414.)

\section{VALPURI VOHTA}

Valpuri Vohta syntyi vuonna 1888 Kallivieren kylässä. Hänen äidinäitinsä Juljaana oli kotoisin Soikkolan Lehmiojalta, äiti Maria Lallo Arsian suomalaiskylästä (Arsiansaari), isä Andreas Orava Kallivierestä. Inkerinsuomalainen Valpuri Vohta meni Andreas Vohdan kanssa naimisiin Vyötermaan kylään ja sai 12 lasta. Vyötermaalla oli Vohdan mukaan "jo toine murre lauluil." Perhe eli siellä neljä vuotta ja muutti sitten uudistilalle Kallivieren lähelle. (SKS KRA Enäjärvi-Haavio 406; Laiho L. 5409; Salminen K. 264.)

Vohdan äiti tunsi "paljon laului." Isä "oliki oikee kerkee jalalt laulaja ja tatsija, pulmis mäni keputteli nii et". Häälaulut Vohta kertoi oppineensa " mammalt, ämmält ja tätilt." Ämmä eli isoäiti "oliki oikee vanhanaikane ihmine, pilupaitaa kanto," täti oli Valpuri Orava. Vohta itse oli laulanut usein häissä esilaulajana, vaikka valittikin äänensä ja muistinsa nuorena olleen paremman. (SKS KRA Laiho L. 5409.) Väinö Salmiselle (SKS KRA 3015) "Valpuri Vohta kertoi, että luterinuskoiset harvoin kävivät ižoonkylissä Soikkolassa." Vohta oli kuitenkin ollut "Joenperässä piikana kolme vuotta" ja oppinut siellä " hieman vatjaakin." Hän lauloi kerääjille myös inkeroisilta tai venäjänuskoisilta oppimikseen mainitsemia runoja (esim. SKS KRA Enäjärvi 500; Laiho L. 4969; Salminen V. 3019). Tämä epäilemättä helpotti laulamista yhdessä inkeroisnaisten kanssa vuoden 1937 äänityksissä.

17-vuotiaana Vohta oli "lukenut" virren Matti Mannas mie[s] matala "kahel nuorel Suomen pojal." Vuosina 1905 ja 1906 alueella kävivät Launis ja Salminen, joiden keräelmissä ei Vohdan nimeä näy - voi tietenkin olla, että laulua ei tallennettu. Kolme Eesti Rahvaluule Arhiivissa (ERA, Fon. 372) olevaa laulaja- ja äänittäjätiedotonta fonogrammiäänitystä paikantuvat Vohdan vuonna 1937 laulamien laulujen (SKSÄ A 90c, 95c ja d, 100b ) ja hänen oman kertomansa (SKS KRA Laiho 5410; vrt. Salminen K. 264) pohjalta hänen 20-luvun alussa kielentutkija Julius Mägistelle laulamikseen. Vohta oli myös käynyt vuonna 1936 Tallinnassa maatalousnäyttelyssä nuorempien tyttöjen kanssa laulamassa ainakin laulun Helise heliä metsä (SKS KRA Laiho L. 5409).

Vohdan kohdalla näkyy selkeänä eri tallentajien suhtautumiserot ja henkilökohtaisten suhteiden vaikutus laulajien kuvaamiseen. Elsa Enäjärvi-Haavion kuvaus on ristiriitainen: "Valpuri Vohdassa on vauhtia. Hän innostuu kertomaan tavattomalla voimalla. Perhe ei ole erikoisen kehittyneellä tasolla kuitenkaan. Miehellä ja pojalla lienee punaisia sympatioita. Poika ollut karkumatkalla venäjän puolella $5 \mathrm{kk}$. Valpuri Vohta ei suhtaudu joka kerta erikoisen kunnioittavasti Jumalan sanaan; ja hän kertoo profaaneja ja rohkeitakin juttuja. Mutta hän on varmaan pohjaltaan hyvä ihminen, ja otti kerääjän ystävällisesti vastaan." (SKS KRA Enäjärvi-Haavio 406.) Aili Laiho (Simonsuuri 1961, 23) taas kuvasi Vohtaa mutkattomammin riuskaksi naiseksi, jonka muisti "oli vireä, luonteensa suorasukainen." Toisin 
kuin Matrona Bässinan, Anna Kivisoon, Darja Lehden ja Katri Vohdan, Haavio $(1948,309)$ mainitsee kirjassaan Viimeiset runonlaulajat Vohdan ainoastaan lakonisesti kuvatekstissä: "Taitava runonlaulaja, joka esitti Elsa Haaviolle useita kymmeniä runoja." Kaarina Salminen (Salminen K. 1931, 34) sitä vastoin kertoo, että Vohta, "suurten kärsimysten ja koettelemusten jalostama ihminen" jätti hänen mieleensä "unohtumattoman muiston."

\section{DARJA LEHTI}

Darja Lehti, omaa sukua Maršitšova, syntyi vuonna 1880 Joenperällä. Hänen äitinsä oli inkeroinen Säätinältä, isä vatjalainen Joenperältä, sisko meni miehelle Saarovelle. Isän äitikin oli Venakontsan inkeroiskylästä (Laiho 1940, 228). Kolmetoistavuotiaana Lehti meni ensi kotikyläänsä lastenhoitajaksi, sitten ortodoksipapin palvelukseen, sitten viinapuotiin myyjäksi. Miehelään hän muutti Narvusin Vanhakylään mykälle Loginoville. (SKS KRA Haavio 2291, 2292, 2491; Laiho L. 5413.) Lehti mainitaan yleensä vatjalaiseksi. Väinö Salmisen (esim. SKS KRA Salminen V. 2891) keräelmissä esiintyy nimellä Tarja Lahti, Kaarina Salmisen (esim. SKS KRA Salminen K. 75) nimellä Tara Leht.

Lehti kertoo kuitenkin oppineensa laulut soikkolalaiselta (inkeroiselta) inkeroisäidiltään eli maamoltaan ja isoäidiltään eli ämmältään, jotka olivat "laulajia" - ainoastaan isä puhui vatjaa (SKS KRA Laiho L. 5413). Hänen mukaansa avioliitot vatjalaisten ja soikkolalaisten välillä olivat yleisiä (SKS KRA Haavio 2291) ja Joenperässä laulettiin Soikkolan kielellä eli inkeroiseksi, ei vatjaksi (SKS KRA Haavio 2303). Hänen laulunsa näyttävätkin keskimäärin olevan melko inkeroiskielisiä, proosaperinne sen sijaan vatjavoittoista (ks. myös Haavio 1948, 326). Haavio $(1948,326)$ ei onnistunut etsimiään vatjalaisia runoja Lehdeltä tallentamaan, mutta Väinö Salminen (SKS KRA Salminen V. 2891-2895) tallensi Lehdeltä joitain vatjalaisia piirteitä sisältäviä kehtolauluja. Suomalais-inkeroisen Vanhakylän ympäristössä Lehteä ei Aili Laihon (Simonsuuri 1961, 23) mukaan oltu täysin hyväksytty: "Ei oo laivas ommaa, venehes ei vellovaa. Mie oon yksin tääl." Vatjalainen puhetapa erotti muista.

Lehdeltä tallennettiin paljon etenkin vatjankielen tutkimuksen tarpeisiin (ERA, ETMM M 234:1, s. 570; SKS KRA Laiho L. 5413.) Vuosina 1923-1932 hän oli myös mukana virolaisen August Pulstin järjestämissä konserteissa ja musiikkikiertueilla pitkin Viroa, yhteensä 189 esityksessä. Hän oli siis vuoden 1937 äänitysten naisista rutinoitunein esiintyjä. Viron kiertueilla ohjelmisto oli sangen vakiintunutta: Lehti esitti yleensä paimentorven kanssa laulun Yö ei ole vielä tullut, yksin laulut Oma kylä hyvä kylä tai Nuori nuorista ja Mamma minnuu synnyttänyt sekä kertomuksen Moision teolle meneminen (Möisa teoleminek). (ERA, ETMM M 234:1 234:1, s. 122, 150, 177, 570; ks. myös Sildoja 1998; vrt. SKS KRA Laiho L. 5413.) Pulst (ERA, ETMM M 234:1 234:1, s. 570) kehuu häntä hyväksi esiintyjäksi: ”Ta omas head, selget, puhast ja hästi kõlavat lauluhäält. Laval esines ta ju [sel]gelt, hoogsalt ja vabalt, läbilöövalt."983 Kun esityksen jälkeen pidettiin tanssit, oli Lehti Pulstin (ERA, ETMM M 234:1234:1, s. 577) mukaan virolaislaulaja Mari Kilun kanssa usein ensimmäisenä tanssimassa. Martti Haavion $(1948,326)$ näkökulmasta Lehti lauloi "harvinaisen tottuneesti,

\footnotetext{
${ }^{983}$ Hänellä oli hyvä, selkä, puhdas ja hyvin kuuluva lauluääni. Lavalla hän esiintui selkeästi, arvokkaasti ja vapaasti, valloittavasti.
} 
hieman brutaalin-rajusti ja välinpitämättömästi; hänessä ei ollut samaa hienoutta ja ujoa vaatimattomuutta kuin muissa kohtaamissani laulajattarissa.” Tämän Haavio tulkitsee johtuvan juuri kiertuekokemuksista, vaikka luonnehdinnassa näkyy käsittääkseni myös Haavion käsitys ideaalisesta runolaulajasta. (Lehdestä ks. myös Haavio 1948, 326; Nenola 2002, 835; Simonsuuri 1961, 23.)

\section{MARi VAHTER}

Inkeroinen Mari Vahter (os. Jefimof) syntyi vuonna 1895 Ropsussa. Isä Slabu (Slobsanoff) oli kotoisin Ropsusta, äiti Justiina Isaijef Soikkolasta. Vahter ei käynyt muualla palveluksessa. Hän meni naimisiin Ropsusta kotoisin olevan Mihkel Vahterin kanssa ja he muuttivat Haniken kylän lähelle uudistilalle. (SKS KRA Laiho L. 5415.)

Lauri Laihon (SKS KRA 5415) mukaan Vahterin äiti "ei ollut laulaja." Vahter silti kertoi: "Mie elin tyttöpolven nii ilosest, lasin lauluu ja tantsii." Lauluja hän kertoo oppineensa synnyinkylässään ja mainitsee erityisesti ilmeisesti omaan ikäryhmäänsä kuuluneen Tatjana Nikolajevan. Hän itse ei osannut "laulaa sanoja, mutta omaa hyvän heleän äänen, joten pystyy laulamaan jälestä", eli hän oli hyvä laulaja mutta ei esilaulaja. Niinpä hän olikin ollut Jeodokia Räkälän ja kahden muun naisen mukana vuonna 1931 Helsingissä IV suomalaisugrilaisessa kulttuurikonferenssissa mukana laulamassa, ja hänet pyydettiin mukaan myös vuoden 1937 äänitysmatkalle. (Simonsuuri 1961, 22-23; SKS KRA Laiho L. 5415.)

\section{PARO MäGI}

Paraskovie Habukin eli Paro Mägi syntyi noin vuonna 1873 Väikylässä. Hänen äitinsä oli inkeroinen Kallivierestä. Mägi oli piikana Väikylässä, mutta ei juuri muualla. Hän meni miehelle Saarkylään Johanne Habukinille. Mägi kertoi miehensä olevan juoppo. Mägi kertoi oppineensa lauluja äidiltään, joka "oli laulaja" (SKS KRA Laiho A. 2625; Laiho L. 5108, 6060.) Paro Mägi oli parantaja ja osasi paljon loitsuja (Simonsuuri 1961, 23-24).

\section{Maria Otsa}

Inkerinsuomalainen Maria Otsa syntyi noin vuonna 1870 Vyötermaassa. Hänen äitinsä Maria Pietarintytär Säkki oli kotoisin Kallivierestä, isä Mikkeli Rosaus Vyötermaalta. Äiti kuoli Otsan ollessa nuori, taloon tuli äitipuoli ja Otsa lähti ensin lapsenpiiaksi Kalliviereen, sitten "työpiiaks". Naimisiin hän meni Johannes Matinpoika Otsan kanssa Kalliviereen. Sota-aikana he olivat olleet Vipiässä paossa, ilmeisesti Otsan nuoremman sisaren luona. Otsa kertoi oppineensa laulunsa äidiltään ja kyläkeinulla. (Simonsuuri 1956; SKS KRA Laiho L. 5411). Aili Laihon (Simonsuuri 1956, 19) mukaan Otsa oli yksi heidän parhaita kertojiaan ja keskeisin informantti Laihon kerätessä murretietoja vuonna 1938. 


\section{Katri Vohta}

Inkerinsuomalainen Katri Vohta oli syntynyt noin vuonna 1873 vauraassa talossa Sutelan kylässä. Hänen isänsä oli Mikkel Ahonen, äiti Maria Ahonen Hakajan kylästä, Yllö sukumimeltään. Maria Ahoselta oli runoja tallentanut jo Vihtori Alava (Haavio 1948, 316). Katri Vohta meni naimisiin vyötermaalaisen Mikkel Vohdan kanssa. Pariskunta sai yhden tyttären. Enäjärvi-Haavion (SKS KRA Enäjärvi-Haavio 404) mukaan Vohta oli yksi hänen parhaista kertojistaan, vaikka "ei osannut lauluja kovin paljon, kun oli vähemmän ottanut osaa ilonpitoihin, ollut hiljainen ja nöyrän arvokas olemukseltaan. Häälauluja hän osasi, oli opettanut ne nuoremmalle sisarelleenkin. Hänen tietonsa olivat hyviä ja luotettavia. Hänen tyylinsä oli erittäin hyvä. Näin ollen oli työskentely hänen kanssaan harvinaisen miellyttävää ja antoisaa.” (SKS KRA Enäjärvi-Haavio 405.) Vohta kertoi sekä inkerinsuomalaisten että inkeroisten tavoista (ks. esim. SKS KRA Enäjärvi-Haavio 734, 771, 791, 792, 802-806; ks. myös Haavio 1948, 318.)

\section{JuljaAna Pohjalainen}

Inkerinsuomalainen Juljaana Pohjalainen (os. Reiju) oli syntynyt noin vuonna 1860 Kullan kylässä. Hänen isänsä oli Jaakko Reijo, äiti Anni Kipatsi Pärspäästä. Pohjalainen ei käynyt muulla palveluksessa, vaan meni 22-vuotiaana naimisiin Mikkeli Andreaksenpoika Pohjalaisen kanssa. Pariskunta sai viisi lasta. (SKS KRA Laiho A. 2618; Laiho L. 5407; Haavio 2296.) Pohjalainen kertoi oppineensa laulunsa Pärspään ja Sutelan praasnikoilla sekä paimenessa lapsena: hänen äitinsä "rakasti Jumalan sannaa, ei hän laulant" (SKS KRA Laiho L. 5407). Pohjalainen kertoo itsekin laulaneensa aikuisena vain vähän. Uskonnollisia lauluja hän osasi Haavion $(1948,356)$ mukaan paljon (ks. myös SKS KRA Haavio 2296). Häneltä tallensi runoja jo Volmari Porkka, ja monet runonkerääjät majoittuivat hänen perheensä luokse. (Haavio 1948, 352; SKS KRA L. Laiho 5407.) Vaikka Martti Haavio (1948, 351-363) nosti Pohjalaisen esikuvalliseksi viimeiseksi runolaulajaksi, hän ei selvästikään omassa yhteisössään toiminut esilaulajana tai ollut arvostettu laulaja. (Pohjalaisen laulajuudesta ks. luku 8: Esilaulaja ja jälestälaulajat.) Pohjalaisenkin kohdalla kerääjien kuvaukset vaihtelevat: siinä, missä Haavio kirjoitti hänestä pitkän runollisen esseen, mainitsi Kaarina Salminen vain hänen olleen "hiljainen uskonnollismielinen 71 v. mummo" (Salminen 1931a, 612).

\section{Matrona Bässina}

Inkeroinen Matrona Pässi eli Matrona Filipovna (t. Ivanova) Bässina syntyi vuonna 1851 Vanhakylässä (SKS KRA Haavio 2439). Hän oli jo 6-vuotiaana joutunut lastenhoitajaksi kotikyläänsä kolmeksi kesäksi; sen jälkeen hän oli ollut palveluksessa Kukkosissa, Kullalla, Arsiansaarella, Mannakassa, Tiensuussa, Iljesissä, Vanhassakylässä, tehtaassa ja Väikylässä. 20-vuotiaana hän oli mennyt naimisiin Nikolai (t. Mikalai) Bässinin kanssa Väikylään. Pässi oli heidän 1920-luvulla virolaistettu nimensä. Keruiden aikaan hän eli leskenä ja elätti itseään kerjäämällä, mutta hän oli myös "kautta kylän tunnettu parantajana." (SKS KRA Haavio 2287, 2287; Salminen K. 252; ks. myös Haavio 1948, 310-312.) 
Kuten Anna Kivisoo myöhemmin, Bässinakin toi tullessaan Väikylään lauluja, ja hän kertoi ennen lauletun venäjäksi (SKS KRA Haavio 2286). Haavio mainitsee Bässinan olleen esilaulaja: "Vieläkin nähdään, miten hän toisinaan ikään kuin ojentautuu reippaaseen asentoon, heilauttaa yläruumistaan, temmaten, jalat tapailevat tihtii, nopeata tanssiaskelta, ja silmät alkavat säihkyä. Hän valittaa sitä, että on paljon unohtanut, väittää, ettei päässä ole sahajauhoja parempaa. Kuitenkin hän taitaa yhä uutta; hän sanelee laulut, suostumatta niitä edes hyräilemään. [...] Laulanut Salmiselle, sanellut Mägistelle." (SKS KRA Haavio 2286.) Sitaatin antamaa viimeinen tieto on erityisen merkittävä: sanelu kenties selittää jotkut Bässinan mitaltaan melko väljät runot (esim. SKS KRA Laiho A. 2132; Haavio 2430, 2432). Viimeiset runolaulajat -kirjassaan Haavio (1948, 310; vrt. kuit. 312) kuitenkin muokkasi kyseisen sitaatin kertomaan laulavasta Bässinasta. Sanelemisen syistä ei ole tarkempaa tietoa, ainoastaan yksi mahdollinen viite T. Koilon muistiinpanoissa: "A ei tye miele, ei tye mielee. Pää niku rautpata. Mitte ei tye mielee. Jos dohter (= proff Salminen) vielä olisi enemmän kysellyt, siis miul olis olt kai pääss puhtaass." (SKS KRA Koilo 224.) Olisiko Bässina katsonut kerääjälle laulamisen vieneen lauluja hänen muististaan ja päättäneen sanella seuraaville? Tarkemmin ottaen Väinö Salminen ei pannut muistiin Bässinan lauluja vaan hänen vaimonsa Kaarina (SKS KRA Salminen K. 252-260), ja Bässina valitteli jo tällöin muistiaan ainakin yhden laulun kohdalla (SKS KRA Salminen K. 259).

Bässina tuntuu usein korostaneen toisaalta laulun voimaa (SKS KRA Laiho A. 2330, 2133), toisaalta omaa laulutaitoaan ja esilaulajuuttaan: "Laulanut jo nuorena tyttönä suomalaiselle, jolloin muut naiset kadehtien sanoneet, että suomalainen aikoo niitä lauluja saarnata pappina." (SKS KRA Haavio 2286). Olostaan lapsenpiikana hän kertoo: "Siis mie laului lauloin omast elust itsest kaik korjasin, toiset, kel tarvis oli, oppisivat miult neit" (SKS KRA Haavio 2439). (Ks. myös SKS KRA Haavio 2287, 2453, 2689; Laiho A. 2575; Laiho L. 5419.) Monet hänen laulunsa vaikuttavat muun aineiston valossa omaperäisiltä (ks. esim. SKS KRA Laiho A. 2132). Praasnikkatietojen kohdalla (ks. liite 3) nousee kysymys Bässinan antamien tietojen luotettavuudesta. Hän oli viettänyt aikaa nuoruudessaan useassa alueen kylässä, mutta hänen kuvauksensa poikkeavat useassa kohtaa muiden antamista tiedoista. Oletan, että hän halusi esiintyä hyvänä laulajana ja perinteen taitajana, ja toisaalta hänen muistinsa on saattanut vanhemmiten heikentyä. Niinpä käytän häneltä tallennettua aineistoa paikoin varauksin.

\section{JEODOKIA R $\ddot{K}$ ÄL $\ddot{A}$}

Jevdokia (Eudokia, Jeodokia) Danilovna Feodorova syntyi vuonna 1867 Ropsussa. Hänen äitinsä oli vatjalainen Vasilista Petrovna Joenperältä, maininnoitta jäänyt isä ilmeisesti inkeroinen. Jeodokian Salminen (1931a, 545) mainitsee inkeroiseksi. Feodorovna meni naimisiin Niia Räkälän kanssa 17-vuotiaana. Väinö Salmisen mukaan häntä nimitettiin Ot'juaksi ja Petran naiseksi. (SKS KRA Salminen K. 46; Salminen V. 2946; ks. myös Nenola 2002, 830-831.) Väinö ja Kaarina Salminen haastattelivat häntä pitkälti: Räkälä taisi esimerkiksi runsaasti inkeroisten häälauluja (SKS KRA Salminen K. 44-45, 59; Salminen V. 2904-2910, 2921-2948). Salminen (1931a, 546) kertoo Jevdokian olleen taitava sanelemaan runoja kerääjille. 
Virolaiset haastattelivat Räkälää 1920-luvulla (Salminen 1931a, 545; SKS KRA Angerja (1923)). Räkälä kävi vuonna 1931 Helsingissä IV suomalais-ugrilaisessa kulttuurikonferenssissa laulamassa kuoron erilaulajana (SKS KRA Laiho L. 5415). Tällöin A. O. Väisänen äänitti laulajilta viisi laulunalkua (SKSÄ A 507/8-9). Ilmeisesti Jeodokia Räkälä kuitenkin kuoli tai palasi Venäjälle ennen Haavioiden ja Laihojen kenttätöitä, sillä myöhemmissä kokoelmissa häntä ei löydy. Hän oli niitä harvoja 1930-luvun laulajia, jotka Salminen (1931a, 545-546) otti mukaan SKVR:n Inkerin runonlaulajat -liitteeseen mainiten tämän laulamien runojen tulevan julkaistuksi lisäosissa, joita ei koskaan ilmestynyt.

\section{LiIte 2: LAULAJiEN TAUStatietoja}

Nimien kirjoitusmuodot noudattavat eri lähteissä esiintyviä vaihtelevia käytäntöjä. Epävarmat etniset ryhmät on merkitty tähdellä * .

\begin{tabular}{|c|c|c|c|c|}
\hline Nimi & Rунмӓ & SYNNYINKYLÄ & KOTIKYLÄ & SYNTYMÄAIKA \\
\hline Ahonen, Katri & luterilainen & Narvusi & Alakylä & n. 1886 \\
\hline $\begin{array}{l}\text { Aleksandrova, Jekaterina } \\
\text { (Katoi) Andrejevna }\end{array}$ & inkeroinen & Voloitsa & Voloitsa & 1902 \\
\hline Aleksinen, Nadja & *inkeroinen & & Posolka & 1892 \\
\hline Andrejeva Anna & inkeroinen & & Oussimäki & 1872 \\
\hline An'u & *vatjalainen & & Joenperä & n. 1865 \\
\hline Arehjeva, Anna & *inkeroinen & & Oussimäki & 1872 \\
\hline Artamonov, Olga & inkeroinen & Magdeburg & & n. 1888 \\
\hline Beda, Anni & inkeroinen & Narvusi & Väikylä & \\
\hline Bässina (Pässi), Matrona & inkeroinen & Vanhakylä & Väikylä & 1851 \\
\hline Elina (Jelena) & inkeroinen & & Ropsu & n. 1870 \\
\hline Figurova, Oudekki & vatjalainen & & Joenperä & 1891 \\
\hline Filippova, Fenja & $\begin{array}{l}\text { inkerois- } \\
\text { suomalainen }\end{array}$ & & Pärspää & 1900 \\
\hline Habukin, Aleksandra & $?$ & Kotko & Saarkylä & n. 1888 \\
\hline Hauki, Anastasija (o.s. Joutsi) & inkeroinen & Vanhakylä & Väikylä & 1908 \\
\hline Hauki, Maria & inkeroinen & Väikylä & Väikylä & n. 1882 \\
\hline Haukka, Katri (o. s. Tammi) & ${ }^{\star}$ luterilainen & Vipiä & Kallivieri & \\
\hline Haukka, Valpuri (o.s. Säkki) & luterilainen & Kallivieri & Kallivieri & 1868 \\
\hline Hovaskin, Anna (o.s. Voipää) & luterilainen & Vyötermaa & Kallivieri & 1895 \\
\hline $\begin{array}{l}\text { Ivanoff, Ustenja (Stiina } \\
\text { Somerlehto) }\end{array}$ & inkeroinen & & Repola & \\
\hline Ivanov, Matrona & inkeroinen & Pärspää & & 1859 \\
\hline Jegorova, Tatjana & inkeroinen & Ropsu & Hanikke & n. 1894 \\
\hline Joutsen, J. & inkeroinen & Suija & & n. 1896 \\
\hline Joutsi, Anni & $?$ & & Suija & 1896 \\
\hline Kajava, Hourenja Platonovna & vatjalainen & Luušitsa & Hanikke & n. 1861 \\
\hline Kaloin Natu (Nato) & inkeroinen & Loukkula & & n. 1860 \\
\hline Kataks, Sofia & inkeroinen & Mannakka & Kallivieri & n. 1876 \\
\hline Kaurila, Paraskeva & inkeroinen & & Venakontsa & 1885 \\
\hline Kipatsa, Uljaana & *inkeroinen & & Laukaansuu & n. 1842 \\
\hline $\begin{array}{l}\text { Kivisoo, Anna (Bussina, } \\
\text { Suursoo, o. s. Kajava) }\end{array}$ & $\begin{array}{l}\text { inkeroinen } \\
\text { (äiti vatjalainen) }\end{array}$ & Ropsu & Väikylä & n. 1881 \\
\hline
\end{tabular}




\begin{tabular}{|c|c|c|c|c|}
\hline Nimi & Rунмӓ & SYNNYINKYLÄ & Котікуцӓ & SYNTYMÄAIKA \\
\hline Koivunen, Darja & *inkeroinen & Kotko & Vanhakylä & \\
\hline Kuuli, Sarlotta & *inkeroinen & ?Kurkola & Väikylä & n. 1879 \\
\hline $\begin{array}{l}\text { Kuusik, Jeodokia } \\
\text { (o.s. Matfeijev) }\end{array}$ & *inkeroinen & Räkälä & Räkälä & \\
\hline $\begin{array}{l}\text { Lehti, Darja (Loginov, o.s. } \\
\text { Maršitšova) }\end{array}$ & $\begin{array}{l}\text { vatjalainen } \\
\text { (äiti inkeroinen) }\end{array}$ & Joenperä & Vanhakylä & 1880 \\
\hline $\begin{array}{l}\text { Leppi(k), Matroona } \\
\text { (o.s. Nikitits) }\end{array}$ & inkeroinen & Kurkola & Vanhakylä & n. 1882 \\
\hline Leppik, Anastiija (Asastiija) & inkeroinen & Väikylä & Vanhakylä & 1855 \\
\hline Liivandi, Peeter (Bugatseff) & inkeroinen & Kallivieri & Magenburg & 1883 \\
\hline Lohi, Katri (o.s. Pärnänen) & luterilainen & Vanhakylä & Vanhakylä & n. 1891 \\
\hline Lukina, Natalja Ivanovna & inkeroinen & & Joenperä & 1898 \\
\hline Lulla, Anja & luterilainen & Vyötermaa & Kulla & n. 1887 \\
\hline Lulla, Juljaana & luterilainen & Kulla & Kulla & 1882 \\
\hline Lutsu, Euvdagia & inkeroinen & Tiensuu & Vanhakylä & n. 1860 \\
\hline Mapu & inkeroinen & Uusikylä & Oussimäki & \\
\hline Mark, Katri & inkeroinen & Vyötermaa & Väikylä & $1878 / 883$ \\
\hline Markus, Anna & inkeroinen & Väikylä & Väikylä & n. 1888 \\
\hline Moisef, Anni & inkeroinen & Loka & & n. 1892 \\
\hline $\begin{array}{l}\text { Mägi, Paro (Habukin, Parasko- } \\
\text { vie eli Palaga, "Saavitšan nain") }\end{array}$ & inkeroinen & Väikylä & Saarkylä & $1870-75$ \\
\hline Naastoi Säätinältä & inkeroinen & Säätinä & Säätinä & $\begin{array}{l}\text { "vanha leski" } \\
\text { vuonna } 1892\end{array}$ \\
\hline Naastoi Tarinaisista & inkeroinen & Tarinaisi & Säätinä & \\
\hline Ogru Timon nainen & *inkeroinen & Hamala & Narvusi & n. 1851 \\
\hline Okkuli & inkeroinen & Savimäki & & \\
\hline Olena & inkeroinen & Uusikylä & Oussimäki & n. 1822 \\
\hline Olena Osipan nainen & vatjalainen & & Joenperä & \\
\hline Ol’ona, leskiemäntä & $\begin{array}{l}\text { inkeroinen/ } \\
\text { vatjalainen }\end{array}$ & Joenperä & & n. 1847 \\
\hline Orava, Mari (o.s. Otsanen) & luterilainen & Kallivieri & Kallivieri & 1865 \\
\hline Otsa, Maria (o.s. Rosaus) & luterilainen & Vyötermaa & Kallivieri & n. 1870 \\
\hline Oute, $16-17$ v. vadjan tyttö & vatjalainen & Joenperä & & n. 1860 \\
\hline Paju, Olga & *inkeroinen & Räkälä & & \\
\hline Pajunen, Varpu & inkeroinen & Kotko & Hanikke & 1858 \\
\hline $\begin{array}{l}\text { Pajunen, Varpu Pajusen } \\
\text { miniä, o.s. Vahter }\end{array}$ & inkeroinen & Hanikke & Hanikke & 1905 \\
\hline Patanen, Sofia & kr. kat. babtisti & Kukkosi & Vanhakylä & 1865 \\
\hline Pekkonen, Maria & luterilainen & Laukaansuu & Kallivieri & n. 1857 \\
\hline Petrova, Maria & *inkeroinen & & Viistinä & 1877 \\
\hline Pohjalainen, Anni & ${ }^{\star}$ luterilainen & Kallivieri & Kallivieri & 1893 \\
\hline $\begin{array}{l}\text { Pohjalainen, Juljaana } \\
\text { (o.s. Reiju) }\end{array}$ & luterilainen & Kulla & Kallivieri & 1857 \\
\hline Porissa (Tupina), Anni & ${ }^{\star}$ luterilainen & & Kaipaala & n. 1824 \\
\hline Reponen, Pauli & *inkeroinen & & Loukkula & \\
\hline Reponen, Pauliina & inkeroinen & & Loukkula & 1894 \\
\hline Ruokonen, Anastasi & *inkeroinen & Loka & Venakontsa & 1906 \\
\hline $\begin{array}{l}\text { Räkälä, Jevdokia (Eudokia, } \\
\text { Jeodokia) Danilovna Feodorova }\end{array}$ & $\begin{array}{l}\text { inkeroinen } \\
\text { (äiti vatjalainen) }\end{array}$ & Ropsu & Räkälä & 1867 \\
\hline Saksa Valpuri (Vappu) & luterilainen & Kulla & Hanikke & n. 1861 \\
\hline $\begin{array}{l}\text { Siller Maria } \\
\text { (o.s. Alekseintytär Munts) }\end{array}$ & $?$ & Kallivieri & Räkälä & 1904 \\
\hline $\begin{array}{l}\text { Siller Maria Semonontytär } \\
\text { (o.s. Kirilov) }\end{array}$ & $?$ & Räkälä/ Kotko? & $\begin{array}{l}\text { Räkälä/ } \\
\text { Vanhakylä? }\end{array}$ & 1875 \\
\hline
\end{tabular}




\begin{tabular}{|c|c|c|c|c|}
\hline Nimi & Rунмё & SYNNYINKYLÄ & KотіKуLÄ & SYNTYMÄAIKA \\
\hline Stepanof, Anni & inkeroinen & & Kolkanpää & 1890 \\
\hline Säkki, Helena & ${ }^{\star}$ luterilainen & Uusikylä & Kallivieri & \\
\hline Tammikko, Anna & inkeroinen & Kosemkina & Vanhakylä & 1882 \\
\hline Tanilan Serkei & inkeroinen & & Loukkula & n. 1797 \\
\hline Teppanja & inkeroinen & & Oussimäki & $\begin{array}{l}\text { nuori miniä } \\
\text { vuonna } 1892 \\
\end{array}$ \\
\hline Tuisk, Maria & inkeroinen & Kallivieri & Vanhakylä & n. 1862 \\
\hline Tun’a & inkeroinen & & Väikylä & $\begin{array}{l}\text { "vanha nainen" } \\
\text { vuonna } 1892\end{array}$ \\
\hline Uljaana & ${ }^{*}$ inkeroinen & & Säätinä & \\
\hline $\begin{array}{l}\text { Vahter, Mari (o.s. Jefimof, } \\
\text { Slobsanoff, "Slabun Mari") }\end{array}$ & inkeroinen & Ropsu & Hanikke & n. 1895 \\
\hline Varkki, Kati & luterilainen & Vanhakylä & Vanhakylä & n. 1962 \\
\hline Vohta, Katri (o.s. Ahonen) & luterilainen & Sutela & Vyötermaa & n. 1873 \\
\hline $\begin{array}{l}\text { Vohta, Valpuri } \\
\text { (o.s. Orava, äiti Lallo) }\end{array}$ & luterilainen & Kallivieri & Vyötermaa & 1888 \\
\hline Vöglä, tyttö & *inkeroinen & & Savimäki & n. 1866 \\
\hline Yrjönen, Aleksandra & inkeroinen & & Loukkula & 1896 \\
\hline Väärnojan Kati, Kati-akka & ${ }^{\star}$ luterilainen & & Väärnoja & \\
\hline Väärnojan Katin tytär & ${ }^{\star}$ luterilainen & Väärnoja & Uusikylä & \\
\hline
\end{tabular}

\section{LIITE 3: KYLÄT, ETNISET RYHMÄT JA KESKEISET PRAASNIKAT}

Kylien etnisyyden osalta käytetty pääosin arkistolähteillä täydennettyä kirjallisuutta: Nevalainen \& Sihvo 1991, 408-409 (sama kuin Mustonen 1931, 60, 63-64, jolla lähteenä myös Köppen (1849, 1867)); Laiho 1940; SKS KRA Alava VII b 1892, 24, 52, 55-56, 59, 62-63, 74, 96, 117-120, 183 sekä erityisesti SKS KRA Enäjärvi-Haavio 771 (Sutela), Laiho L. 5414 (Ropsu), Laiho L. 4962 (Karstala ja Popofka).

Praasnikkojen kohdalla on käytetty ennen kaikkea arkistolähteitä, joita verrattu kirjallisuudessa esitettyihin tietoihin. Keskeisiä informantteja ovat Anna Kivisoo (SKS KRA Haavio 2748, 2795; Enäjärvi-Haavio 730); Darja Lehti (SKS KRA Haavio 2746, 2785-2788, 2792) sekä Katri Vohta (SKS KRA Haavio 2749; Enäjärvi-Haavio 728); lisäksi Maria Hauki (SKS KRA Laiho 5230-5231); Darja Koivunen (SKS KRA Haavio 2750); Matroona Leppik (SKS KRA Haavio 2751, 2781, 2783); Katri Mark (SKS KRA Laiho L. 2586, 1587); Valpuri Vohta (SKS KRA Enäjärvi-Haavio 727) sekä Matrona Bässina (SKS KRA Haavio 2747, 2793-2794, 2796-2797), jonka antamat runsaat tiedot ovat tosin monin paikoin ristiriidassa muiden lähteiden kanssa. Yksittäisten kylien kohdalla SKS KRA Haavio 2802 (Arsiansaari); 2779 (Haavikko); Mannonen 9842 (Kolkanpää); Alava VII B II, 56 (Koskinen, Saarove, Tarinaisi, Venakontsa); Laiho A. 3296 (Kotko); Haavio 2800, Laiho A. 2606 (Kulla); Mannonen 5705, vrt. 9842 (Loka); Mannonen 9842, 11148 (Loukkula); Laiho A. 3296 (Mannakka); Haavio 2777, 2778, 2791 (Pärspää); Mannonen 5705 (Ruutsia?); Mannonen 5705, 5706 (Suija); Laiho A. 3296 (Tiensuu); SKVR III 2079 (Uusikylä); SKS KRA Mannonen 5446, 5705 (Viistinä); Mannonen 5705 (Voloitsa); Haavio 2799, Laiho L. 1587, 5226, 2586, (Väikylä); Haavio 2801 (Vyötermaa). Kirjallisuudesta: Lukkarinen 1911, 39-40 (Soikkolan kylät); IMS: iliä, jaani, joulu, pedro, suBotta, troitsa. Sarmelaisen $(1969,79-80)$ kattavaa selvitystä on 
käytetty varoen, sillä mukana näyttävät olevan kaikki mahdolliset maininnat ja siten paljon muitakin kuin kylien keskeisimpiä praasnikkoja. Monien Soikkolan kylien kohdalla Sarmela on kuitenkin keskeinen lähde, sillä selvityksessä käytetyt toisen maailmansodan jälkeiset aineistot eivät kuulu tämän työn aineistorajauksen piiriin.

Lähteet kattavat siis asutuksen osalta tietoja 1800-luvun puolivälistä (Köppen) toiseen maailmansotaan asti, kun taas praasnikkalähteet painottuvat 1900-luvun puolelle, erityisesti 1930-luvun Viron Inkeriin (SKS KRA) sekä Suomeen muuttaneisiin inkeroisiin (IMS). Kylien osalta on mainittu lähinnä aineistossa käytetyt nimet, vaikka kaikilla on myös venäjänkieliset nimet. Alava (SKS KRA Alava VII b, 117-120) mainitsee kyläluettelossaan myös kolme virolaisten, saksalaisten tai venäläisten omistamaa moisiota. Laukaansuun vatjalaiskylät (Joenperä, Liivakylä, Luuditsa, Risumäki) on lähteissä vaihdellen tulkittu joko Narvusiin tai Soikkolaan kuuluviksi; laulujensa puolesta ne näyttävät olleen lähempänä Soikkolaa. Luuditsan (Ala-Luuditsa) ja Risumäen (Ylä-Luuditsa) nimitykset ja sijainnit vaihtelevat eri teoksissa eniten ja saatavat yksittäisissä muistiinpanoissa mennä sekaisin lähempänä Jaamaa sijaitsevien Luuskan kylien kanssa. Muutamat Narvusin kylät taas rakennettiin Laihon (1940) mukaan 1900-luvulla (Alakylä ja Rajakylä 1930-luvulla, Hanike 1910).

Sulut etnisyysmerkinnän ympärillä tarkoittavat asutuksen pienuutta suhteessa kylän valtaväestöön: muutamatkin mainitut talot (etenkin Alavan muistiinpanoissa) on tässä otettu huomioon, vaikka ne useissa lähteissä jätetään huomiotta. Praasnikoiden kohdalla on pyritty merkitsemään ainoastaan varmoilta kylän keskeispraasnikoilta eri lähteiden perusteella vaikuttavat juhlat, sulut tarkoittavat epävarmoja, usein vain yhden lähteen antamia tietoja. Etenkin pienistä kylistä tietoja on usein niukalti. Joka kylässä vietetyiksi mainittuja juhlia (joulu, pääsiäinen, Jyri, juhannus, Martti Narvusissa) ei taulukkoon ole merkitty, vaikka niistä on paljon mainintoja. Etenkin joulu mainitaan praasnikaksi niiden kylien kohdalla, joista ei muita tietoja ole. Sekakylissä praasnikka on usein lähinnä joko ortodoksien (Pedro, Iilia, Miikkula) tai luterilaisten (Mikkeli) viettämä. Usein ortodoksikylissä on vietetty joko Iiliaa tai Pedroa kesällä ja Miikkulaan talvella. Miikkulan kohdalla täysin varma ei tosin voi olla siitä, tarkoittaako joku lähde Talvi-Miikkulan sijasta Kevät-Miikkulaa, sillä näitä ei yleensä ole mainittu erikseen. Subotan vietosta ei ole paljoakaan tietoa, vaikka IMS (subotta) mainitsee sitä vietetyn useassa Soikkolan pienessä kylässä ja sen liittyneen vainajien muistamiseen.

$\mathrm{i}=$ inkeroinen, $s=$ inkerinsuomalainen (äyrämöisiä, savakkoja ja Narvusin suomalaisia ei ole tässä eroteltu), vat=vatjalainen, v=venäläinen, vir=virolainen .

\begin{tabular}{llcl} 
Kylä & Alue & ETNISET RYHMÄt & KeSKeiset PRAASNiKat \\
Alakylä & $\begin{array}{l}\text { Narvusi } \\
\text { (Viron Inkeri) }\end{array}$ & $\mathrm{s}(-\mathrm{i})$ & \\
\hline Arsiansaari, Arzensaari & Narvusi & $\mathrm{s}(-\mathrm{i})$ & Mikkeli \\
\hline Haavikko (Keikino) & Narvusi & $\mathrm{i}$ & Pedro \\
\hline Hakaja & Narvusi & $\mathrm{s}$ & (Andreas?) \\
\hline Hamala & Narvusi & i-s & Troitsa \\
\hline Hamala & Soikkola & $\mathrm{s}$ & \\
Hanike & $\begin{array}{l}\text { Narvusi } \\
\text { (Viron Inkeri) }\end{array}$ & $\mathrm{s}$ & (Troitsa?)
\end{tabular}


KYLÄ

\begin{tabular}{l} 
KYLÄ \\
Harkkola \\
\hline Hinnola \\
\hline Joenperä, Krakolje \\
\hline Järvenperä \\
Kaipaala \\
\hline
\end{tabular}

Karstala (Korostell, Gorka)

\begin{tabular}{l} 
Kiiskala \\
\hline Kirjamo \\
\hline Kirkonmäki \\
\hline Kolkanpää \\
\hline Kontu \\
\hline Korovina \\
\hline Koskina \\
\hline Kotko \\
\hline Kukkosiä (Kurovits) \\
\hline Kullankylä \\
\hline Kurkula \\
\hline Laukaansuu \\
Liivakylä
\end{tabular}

Loka (Loas, Loankylä)

Loukkula

Luttova

Luuditsa (Ala-Luuditsa, Ala-Luzitsa, Ala-Luuskaja )

Magdeburg

Mannakka

Metsäkylä

Mäkkylä

Mättäsi

Narvusi, Narusi, Kosemkina

Otsave

Oussinmäki

Peipiä

Pieni Somero

Pärspää

Pätsinä

Rajakylä

Repola

Risumäki (Ylä-Luuditsa, Ylä-Luzitsa)

Ropsu

Ruutsia

Räkälä
Alue

Soikkola

Narvusi

Soikkola/

Narvusi

Soikkola

Narvusi

Narvusi

(Viron Inkeri)

Narvusi

(Viron Inkeri)

Narvusi

Narvusi

Soikkola

Soikkola

Narvusi

Narvusi

Soikkola

Soikkola

Narvusi

Narvusi

Narvusi

(Viron Inkeri)

Narvusi

Narvusi

Soikkola/

Narvusi

Soikkola

Soikkola

Narvusi

Soikkola/

Narvusi

Narvusi

(Viron Inkeri)

Narvusi i Iilia, subotta

Soikkola i $\quad$ Miikkula, (Iilia?)

Soikkola

Soikkola

Narvus

Narvusi

Soikkola

Soikkola

Soikkola

Soikkola

Narvusi

Soikkola

Narvusi (Viron

Inkeri)

Soikkola

Soikkola/

Narvusi

Narvusi

Soikkola

Narvusi (Viron

Inkeri)
ETNISET RYHMÄT KESKEISET PRAASNIKAT

Iilia, Miikkula

Pedro, Miikkula (Iilia?)

Mikkeli

(Pedro?)

(Pedro?)

Pyhäinmiesten päivä?

Pedro, Miikkula

Pedro, Miikkula

(Pedro?)

i-vir

i Iilia, (Miikkula, subotta?)

i Iilia, Miikkula

vat-i Troitsa, Miikkula

s(-i) Mikkeli

(-i) (Pedro?)

i-s Pedro, Miikkula, (Mikkeli?)

i-vat Pedro, Miikkula

i Pedro, Miikkula

i Iilia, (Miikkula?)

s

i Iilia, (subotta, Miikkula?)

i Troitsa

i-s Pedro, Miikkula

(-s) (Iilia, Miikkula, subotta?)

i Iilia, (Miikkula, subotta?)

s-i

i (subotta?)

i(-s) Iilia, Nastassie, (Miikkula?)

i-v (Pedro?)

$s(-i)$

i Troitsa, Miikkula

i-vat-v Pedro, Miikkula

i-s Troitsa

v-i Pedro, (Miikkula?)

$s(-i)$ 


\begin{tabular}{|c|c|c|c|}
\hline KYLÄ & Alue & ETNISET RYHMÄT & KESKEISET PRAASNIKAT \\
\hline Röllölä & Soikkola & $\mathrm{i}$ & Troitsa \\
\hline Saarkylä, Säärkylä & $\begin{array}{l}\text { Narvusi (Viron } \\
\text { Inkeri) }\end{array}$ & $\mathrm{i}(-\mathrm{s})$ & Iilia, Miikkula \\
\hline Saarove & Soikkola & $\mathrm{i}$ & Iilia, (Miikkula?) \\
\hline Salansuu & Narvusi & $s-i$ & \\
\hline Savimäki & Soikkola & $\mathrm{i}$ & Troitsa, Pedro, Miikkula \\
\hline Struuppova & Narvusi & $\mathrm{s}$ & Mikkeli \\
\hline Suija & Soikkola & $\mathrm{i}$ & Iilia, Miikkula, (subotta?) \\
\hline Suokylä, (Dubrofka) & Narvusi & $\mathrm{s}$ & \\
\hline Sutela & Narvusi & $\mathrm{i}(-\mathrm{s})$ & Troitsa \\
\hline Suuri Somero & Soikkola & $\mathrm{v}-\mathrm{i}$ & subotta \\
\hline Säätinä (Slobodka, ilm. Posolka) & Soikkola & $\mathrm{i}(-\mathrm{s})$ & Troitsa, (Iilia, Miikkula?) \\
\hline Takaväljä & Narvusi & i-s & Troitsa, joulu \\
\hline Tammikontu & Soikkola & $\mathrm{i}$ & $\begin{array}{l}\text { Iilia, (Troitsa, subotta, } \\
\text { Miikkula?) }\end{array}$ \\
\hline Tarinaisi & Soikkola & $\mathrm{i}$ & Iilia, Miikkula \\
\hline Tervola (Smolka & $\begin{array}{l}\text { Narvusi } \\
\text { (Viron Inkeri) }\end{array}$ & s & \\
\hline Tiensuu, Izvoz (Täyssinä) & Narvusi & $\mathrm{i}$ & Iilia, subotta \\
\hline Uusi Arsia & $\begin{array}{l}\text { Narvusi } \\
\text { (Viron Inkeri) }\end{array}$ & s & \\
\hline Uusi Feodormaa & $\begin{array}{l}\text { Narvusi } \\
\text { (Viron Inkeri) }\end{array}$ & s & \\
\hline Uusi Harkkola & Soikkola & $s-i$ & \\
\hline Uusi Narvusi (Krivulka) & Narvusi & i-s & \\
\hline Uusi Ropsu & $\begin{array}{l}\text { Narvusi } \\
\text { (Viron Inkeri) }\end{array}$ & i-s & \\
\hline Uusi Struuppova & Narvusi & $\mathrm{s}$ & \\
\hline Uusikylä & Soikkola & $\mathrm{s}$ & (Pedro?) \\
\hline Vanhakylä & $\begin{array}{l}\text { Narvusi (Viron } \\
\text { Inkeri) }\end{array}$ & $\mathrm{i}-\mathrm{s}$ & Iilia \\
\hline Vena & Narvusi & $\mathrm{s}$ & (Pedro, Iilia?) \\
\hline Venakontsa & Soikkola & $\mathrm{i}$ & Iilia, (Miikkula?) \\
\hline Viistinä & Soikkola & $\mathrm{i}$ & $\begin{array}{l}\text { Pedro, Miikkula, (Troitsa, } \\
\text { Iilia?) }\end{array}$ \\
\hline Vipiä & Narvusi & $\mathrm{s}$ & (Pedro?) \\
\hline Voloitsa & Soikkola & $\mathrm{i}$ & Pedro, (Miikkula?) \\
\hline Vyötermaa & Narvusi & $s-i$ & Mikkeli \\
\hline Väikylä & $\begin{array}{l}\text { Narvusi (Viron } \\
\text { Inkeri) }\end{array}$ & $i-v$ & Pedro, Miikkula, (Nastassie?) \\
\hline Vääräoja & Soikkola & s & (Iilia, Miikkula?) \\
\hline
\end{tabular}




\section{LIITE 4: SÄVELMÄAINEISTO}

Tähän liitteeseen on koottu tiedot sävelmäaineistosta kerääjittäin ja keräelmittäin. Mukana ovat vuosina 1853-1938 Soikkolasta, Narvusista, Kattilasta, Hevaalta ja Tyröstä tallennetut runosävelmät tai niitä läheisesti muistuttavat, tässä työssä käytetyt sävelmät. Samat kerääjät tallensivat myös esimerkiksi itkusävelmiä, rekilauluja ja muita uusimittaisia lauluja, joitain venäläisiä ja virolaisia lauluja sekä soitinsävelmiä, mutta näitä ei ole otettu taulukkoon mukaan silloinkaan, kun ne on tässä työssä mainittu. Taulukkoon on merkitty hieman kokoelmittain vaihdellen:

1. tässä työssä käytetyt viitetiedot (usein lyhennettyinä, selitys taulukon alussa)

2. muut viitetiedot

3. sävelmän numero Inkerin runosävelmät -julkaisussa (IRS)

4. tallennuspaikka

5. tallennuskylä/laulajan kotikylä

6. laulaja (jos tiedossa)

7. kuoro tai jälestälaulaja $(\mathrm{K})$

8. laulun alkusäe tai -säkeet (mukaan on otettu yhdestä kahteen säettä mahdollisine osakertauksineen ja refrenkeineen).

\section{EUROPAEUS 1953 (SKS KRA)}

Viitteet: 12: = SKS KRA Europaeus 12

\begin{tabular}{llllll} 
ViIte & MUUt ViItTeEt & IRS & PAIKKa & Kylä & ENSIMmäInEN säE \\
12: 184 & SKVR III:34 & 867 & Narvusi & Vanhakylä & Aja aja velvyeni \\
\hline 12: (194), 194a & (SKVR III:44) & 869 & Narvusi & Vanhakylä & La kuin katson liekkuani \\
\hline 12: (194), 194b & SKVR III:44 & 879 & Narvusi & Vanhakylä & Ehittelin jo velloani juono \\
\hline 12: 199a & SKVR III:49 (ja 46, 47) & 868 & Narvusi & Vanhakylä & Laslavikka laulamahan \\
\hline 12: 027 & SKVR IV1:476 & 878 & Tyrö & Kaarostan takakylät & Oi sie laiska lesken poika
\end{tabular}

\section{BORENIUS 1877 (SKS KRA)}

Viitteet:

e) $=$ SKS KRA Borenius e)

6: $=$ SKS KRA Borenius 6

\begin{tabular}{|c|c|c|c|c|c|c|}
\hline ViIte & MuUt Virtteet & IRS & PAIKKA & KYLÄ & LAULAJA & K. Alkusäe \\
\hline e) 108 & $\begin{array}{l}\text { 6:853; SKVR } \\
\text { IV2:1786 }\end{array}$ & 401 & Tyrö & $\begin{array}{l}\text { Hovi- } \\
\text { mäen } \\
\text { Alakylä }\end{array}$ & $\begin{array}{l}\text { Hilipän Ten’a } \\
\text { (Fen’a), n. } 20 \text { v., } \\
\text { inkeroinen }\end{array}$ & $\begin{array}{l}\text { Katrina kotikainainen, Katri kok- } \\
\text { K koi linnukkainen, linnu linnuk- } \\
\text { kainen, linnukkainen joonoi }\end{array}$ \\
\hline e) 109 & $\begin{array}{l}\text { 6:854, SKVR } \\
\text { IV2:1787 }\end{array}$ & 675 & Tyrö & $\begin{array}{l}\text { Hovi- } \\
\text { mäen } \\
\text { Alakylä }\end{array}$ & $\begin{array}{l}\text { Aavon Helena, } 21 \\
\text { v., luterilainen }\end{array}$ & $\begin{array}{l}\text { Kerittelin vellojaini, ai lole lole } \\
\text { vellojaini }\end{array}$ \\
\hline
\end{tabular}




\begin{tabular}{|c|c|c|c|c|c|c|}
\hline VIITE & MuUt VittTeEt & IRS & PAIKKA & KYLÄ & LAULAJA & K. AlkusäE \\
\hline e) 110 & $\begin{array}{l}\text { 6:855, SKVR } \\
\text { IV2:1788 }\end{array}$ & 406 & Tyrö & $\begin{array}{l}\text { Hovi- } \\
\text { mäen } \\
\text { Alakylä }\end{array}$ & $\begin{array}{l}\text { Aavon Helena, } 21 \\
\text { v., luterilainen }\end{array}$ & $\begin{array}{l}\text { Velloini venoisen seppoi, laivoi } \\
\text { K seppoi lagluve, e oi lagluvein, } \\
\text { laivoi seppoi lagluvein }\end{array}$ \\
\hline e) 111 & $\begin{array}{l}\text { 6:856, SKVR } \\
\text { IV2:1789 }\end{array}$ & 584 & Tyrö & $\begin{array}{l}\text { Hovi- } \\
\text { mäen } \\
\text { Alakylä }\end{array}$ & $\begin{array}{l}\text { Murun Mari } \\
\text { (ja Murun Anni) } \\
\text { Rapolasta }\end{array}$ & $\begin{array}{l}\text { Läksin kouluihen kojista, oppi- } \\
\text { (K) hen omilta mailt, Ai kal'inuska } \\
\text { maja, ai mal'inuska maj'a }\end{array}$ \\
\hline e) 112 & $6: 857$ & 394 & Tyrö & $\begin{array}{l}\text { Hovi- } \\
\text { mäen } \\
\text { Alakylä }\end{array}$ & $\begin{array}{l}\text { Murun Mari } \\
\text { (ja Murun Anni) } \\
\text { Rapolasta }\end{array}$ & K Pääskyläinen päivälintu \\
\hline e) 113 & & 140 & Tyrö & $\begin{array}{l}\text { Hovi- } \\
\text { mäen } \\
\text { Alakylä }\end{array}$ & $\begin{array}{l}\text { Murun Mari } \\
\text { (ja Murun Anni) } \\
\text { Rapolasta } \\
\end{array}$ & K Miss sie mökkö myöhään viivyit \\
\hline e) 114 & & 332 & Tyrö & $\begin{array}{l}\text { Hovi- } \\
\text { mäen } \\
\text { Alakylä }\end{array}$ & $\begin{array}{l}\text { Murun Mari } \\
\text { (ja Murun Anni) } \\
\text { Rapolasta }\end{array}$ & $\begin{array}{l}\text { Ottajat omenuveini ja omenu, } \\
\text { K puhemiehet puoluveini, puolu- } \\
\text { veini }\end{array}$ \\
\hline e) 115 & & 187 & Tyrö & $\begin{array}{l}\text { Hovi- } \\
\text { mäen } \\
\text { Alakylä }\end{array}$ & $\begin{array}{l}\text { Murun Mari } \\
\text { (ja Murun Anni) } \\
\text { Rapolasta }\end{array}$ & $\begin{array}{l}\text { (K) } \begin{array}{l}\text { Miss sie mökkö myöhään viivyit, } \\
\text { myöhään viivyit joi }\end{array}\end{array}$ \\
\hline e) 116 & & 360 & Tyrö & $\begin{array}{l}\text { Hovi- } \\
\text { mäen } \\
\text { Alakylä }\end{array}$ & $\begin{array}{l}\text { Murun Mari } \\
\text { (ja Murun Anni) } \\
\text { Rapolasta }\end{array}$ & K Kati siityine sissoini ja sissoini \\
\hline e) 117 & SKVR IV2:1790 & 589 & Tyrö & Ylikylä & $\begin{array}{l}\text { Murun Mari } \\
\text { (ja Murun Anni) } \\
\text { Rapolasta }\end{array}$ & $\begin{array}{l}\text { (K) })_{\text {Minun ehtoinen emon'i, paistoi }} \\
\text { miulle pannukaakun }\end{array}$ \\
\hline e) 118 & & 585 & Tyrö & Rapala & $\begin{array}{l}\text { Marttilan (Helena) } \\
\text { Heloi Rapalan } \\
\text { kylästä }\end{array}$ & $\mathrm{K} \begin{array}{l}\text { Velloini venoisen seppä, laivoin } \\
\text { seppä lakluvein ee oo lakluvein }\end{array}$ \\
\hline e) 121 & & 420 & Tyrö & Ylikylä & $\begin{array}{l}\text { Kennan Helena } \\
\text { Leppäsist. }\end{array}$ & $\begin{array}{l}\text { Ei uo turvaisa miulla, miull on } \\
\text { turva turpehiss:|: }\end{array}$ \\
\hline e) 122 & & 422 & Tyrö & Ylikylä & $\begin{array}{l}\text { Kennan Helena } \\
\text { Leppäsist. }\end{array}$ & Lauloi yksi lauloi toine \\
\hline e) 123 & & 545 & Tyrö & Ylikylä & $\begin{array}{l}\text { Kennan Helena } \\
\text { Leppäsist. }\end{array}$ & $\begin{array}{l}\text { Lauloi yksi lauloi toine, lauloi } \\
\mathrm{K} \text { kolmansi keralla, ja keralla ja } \\
\text { keralla hoile }\end{array}$ \\
\hline e) 124 & & 476 & Tyrö & Ylikylä & $\begin{array}{l}\text { Kennan Helena } \\
\text { Leppäsist. }\end{array}$ & K $\begin{array}{l}\text { Mitä myö ilota uoma, lapset } \\
\text { lauluta eläm }\end{array}$ \\
\hline e) 125 & & 651 & Tyrö & Ylikylä & $\begin{array}{l}\text { Kennan Helena } \\
\text { Leppäsist. }\end{array}$ & $\begin{array}{l}\text { La mie katson liekkujaini, onko } \\
\text { liekku leppiäi, leppi leppiäinen, } \\
\text { leppiäinen joonoi }\end{array}$ \\
\hline e) 127 & & 652 & Tyrö & Hanttula & $\begin{array}{l}\text { Setälän Mari, } \\
22 \text { v. tyttö }\end{array}$ & $\begin{array}{l}\text { Kutroitukka mein kuninga, } \\
\text { Kalkoipääkkö valla herra; Sei } \\
\text { jumavei jumavei jumajuu yksi } \\
\text { kaksi kolmet neljät }\end{array}$ \\
\hline e) 128 & & 590 & Tyrö & Hanttula & $\begin{array}{l}\text { Helkalan Sohvi } \\
15 \mathrm{v} .\end{array}$ & $\begin{array}{l}\text { Tuutin tuutin tyttö lasta, sen } \\
\text { paremmin poikalasta }\end{array}$ \\
\hline e) 129 & & 199 & Tyrö & $\begin{array}{l}\text { Kirkon- } \\
\text { kylä }\end{array}$ & $\begin{array}{l}\text { Mari Tiisniekka, } \\
14 \mathrm{v} \text {. }\end{array}$ & $\begin{array}{l}\text { Kos mun tuttuni tulisi, ai da l'ole } \\
\text { l'ole ja tulisi }\end{array}$ \\
\hline e) 169 & SKVR IV2:1792 & 281 & Tyrö & Asikkala & $\begin{array}{l}\text { Riikosen Olena, } \\
\text { vanha ämmä, } 70 \\
\text { paikoilla }\end{array}$ & $\begin{array}{l}\text { Velloini vet se venoisen seppoi } \\
\text { joo; ai lole lole ja venoisen se }\end{array}$ \\
\hline e) 170 & & 549 & Tyrö & Asikkala & $\begin{array}{l}\text { Siitkone, Juosepp } \\
\text { Juhananp. }\end{array}$ & $\begin{array}{l}\text { Velloini venoisen seppoi, Laivoin } \\
\text { seppoi lakluveini (laglu lagluvei- } \\
\text { ni, lagluveini hoile) }\end{array}$ \\
\hline $\begin{array}{l}\text { e) } \\
171 \mathrm{a} \\
\end{array}$ & $\begin{array}{l}\text { 6:893, SKVR } \\
\text { IV2:1793 }\end{array}$ & 381 & Hevaa & Vepsä & $\begin{array}{l}\text { Kupsan Oute, } \\
\text { inkeroinen }\end{array}$ & $\begin{array}{l}\text { Mie olin ennen orjuuvein, Pahoin } \\
\text { lakain piikuvein }\end{array}$ \\
\hline $\begin{array}{l}\text { e) } \\
171 b\end{array}$ & SKVR IV2:1804 & 388 & Hevaa & Vepsä & $\begin{array}{l}\text { Kupsan Oute, } \\
\text { inkeroinen }\end{array}$ & $\begin{array}{l}\text { Manteroin mattala seppoi; se } \\
\mathrm{K} \text { mattala se, manteroin mattala } \\
\text { seppoi }\end{array}$ \\
\hline e) 172 & $\begin{array}{l}\text { 6:895; SKVR } \\
\text { IV2:1795, }\end{array}$ & 510 & Hevaa & Vepsä & $\begin{array}{l}\text { Irina, Riikalin } \\
\text { tytär, n. } 30 \text { v. }\end{array}$ & $\begin{array}{l}\text { Nouskahan norollen nuoret, } \\
\text { K kesoin kempit kallioillen, kalli } \\
\text { kallioille, kallioille joonoi }\end{array}$ \\
\hline
\end{tabular}




\begin{tabular}{|c|c|c|c|c|c|c|}
\hline ViIte & MuUt Virtteet & IRS & PAIKKA & A KYLÄ & LAULAJA & K. Alkusäe \\
\hline e) 173 & $\begin{array}{l}\text { 6:896; SKVR } \\
\text { IV2:1796; }\end{array}$ & 415 & Hevaa & Vepsä & $\begin{array}{l}\text { Tatjana Tarassi- } \\
\text { man tytär }\end{array}$ & $\begin{array}{l}\text { Iivana kojoisen poikoi, itsek } \\
\text { K iivana kojoi, ja kojoi kojoinen, ja } \\
\text { koijoine joono }\end{array}$ \\
\hline e) 174 & $\begin{array}{l}\text { 6:897; SKVR } \\
\text { IV2:1797, }\end{array}$ & 387 & Hevaa & Vepsä & Iivan(an) Maura & $\begin{array}{l}\text { Kesoilintu keeloili(ntu), päivöi- } \\
\text { K lintu pääskylintu, ee keeloi li, } \\
\text { päivöilintu keeloilii }\end{array}$ \\
\hline e) 175 & $\begin{array}{l}\text { [Oute: SKVR } \\
\text { IV2:1794] }\end{array}$ & 211 & Hevaa & Vepsä & $\begin{array}{l}\text { Tatjana Tarassi- } \\
\text { man tytär }\end{array}$ & 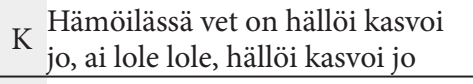 \\
\hline e) 176 & $\begin{array}{l}\text { [Oute: SKVR } \\
\text { IV2:1798] }\end{array}$ & 604 & Hevaa & Vepsä & $\begin{array}{l}\text { Paraskoi Huoterin } \\
\text { tytär }\end{array}$ & $\begin{array}{l}\text { Eipä tuota ennen ollut, kuin } \\
\text { kanto meroihen ka }\end{array}$ \\
\hline e) 177 & $\begin{array}{l}\text { [Iivanan } \\
\text { Maura: SKVR } \\
\text { IV2:1799] }\end{array}$ & 528 & Hevaa & Vepsä & $\begin{array}{l}\text { Paraskoi Huoterin } \\
\text { tytär }\end{array}$ & $\begin{array}{l}\text { Ennen päivytäk eletty, kupaeltu } \\
\mathrm{K} \text { ilman kuutak, ilman ilman kuu- } \\
\text { tak, ilman kuutak joonoi }\end{array}$ \\
\hline e) 178 & SKVR IV2:1800 & 60 & Hevaa & Vepsä & Iivan(an) Maura & $\begin{array}{l}\text { Kävy uuven uusikkaine, vävy } \\
\text { uuven uusikkaine }\end{array}$ \\
\hline e) 179 & $\begin{array}{l}\text { [Iivanan } \\
\text { Maura: SKVR } \\
\text { IV2:1801] }\end{array}$ & 351 & Hevaa & Vepsä & $\begin{array}{l}\text { Paraskoi Huoterin } \\
\text { tytär }\end{array}$ & $\begin{array}{l}\text { Et luvannut lähtöväisi lähtöväisi, } \\
\text { etkä [pois pakenovasi] ja pakeno }\end{array}$ \\
\hline e) 180 & SKVR IV2:1802 & 194 & Hevaa & Vepsä & Iivan(an) Maura & $\mathrm{K} \begin{array}{l}\text { Mikkäli päin töö tulitta, kuka } \\
\text { teillen teetä [näytti] }\end{array}$ \\
\hline e) 181 & $\begin{array}{l}\text { Tatjana: SKVR } \\
\text { IV2:1803 }\end{array}$ & 253 & Hevaa & Vepsä & $\begin{array}{l}\text { Iivan(an) Maura / } \\
\text { Tatjana }\end{array}$ & $\begin{array}{l}\text { Kalervikkoi vet on kylvi kakroin } \\
\text { oi l'ole l'ole kylvi kakroin oi }\end{array}$ \\
\hline e) 182 & SKVR IV2:1805 & 592 & Hevaa & Vepsä & $\begin{array}{l}\text { Paroi (=Paraskoi) } \\
\text { [Huotarin tytär?] }\end{array}$ & $\begin{array}{l}\text { Nukuta Jumala lasta, pyhä Maa- } \\
\text { ria makoitak }\end{array}$ \\
\hline e) 183 & SKVR IV2:1806 & 473 & Hevaa & Vepsä & $\begin{array}{l}\text { Tatjana [ilm. Ta- } \\
\text { rassiman tytär] }\end{array}$ & $\begin{array}{l}\text { Nuku nuku nurme lintu, vaivu } \\
\text { valkea kanaine }\end{array}$ \\
\hline e) 184 & $\begin{array}{l}\text { Oute: SKVR } \\
\text { IV2:1807 }\end{array}$ & 527 & Hevaa & Vepsä & $\begin{array}{l}\text { Paroi (=Paraskoi) } \\
\text { [Huotarin tytär?] }\end{array}$ & $\begin{array}{l}\text { Juoksi hervi Hiien maita, potki } \\
\text { ? puolen kankahalta, kanka kanka- } \\
\text { halta, kankahalta joonoi }\end{array}$ \\
\hline $\begin{array}{l}\text { e) } \\
185 a\end{array}$ & & 7 & Hevaa & Vepsä & $\begin{array}{l}\text { Oute [ilm. Kup- } \\
\text { san Oute, inke- } \\
\text { roinen] }\end{array}$ & (ei sanoja, vrt. seuraava) \\
\hline $\begin{array}{l}\text { e) } \\
185 b\end{array}$ & SKVR IV2:1809 & 8 & Hevaa & Vepsä & $\begin{array}{l}\text { Oute [ilm. Kup- } \\
\text { san Oute, inke- } \\
\text { roinen] }\end{array}$ & $\begin{array}{l}\text { Mänin too metsähän kesoille, kes } \\
\text { kesoilla mie heinajoilla }\end{array}$ \\
\hline e) 186 & SKVR IV2:1808 & 456 & Hevaa & Vepsä & $\begin{array}{l}\text { Oute [ilm. Kup- } \\
\text { san Oute, inke- } \\
\text { roinen] }\end{array}$ & $\begin{array}{l}\text { Kasvoi tammi tanhavalle, isän } \\
\text { ikkunan alalle }\end{array}$ \\
\hline e) 187 & SKVR III:584 & 699 & $\begin{array}{l}\text { Soik- } \\
\text { kola }\end{array}$ & Loukkula & $\begin{array}{l}\text { Okru, keski- } \\
\text { ikäinen nainen }\end{array}$ & K $\begin{array}{l}\text { Pääsköi lintu päivöi lintu, lintu } \\
\text { päivöi lintu, lintu päivöi lintu }\end{array}$ \\
\hline e) 188 & $\begin{array}{l}\text { [Okru: SKVR } \\
\text { III:585] }\end{array}$ & 349 & $\begin{array}{l}\text { Soik- } \\
\text { kola }\end{array}$ & Loukkula & $\begin{array}{l}\text { Natu [ilm. Kaloin } \\
\text { Natu, noin } 15 . \\
\text { vuotias tyttö] ja } \\
\text { Okru }\end{array}$ & $\begin{array}{l}\text { Läksin kouluhu koista koista; } \\
\text { oppihe omilta mailta omilta }\end{array}$ \\
\hline e) 189 & SKVR III:588 & 409 & $\begin{array}{l}\text { Soik- } \\
\text { kola }\end{array}$ & Loukkula & $\begin{array}{l}\text { Natu [ilm. Kaloin } \\
\text { Natu, noin } 15 . \\
\text { vuotias tyttö] }\end{array}$ & $\begin{array}{l}\text { La laulan suruisen verren, suruk- } \\
\text { kahan suita möö }\end{array}$ \\
\hline e) 190 & SKVR III:587 & 782 & $\begin{array}{l}\text { Soik- } \\
\text { kola }\end{array}$ & Loukkula & $\begin{array}{l}\text { Natu, n. } 15 \text { vuoti- } \\
\text { as tyttö }\end{array}$ & $\begin{array}{l}\text { Katrina kotikanaine, koti kokkoi } \\
\text { linnukkaine }\end{array}$ \\
\hline e) 191 & SKVR III:589 & 459 & $\begin{array}{l}\text { Soik- } \\
\text { kola }\end{array}$ & $\begin{array}{l}\text { Tarinai- } \\
\text { nen }\end{array}$ & $\begin{array}{l}\text { Tanilan Serkei, } \\
\text { vanha ukko, n. } \\
80 \mathrm{v} .\end{array}$ & $\begin{array}{l}\text { Ukokkine akakkine, männää } \\
\text { möö savitsomaha }\end{array}$ \\
\hline e) 192 & & 911 & $\begin{array}{l}\text { Soik- } \\
\text { kola }\end{array}$ & $\begin{array}{l}\text { Tarinai- } \\
\text { nen }\end{array}$ & $\begin{array}{l}\text { Tanilan Serkei, } \\
\text { vanha ukko, n. } \\
80 \mathrm{v} \text {. } \\
\end{array}$ & (ei sanoja) \\
\hline e) 193 & SKVR III:591 & 138 & $\begin{array}{l}\text { Soik- } \\
\text { kola }\end{array}$ & Savimäki & $\begin{array}{l}\text { Vöglä, } 21- \\
\text { i vuotinen tyttö \& } \\
\text { Okkuli }\end{array}$ & K Kylvekä kypenyeveni \\
\hline
\end{tabular}




\begin{tabular}{|c|c|c|c|c|c|c|}
\hline VIITE & MuUt virtteet & IRS & PAIKKA & A KYLÄ & LAULAJA & K. Alkusäe \\
\hline e) 194 & SKVR III:593 & 251 & $\begin{array}{l}\text { Soik- } \\
\text { kola }\end{array}$ & Savimäki & $\begin{array}{l}\text { Vöglä, } 21- \\
\text { i vuotinen tyttö \& } \\
\text { Okkuli }\end{array}$ & $\begin{array}{l}\text { Päämees on pojut Kalervoi, } \\
\text { päämees on pojut kalervoi }\end{array}$ \\
\hline e) 195 & SKVR III:594 & 350 & $\begin{array}{l}\text { Soik- } \\
\text { kola }\end{array}$ & Savimäki & $\begin{array}{l}\text { Vöglä, } 21- \\
\text { i vuotinen tyttö \& } \\
\text { Okkuli }\end{array}$ & $\mathrm{K} \begin{array}{l}\text { Teekkä risti rinnalle rinnallesi, } \\
\text { rinnallesi }\end{array}$ \\
\hline e) 196 & SKVR III:595 & 752 & $\begin{array}{l}\text { Soik- } \\
\text { kola }\end{array}$ & $\begin{array}{l}\text { Savi- } \\
\text { mäki }\end{array}$ & $\begin{array}{l}\text { Vöglä, } 21- \\
\text { vuotinen tyttö \& } \\
\text { Okkuli }\end{array}$ & $\begin{array}{l}\text { Kuulin kukkuva käkköisen, } \\
\text { kuulin kukkuva käkköisen }\end{array}$ \\
\hline e) 197 & SKVR III:596 & 389 & $\begin{array}{l}\text { Soik- } \\
\text { kola }\end{array}$ & $\begin{array}{l}\text { Savi- } \\
\text { mäki }\end{array}$ & $\begin{array}{l}\text { Vöglä \& Okkuli } \\
\text { sekä pieni tyttö }\end{array}$ & $\begin{array}{l}\text { Mees köyhä vähäväkkiine, vään- } \\
\text { K täjä vähä-rammoine, ja vähäram- } \\
\text { moine, ja rammoine joonoo }\end{array}$ \\
\hline e) 198 & SKVR III:597 & 178 & $\begin{array}{l}\text { Soik- } \\
\text { kola }\end{array}$ & $\begin{array}{l}\text { Savi- } \\
\text { mäki }\end{array}$ & $\begin{array}{l}\text { Vöglä \& Okkuli } \\
\text { sekä pieni tyttö }\end{array}$ & $\begin{array}{l}\text { Leekuttaja keekuttaja, vaskise } \\
\text { vinahuttaja }\end{array}$ \\
\hline e) 199 & SKVR III:598 & 768 & $\begin{array}{l}\text { Soik- } \\
\text { kola }\end{array}$ & $\begin{array}{l}\text { Savi- } \\
\text { mäki }\end{array}$ & $\begin{array}{l}\text { Vöglä \& Okkuli } \\
\text { sekä pieni tyttö }\end{array}$ & K Käy neitoi rekoihesseini \\
\hline e) 200 & SKVR III:600 & 45 & $\begin{array}{l}\text { Soik- } \\
\text { kola }\end{array}$ & $\begin{array}{l}\text { Joen- } \\
\text { perä }\end{array}$ & $\begin{array}{l}\text { Oute } 16-17 \text { v., } \\
\text { Vadjan tyttö }\end{array}$ & K Lõekkujani kõekkujani \\
\hline e) 201 & SKVR III:599 & 223 & $\begin{array}{l}\text { Soik- } \\
\text { kola }\end{array}$ & $\begin{array}{l}\text { Joen- } \\
\text { perä }\end{array}$ & $\begin{array}{l}\text { Oute } 16-17 \mathrm{v} . \\
\text { Vadjan tyttö }\end{array}$ & $\begin{array}{l}\text { Velloini vennoisen seppoi, ai lole } \\
\text { lole ja venoisen }\end{array}$ \\
\hline e) 202 & SKVR III:601 & 754 & $\begin{array}{l}\text { Soik- } \\
\text { kola }\end{array}$ & $\begin{array}{l}\text { Joen- } \\
\text { perä }\end{array}$ & $\begin{array}{l}\text { Oute } 16-17 \mathrm{v} . \\
\text { Vadjan tyttö }\end{array}$ & $\begin{array}{l}\text { Pääsköilintu päivöilintu, lintu } \\
\text { päivöi lintu lintu päivöi lintu }\end{array}$ \\
\hline e) 203 & SKVR III:602 & 284 & $\begin{array}{l}\text { Soik- } \\
\text { kola }\end{array}$ & $\begin{array}{l}\text { Joen- } \\
\text { perä }\end{array}$ & $\begin{array}{l}\text { Oute } 16-17 \mathrm{v} . \\
\text { Vadjan tyttö }\end{array}$ & $\begin{array}{l}\text { Oi An’u siaruen'i, oi An’u } \\
\text { siaruen'i }\end{array}$ \\
\hline e) 204 & SKVR III:603 & 115 & $\begin{array}{l}\text { Soik- } \\
\text { kola }\end{array}$ & $\begin{array}{l}\text { Joen- } \\
\text { perä }\end{array}$ & $\begin{array}{l}\text { Ol'ona, n. 30. v. } \\
\text { leskiemäntä }\end{array}$ & $\begin{array}{l}\text { Klasloviitekka jumala, avittakka } \\
\text { armolline }\end{array}$ \\
\hline e) 205 & SKVR III:604 & 312 & $\begin{array}{l}\text { Soik- } \\
\text { kola }\end{array}$ & $\begin{array}{l}\text { Joen- } \\
\text { perä }\end{array}$ & $\begin{array}{l}\text { Olona, n. 30.v. } \\
\text { leskiemäntä }\end{array}$ & $\mathrm{K} \begin{array}{l}\text { Terve kuu terve päivä, terve kuu } \\
\text { kumettimast }\end{array}$ \\
\hline e) 206 & SKVR III:605 & 601 & $\begin{array}{l}\text { Soik- } \\
\text { kola }\end{array}$ & $\begin{array}{l}\text { Joen- } \\
\text { perä }\end{array}$ & An'u, n. 12 v. tyttö & $\begin{array}{l}\text { Emoi synnytti minuista, emoi } \\
\text { K synnytti minuista, oilia ja min- } \\
\text { nuista oilia ja minnuista }\end{array}$ \\
\hline e) 207 & & 92 & Kattila & $\begin{array}{l}\text { Matin- } \\
\text { kylä }\end{array}$ & "n. $60-70$ v. akka" & $\begin{array}{l}\text { K čylähäni lidnattani, čylättäni } \\
\text { lidnattani }\end{array}$ \\
\hline e) 208 & & 118 & Kattila & $\begin{array}{l}\text { Matin- } \\
\text { kylä }\end{array}$ & "n. $60-70$ v. akka" & 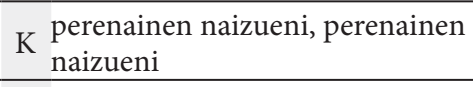 \\
\hline e) 209 & & 33 & Kattila & $\begin{array}{l}\text { Matin- } \\
\text { kylä }\end{array}$ & "n. $60-70$ v. akka" & $\begin{array}{l}\text { Löe löekku čii čiikku, löe löekku } \\
\text { čii čiikku }\end{array}$ \\
\hline e) 210 & & 91 & Kattila & $\begin{array}{l}\text { Matin- } \\
\text { kylä }\end{array}$ & "n. $60-70$ v. akka" & $\begin{array}{l}\text { Löeril löeril velvyttäni, löeril } \\
\text { löeril velvyttäni }\end{array}$ \\
\hline e) 211 & & 57 & Kattila & $\begin{array}{l}\text { Matin- } \\
\text { kylä }\end{array}$ & Marina & 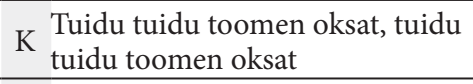 \\
\hline e) 212 & & 48 & Kattila & $\begin{array}{l}\text { Matin- } \\
\text { kylä }\end{array}$ & Marina & $\mathrm{K} \begin{array}{l}\text { Last avitekka jumala, last avitak- } \\
\text { ka jumala }\end{array}$ \\
\hline e) 213 & & 51 & Kattila & $\begin{array}{l}\text { Matin- } \\
\text { kylä }\end{array}$ & Marina & $\begin{array}{l}\text { Kaazikkaine maazikkaine, kaa- } \\
\text { zikkaine maazikkaine }\end{array}$ \\
\hline e) 214 & & 506 & Kattila & $\begin{array}{l}\text { Matin- } \\
\text { kylä }\end{array}$ & Marina & $\begin{array}{l}\text { L'uu l'uu lintuani, 'l'uu l'uu paa- } \\
\text { vilani }\end{array}$ \\
\hline e) 215 & & 600 & Kattila & $\begin{array}{l}\text { Matin- } \\
\text { kylä }\end{array}$ & nuoret tytöt & $\begin{array}{l}\text { Emo synnytti minuista, miä vai } \\
\text { K syytä synnytteli; oi kaalina, oi } \\
\text { maalina }\end{array}$ \\
\hline e) 216 & & 128 & Kattila & Kattila & $\begin{array}{l}\text { Petroi Sašu Stopa- } \\
\text { nan naa n. } 50 \mathrm{v}\end{array}$ & $\begin{array}{l}\text { Last avitekka jumala, last avitak- } \\
\text { ka jumala }\end{array}$ \\
\hline e) 217 & & 63 & Kattila & Kattila & $\begin{array}{l}\text { Petroi Sašu Stopa- } \\
\text { nan naa n. } 50 \mathrm{v}\end{array}$ & $\begin{array}{l}\text { Unnimannista matukka, matu- } \\
\text { kasta maitopaara }\end{array}$ \\
\hline e) 218 & & 127 & Kattila & $\begin{array}{l}\text { Pum- } \\
\text { mala }\end{array}$ & $\begin{array}{l}\text { Lilia Varve, Jaa- } \\
\text { kon na[inen], } \\
73 \mathrm{v} \text {. }\end{array}$ & $\mathrm{K} \begin{array}{l}\text { Last avitekka jumala, last avitak- } \\
\text { ka jumala }\end{array}$ \\
\hline
\end{tabular}




\begin{tabular}{|c|c|c|c|c|c|c|}
\hline Virte & MuUt VIITTEET & IRS & PAIKKA & A Kylä & LAUlaja & K. AlkusÄE \\
\hline e) 219 & & 38 & Kattila & $\begin{array}{l}\text { Pum- } \\
\text { mala }\end{array}$ & $\begin{array}{l}\text { Lilia Varve, Jaa- } \\
\text { kon na[inen], } \\
73 \text { v. }\end{array}$ & $\mathrm{K} \begin{array}{l}\text { Peremmees pere izäätä, perem- } \\
\text { mees pere izäätä }\end{array}$ \\
\hline e) 220 & & 105 & Kattila & Lempola & $\begin{array}{l}\text { Arh naa [Arhin } \\
\text { nainen] }\end{array}$ & $\begin{array}{l}\mathrm{K} \\
\text { Terve kuu terve päivä, terve kuu } \\
\text { terve päivä }\end{array}$ \\
\hline e) 223 & & 889 & Kattila & Lempola & $\begin{array}{l}\text { Oude Overan naa } \\
\text { n. } 50 \mathrm{v} \text {. }\end{array}$ & $\begin{array}{l}\text { Tansieka tammueni tammueni, } \\
\text { veere veerakkaisueni kaisueni }\end{array}$ \\
\hline e) 224 & & 870 & Kattila & Lempola & $\begin{array}{l}\text { Oude Overan naa } \\
\text { n. } 50 \text { v.? }\end{array}$ & $\begin{array}{l}\text { Nukuta jumala lasta, makauta } \\
\text { pyhä maarja }\end{array}$ \\
\hline
\end{tabular}

\section{AlaVA 1891-1897 (SKS KRA)}

SKS KRA = SKS KRA Alava.

\begin{tabular}{|c|c|c|c|c|c|}
\hline SKS KRA & MuUt ViItTeEt & ГРАІККА & KYLÄ & LAULAJA & RunO \\
\hline VIIa:425 & $\begin{array}{l}\text { SKVR III 2254; } \\
\text { vrt. } 1068\end{array}$ & Narvusi & Kaipaala & Anni Porissa & Hyppää nukke karkaa nukke \\
\hline pk IV 706 & $\begin{array}{l}\text { Kuusi 1983b, } \\
\text { 58; SKVR III } \\
\text { 1897-1904 }\end{array}$ & Narvusi & Kaipaala & Anni Porissa & [Peremies pere-isäntä] \\
\hline pk IV 706 & $\begin{array}{l}\text { Kuusi 1983b, } \\
\text { 58; SKVR III } \\
1905 ; 1069 \\
\end{array}$ & Narvusi & Kaipaala & Anni Porissa & Olin orja vellolleni \\
\hline $\mathrm{X}: 85$ & SKVR III 2423 & Narvusi & Ropsu & Elina 1. Jelena, $27 \mathrm{v}$. & Tulkat kokkii kiittämää \\
\hline X s. 21 & SKVR III 2424 & Narvusi & Ropsu & Elina 1. Jelena, $27 \mathrm{v}$. & Tässä on istunut kivellä \\
\hline X s.22-25 & SKVR III 2425 & Narvusi & Ropsu & Elina 1. Jelena, $27 \mathrm{v}$. & Rattahilla rapsutteli \\
\hline X s. 26-27 & SKVR III 2426 & Narvusi & Ropsu & Elina 1. Jelena, $27 \mathrm{v}$. & $\begin{array}{l}\text { Elä ite tyttäreni oi lo lii jne. ja } \\
\text { tyttäreni }\end{array}$ \\
\hline X s. 28 & SKVR III 2427 & Narvusi & Ropsu & Elina 1. Jelena, $27 \mathrm{v}$. & Oi miun ehtoisa emoni \\
\hline X s. 28 & ei SKVR III & Narvusi & Ropsu & Elina 1. Jelena, $27 \mathrm{v}$. & $\begin{array}{l}\text { En ole leski vanoi leski enko } \\
\text { leine ja varatoin vaimo }\end{array}$ \\
\hline $\mathrm{X}: 103$ & SKVR III 2440 & Narvusi & Ropsu & Elina 1. Jelena, $27 \mathrm{v}$. & Terve kuu terve päivä \\
\hline $\mathrm{X}: 104 \mathrm{a}$ & SKVR III 2441 & Narvusi & Ropsu & Elina 1. Jelena, $27 \mathrm{v}$. & Olkoot kiitetty Jumala \\
\hline $\mathrm{X}: 104 \mathrm{~b}$ & SKVR III 2442 & Narvusi & Ropsu & Elina 1. Jelena, $27 \mathrm{v}$. & Passipo minnolleni \\
\hline VI A II: $724 a$ & & Narvusi & Kaipaala & Nuoret tytöt & $\begin{array}{l}\text { Siniseilin vanoi seilaavana } \\
\text { jo-oo; oo-oi loi lee loi leetai } \\
\text { seilaavana jo-oo }\end{array}$ \\
\hline VIIa:491 & SKVR III 2304 & Soikkola & Oussimäki & Mapu & Oi vävy kuvattu kulta \\
\hline VIIa:494b & & Soikkola & Oussimäki & Mapu & Too tyttö on opissa ollut \\
\hline VII b s. 216 & & Soikkola & Oussimäki & Olena & Itse on ilkiän näkinä ja näkinä \\
\hline VII b s. 217 & & Soikkola & Oussimäki & Olena & [kehtolaulu, ei sanoja] \\
\hline VI a 826 & SKVR III 1927 & Soikkola & Venakontsa & $\begin{array}{l}\text { Paraske, } \\
\text { Annike(e)n tytär }\end{array}$ & Iilia pyhä isäntä \\
\hline VIIa:492 & SKVR III 2305 & Soikkola & Oussimäki & Teppanja & Lankoiset, lintuiset \\
\hline VIIa:494a & SKVR III 2307 & Soikkola & Oussimäki & Teppanja & Tulkaa kulloinit kujalle \\
\hline VIIa:496 & SKVR III 2310 & Soikkola & Oussimäki & Teppanja & Hyvää iltaha taloihe \\
\hline
\end{tabular}




\section{LAUNIS 1903 (SIBA)}

Kylien merkinnät perustuvat kenttäkäsikirjoitukseen (SibA Launis 1903), jota on paikoin täydennetty IRS:n paikoin epävarmoilta ja nopeasti tehdyiltä vaikuttavien merkintöjen sekä matkakertomuksen (KK Coll. 123.22. Launis 1903) perusteella. Yhdestäkään Launiksen ensimmäisen matkan laulajasta ei ole tiedossa nimeä, mutta paikoin käsikirjoituksesta käy ilmi kuoron tai jälestälaulajan osallistuminen. Launiksen Inkerin runosävelmiin lisäämiä kohtia ja kummallisten säkeiden todennäköisempiä muotoja on paikoin lisätty hakasulkeissa, muuten on noudatettu muistiinpanojen alkuperäismuotoa.

SibA = SibA Launis 1903 (kenttäkäsikirjoitus).

SKS = SKS KRA Launis 1903 (puhtaaksikirjoitus, johon Launis viittaa julkaisussaan (IRS).

\begin{tabular}{|c|c|c|c|c|c|c|}
\hline Sib A & SKS & IRS & PAIKKA & KYLÄ & K & AlKusÄE \\
\hline 1 & 263 & 222 & Narvusi & Vyötermaa & & Pääskylintu päivälintu, ee oi pääskylintu päivälintu \\
\hline 2 & 264 & 638 & Narvusi & Vyötermaa & & Osais osais miun emoni, osais omenan teh \\
\hline 3 & 265 & 628 & Narvusi & Vyötermaa & & Osais osais miun emoni \\
\hline 4 & 266 & 399 & Narvusi & Vyötermaa & & Ehittelin velloani, ehittelin kengittelin \\
\hline 5 & 267 & 700 & Narvusi & Vyötermaa & $\mathrm{K}$ & Kun elin ison kotona, ja ison kotona, ja ison kotona \\
\hline 6 & 268 & 509 & Narvusi & Vyötermaa & & $\begin{array}{l}\text { Oi tytöt sulat sisaret, sulat suliat omani [yl. sulitut } \\
\text { omenat], oi kaalina oi maalina }\end{array}$ \\
\hline 7 & 269 & 80 & Narvusi & Vyötermaa & & Mitä noisen laulamahan, joe oi laulamahan jo \\
\hline 9 & 271 & 237 & Narvusi & Vyötermaa & K & $\begin{array}{l}\text { Eivät kasva kaikki lapset, oi lole lole kaikki lapset, } \\
\text { kaiken [yl. kaik ei] kannetut ylene, oi lole lole ja } \\
\text { ylene }\end{array}$ \\
\hline 10 & 272 & 402 & Narvusi & Vyötermaa & & $\begin{array}{l}\text { Marjukkainen karjukkainen, marjukkain oli miun } \\
\text { emoni, karjukkain oli kantajani, laadoi laadoi } \\
\text { laadoi majoi }\end{array}$ \\
\hline 11 & 273 & 302 & Narvusi & Vyötermaa & & Vieras mamma viekas mamma, viekas mamma \\
\hline 12 & 274 & 145 & Narvusi & Kallivieri & & Mihin viivy[i]t velvyeni, kauvatsut hyvä kalani \\
\hline 14 & 275 & 260 & Narvusi & Kallivieri & & $\begin{array}{l}\text { Työ käsette laulamaan, laulamaan; tohtinenko } \\
\text { ruohtinenko, ruohtinenko }\end{array}$ \\
\hline 15 & 276 & 762 & Narvusi & Kallivieri & K & $\begin{array}{l}\text { Täss on tykky tyttäriä, täss on tykky tyttäriä, sarka } \\
\text { saaren neitosia }\end{array}$ \\
\hline 17 & 277 & 310 & Narvusi & Arsiansaari & & Avatkaa Viron veräjä, Viron vierahat tulloo \\
\hline $17 \mathrm{~b}$ & 278 & 423 & Narvusi & Arsiansaari & & Oikko poikko minuani, oi minua onnetonta \\
\hline 19 & 279 & 328 & Narvusi & Arsiansaari & & Marjukkain oli miun emoni miun emoni \\
\hline 20 & 280 & 719 & Narvusi & Arsiansaari & & Neito linnas lässii, Savon maalla sairastaa \\
\hline 21 & 282 & 784 & Narvusi & Arsiansaari & & Kylähäni linnahani, maan paras[ta] paikkahani \\
\hline 22 & 283 & 250 & Narvusi & Ropsu & & Täss on lusti nuoren noista, lusti luita liikutella \\
\hline 23 & 284 & 313 & Narvusi & Ropsu & & Mie kävin kyliä paljon, liiku[i]n paljon linnaloita \\
\hline 24 & 285 & 688 & Narvusi & Ropsu & & Älkää tehkö toinen tyttö, kuin tein minä poloin \\
\hline 25 & 286 & 479 & Narvusi & Ropsu & & $\begin{array}{l}\text { Tietäisin emon elämän [elävän], maamma maata } \\
\text { tallajais }\end{array}$ \\
\hline 26 & 287 & 74 & Narvusi & Ropsu & & Ee, isämies isyyen poika, päämies päätetty kypärä \\
\hline 27 & 288 & 125 & Narvusi & Ropsu & & Kylähäni linnahani, maan parasta paikkahani \\
\hline 29 & 290 & 239 & Narvusi & Ropsu & & Kylähäni linnahani, maan paras[ta] paikkahani \\
\hline $29 \mathrm{~b}$ & 291 & 641 & Narvusi & Ropsu & & Tietäisin emon elämän, maammani maata tallajais \\
\hline 30 & 292 & 275 & Narvusi & Ropsu & & Laskaa suojahan väkeni, uujumasta uppomasta \\
\hline $30 \mathrm{~b}$ & 293 & 236 & Narvusi & Ropsu & & La mie kysyn langot teiltä, luppaatteko meil tupaista \\
\hline 31 & 295 & 913 & Narvusi & Ropsu & & La istun ilokivellä, lasken laulukallahalla \\
\hline
\end{tabular}




\begin{tabular}{|c|c|c|c|c|c|c|}
\hline Siв A & SKS & IRS & PAIKKA & KYLÄ & K & AlKusäE \\
\hline 32 & 294 & 324 & Narvusi & Ropsu & & Kuin mie kasvelin kanainen, kanainen \\
\hline 33 & 296 & 221 & Narvusi & Ropsu & & Helise heliä metsä, helise heliä metsä \\
\hline 34 & 297 & 856 & Narvusi & Ropsu & K & $\begin{array}{l}\text { Mikä lienee ee minulle, ee minulle, Oi laad(/t)oi } \\
\text { laad(/t)oi ja minulle }\end{array}$ \\
\hline 35 & 298 & 832 & Narvusi & Ropsu & $\mathrm{K}$ & $\begin{array}{l}\text { Lauloi suuri lauloi pieni, oi lole l'ole lauloi pieni; } \\
\text { Lauloi kerran keskimmäinen, oi lole lole } \\
\text { keskimmäinen }\end{array}$ \\
\hline 36 & 299 & 849 & Narvusi & Ropsu & & Täss on ollut ennen kylä, ennen kylä eilen kylä \\
\hline 37 & 300 & 805 & Narvusi & Ropsu & & La mie katson liekkujani, kiusaelen kiekkujani \\
\hline 38 & 301 & 715 & Narvusi & Ropsu & & Olin pulmissa monissa ja monissa \\
\hline 39 & 302 & 240 & Narvusi & Ropsu & & $\begin{array}{l}\text { Myö määmme sinujn jätämme, tähän kylmähän } \\
\text { kylähän }\end{array}$ \\
\hline $40 \mathrm{~b}$ & 303 & 329 & Narvusi & Vipiä & & Hyvä kokki kaunis kokki, kaunis kokki \\
\hline 41 & 304 & 75 & Narvusi & Vipiä & & Lankoiseni lintuiseni, langot linnukkaisueni \\
\hline 42 & 305 & 788 & Narvusi & Vipiä & K & $\begin{array}{l}\text { Osais osais miun emoni, osais osais miun emoni, } \\
\text { osais osais miun emoni }\end{array}$ \\
\hline 43 & 306 & 311 & Narvusi & Vipiä & & Menin pilven piirtä myöten, taivasten rajoja myöten \\
\hline 44 & 307 & 910 & Narvusi & Vipiä & & $\begin{array}{l}\text { Oi älkää menkö piikuuvehen, ohvotalla orjuuehen; } \\
\text { oi kukka kaalina, oi kukka maalina }\end{array}$ \\
\hline 45 & 308 & 244 & Narvusi & Vipiä & & $\begin{array}{l}\text { Oi kuulkaa kuulkaa kuin mie laulan, pankaa pää- } \\
\text { hän kuin pajatan }\end{array}$ \\
\hline 46 & 309 & 934 & Narvusi & Vipiä & & Laulaisin hyväisen virren, sanoisin sanat paremmat \\
\hline 48 & 311 & 346 & Narvusi & Pärspää & & Meil on viinat viiellaiset viiellaiset \\
\hline 49 & 312 & 440 & Narvusi & Pärspää & K & $\begin{array}{l}\text { Emo neuvoi neitoja, opasti omenutta, oi kaalina } \\
\text { timoja, oi maalina timoja }\end{array}$ \\
\hline$\underline{50}$ & 313 & 789 & Narvusi & Pärspää & K & Lauloi suuri lauloi pieni, oi laadoi laadoi lauloi pieni \\
\hline$\underline{51}$ & 314 & 413 & Narvusi & Pärspää & & Syöttelin ison oroja, katsoin vellon kankaroja \\
\hline 52 & 315 & 872 & Narvusi & Pärspää & & $\begin{array}{l}\text { La laulan suruisen virren jo, surukkaisen suita } \\
\text { myöten jo }\end{array}$ \\
\hline 53 & 316 & 478 & Narvusi & Pärspää & K & $\begin{array}{l}\text { Emo synnytti minuista, mie vaan syäntä } \\
\text { synnyttelin, synnyttelin synnyttelin }\end{array}$ \\
\hline$\underline{54}$ & 317 & 242 & Narvusi & Pärspää & & Käki kukkui maa kumisi jo, lintu lauloi lehti liikkui jo \\
\hline 55 & 318 & 787 & Narvusi & Pärspää & & Kuuulin koissa kolkitttiin, veräjillä veistettiin \\
\hline $55 \mathrm{~b}$ & 319 & 710 & Narvusi & Pärspää & & Oi emo synnytti emo synnytti minuist \\
\hline 56 & 320 & 587 & Narvusi & Pärspää & & Meni marjahan emoni, karpalohon kantajani \\
\hline 58 & 322 & 318 & Narvusi & Pärspää & & Mitä otan virrekseni, kuta kukkuellakseni \\
\hline 59 & 323 & 823 & Narvusi & Pärspää & & Sanon siulle siulle tään kesoja tään kesoja \\
\hline 60 & 324 & 624 & Narvusi & Pärspää & & $\begin{array}{l}\text { Oli tässä ennen kylä; ennen kylä, ennen kylä; nyt } \\
\text { on noussut, noussut, nyt on noussut nuori metsä }\end{array}$ \\
\hline 61 & 326 & 881 & Narvusi & Pärspää & & $\begin{array}{l}\text { Pääskylintu päivälintu ee, oi pääskylintu se ihana } \\
\text { ilman lintu }\end{array}$ \\
\hline 62 & 325 & 736 & Narvusi & Pärspää & & Pääskylintu päivälintu, se ihana ilman lintu \\
\hline 63 & 327 & 340 & Narvusi & Pärspää & & $\begin{array}{l}\text { Oo, miun vello venoisen seppo venoisen seppo, } \\
\text { laivoi seppä laglueni laglueni }\end{array}$ \\
\hline 64 & 328 & 785 & Narvusi & Pärspää & & $\begin{array}{l}\text { Oo emo synnytti minuista, mie vaan syäntä } \\
\text { synnyttelin }\end{array}$ \\
\hline 65 & 329 & 899 & Narvusi & Pärspää & & Oli miulla aino vello, aino vello pikkarain \\
\hline 66 & 330 & 757 & Narvusi & Pärspää & & Miks on meitä näin vähäisen, kanaisia näin kasin \\
\hline 67 & 331 & 613 & Narvusi & Pärspää & & Miks on meitä näin vähäisen, kanaisia näin kasin \\
\hline 68 & 332 & 693 & Narvusi & Pärspää & K & $\begin{array}{l}\text { Oo käki kukkui, oo käki kukkui, käki kukkui maa } \\
\text { kumisi maa kumisi, käki kukkui maa kumisi maa } \\
\text { kumisi }\end{array}$ \\
\hline 69 & 333 & 825 & Narvusi & Pärspää & K & $\begin{array}{l}\text { Tässä tanssivat tasaiset; tanssivat tasaiset tanssivat } \\
\text { tasaiset }\end{array}$ \\
\hline 70 & 334 & 403 & Narvusi & Pärspää & & Täss on lusti nuorelle noista, lusti luita liikutella \\
\hline
\end{tabular}




\begin{tabular}{|c|c|c|c|c|c|c|}
\hline Siв A & SKS & IRS & PAIKKA & KYLÄ & K & AlKusÄE \\
\hline 71 & 335 & 626 & Narvusi & Pärspää & & Mie synnyin ilokylässä, kasvoin laulukallahalla \\
\hline 72 & 336 & 629 & Narvusi & Pärspää & & Emo synnytti minuista, mie vaan syäntä synnyttelin \\
\hline 73 & 337 & 285 & Narvusi & Pärspää & & Oo, en mie rahatta laula, suut en kullatta kuluta \\
\hline 74 & 338 & 306 & Narvusi & Pärspää & & $\begin{array}{l}\text { Aa, mitä on pääsky pääsi maassa, sirkku on silmäsi } \\
\text { vesiset }\end{array}$ \\
\hline 75 & 339 & 690 & Narvusi & Pärspää & & Emo neuvoi neiolleen, opetti omenalleen \\
\hline 76 & 340 & 296 & Narvusi & Kurkola & $\mathrm{K}$ & Miks on meitä näin vähäisen, kanaisia kassapäitä \\
\hline 77 & 341 & 701 & Narvusi & Kurkola & K & $\begin{array}{l}\text { Ei miun laulaman pitäisi, laulaman pitäisi, laula- } \\
\text { man pitäisi }\end{array}$ \\
\hline 79 & 343 & 133 & Narvusi & Kurkola & & [oi] Terve kuu terve päivä, terve vastainen vävyni \\
\hline $82 b$ & 345 & 930 & Narvusi & Kurkola & & $\begin{array}{l}\text { Kasvatti minun emoni, kasvatti kanoja paljon, } \\
\text { suuren joukon joutsenia, suuren joukon joutsenia }\end{array}$ \\
\hline 83 & 346 & 907 & Narvusi & Kurkola & & $\begin{array}{l}\text { Ei miun laulaman pitäisi, ei iloita ensinkään, hei } \\
\text { juu jupatali juu, ei iloita ensinkään }\end{array}$ \\
\hline 84 & 347 & 901 & Narvusi & Kurkola & & $\begin{array}{l}\text { Nouskaa ylös nukkuneet, jopa on käet kukkuneet, } \\
\text { kana sanoo kakakaa, älkää enää makakaa }\end{array}$ \\
\hline $84 \mathrm{~b}$ & 348 & 36 & Narvusi & Kurkola & & Terve kuu terve päivä, terve vastuinen vävyni \\
\hline 85 & & & Narvusi & Kurkola & & Menin metsähän kesolla, kantajalle karpaloon \\
\hline 86 & 350 & 258 & Narvusi & Kurkola & & Löin minä jalkani kivehen, varpahani vaaherpuuhun \\
\hline 87 & & & Narvusi & Kurkola & & Oo terve kuu terve päivä, [terve] vastuinen vävyni \\
\hline 88 & 351 & 269 & Narvusi & Kurkola & & Oo, ei miun laulaman pitäisi, eik iloita ensinkään \\
\hline 89 & 352 & 32 & Narvusi & Kurkola & & Osaisi minun emoni, osasi omanan tehdä \\
\hline 90 & 353 & 315 & Narvusi & Kurkola & & Käki kukku maa kumisi kumisi \\
\hline 91 & 354 & 330 & Narvusi & Kurkola & & $\begin{array}{l}\text { Kolt oli veljestä kovoa kovoa, kaks oli aivan ahke- } \\
\text { raa ahkeraa }\end{array}$ \\
\hline 92 & 355 & 555 & Narvusi & Kurkola & & Oo läksi koista kulkemahan, veräjiltä vieremähän \\
\hline 93 & 356 & 252 & Narvusi & Kurkola & & (oo) läksin koulusta kotia, oppihi omilta mailta \\
\hline 94 & 357 & 230 & Narvusi & Kurkola & & $\begin{array}{l}\text { Käki kukku vaan kuusikossa jo, mie vaan } \\
\text { kuuntelin kujalla jo }\end{array}$ \\
\hline 95 & 358 & 443 & Narvusi & Kurkola & & $\begin{array}{l}\text { Täss on lusti nuoren noista, kaunis kassapään } \\
\text { karat(a) ee oi ja karata kaunis kassapään karata }\end{array}$ \\
\hline 96 & 359 & 807 & Narvusi & Kurkola & & Älköön tehkö toinen tyttö, kuin tein mie poloinen \\
\hline 97 & 360 & 900 & Narvusi & Kurkola & & Minnen otan virrekseni, kunnen laain laulukseni \\
\hline 98 & 361 & 687 & Narvusi & Kurkola & & Marjukkain oli miun emoni miun emoni \\
\hline 99 & 362 & 89 & Narvusi & Kurkola & & Nuorikko mäellä itki, heläytti heinämaalla \\
\hline 100 & 363 & 848 & Narvusi & Kurkola & & Läksin koista kulkemahan, veräjiltä vieremähän \\
\hline 101 & 364 & 654 & Narvusi & $\begin{array}{l}\text { Kurkola (IRS: } \\
\text { Vyötermaa) }\end{array}$ & & $\begin{array}{l}\text { En ilkii kujalle mennä, potriloista poikiloista, } \\
\text { potriloista poikiloista, uhkeoista tyttölöistä }\end{array}$ \\
\hline 102 & 365 & 908 & Narvusi & Kurkola & & Kuin mie kasvelin kanainen, noisin neito nuorekkain \\
\hline 103 & 366 & 295 & Narvusi & Kurkola & & $\begin{array}{l}\text { Miks on tyynit nurmen nurkat, nurmen nurkat } \\
\text { korven kolkat }\end{array}$ \\
\hline 104 & 367 & 70 & $\begin{array}{l}\text { Narvusi } \\
\text { (Lavansaari }\end{array}$ & & & La mie koitan liekkuani, kiusaelen kiekkuani \\
\hline $105 \mathrm{~b}$ & & & Narvusi & Kaipaala & & Läksin koista kulkemaan \\
\hline 106 & 369 & 694 & Narvusi & $\begin{array}{l}\text { Kaipaala (IRS: } \\
\text { Kirjamo) }\end{array}$ & & $\begin{array}{l}\text { Kuuleppas sinä - - - Kuuleppas sinä kullan nuppu } \\
\text { - - - - [IRS: Taikina Matti Taikina Matti, Taikina } \\
\text { Matti tahtois naista, Taikina Matti tahtois naista] }\end{array}$ \\
\hline 107 & 370 & 304 & Narvusi & Kaipaala & & Täss on lusti nuoren noista, kaunis kassapään karata \\
\hline $107 \mathrm{~b}$ & 375 & 305 & Narvusi & Kaipaala & & Aja aina velvyeni, tietä myöten tetryeni \\
\hline 109 & 371 & 676 & Narvusi & Kaipaala & & Älkää antaka suuri luoja luoja, sitä lasta syntymähän \\
\hline 110 & 372 & 276 & Narvusi & Kaipaala & & $\begin{array}{l}\text { Täss on lusti nuoren noista jo, kaunis kassapään } \\
\text { karata jo }\end{array}$ \\
\hline 112 & 374 & 441 & Narvusi & Kaipaala & & $\begin{array}{l}\text { Täss on lusti nuoren noista, nuoren nuoren noista, } \\
\text { nuoren noista joonaa }\end{array}$ \\
\hline
\end{tabular}




\begin{tabular}{|c|c|c|c|c|c|}
\hline SibA & SKS & IRS & PAIKKA & KYLÄ & AlKusäE \\
\hline 113 & 377 & 696 & Narvusi & Kaipaala & $\begin{array}{l}\text { Miks on meillä maat matalat; miks on meillä maat } \\
\text { matalat, miks on meillä maat matalat }\end{array}$ \\
\hline 115 & 379 & 931 & Narvusi & Kaipaala & Kotihinsa muut menevät, majoihinsa matko(a)vat \\
\hline 116 & 380 & 691 & Narvusi & Kaipaala & Ehittelin ehittelin vellojani \\
\hline 117 & 381 & 449 & Narvusi & Kaipaala & Mitä työ tytöt suretta, kanat kainostaletta \\
\hline 118 & 382 & 134 & Narvusi & Kaipaala & Juko hellä velvyeni, Jukoni emäni lapsi \\
\hline 119 & 383 & 836 & Narvusi & Kaipaala & Käki kukku maa kumisi, mie vaa kuuntelin kujalla \\
\hline 123 & 387 & 826 & Narvusi & Kaipaala & Marjukkain oli miun emoni, karjukkain oli kantajani \\
\hline 124 & 388 & 18 & Narvusi & Kaipaala & Lammas lakkahan muninut, kana poiki karsinahan \\
\hline 125 & 389 & 293 & Narvusi & Kontu & Läksin koista kulkemahan veräjiltä vieremähän \\
\hline 126 & 391 & 95 & Narvusi & Kontu & Liekkuani kiekkuani, liekku miulle lehmän maksaa \\
\hline 127 & 392 & 25 & Narvusi & Kontu & $\begin{array}{l}\text { Tali lii tali lii, Liisan liivit Hannan hameet, Esko- } \\
\text { kaiman kaulavaatteet, tali lii tali lii }\end{array}$ \\
\hline 129 & 394 & 66 & Narvusi & Kirjamo & Olin orja vellolleni, isälle ikuinen piika \\
\hline 130 & 395 & 608 & Narvusi & Kirjamo & Jos mun tuttuni tulisi, armahani astelis \\
\hline 131 & 396 & 756 & Narvusi & Kirjamo & Peremies pereen isäntä, perenainen naisukkainen \\
\hline 133 & 398 & 920 & Narvusi & Kirjamo & Menin pilven piirtä myöten, taivasten rajoja myöten \\
\hline 134 & 399 & 914 & Narvusi & Kirjamo & Laai linttisi lipulle, kääri kyynelees kerälle \\
\hline 136 & 401 & 410 & & & Tunnen vävyn tulevan, arvaan vävyn ajava \\
\hline 137 & 402 & 755 & Narvusi & Kirjamo & $\begin{array}{l}\text { Osais osais miun emoni; osais osais miun emoni, } \\
\text { osais osais miun emoni }\end{array}$ \\
\hline 138 & 403 & 142 & Narvusi & Kirjamo & Kävin maita polttamassa, ilmoja kyettämässä \\
\hline 139 & 404 & 129 & Narvusi & Kirjamo & Pääskylintu päivälintu, se ihana ilmalintu \\
\hline 140 & 405 & 673 & & & Menin suurelle va mäelle jo, korkealle va kallahalle jo \\
\hline 142 & 407 & 439 & Narvusi & Kirjamo & $\begin{array}{l}\text { Oi niitä omia maita, omia maita mairehia, laadoi } \\
\text { laadoi, laadoi majoi }\end{array}$ \\
\hline 143 & 408 & 822 & Narvusi & Struuppaa & La kun katson liekkuani, kiusaelen kiekkuani \\
\hline 144 & 409 & 471 & Narvusi & Struuppaa & $\begin{array}{l}\text { Mitä noisen laulamaa, kuta noisen kukkumaan, } \\
\text { hee kukkumaan hoilee }\end{array}$ \\
\hline 145 & & & Narvusi & Struuppaa & Peremies pereen isäntä, perenainen naisukkainen \\
\hline 146 & 410 & 758 & Narvusi & Struuppaa & Kylähäni linnahani, maan parasta paikkahani \\
\hline $146 b$ & 411 & & Narvusi & Struuppaa & $\begin{array}{l}\text { Kun mie synnyin synnyinmaalla, ainoi maalla } \\
\text { annettii, rantsi rantsi pervoi rantsi, rattattuski } \\
\text { rattattaa }\end{array}$ \\
\hline 147 & 412 & 508 & Narvusi & Struuppaa & Tule uni ulkomailta, käy lapsen kätkyehen \\
\hline 148 & 413 & 759 & Narvusi & Struuppaa & La kun vieretän vilulla \\
\hline 149 & 414 & 751 & Narvusi & & Emo kasvatti minuista, mie vaa kassaa kasvattelin \\
\hline 150 & 415 & 405 & Narvusi & Struuppaa & Ee, käki kukkui kuusikoss, sisova pani pajus \\
\hline 151 & 416 & 621 & Soikkola & $\begin{array}{l}\text { (Säätinän } \\
\text { praasnikoilla) }\end{array}$ & Sisovan sanat parempi, käen kieli kerkeämpi \\
\hline 152 & 417 & 321 & Soikkola & Säätinä (IRS) & $\begin{array}{l}\text { Pyhä Iilia isäntä ja isäntä, pyhä Petro armollinen } \\
\text { ja armollinen }\end{array}$ \\
\hline 153 & 418 & 556 & Soikkola & (Säätinän praas.) & Mitä otan virrekseni, kuta kukkuellakseni \\
\hline $153 \mathrm{~b}$ & 419 & 791 & Soikkola & (Säätinän praas.) & En mie laulaa luvannut, en iloita ensinkänä \\
\hline 154 & 420 & 229 & Soikkola & (Säätinän praas.) & Mitä otan virrekseni, kuta kukkuellakseni \\
\hline 155 & 421 & 47 & Soikkola & (Säätinän praas.) & Ai sie seppä rautanokka, tao miulle rautakeppi \\
\hline 156 & 422 & 404 & Soikkola & (Säätinän praas.) & Teimme illalla iloa, päivän männölle mänöä \\
\hline 157 & 423 & 707 & Soikkola & (Säätinän praas.) & Käki kukku maa kumisi, mie vaa kuuntelin kujalla \\
\hline 158 & 424 & 735 & Soikkola & (Säätinän praas.) & Issuit kannes ihala, kannessa isoittomassa \\
\hline 159 & 425 & 904 & Soikkola & (Säätinän praas.) & En mie laululle luvannut, iloita sinä ikänä \\
\hline 160 & 426 & 692 & Soikkola & (Säätinän praas.)K & $\begin{array}{l}\text { Oi miks on nytten [oi] miks on nytten, nyt on } \\
\text { aikuin maalla marras maalla marras }\end{array}$ \\
\hline 161 & 427 & 607 & Soikkola & (Säätinän praas.) & Vet en laula laulujani, en ilo iloisiani \\
\hline
\end{tabular}




\begin{tabular}{|c|c|c|c|c|c|}
\hline Sib A & SKS & IRS & PAIKKA & KYL ̈̈ & ALKusÄE \\
\hline 162 & 428 & 808 & Soikkola & (Säätinän praas.) & $\begin{array}{l}\text { [Ee] käki kukku maa kumisi, mie vaan kuuntelin } \\
\text { kujalla }\end{array}$ \\
\hline 163 & 429 & 803 & Soikkola & (Säätinän praas.) & $\begin{array}{l}\text { Oo, mihin jouvuin kuhun jouvuin, jouvuin joutava } \\
\text { jummala [yl. jouvuin juottohon jumalan] }\end{array}$ \\
\hline 64 & 430 & 720 & Soikkola & (Säätinän praas.) & $\begin{array}{l}\text { Oo, mitä noisen laulamahan, mitä kurja kukku- } \\
\text { mahan }\end{array}$ \\
\hline 65 & 431 & 480 & Soikkola & Säätinän praas.) & Mitä otan virrekseni, kuta kukkuellakseni \\
\hline 66 & 432 & 282 & Soikkola & Säätinän praas.) & Turoi tuima mies kavala, turoi linasta tuloa \\
\hline 167 & 433 & 815 & Soikkola & (Säätinän praas.) & Mikä meijän va ikkunalla, meroi meijän va ikkunalla \\
\hline 168 & 434 & 292 & Soikkola & Säätinän praas.) & Oi, mitä noisen laulamahan, oi mitä kurja kukkumahan \\
\hline 169 & 435 & 81 & Soikkola & (Säätinän praas.) & $\begin{array}{l}\text { Oo, kuhun viivyt velvyeni, kauvatsut hyvä kanani } \\
\text { [kalani] }\end{array}$ \\
\hline 170 & 436 & 739 & Soikkola & (Säätinän praas.) & \\
\hline 71 & 437 & 729 & Soikkola & Säätinän praas.) & n laulamahan, kuta noisen kukkumahan \\
\hline 172 & 438 & 299 & Soikkola & Säätinän praas.) & Oi, mitä otan virrekseni, kuta otan kukkuellakseni \\
\hline 73 & 439 & 926 & Soikkola & Säätinän praas.) & Tilu ranta traluilu trai rallalei ja nousen laulamahan \\
\hline & 442 & 264 & & & \\
\hline & 443 & 273 & & & \\
\hline 178 & 444 & 653 & Soikkola & (Säätinän praas.) & $\begin{array}{l}\text { La pu } \\
\text { valke: }\end{array}$ \\
\hline 79 & 445 & 639 & Soikkola & & in mill ajoill, kuta kulloin ku(u)llekin \\
\hline $79 \mathrm{~b}$ & 446 & 193 & & & \\
\hline & 447 & 241 & & & \\
\hline & 448 & 152 & & & \\
\hline 181 & 449 & 37 & Soikkola & raas.) & Pääskylin \\
\hline 182 & 450 & 519 & Soikkola & (Säätinän praas.) & $\begin{array}{l}\text { Tiraruu tararuu, meiä } \\
\text { kukko tapettii, kanan }\end{array}$ \\
\hline & 451 & 124 & & & \\
\hline 184 & 452 & 602 & Soikkola & (Säätinän praas.)K & $\begin{array}{l}\text { La mie la } \\
\text { liiaa laula }\end{array}$ \\
\hline 85 & 453 & 287 & Soikkola & Säätinän praas.) K & oi selednoi saadu \\
\hline 86 & 454 & 903 & Soikkola & Säätinän praas.) & Oo, mitä n \\
\hline 187 & 455 & 559 & Soikkola & (Säätinän praas.)K & \\
\hline 188 & 456 & 558 & Soikkola & (Säätinän praas.)K & $\begin{array}{l}\text { Emo synnytti minuista, mie vaan syytä syn } \\
\text { kaalina maalina }\end{array}$ \\
\hline & 457 & & & & \\
\hline 190 & 458 & 339 & Soikkola & (Säätinän praas.) & $\begin{array}{l}\text { ni, virrekseni; kuta kukkuel- } \\
\text { i }\end{array}$ \\
\hline 191 & 459 & 864 & & & Oi, mitä noisen vaan laulamahan, laulamahan \\
\hline 192 & 460 & 448 & Soikkola & (Säätinän praas.) & Noisin suurelle mäelle, korkialle kukkulalle \\
\hline 193 & 461 & 158 & Soikkola & (Säätinän praas.)K & Oo, mitä i \\
\hline 194 & 462 & 883 & Soikkola & (Säätinän praas.) & $\begin{array}{l}\text { Nyt on aikuin aikuin maalla marras, ilmoilla } \\
\text { idukas aiga }\end{array}$ \\
\hline 195 & 463 & 650 & Soikkola & (Säätinän praas.)K & $\begin{array}{l}\text { En mie laulella luvannut, en iloita ensinkänä; usti } \\
\text { vernai ti vernai milai moi }\end{array}$ \\
\hline 196 & 464 & 436 & Soikkola & (Säätinän praas.)K & $\begin{array}{l}\text { Elettiin ennen meillä, oltiin ojan takana; oi svjetii } \\
\text { Kaalina drugoi galobnika }\end{array}$ \\
\hline 197 & 465 & 335 & Soikkola & (Säätinän praas.) & $\begin{array}{l}\text { Emo synnytti minuista minuista, mie vaan syytä } \\
\text { synnyttelin, synnyttelin }\end{array}$ \\
\hline 200 & 468 & 146 & Soikkola & & Meren rannoille kesoilla, kesk'kesoilla hein'ajoilla \\
\hline 201 & 469 & 793 & Soikkola & (Säätinän praas.) & $\begin{array}{l}\text { Olin ennen vaan vellolleni, olin ennen vaan vellol- } \\
\text { leni, eitsenikka vaan äitilleni }\end{array}$ \\
\hline
\end{tabular}




\begin{tabular}{|c|c|c|c|c|c|}
\hline SibA & SKS & IRS & PAIKKA & KYLÄ & AlKusäE \\
\hline $201 \mathrm{~b}$ & 470 & 155 & Soikkola & (Säätinän praas.) & Oi, hyvä tyttöin elää, kaunis olla kassapäänä \\
\hline 202 & 471 & 874 & Soikkola & (Säätinän praas.) & Tule tyttö lepikkoon, mitä sinne lepikkoon \\
\hline 203 & 472 & 636 & Soikkola & (Säätinän praas.) & $\begin{array}{l}\text { Läksin koista kulkemahan, veräjiltä vieremään; } \\
\text { läksin koista kulkemaan, veräjiltä vieremään }\end{array}$ \\
\hline 204 & 473 & 268 & Soikkola & (Säätinän praas.) & $\begin{array}{l}\text { Teki tuu, teki turhin miun emoni, teki tuu, teki } \\
\text { turhin tuutijan }\end{array}$ \\
\hline 205 & 474 & 813 & Soikkola & (Säätinän praas.) & Noisin suurelle mäelle, korkialle kukkulalle \\
\hline 206 & 475 & 780 & Soikkola & (Säätinän praas.) & La ku(n) katson liekkuani, kiusaelen kiekkuani \\
\hline 209 & 781 & 632 & Soikkola & (Säätinän praas.) & Vet ei vanhoista iloa, iloa elänehistä \\
\hline 210 & 478 & 725 & Soikkola & (Säätinän praas.) & Enempä miun vaa miun emoini, sen ennen \\
\hline 211 & 479 & 828 & Soikkola & (Säätinän praas.) & Ennempä miun emoinee ja sen ennen ehottajan \\
\hline 212 & 480 & 935 & Soikkola & (Säätinän praas.) & Ennempä miun emoini, sen ennen ehoittajan \\
\hline 213 & 481 & 643 & Soikkola & (Säätinän praas.) & Läksin koista kulkemahan, veräjiltä vieremään \\
\hline 214 & 482 & 834 & Soikkola & $\begin{array}{l}\text { Oussimäki } \\
\text { (IRS) (Sääti- } \\
\text { nän praas.) }\end{array}$ & $\begin{array}{l}\text { Ettehän vilulla kuule, kauvan kuului kastehella } \\
\text { [Etähäl vilulla kuulun, kauvas kuulun kastehella] }\end{array}$ \\
\hline 215 & 782 & 936 & Soikkola & (Säätinän praas.) & Läksin koista kulkemahan, veräjiltä vieremähän \\
\hline 217 & 484 & 470 & Soikkola & (Säätinän praas.) & Ossin mettä join olutta, rummensi nukuttamaan \\
\hline 218 & 485 & 860 & Soikkola & (Säätinän praas.) & $\begin{array}{l}\text { Mitä lauloi mill ajoilla mila ajoill, kuta kulloin } \\
\text { huummuksella huummuksella }\end{array}$ \\
\hline 220 & 487 & 143 & Soikkola & (Säätinän praas.) & Vaka vanha väinämöinen, kauvan soitti kanteleella \\
\hline 221 & 488 & 277 & Soikkola & (Säätinän praas.) & Saaroin maat saroin jaettu, pellot piussoin mittaeltu \\
\hline 222 & 489 & 814 & Soikkola & Tarinainen & Sanokaatte sanat tytöistä, kaksi kaikista arttelista \\
\hline $222 b$ & 490 & 320 & Soikkola & $\begin{array}{l}\text { Tarinainen } \\
\text { (IRS: Soikkola) }\end{array}$ & Jo toi illakko tulloo, hämärikkö veettelöö \\
\hline 223 & 491 & 44 & Soikkola & $\begin{array}{l}\text { Tarinainen } \\
\text { (IRS: Soikkola) }\end{array}$ & Läksin koista kulkomahan, veräjiltä vieremähän \\
\hline 224 & 492 & 795 & Soikkola & Tarinainen & Kysyin maata velloltan, anoin ainavoiseltan \\
\hline 225 & 493 & 862 & Soikkola & Tarinainen & $\begin{array}{l}\text { En voint katsoa katala ja katala, noavutella neitoi } \\
\text { nuori neitoi nuori }\end{array}$ \\
\hline 226 & 494 & 286 & Soikkola & Tarinainen & $\begin{array}{l}\text { Lootika (se vaan) pohulle polvin, maahan Maarian } \\
\text { etehen }\end{array}$ \\
\hline 227 & 495 & 810 & Soikkola & $\begin{array}{l}\text { Tarinainen } \\
\text { (IRS: Soikkola) }\end{array}$ & $\begin{array}{l}\text { Ei tekstiä, IRS otettu seuraavan tekstistä } \\
\text { ensimmäinen säe (Pääskylintu päivälintu) }\end{array}$ \\
\hline $227 \mathrm{~b}$ & 496 & 301 & Soikkola & Tarinainen & Pääskylintu päivälintu, se ihala ilmalintu \\
\hline 228 & 497 & 322 & Soikkola & Tarinainen & $\begin{array}{l}\text { Oi pitkä keeloi keeloi pettelikko, peteli miun miun } \\
\text { sisoini }\end{array}$ \\
\hline 229 & 498 & 760 & Soikkola & Tarinainen & $\begin{array}{l}\text { Oi, emoin, emoin neivoi neitoja, oi opasti opasti } \\
\text { omenutta }\end{array}$ \\
\hline 230 & 499 & 288 & Soikkola & Tarinainen & $\begin{array}{l}\text { Näin mie laivoin lainehtivan, näin mie vieruvan } \\
\text { venoisen }\end{array}$ \\
\hline $230 \mathrm{~b}$ & 500 & 818 & Soikkola & Tarinainen & Luoja ratsailla ajaa(haa), hepoisella hiirakalla \\
\hline 231 & 501 & 773 & Soikkola & Tarinainen & Luulin tuulosen tuloovan, ahavaisen ajavaisen \\
\hline 232 & 502 & 522 & Soikkola & Tarinainen & Menin pilven piirtä myöten, taivasten rajoja myöten \\
\hline 233 & 503 & 122 & Soikkola & $\begin{array}{l}\text { Tarinainen } \\
\text { (IRS: Soikkola) }\end{array}$ & Livukka rekoi lippiä, lipiäistä tietä myöten \\
\hline 234 & 504 & 771 & Soikkola & $\begin{array}{l}\text { Tarinainen } \\
\text { (IRS: Viistinä) }\end{array}$ & $\begin{array}{l}\text { Saottiin Saaren maat paloivat, koiviston kylät } \\
\text { kytöivät }\end{array}$ \\
\hline 236 & 506 & 458 & Soikkola & $\begin{array}{l}\text { Tarinainen } \\
\text { (IRS: Soikkola) }\end{array}$ & Jouvuin hulluille uroille, hupeloille hoitajille \\
\hline 237 & 507 & 680 & Soikkola & Tarinainen & $\begin{array}{l}\text { Kaks oli kallioll jänöä ja jänöä, kolt oli korven } \\
\text { kirjavaista kirjavaista }\end{array}$ \\
\hline 238 & 508 & 500 & Soikkola & Tarinainen & Menin metsään yöjalalle, tuli likka vastahani \\
\hline 239 & 509 & 684 & Soikkola & $\begin{array}{l}\text { Tarinainen } \\
\text { (IRS: Soikkola) }\end{array}$ & $\begin{array}{l}\text { Älä hirvi (vaa) hirvi hirvittele, metsän korpi (vaa) } \\
\text { korpi kuohuttele }\end{array}$ \\
\hline
\end{tabular}




\begin{tabular}{|c|c|c|c|c|c|}
\hline Sib A & SKS & IRS & PAIKKA & KYLÄ & AlKusÄE \\
\hline 240 & 510 & 745 & Soikkola & Tarinainen & Andreas Kojoisen poika, käpykenkä nahkapagla \\
\hline 241 & 511 & 111 & Soikkola & Tarinainen & $\begin{array}{l}\text { Lauri poika lappalainen, möi hän maansa ja } \\
\text { elonsa, itse rengiksi rupeisi }\end{array}$ \\
\hline 243 & 513 & 593 & Soikkola & Tarinainen & Pienen petteli emoi, valehteli vanhempain \\
\hline 244 & 514 & 839 & Soikkola & $\begin{array}{l}\text { Tarinainen } \\
\text { (IRS: Soikkola) }\end{array}$ & Tuli varas varvikosta, nousi vihainen vitsikosta \\
\hline 245 & 515 & 830 & Soikkola & Tarinainen & Ai miun ehtoisa emoini, ai miun maamma marjaiseni \\
\hline 246 & 516 & 256 & Soikkola & (ilm. Voloitsa) & Kylän pyysi pyssyn seppoi, tahtoi takojan seppoi [?] \\
\hline 247 & 517 & 661 & Soikkola & (ilm. Voloitsa) & Niin mie vierin velloistani, sirkkusin siaristan \\
\hline 248 & 518 & 670 & Soikkola & (ilm. Voloitsa) & $\begin{array}{l}\text { Menin metsähän kesolla, keskkesolla, keskkesoilla } \\
\text { heinajoill }\end{array}$ \\
\hline 249 & 519 & 46 & Soikkola & (ilm. Voloitsa) & $\begin{array}{l}\text { Kuulin kukkuvan käen, linnun laihan laulavan, } \\
\text { käki kukku maa kumisi }\end{array}$ \\
\hline 250 & 520 & 741 & Soikkola & (ilm. Voloitsa) & $\begin{array}{l}\text { Oi vävyin se vaa (va) sison suloinen, oi vävyi se vaa } \\
\text { (va) kuvattu kultoi }\end{array}$ \\
\hline 252 & 522 & 595 & Soikkola & (ilm. Voloitsa) & $\begin{array}{l}\text { Mitä noisen laulamaa, kuta noisen kukkumaan, } \\
\text { kukku kukku kukkumaan, kukkumahan jonoo }\end{array}$ \\
\hline 53 & 523 & 622 & Soikkola & (ilm. Voloitsa) & Näin mie neito ennen lauloin, sinisilmä sirkuttelin \\
\hline 254 & 524 & 197 & Soikkola & (ilm. Voloitsa) & Mikä täällä pellon päällä, velloi tälllä pellon päällä \\
\hline 255 & 525 & 877 & Soikkola & (ilm. Voloitsa) & Noisin laivoi mastin päälle, laivoi kepjuille keijahin \\
\hline 256 & 526 & 615 & Soikkola & (ilm. Voloitsa) K & $\begin{array}{l}\text { Rikas viepi liputtaa, rahallinen raisuttaa; pantiin } \\
\text { rikkahan rekeen, rahallisen rattahill }\end{array}$ \\
\hline 57 & 527 & 713 & Soikkola & (ilm. Voloitsa) & Läksin koista kulkemaan, veräjiltä vieremään \\
\hline 58 & 528 & 73 & Soikkola & & $\mathrm{n}$ tulloovan, ahavaisen ajavan \\
\hline 259 & 529 & 113 & Soikkola & (ilm. Voloitsa) & Lauri poika lappalainen, myi maansa ja elonsa \\
\hline 260 & 530 & 779 & Soikkola & (ilm. Voloitsa) & Lootika pohulle polvin, oi dai lootika se vaa \\
\hline 261 & 533 & 336 & Soikkola & (ilm. Voloitsa) & $\begin{array}{l}\text { jahan mäelle ja mäelle, karpalohon } \\
\text { kantajalle }\end{array}$ \\
\hline $263 \mathrm{a}$ & 531 & 144 & Soikkola & (ilm. Voloitsa) & Leinää leinää hyvä prouva, lase itseäs alemma \\
\hline $263 \mathrm{~b}$ & 535 & 34 & Soikkola & (ilm. Voloitsa) & La kun katson liekkujani, kiusaelen \\
\hline 264 & 536 & 267 & Soikkola & (ilm. Voloitsa) & $\begin{array}{l}\text { Velloini velloini venoisen seppoi, laivoin sep lai- } \\
\text { voin seppoi lagluen }\end{array}$ \\
\hline 265 & 537 & 30 & Soikkola & (ilm. Voloitsa) & Neito linnassa lässii, savon maalla sairastaa \\
\hline 266 & 538 & 551 & Soikkola & (ilm. Voloitsa) K & $\begin{array}{l}\text { ä, olttiigi ojan takana; ai l'uli } \\
\text { akana }\end{array}$ \\
\hline 267 & 539 & 683 & Soikkola & (ilm. Voloitsa) & Älä hirvoi vaan hirvoi hervittele oi älä sinä hirvoi \\
\hline 268 & 540 & 523 & Soikkola & (ilm. Voloitsa) & Maaria pyhäinen vaimo, itse maaria vähän \\
\hline 269 & 541 & 573 & Soikkola & (ilm. Voloitsa) & Kysyin maata velloltani, ainoin ainoaiseltani \\
\hline 270 & 542 & 733 & Soikkola & (ilm. Voloitsa) & $\begin{array}{l}\text { Souva vaan laivoi jouva vaan laivoi, souva vaan } \\
\text { tuolle saaruelle }\end{array}$ \\
\hline 271 & 543 & 831 & Soikkola & (ilm. Voloitsa) & Oi vet en voi se vaan vaan ilota olla \\
\hline 272 & 544 & 865 & Soikkola & (ilm. Voloitsa) & Emo synnytti vaa minuista ja minuist \\
\hline 273 & 545 & 644 & Soikkola & (ilm. Voloitsa) & $\begin{array}{l}\text { Miks on miulta äänöi vaan pieni, marjoilla vaan } \\
\text { syän matala }\end{array}$ \\
\hline 274 & 546 & 642 & Soikkola & (ilm. Voloitsa) & Jo on noisseet nuoret metsät, kasvaneet komiat metsät \\
\hline 275 & 547 & 921 & Soikkola & (ilm. Voloitsa) & Emo neuvoi neitojaga, opasti omenutta \\
\hline $276 \mathrm{a}$ & 548 & 55 & Soikkola & (ilm. Voloitsa) & Läksin koista kulkemahan, veräjiltä vieremähän \\
\hline $276 \mathrm{~b}$ & 549 & 750 & Soikkola & (ilm. Voloitsa) & Noisin suurelle suurelle mäelle \\
\hline 277 & 550 & 835 & Soikkola & (ilm. Voloitsa) & Marojani sisojani, oi maroi siaruen \\
\hline 281 & 554 & 249 & Soikkola & (ilm. Voloitsa) & Vet en lau, vet en laula laulujan; en ilo, en ilo iloisian \\
\hline $281 \mathrm{~b}$ & 555 & 379 & Soikkola & (ilm. Voloitsa) & Avatkaa uksianne, lipatkaa linnojanne \\
\hline 282 & 556 & 161 & Soikkola & (ilm. Voloitsa) & $\begin{array}{l}\text { Illakko miun isoin, hämärikkö velvyeni, ilasta } \\
\text { isoin kuoli, hämärissä velvyeni }\end{array}$ \\
\hline
\end{tabular}




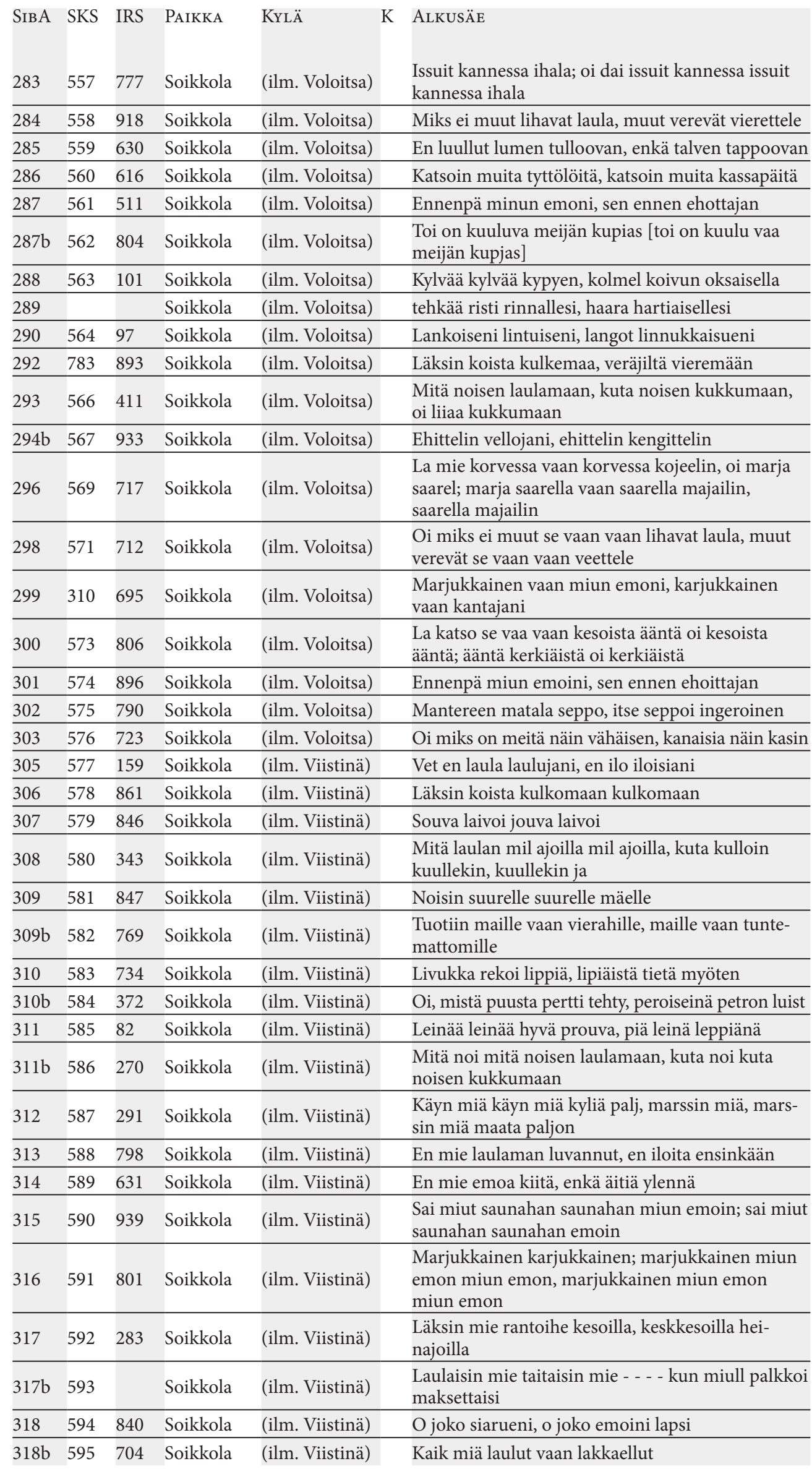




\begin{tabular}{|c|c|c|c|c|c|}
\hline Sib A & SKS & IRS & PAIKKA & KYLÄ & AlKusäE \\
\hline 319 & 596 & 160 & Soikkola & (ilm. Viistinä) & Oi lootika Pohulle polvin, maahan Maarian etehen \\
\hline $319 b$ & 597 & 337 & Soikkola & (ilm. Viistinä) & $\begin{array}{l}\text { O, mitä työ tytöt suretta ja suretta, kanat kainosta- } \\
\text { eletta ja eletta }\end{array}$ \\
\hline 320 & 598 & 647 & Soikkola & (ilm. Viistinä) & Mies köyhä vähäväkinen, vääntäjä vähäväkinen \\
\hline 321 & 599 & 686 & Soikkola & (ilm. Viistinä) $\mathrm{K}$ & $\begin{array}{l}\text { Emo neuvoi neuvoi neitojaan neitojaan; oi emo } \\
\text { neuvoi neitojaan }\end{array}$ \\
\hline 322 & 600 & 854 & Soikkola & (ilm. Viistinä) $\mathrm{K}$ & Joo toi illakkoi illakkoi tulloo; illakkoi tulloo \\
\hline 323 & 601 & 796 & Soikkola & (ilm. Viistinä) & Valkene vahainen päivä, noise päivä nuorekkainen \\
\hline $323 \mathrm{~b}$ & 602 & 605 & Soikkola & (ilm. Viistinä) & Kuin miulla emo eläisi, maammo maata tallajais \\
\hline 324 & 603 & 231 & Soikkola & (ilm. Viistinä) $\mathrm{K}$ & kenen tuo kylä näkyy, kenen linna liglattaa \\
\hline 325 & 604 & 62 & Soikkola & (ilm. Viistinä) & Oi la lähen läpi kyläisen, läpi uuen kuuen linnan \\
\hline 326 & 608 & 915 & Soikkola & $\begin{array}{l}\text { (ilm. Viistinä tai } \\
\text { Tammikontu) }\end{array}$ & Ei miun laulella pitäisi, iloella ensinkää \\
\hline 327 & & & Soikkola & $\begin{array}{l}\text { (ilm. Viistinä tai } \\
\text { Tammikontu) }\end{array}$ & $\begin{array}{l}\text { mitä tytöt myö suremme, myö suremme, kanat } \\
\text { kainosti elämme ja elämme }\end{array}$ \\
\hline 328 & 610 & 477 & Soikkola & $\begin{array}{l}\text { (ilm. Viistinä tai } \\
\text { Tammikontu) }\end{array}$ & $\begin{array}{l}\text { Emo synnytti minuista, mie vaan syytin synnyt- } \\
\text { telin }\end{array}$ \\
\hline $328 b$ & 605 & 156 & Soikkola & $\begin{array}{l}\text { (ilm. Viistinä tai } \\
\text { Tammikontu) }\end{array}$ & Illasta ilot paremmat, päivän laskust laatuisammat \\
\hline 329 & 611 & 308 & Soikkola & $\begin{array}{l}\text { (ilm. Viistinä tai } \\
\text { Tammikontu) }\end{array}$ & La mie laulan laiha lintu, vieretän vähäverinen \\
\hline 330 & 612 & 609 & Soikkola & $\begin{array}{l}\text { (ilm. Viistinä tai } \\
\text { Tammikontu) }\end{array}$ & Mantereen matala seppo, itse seppo Ingeroin \\
\hline 331 & 613 & 764 & Soikkola & $\begin{array}{l}\text { (ilm. Viistinä tai } \\
\text { Tammikontu) }\end{array}$ & $\begin{array}{l}\text { Vet ei vanhoista vanhoista iloa, kun ei meistä vaan } \\
\text { meistä tyttölöistä }\end{array}$ \\
\hline $331 b$ & 606 & 809 & Soikkola & $\begin{array}{l}\text { iistinä tai } \\
\text { kontu) }\end{array}$ & Kylvekää vaan kypenueni, valaelkaa vaan vahtueni \\
\hline 332 & 614 & 778 & Soikkola & $\begin{array}{l}\text { (ilm. Viistinä tai } \\
\text { Tammikontu) }\end{array}$ & oi nyt \\
\hline 333 & 615 & 490 & Soikkola & $\begin{array}{l}\text { (ilm. Viistinä tai } \\
\text { Tammikontu) }\end{array}$ & Mitä otan virrekseni, kuta kukkuellaksen \\
\hline $333 b$ & 607 & 31 & Soikkola & $\begin{array}{l}\text { (ilm. Viistinä tai } \\
\text { Tammikontu) }\end{array}$ & Velloini venoisen seppo, laivoin seppo laglueni \\
\hline 334 & 616 & 748 & Soikkola & $\begin{array}{l}\text { (ilm. Viistinä tai } \\
\text { Tammikontu) }\end{array}$ & $\begin{array}{l}\text { n vaa, } \\
\text { aan }\end{array}$ \\
\hline 335 & 617 & 792 & Soikkola & $\begin{array}{l}\text { (ilm. Viistinä tai } \\
\text { Tammikontu) }\end{array}$ & Miks on meitä näin vähäisen, kanaisia näin kasin \\
\hline $335 b$ & 609 & 742 & Soikkola & $\begin{array}{l}\text { (ilm. Viistinä tai } \\
\text { Tammikontu) }\end{array}$ & Miks on meitä vaan meitä näin vähäsen \\
\hline 336 & 618 & 850 & Soikkola & $\begin{array}{l}\text { (ilm. Viistinä tai } \\
\text { Tammikontu) }\end{array}$ & $\begin{array}{l}\text { Oi la mie vieretän oi vieretän vilulla; vieretän } \\
\text { vilulla oi }\end{array}$ \\
\hline 337 & 619 & 157 & Soikkola & $\begin{array}{l}\text { (ilm. Viistinä tai } \\
\text { Tammikontu) }\end{array}$ & Olin orja vellolleni, oi dai lole vellolleni \\
\hline $337 \mathrm{~b}$ & 620 & 93 & Soikkola & $\begin{array}{l}\text { (ilm. Viistinä tai } \\
\text { Tammikontu) }\end{array}$ & Mihin viivyt velvyeni, viivyt viivyt velvyeni \\
\hline 338 & 621 & 677 & Soikkola & Mäkkylä & $\begin{array}{l}\text { Nyt antoi volin emoin, volin emoin emoin; oi l'ole } \\
\text { l'ole ja emoin emoin }\end{array}$ \\
\hline 339 & 622 & 563 & Soikkola & Mäkkylä & $\begin{array}{l}\text { Oi, la mie laulan nyt mie jouvan, nyt mie jouvan } \\
\text { laulamaan }\end{array}$ \\
\hline 340 & 623 & 838 & Soikkola & Mäkkylä $\quad \mathrm{K}$ & Mitä noisen laulamahan; mitä noisen laulamahan \\
\hline 341 & 624 & 727 & Soikkola & $\begin{array}{l}\text { Mäkkylä } \\
\text { (IRS: Soikkola) }\end{array}$ & $\begin{array}{l}\text { Meiän kutroipää kuningas; meijän kutroipääku- } \\
\text { ningas vahoitukka }\end{array}$ \\
\hline 342 & 625 & 885 & Soikkola & Mäkkylä & Olin orja orja vellollan, karjusti kalervoiselleni \\
\hline $342 b$ & 626 & 104 & Soikkola & $\begin{array}{l}\text { Mäkkylä (IRS: } \\
\text { Tarinainen) }\end{array}$ & Oo, kylvekää kypenyen, valaele vahtuen \\
\hline 343 & 627 & 737 & Soikkola & $\begin{array}{l}\text { Mäkkylä (IRS: } \\
\text { Tarinainen) }\end{array}$ & $\begin{array}{l}\text { Kasvoi miulle kasvoi miulle kassoi pitkä; laadoi } \\
\text { laadoi laadoi majoi }\end{array}$ \\
\hline
\end{tabular}




\begin{tabular}{|c|c|c|c|c|c|c|}
\hline Siв A & SKS & IRS & PAIKKA & KYLÄ & K & ALKusÄE \\
\hline 344 & 628 & 225 & Soikkola & Mäkkylä & & Aikoi lou lounatta anoa, oi aikoi lounatta lounatta anoa \\
\hline 345 & 629 & 430 & Soikkola & Soikkola & K & $\begin{array}{l}\text { Emo neuvoi neitojaan, emo neuvoi neitojaan; neito } \\
\text { neitojaan, neitojaan joonaa }\end{array}$ \\
\hline 346 & 630 & 515 & Soikkola & Mäkkylä & K & $\begin{array}{l}\text { Yks oli ounapuu kylässä, yks oli ounapuu kylässä; } \\
\text { ja kylässä ja kylässä }\end{array}$ \\
\hline 347 & 631 & 682 & Soikkola & Mäkkylä & & $\begin{array}{l}\text { Vet ei vanahoista iloa vaan joi, kun ei meistä } \\
\text { tyttölöistä joi }\end{array}$ \\
\hline 348 & 632 & 514 & Soikkola & Mäkkylä & & Noisin suurelle mäelle, korkialle kalliolle \\
\hline $348 \mathrm{~b}$ & 633 & 53 & Soikkola & Mäkkylä & & Vet en laula laulujani, en iloise ilosiani \\
\hline 349 & 634 & 461 & Soikkola & $\begin{array}{l}\text { Mäkkylä } \\
\text { (IRS: Soikkola) }\end{array}$ & & Lähe neitonen miulle, lähe neitoi vellolleni \\
\hline 350 & 635 & 886 & Soikkola & Mäkkylä & & Oi vet en laula laulujani, oi vet en iloise iloisiani \\
\hline 351 & 636 & 665 & Soikkola & Mäkkylä & & $\begin{array}{l}\text { Päivän poikoi valkiainen, manun poikoi mies } \\
\text { matala }\end{array}$ \\
\hline 352 & 637 & 859 & Soikkola & Mäkkylä & & $\begin{array}{l}\text { Katsoin ilmat katsoin kalmat katsoin kalmat; kat- } \\
\text { soin mättä mättähät meroiset ja meroiset }\end{array}$ \\
\hline 353 & 638 & 109 & Soikkola & Mäkkylä & & Vet en laula laulujani, en ilo iloisiani \\
\hline $353 b$ & 639 & 905 & Soikkola & Mäkkylä & & $\begin{array}{l}\text { Ei miun laulaman pitäis, ei iloita ensin kana [IRS: } \\
\text { En mie laululle luvannut, iloita sinä ikänä] }\end{array}$ \\
\hline 354 & 640 & 890 & Soikkola & Mäkkylä & & Etähäll on miun emoi; etähällä etähäll on miun emoi \\
\hline 355 & 641 & 924 & Soikkola & Mäkkylä & & Matist kasvoi mamman poika, Johanista juomarätti \\
\hline 356 & 642 & 667 & Soikkola & Mäkkylä & & Kullervoin kalervon poikoi, hellervoin heliä viitta \\
\hline 357 & 643 & 853 & Soikkola & Soikkola & & Mitä noisen vaan noisen laulamaan oi \\
\hline $357 \mathrm{~b}$ & 644 & 358 & Soikkola & Mäkkylä & & Aja aja ainueni, aja ainuu velvyeni \\
\hline 358 & 645 & 740 & Soikkola & Mäkkylä & & $\begin{array}{l}\text { Oi jokoi se vaan vaan siarueni; oi jokoi se vaan } \\
\text { vaan emoni lap(a)si }\end{array}$ \\
\hline 359 & 646 & 347 & Soikkola & Mäkkylä & & $\begin{array}{l}\text { La mie laulan nyt mie jouvan nyt mie jouvan, nyt } \\
\text { mie jouvan laulamaan laulamahan }\end{array}$ \\
\hline $359 b$ & 647 & 570 & Soikkola & Mäkkylä & & $\begin{array}{l}\text { Nyt mie laulan nyt mie jouvan, nyt mie jouvan } \\
\text { laulamahan }\end{array}$ \\
\hline 360 & 648 & 85 & Soikkola & Mäkkylä & & Mitä noisen laulamahan, kuta noisen kukkumahan \\
\hline 361 & 650 & 797 & Soikkola & Mäkkylä & & $\begin{array}{l}\text { Oi ehittelin vellojani vellojani, oi ehittelin } \\
\text { kengittelin kengittelin }\end{array}$ \\
\hline 362 & 651 & 887 & Soikkola & Mäkkylä & & Oi mitä noisen vaa aa oi lauulamahan \\
\hline 363 & 652 & 819 & Soikkola & Mäkkylä & & Oi vet en laula laula laulujani laulujan \\
\hline 364 & 653 & 703 & Soikkola & Mäkkylä & K & $\begin{array}{l}\text { Oi dai vet en laula oi dai vet en laula; vet en laula } \\
\text { laulujani laulujani, vet en laula laulujani laulujani }\end{array}$ \\
\hline 365 & 654 & 331 & Soikkola & Mäkkylä & & Suvannotkaa maat sulaiset, suvannotkaa salinotkaa \\
\hline 366 & 655 & 309 & Soikkola & Mäkkylä & & $\begin{array}{l}\text { Lauloin ennen lapsempana, kukuin ennen pie- } \\
\text { nempänä }\end{array}$ \\
\hline $366 \mathrm{~b}$ & 656 & 307 & Soikkola & Mäkkylä & & Käin sutena suuret metsät, karhuna kamalat korvet \\
\hline 367 & 659 & 42 & Soikkola & $\begin{array}{l}\text { Mäkkylä } \\
\text { (IRS: Soikkola) }\end{array}$ & & Kaikkipa ilot unohin, kaikki laulut lakkaelin \\
\hline 368 & 660 & 802 & Soikkola & Suija & & $\begin{array}{l}\text { Kosolainen lainen kielikoira kielikoira; kosolainen } \\
\text { lainen kielijoira }\end{array}$ \\
\hline 369 & 661 & 84 & Soikkola & Suija & & Menin vellol vierahaksi, isoni ikitilalle \\
\hline 370 & 662 & 852 & Soikkola & Suija & & Mitä kullet vaan kullet kuuntelemaan \\
\hline 371 & 663 & 300 & Soikkola & Suija & & Jootoo illakkoi tulloo, hämärikkö veettelöö \\
\hline $371 \mathrm{~b}$ & 658 & 685 & Soikkola & Suija & & Mitä noisen laulamahan \\
\hline 372 & 664 & 94 & Soikkola & Oussimäki & & Sinis itkin poikojan, kunis purjepuut näkyit \\
\hline $372 b$ & & & Soikkola & Oussimäki & & ikä on isotoin ilma, halu eiton [emoton] elämä \\
\hline 373 & 665 & 137 & Soikkola & Oussimäki & & Kuhun viivyt velvyeni, kauvatsut kalervoiseni \\
\hline $373 b$ & 666 & 594 & Soikkola & Oussimäki & & Lähemmä läpi kyläisen, läpi uulitsan utuisen \\
\hline 374 & 667 & 738 & Soikkola & $\begin{array}{l}\text { Oussimäki } \\
\text { (IRS: Soikkola) }\end{array}$ & & $\begin{array}{l}\text { Velloini vaan velloini venoisen seppoi; laivoin } \\
\text { seppoi laivoin seppoi lagluveni }\end{array}$ \\
\hline
\end{tabular}




\begin{tabular}{|c|c|c|c|c|c|c|}
\hline Sib A & SKS & IRS & PAIKKA & KYLÄ & K & AlKusÄE \\
\hline 375 & 668 & 114 & Soikkola & Oussimäki & & Lensi lintu alta linnan, sulka valkia vaist \\
\hline $375 \mathrm{~b}$ & 669 & 763 & Soikkola & Oussimäki & & Nyt on aikuin vaan maalla marras \\
\hline 376 & 670 & 96 & Soikkola & Oussimäki & & Ristimä rinnallesi, ota sie suka sulia \\
\hline $376 \mathrm{~b}$ & 671 & 499 & Soikkola & Oussimäki & & Meijän kupjas velloin kuulu, meijän taarasta tasain \\
\hline 377 & 672 & 87 & Soikkola & Oussimäki & & Oi, en it(e) emoini päälle, en it(e) isoini päälle \\
\hline $377 \mathrm{~b}$ & 673 & 218 & Soikkola & Oussimäki & & Kysyin maata velloiltani, ainoin maata velloiltani \\
\hline 378 & 674 & 298 & Soikkola & Oussimäki & & $\begin{array}{l}\text { Jo kaik ilot unohin(i) jo, kaik mie laulut } \\
\text { lakkalelin(i) jo }\end{array}$ \\
\hline 379 & 675 & 141 & Soikkola & Oussimäki & & kohoo kupeli leipä, noise noise nuori leipä \\
\hline $379 b$ & 676 & 263 & Soikkola & Oussimäki & & $\begin{array}{l}\text { mitä laulan mill ajoilla mill ajoilla, kuta kulloin } \\
\text { huomuksella huomuksella }\end{array}$ \\
\hline 380 & 677 & 863 & Soikkola & $\begin{array}{l}\text { Oussimäki } \\
\text { (IRS: Soikkola) }\end{array}$ & & Oi la katson vaan kesoista kieltä vaan ja kesoist \\
\hline $380 \mathrm{~b}$ & 678 & 376 & Soikkola & Oussimäki & & Emo neuvoi neitojaan, opasti omenuttaan \\
\hline 381 & 679 & 431 & Soikkola & Oussimäki & K & $\begin{array}{l}\text { Olin orjoina Viroissa, käyn palkkoin pahoilla mail- } \\
\text { la; paavele jo, paavele jo, rasveli naveli, tiveli naveli, } \\
\text { veliveli jo, veliveli jo }\end{array}$ \\
\hline 382 & 680 & 179 & Soikkola & Oussimäki & & Oi la mie vellotoin oi siaritoin \\
\hline $382 b$ & 681 & 426 & Soikkola & Oussimäki & & $\begin{array}{l}\text { Oi miun ehtoisa emoni, oi minun maire maam- } \\
\text { moiseni, maa maammoiseni }\end{array}$ \\
\hline 383 & 682 & 491 & Soikkola & $\begin{array}{l}\text { Oussimäki } \\
\text { (IRS: Soikkola) }\end{array}$ & & Läksin kouluhun koista, oppihin omilta mailta \\
\hline $383 b$ & 683 & 702 & Soikkola & Oussimäki & & $\begin{array}{l}\text { Sen(en) minä tieän kuhun minä synnyin, iän miä } \\
\text { kaiken kussa kasvoin }\end{array}$ \\
\hline 384 & 684 & 257 & Soikkola & Oussimäki & & Ei miun laulella pitäisi, ei iloita ensinkänä \\
\hline $384 b$ & 685 & 262 & Soikkola & Oussimäki & & $\begin{array}{l}\text { Olin vaan mie yksin äidilleni jo, maksoin vaan mie } \\
\text { kaksi maammalleni }\end{array}$ \\
\hline 385 & 686 & 400 & Soikkola & Oussimäki & K & $\begin{array}{l}\text { Köyhä mies vähäramoinen, vähäinen vääntäjä } \\
\text { väkinen; ja väki väkinen ja väkinen joonoo }\end{array}$ \\
\hline 387 & 689 & 794 & Soikkola & Venakontsa & & $\begin{array}{l}\text { Velloini venoi velloini venoi; ja venoisen ee oi ja } \\
\text { venoisen ee oi }\end{array}$ \\
\hline 388 & 690 & 705 & Soikkola & Venakontsa & K & $\begin{array}{l}\text { Nyt on aikuin maalla [/Siba: vaan ku] maalla mar- } \\
\text { ras jo; rannoi rannoi rannoi rannoi rannoi rannoi }\end{array}$ \\
\hline 389 & 691 & 100 & Soikkola & Venakontsa & & Kylve kylve kyypyen, kylvekää kypenyen \\
\hline $389 \mathrm{~b}$ & 692 & 290 & Soikkola & Venakontsa & & Riitelit kälyksen kolmen, kolmen kynnyksen ylitse \\
\hline 390 & 693 & & Soikkola & Venakontsa & K & $\begin{array}{l}\text { Mitä kulloit kuuntelemaan, aikuet ajattelemaan; e } \\
\text { oi ajatteleen aikuet ajatteleen }\end{array}$ \\
\hline $390 \mathrm{~b}$ & 694 & 588 & Soikkola & Venakontsa & & $\begin{array}{l}\text { Mantereen matala seppo, itse seppo Ingeroin; oi } \\
\text { liiaa laulamaan, oi liiaa laulamaan }\end{array}$ \\
\hline 391 & 695 & 678 & Soikkola & Venakontsa & & Miksipä miä vaan mokoma; oi l’ole lole ja mokoma ja \\
\hline 392 & 696 & 706 & Soikkola & Mättynen & & Oi kullervo kalervon poika, oi heliä hellervoi viitta \\
\hline 393 & 697 & 86 & Soikkola & Mättynen & & Jo mie käyn kyliä paljon, jo mie marssin maita paljon \\
\hline $393 b$ & 698 & 698 & Soikkola & Mättynen & & Livukka rekoi lipiäistä, lipiäistä tietä myöten \\
\hline 394 & 699 & 39 & Soikkola & Mättynen & & Kylvekää kypenyen, vahtaele vahtuen \\
\hline $394 \mathrm{~b}$ & 700 & 354 & Soikkola & Mättynen & & Aja aja ainueni, aja aja vel(e)vyeni \\
\hline 395 & 702 & 27 & Kattila & Kirkonkylä & & čyhyze kurzi, kaunis kuori, ahi lavvaa ladjutta \\
\hline 395 & 701 & 52 & Kattila & Kirkonkylä & & čyhyze kurzi, kaunis kuori, ahi lavvaa ladjutta \\
\hline 396 & 703 & 28 & Kattila & Kirkonkylä & & Yhs eli öhsä eunapuussa, yhs eli euna öhsällä \\
\hline 452 & 706 & 662 & Soikkola & Uusikylä & & Mitä lauloinpa mill ajoilla, kuta kulloinpa huomuksella \\
\hline 453 & 707 & 827 & Soikkola & Uusikylä & & $\begin{array}{l}\text { Mitä myö tytöt suremme, kanat } \\
\text { kainostaelemm(me) }\end{array}$ \\
\hline 454 & 708 & 824 & Soikkola & Uusikylä & K & $\begin{array}{l}\text { Meijän kutroipää kuningas, vahoitukkoi linnoi } \\
\text { vanhin; meijän kutroipää kuningas vahoitukkoi } \\
\text { linnoi vanhin, meijän kutroipää kuningas vahoi- } \\
\text { tukkoi linnoi vanhin }\end{array}$ \\
\hline
\end{tabular}




\begin{tabular}{|c|c|c|c|c|c|c|}
\hline SibA & SKS & IRS & PAIKKA & KYLÄ & K & AlKusäE \\
\hline 455 & 709 & 716 & Soikkola & Uusikylä & & $\begin{array}{l}\text { Saoin siul saoin siul saoin siulle tän kesoin; tän mie } \\
\text { vuott tän mie vuott tän mie vuotta vonkutin }\end{array}$ \\
\hline 456 & 710 & 842 & Soikkola & Uusikylä & K & $\begin{array}{l}\text { Kuulin käen vaan kuulin käen vaan; kuulin käen kuk- } \\
\text { kuvan kukkuvan, kuulin käen kukkuvan kukkuvan }\end{array}$ \\
\hline 457 & 711 & 385 & Soikkola & Uusikylä & & Laulaisin luettelisin, veistäisin Viron venettä \\
\hline $457 \mathrm{~b}$ & 712 & 112 & Soikkola & Uusikylä & & Jo näin näölliseksi, ja viitsin verelliseksi \\
\hline 458 & 713 & 640 & Soikkola & Uusikylä & $\mathrm{K}$ & $\begin{array}{l}\text { Kysyin maata velloiltani, ainoin ainovaiseltani; } \\
\text { kysyin maata velloltani, ainoin ainavoiseltan }\end{array}$ \\
\hline 459 & 714 & 882 & Soikkola & Uusikylä & & $\begin{array}{l}\text { Näin mie laivan vaan lainehtivan jo, näin mie } \\
\text { vierevän vaan venoisen jo }\end{array}$ \\
\hline 460 & 715 & 634 & Soikkola & $\begin{array}{l}\text { Uusikylä } \\
\text { (IRS: Soikkola) }\end{array}$ & & Katsoin merta ikkunasta, kuin meroi poraeloo \\
\hline 461 & 716 & 912 & Soikkola & Uusikylä & $\mathrm{K}$ & $\begin{array}{l}\text { Menin metsähän kesoilla, keskkesoilla heinajoill; } \\
\text { menin metsähän kesoilla keskkesoilla heinajoill }\end{array}$ \\
\hline 462 & 718 & 610 & Soikkola & Uusikylä & & $\begin{array}{l}\text { Tyttölöjä varkahin iiaa, siaria alkahii, vellon } \\
\text { purnun purkajii }\end{array}$ \\
\hline 64 & 717 & 597 & Soikkola & Uusikylä & & Mitroi kutroi poisikina, sanoin linnasta lähetti \\
\hline
\end{tabular}

\section{LEVóN 1903 (SKS KRA)}

Viite: Levón = SKS KRA Levón 1903.

\begin{tabular}{|c|c|c|c|c|}
\hline LEVón & IRS & PAIKKa & KYLÄ & K AlkusäKeEt \\
\hline 313 & 472 & Tyrö & Kirkonkylä & Velloini venosen seppo, laulu seppo lakluveni \\
\hline 314 & 279 & Tyrö & Kirkonkylä & Mikä saarella palavi, oi oi oi \\
\hline 315 & 352 & Tyrö & Kirkonkylä & Mari siityinen sisoi, kysyn seukko mie siulta \\
\hline 318 & 333 & Tyrö & Kirkonkylä & $\begin{array}{l}\text { Pankaa kiinni kirjan kannet kirjan kannet, ei nyt kirjasta } \\
\text { kinellä ja kinellä }\end{array}$ \\
\hline $318 \mathrm{~b}$ & 314 & Tyrö & Kirkonkylä & $\begin{array}{l}\text { Pankaa kiinni kirjan kannet kirjan kannet, ei nyt kirjasta } \\
\text { kinellä ja kinellä }\end{array}$ \\
\hline $318 c$ & 348 & Tyrö & Kirkonkylä & $\begin{array}{l}\text { Pankaa kiinni kirjan kannet kirjan kannet, ei nyt kirjasta } \\
\text { kinellä ja kinellä }\end{array}$ \\
\hline 336 & 175 & Tyrö & Latikan kylät & Etsin etsin neittä vellolleni jo, kumppa kumppalia kullalleni jo \\
\hline 337 & 586 & Tyrö & Latikan kylät & Velloini venosen seppo, laulu seppo lakluven \\
\hline 340 & 266 & Tyrö & Latikan kylät & Kasvatti emo kanaisia joi, ai luli luli jaa kanaisia jo \\
\hline 342 & 192 & Tyrö & Latikan kylät & Lauloin ennen lapsenpana, ai ta lole lole lapsenpana \\
\hline 343 & 546 & Tyrö & Latikan kylät & Matti poika maire poika, käy kosissa kolme vuotta \\
\hline 344 & 364 & Tyrö & Latikan kylät & Istuu tuos isoton poika, armoton ajatteloo \\
\hline 346 & 265 & Tyrö & Latikan kylät & Kalervoinen kylvi kagran, untamoisen kujan perään \\
\hline 347 & 747 & Tyrö & Latikan kylät & Kuhun tästä tie männööpi, kuhun tästä tie männööpi \\
\hline 348 & 107 & Tyrö & Latikan kylät & Tulkaa ka tytöt kokoille, valvokaaha valkealle \\
\hline 349 & 216 & Tyrö & $\begin{array}{l}\text { Hovinmättään } \\
\text { kylät }\end{array}$ & Lankoiseni lintuiseni, pasta miulle paksu kakku \\
\hline 350 & 564 & Tyrö & $\begin{array}{l}\text { Hovinmättään } \\
\text { kylät }\end{array}$ & Mahtuuko vävy tupaani, ilman orren ottamatta \\
\hline 351 & 368 & Tyrö & $\begin{array}{l}\text { Hovinmättään } \\
\text { kylät }\end{array}$ & $\begin{array}{l}\text { Iikko velloini verevä ja verevä, jos on siulle iloitta ja siulle } \\
\text { iloitta }\end{array}$ \\
\hline 353 & 210 & Tyrö & $\begin{array}{l}\text { Hovinmättään } \\
\text { kylät }\end{array}$ & Mitä myö issumma ilotta, ilman lauluta elämme \\
\hline 354 & 391 & Tyrö & $\begin{array}{l}\text { Hovinmättään } \\
\text { kylät }\end{array}$ & $\begin{array}{l}\text { Mie olin tyttö pikkarainen, kesen kasvoine kanai; ja kana } \\
\text { kanainen, ja kanainempa joonoi }\end{array}$ \\
\hline
\end{tabular}




\begin{tabular}{|c|c|c|c|c|}
\hline LEvóN & IRS & PAIKKA & KYLÄ & K AlkusäkeEt \\
\hline 357 & 572 & Tyrö & Yhimäki & $\begin{array}{l}\text { Katriina kotikanainen, katri kokkoi linnukkainen; oi linnuk- } \\
\text { kainen, linnukkainen joonoi }\end{array}$ \\
\hline 360 & 927 & Tyrö & Yhimäki & Hyvä on tyttönä elellä, ja ele elellä ja elellä joonoi \\
\hline 361 & 191 & Tyrö & Yhimäki & Emoi miu, miu synnytteli, ai ta lole lole synnytteli \\
\hline 362 & 656 & Tyrö & Yhimäki & $\begin{array}{l}\text { Läksin suolle sotkemahan ninonii, lähteelle läpyttämähän } \\
\text { ninonii; nonno nonnonnoo ninonii, nonno nonnonnoo } \\
\text { ninonii }\end{array}$ \\
\hline 363 & 888 & Tyrö & Yhimäki & $\begin{array}{l}\text { Jos minä kirpun kiinni saisin luuri illalla; ilo illalla luuri } \\
\text { illalla }\end{array}$ \\
\hline 367 & 204 & Tyrö & Yhimäki & Pääsköilintu, päivälintu; Rozal' moja li vinograd zelënyj \\
\hline 368 & 232 & Tyrö & Yhimäki & Varpu rikko neito nuori; ai lole lole neito nuori \\
\hline 369 & 529 & Tyrö & Yhimäki & $\begin{array}{l}\text { Mikula meroin isäntä, Pyhä jyrki armollinen, armo } \\
\text { armollinen, armollinene joonoi }\end{array}$ \\
\hline 370 & 378 & Tyrö & Yhimäki & $\begin{array}{l}\text { Tuossa tanssivat tasaiset, tuossa tanssivat tasaiset; oo ja } \\
\text { tasaiset, oo ja tasaiset }\end{array}$ \\
\hline 371 & 377 & Tyrö & Yhimäki & Mansikka mäellä huusi, mansikka mäellä huusi \\
\hline 372 & 876 & Tyrö & Yhimäki & Nuku nuku nurmilintu, vaivu valkoinen kanani \\
\hline 373 & 59 & Tyrö & Yhimäki & Istu jamppana jakulle, riinasilmä ristilöille \\
\hline 374 & 543 & Tyrö & Yhimäki & Aika on kotihin mennä, aika onnella sopassu \\
\hline 375 & 714 & Tyrö & Yhimäki & $\begin{array}{l}\text { Uro umpi ruotsalainen ruotsalainen, mies kuin saaren } \\
\text { saksalainen saksalainen }\end{array}$ \\
\hline 377 & 875 & Tyrö & Yhimäki & Uni ulkonta kysyvi, onks teill lasta kätkyessä \\
\hline 378 & 226 & Tyrö & Yhimäki & Pai pai pai pai, nuku silmä nuku toin, tuo uni ulkomailt \\
\hline 380 & 421 & Tyrö & Yhimäki & Anna Jumal alkun, ennen päivän laskun, elä liekku langettele \\
\hline 381 & 432 & Tyrö & Yhimäki & $\begin{array}{l}\text { Tulkaa tytöt yötulille, valukaahan valkeill; ai luli ai luli, } \\
\text { valukaahan valkeill }\end{array}$ \\
\hline 382 & 454 & Tyrö & Yhimäki & $\begin{array}{l}\text { Ennen oisi miun emoini, sen vuuven mahona maant; } \\
\text { eehheh haa, sen vuuven mahona maant }\end{array}$ \\
\hline 383 & 544 & Tyrö & Yhimäki & $\begin{array}{l}\text { Osasi miun emoni, osasi omenan teh; oi ja omen, osasi miun } \\
\text { emoni teh }\end{array}$ \\
\hline 387 & 29 & Tyrö & Yhimäki & Päs̈skyläinen päivälintu, pääskyläinen päivälintu \\
\hline 388 & 483 & Tyrö & Yhimäki & $\begin{array}{l}\text { Menin pienen kyntämähän, kynsin vaan kynsin kaksi; ai luli } \\
\text { luli lu kyntämähän, ai luli luli lu kyntämähän }\end{array}$ \\
\hline 389 & 99 & Tyrö & Yhimäki & Kalervikko kylvi kagroin, Untamon kujan perähän \\
\hline 390 & 356 & Tyrö & Yhimäki & $\begin{array}{l}\text { Ennen ois miun emoni ja miun emoni, juossut vuoden } \\
\text { joutavana ja joutavana }\end{array}$ \\
\hline 393 & 189 & Tyrö & Yhimäki & Eipä laulella pitäisi, ei ilota ensinkänä \\
\hline 394 & 198 & Tyrö & Yhimäki & Eipä laulella pitäisi, ei ilota ensinkänä \\
\hline 395 & 165 & Tyrö & Yhimäki & $\begin{array}{l}\text { Kokkolintu korven lintu, sakkali salomelintu, lens hän laivoi } \\
\text { mastipuillen, laivoin kepeille kejahti }\end{array}$ \\
\hline 396 & 569 & Tyrö & Yhimäki & Vellon kompi koisois teitä, käy neion keräysteitä \\
\hline 397 & 419 & Tyrö & Yhimäki & Venähen kunervoi veikko, Ervoi veikko venhäläin \\
\hline 398 & 201 & Tyrö & Yhimäki & Nukuttele vaivuttele, anna unta armollista \\
\hline 399 & 195 & Tyrö & Yhimäki & kerralliset pois menevät, miun sitt täytyy tänne jäädä \\
\hline 400 & 245 & Tyrö & Yhimäki & Sepän nainen on selvä nainen, löysi lapsen ka lastuloista \\
\hline 401 & 238 & Tyrö & Yhimäki & Kylästäni linnastani; saatulmoi saatu selenoi saatu \\
\hline 402 & 455 & Tyrö & Yhimäki & $\begin{array}{l}\text { Olin orjana Venoss, palkkoina pahoilla mail; lepeta lepeta } \\
\text { lepeta moi peeloja }\end{array}$ \\
\hline 403 & 407 & Tyrö & Yhimäki & $\mathrm{K} \begin{array}{l}\text { Emosen mun ehtosen, maammosen miun marjasen; ai luli } \\
\text { spaluli, maammosein mun marjaisein }\end{array}$ \\
\hline 404 & 497 & Tyrö & Yhimäki & $\begin{array}{l}\text { Veljeni venosen seppo, laivoi seppo lakluven; lai luuli } \\
\text { lakluven, ai luuli lagluven }\end{array}$ \\
\hline 405 & 373 & Tyrö & Yhimäki & $\begin{array}{l}\text { Meroin tyttö metsoin sulho, korven korkiea sevihka, ai luli } \\
\text { spai luli, korven korkea sevihka }\end{array}$ \\
\hline
\end{tabular}




\begin{tabular}{|c|c|c|c|c|}
\hline LEvón & IRS & PAIKKA & KYLÄ & K AlkusäKeEt \\
\hline 406 & 938 & Tyrö & Yhimäki & $\begin{array}{l}\text { poika liikkui tukka löyhki, tupa kuusin kumisi; eto pravda } \\
\text { eto pravda, etp pravda vsë bylo }\end{array}$ \\
\hline 407 & 532 & Tyrö & Yhimäki & $\begin{array}{l}\text { Kuin miun eukkoin ois elän(y)t, niin pitsipaitoja mie } \\
\text { pitän }(y) t\end{array}$ \\
\hline 408 & 397 & Hevaa & Harmaala & Ennen päivätä on eletty, kupaeltu ilman kuuta \\
\hline 409 & 711 & Hevaa & Harmaala & $\begin{array}{l}\text { Hoi pääskyläinen päivän lintu; pääskyläinen päivönlintu, } \\
\text { pääskyläinen päivönlintu }\end{array}$ \\
\hline 410 & 518 & Hevaa & Harmaala & $\begin{array}{l}\text { Laari poika laatu poika, laari laatu poisikkainen; oi poisik- } \\
\text { kainen, poisikkaienn joonoi }\end{array}$ \\
\hline 411 & 617 & Hevaa & Harmaala & Kokkolintu korven lintu, sakkari salomen lint \\
\hline 412 & 799 & Hevaa & Harmaala & Hyvä meil elää elällä; vot skalina da vot smalina \\
\hline 413 & 148 & Hevaa & Harmaala & Sie neito meijän miinoi, älä tusi tullessasi \\
\hline 414 & 525 & Hevaa & Harmaala & Hekko tyttö hemmo tyttö, hekko hemmoa käppee \\
\hline 415 & 150 & Hevaa & Harmaala & Untamoin sota tulloopi, kalervoja tappamaan \\
\hline 416 & 568 & Hevaa & Harmaala & $\begin{array}{l}\text { Miks on hoikka miun emoni, sill on hoikka miun emoni; ai } \\
\text { svjeti kalinikoi, ja drugoi kalubnikoi }\end{array}$ \\
\hline 418 & 375 & Hevaa & Harmaala & la ka katson lautoja, Silittelen siltoja \\
\hline 419 & 110 & Hevaa & Harmaala & Jo on aika kotihin mennä, aika marssia majoil \\
\hline 420 & 674 & Hevaa & Harmaala & K Tulkaa ka työ tytöt yötulelle jo; ai lole lole yötulelle jo \\
\hline 421 & 359 & Hevaa & Harmaala & La ka katson liekkuani liekkuani \\
\hline 422 & 833 & Hevaa & Harmaala & La mie laulan kons mie jouan, kons mie jouan laulamahan \\
\hline 423 & 176 & Hevaa & Harmaala & La ka katson äänöjäni, kiusaelen kielojani \\
\hline 424 & 151 & Hevaa & Harmaala & Kuokin mie kesoisen päivän, kuorman heinijä kokosin \\
\hline 425 & 625 & Hevaa & Harmaala & Mäni sinoin kitkijäks, pellervoin puhastajaks \\
\hline 426 & 77 & Hevaa & Harmaala & Mie oon tyttöi pikkarainen, matalainen maan tasainen \\
\hline 427 & 184 & Hevaa & Harmaala & Jeesus kirkkohon männööpi, hevoisella hiirakalla \\
\hline 428 & 205 & Hevaa & Harmaala & Sulho poikoi poitulainen, siniviittoi veetyläin \\
\hline 429 & 488 & Hevaa & Harmaala & Kun miun emoni eläisi, en minä naisi ensinkänä \\
\hline 430 & 655 & Hevaa & Harmaala & $\begin{array}{l}\text { Minä tyttö pikkarainen, matalainen marjukkain; minä tyttö } \\
\text { pikkarainen, matalainen marjukkain }\end{array}$ \\
\hline 431 & 574 & Hevaa & Harmaala & Tunnen tuulet tunnen tyynet, en tunne emännän kieltä \\
\hline 432 & 512 & Hevaa & Kantakylä & Mitä laulan kuta laulan, mitä otan minä virreksein \\
\hline 433 & 49 & Hevaa & Kantakylä & Mahtuuko vävy tupahan, ilman orren ottamatta \\
\hline 434 & 362 & Hevaa & Kantakylä & $\begin{array}{l}\text { Mist sie tunsit turnust tulla turnust tulla, sian kärsä tänne } \\
\text { käyä tänne käyä }\end{array}$ \\
\hline 435 & 371 & Hevaa & Kantakylä & Jopa illakko tulloopi, hämärikkö liitelee \\
\hline 436 & 119 & Hevaa & Kantakylä & Läkkön myö vet oi läpi kyläisen jo, ai lole lole ja kyläisen jo \\
\hline 437 & 536 & Hevaa & Kantakylä & $\begin{array}{l}\text { Tulkaa tytöt yötulelle, valukaatte valkealle; oi valkealle, } \\
\text { valkealle joonoi }\end{array}$ \\
\hline 438 & 562 & Hevaa & Ojankylä & $\begin{array}{l}\text { Kerittelin vellojani, kerittelin kengittelin; ai kengittelin, } \\
\text { kengittelin joonoi }\end{array}$ \\
\hline 439 & 671 & Hevaa & Ojankylä & $\begin{array}{l}\text { Souvelkaa ka vetsaa jouvelkaa ka jo, jo ai li ai lu li tää, jouel- } \\
\text { kaa ka joi }\end{array}$ \\
\hline 440 & 489 & Hevaa & Ojankylä & $\begin{array}{l}\text { La ka mie nousen laulamahan, ja itse mie iloitsemahan; ja } \\
\text { ilo iloitse, ja iloitsemahan }\end{array}$ \\
\hline 441 & 786 & Hevaa & Ojankylä & $\begin{array}{l}\text { Täss on lusti luita lyöä luita lyöä; saaduljmoi saadu sekeljen- } \\
\text { nai saadu }\end{array}$ \\
\hline 442 & 718 & Hevaa & Ojankylä & La ka mie katson liekkujani, kiusaelen mie kiekkujani \\
\hline 443 & 663 & Hevaa & Ojankylä & $\begin{array}{l}\text { Maijukkainen vaan miun emoni, maijukkaine vaan kaijuk- } \\
\text { kain }\end{array}$ \\
\hline 444 & 550 & Hevaa & Vepsä & $\begin{array}{l}\text { Kesoilintu keloi lintu, päivöilintu pääsköilint; pääsköi pääs- } \\
\text { köi lintu, pääsköilintu joonoi }\end{array}$ \\
\hline 445 & 280 & Hevaa & Vepsä & Katriina veti kotikanaienn jo, ai lole lole ja kanainen jo \\
\hline 446 & 180 & Hevaa & Vepsä & Mitä se mökkö myöhään nousit, kauvan kolkkimus makasit \\
\hline
\end{tabular}




\begin{tabular}{|c|c|c|c|c|}
\hline LEVóN & IRS & PAIKKA & KYLÄ & K AlkusäkeEt \\
\hline 447 & 188 & Hevaa & Vepsä & Mie taian miksen taia, hepo telkkii teetä myöten \\
\hline 448 & 603 & Hevaa & Vepsä & La ka katson lautojan, silittelen siltojan \\
\hline 449 & 243 & Hevaa & Vepsä & Laka katson(o) metsojani, helisevätkö hemme metsät \\
\hline 450 & 41 & Hevaa & Vepsä & Minä tyttö pikkarainen, mie marjoi maan tasainen \\
\hline 451 & 513 & Hevaa & Vepsä & $\begin{array}{l}\text { Lankoisenne lintuisenne, lankoisenneko lintuisen; lintui } \\
\text { lintuisenne, lintuisenne joonoi }\end{array}$ \\
\hline 452 & 78 & Hevaa & Vepsä & La ka katson liekkujani, kiusaelen kiekkujani \\
\hline 453 & 679 & Hevaa & Vepsä & Virolainen on virolainen poika viisas, karjalainen mies kavala \\
\hline 454 & 928 & Hevaa & Vepsä & ... oi ja käppee, hekko hemmo ja käppee \\
\hline 455 & 398 & Hevaa & Vepsä & Venöin on kuninkas viikas, Ruti rohkea kuninkas \\
\hline 456 & 121 & Hevaa & Lenttinen & Näki oksalta omenan, näki puulta pähkinäisen \\
\hline 457 & 369 & Hevaa & Lenttinen & Katriina kotikanainen, kati kokkoi linnukkainen \\
\hline 458 & 535 & Hevaa & Lenttinen & Hypätkäämme hyrjätkäämme; maan valiot vaeltakaamme \\
\hline 459 & 167 & Hevaa & Lenttinen & Vanha rahvas muisteloovat, sykysyiset imehtelevät \\
\hline$\underline{460}$ & 418 & Hevaa & Lenttinen & Venähen kunervoi viikas, hervoi viikas venäläin \\
\hline 461 & 132 & Hevaa & Lenttinen & Meijän kylläiset kylässä, ratkoisesta rahvahasta \\
\hline 462 & 177 & Hevaa & Lenttinen & Meroin tyttö metsoin suljo, korven korkea sevikka \\
\hline 463 & 72 & Hevaa & Lenttinen & La ka katson(o) liekkujani, kiusaelen kiekkujani \\
\hline 464 & 468 & Hevaa & Lenttinen & Punokaatte nuorakerä, nuorakerä ja lakea \\
\hline 465 & 71 & Hevaa & Lenttinen & Täss on tykky tyttölöjä, riuku rinnoin seisovia \\
\hline 466 & 460 & Hevaa & Lenttinen & Seppyeni selvyeni, takojani tammuen \\
\hline 467 & 108 & Hevaa & Lenttinen & Mie köyhäinen kehrääjä, söi riissoi talon hävitin \\
\hline 469 & 50 & Hevaa & Lenttinen & Mie tyttöi pikkarainen, mie marjoi maan tasain \\
\hline 470 & 117 & Hevaa & Lenttinen & Ilia pyhä isäntä, anna maillesi makua \\
\hline 471 & 88 & Hevaa & Lenttinen & Hospoti opastamahan, last avikkoi laulamahan \\
\hline 472 & 534 & Hevaa & Lenttinen & $\begin{array}{l}\text { La mie viukkasen vilulla, la mie kaljun kastehessa; ai lole ai } \\
\text { lole, la mie kaljun kastehess }\end{array}$ \\
\hline 473 & 353 & Hevaa & Tönttölä & $\begin{array}{l}\text { Pyhä ot Jyrki armollinen armollinen, Miikkula sie meroin } \\
\text { isäntä ja isäntä }\end{array}$ \\
\hline 474 & 467 & Hevaa & Tönttölä & $\begin{array}{l}\text { Kelle vooroi kulle vooroi, kelle vooroi kulle vooroi; kulle } \\
\text { kulle vooroi, kulle vooroi joonoi }\end{array}$ \\
\hline 476 & 453 & Hevaa & Tönttölä & $\begin{array}{l}\text { Venäen kanervoi veikko, herroi veikkoi venäläin; ai tili tili } \\
\text { moi, koko hattu omenoi }\end{array}$ \\
\hline 477 & 408 & Hevaa & Tönttölä & Laari poika laatu poika, veisti suksia sykysin \\
\hline 478 & 393 & Hevaa & Tönttölä & $\begin{array}{l}\text { La ka katson lautojan, La ka katson lautojan; lautojan lauto- } \\
\text { jan, la ka katson lautojan }\end{array}$ \\
\hline 479 & 516 & Hevaa & Tönttölä & Korpi kultainen kumae, helloie sie metsoi hellee \\
\hline 480 & 434 & Hevaa & Tönttölä & $\begin{array}{l}\text { Menin minä miennä ku kyntämähän, varahan on vakkoo- } \\
\text { mahan }\end{array}$ \\
\hline 481 & 708 & Hevaa & Tönttölä & Raukka rannalla elää, vaarallinen vettä vassek \\
\hline 482 & 450 & Hevaa & Tönttölä & Hekkoi tyttöi hemme tyttöi, hekkoi tyttöi hemme tyttöi \\
\hline 483 & 220 & Hevaa & Tönttölä & Hekkoi tyttöi hemme tyttöi, etsiipi on emännän päätä \\
\hline 484 & 531 & Hevaa & Tönttölä & $\begin{array}{l}\text { Tulkaa tytöt yötulelle, valukaatte valkealle; ai lole ai lole, } \\
\text { valukaatte valkeall }\end{array}$ \\
\hline 485 & 533 & Hevaa & Tönttölä & $\begin{array}{l}\text { läkkän mie läpi kyläsen, läpi ton on toisen miehen; oi toisen } \\
\text { miehen, oi toisen miehen }\end{array}$ \\
\hline 486 & 67 & Hevaa & Tönttölä & Terve suukkoi juuaksesi, terve suukkoi kanna kakloi \\
\hline 487 & 442 & Hevaa & Tönttölä & $\begin{array}{l}\text { Meroi tyttö metsoin sulho, korven korkea sevikka; ai ai ja } \\
\text { sevikk, korven korkea sevikk }\end{array}$ \\
\hline 488 & 646 & Hevaa & Tönttölä & $\begin{array}{l}\text { Venähen kanervoi veikko, hervoi veikko venäläin venäläin, } \\
\text { hervoi veikko venäläin }\end{array}$ \\
\hline 489 & 370 & Hevaa & Tönttölä & $\begin{array}{l}\text { Kokko lintu korven lintu korven lintu, sakkali salomen lintu } \\
\text { ja salomen }\end{array}$ \\
\hline 490 & 390 & Hevaa & Tönttölä & Kysyin maata velloltani, anoin maata ainoltani \\
\hline
\end{tabular}




\begin{tabular}{|c|c|c|c|c|}
\hline LEvón & IRS & PAIKKA & KYLÄ & K AlKusÄKeEt \\
\hline 491 & 648 & Hevaa & Tönttölä & $\begin{array}{l}\text { Velloini venosen seppo, laivoi seppo lakluven; ai velloini } \\
\text { venosen seppo, laivoi seppo lakluven }\end{array}$ \\
\hline 492 & 537 & Hevaa & Tönttölä & Ei oo ku pilveti eik pimeäti, ei oo ku savuti eik sakeat \\
\hline 493 & 181 & Hevaa & Tönttölä & La laulan pojaton vaimo, laulan tyhjä tyttärettä \\
\hline 494 & 166 & Hevaa & Vanha Huurala & Meillä kukkoi tapettihin, kanan kahla leikattihin \\
\hline 496 & 169 & Hevaa & Vanha Huurala & poika liikkui, tukkoi löyhki, kätkyt pärnäinen pärisi \\
\hline 498 & 414 & Hevaa & Vanha Huurala & Hiiri juoksi hipsutteli, rannan teitä rapsutteli \\
\hline 499 & 196 & Hevaa & Vanha Huurala & Mikä tu(v)olla näkyvi, talo tu(v)olla näkyvi \\
\hline 500 & 164 & Hevaa & Vanha Huurala & Jumalainen taimet talloi, Jumala rutjoi rukihit \\
\hline 501 & 567 & Hevaa & Vanha Huurala & Kauroi velloini verevä, kauroini kalaisueni \\
\hline 502 & 172 & Hevaa & Vanha Huurala & Laulaisin luettelisin, laulaisin mie mokoman virren \\
\hline 504 & 526 & Hevaa & Vanha Huurala & Vot ei laulella miun pitäisi, iloella ensinkään \\
\hline 505 & 412 & Hevaa & Vanha Huurala & La ka katson kannoillani, vieren varpahaisillan \\
\hline 506 & 255 & Hevaa & Vanha Huurala & Kylä ono tässä ennen ollut, kylä ono ennen kylä eglen \\
\hline 507 & 123 & Hevaa & Vanha Huurala & Mitä laulan kuta laulan, mitä otan virrekseni \\
\hline 508 & 504 & Hevaa & Vanha Huurala & kunpa nouvaan laulamaan, ja saan mie sanelemaan \\
\hline 509 & 503 & Hevaa & Vanha Huurala & Ennen olin aikoin aamuena, pyhä huomenna varahin \\
\hline 510 & 212 & Hevaa & Vanha Huurala & Ennen aikoina monina, ilman päivytä elettiin \\
\hline 511 & 182 & Hevaa & Vanha Huurala & jo alkoi kotihin mennä, aikoi marssia majoihin \\
\hline 512 & 185 & Hevaa & Vanha Huurala & hyvä iltanen taloihin, terve tänne teoillahaan \\
\hline 513 & 452 & Hevaa & Vanha Huurala & Kun mie nousen laulamahan, ja saaen sanelemahan \\
\hline 514 & 183 & Hevaa & Vanha Huurala & Tulkaa tytöt yötulelle, valukaatte valkealle \\
\hline 515 & 578 & Hevaa & Vanha Huurala & Kaukamoi poijut Kalervon, iski veitsen poijan päälle \\
\hline 516 & 576 & Hevaa & Vanha Huurala & Menin minä suolle sotkemaan, pellolle pusertamaan \\
\hline 517 & 98 & Hevaa & Vanha Huurala & Ennen aikoin aamuena, niin oli emolla poikoi \\
\hline 518 & 126 & Hevaa & Vanha Huurala & Ennen aikoin aamuena, ajoi meidän Luojoi julki \\
\hline 519 & 498 & Hevaa & Vanha Huurala & La ka katson lautojan, la siloita siltojan \\
\hline 520 & 466 & Hevaa & Vanha Huurala & $\begin{array}{l}\text { Jouvuin jouvuin mie muihen verroin, sain rahatta mie } \\
\text { ennen muita }\end{array}$ \\
\hline 522 & 548 & Hevaa & Uusi Huurala & Maijukainen miun emon, maijukkainen kaijukkainen \\
\hline 523 & 69 & Hevaa & Uusi Huurala & Ei mahu vävy tupahan, vävy kuusen suurukkainen \\
\hline 524 & 58 & Hevaa & Uusi Huurala & Elä liekkoi langettele, ei oo maasta nostajaista \\
\hline 525 & 338 & Hevaa & Uusi Huurala & Istu sie isotoin tyttö ja isotoin, ahin armoton asetu ja asetu \\
\hline 526 & 744 & Hevaa & Uusi Huurala & Oi oi taroi sie emoni lapsi ja emoin; oi oi taroi sie emoini laps \\
\hline 527 & 923 & Hevaa & Uusi Huurala & $\begin{array}{l}\text { Menin soikkolan sotahan, pärehinen miekka vyöllä; hm hää } \\
\text { tili tala juu, pärehinen miekka vyöll }\end{array}$ \\
\hline 529 & 203 & Tyrö & Tyrö & $\begin{array}{l}\text { Kuin ois kuin ois tuuli mieloillinen jo, tuinja moi tuinja } \\
\text { motyhai tuinja }\end{array}$ \\
\hline 530 & 845 & Tyrö & Ylikylä & K Puistin puistin maata velloiltani jo; ai lole lo jo velloiltani jo \\
\hline 533 & 672 & Tyrö & Ylikylä & Tulkaa tulkaa työ tytöt kokolle jo, ai lole lole ja kokolle jo \\
\hline 534 & 598 & Tyrö & Ylikylä & $\begin{array}{l}\text { Ee oita veikkoini veno; Veikkoini venosen seppo, laivoi sep- } \\
\text { po lakluven; ee oita laivoi seppo ja, laivoi seppo lakluven }\end{array}$ \\
\hline 537 & 396 & Tyrö & Porsaala & $\begin{array}{l}\text { Lopitsas oli loukka käyä, hei voi hoile, vaan oli paljo parsi- } \\
\text { mista, likatietä liukumista, hei lei liukumista hoile }\end{array}$ \\
\hline 538 & 724 & Tyrö & Porsaala & Naitteli isoi pojoista, kun et naittele pojoista \\
\hline 539 & 689 & Tyrö & Porsaala & $\begin{array}{l}\text { Ylen mies ylen ylen mies ylen hyvänen, toi ylimmäisen } \\
\text { ylimmäisen miehen poik }\end{array}$ \\
\hline
\end{tabular}




\section{LAUNIS 1906 (SKSÄ A 300-301)}

Launiksen fonogrammit (fon.) on siirretty kahteen otteeseen mangneettinauhoille ja digitoitu niistä (A ja fonokop). Kopiot ovat osin erilaiset ja paikoin vahalieriöt ovat menneet sekaisin.

Joitain samankaltaisia sävelmätoisintoja Launis julkaisi yhtenä nuottina (jommankumman äänitteen sanoilla varustettuna): IRS-viitteen perässä on tähti* niiden äänitteiden kohdalla, jotka noudattavat vähemmän Launiksen julkaiseman nuotin piirteitä.

Launiksen äänitysten kuorojen kokoonpanosta ei ole tarkempia tietoja.

$\mathrm{A}=\mathrm{SKSÄ} \mathrm{A}$.

fon. $=$ SKSÄ Launiksen fonogrammit Inkeristä vuodelta 1906.

$\mathrm{fk}=$ fonokop.

t. = tytär, n. = nainen .

\begin{tabular}{|c|c|c|c|c|c|c|c|}
\hline ViIte & & IRS & PAIKKA & KYLÄ & LAULAJA & $\mathrm{K}$ & ALKUSÄE \\
\hline A $300 / 9 a$ & $\begin{array}{l}\text { fon. } 1 \mathrm{a} ; \\
\mathrm{fk} 2 / 6\end{array}$ & 816 & Soikkola & Säätinä & $\begin{array}{l}\text { Naasto } \\
\text { Savasteint. }\end{array}$ & & $\begin{array}{l}\text { Pääsköilindu vaa päivöilindu vaa, } \\
\text { too ihala vaa ilmoillindu vaa }\end{array}$ \\
\hline A $300 / 9 b$ & $\begin{array}{l}\text { fon. } 1 b ; \\
\text { fk } 2 / 6\end{array}$ & & Soikkola & Säätinä & $\begin{array}{l}\text { Anna Tromifont. } \\
\text { Miikkulan n. }\end{array}$ & & $\begin{array}{l}\text { Oi marjukkaane mium maammoi- } \\
\text { ne maammoine }\end{array}$ \\
\hline A $300 / 9 c$ & $\begin{array}{l}\text { fon. } 1 \mathrm{c} ; \\
\mathrm{fk} 2 / 6\end{array}$ & 90 & Soikkola & Säätinä & $?$ & & $\begin{array}{l}\text { Teki tur(i)hin miun emmoine, } \\
\text { tekipa turuhin miun emmoini }\end{array}$ \\
\hline A $300 / 9$ c & $\begin{array}{l}\text { fon. } 1 \mathrm{~d} ; \\
\mathrm{fk} 2 / 6\end{array}$ & 259 & Soikkola & Säätinä & $?$ & & $\begin{array}{l}\text { Kadriina kotikannaine, kazvo } \\
\text { kallehin koissa }\end{array}$ \\
\hline A $300 / 9 c 2$ & $\begin{array}{l}\text { fon. } 1 \mathrm{~d} 2 \text {; } \\
\mathrm{fk} 2 / 6\end{array}$ & & Soikkola & Säätinä & $?$ & & $\begin{array}{l}\text { Kadri kokkoilinnukkaine, kauva too } \\
\text { kazveli koissa }\end{array}$ \\
\hline A $300 / 10 a$ & $\begin{array}{l}\text { fon. } 2 \mathrm{a} ; \\
\mathrm{fk} 2 / 7\end{array}$ & 817 & Soikkola & Säätinä & $\begin{array}{l}\text { Maria } \\
\text { Omeljant. }\end{array}$ & & $\begin{array}{l}\text { Meni soolle vaa kyndämähä, mäni } \\
\text { soolle vaa kyndämähä va }\end{array}$ \\
\hline A $300 / 10 b$ & $\begin{array}{l}\text { fon. } 2 \mathrm{~b} \\
\mathrm{fk} 2 / 7\end{array}$ & 154 & Soikkola & Säätinä & $\begin{array}{l}\text { Maria } \\
\text { Omeljant. }\end{array}$ & & $\begin{array}{l}\text { No meroiba meijen ikkunalla, } \\
\text { meroi meijen ikkunalla }\end{array}$ \\
\hline A $300 / 11 a$ & $\begin{array}{l}\text { fon. } 3 \mathrm{a} \\
\mathrm{fk} 2 / 8\end{array}$ & 316 & Soikkola & Säätinä & $\begin{array}{l}\text { Maria } \\
\text { Omeljant. }\end{array}$ & & $\begin{array}{l}\text { Oi eHittelin vellojani vellojani, } \\
\text { eHittelin vellojani vellojani }\end{array}$ \\
\hline A $300 / 11 b$ & $\begin{array}{l}\text { fon. } 3 b \text {; } \\
\text { fk } 2 / 8\end{array}$ & 334 & Soikkola & Viistinä & $\begin{array}{l}\text { Tatjana Grigo- } \\
\text { riant. }\end{array}$ & & $\begin{array}{l}\text { Kullervoi kalervoi poiGui ja } \\
\text { kaler(e)voi, kulervo kalervoi kuller }\end{array}$ \\
\hline A $300 / 12 a$ & $\begin{array}{l}\text { fon. } 4 \mathrm{a} ; \\
\mathrm{fk} 2 / 9\end{array}$ & 775 & Soikkola & Säätinä & $\begin{array}{l}\text { Naasto } \\
\text { Savasteint. }\end{array}$ & $\mathrm{K}$ & $\begin{array}{l}\text { Oi issuit kannessa ihala; oi dai issuit } \\
\text { kannes issuit kannessa iso }\end{array}$ \\
\hline A $300 / 13$ & $\begin{array}{l}\text { fon. } 5 \\
\text { fk } 2 / 10\end{array}$ & 65 & Soikkola & Säätinä & $\begin{array}{l}\text { Naasto } \\
\text { Savasteint. }\end{array}$ & $\mathrm{K}$ & $\begin{array}{l}\text { Oi kylvekkää kypenyveni; kylvekkä } \\
\text { kypenyveni }\end{array}$ \\
\hline A $300 / 14 a$ & $\begin{array}{l}\text { fon. } 6 \mathrm{a} \\
\mathrm{fk} 2 / 11\end{array}$ & 227 & Soikkola & Säätinä & $\begin{array}{l}\text { Naasto } \\
\text { Savasteint. }\end{array}$ & K & $\begin{array}{l}\text { Läksiv vaa koista kulkomaha; saa- } \\
\text { dulmoi saadu selennoi saadu }\end{array}$ \\
\hline A $300 / 14 b$ & $\begin{array}{l}\text { fon. } 6 \mathrm{~b} \\
\mathrm{fk} 2 / 11\end{array}$ & 345 & Soikkola & Säätinä & $\begin{array}{l}\text { Naasto } \\
\text { Savasteint. }\end{array}$ & K & $\begin{array}{l}\text { Oi marjukkaine mium maammione } \\
\text { maammo }\end{array}$ \\
\hline A $300 / 15$ & $\begin{array}{l}\text { fon. } 7 \\
\mathrm{fk} 2 / 12\end{array}$ & 858 & Soikkola & Säätinä & $\begin{array}{l}\text { Naasto } \\
\text { Savasteint. }\end{array}$ & $\mathrm{K}$ & $\begin{array}{l}\text { Oi la laulan suruisev verrej ja sura, } \\
\text { oi l'oile laadoi sejelaa sejelaa }\end{array}$ \\
\hline A $300 / 16 b$ & $\begin{array}{l}\text { fon. } 8 \mathrm{~b} \\
\mathrm{fk} 2 / 13\end{array}$ & 153 & Soikkola & Tammik. & $\begin{array}{l}\text { Nadja } \\
\text { Kortteint. }\end{array}$ & $\mathrm{K}$ & $\begin{array}{l}\text { Velloini vennoisen seppoi; oi dai } \\
\text { l'ole ja vennoisen }\end{array}$ \\
\hline A $300 / 17 a$ & $\begin{array}{l}\text { fon. } 9 \mathrm{a} ; \\
\mathrm{fk} 3 / 2\end{array}$ & 427 & Soikkola & Tammik. & $\begin{array}{l}\text { Nadja } \\
\text { Kortteint. }\end{array}$ & $\mathrm{K}$ & $\begin{array}{l}\text { Elettihe ennem meil, eletti ojiin } \\
\text { takkaan; ai l'ole pa l'ole, elettiin ojan } \\
\text { takkaa/ee }\end{array}$ \\
\hline A $300 / 17 b$ & $\begin{array}{l}\text { fon. } 9 \mathrm{~b} \\
\mathrm{fk} 3 / 2\end{array}$ & 303 & Soikkola & Säätinä & $\begin{array}{l}\text { Naasto } \\
\text { Savasteint. }\end{array}$ & $\mathrm{K}$ & $\begin{array}{l}\text { Langoiseni linduiseni; langoiseni } \\
\text { linduiseni }\end{array}$ \\
\hline
\end{tabular}




\begin{tabular}{|c|c|c|c|c|c|c|c|}
\hline ViIte & & IRS & РAIKKA & KYLÄ & LAULAJA & K & AlKusäE \\
\hline A $300 / 18 a$ & $\begin{array}{l}\text { fon. 10a; } \\
\text { fk3/3 }\end{array}$ & 557 & Soikkola & Koskina & Liisa Petront. & K & $\begin{array}{l}\text { Kullervoi kalervoi poigoi, Hellervoi } \\
\text { Heliä viitta; kaalina/oi maalin/oi }\end{array}$ \\
\hline A $300 / 18 b$ & $\begin{array}{l}\text { fon. } 10 \mathrm{~b} ; \\
\mathrm{fk} 3 / 3\end{array}$ & 599 & Soikkola & Koskina & Liisa Petront. & K & $\begin{array}{l}\text { Oi elkää looGo suuri loojoi, sitä } \\
\text { lasta synDymää; oi liaa syndymää, } \\
\text { sitä lasta synDymää }\end{array}$ \\
\hline A $300 / 19 a$ & $\begin{array}{l}\text { fon. 11a; } \\
\text { fk3/4 }\end{array}$ & 344 & Soikkola & Koskina & $\begin{array}{l}\text { Okkuliina } \\
\text { Ivanant. }\end{array}$ & K & $\begin{array}{l}\text { Oi miks on miulla äänöi peeni } \\
\text { äänöi peee }\end{array}$ \\
\hline A $300 / 19 b$ & $\begin{array}{l}\text { fon. } 11 \mathrm{~b} ; \\
\mathrm{fk} 3 / 4\end{array}$ & 135 & Soikkola & Säätinä & $\begin{array}{l}\text { Tarja Plato- } \\
\text { nont. }\end{array}$ & K & $\begin{array}{l}\text { Avatkaa virov veräjä; avatkaa virov } \\
\text { veräjä }\end{array}$ \\
\hline A $300 / 20 a$ & $\begin{array}{l}\text { fon. 12a; } \\
\text { fk3/5 }\end{array}$ & 136 & Soikkola & Koskina & $\begin{array}{l}\text { Okkuliina } \\
\text { Iivanant. }\end{array}$ & K & $\begin{array}{l}\text { Avatkaa virov veräjä; avatkaa virov } \\
\text { veräjä }\end{array}$ \\
\hline A $300 / 20 b$ & $\begin{array}{l}\text { fon. } 12 \mathrm{~b} ; \\
\text { fk3/5 }\end{array}$ & 254 & Soikkola & Koskina & Liisa Petront. & K & $\begin{array}{l}\text { Meijän(ä) lintu meijäl liitso; meijäl } \\
\text { lintu mejel liitso }\end{array}$ \\
\hline A $300 / 20 c$ & $\begin{array}{l}\text { fon. } 12 \mathrm{c} ; \\
\mathrm{fk} 3 / 5\end{array}$ & 774 & Soikkola & Koskina & Liisa Petront. & K & $\begin{array}{l}\text { I otojani sizojani; oi dai otojani } \\
\text { otojani sizoja }\end{array}$ \\
\hline A $300 / 21 a$ & $\begin{array}{l}\text { fon. } 13 \mathrm{a} ; \\
\mathrm{fk} 3 / 6\end{array}$ & & Soikkola & Säätinä & $\begin{array}{l}\text { Marfa Savas- } \\
\text { teint. }\end{array}$ & K & $\begin{array}{l}\text { Oi oi miun ehtoisa emoin; ehtoisa } \\
\text { ehoittajaa; oi kaalina timojaa, oi } \\
\text { maalina timoja }\end{array}$ \\
\hline $300 / 21 b$ & $\begin{array}{l}\text { fon. } 13 \mathrm{~b} \text {; } \\
\mathrm{fk} 3 / 6\end{array}$ & 542 & Soikkola & Koskina & Liisa Petront. & K & $\begin{array}{l}\text { Oi käki kukkui maa kumis, lindu } \\
\text { lauloi lehti lee; oi kalina timoja, oi } \\
\text { malina timoja }\end{array}$ \\
\hline A $300 / 22 a$ & $\begin{array}{l}\text { fon. } 14 \mathrm{a} \text {; } \\
\mathrm{fk} 3 / 7\end{array}$ & 542 & Soikkola & Koskina & Liisa Petront. & K & $\begin{array}{l}\text { Oi käki kukkui maa kumis, lindu } \\
\text { lauloi lehti lee; oi kalina timoja, oi } \\
\text { malina timoja }\end{array}$ \\
\hline A $300 / 22$ b & $\begin{array}{l}\text { fon. } 14 \mathrm{~b} ; \\
\mathrm{fk} 3 / 7\end{array}$ & 463 & Soikkola & Koskina & Liisa Petront. & K & $\begin{array}{l}\text { EHIttelin vellojani, eHittelin ken- } \\
\text { Gitte; ras kalina maja, ras malina } \\
\text { maja }\end{array}$ \\
\hline A $300 / 23 a$ & $\begin{array}{l}\text { fon. } 15 \mathrm{a} ; \\
\mathrm{fk} 3 / 8\end{array}$ & 424 & Soikkola & Koskina & Liisa Petront. & K & $\begin{array}{l}\text { Oi elettiHe ennem meillä, olttiHe } \\
\text { ojan takkaa; oi sveti kalinika, oi } \\
\text { drugoi galobnika/oi }\end{array}$ \\
\hline A $300 / 23 b$ & $\begin{array}{l}\text { fon. } 15 b ; \\
\text { fk3/8 }\end{array}$ & 851 & Soikkola & Koskina & Liisa Petront. & K & $\begin{array}{l}\text { laulella i pittää- } \\
\text { ä }\end{array}$ \\
\hline A $300 / 24 a$ & $\begin{array}{l}\text { fon. } 16 \mathrm{a} ; \\
\mathrm{fk} 4 / 1\end{array}$ & 851 & Soikkola & Koskina & Liisa Petront. & K & $\begin{array}{l}\text { Ei miun laulella ha laulella i pittää- } \\
\text { Hä, laulella pittäähä; ilota se la ha oi } \\
\text { vai sinä ikänä, ja sinä ikänä }\end{array}$ \\
\hline A $300 / 24 b$ & $\begin{array}{l}\text { fon. } 16 \mathrm{~b} ; \\
\text { fk4/1 }\end{array}$ & 319 & Soikkola & Koskina & Liisa Petront. & K & $\begin{array}{l}\text { sin suurelle mäelle, noisin } \\
\text { le mäelle }\end{array}$ \\
\hline A $300 / 25 a$ & $\begin{array}{l}\text { fon. } 17 \mathrm{a} ; \\
\mathrm{fk} 4 / 2\end{array}$ & 541 & Soikkola & Koskina & Liisa Petront. & K & $\begin{array}{l}\text { en laula laulujan, en ilo } \\
\text { an; vet en laula lauluja, en ilo } \\
\text { n }\end{array}$ \\
\hline A $300 / 25 b$ & $\begin{array}{l}\text { fon. } 17 \mathrm{~b} ; \\
\mathrm{fk} 4 / 2\end{array}$ & 395 & Soikkola & Koskina & Liisa Petront. & K & $\begin{array}{l}\text { Oi pääsköilindu päivöilindu, tuu } \\
\text { ihhaala ilmolilii; ras kalina maja, ras } \\
\text { malina maja }\end{array}$ \\
\hline A $300 / 26 a$ & $\begin{array}{l}\text { fon. 18a; } \\
\text { fk } 4 / 3\end{array}$ & 83 & Soikkola & Säätinä & $\begin{array}{l}\text { Ljuboi } \\
\text { Jeyssen n. }\end{array}$ & K & $\begin{array}{l}\text { Leinää leinää hyvä prouva; leinää } \\
\text { leinää hyvä prouva }\end{array}$ \\
\hline A $300 / 26 b$ & $\begin{array}{l}\text { fon. } 18 \mathrm{~b} ; \\
\mathrm{fk} 4 / 3\end{array}$ & 540 & Soikkola & Säätinä & $\begin{array}{l}\text { Ljuboi } \\
\text { Jeyssen n. }\end{array}$ & K & $\begin{array}{l}\text { Oi läksin koista kulgomaHa, ve- } \\
\text { räjiltä veerömää; oi liaa veerömää, } \\
\text { veräjildä veerömää }\end{array}$ \\
\hline A $300 / 27 a$ & $\begin{array}{l}\text { fon. 19a; } \\
\text { fk4/4 }\end{array}$ & 781 & Soikkola & Säätinä & $\begin{array}{l}\text { Ljuboi } \\
\text { Jeyssen n. }\end{array}$ & K & $\begin{array}{l}\text { La ka katsol leekkuvaa(ee); la ka vaa } \\
\text { katson leekkuvaaha }\end{array}$ \\
\hline A $300 / 27 b$ & $\begin{array}{l}\text { fon. } 19 \mathrm{~b} ; \\
\mathrm{fk} 4 / 4\end{array}$ & 841 & Soikkola & Säätinä & $\begin{array}{l}\text { Ljuboi } \\
\text { Jeyssen n. }\end{array}$ & K & $\begin{array}{l}\text { Kenen too kylä näkyyHö; kenen too } \\
\text { kylä näkyyö }\end{array}$ \\
\hline A $300 / 28 a$ & $\begin{array}{l}\text { fon. 20a; } \\
\text { fk } 4 / 5\end{array}$ & 215 & Soikkola & Säätinä & $\begin{array}{l}\text { Ljuboi } \\
\text { Jeyssen n. }\end{array}$ & K & $\begin{array}{l}\text { Emoi synnöt synnötti minoo; emo } \\
\text { synnöt synnötti minoo }\end{array}$ \\
\hline A $300 / 28 c$ & $\begin{array}{l}\text { fon. } 20 \mathrm{c} ; \\
\mathrm{fk} 4 / 5\end{array}$ & 919 & Soikkola & Säätinä & $\begin{array}{l}\text { Ljuboi } \\
\text { Jeyssen n. }\end{array}$ & & $\begin{array}{l}\text { Oi ene kiidäkkää emoja, en ylennä } \\
\text { ättiää, oi kalina kamaja, oi malina } \\
\text { kamaja }\end{array}$ \\
\hline A $300 / 29 a$ & $\begin{array}{l}\text { fon. 21a; } \\
\text { fk } 4 / 6\end{array}$ & 429 & Soikkola & Säätinä & $\begin{array}{l}\text { Naasto } \\
\text { Savasteint. }\end{array}$ & & $\begin{array}{l}\text { Oi tiraruu tararuu, meijen kukkoi } \\
\text { tapettii; meijen kukkoi tapettii, } \\
\text { kanan kagla leigattii }\end{array}$ \\
\hline
\end{tabular}




\begin{tabular}{|c|c|c|c|c|c|c|c|}
\hline ViIte & & IRS & PAIKKA & KYLÄ & LAULAJA & K & AlKusÄE \\
\hline A $300 / 29 b$ & $\begin{array}{l}\text { fon. } 21 \mathrm{~b} ; \\
\mathrm{fk} 4 / 6\end{array}$ & 428 & Soikkola & Säätinä & $\begin{array}{l}\text { Naasto } \\
\text { Savasteint. }\end{array}$ & $\mathrm{K}$ & $\begin{array}{l}\text { Oi midä myy tytöt sure, ilmal } \\
\text { lauluda elä; ai l'ole pai lole, ilmal } \\
\text { lauluda elä }\end{array}$ \\
\hline A $300 / 29 b$ & $\begin{array}{l}\text { fon. } 21 \mathrm{c} ; \\
\mathrm{fk} 4 / 6\end{array}$ & 435 & Soikkola & Säätinä & $\begin{array}{l}\text { Naasto } \\
\text { Savasteint. }\end{array}$ & $\mathrm{K}$ & $\begin{array}{l}\text { Olin yksi äidilleni, maksoin kaksi } \\
\text { mammalle; ai l'ole pai l'ole, maksoin } \\
\text { kaksi mammalle }\end{array}$ \\
\hline 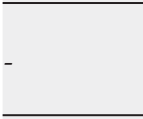 & $\begin{array}{l}\text { fon. } 22 \mathrm{~b} ; \\
\mathrm{fk} 4 / 7\end{array}$ & 776 & Soikkola & Mäkkylä & $\begin{array}{l}\text { Anna Mitrint. } \\
\text { Frolgan } n \text {. }\end{array}$ & K & $\begin{array}{l}\text { Oi nyd miä laulan nyd(e) miä jou- } \\
\text { van; oi dai nyt miä la[ulan nyD miä } \\
\text { laulan nyD miä jou] }\end{array}$ \\
\hline - & $\begin{array}{l}\text { fon. } 22 \mathrm{a} ; \\
\mathrm{fk} 4 / 7\end{array}$ & 891 & Soikkola & Mäkkylä & $\begin{array}{l}\text { Anna Mitrint. } \\
\text { Frolgan } \mathrm{n} \text {. }\end{array}$ & $\mathrm{K}$ & $\begin{array}{l}\text { EdäHäl om miun emo; edäHällä } \\
\text { edäHällä miun emo }\end{array}$ \\
\hline A $300 / 30 a$ & $\begin{array}{l}\text { fon. 23a; } \\
\mathrm{fk} 4 / 8\end{array}$ & 898 & Soikkola & Mäkkylä & $\begin{array}{l}\text { Anna Mitrint. } \\
\text { Frolgan } n .\end{array}$ & $\mathrm{K}$ & $\begin{array}{l}\text { Päivöim poigoi valgijaine, manum } \\
\text { poigoi miis mattaa; päivöim poigoi } \\
\text { valgijaine, manum poigoi miis mattaa }\end{array}$ \\
\hline A $300 / 30 b$ & $\begin{array}{l}\text { fon. } 23 \mathrm{~b} \\
\mathrm{fk} 4 / 8\end{array}$ & 462 & Soikkola & Mäkkylä & $\begin{array}{l}\text { Anna Mitrint. } \\
\text { Frolgan n. }\end{array}$ & $\mathrm{K}$ & $\begin{array}{l}\text { LäHe neitoinem minulle, läHe } \\
\text { neidoi velloilleni; vot i kalina dai } \\
\text { vot i malina }\end{array}$ \\
\hline A $300 / 31 a$ & $\begin{array}{l}\text { fon. 24a; } \\
\text { fk4/9 }\end{array}$ & 681 & Soikkola & Mäkkylä & $\begin{array}{l}\text { Anna Mitrint. } \\
\text { Frolgan } \mathrm{n} \text {. }\end{array}$ & $\mathrm{K}$ & $\begin{array}{l}\text { VeD ei van(a)Hoista iloa va jooi; } \\
\text { veD ei vanHoista iloa va jooi }\end{array}$ \\
\hline A $300 / 31 b$ & $\begin{array}{l}\text { fon. } 24 \mathrm{~b} ; \\
\text { fk } 4 / 9\end{array}$ & 664 & Soikkola & Mäkkylä & $\begin{array}{l}\text { Anna Mitrint. } \\
\text { Frolgan } n .\end{array}$ & $\mathrm{K}$ & $\begin{array}{l}\text { Päivöim poigoi valgijaine, manum } \\
\text { poigoi miiz mattaala; päivöim } \\
\text { poigoi valgijaine, manum poigoi } \\
\text { miis mattaa }\end{array}$ \\
\hline A $300 / 32 a$ & fon. $25 \mathrm{a}$; & 666 & Soikkola & Mäkkylä & $\begin{array}{l}\text { Anna Mitrint. } \\
\text { Frolgan n. }\end{array}$ & K & $\begin{array}{l}\text { Kullervoi kalervoi poigoi, Hellervoi } \\
\text { Heliä vee; kullervoi kalervoi poiGoi, } \\
\text { hellervoi heliä vee }\end{array}$ \\
\hline A $300 / 32 b$ & fon. $25 b$ & 272 & Soikkola & Mäkkylä & $\begin{array}{l}\text { Anna Mitrint. } \\
\text { Frolgan } \mathrm{n} \text {. }\end{array}$ & K & $\begin{array}{l}\text { Oi midä noo midä noise laulamaa; } \\
\text { midä noo midä noise laulamaa }\end{array}$ \\
\hline A $300 / 33 a$ & $\begin{array}{l}\text { fon. 26a; } \\
\text { fk } 4 / 10\end{array}$ & 341 & Soikkola & Mäkkylä & $\begin{array}{l}\text { Anna Mitrint. } \\
\text { Frolgan } \mathrm{n} \text {. }\end{array}$ & $\mathrm{K}$ & $\begin{array}{l}\text { EHittelin vellojani vellojani; } \\
\text { rasel'(e)moi ja lovina drasel’a/oi }\end{array}$ \\
\hline A $300 / 33$ b & $\begin{array}{l}\text { fon. } 26 \mathrm{~b} ; \\
\mathrm{fk} 4 / 10\end{array}$ & 726 & Soikkola & Mäkkylä & $\begin{array}{l}\text { Anna Mitrint. } \\
\text { Frolgan } \mathrm{n} .\end{array}$ & $\mathrm{K}$ & $\begin{array}{l}\text { Meijen kudroipää kuniigas; meijen } \\
\text { kudroipää kuniigas; meijen kudroi- } \\
\text { pääkuniigas vaHHoitukka; meijen } \\
\text { kudroipää kuniigas vaHHoitukka }\end{array}$ \\
\hline A $300 / 34 a$ & $\begin{array}{l}\text { fon. } 27 \mathrm{a} ; \\
\text { fk } 4 / 11\end{array}$ & 582 & Soikkola & Mäkkylä & $\begin{array}{l}\text { Anna Mitrint. } \\
\text { Frolgan } n .\end{array}$ & $\mathrm{K}$ & $\begin{array}{l}\text { Oi emoi neuvoi neiDojaa, oBasti } \\
\text { omenuttaa; emoi neuvoi neiDojaa, } \\
\text { oBasti omenuttaa }\end{array}$ \\
\hline A $300 / 34 b$ & $\begin{array}{l}\text { fon. } 27 \mathrm{~b} \\
\text { fk } 4 / 11\end{array}$ & 392 & Soikkola & Mäkkylä & $\begin{array}{l}\text { Anna Mitrint. } \\
\text { Frolgan } \mathrm{n} \text {. }\end{array}$ & $\mathrm{K}$ & $\begin{array}{l}\text { Yks oli oinepuu kylässä, yks oli oi- } \\
\text { nepuu kylässä; ja kylässä ja kylässä }\end{array}$ \\
\hline A $300 / 35 a$ & $\begin{array}{l}\text { fon. 28a; } \\
\text { fk } 4 / 12\end{array}$ & 857 & Soikkola & Mäkkylä & $\begin{array}{l}\text { Anna Mitrint. } \\
\text { Frolgan } n .\end{array}$ & $\mathrm{K}$ & $\begin{array}{l}\text { Oi katsoin il(i)mat vaa katsoin } \\
\text { kalmat katsoin ka; oi l'uuli laadoi } \\
\text { sejelaa sejelaa }\end{array}$ \\
\hline A $300 / 35$ b & $\begin{array}{l}\text { fon. } 28 \mathrm{~b} ; \\
\text { fk } 4 / 12\end{array}$ & 547 & Soikkola & Mäkkylä & $\begin{array}{l}\text { Anna Mitrint. } \\
\text { Frolgan n. }\end{array}$ & $\mathrm{K}$ & $\begin{array}{l}\text { oi miul laulella pitäisi, eik ilota } \\
\text { ensinkää; kalena malena }\end{array}$ \\
\hline A $300 / 36 a$ & $\begin{array}{l}\text { fon. } 29 \mathrm{a} ; \\
\text { fk5/1 }\end{array}$ & 234 & Soikkola & Mäkkylä & $\begin{array}{l}\text { Anna Mitrint. } \\
\text { Frolgan } \mathrm{n} \text {. }\end{array}$ & K & $\begin{array}{l}\text { [Lähem]mä läpi kyläise; oi saadu } \\
\text { saadu selennoi saadu }\end{array}$ \\
\hline A $300 / 36 b$ & $\begin{array}{l}\text { fon. } 29 \mathrm{~b} ; \\
\text { fk } 5 / 1\end{array}$ & 581 & Soikkola & Mäkkylä & $\begin{array}{l}\text { Anna Mitrint. } \\
\text { Frolgan n. }\end{array}$ & K & $\begin{array}{l}\text { Oi läksin koista kulkomaHa, veräjil- } \\
\text { tä veerömää; oi kalina oi malina }\end{array}$ \\
\hline A $300 / 37 a$ & $\begin{array}{l}\text { fon. 30a; } \\
\text { fk } 5 / 2\end{array}$ & 493 & Soikkola & Mäkkylä & $\begin{array}{l}\text { Anna Mitrint. } \\
\text { Frolgan } \mathrm{n} \text {. }\end{array}$ & $\mathrm{K}$ & $\begin{array}{l}\text { oi velloine venoisen seppoi, laivoin } \\
\text { seppoi lagluvee; oi tunjuška ma } \\
\text { tunja, tunja ja ka kamaja }\end{array}$ \\
\hline A $300 / 37 b$ & $\begin{array}{l}\text { fon. } 30 \mathrm{~b} \\
\text { fk } 5 / 2\end{array}$ & 103 & Soikkola & Mäkkylä & $\begin{array}{l}\text { Anna Mitrint. } \\
\text { Frolgan } \mathrm{n} \text {. }\end{array}$ & $\mathrm{K}$ & $\begin{array}{l}\text { Oi kylvekkää kypenyveni; kylvek- } \\
\text { kää kypenyveni }\end{array}$ \\
\hline A $300 / 38 a$ & $\begin{array}{l}\text { fon. 31a; } \\
\text { fk } 5 / 3\end{array}$ & 844 & Soikkola & Mäkkylä & $\begin{array}{l}\text { Anna Mitrint. } \\
\text { Frolgan n. }\end{array}$ & $\mathrm{K}$ & $\begin{array}{l}\text { Souva laivoi jouva laivoi; souva } \\
\text { laivoi jouva laivoi; souva sille saa- } \\
\text { ruelle/oi; souva sille saaruvelle (oi) }\end{array}$ \\
\hline A $300 / 38 b$ & $\begin{array}{l}\text { fon. } 31 \mathrm{~b} ; \\
\mathrm{fk} 5 / 3\end{array}$ & 821 & Soikkola & Mäkkylä & $\begin{array}{l}\text { Anna Mitrint. } \\
\text { Frolgan } n .\end{array}$ & $\mathrm{K}$ & $\begin{array}{l}\text { Oi ei miul laulel laulella pittäisi ja } \\
\text { pittää; oi ei miul laulel laulella pittää }\end{array}$ \\
\hline
\end{tabular}




\begin{tabular}{|c|c|c|c|c|c|c|}
\hline ViIte & & IRS & PAIKKA & KYLÄ & LAULAJA & AlKusÄE \\
\hline A $300 / 39 a$ & $\begin{array}{l}\text { fon. 32a; } \\
\text { fk } 5 / 4\end{array}$ & 906 & Soikkola & Mäkkylä & $\begin{array}{l}\text { Anna Mitrint. } \mathrm{K} \\
\text { Frolgan } \mathrm{n} .\end{array}$ & $\begin{array}{l}\text { Oi vet ei vanHoista iloa, ku ei meis- } \\
\text { tä tyttöläi; hei hei l'juba dai l'ole, ko } \\
\text { ei meistä tyttölöi }\end{array}$ \\
\hline A $300 / 39 b$ & $\begin{array}{l}\text { fon. } 32 \mathrm{~b} ; \\
\text { fk5/4 }\end{array}$ & 102 & Soikkola & Mäkkylä & $\begin{array}{l}\text { Anna Mitrint. } \mathrm{K} \\
\text { Frolgan } \mathrm{n} .\end{array}$ & $\begin{array}{l}\text { Oi ka pois kaima kapakkaa; ka pois } \\
\text { kaima kapakkaa }\end{array}$ \\
\hline A $300 / 40 a$ & $\begin{array}{l}\text { fon. 33a; } \\
\text { fk5/5 }\end{array}$ & 465 & Soikkola & Mäkkylä & $\begin{array}{l}\text { Anna Mitrint. } \mathrm{K} \\
\text { Frolgan } \mathrm{n} .\end{array}$ & $\begin{array}{l}\text { Oi la laulam mokkoomav verrej, } \\
\text { KoD ei voi jumalakkaa; ras kalina } \\
\text { maja, ras malina maja }\end{array}$ \\
\hline A $300 / 40 b$ & $\begin{array}{l}\text { fon. } 33 \mathrm{~b} ; \\
\text { fk } 5 / 5\end{array}$ & 766 & Soikkola & Mäkkylä & $\begin{array}{l}\text { Anna Mitrint. } \mathrm{K} \\
\text { Frolgan } \mathrm{n} .\end{array}$ & $\begin{array}{l}\text { Oi njo njo njo Heboisueni; njo njo } \\
\text { njo Heboisueni }\end{array}$ \\
\hline A $300 / 41 b$ & $\begin{array}{l}\text { fon. } 34 \mathrm{~b} ; \\
\text { fk5/6 }\end{array}$ & 524 & Soikkola & Mäkkylä & $\begin{array}{l}\text { Matreuna Mi- } \\
\text { ront. Onoin } \mathrm{n} .\end{array}$ & $\begin{array}{l}\text { Turoi linnasta tullooHo, viiBurista } \\
\text { viuhkajaa; selinnikoi selajaa }\end{array}$ \\
\hline A $300 / 42 a$ & $\begin{array}{l}\text { fon. } 35 \mathrm{a} \text {; } \\
\text { fk5/7 }\end{array}$ & 464 & Soikkola & Mäkkylä & $\begin{array}{l}\text { Ustenja Miikku- } \\
\text { lant. Porfein } \mathrm{K} .\end{array}$ & $\begin{array}{l}\text { Oi emoi kazvatti minuista, miä } \\
\text { kassoin kazvattelin; vot i kalina dai, } \\
\text { vot i malina, vot kalina vot malina, } \\
\text { lekla jaga da ba dila, vot i kalina dai, } \\
\text { vot i malina }\end{array}$ \\
\hline A $300 / 42 b$ & $\begin{array}{l}\text { fon. } 35 b ; \\
\text { fk5/7 }\end{array}$ & 583 & Soikkola & Mäkkylä & $\begin{array}{l}\text { Ustenja Miikku- } \mathrm{K} \\
\text { lant. Porfein } \mathrm{n} .\end{array}$ & $\begin{array}{l}\text { Ee nuGuta jumala lasta, maGahuta } \\
\text { maaria; nukuta jumala last, maGa- } \\
\text { Huta maaria }\end{array}$ \\
\hline A $300 / 43 b$ & $\begin{array}{l}\text { fon. } 36 \mathrm{~b} ; \\
\text { fk } 5 / 8\end{array}$ & 323 & Soikkola & Mäkkylä & $\begin{array}{l}\text { Ustenja Miikku-- } \\
\text { lant. Porfein n. }\end{array}$ & $\begin{array}{l}\text { Ohoi la laulan ilta(oi)vilulla; la } \\
\text { laulan iltaviluu }\end{array}$ \\
\hline A $300 / 44 a$ & $\begin{array}{l}\text { fon. } 37 \mathrm{a} ; \\
\text { fk5/8 }\end{array}$ & 213 & Soikkola & Mäkkylä & $\begin{array}{l}\text { Ustenja Miikku-- } \\
\text { lant. Porfein } \mathrm{n} \text {. }\end{array}$ & $\begin{array}{l}\text { Oi teki väärim miun emmoine ja; } \\
\text { teki väärim miun emmoine ja }\end{array}$ \\
\hline A $300 / 44 b$ & $\begin{array}{l}\text { fon. } 37 \mathrm{~b} ; \\
\text { fk5/10 }\end{array}$ & 416 & Soikkola & Mäkkylä & $\begin{array}{l}\text { Ustenja Miikku- } \\
\text { lant. Porfein } \mathrm{n} .\end{array}$ & $\begin{array}{l}\text { Oi miun too ehtoisa emoim, miun } \\
\text { too ehtoisa emoin; ja emo emoine, } \\
\text { ja emoine joonoo }\end{array}$ \\
\hline A $300 / 44$ b & $\begin{array}{l}\text { fon. } 38 \mathrm{a} ; \\
\mathrm{fk} 5 / 10\end{array}$ & 611 & Soikkola & Mäkkylä & $\begin{array}{l}\text { Ustenja Miikku- } \\
\text { lant. Porfein } \mathrm{n} .\end{array}$ & $\begin{array}{l}\text { Oi miks om meitä näin väHHäisen } \\
\text { i ja ja väHHä; näin väHHäisej joo }\end{array}$ \\
\hline A $300 / 45 a$ & $\begin{array}{l}\text { fon. } 38 \mathrm{~b} ; \\
\text { fk5/10 }\end{array}$ & 76 & Soikkola & Mäkkylä & $\begin{array}{l}\text { Ustenja Miikku-- } \\
\text { lant. Porfein } \mathrm{n} \text {. }\end{array}$ & $\begin{array}{l}\text { Nii zaa terve suukkoi juuvakseni; } \\
\text { tere suukkoi jooakseni }\end{array}$ \\
\hline A $300 / 46 a$ & $\begin{array}{l}\text { fon. 39a; } \\
\text { fk5/11 }\end{array}$ & 553 & Soikkola & Mäkkylä & $\begin{array}{l}\text { Ustenja Miikku- } \\
\text { lant. Porfein } n .\end{array}$ & $\begin{array}{l}\text { O meijen kudroipää kuniigas, } \\
\text { vaHHoi tukkoi linnoin vanhin; } \\
\text { selinnikoi selajaa }\end{array}$ \\
\hline A $300 / 46 b$ & $\begin{array}{l}\text { fon. } 39 \mathrm{~b} ; \\
\text { fk } 5 / 11\end{array}$ & 271 & Soikkola & Mäkkylä & $\begin{array}{l}\text { Ustenja Miikku- } \\
\text { lant. Porfein } n .\end{array}$ & $\begin{array}{l}\text { Oi la miä lau la miä laulan nyt miä } \\
\text { jou; la miä lau la miä laulan nyt } \\
\text { miä jou }\end{array}$ \\
\hline A $300 / 47 a$ & $\begin{array}{l}\text { fon. } 40 \mathrm{a} ; \\
\text { fk5/12 }\end{array}$ & 538 & Soikkola & Mäkkylä & $\begin{array}{l}\text { Ustenja Miikku- } \\
\text { lant. Porfein } n .\end{array}$ & $\begin{array}{l}\text { Oi miuv velloi venoisen seppoi, } \\
\text { seppoi laivoil lagluven; miuv velloi } \\
\text { venoisen seppois, laivoin seppoi } \\
\text { lagluven }\end{array}$ \\
\hline A $300 / 47 b$ & $\begin{array}{l}\text { fon. } 40 \mathrm{~b} ; \\
\text { fk5/12 }\end{array}$ & 317 & Soikkola & Säätinä & $\begin{array}{l}\text { Ustenja Miikku-- } \\
\text { lant. Porfein } n .\end{array}$ & $\begin{array}{l}\text { Oi ilija pyhä izända izända; ilija } \\
\text { pyhä izändä izändä }\end{array}$ \\
\hline A $300 / 48 a$ & $\begin{array}{l}\text { fon. 41a; } \\
\text { fk6/1 }\end{array}$ & 772 & Soikkola & Mäkkylä & $\begin{array}{l}\text { Ustenja Miikku-- } \\
\text { lant. Porfein } n .\end{array}$ & $\begin{array}{l}\text { O livukka rekoi lippijä; livukka } \\
\text { rekoi lippijä }\end{array}$ \\
\hline A $300 / 48 b$ & $\begin{array}{l}\text { fon. } 41 \mathrm{~b} ; \\
\mathrm{fk} 6 / 1\end{array}$ & 820 & Soikkola & Mäkkylä & $\begin{array}{l}\text { Ustenja Miikku- } \\
\text { lant. Porfein } \mathrm{n} .\end{array}$ & $\begin{array}{l}\text { Oi oi jokoi vaa ja sijaruveni jaruve; } \\
\text { oi oi jokoi vaa ja sijaruve }\end{array}$ \\
\hline A $300 / 49 a$ & $\begin{array}{l}\text { fon. } 42 \mathrm{a} \text {; } \\
\text { fk6/2 }\end{array}$ & 620 & Soikkola & Viistinä & Katoi Vydrent. K & $\begin{array}{l}\text { Oi miun ehtoisa emoine, ehtoisa } \\
\text { ehoittajain; oi miun ehtoisa emoine, } \\
\text { ehtoisa ehoittajoo }\end{array}$ \\
\hline A $300 / 49 b$ & $\begin{array}{l}\text { fon. } 42 b ; \\
\text { fk6/2 }\end{array}$ & 637 & Soikkola & Viistinä & Katoi Vydrent. K & $\begin{array}{l}\text { Läksin koisDa kulgomaHA, veräjil- } \\
\text { dä viirömään; läksin koista kulgo- } \\
\text { maHa, veräjildä veerömää }\end{array}$ \\
\hline A $300 / 50 a$ & $\begin{array}{l}\text { fon. 43a; } \\
\text { fk6/3 }\end{array}$ & $620^{*}$ & +Soikkola & Viistinä & Katoi Vydrent. K & $\begin{array}{l}\text { Mänim mar(i)jaham maammoille, } \\
\text { karpaloHo kandaja (oi); mänim } \\
\text { mar(i)jaHam maamoille, karpalo- } \\
\text { Ho kandaja (oi) }\end{array}$ \\
\hline A $300 / 50 b$ & $\begin{array}{l}\text { fon. } 43 b \text {; } \\
\text { fk } 6 / 3\end{array}$ & 894 & Soikkola & Viistinä & Katoi Vydrent. & $\begin{array}{l}\text { La miä laulal laiHa lindu, veeretäv } \\
\text { väHäveriin }\end{array}$ \\
\hline
\end{tabular}




\begin{tabular}{|c|c|c|c|c|c|c|c|}
\hline ViIte & & IRS & PAIKKA & KYLÄ & LAULAJA & K & ALKUSÄE \\
\hline A $300 / 51 a$ & $\begin{array}{l}\text { fon. } 44 \mathrm{a} ; \\
\mathrm{fk} 6 / 4\end{array}$ & 492 & Soikkola & Viistinä & Katoi Vydrent. & $\mathrm{K}$ & $\begin{array}{l}\text { Tookki nain sanoi minuist, tookki } \\
\text { leukoi leekuttee; tookki nain saoi } \\
\text { minnuist, tookki laukoi leekuttee }\end{array}$ \\
\hline A $300 / 51 a$ & $\begin{array}{l}\text { fon. } 44 \mathrm{~b} ; \\
\text { fk } 6 / 4\end{array}$ & 645 & Soikkola & Viistinä & Katoi Vydrent. & $\mathrm{K}$ & $\begin{array}{l}\text { Oi ei miul laulella pittäizi, eig ilolDa } \\
\text { ensinkää; ei miul laulella pittäizi, } \\
\text { eig iloDa ensinkää }\end{array}$ \\
\hline 301/01a & $\begin{array}{l}\text { fon. } 45 \mathrm{a} ; \\
\text { fk6/6 }\end{array}$ & 261 & Soikkola & Viistinä & Katoi Vydrent. & $\mathrm{K}$ & $\begin{array}{l}\text { Oi läksir raintoiHe kezoilla; oi } \\
\text { läksir rantoiHe kezoilla }\end{array}$ \\
\hline A $301 / 01 b$ & $\begin{array}{l}\text { fon. } 45 \mathrm{~b} \text {; } \\
\text { fk6/6 }\end{array}$ & 731 & Soikkola & Viistinä & $\begin{array}{l}\text { Vögle Timont. } \\
\text { Semoin n. }\end{array}$ & K & $\begin{array}{l}\text { Oi kuulin kukkuvan käköisen; kuk- } \\
\text { kuvan käkköi, kukkuvan käkköi }\end{array}$ \\
\hline $301 / 02 a$ & $\begin{array}{l}\text { fon. } 46 \mathrm{a} ; \\
\text { fk6/5 }\end{array}$ & 770 & Soikkola & Viistinä & Katoi Vydrent. & $\mathrm{K}$ & $\begin{array}{l}\text { Oi miun ehtoiza emmoine; oi miun } \\
\text { ehtoisa emmoine }\end{array}$ \\
\hline $301 / 02 b$ & $\begin{array}{l}\text { fon. } 46 \mathrm{~b} ; \\
\mathrm{fk} 6 / 5\end{array}$ & 384 & Soikkola & Viistinä & Katoi Vydrent. & $\mathrm{K}$ & $\begin{array}{l}\text { Olin orjoi velloillein, karjusti ka- } \\
\text { lervoillein; olin orjoi velloillein, } \\
\text { karjusti kalervoillei }\end{array}$ \\
\hline $301 / 03 a$ & $\begin{array}{l}\text { fon. } 47 \mathrm{a} \text {; } \\
\text { fk6/7 }\end{array}$ & 274 & Soikkola & Viistinä & iont. & $\mathrm{K}$ & $\begin{array}{l}\text { lla vaa kynnettiiihe; ai } \\
\text { ttihe }\end{array}$ \\
\hline A 301/03a & $\begin{array}{l}\text { fon. } 47 \mathrm{~b} ; \\
\text { fk6/7 }\end{array}$ & 561 & Soikkola & Viistinä & $\begin{array}{l}\text { Vögle Timont. } \\
\text { Semoin n. }\end{array}$ & $\mathrm{K}$ & $\begin{array}{l}\text { Oi tuli kukkoi tuuDarista, lindu } \\
\text { valkkia vaHista; oi travuska travus- } \\
\text { ka trava selono }\end{array}$ \\
\hline $301 / 04 a$ & $\begin{array}{l}\text { fon. } 48 \mathrm{a} \text {; } \\
\mathrm{fk} 6 / 8\end{array}$ & 457 & Soikkola & Viistinä & $\begin{array}{l}\text { Vögle Timont. } \\
\text { Semoin n. }\end{array}$ & $\mathrm{K}$ & $\begin{array}{l}\text { Oi rootsin rohkia kuniiGas meije } \\
\text { veeGas veGälä; rootsin rohkia } \\
\text { kuniiGas meije veeGas veGäläin }\end{array}$ \\
\hline $301 / 04 b$ & $\begin{array}{l}\text { fon. } 48 \mathrm{~b} ; \\
\text { fk6/8 }\end{array}$ & 668 & Soikkola & Viistinä & Katoi Vydrent. & & $\begin{array}{l}\text { Ei miun laulella pitäi, } \\
\text { vaa, eik iloiDa ensinG: }\end{array}$ \\
\hline $301 / 05 b$ & $\begin{array}{l}\text { fon. } 49 \mathrm{~b} ; \\
\text { fk6/9 }\end{array}$ & 937 & Soikkola & Viistinä & Katoi Vydrent. & & $\begin{array}{l}\text { ti minuist, miä vaa } \\
\mathrm{e}\end{array}$ \\
\hline A 301/06a & $\begin{array}{l}\text { fon. } 50 \mathrm{a} ; \\
\text { fk6/10 }\end{array}$ & 843 & Soikkola & Viistinä & $\begin{array}{l}\text { Vögle Timont. } \\
\text { Semoin n. }\end{array}$ & K & \\
\hline $301 / 06 b$ & $\begin{array}{l}\text { fon. } 50 \mathrm{~b} ; \\
\text { fk6/10 }\end{array}$ & 606 & Soikkola & Viistinä & $\begin{array}{l}\text { Vögle Timont. } \\
\text { Semoin } \mathrm{n} .\end{array}$ & K & $\begin{array}{l}\text { Oi kuin katsom meroizem päälle, } \\
\text { niinkuin suuren surmam päal; kuin } \\
\text { katson meroizen päälle, niinkuin } \\
\text { suuren surmam pääl }\end{array}$ \\
\hline $301 / 07 a$ & $\begin{array}{l}\text { fon. 51a; } \\
\text { fk6/11 }\end{array}$ & 669 & Soikkola & Viistinä & $\begin{array}{l}\text { Vögle Timont. } \\
\text { Semoin } n .\end{array}$ & & $\begin{array}{l}\text { La kyzyn kylän agoilda vaan em } \\
\text { muilda, vaan en muilta mie vane- } \\
\text { hild i }\end{array}$ \\
\hline $301 / 07 b$ & $\begin{array}{l}\text { fon. } 51 b ; \\
\text { fk6/11 }\end{array}$ & 444 & Soikkola & Viistinä & $\begin{array}{l}\text { Vögle Timont. } \\
\text { Semoin } n .\end{array}$ & $\mathrm{K}$ & $\begin{array}{l}\text { La puhun puhas omena, laulan } \\
\text { laukkoi valgijain; la puhun puhas } \\
\text { omena, laulan laukkoi valgiain }\end{array}$ \\
\hline A 301/08a & $\begin{array}{l}\text { fon. } 52 \mathrm{a} ; \\
\text { fk6/12 }\end{array}$ & 447 & Soikkola & Viistinä & $\begin{array}{l}\text { Vögle Timont. } \\
\text { Semoin n. }\end{array}$ & K & $\begin{array}{l}\text { täisi, eiG iloota } \\
\text { aulella pittäisi, } \\
\text { än }\end{array}$ \\
\hline A $301 / 08 b$ & $\begin{array}{l}\text { fon. } 52 b ; \\
\text { fk6/12 }\end{array}$ & 855 & Soikkola & Viistinä & mont. & K & $\begin{array}{l}\text { xo i vaa illakkoi tuloo; } \\
\text { o }\end{array}$ \\
\hline A $301 / 09 a$ & $\begin{array}{l}\text { fon. } 53 \mathrm{a} ; \\
\mathrm{fk} 7 / 1\end{array}$ & 577 & Soikkola & Viistinä & $\begin{array}{l}\text { Vögle Timont. } \\
\text { Semoin n. }\end{array}$ & K & $\begin{array}{l}\text { i tuimoi miiss kavvaala, uroi } \\
\text { otsalai; turoi tuimoi miis } \\
\text { la, uroi umpirootsalai }\end{array}$ \\
\hline A $301 / 09$ b & $\begin{array}{l}\text { fon. } 53 \mathrm{~b} ; \\
\mathrm{fk} 7 / 1\end{array}$ & 767 & Soikkola & Viistinä & $\begin{array}{l}\text { Vögle Timont. } \\
\text { Semoin n. }\end{array}$ & $\mathrm{K}$ & $\begin{array}{l}\text { ekuttajaD; leekut- } \\
\mathrm{D}\end{array}$ \\
\hline A $301 / 10 a$ & $\begin{array}{l}\text { fon. 54a; } \\
\text { fk7/2 }\end{array}$ & 575 & Soikkola & Viistinä & $\begin{array}{l}\text { Vögle Timont. } \\
\text { Semoin } \mathrm{n} .\end{array}$ & $\mathrm{K}$ & $\begin{array}{l}\text { Oi velloini vennoisen seppoi, } \\
\text { laivoin seppoi laglueni; laglueni } \\
\text { laglueni }\end{array}$ \\
\hline A $301 / 10 b$ & $\begin{array}{l}\text { fon. } 54 \mathrm{~b} ; \\
\mathrm{fk} 7 / 2\end{array}$ & 721 & Soikkola & Viistinä & $\begin{array}{l}\text { Vögle Timont. } \\
\text { Semoin } n .\end{array}$ & K & $\begin{array}{l}\text { Oi noisin suurelle vaa mäelle; noi- } \\
\text { sin suurelle vaa mäelle; korkialle } \\
\text { vaa kallijolle; korkijalle vaa kallijolle }\end{array}$ \\
\hline A $301 / 11 a$ & $\begin{array}{l}\text { fon. } 55 \mathrm{a} ; \\
\mathrm{fk} 7 / 3\end{array}$ & $606^{*}$ & * Soikkola & Viistinä & $\begin{array}{l}\text { Vögle Timont. } \\
\text { Semoin n. }\end{array}$ & $\mathrm{K}$ & $\begin{array}{l}\text { Ei miul laulella pittäizi, eig iloota } \\
\text { ensinkää }\end{array}$ \\
\hline A $301 / 11 b$ & $\begin{array}{l}\text { fon. } 55 \mathrm{~b} ; \\
\mathrm{fk} 7 / 3\end{array}$ & 342 & Soikkola & Viistinä & $\begin{array}{l}\text { Vögle Timont. } \\
\text { Semoin } n .\end{array}$ & K & $\begin{array}{l}\text { Oi kaik miä ilot unoHij ja unoHin } \\
\text { oi; kaik miä ilot unoHij ja uno (oi) }\end{array}$ \\
\hline
\end{tabular}




\begin{tabular}{|c|c|c|c|c|c|c|}
\hline ViIte & & IRS & PAIKKA & KYLÄ & LAULAJA & AlKusÄE \\
\hline A $301 / 12 a$ & $\begin{array}{l}\text { fon. } 56 \mathrm{a} ; \\
\mathrm{fk} 7 / 4\end{array}$ & 438 & Soikkola & Viistinä & $\begin{array}{l}\text { Vögle Timont. } \mathrm{K} \\
\text { Semoin } \mathrm{n} .\end{array}$ & $\begin{array}{l}\text { (j)oi läksiv velloiv veeraHaksi, } \\
\text { kyzyin kyyltäni Hevoista; läksiv } \\
\text { velloiv veeraHaksi, kyzyin kyyltäni } \\
\text { Hevoista joonoi }\end{array}$ \\
\hline A $301 / 12 b$ & $\begin{array}{l}\text { fon. } 56 \mathrm{~b} \\
\text { fk7/4 }\end{array}$ & 660 & Soikkola & Viistinä & $\begin{array}{l}\text { Vögle Timont. } \mathrm{K} \\
\text { Semoin } \mathrm{n} .\end{array}$ & $\begin{array}{l}\text { Oi kaik miä ilot unoHin, kaik miä } \\
\text { laulau lakkae; oi kaik miä ilot un- } \\
\text { nooHin, kaik miä laulut lakkae }\end{array}$ \\
\hline A $301 / 13$ & $\begin{array}{l}\text { fon. } 57 \\
\text { fk7/5 }\end{array}$ & $660^{*}$ & Soikkola & Viistinä & $\begin{array}{l}\text { Vögle Timont. } \mathrm{K} \\
\text { Semoin } \mathrm{n} .\end{array}$ & $\begin{array}{l}\text { Oi sem miä tiijän kuHun synnyin, } \\
\text { aijan kaiken kussa kazevoin; sem } \\
\text { miä tiijän kuHun synnyin, aijan } \\
\text { kaiken kussa ka(ee) }\end{array}$ \\
\hline A $301 / 14 a$ & $\begin{array}{l}\text { fon. } 58 \mathrm{a} ; \\
\mathrm{fk} 7 / 6\end{array}$ & 925 & Soikkola & Viistinä & $\begin{array}{l}\text { Vögle Timont. } \mathrm{K} \\
\text { Semoin } \mathrm{n} .\end{array}$ & $\begin{array}{l}\text { Oi tuli ruikkoi raikkovasta, seme- } \\
\text { ritsa seppälästä; tuli ruikkoi raikko- } \\
\text { vast, semeritsa seppäläst, tuli ruik- } \\
\text { koi raikkovast, semeritsa seppäläst }\end{array}$ \\
\hline A $301 / 14 b$ & $\begin{array}{l}\text { fon. } 58 b ; \\
\text { fk7/6 }\end{array}$ & 730 & Soikkola & Viistinä & $\begin{array}{l}\text { Timont. } \mathrm{K} \\
\text { in } \mathrm{n} \text {. }\end{array}$ & $\begin{array}{l}\text { El laula vaa käpeHyttäne; ja käpe- } \\
\text { Hyttä, ja käpeHyttä oi }\end{array}$ \\
\hline A $301 / 15 a$ & $\begin{array}{l}\text { fon. } 59 b \\
\text { fk7/7 }\end{array}$ & 386 & Hevaa & Vepsä & $\begin{array}{l}\text { Vedjka Ivanint. } \mathrm{K} \\
\text { Midrein } \mathrm{n} .\end{array}$ & $\begin{array}{l}\text { Vaan kokkoilindu vaa korvellindu, } \\
\text { sakkali solomenelinDu; ja salo salo- } \\
\text { me, ja salomelinDu [myöhemmissä } \\
\text { säkeissä joonno(i)] }\end{array}$ \\
\hline A $301 / 15 b$ & $\begin{array}{l}\text { fon. } 59 \mathrm{~b} \\
\text { fk7/7 }\end{array}$ & 530 & Hevaa & Vepsä & $\begin{array}{l}\text { Vedjka Ivanint. } \mathrm{K} \\
\text { Midrein } \mathrm{n} .\end{array}$ & $\begin{array}{l}\text { Kokkoilindu korvellindu, sakkali } \\
\text { yli salome; ja salo salome, ja salo- } \\
\text { melinDu [myöhemmissä säkeissä } \\
\text { joonno(i)] }\end{array}$ \\
\hline A $301 / 16 a, b$ & $\begin{array}{l}\text { fon. 60a, } \\
\mathrm{b} ; \text { fk } 7 / 8\end{array}$ & 502 & Hevaa & Vepsä & $\begin{array}{l}\text { na } \\
\text { nant. } \\
\mathrm{n} \mathrm{n} .\end{array}$ & $\begin{array}{l}\text { kadriina kotikan(n)ainen i, kadriina } \\
\text { kotikanainen; ja kana kan(n)ainen, } \\
\text { ja kanainen joonoi }\end{array}$ \\
\hline A $301 / 16 c$ & $\begin{array}{l}\text { fon. } 60 \mathrm{c} \\
\mathrm{fk} 7 / 8\end{array}$ & 495 & Hevaa & Vepsä & $\begin{array}{l}\text { Okuliina } \\
\text { Nikkanant. } \\
\text { Sergein n. }\end{array}$ & $\begin{array}{l}\text { La Ga korvessa kumae, la Ga kor- } \\
\text { vessa kumae }\end{array}$ \\
\hline A $301 / 17 a$ & $\begin{array}{l}\text { fon. 61a; } \\
\text { fk7/9 }\end{array}$ & 495 & Hevaa & Vepsä & $\begin{array}{l}\text { Okuliina } \\
\text { Nikkanant. } \\
\text { Sergein n. }\end{array}$ & $\begin{array}{l}\text { La Ga korvessa kumae, la Ga kor- } \\
\text { vessa kumae }\end{array}$ \\
\hline A $301 / 17 b$ & $\begin{array}{l}\text { fon. } 61 \mathrm{~b} \\
\text { fk7/9 }\end{array}$ & 297 & Hevaa & Vepsä & $\begin{array}{l}\text { ant. } \\
\text { an. }\end{array}$ & $\begin{array}{l}\text { Kazvoi miulle kassoi pitkä, kassoi } \\
\text { pitkä tuimoi tu }\end{array}$ \\
\hline A $301 / 18 \mathrm{a}$ & $\begin{array}{l}\text { fon. 62a; } \\
\text { fk7/10 }\end{array}$ & 709 & Hevaa & Vepsä & $\begin{array}{l}\text { Okuliina } \\
\text { Nikkanant. } \\
\text { Sergein n. }\end{array}$ & $\begin{array}{l}\text { Vet ei laulella pittäisi, vet ei laulella } \\
\text { pittäisi, eig ilootaG ensinkänä, em } \\
\text { miä laulella luvannu }\end{array}$ \\
\hline A $301 / 18 b$ & $\begin{array}{l}\text { fon. } 62 \mathrm{~b} \\
\mathrm{fk} 7 / 10\end{array}$ & 168 & Hevaa & Vepsä & $\begin{array}{l}\text { Okuliina } \\
\text { Nikkanant. } \\
\text { Sergein } \mathrm{n} . \\
\end{array}$ & $\begin{array}{l}\text { Mikä toalla näkkyypi, mikä toalla } \\
\text { näkkyypi }\end{array}$ \\
\hline A $301 / 20 a$ & $\begin{array}{l}\text { fon. } 64 \mathrm{a} \\
\text { fk8/1 }\end{array}$ & 749 & Hevaa & Vepsä & $\begin{array}{l}\text { Okuliina } \\
\text { Nikkanant. } \\
\text { Sergein n. }\end{array}$ & $\begin{array}{l}\text { El(ä)kääHä kylä kerotak, el(e) } \\
\text { kääHä kylä kerota }\end{array}$ \\
\hline A $301 / 20 b$ & $\begin{array}{l}\text { fon. } 64 \mathrm{~b} ; \\
\text { fk8/1 }\end{array}$ & 235 & Hevaa & Vepsä & $\begin{array}{l}\text { Katriina Alek- } \\
\text { seint. Vaskon n. }\end{array}$ & $\begin{array}{l}\text { Kui miä noisen i laulamaha; saadul- } \\
\text { moi saadu selennoi saadu }\end{array}$ \\
\hline A $301 / 21 \mathrm{a}$ & $\begin{array}{l}\text { fon. } 65 \mathrm{a} ; \\
\mathrm{fk} 8 / 2\end{array}$ & 40 & Hevaa & Vepsä & $\begin{array}{l}\text { Katriina Alek- } \\
\text { seint. Vaskon n. }\end{array}$ & $\begin{array}{l}\text { Veräläin kullervoi vee, veräläin } \\
\text { kullervoi vee }\end{array}$ \\
\hline A $301 / 21 b$ & $\begin{array}{l}\text { fon. } 65 \mathrm{~b} ; \\
\mathrm{fk} 8 / 2\end{array}$ & 43 & Hevaa & Vepsä & $\begin{array}{l}\text { Katriina Alek- } \\
\text { seint. Vaskon n. }\end{array}$ & $\begin{array}{l}\text { Pääsköilindu päivöilindu, pääsköi- } \\
\text { lindu päivöilee }\end{array}$ \\
\hline A $301 / 22 a$ & $\begin{array}{l}\text { fon. } 66 \mathrm{a} \\
\mathrm{fk} 8 / 3\end{array}$ & $40^{*}$ & Hevaa & Vepsä & $\begin{array}{l}\text { Katriina Alek- } \\
\text { seint. Vaskon n. }\end{array}$ & $\begin{array}{l}\text { Mänin sinoin kylväjäks, pellervoin } \\
\text { valelijas }\end{array}$ \\
\hline A $301 / 22 b$ & $\begin{array}{l}\text { fon. } 66 \mathrm{~b} \\
\text { fk } 8 / 3\end{array}$ & 208 & Hevaa & Vepsä & $\begin{array}{l}\text { Katriina Alek- } \\
\text { seint. Vaskon n. }\end{array}$ & $\begin{array}{l}\text { Mäniv vet e sinoin kyl(y)väksi joo, } \\
\text { mäniv vet oi sinoin kylväjäksi joo }\end{array}$ \\
\hline A $301 / 23 a$ & $\begin{array}{l}\text { fon. } 67 \mathrm{a} ; \\
\text { fk8/4 }\end{array}$ & 233 & Hevaa & Vepsä & $\begin{array}{l}\text { Katriina Alek- } \\
\text { seint. Vaskon n. }\end{array}$ & $\begin{array}{l}\text { Läksin i koista kulkomaha, läksin i } \\
\text { koista kulkomaha }\end{array}$ \\
\hline A $301 / 23 b$ & $\begin{array}{l}\text { fon. } 67 \mathrm{~b} \\
\text { fk } 8 / 4\end{array}$ & 162 & Hevaa & Vepsä & $\begin{array}{l}\text { Katriina Alek- } \\
\text { seint. Vaskon n. }\end{array}$ & $\begin{array}{l}\text { Kun olin isoini koissa, ja koissa } \\
\text { korottajani }\end{array}$ \\
\hline
\end{tabular}




\begin{tabular}{|c|c|c|c|c|c|c|}
\hline \multicolumn{2}{|l|}{ VIITE } & \multirow{2}{*}{$\begin{array}{l}\text { IRS } \\
130\end{array}$} & \multirow{2}{*}{$\begin{array}{l}\text { PAIKKA } \\
\text { Hevaa }\end{array}$} & \multirow{2}{*}{$\begin{array}{l}\text { KYLÄ } \\
\text { Vepsä }\end{array}$} & \multirow{2}{*}{$\begin{array}{l}\text { LAUlajA K } \\
\text { Katriina Alek- } \\
\text { seint. Vaskon n. }\end{array}$} & \multirow{2}{*}{$\begin{array}{l}\text { ALKUSÄE } \\
\text { Emoiseni ehtoiseni, emoiseni eh- } \\
\text { toiseni }\end{array}$} \\
\hline A $301 / 24 a$ & $\begin{array}{l}\text { fon. } 68 \mathrm{a} \\
\text { fk } 8 / 5\end{array}$ & & & & & \\
\hline A $301 / 24 b$ & $\begin{array}{l}\text { fon. } 68 \mathrm{~b} \\
\text { fk } 8 / 5\end{array}$ & 131 & Hevaa & Vepsä & $\begin{array}{l}\text { Katriina Alek- } \\
\text { seint. Vaskon n. }\end{array}$ & $\begin{array}{l}\text { Mist se tunzi langoiheni, mistä } \\
\text { tuuzi mistä tiizi }\end{array}$ \\
\hline A $301 / 25 a$ & $\begin{array}{l}\text { fon. } 69 \mathrm{a} ; \\
\text { fk8/6 }\end{array}$ & 163 & Hevaa & Vepsä & $\begin{array}{l}\text { Katriina Alek- } \\
\text { seint. Vaskon n. }\end{array}$ & $\begin{array}{l}\text { Mahtuuko vävöi tuppaaha, ilman or- } \\
\text { ren ottamata, ilman orren ottamata }\end{array}$ \\
\hline A $301 / 25$ b & $\begin{array}{l}\text { fon. } 69 \mathrm{~b} ; \\
\text { fk } 8 / 6\end{array}$ & 54 & Hevaa & Vepsä & $\begin{array}{l}\text { Katriina Alek- } \\
\text { seint. Vaskon n. }\end{array}$ & $\begin{array}{l}\text { Laaroi poigoi laatu poigoi, laaroi } \\
\text { laaDupoisikkaine }\end{array}$ \\
\hline A $301 / 26 a$ & $\begin{array}{l}\text { fon. } 70 \mathrm{a} \\
\mathrm{fk} 8 / 7\end{array}$ & 147 & Hevaa & Vepsä & $\begin{array}{l}\text { Okuliina } \\
\text { Nikkanant. } \\
\text { Sergein } \mathrm{n} . \\
\end{array}$ & Kui miä syntynyt sopinut \\
\hline A $301 / 26$ b & $\begin{array}{l}\text { fon. } 70 \mathrm{~b} \\
\mathrm{fk} 8 / 7\end{array}$ & 120 & Hevaa & Vepsä & $\begin{array}{l}\text { Okuliina } \\
\text { Nikkanant. } \\
\text { Sergein n. }\end{array}$ & $\begin{array}{l}\text { Möö määmmä siuj jätämmä, möö } \\
\text { määmmä siuj jätämmä }\end{array}$ \\
\hline A $301 / 27 a$ & $\begin{array}{l}\text { fon. } 71 \mathrm{a} \\
\text { fk8/8 }\end{array}$ & 433 & Hevaa & Vepsä & $\begin{array}{l}\text { Okuliina } \\
\text { Nikkanant. } \\
\text { Sergein } \mathrm{n} . \\
\end{array}$ & $\begin{array}{l}\text { Undamoilla uljas ukko, undamoilla } \\
\text { uljas ukko; ai lole ai lole, undamoil- } \\
\text { la uljas uu }\end{array}$ \\
\hline A $301 / 27$ b & $\begin{array}{l}\text { fon. } 71 b ; \\
\text { fk } 8 / 8\end{array}$ & 219 & Hevaa & Vepsä & $\begin{array}{l}\text { Katriina Alek- } \\
\text { seint. Vaskon n. }\end{array}$ & $\begin{array}{l}\text { Kokkolintu vet e korvellindu joo, ai } \\
\text { lole lole korvellindu joo }\end{array}$ \\
\hline A $301 / 28 a$ & $\begin{array}{l}\text { fon. } 72 \mathrm{a} \\
\text { fk8/9 }\end{array}$ & 219 & Hevaa & Vepsä & $\begin{array}{l}\text { Katriina Alek- } \\
\text { seint. Vaskon n. }\end{array}$ & $\begin{array}{l}\text { Kokkolintu vet e korvellindu joo, ai } \\
\text { lole lole korvellindu joo }\end{array}$ \\
\hline A $301 / 28 b$ & $\begin{array}{l}\text { fon. } 72 b \\
\text { fk } 8 / 9\end{array}$ & 217 & Hevaa & Vepsä & $\begin{array}{l}\text { Palaga Jefimont. } \\
\text { Semenon n. }\end{array}$ & $\begin{array}{l}\text { Virolaine poigoi viisas poikoi vii- } \\
\text { sas, karjalainen mees kavala mees } \\
\text { kavala }\end{array}$ \\
\hline A $301 / 29 a$ & $\begin{array}{l}\text { fon. } 73 a \text {; } \\
\text { fk8/10 }\end{array}$ & 517 & Hevaa & Vepsä & $\begin{array}{l}\text { Palaga Jefimont. } \\
\text { Semenon n. }\end{array}$ & $\begin{array}{l}\text { Miä tyttöi pikkarainen, kezenkas- } \\
\text { voinen kannainen; vot kalina dai } \\
\text { vot malina }\end{array}$ \\
\hline A $301 / 29 b$ & $\begin{array}{l}\text { fon. } 73 b \\
\text { fk } 8 / 10\end{array}$ & 206 & Hevaa & Vepsä & $\begin{array}{l}\text { Palaga Jefimont. } \\
\text { Semenon n. }\end{array}$ & $\begin{array}{l}\text { Olin orjoina vet oi venoissa joo, ai } \\
\text { lole lole ja venoissa joo }\end{array}$ \\
\hline A $301 / 30 a$ & $\begin{array}{l}\text { fon. } 74 \mathrm{a} ; \\
\text { fk8/11 }\end{array}$ & $484^{*}$ & tHevaa & Vepsä & $\begin{array}{l}\text { Palaga Jefimont. } \\
\text { Semenon n. }\end{array}$ & $\begin{array}{l}\text { Eij oo ennem mein kylässä, ku eik } \\
\text { oo meijen i rahvaHas }\end{array}$ \\
\hline A $301 / 30 b$ & $\begin{array}{l}\text { fon. } 74 b ; \\
\text { fk8/11 }\end{array}$ & 484 & Hevaa & Vepsä & $\begin{array}{l}\text { Palaga Jefimont. } \\
\text { Semenon n. }\end{array}$ & $\begin{array}{l}\text { Eij oo ennem mein kylässä, ai kali } \\
\text { ai kali, ai kalinuska moja }\end{array}$ \\
\hline A $301 / 31 a$ & $\begin{array}{l}\text { fon. } 75 a \\
\text { fk } 8 / 12\end{array}$ & 207 & Hevaa & Vepsä & $\begin{array}{l}\text { Palaga Jefimont. } \\
\text { Semenon n. }\end{array}$ & $\begin{array}{l}\text { Lauloin ennen vet oi lapsemBana } \\
\text { joo, huuzin ennen vet oi Hullum- } \\
\text { pana joo }\end{array}$ \\
\hline A $301 / 31 b$ & $\begin{array}{l}\text { fon. } 75 b \\
\text { fk } 8 / 12\end{array}$ & 485 & Hevaa & Vepsä & $\begin{array}{l}\text { Palaga Jefimont. } \\
\text { Semenon n. }\end{array}$ & $\begin{array}{l}\text { Oo ei miul laulella pittäizi, eik } \\
\text { ilootak ensinkää; ei miul laulella } \\
\text { pittäizi, ei ilootak ensinkää }\end{array}$ \\
\hline A $301 / 32 a$ & $\begin{array}{l}\text { fon. } 76 a \text {; } \\
\text { fk9/1 }\end{array}$ & 520 & Hevaa & Murtove & $\begin{array}{l}\text { Vassu Kaurilant. } \\
\text { Ottipann. }\end{array}$ & $\begin{array}{l}\text { Kadriina kotikannainen e, kadriina } \\
\text { kotikannaine; kadriina kotikanain, } \\
\text { kadriina kotikanain }\end{array}$ \\
\hline A $301 / 33 a$ & $\begin{array}{l}\text { fon. 77a; } \\
\text { fk9/2 }\end{array}$ & 505 & Hevaa & Murtove & $\begin{array}{l}\text { Vassu Kaurilant. } \mathrm{K} \\
\text { Ottipann. }\end{array}$ & $\begin{array}{l}\text { Lauloim miä ennen i lapsempana, } \\
\text { lauloim miä ennen i lapsempana; } \\
\text { lapsel lapsempana, lapsempana } \\
\text { oonoi }\end{array}$ \\
\hline A $301 / 33 b$ & $\begin{array}{l}\text { fon. } 77 \mathrm{~b} \\
\text { fk9/2 }\end{array}$ & & Hevaa & Murtove & $\begin{array}{l}\text { Vassu Kaurilant. } \mathrm{K} \\
\text { Ottipann. }\end{array}$ & $\begin{array}{l}\text { Kyllä on virsiä miulla ja miulla; } \\
\text { kyllä on versijä miulla ja miulla }\end{array}$ \\
\hline A $301 / 34 a$ & $\begin{array}{l}\text { fon. } 78 \mathrm{a} \\
\text { fk9/3 }\end{array}$ & 116 & Hevaa & Lenttinen & $\begin{array}{l}\text { eräs akka } \\
\text { Lenttisissä }\end{array}$ & $\begin{array}{l}\text { Pyhä ukko armolline, ilea pyHä } \\
\text { isända }\end{array}$ \\
\hline A $301 / 34 b$ & $\begin{array}{l}\text { fon. } 78 b \text {; } \\
\text { fk } 9 / 3\end{array}$ & 580 & Hevaa & Murtove & $\begin{array}{l}\text { Vassu Kaurilant. } \mathrm{K} \\
\text { Ottipann. }\end{array}$ & $\begin{array}{l}\text { Iivana on kojoisen(i) poikoi, iivana } \\
\text { on kojoisen(i) poiko(i); ja kojo } \\
\text { kojoisej, ja kojoisem poikoi }\end{array}$ \\
\hline A $301 / 35 a$ & $\begin{array}{l}\text { fon. } 79 a \\
\text { fk9/4 }\end{array}$ & 837 & Hevaa & Murtove & $\begin{array}{l}\text { Vassu Kaurilant. } \\
\text { Ottipann. }\end{array}$ & $\begin{array}{l}\text { A kyzyin i maaDa, kyzyin i maaDa; } \\
\text { kyzyim maaDa velloilta velloilta, } \\
\text { kyzyin maaDa velloilta velloilta }\end{array}$ \\
\hline A $301 / 35 b$ & $\begin{array}{l}\text { fon. } 79 b \text {; } \\
\text { fk } 9 / 4\end{array}$ & 732 & Hevaa & Murtove & $\begin{array}{l}\text { Vassu Kaurilant. } \mathrm{K} \\
\text { Ottipann. }\end{array}$ & $\begin{array}{l}\text { A Hekkoi tyttöi, Hekkoi tyttöi; Hek- } \\
\text { koi tyttöi Hemme tyttöi, Hekkoi } \\
\text { tyttöi Hemme tyttöi }\end{array}$ \\
\hline
\end{tabular}




\begin{tabular}{|c|c|c|c|c|c|c|}
\hline VIITE & & IRS & PAIKKA & KYLÄ & LAULAJA & AlKusÄE \\
\hline A $301 / 36 a$ & $\begin{array}{l}\text { fon. } 80 \mathrm{a} \text {; } \\
\text { fk } 9 / 5\end{array}$ & 149 & Hevaa & Vepsä & $\begin{array}{l}\text { Vassu Kaurilant. } \mathrm{K} \\
\text { Ottipann. }\end{array}$ & $\begin{array}{l}\text { Jouluna jumala synDyi; jouluna } \\
\text { jumala synDyi }\end{array}$ \\
\hline A $301 / 36 b$ & $\begin{array}{l}\text { fon. } 80 \mathrm{~b} \text {; } \\
\text { fk } 9 / 5\end{array}$ & 565 & Hevaa & Murtove & $\begin{array}{l}\text { Vassu Kaurilant. } \mathrm{K} \\
\text { Ottipann. }\end{array}$ & $\begin{array}{l}\text { A mitä miä laulan ku kuta laulam, } \\
\text { mitä miä laulan ku kuta laulan; oi } \\
\text { kuta laulan, kuta laulan oonoi }\end{array}$ \\
\hline A $301 / 37 a$ & $\begin{array}{l}\text { fon. } 81 b ; \\
\text { fk9/6 }\end{array}$ & 79 & Hevaa & Murtove & $\begin{array}{l}\text { Vassu Kaurilant. } \mathrm{K} \\
\text { Ottipann. }\end{array}$ & $\begin{array}{l}\text { Mitä mökköi mööHäs nousit; mitä } \\
\text { mökkö mööHäs nousit }\end{array}$ \\
\hline A $301 / 37 a$ & $\begin{array}{l}\text { fon. 81a; } \\
\text { fk9/6 }\end{array}$ & 521 & Hevaa & Murtove & $\begin{array}{l}\text { Vassu Kaurilant. } \mathrm{K} \\
\text { Ottipann. }\end{array}$ & $\begin{array}{l}\text { A la ka katson(o) kannoilla, la ka } \\
\text { katson(o) kannoilla(e); la ka katson } \\
\text { kannoilla, la ka katson kannoilla }\end{array}$ \\
\hline A $301 / 38 a$ & $\begin{array}{l}\text { fon. } 82 \mathrm{a} \\
\mathrm{fk} 9 / 7\end{array}$ & 228 & Hevaa & Murtove & $\begin{array}{l}\text { Vassu Kaurilant. } \\
\text { Ottipann. }\end{array}$ & $\begin{array}{l}\text { Oi la kaljuv vaa kaduisillan; oi ul(u) } \\
\text { votoi uulitsaisilla }\end{array}$ \\
\hline A $301 / 38 b$ & $\begin{array}{l}\text { fon. } 82 \mathrm{~b} ; \\
\mathrm{fk} 9 / 7\end{array}$ & 566 & Hevaa & Murtove & $\begin{array}{l}\text { Vassu Kaurilant. } \mathrm{K} \\
\text { Ottipann. }\end{array}$ & $\begin{array}{l}\text { A kaler(e)vikoi kylvi kagroi, } \\
\text { kaler(e)vikkoi kylvi kagroi; kylvi } \\
\text { kylvi kagroin, kylvi kagroin joonoi }\end{array}$ \\
\hline A $301 / 39 a$ & $\begin{array}{l}\text { fon. } 83 a \text {; } \\
\text { fk } 9 / 8\end{array}$ & 623 & Hevaa & Murtove & $\begin{array}{l}\text { Vassu Kaurilant. } \\
\text { Ottipann. }\end{array}$ & $\begin{array}{l}\text { marjukkaninen on miun emoinim, } \\
\text { karjukkainine on kanDajaini; mar- } \\
\text { jukkaine miun emmoini, karjukkai- } \\
\text { ni kanDaja }\end{array}$ \\
\hline A $301 / 39 b$ & $\begin{array}{l}\text { fon. } 83 \mathrm{~b} \\
\text { fk } 9 / 8\end{array}$ & 722 & Hevaa & Murtove & $\begin{array}{l}\text { Vassu Kaurilant. } \mathrm{K} \\
\text { Ottipann. }\end{array}$ & $\begin{array}{l}\text { A velloini ja vaa toi vennoisen } \\
\text { seppoi; rosaska ja loja }\end{array}$ \\
\hline A $301 / 40 a$ & $\begin{array}{l}\text { fon. } 84 \mathrm{a} \\
\mathrm{fk} 9 / 9\end{array}$ & 829 & Tyrö & Yhimäki & $\begin{array}{l}\text { Katriina } \\
\text { Joosepint. Josu }\end{array}$ & $\begin{array}{l}\text { Mänin suolle sotkomaHa liilolii; loo } \\
\text { loo lollolloo liilolii, loo loo lollolloo } \\
\text { liilolii }\end{array}$ \\
\hline A $301 / 40 b$ & $\begin{array}{l}\text { fon. } 84 \mathrm{~b} \\
\text { fk } 9 / 9\end{array}$ & 361 & Tyrö & Yhimäki & $\begin{array}{l}\text { Katriina } \\
\text { Joosepint. Josu }\end{array}$ & Istuu tyttö mustatukka mustatukka \\
\hline A $301 / 41 \mathrm{a}$ & $\begin{array}{l}\text { fon. } 85 \mathrm{a} \\
\text { fk9/10 }\end{array}$ & 363 & Tyrö & Yhimäki & $\begin{array}{l}\text { Katriina } \\
\text { Joosepint. Josu }\end{array}$ & $\begin{array}{l}\text { Miss siä mökkö mööhääv viivyit; } \\
\text { kauvan kankelo makaisit ja makai- } \\
\text { sit; kyl miä tiijem missä viivyit }\end{array}$ \\
\hline A $301 / 41 b$ & $\begin{array}{l}\text { fon. } 85 b ; \\
\text { fk9/10 }\end{array}$ & 200 & Tyrö & Yhimäki & $\begin{array}{l}\text { Katriina } \\
\text { Joosepint. Josu }\end{array}$ & $\begin{array}{l}\text { La laulan liki kotija; ai ta lole lole } \\
\text { ja kotija }\end{array}$ \\
\hline A $301 / 42 \mathrm{a}$ & $\begin{array}{l}\text { fon. 86a; } \\
\text { fk9/11 }\end{array}$ & 501 & Tyrö & Yhimäki & $\begin{array}{l}\text { Katriina } \\
\text { Joosepint. Josu }\end{array}$ & $\begin{array}{l}\text { Anni tyttöj ainoi tyttöj, oli yksi } \\
\text { maksoi kaksi; maksoi maksoi kaksi, } \\
\text { maksoi kaksi joonoi }\end{array}$ \\
\hline A $301 / 42 b$ & $\begin{array}{l}\text { fon. } 86 \mathrm{~b} \\
\text { fk9/11 }\end{array}$ & 922 & Tyrö & Yhimäki & $\begin{array}{l}\text { Katriina } \\
\text { Joosepint. Josu }\end{array}$ & $\begin{array}{l}\text { Mänin soikkolan sottaa, pärehinen } \\
\text { miekka vyöl; hy hä tilutalujaa, } \\
\text { pärehinen miekka vyöl }\end{array}$ \\
\hline A $301 / 43 a$ & $\begin{array}{l}\text { fon. } 87 \mathrm{a} \\
\text { fk } 9 / 12\end{array}$ & 596 & Tyrö & Yhimäki & $\begin{array}{l}\text { Onikka Joko- } \\
\text { ront. Juhanan n. }\end{array}$ & $\begin{array}{l}\text { SaDoi ukko uutta lunDa, uuden } \\
\text { kuominan ettee; ja ettee etteehe, ja } \\
\text { etteehe joonoi }\end{array}$ \\
\hline A $301 / 43 b$ & $\begin{array}{l}\text { fon. } 87 \mathrm{~b} ; \\
\text { fk9/12 }\end{array}$ & $200^{*}$ & * Tyrö & Yhimäki & $\begin{array}{l}\text { Katriina } \\
\text { Joosepint. Josu }\end{array}$ & $\begin{array}{l}\text { Olim miä tyttöi pikkarainen; ai ta } \\
\text { lole lole pikkarainen }\end{array}$ \\
\hline A $301 / 43$ c & $\begin{array}{l}\text { fon. } 87 \mathrm{c} ; \\
\text { fk9/12 }\end{array}$ & 214 & Tyrö & Yhimäki & $\begin{array}{l}\text { Onikka Joko- } \\
\text { ront. Juhanan n. }\end{array}$ & $\begin{array}{l}\text { Katriina kotikannainen; kati kok- } \\
\text { koilinnukkainen }\end{array}$ \\
\hline A $301 / 44 a$ & $\begin{array}{l}\text { fon. } 88 \mathrm{~b} ; \\
\text { fk10/1 }\end{array}$ & 783 & Tyrö & Yhimäki & $\begin{array}{l}\text { Katriina } \\
\text { Joosepint. Josu }\end{array}$ & mänin metsäHä kezoilla rallalla \\
\hline A $301 / 44 a$ & $\begin{array}{l}\text { fon. 88a; } \\
\text { fk10/1 }\end{array}$ & $361^{*}$ & * Tyrö & Yhimäki & $\begin{array}{l}\text { Katriina } \\
\text { Joosepint. Josu }\end{array}$ & Ulos savu saunoistasi saunoistasi \\
\hline A $301 / 45 a$ & $\begin{array}{l}\text { fon. } 89 \text { a; } \\
\text { fk10/2 }\end{array}$ & 170 & Hevaa & Yhimäki & $\begin{array}{l}\text { Onikka Joko- } \\
\text { ront. Juhanan n. }\end{array}$ & $\begin{array}{l}\text { [...] Lendeli kessoisem päivöin; ai } \\
\text { ta lole lole ja kessoisen }\end{array}$ \\
\hline A $301 / 45 b$ & $\begin{array}{l}\text { fon. } 89 \mathrm{~b} ; \\
\text { fk } 10 / 2\end{array}$ & 383 & Hevaa & Yhimäki & $\begin{array}{l}\text { Onikka Joko- } \\
\text { ront. Juhanan n. }\end{array}$ & $\begin{array}{l}\text { Veikkoni vennoisen seppoi, laivoin } \\
\text { seppoi lagluen; ai luuli laglueil, } \\
\text { laivoin seppoi laglueil }\end{array}$ \\
\hline A $301 / 46 a$ & $\begin{array}{l}\text { fon. 90a; } \\
\text { fk10/3 }\end{array}$ & 209 & Hevaa & Yhimäki & $\begin{array}{l}\text { Onikka Joko- } \\
\text { ront. Juhanan } \mathrm{n} .\end{array}$ & $\begin{array}{l}\text { Kerallizet pois männöövät; keralli- } \\
\text { zet pois männöövät }\end{array}$ \\
\hline A $301 / 46 b$ & $\begin{array}{l}\text { fon. } 90 \mathrm{~b} \\
\text { fk10/3 }\end{array}$ & 209 & Hevaa & Yhimäki & $\begin{array}{l}\text { Onikka Joko- } \\
\text { ront. Juhanan n. }\end{array}$ & $\begin{array}{l}\text { Tulgaa tytöt yötulille, tulgaa tytöt } \\
\text { yötulille }\end{array}$ \\
\hline
\end{tabular}




\begin{tabular}{|c|c|c|c|c|c|c|}
\hline Virte & & IRS & PAIKKa & KYLÄ & LAULAJA & AlKusÄE \\
\hline A $301 / 47 a$ & $\begin{array}{l}\text { fon. 91a; } \\
\text { fk10/4 }\end{array}$ & 382 & Tyrö & Yhimäki & $\begin{array}{l}\text { Onikka Joko- } \\
\text { ront. Juhanan n. }\end{array}$ & $\begin{array}{l}\text { Jo meillä ero tuloo, vaikeva o,on } \\
\text { harota; ai luuli ja harot, vaikea ono } \\
\text { harota }\end{array}$ \\
\hline A $301 / 47 b$ & $\begin{array}{l}\text { fon. } 91 \mathrm{~b} \\
\text { fk } 10 / 4\end{array}$ & 579 & Tyrö & Yhimäki & Mari Juhanant. K & $\begin{array}{l}\text { Oli ennen meihen kaul, suuri ringi } \\
\text { tyttölöi; ai luuli tyttölöi, suuri ringi } \\
\text { tyttölöi }\end{array}$ \\
\hline A $301 / 48 a$ & $\begin{array}{l}\text { fon. 92a; } \\
\text { fk10/5 }\end{array}$ & 451 & Tyrö & Yhimäki & $\begin{array}{l}\text { Vassu } \\
\text { Kontratant. }\end{array}$ & $\begin{array}{l}\text { Pettelikkoi miun emoini, pettelikkoi } \\
\text { miun emoini; ja emo emoini, ja } \\
\text { emoini joonoi }\end{array}$ \\
\hline A $301 / 48 b$ & $\begin{array}{l}\text { fon. } 92 b \\
\text { fk10/5 }\end{array}$ & $451^{\star}$ & +Tyrö & Yhimäki & $\begin{array}{l}\text { Vassu } \\
\text { Kontratant. }\end{array}$ & $\begin{array}{l}\text { Iivana kojosem poikoi, iivana ko- } \\
\text { joisem poikoi; ja kojo kojoisen, ja } \\
\text { kojoisem poikoi }\end{array}$ \\
\hline A $301 / 49 a$ & $\begin{array}{l}\text { fon. 93a; } \\
\text { fk10/6 }\end{array}$ & 494 & Tyrö & Yhimäki & $\begin{array}{l}\text { Anni Sakarint. } \\
\text { Varttunen }\end{array}$ & $\begin{array}{l}\text { Anni tyttöi ainoi tyttö, anni tyttöi } \\
\text { ainoi tyttö, ainoi tyttö }\end{array}$ \\
\hline A $301 / 49 b$ & $\begin{array}{l}\text { fon. } 93 \mathrm{~b} ; \\
\text { fk10/6 }\end{array}$ & 487 & Tyrö & Yhimäki & $\begin{array}{l}\text { Anni Sakarint. } \mathrm{K} \\
\text { Varttunen }\end{array}$ & $\begin{array}{l}\text { La laulan liki kotija, lik iusta } \\
\text { uikuttal(le); uikutte uikutte, liki } \\
\text { usta uikutte }\end{array}$ \\
\hline A $301 / 50 a$ & $\begin{array}{l}\text { fon. } 94 \mathrm{a} ; \\
\text { fk10/7 }\end{array}$ & 380 & Tyrö & Yhimäki & $\begin{array}{l}\text { Anni Sakarint. } \\
\text { Varttunen }\end{array}$ & $\begin{array}{l}\text { Kadri kuuluda kuningas, suotta } \\
\text { teGi suomel linnoi; ai sveti kalinkoi, } \\
\text { ja grugoi galobnikkoi }\end{array}$ \\
\hline A $301 / 50 b$ & $\begin{array}{l}\text { fon. } 94 \mathrm{~b} ; \\
\text { fk10/7 }\end{array}$ & 190 & Tyrö & Yhimäki & $\begin{array}{l}\text { Anni Sakarint. } \\
\text { Varttunen }\end{array}$ & $\begin{array}{l}\text { la miä laulal lapselleni, pojalleni } \\
\text { poimettelen }\end{array}$ \\
\hline A $301 / 50 c$ & $\begin{array}{l}\text { fon. } 94 \mathrm{c} \\
\text { fk } 10 / 7\end{array}$ & 224 & Tyrö & Yhimäki & $\begin{array}{l}\text { Anni Sakarint. } \\
\text { Varttunen }\end{array}$ & $\begin{array}{l}\text { lens too kukkoi kuurimmaalda, } \\
\text { laskisi lapesta linDu }\end{array}$ \\
\hline A $301 / 56 a$ & $\begin{array}{l}\text { fon. } \\
100 \mathrm{a} \\
\text { fk } 10 / 13\end{array}$ & & Tyrö? & & $\begin{array}{l}\text { tuntematon } \\
\text { laulaja }\end{array}$ & $\begin{array}{l}\text { Pettelikkoi miun emoini, pettelikkoi } \\
\text { miun emoini; ja emo emoini, ja } \\
\text { emoini joonoi }\end{array}$ \\
\hline
\end{tabular}

\section{Mägiste 1920- TAI 1930-LUvUlla (ERA Fon. 372)}

\begin{tabular}{|c|c|c|c|c|}
\hline VIITE & PAIKKa & KYLÄ & LAULAJA & AlKusÄKeEt \\
\hline ERA Fon $372 \mathrm{a}$ & Narvusi & Kallivieri & Valpuri Vohta & tule uni [ulkoteiltä], käy lapsen kätkyve \\
\hline ERA Fon $372 b$ & Narvusi & Kallivieri & Valpuri Vohta & $\begin{array}{l}\text { [tunnen tunnen ken vaa tulloo, arvaan, ar] } \\
\text { vaan ken aijaaha }\end{array}$ \\
\hline ERA Fon $372 c$ & Narvusi & Kallivieri & Valpuri Vohta & $\begin{array}{l}\text { yks oli väärä miun emoini, miun emoini; toin } \\
\text { oli väärä miun issoini miun issoini }\end{array}$ \\
\hline
\end{tabular}

\section{Kreek 1922 (ERA Fon. 207-209)}

\begin{tabular}{llll} 
ViIte & Paikka Kylä & Laulaja & AlkusäE \\
ERA Fon. 207 & Soikkola Joenperä & Darja Lehti & I mammani minnoo synnytteli, mustas savutuvas \\
\hline ERA Fon. 208 & Soikkola Joenperä & Darja Lehti & TeGi turhin miun emmoine, teki vaa turHin tuutijain \\
\hline ERA Fon. 209 a & Soikkola Joenperä & Darja Lehti & Ter(e)ve (o) tuttua tuppaaHa, ter(e)ve tuttua tuppaHa \\
\hline ERA Fon. 209 b & Soikkola Joenperä & Darja Lehti & Oi juu vaa kurkku kanna kagla \\
\hline ERA Fon. 209 c & Soikkola Joenperä & Darja Lehti & Oi täss on lusti noori(in) noista noori(in) noista
\end{tabular}


VÄISÄNEN 1914 (SKSÄ A 302-303)

Viitteet:

s) = SKS KRA Väisänen A.O. 1913-1915 s);

Laat. 3:3 = SKS KRA laatikko 3:3 Inkerinmaa. Vihko sävelmämuistiinpanoja.

\begin{tabular}{|c|c|c|c|c|c|}
\hline ViIte & MuUt viltteet $\mathrm{F}$ & PAIKKa & KYLÄ & LAULAJA & AlkusäE \\
\hline SKSÄ A 302/97 & $\begin{array}{l}\text { s) } 10 \text {; fono- } \\
\text { kop028_07 }\end{array}$ & Narvusi & Kirjamo & $\begin{array}{l}\text { Maarja Kiiranen ja } \\
\text { kolme nuorta naista }\end{array}$ & $\begin{array}{l}\text { Terve kuu terve päivä, } \\
\text { terve kuu terve päivä }\end{array}$ \\
\hline SKSÄ A 302/98c & fonokop028_07 I & Narvusi & Kirjamo & $\begin{array}{l}\text { "Kaksi naista" (tai } \\
\text { enemmän?) }\end{array}$ & $\begin{array}{l}\text { Lie lie liekku kie kie } \\
\text { kiekku, lie lie liekku } \\
\text { kie kie kiekku }\end{array}$ \\
\hline SKSÄ A 303/7 & $\begin{array}{l}\text { s) } 16 \text {; Laat. } 3: 3 \text {, } \\
\text { s. } 2 \text {; } \\
\text { fonokop028_09 }\end{array}$ & Narvusi & Ropsu & Matti Pukonen & $\begin{array}{l}\text { Olin orjana Virossa ja } \\
\text { Virossa, käin kylässä } \\
\text { käskyläissä käskyläissä }\end{array}$ \\
\hline SKSÄ A 303/8 & $\begin{array}{l}\text { s) 16; Laat. 3:3, s. 2; } \\
\text { fonokop028_09 }\end{array}$ & NNarvusi & Ropsu & Matti Pukonen & $\begin{array}{l}\text { Läksin suolle soutamahan, } \\
\text { aholle ajelemahan }\end{array}$ \\
\hline SKSÄ A 303/13 & $\begin{array}{l}\text { s) } 25 \text {; Laat. } 3: 3 \text {, s. } 3 \text {; } \\
\text { fonokop028_10 }\end{array}$ & 'Narvusi & Ropsu & Matti Pukonen & $\begin{array}{l}\text { Läksin koista kulemahan, } \\
\text { veräjiltä vieremähän }\end{array}$ \\
\hline s) 59 & Laat. $3: 3$, s. 5 & Soikkola & Risumäki & & $\begin{array}{l}\text { Mikä meien ikkunalla, } \\
\text { meroi meien ikkunalla }\end{array}$ \\
\hline s) 60 & Laat. $3: 3$, s. 5 & Soikkola & Risumäki & & $\begin{array}{l}\text { Laga mie katson liek- } \\
\text { kujame, kiusa-mie-elen } \\
\text { kiekkujame }\end{array}$ \\
\hline
\end{tabular}

\section{VÄISÄNEN 1931 (SKSÄ A 507)}

Mari Vahterin mukaan hän kävi mukana laulamassa kuorossa vuonna 1931 pidetyssä IV suomalais-ugrilaisessa kulttuurikongressissa (16-18.6.) Esilaulajana oli Jevdokia Räkälä, muina laulajina Olga Paju Räkälästä ja Mari Väimel Kallivierestä. (SKS KRA Laiho L. 5415.) Ilmeisesti Väisänen teki esilaulajan nimeä lukuunottamatta kontekstitiedottomiksi jääneet äänityksensä tässä yhteydessä.

\begin{tabular}{llll} 
VIIte & PAIKKA LAUlAJA & K & AlKusäKeEt \\
SKSÄ A 507/8 a Narvusi Jeodokia Räkälä & K & Tulin maille vierahille, tulin maille vierahille \\
\hline SKSÄ A 507/8 b Narvusi Jeodokia Räkälä K K & $\begin{array}{l}\text { Helise heliä metsä, kolise komia koropi; ja komia } \\
\text { korpi ja komia korpi }\end{array}$ \\
\hline SKSÄ A 507/9 a Narvusi Jeodokia Räkälä & K & Mie liehe lie liekkujani, mie he lie lie liekkujani \\
\hline SKSÄ A 507/9 b Narvusi Jeodokia Räkälä & K & $\begin{array}{l}\text { Aa tytöt(e) lustit(e) luuraeltii luuraeltii, tytöt(e) } \\
\text { lustit(e) luuraeltii luuraeltii }\end{array}$ \\
\hline
\end{tabular}

SKSÄ A 507/9 c Narvusi Jeodokia Räkälä K Emo neuvoi neitojani, neuvo neitojani neuvo neitojani 


\section{LAIHO JA Viron YLEISRAdIO 1937 (SKSÄ L 87-101)}

Äänityksistä tarkemmin luvussa 2: Aili ja Lauri Laiho; laulajista ja heidän kotikylistään tarkemmin lisäksi liitteessä 1 . Kuorossa laulaa ilmeisesti aina viisi laulajaa eli ne, jotka eivät laula esilaulua, sooloesityksiä on vain muutama. Pitkät laulut on nauhoitettu useassa pätkässä, jotka eivät aina sijoitu peräkkäisiksi viitteiksi. Nauhat L 99b, 100a ja 100c ovat samaa jatkumoa, mutta erillisiä kokonaisuuksia.

Viite: $\mathrm{L}=\mathrm{SKSÄ} \mathrm{L}$.

\begin{tabular}{|c|c|c|c|}
\hline VIITE & PAIKKA & LAULAJA & K AlKusÄE \\
\hline L 87a & Narvusi & Tatjana Jegorov & $\mathrm{K} \begin{array}{l}\text { Oi Annikka turuisen tyttö joi turuisen; Annikka turuisen tyttö } \\
\text { joi turuisen }\end{array}$ \\
\hline L $87 b$ & Narvusi & Tatjana Jegorov & $\mathrm{K} \begin{array}{l}\text { Oo la miä tantsin tapsuttelen tapsuttelen; la miä tantsin tapsut- } \\
\text { telen tapsuttelen }\end{array}$ \\
\hline L 87c & Narvusi & Mari Vahter & $\begin{array}{l}\text { Helise helijä metsä, komise komia kor(o)pi; ja komia korpi, ja } \\
\text { komia korpi }\end{array}$ \\
\hline$\underline{\mathrm{L} 87 \mathrm{~d}}$ & Narvusi & Tatjana Jegorov & K Ohtoni ohto miun osaksi; oi galina lee miun osaksi \\
\hline $\begin{array}{l}\text { L } 88 \mathrm{a}-\mathrm{c}, \\
89 \mathrm{a}\end{array}$ & Narvusi & Anna Kivisoo & $\begin{array}{l}\text { Anni tyttö aino tyttö, oli ainava emolla; } \\
\text { estradza, oli ainava emolla, estradza, oli ainava emolla }\end{array}$ \\
\hline L $89 b$ & Narvusi & Anna Kivisoo & $\mathrm{K} \begin{array}{l}\text { Ooo nyt on lusti nuoren noissa nuoren noissa; } \\
\text { nyt on lusti nuoren noissa nuoren noissa }\end{array}$ \\
\hline L $89 c$ & Narvusi & Anna Kivisoo & $\mathrm{K} \begin{array}{l}\text { Tupa täyn on tuppasuita tuppasuita; tupa täyn on tuppasuita } \\
\text { tuppasuita }\end{array}$ \\
\hline L 90a & Soikkola & Darja Lehti & $\mathrm{K} \begin{array}{l}\text { Oi pääskölintu päivälintu, too ihhala ilmal lintu; } \\
\text { pääskylintu päivälintu, too ihhala ilmal lintu }\end{array}$ \\
\hline L 90b & Narvusi & Mari Vahter & Ää ää ämmäl lasta, ää ää pikkaraista, vai vai vai vai \\
\hline L 90b & Narvusi & Valpuri Vohta & Nukuta Jumala lasta, makauta Maarijaisen, ää ää ääää \\
\hline L 90c & Narvusi & Anna Kivisoo & $\begin{array}{l}\text { Nuku nuku yksi silmä, tor(o)ku tor(o)ku toine sil(i)mä, bai bai } \\
\text { bai bai }\end{array}$ \\
\hline $\begin{array}{l}\text { L } 91 a, L \\
92 a 2, L \\
91 b\end{array}$ & Narvusi & Anna Kivisoo & $\begin{array}{l}\text { Kui tulloo syvä sykysy, kova tal(a)vi tallajaa; kaalinna kaalinna } \\
\text { K kaalinam maja, kova talvi tallajaa, kaalinna kaalinna kaalinam } \\
\text { maja, kova talvi tallajaa }\end{array}$ \\
\hline L 91b2 & Narvusi & Anna Kivisoo & $\begin{array}{l}\text { Tuttu luttu miä trubitin, paappa minnuu paimeneksi; kaalinna } \\
\text { K kaalinna kaalinam maja, paappa minnuu paimenekse, kaalinna } \\
\text { kaalinna kaalinam maja, paappa minnuu paimenekse }\end{array}$ \\
\hline L 92b & Narvusi & Tatjana Jegorov & $\begin{array}{l}\text { Tulkaa kokkii kittämää vaa kiittämää vaa; tulkaa kokkii kiittä- } \\
\text { mää vaa kiittämää vaa }\end{array}$ \\
\hline L 92c & Narvusi & Valpuri Vohta & $\begin{array}{l}\text { Tulkaa kokkii kittämää vaa kiittämää vaa; tulkaa kokkii kiittä- } \\
\text { mää (vaa) kiittämää vaa }\end{array}$ \\
\hline $\begin{array}{l}\text { L 93a, } \\
\text { L 94a, } \\
\text { L 93b }\end{array}$ & Narvusi & Anna Kivisoo & $\begin{array}{l}\text { Menin maammalleni marjah, kantajalle karpaloo; menin } \\
\text { maamma/olleni marjah, kantajalla karpalooh }\end{array}$ \\
\hline L 94b & Narvusi & Mari Vahter & $\begin{array}{l}\text { Hoz miä itken hoz miä laulan, ei mium päiväni parene; hoz } \\
\text { miä itken hoz miä laulan, ei mium päiväni pare(ne) }\end{array}$ \\
\hline L 95a & Narvusi & Anna Kivisoo & $\mathrm{K} \begin{array}{l}\text { La ko vieretäv vilulla, kajahotan kasteHella; la ko vieretäv } \\
\text { vilulla, kajahu/otan kasteHella }\end{array}$ \\
\hline$\underline{\mathrm{L} 95 \mathrm{~b}}$ & Narvusi & Tatjana Jegorov & K La läHel läpi kyläistä; la lähel läpi kyläisen \\
\hline L 95c & Narvusi & Valpuri Vohta & $\mathrm{K} \begin{array}{l}\text { Tehkää yksi ympärikko ympärikko; tehkää yksi ympärikko } \\
\text { ympärikko (kuin miä kasvelin kanainen) }\end{array}$ \\
\hline L 95d & Narvusi & Valpuri Vohta & $\begin{array}{l}\text { Yks oli väärä miun emoini miun emoini; yks oli väärä miun } \\
\text { emoini miun emoini }\end{array}$ \\
\hline L 96a & Narvusi & Anna Kivisoo & $\begin{array}{l}\text { Ei mium pitäs lauleHella, eig ilota ensinkä(nä); kaal'inna } \\
\text { K kaal'inna kaal'inammajaa, ei(j) ilota ensinkä(n)ä, kaal'inna } \\
\text { kaal'inna kaal'inammajaa, ei(j/g) ilota ensinkää }\end{array}$ \\
\hline
\end{tabular}




\begin{tabular}{llll} 
Virte & PAikKa & LAULAJA & K AlKusäE \\
L 96b & Narvusi & Valpuri Vohta & $\begin{array}{c}\text { Käksin i raukka raatamaa, kultani kanssa kuokkimaa; hoi goore } \\
\text { ni kanssa kuokkimaa }\end{array}$ \\
\hline L 97a & Narvusi & Anna Kivisoo & K Oi Mari sisarueni; oi Mari sisaruveni \\
\hline L 97b & Narvusi & Anna Kivisoo & K Oo lankoiseni lintuiseni; lankoiseni lintuiseni \\
\hline L 97c & Narvusi & Anna Kivisoo & K Oi isämies isyvem poika; isämies isyvem poika \\
\hline L 98a & Narvusi & Anna Kivisoo & K Oi Mari sisarueni; oi Mari sisaruveni \\
\hline L 98b & Narvusi & Anna Kivisoo & K Menkää eestä ristirahvas; menkää eestä ristirahvas \\
\hline L 98c & Narvusi & Anna Kivisoo & K Oo olkoon tienattu Jumala; olkoon tienattu Jumala \\
\hline L 98d & Narvusi & Valpuri Vohta & K Mihin viivyit i velvyiveni; mihin viivyit velvyivene \\
\hline L 99a & Narvusi & Anna Kivisoo & K Oo oi Mari sisaruveni; oi Mari sisaruveni \\
\hline L 99b & Narvusi & Anna Kivisoo & K Oi Mari sisaruveni; oi Mari sisaruveni \\
\hline L 100a & Narvusi & Anna Kivisoo & K Oo oi Mari sisaruveni; oi Mari sisaruveni \\
\hline L 100b & Narvusi & Valpuri Vohta & K Tunnen tunnen kev vaa tulloo; tunnen tunnen kev vaa tulloo \\
\hline L 100c & Narvusi & Valpuri Vohta & K Oi vävy vävyjyeni; oi vävy vävyjyeni \\
\hline L 100d & Narvusi & Anna Kivisoo & K Oo älä huuva hullu kuusi; älä huuva hullu kuusi \\
\hline L 101a & Narvusi & Tatjana Jegorov & K Ooi hups hups hups hups Martikkine Martikkine; hups hups \\
\hline L 101b & Soikkola Darja Lehti & K Oi pyhä Ilija isäntä isäntä; oi pyhä Ilija isäntä isäntä; pyhä \\
\hline L 101c & Narvusi & Anna Kivisoo & K (Oo tulkaa tyttäret tulella tulella \\
\hline L 101d & Narvusi & Anna Kivisoo & K Oo peremies peren isäntä; oi galina lee ja isäntä \\
\hline L 101e & Soikkola Darja Lehti & Oi juua kurkku kanna kagla, kyl jalat kottiiHe veeväD
\end{tabular}

\section{LiIte 5: TEEMOTTAISIA AINEISTOKOKONAISUUKSIA}

Lukuihin 4-7 liittyvät keskeiset aineistokokonaisuudet teemoittain. Sävelmäviitteet on annettu tarkemmin kerääjittäin liitteessä 4 .

\section{PAIKALLISET NIMITYKSET}

Tanssiin, leikkiin ja paikoillaan laulamiseen liittyvät nimitykset (tantsu-, hyppy-, rinki-, ympärikko-, leikki- ja ilta-):

TANTsU/hypPY: SKVR III 234; SKS KRA Kohtamäki VK 41:5; L. Laiho 4735; SibA Launis 187; SKSÄ L 87b, 89b.

HYPPY: SKVR III 97 (alaviite), 3967.

RINKI: SKVR III 1581, 3967.

YмрӓRIкко: SKVR III 1581; SKS KRA K. Salminen 193; V. Salminen 2948.

LEIKKI: SKVR III 1067, 1068, 1582, 1583.

ILTA: SKVR III 1052, 1057; SibA Launis 322.

Kalendaarirunoihin liittyvät nimitykset (laskiais-, liekku-, urpa-, jaani-, Iilia-, Pedro-, Martin-, kiletoi-, joulu-, praasnikka-, kiitos-):

LASKIAIS: SKS KRA Mannonen 5514, 7672. 
LIEKKU: SKVR III 44; 1069, 1905; SKS KRA Borenius e) 200, 600; SKS KRA L. Laiho 5342, 5390; Sääski 5529, 5618; SibA Launis 104.

URPA: SKVR III 1051, 2125.

JAANi(TULI)/Kокко: SKS KRA V. Salminen 2968, 2971; SKSÄ L 101c.

Iilia/Pedro: SKVR III 576, 1569, 1570; SKS KRA Enäjärvi-Haavio 536; Mannonen 5446.

MARTTI: SKVR III 241, 1805; SKSÄ L 101a.

KILETOI: SKVR III 73, 227, 228, 1047, 1904, 2284, 3657; SKS KRA K. Salminen 216.

PRAASNIKKA: SKVR III 1048, 1565, 1566, 1568, 3535; SKSÄ L $101 \mathrm{~b}$.

KIITOS: SKVR III 2079, 3497; SKS KRA Haavio 2719.

Häärunoihin liittyvät nimitykset (pulma-, hää-, kylvetys-, sauna-, istuttamis-, tervehtimis-, pöydän lunastamis-, kans-, opetus-, neuvo-, suku-, kokin kiitos-, lähtö-):

Pulma: SKVR III 2137, 2145, 2373, 2440, 2441, 2515; SKS KRA Angeria ERA:68, 85, 86, 87, 8892, 98, 99; Borenius e) 193-195, 203, 204, 591, 594, 602; Haavio 2447, 2466, 2468, 2568; Haltsonen 6530:38; A. Laiho 2092, 2145, 2179; L. Laiho 4994, 4996, 5108, 5307, 5409; Sääski 5905, 5974; K. Salminen 265; SibA Launis 22, 30a, 30b, 84b; SKSÄ L 97a, 98a; 97b-100d; SKSÄ A 303/8.

HäÄ: SKVR III 414, 415, 440, 3853, 3862, 3948, 4008, 4204; SKS KRA Enäjärvi-Haavio 857-859, 866; Mannonen 11116; V. Salminen 2905; Sääski 5921, 5905, 5962-5970; 5974.

KylvettäMINEN: SKS KRA Borenius e) 591; (Enäjärvi-Haavio 853); L. Laiho 4987, 5307; Sääski 5982; V. Salminen 2950; SKSÄ L 97a, 98 a, 98b.

SAUnA(stATUlo): SKS KRA L. Laiho 4987, 5307; SKSÄ L 98 b.

IsTUTTAMIS: SKS KRA L. Laiho 5309; SKSÄ L 99a.

Tervehtimis/Tervetulo: SKVR III 2146; SKS KRA Sääski 5954, 5973; 5977-5978.

PÖydÄN LUNASTAMISVIRSI: SKS KRA L. Laiho 5312; SKSÄ L 79c.

KANS(I): SKS KRA Sääski 5973, 5978.

Opetus/Neuvo/NEuvokki: SKVR III 2264; SKS KRA Enäjärvi-Haavio 900; L. Laiho 4994; K. Salminen 115, 269; SKSÄ L 100c.

KokIn (KIITOs): SKVR III 2550; SKS KRA Haavio 2467; A. Laiho 3441; K. Salminen 166, 267; SKSÄ L SKSÄ L 92 b, c.

LÄнтӧ: SKVR III 3483; SKS KRA L. Laiho 5316; SKSÄ L 99b.

Muihin paikallisiin lajeihin liittyvät nimitykset (lapsen-, liekutus-, kehto-, narri-, sotamiehen-, paimen-, eitsi-, öitsnikka-):

LAPSEN/LAPSIEN: SKVR III 3814; SKS KRA Haavio 2532; L. Laiho 5133; Mannonen 5463, 7636, 7638, 7655, 7657, 7658, 7659, 9776, 9780; K. Salminen 284.

LIEKUTUS: SKS KRA Borenius e) 198; L. Laiho 5340.

Kehtolaulu: SKVR III 1061, 1062, 1063, 1065; SKS KRA Enäjärvi-Haavio 526, 527; SibA Launis 37.

NARRI(MIS), NALJA, RAIPPA: SKVR III 1071; SKS KRA Haavio 2728; A. Laiho 2165; L. Laiho 4862, 4863, 4926, 4991; SKSÄ L 100b ja d.

SotAmieHEN: SKS KRA L. Laiho 5323; Mannonen 5514, 7639, 7654; K. Salminen 42; SKSÄ L 91 . PAIMEN, EITSI, ÖITSNIKKA: SKVR III 327, 328, 1596, 1597, 3842, 3937, 3960; SKS KRA Mannonen. 5448

VIRON VIRSI: SKVR III 2521, 3825, 3993.

Suru/HALleE: SKVR III 563; SKS KRA Kohtamäki VK 41:4; A. Laiho 2151, 2291. 


\section{LIIKEKUVAUKSET}

Taulukossa ovat keskeisimmät runokäsikirjoitusaineistoon sisältyvät liikkeen, laulutilanteiden ja laulamisen tapojen kuvaukset.

Viite $=$ SKS KRA (+kerääjä ja numero) tai SKVR (numero). $S=$ viite sävelmään tai laulun muotorakenteeseen.

\begin{tabular}{|c|c|c|c|c|c|c|}
\hline ViIte & LaUlaja & RunO & Tilanne & Miten & Кеткё & S \\
\hline $\begin{array}{l}\text { Enäjärvi- } \\
\text { Haavio } 460\end{array}$ & Kivisoo, Anna & $\begin{array}{l}\text { Anni tyttö aino } \\
\text { tyttö }\end{array}$ & & ympärikko & tytöt & S \\
\hline $\begin{array}{l}\text { Enäjärvi- } \\
\text { Haavio } 463\end{array}$ & Kivisoo, Anna & $\begin{array}{l}\text { Läksin koista } \\
\text { kulkemaa }\end{array}$ & Tuvassa & ympärikko & $\begin{array}{l}\text { armotoin } \\
\text { laps } \\
\text { [esilaulaa] }\end{array}$ & \\
\hline $\begin{array}{l}\text { Enäjärvi- } \\
\text { Haavio } 464\end{array}$ & Orava, Mari & $\begin{array}{l}\text { Varrain heitti } \\
\text { miun emoni }\end{array}$ & & töitä tehdessä & mies & \\
\hline $\begin{array}{l}\text { Enäjärvi- } \\
\text { Haavio } 465\end{array}$ & Mark, Katri & $\begin{array}{l}\text { Läksin skouluun } \\
\text { mie kotonta }\end{array}$ & & $\begin{array}{l}\text { tanssiessa / } \\
\text { istuessa }\end{array}$ & & \\
\hline $\begin{array}{l}\text { Enäjärvi- } \\
\text { Haavio } 467\end{array}$ & Vohta, Valpuri & $\begin{array}{l}\text { Helise helïa } \\
\text { metsä }\end{array}$ & $\begin{array}{l}\text { Jyrin päivä; } \\
\text { häissä }\end{array}$ & istuessa & naiset & S \\
\hline $\begin{array}{l}\text { Enäjärvi- } \\
\text { Haavio } 468\end{array}$ & Kivisoo, Anna & $\begin{array}{l}\text { Täss on ollut } \\
\text { ennen kylä; Nyt } \\
\text { on lusti nuoren } \\
\text { noista }\end{array}$ & & & & S \\
\hline $\begin{array}{l}\text { Enäjärvi- } \\
\text { Haavio } 469\end{array}$ & $\begin{array}{l}\text { Pohjalainen, } \\
\text { Juljaana }\end{array}$ & & Kesällä veneessä & istuessa & & S \\
\hline $\begin{array}{l}\text { Enäjärvi- } \\
\text { Haavio } 470 \\
\end{array}$ & Vohta, Katri & T.ten hukuttaja & & $\begin{array}{l}\text { istuessa / } \\
\text { ympärikko }\end{array}$ & & \\
\hline $\begin{array}{l}\text { Enäjärvi- } \\
\text { Haavio } 471\end{array}$ & Vohta, Katri & $\begin{array}{l}\text { Pääskylintu } \\
\text { päivälintu }\end{array}$ & $\begin{array}{l}\text { Kylän kadulla } \\
\text { kesällä, tuvassa } \\
\text { talvella }\end{array}$ & & & \\
\hline $\begin{array}{l}\text { Enäjärvi- } \\
\text { Haavio } 472\end{array}$ & Kivisoo, Anna & $\begin{array}{l}\text { Nyt tuloo syvä } \\
\text { sykysy }\end{array}$ & Tuvassa & ympärikko & & \\
\hline $\begin{array}{l}\text { Enäjärvi- } \\
\text { Haavio } 474\end{array}$ & Kivisoo, Anna & Viron orja & & & & S \\
\hline $\begin{array}{l}\text { Enäjärvi- } \\
\text { Haavio } 475 \\
\end{array}$ & Kivisoo, Anna & $\begin{array}{l}\text { Laulaisin hyväisen } \\
\text { virren }\end{array}$ & & & & S \\
\hline $\begin{array}{l}\text { Enäjärvi- } \\
\text { Haavio } 482\end{array}$ & Kivisoo, Anna & $\begin{array}{l}\text { Täss on tykky } \\
\text { tyttölöi }\end{array}$ & Pyhänä & & tytöt? & \\
\hline $\begin{array}{l}\text { Enäjärvi- } \\
\text { Haavio } 486 \\
\end{array}$ & Vohta, Valpuri & $\begin{array}{l}\text { Yks oli väärä } \\
\text { miun emoni }\end{array}$ & Pyhäiltoina & $\begin{array}{l}\text { ympärikko / } \\
\text { istuessa }\end{array}$ & tytöt & S \\
\hline $\begin{array}{l}\text { Enäjärvi- } \\
\text { Haavio } 488 \\
\end{array}$ & Vohta, Valpuri & $\begin{array}{l}\text { Noin saneli miun } \\
\text { emoni }\end{array}$ & & ympärikko & & S \\
\hline $\begin{array}{l}\text { Enäjärvi- } \\
\text { Haavio } 490\end{array}$ & Kivisoo, Anna & $\begin{array}{l}\text { Tytöt lustit } \\
\text { luuraelloot }\end{array}$ & & pitkällä äänellä & & S \\
\hline $\begin{array}{l}\text { Enäjärvi- } \\
\text { Haavio } 491\end{array}$ & Kivisoo, Anna & $\begin{array}{l}\text { Kui mie kazvelin } \\
\text { kanane }\end{array}$ & $\begin{array}{l}\text { Ulkona, kylän } \\
\text { kadulla }\end{array}$ & kulkien & tytöt & S \\
\hline $\begin{array}{l}\text { Enäjärvi- } \\
\text { Haavio } 497\end{array}$ & Vohta, Katri & $\begin{array}{l}\text { Oi tytöt sulat } \\
\text { sisaret }\end{array}$ & & $\begin{array}{l}\text { suurel äänel, } \\
\text { guljanjella }\end{array}$ & & \\
\hline $\begin{array}{l}\text { Enäjärvi- } \\
\text { Haavio } 499 \\
\end{array}$ & Vohta, Valpuri & $\begin{array}{l}\text { Oi sitä omaa } \\
\text { emyttä }\end{array}$ & & ympärikko & & S \\
\hline $\begin{array}{l}\text { Enäjärvi- } \\
\text { Haavio } 500 \\
\end{array}$ & Vohta, Valpuri & $\begin{array}{l}\text { Varhain kuoli } \\
\text { miun emoni }\end{array}$ & Häissä / pellolla & ympärikko / ? & & \\
\hline $\begin{array}{l}\text { Enäjärvi- } \\
\text { Haavio } 503\end{array}$ & $\begin{array}{l}\text { Pohjalainen, } \\
\text { Juljaana }\end{array}$ & $\begin{array}{l}\text { Kassa'ani } \\
\text { kallistani }\end{array}$ & Tuvassa /? & istuessa / kulkien & & \\
\hline
\end{tabular}




\begin{tabular}{|c|c|c|c|c|c|c|}
\hline VIITE & LAULAJA & Runo & Tilanne & Miten & Кеткё & S \\
\hline $\begin{array}{l}\text { Enäjärvi- } \\
\text { Haavio } 504\end{array}$ & Mark, Katri & $\begin{array}{l}\text { Kylähäni } \\
\text { linnahani }\end{array}$ & & kulkien & tytöt & \\
\hline $\begin{array}{l}\text { Enäjärvi- } \\
\text { Haavio } 505\end{array}$ & Kivisoo, Anna & $\begin{array}{l}\text { Menin metsähän } \\
\text { kesolla }\end{array}$ & $\begin{array}{l}\text { Metsään } \\
\text { mennessä }\end{array}$ & kulkien & lapset & \\
\hline $\begin{array}{l}\text { Enäjärvi- } \\
\text { Haavio } 506\end{array}$ & $\begin{array}{l}\text { Pohjalainen, } \\
\text { Juljaana }\end{array}$ & $\begin{array}{l}\text { La ko vieretän } \\
\text { vilulla }\end{array}$ & & laulun aloitus & & \\
\hline $\begin{array}{l}\text { Enäjärvi- } \\
\text { Haavio } 507\end{array}$ & Kivisoo, Anna & $\begin{array}{l}\text { La ko vieretän } \\
\text { vilulla }\end{array}$ & Illalla & seisten & & S \\
\hline $\begin{array}{l}\text { Enäjärvi- } \\
\text { Haavio } 510 \\
\end{array}$ & Kivisoo, Anna & Tuterina taterina & Nastassie & tanssi, tihtii & $\begin{array}{l}\text { vanha } \\
\text { akka }\end{array}$ & S \\
\hline $\begin{array}{l}\text { Enäjärvi- } \\
\text { Haavio } 519\end{array}$ & Kivisoo, Anna & $\begin{array}{l}\text { Soua laiva } \\
\text { joua laiva }\end{array}$ & Veneessä & istuessa & tytöt & \\
\hline $\begin{array}{l}\text { Enäjärvi- } \\
\text { Haavio } 520 \\
\end{array}$ & Vohta, Katri & $\begin{array}{l}\text { Käin kylässä, } \\
\text { Väin kylässä }\end{array}$ & & juovuksissa & vanha mies & \\
\hline $\begin{array}{l}\text { Enäjärvi- } \\
\text { Haavio } 536\end{array}$ & Kivisoo, Anna & Iliä pyhä isänt & Iilia? & $\begin{array}{l}\text { ympärikko, } \\
\text { kävelyaskelin }\end{array}$ & tytöt & \\
\hline $\begin{array}{l}\text { Enäjärvi- } \\
\text { Haavio } 539 \\
\end{array}$ & Kivisoo, Anna & Lie lie liekkujani & & liekulla & & S \\
\hline $\begin{array}{l}\text { Enäjärvi- } \\
\text { Haavio } 546 \\
\end{array}$ & Vohta, Valpuri & $\begin{array}{l}\text { Läksin raukka } \\
\text { raadamaa }\end{array}$ & & & & S \\
\hline $\begin{array}{l}\text { Enäjärvi- } \\
\text { Haavio } 548 \\
\end{array}$ & Vohta, Valpuri & & & toisel sanal & & S \\
\hline $\begin{array}{l}\text { Enäjärvi- } \\
\text { Haavio } 549 \text { (1) }\end{array}$ & Kivisoo, Anna & $\begin{array}{l}\text { Puhtaasti lyyrilli- } \\
\text { siä lauluja, esim. } \\
\text { La ko vieretän } \\
\text { vilulla tai Nyt on } \\
\text { tyynet nurmen } \\
\text { nurkat }\end{array}$ & $\begin{array}{l}\text { Ulkona ja } \\
\text { muuallakin }\end{array}$ & seisten tai istuen & & \\
\hline $\begin{array}{l}\text { Enäjärvi- } \\
\text { Haavio } 549 \text { (2) } \\
\end{array}$ & Kivisoo, Anna & useimmat laulut & & $\begin{array}{l}\text { ympärikko, taval- } \\
\text { lisin askelin / tihtii }\end{array}$ & & \\
\hline $\begin{array}{l}\text { Enäjärvi- } \\
\text { Haavio } 549 \text { (3) }\end{array}$ & Kivisoo, Anna & $\begin{array}{l}\text { Esim. Tytöt lustit } \\
\text { luuraelee }\end{array}$ & & $\begin{array}{l}\text { ympärikko, } \\
\text { hitaasti, pitkä ääni }\end{array}$ & & S \\
\hline $\begin{array}{l}\text { Enäjärvi- } \\
\text { Haavio } 549 \text { (4) }\end{array}$ & Kivisoo, Anna & $\begin{array}{l}\text { Esim. Veneeseen } \\
\text { surmattu veli, } \\
\text { Emon kuolo, } \\
\text { Läksin koista } \\
\text { kulkemaa } \\
\end{array}$ & Tuvassa & $\begin{array}{l}\text { ympärikko, } \\
\text { tavallisin tai } \\
\text { hitain askelin }\end{array}$ & & \\
\hline $\begin{array}{l}\text { Enäjärvi- } \\
\text { Haavio } 549 \text { (5) }\end{array}$ & Kivisoo, Anna & $\begin{array}{l}\text { Esim. Täss on } \\
\text { tykky tyttöläitä }\end{array}$ & Pyhänä & guljanje & & \\
\hline $\begin{array}{l}\text { Enäjärvi- } \\
\text { Haavio } 549 \text { (6) }\end{array}$ & Kivisoo, Anna & Keinulauluja & Liekulla & & & \\
\hline $\begin{array}{l}\text { Enäjärvi- } \\
\text { Haavio } 549 \text { (7) }\end{array}$ & Kivisoo, Anna & & Pyhänä, kadulla & kulkien, tanssi & tytöt & \\
\hline $\begin{array}{l}\text { Enäjärvi- } \\
\text { Haavio } 550 \text { (1) }\end{array}$ & Mark, Katri & & Läpi kylän & kulkien, tanssi & tytöt & \\
\hline $\begin{array}{l}\text { Enäjärvi- } \\
\text { Haavio } 550 \text { (2) }\end{array}$ & Mark, Katri & & $\begin{array}{l}\text { Ulkona, kylän } \\
\text { kadulla }\end{array}$ & $\operatorname{tanssi}$ & $\begin{array}{l}\text { tytöt ja } \\
\text { pojatkin }\end{array}$ & \\
\hline $\begin{array}{l}\text { Enäjärvi- } \\
\text { Haavio } 550 \text { (3) }\end{array}$ & Mark, Katri & & $\begin{array}{l}\text { Ulkona, kylän } \\
\text { kadulla }\end{array}$ & ympärikko, tihtii & tytöt & \\
\hline $\begin{array}{l}\text { Enäjärvi- } \\
\text { Haavio } 550 \text { (4) }\end{array}$ & Mark, Katri & & & $\begin{array}{l}\text { ympärikko, } \\
\text { tihtii / vienoo }\end{array}$ & & \\
\hline $\begin{array}{l}\text { Enäjärvi- } \\
\text { Haavio } 550 \text { (5) }\end{array}$ & Mark, Katri & & Kallaalla & istuessa & $\begin{array}{l}\text { tytöt, pojat } \\
\text { kuunt. }\end{array}$ & \\
\hline $\begin{array}{l}\text { Enäjärvi- } \\
\text { Haavio } 550 \text { (6) }\end{array}$ & Mark, Katri & & & lyhyt laulu & & S \\
\hline $\begin{array}{l}\text { Enäjärvi- } \\
\text { Haavio } 551 \text { (1) }\end{array}$ & $\begin{array}{l}\text { Bässina, } \\
\text { Matrona }\end{array}$ & $\begin{array}{l}\text { Läksin koista } \\
\text { kulkemaa }\end{array}$ & & tanssi, nopea & & S \\
\hline
\end{tabular}




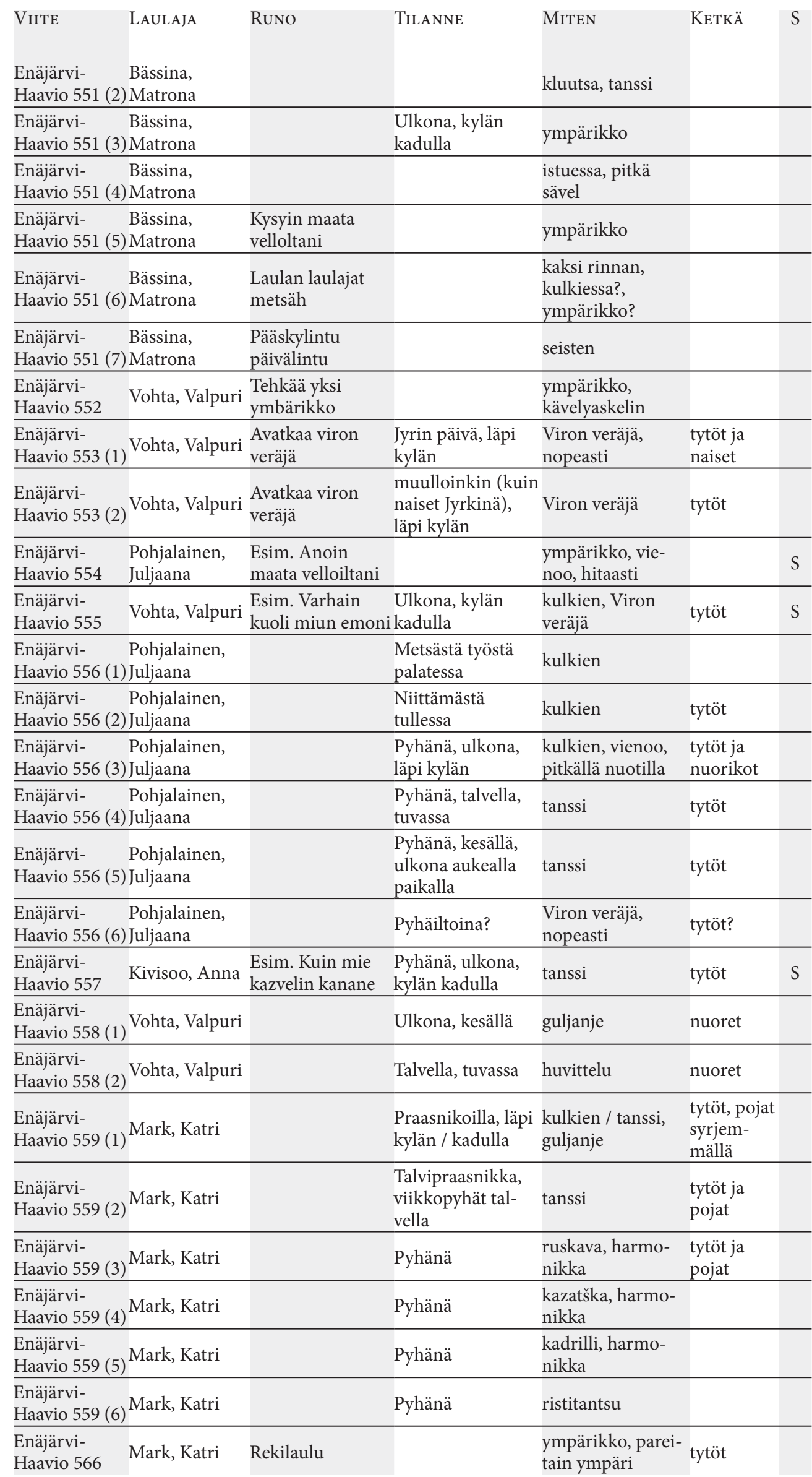




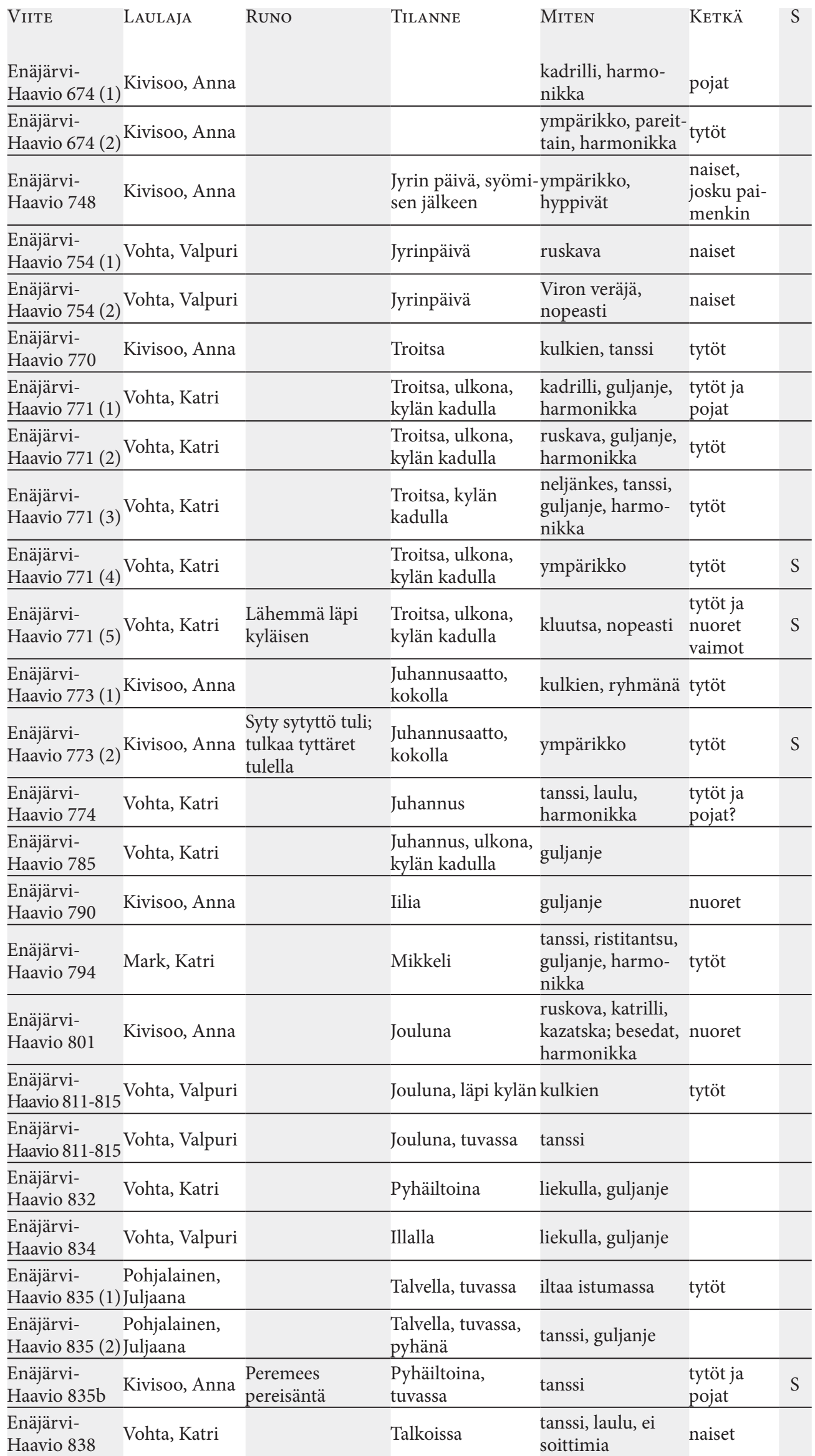




\begin{tabular}{|c|c|c|c|c|c|}
\hline ViIte & LAULAJA & RunO & Tillanne & Miten & КеткÄ \\
\hline $\begin{array}{l}\text { Enäjärvi- } \\
\text { Haavio } 864\end{array}$ & Vohta, Katri & $\begin{array}{l}\text { Terve kuvattu } \\
\text { kulta }\end{array}$ & $\begin{array}{l}\text { Häissä, morsius- } \\
\text { talossa }\end{array}$ & permannolla & $\begin{array}{l}\text { tytöt mor- } \\
\text { siamen } \\
\text { puolelta }\end{array}$ \\
\hline $\begin{array}{l}\text { Enäjärvi- } \\
\text { Haavio 867-868 } \\
\end{array}$ & Vohta, Katri & $\begin{array}{l}\text { Syökää langot } \\
\text { juokaa langot }\end{array}$ & $\begin{array}{l}\text { Häissä, morsius- } \\
\text { talossa }\end{array}$ & $\begin{array}{l}\text { pöytien luona } \\
\text { kiertäen }\end{array}$ & tytöt \\
\hline $\begin{array}{l}\text { Enäjärvi- } \\
\text { Haavio } 869\end{array}$ & Vohta, Katri & Kokin kiitos & Häissä & ympärikko & $\begin{array}{l}\text { naiset, } \\
\text { ehkä joku } \\
\text { mieskin } \\
\text { mukana } \\
\end{array}$ \\
\hline $\begin{array}{l}\text { Enäjärvi- } \\
\text { Haavio } 870\end{array}$ & Vohta, Katri & $\begin{array}{l}\text { Kus sie lanko otit } \\
\text { nämä tuumat }\end{array}$ & Häissä & ympärikko & $\begin{array}{l}\text { naiset, } \\
\text { ehkä joku } \\
\text { mieskin } \\
\text { mukana }\end{array}$ \\
\hline $\begin{array}{l}\text { Enäjärvi- } \\
\text { Haavio 871-872 } \\
\end{array}$ & Vohta, Katri & $\begin{array}{l}\text { Yhen muotoiset } \\
\text { molemmat }\end{array}$ & $\begin{array}{l}\text { Häissä, } \\
\text { sulhastalossa }\end{array}$ & $\begin{array}{l}\text { istuvalle morsius- } \\
\text { parille }\end{array}$ & \\
\hline $\begin{array}{l}\text { Enäjärvi- } \\
\text { Haavio } 879 \\
\end{array}$ & Vohta, Katri & $\begin{array}{l}\text { Saimme saunan } \\
\text { lämmittäjän }\end{array}$ & $\begin{array}{l}\text { Häissä, } \\
\text { sulhastalossa }\end{array}$ & ympärikko & $\begin{array}{l}\text { sulhasen } \\
\text { sukulaiset }\end{array}$ \\
\hline $\begin{array}{l}\text { Enäjärvi- } \\
\text { Haavio 881-882 } \\
\end{array}$ & Vohta, Katri & $\begin{array}{l}\text { Kenen tämä kylä } \\
\text { kulune }\end{array}$ & Häissä, läpi kylän & ajaessa & $\begin{array}{l}\text { morsiamen } \\
\text { sukulaiset }\end{array}$ \\
\hline $\begin{array}{l}\text { Enäjärvi- } \\
\text { Haavio } 884 \\
\end{array}$ & Vohta, Katri & $\begin{array}{ll}\text { La ko katson } \\
\text { langon sillat }\end{array}$ & $\begin{array}{l}\text { Häissä, } \\
\text { sulhastalossa }\end{array}$ & ympärikko & $\begin{array}{l}\text { morsiamen } \\
\text { sukulaiset }\end{array}$ \\
\hline $\begin{array}{l}\text { Enäjärvi- } \\
\text { Haavio } 885\end{array}$ & Vohta, Katri & $\begin{array}{l}\text { Kyll on lakkeet, } \\
\text { kyll on käppeet }\end{array}$ & $\begin{array}{l}\text { Häissä, } \\
\text { sulhastalossa }\end{array}$ & ympärikko & $\begin{array}{l}\text { morsiamen } \\
\text { sukulaiset }\end{array}$ \\
\hline $\begin{array}{l}\text { Enäjärvi- } \\
\text { Haavio } 895 \\
\end{array}$ & Vohta, Katri & $\begin{array}{l}\text { Ei oom maannut } \\
\text { meie minoi }\end{array}$ & $\begin{array}{l}\text { Häissä, } \\
\text { sulhastalossa }\end{array}$ & ympärikko & naiset \\
\hline $\begin{array}{l}\text { Enäjärvi- } \\
\text { Haavio } 896(1)\end{array}$ & & & $\begin{array}{l}\begin{array}{l}\text { Häissä, } \\
\text { sulhastalossa }\end{array} \\
\end{array}$ & $\operatorname{tanssi}$ & nuoret \\
\hline $\begin{array}{l}\text { Enäjärvi- } \\
\text { Haavio } 896(2) \\
\end{array}$ & & & $\begin{array}{l}\begin{array}{l}\text { Häissä, } \\
\text { sulhastalossa }\end{array} \\
\end{array}$ & ympärikko & \\
\hline $\begin{array}{l}\text { Enäjärvi- } \\
\text { Haavio } 896 \text { (3) } \\
\end{array}$ & & & $\begin{array}{l}\text { Häissä, } \\
\text { sulhastalossa }\end{array}$ & $\begin{array}{l}\text { ruskova, harmo- } \\
\text { nikka }\end{array}$ & miehet \\
\hline $\begin{array}{l}\text { Enäjärvi- } \\
\text { Haavio } 907\end{array}$ & Vohta, Valpuri & $\begin{array}{l}\text { (Mari) sirkkune } \\
\text { sisoni, mitä istut } \\
\text { silmät veessä }\end{array}$ & $\begin{array}{l}\text { Häissä, } \\
\text { morsiustalossa }\end{array}$ & & \\
\hline $\begin{array}{l}\text { Enäjärvi- } \\
\text { Haavio } 908 \\
\end{array}$ & Vohta, Valpuri & $\begin{array}{l}\text { Katso kaikki } \\
\text { ristirahvas }\end{array}$ & $\begin{array}{l}\text { Häissä, } \\
\text { sulhastalossa }\end{array}$ & $\begin{array}{l}\text { permannolta } \\
\text { seisten }\end{array}$ & $\begin{array}{l}\text { tytöt (ky- } \\
\text { län tytöt) }\end{array}$ \\
\hline $\begin{array}{l}\text { Enäjärvi- } \\
\text { Haavio } 910\end{array}$ & Kivisoo, Anna & $\begin{array}{l}\text { Annini sisarueni; } \\
\text { myö määmme } \\
\text { sinun jätämme }\end{array}$ & $\begin{array}{l}\text { Häissä, } \\
\text { sulhastalossa }\end{array}$ & & $\begin{array}{l}\text { morsiamen } \\
\text { suku }\end{array}$ \\
\hline Haavio 2429 & $\begin{array}{l}\text { Bässina, Ma- } \\
\text { trona }\end{array}$ & $\begin{array}{ll}\text { Katso kuk } \\
\text { linnukkaine }\end{array}$ & $\begin{array}{l}\text { Häissä, } \\
\text { sulhastalossa }\end{array}$ & seisten & $\begin{array}{l}\text { morsiamen } \\
\text { suku }\end{array}$ \\
\hline Haavio 2431 & $\begin{array}{l}\text { Bässina, Ma- } \\
\text { trona }\end{array}$ & $\begin{array}{l}\text { Pääskylintu } \\
\text { päivälintu }\end{array}$ & & istutaan, venyttäen & ntytöt \\
\hline Haavio 2445 & $\begin{array}{l}\text { Bässina, Ma- } \\
\text { trona }\end{array}$ & $\begin{array}{l}\text { La ko vieretän } \\
\text { vilulla }\end{array}$ & Illalla? & pitkä sävel & \\
\hline Haavio 2453 & $\begin{array}{l}\text { Bässina, Ma- } \\
\text { trona }\end{array}$ & $\begin{array}{l}\text { Mitä työ tytöt } \\
\text { suretta }\end{array}$ & Ulkona & $\begin{array}{l}\text { sotamiehiä saatta- } \\
\text { massa }\end{array}$ & $\begin{array}{l}\text { itse (tytöt, } \\
\text { naiset) }\end{array}$ \\
\hline Haavio 2456 & $\begin{array}{l}\text { Bässina, Ma- } \\
\text { trona }\end{array}$ & $\begin{array}{l}\text { Läksin koista } \\
\text { kulkemaa }\end{array}$ & & kluutsa, tanssi & \\
\hline Haavio 2462 & $\begin{array}{l}\text { Bässina, Ma- } \\
\text { trona }\end{array}$ & Sotasanomat & Pyhänä & istuessa & tytöt \\
\hline Haavio 2464 & $\begin{array}{l}\text { Bässina, Ma- } \\
\text { trona }\end{array}$ & T.ten hukuttaja & $\begin{array}{l}\text { Läpi kylän / } \\
\text { paikoillaan }\end{array}$ & istuessa / kulkien & \\
\hline Haavio 2472 & $\begin{array}{l}\text { Bässina, Ma- } \\
\text { trona }\end{array}$ & $\begin{array}{l}\text { Laulaisin hyväisen } \\
\text { virren }\end{array}$ & Tuvassa tai tiellä & ympärikko & \\
\hline Haavio 2475 & Kivisoo, Anna & $\begin{array}{l}\text { Mänin emolle } \\
\text { marjaa }\end{array}$ & Marjaan mennessä & äkulkien & tytöt \\
\hline
\end{tabular}




\begin{tabular}{|c|c|c|c|c|c|}
\hline Haavio 2495 & Lehti, Darja & $\begin{array}{l}\text { RuNo } \\
\text { Täss on lusti } \\
\text { nuoren noissa, } \\
\text { varatoin oon } \\
\text { vanhemmista }\end{array}$ & Tilanne & ympärikko & Кеткё \\
\hline Haavio 2496 & Lehti, Darja & $\begin{array}{l}\text { Nyt tulloo syvä } \\
\text { sykysy }\end{array}$ & & $\begin{array}{l}\text { sotamiehiä saatta- } \\
\text { massa }\end{array}$ & tytöt \\
\hline Haavio 2498 & Lehti, Darja & $\begin{array}{l}\text { Oi pääskylintu } \\
\text { päivälintu }\end{array}$ & & ympärikko & \\
\hline Haavio 2500 & Lehti, Darja & $\begin{array}{l}\text { Ilotkaat iloized } \\
\text { nuoret }\end{array}$ & & töitä tehdessä & $\begin{array}{l}\text { vanha } \\
\text { ämmä }\end{array}$ \\
\hline Haavio 2514 & $\begin{array}{l}\text { Pohjalainen, } \\
\text { Juljaana }\end{array}$ & $\begin{array}{l}\text { Jopa illakko } \\
\text { tulloo }\end{array}$ & illalla & & piikatyttö \\
\hline Haavio 2525 & $\begin{array}{l}\text { Haukka, } \\
\text { Valpuri }\end{array}$ & $\begin{array}{l}\text { Kulerva kalerva- } \\
\text { lainen; Lähemmä } \\
\text { läpi kyläisen }\end{array}$ & $\begin{array}{l}\text { kluutsa / } \\
\text { ympärikko }\end{array}$ & $\begin{array}{l}\text { kluutsa / } \\
\text { ympärikko }\end{array}$ & \\
\hline Haavio 2541 & $\begin{array}{l}\text { Pohjalainen, } \\
\text { Juljaana }\end{array}$ & $\begin{array}{l}\text { Tehkää illalla } \\
\text { illoo }\end{array}$ & Nastassie & laulun aloitus & tytöt \\
\hline Haavio 2547 & $\begin{array}{l}\text { Pohjalainen, } \\
\text { Juljaana }\end{array}$ & $\begin{array}{l}\text { Oi tytöt sulat } \\
\text { sisaret }\end{array}$ & & töitä tehdessä & \\
\hline Haavio 2558' & $\begin{array}{l}\text { Pohjalainen, } \\
\text { Juljaana }\end{array}$ & $\begin{array}{l}\text { Annikka turusen } \\
\text { tyttö }\end{array}$ & $\begin{array}{l}\text { Pyhänä, tuvassa / } \\
\text { liekulla }\end{array}$ & $\begin{array}{l}\text { ympärikko, } \\
\text { hitaasti }\end{array}$ & \\
\hline Haavio 2560 & $\begin{array}{l}\text { Pohjalainen, } \\
\text { Juljaana }\end{array}$ & $\begin{array}{l}\text { Tuttu luttu mie } \\
\text { trubitin }\end{array}$ & Ulkona & & poikaset \\
\hline Haavio 2568 & $\begin{array}{l}\text { Haukka, } \\
\text { Valpuri }\end{array}$ & $\begin{array}{l}\text { Poika tuoreesta } \\
\text { tuloo; aja aja } \\
\text { veljyveni }\end{array}$ & $\begin{array}{l}\text { Häissä, sulhas- } \\
\text { talossa }\end{array}$ & seisten?, kujalla & tytöt \\
\hline $\begin{array}{l}\text { Haavio } 2570 \\
\text { (1) }\end{array}$ & $\begin{array}{l}\text { Haukka, } \\
\text { Valpuri }\end{array}$ & $\begin{array}{l}\text { La kyselen kan- } \\
\text { nottele }\end{array}$ & Kallaalla & istuessa & tytöt \\
\hline $\begin{array}{l}\text { Haavio } 2570 \\
(2)\end{array}$ & $\begin{array}{l}\text { Haukka, } \\
\text { Valpuri }\end{array}$ & & Kallaalla & leikki; tanssi & $\begin{array}{l}\text { tytöt ja } \\
\text { pojat }\end{array}$ \\
\hline Haavio 2603 & $\begin{array}{l}\text { Pohjalainen, } \\
\text { Juljaana }\end{array}$ & $\begin{array}{l}\text { balladi: Nuori } \\
\text { meis kihlas } \\
\text { morsiamen }\end{array}$ & & $\begin{array}{l}\text { laulettiin harmo- } \\
\text { nikan kanssa }\end{array}$ & tytöt \\
\hline Haavio 2688 & $\begin{array}{l}\text { Pohjalainen, } \\
\text { Juljaana }\end{array}$ & $\begin{array}{l}\text { Avatkaa viron } \\
\text { veräjä }\end{array}$ & $\begin{array}{l}\text { Läpi kylän, Jyrin } \\
\text { päivänä ja muul- } \\
\text { loin, talkoissa }\end{array}$ & $\begin{array}{l}\text { Viron veräjä, } \\
\text { nopeasti }\end{array}$ & $\begin{array}{l}\text { tytöt ja } \\
\text { pojatkin } \\
\text { joskus }\end{array}$ \\
\hline Haavio 2692 & $\begin{array}{l}\text { Leppik, } \\
\text { Asastiija }\end{array}$ & & $\begin{array}{l}\text { Jyrinpäivä, toiseen } \\
\text { kylään }\end{array}$ & tanssi, guljanje & naiset \\
\hline Haavio 2695 & $\begin{array}{l}\text { Siller, Maria } \\
\text { Semonont. } \\
\text { Siller } \\
\end{array}$ & & Jyrinpäivä & guljanje & naiset \\
\hline $\begin{array}{l}\text { Haavio } 2697 \\
\text { (1) }\end{array}$ & Lehti, Darja & & Jyrinpäivä & $\begin{array}{l}\text { ympärikko, } \\
\text { guljanje }\end{array}$ & naiset \\
\hline $\begin{array}{l}\text { Haavio } 2697 \\
(2)\end{array}$ & Lehti, Darja & & $\begin{array}{l}\text { Pedro, Miikkula, } \\
\text { Maaria ja Jyri }\end{array}$ & tanssi, guljanje & naiset \\
\hline Haavio 2704 & $\begin{array}{l}\text { Haukka, } \\
\text { Valpuri }\end{array}$ & $\begin{array}{l}\text { Avatkaa viron } \\
\text { veräjä }\end{array}$ & $\begin{array}{l}\text { Jyrin päivä, } \\
\text { läpi kylän }\end{array}$ & $\begin{array}{l}\text { Viron veräjä, } \\
\text { tanssi }\end{array}$ & \\
\hline Haavio 2729 & Saksa, Valpuri & & Igrissat & $\begin{array}{l}\text { barabanan lyönti, } \\
\text { laulaminen }\end{array}$ & nuoret \\
\hline Haavio 2733 & Kivisoo, Anna & $\begin{array}{l}\text { Giledoi galedoi, } \\
\text { kana sittu ka- } \\
\text { nervoi }\end{array}$ & Kiletoi & ympärikko, tanssi & tytöt \\
\hline $\begin{array}{l}\text { Haavio } 2771 \\
\text { (1) }\end{array}$ & $\begin{array}{l}\text { Bässina, Ma- } \\
\text { trona }\end{array}$ & $\begin{array}{l}\text { Pyhä Pedru ko- } \\
\text { rmelits }\end{array}$ & Pedro, läpi kylän & kulkien & $\begin{array}{l}\text { tytöt ja } \\
\text { nuoret nai- } \\
\text { set (oman } \\
\text { kylän) } \\
\end{array}$ \\
\hline $\begin{array}{l}\text { Haavio } 2771 \\
\text { (2) }\end{array}$ & $\begin{array}{l}\text { Bässina, Ma- } \\
\text { trona }\end{array}$ & & Pedro, läpi kylän & kulkien, tanssi & vieraat \\
\hline
\end{tabular}




\begin{tabular}{|c|c|c|c|c|c|}
\hline Viite & LaUlaja & Runo & Tilanne & Miten & КеткÄ \\
\hline Haavio 2773 & $\begin{array}{l}\text { Bässina, Mat- } \\
\text { rona }\end{array}$ & $\begin{array}{l}\text { Oi tytöt sulat } \\
\text { sisaret }\end{array}$ & $\begin{array}{l}\text { Praasnikoilla, } \\
\text { syömisen jälkeen, } \\
\text { läpi kylän }\end{array}$ & kulkien & tytöt \\
\hline Haavio 2792 & Lehti, Darja & & $\begin{array}{l}\text { Pedro, ulkkona, } \\
\text { sillalla }\end{array}$ & $\begin{array}{l}\text { tanssi, guljanje, } \\
\text { harmonikka }\end{array}$ & tytöt, pojat \\
\hline Haavio 2810 & $\begin{array}{l}\text { Leppik, } \\
\text { Asastiija }\end{array}$ & & Kesällä, veneessä & istuessa & \\
\hline Haavio 2833 & $\begin{array}{l}\text { Bässina, } \\
\text { Matrona }\end{array}$ & & $\begin{array}{l}\text { iltaa istumassa, } \\
\text { saunassa }\end{array}$ & töitä tehdessä & tytöt, pojat \\
\hline $\begin{array}{l}\text { Haltsonen } \\
6530: 39\end{array}$ & $\begin{array}{l}\text { Haukka, } \\
\text { Valpuri }\end{array}$ & $\begin{array}{l}\text { Avatkaa viron } \\
\text { veräjä }\end{array}$ & $\begin{array}{l}\text { Jyrin päivä, läpi } \\
\text { kylän }\end{array}$ & $\begin{array}{l}\text { kulkien, tanssi, } \\
\text { nopeasti }\end{array}$ & \\
\hline $\begin{array}{l}\text { Kohtamäki } \\
\text { VK 41:5 } \\
\end{array}$ & Paju, Olga & $\begin{array}{l}\text { Tytöt lustit luu- } \\
\text { raellot }\end{array}$ & & $\operatorname{tanssi}$ & \\
\hline Laiho A. 2082 & $\begin{array}{l}\text { Haukka, } \\
\text { Valpuri }\end{array}$ & $\begin{array}{l}\text { Kylähäni lin- } \\
\text { nahani }\end{array}$ & $\begin{array}{l}\text { Kallaalla / läpi } \\
\text { kylän }\end{array}$ & & \\
\hline Laiho A. 2086 & $\begin{array}{l}\text { Haukka, } \\
\text { Valpuri }\end{array}$ & $\begin{array}{l}\text { Mitä työ tytöt } \\
\text { suretta }\end{array}$ & Kallaalla & & \\
\hline Laiho A. 2086 & $\begin{array}{l}\text { Haukka, } \\
\text { Valpuri }\end{array}$ & $\begin{array}{l}\text { Mitä työ tytöt } \\
\text { suretta }\end{array}$ & Kallaalla & & \\
\hline Laiho A. 2088 & $\begin{array}{l}\text { Haukka, } \\
\text { Valpuri }\end{array}$ & $\begin{array}{l}\text { Olin orja velloil- } \\
\text { leni }\end{array}$ & Häissä & tanssi, guljanje & \\
\hline Laiho A. 2096 & $\begin{array}{l}\text { Haukka, } \\
\text { Valpuri }\end{array}$ & $\begin{array}{l}\text { Oi sie poika } \\
\text { puolukkain }\end{array}$ & Kallaalla & & tytöt \\
\hline Laiho A. 2097 & $\begin{array}{l}\text { Haukka, } \\
\text { Valpuri }\end{array}$ & $\begin{array}{l}\text { Mari marjasta } \\
\text { tulloo }\end{array}$ & Kallaalla & & \\
\hline Laiho A. 2105 & $\begin{array}{l}\text { Bässina, } \\
\text { Matrona }\end{array}$ & $\begin{array}{l}\text { Elina sepän } \\
\text { emäntä }\end{array}$ & Karjaa ajaessa & & tytöt \\
\hline Laiho A. 2132 & $\begin{array}{l}\text { Bässina, } \\
\text { Matrona }\end{array}$ & $\begin{array}{l}\text { Hoz mie itken ho } \\
\text { mie laulan }\end{array}$ & $\begin{array}{l}\text { zKallaalla / läpi } \\
\text { kylän }\end{array}$ & & \\
\hline Laiho A. 2133 & $\begin{array}{l}\text { Bässina, } \\
\text { Matrona }\end{array}$ & $\begin{array}{l}\text { La ko vieretän } \\
\text { vilulla }\end{array}$ & $\begin{array}{l}\text { Heinämaalla, } \\
\text { illalla }\end{array}$ & & niittäjät \\
\hline Laiho A. 2147 & Mark, Katri & $\begin{array}{l}\text { Lähemmä läpi } \\
\text { kyläisen }\end{array}$ & $\begin{array}{l}\text { Kallaalla / läpi } \\
\text { kylän }\end{array}$ & & \\
\hline Laiho A. 2148 & Mark, Katri & $\begin{array}{l}\text { Pääskylintu } \\
\text { päivälintu }\end{array}$ & Kallaalla & seisten & \\
\hline Laiho A. 2166 & $\begin{array}{l}\text { Hauki, } \\
\text { Anastasija }\end{array}$ & $\begin{array}{l}\text { La ko katson } \\
\text { langon sillat }\end{array}$ & & ympärikko & \\
\hline Laiho A. 2210 & $\begin{array}{l}\text { Pajunen, } \\
\text { Varpu }\end{array}$ & $\begin{array}{l}\text { La lähen läpi } \\
\text { kyläisen }\end{array}$ & & kluutsa & \\
\hline Laiho A. 2217 & $\begin{array}{l}\text { Varpu Pajusen } \\
\text { miniä }\end{array}$ & $\begin{array}{l}\text { La ko katson } \\
\text { langon sillat }\end{array}$ & $\begin{array}{l}\text { Häissä, } \\
\text { sulhastalossa }\end{array}$ & $\begin{array}{l}\text { seisten; } \\
\text { ympärikossa }\end{array}$ & $\begin{array}{l}\text { morsiamen } \\
\text { sukulaiset }\end{array}$ \\
\hline Laiho A. 2221 & Lehti, Darja & $\begin{array}{l}\text { Täss on lusti } \\
\text { nuoren noissa, } \\
\text { varatoin oon } \\
\text { vanhemmista }\end{array}$ & ympärikko & ympärikko & \\
\hline Laiho A. 2264 & Lulla, Juljaana & $\begin{array}{l}\text { Muijen muijal } \\
\text { päät olla (väli- } \\
\text { muotoinen) }\end{array}$ & & ympärikko, tiukl & a tytöt \\
\hline Laiho A. 2276 & Otsa, Maria & $\begin{array}{l}\text { Olin orjana } \\
\text { virossa }\end{array}$ & Häissä & ympärikko & äiti \\
\hline Laiho A. 2277 & Otsa, Maria & $\begin{array}{l}\text { Soua laiva joua } \\
\text { laiva }\end{array}$ & Veneessä & istuessa & \\
\hline $\begin{array}{l}\text { Laiho A. } 2291 \\
\text { (1) }\end{array}$ & Vohta, Valpuri & $\begin{array}{l}\text { Helise heliä } \\
\text { metsä }\end{array}$ & $\begin{array}{l}\text { Kallalla, kesällä / } \\
\text { häissä }\end{array}$ & $\begin{array}{l}\text { istuessa, hallee } \\
\text { laulu }\end{array}$ & \\
\hline Laiho A. 2295 & $\begin{array}{l}\text { Pekkonen, } \\
\text { Maria }\end{array}$ & $\begin{array}{l}\text { Läksin koista } \\
\text { kulkemaa }\end{array}$ & Häissä & $\operatorname{tanssi}$ & \\
\hline Laiho A. 2329 & Vohta, Katri & & & $\begin{array}{l}\text { tanssi, } \\
\text { harmonikka }\end{array}$ & \\
\hline
\end{tabular}




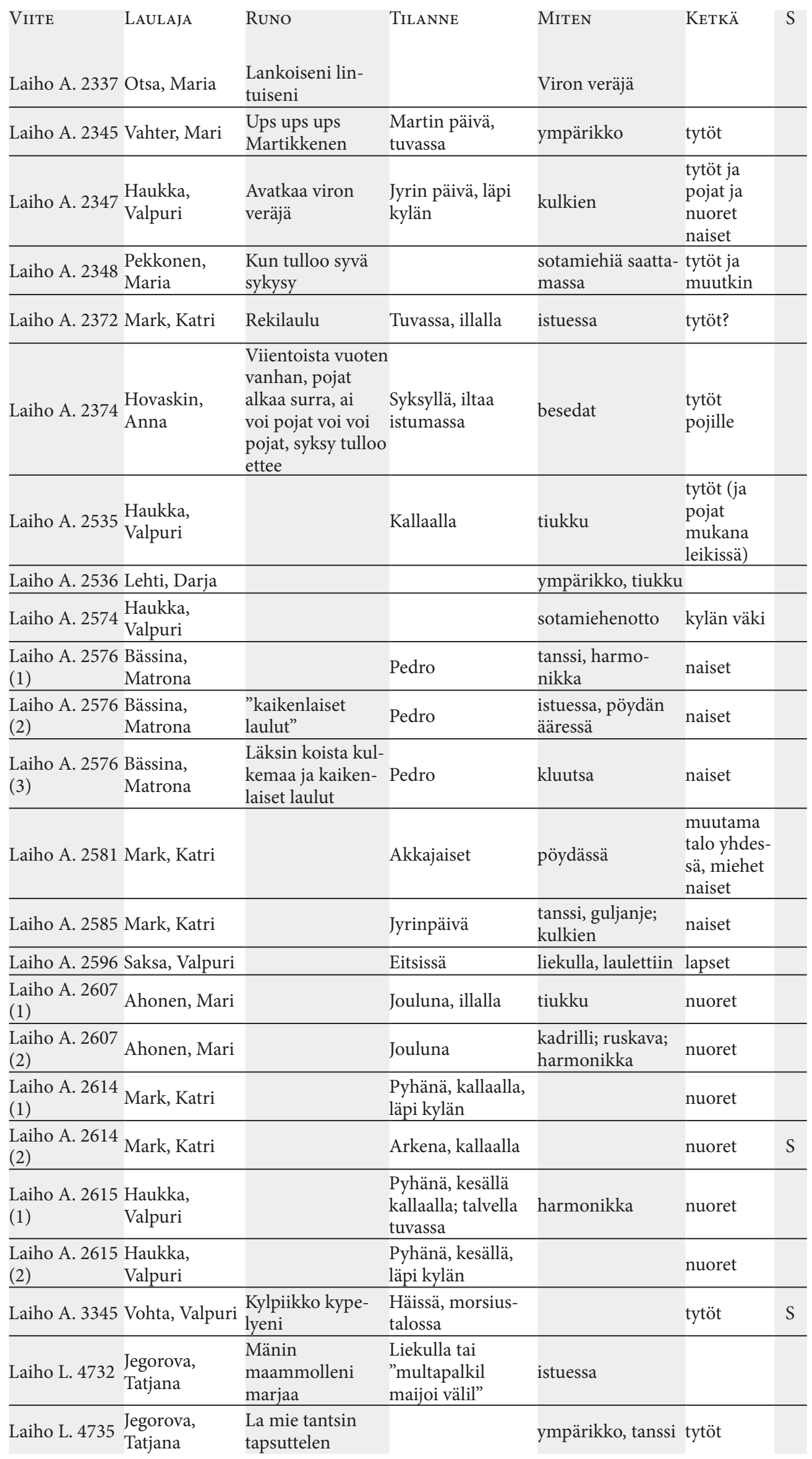




\begin{tabular}{|c|c|c|c|c|c|}
\hline Viite & LaUlaja & Runo & Tillanne & Miten & КеткÄ \\
\hline Laiho L. 4736 & $\begin{array}{l}\text { Jegorova, } \\
\text { Tatjana }\end{array}$ & $\begin{array}{l}\text { La lähen läpi } \\
\text { kyläisen }\end{array}$ & $\begin{array}{l}\text { Kihlajaisissa, läpi } \\
\text { kylän }\end{array}$ & & tytöt \\
\hline Laiho L. 4750 & $\begin{array}{l}\text { Jegorova, } \\
\text { Tatjana }\end{array}$ & $\begin{array}{l}\text { Ups ups ups } \\
\text { Martikkenen }\end{array}$ & Martinpäivä & ympärikko & \\
\hline Laiho L. 4832 & Otsa, Maria & $\begin{array}{l}\text { Täss on lusti } \\
\text { nuoren noissa; } \\
\text { Täss on ollut enne } \\
\text { kylä }\end{array}$ & $e^{\text {Kallaalla }}$ & ympärikko & nuoret \\
\hline Laiho L. 4848 & Otsa, Maria & $\begin{array}{l}\text { Mitä suonen } \\
\text { peren isälle }\end{array}$ & $\begin{array}{l}\text { Häissä, sulhasta- } \\
\text { lossa }\end{array}$ & ympärikko & pulmaväki \\
\hline Laiho L. 4902 & Otsa, Maria & $\begin{array}{l}\text { "vaik milline virs, } \\
\text { mikä sopi vaa" }\end{array}$ & & kluutsa & tytöt \\
\hline Laiho L. 4916 & Otsa, Maria & & $\begin{array}{l}\text { Iltaa istumassa, } \\
\text { saunassa }\end{array}$ & $\begin{array}{l}\text { istuessa, arvoi- } \\
\text { tuksia }\end{array}$ & $\begin{array}{l}\text { tytöt ja } \\
\text { pojat }\end{array}$ \\
\hline Laiho L. 4979 & Vohta, Valpuri & $\begin{array}{l}\text { Liuvu vene ter- } \\
\text { varinta }\end{array}$ & Kesällä, veneessä & istuessa & $\begin{array}{l}\text { tytöt (ja } \\
\text { pojat } \\
\text { soutivat) }\end{array}$ \\
\hline Laiho L. 4980 & Vohta, Valpuri & $\begin{array}{l}\text { Terve tupa neljän- } \\
\text { urkka }\end{array}$ & $\begin{array}{l}\text { - Häissä, } \\
\text { sulhastalossa }\end{array}$ & seisten & $\begin{array}{l}\text { morsiamen } \\
\text { sukulaiset }\end{array}$ \\
\hline Laiho L. 4981 & Vohta, Valpuri & $\begin{array}{l}\text { La ko katson } \\
\text { langon siltoi }\end{array}$ & $\begin{array}{l}\begin{array}{l}\text { Häissä, } \\
\text { sulhastalossa }\end{array} \\
\end{array}$ & $\begin{array}{l}\text { ympärikko, } \\
\text { hyppivät }\end{array}$ & \\
\hline Laiho L. 4982 & Vohta, Valpuri & $\begin{array}{l}\text { Lankoiseni lin- } \\
\text { tuiseni }\end{array}$ & $\begin{array}{l}\text { Häissä, } \\
\text { sulhastalossa }\end{array}$ & pöydässä & \\
\hline Laiho L. 4993 & Vohta, Valpuri & $\begin{array}{l}\text { Tunnen tunnen } \\
\text { ken tulloo }\end{array}$ & Häissä & ympärikko & \\
\hline Laiho L. 4994 & Vohta, Valpuri & Oi vävy vävyjueni & i Häissä & & pulmaväki \\
\hline Laiho L. 4998 & Vohta, Valpuri & $\begin{array}{l}\text { Tehkää yksi ym- } \\
\text { pärikko; Kui mie } \\
\text { kazvelin kanaine }\end{array}$ & ympärikko & ympärikko & \\
\hline Laiho L. 5000 & Vohta, Valpuri & $\begin{array}{l}\text { Älkää pankaa työ } \\
\text { pahaksi }\end{array}$ & & ympärikko & $\begin{array}{l}\text { tytöt (ilman } \\
\text { poikia) }\end{array}$ \\
\hline Laiho L. 5001 & Vohta, Valpuri & $\begin{array}{l}\text { Läksin raukka } \\
\text { raatamaa }\end{array}$ & Häissä & & eno \\
\hline Laiho L. 5053 & Lulla, Juljaana & & Talkoissa & tanssi & \\
\hline Laiho L. 5103 & $\begin{array}{l}\text { Artamonov, } \\
\text { Olga }\end{array}$ & $\begin{array}{l}\text { Marjukkaine } \\
\text { miun emoni }\end{array}$ & & ympärikko & \\
\hline Laiho L. 5111 & Vohta, Katri & $\begin{array}{l}\text { Avatkaa viron } \\
\text { veräjä }\end{array}$ & $\begin{array}{l}\text { Häissä, morsius- } \\
\text { talossa }\end{array}$ & seisten? & pulmaväki \\
\hline Laiho L. 5136 & Lehti, Darja & $\begin{array}{l}\text { Oi, teki turhin } \\
\text { miun emoni }\end{array}$ & & ympärikko & \\
\hline $\begin{array}{l}\text { Laiho L. } 5165 \\
\text { (1) }\end{array}$ & Lehti, Darja & & $\begin{array}{l}\text { Jyrin päivä, kylän } \\
\text { kadulla }\end{array}$ & tanssi, truba & $\begin{array}{l}\text { paimen } \\
\text { laski trubaa }\end{array}$ \\
\hline $\begin{array}{l}\text { Laiho L. } 5165 \\
\text { (2) }\end{array}$ & Lehti, Darja & & $\begin{array}{l}\text { Jyrin päivä, tu- } \\
\text { vassa }\end{array}$ & tantsu & $\begin{array}{l}\text { esilaulaja } \\
\text { kiukaalla }\end{array}$ \\
\hline Laiho L. 5168 & Lehti, Darja & Pyhä Iilja isäntä & Iilia ja Pedro & ympärikko & $\begin{array}{l}\text { tytöt ja } \\
\text { nuoret } \\
\text { naiset }\end{array}$ \\
\hline Laiho L. 5177 & $\begin{array}{l}\text { Leppik, } \\
\text { Asastiija }\end{array}$ & & Pyhänä & guljanje & tytöt \\
\hline Laiho L. 5213 & Hauki, Maria & $\begin{array}{l}\text { Kylähäni linnaha- } \\
\text { ni; ei miun laulel- } \\
\text { la pitäisi }\end{array}$ & & kulkien & tytöt \\
\hline $\begin{array}{l}\text { Laiho L. } 5225 \\
\text { (1) }\end{array}$ & Hauki, Maria & & $\begin{array}{l}\text { Syksyllä, iltaa } \\
\text { istumassa }\end{array}$ & $\begin{array}{l}\text { töitä tehdessä, } \\
\text { besedat }\end{array}$ & tytöt, pojat \\
\hline $\begin{array}{l}\text { Laiho L. } 5225 \\
\text { (2) }\end{array}$ & Hauki, Maria & & Neljäs päivä & tanssi & $\begin{array}{l}\text { tytöt ja } \\
\text { pojat }\end{array}$ \\
\hline
\end{tabular}




\begin{tabular}{|c|c|c|c|c|c|}
\hline $\begin{array}{l}\text { Laiho L. } 5225 \\
\text { (3) }\end{array}$ & Hauki, Maria & Runo & Etoispäivä & Miten & $\begin{array}{l}\text { Кеткё } \\
\text { tytöt ja po- } \\
\text { jat (vieraan } \\
\text { kylän) }\end{array}$ \\
\hline Laiho L. 5226 & Hauki, Maria & venäjäksi & Nastassie & $\begin{array}{l}\text { tanssi, } \\
\text { harmonikka }\end{array}$ & naiset \\
\hline Laiho L. 5228 & Hauki, Maria & venäjäksi & $\begin{array}{l}\text { Miikkula, talosta } \\
\text { taloon }\end{array}$ & $\begin{array}{l}\text { tanssi, guljanje, } \\
\text { harmonikka }\end{array}$ & \\
\hline Laiho L. 5229 & Hauki, Maria & venäjäksi & Jyrinpäivä & $\begin{array}{l}\text { tanssi, guljanje, } \\
\text { truba }\end{array}$ & $\begin{array}{l}\text { naiset (ja } \\
\text { paimen) }\end{array}$ \\
\hline $\begin{array}{l}\text { Laiho L. } \\
\text { 5232-5235 }\end{array}$ & Hauki, Maria & venäjäksi & Praasnikoilla & $\begin{array}{l}\text { liekulla, } \\
\text { harmonikka }\end{array}$ & \\
\hline Laiho L. 5248 & $\begin{array}{l}\text { Hovaskin, } \\
\text { Anna }\end{array}$ & $\begin{array}{l}\text { Akka teki priski } \\
\text { osainen }\end{array}$ & $\begin{array}{l}\text { Pellolla niittämisen } \\
\text { jälkeen }\end{array}$ & & niittäjät \\
\hline Laiho L. 5249 & $\begin{array}{l}\text { Hovaskin, } \\
\text { Anna }\end{array}$ & & $\begin{array}{l}\text { Laskiainen, } \\
\text { toisissa kylissä }\end{array}$ & tanssi, besedat & $\begin{array}{l}\text { tytöt ja } \\
\text { pojat }\end{array}$ \\
\hline Laiho L. 5250 & $\begin{array}{l}\text { Hovaskin, } \\
\text { Anna }\end{array}$ & & Eitsissä & tanssi, truba & pojat \\
\hline $\begin{array}{l}\text { Laiho L. } 5255 \\
\text { (1) }\end{array}$ & $\begin{array}{l}\text { Hovaskin, } \\
\text { Anna }\end{array}$ & & Talvella, tuvassa & besedat & \\
\hline $\begin{array}{l}\text { Laiho L. } 5255 \\
(2)\end{array}$ & $\begin{array}{l}\text { Hovaskin, } \\
\text { Anna }\end{array}$ & & Kesällä, ulkona & guljanje & \\
\hline Laiho L. 5256 & $\begin{array}{l}\text { Hovaskin, } \\
\text { Anna }\end{array}$ & & Talvella, tuvassa & $\begin{array}{l}\text { ruskava parittain/ } \\
\text { ympärikko; kadrilli; } \\
\text { polkka; besedat, } \\
\text { harmonikka }\end{array}$ & \\
\hline Laiho L. 5309 & Kivisoo, Anna & $\begin{array}{l}\text { Issut kannessa } \\
\text { ihala }\end{array}$ & $\begin{array}{l}\text { Häissä, } \\
\text { morsiustalossa }\end{array}$ & pöydässä & tytöt \\
\hline Laiho L. 5314 & Kivisoo, Anna & $\begin{array}{l}\text { Lankoiseni lin- } \\
\text { tuiseni }\end{array}$ & $\begin{array}{l}\text { Häissä, } \\
\text { sulhastalossa }\end{array}$ & pöydässä & $\begin{array}{l}\text { morsiamen } \\
\text { sukulaiset }\end{array}$ \\
\hline Laiho L. 5324 & Kivisoo, Anna & $\begin{array}{l}\text { Helise heliä metsä } \\
\text { (leino leski) }\end{array}$ & Marjaan mennessäl & kulkien & tytöt \\
\hline Laiho L. 5328 & Kivisoo, Anna & $\begin{array}{l}\text { La ko vieretän } \\
\text { vilulla }\end{array}$ & Illalla & guljanje & tytöt \\
\hline Laiho L. 5337 & Kivisoo, Anna & $\begin{array}{l}\text { La lähen läpi } \\
\text { kyläisen }\end{array}$ & & kluutsa & \\
\hline Laiho L. 5338 & Kivisoo, Anna & Täs oli enne kylä & & kluutsa & \\
\hline Laiho L. 5339 & Kivisoo, Anna & $\begin{array}{l}\text { Kui tulloo syvä } \\
\text { sykysy }\end{array}$ & & $\begin{array}{l}\text { sotamiehiä } \\
\text { saattamassa }\end{array}$ & tytöt \\
\hline Laiho L. 5343 & Kivisoo, Anna & $\begin{array}{l}\text { Peremies } \\
\text { pereisäntä }\end{array}$ & Talvella & ympärikko & tytöt \\
\hline Laiho L. 5347 & Kivisoo, Anna & $\begin{array}{l}\text { Annikka turusen } \\
\text { tyttö }\end{array}$ & & kulkien & tytöt \\
\hline Laiho L. 5348 & Kivisoo, Anna & $\begin{array}{l}\text { Laulaisin hyväisen } \\
\text { virren }\end{array}$ & & kulkien & tytöt \\
\hline Laiho L. 5350 & Kivisoo, Anna & $\begin{array}{ll}\text { Tuttu luttu mie } \\
\text { trubitin }\end{array}$ & $\begin{array}{l}\text { Metsässä, } \\
\text { paimenessa }\end{array}$ & & $\begin{array}{l}\text { paimen- } \\
\text { pojat }\end{array}$ \\
\hline Laiho L. 5353 & Kivisoo, Anna & $\begin{array}{l}\text { Jauhan jauhan } \\
\text { jaaruttelen }\end{array}$ & & töitä tehdessä & \\
\hline Laiho L. 5354 & Kivisoo, Anna & $\begin{array}{l}\text { Keträän keträän } \\
\text { keikuttelen }\end{array}$ & & töitä tehdessä & \\
\hline Laiho L. 5360 & Kivisoo, Anna & $\begin{array}{l}\text { Pääskylintu } \\
\text { päivälintu }\end{array}$ & Kesällä, ulkona & tanssi, guljanje & tytöt \\
\hline Laiho L. 5390 & Kivisoo, Anna & Liekkuvirsi & & liekulla, laulettiin & \\
\hline Laiho L. 5396 & Markus, Anna & Kokin kiitos & Häissä & $\begin{array}{l}\text { ympärikko, } \\
\text { nopeasti }\end{array}$ & \\
\hline Laiho L. 5899 & Ahonen, Katri & $\begin{array}{l}\text { La ko katson } \\
\text { langon sillat }\end{array}$ & $\begin{array}{l}\text { Häissä, } \\
\text { sulhastalossa }\end{array}$ & $\operatorname{tanssi}$ & \\
\hline
\end{tabular}




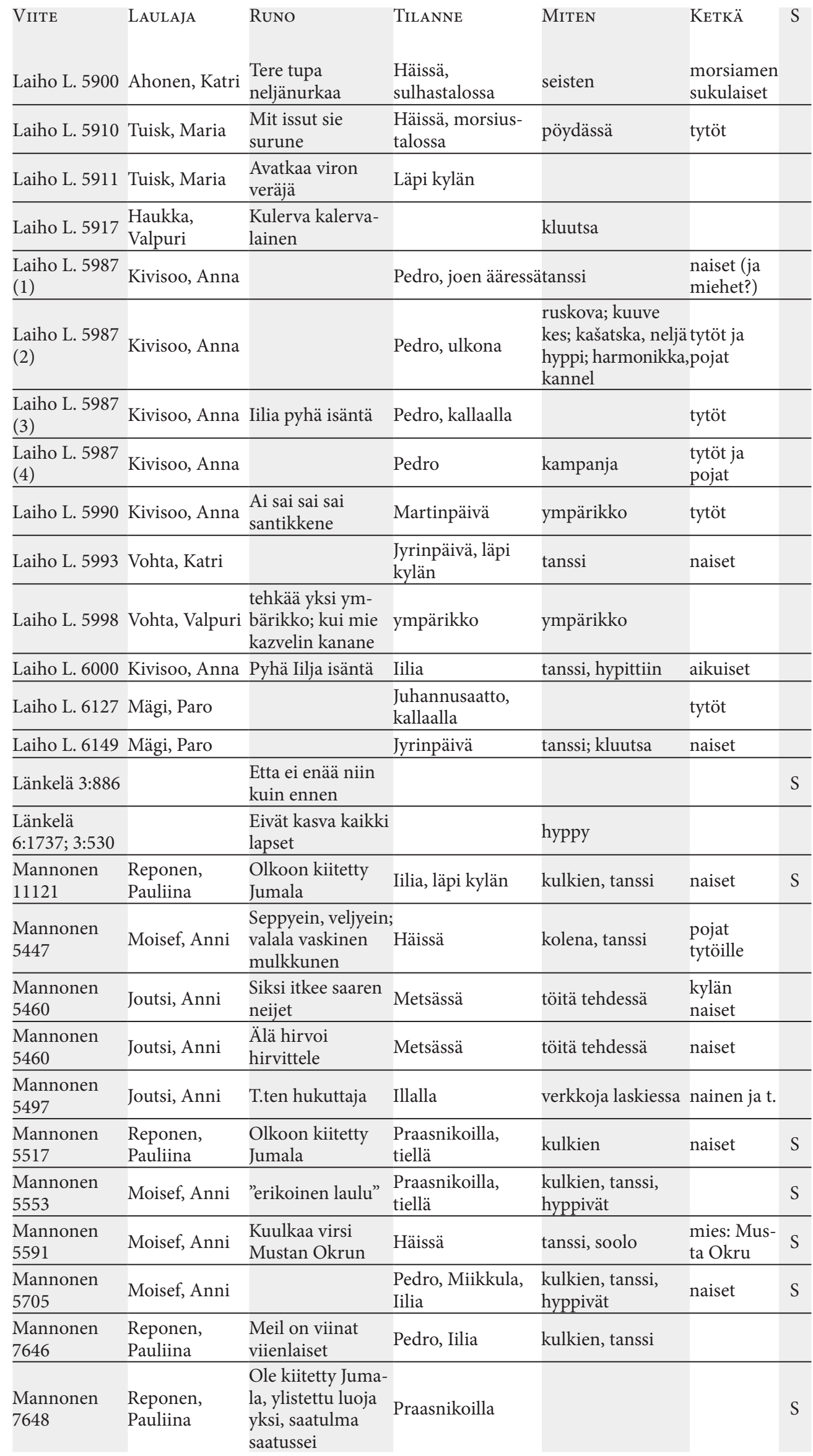




\begin{tabular}{|c|c|c|c|c|c|c|}
\hline ViIte & LAULAJA & RunO & Tilanne & Miten & Кеткё & $\mathrm{S}$ \\
\hline $\begin{array}{l}\text { Mannonen } \\
7663\end{array}$ & $\begin{array}{l}\text { Reponen, } \\
\text { Pauliina }\end{array}$ & & $\begin{array}{l}\text { Häissä, sulhasta- } \\
\text { lossa }\end{array}$ & tanssi, laulu & & \\
\hline $\begin{array}{l}\text { Mannonen } \\
7672\end{array}$ & Joutsen J. & Rekilaulu & & tanssi & & \\
\hline $\begin{array}{l}\text { Mannonen } \\
9785\end{array}$ & Moisef, Anni & venäjäksi & & tanssi & & \\
\hline $\begin{array}{l}\text { Mannonen } \\
9838\end{array}$ & Stepanov, Anni & $\begin{array}{l}\text { Skasii kenellä on } \\
\text { lupa kulaijaa }\end{array}$ & Pedro, vakkovilla & $\begin{array}{l}\text { tanssi, sukkelaan, } \\
\text { vastakkain, pa- } \\
\text { reittain }\end{array}$ & naiset & \\
\hline $\begin{array}{l}\text { Mannonen } \\
9839\end{array}$ & Stepanov, Anni & & & ripatska & miehet & \\
\hline $\begin{array}{l}\text { Salminen K. } \\
101\end{array}$ & Beda, Anni & $\begin{array}{l}\text { Morsian mäjellä } \\
\text { huusi }\end{array}$ & Kylän kadulla & & nuorikko & \\
\hline $\begin{array}{l}\text { Salminen K. } \\
170\end{array}$ & Kivisoo, Anna & $\begin{array}{l}\text { Tytöt lustit } \\
\text { luuraeltii }\end{array}$ & & ympärikko & & \\
\hline $\begin{array}{l}\text { Salminen K. } \\
186\end{array}$ & Kataks, Sofia & $\begin{array}{l}\text { Kirpukkaine } \\
\text { neijokkaine }\end{array}$ & & leipoessa & & \\
\hline $\begin{array}{l}\text { Salminen K. } \\
188 \\
\end{array}$ & Kataks, Sofia & $\begin{array}{l}\text { Soua laiva joua } \\
\text { laiva }\end{array}$ & Veneessä & istuessa & tytöt & \\
\hline $\begin{array}{l}\text { Salminen K. } \\
189\end{array}$ & Kataks, Sofia & $\begin{array}{l}\text { Lähemmä läpi } \\
\text { kyläisen }\end{array}$ & & kluutsa, tanssi & tytöt & \\
\hline $\begin{array}{l}\text { Salminen K. } \\
193\end{array}$ & Kataks, Sofia & $\begin{array}{l}\text { Eläkää tytöt } \\
\text { hyväst }\end{array}$ & Häissä? & ympärikko & & \\
\hline $\begin{array}{l}\text { Salminen K. } \\
199\end{array}$ & Kataks, Sofia & $\begin{array}{l}\text { Sato taivas uutta } \\
\text { lunta }\end{array}$ & & sotamiehenotto & tytöt? & \\
\hline $\begin{array}{l}\text { Salminen K. } \\
208 \\
\end{array}$ & $\begin{array}{l}\text { Pohjalainen, } \\
\text { Juljaana }\end{array}$ & $\begin{array}{l}\text { Mihi viipy teien } \\
\text { vello }\end{array}$ & $\begin{array}{l}\text { Häissä, } \\
\text { morsiustalossa }\end{array}$ & permannolla & tytöt & \\
\hline $\begin{array}{l}\text { Salminen K. } \\
210\end{array}$ & $\begin{array}{l}\text { Pohjalainen, } \\
\text { Juljaana }\end{array}$ & $\begin{array}{l}\text { Terve kuu terve } \\
\text { päivä }\end{array}$ & $\begin{array}{l}\text { Häissä, } \\
\text { morsiustalossa }\end{array}$ & permannolla & tytöt & \\
\hline $\begin{array}{l}\text { Salminen K. } \\
212 \\
\end{array}$ & $\begin{array}{l}\text { Pohjalainen, } \\
\text { Juljaana }\end{array}$ & $\begin{array}{l}\text { Olkoon kiitetty } \\
\text { Jumala }\end{array}$ & $\begin{array}{l}\text { Häissä, } \\
\text { morsiustalossa? }\end{array}$ & ympärikko & $\begin{array}{l}\text { sulhasen } \\
\text { sukulaiset? }\end{array}$ & \\
\hline $\begin{array}{l}\text { Salminen K. } \\
214\end{array}$ & $\begin{array}{l}\text { Pohjalainen, } \\
\text { Juljaana }\end{array}$ & Kokin kiitos & $\begin{array}{l}\text { Häissä?, syömisen } \\
\text { jälkeen }\end{array}$ & tanssi & & \\
\hline $\begin{array}{l}\text { Salminen K. } \\
217\end{array}$ & $\begin{array}{l}\text { Kajava, } \\
\text { Hourenja } \\
\text { Platonovna } \\
\end{array}$ & $\begin{array}{l}\text { Eväd oo heikod } \\
\text { meiän herrad }\end{array}$ & Töitä tehdessä & niittäessä & niittäjät & \\
\hline $\begin{array}{l}\text { Salminen K. } \\
265\end{array}$ & Vohta, Valpuri & $\begin{array}{l}\text { Kui mie kazvelin } \\
\text { kanaine }\end{array}$ & Häissä & ympärikko & & \\
\hline $\begin{array}{l}\text { Salminen K. } \\
267\end{array}$ & Vohta, Valpuri & Kokin kiitos & Häissä & & & S \\
\hline $\begin{array}{l}\text { Salminen V. } \\
2927\end{array}$ & $\begin{array}{l}\text { Feodorovna, } \\
\text { Jevdokia Da- } \\
\text { nilovna }\end{array}$ & $\begin{array}{l}\text { La ko katson } \\
\text { langon sillat }\end{array}$ & $\begin{array}{l}\text { Häissä, } \\
\text { sulhastalossa }\end{array}$ & ympärikko & $\begin{array}{l}\text { morsiamen } \\
\text { sukulaiset }\end{array}$ & \\
\hline $\begin{array}{l}\text { Salminen V. } \\
2927\end{array}$ & $\begin{array}{l}\text { Feodorovna, } \\
\text { Jevdokia Da- } \\
\text { nilovna }\end{array}$ & $\begin{array}{l}\text { Lankoiseni lin- } \\
\text { tuiseni }\end{array}$ & $\begin{array}{l}\text { Häissä, } \\
\text { sulhastalossa }\end{array}$ & & $\begin{array}{l}\text { morsiamen } \\
\text { sukulaiset }\end{array}$ & \\
\hline $\begin{array}{l}\text { Salminen V. } \\
2929\end{array}$ & $\begin{array}{l}\text { Feodorovna, } \\
\text { Jevdokia Da- } \\
\text { nilovna }\end{array}$ & $\begin{array}{l}\text { Saottii mei } \\
\text { vellojamme }\end{array}$ & $\begin{array}{l}\text { Häissä, } \\
\text { sulhastalossa }\end{array}$ & maasta & $\begin{array}{l}\text { sulhasen } \\
\text { puoli }\end{array}$ & \\
\hline $\begin{array}{l}\text { Salminen V. } \\
2942\end{array}$ & $\begin{array}{l}\text { Feodorovna, } \\
\text { Jevdokia Da- } \\
\text { nilovna }\end{array}$ & $\begin{array}{l}\text { Terve kuu terve } \\
\text { päivä }\end{array}$ & $\begin{array}{l}\text { Häissä, } \\
\text { morsiustalossa }\end{array}$ & maasta & $\begin{array}{l}\text { morsiamen } \\
\text { suku }\end{array}$ & \\
\hline $\begin{array}{l}\text { Salminen V. } \\
2948 \\
\end{array}$ & Sohvi & $\begin{array}{l}\text { Suur kiitos tähä } \\
\text { talloo }\end{array}$ & $\begin{array}{l}\text { Häissä, muissakin } \\
\text { pidoissa }\end{array}$ & ympärikko & & \\
\hline $\begin{array}{l}\text { Salminen V. } \\
2957\end{array}$ & Sohvi & $\begin{array}{l}\text { La ko katson } \\
\text { langon sillat }\end{array}$ & $\begin{array}{l}\text { Häissä, } \\
\text { sulhastalossa }\end{array}$ & tanssi & $\begin{array}{l}\text { morsiamen } \\
\text { sukulaiset }\end{array}$ & \\
\hline $\begin{array}{l}\text { Salminen V. } \\
2969\end{array}$ & Beda, Anni & $\begin{array}{l}\text { Soua laiva joua } \\
\text { laiva }\end{array}$ & Veneessä & istuessa & & \\
\hline
\end{tabular}




\begin{tabular}{|c|c|c|c|c|c|}
\hline ViIte & LAULAJA & Runo & Tilannne & Miten & Кеткё \\
\hline $\begin{array}{l}\text { Salminen V. } \\
2975\end{array}$ & Kuuli, Sarlotta & $\begin{array}{l}\text { Kerkiskää iest } \\
\text { ristirahvas }\end{array}$ & $\begin{array}{l}\text { Häissä, morsius- } \\
\text { talossa }\end{array}$ & ympyrässä & \\
\hline $\begin{array}{l}\text { Salminen V. } \\
2985\end{array}$ & & $\begin{array}{l}\text { La ko katson } \\
\text { langon sillat }\end{array}$ & $\begin{array}{l}\text { Häissä, sulhasta- } \\
\text { lossa }\end{array}$ & $\operatorname{tanssi}$ & $\begin{array}{l}\text { sulhas- } \\
\text { kansa }\end{array}$ \\
\hline $\begin{array}{l}\text { Salminen V. } \\
2986\end{array}$ & Kataks, Sofia & $\begin{array}{l}\text { Avatkaa viron } \\
\text { veräjä }\end{array}$ & $\begin{array}{l}\text { Häissä, morsius- } \\
\text { talossa }\end{array}$ & seisten & $\begin{array}{l}\text { sulhas- } \\
\text { kansa }\end{array}$ \\
\hline $\begin{array}{l}\text { Salminen V. } \\
3013\end{array}$ & Vohta, Valpuri? & $\begin{array}{l}\text { Tehkää yksi ym- } \\
\text { ?pärikko; Yks oli } \\
\text { väärä miun emoni }\end{array}$ & ympärikko & ympärikko & Tytöt \\
\hline $\begin{array}{l}\text { Salminen V. } \\
3018\end{array}$ & Vohta, Valpuri & $\begin{array}{l}\text { Anni sirkkune } \\
\text { sisone; mitä } \\
\text { istut sirkku silmät } \\
\text { veessä }\end{array}$ & $\begin{array}{l}\text { Häissä, morsius- } \\
\text { talossa }\end{array}$ & maasta & tytöt \\
\hline $\begin{array}{l}\text { Salminen V. } \\
3019\end{array}$ & & $\begin{array}{l}\text { Oi tytö sulat } \\
\text { sisaret }\end{array}$ & & ympärikko & $\begin{array}{l}\text { vanha } \\
\text { nainen, } \\
\text { venäjänus- } \\
\text { koiset }\end{array}$ \\
\hline $\begin{array}{l}\text { Salminen V. } \\
3028\end{array}$ & & $\begin{array}{l}\text { La ko katson } \\
\text { langon sillat }\end{array}$ & Häissä & ympärikko & $\begin{array}{l}\text { pulmaväki } \\
\text { (koko } \\
\text { rahvas) }\end{array}$ \\
\hline SKVR III 0599 & $\begin{array}{l}9 \text { Oute, vadjan } \\
\text { tyttö }\end{array}$ & $\begin{array}{l}\text { Velloini venoisen } \\
\text { seppoi }\end{array}$ & & ympärikko & \\
\hline SKVR III 0709] & 9Kati-akka & $\begin{array}{l}\text { Tasasemp on mei- } \\
\text { jen tantsu (Untar- } \\
\text { mo ja Kalervo) }\end{array}$ & tanssi & $\operatorname{tanssi}$ & \\
\hline SKVR III 1052 & 2 Kati & Jopa illakko tulloo & oIllalla & & \\
\hline SKVR III 1053I & 3Katriina & $\begin{array}{l}\text { Älä nukuta un- } \\
\text { oine }\end{array}$ & Iltaa istumassa & & tytöt? \\
\hline SKVR III 1056 & & $\begin{array}{l}\text { Niittäkäämme, } \\
\text { reutakaamme }\end{array}$ & Pellolla & niittäessä & \\
\hline SKVR III $1057^{\circ}$ & $\begin{array}{l}\text { Stepu Ha- } \\
\text { malasta }\end{array}$ & $\begin{array}{l}\text { Nyt on tyynet } \\
\text { nurmen nurkat }\end{array}$ & Pellolla, illalla & niittäessä & \\
\hline SKVR III 1067 & & Leikarit & & leikki & \\
\hline SKVR III 1068 & 8Porissa, Anni & hyppää nukke & & $\begin{array}{l}\text { leikki, tanssi, } \\
\text { parittain }\end{array}$ & \\
\hline SKVR III 1580 & OKati-akka & $\begin{array}{l}\text { La kysyn kylän } \\
\text { akoilta }\end{array}$ & $\begin{array}{l}\text { Pyhänä?, kesä- } \\
\text { iltana }\end{array}$ & $\begin{array}{l}\text { kulkien, pitkin } \\
\text { kylää }\end{array}$ & tytöt \\
\hline SKVR III 1581 & $\begin{array}{l}\text { Uljaana } \\
1 \text { Säätinältä }\end{array}$ & Rikas ja köyhä & & ympärikko, leikki & \\
\hline SKVR III 1582 & 2Kati-akka & $\begin{array}{l}\text { Lohikäärme ja } \\
\text { neito }\end{array}$ & & leikki & \\
\hline SKVR III 1583 & 3Olkka & Rikas ja köyhä & & leikki & \\
\hline SKVR III 1675 & $\begin{array}{l}5 \text { Olena Osipan } \\
\text { nainen }\end{array}$ & Anu, sisarueni & $\begin{array}{l}\text { Häissä, morsius- } \\
\text { talossa }\end{array}$ & pöydässä & tytöt \\
\hline SKVR III 1696 & $\begin{array}{l}6 \text { Olena Osipan } \\
\text { nainen }\end{array}$ & $\begin{array}{l}\text { Terve kuu terve } \\
\text { päivä }\end{array}$ & $\begin{array}{l}\text { Häissä, morsius- } \\
\text { talossa }\end{array}$ & permannolla & kylän tytöt \\
\hline SKVR III 1704 & $\begin{array}{l}4 \text { Olena Osipan } \\
\text { nainen }\end{array}$ & $\begin{array}{l}\text { Kosjolainen mies } \\
\text { korria }\end{array}$ & $\begin{array}{l}\text { Häissä, morsius- } \\
\text { talossa }\end{array}$ & maasta & $\begin{array}{l}\text { tytöt (ky- } \\
\text { län) }\end{array}$ \\
\hline SKVR III 1710 & $\begin{array}{l}\text { Olena Osipan } \\
\text { nainen }\end{array}$ & $\begin{array}{l}\text { Olkoon kiitetty } \\
\text { Jumala }\end{array}$ & $\begin{array}{l}\text { Häissä, morsius- } \\
\text { talossa }\end{array}$ & $\operatorname{tanssi}$ & \\
\hline $\begin{array}{l}\text { SKVR III } 1717 \\
\text { (1) }\end{array}$ & $\begin{array}{l}\text { 7Olena Osipan } \\
\text { nainen }\end{array}$ & & $\begin{array}{l}\text { Häissä, sulhasta- } \\
\text { lossa }\end{array}$ & tanssi & $\begin{array}{l}\text { morsiamen } \\
\text { sukulaiset }\end{array}$ \\
\hline $\begin{array}{l}\text { SKVR III } 1717 \\
(2)\end{array}$ & $\begin{array}{l}\text { 7Olena Osipan } \\
\text { nainen }\end{array}$ & $\begin{array}{l}\text { Lankoiseni lin- } \\
\text { tuiseni }\end{array}$ & $\begin{array}{l}\text { Häissä, sulhasta- } \\
\text { lossa }\end{array}$ & istuessa & $\begin{array}{l}\text { morsiamen } \\
\text { sukulaiset }\end{array}$ \\
\hline SKVR III 1728 & & Aja aja velvyeni & Häissä & ajaessa & \\
\hline SKVR III 1899] & 9Porissa, Anni & Passipo pereisälle & $\begin{array}{l}\text { Praasnikoilla, } \\
\text { tahvana-iltan }\end{array}$ & ympärikko & tytöt \\
\hline SKVR III 1900 & OPorissa, Anni & Passipo pereisälle & $\begin{array}{l}\text { Praasnikoilla, } \\
\text { tahvana-iltan }\end{array}$ & $\operatorname{tanssi}$ & tytöt \\
\hline
\end{tabular}




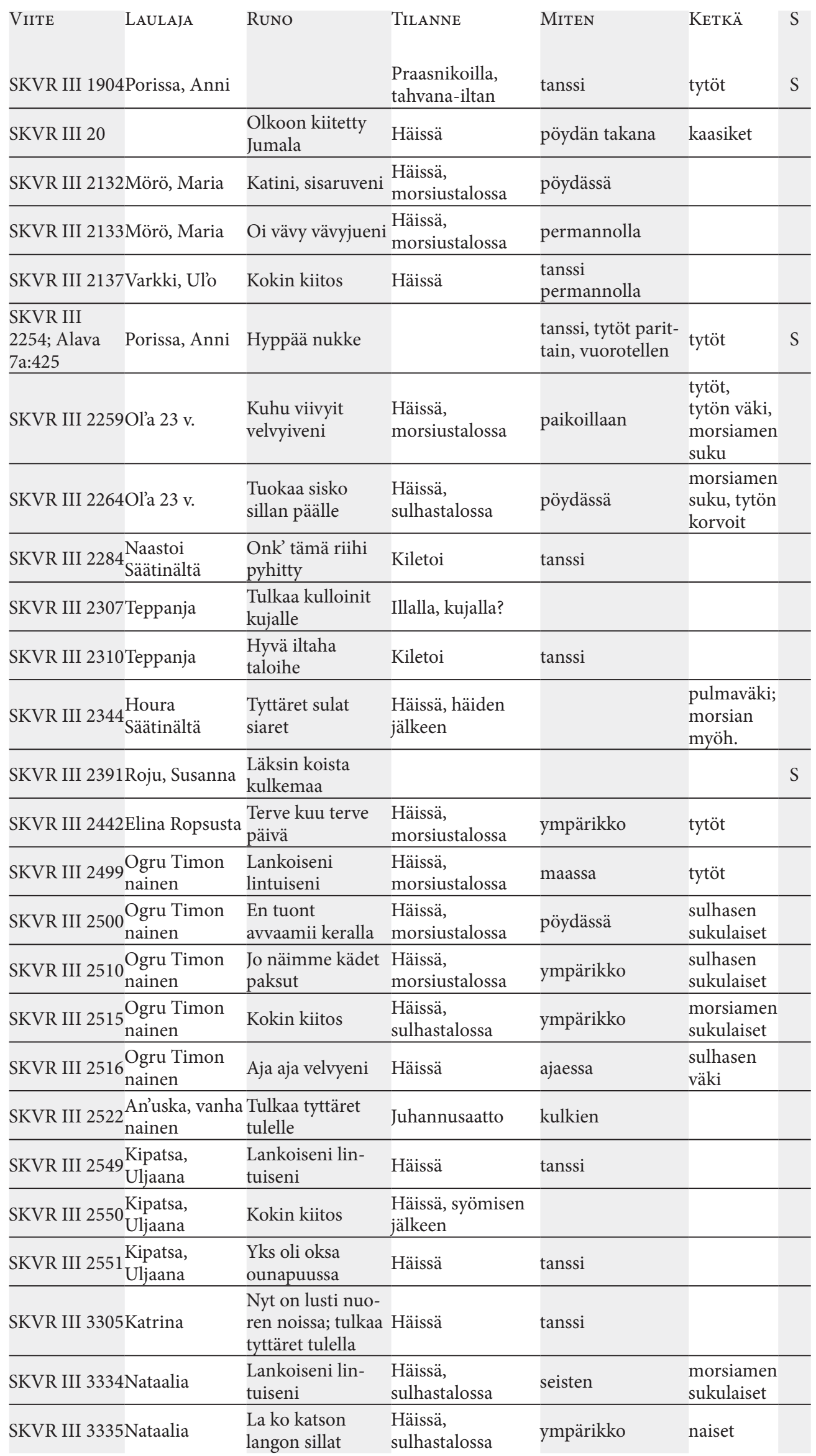




\begin{tabular}{|c|c|c|c|c|c|}
\hline Virte & LAULAJA & Runo & Tillanne & Miten & КеткÄ \\
\hline SKVR III 3337I & Nataalia & $\begin{array}{l}\text { Lankoiseni lin- } \\
\text { tuiseni }\end{array}$ & $\begin{array}{l}\text { Häissä, } \\
\text { sulhastalossa }\end{array}$ & pöydässä & $\begin{array}{l}\text { morsiamen } \\
\text { sukulaiset }\end{array}$ \\
\hline SKVR III 3338I & Nataalia & Kokin kiitos & $\begin{array}{l}\begin{array}{l}\text { Häissä, } \\
\text { sulhastalossa }\end{array} \\
\end{array}$ & $\begin{array}{l}\text { "noistaan syö- } \\
\text { mästä" }\end{array}$ & $\begin{array}{l}\text { morsiamen } \\
\text { sukulaiset }\end{array}$ \\
\hline SKVR III 3482 & & $\begin{array}{l}\text { Issut kannessa } \\
\text { ihala }\end{array}$ & $\begin{array}{l}\text { Häissä, } \\
\text { morsiustalossa }\end{array}$ & & \\
\hline SKVR III 3493 & & Avatkaa uksianne & Miikkula & $\begin{array}{l}\text { taloon tullessa; } \\
\text { ympärikko }\end{array}$ & tytöt \\
\hline SKVR III $3535_{1}^{\mathrm{D}}$ & $\begin{array}{l}\text { Mikulkan } \\
\text { nainen }\end{array}$ & $\begin{array}{l}\text { Loiko luoja } \\
\text { luotinkättä }\end{array}$ & Praasnikoilla & & tytöt \\
\hline SKVR III 4174 & & Leikarit & & ajaessa & $\begin{array}{l}\text { sulhasen } \\
\text { sukulaiset }\end{array}$ \\
\hline SKVR III 4632 & & $\begin{array}{l}\text { Livukka rekoi } \\
\text { lippiä }\end{array}$ & Laskiainen & pöydässä & sulhanen \\
\hline Sääski 5008 & $\begin{array}{l}\text { Yrjönen, } \\
\text { Aleksandra }\end{array}$ & & Laskiainen & pöydässä & \\
\hline Sääski 5305 & Andrejev, Fekla & & Pyhäiltoina & hyppivät & \\
\hline Sääski 5312 & $\begin{array}{l}\text { Andrejeva, } \\
\text { Anna }\end{array}$ & & $\begin{array}{l}\text { Juhannusaatto, } \\
\text { kokolla }\end{array}$ & ajaessa & $\begin{array}{l}\text { sulhasen } \\
\text { sukulaiset }\end{array}$ \\
\hline Sääski 5333 & $\begin{array}{l}\text { Arehjeva, } \\
\text { Anna }\end{array}$ & Iilia pyhä isäntä & Iilia, kuominassa & maasta & tytöt \\
\hline Sääski 5361 & $\begin{array}{l}\text { Ivanov, } \\
\text { Matrona }\end{array}$ & & $\begin{array}{l}\text { Kesällä, kylän } \\
\text { kadulla }\end{array}$ & $\operatorname{tanssi}$ & morsian \\
\hline Sääski 5487 & Labanov, Katri & $\begin{array}{l}\text { Oli miulla aino } \\
\text { vello }\end{array}$ & Kylän kadulla & maahan & pulmaväki \\
\hline Sääski 5897 & $\begin{array}{l}\text { Appalonov, } \\
\text { Darja }\end{array}$ & venäjäksi & Häissä illalla & $\begin{array}{l}\text { tanssi, kahdessa } \\
\text { rivissä vastatusten }\end{array}$ & \\
\hline Sääski 5969 & $\begin{array}{l}\text { Aleksinen, } \\
\text { Nadja }\end{array}$ & $\begin{array}{l}\text { Minjuein mar- } \\
\text { juein }\end{array}$ & $\begin{array}{l}\text { Häissä, } \\
\text { sulhastalossa }\end{array}$ & & $\begin{array}{l}\text { morsiamen } \\
\text { sukulaiset }\end{array}$ \\
\hline Sääski 5970 & $\begin{array}{l}\text { Aleksinen, } \\
\text { Nadja }\end{array}$ & $\begin{array}{l}\text { Terve tuttuva } \\
\text { tuppaa }\end{array}$ & $\begin{array}{l}\text { Häissä, } \\
\text { sulhastalossa }\end{array}$ & lehmiä laskiessa & \\
\hline Sääski 5973 & $\begin{array}{l}\text { Ruokonen, } \\
\text { Anastasia } \\
\end{array}$ & $\begin{array}{l}\text { Näyttäkää käköi } \\
\text { kättees }\end{array}$ & $\begin{array}{l}\text { Häissä, } \\
\text { morsiustalossa }\end{array}$ & lehmiä laskiessa & \\
\hline SKVR III 3625 & & $\begin{array}{l}\text { Aja aja velvyeni; } \\
\text { tehkää lahti } \\
\text { lautaportti }\end{array}$ & Häissä & ajaessa & tytöt \\
\hline SKVR III 3661 & & $\begin{array}{l}\text { Isämies isyen } \\
\text { poika }\end{array}$ & Häissä & ajaessa; tanssi & \\
\hline SKVR III 3821 & & $\begin{array}{l}\text { Elä tuskau veljy- } \\
\text { eni }\end{array}$ & $\begin{array}{l}\text { Häissä, sulhasta- } \\
\text { lossa }\end{array}$ & $\begin{array}{l}\text { kulkien; ympä- } \\
\text { rikko }\end{array}$ & tytöt \\
\hline SKVR III 3967 & & Hyppää nukke & & tanssi & \\
\hline SKVR III 3968 & & $\begin{array}{l}\text { Katsokaa kylän } \\
\text { isännät }\end{array}$ & Häissä & ympärikko & \\
\hline SKVR III 403 & & $\begin{array}{l}\text { Terve kuu terve } \\
\text { päivä }\end{array}$ & $\begin{array}{l}\text { Häissä, morsius- } \\
\text { talossa }\end{array}$ & kulkien & \\
\hline SKVR III 409 & & $\begin{array}{l}\text { Yhet sain moko- } \\
\text { mat lahjat }\end{array}$ & $\begin{array}{l}\text { Häissä, sulhasta- } \\
\text { lossa }\end{array}$ & kulkien & \\
\hline SKVR III 410 & & $\begin{array}{l}\text { Neitsyeni naisu- } \\
\text { koni }\end{array}$ & $\begin{array}{l}\text { Häissä, sulhasta- } \\
\text { lossa }\end{array}$ & $\begin{array}{l}\text { tanssi, harmo- } \\
\text { nikka }\end{array}$ & \\
\hline SKVR III 4225 & & $\begin{array}{l}\text { Kosjolainen } \\
\text { koirankieli }\end{array}$ & $\begin{array}{l}\text { Häissä, morsius- } \\
\text { talossa }\end{array}$ & $\begin{array}{l}\text { pöydässä, pitkiä } \\
\text { virsiä }\end{array}$ & \\
\hline SKVR III 4581 & & $\begin{array}{l}\text { Paimenpoika } \\
\text { palkattiin }\end{array}$ & Jyrinpäivä & tupaan tullessa & $\begin{array}{l}\text { morsiamen } \\
\text { sukulaiset }\end{array}$ \\
\hline SKVR III 4627 & & $\begin{array}{l}\text { Pyhä Jyrki metsän } \\
\text { herra }\end{array}$ & Jyrinpäivä & ympärikko & $\begin{array}{l}\text { sulhasen } \\
\text { sukulaiset }\end{array}$ \\
\hline
\end{tabular}




\section{SAADULMOI-SÄVELMÄT}

Viite: A = SKSÄ A; L = SKSÄ L; NPI= Kiuru et al. 1974, nuottiliite; SibA = SibA Launis 1903; SKS $=$ SKS KRA

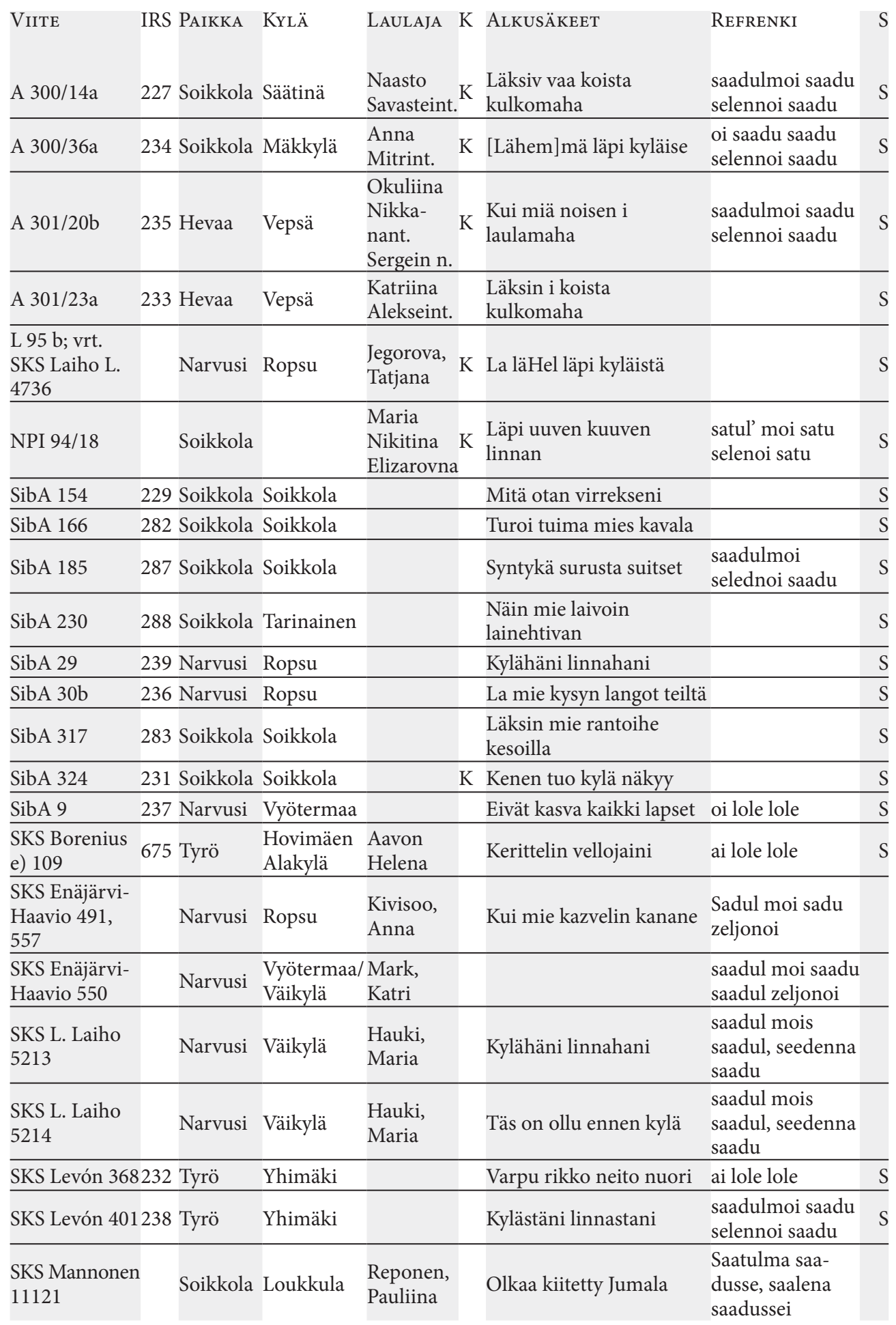




\begin{tabular}{|c|c|c|c|c|c|}
\hline VIITE & IRS PAIKKA & KYLÄ & LAULAJA I & K AlKusÄKeEt & REFRENKI \\
\hline $\begin{array}{l}\text { SKS Mannonen } \\
5517\end{array}$ & Soikkola & Loukkula & $\begin{array}{l}\text { Reponen, } \\
\text { Pauliina }\end{array}$ & Olkoon kiitetty Jumala & $\begin{array}{l}\text { Raas kalina, } \\
\text { kaal malina; } \\
\text { Saatulmoi satul } \\
\text { lennoi, saatussei, } \\
\text { Raas kalina, kaal } \\
\text { malina }\end{array}$ \\
\hline $\begin{array}{l}\text { SKS Mannonen } \\
5553\end{array}$ & Soikkola & Loka & $\begin{array}{l}\text { Moisef, } \\
\text { Anni }\end{array}$ & "erikoinen laulu" & $\begin{array}{l}\text { Raas kalina } \\
\text { mojaa; Saa tuula } \\
\text { saa tussei }\end{array}$ \\
\hline $\begin{array}{l}\text { SKS Mannonen } \\
5705\end{array}$ & Soikkola & Loka & $\begin{array}{l}\text { Moisef, } \\
\text { Anni }\end{array}$ & & $\begin{array}{l}\text { Saa tulma saa } \\
\text { tusse }\end{array}$ \\
\hline $\begin{array}{l}\text { SKS Mannonen } \\
7648\end{array}$ & Soikkola & Loukkula & $\begin{array}{l}\text { Reponen, } \\
\text { Pauliina }\end{array}$ & Ole kiitetty Jumala & $\begin{array}{l}\text { Saatulma } \\
\text { saatussei }\end{array}$ \\
\hline $\begin{array}{l}\text { SKS Sääski } \\
5970\end{array}$ & Soikkola & ilm. Säätinä & $\begin{array}{l}\text { Aleksinen, } \\
\text { Nadja }\end{array}$ & Terve tuttuva tuppaa & $\begin{array}{l}\text { Saa tulenoi } \\
\text { saadusei, lennoi } \\
\text { saadu, raskalua } \\
\text { maja }\end{array}$ \\
\hline
\end{tabular}

\section{TANSSISÄVELMÄT}

Mukaan on otettu tallentajan tai laulajan tanssisävelmiksi nimeämät, tanssinaloitusformulalla alkavat sekä Launiksen tanssikuvauksiin hänen omissa keräelmissään sopivat sävelmätoisinnot Länsi-Inkeristä sekä Hevaalta ja Tyröstä.

\begin{tabular}{|c|c|c|c|c|c|c|c|c|}
\hline Vitite & IRS & PAIKKa & KYLÄ & AlKusÄKeET & REFRENGit & $\begin{array}{l}\text { MUOTO- } \\
\text { RAKENNE }\end{array}$ & RYtмI & A \\
\hline Levón 418 & 375 & Hevaa & Harmaala & La ka katson lautoja & & 1234567 & 2222224 & 4 \\
\hline Levón 448 & 603 & Hevaa & Vepsä & La ka katson lautojan & & 1234567 & 2222224 & 4 \\
\hline Levón 519 & 498 & Hevaa & V. Huurala & La ka katson lautojan, & & 1234567 & 2222224 & 4 \\
\hline Levón 458 & 535 & Hevaa & Lenttinen & $\begin{array}{l}\text { Hypätkäämme } \\
\text { hyrjätkäämme }\end{array}$ & & 12345678 & 22222222 & 4 \\
\hline Levón 465 & 71 & Hevaa & Lenttinen & Täss on tykky tyttölöjä & & 12345678 & 22222222 & 4 \\
\hline $\begin{array}{l}\text { Borenius } \\
\text { e } 208 \\
\end{array}$ & 118 & Kattila & Matinkylä & Perenainen naizueni & & 12345678 & 22222222 & 4 \\
\hline $\begin{array}{l}\text { Borenius } \\
\text { e } 219 \\
\end{array}$ & 38 & Kattila & Pummala & $\begin{array}{l}\text { Peremmees pere } \\
\text { izäätä }\end{array}$ & & 12345678 & 22222222 & 5 \\
\hline $\begin{array}{l}\text { Borenius } \\
\text { e } 213\end{array}$ & 51 & Kattila & Matinkylä & & & 12345678 & 22222222 & 3 \\
\hline Levón 505 & 412 & Hevaa & V. Huurala & $\begin{array}{l}\text { La ka katson } \\
\text { kannoillani }\end{array}$ & & $1234567(8)$ & 22222222 & 4 \\
\hline SibA 22 & 250 & Narvusi & Ropsu & $\begin{array}{l}\text { Täss on lusti nuoren } \\
\text { noista }\end{array}$ & & 12345678 & 22222244 & 4 \\
\hline SibA 110 & 276 & Narvusi & Kaipaala & $\begin{array}{l}\text { Täss on lusti nuoren } \\
\text { noista }\end{array}$ & jo & $12345678^{*}$ & $22222244[4]$ & 6 \\
\hline SibA 76 & 296 & Narvusi & Kurkola & $\begin{array}{l}\text { Miks on meitä näin } \\
\text { vähäisen }\end{array}$ & & 12345678 & 44222244 & $4+1$ \\
\hline NPI 2 & & Soikkola & & $\begin{array}{l}\text { La miä tantsin trak- } \\
\text { suttelen }\end{array}$ & & 12345678 & 44222244 & 4 \\
\hline SibA 107 & 304 & Narvusi & Kaipaala & $\begin{array}{l}\text { Täss on lusti nuoren } \\
\text { noista }\end{array}$ & & 12345678 & $\begin{array}{l}44222244 / \\
44222262 \\
\end{array}$ & 3 \\
\hline $\begin{array}{l}\text { Borenius } \\
\text { e } 201\end{array}$ & 223 & Soikkola & Joenperä & $\begin{array}{l}\text { Velloini vennoisen } \\
\text { seppoi }\end{array}$ & ai lole lole & 12345678 & \begin{tabular}{|l|}
$22442244 \mid$ \\
222242244 \\
\end{tabular} & 5 \\
\hline SibA 201 b & 155 & Soikkola & Säätinä & Oi, hyvä tyttöin elää & & $1234567(8)$ & 22622222 & 4 \\
\hline
\end{tabular}




\begin{tabular}{|c|c|c|c|c|c|c|c|c|}
\hline A $507 / 9$ b & IRS & Narvusi & KYLÄ & $\begin{array}{l}\text { Aa tytöt(e) lustit(e) } \\
\text { luuraeltii }\end{array}$ & REFRENGIT & $\begin{array}{l}\text { MUOTO- } \\
\text { RAKENNE } \\
12345678 \\
5678\end{array}$ & $\begin{array}{l}22222222 \\
2244\end{array}$ & A \\
\hline $\begin{array}{l}\text { Borenius } \\
\text { e } 223 \\
\end{array}$ & 889 & Kattila & Lempola & Tansieka tammueni & & $\begin{array}{l}12345678 \\
5678 \\
\end{array}$ & $\begin{array}{l}22222222 \\
2244 \\
\end{array}$ & 5 \\
\hline $\begin{array}{l}\text { ERA Fon. } \\
209 \text { c }\end{array}$ & & Soikkola & Joenperä & $\begin{array}{l}\text { Oi täss on lusti nuori } \\
\text { noista }\end{array}$ & & $\begin{array}{l}12345678 \\
5678 \\
\end{array}$ & $\begin{array}{l}22222222 \\
2244 \\
\end{array}$ & 5 \\
\hline SKSÄ L 87 b & & Narvusi & Ropsu & $\begin{array}{l}\text { Oo la miä tantsin } \\
\text { tapsuttelen }\end{array}$ & & $\begin{array}{l}12345678 \\
5678 \\
\end{array}$ & $\begin{array}{l}22222222 \\
2244 \\
\end{array}$ & $5+1$ \\
\hline SKSÄ L 89 b & & Narvusi & & $\begin{array}{l}\text { Ooo nyt on lusti } \\
\text { nuoren noissa }\end{array}$ & & $\begin{array}{l}12345678 \\
5678 \\
\end{array}$ & $\begin{array}{l}22222222 \\
2244 \\
\end{array}$ & 4 \\
\hline SKSÄ L 95 c & & Narvusi & Kallivieri & $\begin{array}{l}\text { Tehkää yksi } \\
\text { ympärikko }\end{array}$ & & $\begin{array}{l}12345678 \\
5678 \\
\end{array}$ & $\begin{array}{l}22222222 \\
2244 \\
\end{array}$ & 4 \\
\hline SKSÄ L 95 d & & Narvusi & Kallivieri & $\begin{array}{l}\text { Yks oli väärä miun } \\
\text { emoini }\end{array}$ & & $\begin{array}{l}12345678 \\
5678 \\
\end{array}$ & $\begin{array}{l}22222222 \\
2244 \\
\end{array}$ & $4+2$ \\
\hline Levón 441 & 786 & Hevaa & Ojankylä & $\begin{array}{l}\text { Täss on lusti luita } \\
\text { lyöä }\end{array}$ & $\begin{array}{l}\text { saaduljmoi } \\
\text { saadu } \\
\text { sekeljennai } \\
\text { saadu } \\
\end{array}$ & $\begin{array}{l}12345678 \\
5678 \\
\end{array}$ & $\begin{array}{l}44222222 \\
2244\end{array}$ & 5 \\
\hline SibA 32 & 324 & Narvusi & Ropsu & $\begin{array}{l}\text { Kuin mie kasvelin } \\
\text { kanainen }\end{array}$ & & $\begin{array}{l}12345678 \\
5678 \\
\end{array}$ & $\begin{array}{l}22222222 \\
2244 \\
\end{array}$ & 5 \\
\hline $\begin{array}{l}\text { ERA Fon } \\
372 \mathrm{c}\end{array}$ & & Narvusi & Kallivieri & $\begin{array}{l}\text { Yks oli väärä miun } \\
\text { emoini }\end{array}$ & & $\begin{array}{l}12345678 \\
5678 \\
\end{array}$ & $\begin{array}{l}22222222 \\
2244 \\
\end{array}$ & 4 \\
\hline SibA 343 & 737 & Soikkola & Tarinainen & $\begin{array}{l}\text { Kasvoi miullekassoi } \\
\text { pitkä }\end{array}$ & $\begin{array}{l}\text { laadoi laa- } \\
\text { doi laadoi } \\
\text { majoi }\end{array}$ & $\begin{array}{l}1234 \\
12345678\end{array}$ & $\begin{array}{l}4462 \\
22222222\end{array}$ & $4+1$ \\
\hline SibA 102 & 908 & Narvusi & Kurkola & $\begin{array}{l}\text { Kuin mie kasvelin } \\
\text { kanainen }\end{array}$ & & $\begin{array}{l}12345678 \\
1234567 \\
\end{array}$ & $\begin{array}{l}22222222 \\
2222224 \\
\end{array}$ & 6 \\
\hline SibA 70 & 403 & Narvusi & Pärspää & $\begin{array}{l}\text { Täss on lusti nuorelle } \\
\text { noista }\end{array}$ & & $\begin{array}{l}12345678 \\
12345678 \\
\end{array}$ & $\begin{array}{l}22222222 \\
22222222 \\
\end{array}$ & 5 \\
\hline $\begin{array}{l}\text { SKSÄ A } \\
301 / 37 \mathrm{a} \\
\end{array}$ & 521 & Hevaa & Murtove & $\begin{array}{l}\text { A la ka katson(o) } \\
\text { kannoilla }\end{array}$ & & $\begin{array}{l}1234567(8) \\
1234567(8) \\
\end{array}$ & $\begin{array}{l}22222222 \\
22222222 \\
\end{array}$ & 5 \\
\hline $\begin{array}{l}\text { SKSÄ A } \\
301 / 37 \mathrm{a} \\
\end{array}$ & 521 & Hevaa & Murtove & $\begin{array}{l}\text { A la ka katson(o) } \\
\text { kannoilla }\end{array}$ & & $\begin{array}{l}1234567(8) \\
1234567(8)\end{array}$ & $\begin{array}{l}22222222 \\
22222222 \\
\end{array}$ & 5 \\
\hline $\begin{array}{l}\text { Borenius e } \\
111\end{array}$ & 584 & Tyrö & $\begin{array}{l}\text { Hovimät- } \\
\text { tään kylät }\end{array}$ & $\begin{array}{l}\text { Läksin kouluihen } \\
\text { kojista }\end{array}$ & $\begin{array}{l}\text { ai kal'inuska } \\
\text { maj'a, ai } \\
\text { mal'inuska } \\
\text { maj'a }\end{array}$ & $\begin{array}{l}\text { a } \\
12345678 \\
1234567 \\
\end{array}$ & $\begin{array}{l}22222222 \\
2222224\end{array}$ & 4 \\
\hline SibA 6 & 509 & Narvusi & Vyötermaa & Oi tytöt sulat sisaret & $\begin{array}{l}\text { oi kalina oi } \\
\text { malina }\end{array}$ & $\begin{array}{l}12345678 \\
12345678 \\
\end{array}$ & $\begin{array}{l}22222222 \\
22222222 \\
\end{array}$ & 3 \\
\hline SibA 188 & 558 & Soikkola & Säätinä & $\begin{array}{l}\text { Emo synnytti mi- } \\
\text { nuista }\end{array}$ & $\begin{array}{l}\text { kaalina } \\
\text { maalina }\end{array}$ & $\begin{array}{l}12345678 \\
12345678 \\
\end{array}$ & $\begin{array}{l}22222222 \\
22222222 \\
\end{array}$ & 5 \\
\hline SibA 10 & 402 & Narvusi & Vyötermaa & $\begin{array}{l}\text { Marjukkainen kar- } \\
\text { jukkainen }\end{array}$ & $\begin{array}{l}\text { laadoi laadoi } \\
\text { laadoi majoi }\end{array}$ & $\begin{array}{l}\text { i } 12345678 \\
\text { i1 } 2345678 \\
\end{array}$ & $\begin{array}{l}22222222 \\
22222222 \\
\end{array}$ & 4 \\
\hline SibA 142 & 439 & Narvusi & Kirjamo & Oi niitä omia maita & $\begin{array}{l}\text { laadoi laadoi } \\
\text { laadoi majoi }\end{array}$ & $\begin{array}{l}\text { i } 12345678 \\
\text { i1 } 2345678 \\
\end{array}$ & $\begin{array}{l}22222222 \\
22222222 \\
\end{array}$ & 5 \\
\hline SibA 187 & 559 & Soikkola & Säätinä & Olin yksi äidilleni & oi liaa & $\begin{array}{l}12345678 \\
12345678 \\
\end{array}$ & $\begin{array}{l}22222222 \\
22222222 \\
\end{array}$ & 5 \\
\hline SibA 95 & 443 & Narvusi & Kurkola & $\begin{array}{l}\text { Täss on lusti nuoren } \\
\text { noista }\end{array}$ & ee oi & $\begin{array}{l}12345678 \\
1234567(8) \\
\end{array}$ & $\begin{array}{l}22222222 \\
22222222 \\
\end{array}$ & 5 \\
\hline Levón 370 & 378 & Tyrö & Yhimäki & $\begin{array}{l}\text { Tuossa tanssivat } \\
\text { tasaiset }\end{array}$ & oo & $\begin{array}{l}12345678 \\
12345678 \| \\
\star 5678 \\
\star 5678 \\
\end{array}$ & $\begin{array}{l}22222222 \\
22222222 \| \\
42222 \\
42222\end{array}$ & 7 \\
\hline Levón 478 & 393 & Hevaa & Tönttölä & La ka katson lautojan & & $\begin{array}{l}1234567 \\
1234567 \| \\
567567 \\
1234567 \\
\end{array}$ & $\begin{array}{l}2222224 \\
2222224 \| \\
224224 \\
2222224 \\
\end{array}$ & 5 \\
\hline SibA 112 & 441 & Narvusi & Kaipaala & $\begin{array}{l}\text { Täss on lusti nuoren } \\
\text { noista }\end{array}$ & joonaa & $\begin{array}{l}12345678 \\
\mid 565678 \\
5678^{\star *}\end{array}$ & $\begin{array}{l}22222231 \\
\mid 222244 \\
222244\end{array}$ & 5 \\
\hline
\end{tabular}




\begin{tabular}{|c|c|c|c|c|c|c|c|c|}
\hline Levón 360 & 927 & PAIKKA & Yhimäki & $\begin{array}{l}\text { Hyvä on tyttönä } \\
\text { elellä }\end{array}$ & ReFrengit & $\begin{array}{l}\text { MUOTO- } \\
\text { RAKENNE } \\
12345678 \\
\mid 567678 \\
5678^{\star *} \\
\end{array}$ & $\begin{array}{l}22222222 \\
\mid 222224 \\
2222[44] \\
\end{array}$ & 5 \\
\hline $\begin{array}{l}\text { Alava } \\
\text { VIIa:425. }\end{array}$ & & Narvusi & Kaipaala & $\begin{array}{l}\text { Hyppää nukke } \\
\text { karkaa nukke }\end{array}$ & & $\begin{array}{l}12341234 \| \\
12345678 \\
12345678\end{array}$ & $\begin{array}{l}42424242 \| \\
22224444 \\
22224444\end{array}$ & 4 \\
\hline $\begin{array}{l}\text { SKSÄ A } \\
301 / 35 a\end{array}$ & 837 & Hevaa & Murtove & $\begin{array}{l}\text { A kyzyin i maaDa } \\
\text { velloilta }\end{array}$ & & $\begin{array}{l}12341234 \| \\
1234567 \\
567 \\
1234567 \\
567 \\
\end{array}$ & \begin{tabular}{|l||}
48484848|| \\
2222224 \\
224 \\
2222224 \\
224 \\
\end{tabular} & 5 \\
\hline $\begin{array}{l}\text { SKSÄ A } \\
301 / 35 b\end{array}$ & 732 & Hevaa & Murtove & $\begin{array}{l}\text { Hekkoi tyttöi } \\
\text { Hemme tyttöi }\end{array}$ & & $\begin{array}{l}12341234 \| \\
12345678 \\
12345678\end{array}$ & $\begin{array}{l}48484848 \\
22222222 \\
22222222\end{array}$ & 5 \\
\hline SibA 69 & 825 & Narvusi & Pärspää & $\begin{array}{l}\text { Tässä tanssivat } \\
\text { tasaiset }\end{array}$ & & $\begin{array}{l}12345678 \\
|| 345678 \\
345678 \\
\end{array}$ & $\begin{array}{l}44444444 \\
\mid 222244 \\
222244 \\
\end{array}$ & 4 \\
\hline SibA 15 & 762 & Narvusi & Kallivieri & $\begin{array}{l}\text { Täss on tykky } \\
\text { tyttäriä }\end{array}$ & & $\begin{array}{l}12345678 \mid \\
12345678 \\
12345678\end{array}$ & $\begin{array}{l}44444444 \| \\
22222222 \\
22222222\end{array}$ & 5 \\
\hline SibA 454 & 824 & Soikkola & Uusikylä & $\begin{array}{l}\text { Meijän kutroipää } \\
\text { kuningas }\end{array}$ & & $\begin{array}{l}12345678 \\
12345678 \\
\| 12345678 \\
12345678 \\
12345678 \\
12345678\end{array}$ & $\begin{array}{l}44444444 \\
44444444 \\
\| 22222222 \\
22222222 \\
22222222 \\
22222222\end{array}$ & 7 \\
\hline
\end{tabular}

\section{LASKIAISS ÄVELMÄT}

Viite: Launis = SibA Launis 1903; A = SKSÄ A; NPI = Kiuru et. al. 1974 (nuotti/runo). S: käytettyjä säveliä.

\begin{tabular}{|c|c|c|c|c|c|c|c|}
\hline \multicolumn{7}{|c|}{ LIUKUSÄVELMÄT: SOIKKOLA } & \multirow[b]{2}{*}{$S$} \\
\hline VIITE & IRS & KYLÄ & LAULAJAT & AlKusÄE & $\begin{array}{l}\text { MUOTO- } \\
\text { RAKENNE }\end{array}$ & RYTMI & \\
\hline Launis 233 & 122 & Tarinainen (?) & & Livvakka rekoi lippiä & 12345678 & 22222222 & 4 \\
\hline Launis 310 & 734 & Viistinä (?) & & Livvukka rekoi lippiä & 12345678 & 22222222 & 5 \\
\hline Launis 393b & 698 & Mättynen & & Livvukka rekoi lipiäistä & 12345678 & 22222222 & 5 \\
\hline A $300 / 48 a$ & 772 & Mäkkylä & $\begin{array}{l}\text { Ustenja Miikkulant. } \\
\text { ja kuoro }\end{array}$ & O livukka rekoi lippijä & 12345678 & 22222222 & 5 \\
\hline A $300 / 40 b$ & 766 & Mäkkylä & $\begin{array}{l}\text { Anna Mitrintytär } \\
\text { ja kuoro }\end{array}$ & $\begin{array}{l}\text { Oi njo njo njo HeBoi- } \\
\text { sueni }\end{array}$ & 12345678 & 22222222 & $4+1$ \\
\hline NPI $12 / 30$ & & $\begin{array}{l}\text { Savimäki, } \\
\text { Loka }\end{array}$ & $\begin{array}{l}\text { Maria Elizarovna } \\
\text { Nikitina ja Maria } \\
\text { Feropontevna Jere- } \\
\text { mejeva }\end{array}$ & Liuvukka rekkoi lippiä & 12345678 & 22222222 & 4 \\
\hline
\end{tabular}

\section{LIUKusÄVELMÄT: HeVAA}

e 177;
(SKVR 528 Hevaa, Vepsä $\begin{aligned} & \text { Paraskoi Huoterin } \\ & \text { tytär }\end{aligned}$

Ennen päivytäk eletty, 12345678

$\begin{array}{lll}\text { kupaeltu ilman kuutak, } 12345678 & \|_{22222231} & 4 \\ \text { ilman ilman kuutak, } & 565678\end{array}$

ilman kuutak joonoi 678 joonoi 


\section{LIEKKUSÄVELMÄT}

Viite: A = SKSÄ A; KRA = SKS KRA; SibA = SibA Launis 1903

KRA Väisänen = SKS KRA Väisänen laatikko 3:3 Inkerinmaa, vihko sävelmämuistiinpanoja, s. 5.

S: käytettyjä säveliä.

\begin{tabular}{|c|c|c|c|c|c|c|c|}
\hline ViIte & IRS & PAIKKa & KYLÄ & AlKusÄE & $\begin{array}{l}\text { MUOTO- } \\
\text { RAKENNE }\end{array}$ & Rутмі & \\
\hline $\begin{array}{l}\text { RA Europaeus 12: } \\
94 \mathrm{a}\end{array}$ & 869 & Narvusi & Vanhakylä & La kuin katson liekkuani & 12345678 & 22222222 & \\
\hline KRA Borenius e 200 & 45 & Soikkola & Joenperä & Lõekkujani kõekkujani & 12345678 & 22222222 & 3 \\
\hline ibA $263 b$ & 34 & Soikkola & Soikkola & La kun katson liekkujani & 12345678 & 22222222 & 4 \\
\hline ibA 206 & 780 & Soikkola & Soikk & La ku(n) katson liekkuani & 12345678 & 22222222 & 4 \\
\hline 301 & 767 & Soikkola & Viistinä & ttajaD keekuttajaD & 5678 & 22222222 & $\overline{4}$ \\
\hline $300 /$ & 781 & & Säätinä & & $1234567(8)$ & 22222222 & 5 \\
\hline $507 / 9$ a & & Narvusi & Ropsu & & 12345678 & 22222222 & $\overline{4}$ \\
\hline KRA Väisä & & Soikkola & Risumäki & Laga mie katson liekku & 12345678 & 22222222 & $4+1$ \\
\hline ibA 126 & 95 & Narvusi & Kontu & Liekkuani kiekkuani & 12345678 & 22222222 & 3 \\
\hline ibA 143 & 822 & Narvusi & Struuppaa & La kı & 12345678 & 22222222 & $4+1$ \\
\hline $302 / 98 c$ & & & Kirjamo & Lie li & 12345678 & 22222222 & 3 \\
\hline $\mathrm{RA} A$ & & & Kaipaala & & 12345678 & & $\overline{4}$ \\
\hline ibA 104 & 70 & & & La mie koitan liekkuani & 12345678 & 24242424 & 3 \\
\hline RA Boren & 33 & Kattila & Matinkylä & Löe löekku čii čiikku & 12345678 & 24242424 & 4 \\
\hline RA Bor & 92 & Kattila & Matinkylä & Čylä & 12345678 & 24242424 & 3 \\
\hline $\mathrm{KRA} \mathrm{Le}$ & 72 & Hevaa & Lenttinen & La ka & 12345678 & 22222222 & 3 \\
\hline KRA Levón 524 & 58 & Hevaa & $\begin{array}{l}\text { Uusi } \\
\text { Huurala }\end{array}$ & Elä liekkoi langettele & 12345678 & 22222224 & 3 \\
\hline RA Levón 452 & 78 & & & & & & 3 \\
\hline RA Levón 442 & 718 & Hevaa & Ojank & La ka & 12345678 & 22222222 & 3 \\
\hline ibA 400 & 811 & Kaprio & Pankkala & La m & 12345678 & 22222222 & $\overline{4}$ \\
\hline KRA Ievó & 421 & Tyrö & Yhimäki & & $1234567(8)$ & 22222222 & 4 \\
\hline KRA Borenius e 386 & 56 & & $\begin{array}{l}\text { Ala- } \\
\text { Purskova }\end{array}$ & Mitä otan virrekseni & 12345678 & 22222224 & 4 \\
\hline KRA Borenius e 380 & 800 & Kolpp & $\begin{array}{l}\text { Pieni } \\
\text { Kolppana }\end{array}$ & $\begin{array}{l}\text { Oi } \\
\text { jain }\end{array}$ & $\begin{array}{l}\text { oi } \\
12345678\end{array}$ & [2]11222222 & 5 \\
\hline KRA Borenius e 375 & 812 & Kolppana & & $\begin{array}{l}\text { Joi } \\
\text { päi }\end{array}$ & $\begin{array}{l}\text { joi } \\
12345678\end{array}$ & [2]11222222 & 4 \\
\hline KRA Borenius e 385 & 765 & Skuoritsa & $\begin{array}{l}\text { Ala-Purs- } \\
\text { kova }\end{array}$ & $\begin{array}{l}\text { La minä koittelen liek- } \\
\text { kujaini }\end{array}$ & $\begin{array}{l}\text { joi } \\
12345678\end{array}$ & [2]11222222 & 5 \\
\hline KRA Borenius e 125 & 651 & Tyrö & Ylikylä & $\begin{array}{l}\text { La mie katson liekkujaini, } \\
\text { onko liekku leppiäi, } \\
\text { leppi leppiäinen, } \\
\text { leppiäinen joonoi }\end{array}$ & $\begin{array}{l}12345678 \\
1234567 \| \\
565678 \\
5678 \text { joonoi }\end{array}$ & $\begin{array}{l}44623131 \\
4462314 \\
\| 446244 \\
i 4444[44]\end{array}$ & \\
\hline KRA Levón 421 & 359 & Hevaa & Harmaala & $\begin{array}{l}\text { La ka katson liekkuani } \\
\text { liekkuani }\end{array}$ & $\begin{array}{l}12345678 \\
5678\end{array}$ & $\begin{array}{l}24222262 \\
2262\end{array}$ & \\
\hline
\end{tabular}




\section{KokkosävelmäT}

Viite: KRA = SKS KRA

\begin{tabular}{|c|c|c|c|c|c|}
\hline ViIte & IRS & РАIKKA & AlKusÄKEET & MUOTORAKENNE & RYtмi \\
\hline NPI $31 / 3$ & & Soikkola & Tulkkaha tulelle meijen & 12345678 & 44222244 \\
\hline NPI $32 / 3$ & & Soikkola & Tulkkaa tyttäret tulelle & 12345678 & 44222244 \\
\hline SKSÄ L 101 c & & Narvusi & Oo tulkaa tyttäret tulella tulella & 123456785678 & 222222222244 \\
\hline $\begin{array}{l}\text { KRA Enäjärvi- } \\
\text { Haavio } 773\end{array}$ & & Narvusi & $\begin{array}{l}\text { Syty, sytyttö tuli; oi lado lado } \\
\text { la tuli }\end{array}$ & $\begin{array}{l}1234567(8) \| \\
\text { oi lado lado } 5678\end{array}$ & $\begin{array}{l}\text { (vrt. SibA Lau- } \\
\text { nis } 10,50,142 \text { ) }\end{array}$ \\
\hline KRA Levón 514 & 183 & Hevaa & Tulkaa tytöt yötulelle & 12345678 & 22222262 \\
\hline SKSÄ A 301/46b & 0209 & Hevaa & Tulgaa tytöt yötulille & 12345678 & 22622244 \\
\hline KRA Levón 484 & 531 & Hevaa & $\begin{array}{l}\text { Tulkaa tytöt yötulelle, valu- } \\
\text { kaatte valkealle; } \\
\text { ai lole ai lole, valukaatte } \\
\text { valkeall }\end{array}$ & $\begin{array}{l}1234567812345678 \| \\
\text { ai lole lole } 1234567\end{array}$ & $\begin{array}{l}\mid 22222262 \\
22222222\end{array}$ \\
\hline KRA Levón 437 & 536 & Hevaa & $\begin{array}{l}\text { Tulkaa tytöt yötulelle, valu- } \\
\text { kaatte valkealle; } \\
\text { oi valkealle, valkealle joonoi }\end{array}$ & $\begin{array}{l}1234567812345678 \| \\
\text { oi } 56785678 \text { joonoi }\end{array}$ & $\left.\right|_{2222222}$ \\
\hline KRA Levón 436 & 5119 & Hevaa & $\begin{array}{l}\text { Läkkön myö vet oi läpi } \\
\text { kyläisen jo, } \\
\text { ai lole lole ja kyläisen jo }\end{array}$ & $\begin{array}{l}123 \text { vet oi } 45678 \text { jo } \| \\
\text { ai lole lole } 5678 \text { jo }\end{array}$ & $222[22] 22222[4]$ \\
\hline KRA Levón 420 & 674 & Hevaa & $\begin{array}{l}\text { Tulkaa ka työ tytöt yötulelle } \\
\text { jo; ai lole lole yötulelle jo }\end{array}$ & $\begin{array}{l}12^{\star *} 345678 \text { jo } \| \\
\text { ai lole lole } 5678 \text { jo }\end{array}$ & $42[24] 224242[4]$ \\
\hline KRA Levón 348 & 107 & Tyrö & $\begin{array}{l}\text { Tulkaa ka tytöt kokoille, } \\
\text { valvokaaha valkealle }\end{array}$ & 12345678 & 22312231 \\
\hline KRA Levón 381 & 432 & Tyrö & $\begin{array}{l}\text { Tulkaa tytöt yötulille, valu- } \\
\text { kaahan valkeill; ai luli ai luli, } \\
\text { valukaahan valkeill }\end{array}$ & $\begin{array}{l}\text { 12345678 } 1234567 \text { || } \\
\text { ai luli luli } 1234567\end{array}$ & $\begin{array}{l}22222262 \\
2222224\end{array}$ \\
\hline KRA Levón 533 & 672 & Tyrö & $\begin{array}{l}\text { Tulkaa tulkaa työ tytöt ko- } \\
\text { kolle jo, } \\
\text { ai lole lole ja kokolle jo }\end{array}$ & $\begin{array}{l}1212345678 \text { jo } \| \\
\text { ai lole lole } 5678 \text { jo }\end{array}$ & $4242224242[4]$ \\
\hline
\end{tabular}

\section{KOKKOSÄVELEN KUVAUKSEEN SOPIVAT SÄVELMÄT}

Ai luuli

Viite: A = SKSÄ A; Borenius = SKS KRA Borenius; Launis = SibA Launis 1903; Levón = SKS KRA Levón

Kuoro-osa: ljuuli = lole; ta $=\mathrm{da}$

\begin{tabular}{|c|c|c|c|c|c|c|c|c|}
\hline Vitte & IRS & PAIKKA & KYLÄ & ALKUSÄE & $\begin{array}{l}\text { MUOTO- } \\
\text { RAKENNE }\end{array}$ & KuORO-OSA & Rутмі & $\begin{array}{l}\text { SÄVEL- } \\
\text { ALA }\end{array}$ \\
\hline \multicolumn{9}{|c|}{ YKSISÄKEISET, VENYTETYT } \\
\hline Levón 420 & 674 & Hevaa & Harmaala & $\begin{array}{l}\text { Tulkaa ka työ tytöt } \\
\text { yötulelle jo; ai lole lole } \\
\text { yötulelle jo }\end{array}$ & $\begin{array}{l}12^{\star *} 3456 \\
78^{\star}\end{array}$ & $\begin{array}{l}\text { ai lole lole } \\
5678 \text { joo }\end{array}$ & $\begin{array}{l}42[24] 22 \\
4242[4]\end{array}$ & 3 \\
\hline A $301 / 27 b$ & 219 & Hevaa & Vepsä & $\begin{array}{l}\text { Kokkolintu vet e } \\
\text { korvellindu joo, ai lole } \\
\text { lole korvellindu joo }\end{array}$ & $\begin{array}{l}12^{\star *} 3456 \\
78^{\star} / \\
123^{\star *} 456 \\
78^{\star}\end{array}$ & $\begin{array}{l}\text { ai lole lole } \\
5678 \text { joo }\end{array}$ & $\begin{array}{l}22[22] 22 \\
2222[4]\end{array}$ & 5 \\
\hline
\end{tabular}




\begin{tabular}{|c|c|c|c|c|c|c|c|c|}
\hline ViIte & IRS & РАIKKA & KYLÄ & ALKUSÄE & $\begin{array}{l}\text { MuOTO- } \\
\text { RAKENNE }\end{array}$ & KuORO-OSA & Rутмі & $\begin{array}{l}\text { SäVEL- } \\
\text { ALA }\end{array}$ \\
\hline Levón 445 & 280 & Hevaa & Vepsä & $\begin{array}{l}\text { Katriina veti kotika- } \\
\text { naien jo, ai lole lole ja } \\
\text { kanainen jo }\end{array}$ & $\begin{array}{l}123^{\star \star} 456 \\
78^{\star} / \\
1234^{\star \star} 56 \\
78^{\star}\end{array}$ & $\begin{array}{l}\text { ai lole lole } \\
5678 \text { joo }\end{array}$ & $\begin{array}{l}223[12] \\
23122[4]\end{array}$ & 5 \\
\hline $\begin{array}{l}\text { Borenius } \\
\text { e } 175\end{array}$ & 211 & Hevaa & Vepsä & $\begin{array}{l}\text { Hämöilässä vet on } \\
\text { hällöi kasvoi jo, ai lole } \\
\text { lole, hällöi kasvoi jo }\end{array}$ & $\begin{array}{l}1234^{\star *} 56 \\
78^{\star}\end{array}$ & $\begin{array}{l}\text { ai lole lole } \\
5678 \text { joo }\end{array}$ & $\begin{array}{l}2224[22] \\
2224[4]\end{array}$ & 5 \\
\hline Levón 436 & 119 & Hevaa & Kantakylä & $\begin{array}{l}\text { Läkkön myö vet oi } \\
\text { läpi kyläisen jo, ai lole } \\
\text { lole ja kyläisen jo }\end{array}$ & $\begin{array}{l}123^{\star \star} 456 \\
78^{\star}\end{array}$ & $\begin{array}{l}\text { ai lole lole } \\
5678 \text { joo }\end{array}$ & $\begin{array}{l}222[22] \\
22222[4]\end{array}$ & 5 \\
\hline $\begin{array}{l}\text { Borenius } \\
\text { e } 181\end{array}$ & 253 & Hevaa & Vepsä & $\begin{array}{l}\text { Kalervikkoi vet on } \\
\text { kylvi kakroin oi, ai lole } \\
\text { l'ole kylvi kakroin oi }\end{array}$ & $e_{78^{\star}}^{1234^{\star \star 56}}$ & $\begin{array}{l}\text { ai lole lole } \\
5678 \text { oi }\end{array}$ & $\begin{array}{l}2222[22] \\
2222[4]\end{array}$ & 5 \\
\hline $\begin{array}{l}\text { Borenius } \\
169\end{array}$ & 281 & Tyrö & Asikkala & $\begin{array}{l}\text { Velloini vet se venoi- } \\
\text { sen seppoi joo; ai lole } \\
\text { lole ja venoisen se }\end{array}$ & $\begin{array}{l}123^{\star \star} 456 \\
78^{\star} / 12^{\star \star} \\
345678^{\star} \\
\end{array}$ & $\begin{array}{l}\text { ai lole lole } \\
5678 \text { joo }\end{array}$ & $\begin{array}{l}222[22] \\
22222[4]\end{array}$ & 5 \\
\hline Levón 530 & 845 & Tyrö & Ylikylä & $\begin{array}{l}\text { Puistin puistin maata } \\
\text { velloiltani jo; ai lole lo } \\
\text { jo velloiltani jo }\end{array}$ & $\begin{array}{l}12 \\
12345678^{*}\end{array}$ & $\begin{array}{l}\text { ai lole lole } \\
+5678 \text { joo }\end{array}$ & $\begin{array}{l}6262446 \\
262[8]\end{array}$ & 6 \\
\hline Levón 533 & 672 & Tyrö & Ylikylä & $\begin{array}{l}\text { Tulkaa tulkaa työ tytö } \\
\text { kokolle jo, ai lole lole } \\
\text { ja kokolle jo }\end{array}$ & $\begin{array}{l}12 \\
12345678^{*}\end{array}$ & $\begin{array}{l}\text { ai lole lole } \\
+5678 \text { joo }\end{array}$ & $\begin{array}{l}42422242 \\
42[4]\end{array}$ & 4 \\
\hline Levón 340 & 266 & Tyrö & $\begin{array}{l}\text { Latikan } \\
\text { kylät }\end{array}$ & $\begin{array}{l}\text { Kasvatti emo kanai- } \\
\text { sia joi, ai luli luli jaa } \\
\text { kanaisia jo }\end{array}$ & $12345678^{\star}$ & $\begin{array}{l}+ \text { ai lole lole } \\
5678 \text { joo }\end{array}$ & $\begin{array}{l}224422 \\
224[2]\end{array}$ & 6 \\
\hline \multicolumn{9}{|c|}{ KAKSISÄKEISET, SYLLABISET } \\
\hline Levón 484 & 531 & Hevaa & Tönttölä & $\begin{array}{l}\text { Tulkaa tytöt yötulelle, } \\
\text { valukaatte valkealle; a } \\
\text { lole ai lole, valukaatte } \\
\text { valkeall }\end{array}$ & $\begin{array}{r}12345678 \\
12345678 \\
\end{array}$ & $\begin{array}{l}\text { ai lole ai lole } \\
1234567\end{array}$ & $\begin{array}{l}22222262 \\
22222222\end{array}$ & 4 \\
\hline A $301 / 27 a$ & 433 & Hevaa & Vepsä & $\begin{array}{l}\text { Undamoilla uljas } \\
\text { ukko, undamoilla ul- } \\
\text { jas ukko; ai lole ai lole } \\
\text { undamoilla uljas uu }\end{array}$ & $\begin{array}{l}12345678 \\
123456 \\
7(8)\end{array}$ & $\begin{array}{l}\text { ai lole ai lole } \\
1234567\end{array}$ & $\begin{array}{r}22222222 \\
22222222\end{array}$ & 5 \\
\hline Levón 472 & 534 & Hevaa & Lenttinen & $\begin{array}{l}\text { La mie viukkasen } \\
\text { vilulla, la mie kaljun } \\
\text { kastehessa; ai lole ai } \\
\text { lole, la mie kaljun } \\
\text { kastehess }\end{array}$ & $\begin{array}{l}12345678 \\
12345678\end{array}$ & $\begin{array}{l}\text { ai lole ai lole } \\
1234567\end{array}$ & $\begin{array}{l}22222262 \\
22222222 \\
\|\left[{ }^{2} 22224\right] \\
2222224\end{array}$ & 4 \\
\hline A $301 / 45 b$ & 383 & Hevaa & Vepsä & $\begin{array}{l}\text { Veikkoni vennoisen } \\
\text { seppoi, laivoin seppoi } \\
\text { lagluen; ai luuli lag- } \\
\text { lueil, laivoin seppoi } \\
\text { laglueil }\end{array}$ & $\begin{array}{l}12345678 \\
123456 \\
7(8) \\
\end{array}$ & $\begin{array}{l}\text { ai lole } 567 \\
1234567\end{array}$ & $\begin{array}{l}22222222 \\
22222222\end{array}$ & 5 \\
\hline Levón 381 & 432 & Tyrö & Yhimäki & $\begin{array}{l}\text { Tulkaa tytöt yötulille, } \\
\text { valukaahan valkeill; ai } \\
\text { luli ai luli, valukaahan } \\
\text { valkeill }\end{array}$ & $\begin{array}{l}\text { i } 12345678 \\
1234567\end{array}$ & $\begin{array}{l}\text { ai lole ai lole } \\
1234567\end{array}$ & $\begin{array}{l}22222262 \\
2222224\end{array}$ & 4 \\
\hline A $301 / 47 b$ & 579 & Tyrö & Yhimäki & $\begin{array}{l}\text { Oli ennen meihen } \\
\text { kaul, suuri ringi tyt- } \\
\text { tölöi; ai luuli tyttölöi, } \\
\text { suuri ringi tyttölöi }\end{array}$ & $\begin{array}{l}1234567 \\
1234567\end{array}$ & $\begin{array}{l}\text { ai lole } 567 \\
1234567\end{array}$ & $\begin{array}{l}2222224 \\
2222224\end{array}$ & 6 \\
\hline A $301 / 47 a$ & 382 & Tyrö & Yhimäki & $\begin{array}{l}\text { Jo meillä ero tuloo, } \\
\text { vaikeva o,on harota; a } \\
\text { luuli ja harot, vaikea } \\
\text { ono harota }\end{array}$ & $\begin{array}{l}123456 \\
17(8) \\
123456 \\
7(8) \\
\end{array}$ & $\begin{array}{l}\text { ai lole } 567 \\
12345678\end{array}$ & $\begin{array}{l}22222222 \\
22222222\end{array}$ & 5 \\
\hline Levón 404 & 497 & Tyrö & Yhimäki & $\begin{array}{l}\text { Veljeni venosen sep- } \\
\text { po, laivoi seppo laklu- } \\
\text { ven; lai luuli lakluven, } \\
\text { ai luuli lagluven }\end{array}$ & $\begin{array}{l}12345678 \\
1234567\end{array}$ & $\begin{array}{l}\text { lai lole } 567 \\
\text { lai lole } 567\end{array}$ & $\begin{array}{l}22222231 \\
2222224\end{array}$ & 4 \\
\hline
\end{tabular}




\begin{tabular}{|c|c|c|c|c|c|c|c|c|}
\hline ViIte & IRS & PAIKKA & KYLÄ & AlKusÄE & $\begin{array}{l}\text { MUOTO- } \\
\text { RAKENNE }\end{array}$ & KuORO-OSA I & RYtMI & $\begin{array}{l}\text { SäVEL- } \\
\text { ALA }\end{array}$ \\
\hline Levón 388 & 483 & Tyrö & Yhimäki & $\begin{array}{l}\text { Menin pienen kyntä- } \\
\text { mähän, kynsin vaan } \\
\text { kynsin kaksi; ai luli } \\
\text { luli lu kyntämähän, ai } \\
\text { luli luli lu kyntämähän }\end{array}$ & $\begin{array}{l}12345678 \\
12345678 \\
\end{array}$ & $\begin{array}{l}\text { ai lole lole lo } \\
5678 \text { ai lole } \\
\text { lole lo } 5678\end{array}$ & $\begin{array}{l}22222222 \\
22222222\end{array}$ & 5 \\
\hline Levón 405 & 373 & Tyrö & Yhimäki & $\begin{array}{l}\text { Meroin tyttö metsoin } \\
\text { sulho, korven korkiea } \\
\text { sevihka, ai luli spai } \\
\text { luli, korven korkea } \\
\text { sevihka }\end{array}$ & $\begin{array}{l}12345678 \\
12345678 \\
\end{array}$ & $\begin{array}{l}\text { ai lole } \\
\text { spai lole } \\
12345678\end{array}$ & $\begin{array}{l}22312222 \\
22222222\end{array}$ & 7 \\
\hline A $300 / 17 a$ & 427 & Soikkola & $\begin{array}{l}\text { Tammi- } \\
\text { kontu }\end{array}$ & $\begin{array}{l}\text { Elettihe ennem meil, } \\
\text { eletti ojiin takkaan; ai } \\
\text { l'ole pai l'ole, elettiin } \\
\text { ojan takkaa/ee }\end{array}$ & $\begin{array}{l}1234567 \\
1234567 \\
\end{array}$ & $\begin{array}{l}\text { ai lole pai } \\
\text { lole } 12345672\end{array}$ & $\begin{array}{r}2222224 \\
2222224\end{array}$ & 4 \\
\hline A $300 / 29 b$ & 428 & Soikkola & Säätinä & $\begin{array}{l}\text { Oi midä myy tytöt } \\
\text { sure, ilmal lauluda elä; } \\
\text { ai l'ole pai l'ole, ilmal } \\
\text { lauluda elä }\end{array}$ & $\begin{array}{l}1234567 \\
1234567\end{array}$ & $\begin{array}{l}\text { ai lole } \\
\text { pai lole } \\
12345678\end{array}$ & $\begin{array}{l}2222224 \\
2222224\end{array}$ & 4 \\
\hline A $300 / 29 b$ & 435 & Soikkola & Säätinä & $\begin{array}{l}\text { Olin yksi äidilleni, } \\
\text { maksoin kaksi mam- } \\
\text { malle; ai l'ole pai l’ole, } \\
\text { maksoin kaksi mam- } \\
\text { malle }\end{array}$ & $\begin{array}{l}12345678 \\
123456 \\
7(8)\end{array}$ & $\begin{array}{l}\text { ai lole } \\
\text { pai lole } \\
12345678\end{array}$ & $\begin{array}{l}22222222 \\
22222222\end{array}$ & 4 \\
\hline Launis 266 & 551 & Soikkola $S$ & Soikkola & $\begin{array}{l}\text { Elettiigin ennen meil- } \\
\text { lä, olttiigi ojan takana; } \\
\text { ai l'uli pai l'uli, olttiigi } \\
\text { ojan takana }\end{array}$ & $\begin{array}{l}12345678 \\
12345678 \\
\end{array}$ & $\begin{array}{l}\text { ai lole } \\
\text { pai lole } \\
12345678\end{array}$ & $\begin{array}{l}22222222 \\
22222222\end{array}$ & 5 \\
\hline $\begin{array}{l}\text { Haavio } \\
2558\end{array}$ & & Narvusi & Kulla & $\begin{array}{l}\text { Annikka turusen tyt- } \\
\text { tö, Turun tyttö saaren } \\
\text { neito; ai luuli luulii, } \\
\text { Turun tyttö saaren } \\
\text { neito }\end{array}$ & $\begin{array}{l}12345678 \\
12345678\end{array}$ & $\begin{array}{l}\text { ai luulii } \\
\text { luulii }\end{array}$ & - & - \\
\hline \multicolumn{9}{|c|}{ MUUT YKSISÄKEISET } \\
\hline Launis 9 & 237 & Narvusi & Vyötermaa & $\begin{array}{l}\text { Eivät kasva kaikki } \\
\text { alapset, oi lole lole } \\
\text { kaikki lapset }\end{array}$ & 12345678 & $\begin{array}{l}\text { oi lole lole } \\
5678\end{array}$ & 44224422 & 4 \\
\hline Launis 35 & 832 & Narvusi I & Ropsu & $\begin{array}{l}\text { Lauloi suuri lauloi } \\
\text { pieni, oi l'ole l'ole } \\
\text { lauloi pieni }\end{array}$ & 12345678 & $\begin{array}{l}\text { oi lole lole } \\
5678\end{array}$ & 42224222 & 4 \\
\hline Launis 391 & 678 & Soikkola & Venakontsa & $\begin{array}{l}\text { Miksipä miä vaan } \\
\text { amokoma; oi l'ole lole } \\
\text { ja mokoma ja }\end{array}$ & 12345678 & $\begin{array}{l}\text { ai lole lole } \\
5678 \mathrm{ja}\end{array}$ & 22462246 & 4 \\
\hline $\begin{array}{l}\text { Borenius e } \\
201\end{array}$ & 223 & Soikkola J & Joenperä & $\begin{array}{l}\text { Velloini vennoisen } \\
\text { seppoi, ai lole lole ja } \\
\text { venoisen }\end{array}$ & 12345678 & $\begin{array}{l}\text { ai lole lole } \\
5678\end{array}$ & 22442244 & 5 \\
\hline A $301 / 03 a$ & 274 & Soikkola & Viistinä & $\begin{array}{l}\text { Oi kuin kukoilla vaa } \\
\text { kynnettiiihe; ai lole } \\
\text { lole kynnettihe }\end{array}$ & $\begin{array}{l}1234^{\star} 5678 \\
/ 12345^{\star} 6 \\
78\end{array}$ & $\begin{array}{l}8 \text { ai lole lole } \\
5678\end{array}$ & 22442244 & $4+1$ \\
\hline $\begin{array}{l}\text { Borenius } \\
109\end{array}$ & 675 & Tyrö & $\begin{array}{l}\text { Hovimäen } \\
\text { Alakylä } \\
\end{array}$ & $\begin{array}{l}\text { Kerittelin vellojaini, ai } \\
\text { lole lole vellojaini }\end{array}$ & 12345678 & $\begin{array}{l}\text { ai lole lole } \\
5678\end{array}$ & 44224422 & 5 \\
\hline Levón 368 & 232 & Tyrö & Yhimäki & $\begin{array}{l}\text { Varpu rikko neito } \\
\text { nuori; Ai lole lole } \\
\text { neito nuori }\end{array}$ & 12345678 & $\begin{array}{l}\text { ai lole lole } \\
5678\end{array}$ & 44224422 & 4 \\
\hline SibA 338 & 677 & Soikkola I & Mäkkylä & $\begin{array}{l}\text { Nyt antoi volin emoin, } \\
\text { volin emoin emoin; } \\
\text { oi l'ole lole ja emoin } \\
\text { emoin }\end{array}$ & $\begin{array}{l}1234567 \\
456767\end{array}$ & $\begin{array}{l}\text { ai lole lole } \\
56767\end{array}$ & $\begin{array}{l}2224222 \\
424222\end{array}$ & 5 \\
\hline Launis 50 & 789 & Narvusi I & Pärspää & $\begin{array}{l}\text { Lauloi suuri lauloi } \\
\text { pieni, oi laadoi laadoi } \\
\text { lauloi pieni }\end{array}$ & 12345678 & $\begin{array}{l}\text { oi laadoi laa- } \\
\text { doi } 5678\end{array}$ & 31223122 & 5 \\
\hline
\end{tabular}




\begin{tabular}{|c|c|c|c|c|c|c|c|c|}
\hline ViIte & IRS & РАIKKA & KYLÄ & AlKusÄE & $\begin{array}{l}\text { MUOTO- } \\
\text { RAKENNE }\end{array}$ & KuORO-OSA & RутмI & $\begin{array}{l}\text { SäVEL- } \\
\text { ALA }\end{array}$ \\
\hline Launis 34 & 856 & Narvusi & Ropsu & $\begin{array}{l}\text { Mikä lienee ee mi- } \\
\text { nulle, ee minulle, Oi } \\
\text { laad(/t)oi laad(/t)oi ja } \\
\text { minulle }\end{array}$ & $\begin{array}{l}12345678 \\
5678\end{array}$ & $\begin{array}{l}\text { oi laadoi laa- } \\
\text { doi } 5678\end{array}$ & $\begin{array}{l}-62446244 \\
6262\end{array}$ & 5 \\
\hline A $301 / 45 a$ & 170 & Hevaa & Vepsä & $\begin{array}{l}\text { Lendeli kessoisem } \\
\text { päivöin; ai ta lole lole } \\
\text { ja kessoisen }\end{array}$ & 12345678 & $\begin{array}{l}\text { ai da lole } \\
\text { lole } 5678\end{array}$ & 22622222 & 5 \\
\hline A $301 / 41 b$ & 200 & Tyrö & Yhimäki & $\begin{array}{l}\text { La laulan liki kotija; ai } \\
\text { ta lole lole ja kotija }\end{array}$ & 12345678 & $\begin{array}{l}\text { ai da lole } \\
\text { lole } 5678 \\
\end{array}$ & 22222222 & 5 \\
\hline A $301 / 43 b$ & $200^{*}$ & +Tyrö & Yhimäki & $\begin{array}{l}\text { Olim miä tyttöi pik- } \\
\text { karainen; ai ta lole lole } \\
\text { pikkarainen }\end{array}$ & 12345678 & $\begin{array}{l}\text { ai da lole } \\
\text { lole } 5678\end{array}$ & 22222222 & 5 \\
\hline Levón 342 & 192 & Tyrö & $\begin{array}{l}\text { Latikan } \\
\text { kylät }\end{array}$ & $\begin{array}{l}\text { Lauloin ennen lap- } \\
\text { senpana, ai ta lole lole } \\
\text { lapsenpana }\end{array}$ & 12345678 & $\begin{array}{l}\text { ai da lole } \\
\text { lole } 5678\end{array}$ & 31623122 & 5 \\
\hline e 129 & 199 & Tyrö & $\begin{array}{l}\text { Kirkon- } \\
\text { kylä }\end{array}$ & $\begin{array}{l}\text { Jos mun tuttuni tulisi, } \\
\text { ai da lole l'ole ja tulisi }\end{array}$ & 12345678 & $\begin{array}{l}\text { ai da lole } \\
\text { lole } 5678\end{array}$ & 31623122 & 5 \\
\hline Levón 361 & 191 & Tyrö & Yhimäki & $\begin{array}{l}\text { Emoi miu, miu syn- } \\
\text { nytteli, ai ta lole lole } \\
\text { synnytteli }\end{array}$ & $\begin{array}{l}1234 \\
2345678\end{array}$ & $\begin{array}{l}\text { ai da lole } \\
\text { lole } 5678\end{array}$ & $\begin{array}{l}2222 \\
313122\end{array}$ & 5 \\
\hline Launis 10 & 402 & Narvusi & Vyötermaa & $\begin{array}{l}\text { Marjukkainen karjuk- } \\
\text { kainen, marjukkain } \\
\text { oli miun emoni, kar- } \\
\text { jukkain oli kantajani, } \\
\text { laadoi laadoi laadoi } \\
\text { majoi }\end{array}$ & $\begin{array}{r}12345678 \\
12345678 \\
\end{array}$ & $\begin{array}{l}\text { laadoi laadoi } \\
\text { laadoi majoi }\end{array}$ & $i_{2222222}$ & 4 \\
\hline Launis 343 & 737 & Soikkola & Tarinainen & $\begin{array}{l}\text { Kasvoi miulle kasvoi } \\
\text { miulle kassoi pitkä; } \\
\text { laadoi laadoi laadoi } \\
\text { majoi }\end{array}$ & $\begin{array}{l}1234 \\
12345678\end{array}$ & $\begin{array}{l}\text { laadoi laadoi } \\
\text { laadoi majoi }\end{array}$ & $\begin{array}{l}\text { i } 4462 \\
22222222\end{array}$ & $4+1$ \\
\hline Launis 142 & 439 & Narvusi & Kirjamo & $\begin{array}{l}\text { Oi niitä omia maita, } \\
\text { omia maita mairehia, } \\
\text { laadoi laadoi, laadoi } \\
\text { majoi }\end{array}$ & $\begin{array}{l}12345678 \\
12345678\end{array}$ & $\begin{array}{l}\text { laadoi laa- } \\
\text { doi, laadoi } \\
\text { majoi }\end{array}$ & $\begin{array}{l}22222222 \\
22222222\end{array}$ & 5 \\
\hline Launis 424 & 474 & $\begin{array}{l}\text { Sere- } \\
\text { betta }\end{array}$ & $\begin{array}{l}\text { Kirkon- } \\
\text { kylä }\end{array}$ & $\begin{array}{l}\text { Olin orjan mie virois- } \\
\text { sa, ai ljol' ai ljole }\end{array}$ & 12345678 & ai lol ai lole & 22222222 & 4 \\
\hline
\end{tabular}

\section{Pedron Ja Iilian säVelmät}

Viite: A = SKSÄ A; L = SKSÄ L; KRA = SKS KRA; SibA = SibA Launis 1903

\begin{tabular}{|c|c|c|c|c|c|c|c|}
\hline Jite & IRS & PAIKKA & KYLÄ & LAULAJA & AlKusÄE & $\begin{array}{l}\text { MUOTO- } \\
\text { RAKENNE }\end{array}$ & RYtmi \\
\hline $301 / 34 a$ & 116 & Hevaa & Lenttinen & "eräs akka" & Pyhä ukko armolline & 12345678 & 22222222 \\
\hline $\begin{array}{l}\text { RA Levón } \\
70\end{array}$ & 117 & Hevaa & Lenttinen & & Ilia pyhä isäntä & 12345678 & 22222222 \\
\hline $\begin{array}{l}\text { KRA Alava } \\
\text { VI a } 826\end{array}$ & & Soikkola & Venakontsa & $\begin{array}{l}\text { Paraske, } \\
\text { Annike(e)n } \\
\text { tytär }\end{array}$ & & $\begin{array}{l}12345678 \\
5678\end{array}$ & $\begin{array}{l}31222222 \\
444\end{array}$ \\
\hline ibA 152 & 321 & Soikkola & Säätinä & tuntematon & Pyhä Iilia isäntä ja isäntä & $\begin{array}{l}12345678 \\
5678\end{array}$ & $\begin{array}{l}22222222 \\
2244\end{array}$ \\
\hline L $101 \mathrm{~b}$ & & Soikkola & Joenperä & Darja Lehti & Oi pyhä ilija isäntä isäntä & $\begin{array}{l}12345678 \\
5678\end{array}$ & $\begin{array}{l}22222222 \\
2244\end{array}$ \\
\hline A $300 / 47 b$ & 317 & Soikkola & Säätinä & $\begin{array}{l}\text { Ustenja } \\
\text { Miikkulant. }\end{array}$ & $\begin{array}{l}\text { Oi ilija pyhä izända } \\
\text { izända }\end{array}$ & $\begin{array}{l}12345678 \\
5678 \\
\end{array}$ & $\begin{array}{l}22222222 \\
2244 \text { (var) }\end{array}$ \\
\hline ibA 152 & 346 & Narvusi & Pärspää & & $\begin{array}{l}\text { Meil on viinat viiellaiset } \\
\text { viiellaiset }\end{array}$ & $\begin{array}{l}12345678 \\
5678\end{array}$ & $\begin{array}{l}22222222 \\
3144 / 444\end{array}$ \\
\hline
\end{tabular}




\section{JOULUNAJAN JUHLIEN KUVAUKSET}

Joulunajan juhlien kuvaukset

ET. $=$ etninen ryhmä

AJANK. $=$ ajankohta: $\mathrm{J}=$ joulu-loppiainen; $\mathrm{Ma}=$ Martin päivä; $\mathrm{Mi}=$ Miikkulan päivä; $\operatorname{Pr}=$ praasnikoilla; $\mathrm{T}=$ talvella

NiM. = nimitys: $\operatorname{Ig}=$ igrissat; $\mathrm{Ki}=$ kiletoi; $\mathrm{Kr}=$ Kiletoi-nimitys runossa

PYYT. $=$ antimien pyytäminen: $\mathrm{x}=$ esiintyy kontekstitiedoissa; $\mathrm{r}=$ esiintyy runossa

KIERT. $=$ talosta taloon tai kylästä kylään kiertäminen

TANs. $=$ tanssi: $\mathrm{x}$ : kontekstitiedoissa; $\mathrm{r}=$ runoissa

NAAM. $=$ naamioituminen tai pukautuminen

RuNO = runotyyppi: $\mathrm{M}=$ Martin virsi; $\mathrm{P}=$ peremies, pereisäntä -aloitus; $\mathrm{K}=$ kiletoivirsi;

Kii $=$ Kiitosvirsi ${ }^{*}=$ muu teema

\begin{tabular}{|c|c|c|c|c|c|c|c|c|c|}
\hline VirtTEet & ET. & Seutu & AJANK. & Nim. & Ручт. & KIERT. & TANs. & NAAM. & Runo \\
\hline Laiho L. 5254 & s & Narvusi & & Ig & $\mathrm{x}$ & $\mathrm{x}$ & $\mathrm{x}$ & $\mathrm{x}$ & - \\
\hline Haavio 2738 & $\mathrm{~s}$ & Narvusi & & Ig & & & & $\mathrm{x}$ & - \\
\hline Laiho L 4758 & $\mathrm{~s}$ & Narvusi & & Ig & ei & $\mathrm{x}$ & $\mathrm{x}$ & $\mathrm{x}$ & - \\
\hline Enäjärvi-Haavio 818 & $\mathrm{~s}(\mathrm{i})$ & Narvusi & & Ig & & $\mathrm{x}$ & $\mathrm{x}$ & $\mathrm{x}$ & - \\
\hline Enäjärvi-Haavio 819 & $\mathrm{~s}$ & & & $\mathrm{Ig}$ & $\mathrm{x}$ & & & & - \\
\hline Haavio 2731 & $\mathrm{i}$ & Narvusi & $\mathrm{J}$ & $\operatorname{Ig}$ & & $\mathrm{x}$ & & $\mathrm{x}$ & - \\
\hline Haavio 2741 & $\mathrm{i}$ & Narvusi & $\mathrm{J}$ & Ig & & $\mathrm{x}$ & $\mathrm{x}$ & $\mathrm{x}$ & - \\
\hline Haavio 2730 & (i) & Narvusi & $\mathrm{J}$ & Ig & & $\mathrm{x}$ & & $\mathrm{x}$ & - \\
\hline Laiho L. 5188 & $\mathrm{i}$ & Narvusi & $\mathrm{J}$ & $\operatorname{Ig}$ & $\mathrm{x}$ & $\mathrm{x}$ & & $\mathrm{x}$ & - \\
\hline Haavio 2737 & $\mathrm{~s}$ & Narvusi & $\mathrm{J}$ & $\mathrm{Ig}$ & & $\mathrm{x}$ & & $\mathrm{x}$ & - \\
\hline Enäjärvi-Haavio 817 & $\mathrm{~s}$ & Narvusi & $\mathrm{J}$ & $\mathrm{Ig}$ & & & & $\mathrm{x}$ & - \\
\hline Laiho A. 2599 & $\mathrm{i}$ & Narvusi & $\mathrm{J}$ & Ig & & $\mathrm{x}$ & $\mathrm{x}$ & $\mathrm{x}$ & - \\
\hline Enäjärvi-Haavio 822-824 & $\mathrm{s}$ & Narvusi & $\mathrm{J}$ & Ig & & & & $\mathrm{x}$ & - \\
\hline Haavio 2734 & (i) & Narvusi & $\mathrm{J}$ & $\mathrm{Ig}$ & & $\mathrm{x}$ & & $\mathrm{x}$ & - \\
\hline Haavio 2735 & $\mathrm{i}$ & Narvusi & $\mathrm{J}$ & $\operatorname{Ig}$ & & $\mathrm{x}$ & & $\mathrm{x}$ & - \\
\hline Laiho L. 5235 & $\mathrm{i}$ & Narvusi & & Ig & & $\mathrm{x}$ & $\mathrm{x}$ & $\mathrm{x}$ & - \\
\hline Haavio 2728 & vat & $\begin{array}{c}\text { Soikkola/ } \\
\text { Narvusi }\end{array}$ & $\mathrm{J}$ & $\operatorname{Ig}$ & & $\mathrm{x}$ & & $\mathrm{x}$ & * \\
\hline Laiho A. 2597 & $\mathrm{~s}$ & Narvusi & $\mathrm{J}$ & Ig & ei & & & & - \\
\hline Haavio 2729 & $\mathrm{~s}$ & Narvusi & $(\mathrm{Ma})$ & Ig & & $\mathrm{x}$ & & $\mathrm{x}$ & - \\
\hline Laiho A. 3176 & $\mathrm{~s}$ & Narvusi & $\mathrm{Ma}$ & Ig & $?$ & $?$ & & & $\mathrm{M}$ \\
\hline Laiho A. 2339 & $\mathrm{~s}$ & Narvusi & $\mathrm{Ma}$ & Ig & $\mathrm{x}$ & $?$ & $\mathrm{x}$ & $\mathrm{x}$ & $\mathrm{M}$ \\
\hline Haavio 2718 & $\mathrm{~s}$ & Narvusi & $\mathrm{Ma}$ & & & $\mathrm{x}$ & $\mathrm{x}$ & ei & $\mathrm{M}$ \\
\hline Laiho A. 2138 & $\mathrm{i}$ & Narvusi & $\mathrm{Ma}$ & & $\mathrm{x}$ & $\mathrm{x}$ & $\mathrm{x}$ & $\mathrm{x}$ & $\mathrm{M}$ \\
\hline Laiho L. 5236 & (s) & Narvusi & $\mathrm{Ma}$ & & $\mathrm{x}$ & $\mathrm{x}$ & & & $\mathrm{M}$ \\
\hline Laiho L. 4750 & $\mathrm{i}$ & Narvusi & $\mathrm{Ma}$ & & $\mathrm{x}$ & $\mathrm{x}$ & $\mathrm{x}$ & $\mathrm{x}$ & $\mathrm{M}$ \\
\hline Haavio 2719 & $\mathrm{i}$ & Narvusi & $\mathrm{Ma}$ & & $\mathrm{x}$ & $\mathrm{x}$ & & $\mathrm{x}$ & $\mathrm{M}$ \\
\hline Laiho L. 5362 & $\mathrm{i}$ & Narvusi & $\mathrm{Ma}$ & & $\mathrm{x}$ & $\mathrm{x}$ & $\mathrm{x}$ & $\mathrm{x}$ & $\mathrm{M}$ \\
\hline Laiho L. 5990 & $\mathrm{i}(\mathrm{s})$ & Narvusi & $\mathrm{Ma}$ & & $\mathrm{x}$ & $\mathrm{x}$ & $\mathrm{x}$ & $\mathrm{x}$ & $\mathrm{M}$ \\
\hline SKVR III 1049 & $(\mathrm{~s})$ & Narvusi & $\mathrm{Ma}$ & & $\mathrm{x}$ & $\mathrm{x}$ & & & $\mathrm{M}$ \\
\hline Haavio 2593 & $\mathrm{i}$ & Narvusi & $\mathrm{Ma}$ & & & & & & $\mathrm{M}$ \\
\hline Laiho L. 5180 & i & Narvusi & $\mathrm{Ma}$ & & & & & & M \\
\hline
\end{tabular}




\begin{tabular}{|c|c|c|c|c|c|c|c|c|c|}
\hline $\begin{array}{l}\text { ViItTEET } \\
\text { Haavio } 2721\end{array}$ & $\begin{array}{l}\text { ET. } \\
\text { i }\end{array}$ & $\begin{array}{l}\text { SEUTU } \\
\text { Narvusi }\end{array}$ & $\begin{array}{l}\text { AJAnk. } \\
\text { Ma }\end{array}$ & Nim. & $\begin{array}{l}\text { PYYT. } \\
\qquad x\end{array}$ & $\begin{array}{l}\text { KIERT. } \\
\qquad x\end{array}$ & Tans. & $\begin{array}{l}\text { NAAM. } \\
\text { (x) }\end{array}$ & $\begin{array}{c}\text { Runo } \\
\text { M }\end{array}$ \\
\hline Laiho A. 2342 & $\mathrm{~s}$ & Narvusi & $\mathrm{Ma}$ & & $\mathrm{x}$ & & $\mathrm{x}$ & $\mathrm{x}$ & M \\
\hline Haavio 2716 & $(\mathrm{~s})$ & Narvusi & $\mathrm{Ma}$ & & $\mathrm{x}$ & & & & $\mathrm{M}$ \\
\hline Laiho A. 2341 & $\mathrm{~s}$ & Narvusi & $\mathrm{Ma}$ & & $\mathrm{x}$ & $\mathrm{x}$ & $\mathrm{x}$ & $\mathrm{x}$ & $\mathrm{M}$ \\
\hline Laiho A. 2345 & $\mathrm{i}$ & Narvusi & $\mathrm{Ma}$ & & $\mathrm{x}$ & $\mathrm{x}$ & $\mathrm{x}$ & $\mathrm{x}$ & $\mathrm{M}$ \\
\hline Haavio 2717 & $\mathrm{~s}$ & Narvusi & $\mathrm{Ma}$ & & $\mathrm{x}$ & & $\mathrm{x}$ & & M \\
\hline Laiho A. 2340 & $\mathrm{~s}$ & Narvusi & $\mathrm{Ma}$ & & $\mathrm{x}$ & $\mathrm{x}$ & & $\mathrm{x}$ & $\mathrm{M}$ \\
\hline SKVR III 231 & (s) & $\begin{array}{c}\text { Lavan- } \\
\text { saari }\end{array}$ & $\mathrm{Ma}$ & & $\mathrm{x}$ & $\mathrm{x}$ & $\mathrm{x}$ & & M \\
\hline SKVR III 1805 & (s) & Narvusi & $\mathrm{Ma}$ & & $\mathrm{x}$ & $\mathrm{x}$ & & & $\mathrm{M}$ \\
\hline Laiho A. 2206 & $\mathrm{i}$ & Narvusi & $\mathrm{Ma}$ & & $\mathrm{x}$ & & & & $\mathrm{M}$ \\
\hline SKVR III 241 & $\mathrm{~s} / \mathrm{i}$ & Narvusi & $\mathrm{Ma}$ & & & & & & $\mathrm{M}$ \\
\hline Laiho A. 2586 & $\mathrm{i}$ & Narvusi & $\mathrm{Ma}$ & & & & & & - \\
\hline Laiho A. 2571 & $\mathrm{~s}$ & Narvusi & $\mathrm{Ma}$ & & & & & & - \\
\hline SKVR III 2358 & $\mathrm{~s}$ & Narvusi & $\mathrm{J}$ & $\mathrm{Ki}$ & $\mathrm{x}$ & $\mathrm{x}$ & & & $\mathrm{K}$ \\
\hline SKVR III 1047 & $\mathrm{~s}$ & Narvusi & $\mathrm{J}$ & $\mathrm{Ki}$ & $\mathrm{r}$ & $\mathrm{x}$ & & & $\mathrm{K}$ \\
\hline SKVR III 1897-1904 & $\mathrm{s}$ & Narvusi & $\mathrm{J}$ & $\mathrm{Ki}$ & $\mathrm{r}$ & $\mathrm{x}$ & $\mathrm{x}$ & & $\mathrm{K}$ \\
\hline SKVR III 228 & (i) & Narvusi & $\mathrm{J}$ & $\mathrm{Ki}$ & $\mathrm{x}$ & & & & $\mathrm{K}$ \\
\hline SKVR III 3657 & & Narvusi & $\mathrm{J}$ & $\mathrm{Ki}$ & $\mathrm{x}$ & $\mathrm{x}$ & $\mathrm{r}$ & & $\mathrm{K}$ \\
\hline SKVR III 3914-3915 & & Narvusi & $\mathrm{J}$ & $\mathrm{Ki}$ & $\mathrm{x}$ & $\mathrm{x}$ & & & $\mathrm{K}$ \\
\hline SKVR III 73 & & Narvusi & $\mathrm{J}$ & & & & & & $\mathrm{K}$ \\
\hline Laiho L. 5989 & $\mathrm{i}$ & Soikkola & $\mathrm{Mi}$ & & & & $\mathrm{x}$ & & $\mathrm{K}$ \\
\hline Sääski 5343 & $\mathrm{i}$ & Soikkola & $\mathrm{Mi}$ & & $\mathrm{x}$ & $\mathrm{x}$ & & & \\
\hline SKVR III 2282-2284 & $i$ (+vat) & Soikkola & $\mathrm{Mi}$ & $\mathrm{Ki}$ & $\mathrm{r}$ & $\mathrm{x}$ & $\mathrm{x}$ & & $\mathrm{K}$ \\
\hline SKVR III 2041-2043 & $\mathrm{i} / \mathrm{vat}$ & Soikkola & $\mathrm{Mi}$ & $\mathrm{Ki}$ & $\mathrm{r}$ & & $\mathrm{x}$ & & * \\
\hline SKVR III 1566 & (i) & Soikkola & $\mathrm{Mi}$ & $\mathrm{Kr}$ & $\mathrm{r}$ & $\mathrm{x}$ & $\mathrm{r}$ & & $\mathrm{K}$ \\
\hline SKVR III 3496 & $\mathrm{~s}$ & Soikkola & $\mathrm{Mi}$ & $\mathrm{Kr}$ & $\mathrm{r}$ & & & & $\mathrm{K}$ \\
\hline SKVR III 3493-3495, 3497 & (i) & Soikkola & $\mathrm{Mi}$ & & $\mathrm{r}$ & & $\mathrm{x}$ & & $\mathrm{K}$ \\
\hline SKVR III 1568 & (i) & Soikkola & $\operatorname{Pr}$ & & $\mathrm{r}$ & & $\mathrm{r}$ & & $\mathrm{K}$ \\
\hline SKVR III 1565 & $\mathrm{~s}$ & Soikkola & $\operatorname{Pr}$ & & $\mathrm{r}$ & $\mathrm{x}$ & & & $\mathrm{K}$ \\
\hline Laiho L. 5363 & $\mathrm{i}$ & Soikkola & $\operatorname{Pr}$ & $\mathrm{Ki}$ & & $\mathrm{x}$ & & & $\mathrm{K}$ \\
\hline SKVR III 227 & & Soikkola & $\operatorname{Pr}$ & $\mathrm{Ki}$ & $\mathrm{x}$ & & & & $\mathrm{K}$ \\
\hline SKVR III 1048 & & Narvusi & $\operatorname{Pr}$ & & & & & & $\mathrm{K}$ \\
\hline SKVR III 1567 & & Soikkola & $\operatorname{Pr}$ & & & & & & $\mathrm{K}$ \\
\hline SKVR III 4234 & & Soikkola & $\mathrm{Pr}$ & & & & & & $\mathrm{K}$ \\
\hline Laiho L. 5343 & $\mathrm{i}$ & Narvusi & $\mathrm{T}$ & & & & $\mathrm{x}$ & & $\mathrm{T}$ \\
\hline Haavio 2733 & $\mathrm{i}$ & Soikkola & & $\mathrm{Ki}$ & $\mathrm{x}$ & $\mathrm{x}$ & $\mathrm{x}$ & & $\mathrm{K}$ \\
\hline SKVR III 2310-2312 & $\mathrm{i}$ & Soikkola & & & $\mathrm{r}$ & & $\mathrm{x}$ & & $\mathrm{K}$ \\
\hline
\end{tabular}




\section{MARTIN PÄIVÄN SÄVELMÄT}

Viite: KRS = Launis 1930; L = SKSÄ L

\begin{tabular}{|c|c|c|c|c|}
\hline ViIte & PAIKKA & AlKusÄE & MuOTORAKENNE & RytмI \\
\hline L $101 \mathrm{a}$ & Narvusi & $\begin{array}{l}\text { Ooi hups hups hups hups } \\
\text { martikkine martikkine }\end{array}$ & 123456785678 & 222222222244 \\
\hline KRS 127 & Lavansaari & Hups hups Martikkene & 12345678 & 22222222 \\
\hline
\end{tabular}

\section{KiletoivirRet}

VIITTEET:

\section{SKS KRA Sääski 5343}

2. SKVR III 3493-95, 3497

3. SKVR III 1566, 1567 (praasnikka-runo)

4. SKVR III 3496

5. SKS KRA Ankeria 209 (gilidoittamine

6. SKVR III 2041-43 (geletovirret)

7. SKVR III 2282-84 (kiletoivirsi)

8. SKVR III 1047 (kiletoivirsi)

9. SKVR 1898-1904 (kiletoi-virsi)

10. SKVR III 2358 (käytii kiletoimass)

11. SKVR III 3657 (jouluvirsi, kiletoiminen)
12. SKVR III 3914 (kiletoi-matka)

13. SKVR 73 (jouluvirsi)

14. SKS KRA K. Salminen 216 (kiletoivirsi)

15. SKVR $227+4234$ (kiletoivirsi)

16. SKVR III 1565 (praasnikka-virsi)

17. SKVR III 1048 (praasnikkaruno)

18. SKVR III 1568 (praasnikkaruno)

19. SKVR III 3915

20. SKVR III 3534

21. SKVR III 2310-12

22. SKVR III 3378

$\mathrm{x}$ : runoteema taulukon järjestyksessä; y: runoteema jossain muussa kohden runoa

\begin{tabular}{|c|c|c|c|c|c|c|c|c|c|c|c|c|c|c|c|c|c|c|c|c|c|}
\hline $\begin{array}{l}\text { VIITE } \\
\text { aika (M = Miikkulan päivä; } \\
\text { j= joulunpyhät; jv = jouluvirsi) }\end{array}$ & $\mathrm{M}$ & $\mathrm{M}$ & $\mathrm{M}$ & $\mathrm{M}$ & $\mathrm{M}$ & $\mathrm{M}$ & $\mathrm{M}$ & $\mathrm{j}$ & j & 10 & $\begin{array}{l}11 \\
j\end{array}$ & $\mathrm{j}$ & $\begin{array}{l}13 \\
j v\end{array}$ & 141 & 151 & 161 & 171 & 1819 & 920 & 21 & 22 \\
\hline $\begin{array}{l}\text { Kiletoi kaletoi } \\
\text { Avatkaa uksia } \\
\text { Hyvää iltaa terve teille }\end{array}$ & $\mathrm{x}$ & $\mathrm{X}$ & $\mathrm{x}$ & $\begin{array}{l}\mathrm{x} \\
\mathrm{x}\end{array}$ & $\mathrm{x}$ & & $\mathrm{x}$ & & & & & & $\mathrm{x}$ & $\mathrm{x}$ & & $\begin{array}{l}\mathrm{X} \\
\mathrm{x}\end{array}$ & & $\mathrm{x}$ & $\mathrm{x}$ & $\mathrm{X}$ & $\mathrm{x}$ \\
\hline $\begin{array}{l}\text { Onko riihi tai pirtti pyyhitty } \\
\text { Isäntäväki (peremies, -emäntä) } \\
\text { Laske suojaan väkeni }\end{array}$ & $\mathrm{X}$ & & & & & $\mathrm{x}$ & (x) & $\begin{array}{l}\mathrm{x} \\
\mathrm{x}\end{array}$ & $\begin{array}{l}\mathrm{x} \\
\mathrm{x}\end{array}$ & & $\begin{array}{l}\mathrm{y} \\
\mathrm{x} \\
\mathrm{x}\end{array}$ & & $y$ & $\mathrm{X}$ & $y$ & $\mathrm{x}$ & $\begin{array}{l}\mathrm{y} \\
\mathrm{y} \\
\mathrm{y}\end{array}$ & $\mathrm{X}$ & $\mathrm{y}$ & & \\
\hline $\begin{array}{l}\text { Väki on kylmettynyt } \\
\text { Isäntäväki (peremies, -emäntä) } \\
\text { Tulee luoja joukoineen }\end{array}$ & $\mathrm{X}$ & $\mathrm{X}$ & $y$ & & $y$ & $y$ & $\mathrm{y}$ & $\mathrm{x}$ & $\mathrm{x}$ & & $\mathrm{x}$ & & $x^{2}$ & $\begin{array}{c}x+1 \\
x+\end{array}$ & & $\mathrm{x}$ & $y$ & $\mathrm{x}$ & $\mathrm{x}$ & $\mathrm{x}$ & $\mathrm{X}$ \\
\hline $\begin{array}{l}\text { Saadaanko tupaa tanssiin } \\
\text { Jos ei saada, tanssin ulkona } \\
\text { Saatiin tupa }\end{array}$ & & & $\mathrm{x}$ & & & & $\mathrm{x}$ & & & & $y$ & & $\begin{array}{l}\mathrm{x} \\
\mathrm{x}\end{array}$ & & $\begin{array}{l}\mathrm{x} \\
\mathrm{x}\end{array}$ & $\begin{array}{l}\mathrm{X} \\
\mathrm{X}\end{array}$ & $\mathrm{x}$ & $\mathrm{x}$ & $\mathrm{x}$ & & \\
\hline $\begin{array}{l}\text { Isäntäväki (peremies, -emäntä) } \\
\text { Nouse ylös vuoteesta } \\
\text { Katsele kiletoijia }\end{array}$ & $\mathrm{X}$ & $\begin{array}{l}\mathrm{x} \\
\mathrm{x}\end{array}$ & $\begin{array}{l}\mathrm{x} \\
\mathrm{x}\end{array}$ & $\begin{array}{l}\mathrm{x} \\
\mathrm{x}\end{array}$ & $\begin{array}{l}\mathrm{x} \\
\mathrm{x}\end{array}$ & & $\begin{array}{l}\mathrm{x} \\
\mathrm{x}\end{array}$ & $\begin{array}{l}\mathrm{x} \\
\mathrm{x} \\
\mathrm{x}\end{array}$ & $\begin{array}{l}\mathrm{x} \\
\mathrm{x} \\
\mathrm{x}\end{array}$ & $\begin{array}{l}\mathrm{x} \\
\mathrm{x}\end{array}$ & $\begin{array}{l}\mathrm{x} \\
\mathrm{x} \\
\mathrm{x}\end{array}$ & $\mathrm{x}$ & $\begin{array}{l}\mathrm{x} \\
\mathrm{x}\end{array}$ & $\mathrm{x}$ & $\begin{array}{l}\mathrm{x} \\
\mathrm{x}\end{array}$ & $\begin{array}{l}\mathrm{x} \\
\mathrm{x}\end{array}$ & $\begin{array}{l}\mathrm{y} \\
\mathrm{x} \\
\mathrm{x}\end{array}$ & $\mathrm{X}$ & $\begin{array}{l}\mathrm{x} \\
\mathrm{x} \\
\mathrm{y}\end{array}$ & $\begin{array}{l}\mathrm{x} \\
\mathrm{x}\end{array}$ & $\begin{array}{l}\mathrm{x} \\
\mathrm{x}\end{array}$ \\
\hline $\begin{array}{l}\text { Mene kellariin / kammariin } \\
\text { Tuo olutta (tai olut-teemoja) } \\
\text { Anna rahaa }\end{array}$ & $\begin{array}{l}\mathrm{x} \\
\mathrm{x}\end{array}$ & $\begin{array}{l}\mathrm{x} \\
\mathrm{x}\end{array}$ & $\begin{array}{l}\mathrm{x} \\
\mathrm{x}\end{array}$ & $\begin{array}{l}\mathrm{x} \\
\mathrm{x}\end{array}$ & $\mathrm{x}$ & $\mathrm{x}$ & $\begin{array}{l}\mathrm{x} \\
\mathrm{x}\end{array}$ & $\begin{array}{l}\mathrm{X} \\
\mathrm{x}\end{array}$ & $\begin{array}{l}x \\
y\end{array}$ & & $\begin{array}{l}\mathrm{x} \\
\mathrm{x}\end{array}$ & $\mathrm{x}$ & $\begin{array}{l}\mathrm{x} \\
\mathrm{x}\end{array}$ & $\begin{array}{l}\mathrm{x} \\
\mathrm{x}\end{array}$ & $\begin{array}{l}\mathrm{x} \\
\mathrm{x}\end{array}$ & $\begin{array}{l}\mathrm{X} \\
\mathrm{X}\end{array}$ & $\begin{array}{l}\mathrm{X} \\
\mathrm{X}\end{array}$ & $\mathrm{X}$ & $\mathrm{x}$ & $\begin{array}{l}\mathrm{x} \\
\mathrm{x}\end{array}$ & $\begin{array}{l}\mathrm{x} \\
\mathrm{x}\end{array}$ \\
\hline $\begin{array}{l}\text { Kiitos tai toivotuksia } \\
\text { Moittiminen jos ei mitään saada }\end{array}$ & & $\begin{array}{l}\mathrm{x} \\
\mathrm{x}\end{array}$ & & & $\begin{array}{l}\mathrm{x} \\
\mathrm{x}\end{array}$ & $\mathrm{x}$ & $\mathrm{x}$ & $\begin{array}{l}\mathrm{x} \\
\mathrm{x}\end{array}$ & $\mathrm{x}$ & & $\mathrm{x}$ & $\mathrm{x}$ & & $\mathrm{x}$ & $\mathrm{X}$ & $\mathrm{x}$ & & $\mathrm{x}$ & & $\begin{array}{l}\mathrm{x} \\
\mathrm{x}\end{array}$ & \\
\hline
\end{tabular}




\section{Kiletoi-SÄVELMÄT}

Kiletoisävelmä (Alava) sekä ne tuvanpyyntösävelmät, jotka eivät liity häihin.

Viite: L = SKSÄ L; KRA = SKS KRA; SibA = SibA Launis 1903

LÄNSI-INKERI:

\begin{tabular}{|c|c|c|c|c|c|c|}
\hline ViIte & IRS PAIKKA & KYLÄ & LAULAJA & AlKusäE & $\begin{array}{l}\text { MUOTO- } \\
\text { RAKENNE }\end{array}$ & RутмI \\
\hline $\begin{array}{l}\text { KRA Alava } \\
\text { VI:705 }\end{array}$ & Narvusi & Kaipaala & Anni Porissa & & 12345678 & 22222222 \\
\hline SibA 145 & Narvusi & Struuppaa & & Peremies pereen isäntä & 12345678 & 22222222 \\
\hline SibA 131 & 756 Narvusi & Kirjamo & & Peremies pereen isäntä & 12345678 & 22222222 \\
\hline SibA 281b & 379 Soikkola & Soikkola & & Avatkaa uksianne & 12345678 & 22222222 \\
\hline $\begin{array}{l}\text { KRA Alava } \\
\text { VIIa: } 496 \\
\end{array}$ & Soikkola & Oussimäki & iTeppanja & Hyvää iltaha taloihe & 12345678 & 22222222 \\
\hline L $101 \mathrm{~d}$ & Narvusi & Narvusi & Anna Kivisoo & $\begin{array}{l}\text { Peremies pereisäntä; } \\
\text { oi galina l'ee ja isäntä }\end{array}$ & 12345678 & 22442244 \\
\hline
\end{tabular}

\section{KESKI-INKERI:}

\begin{tabular}{lllllll} 
ViIte & \multicolumn{2}{l}{ IRS Paikka Kylä } & Alkusäe & Muotorakenne & Rytmi & S \\
Levón 512 & 185 Hevaa & Vanha Huurala & Hyvä iltanen taloihin & 12345678 & 22222244 & 4 \\
\hline Borenius 21938 & Kattila & Pummala & Peremmees pere izäätä & 12345678 & 2222222 & 5 \\
\hline Borenius 208 118 Kattila & Matinkylä & Perenainen naizueni & 12345678 & 22222222 & 4
\end{tabular}

\section{HÄISSÄ LAULAMISEN KUVAUKSET}

Viite: SKS KRA (Kerääjä, numero) tai SKVR (numero)

$S$ : viite sävelmään tai muotorakenteeseen

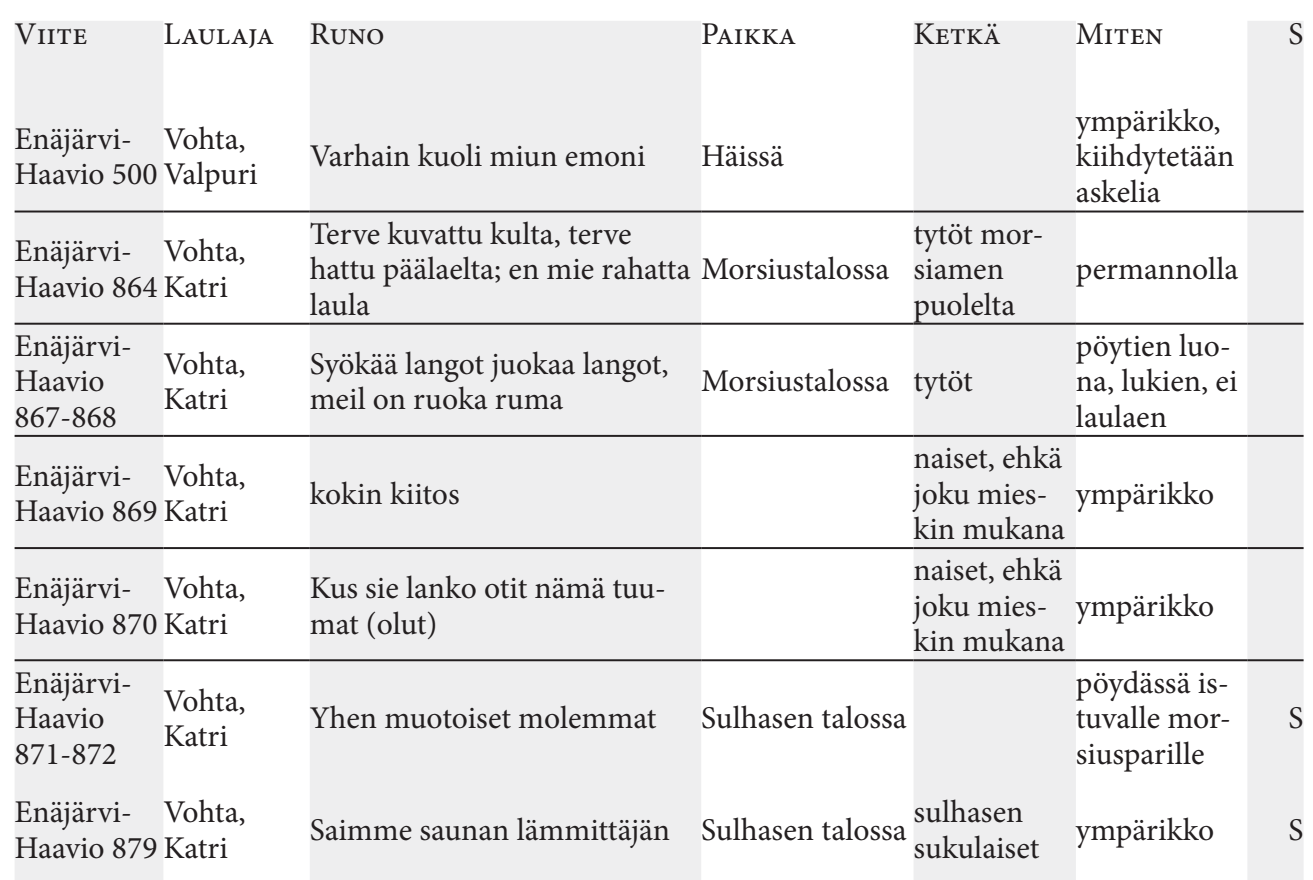




\begin{tabular}{|c|c|c|c|c|c|}
\hline VIITE & LAULAJA & Runo & PAIKKA & КеткÄ & Miten \\
\hline $\begin{array}{l}\text { Enäjärvi- } \\
\text { Haavio } \\
881-882 \\
\end{array}$ & $\begin{array}{l}\text { Vohta, } \\
\text { Katri }\end{array}$ & Kenen tämä kylä kulune & $\begin{array}{l}\text { Sulhastaloon } \\
\text { ajaessa }\end{array}$ & $\begin{array}{l}\text { morsiamen } \\
\text { sukulaiset }\end{array}$ & $\begin{array}{l}\text { reessä tai } \\
\text { rattaissa }\end{array}$ \\
\hline $\begin{array}{l}\text { Enäjärvi- } \\
\text { Haavio } 883 \\
\end{array}$ & $\begin{array}{l}\text { Vohta, } \\
\text { Katri }\end{array}$ & $\begin{array}{l}\text { Terve tultua tuppaa, vastumai- } \\
\text { see majjaa }\end{array}$ & $\begin{array}{l}\text { Sulhastaloon } \\
\text { saavuttua }\end{array}$ & $\begin{array}{l}\text { morsiamen } \\
\text { sukulaiset }\end{array}$ & \\
\hline $\begin{array}{l}\text { Enäjärvi- } \\
\text { Haavio } 884 \\
\end{array}$ & $\begin{array}{l}\text { Vohta, } \\
\text { Katri }\end{array}$ & La ku katson langon siltoi & $\begin{array}{l}\text { Sulhastaloon } \\
\text { saavuttua }\end{array}$ & $\begin{array}{l}\text { morsiamen } \\
\text { sukulaiset }\end{array}$ & ympärikko \\
\hline $\begin{array}{l}\text { Enäjärvi- } \\
\text { Haavio } 885 \\
\end{array}$ & $\begin{array}{l}\text { Vohta, } \\
\text { Katri }\end{array}$ & $\begin{array}{l}\text { Kyll on lakkeet, kyll on kä- } \\
\text { ppeet }\end{array}$ & $\begin{array}{l}\text { Sulhastaloon } \\
\text { saavuttua }\end{array}$ & $\begin{array}{l}\text { morsiamen } \\
\text { sukulaiset }\end{array}$ & ympärikko \\
\hline $\begin{array}{l}\text { Enäjärvi- } \\
\text { Haavio } 895\end{array}$ & $\begin{array}{l}\text { Vohta, } \\
\text { Katri }\end{array}$ & $\begin{array}{l}\text { Ei oom maannut meie minoi, } \\
\text { ei oo hävent hämärikkoo }\end{array}$ & Sulhasen talossa & $\begin{array}{l}\text { naiset jotka } \\
\text { olivat saa- } \\
\text { neet lahjoja }\end{array}$ & ympärikko \\
\hline $\begin{array}{l}\text { Enäjärvi- } \\
\text { Haavio } 896\end{array}$ & & Kokin kiitos & Sulhasen talossa & nuoret & $\begin{array}{l}\text { tanssi; mie- } \\
\text { het venäläisiä } \\
\text { tansseja, } \\
\text { ruskova }\end{array}$ \\
\hline $\begin{array}{l}\text { Enäjärvi- } \\
\text { Haavio } 905 \\
\end{array}$ & $\begin{array}{l}\text { Vohta, } \\
\text { Katri }\end{array}$ & Kylähäni linnahani & Morsiustalossa & $\begin{array}{l}\text { sulhasen } \\
\text { sukulaiset }\end{array}$ & \\
\hline $\begin{array}{l}\text { Enäjärvi- } \\
\text { Haavio } 907\end{array}$ & $\begin{array}{l}\text { Vohta, } \\
\text { Valpuri }\end{array}$ & $\begin{array}{l}\text { (Mari) sirkkune sisoni (mitä } \\
\text { istut silmät veessä) }\end{array}$ & Morsiustalossa & & $\begin{array}{l}\text { pöydän taka- } \\
\text { na istuvalle } \\
\text { morsiamelle }\end{array}$ \\
\hline $\begin{array}{l}\text { Enäjärvi- } \\
\text { Haavio } 908\end{array}$ & $\begin{array}{l}\text { Vohta, } \\
\text { Valpuri }\end{array}$ & $\begin{array}{l}\text { Katso kaikki ristirahvas, yhen } \\
\text { muotoset molemmat }\end{array}$ & Sulhasen talossa & $\begin{array}{l}\text { tytöt (kylän } \\
\text { tytöt) }\end{array}$ & $\begin{array}{l}\text { permannolta } \\
\text { seisten }\end{array}$ \\
\hline $\begin{array}{l}\text { Enäjärvi- } \\
\text { Haavio } 910 \\
\end{array}$ & $\begin{array}{l}\text { Kivisoo, } \\
\text { Anna }\end{array}$ & $\begin{array}{l}\text { Annini sisarueni; myö määm- } \\
\text { me sinun jätämme (neuvokki) }\end{array}$ & $\begin{array}{l}\text { Sulhastalosta } \\
\text { lähdettäessä }\end{array}$ & $\begin{array}{l}\text { morsiamen } \\
\text { suku }\end{array}$ & \\
\hline $\begin{array}{l}\text { Haavio } \\
2429 \\
\end{array}$ & $\begin{array}{l}\text { Pässi, } \\
\text { Matrona }\end{array}$ & $\begin{array}{l}\text { Katso kuk linnukkaine; nyt } \\
\text { erroot omast izäst }\end{array}$ & $\begin{array}{l}\text { Sulhastalosta } \\
\text { lähdettäessä }\end{array}$ & $\begin{array}{l}\text { morsiamen } \\
\text { suku }\end{array}$ & seisten \\
\hline $\begin{array}{l}\text { Haavio } \\
2568\end{array}$ & $\begin{array}{l}\text { Haukka, } \\
\text { Valpuri }\end{array}$ & $\begin{array}{l}\text { Poika tuoreesta tuloo; aja aja } \\
\text { veljuveni }\end{array}$ & $\begin{array}{l}\text { Sulhastaloon } \\
\text { tullessa kylän } \\
\text { kujalla }\end{array}$ & tytöt & $\begin{array}{l}\text { seisten? } \\
\text { (Pulmavirs) }\end{array}$ \\
\hline $\begin{array}{l}\text { Laiho A. } \\
2088\end{array}$ & $\begin{array}{l}\text { Haukka, } \\
\text { Valpuri }\end{array}$ & $\begin{array}{l}\text { Olin orja velloilleni, apikukka } \\
\text { ainolleni }\end{array}$ & & & $\operatorname{tanssi}$ \\
\hline $\begin{array}{l}\text { Laiho A. } \\
2217\end{array}$ & $\begin{array}{l}\text { Varpu } \\
\text { Pajusen } \\
\text { miniä } \\
\end{array}$ & $\begin{array}{l}\text { La ko katson langon sillat; } \\
\text { onko vuolimel vuoltu }\end{array}$ & Sulhasen talossa & $\begin{array}{l}\text { morsiamen } \\
\text { sukulaiset }\end{array}$ & $\begin{array}{l}\text { seisten, sitten } \\
\text { ympärikko }\end{array}$ \\
\hline $\begin{array}{l}\text { Laiho A. } \\
2276\end{array}$ & $\begin{array}{l}\text { Otsa, } \\
\text { Maria }\end{array}$ & $\begin{array}{l}\text { Olin orjana virossa } \\
\text { (oinonluinen kannel, PRS) }\end{array}$ & & äiti & ympärikko \\
\hline $\begin{array}{l}\text { Laiho A. } \\
2291\end{array}$ & $\begin{array}{l}\text { Vohta, } \\
\text { Valpuri } \\
\end{array}$ & Helise heliä metsä & & & $\begin{array}{l}\text { pöydässä, } \\
\text { hallee laulu }\end{array}$ \\
\hline $\begin{array}{l}\text { Laiho A. } \\
2295\end{array}$ & $\begin{array}{l}\text { Pekkonen, } \\
\text { Maria }\end{array}$ & Läksin koist kulkemaa & & & tanssi \\
\hline $\begin{array}{l}\text { Laiho A. } \\
3345\end{array}$ & $\begin{array}{l}\text { Vohta, } \\
\text { Valpuri } \\
\end{array}$ & Kylpiikko kypelyeni & $\begin{array}{l}\text { Morsiustalossa } \\
\text { aattoiltana }\end{array}$ & tytöt & \\
\hline $\begin{array}{l}\text { Laiho L. } \\
4848\end{array}$ & $\begin{array}{l}\text { Otsa, } \\
\text { Maria }\end{array}$ & Mitä suonen peren isälle & $\begin{array}{l}\text { Sulhastalosta } \\
\text { lähdettäessä }\end{array}$ & pulmaväki & ympärikko \\
\hline $\begin{array}{l}\text { Laiho L. } \\
4980\end{array}$ & $\begin{array}{l}\text { Vohta, } \\
\text { Valpuri } \\
\end{array}$ & Terve tupa neljänurkka & $\begin{array}{l}\text { Sulhastaloon } \\
\text { saapuessa }\end{array}$ & $\begin{array}{l}\text { morsiamen } \\
\text { sukulaiset }\end{array}$ & seisten \\
\hline $\begin{array}{l}\text { Laiho L. } \\
4981\end{array}$ & $\begin{array}{l}\text { Vohta, } \\
\text { Valpuri }\end{array}$ & La ko katson langon siltoi & $\begin{array}{l}\text { Sulhastaloon } \\
\text { saavuttua }\end{array}$ & & $\begin{array}{l}\text { ympärikko, } \\
\text { hypättii }\end{array}$ \\
\hline $\begin{array}{l}\text { Laiho L. } \\
4982\end{array}$ & $\begin{array}{l}\text { Vohta, } \\
\text { Valpuri }\end{array}$ & $\begin{array}{l}\text { Lankoiseni lintuiseni, elkää } \\
\text { kantako kakkuloi }\end{array}$ & Sulhasen talossa & & pöydässä \\
\hline $\begin{array}{l}\text { Laiho L. } \\
4993\end{array}$ & $\begin{array}{l}\text { Vohta, } \\
\text { Valpuri } \\
\end{array}$ & Tunnen tunnen ken tulloo & & & ympärikko \\
\hline $\begin{array}{l}\text { Laiho L. } \\
4994\end{array}$ & $\begin{array}{l}\text { Vohta, } \\
\text { Valpuri }\end{array}$ & $\begin{array}{l}\text { Oi vävy vävyjueni } \\
\text { (neuvokkivirsi) }\end{array}$ & & & (Opetusvirs) \\
\hline $\begin{array}{l}\text { Laiho L. } \\
5111\end{array}$ & $\begin{array}{l}\text { Vohta, } \\
\text { Katri }\end{array}$ & Avatkaa viron veräjä & $\begin{array}{l}\text { Morsiustaloon } \\
\text { tullessa }\end{array}$ & pulmaväki & seisten? \\
\hline $\begin{array}{l}\text { Laiho L. } \\
5309\end{array}$ & $\begin{array}{l}\text { Kivisoo, } \\
\text { Anna }\end{array}$ & $\begin{array}{l}\text { Oi Mari sisarueni; issut kan- } \\
\text { nessa ihala }\end{array}$ & $\begin{array}{l}\text { Morsiustalossa } \\
\text { aattoiltana }\end{array}$ & tytöt & pöydässä \\
\hline
\end{tabular}




\begin{tabular}{|c|c|c|c|c|c|}
\hline VIITE & LAULAJA & Runo & PAIKKA & КеткÄ & Miten \\
\hline $\begin{array}{l}\text { Laiho L. } \\
5314\end{array}$ & $\begin{array}{l}\text { Kivisoo, } \\
\text { Anna }\end{array}$ & $\begin{array}{l}\text { Lankoiseni lintuiseni, elkää } \\
\text { kantako kakkuloi }\end{array}$ & Sulhasen talossa & $\begin{array}{l}\text { morsiamen } \\
\text { sukulaiset }\end{array}$ & pöydässä \\
\hline $\begin{array}{l}\text { Laiho L. } \\
5396\end{array}$ & $\begin{array}{l}\text { Markus, } \\
\text { Anna }\end{array}$ & Kokin kiitos & & & $\begin{array}{l}\text { ympärikko, } \\
\text { nopeasti }\end{array}$ \\
\hline $\begin{array}{l}\text { Laiho L. } \\
5899\end{array}$ & $\begin{array}{l}\text { Ahonen, } \\
\text { Katri }\end{array}$ & La ko katson langon sillat & $\begin{array}{l}\text { Sulhastaloon } \\
\text { saapuessa }\end{array}$ & & tanssi \\
\hline $\begin{array}{l}\text { Laiho L. } \\
5900\end{array}$ & $\begin{array}{l}\text { Ahonen, } \\
\text { Katri }\end{array}$ & Tere tupa neljänurkaa & $\begin{array}{l}\text { Sulhastaloon } \\
\text { saapuessa }\end{array}$ & $\begin{array}{l}\text { morsiamen } \\
\text { sukulaiset }\end{array}$ & seisten \\
\hline $\begin{array}{l}\text { Laiho L. } \\
5910\end{array}$ & $\begin{array}{l}\text { Tuisk, } \\
\text { Maria } \\
\end{array}$ & $\begin{array}{l}\text { Mit issut sie surune, petäjäisen } \\
\text { penkin päällä }\end{array}$ & $\begin{array}{l}\text { Morsiustalossa } \\
\text { aattoiltana }\end{array}$ & tytöt & pöydässä \\
\hline $\begin{array}{l}\text { Länkelä } \\
\text { 3:624 }\end{array}$ & & $\begin{array}{l}\text { Neitsyeni naisukoni } \\
\text { (Neuvokkivirsi) }\end{array}$ & Sulhasen talossa & & $\begin{array}{l}\text { uusikkoa } \\
\text { pöyästä } \\
\text { laulaissa } \\
\end{array}$ \\
\hline $\begin{array}{l}\text { Mannonen } \\
5447\end{array}$ & $\begin{array}{l}\text { Moisef, } \\
\text { Anni }\end{array}$ & $\begin{array}{l}\text { Seppyein, veljyein, Tie miulle } \\
\text { tinnainen tilli; valala vaskinen } \\
\text { mulkkunen }\end{array}$ & & pojat tytöille & $\begin{array}{l}\text { venäläiset } \\
\text { etanssit, } \\
\text { kolena }\end{array}$ \\
\hline $\begin{array}{l}\text { Mannonen I } \\
5591\end{array}$ & $\begin{array}{l}\text { Moisef, } \\
\text { Anni }\end{array}$ & Kuulkaa virsi Mustan Okrun & & $\begin{array}{l}\text { mies: Musta } \\
\text { Okru }\end{array}$ & tanssi, soolo \\
\hline $\begin{array}{l}\text { Mannonen } \\
7663\end{array}$ & $\begin{array}{l}\text { Reponen, } \\
\text { Pauliina }\end{array}$ & & Sulhasen talossa & & $\operatorname{tanssi}$ \\
\hline $\begin{array}{l}\text { Salminen } \\
\text { K. } 193\end{array}$ & $\begin{array}{l}\text { Kataks, } \\
\text { Sofia }\end{array}$ & $\begin{array}{l}\text { Eläkää tytöt hyväst (Oma emo } \\
\text { - vieras emo) }\end{array}$ & $\begin{array}{l}\text { Morsiustalossa } \\
\text { aattoiltana? }\end{array}$ & & $\begin{array}{l}\text { ympärikko } \\
\text { (ympärikko- } \\
\text { virsi) }\end{array}$ \\
\hline $\begin{array}{l}\text { Salminen } \\
\text { K. } 208\end{array}$ & $\begin{array}{l}\text { Pohjalainen } \\
\text { Juljaana }\end{array}$ & $\begin{array}{l}\text { 1,Mihi viipy teien vello; ei oo } \\
\text { neitoo kotona }\end{array}$ & Morsiustalossa & tytöt & permannolla \\
\hline $\begin{array}{l}\text { Salminen } \\
\text { K. } 210 \\
\end{array}$ & $\begin{array}{l}\text { Pohjalainen } \\
\text { Juljaana }\end{array}$ & Terve kuu terve päivä & Morsiustalossa & tytöt & permannolla \\
\hline $\begin{array}{l}\text { Salminen } \\
\text { K. } 212 \\
\end{array}$ & $\begin{array}{l}\text { Pohjalainen } \\
\text { Juljaana }\end{array}$ & $\begin{array}{l}\text { 1,Olkoon kiitetty Jumala, mah- } \\
\text { tui sormus sormee }\end{array}$ & Morsiustalossa? & $\begin{array}{l}\text { sulhasen } \\
\text { sukulaiset? }\end{array}$ & ympärikko \\
\hline $\begin{array}{l}\text { Salminen } \\
\text { K. } 214 \\
\end{array}$ & $\begin{array}{l}\text { Pohjalainen } \\
\text { Juljaana }\end{array}$ & nokin kiitos & $\begin{array}{l}\text { Syömisen } \\
\text { jälkeen }\end{array}$ & & $\operatorname{tanssi}$ \\
\hline $\begin{array}{l}\text { Salminen } \\
\text { K. } 265 \\
\end{array}$ & $\begin{array}{l}\text { Vohta, } \\
\text { Valpuri } \\
\end{array}$ & $\begin{array}{l}\text { Kui mie kazvelin kanaine; } \\
\text { vellot sirkutit sisoksi }\end{array}$ & & & $\begin{array}{l}\text { ympärikko } \\
\text { (pulmavirsi) }\end{array}$ \\
\hline $\begin{array}{l}\text { Salminen } \\
\text { K. } 267\end{array}$ & $\begin{array}{l}\text { Vohta, } \\
\text { Valpuri }\end{array}$ & kokin kiitos & & & $\begin{array}{l}\text { (Kokin } \\
\text { kiitosvirsi) }\end{array}$ \\
\hline $\begin{array}{l}\text { Salminen } \\
\text { V. } 2927 \\
\end{array}$ & $\begin{array}{l}\text { Räkälä, } \\
\text { Jevdokia }\end{array}$ & La ko katson langon sillat & $\begin{array}{l}\text { Sulhastaloon } \\
\text { saavuttua }\end{array}$ & $\begin{array}{l}\text { morsiamen } \\
\text { sukulaiset }\end{array}$ & ympärikko \\
\hline $\begin{array}{l}\text { Salminen } \\
\text { V. } 2929 \\
\end{array}$ & $\begin{array}{l}\text { Räkälä, } \\
\text { Jevdokia }\end{array}$ & $\begin{array}{l}\text { Saottii mei vellojamme; ei } \\
\text { saottu saavan naista }\end{array}$ & Sulhasen talossa & $\begin{array}{l}\text { sulhasen } \\
\text { puoli }\end{array}$ & maasta \\
\hline $\begin{array}{l}\text { Salminen } \\
\text { V. } 2942\end{array}$ & $\begin{array}{l}\text { Räkälä, } \\
\text { Jevdokia }\end{array}$ & Terve kuu terve päivä & Morsiustalossa & $\begin{array}{l}\text { morsiamen } \\
\text { suku }\end{array}$ & $\begin{array}{l}\text { maasta, } \\
\text { sulhaskansan } \\
\text { istuuduttua }\end{array}$ \\
\hline $\begin{array}{l}\text { Salminen } \\
\text { V. } 2948\end{array}$ & Sohvi & Suur kiitos tähä talloo & $\begin{array}{l}\text { Sulhastalosta } \\
\text { lähtiessä, muis- } \\
\text { sakin pidoissa } \\
\end{array}$ & & ympärikko \\
\hline $\begin{array}{l}\text { Salminen } \\
\text { V. } 2957\end{array}$ & Sohvi & La ko katson langon sillat & $\begin{array}{l}\text { Sulhastaloon } \\
\text { saavuttua }\end{array}$ & $\begin{array}{l}\text { morsiamen } \\
\text { sukulaiset }\end{array}$ & $\operatorname{tanssi}$ \\
\hline $\begin{array}{l}\text { Salminen } \\
\text { V. } 2975 \\
\end{array}$ & $\begin{array}{l}\text { Kuuli, } \\
\text { Sarlotta }\end{array}$ & $\begin{array}{l}\text { Kerkiskää iest ristirahvas, } \\
\text { saarut saunasta tulloo }\end{array}$ & $\begin{array}{l}\text { Morsiustalossa } \\
\text { aattoiltana }\end{array}$ & & ympyrässä \\
\hline $\begin{array}{l}\text { Salminen } \\
\text { V. } 2986\end{array}$ & $\begin{array}{l}\text { Kataks, } \\
\text { Sofia }\end{array}$ & $\begin{array}{l}\text { Avatkaa viron veräjät; kui vesi } \\
\text { kupaelloo }\end{array}$ & $\begin{array}{l}\text { Morsiustaloon } \\
\text { tullessa }\end{array}$ & $\begin{array}{l}\text { sulhaskansa } \\
\text { (esilaulajat } \\
\text { aloittavat) }\end{array}$ & $\begin{array}{l}\text { seisten, verä- } \\
\text { jän takana }\end{array}$ \\
\hline $\begin{array}{l}\text { Salminen } \\
\text { V. } 3018\end{array}$ & $\begin{array}{l}\text { Vohta, } \\
\text { Valpuri }\end{array}$ & $\begin{array}{l}\text { Anni sirkkune sisone; mitä } \\
\text { istut sirkku silmät veessä }\end{array}$ & $\begin{array}{l}\text { Morsiustalossa } \\
\text { sulhasväkeä } \\
\text { odottaessa }\end{array}$ & tytöt & maasta \\
\hline $\begin{array}{l}\text { Salminen } \\
\text { V. } 3028 \\
\end{array}$ & & La ko katson langon sillat & & $\begin{array}{l}\text { pulmaväki } \\
\text { (koko rahvas) }\end{array}$ & \\
\hline SKVR 0403 & & Terve kuu terve päivä & Morsiustalossa & tytöt & maasta \\
\hline
\end{tabular}




\begin{tabular}{|c|c|c|c|c|}
\hline Vitte Laulaja & Runo & PAIKKA & КеткÄ & Miten \\
\hline SKVR 0409 & Yhet sain mokomat lahjat & $\begin{array}{l}\text { Sulhasen talossa, } \\
\text { lahjoja jakaessa }\end{array}$ & 'morsian & tanssi \\
\hline SKVR 0410 & $\begin{array}{l}\text { Neitsyeni naisukoni (Neuvok- } \\
\text { kivirsi) }\end{array}$ & Sulhasen talossa & pulmaväki & maahan \\
\hline $\begin{array}{l}\text { SKVR } 1675 \text { Olena } \\
\text { Osipan n. }\end{array}$ & $\begin{array}{l}\text { Anu sisarueni (Neitojen linna, } \\
\text { neuvokkivirsi) }\end{array}$ & $\begin{array}{l}\text { Morsiustalossa } \\
\text { aattoiltana }\end{array}$ & tytöt & pöydässä \\
\hline 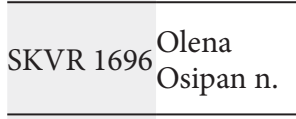 & Terve kuu terve päivä & Morsiustalossa & $\begin{array}{l}\text { tytöt morsia- } \\
\text { men puolesta1 } \\
\text { (kylän tytöt) }\end{array}$ & apermannolla \\
\hline $\begin{array}{l}\text { SKVR } 1702 \text { Olena } \\
\text { Osipan n. }\end{array}$ & $\begin{array}{l}\text { La mie kysyn kannoittelen } \\
\text { (viivyitkö viinatiellä) }\end{array}$ & Morsiustalossa & $\begin{array}{l}\text { tytöt morsia- } \\
\text { men puolesta } \\
\text { (kylän tytöt) }\end{array}$ & \\
\hline 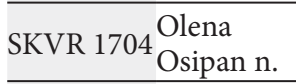 & $\begin{array}{l}\text { Kosjolainen mies korria, pitkä } \\
\text { kieli pettelikko }\end{array}$ & Morsiustalossa & tytöt (kylän) r & maasta \\
\hline 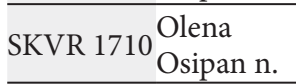 & $\begin{array}{l}\text { Olkoon kiitetty Jumala, jo sain } \\
\text { neion nähdäkseni }\end{array}$ & Morsiustalossa & & tanssi \\
\hline $\begin{array}{l}\text { SKVR } 1717 \text { Olena } \\
(1) \quad \text { Osipan } n .\end{array}$ & & Sulhasen talossa & $\begin{array}{l}\text { morsiamen } \\
\text { sukulaiset }\end{array}$ & tanssi \\
\hline $\begin{array}{l}\text { SKVR } 1717 \text { Olena } \\
(2) \quad \text { Osipan } n .\end{array}$ & $\begin{array}{l}\text { Lankoiseni lintuiseni (elkää } \\
\text { kantako kakkuja) }\end{array}$ & Sulhasen talossa & $\begin{array}{l}\text { morsiamen } \\
\text { sukulaiset }\end{array}$ & pöydässä \\
\hline SKVR 20 & $\begin{array}{l}\text { Olkoon kiitetty jumala; sain } \\
\text { mie sijan sirkuilleni }\end{array}$ & & kaasiket & $\begin{array}{l}\text { pöydän } \\
\text { takana }\end{array}$ \\
\hline $\begin{array}{l}\text { SKVR 2132 Mörö, } \\
\text { Maria }\end{array}$ & Neuvokkivirsi & $\begin{array}{l}\text { Morsiustalossa } \\
\text { ennen pois- } \\
\text { lähtöä }\end{array}$ & & pöydässä \\
\hline $\begin{array}{l}\text { SKVR } 2133 \text { Mörö, } \\
\text { Maria }\end{array}$ & Oi vävy vävyjyeni (älä lyö) & $\begin{array}{l}\text { Morsiustalossa, } \\
\text { lähtiessä }\end{array}$ & & permannolla \\
\hline $\begin{array}{l}\text { SKVR } 2137 \text { Varkki, } \\
\text { Ul’o }\end{array}$ & Kokin kiitos & & & $\begin{array}{l}\text { tanssi, per- } \\
\text { mannolla } \\
\text { (pulmavirs) }\end{array}$ \\
\hline SKVR 2259 Ol’a & $\begin{array}{l}\text { Kuhu viivyit velvyiveni (ka- } \\
\text { pakka) }\end{array}$ & $\begin{array}{l}\text { Morsiustalossa } \\
\text { sulhasen saa- } \\
\text { puessa }\end{array}$ & $\begin{array}{l}\text { tytöt, tytön } \\
\text { väki, mor- } \\
\text { siamen suku }\end{array}$ & paikoillaan \\
\hline SKVR 2264 Ol'a & $\begin{array}{l}\text { Elä laai lankosein (älä kanna } \\
\text { kakkuja, meijän lintu meijän } \\
\text { liitsa) }\end{array}$ & Sulhasen talossa & $\begin{array}{l}\text { morsiamen } \\
\text { suku, tytön } \\
\text { korvoit }\end{array}$ & pöydässä \\
\hline SKVR 2344 Houra & $\begin{array}{l}\text { tyttäret sulat sisaret, kasvakaa } \\
\text { kauan kotona, toiselassa- } \\
\text { kotona }\end{array}$ & Häissä & $\begin{array}{l}\text { pulmaväki } \\
\text { morsiamelle, } \\
\text { morsian häi- } 1 \\
\text { den jälkeen }\end{array}$ & $\begin{array}{l}\text { ei varsinaisia } \\
\text { pulmavirsiä }\end{array}$ \\
\hline $\begin{array}{c}\text { Elina eli } \\
\text { SKVR 2442 Jelena } \\
\text { Ropsusta } \\
\end{array}$ & terve kuu terve päivä & Morsiustalossa & tytöt & ympärikko \\
\hline 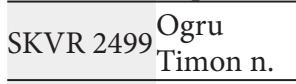 & $\begin{array}{l}\text { ILnkoiseni lintuiseni (neito } \\
\text { aitassa mäellä) }\end{array}$ & Morsiustalossa & tytöt & maasta \\
\hline $\begin{array}{l}\text { SKVR 2500 Ogru } \\
\text { Timon n. }\end{array}$ & En tuont avaimii & Morsiustalossa & $\begin{array}{l}\text { sulhasen } \\
\text { sukulaiset }\end{array}$ & $\begin{array}{l}\text { pöydästä, } \\
\text { permannol- } \\
\text { la oleville } \\
\text { tytöille }\end{array}$ \\
\hline $\begin{array}{l}\text { SKVR 2510 Ogru } \\
\text { Timon n. }\end{array}$ & Jo näimme kädet paksut & Morsiustalossa & $\begin{array}{l}\text { sulhasen } \\
\text { sukulaiset }\end{array}$ & ympärikko \\
\hline 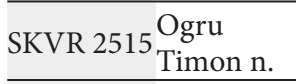 & kokin kiitos & Sulhasen talossa & $\begin{array}{l}\text { morsiamen } \\
\text { sukulaiset }\end{array}$ & ympärikko \\
\hline $\begin{array}{l}\text { SKVR 2516 Ogru } \\
\text { Timon n. }\end{array}$ & Aja aine velvyiveni & $\begin{array}{l}\text { Morsiustaloon } \\
\text { ajaessa }\end{array}$ & $\begin{array}{l}\text { sulhasen } \\
\text { väki }\end{array}$ & \\
\hline $\begin{array}{c}\text { SKVR } 2549 \begin{array}{c}\text { Kipatsa, } \\
\text { Uljaana }\end{array} \\
\end{array}$ & $\begin{array}{l}\text { lankoiseni lintuiseni (kaikki } \\
\text { suku iloinen, meillä hyvä talo) }\end{array}$ & & & $\operatorname{tanssi}$ \\
\hline $\begin{array}{l}\text { SKVR } 2550 \begin{array}{l}\text { Kipatsa, } \\
\text { Uljaana }\end{array} \\
\text { SKV }\end{array}$ & Kokin kiitos & $\begin{array}{l}\text { Sulhas- ja mor- } \\
\text { siustalossa }\end{array}$ & & $\begin{array}{l}\text { syömisen } \\
\text { jälkeen }\end{array}$ \\
\hline
\end{tabular}




\begin{tabular}{|c|c|c|c|c|c|}
\hline ViIte & LAULAJA & Runo & PAIKKA & Кеткӓ & Miten \\
\hline SKVR 2551 & $\begin{array}{l}\text { Kipatsa, } \\
\text { Uljaana }\end{array}$ & $\begin{array}{l}\text { Olkoon kiitetty Jumala (Ou- } \\
\text { napuu) }\end{array}$ & & & $\begin{array}{l}\text { tanssi tai } \\
\text { pöydässä } \\
\text { paikoillaan }\end{array}$ \\
\hline SKVR 3305 & Katrina & $\begin{array}{l}\text { Mitä työ tytöt surette (nyt on } \\
\text { lusti nuoren noissa; tulkaa } \\
\text { tyttäret tulella) }\end{array}$ & & & tanssi \\
\hline SKVR 3334I & 4 Nataalia & $\begin{array}{l}\text { Lankoiseni lintuiseni, avatkaa } \\
\text { ukset auki }\end{array}$ & Sulhasen talossa & $\begin{array}{l}\text { morsiamen } \\
\text { sukulaiset }\end{array}$ & $\begin{array}{l}\text { seisten?, ve- } \\
\text { räjän edessä } \\
\text { (saattamis- } \\
\text { virsi) } \\
\end{array}$ \\
\hline SKVR 3335 & 5 Nataalia & La ko katson langon sillat & Sulhasen talossa & & ympärikko \\
\hline SKVR 3337I & 7 Nataalia & $\begin{array}{l}\text { Lankoiseni lintuiseni (älkää kan- } \\
\text { tako kakkuja, varastettu hanhi) }\end{array}$ & Sulhasen talossa & $\begin{array}{l}\text { morsiamen } \\
\text { sukulaiset }\end{array}$ & pöydässä \\
\hline SKVR 3338 & 3 Nataalia & kokin kiitos & Sulhasen talossa & $\begin{array}{l}\text { morsiamen } \\
\text { sukulaiset }\end{array}$ & $\begin{array}{l}\text { noistaa } \\
\text { syömästä }\end{array}$ \\
\hline SKVR 3625 & & $\begin{array}{l}\text { Aja, aine velyeni (ei tuo tallo } \\
\text { taimianne; tee lahti lautaportti) }\end{array}$ & $\begin{array}{l}\text { Morsiustaloon } \\
\text { ajaessa }\end{array}$ & $\begin{array}{l}\text { sulhasen } \\
\text { sukulaiset }\end{array}$ & \\
\hline SKVR 3661 & & $\begin{array}{l}\text { Isämies isyen poika (onko } \\
\text { mainen matka, miksi pääsky } \\
\text { pääsi maassa) }\end{array}$ & & sulhanen & pöydässä \\
\hline SKVR 3821 & & $\begin{array}{l}\text { Elä tuskau veljyeni (mainen } \\
\text { vai merinen matka) }\end{array}$ & $\begin{array}{l}\text { Sulhastalossa } \\
\text { lähtöaamuna }\end{array}$ & & pöydässä \\
\hline SKVR 3968 & & $\begin{array}{l}\text { Katsokaat kylän isännät (kuin } \\
\text { miun aineni ajaa; elkää } \\
\text { kirotko, ei tallo taimianne) }\end{array}$ & $\begin{array}{l}\text { Morsiustaloon } \\
\text { ajaessa }\end{array}$ & $\begin{array}{l}\text { sulhasen } \\
\text { sukulaiset }\end{array}$ & \\
\hline SKVR 4225 & & $\begin{array}{l}\text { Kosjolainen koirankieli, } \\
\text { pitkäkieli pettelikko }\end{array}$ & Morsiustalossa & $\begin{array}{l}\text { morsiamen } \\
\text { sukulaiset }\end{array}$ & $\begin{array}{l}\begin{array}{l}\text { pöydässä } \\
\text { olevalle } \\
\text { sulhasväelle }\end{array} \\
\end{array}$ \\
\hline Sääski 5897 & $\begin{array}{l}\text { Appalonov } \\
\text { Darja }\end{array}$ & venäjäksi & Illalla & & $\operatorname{tanssi}$ \\
\hline Sääski 5969 & $\begin{array}{l}\text { Aleksinen, } \\
\text { Nadja }\end{array}$ & $\begin{array}{l}\text { Minjuein marjuein (hyvä talo, } \\
\text { älä pelästy) }\end{array}$ & Sulhasen talossa & & $\begin{array}{l}\text { pöydässä, } \\
\text { pitkiä virsiä }\end{array}$ \\
\hline Sääski 5970 & $\begin{array}{l}\text { Aleksinen, } \\
\text { Nadja }\end{array}$ & $\begin{array}{l}\text { Terve tuttuva tuppaa (la mie } \\
\text { koitan kannoillani) }\end{array}$ & Sulhasen talossa & $\begin{array}{l}\text { morsiamen } \\
\text { sukulaiset }\end{array}$ & $\begin{array}{l}\text { tupaan } \\
\text { tullessa }\end{array}$ \\
\hline Sääski 5973 & $\begin{array}{l}\text { Ruokonen, } \\
\text { Anastasia }\end{array}$ & $\begin{array}{l}\text {, Näyttäkää käköi kättees; jo } \\
\text { käet paksut sormet hoikat }\end{array}$ & $\begin{array}{l}\text { Morsiustalossa, } \\
\text { lahjoja saadessa }\end{array}$ & $\begin{array}{l}\text { sulhasen } \\
\text { sukulaiset }\end{array}$ & ympärikko \\
\hline
\end{tabular}

\section{HÄÄSÄVELMÄT}

Käsikirjoitusten ilman säkeenkertoa merkityt, pienen (1-3 säveltä) muunnelman sisältävät toisinnot on tulkittu muotorakenteeltaan yksisäkeisiksi eli lauletuiksi yksi tekstisäe kerrallaan muun aineiston perusteella. 1960-luvun tallenteista huomattavan moni edustaa kuusiiskuista, huomattavan harva taas neli-iskuista varsinaista pulmanuottia; myös oi dai -sävelmiä on runsaasti. Tallinnan vuoden 1937 äänitysten häälauluissa sävelala on keskimäärin laajempi (4-5) kuin aiemmissa tallenteissa (3-4).

Viite: $\mathrm{A}=$ SKSÄ A; Alava $=$ SKS KRA Alava; Borenius = SKS KRA Borenius e; Europaeus = SKS KRA Europaeus; L = SKSÄ L; Levón = SKS KRA Levón; NPI = Kiuru et al. 1974 nuotti/ teksti. $S$ = Käytettyjen sävelten määrä 
LÄNSI-INKERILÄISET HÄÄSÄVELMÄT

Tavallisilla pulmanuoteilla lauletut häärunoteemat Soikkolasta ja Narvusista.

VIITE IRS PAIKKA KYLÄ

Alkusäe (TEema)Muoto-

RYTMI

$S$ Nimitys

KURSI- L. KUPELILEIPÄÄ PAISTAESSA

SibA Launis 379141 Soikkola $\begin{aligned} & \text { Oussi- } \\ & \text { mäki }\end{aligned}$

Kohoo kupeli

RAKENNE

(20)

\section{KYLVETYSVIRSI}

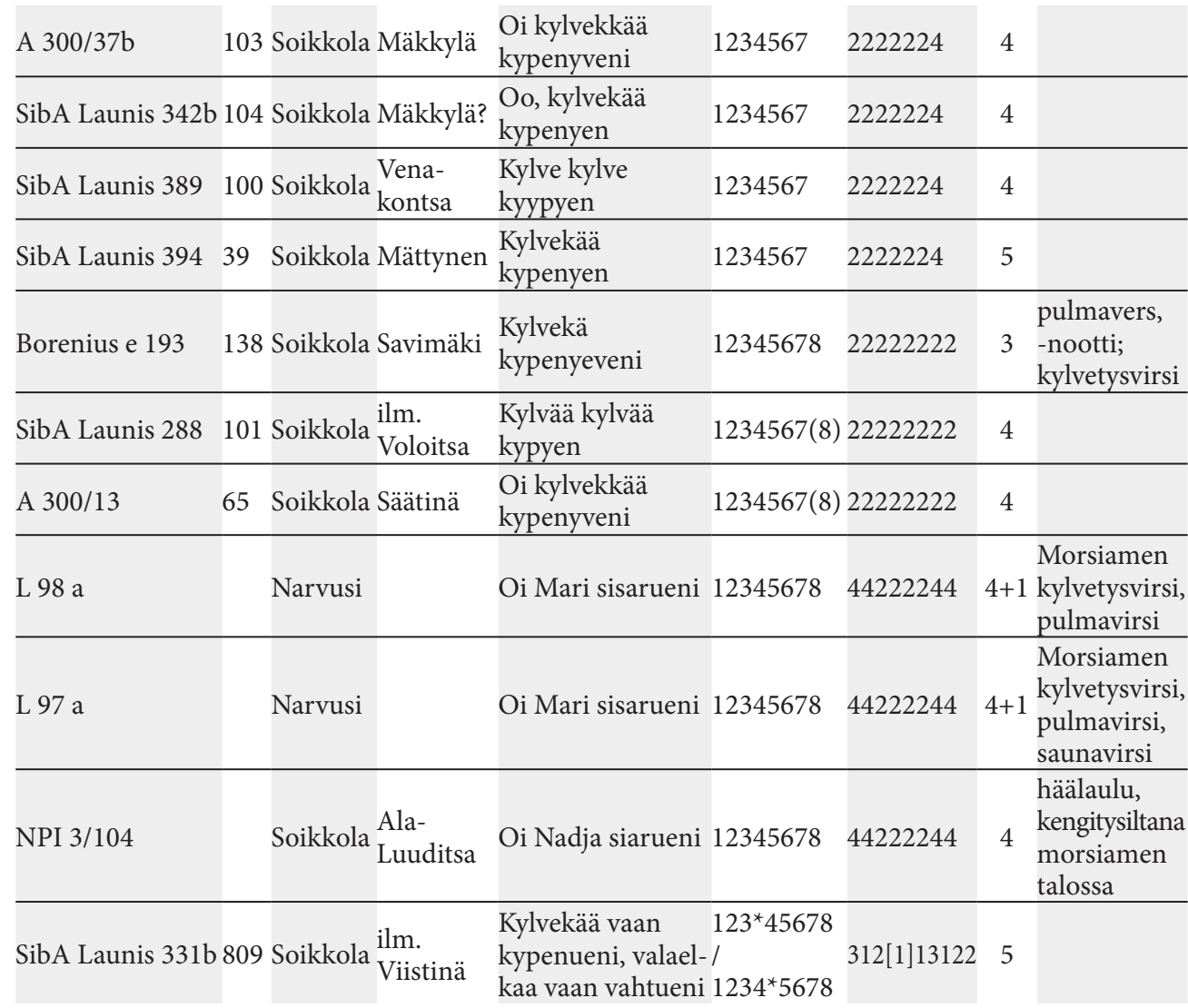

SAUNASTATULOVIRSI, SULHASEN LÄHTÖVIRRET

\begin{tabular}{|c|c|c|c|c|c|c|c|c|}
\hline $\begin{array}{l}\text { Europaeus 12: } \\
\text { 199a }\end{array}$ & 868 & Narvusi & Vanhakylä & $\begin{array}{l}\text { Laslavikka laula- } \\
\text { mahan }\end{array}$ & 12345678 & 22222222 & 4 & \\
\hline Borenius 204 & 115 & 5 Soikkola & Joenperä & $\begin{array}{l}\text { Blasloviitekka } \\
\text { jumala }\end{array}$ & 12345678 & 22222222 & 4 & pulmanootti \\
\hline L 98 b & & Narvusi & & $\begin{array}{l}\text { Menkää eestä } \\
\text { ristirahvas (tiekkö } \\
\text { risti rinnallesi) }\end{array}$ & 12345678 & 22222222 & $5(+1)$ & $\begin{array}{l}\text { Pulmavirsiä: } \\
\text { Saunastatu- } \\
\text { lovirsi }\end{array}$ \\
\hline SibA Launis 376 & 96 & Soikkola & $\begin{array}{l}\text { Oussi- } \\
\text { mäki }\end{array}$ & Ristimä rinnallesi & 12345678 & 22222222 & 4 & \\
\hline SibA Launis 289 & & Soikkola & Soikkola & $\begin{array}{l}\text { Tehkää risti } \\
\text { rinnallesi }\end{array}$ & 12345678 & 42424242 & 5 & \\
\hline NPI 7/114 & & Soikkola & Säätinä & $\begin{array}{l}\text { Ristemähä rinnal- } \\
\text { line (veljen kal- } \\
\text { moilla käynti) }\end{array}$ & 12345678 & 44222244 & 5 & $\begin{array}{l}\text { Hääpäivänä } \\
\text { morsianta } \\
\text { ottamassa }\end{array}$ \\
\hline SibA Launis 74 & 306 & 6 Narvusi & Pärspää & $\begin{array}{l}\text { Aa, mitä on pääsky } \\
\text { pääsi maassa }\end{array}$ & 12345678 & $\begin{array}{l}44222244 ; \\
4422226^{\prime} 2\end{array}$ & $4+1$ & \\
\hline
\end{tabular}




\begin{tabular}{|c|c|c|c|c|c|c|c|}
\hline VIITE & IRS PAIKKA & KYLÄ & Alkusäe (TEEMA) & $\begin{array}{l}\text { MUOTO- } \\
\text { RAKENNE }\end{array}$ & RутмI & S & Nimitys \\
\hline \multicolumn{8}{|c|}{ AVATKAa Viron VERÄJÄ } \\
\hline L 97 b & Narvusi & & $\begin{array}{l}\text { Oo lankoiseni } \\
\text { lintuiseni (avatkaa } \\
\text { avoveräjät) }\end{array}$ & 12345678 & 22222222 & 5 & $\begin{array}{l}\text { Pulmavirsiä: } \\
\text { sulhasjoukko } \\
\text { laulaa saapu- } \\
\text { essaan }\end{array}$ \\
\hline SibA Launis 17 & 310 Narvusi & $\begin{array}{l}\text { Arsian- } \\
\text { saari }\end{array}$ & $\begin{array}{l}\text { Avatkaa Viron } \\
\text { veräjä, Viron } \\
\text { vierahat tulloo } \\
\end{array}$ & $1234567(8)$ & 44222244 & 3 & \\
\hline A $300 / 20 a$ & 136 Soikkola & Koskina & $\begin{array}{l}\text { Avatkaa virov } \\
\text { veräjä; avatkaa } \\
\text { virov veräjä }\end{array}$ & $1234567(8)$ & 22222222 & 4 & \\
\hline A $300 / 19 b$ & 135 Soikkola & Säätinä & $\begin{array}{l}\text { Avatkaa virov } \\
\text { veräjä; avatkaa } \\
\text { virov veräjä }\end{array}$ & $1234567(8)$ & 22222222 & 4 & \\
\hline NPI 3/106 & Soikkola & $\begin{array}{l}\text { Ala- } \\
\text { Luuditsa }\end{array}$ & $\begin{array}{l}\text { Tekkää lahti } \\
\text { lautaportti (tuvan } \\
\text { tervehtäminen, } \\
\text { osta sija sirkul- } \\
\text { leni) }\end{array}$ & 12345678 & 44222244 & 4 & $\begin{array}{l}\text { Hääpäivänä } \\
\text { morsianta } \\
\text { ottamassa }\end{array}$ \\
\hline
\end{tabular}

SUlHASVÄEN SAAPUMISEEN LIITTYVÄ DIALOGI (TERVEHDYS, YLISTYS, PILKKA)

\begin{tabular}{|c|c|c|c|c|c|c|c|c|}
\hline SibA Launis 258 & 73 & Soikkola & $\begin{array}{l}\text { ilm. } \\
\text { Voloitsa }\end{array}$ & $\begin{array}{l}\text { Luulin tuulosen } \\
\text { tulloovan }\end{array}$ & 12345678 & 22222222 & 3 & \\
\hline SibA Launis 169 & 81 & Soikkola & Säätinä & $\begin{array}{l}\text { Oo, kuhun viivyt } \\
\text { velvyeni }\end{array}$ & 12345678 & 22222222 & 3 & \\
\hline SibA Launis 87 & & Narvusi & Kurkola & $\begin{array}{l}\text { Oo terve kuu } \\
\text { terve päivä }\end{array}$ & 12345678 & 22222222 & 3 & \\
\hline A $302 / 97$ & & Narvusi & Kirjamo & $\begin{array}{l}\text { Terve kuu terve } \\
\text { päivä }\end{array}$ & 12345678 & 22222222 & 3 & \\
\hline $\begin{array}{l}\text { KRA Alava } \\
\text { VIIa: } 491\end{array}$ & & Soikkola & $\begin{array}{l}\text { Oussi- } \\
\text { mäki }\end{array}$ & $\begin{array}{l}\text { Oi vävy kuvattu } \\
\text { kulta (toit sen } \\
\text { minkä lupasit) } \\
\end{array}$ & 12345678 & 22222222 & 3 & \\
\hline SibA Launis 136 & 410 & Narvusi & Kirjamo & $\begin{array}{l}\text { Tunnen vävyn } \\
\text { tulevan }\end{array}$ & 12345678 & 22222231 & 3 & \\
\hline SibA Launis 373 & 137 & Soikkola & $\begin{array}{l}\text { Oussi- } \\
\text { mäki }\end{array}$ & $\begin{array}{l}\text { Kuhun viivyt } \\
\text { velvyeni }\end{array}$ & 12345678 & 22222222 & 4 & \\
\hline NPI 29/112 & & Soikkola & Savimäki & $\begin{array}{l}\text { Kuhu viivyit vel- } \\
\text { vyeen (viinatielle) }\end{array}$ & 12345678 & 22222222 & 4 & $\begin{array}{l}\text { Hääpäivänä } \\
\text { morsianta } \\
\text { ottamassa }\end{array}$ \\
\hline NPI 30/111 & & Soikkola & Harkkola & $\begin{array}{l}\text { Luulin tuulen tuu- } \\
\text { lovan (humalassa } \\
\text { hupsuttelit) }\end{array}$ & 12345678 & 22222222 & 4 & $\begin{array}{l}\text { Hääpäivänä } \\
\text { morsianta } \\
\text { ottamassa }\end{array}$ \\
\hline SibA Launis $337 b$ & 93 & Soikkola & $\begin{array}{l}\text { ilm. Tam- } \\
\text { mikontu }\end{array}$ & $\begin{array}{l}\text { Mihin viivyt } \\
\text { velvyeni }\end{array}$ & 12345678 & 22222222 & 4 & \\
\hline ERA Fon 372 b & & Narvusi & & $\begin{array}{l}\text { [Tunnen tunnen } \\
\text { ken vaa tulloo] }\end{array}$ & 12345678 & 22222222 & 4 & \\
\hline SibA Launis $84 \mathrm{~b}$ & 36 & Narvusi & Kurkola & $\begin{array}{l}\text { Terve kuu terve } \\
\text { päivä }\end{array}$ & 12345678 & 22222222 & 4 & pulmanuotti \\
\hline L $100 \mathrm{~d}$ & & Narvusi & & $\begin{array}{l}\text { Oo älä huuva } \\
\text { hullu kuusi (huma- } \\
\text { lassa hupsuttelit) }\end{array}$ & -12345678 & 22222222 & 5 & $\begin{array}{l}\text { Pulmavirsiä, } \\
\text { narrimis- } \\
\text { laulu }\end{array}$ \\
\hline SibA Launis 79 & 133 & Narvusi & Kurkola & $\begin{array}{l}\text { [oi] Terve kuu } \\
\text { terve päivä }\end{array}$ & 12345678 & 22222222 & 5 & \\
\hline L 97 c & & Narvusi & & $\begin{array}{l}\text { Oi isämies isyvem } \\
\text { poika (osta sija } \\
\text { sirkulleni) }\end{array}$ & 12345678 & 22222222 & 5 & $\begin{array}{l}\text { Pulmavirsiä: } \\
\text { Pöydän } \\
\text { lunastamis- } \\
\text { virsi }\end{array}$ \\
\hline
\end{tabular}




\begin{tabular}{|c|c|c|c|c|c|c|c|}
\hline L 98 c & IRS PAIKKA & KYLÄ & $\begin{array}{l}\text { ALKUSÄE (TEEMA) } \\
\text { Oo olkoon } \\
\text { tienattu jumala } \\
\text { (sain miä sijan } \\
\text { sirkulleni) }\end{array}$ & $\begin{array}{l}\text { MuOTO- } \\
\text { RAKENNE }\end{array}$ & 22222222 & $5(+1)$ & $\begin{array}{l}\text { Pulmavir- } \\
\text { siä: Sulhon } \\
\text { istuttaminen } \\
\text { pöytään }\end{array}$ \\
\hline L $98 \mathrm{~d}$ & Narvusi & & $\begin{array}{l}\text { Mihin viivyit i } \\
\text { velvyiveni }\end{array}$ & 12345678 & 22222222 & $5(+1)$ & Pulmavirsiä \\
\hline KRA Alava X:103 & Narvusi & Ropsu & $\begin{array}{l}\text { Terve kuu terve } \\
\text { päivä }\end{array}$ & 12345678 & $22222222 ?$ & 5 & $\begin{array}{l}\text { yleinen } \\
\text { pulmanuotti }\end{array}$ \\
\hline SibA Launis 12 & 145 Narvusi & Kallivieri & $\begin{array}{l}\text { Mihin viivy[i]t } \\
\text { velvyeni }\end{array}$ & 12345678 & $22222222 ?$ & 3 & pulmanuotti \\
\hline SibA Launis 231 & 773 Soikkola & $\begin{array}{l}\text { Tarinai- } \\
\text { nen }\end{array}$ & $\begin{array}{l}\text { Luulin tuulosen } \\
\text { tuloovan }\end{array}$ & 12345678 & $13131322 ?$ & 5 & \\
\hline L $100 \mathrm{~b}$ & Narvusi & & $\begin{array}{l}\text { Tunnen tunnen } \\
\text { kev vaa tulloo }\end{array}$ & 12345678 & 44222244 & 4 & $\begin{array}{l}\text { Pulmavirsiä, } \\
\text { narrimislau- } \\
\text { lu, sulhon } \\
\text { moittimis- } \\
\text { virsi }\end{array}$ \\
\hline NPI 5/110 & Soikkola & Savimäki & $\begin{array}{l}\text { La miä kysyn } \\
\text { lankoiltani (vävyn } \\
\text { hevosen hoito) }\end{array}$ & 12345678 & 44222244 & 4 & $\begin{array}{l}\text { Hääpäivänä } \\
\text { morsianta } \\
\text { ottamassa }\end{array}$ \\
\hline $\begin{array}{l}\text { KRA Borenius } \\
205\end{array}$ & 312 Soikkola & Joenperä & $\begin{array}{l}\text { Terve kuu terve } \\
\text { päivä }\end{array}$ & $1234567(8)$ & 44222244 & 3 & \\
\hline
\end{tabular}

MORSIAMEN ETSIMINEN, SORMUKSEN SOVITTAMINEN, lahjojen Jako (MorsiUstalon pöydässä, Pillopirtissä)

\begin{tabular}{|c|c|c|c|c|c|c|c|}
\hline $\begin{array}{l}\text { KRA Alava } \\
\text { X:104a }\end{array}$ & Narvusi & Ropsu & $\begin{array}{l}\text { Olkoot kiitetty } \\
\text { Jumala (jo sain } \\
\text { nähä minnoani) }\end{array}$ & 12345678 & 22222222 & 3 & \\
\hline $\begin{array}{l}\text { KRA Alava } \\
\mathrm{X}: 104 \mathrm{~b} \\
\end{array}$ & Narvusi & Ropsu & $\begin{array}{l}\text { Passipo } \\
\text { minnolleni }\end{array}$ & 12345678 & 22222222 & 3 & \\
\hline SibA 457b & 112 Soikkola & Uusikylä & Jo näin näölliseksi & 12345678 & 22222222 & 4 & \\
\hline SibA Launis $319 b$ & 372 Soikkola & $\begin{array}{l}\text { ilm. } \\
\text { Viistinä }\end{array}$ & $\begin{array}{l}\text { Oi, mistä puusta } \\
\text { pertti tehty }\end{array}$ & 12345678 & 22222222 & 5 & \\
\hline NPI 3/128 & Soikkola & $\begin{array}{l}\text { Ala- } \\
\text { Luuditsa }\end{array}$ & $\begin{array}{l}\text { Olkkaa kiitetty } \\
\text { Jumala (kiitos mi- } \\
\text { niälle lahjoista) }\end{array}$ & 12345678 & 44222244 & 4 & $\begin{array}{l}\text { Häissä } \\
\text { sulhasen } \\
\text { talossa }\end{array}$ \\
\hline NPI 5/115 & Soikkola & Savimäki & $\begin{array}{l}\text { Lankoiseni lintui- } \\
\text { seni (elkää surko } \\
\text { siskojanne) }\end{array}$ & 12345678 & 44222244 & 4 & $\begin{array}{l}\text { Hääpäivänä } \\
\text { morsianta } \\
\text { ottamassa }\end{array}$ \\
\hline $\begin{array}{l}\text { KRA Borenius } \\
194\end{array}$ & 251 Soikkola & Savimäki & $\begin{array}{l}\text { Päämees on pojut } \\
\text { Kalervoi (Anni on } \\
\text { aitassa hyvässä) }\end{array}$ & 12345678 & 44222244 & 6 & pulmanootti \\
\hline
\end{tabular}

SULHASVÄEN KOTIINSA SAAPUMINEN

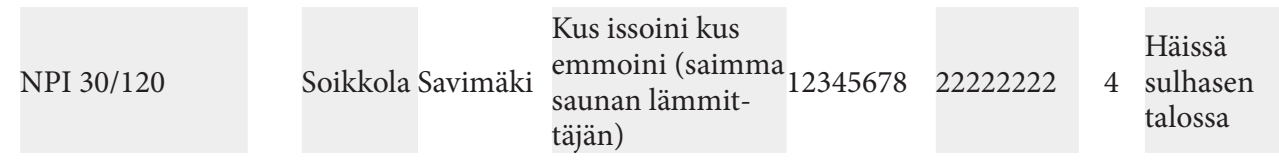

TUVAN TERVEHTIMINEN JA LATTIAN KOKEILU (SULHASEN KODISSA)

\begin{tabular}{|c|c|c|c|c|c|c|c|}
\hline SibA Launis 30 & 275 Narvusi & Ropsu & $\begin{array}{l}\text { Laskaa suojahan } \\
\text { väkeni }\end{array}$ & 12345678 & 44222244 & 4 & pulmavirsiä \\
\hline ERA Fon. 209 a & Soikkola & Joenperä & $\begin{array}{l}\text { Ter(e)ve (o) tuttua } \\
\text { tuppaaHa }\end{array}$ & $a_{12345678}$ & 44222244 & 4 & \\
\hline SibA Launis 30b & 236 Narvusi & Ropsu & $\begin{array}{l}\text { La mie kysyn } \\
\text { langot teiltä, } \\
\text { luppaatteko meil } \\
\text { tupaista }\end{array}$ & 12345678 & 44224422 & 4 & pulmavirsiä \\
\hline
\end{tabular}




\begin{tabular}{|c|c|c|c|c|c|c|}
\hline ViIte & IRS PAIKKA & KYLÄ & $\begin{array}{r}\text { ALKUSÄE (TEEMA)MUOTO- } \\
\text { RAKENNE }\end{array}$ & RутмI & $\mathrm{S}$ & Nimitys \\
\hline NPI $1 / 122$ & Soikkola & Voloitsa & $\begin{array}{l}\text { Mist miä tunsin } \\
\text { tänne tulla (la miä 1234567(8) } \\
\text { katson kannoillaan) }\end{array}$ & $\begin{array}{l}22222222 \\
2222224\end{array}$ & 5 & $\begin{array}{l}\text { Häissä } \\
\text { sulhasen } \\
\text { talossa }\end{array}$ \\
\hline
\end{tabular}

TUVAN TERVEHTIMINEN JA LATTIAN KOKEILU (MORSIAMEN KODISSA)

\begin{tabular}{|c|c|c|c|c|c|c|}
\hline NPI 28/109 & Soikkola Harkkola & Tere tuttuu tuppaa & 12345678 & 22222222 & 4 & $\begin{array}{l}\text { Hääpäivänä } \\
\text { morsianta } \\
\text { ottamassa }\end{array}$ \\
\hline NPI 28/107 & Soikkola Säätinä & $\begin{array}{l}\text { Tere tuttuhu tup- } \\
\text { paha (onk silliiät } \\
\text { lankon sillat) }\end{array}$ & 12345678 & 22222222 & 4 & $\begin{array}{l}\text { Hääpäivänä } \\
\text { morsianta } \\
\text { ottamassa }\end{array}$ \\
\hline NPI 29/108 & Soikkola Savimäki & $\begin{array}{l}\text { Tere tuttuva tup- } \\
\text { paa (mahtuukka } \\
\text { vävöi tuppaa, osta } \\
\text { sija sirkulleni) }\end{array}$ & 12345678 & 22222222 & 4 & $\begin{array}{l}\text { Hääpäivänä } \\
\text { morsianta } \\
\text { ottamassa }\end{array}$ \\
\hline
\end{tabular}

TAhdomme NeITtä NÄHDÄKSEMmE; MeIJÄN LINTU MeIJÄN LIITSA

\begin{tabular}{|c|c|c|c|c|c|c|c|}
\hline A $300 / 20 b$ & 254 Soikkola & Koskina & $\begin{array}{l}\text { Meijän(ä) lintu } \\
\text { meijäl liitso }\end{array}$ & 12345678 & 44222244 & 4 & \\
\hline NPI 5/123 & Soikkola & Savimäki & $\begin{array}{l}\text { Lankoiseni lin- } \\
\text { tuiseni (elkkää } \\
\text { kanttaa kakkuloja, } \\
\text { meien oot lintu } \\
\text { meijen littsa) }\end{array}$ & 12345678 & 44222244 & 4 & $\begin{array}{l}\text { Häissä } \\
\text { sulhasen } \\
\text { talossa }\end{array}$ \\
\hline NPI 26/121 & Soikkola & Savimäki & $\begin{array}{l}\text { Lankoiseni lintui- } \\
\text { seni (tahomma } \\
\text { neittä nähdäk- } \\
\text { semme) }\end{array}$ & 12345678 & 44222244 & 5 & $\begin{array}{l}\text { Häissä } \\
\text { sulhasen } \\
\text { talossa }\end{array}$ \\
\hline
\end{tabular}

\section{Aitassa (huHMarella) KäYNTI}

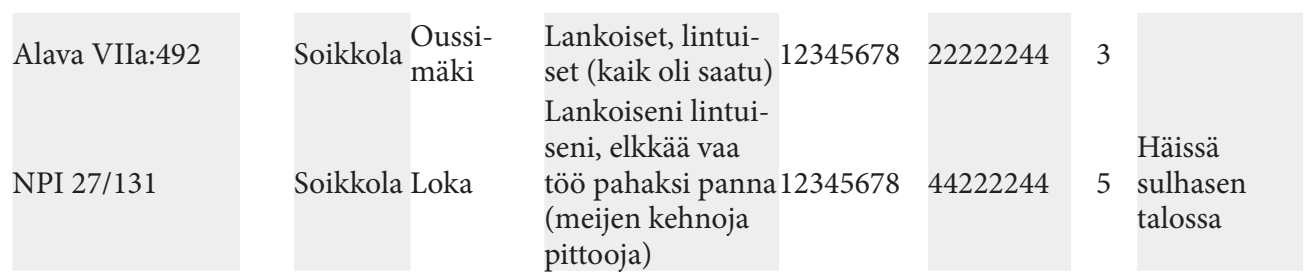

NeUVoKkivirRet, LÄHTÖVIRRET MORSIAMELLE; Me MENEMME, SINUT JÄTÄMME

\begin{tabular}{|c|c|c|c|c|c|c|c|}
\hline SibA Launis 118 & 134 Narvusi & Kaipaala & $\begin{array}{l}\text { Juko hellä velvye- } \\
\text { ni (kuule kuule } \\
\text { kuin opetan) }\end{array}$ & 12345678 & 22222222 & 5 & \\
\hline L 100 c & Narvusi & & $\begin{array}{l}\text { Oi vävy vävyjyeni } \\
\text { (tunsit olla tunne } \\
\text { pitää) }\end{array}$ & 12345678 & 22222222 & 5 & $\begin{array}{l}\text { Pulmavirsiä: } \\
\text { vävyn ope- } \\
\text { tus; sulhon } \\
\text { opetusvirsi }\end{array}$ \\
\hline L 100 a & Narvusi & & $\begin{array}{l}\text { Oo oi mari sisaru- } \\
\text { veni (kun sinnuu } \\
\text { maama malla toi) }\end{array}$ & 12345678 & 22222222 & 5 & Pulmavirsiä \\
\hline SibA Launis 134 & 914 Narvusi & Kirjamo & $\begin{array}{l}\text { Laai linttisi lipulle, } \\
\text { kääri kyynelees } \\
\text { kerälle }\end{array}$ & 12345678 & 22222222 & 7 & \\
\hline NPI 24/117 & Soikkola & Savimäki & $\begin{array}{l}\text { Marojani sisojani, } \\
\text { jo hylkäät hyvän } \\
\text { kylläisi }\end{array}$ & 12345678 & 42424242 & 5 & $\begin{array}{l}\text { Hääpäivänä } \\
\text { morsianta } \\
\text { ottamassa }\end{array}$ \\
\hline NPI 3/125 & Soikkola & $\begin{array}{l}\text { Ala- } \\
\text { Luuditsa }\end{array}$ & $\begin{array}{l}\text { Oi Nadja siarueni } \\
\text { (muutat muodon } \\
\text { vaihdat varren) }\end{array}$ & 12345678 & 44222244 & 4 & $\begin{array}{l}\text { Häissä } \\
\text { sulhasen } \\
\text { talossa }\end{array}$ \\
\hline L 99 b & Narvusi & & $\begin{array}{l}\text { Oi mari sisaruveni } \\
\text { (myö määmmä } \\
\text { siuj jätämmä) }\end{array}$ & i 12345678 & 44222244 & $4+1$ & $\begin{array}{l}\text { Pulmavirsiä: } \\
\text { Morsiamen } \\
\text { suvun laula- } \\
\text { ma lähtövirsi }\end{array}$ \\
\hline
\end{tabular}




\begin{tabular}{|c|c|c|c|c|c|c|c|c|}
\hline VIITE & IRS & PAIKKA & KYLÄ & AlKusÄE (TEEMA) & $\begin{array}{l}\text { MUOTO- } \\
\text { RAKENNE }\end{array}$ & RYтмI & S & Nimitys \\
\hline SibA Launis 39 & 240 & Narvusi & Ropsu & $\begin{array}{l}\text { Myö määmme } \\
\text { sinun jätämme }\end{array}$ & 12345678 & $\begin{array}{l}4422228 \\
44312244\end{array}$ & 4 & \\
\hline \multicolumn{9}{|c|}{ Paikantumattomat PUHUTtelut } \\
\hline SibA Launis 26 & 74 & Narvusi & Ropsu & $\begin{array}{l}\text { Ee, isämies isyyen } \\
\text { poika, päämies } \\
\text { päätetty kypärä }\end{array}$ & 12345678 & 22222222 & $3+$ & \\
\hline SibA Launis 290 & 97 & Soikkola & $\begin{array}{l}\text { ilm. Vo- } \\
\text { loitsa }\end{array}$ & $\begin{array}{l}\text { Lankoiseni lin- } \\
\text { tuiseni, langot } \\
\text { linnukkaisueni }\end{array}$ & 12345678 & 22222222 & 4 & \\
\hline SibA Launis 41 & 75 & Narvusi & Vipiä & $\begin{array}{l}\text { Lankoiseni } \\
\text { lintuiseni, langot } \\
\text { linnukkaisueni, } \\
\text { sanon teille } \\
\text { tiedäkseni }\end{array}$ & 12345678 & 22222222 & 5 & \\
\hline A $300 / 17 b$ & 303 & Soikkola & Säätinä & $\begin{array}{l}\text { Langoiseni lindui- } \\
\text { seni; langoiseni } \\
\text { linduiseni (uusik- } \\
\text { kaset, kananmu- } \\
\text { naset) }\end{array}$ & 12345678 & 44222244 & 4 & \\
\hline SibA Launis 277 & 835 & Soikkola & $\begin{array}{l}\text { ilm. Vo- } \\
\text { loitsa }\end{array}$ & $\begin{array}{l}\text { Marojani sisojani, } \\
\text { oi maroi siaruen }\end{array}$ & 12345678 & $\begin{array}{l}424^{\prime} 24242 \\
424^{\prime} 2426\end{array}$ & 4 & \\
\hline \multicolumn{9}{|l|}{ MuUt } \\
\hline A $303 / 8$ & & Narvusi & Ropsu & $\begin{array}{l}\text { Läksin suolle sou- } \\
\text { tamahan, aholle } \\
\text { ajelemahan }\end{array}$ & 12345678 & 22222222 & 3 & pulmanuotti \\
\hline A $507 / 8$ a & & Narvusi & & $\begin{array}{l}\text { Tulin maille } \\
\text { vierahille (terveh- } \\
\text { dyslaulu yleisölle } \\
\text { ja presidentille) }\end{array}$ & 12345678 & 22222222 & 5 & \\
\hline NPI 2/118 & & Soikkola & $\begin{array}{l}\text { Kolkan- } \\
\text { pää }\end{array}$ & $\begin{array}{l}\text { La miä tantsin } \\
\text { traksuttelen (tus- } \\
\text { kiani tuulluttelen; } \\
\text { lankoisenti lintui- } \\
\text { senti, kaik on tootu } \\
\text { kaik on saatu) }\end{array}$ & 12345678 & 44222244 & 4 & $\begin{array}{l}\text { Hääpäivänä } \\
\text { morsianta } \\
\text { ottamassa }\end{array}$ \\
\hline SibA Launis 84 & 901 & Narvusi & Kurkola & $\begin{array}{l}\text { Nouskaa ylös } \\
\text { nukkuneet, jopa } \\
\text { on käet kukkuneet } \\
\text { (välimuotoinen) }\end{array}$ & 1234567 & 2222224 & 4 & $\begin{array}{l}\text { Ylösherätys- } \\
\text { laulu häissä }\end{array}$ \\
\hline SibA Launis 82 & & Narvusi & Kurkola & $\begin{array}{l}\text { Tänä ohtol vii- } \\
\text { meist kertaa viel } \\
\text { seison teiän ies } \\
\text { (välimuotoinen) }\end{array}$ & & $\begin{array}{l}22442284 \\
444228\end{array}$ & 7 & \\
\hline
\end{tabular}

\section{KoKIN KIITOS}

\begin{tabular}{|c|c|c|c|c|c|c|}
\hline ViIte & IRS PAIKKA & KYLÄ & AlKusÄE & $\begin{array}{l}\text { MUOTO- } \\
\text { RAKENNE }\end{array}$ & RуtмI & S Nimitys \\
\hline SibA Launis 38 & 715 Narvusi & Ropsu & $\begin{array}{l}\text { Olin pulmissa } \\
\text { monissa ja monissa }\end{array}$ & $\begin{array}{l}12345678 \\
5678\end{array}$ & $\begin{array}{l}22222222 \\
2244\end{array}$ & 3 \\
\hline L 92 c & Narvusi & & $\begin{array}{l}\text { Tulkaa kokkii } \\
\text { kittämää vaa } \\
\text { kiittämää vaa }\end{array}$ & $\begin{array}{l}12345678 \\
5678\end{array}$ & $\begin{array}{l}22222222 \\
2244\end{array}$ & $\begin{array}{l}\text { kokin } \\
4 \text { (häiden) } \\
\text { kiitosvirsi } \\
\end{array}$ \\
\hline NPI 31/129 & Soikkola & a Savimäki & $\begin{array}{l}\text { Kusta teil oli kokk } \\
\text { tootu kokki tootu }\end{array}$ & $\begin{array}{l}\text { i } 12345678 \\
5678\end{array}$ & $\begin{array}{l}22222222 \\
2244\end{array}$ & $\begin{array}{l}\text { Häissä sulha- } \\
\text { sen talossa }\end{array}$ \\
\hline
\end{tabular}




\begin{tabular}{|c|c|c|c|c|c|c|}
\hline ViIte & IRS PAIKКA & KYLÄ & AlKusÄE & $\begin{array}{l}\text { MuOTO- } \\
\text { RAKENNE }\end{array}$ & RYtмi & S Nimitys \\
\hline SibA Launis $40 \mathrm{~b}$ & 329 Narvusi & Vipiä & $\begin{array}{l}\text { Hyvä kokki } \\
\text { kaunis kokki, } \\
\text { kaunis kokki }\end{array}$ & $\begin{array}{l}12345678 \\
5678\end{array}$ & $\begin{array}{l}22222222 \\
2244\end{array}$ & 5 \\
\hline L 92 b & Narvusi & & $\begin{array}{l}\text { Tulkaa kokkii } \\
\text { kittämää vaa } \\
\text { kiittämää vaa }\end{array}$ & $\begin{array}{l}12345678 \\
5678\end{array}$ & $\begin{array}{l}22222222 \\
2244\end{array}$ & $\begin{array}{l}\text { kokin } \\
5 \text { (häiden) } \\
\text { kiitosvirsi }\end{array}$ \\
\hline NPI 32 & Soikkola & & $\begin{array}{l}\text { Oi, tulkaa kokkia } \\
\text { kiittämää ja } \\
\text { kiittämää ja }\end{array}$ & $\begin{array}{l}12345678 \\
5678\end{array}$ & $\begin{array}{l}22222222 \\
2244\end{array}$ & $\begin{array}{l}\text { Häissä } \\
5 \text { sulhasen } \\
\text { talossa }\end{array}$ \\
\hline KRA Alava X:85 & Narvusi & Ropsu & $\begin{array}{l}\text { Tulkat kokkii } \\
\text { kiittämää }\end{array}$ & $\begin{array}{l}12345678 \\
78\end{array}$ & $\begin{array}{l}22222444 \\
442 ?\end{array}$ & 4 \\
\hline
\end{tabular}

\section{YKS OLI OUNAPUU KYLÄSSÄ}

\begin{tabular}{|c|c|c|c|c|c|}
\hline VIITE & IRS PAIKKA & KYLÄ & ALKUSÄE & MUOTORAKI & RYTмI \\
\hline SibA Launis 346 & 515 Soikkola & Mäkkylä & $\begin{array}{l}\text { Yks oli ounapuu kylässä, } \\
\text { yks oli ounapuu kylässä; } \\
\text { ja kylässä ja kylässä }\end{array}$ & $\begin{array}{l}12345678 \\
12345678 \| \\
56785678 \\
\end{array}$ & $\begin{array}{l}22222222 \\
2222222 \mid \\
62226222 \\
\end{array}$ \\
\hline A $300 / 34 b$ & 392 Soikkola & Mäkkylä & $\begin{array}{l}\text { Yks oli oinepuu kylässä, } \\
\text { yks oli oinepuu kylässä; ja } \\
\text { kylässä ja kylässä }\end{array}$ & $\begin{array}{c}12345678 \\
a 12345678 \| \\
56785678\end{array}$ & $\begin{array}{l}22222222 \\
22222222 \\
\text { || } 62226222\end{array}$ \\
\hline
\end{tabular}

(Ks. myös NPI 22/99.)

\section{HäÄTALOON AJAMINEN (MATKALLA MORSIAMEN KOTIIN)}

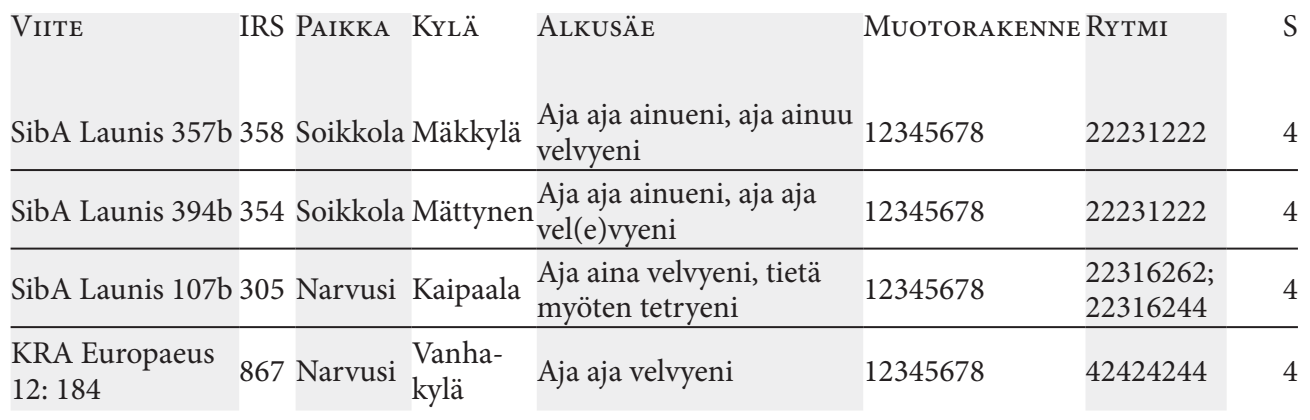




\section{TyttöJen laulu}

Kumarruttamisvirsiä, morsiamelle osoitettua lyriikkaa ja lyyristä epiikkaa (Neitojen linna, Käeltä sanat), itketys-teemoja; myös sulhasen neuvokkivirsien aloitusformuloita sekä puhemiehen pilkkaa. Kursiivilla on merkitty ne tyttöjen laulun sävelmätoisinnot, joiden yhteydessä ei ole suoraa viitettä (aloitusformula tai nimitys) hääkontekstiin. Näistä on otettu mukaan kolmeen suurimpaan sävelmäryhmään kuuluvat toisinnot.

\begin{tabular}{|c|c|c|c|c|c|c|}
\hline ViIte & IRS PAIKKA & KYLÄ & Runo & $\begin{array}{l}\text { MuOTO- } \\
\text { RAKENNE }\end{array}$ & RYTMI & S Nimitys \\
\hline
\end{tabular}

OI DAI -SÄVELMÄT

\begin{tabular}{|c|c|c|c|c|c|c|c|}
\hline SibA Launis 283 & 777 Soikkola & $\begin{array}{l}\text { ilm. } \\
\text { Voloitsa }\end{array}$ & $\begin{array}{l}\text { Issuit kannessa } \\
\text { ihala, oi dai issuit } \\
\text { kannessa issuit } \\
\text { kannessa ihala }\end{array}$ & $\begin{array}{l}12345678 \\
* * 12345 \\
12345678\end{array}$ & $\begin{array}{l}31312211 \\
{[11] 31624} \\
22223131\end{array}$ & 4 & \\
\hline SibA Launis 260 & 779 Soikkola & $\begin{array}{l}\text { ilm. } \\
\text { Voloitsa }\end{array}$ & $\begin{array}{l}\text { Lootika pohulle } \\
\text { polvin, oi dai } \\
\text { lootika se vaa }\end{array}$ & $\begin{array}{l}12345678 \\
* * 12345\end{array}$ & $\begin{array}{l}31312222 \\
{[22] 22624}\end{array}$ & 4 & \\
\hline A $300 / 20 c$ & 774 Soikkola & Koskina & $\begin{array}{l}\text { I otojani sizojani, } \\
\text { oi da Otojani Oto- } \\
\text { jani sizoja (issuit } \\
\text { kannessa ihala) }\end{array}$ & $\begin{array}{l}12345678 \\
-\| * * \\
1234 \\
1234567\end{array}$ & $\begin{array}{l}31312222 \\
\|[22] \\
2284 \\
3122318 \\
\end{array}$ & 5 & \\
\hline A $300 / 12 a$ & 775 Soikkola & Säätinä & $\begin{array}{l}\text { Oi issuit kannessa } \\
\text { ihala; oi dai issuit } \\
\text { kannes issuit } \\
\text { kannessa iso }\end{array}$ & $\begin{array}{l}12345678 \\
\|^{* *} \\
1234 \\
1234567\end{array}$ & $\begin{array}{l}31312222 \\
\|[22] \\
2284 \\
3122318 \\
\end{array}$ & $5+1$ & \\
\hline NPI 23/103 & Soikkola & Savimäki & $\begin{array}{l}\text { Anojani sisojani, } \\
\text { oi dai Anojani } \\
\text { Anojani sisojaan } \\
\text { (issut kannessa } \\
\text { ihala; itke itke } \\
\text { miks et itke; veri- } \\
\text { koira rinnallasi) }\end{array}$ & $\begin{array}{l}12345678 \\
\left.\right|^{* *} \\
1234 \\
12343567\end{array}$ & $\begin{array}{l}22222222 \\
\|[22] \\
2284 \\
3122318\end{array}$ & 4 & $\begin{array}{l}\text { häälaulu, } \\
\text { kengitysiltana } \\
\text { morsiamen } \\
\text { talossa }\end{array}$ \\
\hline NPI 23/127 & Soikkola & Savimäki & $\begin{array}{l}\text { Nastojani sisojani, } \\
\text { oi dai Nastojani } \\
\text { Nastojani siso- } \\
\text { jaan (muistatko } \\
\text { sitä ajutta, käeltä } \\
\text { sanat) }\end{array}$ & $\begin{array}{l}12345678 \\
\left.\right|^{* *} \\
1234 \\
12343567 \\
\end{array}$ & $\begin{array}{l}22222222 \\
\|[22] \\
2284 \\
3122318\end{array}$ & 4 & $\begin{array}{l}\text { Häissä } \\
\text { sulhasen } \\
\text { talossa }\end{array}$ \\
\hline NPI23/101 & Soikkola & Voloitsa & $\begin{array}{l}\text { Marojani sisojani, } \\
\text { oi dai Marojani } \\
\text { Marojani sisoja } \\
\text { (neitojen linna) }\end{array}$ & $\begin{array}{l}12345678 \\
\mid * * \\
1234 \\
12343567 \\
\end{array}$ & $\begin{array}{l}22222222 \\
\|[22] \\
2284 \\
3122318 \\
\end{array}$ & 4 & $\begin{array}{l}\text { häälaulu, } \\
\text { kosittaessa }\end{array}$ \\
\hline SKSÄ Fon. $22 b$ & 776 Soikkola & Mäkkylä & $\begin{array}{l}\text { Oi nyd miä laulan } \\
\text { nyd(e) miä jouvan; } \\
\text { oi dai nyt miä } \\
\text { la[ulan nyd miä } \\
\text { laulan nyd miä } \\
\text { jou] }\end{array}$ & $\begin{array}{l}12345678 \\
\| * * \\
1234 \\
1234567\end{array}$ & $\begin{array}{l}31312222 \\
||[22] 2284 \\
3122314\end{array}$ & 5 & \\
\hline SibA Launis 332 & 778 Soikkola & Soikkola & $\begin{array}{l}\text { Nyt on aika nuo- } \\
\text { ren noista; oi dai } \\
\text { nyt on aikoi nyt on } \\
\text { aikoi nuoren noist }\end{array}$ & $\begin{array}{l}12345678 \\
\mid * * 1234 \\
1234567\end{array}$ & $\begin{array}{l}31222222 \\
\mid[22] 2284 \\
2222314\end{array}$ & 4 & \\
\hline
\end{tabular}

OI JoKOI -sÄVELMÄT

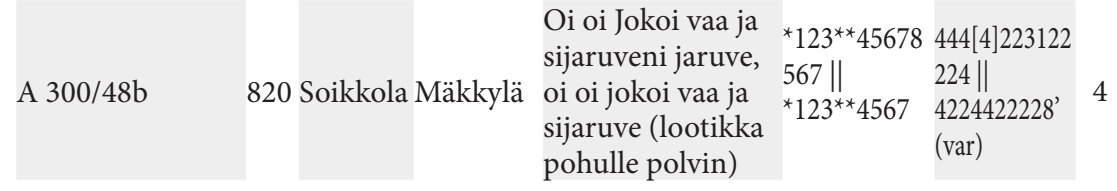




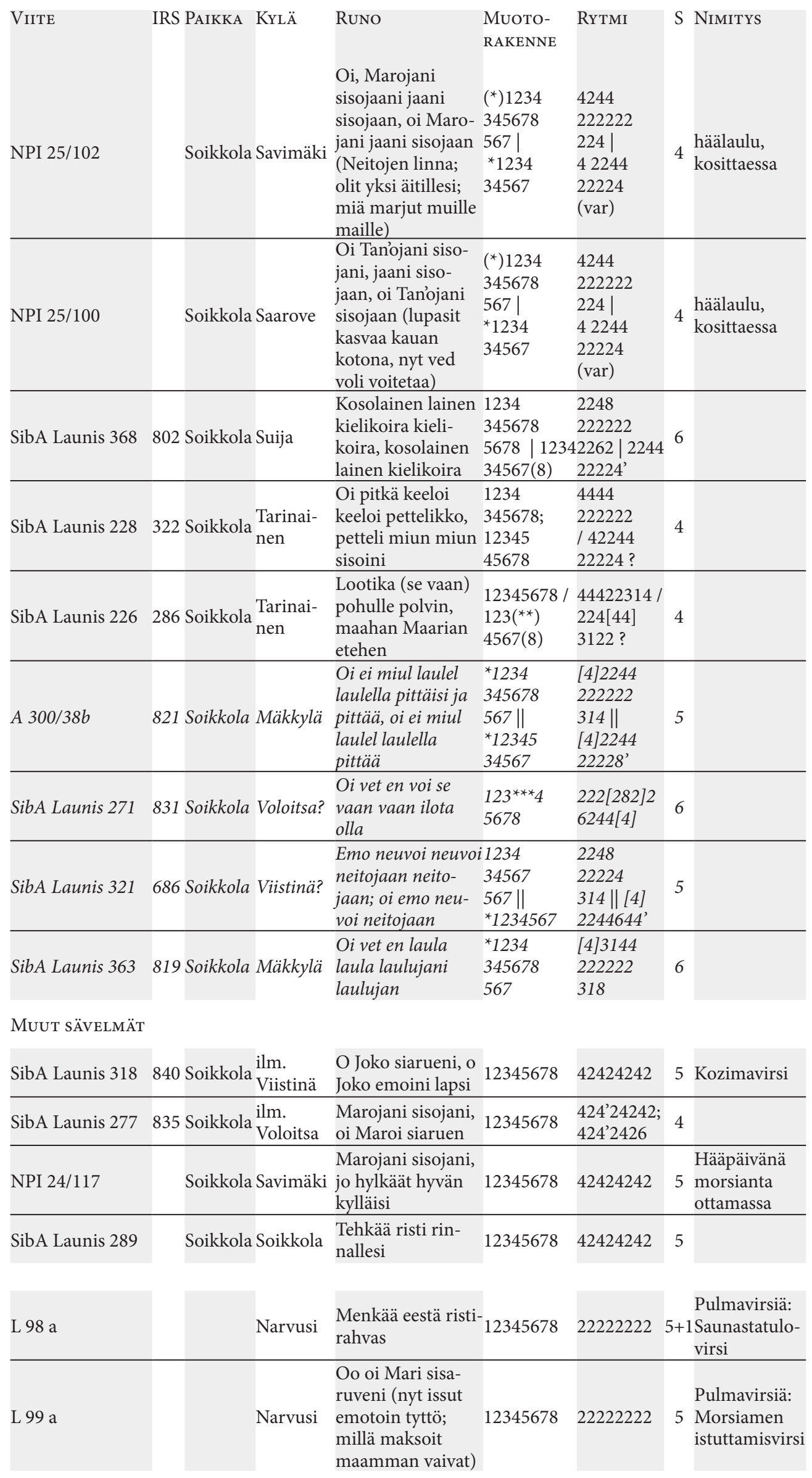




\begin{tabular}{|c|c|c|c|c|c|c|}
\hline ViIte & IRS РАIKKA & KYLÄ & Runo & $\begin{array}{l}\text { MUOTO- } \\
\text { RAKENNE }\end{array}$ & RytмI & S Nimitys \\
\hline $\begin{array}{l}\text { KRA Borenius } \\
203\end{array}$ & 284 Soikkola & Joenperä & $\begin{array}{l}\text { Oi An’u siaruen'i, } \\
\text { oi An’u siaruen'i } \\
\text { (Neitojen linna) }\end{array}$ & 12345678 & 44222244 & 4 pulmanootti \\
\hline SibA Launis 158 & 735 Soikkola & Säätinä & $\begin{array}{l}\text { Issuit kannes ihala, } \\
\text { kannessa isoitto- } \\
\text { massa }\end{array}$ & 12345678 & 22312222 & 4 \\
\hline SibA Launis 319 & 160 Soikkola & $\begin{array}{l}\text { ilm. } \\
\text { Viistinä }\end{array}$ & $\begin{array}{l}\text { Oi lootika Pohulle } \\
\text { polvin, maahan } \\
\text { Maarian etehen }\end{array}$ & 12345678 & 22622222 & $\begin{array}{l}\text { Kun poikia } \\
4 \begin{array}{l}\text { viesään sota- } \\
\text { miehiksi }\end{array}\end{array}$ \\
\hline $\begin{array}{l}\text { KRA Borenius } \\
195\end{array}$ & 350 Soikkola & Savimäki & $\begin{array}{l}\text { Teekkä risti rin- } \\
\text { nalle rinnallesi } \\
\text { rinnallesi (lootti } \\
\text { pohulle polvee; } \\
\text { iso sanoi saata } \\
\text { suohon) }\end{array}$ & $\begin{array}{l}1234567 \\
5678\end{array}$ & $\begin{array}{l}2222224 \\
2244\end{array}$ & 4 pulmavers \\
\hline SibA Launis 170 & 739 Soikkola & Säätinä & $\begin{array}{l}\text { Issuit kannessa } \\
\text { ihala, ihala; kan- } \\
\text { nessa isoittomassa, } \\
\text { isoittomassa }\end{array}$ & $\begin{array}{l}12345678 \\
678 / \\
12345678 \\
45678\end{array}$ & $\begin{array}{l}44446222 \\
444 / \\
44446222 \\
42222\end{array}$ & 4 \\
\hline NPI 22/99 & Soikkola & Savimäki & $\begin{array}{l}\text { Kosolaine keeli- } \\
\text { koira (petteli miun } \\
\text { sissoine; yks oli } \\
\text { ounapuu kylässä) }\end{array}$ & 12345678 & 22626262 & $4+1$ köäälaulu, \\
\hline SibA Launis 250 & 741 Soikkola & $\begin{array}{l}\text { ilm. } \\
\text { Voloitsa }\end{array}$ & $\begin{array}{l}\text { Oi vävyin se vaa } \\
\text { (va) sison suloi- } \\
\text { nen, oi vävyi se } \\
\text { vaa (va) kuvattu } \\
\text { kultoi }\end{array}$ & $\begin{array}{l}123^{\star * *} \\
45678\end{array}$ & $\begin{array}{l}444[482] \\
22244\end{array}$ & 4 \\
\hline SibA Launis 300 & 806 Soikkola & Voloitsa? & $\begin{array}{l}\text { La katso se vaa } \\
\text { vaan kesoista } \\
\text { ääntä, oi kesoista } \\
\text { ääntä; ääntä kerki- } \\
\text { äistä oi kerkiäistä }\end{array}$ & $\begin{array}{l}123^{* * *} \\
456789 \\
* 45678 \mid \\
123456^{*} \\
3456\end{array}$ & $\begin{array}{l}222[282] \\
2226^{\prime} 2 \\
{[4] 2248^{\prime}} \\
\mid 222222 \\
{[4] 2248} \\
\end{array}$ & $4+1$ \\
\hline SibA Launis 380 & 863 Soikkola & $\begin{array}{l}\text { Oussi- } \\
\text { mäki }\end{array}$ & $\begin{array}{l}\text { Oi la katson vaan } \\
\text { kesoista kieltä vaan } \\
\text { ja kesoist }\end{array}$ & $\begin{array}{l}* 123 * 45 \\
678 * 567 \\
\end{array}$ & $\begin{array}{l}{[4] 224[2] 26} \\
242[2] 448\end{array}$ & 6 \\
\hline SibA Launis 59 & 823 Narvusi & Pärspää & $\begin{array}{l}\text { Sanon siulle siulle } \\
\text { tään kesoja tään } \\
\text { kesoja (yl. Neitojen } \\
\text { linna) }\end{array}$ & $\begin{array}{l}1234 \\
345678 \\
5678\end{array}$ & $\begin{array}{l}224422 \\
2244 \\
2224\end{array}$ & $4+1$ \\
\hline SibA Launis 358 & 740 Soikkola & Mäkkylä & $\begin{array}{l}\text { Oi jokoi se vaan } \\
\text { vaan siarueni; oi } \\
\text { jokoi se vaan vaan } \\
\text { emoni lap(a)si } \\
\text { (tai Neito linnassa } \\
\text { lässii) }\end{array}$ & $123^{* * *} 45678$ & $\begin{array}{l}444[482] \\
22244\end{array}$ & 5 \\
\hline SibA Launis $335 b$ & 742 Soikkola & Soikkola & $\begin{array}{l}\text { Miks on meitä } \\
\text { vaan meitä näin } \\
\text { vähäsen }\end{array}$ & $\begin{array}{l}1234^{*} \\
345678\end{array}$ & $\begin{array}{l}4462[8] \\
222244\end{array}$ & \\
\hline SibA Launis 279 & Soikkola & $\begin{array}{l}\text { ilm. } \\
\text { Voloitsa }\end{array}$ & $\begin{array}{l}\text { La istun kantta } \\
\text { kantelokätyen } \\
\text { (itku) }\end{array}$ & & & 4 \\
\hline
\end{tabular}




\section{KESKI-INKERILÄISET HÄÄSÄVELMÄT}

\begin{tabular}{|c|c|c|c|c|c|c|}
\hline VIITE & IRS & S PAIKKA & KYLÄ & RunO & $\begin{array}{l}\text { MUOTO- } \\
\text { RAKENNE }\end{array}$ & Rytмi \\
\hline KRA Levón 418 & 375 & 5 Hevaa & Harmaala & $\begin{array}{l}\text { la ka katson lautoja, Silittelen } \\
\text { siltoja }\end{array}$ & 1234567 & 2222224 \\
\hline KRA Levón 519 & 498 & 8 Hevaa & $\begin{array}{l}\text { Vanha } \\
\text { Huurala }\end{array}$ & $\begin{array}{l}\text { La ka katson lautojan, la siloita } \\
\text { siltojan }\end{array}$ & 1234567 & 2222224 \\
\hline KRA Levón 448 & 603 & 3 Hevaa & Vepsä & $\begin{array}{l}\text { La ka katson lautojan, silittelen } \\
\text { siltojan }\end{array}$ & 1234567 & 2222224 \\
\hline KRA Levón 433 & 49 & Hevaa & $\begin{array}{l}\text { Kanta- } \\
\text { kylä }\end{array}$ & $\begin{array}{l}\text { Mahtuuko vävy tupahan, ilman } \\
\text { orren ottamatta }\end{array}$ & 12345678 & 22222222 \\
\hline KRA Levón 523 & 69 & Hevaa & $\begin{array}{l}\text { Uusi } \\
\text { Huurala }\end{array}$ & $\begin{array}{l}\text { Ei mahu vävy tupahan, vävy kuu- } \\
\text { sen suurukkainen }\end{array}$ & 12345678 & 22222222 \\
\hline A $301 / 37 a$ & 79 & Hevaa & Murtove & Mitä mökköi mööHäs nousit & 12345678 & 22222222 \\
\hline KRA Levón 471 & 88 & Hevaa & Lenttinen & $\begin{array}{l}\text { Hospoti opastamahan, last avikkoi } \\
\text { nlaulamahan }\end{array}$ & 12345678 & 22222222 \\
\hline $\begin{array}{l}\text { KRA Borenius } \\
178\end{array}$ & 60 & Hevaa & Vepsä & $\begin{array}{l}\text { Vävy uuven uusikkaine } \\
\text { (kuin uusi kananmunaine) }\end{array}$ & 12345678 & 22222222 \\
\hline A $301 / 26 b$ & 120 & 0 Hevaa & Vepsä & $\begin{array}{l}\text { Möö määmmä siuj jätämmä, } \\
\text { möö määmmä siuj jätämmä }\end{array}$ & 12345678 & 22222222 \\
\hline A $301 / 24 b$ & 131 & 1 Hevaa & Vepsä & & 12345678 & 22222222 \\
\hline KRA Levón 501 & 567 & 7 Hevaa & $\begin{array}{l}\text { Vanha } \\
\text { Huurala }\end{array}$ & $\begin{array}{l}\text { Kauroi velloin } \\
\text { kauroini kalais }\end{array}$ & 12345678 & 22222222 \\
\hline KRA Levón 446 & 180 & 0 Hevaa & Vepsä & $\begin{array}{l}\text { Mitä se mökkö myöhään nousit, } \\
\text { kauvan kolkkimus makasit }\end{array}$ & 12345678 & 22222244 \\
\hline KRA Levón 413 & 148 & 8 Hevaa & Harmaala & $\begin{array}{l}\text { Sie neito meijän miinoi, } \\
\text { älä tusi tullessasi }\end{array}$ & 12345678 & 22222244 \\
\hline $\begin{array}{l}\text { KRA Borenius } \\
\text { e } 180\end{array}$ & 194 & 4 Hevaa & Vepsä & & 12345678 & 22222244 \\
\hline A $301 / 25 a$ & 163 & 3 Hevaa & Vepsä & $\begin{array}{l}\text { Mahtuuko vävöi t } \\
\text { ilman orren ottan }\end{array}$ & 12345678 & 22222244 \\
\hline $\begin{array}{l}\text { KRA Borenius } \\
\text { e } 428\end{array}$ & 205 & 5 Hevaa & Harmaala & $\begin{array}{l}\text { Sulho poikoi poit } \\
\text { asiniviittoi veetyläi }\end{array}$ & 12345678 & $\begin{array}{l}22443144, \\
2244228\end{array}$ \\
\hline A $301 / 46 a$ & 209 & 9 Hevaa & Yhimäki & $\begin{array}{l}\text { Kerallizet pois männöövät; keralli- } \\
\text { zet pois männöövät }\end{array}$ & 12345678 & 22622244 \\
\hline KRA Levón 525 & 338 & 8 Hevaa & $\begin{array}{l}\text { Uusi } \\
\text { Huurala }\end{array}$ & $\begin{array}{l}\text { Istu sie isotoin tyttö ja isotoin, ahin } \\
\text { armoton asetu ja asetu }\end{array}$ & $\begin{array}{l}12345678 \\
5678\end{array}$ & $\begin{array}{l}44222231 \\
2231 \\
\end{array}$ \\
\hline $\begin{array}{l}\text { KRA Borenius } \\
\text { e } 179\end{array}$ & 351 & 1 Hevaa & Vepsä & $\begin{array}{l}\text { Et luvannut lähtöväisi lähtöväisi, } \\
\text { etkä [pois pakenovasi] ja pakeno }\end{array}$ & $\begin{array}{l}12345678 \\
5678\end{array}$ & $\begin{array}{l}46222222 \\
3144 \\
\end{array}$ \\
\hline KRA Levón 434 & 362 & 2 Hevaa & $\begin{array}{l}\text { Kanta- } \\
\text { kylä }\end{array}$ & $\begin{array}{l}\text { Mist sie tunsit turnust tulla turnust } \\
\text { tulla, sian kärsä tänne käyä tänne } \\
\text { käyä }\end{array}$ & $\begin{array}{l}12345678 \\
5678\end{array}$ & $\begin{array}{l}24222262 \\
2262[2]\end{array}$ \\
\hline KRA Levón 451 & 513 & 3 Hevaa & Vepsä & $\begin{array}{l}\text { Lankoisenne lintuisenne, lankoi- } \\
\text { senneko lintuisen; lintui lintuisen- } \\
\text { ne, lintuisenne joonoi }\end{array}$ & $\begin{array}{l}12345678 \\
1234567 \\
\| 565678 \\
5678 * * \\
\end{array}$ & $\begin{array}{l}22222222 \\
2222222\end{array}$ \\
\hline KRA Levón 526 & 744 & 4 Hevaa & $\begin{array}{l}\text { Uusi } \\
\text { Huurala }\end{array}$ & $\begin{array}{l}\text { Oi oi taroi sie emoni lapsi ja emoin; } \\
\text { oi oi taroi sie emoini laps }\end{array}$ & $\begin{array}{l}{ }^{\star} 123^{\star} \\
145678345 \\
{ }^{\star} 123^{\star} \\
4567\end{array}$ & $\begin{array}{l}4] 224[42] \\
|22222314| \mid \\
{[4] 224[42]} \\
2314 \\
\end{array}$ \\
\hline KRA Levón 478 & 393 & 3 Hevaa & Tönttölä & $\begin{array}{l}\text { La ka katson lautojan, La ka katson } \\
\text { lautojan; lautojan lautojan, la ka } \\
\text { katson lautojan }\end{array}$ & $\begin{array}{l}1234567 \\
1234567 \\
\text { || } 567567 \\
1234567\end{array}$ & $\begin{array}{l}2222224 \\
2222224 \\
\text { || } 224224 \\
2222224\end{array}$ \\
\hline KRA Levón 373 & 59 & Tyrö & Yhimäki & $\begin{array}{l}\text { Istu jamppana jakulle, riinasilmä } \\
\text { ristilöille }\end{array}$ & 12345678 & 22222222 \\
\hline
\end{tabular}




\begin{tabular}{|c|c|c|c|c|c|}
\hline VIITE & IRS PAIKKA & KYLÄ & Runo & $\begin{array}{l}\text { MUOTO- } \\
\text { RAKENNE }\end{array}$ & RYtмI \\
\hline $\begin{array}{l}\text { KRA Borenius } \\
\text { e } 113\end{array}$ & 140 Tyrö & $\begin{array}{l}\text { Hovi- } \\
\text { mäen } \\
\text { Alakylä }\end{array}$ & Miss sie mökkö myöhään viivyit & 12345678 & 22222222 \\
\hline KRA Levón 350 & 564 Tyrö & $\begin{array}{l}\text { Hovin- } \\
\text { mättään } \\
\text { kylät }\end{array}$ & $\begin{array}{l}\text { Mahtuuko vävy tupaani, ilman } \\
\text { orren ottamatta }\end{array}$ & 12345678 & 22222222 \\
\hline KRA Levón 399 & 195 Tyrö & Yhimäki & $\begin{array}{l}\text { kerralliset pois menevät, miun sitt } \\
\text { täytyy tänne jäädä }\end{array}$ & 12345678 & 22222244 \\
\hline $\begin{array}{l}\text { KRA Europaeus } \\
\text { 12: } 027\end{array}$ & 878 Tyrö & $\begin{array}{l}\text { Kaa- } \\
\text { rostan } \\
\text { takakylät }\end{array}$ & oi sie laiska lesken poika & 12345678 & 22442244 \\
\hline KRA Levón 349 & 216 Tyrö & $\begin{array}{l}\text { Hovin- } \\
\text { mättään } \\
\text { kylät }\end{array}$ & $\begin{array}{l}\text { Lankoiseni lintuiseni, pasta miulle } \\
\text { paksu kakku }\end{array}$ & 12345678 & 22622244 \\
\hline KRA Levón 114 & 332 Tyrö & $\begin{array}{l}\text { Hovi- } \\
\text { mäen } \\
\text { Alakylä }\end{array}$ & $\begin{array}{l}\text { Ottajat omenuveini ja omenu, pu- } \\
\text { hemiehet puoluveini, puoluveini }\end{array}$ & $\begin{array}{l}12345678 \\
5678\end{array}$ & $\begin{array}{l}22442231 \\
3131\end{array}$ \\
\hline A $301 / 40 b$ & 361 Tyrö & Yhimäki & $\begin{array}{l}\text { Istuu tyttö mustatukka musta- } \\
\text { tukka; peDäjäisem penkim päälle } \\
\text { penkin pää }\end{array}$ & $\begin{array}{l}12345678 \\
5678\end{array}$ & $\begin{array}{l}24222262 \\
2262\end{array}$ \\
\hline $\begin{array}{l}\text { KRA Borenius } \\
\text { e } 116\end{array}$ & 360 Tyrö & $\begin{array}{l}\text { Hovi- } \\
\text { mäen } \\
\text { Alakylä }\end{array}$ & Kati siityine sissoini ja sissoini & $\begin{array}{l}12345678 \\
5678\end{array}$ & $\begin{array}{l}24222262 \\
2262\end{array}$ \\
\hline A $301 / 44 a$ & $361^{\star}$ Tyrö & Yhimäki & $\begin{array}{l}\text { Ulos savu saunoistasi saunoistasi; } \\
\text { käry huoneHoisestasi hoisesta }\end{array}$ & $\begin{array}{l}12345678 \\
5678 / \\
12345678 \\
3456 \\
\end{array}$ & $\begin{array}{l}24222262 \\
2262\end{array}$ \\
\hline KRA Levón 351 & 368 Tyrö & $\begin{array}{l}\text { Hovin- } \\
\text { mättään } \\
\text { kylät }\end{array}$ & $\begin{array}{l}\text { Iikko velloini verevä ja verevä } \\
\text { (iloilta vai itkuilta) }\end{array}$ & $\begin{array}{l}12345678 \\
\star 5678 ; \\
12345678 \\
\star 45678 \\
\end{array}$ & $\begin{array}{l}? 26222262 \\
{[2] 2242 ;} \\
2622226 \\
{[2] 22244} \\
\end{array}$ \\
\hline A $301 / 41 a$ & 363 Tyrö & Yhimäki & $\begin{array}{l}\text { Miss siä mökkö mööhääv viivyit; } \\
\text { kauvan kankelo makaisit ja ma- } \\
\text { kaisit }\end{array}$ & $\begin{array}{l}12345678 \\
5678 / \\
12345678 / \\
12345678 \\
\star 456 \\
\end{array}$ & $\begin{array}{l}24222262 \\
2262 / \\
24222262\end{array}$ \\
\hline $\begin{array}{l}\text { KRA Borenius } \\
\text { e } 115\end{array}$ & 187 Tyrö & $\begin{array}{l}\text { Hovi- } \\
\text { mäen } \\
\text { Alakylä }\end{array}$ & $\begin{array}{l}\text { Miss sie mökkö myöhään viivyit, } \\
\text { myöhään viivyit joi }\end{array}$ & $\begin{array}{l}12345678 \\
5678 \text { joi }\end{array}$ & $\begin{array}{l}22226222 \\
4444[4]\end{array}$ \\
\hline KRA Levón 315 & 352 Tyrö & $\begin{array}{l}\text { Kirkon- } \\
\text { kylä }\end{array}$ & $\begin{array}{l}\text { Mari siityinen sisoi, kysyn seukko } \\
\text { mie siulta, mikä ilta tää siulla }\end{array}$ & $\begin{array}{l}1234567(8) \\
12345678 \\
\end{array}$ & $\begin{array}{l}2422226 \\
22222222 \\
\end{array}$ \\
\hline KRA Levón 344 & 364 Tyrö & $\begin{array}{l}\text { Latikan } \\
\text { kylät }\end{array}$ & $\begin{array}{l}\text { Istuu tuos isoton poika, armoton } \\
\text { ajatteloo }\end{array}$ & $\begin{array}{l}1234567(8) \\
1234567 \\
\end{array}$ & $\begin{array}{l}44222262 \\
2222222 \\
2222226 \\
2222222 \\
\end{array}$ \\
\hline A $301 / 47 a$ & 382 Tyrö & Yhimäki & $\begin{array}{l}\text { Jo meillä ero tuloo, vaikeva ono } \\
\text { harota; ai luuli ja harot, vaikea ono } \\
\text { harota }\end{array}$ & $\begin{array}{l}1234567(8) \\
1234567(8)\end{array}$ & ) 222222222 \\
\hline $\begin{array}{l}\text { Niukkanainen- } \\
\text { Iivanainen } 5 \mathrm{~b}\end{array}$ & $657 \begin{array}{l}\text { Hieta- } \\
\text { mäki }\end{array}$ & $\begin{array}{l}\text { Hieta- } \\
\text { mäki }\end{array}$ & $\begin{array}{l}\text { Ketä kutsun auttamahan, } \\
\text { ketä kutsun auttamahan; } \\
\text { totta auttamahan, } \\
\text { totta auttamahan }\end{array}$ & $\begin{array}{l}12345678 \\
12345678 \\
\|_{* *}^{* * 5678}\end{array}$ & $\begin{array}{l}22222262 \\
{[2]} \\
22222262 \| \\
22(10) 262 \\
222262\end{array}$ \\
\hline $\begin{array}{l}\text { Niukkanainen- } \\
\text { Iivanainen } 5 \mathrm{a}\end{array}$ & $897 \begin{array}{l}\text { Hieta- } \\
\text { mäki }\end{array}$ & $\begin{array}{l}\text { Hieta- } \\
\text { mäki }\end{array}$ & $\begin{array}{l}\text { Ketä kutsun auttamahan, ketä } \\
\text { kutsun auttamahan; hei vei ketä } \\
\text { kutsun auttamahan, hei vei ketä } \\
\text { kutsun auttamahan }\end{array}$ & $\begin{array}{l}12345678 \\
12345678 \\
\|_{* *}^{* *} 12345678 \\
* 12345678\end{array}$ & $\begin{array}{l}22222231 \\
22222231 \\
\| \\
{[22] 11112231} \\
{[22] 11112231}\end{array}$ \\
\hline
\end{tabular}




\begin{tabular}{|c|c|c|c|c|c|c|}
\hline ViIte & IRS & PAIKKA & KYLÄ & RunO & $\begin{array}{l}\text { MUOTO- } \\
\text { RAKENNE }\end{array}$ & Rутмі \\
\hline $\begin{array}{l}\text { KRA Borenius } \\
\text { e } 379\end{array}$ & 139 & Kolppana & $\begin{array}{l}\text { Pieni } \\
\text { a Kolppana }\end{array}$ & $\begin{array}{l}\text { Läkkä luoja luottammaane, } \\
\text { a Jumala avittammaane }\end{array}$ & 12345678 & 22222222 \\
\hline Inki 5 & 871 & Koprina & Koprina & $\begin{array}{l}\text { Jo on ottajat ovilla, } \\
\text { jo on ottajat ovilla }\end{array}$ & 12345678 & 22222222 \\
\hline Inki $3 b$ & 884 & Koprina & Koprina & $\begin{array}{l}\text { Morsee siityinen sisoni, } \\
\text { morsee siityinen sisoni }\end{array}$ & 12345678 & 22442244 \\
\hline Inki 3 a & 892 & Koprina & Koprina & Morsee siityinen sisoni ja sisoni & $\begin{array}{l}12345678 \\
5678\end{array}$ & $\begin{array}{l}24222262 \\
2262\end{array}$ \\
\hline SibA Launis 415 & 26 & Serebetta & $\begin{array}{l}\text { Kirkon- } \\
\text { kylä }\end{array}$ & $\begin{array}{l}\text { ottaja omenueni, } \\
\text { sison viejät verkaviitat }\end{array}$ & 12345678 & 22222222 \\
\hline SibA Launis 411 & 366 & Serebetta & $\begin{array}{l}\text { Kirkon- } \\
\text { a kylä }\end{array}$ & Kati siityinen sisoinen ja sisoini & $\begin{array}{l}12345678 \\
5678 \\
\end{array}$ & $\begin{array}{l}22222222 \\
3142 \\
\end{array}$ \\
\hline SibA Launis 413 & 355 & Serebetta & $\begin{array}{l}\text { Kirkon- } \\
\text { kylä }\end{array}$ & $\begin{array}{l}\text { Mari siityinen sissoini ja sissoini, } \\
\text { itke itke mikset itke mikset itke }\end{array}$ & $\begin{array}{l}12345678 \\
5678\end{array}$ & $\begin{array}{l}24222242 \\
2262 \\
\end{array}$ \\
\hline SibA Launis 412 & 357 & Serebetta & $\begin{array}{l}\text { Kirkon- } \\
\text { a kylä }\end{array}$ & $\begin{array}{l}\text { Ottajat omenuveini ja omenu, } \\
\text { puhemiehet puoluveini ja puoluveini }\end{array}$ & $\begin{array}{l}12345678 \\
\star 678 / \\
i 12345678 \\
\star 5678 \\
\end{array}$ & $\begin{array}{l}24242242 \\
{[2] 244 /} \\
24242242 \\
{[2] 2422} \\
\end{array}$ \\
\hline SibA Launis 414 & 496 & Serebetta & $\begin{array}{l}\text { Kirkon- } \\
\text { kylä }\end{array}$ & $\begin{array}{l}\text { Anni siityinen sissoin, } \\
\text { anni siityinen sissoini }\end{array}$ & $\begin{array}{l}1234567 \\
12345678\end{array}$ & $\begin{array}{l}2262242 \\
22242244\end{array}$ \\
\hline $\begin{array}{l}\text { KRA Borenius } \\
\text { e } 389\end{array}$ & 202 & Skuoritsa & aSkuoritsa & $\begin{array}{l}\text { Morsia sia sissoini, } \\
\text { morsia sia sissoini }\end{array}$ & 12345678 & 22442244 \\
\hline $\begin{array}{l}\text { KRA Borenius } \\
\text { e } 390\end{array}$ & 247 & Skuoritsa & aSkuoritsa & $\begin{array}{l}\text { Morsia sia sissoini } \\
\text { (kuuleppas sie kui mie laulan) }\end{array}$ & 12345678 & 22442244 \\
\hline $\begin{array}{l}\text { KRA Borenius } \\
\text { e } 387\end{array}$ & 326 & Skuorits & $\begin{array}{l}\text { Ala- } \\
\text { a Purskova }\end{array}$ & Tuos istun isotoin tyttö ja isotoin & $\begin{array}{l}12345678 \\
5678\end{array}$ & $\begin{array}{l}22442231 \\
2231\end{array}$ \\
\hline $\begin{array}{l}\text { KRA Borenius } \\
\text { e } 384\end{array}$ & 367 & Skuoritsa & aSkuoritsa & $\begin{array}{l}\text { Pojat vierot veikkoseni veikkoseni, } \\
\text { pojat vierot veikkoseni veikkoseni }\end{array}$ & $\begin{array}{l}12345678 \\
5678\end{array}$ & $\begin{array}{l}44222262 \\
2262\end{array}$ \\
\hline $\begin{array}{l}\text { KRA Borenius } \\
\text { e } 212\end{array}$ & 48 & Kattila & $\begin{array}{l}\text { Matin- } \\
\text { kylä }\end{array}$ & $\begin{array}{l}\text { Last avitekka jumala, } \\
\text { last avitakka jumala }\end{array}$ & 12345678 & 22222222 \\
\hline $\begin{array}{l}\text { KRA Borenius } \\
\text { e } 213\end{array}$ & 51 & Kattila & $\begin{array}{l}\text { Matin- } \\
\text { kylä }\end{array}$ & $\begin{array}{l}\text { Kaazikkaine maazikkaine, } \\
\text { kaazikkaine maazikkaine }\end{array}$ & 12345678 & 22222222 \\
\hline $\begin{array}{l}\text { KRA Borenius } \\
\text { e } 211\end{array}$ & 57 & Kattila & $\begin{array}{l}\text { Matin- } \\
\text { kylä }\end{array}$ & $\begin{array}{l}\text { Tuidu tuidu toomen oksat, } \\
\text { tuidu tuidu toomen oksat }\end{array}$ & 12345678 & 22222222 \\
\hline $\begin{array}{l}\text { KRA Borenius } \\
\text { e } 210\end{array}$ & 91 & Kattila & $\begin{array}{l}\text { Matin- } \\
\text { kylä }\end{array}$ & $\begin{array}{l}\text { Löeril löeril velvyttäni, } \\
\text { löeril löeril velvyttäni }\end{array}$ & 12345678 & 22222222 \\
\hline SibA Launis 396 & 28 & Kattila & $\begin{array}{l}\text { Kirkon- } \\
\text { kylä }\end{array}$ & $\begin{array}{l}\text { Yhs eli öhsä eunapuussa, } \\
\text { yhs eli euna öhsällä }\end{array}$ & 12345678 & 22222222 \\
\hline SibA Launis 395 & 52 & Kattila & $\begin{array}{l}\text { Kirkon- } \\
\text { kylä }\end{array}$ & $\begin{array}{l}\text { čyhyze kurzi, kaunis kuori, } \\
\text { ahi lavvaa ladjutta }\end{array}$ & 12345678 & 22222222 \\
\hline $\begin{array}{l}\text { KRA Borenius } \\
\text { e } 220\end{array}$ & 105 & Kattila & Lempola & $\begin{array}{l}\text { Terve kuu terve päivä, } \\
\text { terve kuu terve päivä }\end{array}$ & 12345678 & 22222222 \\
\hline $\begin{array}{l}\text { KRA Borenius } \\
\text { e } 218\end{array}$ & 127 & Kattila & Pummala & $\begin{array}{l}\text { Last avitekka jumala, } \\
\text { last avitakka jumala }\end{array}$ & 12345678 & 22222222 \\
\hline $\begin{array}{l}\text { KRA Borenius } \\
\text { e } 216\end{array}$ & 128 & Kattila & Kattila & $\begin{array}{l}\text { Last avitekka jumala, } \\
\text { last avitakka jumala }\end{array}$ & 12345678 & 22222222 \\
\hline SibA Launis 395 & 27 & Kattila & $\begin{array}{l}\text { Kirkon- } \\
\text { kylä }\end{array}$ & $\begin{array}{l}\text { čyhyze kurzi, kaunis kuori, } \\
\text { ahi lavvaa ladjutta }\end{array}$ & $\begin{array}{l}12345678 ; \\
1234567\end{array}$ & 22222222 \\
\hline
\end{tabular}

